РОССИЙСКАЯ АКАДЕМИЯ НАУК ИНСТИТУТ АРХЕОЛОГИИ

RUSSIAN ACADEMY OF SCIENCES INSTITUTE OF ARCHAEOLOGY 
N.A. KRENKE

\section{ARCHAEOLOGY OF MOSKVA RIVER BASIN FROM NEOLITHIC TO MIDDLE AGES}




\section{H.А. КРЕНКЕ \\ ДРЕВНОСТИ БАССЕЙНА МОСКВЫ-РЕКИ ОТ НЕОЛИТА ДО СРЕДНЕВЕКОВЬЯ}




\title{
Кренке, Н.А.
}

Древности бассейна Москвы-реки от неолита до Средневековья : этапы культурного развития, формирование производящей экономики и антропогенного ландшафта. - Москва ; Смоленск, 2019. - 392 с. : 225 илл.

ISBN 978-5-907148-12-3

В монографии представлены результаты раскопок стоянок, городищ, селищ и курганов, расположенных в бассейне Москвыреки и датирующихся от развитого неолита до Средневековья. Хронологический диапазон древностей - от конца V тыс. до н.э. до XIII в. н.э. Анализируются особенности материальной культуры, рассматриваются вопросы о наличии преемственности между памятниками разных эпох. Привлекаются данные естественно-научных исследований - палинологических, остеологических. Особенное внимание уделено результатам радиоуглеродного датирования.

Для археологов, историков, культурологов.

УДК 902/903

ББК 63.4

Научное издание

Кренке Николай Александрович

ДРЕВНОСТИ БАССЕЙНА МОСКВЫ-РЕКИ ОТ НЕОЛИТА ДО СРЕДНЕВЕКОВЬЯ: этапы культурного развития, формирование производящей экономики и антропогенного ландшафта

\author{
Ответственный редактор академик РАН Н.А. Макаров \\ Редакторы М.М. Леренман, И.В. Клюшкина \\ Оформление обложки и форзацев В.Н. Кулебякиной \\ Рисунок-реконструкция вида древнерусского поселения XII-XIII веков в Теплом Стане (Москва) \\ на нижней переплетной крышке Н.А. Кренке \\ Рисунок фатьяновского топора, найденного на Измайловском острове, \\ на шмуц-титуле Л.Б. Ланцмана \\ Технический редактор Н.С. Малышева \\ Корректор А.А. Алексеева \\ Издательство «Свиток». 214025, г. Смоленск, ул. Н.-Неман, д. 31/216. Тел.: 8-910-787-82-59. E-mail: iflim@mail.ru \\ ЛР №06193 от 01.11.2001 г. Подписано в печать 11.01.2019 г. \\ Формат 60x90/8. Бумага офсетная. Гарнитура Times. Печать офсетная. 49 п. л. Тираж 200 экз. Заказ
}

ISBN 978-5-907148-12-3

DOI: 10.25681/IARAS.2018. 978-5-907148-12-3
(C) Федеральное государственное бюджетное учреждение науки Институт археологии Российской академии наук, 2019.

(C) Кренке Н.А., 2019.

(c) Оформление. «Свиток», 2019. 


\section{Содержание}

















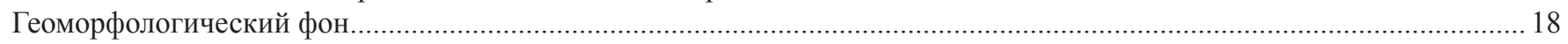





ГЛАВА ІІ. Памятники раннего железного века (дьяковская культура) на Москве-реке .....................................................3 38

Памятники переходного этапа от бронзового века к железному и возникновение городищ на Москве-реке................... 38



Радиоуглеродная хронология памятников дьяковской культуры ….................................................................... 55

Реконструкции структуры расселения и численности населения …….................................................................5

Реконструкции хозяйства и особенностей культурного ландшафта …...................................................................5 56

ГЛАВА ІІІ. Позднедьяковская культура на территории бассейна Москвы-реки ...............................................................6 64



Хронология, характеристика вещевого и керамического комплекса начального этапа

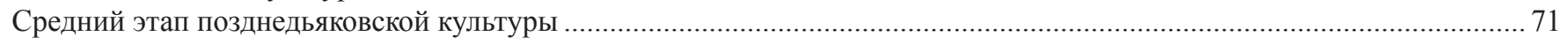





Археологические данные о начальном периоде славянской колонизации Подмосковья ………................................... 83

Археологическая карта древнерусских памятников и пространственная организация



Исследование карты древнерусских курганов бассейна Москвы-реки методом ГИС .................................................. 95



Трансформация культуры во второй половине XIII века после татаро-монгольского нашествия 1238 года.................. 107





ПРИЛОЖЕНИЕ І. Каталог памятников железного века в бассейне Москвы-реки ............................................................ 116

ПРИЛОЖЕНИЕ II. Каталог радиоуглеродных дат по памятникам неолита, бронзового и железного веков, средневековых, расположенных в бассейне Москвы-реки .....

ПРИЛОЖЕНИЕ III. Список древнерусских (домонгольских) памятников в бассейне Москвы-реки

ЛИТЕРАТУРА И АРХИВНЫЕ ИСТОЧНИКИ

ПРИНЯТЫЕ СОКРАЩЕНИЯ 


\section{Введение}

\section{ПОДМОСКОВЬЕ КАК АРХЕОЛОГИЧЕСКИЙ РЕГИОН}

Д иахронное изучение археологии какого-либо региона является достаточно распространенным жанром археологических исследований. Обращаясь к Подмосковью, необходимо поставить несколько первоочередных вопросов. В чем специфичность Подмосковья как региона для комплексного археологического исследования? Насколько древности этой территории изучены, с какой полнотой они интерпретируются современной наукой? Как определяются географические рамки исследования?

Все эти вопросы являются вопросами «регионалистики», научного направления, которое получило существенное развитие в последние годы (Основания регионалистики, 1999). В то же время здесь очень уместно вспомнить термин «месторазвитие», предложенный еще в 1920-е годы П.Н. Савицким (Савиџкий, 1927) в рамках концепции о связи ландшафта и истории. Конечно, континентальные географические масштабы работ П.Н. Савицкого существенно крупнее, чем в настоящей работе. Но заметим, что дихотомия лес - степь, столь важная для глобального евразийского понимания исторического развития, присутствует и в долине Москвы-реки, причем степень «остепненности» ландшафта в период климатического оптимума голоцена, по данным новейших палинологических исследований, была выше, чем предполагалось ранее (Erschova and al., 2014). Задачу комплексного (в том числе археологического) изучения территории Московской губернии сформулировал еще в 1925 г. академик Ю.В. Готье в докладе на заседании общества «Старая Москва» (Филимонов, 1989. С. 72-73). До сих пор в полной мере эта задача остается актуальной.

Методический подход данной работы - это диахронное изучение археологических древностей в определенном ареале; проведение археологических исследований рука об руку с палеогеографией.

Подобный подход - далеко не новость в отечественной и европейской науке. Наиболее масштабной из отечественных работ такого рода, посвященных региону, куда входит и Подмосковье, является монография П.Н. Третьякова «Славяне, финно-угры и балты на Днепре и Верхней Волге», опубликованная в 1966 г. П.Н. Третьякова интересовал «общий ход» развития материальной культуры, но прежде всего - этногенетические процессы. В поисках истоков крупных этнических образований он уходил в глубь времен.
В результате ретроспективному анализу подверглись древности от мезолита/неолита до Средневековья. Широта географического охвата работы П.Н. Третьякова с неизбежностью заставляла его отказываться от рассмотрения деталей и последовательности развития культур в субрегионах, что, на самом деле, не менее важно, чем общий взгляд.

Пример диахронного анализа археологических культур от каменного века до Средневековья, существовавших в одном регионе, представлен в очерке Ю.В. Кухаренко о Полесье (Кухаренко, 1968).

Очевидна целесообразность рассмотрения «в связке» генетически родственных культур бронзового и железного веков (Косменко, 1993), древностей железного века и Средневековья (Седов, 1970).

Даже при отсутствии генетических связей, тем не менее, существовала преемственность в освоении территории, что делает необходимым изучение всего «слоеного пирога» культур лесной зоны в ходе региональных исследований (Макаров и др., 2001). Весьма показателен один из главных выводов этой работы, заключающийся в том, что «сложившийся в неолите основной каркас расселения оказался исключительно устойчив» (Макаров и др., 2001. С. 109).

В археологии очень широко распространено направление, менее ориентированное на этногенетические реконструкции, а нацеленное, в первую очередь, на то, чтобы выделить и описать этапы технологического прогресса и хозяйственного развития. Очевидно, что важнейшим рубежом являлось становление производящей экономики. В работах такого рода можно выделить те, где больше используются чисто археологические методы, например, монография Вальтера Ланга о бронзовом и железном веке Эстонии (Lang, 2007).

Имеется также научная традиция комплексных археолого-естественно-научных исследований. В качестве одного из характерных примеров можно назвать «проект Юстад», реализованный в 1982-1990 гг. в Южной Швеции (The cultural landscape..., 1991; The archaeology of the cultural landscape, 1992). В ходе данного мультидисциплинарного проекта анализировались памятники археологии и природные экосистемы в их динамике на протяжении 6000 лет, от неолита до современности. Основной акцент при этом делался на изучение изменений поселенческих систем, появление и распространение производящих форм экономики, описание форм раннего земледелия. Важно подчеркнуть, что геогра- 
фическая отдаленность Южной Швеции от Подмосковья не снижает актуальности сопоставления данных по памятникам родственных археологических культур, таких как «культура боевых топоров» бронзового века, присутствующих в обоих регионах.

Актуально проецирование на восточно-европейскую территорию результатов, касающихся принципиальных вопросов о времени, характере, динамике распространения открытых антропогенных ландшафтов, полученных по материалам Центральной Европы (Evaluation of land surfaces..., 1994).

В европейской литературе много внимания было уделено изучению механизмов распространения производящих форм хозяйства, но лесная зона Восточной Европы, за исключением Прибалтики, обычно остается белым пятном (Zvelebil, Lillie, 2000; Zvelebil, 2001).

В отечественной литературе существует очень удачная попытка суммирования данных по палеоэкономике лесной полосы Восточной Европы (Краснов, 1971), но специальных полевых мультидисциплинарных исследований, ориентированных на изучение палеоэкономики археологических культур Подмосковья, ранее не проводилось.

Подход, который реализован в настоящей работе, сложился не сразу. Первоначально велась работа в рамках одного хронологического среза - железного века. При этом на помощь археологии были задействованы возможные в наших условиях методы естественных наук - радиоуглеродное и термолюминесцентное датирование, палеоботаника, в том числе палинология, почвоведение, остеология, ландшафтоведение и пр. Итогом стало получение принципиально новой информации, прежде всего в результате изучения материалов Дьякова городища (Кренке, 2011).

В то же время изучение древностей железного века показало, что понимание «системы жизни» даже этого одного хронологического среза без сравнения, учета «обрамляющего хронологического контекста» весьма сложно. Логичным продолжением исследований стало их распространение на древности предшествующих (неолит, бронзовый век) и последующих (Средневековье) эпох.

Преимущества регионального диахронного подхода. Очевидно, что при наличии преемственности в развитии культур, их (культуры) надо изучать в совокупности, реализуя диахронный подход. Оснований для утверждения о существовании преемственности, на первый взгляд, не так много. Материальный облик культур, даже «соседних» на временной шкале, разнится очень значительно. В сущности, это видит каждый даже на своем личном примере - за считанные десятилетия материальный мир вокруг нас меняется почти до неузнаваемости. То есть археология, особенно при изучении периодов, когда человечество совершало технологические прорывы, всегда свидетельствует против наличия преемственности, что, однако, не означает отсутствие связи между сменявшими друг друга культурами.

О наличии преемственности свидетельствуют данные топонимики/гидронимии. Сохранение древних названий невозможно без преемственности населения. Во-вторых, имеется все же и археологический аргумент: преемствен- ность в освоении территории проявляется очень ярко. Даже при ничтожных по площади археологических раскопках (сравнительно с площадью изучаемого региона), как правило, на одном памятнике обнаруживаются древности различных археологических культур. Отчасти эти совпадения могут объясняться природными особенностями или случайностью. Например, удобное место для рыбалки всегда было привлекательным. Однако систематическое «наложение» памятников бронзового и железного веков, которое имеет место в Подмосковье, не может быть объяснено лишь природными особенностями и случайностью. В эти периоды, когда на первый план выдвинулись производящие формы экономики, вероятно, существовала реальная преемственность в освоении территорий.

Собственно говоря, один из главных вопросов, на который нужно искать ответ - как мы можем себе представить историю человеческого освоения региона? Была ли это непрерывная цепь культур или в этой цепи имелись разрывы, насколько продолжительные?

Искомая цель - описать этапы древней истории региона, выявить «пики», отражающие демографические и культурные подъемы, и спады; оценить степень освоенности территории, распространение культурных ландшафтов, наконец, степень культурной обособленности/этнической консолидированности населения региона.

\section{ОСНОВНЫЕ ЗАДАЧИ ИССЛЕДОВАНИЯ}

Изучение палеоэкономики древних обществ в Подмосковье наталкивалось на значительные трудности в связи с тем, что «базовые» характеристики археологических культур, сменявшихся в Подмосковье за последние 6000 лет, имели много лакун. Например, фатьяновская культура была представлена почти исключительно погребениями, дьяковская поселениями, радиоуглеродное датирование не проводилось и т.д. Закрыть эти наиболее очевидные лакуны было первоочередной задачей.

Среди основополагающих задач исследования можно назвать следующие.

Разработка детальной хронологии археологических культур, существовавших в Подмосковье от неолита до Средневековья, с использованием возможностей физических методов датирования.

Получение информации о недостающих сегментах спектра данных по каждой из культур (погребения, поселения, особенности хозяйства, система расселения и т.п.).

Выявление археологического потенциала тех элементов ландшафта, которые до сих пор мало подвергались исследованиям. В первую очередь, развитие геоаллювиального направления исследований в содружестве с геоморфологами, почвоведами и палеоботаниками. В рамках этого направления очень важной задачей являлось изучение стратиграфии пойменных отложений и выяснение того, с какими горизонтами связаны находки древностей различных археологических эпох. Нужно отметить, что это направление исследований имеет особенно большую перспективу. Прослеживается корреляция в функционировании речных систем бассейнов Верхней Волги, 
Верхней Оки и Верхнего Днепра (Александровский, Кренке и $\partial p ., 2005)$. Это дает очень важные «стратиграфические подсказки» для определения хронологической позиции археологических находок из пойменных отложений.

Реконструкция в хронологической динамике развития отдельных элементов материальной и духовной культуры, систем древнего расселения и землепользования, обобщенных палеодемографических параметров.

Реконструкция этнокультурной истории региона в той мере, в какой это возможно на основании археологических источников, а для эпохи Средневековья - с привлечением письменных источников.

«Красной нитью» исследования являлось изучение ранних этапов становления производящей экономики, оценки ее соотношения с присваивающими формами хозяйства, описаний антропогенных изменений природного ландшафта. Именно это обусловило нижнюю хронологическую границу исследований - поздний неолит.

\section{ГЕОГРАФИЧЕСКИЕ РАМКИ ИССЛЕДОВАНИЯ}

Географически определенным ареалом исследования является бассейн Москвы-реки. Действительно, бассейн Москвы-реки являлся ядром территории, где существовали своеобразные культуры - от неолита до «московского» варианта древнерусской культуры. При этом и в том, и в другом случаях к основному ядру примыкали некоторые смежные области, где наблюдались очень похожие древности. Одна из этих смежных территорий тянется на юго-запад, охватывая бассейн р. Протвы; другая - на северо-восток, в сторону бассейна Верхней Клязьмы.

Отсутствие монографического исследования об археологических древностях Подмосковья - это очевидное белое пятно в отечественной историографии. Существующие публикации по памятникам отдельных хронологических срезов (Крайнов, 1972; Кренке, 2011; Юико, 1991) написаны в очень разном стиле и не дают цельной картины. В кратком, но емком очерке Ю.А. Краснова, сделанном для издания «Археологическая карта России», при всей его информационной ценности, намечены лишь общие контуры темы, многие датировки и положения устарели (Краснов, 1994). Имеется серия ценных работ А.А. Формозова, посвященных историографии археологического изучения Подмосковья (Формозов, 2007). Однако и в этом направлении исследований имеются существенные пробелы. Так, например, археологическая деятельность А.В. Чаянова конца 1920-х годов, содержавшая очень много новаторского, вообще осталась «за кадром» очерков А.А. Формозова. Не нашли отражения в историографических обзорах очень ценные исследования древнерусских курганов в бассейне р. Пахры, проводившиеся в первой половине 1920 -х годов сотрудниками ГИМ под руководством В.А. Городцова и А.Я. Брюсова при участии музея Сухановской средней школы (руководитель - П.А. Герасимов).

В данной работе поставлена задача восполнить это «белое пятно» в историографии археологических исследований Москвы и ближайшего Подмосковья.

\section{МЕТОДЫ ИССЛЕДОВАНИЯ}

Проблемы датирования. Для ответа на поставленные выше вопросы чрезвычайно важна информация о датировках археологических памятников. Инерция сопротивления археологов внедрению радиоуглеродного датирования оказалась очень велика. В нашей стране «сопротивление» продолжалось на всем протяжении второй половины XX века. Фактически потребовалась смена поколений ученых, чтобы признать неоспоримую ценность радиоуглеродного датирования (Бочкарёв, 2013). Понятно, что путь радиоуглеродного датирования совсем не так прост. Качество результата датирования зависит от людей, отбирающих образцы в поле, обрабатывающих эти образцы в лаборатории, от лабораторного оборудования, его защищенности от случайных внешних воздействий и т.д. История конкретного образца нам почти всегда не известна. Существует вероятность, что образец мог быть переотложен. Наконец, существуют совершенно объективные ограничения точности результата радиоуглеродного датирования. Особенности формы радиоуглеродной калибровочной кривой, наличие в ней «плато» неизбежно приводят к тому, что датировки, попадающие на эти периоды, оказываются очень «размытыми». Предел точности таких дат - первые сотни лет. То есть массив полученных результатов радиоуглеродного датирования неизбежно включает в себя «шум». Избавление от этого «шума» - специальная аналитическая процедура, которая невозможна без наличия статистически значимого количества дат, полученных в разных лабораториях.

Если говорить о Подмосковье, то мы находимся еще в начальной стадии процесса накопления данных. Пока общее количество датировок составляет около трех сотен, при этом они в силу, главным образом, субъективных причин распределены очень неравномерно между основными хронологическими эпохами. Более половины имеющихся радиоуглеродных датировок получены по памятникам железного века. Древние памятники - бронзового века и неолита - датированы существенно хуже.

Специфика российской ситуации заключается также в отсутствии отечественной лаборатории, где проводилось бы датирование с помощью ускорителя. В результате существенно сужается круг возможностей для отбора образцов. Маленькие образцы, пригодные для датирования на ускорителе, как правило, не используются. Даты, полученные на ускорителях в зарубежных лабораториях, составляют в массиве радиоуглеродных датировок для Подмосковья лишь первые проценты.

Мультидисииплинарный подход. Необходимо еще раз подчеркнуть, что выяснение хозяйственной стратегии древнего населения, решение вопросов о времени появления первых признаков производящей экономики и определение того, когда этот тип экономики стал доминирующим - важнейшие вопросы археологических исследований, которые в основном могут быть решены лишь с помощью смежных дисциплин - археозоологии, палеоботаники, почвоведения. В Подмосковье было проведено несколько «циклов» подобных комплексных работ, в том числе организованных 
автором (помечены звездочкой*). Располагая их в хронологическом порядке исследованных древностей, укажем на самые результативные. Это работы на неолитических стоянках Замостье 2, Воймежная 1, Звенигородская-1*; комплексное изучение территории Звенигородской биостанции МГУ* и находящихся там памятников бронзового века; исследования на поселении фатьяновской культуры бронзового века РАНИС-пойма*. Для периода железного века ключевое значение имеют данные, полученные при изучении Дьякова городища и его окрестностей (г. Москва)*, а также городища Настасьино на р. Северке. При изучении Дьякова городища впервые для древностей этого типа была предпринята попытка детально реконструировать структуру исторического ландшафта, определить характер хозяйственного землепользования конкретных ландшафтных урочищ. При этом использовались оценки потенциальных ресурсов, сделанные ландшафтоведом (В.А. Низовцев). В изучении древностей древнерусского периода основным полигоном, где использовался комплекс палеогеографических методов, стали археологические памятники (селища и курганы) и ландшафты долины р. Язвенки (заповедник «Царицыно», г. Москва).

\section{РЕПРЕЗЕНТАТИВНОСТЬ АРХЕОЛОГИЧЕСКИХ ИСТОЧНИКОВ}

История археологических исследований в Подмосковье насчитывает уже почти две сотни лет (подробнее см. гл. 1). Количество археологических памятников, выявленных на территории Московской области, уже к середине 1990-х гг. достигло более 2700 (АКР: Московская область. Ч. 1-4), а к настоящему времени перевалило за три тысячи. Тем не менее, большие «белые пятна» пока остаются. В частности, это показали систематические разведки, проведенные автором в окрестностях Звенигорода. Здесь за несколько лет работы Звенигородской экспедиции ИА РАН в 2005-2010 гг. было обнаружено три ранее не известных городища железного века (Луцино-2, Николина Гора, Дютьково); погребальный комплекс дьяковской культуры (Дунино 4); поселения и кратковременные стоянки людей бронзового века - культур шнуровой керамики (ЗБС-5), фатьяновской (РАНИС-пойма, ЗБС-4), абашевской (ЗБС-4); значительная серия средневековых селищ. Очень результативными оказались работы по поиску средневековых селищ, проводившиеся в Южном Подмосковье под руководством М.И. Гоняного. Здесь использовалась методика «сплошной» разведки, отработанная при составлении археологической карты Куликова поля. В результате в бассейне р. Пахры были открыты десятки новых селищ. Такой значительный прирост данных о памятниках Подмосковья, причем некоторые из них уникальны, при относительно небольших разведочных работах, свидетельствует о том, что еще имеется очень большой потенциал выявления здесь новых археологических объектов первостепенного научного значения.

Рассмотрим более подробно данные о раскопках памятников различных эпох с учетом их ландшафтного расположения (в долине Москвы-реки или озерных водораздельных областях).
Неолитические стоянки исследовались преимущественно в озерных районах и на местах заторфованных древних озерных котловин. В группах стоянок в районе Тростенского озера, Зареченских, Маслова болота, оз. Воймежное было раскопано до 4000 тыс. кв. м. На два порядка меньше раскопанная площадь на стоянках в долине Москвы-реки. Здесь в совокупности раскопано всего около 50 кв. м (стоянки Григорово 1, Звенигородская 1), что ничтожно мало.

Памятники ранненеолитической верхневолжской культуры пока известны лишь по материалам стоянок, расположенных на водораздельных участках в районах существующих и древних озерных котловин - возле Тростенского озера, в Шатурском районе, в верхнем течении р. Нерской, по течению р. Дубны и др.

В долине Москвы-реки не зафиксированы находки ранненеолитической верхневолжской культуры, а представлены лишь памятники эпохи развитого (льяловская культура) и финального (лапчатая и гребенчатая керамика) неолита.

Остеологические материалы льяловских стоянок опубликованы очень выборочно. Домашние виды, за исключением собаки, не отмечены. В имеющихся публикациях списков фауны отмечается дефектность коллекций, не разделенных на группы в соответствии с археологическими слоями (Данильченко, Карху, 1997). Наиболее полная публикация имеется лишь для стоянки Ивановская VII, которая не входит в Московский регион, но относится к льяловской культуре (Кириллова, 2002; Карху, 2002; Сычевская, 2002).

Проведенные Звенигородской экспедицией ИА РАН раскопки Звенигородской 1-й стоянки показали, что льяловские памятники долины Москвы-реки имеют большой информационный потенциал. Проведенные здесь комплексные исследования дали важную палеогеографическую информацию и серию радиоуглеродных датировок (Кренке, Александровский А.Л. и др., 2012).

Погребения льяловской культуры единичны, радиоуглеродные датировки для них полностью отсутствуют. В Московском регионе известны лишь три погребения на стоянках Маслово болото 2 и Луково озеро 3, которые предположительно определяются как льяловские (Сидоров, 1990).

Количество радиоуглеродных датировок для льяловской культуры в целом достигло около полусотни (Зареиякая, Костылева, 2011; Кренке, Александровский А.Л., и др., 2012). Для Москворецко-Клязьминского региона датировок менее 20. Особенно малочисленны данные для датировки финала культуры.

В целом очевидна диспропорция в исследованиях. Характеристика льяловской культуры построена практически исключительно на материалах водораздельных озерных поселений (Гурина, Крайнов, 1996; Сидоров, 1986), т.е. не может рассматриваться как исчерпывающая.

Энеолитические памятники представлены в Московском регионе культурой с «лапчатой» керамикой и волосовской культурой. Слои с находками этого типа есть на нескольких стоянках в районе Тростенского озера, Полецкой в верховьях p. Нары (расположена всего в нескольких километрах от 
русла Москвы-реки), на берегах озер Воймежное, Святое и др. в Шатурском районе (Энговатова, 1997; Сидоров, Энговатова, 1997). Собственно в долине Москвы-реки находки этого периода единичны. Несколько фрагментов волосовской керамики и каменных орудий было найдено в основании городского культурного слоя Москвы в Зарядье (Рабинович, 1949). Другой пункт с находками орудий и керамики с «лапчатой» орнаментацией - это стоянки Григорово 1 (Дукельский, 1977, 1977а) и Григорово 4 (Кренке, 2013), расположенные на расстоянии 80 км по прямой к западу от центра Москвы.

Памятники эпохи бронзы. Среди памятников эпохи бронзы в Подмосковье лучше всего раскопками изучены фатьяновские могильники. В бассейне Москвы-реки известно 15 фатьяновских могильников (без учета могильников в бассейнах рек Клязьма и Дубна), на которых было суммарно исследовано 26 погребений, что, конечно, немного. Шесть из этих 15 могильников не исследовались профессионально, они известны лишь по случайным находкам. Могильники были обнаружены прежде всего в долине Москвы-реки, а также в долинах ее левых притоков - Рузы и Истры, окрестностях Тростенского озера. Ни одного могильника не известно в бассейне р. Пахры, хотя здесь встречены отдельные находки, указывающие на освоение этого микрорегиона в период фатьяновской культуры.

Поселений со шнуровой и фатьяновской керамикой известно около 20, но относительно масштабными раскопками изучено лишь одно - РАНИС-пойма. Важное значение имеют результаты меньших по масштабу раскопок, проведенных на поселениях ЗБС-5 и Царицыно 1 (Кренке, Агеева u др., 2008, Кренке, 2013), а также на стоянке Воймежная 1, близкой к москворецкому региону (Древние охотники..., 1997).

Случайных находок каменных топоров бронзового века (большая часть из них - фатьяновские) известно около 100 , примерно 60 из них достаточно надежно локализованы. Некоторые сомнения вызывают относительно многочисленные находки каменных топоров на территории средневековых городов - Москвы, Коломны, Звенигорода. Возможно, часть из этих топоров была принесена жителями городов из других мест. Относительно значительное количество выявленных фатьяновских поселений и отдельных находок позволяет составить представление о географии расселения. Собранные данные о палеоэкономике этих поселений (в том числе полученные с помощью естественно-научных методов) фрагментарны и позволяют формулировать лишь гипотезы, требующие дальнейших подтверждений. Имеются единичные археозоологические определения. То же самое можно сказать о результатах радиоуглеродного датирования, так как пока в нашем распоряжении всего около десяти датировок.

Период «постшнуровых» культур бронзового века в Подмосковье представлен всего несколькими находками. Можно сказать, что древности этого периода особенно загадочны. «Фатьяноидная» керамика, видимо, имеет мало или не имеет никакого отношения к собственно фатьяновской (см. подробнее в гл. 1). Древности этого круга в
Подмосковье встречены лишь на нескольких приозерных стоянках вне пределов долины Москвы-реки; погребения не известны вовсе; радиоуглеродные датировки также отсутствуют. Абашевская культура в Подмосковье представлена лишь несколькими пунктами находок (Луньков, Энговатова, 2003). В том числе недавно один из них был обнаружен в среднем течении Москвы-реки (Кренке, 2014). Поселения не известны, радиоуглеродных датировок всего две, но они очень хорошо «вписываются» в контекст других абашевских радиоуглеродных дат. Результаты спорово-пыльцевых исследований абашевского комплекса на ЗБС-4 являются сугубо предварительными, однако дают все же некоторые представления о хозяйственной деятельности людей и их воздействии на окружающую растительность.

Поздний бронзовый век Подмосковья представлен различными вариациями комплексов с текстильной керамикой, в том числе близкими к поздняковской культуре, а также «постпоздняковскими» комплексами с гладкостенной керамикой, орнаментированной редкими ямочными вдавлениями и/или наклонными «тычками». Памятники этой хронологической группы представлены как в долинах крупных рек, так и на приозерных стоянках. Всего зафиксировано около двух десятков поселений, погребений не известно. Имеются единичные радиоуглеродные датировки. Наиболее масштабные раскопки проводились на поселениях Дунино-3, Подол 1 (Гак, 1997; Гак, Гоняныци, 2007), горе «Олимп» в мкр. Дютьково г. Звенигорода (Кренке, Лазукин А.В. и др., 2010). Программа палеоботанических исследований была осуществлена лишь при раскопках поселения Веськово 1, расположенного по соседству с изучаемым регионом на Плещеевом озере (Вишневский, 1990; 1994; Кирьянова, 2005).

Период перехода от позднего бронзового века краннему железному веку представлен несколькими памятниками - селищами и древнейшими городищами, расположенными, как на мелких притоках Москвы-реки - Селецкое, Царицыно-1, Дютьково, так и в долине самой Москвы-реки - Дьяково, Чертов городок, Мамоново, Луцино 2 и др. Данные о древнейших слоях городищ скудны. Это касается как вещевого комплекса, так и состава остеологических и палеоботанических остатков. Погребения не известны. Наиболее полные представления имеются о керамике. Получена также серия из нескольких радиоуглеродных датировок, хорошо увязывающихся друг с другом.

Древности раннего железного века представлены в гораздо большем количестве и лучше изучены, чем предшествующие. На настоящий день в пределах бассейна Москвы-реки известно 290 памятников железного века, в том числе 85 городищ (сведения о нескольких из них сомнительные). Погребальных памятников всего два и исследованы они совершенно недостаточно. На городищах исследованная площадь достигает в совокупности 19 тыс. кв. м; еще 15 тыс. кв. м раскопано на селищах. Подсчеты проведены по каталогу, опубликованному в работе про Дьяково городище (Кренке, 2011).

Эти очень большие цифры раскопанных площадей не стоит переоценивать. Примерно 20 \% этих площадей от- 
носятся к памятникам (например, городища Луковня 1, Кунцево, Боровский курган), материал которых авторы раскопок не обрабатывали и не публиковали, или публиковали очень выборочно, оставляя «за кадром» массовый материал - керамику. То есть эти материалы остаются «под спудом» и не доступны другим исследователям. Материалы довоенных раскопок публиковались очень скупо, и многие из них пропали.

Вещевой комплекс дьяковских памятников опубликован весьма полно, но для «тонких» сопоставлений городищ между собой, для выявления локальных особенностей, сходства и различий памятников по керамическому набору материалов не хватает. Даже коллекции из раскопок Московской экспедиции ИА РАН, функционировавшей в 1950-1970-х гг. (руководитель - А.Ф. Дубынин), которые на общем фоне выглядят наиболее «благополучными», также имеют большие «изъяны» в публикациях, в первую очередь, в публикации керамики. В результате «относительно полноценными» источниками можно считать лишь опубликованные коллекции городищ Троицкое, Дьяково, Щербинское.

Трудно ожидать открытия значительного количества новых городищ, хотя, как отмечалось выше, их число продолжает пополняться. Количество селищ может быть увеличено в несколько раз сравнительно с тем, что известно в настоящее время. Этот прогноз базируется на оценках численности памятников, сделанных по результатам тщательных разведок микрорегионов, таких, например, как окрестности Дьякова городища в Коломенском. Имеются определенные перспективы и в обнаружении новых погребальных комплексов.

Имеющиеся на сегодня данные о географии памятников железного века в бассейне Москвы-реки рисуют довольно ясную картину их пространственного расположения. Они концентрируются в долинах основных рек либо на небольшом (первые километры) удалении от них. Остается вопрос, насколько соответствуют реальности «белые пятна» водоразделов.

Важнейшим достижением исследований памятников дьяковской культуры является то, что были решены многие неясности с хронологией. Этому сильно способствовали многочисленные радиоуглеродные датировки. В бассейне Москвы-реки был датирован 21 памятник (Кренке, Сулержицкий, 2006; Кренке, Лазукин А.В. и др, 2010).

Другим важным достижением в исследованиях памятников дьякова типа было проведение комплексных работ по изучению археозоологических и палеоботанических остатков; почвенно-геоморфологическое изучение стратиграфии пойменных отложений вблизи городищ. На их основании были предложены гипотетические реконструкции типа хозяйства, особенностей культурных ландшафтов. Не хватает, к сожалению, детализированных «фоновых» спорово-пыльцевых диаграмм, которые можно было бы сопоставить с диаграммами по колонкам разрезов культурных слоев (Кренке, 2011).

По-прежнему для Подмосковья актуальна проблема «темных веков», которые приходятся на VII-IX вв. н.э. В результате исследований последних лет наметился неко- торый прогресс в изучении этой темы. Удалось выявить несколько поселений, расположенных в верховьях Москвыреки, на Протве, в верховьях Клязьмы, а также на берегах Оки, где были обнаружены комплексы керамики «последьяковского» времени. Близкие формы сосудов были найдены и на Кикинском дьяковском городище на р. Веле. Таким образом, стало приблизительно понятно, что надо искать, что заполняет лакуну VII-IX вв. На основной территории москворецкого варианта дьяковской культуры пока такой керамики не отмечено, хотя нельзя исключить, что она присутствовала в коллекциях раскопанных городищ, но осталась вне поля внимания и не публиковалась.

Славянские/древнерусские древности Подмосковья составляют корпус древностей, превосходящий как по количеству, так и по масштабам проведенных раскопок все более древние археологические памятники вместе взятые.

А.А. Юшко в работе 1991 г. приводила несколько разнящиеся между собой цифры: 1350 - общее количество древнерусских памятников Подмосковья (Ючко, 1991). При характеристике их отдельных категорий ею указывалось на наличие 57 городищ, 164 селищ и 901 курганной группы древнерусского времени (в сумме - 1122) в пределах ареала, включающего весь бассейн Москвы-реки и соседние бассейны р. Протвы и Верхней Клязьмы.

В бассейне р. Пахры, по данным С.В. Шполянского (Шполянский, 2004), имелось 206 курганных могильников (число курганов - 1676 без учета исчезнувших до проведения фиксации) на площади 2720 кв. км.

В ближайшей сельской округе древнерусского города Москва (в пределах современной МКАД на площади 870 км) известно 135 курганных групп (1034 кургана), 52 селища и 5 средневековых поселений на территории городищ железного века (Кренке, 2003). Сделаны оценки, позволяющие предполагать наличие на этой территории еще 100 селищ и 20 курганных групп, которые утрачены или пока не найдены.

В Звенигородском течении Москвы-реки, по данным А.В. Алексеева (Алексеев, 2005), с добавлением сведений, полученных в последние годы Звенигородской экспедицией ИА РАН, насчитывается 84 курганные группы и 50 селищ.

Всего в бассейне Москвы-реки, по новейшим данным, насчитывается более 800 древнерусских курганных могильников, многие из которых не сохранились и известны только по архивным или картографическим данным. Число поселений XI-XIII вв. - около 400. Подавляющее большинство это селища и поселения на площадках городищ железного века. Лишь в нескольких случаях можно относительно обоснованно говорить об укрепленных городищах древнерусского времени. Достоверны данные лишь о двух городах, существовавших в бассейне Москвы-реки в домонгольское время - это Москва и Коломна. Существование Звенигорода как города в XII-XIII вв. вероятно (Юшко, 2005). Можайск, Руза и Перемышль стали городами уже в следующую историческую эпоху - во второй половине XIII-XIV в.

Очевидно, что многие подмосковные курганы, особенно в долинах крупных рек были бесследно распаханы. Однако имеющиеся данные позволяют сделать оценки 
общей численности памятников. Это возможно благодаря тому, что в распоряжении исследователей имеются такие источники, как детальные топографические карты первой половины XIX в. Москвы и ее окрестностей, выполненные военно-топографическим бюро, на которых фиксировались курганы. Есть и эпизодические данные письменных источников XV-XVII вв. (межевые грамоты), в которых курганы упомянуты в качестве межевых ориентиров. Есть и данные детальных разведок 1920-х гг., проводившихся в долинах рек Пахра, Рожайка, Истра, окрестностях Москвы, позволившие зафиксировать курганы, большая часть из которых ныне утрачена. Таким образом, имеются материалы для того, чтобы исследовать географию и структуру расселения в Подмосковье в древнерусское время, делать палеодемографические оценки. Существенным подспорьем является то, что хронология курганных комплексов была тщательно разработана Т.В. Равдиной, и ею была составлена обширная картотека.

Начиная с конца 1980-х гг. автором в содружестве с другими исследователями, археологами (М.И. Гоняный, Б.Е. Янишевский) и естественниками (А.Л. Александровский, В.С. Гунова, В.А. Низовцев) проводились специальные комплексные археолого-почвенно-ботанические полевые работы для выяснения систем древнерусского расселения и землепользования в микрорегионах. Такими «тестовыми полигонами» стали земли бассейна рек Язвенка и Городенка (парк «Царицыно»); парка «Битцевский лес», заповедника «Горки-Ленинские», бассейн р. Самынки от г. Одинцова до пос. Барвиха. В результате те закономерности в расположении поселений и курганов, которые впервые были отмечены Р.Л. Розенфельдтом (1973a. С. 65; 1973б. С. 199) были подтверждены и детализированы, обнаружены следы древнерусской распашки, проведены спорово-пыльцевые исследования погребенных почв, сделаны карты-реконструкции систем землепользования.

Оиенка полноты археологических данных. Автором была проведена попытка «экспертного» анализа имеющихся у нас данных об археологических древностях Подмосковья от неолита до древнерусского времени. По пятибалльной шкале оценивалось наличие информации по таким параметрам: 1) общая характеристика материальной культуры; 2) данные о поселениях; 3) данные о погребениях; 4) наличие датировок, полученных традиционным археологическим методом; 5) наличие радиоуглеродных датировок; 6) данные о хозяйстве; 7) данные о системе землепользования. Результатом этого анализа стала таблица, представленная на рис. 1. На этой таблице хорошо видно, что лучше всего изучена эпоха Средневековья, хуже, но тоже относительно хорошо изучен период железного века. Удовлетворительно исследованы памятники неолита и бронзового века. Плохо изучены все переходные эпохи, а именно - энеолит; поздняя бронза/раннее железо; эпоха переселения народов/раннее Средневековье.

Задача последующих глав работы - дать характеристику древностей всех перечисленных выше периодов. В первую очередь тех направлений, где удалось продвинуться в закрытии «белых пятен».

\section{ИСТОРИОГРАФИЧЕСКИЙ ОБЗОР}

Свою цель в данном разделе я видел, в первую очередь, в том, чтобы отразить историографическую информацию, отсутствующую в публикациях предшественников (Бадер, 1947; Краснов, 1994; Рабинович, 2005; Формозов, 2007; Юшко, 1991), а также в том, чтобы «расставить акценты» в процессе познания древностей Подмосковья. То есть подчеркнуть основные этапы формулирования и изменений исследовательских парадигм.

Грамоты. Первые описания археологических памятников Подмосковья (не утратившие ценность и сегодня) относятся к периоду существенно более раннему, чем формирование археологии как науки. Древнейшие из них - это грамоты XV в. Так, в грамоте, данной Симонову монастырю на пожни сельца Коробовского (в настоящее время на территории Ленинского района на трассе дороги из Москвы в аэропорт «Домодедово»), датированной 1494-1499 гг., при описании межи упоминаются известные по позднейшим исследованиям коробовские курганы. «Да поперек дороги к могиле, а на могиле липа да осонка подсухая. Да ставши, Елка Съянов своими товарыщи судьи тако рекли: Что есмя вели от сосон с паточиною до Козья болотца и до сех мест до Колычевской дороги до могилы по старой меже, ино направо земля угрешская, Константиновская...» (Акты..., 1958. С. 435). Из данного описания следует, во-первых, что средневековое население XV в. однозначно интерпретировало курганы как могилы. То есть, вероятно, курганы уже раскапывали, так как память о захоронениях XII в. вряд ли могла дожить до XV в., учитывая смену погребального обряда и изменение состава населения! Во-вторых, обращает на себя внимание место курганов в описании межевого хода. Могила-курган являлась главным ориентиром, конечным пунктом межевания. Именно здесь «знахори», проводившие межевание, «встали». «Могила» была единственным пунктом, относительно которого не было расхождений при прокладке межи между представителями двух споривших сторон.

Упоминания о курганах имеются и в межевых документах XVII в. Например, при описании межи отхожей пустоши Сокольниково (расположена в нескольких километрах к югу от с. Коробово, возле д. Старое Съяново на p. Пахре), входившей в состав владений с. Коломенского, курганы упоминаются неоднократно. «... А из того врага с водоточиною вкруте направо меж двух курганов да двух ям, а ямы на кургане ж,... а позади ям по обе стороны дорошки два кургана...» ${ }^{1}$. Скорее всего, упомянутые в тексте ямы на кургане - это специальные межевые ямы, а не следы грабительских раскопок, хотя и последнее не исключено.

Другой пример - в межевых книгах Звенигородского уезда в районе с. Иславского на Москве-реке. «Межа государевой земле пустоши Куриловой от поместья Бориса да Глеба Ивановичей Морозовых села Иславского: от Москвы

\footnotetext{
1 Писцовые межевые книги писца стольника Ивана Афросимова села Коломенского с деревнями 183, 184 и 185 годов (1675-1677). Цитата по копии 1738 г. РГАДА. Ф. 1239. Оп. 2 (52). № 1359. Л. 21, 22.
} 
реки врагом к дороге через курганы по Курилов|скую дорошку, да едучи дорошкою направо по болшому врагу (...) направе земля государева пустоши Куриловой, а налеве земля Бориса да Глеба Ивановичей Морозовых села Ислав|ского...» (Список с писцовых книг... Л. 1083-1083 об). До наших дней эти курганы не дожили.

Kарть ХVIII-XX вв. как археологический источник. Традиция использования древнерусских курганов как межевых знаков продолжается и в XVIII в., они попадают на карты этого времени. На «Плане села Черная Грязь с деревнями» (1775 г.) межа владений усадьбы Кантемиров и крестьян деревни Орехово проходит через курган (Кренке, 2008. Форзац), который был раскопан через 170 лет, в 1944 г. (Арииховский, 1947).

Начиная с 1820-х гг. на территории Москвы и ее ближайших окрестностей начали составляться детальные военно-топографические карты, на которые наносили и курганы (см. подробнее в гл. 4). В конце 1830-х гг. съемки охватили уже всю губернию. Более сотни курганов было нанесено на карты в этот период. Зориан Ходаковский, пионер археологии Подмосковья, в начале 1820-х гг. систематически проработал документы и карты Московской губернской межевой канцелярии с целью извлечения из них археологической информации. Этот правильный и чрезвычайно эффективный подход затем на долгие годы оказался в забвении или реализовывался лишь частично. Вплоть до сегодняшнего дня далеко не все имеющиеся карты проработаны археологами. Так, детальные карты масштаба 1:10000 остались почти не востребованными, карты спортивного ориентирования (где нанесены все земляные насыпи, в том числе курганы) использовались для археологических поисков лишь от случая к случаю и т.п. Попытка автора систематически проработать картографические материалы для территории современной Москвы в пределах МКАД показала, насколько информативны эти источники (Кренке, 2004а). Аналогичная работа для всего Подмосковья - дело будущего.

Данные об археологических исследованиях в Подмосковье $X I X$-первой половины $X X$ в. Очень важная, но мало освещенная в историографической литературе «страница» археологических исследований в Подмосковье - это работы конца XIX-первой четверти XX в. Пробелы в информации возникли из-за прекращения деятельности Московского археологического общества в 1923 г., принципиальных кадровых перемен. Документация по дореволюционным работам далека от полноты. Отчасти здесь виновато противостояние Москвы и официального Петербурга. Очень показательна в этом отношении переписка 1897 г. Императорской археологической комиссии с московским уездным исправником относительно раскопок курганов возле с. Спас-Тушино, произведенных в 1895 г. (Архив ИИМК. Д. 67/1887). Узнав из газет (!) о раскопках курганов в Спас-Тушине, Археологическая комиссия сделала запрос об этом московскому уездному исправнику. Уездный исправник, оправдываясь, объясняет, что работы производились Московским археологическим обществом и административно обеспечивались им, исправником, но письменных распоряжений к нему не поступало, а лишь было дано указание по телефону (!) «принять меры к охранению порядка» по желанию Его Императорского Высочества Августейшего генерал-губернатора (Там же. Л. 421). Очевидно, что никаких отчетов об этих работах в Санкт-Петербург не поступало, но и в Москве они также отсутствуют.

Практически ничего не известно про раскопочную деятельность В.К. Трутовского. Владимир Константинович Трутовский (1862-1932) - опытный археолог, один из «первых лиц» московской археологии конца XIX-начала $\mathrm{XX}$ в. Он являлся членом и секретарем МАО (Московское археологическое общество), редактором издания МАО «Древности», а также «Трудов археологических съездов», директором Оружейной палаты (до 1924 г.), преподавателем Московского археологического института, затем профессором археологического отделения Московского университета (1922-1930). Он вел также и раскопки древнерусских курганов. Об этом есть лишь скупая информация в воспоминаниях Ю.А. Бахрушина (Бахрушин, 2012. С. 445), в усадьбе которого Афинеево (Верино) на р. Десне раскопки были проведены после 1913 г. Этот случай типичен. Практически никакой информации, кроме планшета с находками, в ГИМе не осталось от «показательных» раскопок проф. Д.Я. Самоквасова курганов возле д. Котляково в 1908 г. Без отчета остались «показательные» раскопки курганов, проведенные в период проведения Антропологической выставки 1879 г. в имении Тарычево и возле с. Покров. Одна архивная фотография сохранилась от раскопок кургана возле дачи И.Е. Забелина в Царицыно, в которых участвовал также В.И. Сизов. Есть еще некоторая надежда найти информацию о раскопках в личных фондах ученых, разбросанных в различных архивохранилищах. Пока никто такого поиска не предпринимал (нужно подчеркнуть, что А.А. Формозов, основной историограф московской археологии, видимо, мало работал в архивах, почти нет архивных ссылок в его работах, и нет следов его работы в листах использования архивных документов).

То есть фактически нет отчетов о подмосковных курганных раскопках конца XIX-начала XX в., но значение этих работ не так уж мало. Именно в результате этих раскопок курганов у ведущих исследователей - И.Е. Забелина, В.И. Сизова, Д.Н. Анучина - сформировалось представление о материальной культуре подмосковного древнерусского населения. Показательны строчки из труда И.Е. Забелина, посвященные находкам украшений XII в. в Московском Кремле: «...Форма упомянутых серег о семи лепестках составляет отличительный признак древнего женского убора, находимого только в Московской стороне чуть не в каждом кургане и очень редко в других более отдаленных от Москвы местностях, так что по этим серьгам, мало-помалу, можно выследить границы собственно примосковного древнего населения, имевшего, как видно, особый тип в уборе, указывающий на особенность культуры этого племени» (Забелин, 1905. С. 6). То есть у исследователя сложилось вполне конкретное представление об особенностях набора курганных комплексов. Очевидно, что В.И. Сизов также совсем не случайно писал о «височных кольцах московского типа» (Сизов, 1895). За этим термином стояла большая сравнительная ра- 
бота. Однако подробной сводной работы до революции сделать не удалось. Итогом археологических исследований тех лет стал короткий, но очень емкий очерк Д.Н. Анучина (Анучин, 1909).

В.А. Городцов, Ю.В. Готье, В.К. Трутовский, С.К. Богоявленский, И.К. Линдеман - вот когорта специалистов в Москве, на которых легла задача сохранить «московскую школу» археологических исследований, обеспечить преемственность научных поколений в 1920-е гг. С этой задачей они успешно справились, брошенные ими зерна взошли. Особую роль в этом сыграли полевые работы В.А. Городцова. Эти работы достаточно подробно документированы, дневники раскопок подмосковных курганов, проведенных в 1920-е гг., хранятся в ОПИ ГИМ (фонд 431). Необходимо несколько слов сказать о таком выдающемся участнике работ В.А. Городцова возле Суханова, как Петре Александровиче Герасимове (1906-1998). Важные биографические данные о нем приведены Б.Г. Якеменко (Якеменко, 2008). П.А. Герасимов, учащийся Сухановской школы 2-й ступени создал, можно сказать, шедевр подмосковной археологии - археологическую карту нижнего течения р. Пахры (Архив ИИМК. Ф. 2. Оп. 1. Д. № 101. 1925 г.). Карта, на которой учтены более 600 курганов, была подготовлена в 1923 г., когда П.А. Герасимову было 16 лет. Окончательная версия карты была создана в 1925 г. На очень подробной топографической основе (ручная копия с печатной карты) с высокой точностью топографической привязки нанесены курганные группы. Дальнейшая судьба П.А. Герасимова была связана с геологией.

Противоречивой (активно участвовал в конфликтах с коллегами), но значимой фигурой в подмосковной археологии был Константин Яковлевич Виноградов (18821942(?)). Начал он свою полевую археологическую деятельность как помощник В.А. Городцова на раскопках 1922 г. Огубского городища на Протве, которое, кстати, открыл именно К.Я. Виноградов в 1921 г. Затем как сотрудник Областного краеведческого музея в Воскресенске (г. Истре) он провел очень масштабные разведочные работы на памятниках бронзового, железного веков и средневековых (Кренке, Нефёдова, 1994). Большая часть накопленных им коллекций не была введена в научный оборот, многое погибло в войну, кое-что дожило до наших дней, как, например, коллекция из раскопок Дьякова городища 1935 г. Она была подготовлена к публикации много лет спустя (Кренке, 2011). В архиве ученого нашлись рукописи, которые не потеряли научного значения и через 50 лет. Одна из них была издана (Виноградов, 1994). К.Я. Виноградов был склонен к диахронному анализу, его интересовали древности разных эпох, что нашло отражение в его публикациях (Виноградов, 1925; 1929; 1934). Большое достоинство этих публикаций в том, что они вышли очень оперативно, вскоре после раскопок.

Очень яркой, но трагически короткой была археологическая биография знаменитого экономиста, Александра Васильевича Чаянова (1888-1937). Он работал всего два полевых сезона (1928 и 1929 гг.) в окрестностях Николиной Горы, исследовал Успенское городище дьяковской культуры и древнерусские курганы на территории поселка РАНИС.
Публикация его отчета была выполнена много лет спустя (Чаянов, 2007). В 1930 г. А.В. Чаянова арестовали по политическим мотивам. Значение работ А.В. Чаянова в том, что они на 50 лет опередили науку 1920-х гг. Современники не смогли их оценить. Так, А.А. Спицын написал отрицательную рецензию на научный отчет А.В. Чаянова, посчитав его слишком «многословным». Новаторство, высокое качество работ А.В. Чаянова проявилось в нескольких направлениях. 1. Комплексный подход к историко-археологическому изучению территории (изучение исторических источников, опросы старожилов, проведение археологических разведок и раскопок). Введение в 1928 г. понятия «археологический комплекс» применительно к разновременным памятникам одного региона. 2. Точность географической локализации памятников, использование в отчете не схем, а настоящих топографических карт. 3. Строгая последовательность в проведении работ (движение от изучения исторических источников и данных устной традиции к разведкам и раскопкам). 4. Выявление с помощью частой шурфовки не только видимых объектов (городищ и курганов), но и мест залегания культурного слоя при отсутствии видимых признаков (селищ). Обоснование археологической ценности территории современных деревень, возникновение которых относилось к эпохе Средневековья. 5. Применение новых методов разведки - бур для определения мощности культурного слоя. 6. Проведение инструментальной съемки местности, предваряющей раскопки, и изготовление модели (в этом проявились забытые традиции XVIII в., такие как изготовление моделей дворцов в Коломенском перед их разборкой). 7. Детальное описание сложной стратиграфии культурного слоя городища железного века на основании разреза периферийной части площадки. Правильное определение наиболее перспективного места для изучения стратиграфии культурного слоя городища. 8. Выделение 22 типов керамики железного века на основании различий в орнаментации и фактуре поверхности. Проведение сравнительного анализа особенностей керамики памятников одного микрорегиона (городища Успенское, Знаменское, Барвиха). 9. Новые методические приемы раскопок, исследование Успенского городища по сетке квадратов в 1 м. Нивелировка насыпи кургана с вычерчиванием горизонталей через каждые 10 см. Нанесение на план насыпи всех находок, включая керамику (Кренке, 2007).

Преемником К.Я. Виноградова в Московском областном музее с 1936 г. стал Леонид Иванович Пимакин (19081980-е). Он получил высшее образование по специальности музееведение-археология в Ленинградском историко-лингвистическом институте. До войны раскапывал неолитические стоянки в Подмосковье (на Бисеровом озере и др.). На фронте, будучи солдатом, получил тяжелую контузию и был демобилизован в 1943 г. Он очень много сделал для спасения и восстановления учетной музейной документации из-под руин Ново-Иерусалимского монастыря, взорванного в ходе боевых действий 1941 г. В 1956-1957 гг. Л.И. Пимакин на основании договора с Раменских районным краеведческим музеем провел раскопки городища дьякова типа Круглица (Кренке, Чаукин, 2012). В это время в Подмосковье разво- 
рачивались работы Московской экспедиции ИА РАН под руководством А.Ф. Дубынина, где ведущими сотрудниками являлись Х.И. Крис, К.А. Смирнов, Р.Л. Розенфельдт, И.Г. Розенфельдт. Они также приступили к исследованию городищ дьякова типа и древнерусских памятников.

Kое в чем Л.И. Пимакину удалось превзойти коллег. Отчасти этому способствовал сам памятник с исключительно хорошей стратиграфией, отчасти - удачное сотрудничество с В.Ф. Черниковым, тогда студентом кафедры археологии МГУ. Виталий Федорович Черников (1924-1997) был в 1956 г. вполне взрослым человеком, отслужил на флоте. В последствии он фактически основал археологическую школу в Нижегородском крае. Итогом этого сотрудничества стали исключительно качественные, выполненные в цвете профили разрезов культурного слоя, которые позволили спустя много лет после раскопок понять особенности памятника и подготовить его публикацию (Кренке, Чаукин, 2013). Значение раскопок Круглицы в том, что впервые в археологии Подмосковья были детально и правильно зафиксированы раннедьяковские постройки типа длинных домов, расчищен типичный для них очаг с глиняными бортиками. Успешному завершению полевых, а главное, камеральных работ, подготовке публикации Л.И. Пимакину помешала болезнь, связанная с контузией, а также некоторые психологические особенности личности, не позволившие ему правильно отреагировать на менявшиеся обстоятельства. Все бытовые и производственные перипетии экспедиции 1957 г. детально отражены в полевом дневнике, сохранившемся в Ново-Иерусалимском музее. Нельзя сказать, что материалы раскопок Круглицы лежали полностью «под спудом». Коллекция была представлена на выставке, сопровождавшей ежегодную сессию ИИМК. Наиболее выдающиеся вещи и объекты вошли в публикации коллег (Горюнова, 1961; Крис, 1981; Розенфельдт Р.Л., 1970а). Один из наиболее ценных вещевых комплексов - клад позднедьяковских украшений III вв. н.э., к сожалению, оказался утрачен, но его публикация оказалась возможной (Кренке, Тавлинцева и др., 2013) на основании фотографий из отчетов (Пимакин, 1956, 1957).

Результаты деятельности Московской экспедиции ИА РАН во второй половине 1950-х-1970-е г2. фактически не нуждаются в комментариях, так как все основные результаты вошли в научные публикации, которые на долгие годы стали эталонами (Древнее поселение в Подмосковье, 1970; 1971; Дьяковская культура, 1974). В 1970-е гг. экспедиция получила как бы «второе дыхание» благодаря работам Х.И. Крис и А.А. Юшко. Особенно ценными были новаторские методические подходы А.А. Юшко, на практике реализовавшей программу, намеченную еще А.В. Чаяновым. Изучение археологии велось ею рука об руку с исследованием актовых материалов, карт Генерального межевания XVIII в., микротопонимики, восходящей к XIV-XV вв. и сохраненной современной устной традицией. Важнейший археологический «инструмент» - хронологическая шкала московской керамики, разработанная Р.Л. Розенфельдтом по материалам стратифицированных городских раскопов (Розенфельдт Р.Л., 1968) - был эффективно применен для датирования сельских поселений.
Формально в Московскую экспедицию не входила сотрудница отдела славяно-русской археологии ИА РАН Тамара Владимировна Равдина (1919-1991), однако ее роль в подмосковной археологии чрезвычайно высока. Она систематизировала информацию по древнерусским курганам, проработав все возможные источники (музейные собрания, публикации, отчеты), в итоге создала картотеку комплексов с детальным описанием всего инвентаря. На этой основе Т.В. Равдина детализировала и скорректировала датировки комплексов вещей и керамики, аргументированно оспорила доминировавшую в 1970-е гг. этническую интерпретацию древнерусских древностей Подмосковья.

Работы Московской экспедиции ИА РАН с фундаментальными отчетами, детальными публикациями образовывали своеобразный main stream в науке об археологии Подмосковья. Не опубликованной в качестве отдельной монографии осталась лишь рукопись Р.Л. Розенфельдта «Археологическая карта Московской области», завершенная им в 1988 г. Это плод его поистине титанических работ по разведкам и систематизации сведений. Большая часть этой информации составила «костяк» соответствующих томов Археологической карты России по Московской области (1994-1997).

Археология в музеях. По краям этого основного потока также наблюдались весьма интересные «водовороты», существенно дополнявшие движение стремнины. Бедные (во всех смыслах, кроме богатства материала археологических коллекций) московские и областные музеи постоянно подвергались реорганизациям. Они были и «убежищами» в советскую эпоху, и «ловушками» для тех, кто действительно интересовался древностями. Редкие заинтересованные директора музеев, создававшие вокруг себя среду для развития археологии, с неизбежностью сменялись малокомпетентными чиновниками из бывших военных или партийных функционеров. Таким образом, ситуация часто «провоцировала» способных местных исследователей на начало археологических раскопок, предоставляя им небольшие средства на первом этапе работ, но далее исследователи очень редко получали возможность завершить работу должным образом. Всегда не хватало средств на камеральную обработку, систематизацию и организацию хранения массового материала, художников, фотографов, ученых-естественников, подготовку публикаций и т.п. Важнейшими из таких «водоворотов» стали Московский областной краеведческий музей, Музей истории и реконструкции Москвы, Звенигородский, Бронницкий, Ногинский и Люберецкий краеведческие районные музеи. Археологическую деятельность в 1950-1980-е гг. в них проводили соответственно А.Г. Векслер, А.Е. Кравцов, Г.П. Латышева, М.Г. Рабинович, (МИРМ), Н.А. Краснов, Ю.А. Краснов, А.К. Станюкович (ЗИАХМ), В.В. Сидоров (МОКМ), И.Л. Чернай (Бронницы), Е.И. Диков (Ногинск), Ю.В. Куртов (Люберцы).

Благодаря интенсивным разведкам В.В. Сидорова в полной мере раскрылся научный потенциал торфяников московского региона. Особенно детально им были обследованы берега Тростенского озера и примыкающего к нему ныне заросшего озера на месте Буланинского торфяника, системы 
водораздельных озер и мелких речек бассейна р. Клязьмы в Павлово-Посадском и Орехово-Зуевском районах. В результате были открыты сотни памятников мезолита - бронзового века, имеющие первостепенное значение в силу уникальной сохранности многих из них. Большая часть этих материалов ожидает публикации, в том числе материалы уникального Тростенского фатьяновского могильника, возможно, кладбища одной семьи.

Исследования Е.И. Дикова, к сожалению, непродолжительные, были выполнены в том же русле «торфяниковой археологии». Научное значение проведенных им совместно c B.M. Раушенбах раскопок на Зареченских стоянках (р. Шерна), давших стратиграфически обоснованную последовательность смены культур от неолита до бронзы и перехода к железному веку далеко еще не раскрыто.

А.Г. Векслер (1931-2016) раскопал целую серию городищ дьяковской культуры, древнерусское Жуковское селише (имеющее и более ранние слои), селище и курганные могильники XII-XIII вв. в микрорегионе р. Самынки, имеющем ключевое значение в системе древнерусских памятников бассейна Москвы-реки (см. гл. 4). Очень немногое из материалов этих раскопок, тщательно документированных в научных отчетах, было подготовлено к печати их автором (Векслер, 1970; 1975; 1978; Векслер, Станюкович, 1986). Лишь частично пробел в публикации памятников, раскопанных А.Г. Векслером, заполняет монография И.Г. Розенфельдт (1982).

Игорь Львович Чернай (1931-2014), профессиональный художник-график, житель г. Бронницы, сотрудничавший с местным музеем и передавшим туда свои коллекции, сделал очень существенный вклад в археологию Подмосковья. Этот вклад заключался не только в получении материалов принципиальной важности в результате раскопок древнейшего в регионе хорошо стратифицированного Селецкого городища железного века и участии в раскопках Боршевского городища, но и в разработке новых подходов к анализу материала. И.Л. Чернай фактически первым применил макрофотографию для изучения фактур отпечатков на керамике (Чернай, 1981). Полученные им выводы о наличии отпечатков ткани, однако, подлежат корректировке. Дальнейшие исследования технологии производства «текстильной» керамики показали, что «регулярные» структуры отпечатков получены путем прокатки палочки, обмотанной нитью, или прокаткой стержня еловой шишки (Лопатина, 2015).

Братья Николай (1924-1988) и Юрий Алексеевичи Красновы (1931-2000) добились исключительно важных результатов в обследовании звенигородского течения Москвыреки. Они впервые обнаружили здесь памятники мезолитического возраста, исследовали раскопками Звенигородскую неолитическую стоянку, вели разведки и раскопки городища дьяковской культуры и средневековых памятников.

Андрей Кириллович Станюкович (1948-2016) еще школьником совершил важные археологические открытия (например, обнаружил селище Жуковское), а затем, уже будучи «остепененным» ученым, провел раскопки ряда ключевых памятников, таких как городище железного века у дома отдыха «Связист» в Звенигороде, раннеславянских селищ Покров 5 и Саввинская слобода 2, древнерусского селища Десна.

Отдельно нужно подчеркнуть научную значимость археологических работ в Подмосковье сотрудников ГосударственногоисторическогомузеяВ.А. Городцова (18601945), Л.А. Евтюховой (1903-1974), Н.Г. Недошивиной, А.В. Успенской (1920-2013). Их основная заслуга - в тщательных раскопках городищ железного века (Барвихинское, Успенское) и многочисленных древнерусских курганов (Иславские, Царицынские, Новлянские, Спас-Тушинские и др.). Собранный ими материал лег в основу многих последующих работ.

Исследовательские парадигмы. Завершая данный краткий обзор, нельзя не остановиться на некоторых особенностях «исследовательских парадигм», менявшихся на протяжении более, чем 150 лет археологического изучения Подмосковья.

К концу XIX в. информации об археологических памятниках было уже накоплено достаточно, чтобы в первом приближении создать верную хронологическую шкалу древностей. Примат естественно-научного позитивистского подхода в это время сказался очень положительно на интерпретации археологических памятников. Примечательно, что даже И.Е. Забелин, в большей мере историк, чем археолог, не поддавался на искушение искать и обязательно находить «жесткие связи» письменных и археологических источников. Так, И.Е. Забелин не «ухватился» за летописное упоминание голяди, но вообще поставил его под сомнение, предложил его трактовку как топонима (Людогощ). И.Е. Забелин и его коллега В.И. Сизов видели своеобразие раскопанных ими курганных комплексов в Подмосковье и отмечали это в адекватных терминах, вроде «кольца московского типа» и т.п.

Взвешенность и корректность аналитического подхода прекрасно видна в очерке Д.Н. Анучина (1909). Он ясно обозначил противоречие в данных, полученных смежными науками. Археология с неоспоримостью показывала, что курганные инвентари - древнерусские, славянские, но антропологические признаки также ясно указывали на несходство черепов из курганов и кладбищ средневековой Москвы. Вопрос, можно ли видеть в данном случае влияние финской подосновы, влияние аборигенного населения, проживавшего в Подмосковье до прихода славян, «повис в воздухе» из-за того, что отсутствовали на тот момент черепа из достоверно финских могильников, не было еще представлений об общих трендах изменения краниологических показателей в эпоху Средневековья в Европе.

В 1920-е гг. и позже, когда на словах декларировался материалистический подход, позитивизма заметно поубавилось. Редким (случайно сохранившимся?) словам летописи надо было обязательно найти соответствие в археологических данных. Введение ограничений на свободное использование подробных картографических материалов в сталинской России существенно повлияло на подходы в археологии. Осознанно или нет, но археологи «адаптировались». Не так важно, где находится памятник, что его окружает, каков ланд- 
шафт рядом, а главное - это комплекс находок, именно он стал основным предметом исследования. Изучение микрорегионов невозможно без подробных карт, без них эти микрорегионы «распадаются» на не связанные друг с другом объекты. В этом русле были выполнены работы А.В. Арциховского по подмосковным курганам и ряда других, шедших за ним исследователей. Кажется, что они не замечали очевидного, что рядом с могильником надо искать поселение, что пространственная структура могильников, их ландшафтное положение требуют не менее тщательного описания, чем собственно вещи из погребений. Но таково было общее «веяние эпохи».

Более чем спорным оказалось «склеивание» летописных этнонимов XI в. (вятичи, кривичи) и археологических памятников XII-XIII вв. Даже если этнические корни москворецкого населения XII-XIII вв. уходят к племени вятичей, это ни в коей мере не должно было заменять/отменять изучение реалий этногенетического процесса XII-XIII вв. Лишь после работ Т.В. Равдиной, вернувшейся к «буквоедскому» позитивизму, применившей картографический метод, удалось несколько поколебать торжество наклеенного в 1930 г. на подмосковные курганы ярлыка «курганы вятичей». Впрочем, эта версия интерпретации оказалась очень устойчивой и продолжает жить (Зайщева, Сарачева, 2011).

Р.Л. Розенфельдт в 1970-е гг. вплотную подошел к тому, чтобы перейти к исследованию исторических ландшафтов и археологических комплексов, включавших как поселения, так и погребальные памятники. Он, можно сказать, ногами почувствовал закономерности их взаиморасположения, но карт, на которых эти закономерности можно было наложить, у него не было.

Еще одна тема, которой стоит уделить внимание - это подход к реконструкции хозяйства и социальной структуры. Значимость этой темы была обозначена впервые в работах ученых 1930-х гг., и в этом их неоспоримая заслуга (Арциховский, 1934). Другое дело, как эти реконструкции выполнялись. Архетип сознания, что все развивается исключительно от простого к сложному, видимо, сыграл очень существенную роль. В ХІХ-начале XX в. на севере России еще можно было наблюдать примеры реализации стратегии подсечного земледелия. Эта модель была перенесена автоматически на древность и стала восприниматься как отражающая реалии древнерусского времени, подобно архангельским былинам. Далее следовал вывод, что если у славян в XI-XIII вв. было подсечное земледелие, то до этого никакого земледелия вообще не существовало.

Совершенно новаторской была работа Юрия Алексеевича Краснова (1931-2000) о формах хозяйства в лесной зоне Восточной Европы (Краснов, 1971), основанная лишь на фактических археологических данных, а не на домыслах. Сам Ю.А. Краснов не собирал в процессе раскопок палеоботанические и зооархеологические данные, но очень тщательно собрал и систематизировал все имевшиеся на конец 1960-х гг. сведения этого рода, сопоставил их с немногочисленными археологическими данными о находках пахотных и жатвенных орудий и т.п. Результат был впечатляющим - оказалось, что земледелие как отрасль хозяйства существовала в лесной полосе уже в бронзовом веке, пашенное земледелие должно было существовать уже в железном веке. Этим выводам не хватало фактических обоснований - следов пахотных борозд под датированными насыпями (примеры чего имелись в Западной Европе), систематически отобранных палеоботанических данных.

Именно в этом направлении - проведение комплексных археолого-естественно-научных исследований был достигнут прогресс, начиная с раскопок Дьякова городища 1981 г., осуществленных автором настоящей работы, а затем коллегами В.И. Вишневским, В.Ю. Ковалем, А.В. Энговатовой на других памятниках Подмосковья.

И наконец - социальная структура. Термины «родовой поселок», «гнезда поселений», «община» мелькают нередко в археологической литературе по Подмосковью. Но мы пока никак не продвинулись в том, чтобы обосновать эти положения сколько-нибудь реальными фактами, остаются надежды на антропологов с их анализом генетических маркеров. Нам же необходимо уделять большее внимание тщательному проведению археологических исследований с привлечением и учетом всех данных смежных наук.

В заключение надо отметить, что данная книга появилась в результате длительных полевых работ, в которых принимали участие множество людей. Всем им автор бесконечно обязан. Со мной щедро делились материалом коллеги. Дружескую, а не формальную помощь оказывало руководство института археологии РАН. Мне помогали мои родные. 
ГЛАВА 1

\section{ЭПОХИ НЕОЛИТА И БРОНЗОВОГО ВЕКА HA MOCKBE-PEКE}

$\mathrm{H}$ аши знания о процессе развития и смены культур в эпоху неолита и бронзового века в Подмосковье на сегодняшний день выглядят как пунктир с существенными белыми пятнами. Время и формы перехода к производящей экономике точно не определены. Такая неопределенность обусловлена относительной незначительностью проведенных раскопочных археологических работ, недостаточностью привлечения к исследованиям специалистов естественно-научных дисциплин. Хотя надо подчеркнуть, что самое начало изучение неолита Подмосковья, связанное с открытием в 1922 г. льяловской стоянки на р. Клязьме, давшей название культуре, было «образцовым» комплексным проектом, которым руководил Б.С. Жуков (Доктуровский, 1925; Жуков, 1925; 1927; Линдгольм, 1925; Мешеряков, 1925).

Современные знания о неолитическом периоде в Московском регионе базируются почти исключительно на результатах раскопок, проведенных в озерных районах и на водораздельных торфяниках. Памятники, расположенные здесь, казались более перспективными и удобными для исследований. На подмосковных озерных (и палеоозерных) стоянках раскопано несколько тысяч квадратных метров (Брюсов, 1960; Древние охотники и рыболовы..., 1997; Раушенбах, 1964; 1970; 1979; 1985; Розенфельдт И.Г., 1964; Сидоров, 1975a; 1986; Сидоров, Трусов, 1980). Примерно 50 радиоуглеродных датировок получено для стоянок льяловской культуры, включая и памятники Ивановской области (Зарецкая, Костьлева, 2011; Тимофеев и др., 2004; Кренке, Александровский и др., 2012). Гораздо меньше работ проводилось на стоянках, расположенных на берегах крупных рек.

Всего в бассейне Москвы-реки известно 99 неолитических стоянок и пунктов отдельных находок ямочно-гребенчатой керамики льяловской культуры (рис. 3). Около трети из этих пунктов находятся в долине Москвы-реки и ее левого притока Рузы. Однако они практически не исследовались раскопками (суммарная площадь раскопов на этих памятниках менее 50 кв. м). Такая ситуация объясняется техническими сложностями раскопок в пойме - неолитические культурные слои часто находятся ниже современного уреза воды, перекрыты несколькими метрами отложений аллювия.

Существование долговременных неолитических поселений в долине реки ставилось под сомнение (Сидоров, 1975;
В.В. Сидоров, выступление на 9-м семинаре «Археология Московского региона», 15 февр., 2011 г.). Хотя, надо отметить, что в литературе еще 50 лет назад высказывалось обратное мнение, что Москва-река являлась «первоначальным районом обитания льяловских племен» (Третьяков В.П., 1966. С. 15).

Все представления о климате и ландшафтах конца атлантического - суббореального периодов до сих пор также основывались преимущественно на палеоботанических данных по водораздельным озерам и торфяникам. Согласно этим представлениям, весь Московский регион в период климатического оптимума лежал в зоне широколиственных или хвойно-широколиственных лесов; граница леса и степи проходила значительно южнее Москвы-реки (Нейштадт, 1957; Хотинский, 1977; Климанов, Серебрянная, 1986; Спиридонова, Алешинская, 1999; Dynamic of Terrestrial Landscape Components..., 2002; Atlas-monograph..., 2010; Novenko et al, 2009; 2012).

Учитывая данную ситуацию, мы направили наши силы именно на комплексное исследование стоянок, поселений и естественных разрезов в пойме Москвы-реки и ее долине. Работы проводились в 2005-2013 гг. Звенигородской экспедицией ИА РАН, в финансировании которой принимали участие Президиум РАН и РГНФ. Постоянной базой и ключевой территорией исследований являлась Звенигородская биостанции МГУ.

\section{ГЕОМОРФОЛОГИЧЕСКИЙ ФОН}

Комплексные археолого-географические исследования в пойме Москвы-реки, нацеленные на изучение стратиграфии пойменных отложений, были начаты лишь в последние годы. Большой потенциал пойменных отложений для археологических исследований в Окском бассейне стал ясен после работ 1980-х гг., проведенных мультидисциплинарной командой исследователей (почвовед А.Л. Александровский, геоморфолог М.П. Гласко, палинолог М.А. Гуман, археолог Б.А. Фоломеев) на Климентовской стоянке на левом берегу Оки.

Работы на Москве-реке, проведенные в 1990-е гг., показали, что Ока и Москва-река имеют сходную стратиграфию пойменных отложений. Погребенные почвы в толще аллювия маркируют периоды, когда наблюдалось сильное замедление или прекращение осадконакопления в пойме из-за 
низкого уровня паводков. В эти периоды берега реки становились особенно привлекательными для заселения. Серия погребенных почв (рис. 2), выявленных в аллювиальных отложениях Москвы-реки датируется интервалом от атлантического до субатлантического периодов (Alexandrovskiy, Krenke, 2004; Ershova et al., 2016). Наибольшую мощность и развитый профиль имеет погребенная почва № 4 (считая сверху). Ее гумусовый горизонт имеет темно-серый цвет. Данная почва определяется специалистами как «черноземовидная» или даже чернозем (Alexandrovskiy et al., 2016). Залегает она лишь немного выше современного уреза воды в Москве-реке. Радиоуглеродные датировки (некалиброванные) четвертой почвы, полученные по почвенному гумусу, охватывают интервал от 7000 до 4900 лет (Кренке, Александровский, Ериов, 2014). К погребенной почве № 4 на Москве-реке приурочены стоянки льяловской неолитической культуры - 1-я Звенигородская, Щукинская и др. (Кренке, Александровский и др., 2012; Ershova et al., 2014).

Третья погребенная почва залегает выше почвы 4, ее профиль развит слабо. В некоторых случаях она имеет признаки лесной почвы, в некоторых - луговой. Зафиксированы также случаи, когда почва 3 налегает и сливается с почвой 4 (Александровский, 2008). К почве № 3 приурочены находки бронзового века.

Почва № 2 имеет хорошо развитый профиль и часто определяется как лесная дерново-подзолистая, лишь в некоторых случаях, вблизи археологических памятников, эта почва имеет признаки луговой и несет следы хозяйственного использования (Ershova et al., 2015). Эта почва залегает на глубине около 1 м от современной поверхности поймы. Радиоуглеродные (некалиброванные) даты по почвенному гумусу, полученные для почвы 2, охватывают интервал 28002000 лет (Александровский и др., 2004). Археологические памятники, приуроченные к погребенной почве 2, относятся к раннему железному веку и Средневековью (вплоть до XIV в.).

Геоморфологические исследования поймы Москвыреки, проведенные в последние годы А.В. Паниным (Александровский, Панин, 2013; Панин, 2008; Панин, Сидорчук, 2006; Панин и др., 2004), в том числе в ходе совместных археолого-географических работ на Звенигородской биостанции, показали, что макроизлучины долины имеют позднеплейстоценовый возраст, когда водность реки была существенно выше современной. Отложения поймы голоценового возраста залегают на подстилающих их пойменных отложениях, имеющих позднеплейстоценовый возраст, подтвержденный радиоуглеродным методом и ОСЛ-датированием (примерно 15 тыс. лет). Археологические памятники приурочены в большинстве своем к тем участкам высокой поймы, которые в основании имеют такие древние отложения. Положение русла, по крайней мере, во второй половине голоцена на таких участках мало изменялось (доказывается, в частности, наличием погребенных почв в аллювии на противолежащих берегах).

Наиболее существенными рубежами трансформации рельефа поймы в голоцене были длившиеся по нескольку столетий «эпизоды», когда паводковая активность реки резко увеличивалась. Стабильная до этого поверхность поймы, на которой сформировались хорошо развитые почвы, была перекрыта аллювием, микрорельеф существенно изменен, мелкие водотоки и старицы оказались погребенными. Начало первого эпизода относится ко второй четверти IV тыс. до н.э. (верхние датировки объектов на почве 4 равняются 4900 радиоуглеродных лет, см. табл. 2). Начало второго эпизода относится ко второй четверти III тыс. до н.э.; третий эпизод падает на 1400-1900-е гг. н.э.

\section{НЕолит}

Льяловская культура. 1-я Звенигородская стоянка является ключевым памятником льяловской культуры на Москве-реке. Стоянка расположена на левом берегу р. Москвы, в юго-западной части г. Звенигорода (рис. 3, 4). Она была открыта в 1954 г. Н.А. Красновым, Ю.А. Красновым и А.В. Успенской (Успенская, 1955). В 1954-1957 гг. здесь регулярно проводились сборы подъемных материалов. Результаты этих работ опубликованы (Краснов Ю.А., Краснов Н.А., 1959; Успенская, Краснов Ю.А., 1959). При этом из материалов публикации можно заключить, что стоянка довольно интенсивно разрушалась из-за подмыва берега рекой. В обнажениях были видны несколько кострищ (Там же. С. 90). В 1958 г. на памятнике был заложен раскоп площадью 21 кв. м. Информация об этих работах представлена в отчете Ю.А. Краснова (1958).

Раскопками 1958 г. было зафиксировано наличие двух культурных слоев, разделенных стерильной прослойкой, и остатки углубления, которое авторы раскопок интерпретировали как жилище. Датировку двух слоев Ю.А. Краснов предварительно определил в рамках второй половины III тыс. до н.э. - второй четверти II тыс. до н.э. на основании культурной атрибуции находок как льяловских с архаичными чертами и позднельяловских (Краснов, 1958. С. 13). Часть коллекции, собранной А.В. Успенской, поступила в ГИМ (№ 90019), часть - в Звенигородский музей.

В 1976 г. стоянку обследовал В.Ю. Дукельский, при этом была собрана ямочно-гребенчатая керамика, типичная для льяловской неолитической культуры, и найдены кремневые изделия (Дукельский, 1976), в том числе редкий кинжал или наконечник копья (Кренке, Александровский и др., 2012).

Задачи работ 2010 г. виделись такими: 1) определение точных координат памятника и уточнение его границ и стратиграфического положения; 2) отбор образцов для радиоуглеродного датирования и палеоботанических анализов; 3) сбор археологической и остеологической коллекций.

Ориентирами для поиска 1-й Звенигородской стоянки являлось русло ручья, показанного на плане в отчете Ю.А. Краснова, а также указание на ее расположение в 150 м к Ю3 от здания нарсуда, фундаменты которого сохранились. При осмотре поверхности, проведенном в 2009 г,, было установлено, что следы раскопок 1958 г. не прослеживаются, обнажения культурного слоя отсутствуют.

Исходя из описаний, приведенных в отчете Ю.А. Краснова, можно было предположить, что культурный 
слой стоянки был приурочен к погребенной почве в толще аллювия поймы левого берега Москвы-реки, которая залегала не более 1 м выше уреза воды в реке. Для определения границ памятника применялся метод ручного бурения грунта. Первая скважина была заложена в створе с домом № 30 по ул. Фрунзе, примерно в 1 м от уреза воды. Никаких следов культурного слоя и погребенных почв не было при этом отмечено. Вторую скважину заложили в створе с домом 32, примерно в 50 м выше по течению от первой скважины. Буром был вытащен кремневый отщеп, и стало очевидно, что место стоянки зафиксировано. Здесь была заложена тестовая траншея шириной 1 м и длиной 6 м перпендикулярно берегу. В нижней части траншеи была выявлена погребенная почва с неолитическими находками. Верхние 2 м траншеи (шурф) были прокопаны лишь на глубину 1,5 м, неолитический слой здесь не был достигнут. После этого был размечен раскоп размером $4 \times 5$ м, включивший в себя и нижние 4 м траншеи (рис. 5). Кроме того, было обследовано дно реки (водолазная группа под руководством А.Н. Мазуркевича и Е.В. Долбуновой, Северо-западная экспедиция Гос. Эрмитажа). Древних находок при этом обнаружено не было.

Стратиграфия памятника. Толща пойменных отложений на участке раскопа сложена бурым суглинком, в котором хорошо выделяются погребенные почвы, имеющие более темный цвет (рис. 6). Почва 4а залегала в пределах раскопа на глубине от 0,5 до 1 м от поверхности, слабо понижаясь на север и северо-запад (то есть в глубь берега от русла реки). На уровне этой почвы были обнаружены единичные угольки, не образовавшие скоплений. Толщина почвы 4а составляла 20-30 см, ее кровля и подошва имели размытые границы. Почва 4 залегала примерно на 80 см ниже подошвы почвы 4а, содержала материал неолита и угольки. Кровля почвы 4 понижалась от отметки -415 в юго-восточном углу раскопа до -500 (нулевой репер находился на бровке поймы) в северо-западном углу. То есть почва 4 понижалась, удаляясь от современного русла реки, почти достигая отметок современного уреза воды $(-513$ см относительно репера). Современный летний урез воды искусственно поддерживается на 1,5-2 м выше естественного меженного, но в период формирования почвы 4 урез воды был, вероятно, еще ниже. Мощность почвы 4 нарастала в том же направлении, что и падение ее поверхности. В юго-восточном углу раскопа она составляла $20 \mathrm{~cm}$, а в северо-западной части достигала 40 см. Наиболее сложная стратиграфическая ситуация наблюдалась именно в северо-западном углу раскопа. Здесь темно-бурая почва 4 терялась, постепенно исчезая в серо-голубом суглинке. На исходный уровень ее залегания указывали немногочисленные угольки. В серо-голубом суглинке имелись трещины, которые заполнял бурый и светло-бурый материал вышележащих горизонтов. По результатам палеопочвенных исследований А.Л. Александровским было сделано предположение о диагенетическом происхождении слоистости и голубоватого глеевого слоя северо-западного угла раскопа. На это указывает то, что голубоватый слой и железистые прослойки залегают наклонно, согласно современной поверхности склона поймы к реке, и секут почву 4. Слой оглеения неоднороден. Имеются два клиновидных образования бурого цвета, идущих вдоль трещин и внедряющихся в слой глея на всю его глубину. Предполагается, что в результате поступления воздуха по трещинам, вдоль них анаэробные условия, необходимые для существования глея, исчезают, глей деградирует и возвращается исходная бурая окраска аллювия. Однако остается не вполне ясным распределение археологического материала, которое ясно указывает на обособленность северо-восточного угла (кв. Д-8) - там нет находок кремня и керамики (рис. 5). Видимо, здесь, на переходе к старичному понижению, находился край стоянки.

Состав археологических находок, их пространственное распределение и датирование. Находки начали попадаться на уровне кровли почвы 4, их концентрация несколько возрастала в средней части почвенного горизонта. Наибольшая концентрация керамики - развал почти целого горшка в кв. Б-8 - приходилась на среднюю часть толщи почвы 4, но в целом можно говорить, что находки были относительно равномерно «размазаны» по этой толще, встречались также и на уровне подошвы почвы 4. Это хорошо видно при проецировании находок на профиль (рис. 5). В подстилающем почву 4 более светлом суглинке находки уже не встречались, и эта поверхность была принята за условный «материк», который был прокопан лишь по периметру стен раскопа. На одном уровне с кремнями, керамикой и костями животных встречались обугленные скорлупки лесных орехов, что отмечалось и Ю.А. Красновым при раскопах 1958 г., и многочисленные раковины ракушек-двустворок. Возможно, они являлись кухонными отбросами, так как вне горизонта археологических находок ракушек почти не было.

Статистика кремневых находок приведена в таблице 1. Основную массу (более 2 тыс.) составляли отщепы и чешуйки. Несомненно, на памятнике велась интенсивная обработка кремня. В качестве материала использовался низкокачественный серый, светло- и темно-коричневый кремень (иногда это даже не кремень, а окремнелая порода). При этом необходимо отметить, что нуклевидных обломков практически не было найдено. Орудий и отщепов со следами вторичной обработки было найдено всего 35. Среди орудий выделяются группы листовидных наконечников дротиков и стрел с двусторонней обработкой (рис. 11, 4-б), ножи (рис. 11, 9, 10), скребки (рис. 11, 13, 14) и орудия с выемкой (рис. 12), перфоратор (рис. 11, 17). Ножевидных пластин очень мало - всего девять.

Нужно отметить, что в первой публикации материалов стоянки отмечалось, что для комплекса стоянки характерны пластины и орудия на пластинах (Краснов Ю.А., Краснов Н.А., 1959. С. 251). Просмотр коллекции из раскопок 1958 г. показал, что это утверждение ошибочно (Сидоров, 1975. С. 98).

Керамика была представлена около 220 фрагментами, происходившими как минимум от 20 сосудов. При этом лишь один сосуд был представлен развалом, от остальных сохранилось всего по нескольку фрагментов, они выделялись как отдельные формы по особенностям орнамента и теста. Наиболее полно представленный сосуд (рис. 7,2 ) имел ха- 
рактерную для развитой льяловской керамики сплошную регулярную ямочную орнаментацию (в шахматном порядке), зигзаг из оттисков гребенки под венчиком и вдавления, выполненные той же гребенкой по торцу венчика. Форма остродонная (яйцевидная), венчик почти прямой (чуть вогнутый внутрь), уплощенный по торцу. На внутренней поверхности горшка сохранился слой нагара, по которому была получена радиоуглеродная датировка $5370 \pm 30$ лет (UGAMS-7954) ${ }^{1}$, что соответствует календарному возрасту 4330-4060 лет до н.э. ${ }^{2}$ Аналогичный по форме и орнаментации горшок был найден в 1958 г. в раскопе Ю.А. Краснова (коллекция ЗИАХМ). Очень близкие по своим признакам горшки были найдены на поселении Воймежное 1 в контексте с органическими остатками, давшими тождественные радиоуглеродные даты - около 5300 лет (Энговатова, 1998. С. 243, 244). По А.В. Энговатовой, это средний этап льяловской культуры. Учитывая калибровочные поправки, можно отнести эти находки к последней четверти V тыс. до н.э.

В коллекции имеется ряд фрагментов, отличающихся от вышеописанного сосуда. У них ямки меньшего диаметра и реже расположены (рис. 8), венчик тоньше и имеет профилировку (рис. 9). Из 20 сосудов два были орнаментированы ромбическими ямками (рис. 8). Видимо, эта керамика относится к позднему этапу льяловской культуры. Это дает основание предполагать, что 1-я Звенигородская стоянка была поселением, в жизни которого можно выделить ранний и поздний периоды.

Изделий из кости в раскопе 2010 г. было найдено всего три. Одна из находок - это маловыразительная проколка (рис. 11, 3), два других - изящные подвески. Одна сделана из клыка барсука (все определения фауны выполнены Н.В. Сердюк) и ее верхняя часть вырезана таким образом, что подвеска приобрела черты схематизированной антропоморфной фигурки (рис. 11, 1). Аналогия имеется на стоянке Сахтыш I (Гурина, Крайнов, 1996. Рис. 56, 21) в слое жилища с датой $5150 \pm 40$ (ЛЕ-1024) и на стоянке Ивановская 7 (Жилин и др., 2002. Рис. 33), где авторы относят ее к более раннему мезолитическому слою.

Другая подвеска представляет собой прямоугольную пришлифованную пластинку, в которой двусторонним сверлением прорезано отверстие для подвешивания. По торцам пластинки прорезаны каннелюры кремневым резцом (рис. 11, 2).

Костные остатки относительно хорошо сохранялись в почве 4. Всего было собрано около 200 фрагментов, из которых удалось определить лишь небольшую часть (табл. 3). Определены исключительно дикие животные - бобр, лось, кабан и др. Важно отметить, что на стоянке представлена разнообразная дичь: животные, тяготеющие к водной среде и типично лесные виды. Обращает на себя внимание незначительное количество ихтиофауны. Анализ костных останков не позволяет предполагать приоритетное значение рыболовства для населения стоянки.

\footnotetext{
${ }^{1}$ Лаборатория университета штата Джорджия (США), рук. - А.Е. Черкинский.

2 Здесь и далее калибровка проводилась в программе OxCal v.4.1.7 с использованием калибровочной кривой IntCal09 (Reimer et al., 2009) с интервалом вероятности $95,4 \%$.
}

Анализ пространственного распределения находок показывает, что они тянутся сплошной полосой примерно равной плотности (несколько десятков находок на квадрат площадью 1 кв. м) по диагонали раскопа от юго-западного угла к северо-восточному. Юго-восточный и северо-западный углы имеют гораздо меньшую насыщенность находками. В раскопе не было обнаружено прокала и каких-либо признаков очагов (очажных камней) и столбовых ям, зато было много обугленной скорлупы лесных орехов и рассеянных мелких древесных угольков (большая часть этих угольков относилась к широколиственным деревьям, прежде всего дубу (определение А.Л. Александровского). По одной из скорлупок лещины была получена ускорительным методом


что калибруется в интервал 3800-3650 лет до н.э. По мелким рассеянным уголькам была получена обычным способом


(Ki-16752), т.е. 3960-3510 лет до н.э. Эти датировки (табл. 2) соответствуют датам позднего этапа льяловской культуры. Близкие по возрасту даты получены на стоянках Воймежная и Сахтыш 1 для горизонтов, содержащих находки позднего этапа льяловской культуры (Зареикая, Костьлева, 2011; Энговатова, 1998). Однако следует признать, что радиоуглеродных датировок для позднего этапа льяловской культуры еще недостаточно для того, чтобы сделать надежные выводы о времени окончательного исчезновения этой неолитической традиции.

Bblводы. Проведенные раскопки стоянки показали, что культурный слой приурочен к погребенной почве 4 в толще отложений аллювия. Этот слой имеет хорошую сохранность, содержит разнородные артефакты, в том числе и остеологический материал. Рельеф слоя сложный, границы его распространения не известны (в том числе и в глубь берега). Вероятно, стоянка располагалась в пойме близ берега реки, захватывая и склон старичного понижения. Раскоп 2010 г. не зафиксировал наличия двух разделенных стерильной прослойкой культурных слоев, как было отмечено в раскопе 1958 г., тем не менее, на основании набора находок и радиоуглеродных датировок можно говорить о наличии раннего и позднего этапов жизни на стоянке. Они соответствуют развитому и позднему этапам льяловской культуры. Хронологический диапазон радиоуглеродного возраста образцов - 4900-5300 лет. Календарные калиброванные значения этих радиоуглеродных дат от последней четверти V тыс. до н.э. до второй четверти IV тыс. до н.э. Приведенные выше данные не означают, что стоянка была обитаема непрерывно в течение нескольких сотен лет. Вероятно, были многоразовые посещения и длительное обитание в отдельные периоды. Вывод об интенсивности эксплуатации территории вокруг стоянки подтверждают результаты спорово-пыльцевого анализа, проведенного Е.Г. Ершовой. Спорово-пыльцевая диаграмма (Кренке, Александровский u дp., 2012. С. 33; Erschova et al., 2014) позволяет сделать выводы о частичном сведении широколиственного леса в окрестностях стоянки и присутствии видов, характерных для нарушенного почвенного покрова.

Важнейшее значение имеют данные о наличии в куль- 
турном слое пыльцы Cereale-type (типа культурных злаков). Спектры Звенигородской стоянки оказались во многом близкими к синхронным спектрам Белоруссии (Зерницкая и др., 2001) и Прибалтики (Kriiska, 2009), на основании которых выдвинуты предположения о том, что начальное проникновение земледелия в лесную зону западной части Восточной Европы относится к V тыс. до н.э. Фактические данные о восприятии земледелия «некоторыми общинами» круга неолитических культур с ямочно-гребенчатой керамикой приводил еще Ю.А. Краснов (1965. С. 21; 1971. С. 150), но он опирался на более южные материалы из Среднего Поднепровья и Посеймья. Относительно территории ВолгоОкского междуречья Ю.А. Краснов отмечал, что здесь отсутствуют признаки производящего хозяйства на стоянках с ямочно-гребенчатой керамикой (Краснов Ю.А., 1971. С. 159). Однако 40 лет назад в распоряжении исследователей не было спорово-пыльцевых спектров из культурных слоев стоянок льяловской культуры.

Полученные результаты спорово-пыльцевого анализа образцов с 1-й Звенигородской стоянки позволяют задаться вопросом, не могло ли первое знакомство населения ВолгоОкского междуречья с земледелием относиться к периоду бытования льяловской неолитической культуры (Кренке, Александрвский и др., 2012; Кренке, Александровский, Ершова, 2014). Спорово-пыльцевые данные свидетельствуют о том, что долина Москвы-реки представляла собой открытый или полуоткрытый ландшафт с элементами степной растительности. Важно подчеркнуть, что во всех изученных Звенигородской экспедицией разрезах (РАНИС, 1-я Звенигородская стоянка, ЗБС) в почве 4 представлена пыльца полыни (до 10 \%), которая в данном случае является не антропогенным индикатором, а указывает на характер природного комплекса.

Обилие пыльцы орешника, скорее всего, указывает на сведение человеком широколиственного леса в долине.

Для ответа на вопрос о времени начала земледелия в бассейне Москвы-реки необходимо проведение специальных исследований, в том числе флотации культурного слоя, изучение отпечатков на керамике. Нужно учитывать, что высказанное предположение входит в противоречие с мнением ученых, датирующих формирование производящей экономики на изучаемой территории более поздним временем (Zvelebil, Lillie, 2000).

Остеологические материалы указывают на то, что в хозяйственной специализации жителей стоянки существенное значение имела охота на приречных и лесных животных.

Поздний этап льяловской культуры, ЗБС-5. Комплекс, относящийся к позднему этапу льяловской культуры, был обнаружен на объекте ЗБС-5 (Звенигородская биологическая станция), расположенном в 10 км выше по течению от 1-й Звенигородской стоянки (Кренке, Ершов, Лазукин и др. 2013; Krenke et al., 2013).

Разведочный шурф, а затем раскоп площадью 80 кв. м был заложен на едва заметном повышении в пойме в 50 м в глубь берега от современного русла реки (рис. 13, 14). Развал неолитического горшка льяловской культуры залегал на поверхности погребенной почвы 4 на глубине
140 см от современной поверхности (рис. 15). Рядом были найдены несколько кремневых отщепов и орудий, а также клад каменных орудий из 14 предметов ${ }^{3}$ (рис. 16, 17). Рядом с развалом горшка было зафиксировано пятно прокаленного грунта от очага. Очевидно, на данном участке стояла легкая постройка. Очень показательны два факта - почти полное отсутствие дебитажа и охотничьего оружия. То есть в данной постройке не занимались изготовлением орудий, и это не было жилище охотников. Набор орудий указывает на какую-то деятельность, связанную, скорее всего, с обработкой дерева. Аргументом в пользу того, что набор инвентаря относится именно к неолиту, а не к раннему бронзовому веку (рядом была найдена шнуровая керамика, см. далее), является присутствие в составе комплекса небольших тесел из опоки, совершенно не характерных для фатьяновских могильников, но типичных для льяловских памятников (Сидоров, 1986а. Рис. 7). Изогнутые ножи-ложкари также характерны для льяловских и волосовских комплексов, а не для фатьяновских. Набор инструментов из клада на стоянке ЗБС-5 отчасти напоминает клады № 2 и № 4 на стоянке Владыченская-Береговая 2 (Цветкова, 1985).

Орнаментация горшка выполнена наклонными ямками по тулову, оттиски гребенки есть лишь по обрезу венчика (рис. 7, 3). Ямки сгруппированы в полосы из трех рядов каждая, опоясывающие горшок по диагонали. Между полосами оставлено свободное пространство. Использование исключительно ямочного орнамента типично для позднего льялова (Сидоров, Энговатова, 1996. С. 175). Аналогичные горшки были встречены при раскопках других льяловских стоянок, в частности, стоянки Маслово Болото 7 (Сидоров, 1986а. Рис. 11, 19, 45, 54). В.В. Сидоров находит сходство позднельяловской керамики стоянки Маслово Болото 7 с керамикой из жилища на стоянке Сахтыш 1, по которой были


При калибровке эти даты с наибольшей вероятностью указывают на рубеж первой и второй четвертей IV тыс. до н.э.

Территориально ближайшей аналогией горшку со стоянки ЗБС-5 является фрагмент горшка со стоянки Григорово 1, найденный в пласте 5 (Дукельский, 1977. Рис. 12, 1).

Таким образом, стоянка ЗБС-5 представляет малоизученный тип неолитического памятника - кратковременное место обитания, не связанное с охотничьей деятельностью, расположенное в пойме реки. Вероятно, подобные объекты имеются в большом количестве, но пока не открыты из-за сложности их обнаружения. Очевидно, что люди, оставившие стоянку ЗБС-5, должны были иметь где-то неподалеку базовое поселение.

Типологически сходными со стоянкой ЗБС-5, видимо, нужно признать Щукинскую стоянку в Москве и стоянку в низовьях Москвы-реки, на территории Старо-Голутвина монастыря в Коломне (фонды Коломенского археологического центра). В обоих случаях были найдены единичные

\footnotetext{
${ }^{3}$ Ранее в публикации (Кренке, Александровский и др., 2012), клад рассматривался как принадлежавший к бронзовому веку, однако более детальный анализ состава и морфологии орудий убедил, что клад неолитический.
} 
горшки, не сопровождавшиеся отщепами (Бадер, 1947. C. 122). Эти стоянки относятся к среднему этапу развития льяловской культуры, синхронны раннему комплексу 1-й Звенигородской стоянки.

Культура гребенчато-лапчатой керамики. Важный «куст» неолитических объектов был обнаружен возле д. Григорово на Москве-реке. Первые два объекта - стоянки Григорово 1 и 2 были открыты В.Ю. Дукельским (Дукельский, 1976, 1977). Дополнительные исследования, проведенные в 2011 и 2012 гг., привели к открытию еще двух памятников в непосредственной близости к найденным ранее (рис. 18). По обоим берегам оврага на уровне высокой поймы и высокой надпойменной первой (?) террасы (высота над рекой 18 м) были сделаны находки. Сохранность стоянок плохая, уцелели лишь их фрагменты, так как верхний уровень террасы подвергался многолетней распашке, начиная с железного века, а на уровне высокой поймы добывался белый камень. Тем не менее, можно утверждать, что в эпоху существования льяловской культуры жизнедеятельность протекала на разных высотных уровнях рельефа. В том числе и на уровне террасы высотой 18 м. Ранее подобные факты не были известны. Но теперь на Москве-реке известны и другие подобные случаи. Например, находка льяловской керамики в раскопе 2013 г. на средневековом селище Хотяжи 1 (раскопки А.В. Лазукина).

Концентрация находок в месте, испытавшем очень сильное воздействие в ходе добычи камня и другой хозяйственной деятельности, указывает, что изначально здесь было много неолитических остатков гораздо больше, чем сохранилось.

Топографические особенности стоянки Григорово 1, где был заложен шурф (16 кв. м) В.Ю. Дукельского, не позволяют думать, что здесь могло быть базовое поселение. Место крайне стесненное, заливавшееся периодически водой. Возможно, что прав В.Ю. Дукельский, видевший в этом памятнике мастерскую по добыче кремня (Дукельский, 1977. С. 25). Следовательно, можно предполагать, что основная стоянка была наверху террасы.

Шурф 2012 г., заложенный на поверхности высокой поймы, на правом берегу ручья (рис. 19), напротив стоянки Григорово 1 позволил сделать очень существенные стратиграфические наблюдения. В шурфе размером $1 \times 3$ м прослеживалась следующая свита напластований. Под современной почвой до глубины 40 см залегал слой аллювия (бурая супесь). В нижней части этого слоя прослеживались линзы светлого песка - след сильных паводков. Ниже, на глубине 40-60 см, залегала темно-серая супесь - погребенная почва 2 с углистыми включениями, связанными с деятельностью людей. Под почвой 2, на глубине 60-95 см, залегал слой светло-бурого суглинка, в котором были найдены неолитические находки - керамика, кремневые орудия и отщепы (рис. 20). Под этим горизонтом залегала на глубине 95-125 см погребенная почва (почва 4), представленная темно-бурым суглинком. Под ней шел прослой бурого суглинка. Примерно на глубине 4 м от современной поверхности залегал известняковый цоколь, который был достигнут с помощью ручного бура (рис. 18).
Таким образом, стало ясно, что неолитические находки не связаны с погребенной почвой 4, а относятся к перекрывающему ее слою. То есть их датировка должна быть несколько позднее, чем находок из 1-й Звенигородской стоянки, которые приурочены к почве 4. Состав находок согласуется с этим стратиграфическим наблюдением. Керамика из шурфа (получил обозначение Григорово 4) не относится к льяловской культуре. Это так называемая лапчатая и гребенчатая керамика (рис. 22). Орнамент нанесен косо поставленной палочкой с намотанным на нее тонким шнуром либо гребенчатым штампом. Аналогичная керамика присутствовала в шурфе на стоянке Григорово 1 в верхних пластах не ниже пятого (т.е. на глубине 50 см и выше). Вместе с лапчатой керамикой был найден наконечник дротика ромбической формы с чуть выделенными «шипами» (рис. 23). Подобные находки типичны для волосовских комплексов.

«Лапчатая» и «гребенчатая» керамика была встречена и на других стоянках в Подмосковье, но в значительно меньшем количестве, чем ямочно-гребенчатая керамика льяловской культуры. В.В. Сидоров и А.В. Энговатова привели убедительные аргументы для обоснования невозможности эволюционного развития поздней льяловской керамики в гребенчатую, они делают на этом основании вывод о приходе нового населения в Подмосковье (Сидоров, Энговатова, 1996. С. 176).

В бассейне Москвы-реки лапчатая и гребенчатая керамика была найдена на стоянках Бороденки 2 (АКР. № 1091), поселении Нижнее Сляднево (АКР. № 1168) на левом берегу р. Озерны; стоянке Никольское 2 (АКР. № 1174), поселениях Никольское 3 (АКР. № 177), Городище 1 (АКР. № 1136) на правом берегу Озерны при ее истоке из Тростенского озера. Поздненеолитическая лапчатая керамика была также найдена на трех памятниках в бассейне р. Нерской - это стоянка Беливо 14 (АКР. № 1395), поселения Тереньково 1 и 3 (АКР. № 1455 и 1457). Гребенчатая керамика найдена на стоянке Полецкая 1 в верховьях р. Нары (Сидоров, Энговатова, 1996). Эта стоянка находится в непосредственной близости от Григорово на Москве-реке (менее 10 км).

В бассейне р. Клязьмы о находках керамики, орнаментированной отступающей лопаточкой, на стоянках Бисерова озера пишет М.Е. Фосс и считает, что она позже льяловской (Фосс, 1959. С. 29). На Зареченских стоянках на р. Шерне лапчатая керамика была отмечена В.М. Раушенбах (Раушенбах, 1985. Рис. 2, 1). В.В. Сидоров обнаружил залегание такой керамики на стоянке Маслово Болото 4 выше льяловского слоя (Сидоров, Трусов, 1980. С. 143). Для этого горизонта стоянки Маслово Болото 4 имеется радиоугле-


указывает с наибольшей вероятностью на конец второй четверти IV тыс. до н.э. Эта датировка очень хорошо увязывается с приведенными выше данными о том, что начало этапа интенсивного накопления аллювия, перекрывшего почву 4 на Москве-реке, также относится ко второй четверти IV тыс.

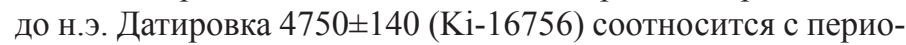
дом кратковременной стабилизации поверхности поймы (почва 4а) на разрезе 1-й Звенигородской стоянки.

В.В. Сидоров вслед за Д.А. Крайновым употребляет 
термин «протоволосово». Протоволосовской В.В. Сидоров называет лапчатую и гребенчатую керамику Маслова Болота 4 (Сидоров, Трусов, 1980; Сидоров, Энговатова, 1996; Сидоров, 2011), предполагает ее западное, верхне-днепровское, а изначально - валдайское происхождение (Сидоров, Энговатова, 1996).

Другие исследователи называют такую керамику (в том числе находки со стоянки Григорово) вслед за Б.А. Фоломеевым (Фоломеев, 1975) дубровичской (Кравцзов, Сорокин, 1984), указывая тем самым на южное направление контактов с Поочьем. Важно отметить, что Б.А. Фоломеев в одной из своих последних работ выделял «протодубровичский» этап. Датировки, по Б.А. Фоломееву, существенно более молодые, чем приведенные выше (Фоломеев, Челяпов, 2000. С. 344-345). Само появление керамики дубровичского типа Б.А. Фоломеев также связывал с западным деснинско-днепровским влиянием.

Bblвoдbl. На малочисленном москворецком материале вопрос о правильной культурной атрибуции лапчатой и гребенчатой керамики решить невозможно. Однако хронологическая позиция этого культурного горизонта в москворецком регионе определяется весьма точно - вторая четверть IV тыс. до н.э. Приход на Москву-реку населения с новыми культурными традициями совпадает с периодом резкой природной трансформации, перестройкой растительности при переходе от атлантического периода к суббореальному, подъемом уровня озер (Спиридонова, Алёиинская, 1999), активизацией паводков.

Анализ карты неолитических памятников свидетельствует о том, что долина Москвы-реки была хорошо освоена. Однако эта карта показывает также неравномерность и существенную неполноту изучения территории.

Скопления известных неолитических памятников лишь отчасти маркируют места их реальной концентрации (окрестности Тростенского озера), а порой приурочены к местам постоянной деятельности отдельных ученых (район Звенигорода, участок возле устья р. Пахры, верховья p. Нерской). Неполнота карты объясняется не только тем, что систематических разведок по всей долине не проводилось, но и сложностью выявления неолитических памятников в пойме из-за подъема уровня воды плотинами. Тем не менее, можно быть уверенным, что «куст» памятников, расположенных по берегам Тростенского озера и связанных с ним заторфованных теперь древних озер, не был единственным. Такие районы как Звенигород, Григорово, окрестности Боровского кургана (ниже устья р. Пахры) наверняка являлись местами концентрации неолитического населения и расположения долговременных поселений. К сожалению, не удалось получить какой-либо достоверной информации о Дьяковской и Алёшкинской стоянках, расположенных в черте г. Москвы. В Музее Москвы хранятся довольно большие коллекции случайных сборов подъемных материалов с этих затопленных рекой памятников, однако специалистам их локализовать не удалось, несмотря на предпринимавшиеся усилия. Если исходить из предложенного В.В. Сидоровым расстояния в 15 км как радиуса «зоны влияния» базовой стоянки/ком- пактной группы стоянок (Сидоров, 1975), то в изучаемом регионе явно остается пара мест, где надо ожидать новых открытий. Это районы Григорово - нижнее течение Рузы и территория от границ современной Москвы до устья р. Истры. Всего, таким образом, в бассейне Москвы-реки могло быть около шести компактных групп неолитического населения (рис. 3).

Находки «волосовского круга» в долине Москвы-реки крайне малочисленны. Они представлены серией предметов из раскопок в московском Зарядье, проведенных в 1950 г. Это кремневый наконечник стрелы и отщеп, три фрагмента керамики и желобчатое долото (Рабинович, 1950, С. 39, 49, 58). Обнаружены они были в разных местах, на довольно значительном удалении друг от друга (раскопы № 4, 5, 6). Находки известны лишь по рисункам в отчете, сами вещи поступили в МИРМ, где обнаружить их спустя 65 лет после раскопок не удалось. Стрела и долото найдены в переотложенном состоянии в нижней части культурного слоя на глубинах -367 и -346 соответственно. Отметки указаны от нулевого репера, значение которого в балтийской системе составляло 125,91 м. Фрагменты керамики происходят из 20-го пласта, с глубины -397 см из основания культурного слоя. Вполне вероятно, что они были найдены где-то рядом с местом их первоначального залегания. В геоморфологическом отношении место этих находок можно определить как тыловую часть пойменной террасы.

Керамика из Зарядья - плоскодонная, орнаментированная нарезками-вдавлениями, образующими узор в виде «горизонтальной елочки», имеет многочисленные аналогии на поздних волосовских памятниках. Наконечник дротика может быть связан с этим же комплексом. Наконечник дротика из Кремля, найденный при строительстве памятника Александру II (Султанов, 1898) близок по форме наконечнику из Зарядья, имеет аналоги в волосовских памятниках (Крайнов, 1987. Рис. 4, 29). Относительно этих наконечников для объективности нужно отметить, что подобная форма была распространена и в неолите (Цветкова, 1970. Рис. 20). Н.В. Султанов интерпретировал находку из Кремля как «громовую стрелу», т.е. предположил, что она была принесена на территорию в качестве амулета или раритета. Такую версию исключить нельзя, но в контексте находок из Зарядья не менее вероятно предположение, что наконечник был утерян на Боровицком холме в неолите (?) или бронзовом веке.

На стоянках в районе Тростенского озера и в верховьях p. Нерской имеются слои волосовской культуры. Керамика и другие находки волосовской культуры были найдена на шести памятниках в округе Тростенского озера и по течению р. Озерны - Городищи, поселение 2 (АКР. № 1137); Никольское, поселения 2, 3 и 5 (АКР. № 1176, 1177, 1179); Скирманово (АКР. № 1199), Бороденки 2 (АКР. № 1091). В бассейне $\mathrm{p}$. Нерской керамика волосовской культуры известна в незначительном количестве на двух стоянках Заволенье (АКР. № 1419) и Тереньково 1 (АКР. № 1455). Гораздо интенсивней людьми волосовской культуры была освоена территория бассейна верхней Клязьмы, включая ее правые притоки, граничащие с бассейном Москвы-реки. 
Это демонстрируют стоянки Маслова Болота, где изучены многочисленные жилища (Сидоров, 2002).

Выводы по эпохам неолита и энеолита. Можно отметить, что в развитом неолите (конец V тыс. до н.э.) территория бассейна Москвы-реки была довольно плотно заселена, включая долину самой реки. Человек оказывал уже ощутимое воздействие на растительность, выразившееся в локальном сведении широколиственных лесов возле стоянок. Относительно высокая плотность стоянок в долине реки и спорово-пыльцевые данные заставляют со всей серьезностью подойти к предположению о возможности существования начатков земледелия в это время. Необходима постановка специальных исследований для проверки этого предположения.

В позднем неолите, в начале IV тыс. до н.э., система расселения сохранялась, затем во второй четверти IV тыс. до н.э. произошли резкие изменения, выразившиеся в прекращении функционирования стоянок льяловской культуры. В бассейне Москвы-реки появились носители другой традиции орнаментации керамики (лапчатой и гребенчатой). Памятников этой новой для региона традиции гораздо меньше, чем предшествовавших им. Во второй половине IV тыс., в период волосовской культуры, поселенческая система была сильно редуцирована сравнительно с эпохой развитого неолита. Сохранился лишь центр в районе Тростенского озера и незначительные следы присутствия в верховьях р. Нерской. Долина Москвы-реки практически не была заселена. Можно предполагать, что в этот период произошла регенерация лесной растительности.

\section{БРОНЗОВЫЙ ВЕК}

Фатьяновская культура. Многие нерешенные вопросы археологии Подмосковья связаны с периодом бронзового века. Это обусловлено состоянием источниковой базы. Поселения фатьяновской культуры до недавнего времени были почти совсем не изучены, радиоуглеродных дат к концу XX в. было получено всего три (Кренке, 2007a). Такие общие проблемы, как происхождение фатьяновской культуры, ее хронология, взаимодействие колонистов с аборигенными культурами, система хозяйства и землепользования, остаются мало разработанными. Фатьяновскую культуру в регионе сменили культуры «постшнурового горизонта» - абашевская и «фатьяноидная». Информации обо всех параметрах этих культур в Подмосковье еще меньше, чем о фатьяновской.

Длительное время лишь могильники фатьяновской культуры и случайные находки каменных топоров являлись единственными археологическими свидетельствами освоения человеком долины Москвы-реки на рубеже III-II тыс. до н.э. (Крайнов, 1963).

Поселения в пойме. Первый поселенческий объект фатьяновской культуры был обнаружен в пойме на левом берегу Москвы-реки, у д. Заозерье, возле Боровского перевоза в 1984 г. В раскопе площадью 42 кв. м была собрана небольшая коллекция фатьяновской керамики, орнаменти- рованной гребенчатым штампом, а также грубой неорнаментированной посуды (Фролов, 1985. Илл. 14). Кроме того, в раскопе был найден кремневый серп, а неподалеку на поверхности пашни - каменный топор.

Следующая существенная находка последовала лишь в 2005 г., когда в толще пойменных отложений на правом берегу Москвы-реки, напротив поселка Николина гора (РАНИС), было обнаружено фатьяновское поселение, названное РАНИС-пойма. Раскопки здесь производились в 2005, 2006 и 2009 гг. (Кренке, Лазукин и др., 2008; Кренке, Лазукин, 2010; Кренке, Александровский и др., 2014). На данном поселении были проведены комплексные почвоведческие (Александровский, 2008), геоморфологические (Панин, 2008) и спорово-пыльцевые (Спиридонова и др., 2008) исследования, выполнена программа радиоуглеродного датирования углистой массы из очагов (табл. 4), получена значительная коллекция фатьяновской керамики, насчитывающая около 2000 фрагментов. Данный памятник может рассматриваться как культурно-стратиграфический «эталон», так как время формирования его культурного слоя было очень невелико. Находки залегают на одном уровне в толще аллювия чуть выше горизонта погребенной почвы 3.

Целенаправленные поиски фатьяновских поселений в пойме Москвы-реки в районе Звенигорода привели к открытию нескольких новых памятников бронзового века. На этих памятниках с привлечением средств РГНФ4 были проведены комплексные исследования, включавшие спорово-пыльцевой анализ, изучение геоморфологии, почв, радиоуглеродное и оптико-люминесцентное датирование и, конечно, собственно археологические раскопки.

Таким образом, в последнее десятилетие информация о памятниках фатьяновской культуры на Москве-реке существенно расширилась. Кроме упомянутого выше поселения РАНИС-пойма, были открыты и исследованы раскопами и шурфами поселения Царицыно 1, Акатово; изучено погребение в могильнике Луцино-Газовик. Важное значение имеет открытие новой категории памятников, расположенных в пойме Москвы-реки. Это так называемые «поселенческие объекты»- сезонные стоянки, связанные с производственной деятельностью (ЗБС-4, ЗБС-5, Кулаково-3 и др.).

Появилась новая информация об отдельных находках как керамики, так и каменных топоров, полученная, в том числе, при раскопках памятников железного века и Средневековья (Кренке, Ершов и др., 2013; Krenke, Erschov et al., 2013).

Карта памятников фатьяновской культуры, расположенных в бассейне Москвы-реки, сейчас насчитывает 117 пунктов (рис. 25), в том числе 15 могильников и 21 поселение и «поселенческий объект». Общее число раскопанных погребений достигло 26, что, конечно, немного. Шесть из 15 могильников не исследовались профессионально, они известны лишь по случайным находкам. Могильники были обнаружены, прежде всего, в долине Москвы-реки, а также в долинах ее левых притоков - Рузы и Истры, окрестностях Тростенского озера. Ни одного могильника пока не известно

\footnotetext{
${ }^{4}$ Номера грантов РГНФ 12-01-18053; 14-01-18046.
} 
в бассейне р. Пахры, хотя здесь встречены отдельные находки, указывающие на освоение этого микрорегиона в период фатьяновской культуры. Значительные раскопки были произведены лишь на одном поселении - РАНИС-пойма, где вскрыта площадь 200,5 кв. м и трех «поселенческих объектах» - ЗБС-5, ЗБС-4, Кулаково-3, где раскопано соответственно 80 кв. м, 51 кв. м и 3750 кв. м. Огромный раскоп на поселении Кулаково 3 в основном вскрыл объекты средневекового селища, находок бронзового века было совсем немного. Керамика с типичной фатьяновской орнаментацией была обнаружена при охранных раскопках по трассе автодороги в тыльной части поймы правого берега Москвы-реки, возле д. Кулаково в 2010 г. (Емельянов, 2011).

Кроме того, имеются коллекции каменных топоров (более двух десятков), хранящихся в ГИМ, Звенигородском и Рузском музеях, точное место находки которых не известно.

В результате упомянутых выше раскопок, а также с учетом новых единичных находок фатьяновской керамики и каменных орудий (Кренке, Лазукин и др., 2010) стало очевидным, что пойма Москвы-реки интенсивно хозяйственно осваивалась в бронзовом веке, и в аллювиальных отложениях сохранились многочисленные остатки поселенческих объектов.

С целью поиска новых памятников бронзового века в 2011-2012 гг. были произведены разведки и раскопки в пойме на правом берегу Москвы-реки в пределах территории Звенигородской биостанции МГУ им. С.Н. Скадовского Обследовался участок протяженностью около 1000 м и шириной около 150 м (рис. 14). Сведения о случайных находках каменных орудий бронзового века в пойме и на террасе коренного берега в районе дачного поселка Луцино указывали на перспективность поиска на данном участке.

При выборе места для закладки шурфов в пойме, верхний горизонт отложений которой сформировался за последние 500-600 лет, учитывались такие признаки микрорельефа, как наличие небольших возвышений, в том числе на месте конусов выносов ручьев, иногда погребенных под толщей аллювия. Шурфы были заложены в девяти точках. В двух случаях были обнаружены объекты бронзового века, получившие наименование ЗБС-4 и ЗБС-5. Каждый из них дал по-своему новые, уникальные материалы (Кренке, Александровский и др., 2014).

Прежде всего дадим описание наиболее показательных комплексов, расположив их в хронологической последовательности, опираясь на существующие представления об относительной хронологии фатьяновских древностей и классификацию форм и орнаментов керамики, разработанную Д.А. Крайновым и О.С. Гадзяцкой.

Относительная хронология фатьяновской культуры. Основные признаки относительной хронологии фатьяновской культуры - топографические особенности могильников, характер оформления могильных ям, тип сечения

\footnotetext{
${ }_{5}^{5}$ Автор выражают признательность руководителям Звенигородской биостанции МГУ, В.М. Гаврилову и А.И. Шилову, за оказанную помощь в проведении работ.
}

клиновидных топоров (прямоугольный или линзовидный), наличие/отсутствие шнуровой орнаментации; форма сосудов (эсовидный профиль, наличие бортика на краю венчика) были описаны Д.А. Крайновым (Крайнов, 1972) и сохраняют свое значение в настоящее время.

Д.А. Крайнов выделил четыре хронологические стадии по материалам могильников (Крайнов, 1972. С. 226). Это разделение было частично оспорено В.В. Сидоровым (Сидоров, Энговатова 1992; Сидоров, 2013), который заметил, что горшки со шнуровой орнаментацией из Ханевского могильника, отнесенного Д.А. Крайновым к третьей стадии развития культуры, весьма близки горшкам из Ивановогорского и Давыдковского могильников, включенных им в древнейшую первую стадию. В.В. Сидоров и А.В. Энговатова предложили более простую трехчастную схему: древнейшую группу составляют могильники Ханево-Новлинский-Ивановогорский с преимущественно шнуровыми горшками, за ними следуют могильники с горшками, частично сохранявшими шнуровую орнаментацию. Завершающая стадия представлена памятниками с горшками без шнуровой орнаментации, венчики которых имели «бортики», а клиновидные топоры - линзовидное сечение (Сидоров, Энговатова, 1992. С. 35). Эта простая схема кажется логичной, но ее можно принять лишь с оговорками. Важно подчеркнуть, что могильник Ханево содержит разновременные погребения. Об этом можно судить по набору горшков, включающему как сугубо ранние шнуровые, так и более поздние сосуды, в том числе с бортиком по краю венчика (Кирьянова, 1976. Рис. 1). То есть нельзя говорить о том, что данный могильник характеризует исключительно древнейшую стадию фатьяновской культуры. Во-вторых, утверждение о полном исчезновении шнуровой орнаментации на позднем этапе культуры, видимо, не совсем верно (см. далее).

Шнуровые протофатьяновские комплексы. Наиболее ранним памятником в бассейне Москвы-реки, относящимся к кругу культур шнуровой керамики является поселенческий объект ЗБС-5, который уже упоминался выше при описании неолитических находок (Кренке, Ершов и др., 2013; Krenke et al., 2013). Находки бронзового века, как и неолитические, были приурочены к поверхности погребенной почвы, залегающей в толще пойменных отложений на глубине 1,4 м.

Керамика бронзового века представлена единичными фрагментами от пяти сосудов, рассеянных на довольно значительной площади раскопа. Так расстояние между фрагментами сосуда № 5 составило около 14 м. Форма и орнаментация этих сосудов не имеет прямых аналогов в фатьяновских могильниках.

Два горшка, характерной особенностью которых является наличие валика, орнаментированного насечками (рис. 26, 4-б), характерны для жуцевской культуры Прибалтики. Аналогии имеются на стоянке Нида (Rimantiene, 1989. Pav. 68). Младшая дата этой стоянки $4070 \pm 50$ лет (Bln-2592), что указывает на конец первой половины III тыс. до н.э. при пересчете в календарный возраст.

Сосуд с рядом вертикальных продолговатых вдавлений иногда называемых «столбиками» (рис. 26, 7), в первую оче- 
редь, находит аналогии в керамике культуры шаровидных амфор ${ }^{6}$. Ближайший опубликованный памятник с такой орнаментацией - это могильник Туринщина на окраине г. Смоленска (Рис. 25, 9; Шмидт, 1992а. Рис. 3; Shmidt,


10082), калиброванные значения - в диапазоне 2670-2410 ВC (Szmyt, 2010. Р. 232).

Сосуды с аналогичной орнаментацией встречены на поселении Струково на р. Червице на верхнем Днепре в окрестностях г. Дорогобужа (сборы научного сотрудника Дорогобужского краеведческого музея В.А. Прохорова) ${ }^{7}$. В северной Польше такой орнамент изредка встречается также в культуре шнуровой керамики и сопровождается радиоуглеродными датировками, указывающими на вторую четверть III тыс. до н.э. (Czebreszuk, Szmyt, 2001. Fig. 9). На фатьяновских горшках такой орнамент очень редок. Можно привести в пример лишь ранний Икшинский могильник (рис. 26, 1).

Говоря о культуре шаровидных амфор, нельзя не вспомнить старую находку целого горшка (в настоящее время хранится в районном музее в г. Раменское) в урочище Барский сад в с. Софьино на Москве-реке (Коняшин, 1940, рис. 4). Форма и орнаментация этого совсем не типичного для фатьяновской культуры горшка (рис. 26, 11), находят аналогии именно в культуре шаровидных амфор (Свешников, 1983. Табл. 3, 7; 4, 4). Отличие заключается в отсутствии у софьинского горшка ушек для подвешивания.

Один из горшков, найденных на ЗБС-5, был декорирован по венчику горизонтальными оттисками двойного тонкого шнура, а на перегибе шейки располагались «подковки» из оттисков одинарного шнура (Рис. 26, 1, 2). Единичные находки шнуровой керамики, орнаментированной арочками, имеются на Смоленщине (Лявданский, 1927. Табл. XVI, 19). Для комплексов среднеднепровской культуры такая орнаментация не характерна. Находка из-под Рославля, опубликованная А.Н. Лявданским, происходит из разрушенного памятника, культурная принадлежность которого неизвестна. В Белоруссии аналогичных находок больше, но они также редки (Артеменко, 1967. Рис. 10, 8; Крыввальцэвіч, 2010. Рис. 6; Кухаренко, 1962. Табл. 4; Лошенков, 1998. Рис. 8, б). Аналогичная ситуация в Среднем Поднепровье (Максимов, Петрашенко, 1988. Рис. 4) и северной Польше (Czebreszuk, Szmyt, 2010. Rys. 12, 2). Серия аналогий происходит из памятников жуцевской культуры Прибалтики - стоянки Нида (Rimantiene, 1989. Р. 109), Прибрежное (Зальциман, 2010. Рис. 84), Ушаково 3 (Zaltsman, 2016. Fig. 12, 2), торфяник Цедмар А (Тимофеев, 2003. Рис. 2, 4; Forssander, 1933. S. 185). Есть аналогии в культуре одиночных погребений в Шлезвиге (Struve, 1955. Taf. 13).

Множество аналогий данному орнаменту имеется на Волыни в городокско-здолбицкой культуре (Самолюк, 2007. Рис. 5, 15; Свешніков, 1974. Рис. 28, 24, 45, 1; Bunyatyan, Pozikhovskyi, 2011). Исследователи отмечают, что именно

\footnotetext{
${ }^{6}$ Автор благодарен Н.Н. Кривальцевичу и Е.П. Бунятян за помощь в атрибуции керамики.

${ }^{7}$ Автор выражает благодарность В.А. Прохорову за информацию об этих находках.
}

этот тип орнаментации является характерным признаком городокско-здолбицкой культуры на Волыни (Артеменко, 1987a. С. 49; Бунятян, 2008. С. 16). Хронология этих древностей (при отсутствии радиоуглеродных дат) определяется параллелями со среднеднепровской (Артеменко, 1987а) и межановицкой культурами. Более достоверна начальная датировка - 2400/2350 лет до н.э. (Bunyatyan, Pozikhovskyi, 2011. Р. 55).

В южной Польше в межановицкой культуре также есть аналогии петлям и подковкам (Gimbutas, 1965. Fig. 250, 2; Machnik, 1966. Tabl. XI). В верховьях Вислы имеются комплексы шнуровой керамики с «подковками» (Kempisty, Włodarczak, 2000. Fig. 12), датированные радиоуглеродным методом серединой III тыс. до н.э. Петли представлены на горшке из Самбожеца (погр. 21), для которого имеется радиоуглеродная датировка - 4080 \pm 50 (Ki-7930), что указывает на середину III тыс. до н.э. (Furholt, 2003. Taf. 22; Włodarczak, 2006. Tabl. LIV). «Подковки» встречаются также на керамике катакомбной культуры (Братченко, 2007).

В ареале фатьяновско-балановских древностей керамика, орнаментированная шнуровыми оттисками в виде петель-подковок и имеющая эсовидную профилировку венчика известна лишь из материалов старых раскопок на стоянке Ибердус 1, расположенной на левом берегу р. Оки, выше г. Касимова (Сидоров, 2003). Расстояние между ЗБС-5 и стоянкой Ибердус 1 около 300 км.

В материалах фатьяновской культуры мы ничего подобного не видим. Лишь два горшка из ранних комплексов фатьяновских могильников - Давыдковского (Рис. 26, 2) и Ханевского (Сидоров, Энговатова, 1992) - имеют в основании шейки при переходе на тулово волнистый оттиск из двойного шнура.

Таким образом, в небольшой коллекции керамики из раскопок поселенческого объекта ЗБС-5 можно проследить традиции культуры шаровидных амфор, шнуровой керамики Прибалтики, эпишнуровых культур Волыни и Южной Польши. Вполне вероятно, что площадка поселения посещалась неоднократно людьми, культура которых входила в круг шнуровых (кубковых) культур. Вероятно, эти группы, взаимодействуя друг с другом на новой для них территории Москворецко-Клязьминского междуречья, положили начало фатьяновской культуре (Кренке, 2014а). Примерно сходный процесс культурной интеграции (при доминировании традиции культур шнуровой керамики) шел параллельно в бассейне Верхнего Днепра и привел к созданию среднеднепровской культуры (Крыввальц̧эвіч, 2011).

Важнейшая задача - определить время начала формирования фатьяновской культуры. Внешние аналогии керамике из комплекса ЗБС-5 охватывают вторую-третью четверти III тыс. до н.э. Серия из четырех радиоуглеродных дат (см. табл. 5), полученных в двух лабораториях (Университет Оттавы, Канада, и Геологический институт РАН, Москва), показывает, что наиболее вероятен возраст в пределах второй четверти III тыс. до н.э.

Для раннего фатьяновского могильника (Кузьминского) имеется пока лишь одна датировка. В 2014 г. в лаборатории в г. Киль (Германия) был датирован уголек, ото- 
бранный автором ${ }^{8}$, прилипший к медному (бронзовому?) кольцу из погребения 5, раскопанного в 1930 г. О.Н. Бадером (Гос. Эрмитаж, колл. 300/39). Получена датировка - 3975 \pm 35 (KIA-50462). Калиброванное значение этой даты - 25802400 cal BC (92\% вероятность).

Имеется серия радиоуглеродных датировок для памятников развитой фатьяновской культуры, полученных из поселений и могильников (Табл. 4; Черныхх и дp., 2011. С. 62). Из этих данных следует, что «сформировавшиеся» фатьяновские памятники имеют возраст в интервале 4100 3800 радиоуглеродных лет. Имеются также несколько более молодых значений возраста около 3600 лет, надежность которых вызывает сомнения. При калибровке радиоуглеродных датировок 4100-3800 лет и определении на их основе календарных дат мы получаем XXVII-XXII вв. до н.э. (Кренке, 2014a).

Имеются стратиграфические наблюдения, важные для датирования. Культурный слой поселения развитой фатьяновской культуры РАНИС, о котором пойдет речь ниже, формировался в пойме, когда уже началась эпоха экстремальных паводков, и на поверхности погребенной почвы 3 начал накапливаться аллювий, тонкая прослойка которого подстилает культурный слой. Протофатьяновские находки поселения ЗБС-5 залегают непосредственно на погребенной почве, аллювий их лишь перекрывает. Таким образом, в качестве рабочей гипотезы можно предположить, что формирование фатьяновской культуры происходило довольно стремительно, и начало этого процесса относится к концу второй четверти III тыс. до н.э.

Ранние фатьяновские комплексы. Поселений пока не найдено. Известно несколько могильников, занимающих территорию в западной части бассейна Москвы-реки и по верховьям правых притоков Волги - Большой Сестры и Дубны. Протяженность этого ареала с юга на север около 200 км при ширине около 100 км (рис. 31). Явно выявляются несколько близких, но отличающихся друг от друга традиций шнуровой орнаментации (рис. 26). Очень близки друг другу горшки из могильников Ханево, Новлянского, Ивановогорского и Кузьминского (рис. 28, 4, 5). У них высокие шейки, орнаментированные горизонтальными оттисками шнура, чередовавшегося с полосами «косой сеточки» (орнамент № 11, по: Гадзяцкая, 1976. С. 117). Вторая традиция - волнистые линии двойного шнура - представлена на горшках из Ханево и Давыдково (рис. 28, 2). Третья традиция - с элементами орнаментации, характерной для культуры шаровидных амфор - представлена Икшинским могильником (рис. 28, 1). В инвентаре могильников этой стадии проявляется южное раннекатакомбное или ямное влияние, документированное молоточковидными костяными булавками. Новейшая работа, посвященная этой категории находок, ясно показывает, что основной хронологический интервал существования этой категории изделий имеет радиоуглеродные датировки (некалиброванные) 4100 4200 лет от наших дней (Шиилина и др., 2013. Табл. 2).

\footnotetext{
${ }_{8}^{8}$ Автор выражает благодарность Тимо Ибсену за содействие в получении этой датировки в лаборатории университета г. Киль.
}

Развитые фатьяновские комплексы. Характерными памятниками этой стадии в западной части Москворечья могут быть признаны могильник Ханево (погр. 4) и поселенческий объект ЗБС-4. Шнуровая орнаментация уже отсутствует, явно прослеживаются связи с соседней среднеднепровской культурой. И.И. Артеменко считал горшок из погребения 4 Ханевского могильника не фатьяновским, а среднеднепровским (Артеменко, 1987a), но с этим трудно согласиться. Можно отметить полное сходство в орнаменте («паркетный» или тип 18, по О.С. Гадзяцкой) у этого горшка со среднеднепровскими сосудами, но форма типично фатьяновская (рис. 28, 2-4). В Новинских могильниках, территориально близких к москворецкому региону, расположенных у западной границы фатьяновской культуры, также обнаружены горшки с этой орнаментацией, но это уже сосуды несколько более поздней стадии развития (Волкова, 2010. Рис. 21). Фрагмент горшка с паркетным орнаментом и типичным фатьяновским приемом оформления венчика вертикальными насечками был найден на поселении РАНИС (рис. 28, 7). Горшок из поселенческого объекта ЗБС-4 (Рис. 28, 6, 8; Кренке, Ершов и др., 2013) близок к «паркетному» среднеднепровскому стилю, но не идентичен ему. Важно, что для этого комплекса была получена радиоуглеродная датировка - 4040 25 лет (UGAMS 10130), указывающая примерно на XXVI-XXV вв. до н.э. Эта дата очень близка к датировкам $(4010 \pm 40 ; 3890 \pm 50)$ погребения 10 могильника Прорва 1 среднеднепровской культуры с ранним горшком «паркетного стиля» (Крыввальизэвіч, 2006. С. 162).

Полные наборы посуды развитой стадии фатьяновской культуры в Москворечье дают коллекции поселений Царицыно 1 (Кренке и др., 2008) и РАНИС (Кренке, Лазукин, Алексеев и др. и др., 2008а).

Постройки. Раскоп на поселении РАНИС-пойма вскрыл серию легких наземных построек, возможно, шатрового типа, оставивших след в грунте в виде пятен прокала на месте очагов (рис. 35). Серия очажных пятен была прослежена вдоль линии берега. Диаметр пятен составлял около 1 м. Толщина прокаленного грунта в центре пятен равнялась 3-5 см (рис. 35). Угля практически не было, видимо, он был унесен паводковой водой. Развалы горшков занимали место не вплотную к очагам. Возможно даже, что разбитые горшки лежали за пределами построек (рис. 36).

Керамический комплекс поселений РАНИС и Царицыно 1. В коллекции поселения РАНИС представлены обломки, происходящие от 37 сосудов. В том числе шесть развалов, представленных десятью и более фрагментами, два сосуда, от которых сохранилось более пяти фрагментов. Остальные 29 сосудов представлены единичными фрагментами (рис. 39, 40). Такие показатели могут указывать на то, что размеры поселения существенно превосходили изученную раскопками площадь (в раскоп попали единичные фрагменты от развалов, находящихся за его пределами). Также можно предполагать, что значительное количество битых горшков указывает на определенную продолжительность функционирования поселения или неоднократность посещения места.

По форме сосуды из коллекции поселения РАНИС-пойма 
относятся к трем отделам по классификации О.С. Гадзяцкой низкошейных (раздел 1), с шейкой средней величины (раздел 2), чашевидных (раздел 4) (Гадзячкая, 1976). Подавляющее большинство (34) относится к разделу 2, к разделу 1 - всего один сосуд, к разделу 4 - две миски. Присутствие низкошейной амфоры следует особенно подчеркнуть (Кренке, Александровский, Ершов и др., 2014), так как Д.А. Крайнов отмечал нехарактерность амфор для московской группы фатьяновских памятников (Крайнов, 1972). Восемь из 35 венчиков имели прямой край, у остальных 27 черновой край был либо загнут наружу и примазан к шейке (13 случаев), либо отогнут наружу в виде небольшого «карнизика» (14 случаев). По крайней мере, шесть сосудов не имели орнаментации. Один из этих сосудов (рис. 39,1 ) удалось склеить до полного профиля, а два - собрать до максимального перегиба тулова. Все эти горшки однотипные. Их форма близка к яйцевидной. Тулово вытянуто. Плечики и венчики составляют тупой угол. При этом профиль нельзя назвать эсовидным. Размеры сосудов довольно значительны. Диаметры горловин около 25 см, высота у целого сосуда - 35 см. Днища уплощенно-округлые без орнамента. Характерной деталью трех сосудов являлись небольшие отверстия (диаметр 1 см), сделанные по сырой глине в придонных частях (на высоте 7-8 см от основания днища). В одном из сосудов таких отверстий как минимум три. Сосуды с подобными отверстиями в могильниках не встречались, но были ранее описаны П.Д. Степановым по материалам городища Ош Пандо в Мордовии (Степанов, 1967. С. 51. Табл. 7-9), где также находили и глиняные пробки к этим отверстиям. Такие сосуды с отверстиями могли использоваться для хранения и приготовления кисломолочных продуктов.

Большинство сосудов орнаментировано. Можно выделить 12 элементов орнаментики, из которых девять соответствуют типологии Гадзяцкой - № 7, 11, 13, 15, 18 19, 33, 34, 40 (Гадзяиякая, 1976. Табл. XVIII), четыре ее дополняют. Характерно практически полное отсутствие шнуровых оттисков (встречен один фрагмент). Наиболее распространенными являются элементы № 7 (косые насечки-вдавления по краю венчика), № 33 (ряд вертикальных отпечатков гребенчатого штампа или просто прочерченных линий), № 15 (попеременно-наклонные группы линий), № 19 (горизонтальная елочка) и № 13 (одинарный зигзаг, обрамляющий снизу орнаментальную зону). Двойной заштрихованный зигзаг (№ 34, по Гадзяцкой), так называемый «балановский» (рис. 40,7$)$ встречен лишь один раз. Несколько хаотично расположенные группы попеременно-наклонных линий (орнамент № 15) находят аналогии в орнаментации горшка из Болшневского могильника в Тверской обл. (Крайнов, 1975. Рис. 4,1$)$, для которого имеется радиоуглеродная датировка $3960 \pm 130$ (ГИН-5240).

Поселение Царицыно 1 дало сходную керамику. Шнуровая орнаментация полностью отсутствует (рис. 49). Важно подчеркнуть сходство орнаментации горшка с многорядным зигзагом (тип 14, по О.С. Гадзяцкой) с поселения Царицыно 1 (Кренке, Агеева и др., 2008, Рис. 44, 2) и сосуда из погребения 5 Тургиновского могильника (Гадзяцุкая,
1971. Рис. 25, 4), по которому получена радиоуглеродная датировка $3780 \pm 130$ лет (Ле-1046). Есть несколько относительно ранних венчиков без «бортиков» с косыми нарезками по краю (Кренке, Агеева и др., 2008. Рис. 38). Есть двойной заштрихованный зигзаг (рис. 49, 6-8). Очень близки по орнаментации наборы других поселений, расположенных в долине Москвы-реки и ее притоков. Это Заозерье (Фролов, 1985), Кулаково 3 (Емельянов, 2011), поселение на городище Настасьино (Энговатова, 2000).

Комплексы кремневых орудий РАНИС и Царищъыно 1. При раскопках поселения РАНИС-пойма была собрана представительная коллекция орудий и отходов производства (рис. 40-43). Ценность этой коллекции в том, что на основании стратиграфических данных можно быть уверенным в ее отношении именно к фатьяновскому комплексу. Состав находок из кремня приведен в таблице 4. Этот набор обладает некоторыми важными особенностями. Во-первых, почти полностью отсутствует вооружение. Найден лишь одни фрагмент наконечника стрелы. Большую часть орудий составляют обыкновенные отщепы со следами сработанности на краях. Много также отщепов со вторичной обработкой лезвия. Из морфологически устойчивых форм на первом месте с большим отрывом от других находятся острия-перфораторы. Также следует обратить внимание на наличие специфических орудий с выемкой. Совершенно отсутствуют топоры, крупные ножи на пластинах, хорошо нам известные по комплексам погребального инвентаря.

Поселение РАНИС на сегодняшний день уникально, но вероятно, является примером поселений фатьяновской культуры, которые еще предстоит открыть. Скорее всего, оно было сезонным. Среди находок доминируют вещи, предположительно связанные с женскими видами деятельности.

На поселении Царицыно 1 набор орудий был существенно меньше (рис. 46). Важно отметить наличие морфологически устойчивых форм перфораторов, известных и по погребальным комплексам. На поселении был найден скол с лезвия полированного топора и половинка двушипной стрелы. Таким образом, можно предполагать, что имелись различия в наборах орудий на поселении РАНИС-пойма и Царицыно 1. Возможно, за этим кроются и функциональные различия двух поселений. Заметим, что их ландшафтное положение также различно: РАНИС расположено у кромки русла реки в пойме, Царицыно 1 - на относительно высоком холме, где позднее, на рубеже бронзового и железного веков, возникло городище.

Могильник Луциино-Газовик. Новейшая находка - это погребение, раскопанное в ходе охранных раскопок, проведенных Звенигородской экспедицией в 2013 г. Могильник расположен на водораздельном холме, по которому проходит Луцинское шоссе возле академического дачного поселка. Первые находки были сделаны внуками академика С.Б. Веселовского в 1950-е гг. В 2013 г. при прокладке кабеля интернета вдоль полотна дороги был вынут из земли целый горшок. Раскопки на этом месте позволили выявить остатки захоронения, нарушенного, видимо, при строительстве дороги. Костяк не сохранился, но были найдены два целых горшка, клиновидный каменный топор с линзо- 
видным сечением и кремневая пластина-нож без ретуши, но со следами сработанности режущей кромки.

Один из горшков (рис. 29, 2) имел орнамент «горизонтальная елочка» вдоль плечика и попеременно-наклонные линии по шейке (№ 15 и 19, по О.С. Гадзяцкой). Эта орнаментация широко представлена, в том числе на памятниках в бассейне Москвы-реки. Более интересен другой горшок (рис. 29, 1), у которого на шейке орнамент в виде «стопочек» слегка наклонных линий (№ 31, по О.С. Гадзяцкой). Орнамент этого типа локализуется довольно узко - преимущественно в ареале Ярославского Поволжья (рис. 31). Ближайшей аналогией горшку из могильника ЛуциноГазовик является горшок из погребения 3 Мытищенского могильника в Ивановской области (Гадзяц̧кая, 1976. С. 115). Расстояние между этими двумя памятниками около 300 км.

Видимо, «радиус индивидуальной активности» (термин введен при изучении генетики популяций Н.В. ТимофеевымРесовским, см.: Свирежев, 1987. С. 12) был весьма высоким у фатьяновского населения, что обеспечивало связь между отдаленными регионами и способствовало поддержанию культурного единства.

Другой важной аналогией горшку с орнаментом № 31 из могильника Луцино-Газовик является горшок из ВолосовоДаниловского могильника, погребение 58 (Крайнов, Гадзяцкая, 1987. Табл. 29), по которому была получена радиоуглеродная датировка $3650 \pm 80$ (Ле-1044) ${ }^{9}$. Сходство орнаментов на сосуде из могильника Луцино-Газовик с горшком из Волосово-Даниловского могильника не такое полное, как с горшком из Мытищенского могильника.

Радиоуглероднье датировки для поселения РАНИС показывают весьма ранний возраст - в интервале 3900-4100 радиоуглеродных лет. Если доверять этим датам, то следует заключить, что процесс формирования специфического керамического комплекса фатьяновской культуры протекал очень быстро, и к середине III тыс. до н.э. особенности этого важнейшего компонента культуры уже полностью сформировались.

Серия молодых датировок в интервале 3600-3700 «радиоуглеродных лет» для образцов с поселения РАНИС-пойма (табл. 5) вызывает определенные сомнения. Фактически одни и те же образцы рассылались в разные лаборатории, и поздняя группа датировок была получена исключительно в киевской лаборатории. Можно предположить отклонение датировок киевской лаборатории, полученных по незначительным по объему образцов без применения AMS-технологии.

Поздняя стадия фатьяновской культурыл. В бассейне Москвы-реки имеются несколько могильников и единичные находки керамики на поселениях, которые могут быть отнесены к поздней стадии. Керамика поздних москворецких памятников характеризуется своеобразными чертами морфологии и орнаментации. Бортик на торце венчиков превращается в массивный валик, иногда двойной и тройной (рис. 30, 1, 3, 5), плечики становятся более пока-

\footnotetext{
9 Автор благодарен Г.И. Зайцевой (ИИМК РАН) за уточняющую информацию о месте отбора образца для датирования.
}

тыми. Орнаментация утрачивает «тонкую изящность» более ранних периодов. Мы видим широкие глубоко прочерченные горизонтальные линии - каннелюры, «шагающий» орнамент из попеременно наклонных линий по шейке венчика и обязательную орнаментацию верхней половины тулова, часто каннелюра проходит по «экватору» горшка. Ранние традиции получили новое выражение. Это хорошо видно по горшку из Истринского могильника. На его тулове нанесена полоса «косой сеточки» (рис. 30, 1). Этот орнамент был характерен еще для самых ранних шнуровых фатьяновских горшков, но теперь характер исполнения орнамента и место его нанесения другие. Важно подчеркнуть, что шнуровые оттиски все-таки присутствуют на этих горшках (рис. 28, 2, 3), хотя их место в орнаменте иное, чем в ранних сосудах. Теперь шнуровой оттиск почти не виден, шнур играл вспомогательную роль при создании валиков на венчике. В некоторых случаях шнур заменялся глубокими горизонтальными канелюрами. Керамика такого рода найдена на поселении Акатово (рис. 28, 6-8), стоянках в районе Тростенского и Заболоцкого озер (Сидоров, 2013. Рис. 4a, 4б), поселении Беседы (раскопки М.И. Гоняного, 20152016 гг $)^{10}$. На горшке из могильника Николо-Перевоз также имеется отпечаток шнура. Таким образом, в Москворечье традиции шнуровой орнаментации и традиции технологического использования шнуров в гончарстве не были полностью утрачены до самого финала фатьяновской культуры.

Можно предполагать, что на позднем этапе развития фатьяновской культуры население бассейна Москвы-реки не было однородным. Здесь, видимо, проживали и потомки первых колонистов, и люди, пришедшие из других регионов, скорее всего, из Ярославского Поволжья (так называемый «балановский зигзаг» вполне мог быть занесен именно оттуда, что доказывается комплексами ВолосовоДаниловского могильника).

Вопрос о датировке позднего этапа решается пока предварительно. Важное значение имеют данные, полученные при изучении поселенческого объекта ЗБС-4. Здесь, в толще стратифицированных отложений на конусе выноса из оврага, были найдены фатьяновские и абашевские находки (Кренке, 2014). Фатьяновский горизонт перекрыт абашевским, и для него получены радиоуглеродные датировки

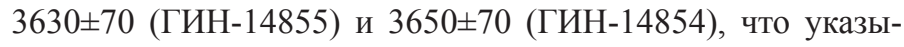
вает на рубеж III и II тыс. до н.э. (рис. 31). Эти даты полностью совпадают с другими датировками средневолжской абашевской культуры.

Таким образом, на рубеже III и II тыс. до н.э. фатьяновский этап в Подмосковье уже закончился. Есть некоторые косвенные данные (спорово-пыльцевые), позволяющие предварительно предполагать, что был некоторый хронологический «зазор» между фатьяновским и абашевским этапами заселения региона ${ }^{11}$. Так, в разрезе ЗБС-4 фиксировалось некоторое восстановление леса в промежутке между почвой 3 («фатьяновский» этап) и почвой 3а («абашевский»

\footnotetext{
${ }^{10}$ Автор выражает благодарность М.И. Гоняному за возможность ознакомиться с материалом.

${ }^{11}$ Автор благодарен Е.Г. Ершовой за консультации.
} 
этап). Хотя, конечно, это единичный случай, который может отражать лишь локальные особенности. Ошурковский поздний фатьяновский могильник, расположенный рядом с г. Тверь, демонстрирует «соприкосновение» фатьяновской и абашевской культур (Крайнов, 1986. Рис. 1, 3).

Данные о хозяйстве. Прогресс в накоплении данных о хозяйстве людей, оставивших памятники фатьяновской культуры, есть, но нельзя его признать значительным. Судя по данным, имеющимся для шнуровых культур Восточной Европы (Березанская, 1975), хозяйство у носителей этих культур было комплексным, включавшим и земледелие. На днищах сосудов из могильника Туринщина (культура шаровидных амфор) были отмечены зерна культурных злаков ячменя или пшеницы (Шмидт, 1992. C. 161; Shmidt, Szmyt, 1996. Fig. 4). При осмотре горшков из Туринщины в Смоленском музее, на них были обнаружены дополнительные отпечатки зерен (рис. 27), которые были определены как зерна культурных злаков (определение - Alice Telka, Оттава, Канада).

Кость на поселении РАНИС-пойма сохранялась очень плохо, лишь отдельные зубы поддавались определению. Эта информация, тем не менее, очень важна, ведь впервые появились надежные данные, не из погребальных комплексов, а из жилых горизонтов. Всего было передано в лабораторию чуть более 20 образцов, из которых лишь несколько поддавались определению. Были определены зубы домашней лошади, коровы, овцы/козы (Н.В. Сердюк, Е.Л. Дмитриева, ПИН).

Спорово-пальцевые данные подробнее рассмотрены в статьях Е.Г. Ершовой (Ершова, 2014; Ершова и др., 2013) и Е.А. Спиридоновой с соавторами (Спиридонова и др., 2008). Здесь же следует указать лишь на общий, пока еще предварительный вывод. Люди, создавшие в Москворечье фатьяновскую культуру, столкнулись в долине реки с еловым лесом. На водоразделах и по бортам долины произрастали смешанные, в том числе широколиственные леса. Воздействие людей на растительность фиксируется в споро-пыльцевых диаграммах незначительно, но все же некоторые признаки антропогенных изменений присутствуют. Можно отметить, что ближайшие окрестности поселений в пойме были расчищены от леса, здесь сформировался травянистый покров, включавший типичные рудеральные виды сорных растений. Имеются незначительные, едва уловимые признаки земледельческой деятельности. В том числе на поселении ЗБС-4 была обнаружена пыльца конопли и признаки пахотного горизонта в разрезе почвы.

На водоразделе пыльца из фатьяновского погребения (Луцино-Газовик) дает представление о естественном природном лесном комплексе суббореального времени. Имеются также некоторые признаки сведения леса и формирования рудерального травянистого комплекса возле могильника.

Bblвoдbl. 1. Исследования памятника протофатьяновского этапа ЗБС-5 проливает новый свет на механизм формирования фатьяновской культуры. Вероятно, ее сложение происходило в западной части Подмосковья, в том числе в пределах бассейна Москвы-реки. В качестве слагающих выступали разнородные группы, входившие в круг шнуровых культур и культуры шаровидных амфор. Процесс этот шел параллельно с формированием соседней среднеднепровской культуры. В зоне пограничья между культурами прослеживается контакт.

2. Начало процесса сложения фатьяновской культуры, видимо, существенно древнее, чем считалось исследователями в 1980-1990-е гг. Пока можно его относить к середине III тыс. до н.э., но не исключено, что датировку нужно будет сместить во вторую четверть этого тысячелетия. Полученные в Подмосковье новые данные хорошо «вписываются» в контекст более широких представлений о хронологии средней поры бронзового века в Восточной Европе. Кристиан Карпелан уже высказывал предположение, основанное на сопоставлении радиоуглеродных дат для культур родственных с фатьяновской, что последняя начинается примерно 2800 лет до н.э. (Carpelan, Parpola, 2001. Р. 86). Новые данные укрепляют эту гипотезу.

3. Процесс становления фатьяновской культуры был очень стремительным и занял одно-два столетия. В середине, третьей четверти III тыс. до н.э. в долине Москвыреки обитали люди, изготавливавшие горшки развитой стадии культуры. Явно прослеживаются тесные контакты с соседними, довольно удаленными областями, например, Ярославским Поволжьем.

4. Финал культуры относится к концу III тыс. до н.э. Этот период хорошо вычленяется по форме и, главное, орнаментации горшков, продолжавшей сохранять в переработанном виде традиции использования шнуров.

5. Нижние уровни долины, пойма Москвы-реки были местом интенсивного селитебного и хозяйственного освоения. В то же время существовали поселения на верхних уровнях рельефа, а также могильники на водоразделах, вблизи от расположенных там небольших водоемов и болот. В настоящее время можно сказать, что мы видим систему поселений, но не видим все звенья этой системы. По-прежнему актуален вопрос, где же находятся стационарные зимние поселения с охотничьим и боевым вооружением, топорами и прочими атрибутами «мужской культуры»? Скорее всего они находились на возвышенных местах, мысах коренных берегов. Видимо, к этому типу относиться поселение Царицыно 1.

6. Фатьяновское население обладало полным набором домашнего скота - лошади, крупный и мелкий рогатый скот, свиньи. Молочные продукты играли существенную роль в питании.

7. Спорово-пыльцевые и почвоведческие данные указывают на большую вероятность существования начатков земледелия.

8. Хозяйственная деятельность людей фатьяновской культуры не привела к созданию в долине Москвы-реки устойчивых культурных ландшафтов. Лесной покров быстро восстанавливался по мере ухода людей.

Абашевская культура. Редкая сеть абашевских памятников в долине среднего течения Оки и такого ее левого притока, как Протва, позволяла предполагать, что и на Москвереке могут быть обнаружены подобные находки (Ахмедов $u$ др., 2013; Луньков, Энговатова, 2003). И вот, наконец, первая находка была сделана на объекте ЗБС-4. Поселенческохозяйственный объект ЗБС-4 расположен на конусе выноса 
Бардинского оврага в тыловой части пойменного расширения правого берега Москвы-реки. Весьма важен верхний горизонт находок на памятнике, приуроченных к почве 3a, которая залегает на 15-20 см выше почвы 3. Их разделяет стерильный песчаный прослой. Почва За находится на глубине 60-70 см от современной поверхности. На ней найдено обширное скопление обожженных камней с углисто-золистым пятном в центре. В центре развала обожженных камней наблюдалось пятно концентрации золы и мелких угольков диаметром около 1,5 м (оно начало прослеживаться чуть выше слоя камней). Толщина слоя обожженных камней в этом месте достигала 15-20 см (рис. 33). Можно предполагать, что именно здесь находился центр всего объекта, давшего развал обожженных камней. По углям из центрального углисто-золистого пятна, как уже отмечалось выше, были получены две идентичные радиоуглеродные


Калиброванные значения этих датировок, определенные по программе OxCal (версия 3.10), равняются соответственно 2040-1880 гг. до н.э. (вероятность 55,8 \%) и 2140-1920 гг. до н.э. (вероятность 68,2 \%). То есть наиболее вероятное значение этих дат приходится на рубеж III и II тыс. до н.э.

В слое развала камней на границе центрального углистого пятна был найден венчик абашевского горшка. Это была единственная находка керамики во всем горизонте. Венчик имел дугообразный отгиб наружу, судя по которому можно считать, что форма горшка было «колоколовидной», что типично для абашевской культуры. В орнаментации венчика можно выделить следующие элементы: 1) ряд вертикальных насечек по внешней кромке; 2) горизонтальные параллельные линии в верхней части венчика; 3) горизонтальные «лесенки» под ними; 4) горизонтальные ряды мелких ямок диаметром 2-3 мм на тулове (Кренке, 2014). Все эти элементы типичны для орнаментации посуды средневолжской абашевской культуры (Большов, 2003. Рис. 11-13; Кузьмина, 1999; Пряхин, Халиков, 1987). А.Д. Пряхин приводит весьма обоснованные аргументы для отнесения всей средневолжской группы абашевских памятников к позднему этапу этой культуры (Пряхин, 1977). Можно отметить, что такой орнаментальный элемент, как «горизонтальные лесенки», встречается именно на средней Волге и Южном Урале, но не в верховьях Дона. Особенно важно, что имеются близкие параллели в посуде Пепкинского кургана, содержавшего коллективное захоронение (Халиков и др., 1966. Табл. 1-3). По типологическим признакам Пепкинский курган исследователи относят к позднему абашеву (Большов, 2003. С. 49). Очень важно, что для этого памятника имеются серийные радиоуглеродные датировки, с которыми можно сравнивать даты ЗБС-4.

Всего для Пепкинского кургана имеются девять датировок (Добровольская, Медникова, 2011), полученных в трех лабораториях (Хельсинки, Киев, Маннгейм). Крайние значения датировок всей серии - 3597 и 3853 лет, шесть датировок компактно распределились в интервале 3640-3690 лет от наших дней (некалиброванные даты).

Как видим, полученные на ЗБС-4 датировки идеально соответствуют наиболее надежной серии дат из Пепкинского кургана.
Таким образом, стратиграфические данные по раскопу ЗБС-4 и результаты радиоуглеродного датирования хорошо согласуются друг с другом. Можно с большой долей уверенности думать, что абашевская находка на ЗБС-4 относится именно к рубежу III и II тыс. до н.э.

В бассейне Москвы-реки абашевская находка на ЗБС-4 является первой. Всего же в междуречье Оки и Клязьмы известно еще восемь памятников (Луньков, Энговатова, 2003; Ахмедов и др., 2013). Ближайшими являются курган на р. Протве в районе д. Огубь, раскопанный В.А. Городцовым; курганы у д. Орлово на р. Воре, раскопанные Р.Л. Розенфельдтом, и курганный могильник Кухмарь на Плещеевом озере, раскопанный Д.А. Крайновым (Крайнов, 1962; Крайнов, Уткин, 1991).

На всех этих памятниках представлены те же самые орнаментальные элементы, что и на горшке с ЗБС-4. Вероятно, эти памятники синхронны и родственны друг другу, их можно обозначить как «западная группа».

Учитывая значительно большую концентрацию абашевских памятников на средней Волге в Марийской и Чувашской республиках логично было бы предположить, что колонизация шла именно оттуда, вверх по течениям рек Клязьма, Ока, Москва-река. Это предположение было ранее высказано С.В. Большовым (Большов, 2003. С. 53).

На сложности интерпретации указывают материалы наиболее представительного памятника западной группы Кухмарского могильника. Д.А. Крайнов и В.А. Уткин отмечают для него наличие ряда уникальных черт, не имеющих аналогов в абашевских памятниках средней Волги (Крайнов, Уткин, 1991. С. 151). Во всяком случае, важно подчеркнуть, что средневолжские и москворецкие находки абсолютно синхронны с точки зрения радиоуглеродного датирования. Возраст этих памятников, как выяснилось при радиоуглеродном датировании, на два-три столетия более древний, чем считалось ранее (Больщов, 2003), а именно XXI-XIX вв. до н.э., а не XVII-XVI вв. до н.э (Кренке, 2014).

Хозяйство. Согласно полученной на ЗБС-4 спорово-пыльцевой диаграмме, сведение леса в пойме в «абашевское время» было расширено сравнительно с фатьяновским периодом (Ериова, 2014).

Интерпретащия. К сожалению, пока трудно предложить какую-либо надежно обоснованную функциональную интерпретацию абашевского комплекса на ЗБС-4. Вообще надо отметить, что открытые очаги с камнями были неоднократно зафиксированы на территориях абашевских могильников. В том числе, они представлены на Кухмарьском могильнике. Доказательства того, что мы имеем дело с разрушенной постройкой, лишь косвенные. Можно предполагать, что сама сохранность центрального очажного места была бы невозможна (?), если бы его не защищала некая конструкция, следов которой проследить не удалось. Незначительное количество бытового мусора указывает на то, что хозяйственная активность была здесь спорадической.

Исследователи отмечали, что имеется ряд примеров, обосновывающих «соприкосновение» балановских и абашевских древностей (Большов, 2003. С. 50). В Москворецком регионе такие примеры пока не известны. Скорее всего хро- 
нологический «зазор» между поздними фатьяновскими и абашевскими памятниками был небольшим. Вероятно, верхнюю границу фатьяновских древностей надо определять примерно 3700 радиоуглеродных лет (XXII-XXI вв. до н.э.), a «абашевский цикл» приходится на интервал датировок 3650-3500, что при учете калибровки радиоуглеродных датировок указывает на XX-XVII вв. до н.э. (Ахмедов и др., 2013; Кренке, Ершов и др., 2013; Черньхх и др., 2011).

Серия радиоуглеродных датировок Старшего Никитинского могильника примерно на столетие моложе, чем даты Пепкинского кургана и ЗБС-4, они концентрируются вокруг значения 3550 лет (Амедов и др., 2013. Табл. 2). Таким образом, логичное, с географической точки зрения, предположение, что вектор абашевской колонизации был направлен вверх по течению Оки, а затем вверх по Москвереке, не находит подтверждения. Получается, что москворецкая находка немного старше окской.

Видимо, надо внимательнее отнестись к версии о возможных продвижениях абашевцев в разных направлениях, в том числе и на юг, и на запад из «северного центра» (условно - Кухмарь). Наличие самого западного следа абашевской культуры в фатьяновском могильнике Ошурковский возле Твери (Крайнов, 1986) указывает на раннее проникновение абашевцев в верхневолжский регион.

Абашевские находки западной группы синхронны погребениям шагарского могильника (Каверзнева, Фоломеев, 1998). Таким образом, можно предполагать, что абашевские колонизационные потоки обходили такие густо заселенные места Окско-Клязьминского междуречья как озерная Мещера, оставляя лишь след соприкосновения. В орнаментации керамики шагарской культуры можно усмотреть некоторые параллели с абашевской - «горизонтальные лесенки» (Каверзнева, Фоломеев, 1998. Рис. 5, 4). На стоянке Воймежная 1 был найден абашевский медный топор.

"Фатьяноидная" культура оказалась «на слуху» в последнее время (Сидоров, 2013). Наиболее существенный анализ материала этой культурной группы был выполнен О.С. Гадзяцкой (Гадзяцкая, 1992), а в недавнее время А.М. Жульниковым (Жульников, 2008) и М.А. Юшковой (Юшкова, 2011). Орнаментальные и морфологические особенности «фатьяноидной» керамики подробно описаны в вышеперечисленных публикациях. Керамика имеет органические примеси в тесте, форма венчика часто «желобчатая», орнаментация нанесена не только на внешнюю, но и на внутреннюю сторону. Очень характерны композиции гребенчатого штампа в виде горизонтальных зигзагов-волн. Вероятно, это символы воды, так как в некоторых случаях по орнаментальным волнам плывут «уточки» (рис. 57).

В бассейне Москвы-реки «фатьяноидная» керамика известна лишь на стоянках в районе Тростенского озера (Сидоров, 2013. Рис. 5). Название этой культурной традиции вытекает из гипотезы о ее происхождении. Исследователи в 1960-1980-е гг. (Н.Н. Гурина, А.Х. Халиков, О.С. Гадзяцкая, И.В. Гаврилова и др.) видели в этой керамике результат «гибридизации» фатьяновской культуры с местным субстратом (Гаврилова, 1983). Первым на противоречия этой версии указал В.В. Сидоров (Сидоров, 2011, 2013). Однако его пред- ложение переименовать данный комплекс в «липовский» кажется неудачным, так как стоянка Липовка не имеет представительной коллекции.

«Фатьяноидная» керамика ни разу не была встречена в фатьяновских погребениях. Нет каких-либо переходных форм. Этого совершенно невозможно представить, если видеть в данном керамическом стиле результат смешения фатьяновской традиции и местных аборигенных культур. Мы не знаем ни одного погребения «фатьяноидов». То есть погребальный обряд этой группы не имел ничего общего с фатьяновской культурой. Принципы орнаментации (двусторонняя) и моделирования венчиков (желобчатые) также совершенно не схожи с фатьяновскими. Таким образом, следует предполагать, что генетической связи «фатьяноидной» традиции с фатьяновской культурой нет.

«Фатьяноидная» керамическая традиция имеет огромный ареал распространения (рис. 53), от Волго-Окского междуречья до Эстонии, Онежского озера, Северной Двины (Жульников, 2008. Рис. 3). При этом она сохраняет удивительное единообразие.

Пока, к сожалению, есть лишь одна радиоуглеродная датировка по нагару с горшка с орнаментацией фатьяноидного типа и текстильными отпечатками на поверхности (Крийска, Лавенто, 2007; Kriiska et al., 2005). Это сосуд со стоянки Кулламяги (Эстония), давший дату $3605 \pm 40$ (Hela-755). При калибровке данная датировка указывает с наибольшей вероятностью (50,7 \%) на интервал 1980-1890 гг. до н.э., т.е. $\mathrm{XX} \mathrm{в.} \mathrm{до} \mathrm{н.э.}$

Можно предполагать, что «фатьяноидная» керамика была синхронна абашевской. Этому есть и другие подтверждения (см. далее).

Сходство признаков «фатьяноидной» керамики на удаленных друг от друга территориях свидетельствует об интенсивном обмене информацией внутри общности, где она производилась. Этому получены подтверждения. Так, при просмотре материалов стоянки Замостье 2 из раскопок 1991 г. был обнаружен горшок с орнаментом-знаком в виде двушипной стрелы с раздвоенным хвостом (рис. 54). Этот знак тождественен знаку на горшке со стоянки Сахтыш 1 (Гадзяцкая, 1992. Рис. 7, 3). Сходство настолько полное, что можно думать о том, что оба знака нанесены одним человеком. Расстояние между двумя пунктами 300 км. Скорее всего, «фатьяноидная» традиция возникла где-то в пределах ареала ее распространения (т.е. к северу от Москвы, в бассейне Верхней Волги и Клязьмы).

Данные о хозяйстве. Определение костей, собранных сотрудниками Звенигородской экспедиции в 2013 г. вместе с «фатьяноидной» и более поздней текстильной керамикой в русле реки Сулать (определения А.К. Каспарова, ИИМК), показало, что в наборе присутствуют в довольно большом количестве домашние лошади, коровы и свиньи, но преобладают дикие - лось, медведь, бобр и др. (табл. 6). Возможно, что «фатьяноиды» являлись мобильными скотоводамиохотниками-рыболовами. Важно отметить наличие довольно большого количества костей северного оленя.

Интерпретация. «Фатьяноидная» керамическая традиция, видимо, маркирует какой-то очень важный, яркий и 
короткий феномен этнической консолидации на огромной территории, который еще не получил должной оценки.

Москворецкий бассейн они занимали лишь частично, его северную часть. Долину Москвы-реки, видимо, контролировал кто-то другой, может быть, абашевцы?

В связи с последним предположением следует вернуться к рассмотрению гипотезы А.Л. Никитина о том, что «фатьяноидная» керамика - это дериват абашевской (Никитин, 1975. С. 137; 1976). Отмеченное А.Л. Никитиным сходство сосуда из кургана 13 абашевского могильника Кухмарь (Крайнов, 1962. Рис. 13. С. 59) с «фатьяноидными» горшками несомненно. Особенно важно подчеркнуть наличие знаков-изображений рыб на внутренней поверхности венчика, стилистически сходных со знаком на горшке со стоянок Замостье 2 и Сахтыш 1. То есть можно утверждать, что две культуры, абашевская и «фатьяноидная», соприкасались. Было ли между ними родство остается неясным. Абашевская орнаментация и формы горшков сильно отличаются от «фатьяноидных». На мой взгляд, «фатьяноидная» керамика - это результат очень мощного творческого импульса (а не «механического» смешивания разнородных традиций), создавшего нечто совершенно новое. Общество, которое генерировало этот импульс, затем какое-то время требовало сохранения традиции в неприкосновенности, поддерживало ее путем интенсивных внутренних контактов, простиравшихся на довольно значительные расстояния в сотни километров.

Культуры поздней бронзы. На территории Москворечья во второй половине II тыс. до н.э. прослеживаются несколько культурных традиций. Все они представлены единичными памятниками или отдельными находками. То есть материала недостаточно для того, чтобы представить полную картину, он напоминает разрозненную мозаику.

Венчик сосуда, орнаментированного рядами треугольных штампов, был обнаружен на Кунцевском городище в Москве (рис. 58, 2). На левом берегу Оки, сравнительно недалеко от устья Москвы-реки в Соколовой Пустыни при раскопках О.Ю. Потемкиной 2010 г. был найден гладкостенный горшок, орнаментированный треугольными ямками (рис. 58, 5). По форме и орнаментации его можно сопоставить с находками в верховьях Дона на поселении Красное 1, которое относится к раннесрубной культуре (Гак, 2011). Предположительная датировка, основанная на культурных параллелях, - вторая четверть II тыс. до н.э.

Рядом с устьем Москвы-реки, на территории СтароГолутвина монастыря, в 2008 г. при раскопках был найден гладкостенный горшок с резким перегибом тулова в верхней трети, орнаментированный в верхней части рядами узких вертикальных ямок-насечек (рис. 58, 1). Видимо, это один из вариантов позднебронзовой «тычковой» керамики, распространенной в бассейне среднего течении Оки. Отличие данного сосуда заключается в том, что ямки нанесены тонким инструментом.

На территории г. Подольска, на левом берегу р. Пахры, была исследована расположенная в пойме стоянка Подол 1 (Гак, Гоняный, 2007). Полученный материал уникален для Подмосковья. Основу комплекса составляла гладкостенная керамика с редкими глубокими круглыми ямками под вен- чиком и продолговатыми нарезками. Авторы раскопок трактуют данный комплекс как пережиточный поздняковский. Ближайшая аналогия - поздняковское поселение Октябрьское 5 на р. Упе в Тульской области (Екимов, 1992).

Таким образом, в нижнем и среднем течении Москвыреки, в бассейне р. Пахры в позднем бронзовом веке явно прослеживаются южные влияния и культурные связи.

Иная ситуация прослеживается в долине Москвы-реки выше г. Москвы. Обнаруженные здесь памятники относятся к иному культурному кругу, а именно заключительной фазе культуры текстильной керамики бронзового века (Кренке, Лазукин и др., 2010). Параллели, скорее, уводят на север, чем на юг. Здесь в районе г. Звенигорода были исследованы два сходных в культурном отношении поселения Дютьково (Олимп) и Дунино 3 (рис. 59). Остатки сходного памятника были изучены при раскопках на территории НовоИерусалимского монастыря. Комплекс кремневых орудий представлен, в первую очередь, стрелами, имеющими форму вытянутых треугольников с четко выделенными черешками (рис. 60, 1, 2). Найдены сверлины и обломки проушных каменных топоров. Имеются также перфораторы, отщепы-ножи со вторичной обработкой по краям, отбойники, серповидный нож, нуклевидные отщепы и сработанные нуклеусы. Керамика представлена текстильными и гладкостенными фрагментами (рис. 61, 1-9), орнаментированными ямками-жемчужинами, вдавлениями наклонной палочки (тычки), ямками треугольной формы в сочетании с гребенчатым штампом, ямками по всему тулову и венчику. В комплексе явно присутствуют разновременные компоненты. Наиболее ранними нужно признать формы с высоким прямым венчиком и расширенными округлыми плечиками. Характерная особенность - сплошное покрытие тулова ямками. Ямки-жемчужины, нанесенные с внутренней стороны, также можно признать характерными для культуры текстильной керамики позднего бронзового века. В то же время на обоих памятниках представлена толстостенная керамика с короткими венчиками, орнаментированная гребенчатым штампом. Она очень близка к находкам в древнейших слоях дьяковских городищ.

Находки единичных бронзовых предметов дают параллели в Старшем Ахмыловском могильнике, т.е. указывают на VIII-VII вв. до н.э. Эту дату подтверждают радиоуглеродные датировки, полученные для Дунино 3. Большинство из них имеет возраст около 2600 радиоуглеродных лет, что соответствует IX-VIII вв. до н.э. ${ }^{12}$

Интерпретация. Памятники финального бронзового века с текстильной керамикой и каменным инвентарем, расположенные на бровках высоких берегов в долине Москвыреки и Истры, могут рассматриваться как непосредственные предшественники культуры городищ железного века. Судя по данным, полученным при раскопках селища Веськово 1 на Плещеевом озере, а также учитывая особенности топографической приуроченности памятников, можно думать, что это долговременные поселения людей, занимавшихся скотоводством и земледелием.

\footnotetext{
${ }^{12}$ Автор благодарит А.Е. Кравцова за возможность ознакомиться с материалами раскопок и результатами датирования.
} 
Таблица 1. Статистика кремневого инвентаря из раскопа Звенигородской 1-й стоянки. Раскопки 2010 г.

\begin{tabular}{|l|l|l|l|}
\hline$№$ пlп & Наименование & Количество & Примечания \\
\hline 1 & Отщепы, их обломки и осколки & 1146 & \\
\hline 2 & Чешуйки & 937 & $198-$ из промывки почвы (к/с) \\
\hline 3 & Ножевидные пластинки и их обломки & 9 & \\
\hline 4 & Нуклевидные обломки & 4 & \\
\hline 5 & Ретушёр-отбойник & 1 & \\
\hline 6 & $\begin{array}{l}\text { Отщепы со следами работы или } \\
\text { с нерегулярной ретушью по краю }\end{array}$ & 12 & \\
\hline 7 & Скребки & 3 & \\
\hline 8 & Резцы & 3 & \\
\hline 9 & Ножи (отщепы и пластинчатые отщепы с ретушью по краям) & \\
\hline 10 & $\begin{array}{l}\text { Наконечники стрел листовидные с двусторонней обработкой } \\
\text { и их обломки и заготовки }\end{array}$ & 4 & \\
\hline 11 & $\begin{array}{l}\text { Наконечники копий и дротиков листовидные с двусторонней } \\
\text { обработкой и их обломки и заготовки }\end{array}$ & 3 & 9 \\
\hline Итого & из них орудий и отщепов со следами работы & $\mathbf{2 1 3 1}$ \\
\hline
\end{tabular}

Таблица 2. Радиоуглеродные датировки 1-й Звенигородской неолитической стоянки

\begin{tabular}{|c|c|c|c|c|}
\hline \begin{tabular}{|l|} 
Индекс \\
лаборатории \\
\end{tabular} & \begin{tabular}{|l|} 
Номер \\
полевой
\end{tabular} & Дата & $\begin{array}{l}\text { Калиброванная календарная } \\
\text { дата (вероятность } 1 \text { б) } \\
\end{array}$ & Паспорт \\
\hline UGAMS-7955 & 2 & $4960 \pm 30$ & $3775-3700 \mathrm{BC}(68,2 \%)$ & Почва 4 Орехи кв. 10, глубина -412-432 \\
\hline Ki-16752 & & $4920 \pm 100$ & $\begin{array}{l}3910-3870 \text { BC }(6,3 \%) \\
3810-3630 \text { BC }(59,3 \%) \\
3560-3540 \text { BC }(2,6 \%) \\
\end{array}$ & $\begin{array}{l}\text { Почва 4, глубина -489. } \\
\text { Угли и углистая масса }\end{array}$ \\
\hline Ki-16753 & & $6030 \pm 110$ & $5060-4770 \mathrm{BC}(68,2 \%)$ & $\begin{array}{l}\text { Почва 4, гумус, кв. В-8 вост. борт, } \\
\text { глубина }-480-500\end{array}$ \\
\hline Ki-16756 & & $4750 \pm 140$ & $3670-3360 \mathrm{BC}(68,2 \%)$ & $\begin{array}{l}\text { Почва 4а, гумус кв. В-8 вост. борт, } \\
\text { глубина }-380-400\end{array}$ \\
\hline
\end{tabular}

Таблица 3. Остеологический материал

1-й Звенигородской неолитической стоянки (определения Н.В. Сердюк)

\begin{tabular}{|l|l|l|}
\hline Таксон & Количество & $\%$ \\
\hline Meles meles (барсук) & 1 & 0,46 \\
\hline Martes sp. (куньи) & 2 & 0,93 \\
\hline Canidae (псовые) & 2 & 0,93 \\
\hline Castor fiber (бобр) & 12 & 5,63 \\
\hline $\begin{array}{l}\text { Arvicola terrestris } \\
\text { (водяная крыса) }\end{array}$ & 4 & 1,87 \\
\hline $\begin{array}{l}\text { Microtus arvalis } \\
\text { (полевка обыкновенная) }\end{array}$ & 1 & 0,46 \\
\hline Alces alces (лось) & 3 & 1,4 \\
\hline Sus scrofa (кабан) & 4 & 1,87 \\
\hline Aves indet. (птицы) & 6 & 2,81 \\
\hline Esox lucius (щука) & 2 & 0,93 \\
\hline Pisces indet. (рыбы) & 4 & 1,87 \\
\hline Неопределимые фрагменты & 170 & 80,74 \\
\hline Bсего & $\mathbf{2 1 3}$ & \\
\hline
\end{tabular}


Таблица 4. Статистика каменного инвентаря поселения РАНИС-пойма по итогам работ 2005, 2006, 2009 гг. (составлена И.Н. Ершовым)

\begin{tabular}{|c|c|c|c|c|}
\hline Тип изделия & 2005 г. & 2006 г. & 2009 г & Всего: \\
\hline Нуклеусы, нуклевидные обломки & 1 & 13 & 13 & $27(2 \%)$ \\
\hline Отбойники и ретушёры & - & 3 & 10 & $13(1,0 \%)$ \\
\hline Отщепы & 1 & 56 & 172 & $229(17,1 \%)$ \\
\hline Пластины & - & 6 & 7 & $13(1,0 \%)$ \\
\hline Из орудий по типам: & \multicolumn{4}{|c|}{ Процентное соотношение среди группы орудий труда } \\
\hline Отщепы со следами работы & 1 & 8 & 33 & $42(30,2 \%)$ \\
\hline Отщепы и пластины с ретушью & - & 4 & 17 & $21(15,1 \%)$ \\
\hline Перфораторы & $2(?)$ & 19 & 32 & $53(38 \%)$ \\
\hline Наконечники стрел & - & - & 1 & $1(0,7 \%)$ \\
\hline Изделия с выемкой & - & 2 & 1 & $3(2,1 \%)$ \\
\hline Вкладыши (?) & - & - & 1 & $1(0,7 \%)$ \\
\hline Долотовидные орудия & $1(?)$ & $1(?)$ & 2 & $4(3 \%)$ \\
\hline Шлифовальные плиты & - & - & 3 & $3(2,1 \%)$ \\
\hline Всего: & 15 & 607 & 713 & $1324(100 \%)$ \\
\hline
\end{tabular}

Таблица 5. Радиоуглеродные датировки для поселений бронзового века в пойме Москвы-реки

\begin{tabular}{|c|c|c|c|}
\hline Лабораторный индекс & Место отбора образца & Датировка & Калибровка \\
\hline \multicolumn{4}{|c|}{ Поселение РАНИС-пойма } \\
\hline ГИН-13777 & $\begin{array}{l}\text { Почва } 3 \text { гумус. } \\
\text { Шурф } 3 \text {, северный борт, верх +55 +65 }\end{array}$ & $4400 \pm 100$ & $\begin{array}{l}3320-3230 \text { BC }(15 \%) \\
3180-3150 \text { BC }(22 \%) \\
3120-2900 \text { BC }(50,9 \%)\end{array}$ \\
\hline $\mathrm{Ki}-13227$ & Раскоп 1 (2005 г.), основной углистый горизонт & $3590 \pm 70$ & $\begin{array}{l}2040-1870 \text { BC }(59,5 \%) \\
1850-1820 \text { BC }(4,5 \%) \\
1800-1770 B C(4,2 \%)\end{array}$ \\
\hline Ki-16755 & РАНИС-2009, участок 5, +95 +90, угли & $3650 \pm 100$ & $\begin{array}{l}2200-2170 \text { BC }(2,3 \%) \\
2150-1880 \text { BC }(65,9 \%)\end{array}$ \\
\hline ГИН-13776 & $\begin{array}{l}\text { Раскоп } 2 \text { (2006 г.), южная прирезка, низ основного } \\
\text { горизонта, глубина +95 +100, уголь }\end{array}$ & $3950 \pm 250$ & 2900 BC - 2050 BC $(68,2 \%)$ \\
\hline Hela-2538 & $\begin{array}{l}\text { РАНИС-2009, участок 3, глубина +89, } \\
\text { образец № 2, очаг }\end{array}$ & $4118 \pm 35$ & $2700-2620$ BC $(36,4 \%)$ \\
\hline UGAMS-7956 & РАНИС-2009, участок 5, очаг, глубина +81 & $4100 \pm 25$ & $2670-2570$ BC $(51,9 \%)$ \\
\hline \multicolumn{4}{|l|}{ Объект ЗБС-4 } \\
\hline UGAMS-10130 & Бровка, кв. 5, глубина -120 & $4040 \pm 25$ & $2630-2470$ BC $(95,4 \%)$ \\
\hline
\end{tabular}


Продолжение табл. 5

\begin{tabular}{|l|l|l|l|}
\hline Лабораторный индекс & Место отбора образца & Датировка & Калибровка \\
\hline Объект ЗБС-5 & 2012 шурф 1, кВ. 16 глубина -193 & $4114 \pm 38$ & $\begin{array}{l}2860(20,0 \%) 2810 \text { ВC } \\
2700(43,3 \%) 2580 B C\end{array}$ \\
\hline UOS 3728 & 2012 шурф 1, кВ. 15 углистое пятно, глубина -170 & $4290 \pm 80$ & $\begin{array}{l}3030(53,4 \%) 2860 \mathrm{BC} \\
2810(10,2 \%) 2750 \mathrm{BC}\end{array}$ \\
\hline ГИН-15408 & 2012 шурф 1, кВ. 15, глубина -177 & $4067 \pm 38$ & $2630(37,9 \%) 2550 \mathrm{BC}$ \\
\hline UOC-3729 & 2012 шурф 1, кВ. 8, глубина -170 & $4132 \pm 38$ & $2710(32,2 \%) 2620 \mathrm{BC}$ \\
\hline UOC-3730 & & & \\
\hline
\end{tabular}

Таблица 6. Состав остеологических остатков из русла реки Сулать на участке Сулать 1 (сборы 2013 г. Определения А.К. Каспарова)

\begin{tabular}{|c|c|c|}
\hline Вид & Количество костей & Анатомически набор \\
\hline Человек & 2 & Верхняя челюсть, коленная чашечка \\
\hline Лошадь & 2 & Ребро, заплюсневая \\
\hline Овца (?) & 1 & Локтев. \\
\hline Свинья или кабан & 5 & Череп, верхняя челюсть, нижняя челюсть \\
\hline Собака & 4 & Позв., верхний. зуб, локтевая, лучевая \\
\hline Сев. олень & 5 & Нижняя челюсть, бедро \\
\hline Кабан & 3 & Пяточная, метаподий, \\
\hline Лось & 58 (5 особей, в том числе одна молодая) & $\begin{array}{l}\text { Череп, нижний зуб, ребра, плечо, лучевая, } \\
\text { метаполий, фаланги, таз, бедро, б. берц, } \\
\text { запястные, пяточные, заплюсневая, метаполий }\end{array}$ \\
\hline Бобр & 38 & $\begin{array}{l}\text { Верхняя челюсть, нижняя челюсть, резцы, } \\
\text { позвонки, ребро, локтевая, лучевая, таз, бедро, б. берц., } \\
\text { таранная }\end{array}$ \\
\hline Куница & 5 & Нижняя челюсть, плечо бедро, таз \\
\hline Барсук & 3 & Нижняя челюсть, клык \\
\hline Росомаха & 1 & Нижняя челюсть \\
\hline Всего определимых костей & 172 & \\
\hline
\end{tabular}


ГЛАВА II

\section{ПАМЯТНИКИ РАННЕГО ЖЕЛЕЗНОГО ВЕКА (ДЬЯКОВСКАЯ КУЛЬТУРА) НА МОСКВЕ-РЕКЕ}

ПАМЯТНИКИ ПЕРЕХОДНОГО ЭТАПА ОТ БРОНЗОВОГО ВЕКА К ЖЕЛЕЗНОМУ И ВОЗНИКНОВЕНИЕ ГОРОДИЩ НА МОСКВЕ-РЕКЕ

B результате проведения раскопок на стратифицированных памятниках - городищах Селецком, Дьяково, Саввино-Сторожевском, а также селищах Чертов городок и Царицыно 1 - появилась возможность выделить для Москворечья комплекс керамики и вещей, относящихся к периоду ранее V в. до н.э. (Краснов Ю.А., Краснов Н.А., 1963; Кренке, 1995; Крис и др., 1984). Этот комплекс находок еще не имеет признаков, характерных собственно для дьяковской культуры (см. далее), и может быть обозначен как комплекс начального этапа железного века, культурная принадлежность которого пока не определена. Термин «начальный железный век» для близкого региона бассейна верховий Западной Двины был предложен А.М. Микляевым (Микляев, 1995) и вполне приемлем для памятников ВолгоОкского междуречья.

В качестве индикаторов древностей начального периода железного века можно признать гладкостенную либо текстильную керамику, орнаментированную гребенчатым штампом или тычками, выполненными палочкой, поставленной под углом к стенке горшка.

Подобные находки встречались на целой серии дьяковских памятников, например, на городищах Мамоново (Качанова, 1954. Рис. 12), Щербинском (Розенфельдт, 1974), Кунцево и др., но из-за нечеткости их стратиграфической привязки оставались неясности в датировках, что нашло отражение в итоговой таблице развития керамического комплекса дьяковской культуры, составленной И.Г. Розенфельдт (Розенфельдт, 1974. Рис. 43).

Нужно сказать, что керамика, орнаментированная наклонными тычками и гребенчатым штампом, имеет широкий ареал распространения. Она была встречена в нижнем слое городища Анашкино, расположенном на Жижицком озере на юге Псковской области (Короткевич, 2005), на городище Подгай на р. Торопе (Станкевич, 1960. Рис. 11), на городище Городок на р. Ловать (Орлов, 1962). Таким образом, бассейн p. Ловать является приблизительной западной границей памятников начального железного века со сходной керамикой. Далее на северо-запад, в бассейне Волхова в первой четверти I тыс. до н.э. были распространены памятники так называемого «волховского типа», выделенные в особую группу М.А. Юшковой (Юшкова, 2011). Керамика памят- ников «волховского типа» имеет специфические виды орнаментов, не встречающиеся в Подмосковье.

Если обратиться к памятникам, расположенным на восток от бассейна Москвы-реки, то можно указать, что керамика с наклонными тычками была найдена на Зареченской стоянке на р. Шерне (раскопки Е.И. Дикова 1968 г.). Е.И. Диков и В.М. Раушенбах употребляли для описания керамики данного типа термин «преддьяковская» и рассматривали ее как позднейшую фазу развития керамики поздняковской культуры.

Гладкостенная керамика с орнаментом, выполненным наклонными тычками и гребенчатым штампом, характерна для памятников бассейна средней Оки.

Тычковую керамику, встреченную на правобережье Оки, называют «керамика бондарихинского типа» (Археология Мордовского края, 2008. С. 207).

Большую близость к москворецким материалам обнаруживают комплексы Климентовской стоянки на левом берегу Оки возле г. Спасска (Третьяков, 1966) и селища Дубровичи 1 (Иванов, 2011). Б.А. Фоломеев отмечал близость климентовской керамики к бондарихинской, но подчеркивал и существующие различия (Фоломеев и др., 1988). С этим замечанием Б.А. Фоломеева нельзя не согласиться. Бондарихинская керамика имеет совершенно другие формы горшков, наклонные тычки для нее типичны, но это не единственный вид ее орнаментации ${ }^{1}$.

Аналогии рассматриваемому комплексу керамики имеются на Шишкинском городище, которое расположено в бассейне р. Прони (Фоломеев, 1994). Этот памятник важен тем, что для него была получена ранняя датировка $2920 \pm 60$ лет (ГИН-5367). Аналогии текстильной керамике с наклонными ямками есть и на городище Тюков городок в Мещере в верховьях р. Пры (Фоломеев, 1975a; 1993), для древнейшего слоя которого имеются датировки $2700 \pm 40$



На городищах каширского течения реки Оки, на ее правом берегу также встречена керамика, орнаментация которой находит прямые параллели в долине Москвы-реки (Сидоров, 2004. Рис. 15; Лопатина, 2005. Рис. 3; 2009). Причем здесь доминирует гладкостенная керамика с гребен-

\footnotetext{
1 Автор благодарит сотрудников института археологии НАН Украины, обеспечивших в 2012 г. возможность ознакомиться с материалами раскопок 1953 г. стоянок Бондарихинская и Малые Будки, проведенных В.А. Ильинской и Д.Я. Телегиным.
} 
чатым орнаментом, а текстильная керамика почти не встречается (Лопатина, 2009). А.С. Сыроватко оправданно отмечает наличие сходства керамики на памятниках в ареале среднего течения р. Оки от устья Прони до устья Лопасни, а также по нижнему течению р. Москвы от устья до г. Москвы (Сыроватко, 2013).

Вероятно, границы этого ареала были несколько шире, чем показано в статье А.С. Сыроватко. Гладкостенная керамика с несколькими рядами наклонных тычков по тулову, аналогичная керамике селища Царицыно 1 была встречена на верхней Оке на стоянке Воронино (Грудинкин, 2013. Рис. 5, 2), а также при раскопках у с. Гремячее (Бульчев, 1899).

Далее на юг, на берегу р. Воронеж расположено Пекшевское городище, в нижнем слое которого была найдена гладкостенная и текстильная керамика. Орнаментация гладкостенной посуды Пекшевского городища ямками и тычками находит аналогии в басс. Москвы-реки. Данный керамический комплекс А.П. Медведев датирует на основании стратиграфических данных VII - началом VI в. до н.э. и связывает его с «подстилающим субстратом», общим как для дьяковской, так и городецкой культуры (Медведев, 1999. С. 37).

Требуется детальное рассмотрение москворецких материалов для выявления их специфических особенностей на фоне сходных памятников, занимающих обширный ареал от верховьев Западной Двины до Средней Оки и бассейна Верхнего Дона.

Всего в пределах бассейна Москвы-реки известно 40 поселений (городищ и селищ), где была зафиксирована керамика, орнаментированная наклонными тычками и гребенчатым штампом (рис. 63). Они расположены главным образом в среднем течении р. Москвы и в долине р. Пахры. В верховьях Москвы-реки, в бассейнах рек Руза и Озерна памятники начального железного века единичны (выше по течению Москвы-реки от городища Каринское известен лишь одни пункт - городище г. Можайска 2 ).

Лишь совсем недавно были проведены раскопки памятников, которые дали материалы, вероятно, непосредственно предшествующие комплексам из древнейших слоев городищ дьякова типа. Это поселения Дютьково («Олимп»), Дунино 3, которые были описаны в предшествующей главе. Вероятно, эти памятники эпохи финальной бронзы генетически связаны с рассматриваемой хронологической группой поселений начального этапа железного века. Не случайно Звенигородский участок бассейна Москвы-реки, начиная от с. Успенского и до с. Луцино, демонстрирует высокую плотность памятников начального железного века. Памятники расположены как по берегам самой Москвы-реки, так и на впадающих в нее малых притоках, таких как реки Вяземка и Сторожка.

Преемственность в культуре памятников, относимых $\kappa$ бронзовому веку и к начальной фазе железного века, наблюдается прежде всего по керамике. Различия проявляются в наличии/отсутствии кремневой индустрии, следов изготовления и использования каменных топоров. Фактически

2 Раскопки Б.Е. Янишевского, 2005 г. (раскоп 5, яма 5). Автор благодарит Б.Е. Янишевского за предоставление материалов. можно говорить о пока не получившей названия культуре финальной бронзы - начального железного века, развитие которой заняло около 400-500 лет (отчасти сходным, но существенно более ярким явлением была кобанская культура на Кавказе). Термины «культура текстильной керамики» и «культура тычковой керамики» для данного феномена не подходят, так как речь идет о культуре, являющейся синтезом этих двух культурных традиций. Более точен, хотя и не очень благозвучен термин «преддьяковская культура».

Структура расселения. В бассейне Москвы-реки существовали крупные центры, такие как городища Селецкое, Мамоново, Знаменское, Успенское, Дунино, Щербинское, селище Дубровицы 2, Царицыно 1. Перечисленные крупные памятники сравнительно редко (с интервалом 10-20 км) располагаются в бассейне нижнего и среднего течения Москвыреки и по р. Пахре. Наряду с ними для данного периода типичны небольшие мысовые поселения (иногда укрепленные), площадь которых иногда не превышает всего несколько сотен квадратных метров (городища Тушинское 2, Луцино 2, Дютьково,).

Вокруг крупных центров начали формироваться селитебно-хозяйственные комплексы, описанные по материалам Дьякова городища и его округи (Кренке, 2011). Об этом свидетельствует наличие групп памятников, расположенных очень близко друг к другу: округа городища Дунино; нижнее течение р. Сторожки в пределах Звенигорода (Кренке, Лазукин и др., 2010).

Хронологические рамки. Нижняя хронологическая граница описываемого пласта древностей определяется условно на основании единичных радиоуглеродных датировок. Определение верхней хронологической границы более надежно.

Информация о хронологическом горизонте, которому соответствуют находки из погребенной почвы на городище Дьяково и раскопа 1 на селище Чертов городок, существенно дополнилась за последние годы. Целая серия памятников этого времени исследовалась в среднем течение Москвы-реки, особенно в Звенигородском регионе (городища у д/о «Связист», Знаменское, Дютьково, Луцино 2, селища Дунино-4, Горышкино 3) и в г. Москве (селище Царицыно-1).

Теперь имеется серия радиоуглеродных дат, образующих компактную группу (табл. 7). В силу того, что на калибровочной радиоуглеродной кривой дата 2500 лет приходится на «плато», калиброванные даты этого возраста сильно «растягиваются». Почти с равной вероятностью они могут относиться к любому из столетий в интервале VIII-VI вв. до н.э. Даты возрастом 2600 лет попадают уже на «нормальный» участок калибровочной кривой и дают узкий интервал около рубежа IX-VIII вв. до н.э. Пока, к сожалению, таких дат мало ${ }^{3}$. Однако важно подчеркнуть, что имеются две даты с


связанные с «постпоздняковским» комплексом финальной

\footnotetext{
${ }^{3}$ Серия из трех датировок в интервале возраста 2600-2660 была получена на селище Дунино 3, но эти данные пока не опубликованы, а лишь были представлены на Подмосковном семинаре в ИА РАН (доклад А.Е. Кравцова в 2012 г.).
} 
бронзы (Гак, Гоняныци, 2007. С. 16). Калиброванное календарное значение этих дат укладывается в интервал конец XI-начало IX в. до н.э. «Постпоздняковские» находки с поселения Подол 1 , вероятно, более древние, чем описываемый комплекс начального железного века.

Таким образом, можно предположить, что нижняя хронологическая граница культуры начального железного века приходится на IX в. до н.э.

Верхняя хронологическая граница приходится на V в. до н.э., исходя из радиоуглеродной хронологии нижнего слоя Дьякова городища. Поэтому можно предполагать, что комплекс находок начального железного века с площадок городищ датируются концом IX - VI в. до н.э.

«Протогородища». Установлено, что в этот период появляются небольшие поселения, укрепленные рвами, предшественники будущих городищ. На двух таких памятниках - селище Царицыно 1, городище Дютьково раскопаны небольшие рвы (глубина - 1-1,5 м, ширина - 4-5 м) с напольной стороны (Кренке, 2008; Кренке и др., 2010). Данные о валах отсутствуют. В случае с городищем Дютьково (рис. 64) можно предполагать, что вала не было.

\section{Характеристика керамики - процесс культурной интеграции}

Характеристика керамики будет дана по коллекциям четырех памятников: городища Дьяково, Знаменское, Луцино 2, селище Царицыно 1.

Предваряя описание, следует отметить, что в ходе работы создалось впечатление о наличии в комплексах двух разновременных компонентов - более раннего (керамика с наклонными тычками) и более позднего (с гребенчатым штампом). Окончательных доказательств, подкрепленных стратиграфией, пока получить не удалось, но некоторые аргументы в пользу данного предположения все же есть (см. далее). Вероятно, был период, когда оба типа керамики сосуществовали. Аналогичная ситуация была описана А.П. Медведевым при работе со сходным материалом Пекшевского городища (Медведев, 1999. С. 36).

Коллекция керамики Дьякова городища из погребенной под культурным слоем почвы (раскопки 1981-1984 гг.) состоит из 265 фрагментов. Целых форм в коллекции нет, есть лишь несколько сравнительно крупных фрагментов. Все сосуды из погребенной почвы относятся к горшкам. Максимальное расширение приходится на верхнюю часть тулова. Короткий венчик обычно отогнут наружу, иногда он почти прямой. У некоторых горшков выделены плечики. По И.В. Ислановой, данная керамика, имеющая s-видную профилировку венчика объединена в группу 3 (Исланова, 2008). О.А. Лопатина классифицировала формы сходных горшков изгруппы каширских городищпо методике А.А. Бобринского, когда сосуд рассматривается как совокупность элементарных функциональных частей. По О.А. Лопатиной (Лопатина, 2009), сосуды, аналогичные керамике из погребенной почвы Дьякова городища, объединены в группы 1 и 2 (губа+щека+плечо; губа+шея/щека+плечо). Керамика из погребенной почвы делится на гладкостенную и текстильную.
На некоторых гладкостенных фрагментах видны бороздчатые следы сглаживания гребенчатым инструментом. Иногда такую керамику ошибочно называют штрихованной, что вносит путаницу в терминологию. Характерны «стежковые», по классификации И.Л. Черная (Чернай, 1981. C. 72), и ниточно-жгутовые отпечатки. Причем в ряде случаев можно было отчетливо проследить, что параллельно расположенные «жгуты» были организованы в «систему», соединялись переплетающими их по диагонали более тонкими нитями. Наиболее детально подобные отпечатки были изучены Б.А. Фоломеевым (Фоломеев, 1998). Встреченные на Дьяковом городище образцы соответствуют отпечаткам, классифицированным Б.А. Фоломеевым как тип 4 (ниточно-жгутовые) и тип 5 (ниточно-шнуровые). Эксперименты, проведенные Байбой Думпе, показали, что сходные оттиски получаются при прокатке по поверхности сосуда шнура, сплетенного из нескольких нитей (Dumpe, 2006). К аналогичным выводам пришла и О.А. Лопатина (Лопатина, 2009). В очень редких случаях текстильные отпечатки заходят на внутреннюю поверхность венчика (Селецкое городище, коллекция Бронницкого краеведческого музея).

Соотношение керамики с различными типами обработки поверхности представлено в таблице 8.

Керамика из погребенной почвы Дьякова городища орнаментировалась преимущественно «наклонными тычками» (вдавления наносились предметом типа узкой щепки, поставленной под углом к стенке сосуда) и отпечатками гребенчатого штампа. Круглые ямки, выполненные предметом, поставленным перпендикулярно стенке сосуда, более редки.

Об орнаментальных композициях из-за малочисленности фрагментов судить трудно. Ясно лишь, что орнамент, выполненный техникой наклонных тычков, наносился преимущественно на перегибе плечиков под венчиком. Тычки образовывали один или два ряда. Характер оттисков, выполненных гребенчатым штампом, позволяет допустить, что штамп был округлой формы и прокатывался по поверхности сосуда. В результате в центре оттиска ямки более глубокие, а по краям постепенно сходят на нет. Возможно, для этого использовались роговые «грузики» (предположение O.А. Лопатиной). Отпечатки штампа обычно образовывали несколько параллельных линий, расположенных под острым углом к горизонтальной поверхности. Характерно также подчеркивание штампом перегиба шейки, отпечатки штампа образуют горизонтальную линию. От этой линии под острым либо под прямым углом отходили вниз дополнительные оттиски.

Коллекция керамики начального этапа железного века с селища Царицыно 1 насчитывает 334 фрагмента (рис. 6668). Вся керамика текстильная. Горшки имели плоское дно и отогнутый наружу s-видный венчик. По пропорциям и общей форме выделяются две группы горшков. Первая округлобокие горшки невысоких пропорций, дно без закраины; вторая - горшки более высоких пропорций, нижняя часть в виде усеченного конуса, дно имеет закраину. Тесто у всех текстильных горшков плотное, включает дресву. Отпечатки «текстиля» есть только на внешней поверхности сосудов. Иногда создается впечатление, что отпечатки 
оставлены отдельными нитями или каким-то штампом, однако при изменении направления освещения становится ясно, что отпечаток на керамике имеет сетчатую структуру. На поверхности черепков иногда имеются следы вторичного сглаживания, что убеждает в технологической природе текстильных отпечатков. Иногда видно, что текстильный отпечаток более рельефный на участках углублений на внешней поверхности. Керамика имеет «узнаваемую» орнаментацию, отличающую ее от текстильной керамики городищ дьякова типа третьей четверти I тыс. до н.э. Чаще всего встречаются ямки-вдавления (тычки) прямоугольной формы, нанесенные на плечики горшка с помощью палочки (?), приложенной под острым углом к стенке горшка. Также характерен орнамент в виде круглых ямок с плоским дном, нанесенных инструментом, поставленным перпендикулярно стенке. Ямки расположены горизонтальными рядами в верхней части сосуда, начиная с «шейки» (перегиб от венчика к плечикам). Оттиски гребенчатого штампа также встречаются, но реже, чем тычки. Особенность оттисков гребенчатого штампа не совсем ровные края ямок, некоторая нечеткость формы. Возможно, - это индивидуальные особенности, обусловленные износом орнаментира.

На городище Луцино 2 были прорезаны «миниатюрные» вал и ров на склоне и в тыльной части поймы, примыкающей к склону городища, были выкопаны шурфы (рис. 69), давшие коллекцию сравнительно однородной керамики, всего около 120 фрагментов (рис. 70). Фрагменты с текстильными отпечатками составляют около 30 \%, остальные - гладкостенные. На некоторых видны следы «бороздчатого сглаживания», выполненного гребенчатым штампом. Орнаментация в виде наклонного тычка встречена один раз, круглые плоские ямки - два раза, отпечатки гребенчатого штампа - десять раз. Профиль венчиков почти вертикальный, слегка отогнут наружу, имеется резкий перегиб при переходе к плечику. Некоторые фрагменты были сильно окатаны. Можно предположить, что данный комплекс - самый поздний из трех вышеописанных, так как орнаментация в виде наклонных тычков на городище Луцино 2 редка.

В коллекциях, полученных из древнейших слоев городищ дьякова типа, нет ни одного собранного до полного профиля горшка, орнаментированного наклонными ямками, зато есть серия целых горшков с гребенчатым штампом. Есть керамические комплексы (городища Знаменское, Щербинское, Дунино, селище Дубровицы 2 и др.), где почти нет «наклонных ямок», но многочисленны фрагменты с гребенчатыми штампами. Эти наблюдения убеждают в том, что традиция орнаментировать керамику гребенчатым штампом существовала дольше (по крайней мере, в бассейне Москвыреки), чем традиция орнаментации наклонными ямками. Видимо, к VI в. до н.э. именно орнаментация гребенчатым штампом стала доминирующей традицией на городищах дьякова типа.

Наиболее полная серия форм горшков с орнаментацией гребенчатым штампом была получена при раскопках Знаменского городища (Разуваев, 2012). Ведущим типом горшков являлись сосуды с усечено-коническим туловом, хорошо выраженной закраиной днища, с крутым перегибом плечиков и прямостоящим венчиком, отогнутым вверх от линии шейки (рис. 124). Высота венчика довольно сильно варьирует: в некоторых случаях он совсем короткий, в других - довольно высокий, покрыт несколькими горизонтальными рядами гребенчатого штампа. Более редкий тип горшков такой же усечено-конической формы, у которых от максимального расширения плечиков идет вверх высокий венчик, скошенный внутрь, шейка горшка совсем не выделена. Есть также округлобокие горшки, плечики которых почти не выражены с коротким, чуть отогнутым вверх или наружу венчиком. Среди горшков, орнаментированных или обработанных гребенчатым штампом (поверхность с бороздчатым сглаживанием), имеется группа, у которой как бы отсутствует верхняя лента. Конструирование этих горшков было завершено на уровне максимального расширения, и венчик, совершенно не выделенный, был чуть загнут внутрь (Розенфельдm, 1974. Рис. 43, 15, 21). Эта форма горшков получила большое распространение в более позднее время и указывает тем самым на культурную преемственность.

Пытаясь определить происхождение и место москворецких древностей начального железного века в системе синхронных памятников, следует отметить следующее. Для памятников финала бронзового века, таких как поселения Дютьково, Дунино 3, стоянки Польцо, Плещеево III и Веськово 1 на оз. Плещеево, характерна керамика с текстильными отпечатками на поверхности, гребенчатым штампом и круглыми ямками в несколько рядов, ямками с внутренней стороны, образующими на внешней стороне «жемчужины» (Никитин, 1975; 1976; Вишневский, 1990).

На памятниках со слоями эпохи финальной бронзы, расположенных к востоку от Москвы-реки, типична керамика с текстильной поверхностью, орнаментированная круглыми ямками и наклонными тычками, гребенчатый штамп редок. Это Тюков городок (Фоломеев, 1975a), Зареченская стоянка на р. Шерне (Диков, 1968). Южнее, на берегах Оки была распространена керамика с гладкой поверхностью.

Таким образом, комплексы керамики памятников начального железного века, исследованных на Москве-реке, демонстрируют смешение нескольких традиций: 1) гладкая керамика + наклонные тычки; 2) гладкая керамика + гребенчатый штамп; 3) текстильная керамика + наклонные тычки; 4) текстильная керамика + круглые ямки + гребенчатый штамп. Такое смешение традиций соответствует срединному положению памятников в бассейне Москвы-реки по отношению к памятникам Оки, Мещеры, бассейну Верхней Волги. Можно предположить, что в бассейне Москвы-реки на рубеже бронзового и железного веков шел процесс культурной интеграции.

\section{Вещевой комплекс памятников начального этапа железного века}

Отметим находки кельтов меларского типа. Один был найден на Успенском городище Р.Л. Розенфельдтом, другой обнаружен на селище Горышкино 3 А.В. Алексеевым (расстояние между двумя этими пунктами менее 2 км).

Серией представлены булавки. Это фрагмент стержня 
бронзовой булавки квадратного сечения найденный в погребенной почве на городище Дьяково (рис. 121, № 341-81). Тип булавки не определим из-за отсутствия навершия. Подобные изделия были широко распространены в «скифоидных» городищах лесостепной зоны в Курской области (Пузикова, $1981 ; 1997)$ и севернее, в Тульской области (Изюмова, 1967. Рис. 2).

В погребенной почве на городище Дьяково был обнаружен фрагмент створки разъемной глиняной формы для отливки булавки с двуспиральным навершием. На внутренней поверхности сохранилось изображение двух смыкающихся спиралей диаметром 15 мм каждая и небольшое углубление между ними, видимо, для стержня булавки. Негатив изделия был получен путем отпечатка модели в глине. Выпуклая скругленная внешняя поверхность обломка свидетельствует о том, что он представлял собой фрагмент верхней створки формы. Образец обнаруживает большое сходство с формами для отливки браслетов (см. далее) по составу исходного сырья (ожелезненная глина с естественной примесью слюды, пылевидного и мелкого песка) и по характеру искусственной примеси (навоз в концентрации 20-25\%).

Аналогии подобным булавкам есть в древностях конца II тыс. до н.э - VII в. до н.э. Восточной Европы и Северного Кавказа (Смирнова, 2006. Рис. 5; Патрушев, 1984. Рис. 25; Козенкова, 1977; 1998. С. 64). Бронзовая булавка, очень похожая на оттиск в форме с Дьякова городища, была найдена на Днепро-Двинском городище Дроветчино на верхнем Днепре (Шмидт, 1992. Табл. 11, 4).

На городище Дютьково была найдена биметаллическая булавка (рис. 65) с железным стержнем и бронзовыми двуспиральными украшениями (Кренке, Лазукин и др., 2010). Аналогичное навершие железной булавки найдено на селище Веськово 1 на Плещеевом озере (Вишневский, 1990).

В.С. Патрушев предполагал, что подобные булавки имеют истоки в «кобанско-колхидских древностях» (Патрушев, 1984. С. 23).

На Дьяковом городище была найдена плоская бронзовая подвеска, по форме близкая к треугольной со скругленными углами (рис. 121, № 879-84). Аналогичные подвески встречены на Днепро-Двинском городище у д. Анашкино на Жижицком озере (Короткевич, 2004. Рис. 34, 5-7). Автором раскопок они отнесены к третьей четверти I тыс. до н.э. Однако керамика, сопровождавшая эти находки (короткий профилированный венчик, орнаментация гребенчатым штампом), близка к керамике из погребенной почвы Дьякова городища и, вероятно, датируется второй четвертью I тыс. до н.э.

На наличии связей населения Москворечья с кругом лесостепных культур в VII-VI вв. до н.э. ранее акцентировал внимание К.А. Смирнов (Smirnov, 1984). Факт контактов подтверждается, в частности, находками ранних двухлопастных бронзовых втульчатых стрел в пределах ареала памятников дьякова типа на Саввино-Сторожевское городище (сборы 2003 г., коллекция ЗИАХМ), Ростиславле, Зарудне, Заборье (Городцуов. 1933. Рис. 11; Медведь, 2007. С. 56; Сыроватко, 2009. С. 152).

В слое погребенной почвы на городище Дьяково были найдены шесть фрагментов глиняных литейных форм, предназначавшихся для отливки бронзовых «браслетов» диаметром 12-14 см с круглым сечением размером 5-7 мм (Кренке, 2011. Рис. 52). В кавычки слово браслеты взято потому, что диаметр 13-14 см в большей степени соответствует диаметру гривны. Аналогичные литейные формы известны на памятниках I тыс. до н.э. в Литве (Luchtanas, 1981. S. 8, 9. Fig. 3, 4; Grigalavičiene, 1986. Fig. 24; 1992. Fig. 12), Латвии (Дайга, 1960. С. 79, 81; Graudonis, 1989. Tab. XXXV; Vasks, 1994. S. 121, 123), Эстонии (Indreko, 1939. S. 35; Vassar, 1939. S. 78, 79, fig. 43,44; Lang, 2007. Fig. 52), Карелии, Финляндии (Фосс, 1952. С. 95, 99, рис. 53; Манюхин, 1996. С. 234, рис. 58, 9), Белоруссии (Егорейченко, 2006. Табл. 39), на территории современных Псковской и Тульской областей, на Верхней Волге (Третьяков П.Н., 1976. С. 208; Изюмова, 1967. Рис. 5, 1; Смирнов, 1992. С. 52).

В Москворечье, кроме Дьякова городища, аналогичные формы известны еще на Щербинском городище (Дубынин, 1974. Табл. XVII, 5; Смирнов, 1974. С. 68, 88, Табл. IX, 2).

Сами бронзовые браслеты, круглые в сечении, были найдены на Москве-реке на городище у дома отдыха «Связист» (рис. 122, 2) в черте г. Звенигорода (Нефёдова, Янишевский, 1990) и Селецком; Щербинском городище на р. Пахре; на правом берегу Оки в пределах Московской области - на городищах Мутенковском (Сидоров, 2004. С. 115), Старшем Каширском и Свиридоново III (Сыроватко, Сапрыкина, 2011). Возможно, что некоторые из этих браслетов относятся к более позднему периоду. Важно отметить, что на городище Свиридоново III был зафиксирован культурный слой с керамикой, орнаментированной гребенчатым штампом и наклонными ямками-тычками.

На склоне городища Дютьково была найдена бронзовая нашивка-лунница (рис. 65). Близкие вещи были найдены в Старшем Ахмыловском могильнике (Патрушев, 1984. Рис. 26, 1), который датируются VII-VI вв. до н.э. Аналогию в этом могильнике находит и коническая подвеска с селища Дунино 3 (Патрушев, 1984. Рис. 26, 34).

Вероятно, к древнейшим находкам относится бронзовая рукоять с Мамонова городища. На этом же городище найдена близкая по форме костяная рукоять. На костяной рукояти имеется гравировка (рис. 93, 96), изображающая птицу (глухарь?) и лошадку (Качанова, 1954. Рис. 22а). Изображение лошадки находит параллели в бронзовых миниатюрных изделиях, встреченных в Смоленской, Курской областях и на городище Свиридоново в Московской области (Обломский $и$ др., 2012; Шпилев, 2012). К сожалению, возраст этих подвесок-коньков пока остается не выясненным.

По-видимому, к комплексу инвентаря, характерного для начального этапа железного века, следует отнести удлиненные костяные одношипные стрелы ранней группы (селище Дубровицы 2, Дьяково городище), а также роговые грузики (рис. 98), возможно, использовавшиеся и как орнаментиры для керамики (городища Щербинское, Круглица).

Имеется экземпляр глиняного рогатого кирпича (городище Знаменское), который, судя по наличию орнаментации гребенчатым штампом, следует отнести к начальному железному веку. Последняя находка очень важна, она фиксирует 
появление того «образа жизни», который был так характерен для населения городищ дьякова типа. Рогатые кирпичи являлись потом непременным атрибутом интерьеров жилищ на городищах в течение многих столетий.

Особенности хозяйства населения басс. Москвы-реки в начальный период железного века реконструируются по остеологическим коллекциям и данным спорово-пыльцевого анализа, а также на основании анализа системы расселения и аналогий.

Остеологические данные. В нашем распоряжении имеются относительно небольшие остеологические коллекции. Они получены на городищах Дьяково, Селецкое и селище Чертов Городок, расположенном возле городища Дьяково.

На Селецком городище в древнейшем слое 6 домашние составляли 63,3\% определимых костей, дикие - 36,7 \% (Данильченко, 1984). Послойные списки определений видов животных для Селецкого городища, к сожалению, опубликованы не были.

Судя по набору керамики, культурный слой Мамонова городища в Москве в основном относился к VI-V вв. до н.э. Видовой набор остатков, по определению В.И. Цалкина (Цалкин, 1962. С. 74), представлен на табл. 12.

Представленные данные, несмотря на малочисленность коллекций, однозначно указывают на доминирование животноводства над охотой. Примечателен состав домашних животных. В двух коллекциях из трех, причем более многочисленных, превалируют остатки крупного рогатого скота. Отметим, что преобладает крупный рогатый скот (определения Е.Е. Антипиной) и в комплексе ямы на стоянке финальной бронзы - начального железного века - Зарудня (Сыроватко А.С. и др., 2013).

В более поздних слоях дьяковских городищ мы видим иную картину: на первом месте всегда остатки лошади и свиньи (см. далее). Возможно, скотоводство жителей древнейших городищ имело отличие от более позднего скотоводства второй половины I тыс. до н.э. Более высокая доля крупного скота в «археозоологическом спектре», по данным Ю.А. Краснова, характерна для западных областей лесной зоны Восточное Европы (Краснов, 1971. С. 134). Этот вопрос требует дальнейшего изучения.

Палинологические данные. Спорово-пыльцевые спектры, полученные из погребенного дерна Дьякова городища (Гунова и др., 1996. С. 105), свидетельствуют о сведении лесов. Аналогичные данные получены при исследовании пыльцы из ямы с находками керамики начального этапа железного века на территории Ново-Иерусалимского монастыря, в погребенной почве с находками керамики начального железного века под курганами в группе Волково (материалы Е.Г. Ершовой). Эти результаты могут являться косвенным указанием на развитие земледелия. Прямых данных, указывающих на земледелие (пыльцы культурных злаков), в изученных разрезах нет. В то же время данные о земледелии (зерна ячменя, пшеницы и проса) были получены при промывке культурного слоя стоянки Веськово 1 на Плещеевом озере (Вишневский, 1990; 1994), которая датируется первой половиной I тыс. до н.э. В Приильменье для этого периода также получены спорово-пыльцевые данные, указывающие на земледелие (Юикова, 2011. С. 65). Таким образом, есть все основания предполагать, что население, оставившее памятники начального железного века в Москворечье, земледелием занималось.

\section{КУЛЬТУРА ГОРОДИЩ ДЬЯКОВА ТИПА В V-II ВЕКАХ ДО Н.Э.}

Представления о культуре городищ дьякова типа на Москвереке, которые по времени соответствуют скифскому и раннесарматскому периодам в степной зоне, базируются на раскопках нескольких городищ, изученных значительными площадями. Это городища Кунцево, Дьяково, Круглица, Боршева, Селецкое, Щербинское, Кузнечики, Настасьино, Городищи. Два из этих памятников опубликованы монографически (Дубынин, 1974; Розенфельдт И.Г., 1974; Кренке, 2011), остальные - в виде статей.

Всего в пределах бассейна Москвы-реки было выявлено 162 памятника, которые могут быть отнесены в V-II вв. до н.э. (рис. 63; прил. 1) К памятникам этой хронологической группы относились те поселения, где была найдена непрофилированная текстильная керамика с характерной ямочной орнаментацией, сходная с материалами нижнего слоя Дьякова городища (см. далее). По размерам памятники VIII вв. до н.э. можно разделить на четыре группы. 1. Крупные городища площадью 1000-2500 кв. м с культурным слоем, насыщенным керамикой и находками. 2. Мысовые поселения средних размеров, укрепленные или неукрепленные валами площадью 400-1000 кв. м. 3. Небольшие неукрепленные поселения, расположенные на открытых участках в пойме, на коренных берегах рек. Точную площадь этих поселений определить трудно, так как естественных границ они не имеют, а поверхность их распахивалась. Ясно лишь, что площадь была менее 1000 кв. м, а мощность культурного слоя не превышала 10-20 см. 4. Местонахождения единичных фрагментов керамики при отсутствии культурного слоя.

Число городищ на Москве-реке и ее притоках, где была обнаружена текстильная керамика, равняется 69. При этом надо учитывать, что в нескольких случаях (например, Троицкое городище) у нас есть информация о находках текстильной керамики на площадке городища, но нет данных о наличии укреплений V-II вв. до н.э.

В V-III вв. до н.э. были освоены ранее не занятые территории верховьев Москвы-реки, долины рек Руза, Озерна, Истра. Можно выделить несколько скоплений памятников, разделенных относительно пустыми промежутками: 1) низовья Москвы-реки; 2) среднее течение Москвы-реки; 3) бассейн Пахры; 4) среднее течение р. Истры; 5) верховья Озерны и окрестности Тростенского озера; 6) верховья Москвы-реки в районе г. Можайска.

Стратифицированные напластования культурного слоя на городищах Дьяково, Боршева, Круглица, Настасьино сохранили многочисленные остатки построек относительно хорошей сохранности. Сами эти постройки и комплексы находок, связанные с ними, являются надежным археологическим источником. На городищах Щербинском и Кузнечики, 
в силу разных причин, сохранность построек была существенно хуже, хотя сам тип построек, вероятно, был таким же, как и на четырех городищах, перечисленных в начале (Сыроватко Н.A., Сыроватко А.С., 2009). Важны также данные, полученные при изучении фортификационных сооружений - древнейших валов.

\section{Характеристика построек}

Впервые постройки были зафиксированы при раскопках городища Круглица (рис. 77, 88) в 1956 и 1957 гг. под руководством Л.И. Пимакина (Кренке, Чаукин, 2012; 2013). Л.И. Пимакин выделил четыре комплекса остатков строений в центре городища (обозначены буквами А-Г) и пятый (Д) - на северном краю, связанном с укреплениями (рис. 88). Подобное разделение предполагается не совсем верным. Вероятно, в границах раскопа присутствуют две постройки типа длинных домов, которые располагаются в комплексах «A-B» и «Б-Г». Состоят данные постройки из двух помещений, разделенных между собой тамбуром. Внутри одного из помещений располагается глинобитный очаг с бортиком (участок 70 раскопа, на рис. 88 обозначен буквой «Ж»). Кроме того, возможно, в комплексах «А-Г» присутствуют фрагменты более поздних построек с ориентировкой север-юг. Очевидна многократная перестройка стен длинных домов, этим объясняется столь частое расположение угольных прослоек на одном уровне вблизи предполагаемых стен построек. Аналогичные комплексы встречены при раскопках городищ Дьяково и Настасьино. Можно предполагать, что более широкие канавки оставлены более древними постройками, а более узкие канавки - это следы построек, которые возводились позднее на уже накопившемся культурном слое, и, соответственно, на материке оставили более узкий след (это наблюдение было достоверно доказано при раскопках Дьякова городища). Вероятно, постройки, возводившиеся в период накопления верхней части нижнего культурного слоя, вообще не оставили следов в материке. Глубина канавок стен построек не более 40 см, и, следовательно, когда накопилось около 0,5 м культурного слоя, дно канавок уже не задевало материк. Исходя из сводного чертежа, можно думать, что постройки возводились примерно на одних и тех же местах, но их ориентировка менялась.

Таким образом, постройки нижнего слоя представляли собой многокамерные «длинные дома» шириной около 4 м. В средней части помещений находились отопительные устройства. Был расчищен очаг с глиняным бортиком и еще несколько открытых очагов без бортиков, описанных в тексте отчета, но не зафиксированных графически. Л.И. Пимакин предполагал, что жилища могли иметь срубную конструкцию. Теперь, имея результаты раскопок построек на городище Дьяково, мы можем смело утверждать, что конструкции были столбовыми. Просто канавки при раскопках 1950-х гг. не удалось расчистить правильным образом, чтобы увидеть следы столбов.

На городище Боршева были обнаружены сооружения, которые Х.И. Крис описывала как изолированные глиняные платформы подпрямоугольной формы, «расположенные в определенной системе» (Крис, Чернай, 1980. С. 16). Так как культурный слой городища Боршева практически нигде не был докопан до материка, то связь некоторых из глиняных платформ с одними и теми же длинными постройками не всегда казалась очевидной. Однако при раскопках городища Боршева 1977 г. на уровне предматерика были обнаружены канавки внешних стен построек, объединявшие глиняные платформы в одно сооружение типа длинного дома (рис. 87, 91, 92). Две секции длинного дома были прослежены на городище Боршева в раскопе 1978 г. Планировка постройки, исследованной в 1977 г., полностью совпадала с планировкой длинных домов с городищ Дьяково и Кузнечики. Отапливаемые секции дома имели длину 5-6 м при ширине менее 4 м. Между секциями с очагами располагались узкие «тамбуры» шириной около 2 м без очагов.

Наиболее детально были изучены постройки на городищах Ростиславль и Дьяково. На городище Дьяково в раскопе 1982-1986 гг. на площадке в нижнем слое были зафиксированы две постройки типа длинных домов, стоявшие параллельно друг другу (рис. 82-86). Они были обозначены как постройка «А» (западная) и «Б» (восточная). Они обе неоднократно горели, а затем обновлялись.

Стратиграфия участка культурного слоя, где располагались постройки, представляла собой чередование прослоек серой супеси с включением угольков, тонких белесых прослоек золы («полы» построек), пачек микропрослоек коричневого цвета с высоким содержанием органики, песчаные линзы очагов.

Специфику нижнего слоя городища составляют прослойки коричневой земли, насыщенной органикой. На периферии площадки они составляют основу слоя, ближе к центру, на местах, где стояли постройки, - выклиниваются. Для выяснения генезиса этих прослоек был применен комплекс естественно-научных методов.

Почвовед Е.А. Ярилова провела микроскопический анализ шлифов, на основании чего ею был сделан вывод о том, что органическая составляющая прослоек является в различной степени преобразованными остатками разнородных растительных тканей. Важное значение для интерпретации прослоек коричневой органики имеют найденные в них многочисленные остатки надкрыльев жуков-бронзовок Cetonia aurata (определение В.В. Янушева и Р.Д. Жантиева). По мнению энтомологов, жуки синхронны слою. Для жуков данного вида типично выплаживание в кучах из слежавшейся массы листьев и веток. Наличие таких запасов на городище вполне можно допустить. Они могли использоваться как корм скоту, быть строительным материалом (стены длинных домов были из плетня).

Палинологическим методом Е.А. Спиридоновой был проанализирован отдельный образец такой прослойки. Оказалось, что в его спектрах присутствует пыльца культурных злаков, причем в большом количестве и часто в скоплениях. На этом основании Е.А. Спиридонова предположила, что прослойка представляет собой истлевшую злаковую солому.

Л.И. Абрамова (биофак МГУ) провела ботанический анализ остатков растительной ткани. Вывод по результатам 
исследования следующий: в образце преобладают остатки Тростника обыкновенного, или южного (Phragmites australis (Cav.) Trin.ex Stend. (P. Communis Trin.). Были выявлены фрагменты эпидермиса корневища тростника, состоящие из длинных с извилистыми стенками клеток, иногда между ними видны короткие, иногда согнутые клетки; фрагменты эпидермиса стебля, состоящие из удлиненных с сильно извилистыми стенками клеток, между длинными клетками располагаются округло-квадратные клетки с толстыми оболочками.

Е.Г. Ершова продолжила работу Л.И. Абрамовой, проанализировав несколько микропрослоев (мощность каждого составляла около 1 мм). Оказалось, что прослои значительно отличаются друг от друга. В одном преобладали остатки тростника, а в другом - ячменя. Кроме того, по мнению Е.Г. Ершовой, органогенные прослойки могли включать экскременты животных (?). Это подтверждается слабой степенью сохранности растительных тканей, как будто бы прошедших через кишечный тракт.

В постройке «А» зафиксировано четыре строительных горизонта, притом, что планировка постройки практически не менялась. В постройке «Б» также выявлено четыре строительных горизонта. Преемственность в планировке прослежена лишь в южной части сооружения. В верхней части нижнего слоя в двух метрах к западу от постройки «А» были обнаружены остатки двух очагов, условно объединенные в постройку «В». Остатки еще одной постройки «Г» были зафиксированы на западном краю площадки.

Наиболее полную информацию дали комплексы построек «А» и «Б».

Постройка «А» отстояла от западного края площадки на 10 м. Постройка была зафиксирована на участке длиной 8 м. Четыре стратиграфических уровня этой постройки обозначены как А-1, А-2, А-3, A-4.

С постройкой A-1 связаны две внешние стены, которые были прослежены на уровне материка в виде канавок со столбовыми ямками и продольно лежавшей древесиной (рис. 82). Расстояние между осями канавок - 3,6 м. Пространство постройки разделяли две внутренние перегородки, перпендикулярные внешним стенам, сохранившиеся также в виде канавок. Расстояние между этими перегородками составляло 1,8 м. Таким образом, исследованная часть постройки A-1 состояла из трех помещений. В центре располагалось вышеописанное узкое помещение типа тамбура или сеней. Северное помещение имело размеры в длину более 2,5 м. Южное - более 3,2 м. В северном помещении располагался очаг, вырезанный в материковом суглинке. Очаг имел овальную форму размером $1,1 \times 0,7$ м. Бортик возвышался над дном чашевидного углубления на 10 см. Заполнен очаг был речным песком. Очаг располагался не точно по оси постройки, а был смещен на 0,5 м в сторону западной стены. От внутренней перегородки очаг отстоял на 1 м. Жилая поверхность постройки А-1 была выше поверхности материка всего на 1-3 см. Сохранилась эта поверхность фрагментарно в виде пятен белой золы от сгоревших растительных выстилок. В том числе участок этой поверхности сохранился возле очага.

Постройка А-2 имела ориентировку, отличавшуюся на
17 градусов от постройки А-1. В остальном ее конструкции были аналогичны предшествовавшей. Ширина постройки была на 40 см уже - всего 3,2 м. Уровень постройки А-2 был примерно на 10-15 см выше, чем уровень постройки А-1.

От внутренних перегородок сохранились нижние сгоревшие жерди, зажатые вертикальными столбами, на основании которых можно судить о ширине тамбура -1 м. Северное помещение имело длину более 3 м, южное более 4 м. В этих помещениях были очаги в виде линз песка овальной формы диаметром около 1 м. Оба очага были несколько смещены к восточной стенке дома. Очаговые линзы песка имели выпуклую форму и возвышались над поверхностью пола на 5-10 см.

Поверхность пола была представлена прослойкой белой золы толщиной около 0,5 см, происходившей от какой-то выстилки из растительных материалов. Определение остатков растительных тканей было проведено Е.Д. Лапшиной (НИИ биологии и биофизики, Томск). В своем заключении она отметила следующее:

«Необгоревшие остатки, сохранившие клеточную структуру, составляют ничтожную часть общей массы. По мере приближения к поверхности выстилки они исчезают. Встречаются более крупные макроостатки до 0,3-0,5 см.

Выстилка имеет устойчивый состав с постоянным набором остатков. Выделено около восьми видов тканей. Характер клеточной сети, форма, консистенция и цвет остатков указывают на то, что они принадлежат небольшому (два-три) числу видов растений. На 80-90 \% образец состоит из остатков травянистых растений, вероятнее всего, злаков. Им принадлежат ткани с длинными, сильно волнистыми по краям клетками, которые чередуются с более мелкими, округлой формы. Хорошо сохранившиеся устьица также имеют характерную для злаков форму и линейное расположение. Зубовидные выросты и щетинки на обугленных остатках могут располагаться на остях, по ребрам стеблей.

На 5-10\% зола сложена остатками иного типа. В процентном соотношении сохранность их значительно выше. Они представляют собой мелкие, светло-коричневые пластины с хорошо выраженным рисунком в виде „клеточной сети“. Выросты клеток глубоко вдаются в соседние, разветвляясь на два-три отростка. Клетки располагаются правильными рядами. Видовую принадлежность их определить затруднительно, но характер края остатков говорит об их органо-минеральной или неорганической природе. В составе золы выстилки встречаются прозрачные, стекловидные клетки с сильно изрезанным краем. Они сходны с кремнистыми включениями в растительных тканях - „фитолитами“ и образуют пластинки или рыхлые скопления округлой формы, легко разрушающиеся при прикосновении». Дополнительное исследование остатков выстилки, проведенное Е.Г. Ершовой, позволило ей прийти к заключению, что основой являлся тростник.

В плане поверхность выстилки пола прослеживалась по всей постройке, вплотную подступала к очагам и внешней восточной стене. В западной части постройки, исследованной в 1982 г. на более низком методическом уровне, выстилка пола зачищена не была.

Остатки постройки А-3 располагались на 10 см выше 
постройки А-2 и, соответственно, на 25-30 см выше поверхности материка. В материке четко прослеживалась канавка от восточной стены постройки. Дно канавки от западной стены, видимо, не достигло поверхности материка. В северной части прослеживался ряд столбовых ямок, вероятно, относившихся к этой стене. Судя по ним, ширина постройки была 3 м. Ориентирована постройка А-3 почти по линии север-юг. Хорошо сохранилась поверхность сгоревшей растительной выстилки на полу. С востока эту поверхность оконтуривали остатки сгоревшей стены. В 2018 г. образцы выстилки были изучены М.С. Блинниковым и Е.Г. Ершовой (биофак МГУ). Они пришли к выводу, что основой являлась солома проса 4 .

«Тамбур» находился примерно на том же месте, что и в двух предшествовавших постройках. Сохранились остатки двух его стен, которые, видимо, оказались несколько смещены. Расстояние между двумя лежавшими параллельно жердями было всего 40 см. Остатки северной стенки тамбура, видимо, оказались смещенными на юг. Южная стенка, вероятно, осталась на своем месте, что доказывает лежавшее впритык к ней непотревоженное обугленное днище берестяного туеса. В северном и южном помещениях были прослежены очаговые линзы песка. У очага в северном помещении сохранился с одной стороны деревянный «бортик». Очаговые линзы имели овальную форму, чуть более 1 м в диаметре и возвышались примерно на 10 см над поверхностью пола.

Постройка A-4 имела иную сохранность по сравнению с лежавшими ниже. Золистый пол отсутствовал. Возможно, условия были иными, выстилка не горела. От постройки сохранились две очаговые линзы с фрагментами деревянных бортиков и часть восточной стены. Ориентация постройки A-4 отличалась от ориентации постройки A-3 и почти точно соответствовала более ранней постройке А-2. Планировка, видимо, не претерпела изменений. Остатков «тамбура» не сохранилось, но можно предполагать, что он находился примерно на прежнем месте, между двумя помещениями с очагами.

Форма очагов была близка к квадрату со стороной 2 м. Лучше сохранился очаг северного помещения, удалось проследить прямой угол конструкции. Обугленные остатки восточной внешней стены отстояли от очага примерно на 1 м. Если допустить, что очаг находился примерно на оси дома, то можно предполагать, что ширина постройки равнялась 4 м.

Постройка Б-1 была прослежена на уровне материка. В раскоп вошла ее западная внешняя стена и две внутренние перегородки. На дне канавки от внешней стены четко прослеживались два ряда ямок через интервалы в 30 см от жердей, забитых в материк. Кроме того, в канавке прослеживались остатки продольно лежавшего бревна. Вероятно,

\footnotetext{
${ }^{4}$ Нужно отметить, что ненцы покрывали матами из ольховых прутьев или других подобных материалов пол построек, особенно спальные места. Так обеспечивалась тепло- и гидроизоляция (сведения сообщены автору ненками из поселка Нельмин нос Ненецкого автономного округа Ф.С. Кауц и А.А. Помылевой, которые участвовали в раскопках поселения РАНИСпойма в 2009 г.). Циновки из хвороста или пучков травы, переплетенной бечевками, известны у хантов и других народов Сибири (Лукина, 1985. C. 267-268).
}

стена имела сложную конструкцию «пакета» - внешний плетень, внутренний плетень и какое-то заполнение между ними, может быть, из горизонтально положенных бревен. Постройка была ориентирована почти так же, как и постройка А-1. Расстояние между постройками А-1 и Б-1 равнялось 1,4 м. Фрагмент постройки Б-1, вошедший в раскоп, был разделен на три секции. Центральная секция - «тамбур» имела ширину 1,5 м. Северное помещение имело длину более 4,5 м, а южное - более 3 м. Северное и южное помещения имели очаги - чашевидные углубления глубиной до 10 см, вырезанные в материковом суглинке, заполненные песком. Очаги имели вид прямоугольников со скругленными углами размером $1 \times 1$ и 1,2×0,8 м. Пол постройки был прослежен только в южном помещении в виде прослойки золы от сгоревшей выстилки. Уровень пола был всего на несколько сантиметров выше материка. По продольной оси постройки прослежены ямы от крупных столбов, на которых, видимо, держался конек двускатной крыши.

Постройка Б-2 прослеживалась на уровне материка лишь в юго-восточной части раскопа. Были прослежены две канавки от внешних стен, расстояние между стенами равнялось 3,4 м. На дне канавок прослежены столбовые ямки от забитых в землю колов плетня. Поверхность пола постройки была выявлена на отметках -354-370, т.е. на 5-20 см выше материка. Пол помещения представлял собой прослойку светло-бурого материкового суглинка. В центре комнаты у очага поверхность пола была выше, в сторону стен шло понижение, перепад высот составлял 20 см. Очаг читался как «окно» размером $1 \times 1,1$ м в суглинке обмазки пола и имел овальную форму. Очаг был заполнен желтым песком с примесью золы. Сохранились остатки внешней и внутренней (?) стен постройки в виде полос древесного тлена, оконтуривавших вымазанный глиной пол с западной и северной стороны. Остается не вполне ясным, продолжалась ли постройка Б-2 на север за пределы описанного выше помещения. Если продолжалась, то от северной части постройки удалось проследить лишь фрагменты поверхности золистого пола, не дающие представления о планировке.

Постройка Б-3 прослеживалась в материке в виде цепочки столбовых ямок, оставшихся от ее западной стены. Хорошо сохранился пол помещения, обмазанного глиной на уровне 10-35 см выше материка. Постройка горела. На поверхности глиняной обмазки пола прослеживалась зола от сгоревшей травянистой выстилки. На линии продольной оси помещения хорошо сохранился очаг с глиняным бортиком овальной формы размером $1,5 \times 1$ м. В заполнении очага была линза песка.

Постройка Б-4 выявлена в северо-восточной части раскопа. От нее удалось проследить лишь очаговую линзу песка с деревянным бортиком прямоугольной формы. Вероятно, очаг несколько раз перестраивался, линии его стен при этом немного смещались. В районе очага удалось проследить лишь небольшие фрагменты поверхности пола в виде прослойки золы. Как далеко продолжалась постройка Б-4 на юг, осталось неясным.

На основании вышеприведенных данных можно сделать следующие выводы о конструкциях построек, суще- 
ствовавших в период накопления нижнего слоя Дьякова городища.

Дома имели вид вытянутых прямоугольников, разделенных на отсеки. Ширина домов составляла 3-3,6 м. Длина превышала 10 м. Внутреннее пространство было разделено перегородками на отапливаемые комнаты и узкие холодные тамбуры шириной всего 1-1,5 м. Вход в дом, вероятно, был через тамбур. Внешние стены состояли из плетня (иногда двойного) и горизонтально положенных бревен, зажатых плетнем и столбами. Возможно, использовались какие-то «уплотнители», вроде кусков дерна и т.П., но конкретных их следов обнаружить не удалось.

Высота стен, судя по диметру колов плетня (2-5 см) не превышала 2 м. Внутренние перегородки были сделаны из горизонтально положенных жердей, зажатых между столбами. Дома имели двускатную крышу, на что указывают крупные столбовые ямы (диаметр 15-20 см), расположенные примерно по продольной оси построек с интервалом 2,5-3 м. Эти столбы располагались не в центре комнат, а вблизи перегородок. Края крыши, вероятно, опирались на горизонтально положенные жерди, поддерживаемые дополнительными столбами, поставленными вдоль внешних стен на расстоянии 20-40 см от них. Внутренние перегородки также могли служить опорами для слег. Очаги располагались примерно по оси сооружения, внутри комнат они были смещены к одной из перегородок. Форма очагов могла быть как овальной, так и прямоугольной, у них имелся глиняный или деревянный бортик, а внутрь насыпался песок. Аналогичные конструкции очагов были зарисованы этнографами у хантов (рис. 87, 3). Вероятно, над очагами в крыше имелись отверстия - дымоходы, игравшие роль световых окон. Пол построек выстилали различными растительными материалами - тростником или соломой культурных злаков (просо). Эти выстилки периодически заменялись (возможно, из санитарно-гигиенических соображений). Видимо, отходы строительства и снятых выстилок откладывались на периферии площадки городища.

На городище Настасьино основная информация была получена по конструкциям, углубленным в материк (рис. 89). Большая площадь раскопа (вскрыто около 50 \% площади городища) дала исключительно ценные данные о габаритах построек и порядке их расположения на площадке (Энговатова, 2004; 2009). Здесь был выявлен своеобразный «элементарный модуль» - постройка, состоящая из трех отсеков (постройка № 5). Центральная комната с очагом в центре, размеры $-5,5 \times 4$ м. С обеих сторон к этой комнате примыкали одинаковые тамбуры шириной чуть более двух метров. Таким образом, общая длина постройки составляла 10 м. На торцах постройки длинные стены имели характерные выступы длиной 20-30 см за линию поперечной стены. То есть крыша образовывала небольшой «козырек» над торцовой стеной.

Аналогичная особенность прослежена на городище Круглица. Нужно отметить, что описанные конструктивные особенности жилых построек, видимо, были типичны для более широкого региона, нежели бассейн Москвы-реки. Так, на городище Николо-Ленивец, расположенном на р. Угре,
Т.Н. Никольской были выявлены постройки, сходные с «первичным модулем» (комната с двумя тамбурами по торцам), а также постройки с «выступами» длинных стен за линию поперечной торцовой стены (Никольская, 1959. Рис. 10; 1962. Рис. 1; АКР: Калужская обл., 2006. Рис. 54).

Четыре постройки на городище Настасьино имели вид соединенных в единое целое двух первичных «модулей» (постройки № 3, 4, 6, 11). Эти постройки представляли собой две комнаты, разделенные находившимся в центре тамбуром. Тамбуры также обрамляли торцы построек. Таким образом, общая длина этих «двухкомнатных» построек составляла около 17 м при ширине около 4 м. Не вполне ясным остается вопрос относительно построек № 9 и № 10. Либо это две разновременные «духкомнатные» постройки (что более вероятно), либо одна «мегапостройка», в центре которой находилось три «тамбура». Третий тамбур возник как соединение двух «двухкомнатных» построек, поставленных в линию. Общая длина этой постройки - 32 м.

Типичность планировки построек, прослеженных на городище Настасьино, подтверждают материалы городища Кузнечики, расположенного на р. Петрице, правом притоке р. Моча (Дубынин, 1970. Сыроватко, 2008). Здесь сохранность объектов (и качество фиксации) были хуже, чем на городище Настасьино. Однако выявлены однокомнатная постройка - «модуль» с двумя тамбурами по краям (постройка № 12), двухкомнатная постройка (№ 2а и 2б). Вдоль восточного края площадки городища тянулась очень длинная постройка (№ 1), также состоявшая из чередования комнат и узких тамбуров. Ее общая длина около 40 м (рис. 90). Постройка аналогичной длины была зафиксирована на городище Ростиславль (раскопки В.Ю. Коваля и Е.Ю. Тавлинцевой). Эти исключительно важные материалы пока еще не опубликованы.

Планировка городищ. Наиболее полные, хотя и недостаточные данные о планировке укрепленных поселений V-II вв. до н.э. получены на городищах Настасьино, Боршева, Кузнечики, Дьяково, Круглица, Щербинское. Центральная часть площадок всех городищ была занята длинными домами. Судя по наиболее представительным материалам городища Настасьино, дома стояли по периметру площадки, образуя нечто вроде каре. Внутренняя часть этого каре также была занята домами, стоявшими параллельными рядами через промежутки 2-4 м (Энговатова, 2004. Рис. 1). Постройки по периметру площадок прослежены на городищах Кузнечики и Боршева, при этом центральная часть этих городищ также была занята постройками, но их планировка была прослежена плохо. Раскопки Дьякова городища свидетельствуют о том, что основные постройки стояли в центре городища близко друг к другу, вытянувшись параллельными рядами по направлению от оборонительного вала в сторону въезда.

Оборонительные укрепления. Валы и рвы были исследованы на 16 раннедьяковских городищах в бассейне Москвыреки. На уровне современной методики фиксации были изучены валы и рвы городищ Настасьино, Знаменское, Дьяково, Луковня 2, Луцино 2. Лишь в двух случаях, на городищах Настасьино и Знаменское, оборонительные укрепления 
изучались не узкими разрезами, а раскопами. Из «узких разрезов» наиболее информативным было изучение валов городищ Дьякова (Кренке, 2011) и Луковня 2 (Александровский $u$ дp., 1998). Здесь нельзя также не упомянуть изучение вала и рва городища Ростиславль на р. Оке (Коваль, 2011; 2012; Медведь, 2009). Хотя это городище находится на территории, оставшейся за рамками данной работы, но по своим конструктивным особенностям оно мало или совсем не отличается от москворецких памятников. По результатам изучения вала городища Ростиславль, В.Ю. Коваль предложил новую версию реконструкции конструктивной системы оборонительных укреплений городищ дьякова типа, которая будет рассмотрена далее.

Вал Дьякова городища изучался в 1935 и 1982 гг. В 1982 г. вал был разрезан траншеей $2 \times 8$ м, располагавшейся примерно в 12 м к востоку от западного склона (рис. 81). Разрез начинался от подошвы вала со стоны площадки. Максимальный перепад между гребнем вала и материковой западиной под его внутренней полой составил 6 м. Верхний метр насыпи являлся позднейшими выбросами из археологической траншеи XIX в. и, возможно, результатом какой-то строительной активности в конце XVII в. при устройстве «потешного городка».

В профилях бортов разрезов 1935 и 1982 гг. четко прослеживались линии скольжения разнонаправленных оползней. Примерно половина насыпи сместилась вниз внутрь площадки городища. Вызванное оползнем смещение слоев составило около $20 \mathrm{~cm}$. Менее значительным был оползень, вызвавший смещение слоев во внешнюю сторону. Не исключено, что причиной оползней были проявления сейсмической активности.

Вал неоднократно подсыпался, а деревянные оборонительные конструкции на его гребне возобновлялись. Далее дано описание нижней части разреза вала, которое имеет отношение к раннедьяковскому периоду. В настоящем описании исправлены неточности в нумерации реконструируемых «стен», которые были допущены в прежней публикации (Кренке, 2011).

Под насыпью вала на условных отметках около -370400 прослеживалась понижавшаяся на север погребенная почва (154,54-154,84 м в балтийской системе высот), гумусовый горизонт которой плохо сохранился и сильно трансформировался (изменил цветность, стал светло-бурым, а не серым). В разрезе вала отметки погребенной почвы под насыпью имели значение -370. В эту погребенную почву была врезана частокольная канавка, являющаяся остатком укрепления, предшествовавшего валу. Столбовые ямки в канавке расположены разреженно с интервалом около 5-20 см. Данное укрепление обозначено на чертеже как «стена 1».

В северной части разреза под валом прослеживается небольшая ложбина глубиной до 60 см и шириной около 3,5 м. Исследования 2001-2003 гг. (руководитель - А.Г. Векслер), результаты которых еще ждут публикации, показали наличие севернее ложбины еще одной внутренней линии оборонительных сооружений, представленной цепочкой крупных столбовых ям. Таким образом, «стена 1», видимо, была лишь частью более сложной системы укреплений.
Древнейшая насыпь (насыпь 1а) имела высоту около 80 см и была сооружена из материкового суглинка. С внутренней стороны на скате этой насыпи стояла деревянная стена (стена 2), от которой сохранились столбовые ямы глубиной до 1 м и диаметром около $15 \mathrm{~cm}^{5}$. По внешней стороне гребня были прослежены остатки деревянной конструкции в виде плах (?), лежавших вдоль оси вала. Возможно, это были «армирующие» насыпь конструкции, либо дополнительная стенка с внешней стороны.

Спустя очень непродолжительное время, на что указывает то обстоятельство, что на поверхность полы насыпи, обращенной в сторону площадки, не отложился культурный слой, насыпь 1а была досыпана (также материковым суглинком). Эта новая насыпь (насыпь 1б) имела высоту над уровнем почвы до 1,5 м. На ее внутреннем скате несколько ниже гребня зафиксировано несколько рядов столбов диаметром до 20 см, вкопанных на глубину около 1 м. Наблюдения над планиграфией и микростратиграфией позволяют предполагать, что эти столбы были не одновременными, а относились к двум конструкциям (стены 3 и 4), сменившим друг друга (уровень, с которого прослеживались столбовые ямы, различался примерно на 20 см). Стена 3, до того как сгореть, простояла длительное время, за которое пола насыпи вала была перекрыта культурным слоем мощностью до 0,4 м. Стена 4 простояла очень недолго, за это время накопилось менее 10 см культурного слоя, и также сгорела. Нельзя полностью исключить того, что изложенная выше интерпретация «переусложнена», т.е. «стена 3» и «стена 4»это развал единой конструкции. Если это так, то тогда это двойная (засыпная ?) стена.

Структура слоя, перекрывшего насыпь 16 (прослойки коричневого цвета, насыщенные органикой, чередующиеся с золистой супесью), и найденная в нем керамика (по преимуществу текстильная) позволяют отождествить его с нижним слоем городища.

Вскоре после того, как стена 4 (или 3+4) сгорела, укрепления были восстановлены. Вал досыпан на 40 см материковым суглинком (насыпь 2), а на гребне сооружена конструкция, от которой сохранились столбовые ямы, а также скопление обугленных бревен и плашек, ориентированных вдоль оси вала (стена 5). Конструкции этих укреплений, вероятно, были аналогичны предшествующим. Возможно, на гребне насыпи 2 сохранились следы двух или трех разновременных стен, либо стены, состоявшей из нескольких линий, так как столбы идут тремя рядами. Стратиграфически расчленить горизонты, связанные с каждой из этих стен невозможно, поэтому они условно объединены в горизонт, обозначенный как стена 5. Пожар стены 5 и пожар стены 3/4, видимо, разделял незначительный промежуток времени. На это указывает то, что на внутренней поле насыпи горизонты этих пожаров разделяет лишь около 10 см культурного слоя в промежутке между ними. Это стратиграфическое наблюдение подтверждается сходством радиоуглеродных дати-

\footnotetext{
${ }^{5}$ В предшествующей публикации (Кренке, 1986) эти конструкции интерпретировались как внутривальные, что при более тщательном изучении материала мне показалось неправильным.
} 
ровок образцов из стены $3 / 4$ и стены 5 , а также тем, что керамика, найденная в насыпи 2, соответствует керамике нижнего слоя городища.

После пожара стены 5 насыпь была вновь увеличена на 20-30 см. Досыпка была сделана серо-бурым суглинком (насыпь 3). Со стороны площадки насыпь 3 перекрыта культурным слоем идентичным нижнему слою на площадке с коричневыми органогенными прослойками. Следовательно, насыпь 3 также соответствует по времени нижнему слою. От деревянных сооружений, которые, вероятно, дополняли насыпь 3, ничего не сохранилось. На внешнем скате этой насыпи прослежен мощный слой золы и пепла. В основании этого слоя были прослежены сгоревшие деревянные конструкции, образовавшие прямой угол. Можно предположить, что это остатки стены 6.

От стены 7, сменившей стену 6, сохранились мощные столбовые ямы, прослеженные в профилях бортов. Эти ямы имели глубину до 1,3 м и верхний диаметр 25 см. За время существования стены 7 поверх насыпи 3 накопился довольно мощный культурный слой, идентичный по структуре нижнему слою площадки городища. Непосредственно у стены толщина этого слоя составила 20 см, а ниже по скату насыпи его мощность возрастала до 40-50 см. Следов пожара стены 7 не прослежено. Возможно, она была разобрана. Горизонт стены 7 перекрыт культурным слоем - тонкими прослойками серой супеси и коричневой органики, которые производили впечатление залегавших in situ. На мой взгляд, это могло произойти лишь в том случае, если в период отложения этих прослоек стена была выдвинута несколько дальше на юг, на внешний скат вала, который был вне переделов раскопа. Эта реконструируемая стена будет иметь номер 8. По-видимому, шлейф пожара стены 8 прослеживается в разрезе. Уровень этого пожара на гребне насыпи равнялся -120. Стена 8, видимо, была последним по времени укреплением, существовавшим в период накопления нижнего слоя. Высота гребня вала от уровня погребенной под ним почвы достигала 2,5 м. Прослойка пожара стены 8 была перекрыта на внутреннем скате насыпи светлым слоем пепла, тождественного стерильному слою, разделявшему нижний и верхний слои на площадке городища.

Таким образом, укрепления Дьякова городища, относящиеся к периоду V-II вв. до н.э., имеют не менее пяти основных строительных периодов. Древнейшее укрепление существовало до насыпки вала. Четыре нижних горизонта насыпи вала соответствуют периоду накопления нижнего слоя на площадке. Возможно, оборонительные стены на валу за этот период обновлялись семь раз. Мощность укреплений поэтапно наращивалась с каждой новой перестройкой. Ширина вала изменялась от примерно 6 м до 10-12 м; высота гребня - от 0,8 м до 2,5 м. Изучение внешнего рва городища, производившееся экспедицией под руководством А.Г. Векслера, также показало, что он имел сложную историю, его ось несколько раз незначительно смещалась. Перепад высот между гребнем вала и дном рва достигал 10 м.

Большое значение имеют раскопки Знаменского городища (автор раскопок - Ю.Д. Разуваев), единственного, на котором древний дьяковский вал был изучен раскопом на большой площади. Материком и материалом для сооружения валов на Знаменском городище являлся песок. Это существенно затрудняло фиксацию. Тем не менее, с высокой степенью надежности было установлено, что на раннем этапе существования городища оно было защищено с напольной стороны одним валом и рвом. Вал досыпался два раза, ров также углублялся и расширялся, постепенно смещаясь в напольную сторону (Разуваев, 2012). В итоге ширина вала составила 8 м при высоте 1 м, а ширина рва - 4 м при глубине 1 м. По гребню вала (ровики 1 и 2) прослежена канавка. Вероятно, это канавка от стены, характер конструкции которой остался невыясненным. По-видимому, в валу имелся проход, обрамленный двумя легкими стенками (канавки 1 и 2) из плетня (?). Ширина прохода составляла около 1,5 м. Проход имел характерный изгиб, заставляющий входящего в крепость развернуться правой стороной (не защищенной щитом) к оборонительной стене. Аналогичный проход через вал был зафиксирован при раскопах на Ростиславле (Коваль, 2012).

Достоверность существования проходов через валы доказывается результатами раскопок на городище Настасьино. Здесь была обнаружена перемычка во рву, которая соответствовала проходу (Энговатова, 2009. Рис. 2). Ширина внутреннего рва на городище Настасьино составляла около 8 м, а глубина от поверхности материка на краю площадки около 1,5 м.

В публикации по результатам исследования вала городища Ростиславль В.Ю. Коваль высказал сомнения в том, что гребни дьяковских валов были укреплены стенами. По версии В.Ю. Коваля, на вершинах валов сооружалось нечто вроде баррикад из стволов деревьев и веток (Коваль, 2012). Можно выставить три группы аргументов против этой версии. Во-первых, есть общие соображения. Жители городищ умели создавать сложные деревянные конструкции большой протяженности - «длинные дома», тратили большие усилия на возведение земляного вала. Трудно представить, что свою работу они завершали столь странным образом, ведь баррикада недолговечна, уязвима, неудобна для обороны и т.д. Во-вторых, системы глубоких столбовых ям прослежены на гребнях валов. Наиболее полно - на городище Дьяково, но и на городище Ростиславль они также имеются (Коваль, 2012. Рис. 3, цв. вклейка). Стратиграфический разрез убедительно показывает, что эти ямы связаны с оборонительными конструкциями, а не с позднейшим обживанием участка. Возможно, В.Ю. Коваль прав в том, что частоколов не было. Однако стены - это не обязательно частоколы. Вероятно, существовали какие-то системы «заплотов», когда вертикальные столбы «зажимали» горизонтальные бревна. В-третьих, канавки на валах Знаменского городища, канавки по периметрам площадок городищ вне валов (см. далее) указывают именно на наличие стен. Окончательное решение спора возможно лишь при дополнительном площадном изучении валов.

Основным источником для суждения о том, как укреплялся периметр площадок городищ дьякова типа, являются материалы раскопок Щербинского городища (Дубынин, 
1974). Здесь было прослежено до шести примерно параллельных канавок, которые, изгибаясь, опоясывали площадку городища. Возможно, что стена была двойной (засыпной?), но доказать это не представляется возможным.

Важную дополнительную информацию на эту тему можно извлечь из документации раскопок городища Круглица 1956 г. (профили зачерчены В.Ф. Черниковым). На профилях и плане хорошо видно, что по северному краю городища вдоль бровки склона идут две параллельные канавки на расстоянии около 1 м друг от друга (рис. 88). В одной из канавок прослежена столбовая яма глубиной до 1 м (Кренке, Чаукин, 2012. Рис. 4, цв. вклейка).

\section{Материальная культура}

Керамика и ее орнаментация. Наиболее массовой категорией находок является керамика. Совокупная численность коллекций из раннедьяковских слоев городищ составляет многие десятки тысяч фрагментов, более сотни целых форм.

Коллекция керамики из нижнего слоя Дьякова городища, которая может служить эталоном, состоит из 15 тысяч фрагментов. Около 30 сосудов удалось склеить до полного профиля или до такой степени, что профиль графически достоверно реконструируется (рис. 128, 129). Объем измеренных сосудов из нижнего слоя колеблется от 220 миллилитров до 27 литров. Преобладают горшки средних и крупных размеров с диаметром венчиков 16-34. Распределение венчиков по размерам позволяет сделать заключение, что маломерные сосуды составляли лишь около 5 \% комплекса; средние сосуды объемом 1-5 литров составляли около $55 \%$ комплекса, а на долю крупных, объемом 8-16 литров, приходились остальные $40 \%$. Горшки объемом более 20 литров были очень редки.

Сосуды из нижнего слоя относятся к непрофилированным. По классификации О.А. Лопатиной, они относятся к группам 3-5 (Лопатина, 2009. Рис. 5), по И.В. Ислановой (Исланова, 2008) - к группе 1. Шейка у них отсутствует (исключение составляют сосуды из верхней части слоя). Максимальное расширение в большинстве случаев приходится на 2,5-6 см ниже обреза венчика. Вероятно, это расстояние соответствует ширине глиняной ленты, употреблявшейся при формовке сосуда. Процесс лепки сосуда можно представить следующим образом: сначала изготавливалось дно, затем усеченно-коническая емкость (в редких случаях на этом процесс формовки заканчивался). После этого прикреплялась верхняя глиняная лента, образовывавшая венчик. Она обычно слегка загибалась вовнутрь, а потом самый край венчика мог быть отогнут наружу. Эта последняя деталь, возможно, была обусловлена технологией изготовления. Так, иногда под отгибом венчика прослеживаются следы веревки, которая, видимо, использовалась при формовке горшка. Небольшой отгиб самого края венчика был необходим для того, чтобы веревка не соскальзывала.

В целом, форма посуды из нижнего слоя Дьякова городища отличается ярко выраженным стилистическим единством. В пропорциях наблюдаются небольшие отличия между горшками маленьких и больших размеров.
Исключение составляют некоторые сосуды из самой верхней части нижнего слоя. Они более вытянуты, венчик у них плавно отогнут наружу, имеется шейка. По-видимому, в финальный период отложения нижнего слоя начинает формироваться новый стиль оформления посуды.

На основании общей формы и особенности профилировки венчика можно выделить несколько типов.

Тип 1. Усеченно-конические. Вариант «а», венчик не выделен (№ 35); вариант «б», венчик выделен слабым отгибом (№ 37) (Рис. 128).

Тип 2. Усеченно-конические с перегибом (рис. 128). Выделено плечо и венчик почти прямой (№ 33).

Тип 3. Округлобокие закрытые (рис. 128). Вариант «а», венчик не выделен (№ 31, 38, 39 и пр.); вариант «б», венчик слегка отогнут наружу (№ 26). Между типами 2 и 3 имеются переходные формы.

Тип 4. Баночные, венчик слегка отогнут наружу (№ 59). Встречен только в верхней части нижнего слоя (рис. 129).

Тип 5. Ведрообразные (рис. 129). Сосуды обладают высокими пропорциями, диаметр максимального расширения превосходит диаметр дна не более чем в два раза. Вариант «а», венчик короткий почти прямой, выделен слабо; вариант «б» венчик дугообразно отогнут наружу (№ 62, 63). Вариант «б» встречен только в верхней части нижнего слоя.

По характеру обработки поверхности керамика из нижнего слоя Дьякова городища делится на три группы: текстильную, гладкостенную и рогожную. Доля рогожной керамики минимальная $(0,3 \%)$. Всего было найдено 47 фрагментов с рогожными отпечатков ${ }^{6}$, вероятно, от одного сосуда, разбитого в период отложения верхнего горизонта нижнего слоя. Отпечатки не очень четкие, имеют вид системы «квадратиков», организованных в ряды. Обнаружение единичных фрагментов рогожной керамики на Дьяковом городище хорошо согласуется с имеющимися данными по городищам нижнего течения Москвы-реки. Здесь количество рогожной керамики колеблется в пределах 0,5-1 \%, и она также залегала в верхней части раннедьяковских слоев (Сыроватко, 2009. С. 172). Эти находки могут рассматриваться как результат контактов с населением средней и нижней Оки.

На таблице 13 приведены количественные данные о соотношении текстильной и гладкостенной керамики. Текстильная керамика, безусловно, доминирует (80\%). Никаких различий в форме гладкостенной и текстильной керамики не прослеживается. В коллекции представлены «рябчатые» и «нитчатые» отпечатки. К первым относятся те, где система параллельных нитей не прослеживается, а ко вторым относятся отпечатки, где они прослеживаются. Нужно отметить, что это разграничение весьма условно. Например, на некоторых сосудах (№ 35) имеются участки, где хорошо видны параллельные нити, а рядом расположены участки, где четкой системы не прослеживается. Вполне вероятна версия, что отпечатки получались путем прокатки плетенного из шнуров валика (Dumpe, 2006. Рис. 9).

${ }^{6}$ Рогожные отпечатки - это условный термин. По мнению О.А. Лопатиной, на самом деле они наносились путем прокатки специального штампа. 
Эксперименты, поставленные О.А. Лопатиной, показали, что очень схожую с рябчатыми отпечатками фактуру можно получить при прокатке стержня еловой шишкой.

На примере сосуда № 59 хорошо видны следы работы по обработке поверхности с рябчатыми отпечатками. Усилия мастера были направлены на улучшение прикрепления стенок и дна. По всему периметру придонной части стенки тулова пальцем были нанесены вдавления. Затем рука мастера двигалась по стенке вверх, оставляя параллельные вертикальные полосы от пальцев.

При внимательном рассмотрении большинства рябчатых отпечатков можно увидеть, что они расположены не хаотично, а элементы (вдавления) образуют систему «сетки». Нитчатые отпечатки на керамике нижнего слоя не такие рельефные, как на горшках из погребенной почвы. На примере сосуда № 62 видны большие участки-полосы с отпечатками параллельных нитей. Полосы пересекаются друг с другом под углом, оставляя впечатление, что по поверхности сосуда прокатывали плетеный валик шириной около $10 \mathrm{~cm}$.

Дно лепилось, как лепешка, которую разминали, наносили на поверхность рельеф то одной, то другой стороной. Таким образом, текстильные отпечатки оказывались на обеих сторонах дна. При соединении дна со стенками мастер проглаживал стык пальцем. В результате получалось кольцо гладкой поверхности по периметру дна.

Очень интересен сосуд № 42 с Дьякова городища (рис. 129). Его поверхность покрыта рельефными расчесами гребенчатым инструментом поверх текстильных отпечатков. Гребенчатый инструмент, видимо, имел восемь зубьев расположенных с интервалом 4-5 мм, а сами зубья имели ширину 1-2 мм. То есть данный инструмент совсем не был похож на гребенчатые штампы, которые использовались при обработке поверхности и орнаментации керамики из погребенной почвы. На фото хорошо видно, что следы «редкого гребня» пересекают и заминают текстильные отпечатки на поверхности сосуда. Расчесы гребнем идут под углом друг к другу. Подобный тип обработки поверхности был встречен и на городище Настасьино (Энговатова, 2009. Рис. 7).

Орнаментация. Около 30 \% сосудов из нижнего слоя Дьякова городища были орнаментированы. Эта цифра была получена следующим образом: был произведен подсчет орнаментированных и неорнаментированных крупных венчиков. Размер выборки равнялся 250 ед. Такой подход оправдан по отношению к раннедьяковской керамике, так как в большинстве случаев орнаментировалась лишь самая верхняя часть сосудов. Орнамент наносился на 1-5 см ниже обреза венчика. Торец венчика в подавляющем большинстве случаев не орнаментировался. В целом по нижнему слою не более $2 \%$ венчиков орнаментировано по торцу. Орнаментировался торец венчика насечками, поперечными вдавлениями, в том числе ногтевыми. Возможно, в самой верхней части нижнего слоя процент венчиков, орнаментированных по торцу, увеличивается, но материал слишком малочисленный для надежных выводов.

В период отложения нижнего слоя господствовал ямочный орнамент. Обычно ямки имели круглую форму.
Вероятно, использовались прутики или кости круглого сечения, а также стержни шишек (Лопатина, 2015), верхушки которых при подкручивании образовывали ямку-розетку. Гораздо реже ямки наносились предметами прямоугольного сечения. Редкими, но характерными, являются двудольные оттиски, наносившиеся расщепленным круглым в сечении предметом. В единичных случаях встречен прочерченный орнамент, насечки, вдавления пальцем и защипы. Защипной орнамент встречен лишь в самой верхней части нижнего слоя. Количественные соотношения между орнаментами представлены в таблице 14. Гребенчатый орнамент отсутствует.

На керамике Дьякова городища отмечены следующие орнаментальные композиции.

1. Одинарный непрерывный горизонтальный ряд ямок. Зафиксировано 22 случая. Расстояние между ямками от нескольких миллиметров до 2-2,5 см.

2. Двойные горизонтальные непрерывные ряды ямок. Отмечено лишь два случая.

3. Непрерывный зигзаг. Редкий вид орнамента, выполнялся в различной технике. Отмечен три раза.

4. Комбинации из групп вдавлений. Наиболее распространенными являлись варианты, когда ямки образуют ромбы, треугольники вершинами вниз, сдвоенные ямки, разделенные пустыми интервалами.

5. Два горизонтальных ряда, верхний - цепочка одинарных ямок, нижний - треугольники вершинами вверх. Зафиксирован только один раз.

Горшки из нижнего слоя Дьякова городища имеют многочисленные аналогии на других памятниках дьякова типа, прежде всего в бассейне Москвы-реки, а также на Верхней Волге и на городищах каширского течения Оки.

П.Н. Третьяков именно такие баночные горшки со слабо профилированным венчиком считал типичными для дьяковских городищ второй половины I тыс. до н.э. (Третьяков П.Н., 1966а. С. 151).

Большие серии горшков, аналогичных горшкам из нижнего слоя Дьякова городища, происходят с городищ нижнего течения Москвы-реки. Это Боршева (Крис и др., 1984. С. 132) и Настасьино (Энговатова, 2009. Рис. 7). Датировка слоя Боршевы, откуда происходят горшки (рис. 127), аналогичные горшкам из нижнего слоя Дьякова городища, по набору вещей была определена Х.И. Крис в интервале IVIII вв. до н.э. На городище Городищи, расположенном на p. Коломенке, также были найдены горшки очень близкой «закрытой» формы с плавно загнутой вовнутрь верхней частью (Сыроватко, 2009. Рис. 76, 77). Радиоуглеродная датировка (ГИН-9427а 2250土40) «по контексту» для одного из горшков с этого памятника указывает на IV-III вв. до н.э. (Сыроватко, 2009. С. 246).

Наряду со сходством можно отметить и некоторые отличия. Горшки с городищ Настасьино и Городищи, видимо, отличаются от посуды Дьякова городища тем, что сосуды высоких пропорций представлены в этих коллекциях большим числом.

На городищах нижнего течения Москвы-реки встречаются текстильные горшки, характерные для территории, при- 
мыкающей к бассейну Москвы-реки с востока и юго-востока. К таким горшкам можно отнести сосуды с рядом дырочек под венчиком (Кренке, Чаукин, 2013). Аналогичная орнаментация встречена на городище Тюков городок в Мещере, городище Васильково на р. Нерль Клязьминская (Кренке, Ершов, 2016) и городище Пекшевское на р. Воронеж (Медведев, 1999).

Уникален текстильный горшок из раскопок Знаменского городища с налепным валиком по плечику (рис. 124, 2).

Соотношение групп керамики, выделенных по способу обработки поверхности (текстильная/гладкостенная), в нижнем слое Дьякова городища и на городищах Настасьино и Городищи близки друг другу, но не тождественны. На городищах нижнего течения Москвы-реки доля текстильной керамики несколько меньше (50-60 \%), чем на Дьяковом городище $(80 \%)$.

Городища среднего течения Москвы-реки и бассейна p. Пахры содержат керамику, очень близкую по форме и орнаментации к керамике нижнего слоя Дьякова городища. Прежде всего, надо отметить коллекции с городищ Щербинское, Кузнечики (Розенфельдт И.Г., 1973; 1974), Борисоглебское (Розенфельдт Р.Л., 1967. Рис. 36) и Боровский курган (Кренке, Лопатина, 2008). Характерна радиоуглеродная датировка, полученная для слоя городища Боровский курган с керамикой, аналогичной нижнему слою Дьякова городища - 2170土60 лет (Кі-12511), что указывает на интервал 357-119 гг. до н.э. с пиком вероятности, приходящимся на 200 г. до н.э. Аналогичная керамика происходит из слоев Сетунского и Мамонова городищ в Москве (Розенфельдт Р.Л., 1969. Рис. 1, 2; Розенфельдт И.Г., 1971. Рис. 9, 2,8,10). Сетунское городище интересно также тем, что оно почти идентично нижнему слою Дьякова городища по соотношению гладкостенной и текстильной керамики. Текстильная керамика на этом памятнике составляет около 70 \%. (Розенфельдт И.Г., 1973. Рис. 45).

На городищах звенигородского течения Москвы-реки также широко представлена текстильная керамика, аналогичная нижнему слою Дьякова городища. Здесь не было больших раскопок, поэтому целые формы горшков отсутствуют. Наиболее показательными являются коллекции городищ Успенское (Краснов Ю.А., Краснов Н.А., 1963. Рис. 8; Успенская, 1957. Рис. 45) и Дунино (материалы раскопок Г.Г. и П.Г. Дервизов), где, правда, «примешаны» и более ранние материалы.

Материалы третьей четверти I тыс. до н.э. с памятников верхнего течения Москвы-реки очень незначительны.

Памятники, расположенные к северу от Дьякова городища на относительно небольшом расстоянии (в пределах 100-150 км), а именно, городища Кикино и Синьковское в бассейне р. Дубны, Максимковское селище на Клязьме дали весьма похожий на Дьяково городище набор форм (Вишневский, 1998. Рис. 5, 1; 2009. Рис. 4, 1-5). Сходство прослеживается также в том, что доминирующим приемом орнаментации являлись ямки-розетки. Соотношение текстильной и гладкостенной керамики в комплексах этих памятников очень близко к нижнему слою Дьякова городища. Текстильная керамика составляет 80-86\% (Вишневский,
2009. Табл. 2). В свете данных, имеющихся по Дьякову городищу, можно утверждать, что керамический комплекс этого памятника очень близок к керамике памятников волжского бассейна на севере Московской области.

Если проводить сравнение с собственно верхневолжскими городищами, то различия между ними и керамикой нижнего слоя Дьякова городища наблюдаются существенные. Боченковидные формы Кубринского городища (Вииневский, 1989, Рис. 2, 2) или высокие широкодонные банки с городища у с. Городище около Калязина (Третьяков П.Н., 1941. Рис. 17, 1) и Пекуновского (Бадер, 1950. Рис. 49,1$)$ не находят аналогий на Дьяковом городище. Очень существенны различия в орнаментации. На керамике верхневолжских городищ распространены «богатые» узоры, полученные комбинацией оттисков гребенчатых штампов и ямок. Не очень понятно, правда, насколько долго сохранялись эти традиции, восходившие к позднему бронзовому веку.

В то же время надо отметить, что керамика городища Отмичи (группы 1 и 2, по И.В. Ислановой) близка к Дьякову городищу.

Сравнение с «каширскими» городищами, расположенными на правобережье р. Оки показывает, что формы горшков, насколько это можно судить по публикациям коллекций Старшего Каширского и Мутенковского городищ (Лопатина, 2009; Сидоров, 2004), весьма близки к керамике нижнего слоя Дьякова городища (группы III, IV, V, по O.А. Лопатиной). Существенное отличие заключается в том, что на городищах правобережья Оки гладкостенная керамика преобладает над текстильной.

По материалам городища Ростиславль отмечается, что древнейший этап доминирования гладкостенной керамики сменился периодом резкого возрастания доли текстильной (Сыроватко, 2009. С. 127). По материалам Мутенковского городища можно отметить, что здесь имеются очень близкие аналогии профилированным текстильным горшкам с пальцевым орнаментом из самой верхней части нижнего слоя Дьякова городища (Сидоров, 2004. Рис. 4, 8). Может быть, в это время происходила экспансия «северной традиции» в долину Оки?

Для керамических комплексов городищ Дьякова типа характерны миниатюрные сосуды.

Если ориентироваться на такие показатели, как орнаментация, форма, процентное соотношение керамики с текстильными отпечатками на поверхности и гладкими, то можно предполагать, что керамика москворецких городищ дьякова типа V-II вв. до н.э. представляла синтез традиций, которые можно условно обозначить как «волжская», «москворецкая» и «окская». Относительно приземистые округлобоко-вогнутые формы типичны как для «волжской» (Исланова, 2007. Группа 1), так и для «окской» каширской традиции (Лопатина, 2009. Группа III). Судя по такому показателю, как пропорция текстильной/гладкостенной керамики, «волжская» («текстильная») традиция проявляется в материалах нижнего слоя Дьякова городища сильнее, чем «окско-каширская» («гладкая») традиция. Лаконичность орнаментации связывает керамику нижнего слоя Дьякова горо- 
дища с «москворецкой» традицией керамики рубежа бронзового/железного веков.

На протяжении третьей четверти I тыс. до н.э. происходили изменения в керамическом комплексе. Остается неясным вопрос о том, как следует интерпретировать полное исчезновение из обихода горшков, орнаментированных гребенчатым штампом на рубеже VI-V вв. до н.э. В V-III вв. до н.э. формируются устойчивые стандарты форм и типов орнаментации горшков. В III-II вв. до н.э. появились горшки, отличавшиеся более стройными пропорциями, наличием орнаментации венчиков, пальцевыми вдавлениями-защипами на плечиках (рис. 129, № 62, 63).

Набор вещеей. Среди вещей V-II вв. до н.э. преобладают изделия из кости (рис. 93-112). Этот набор представлен, в первую очередь, двумя большими группами - инструментами и стрелами. Важно отметить отсутствие элементов упряжи, характерных для городищ Прикамья (Аиихмина и др, 2006. Рис. 27-31).

В группу инструментов входили: 1) небольшие проколки и иглы из малой берцовой кости свиньи или грифельной кости лошади, 2) массивные проколки из грифельной кости лошади или боковой метаподиальной кости лося, 3 ) долотообразный инструмент с устойчивой шириной рабочей части, изготавливавшийся из метаподиев крупных копытных, 4) скобели из ребер, 5) струги из метаподиальных костей, 6) черешковые ножи, 7) четырех-трехвильчатые орудия неясного назначения. Таким образом, инструменты из кости позволяли выполнять широкий набор трудовых операций прокалывать, долбить, резать, скрести, плести (?) и т.П. О сложившихся технологических традициях костяной индустрии свидетельствует строгий отбор сырья и то, что орудия имели устойчивые формы.

Охотничье оружие представлено почти исключительно стрелами. Гарпуны редки. Комплекс стрел имеет ярко выраженную специфику. Более половины всех стрел относятся к типу одношипных со скосом на противолежащей шипу стороне (рис. 102, 103). Меньшим количеством представлены стрелы с подтреугольным пером без шипов, с утолщением (утяжеленные наконечники) при переходе от пера к черешку. Единичны стрелы с пулевидным, фигурным тупым пером. Вероятно, вышеперечисленные типы стрел имели разное функциональное назначение, этим обуславливалась степень их распространенности в древности и, соответственно, частота нахождения при раскопках. Важно отметить, что сравнение форм стрел, найденных на разных уровнях нижнего слоя Дьякова городища, позволяет наметить некоторую эволюцию их форм. Тенденция изменений заключалась в появлении стрел удлиненных пропорций трехгранного сечения.

Предметы икусства. Количество предметов местного искусства с территории Москворечья невелико, но они достаточно яркие и показательные (рис. 93-96). Роговая пластина с городища Боршева, рукояти ножей с городища Мамоново и Дубровицы II, костяной диск и рукоять из городища Настасьино (Энговатова, 2009) демонстрируют совершенно новый собственный стиль и набор образов. Это, в первую очередь, гравировка. Изображение включает короткие прямые и изогнутые линии, заканчивающиеся точ- ками-ямками. Изображения птицы и трехпалых следов (птичьих) на пластине из Боршевы, диске с городища Настасьино (рис. 93) указывают на существование набора семантически связанных символических изображений. В эту серию необходимо добавить костяную рукоять с изображениями трехпалых следов с Максимковского селища на Клязьме (Вишневский, 2009. Рис. 3, 12). Изображаются птица (одна и та же), крупное животное с торчащим вверх ухом (видимо, лошадь).

Нужно отметить, что находки, выполненные в данном стиле, встречены на городищах дьякова типа и за пределами Москворечья (Башенькин, Васенина, 2004 а. Рис. 10).

Стиль резьбы на кости находит отклик в глиняных изделиях - в орнаментации грузиков дьякова типа. Можно сказать, что этот собственный стиль с успехом «противостоял» влиянию скифского звериного стиля. Предметы скифо-сарматского искусства проникали в Москворечье, но подражаний этим импортам не найдены, как, например, в Прикамье.

Второе направление местного искусства - это мелкая глиняная пластика (рис. 115, 116). Серия зооморфных очень примитивных фигурок, найденных на городищах Дьяково, Бушарино, Протопоповском, Топорок, селище Дунино-4, с трудом поддаются атрибуции. Это могут быть поросенок (кабан?), медведь, бобр. Данный комплекс находит близкие аналогии на скифоидных городищах лесостепи, в частности Курского Посеймья (Пузикова, 1997. Рис. 26).

Там, где святилища бронзового-железного веков хорошо изучены, как, например, в Эгейском регионе, мелкая зооморфная пластика являлась их непременным атрибутом. Вероятно, москворецкие находки также были связаны с местной культовой практикой.

В V-III вв. до н.э. у жителей москворецких городищ, безусловно, были в ходу глиняные грузики дьякова типа (рис. 113, 114). Они несколько отличаются по своим характеристикам от грузиков более позднего времени. Лишь в раннее время встречались двухплощадочные (катушкообразные) грузики и крупные конические типа 1А, по К.А. Смирнову.

Важную роль в комплексе бытового инвентаря играли предметы из камня. В первую очередь, это «утюжки» с выпуклой спинкой и плоской заполированной рабочей частью и камни со сверлиной неясного назначения (рис. 120).

Железоделательное и бронзолитейное производства, безусловно, имели существенное развитие. Следы работы железным ножом по кости многочисленны, но самих находок ножей мало, это были еще относительно редкие и весьма ценимые инструменты. Можно предполагать, что существовали две основные формы ножей - серповидные и с горбатой спинкой (рис. 121). Это подтверждает значительная серия их «дешевых заменителей»- костяных ножей (рис. 105, 106).

Численное соотношение железных и костяных предметов является одной из важных диагностических характеристик. Число изделий из кости во много (примерно в 20 раз) больше, чем железных.

Довольно значительная серия обломков льячек (рис. 118) 
и выплески бронзы подтверждают, что на москворецких городищах существовало развитое производство бронзовых украшений. По-видимому, для этого периода (в отличие от более позднего времени) не были характерны сложносоставные украшения с мелкими подвижными деталями.

Наиболее крупными украшениями являлись пекторали и гривны (рис. 122, 123). Известна одна целая пектораль, найденная на Селецком городище (Чернай, 1980). Обломки схожей с ней были обнаружены на городище Мамоново. Эти изделия характерны для широкого региона. На смоленском Мокрядинском городище была найдена однотипная пектораль (Шмидт, 1992. Табл. 16). Аналогичные литейные формы найдены в бассейне Верхней Оки (Столяров, 2017). Гривна из коллекции Знаменского городища (Разуваев, 2012) также находит аналогии на Смоленщине, а именно в коллекции с городища Холмец (Шмидт, 1992. Табл. 16). Для этих украшений характерно сочетание основы с имитацией обмотки и «налепных» восьмеркообразных волют. Нужно отметить, что эти бронзовые престижные изделия «не укладываются» в какую-либо одну из лесных культур железного века (днепро-двинская, дьяковская, верхнеокская). Тождественные вещи встречаются в ареалах всех трех культур. Это очень значимый «транскультурный» феномен.

Находок, относящихся к начальному этапу эволюции умбоновидных подвесок, известно немногим более десятка. Можно перечислить следующие памятники: городища Знаменское, Дьяково (нижний слой), Настасьино, Боршева, Селецкое, Дунино-4, Городищи, Щербинское, Мутенковское, Ростиславль, селища Дубровицы II, Максимковское 1 (Вишневский, 2009. Рис. 4; Гоняный, Кренке, 1988. Рис. 2, 15; Дубынин, 1974. С. 271. Табл. XVII11; Коваль, 2004а, табл. 30, 212; Кренке, Лазукин А.В. и др., 2010. Рис. 9; Сапрыкина, 2005. Рис. 1, 2; 2006; Сапрыкина, Энговатова, 2002. Рис. 3; Сидоров, 2004. Рис. 5; Сыроватко, 2009. Рис. 102; Тавлинцева, Лопатина, 2009. Рис. 4). На четырех из перечисленных памятников (Щербинское, Мутенковское, Ростиславль, Дубровицы II) найдены литейные формы для подвесок. Стилистически эти украшения составляют особую группу. Они имеют следующие особенности: сильно выступающий щиток, длинная дужка часто без дополнительных декоративных элементов. Дужка всегда крепится к центру щитка с внутренней стороны.

По всей видимости, прямыми прототипами подвесок ранней серии были украшения, представленные находкой со Щербинского городища (рис. 143, 1). Эта умбоновидная подвеска имела маленький щиток, образованный закрученными в спираль нитями и длинную дужку (тип 1). Какие-либо дополнительные декоративные элементы отсутствовали. Этой находке чрезвычайно близка подвеска, найденная на селище Дунино-4 (рис. 143, 2). В то же время она имеет и некоторые отличия: щиток подвески увеличен, а по его краю пущен кант из перевитой нити. Подвеска из Дунино-4, вероятно, относится к переходному варианту от умбоновидных подвесок типа 1 к подвескам типа 2.

Можно также предположить, что умбоновидные подвески явились результатом синтеза простой формы конусовидных серег скифского типа и более сложного височ- ного украшения, характерного именно для лесной зоны, Находки этих весьма специфических украшений известны на Смоленщине (Шмидт, 1992. Табл. 14, 20) и Северной Белоруссии (Шадыро, 1985. Рис. 45, 1, 2), литейная форма найдена на селище Дубровицы 2 в Подмосковье (Гоняный, Кренке, 1988). Украшение представляет собой круг, выполненный в виде спирали из жгута, к которому прикреплены четыре волюты и сложная дужка, состоящая из трех стержней, окантовка из перевитого жгута отсутствует. Переходный вариант от этого украшения к умбоновидной подвеске происходит с городища Дунино. На нем мы видим вместо четырех волют лишь одну, появляется окантовка из перевитого жгута, дужка простая (рис. 143, 5).

В основном ранняя стадия развития москворецких умбоновидных подвесок представлена украшениями двух типов: с цельным щитком (тип 2) и с ажурным щитком (тип 3). По всей видимости, украшения с ажурными и слитными щитками существовали одновременно и имели параллельные линии развития.

Подвески типа 2 продолжали линию развития типа 1. Они представляют собой украшения со щитками средних размеров (диаметр - до 3 см, высота умбона до 1,5 см) с декором из нитей, уложенных по спирали. По краю пущен бордюр из витой нити; был также отмечен случай ее имитации с помощью насечек (подвеска с Максимковского селища). Дужка короче, чем у подвесок типа 1, но по-прежнему крепится к центру щитка (рис. 143, 5). Датировка на основании сопутствовавшей керамики и находок на селищах Дунино-4 и Максимково-1 - около V-III (II) вв. до н.э.

Время появления подвесок типа 3 на сегодняшний день не совсем ясно. В целом, повторяя основные признаки типа 2 (выступающий щиток, укороченная дужка, подведенная к центру щитка), они отличались ажурной, сложной формой щитка. Он представлял собой несколько отдельных окружностей в виде завернутых в спираль нитей, которые соединялись перемычками. По краю щитка шел бордюр из витой или зигзагообразной нити (рис. 143, 3, б), либо шариков зерни (рис. 143, 7). Внутри этого типа можно выделить несколько разновидностей, которые определяются, прежде всего, использованием при оформлении щитка мелких декоративных деталей разных типов: зигзагообразной нити, лент или «зерни». Можно высказать осторожное предположение, что между этими вариантами существуют определенные хронологические различия, однако эта гипотеза нуждается в дальнейшей проверке. На основании находки из нижнего слоя Дьякова городища можно утверждать, что конические щитки с зигзагообразным декором бытовали уже в IV-III вв. до н.э. (рис. 143, 3). По все видимости, другие варианты типа 3 появляются позднее.

Уникальная находка днища берестяного туеса на Дьяковом городище указывает на наличие значительного пласта вещей из бересты, о которых мы ничего не знаем. О том, сколь разнообразными и «культуроопределяющими» могли быть формы, орнаменты этих изделий показывают этнографические данные, в частности, по народам Западной Сибири.

Наконец, нужно отметить, что такие элементы ин- 
терьера «приочажного пространства», как рогатые кирпичи, характерны в I тыс. до н.э. для очень обширной территории - Центральная и Северная Европа, Причерноморье, восточноевропейская лесостепь (Пузикова, 1997. Рис. 27). В этом отношении культура жителей Дьякова городища «вписывалась» в стиль эпохи.

Импорты представлены стеклянными глазчатыми бусинами (египетского производства?), костяными и железными вещами скифского круга, указывающими на связи со Средним Доном (Крис, 1981) и Прикамьем (Гуляев, 1963).

Вопрос о преемственности дьяковской и преддьяковской культур

Керамический комплекс V-III вв. до н.э., описанный по материалам нижнего слоя Дьякова городища и сходных с ним находок из нижних слоев городищ Селецкое и Боршева, существенно отличается от керамики предшествующего времени. Разница проявляется в форме, характере отпечатков текстиля на поверхности, орнаментации сосудов. В вещевом комплексе также очевидны различия. Характерные для VIII вв. до н.э. костяные стрелы, набор костяных орудий, глиняные грузики дьякова типа не находят аналогий в более древних памятниках. В то же время наблюдается преемственность в освоении территории региона в целом, микрорегионов и площадок конкретных поселений.

Таким образом, мы видим противоречивые факты. С одной стороны, существенная культурная трансформация в Москворечье очевидна; с другой стороны, если предполагать приход какого-то нового населения в бассейн Москвыреки, то сразу встает вопрос - откуда? На него ответить трудно. Оставляя версию автохтонного развития, как более вероятную, можно выдвинуть несколько косвенных аргументов в ее пользу. На культурное развитие в третьей четверти I тыс. до н.э. существенным образом могло повлиять повсеместное внедрение орудий из железа. Появление новых эффективных железных инструментов (ножей) должно было привести к новым приемам и подходам к обработке кости и, соответственно, выработке новых форм костяных изделий. Второй аргумент также исходит из общих соображений. Если допускать, что в середине I тыс. до н.э. в результате развития земледелия и скотоводства (чему есть палеоботанические и археозоологические подтверждения) происходило интенсивное хозяйственное освоение региона, демографический рост (см. ниже), то логично предполагать и наличие процессов культурно-этнической интеграции. Такие процессы должны были сопровождаться генерированием новых черт материальной культуры, становлением ее новой «нормы». Поэтому наличие существенных различий в материальной культуре еще не означает отсутствие преемственности между населением, оставившим памятники VIII-VI вв. до н.э. и V-II вв. до н.э.

Сделанное выше предположение, как мне кажется, находит подтверждение в археологическом материале. Сравнивая керамику, вещевые находки, постройки раннедьяковских городищ Москворечья V-II вв. до н.э. можно лишь удивляться их схожести. Это действительно проявление новой «нормы». Рост этнической консолидации обычно проявляется также в выработке новых стилей предметов ис- кусства. Развитие собственной художественно-культовой традиции в сочетании с активизацией дальних связей, вероятно, можно считать показателем роста благосостояния и этической консолидации. Именно эти черты прослеживаются в культуре москворецких раннедьяковских городищ.

Важно подчеркнуть еще одну особенность. Дьяковские и днепро-двинские городища существенно различаются по керамическим наборам, но весьма близки по формам бронзовых украшений, которые обладают как бы «надкультурным» статусом. Причины этого явления требуют дальнейшего углубленного изучения.

\section{РАДИОУГЛЕРОДНАЯ ХРОНОЛОГИЯ ПАМЯТНИКОВ ДьякОВскОЙ кУЛЬТУРЫ}

Весь корпус радиоуглеродных дат для памятников железного века бассейна Москвы-реки в настоящее время насчитывает 246. Они получены для 21 городища и селища (табл. 15; каталог дат приведен в приложении II). Анализ этого массива показывает, что имеется очень значительное число дат (79) с радиоуглеродным возрастом в интервале 2100-2500. Это, безусловно, служит показателем высокой «активности жизни» в данный период. При рассмотрении суммированной вероятности всех калиброванных датировок также выделяется «пик», приходящийся на V-I вв. до н.э. Если анализировать лишь материалы Дьякова городища (125 датировок с учетом данных по образцам из раскопок 2000-2003 гг,), то «пик» вероятности калиброванных значений датировок в интервале V-I вв. до н.э. выделяется еще более отчетливо.

\section{РЕКОНСТРУКЦИИ СТРУКТУРЫ РАССЕЛЕНИЯ И ЧИСЛЕННОСТИ НАСЕЛЕНИЯ}

Сравнение числа известных памятников VIII-VI вв. до н.э. и V-II вв. до н.э. (увеличение в четыре раза!) дает основание для предположения, что в третьей четверти I тыс. до н.э. происходил быстрый рост населения в бассейне Москвы-реки.

Как было отмечено выше, памятники располагаются несколькими скоплениями. Наиболее отчетливо выделяются скопления поселений, расположенных на крупных притоках Москвы-реки - Истре, Пахре, Рузе. Можно попытаться произвести приблизительную демографическую оценку этих групп поселений. Например, в долине р. Пахры расположено десять крупных и средних поселений. Судя по данным, полученным при раскопках городищ Кузнечики, Боршева, Дьяково, Настасьино, на таких поселениях располагалось одновременно несколько домов. Можно примерно оценить число обитателей этих домов, исходя из площади построек. При расчете используется соотношение 1 человек на 6-10 м² пола постройки. (Casselberry, 1974; Naroll, 1962; Milisauskas, 1986. Р. 219). При таком подходе численность жителей на вышеперечисленных и подобных им городищах может быть оценена в 60-80 человек. Соответственно, численность населения такого микрорегиона, как бассейн p. Пахры, может быть оценена в 600-800 человек. Это как раз то количество людей, которое необходимо для того, 
чтобы воспроизводство популяции происходило без существенного притока мигрантов и чтобы не нарушался широко распространенный в примитивных обществах запрет на браки между родственниками ближе четвертого колена (Бунак, 1980. С. 254; Мурашко, 1984). Можно предполагать, что жители территориально обособленной группы раннедьяковских памятников на р. Пахре составляли популяцию с замкнутым кругом брачных связей.

Группа поселений в среднем течении Москвы-реки численно превосходит пахринскую в три раза и протянулась на расстояние около 100 км. Соответственно, численность населения, проживавшего здесь, должна оцениваться примерно в 2,5-3 тыс. человек. В пределах данной группы нет ясно выраженного центрального наиболее крупного поселения. Городища, как бусы, нанизаны на русло Москвыреки. Есть несколько участков, где прослеживается некоторая их разреженность. На основании этого можно предположительно разделить данный массив на несколько подгрупп: 1) Тучково - Успенское; 2) Знаменское - Тушино; 3) Кунцево - Капотня; 4) Соколова гора - Боршева.

Население всего бассейна Москвы-реки могло равняться 4000-5500 человек (минимальные цифры), учитывая, что всего городищ V-II вв. до н.э. в регионе было 69.

Видимо, это число жителей соответствовало «ресурсной емкости» территории при существовавших тогда производственных возможностях. Во всяком случае, дальнейший рост численности почти не происходил на протяжении тысячи лет, так как число и размеры позднедьяковских и раннедьяковских памятников практически одинаковы. Возможно, что за тысячелетнюю историю были периоды резкого снижения численности населения в бассейне Москвы-реки, которая затем опять возрастала до пределов, лимитировавшихся уровнем хозяйственного развития, природным окружением и другими факторами.

\section{РЕКОНСТРУКЦИИ ХОЗЯЙСТВА И ОСОБЕННОСТЕЙ КУЛЬТУРНОГО ЛАНДШАФТА}

Особенности хозяйства. Наиболее доступными данными для реконструкции хозяйства являются результаты определений обугленных зерен, полученных из культурного слоя при флотации и просеве через мелкое сито, а также остеологические коллекции кухонных остатков. Результаты спорово-пыльцевых анализов определяются многими факторами, и их интерпретация является сложной процедурой. Тем не менее, именно спорово-пыльцевые данные позволяют реконструировать главные черты ландшафта и растительности в определенном месте в определенное время. Сопоставление данных, полученных разными методиками, повышает надежность выводов.

Результаты карпологического анализа. Небольшие зерновые материалы были получены при раскопках Дьякова городища еще в XIX в. В.И. Сизов писал о находке «запаса каких-то зерен, частью обугленных, а частью перегнивших», не поддававшихся определению из-за плохой сохранности (Сизов, 1897. С. 265).

С целью получить более достоверную информацию о занятиях земледелием жителей Дьякова городища в 1982-1987 гг. впервые на памятниках этой культуры был применен метод получения зерновых материалов путем отмывки водой (флотации) и отсева через одно- и трехмиллиметровую сетку. Объем отбиравшихся образцов приблизительно равнялся 1 л.

Всего на исследование в лабораторию естественнонаучных методов Института археологии РАН поступило 567 отмывок из верхнего и нижнего культурных слоев. Все определения были произведены Н.А. Кирьяновой. Зерна были обнаружены в 346 отмывках в количестве более 2 тыс. целых экземпляров.

В последующие годы на ряде других памятников дьякова типа были проведены аналогичные работы по серийному отбору образцов, которые характеризуют все периоды их существования.

Так, на селище Веськово I на Плещеевом озере, датируемом первой половиной I тыс. до н.э. (преддъяковский памятник) был отобран 21 образец (Вишневский, 1994; Кирьянова, 2005), давший находки зерна.

На городище Настасьино, основной культурный слой которого синхронен нижнему слою Дьякова городища, было исследовано 1265 образцов, в том числе 237 образцов, относившихся именно к слою железного века. В 109 образцах (46\%) были обнаружены обугленные зерна культурных злаков (Антипина, Лебедева, 2005. С. 74; Лебедева, 2013). При этом каждый образец имел объем около 10 л.

На многослойном городище Ростиславль, где имеются напластования как раннедьяковского (слой 2), так и позднедьяковского (слой 1) времени было отобрано более 30 образцов (Лебедева, 2005; 2009). Все они содержали зерновые материалы.

Таким образом, в настоящее время имеется представительный материал для сравнения.

Рассмотрим подробнее находки с Дьякова городища. Отбор производился в раскопе 1983-1984 гг. по нескольку десятков образцов из каждого десятисантиметрового пласта, зерна встречены более чем в 50 \% отмывок. Довольно часто встречаются зерна и остатки колосков в отмывках из нижнего слоя.

Почти все найденные зерна обуглены. Значительное число зерен деформировано, из-за чего не удается все найденные материалы отнести к определенному роду сельскохозяйственных культур, но большинство зерен все же поддавалось определению. Обломки зерен, по которым можно определить только род культуры, учитывались лишь при подсчетах ее встречаемости в слоях 7 .

Нижний культурный слой представлен 120 отмывками, в 70 из которых обнаружены зерна. Первое место по встречаемости в образцах, содержащих зерно, занимает просо (Panicm miliaceum L.), второе - пшеница, представленная зерном пленчатых и голозерных видов культуры. В этом слое среди золы от сгоревшей органики найдены основания

\footnotetext{
${ }^{7}$ Под встречаемостью культур понимается отношение количества отмывок с зерном данной культуры к общему количеству отмывок, содержащих зерновые находки.
} 
колосков («вилочки») и обломок колоскового стержня пленчатой пшеницы. На третьем месте стоит ячмень (Hordeum vulgare L.). Половину всех найденных зерен ячменя составляет пленчатый ячмень. На обломках керамики из этого слоя сохранились отпечатки зерен ячменя, пшеницы и проса.

В нижнем слое Дьякова городища чаще встречались зерна пленчатой пшеницы. Можно говорить, что в нижнем слое встречаются зерна культур, которые хорошо развиваются на малоокультуренных почвах.

О развитии земледелия свидетельствуют находки остатков соломы ячменя в прослойках коричневой органики, отложившейся на периферии площадки городища рядом с постройками. Вероятно, эта солома как-то использовалась для подстилок или кровли.

На городище Настасьино были обнаружены те же самые культуры и в той же последовательности по частоте встречаемости: просо, пшеница, ячмень (Лебедева, 2013. С. 209). Кроме того, здесь был выявлен набор семян растений, характерных для нарушенных местообитаний.

В обзорной статье, в которой привлекаются также данные по городищу Ростиславль, Е.Ю. Лебедева отмечает существенный разброс в удельных значениях насыщенности культурного слоя дьяковских городищ зернами культурных злаков. Эти различия достигают 30 раз между городищем Ростиславль (на первом месте) и Настасьино (на последнем месте). На этом основании автор делает выводы о различной роли земледелия в хозяйстве данных поселений, подчиненной роли земледелия в Настасьино (Лебедева, 2013. С. 219-221). Мне представляется такой вывод методически некорректным. Во-первых, насыщенность слоя карбонизированными остатками зерен зависит от очень многих факторов. Во-вторых, методика промывки и хранения образцов могут оказать решительное влияние. Если, например, образцы оставлять сушить на открытом воздухе, то зерна просто сдувает ветром. Например, все образцы с Дьякова городища, где концентрация зерен в 10 раз выше, чем в Настасьино, сушились в закрытом помещении. Городища Дьяково и Настасьино по «археологическим параметрам» очень похожи друг на друга. Это «базовые поселения», площадки которых были заняты домами одинаковой конструкции. Набор находок характеризует очень сходную материальную культуру. Оба памятника расположены в удобных долинах рек с почвами, пригодными для земледелия. При этом степень сохранности культурного слоя этих двух поселений была различной. Если на городище Дьяково сохранность остатков жилищ и прослоек нижнего слоя была очень хорошей, то в Настасьино культурный слой был сильно переработан позднейшей многовековой хозяйственной деятельностью. Именно в этом следует видеть главную причину низкой удельной концентрации зерен на единицу объема культурного слоя.

Спорово-пыльцевые данные могут привлекаться для характеристики степени открытости ландшафта и трансформации растительности под воздействием человека. Спорово-пыльцевые данные имеются по двум памятникам городищам Дьяково и Настасьино. К сожалению, в обоих случаях эксперимент был поставлен не совсем корректно.
Образцы в колонках на городище Дьяково в 1981 и 1984 гг. отбирались через слишком большие интервалы - 10-15 см. Количество определенных пыльцевых зерен далеко не всегда достигало 400 (принятый стандарт для исключения случайных погрешностей). На городище Настасьино отбор проводился чаще, но не было произведено детального исследования (в том числе археологического!) генезиса отложений, из которых отбиралась пыльца, не была выполнена их стратиграфическая корреляция. Использование образцов из заполнения рва городища (Спиридонова и др., 2011), который, скорее всего, был засыпан в относительно недавнее время (последние 100-300 лет), на мой взгляд, существенным образом помешала корректному анализу результатов. Подробный разбор методических аспектов, которые заставляют пересмотреть выводы, сделанные по результатам анализов образцов из городищ Дьяково и Настасьино, был выполнен Е.Г. Ершовой (Ершова, Кренке, 2014). Суть замечаний заключается в том, что проценты соотношений травянистой и древесной растительности могут быть очень сильно искажены в образцах культурного слоя сравнительно с фоновыми. Различные травянистые подстилки, солома и т.п., которые присутствовали в прослойках построек, из которых отбирались образцы, могли очень сильно повлиять на результаты анализа. Сильное колебание в количестве пыльцы сорной растительности также может быть объяснено условиями отбора. В нижнем слое образцы отбирались из внутренней части построек (речь идет о городище Дьяково), куда, вероятно, почти не попадала пыльца снаружи. В верхнем слое колонка отобранных образцов пришлась на участок между постройками. Таким образом, пыльца сорной растительности, которая росла между домами, должна была проявить себя в образцах, что и было отмечено. В связи с этим находится под большим вопросом предложенная ранее интерпретация изменений в соотношениях групп видов на спорово-пыльцевых диаграммах как «циклов» увеличения антропогенного пресса на ландшафт, сменявшихся периодами его регенерации. Достоверность подобных циклов может быть проверена лишь при сопоставлении с фоновой колонкой, отобранной за пределами поселения. Тем не менее, факт существенной земледельческой активности подтверждается спорово-пыльцевыми данными. Существование вокруг городища открытых пространств несомненно.

Предположение о существовании исключительно подсечно-огневого земледелия не имеет веских доказательств. Наоборот, многовековое стационарное положение поселка на одном месте, должно было привести к масштабному сведению леса вокруг. Соответственно подсечное земледелие было бы в таких условиях почти невозможно. Важно подчеркнуть, что в культурах железного века лесной полосы Восточной Европы, очень сходных между собой по многим признакам, есть единичные находки пахотных орудий. Очень показательным предметом такого рода является уваровичское роговое рало из Гомельской области (Дробушевский, 1996). Очень интересным является лингво-географическое наблюдение А.Е. Дробушевского об ареале употребления слова «нарог» в значении лемеха плуга (Дробушевский, 1996. 
Рис. 2). Роговой предмет, похожий на наконечник рала, был найден на городище Пекуново на Верхней Волге, которое относится к дьяковской культуре (фонды музея г. Дубна).

Важно подчеркнуть, что имеются почвоведческие наблюдения над профилями погребенных почв под валами дьяковских городищ Луковня 2, Коробово, Троицкое, которые, скорее всего, указывают на существование пахотных горизонтов (Александровский, Кренке и др., 1998).

Палинологические исследования, проведенные в пойменной излучине между городищами Успенское и Николина Гора (разрезы РАНИС-1 и РАНИС-2), показали, что в долине Москвы-реки в период существования раннедьяковских городищ сохранялись участки, занятые лесом (в том числе хвойным). Эти залесенные участки находились между «пятнами» сильноокультуренного ландшафта. Особенно показательные результаты были получены на правобережной пойме Москвы-реки, противолежащей городищу Николина Гора. Здесь было установлено, что в радиусе около 1,5 км от городища на пойме встречены лишь луговые почвы, насыщенные угольками от сведенного леса (исследования А.Л. Александровского, Е.Г. Ершовой).

Археозоологические коллекциии для раннедьяковских городищ весьма представительны: городище Дьяково 5,3 тыс. определимых костей (Кренке, 2011. Табл. 49); Настасьино - 3,9 тыс. определенных костей (Антипина, 2013); Круглица - 2058 определенных костей (Цалкин, 1962. С. 75). Сравнение их между собой показывает значительное сходство. В первую очередь, сходство видно в процентном соотношении домашних и диких животных. Проценты домашних по трем памятникам очень схожи и колеблются в интервале 93-96 \% (табл. 17). Практически одинакова и последовательность основных видов домашних животных. При расположении домашних видов в порядке убывания численности мы видим следующую последовательность: свинья, лошадь, крупный рогатый скот, мелкий рогатый скот. Лишь на городище Настасьино мелкий рогатый скот занимает не четвертую, а третью позицию.

Анализ анатомического набора костей и учет веса животных разных видов убеждает, что на первом месте в мясной части диеты жителей городищ стояла конина (Кренке, 2011. С. 156; Антипина, 2013. С. 153), а затем - свинина.

Более существенна, чем это может показаться из простого прочтения таблицы 17 , была роль охотничьей добычи. Судя по анатомическим наборам костей, разделка охотничьей добычи - медведей и лосей - происходила вне городища. Показатели по этим животным необходимо умножать на 4 для корректного сопоставления с теми животными, разделка которых производилась на городище (Кренке, 2011. C. 155). Еще надо учесть, что вес лося был примерно в три раза больше, чем у мелкой дьяковской лошади, которую оценивают в 150 кг (Антипина, 2013. С. 152). Вводя эти поправки, можно допустить, что мясо, полученное в результате охоты (лось+медведь+бобр), занимало третью-четвертую строчку в балансе мясной диеты, конкурируя по значению с мясом крупного и мелкого рогатого скота. Показательна в этом отношении коллекция остеологических остатков с Максимковского селища на Клязьме, географически близкого к москворецким памятникам и имеющего с ними значительное сходство в материальной культуре. Из 800 определенных А.К. Каспаровым костей 326 (40,8 \%) принадлежали бобрам (Вишневский, 2009. Табл. 3).

Таким образом, роль охоты была весьма существенна, что находит отражение и в обилии костяных стрел разнообразных форм, очевидно, специализированных для охоты на различные виды животных.

Для того, чтобы сравнивать «вклад» в экономику жителей городищ дьякова типа земледелия и скотоводства, данных пока не хватает. Утверждать, как это делают Е.Е. Антипина и Е.Ю. Лебедева, что земледелие занимало подчиненное положение, мне кажется ошибочным.

Информации о рыболовстве немного. Небольшая коллекция определенных остатков рыб происходит из нижнего слоя Дьякова городища (Кренке, Цепкин, 1991). Всего было отобрано 17 образцов, в которых определены виды: щука, судак, лещ, плотва. Биотопические особенности вышеуказанных видов рыб указывают, скорее всего, что основным орудием лова была сеть.

Bblвoдbl. Новые данные по стратифицированным памятникам, значительная серия радиоуглеродных дат позволили упрочить представления о хронологии памятников дьякова типа в Московском регионе. Можно утверждать, что формирование раннедьяковской культуры произошло в VI-V вв. до н.э. Этот процесс характеризовали многочисленные культурные инновации. Наблюдался быстрый рост населения. Экологическая емкость долины Москвы-реки, видимо, была почти исчерпана. Жители городищ сформировали устойчивую модель хозяйства, опиравшегося, в первую очередь, на производящие формы экономики - земледелие и скотоводство,

Наряду с очень специфичными местными особенностями культуры, которые проявлялись в керамическом производстве, наборе костяного инвентаря наблюдаются и «надкультурные» явления. Так, престижные украшения из бронзы роднят раннедьяковскую культуру с соседней днепро-двинской. В особенностях домостроительства, способах оформления интерьеров также можно увидеть многочисленные параллели между городищами дьякова типа Москворечья и восточно-европейскими памятниками смежных регионов. Можно утверждать, что образ жизни жителей городищ дьякова типа вполне соответствовал «стандартам», установившимся в лесной зоне Европы в середине I тыс. до н.э.

На основе раскопок уникального для раннедьяковской культуры объекта - погребения по обряду трупосожжения на селище Дунино-4 - и привлечения других данных о находках человеческих костей на дьяковских городищах можно предполагать существование «многоступенчатого» погребального обряда (Кренке, 2011). 
Таблица 7. Радиоуглеродные даты для памятников начального этапа железного века на Москве-реке



Таблица 8. Техника орнаментации и способы обработки поверхности у керамики из погребенной почвы Дьякова городища

\begin{tabular}{|c|c|c|c|c|c|}
\hline \multirow[t]{2}{*}{ Поверхность } & \multicolumn{5}{|c|}{ Техника орнаментации } \\
\hline & Гребенчатый штамп & Круглые ямки & Наклонные тычки & Без орнамента & Всего \\
\hline Текстильная & 19 & 5 & 26 & 134 & $184(70 \%)$ \\
\hline Бороздчатое заглаживание & - & - & - & 7 & $7(2 \%)$ \\
\hline Неопределимая & - & - & 1 & 19 & $20(7 \%)$ \\
\hline
\end{tabular}

\section{Таблица 9. Виды орнаментации керамики с городища Луцино 2}

\begin{tabular}{|l|l|l|l|}
\hline Название & Лепная текстильная & Лепная гладкостенная & Лепная неопределимая (сильно замытая) \\
\hline Венчики (без орнамента) & 6 & 1 & \\
\hline $\begin{array}{l}\text { Венчики, орнамент гребенчатый } \\
\text { штамп }\end{array}$ & 4 & \\
\hline Венчики, орнамент круглые ямки & 2 & & \\
\hline Венчики, орнамент тычки & & 1 & 13 \\
\hline Стенки (без орнамента) & 22 & 59 & \\
\hline Стенки, гребенчатый штамп & 4 & 2 & \\
\hline Стенки, орнамент ямки & & & \\
\hline Всего стенок & & 3 & 13 \\
\hline Донца & 1 & $\mathbf{7 0}$ & \\
\hline Итого & $\mathbf{3 5}$ & 3 & \\
\hline
\end{tabular}


Таблица 10. Состав фаунистических остатков из раскопок Дьякова городища 1982-1984 гг. Погребенная почва (материк)

\begin{tabular}{|l|l|l|}
\hline Виды животных & Количество остатков & Относительное содержание видов в \% \\
\hline Лошадь (Equus caballus) & 18 & 17,0 \\
\hline Свинья (Sus scrofa) & 54 & 50,9 \\
\hline Крупный рогатый скот (Bos taurus) & 13 & 12,3 \\
\hline Мелкий рогатый скот (Ovis aries, Carpa hircus) & 8 & 7,6 \\
\hline Всего домашних & $\mathbf{9 3}$ & $\mathbf{8 7 , 7}$ \\
\hline Бобр (Castor fiber) & 10 & 9,5 \\
\hline Лисица & 1 & 0,9 \\
\hline Лось (Аlces alces) & 1 & 0,9 \\
\hline Заяц & 1 & 0,9 \\
\hline Всего диких & $\mathbf{1 3}$ & $\mathbf{1 2 , 3}$ \\
\hline Количество определимых остатков & 106 & 100 \\
\hline Количество неопределимых остатков & 259 & \\
\hline Всего остатков & $\mathbf{3 6 5}$ & \\
\hline
\end{tabular}

Таблица 11. Состав фаунистических остатков из раскопок селища Чертов Городок

\begin{tabular}{|c|c|c|c|}
\hline Виды животных & Количество остатков & $\begin{array}{l}\text { Минимальное число } \\
\text { особей }\end{array}$ & $\begin{array}{l}\text { Относительное } \\
\text { содержание видов в \% }\end{array}$ \\
\hline Лошадь (Equus caballus) & 13 & 1 & 9,8 \\
\hline Крупный рогатый скот (Bos taurus) & 46 & 1 & 34,6 \\
\hline Мелкий рогатый скот (Ovis aries, Carpa hircus) & 10 & 1 & 7,5 \\
\hline Лось (Alces alces) & 4 & 1 & \\
\hline Бурый медведь (Ursus arctos) & 4 & 1 & \\
\hline Бобр (Castor fiber) & 8 & 2 & 6 \\
\hline Водяная полевка (Arvicola terrestris) & 3 & 2 & \\
\hline Количество определимых остатков & 135 & & \\
\hline Количество неопределимых остатков & 390 & & \\
\hline Всего остатков & 525 & & \\
\hline
\end{tabular}

\section{Таблица 12. Состав фауны Мамонова городища (по В.И. Цалкину)}

\begin{tabular}{|l|l|l|l|}
\hline Виды животных & Количество остатков & $\begin{array}{l}\text { Минимальное } \\
\text { число особей }\end{array}$ & $\begin{array}{l}\text { Относительное содержание } \\
\text { видов в \% }\end{array}$ \\
\hline Лошадь (Equus caballus) & 177 & 27 & 17 \\
\hline Свинья (Sus scrofa) & 256 & 51 & 25 \\
\hline Крупный рогатый скот (Bos taurus) & 267 & 40 & 26 \\
\hline Мелкий рогатый скот (Ovis aries, Carpa hircus) & 59 & 18 & 6 \\
\hline Собака (Canis familiaris) & 5 & 2 & \\
\hline
\end{tabular}


Продолжение табл. 12

\begin{tabular}{|l|l|l|l|}
\hline Виды животных & Количество остатков & $\begin{array}{l}\text { Минимальное } \\
\text { число особей }\end{array}$ & $\begin{array}{l}\text { Относительное содержание } \\
\text { видов в }\end{array}$ \\
\hline Всего домашних & 764 & & $\mathbf{7 4}$ \\
\hline Лось (Alces alces) & 52 & 20 & \\
\hline Северный олень & 6 & 2 & \\
\hline Кабан & 19 & 7 & \\
\hline Бурый медведь (Ursus arctos) & 15 & 6 & \\
\hline Лисица & 5 & 4 & \\
\hline Куница лесная & 10 & 6 & 15 \\
\hline Заяц & 2 & 1 & $\mathbf{2 6}$ \\
\hline Бобр (Саstor fiber) & 154 & 34 & \\
\hline Всего диких & $\mathbf{2 6 3}$ & & \\
\hline Количество определимых остатков & $\mathbf{1 0 2 7}$ & & \\
\hline
\end{tabular}

Таблица 13. Соотношение групп керамики из нижнего слоя Дьякова городища, выделенных по способу обработки поверхности

\begin{tabular}{|l|l|l|}
\hline $\begin{array}{l}\text { Характер обработки } \\
\text { поверхности }\end{array}$ & Количество & Процент \\
\hline Гладкостенная & 2701 & 17,7 \\
\hline Текстильная & 12311 & 80,4 \\
\hline Рогожная & 47 & 0,3 \\
\hline Неопределимая & 243 & 1,6 \\
\hline Всего & 15304 & 100,0 \\
\hline
\end{tabular}

Таблица 14. Соотношение различных приемов орнаментации сосудов из нижнего слоя

\begin{tabular}{|l|l|}
\hline Приемы орнаментации & Количество \\
\hline Округлые ямки (в том числе ямки-розетки) & 268 \\
\hline Насечки & 12 \\
\hline Прямоугольные тычки & 5 \\
\hline Двудольные оттиски & 6 \\
\hline Прочерченный & 5 \\
\hline Вдавления пальцем & 1 \\
\hline Защипы & 2 \\
\hline Всего & 299 \\
\hline
\end{tabular}

Таблица 15. Некалиброванные радиоуглеродные даты для памятников «дьякова типа» в бассейне Москвы-реки

\begin{tabular}{|c|c|c|c|c|c|}
\hline $\begin{array}{l}\text { Радиоуглеродный возраст } \\
\text { в годах (ВР) }\end{array}$ & $\begin{array}{l}\text { Распределение дат }{ }^{1} \text { для } \\
\text { памятников «дьякова } \\
\text { типа» бассейна Москвы- } \\
\text { реки }\end{array}$ & \multicolumn{3}{|c|}{ Городища } & Количество дат \\
\hline $400-500$ & ] & 1 & - & - & 1 \\
\hline $500-600$ & ] ] & 1 & 2 & - & 3 \\
\hline $700-800$ & & - & - & - & - \\
\hline $800-900$ & ] & - & - & 1 & 1 \\
\hline 900-1000 & & - & - & - & - \\
\hline $1000-1100$ & ] & - & 1 & - & 1 \\
\hline $1400-1500$ & ] ] & 1 & - & 2 & 3 \\
\hline $1500-1600$ & ] ] & 2 & - & 1 & 3 \\
\hline
\end{tabular}


Продолжение табл. 15

\begin{tabular}{|c|c|c|c|c|c|}
\hline \multirow{2}{*}{$\begin{array}{l} \\
\text { Радиоуглеродный возраст } \\
\text { в годах (ВР) }\end{array}$} & \multirow[b]{2}{*}{$\begin{array}{l}\text { Распределение дат }{ }^{1} \text { для } \\
\text { памятников «дьякова } \\
\text { типа» бассейна Москвы- } \\
\text { реки }\end{array}$} & \multicolumn{3}{|l|}{ Городища } & \multirow[b]{2}{*}{ Количество дат } \\
\hline & & Дьяково & Настасьино & $\begin{array}{l}\text { Остальные } \\
\text { памятники }\end{array}$ & \\
\hline $1600-1700$ & ]נבנבנבנבנב] & 9 & - & 2 & 11 \\
\hline $1700-1800$ & ]בנבנבנבנבנ]נ] [ & 12 & - & 1 & 13 \\
\hline $1800-1900$ &  & 23 & 1 & 6 & 30 \\
\hline $1900-2000$ & נבנבנבנבנבנבנבנבנבנבנבנבנבנבנבנ] & 14 & 5 & 9 & 28 \\
\hline $2000-2100$ & בנבנבנבנבנבנבנבנבנבנבנ] & 7 & 6 & 6 & 19 \\
\hline $2100-2200$ & נבנבנבנבנבנבנבנבנבנבנבנבנבנ] & 12 & 6 & 6 & 24 \\
\hline $2200-2300$ & בנבבנבנבנבנבנבנבנבנבנבנבנ] & 11 & 5 & 7 & 23 \\
\hline $2300-2400$ & בנבנבנבנבנבנבנבנבנבנבנבנ] & 11 & 4 & 7 & 22 \\
\hline $2400-2500$ & ]בנבנבנבנבנ]ב] & 8 & 1 & 4 & 13 \\
\hline $2500-2600$ & [נבנבנבנבנ] & 2 & 2 & 6 & 10 \\
\hline $2600-2700$ & ]בנבנ]ב] & 3 & 5 & - & 8 \\
\hline $2700-2800$ & ] נבנ] & 2 & 2 & - & 4 \\
\hline $2800-2900$ & ]] & 1 & - & 1 & 2 \\
\hline $2900-3000$ & & - & - & - & - \\
\hline $3000-3100$ & ] & - & 1 & - & 1 \\
\hline $3100-3200$ & ] & - & - & 1 & 1 \\
\hline $3200-3300$ & ] & - & 1 & - & 1 \\
\hline $3300-3400$ & ] & - & 1 & - & 1 \\
\hline $3400-3500$ & & - & - & - & - \\
\hline $3500-3600$ & & - & - & - & - \\
\hline $3600-3700$ & & - & - & - & - \\
\hline $3700-3800$ & ] & 1 & - & - & 1 \\
\hline $3800-3900$ & & - & - & - & - \\
\hline $3900-4000$ & & - & - & - & - \\
\hline \multicolumn{5}{|l|}{ Bcero: } & 233 \\
\hline
\end{tabular}

${ }^{1}$ Символ каждой отдельной даты (] ) помещен в наиболее вероятный для данной даты 100-летний интервал.

Таблица 16. Находки остатков культурных растений в отмывках и отсевках нижнего культурного слоя Дьякова городища (раскопки 1983, 1984, 1987 гг.)

\begin{tabular}{|l|l|l|l|l|l|l|}
\hline Слои & Просо & Пшеница & Ячмень & Обломки зерен & Число отмывок/ отсевок с зерном & Всего отмывок \\
\hline Нижний слой & $36 / 217$ & $33 / 37$ & $22 / 26$ & 42 & $70 / 3$ & 120 \\
\hline
\end{tabular}

Примечание: в числителе - число отмывок, в знаменателе - число зерен.

Таблица 17. Видовой состав костных остатков с трех городищ «дьякова типа»: Круглица, Дьяково, Настасьино

\begin{tabular}{|c|c|c|c|c|c|c|}
\hline \multirow[t]{3}{*}{ Вид } & \multicolumn{6}{|c|}{ Городища } \\
\hline & \multicolumn{2}{|c|}{ Круглица } & \multicolumn{2}{|c|}{ Дьяково } & \multicolumn{2}{|c|}{ Настасьино (Мячково) } \\
\hline & Костей & $\%$ & Костей & $\%$ & Костей & $\%$ \\
\hline Мелкий рогатый скот & 143 & 7 & 613 & 11 & 319 & 8 \\
\hline Свинья & 798 & 39 & 2296 & 43 & 2270 & 57 \\
\hline
\end{tabular}


Продолжение табл. 17

\begin{tabular}{|c|c|c|c|c|c|c|}
\hline \multirow[t]{3}{*}{ Вид } & \multicolumn{6}{|c|}{ Городища } \\
\hline & \multicolumn{2}{|c|}{ Круглица } & \multicolumn{2}{|c|}{ Дьяково } & \multicolumn{2}{|c|}{ Настасьино (Мячково) } \\
\hline & Костей & $\%$ & Костей & $\%$ & Костей & $\%$ \\
\hline Собака & 14 & & - & & 6 & \\
\hline Всего домашних & 1918 & 93 & 5082 & 94 & 3802 & 96 \\
\hline Лось & 42 & 2 & 49 & 1 & 63 & 1,5 \\
\hline Кабан & 8 & & 6 & & 2 & \\
\hline Косуля & - & & 1 & & - & \\
\hline Оленьи & - & & 2 & & - & \\
\hline Северный олень & - & & 3 & & - & \\
\hline Хорек & - & & 5 & & - & \\
\hline Куница лесная & 4 & & 35 & & 10 & \\
\hline Выдра & - & & 4 & & 4 & \\
\hline Барсук & - & & 1 & & - & \\
\hline Ёж & - & & 3 & & - & \\
\hline Белка & - & & 1 & & - & \\
\hline Заяц беляк & 6 & & 2 & & 7 & \\
\hline Полевка & - & & 2 & & - & \\
\hline
\end{tabular}


ГлАВА III

\section{ПОЗДНЕДЬЯКОВСКАЯ КУЛЬТУРА НА ТЕРРИТОРИИ БАССЕЙНА МОСКВЫ-РЕКИ}

$\mathbf{T}$ ермин «позднедьяковская культура», предложенный в 1966 г. П.Н. Третьяковым (Третьяков, 1966), прочно вошел в употребление, так как оказался адекватным материалам раскопок городищ и селищ железного века, проведенных в последние три десятилетия в пределах бассейна Москвы-реки.

Наиболее «чистый» позднедьяковский материал в пределах москворецкого бассейна был получен при раскопках Троицкого городища, расположенного выше Можайска, Дьякова городища в Москве, городищ Щербинское, Луковня 1, Кузнечики в бассейне р. Пахры ${ }^{1}$. Материалы именно этих памятников легли в основу написания данной работы.

Городища Троицкое и Луковня 1 являлись позднедьяковскими хорошо укрепленными поселками, основанными на месте незначительных более ранних поселений. Примесь материалов третьей четверти I тыс. до н.э. в коллекциях с этих памятников невелика. На городище Дьяково позднедьяковский комплекс надежно выделяется благодаря исключительно ясной стратиграфии, позднедьяковские находки связаны с верхним слоем городища, отделенного от нижнего «стерильной» прослойкой (на большей части памятника). Мощный стратифицированный культурный слой Дьякова городища позволил достоверно проследить развитие материальной культуры на протяжении тысячи лет - c V в. до н.э. по V в. н.э. На городищах Щербинское и Кузнечики позднедьяковские находки связаны с верхними слоями.

Всего же для позднедьяковского периода в бассейне Москвы-реки известны 73 городища и 101 селище. Кроме этого, известно несколько городищ и более десятка селищ, на которых наличие позднедьяковского материала находится под вопросом (Кренке, 2011. С. 241-252).

Помимо находок, рассеянных в культурных слоях городищ, для характеристики позднедьяковской культуры большое значение имеют кладовые комплексы, также связанные с поселениями. Это клады с городищ Щербинское, Троицкое, Дютьково, Круглица, Дьяково, Ичского (Алтуховского), селища Заболотье-3.

\footnotetext{
${ }^{1}$ Городища Троицкое, Щербинское и Кузничики раскопаны Московской экспедицией ИА РАН под руководством А.Ф. Дубынина; городище Луковня 1 исследовано экспедицией Музея истории и реконструкции Москвы под руководством А.Г. Векслера; городище Дьяково исследовано экспедицией Дирекции охранной зоны заповедника «Коломенское» под руководством Н.А. Кренке.
}

Исследование вышеперечисленных памятников показали, что хотя у П.Н. Третьякова и были некоторые «натяжки» при выделении позднедьяковской культуры (например, утверждение, что грузики дьякова типа характерны только для позднедьяковской культуры), но в целом неоспоримо, что на рубеже эр или столетием раньше произошла серьезная культурная трансформация, существенно изменившая облик материальной культуры жителей городищ дьякова типа. Поэтому оправдано введение особых терминов, для обозначения культуры, существовавшей до этой трансформации и после нее. При этом присутствие континуитета традиций, наряду с отличиями, подчеркивается употреблением однокоренных слов - «дьяковская культура» (или «раннедьяковская») и «позднедьяковская культура».

И.В. Исланова при анализе древностей железного века района Верхней Волги вслед за К.А. Смирновым (Смирнов, 1974) предложила трехчастную периодизацию, включающую ранне-, средне- и позднедьяковские этапы (Исланова, 2008. С. 47). Логика такого подразделения культуры заключалась в том, чтобы подчеркнуть отличия заключительного этапа с яркими, легко опознаваемыми чертами керамики «мощинского круга». Финальный этап дьяковской культуры в бассейне Москвы-реки действительно имеет ряд важных особенностей (см. далее), но, на мой взгляд, черты преемственности преобладают. Возможно, в верхневолжском регионе трансформации, связанные с влиянием мощинской культуры были более существенными, чем в Москворечье (об этом можно судить, например, по большему проценту лощеной керамики в верхних слоях верхневолжских городищ), поэтому для этого региона подходит трехчастная периодизация. Для древностей железного века бассейна Москвы-реки логичнее выглядит периодизация, включающая два больших периода - ранне- и позднедьяковский, которые, в свою очередь, подразделяются на этапы.

\section{ФОРМИРОВАНИЕ ПОЗДНЕДЬЯКОВСКОЙ КУЛЬТУРЫ}

Если сравнивать вещевые наборы из нижнего слоя Дьякова городища V-II вв. до н.э. и верхнего слоя, то наиболее бросающимся в глаза отличием является смена «костяной индустрии», железными изделиями. Горизонты нижнего культурного слоя насыщены костяными предметами различного функционального назначения - проколки, булавки, иглы, струги/скобели, долота, ножи, стрелы. Железные предметы 
представлены лишь редкими ножами. В целом, в нижнем слое железных изделий в 20 раз меньше, чем костяных. В верхнем слое, начиная с его основания, наблюдается совсем иная картина - доминируют предметы из железа. В нижнем горизонте верхнего слоя Дьякова городища железных находок в 2,4 раза больше, чем костяных изделий. В первую очередь, это разнообразные стержни, заготовки, ножи, серпы, стрелы. Эти изменения, видимо, были обусловлены развитием в лесной зоне технологии железообработки на исходе I тыс. до н.э. То есть данные признаки, в первую очередь, отражают технический прогресс.

Обращаясь к тем сторонам материальной культуры, которые менее зависят от технического прогресса, можно отметить следующее. Керамика начальной фазы позднедьяковского этапа имеет бросающиеся в глаза отличия от керамики предшествующего времени. Исчезает керамика с текстильными отпечатками на поверхности ${ }^{2}$, которая ранее доминировала в комплексе, исчезают некоторые приемы орнаментации - двудольные ямки, ямки-розетки и пр. То есть происходит очень важная смена традиции керамического производства. Однако нужно отметить, что смена текстильной керамики на гладкостенную не была повсеместной. На периферии основного ареала распространения позднедьяковских городищ в Москворечье традиция изготовления керамики с текстильными отпечатками, видимо, сохранялась. В первые века новой эры даже наблюдается частичное «возвращение» этой традиции в центральном и особенно нижнем Москворечье, но уже в очень незначительных масштабах (доля такой керамики составляла первые проценты от общего комплекса) $)^{3}$. Есть и иные общие черты позднедьяковской керамики с керамикой предшествующего времени. Их сближает слабопрофилированная форма крупных и средних горшковидных сосудов (при отсутствии мисок), орнаментация венчиков насечками, а плечиков - отпечатками пальцев и защипами. Технология составления формовочных масс почти не изменилась. В качестве основной примеси использовалась дресва и реже органика. Новацией являлось то, что в позднедьяковской керамике начинают изредка встречаться сосуды, в тесто которых помимо дресвы был добавлен шамот (Лопатина, 2011).

О трансформации культурной традиции говорит сравнительный анализ охотничьего вооружения. Костяные стрелы из нижнего слоя Дьякова городища резко отличаются по форме от сменивших их стрел из основания верхнего слоя. Вытянутые наконечники трехгранного сечения, характерные для периода рубежа эр (рис. 132, 14-16), совершенно отсутствовали в более ранний период.

\footnotetext{
2 «Текстильная керамика» - условный термин. Как было установлено О.А. Лопатиной, «текстильная» фактура на керамике из городищ дьякова типа получалась различными способами, среди которых был распространен способ прокатки по поверхности горшка стержня еловой шишки, обгрызенной мышами. Орнаментация «розетками» - это «тычки с прокруткой», выполненные той же шишкой (Лопатина, 2015).

${ }^{3}$ Серии горшков с «текстильными» отпечатками, но в то же время имевшими типичные позднедьяковские формы с отогнутыми наружу под углом прямыми высокими венчиками, встречены на городищах Дьяково и Боршева.
}

Для нижнего слоя Дьякова городища и синхронных ему слоев других городищ Москворечья была характерна мелкая глиняная зооморфная пластика - фигурки поросят, бобров и т.п., а также некоторые другие виды изделий вроде моделей «рогатых кирпичей», «хлебцев» и т.п. (Кренке, 2011. Рис. 97; Кренке, Лазукин и др., 2010; Сыроватко, 2009. Рис. 103). Эта традиция была широко распространена в культурах городищ лесной и лесостепной зоны в скифское время и, видимо, была связана с определенной культовой практикой, имевшей важное значение для характеристики культуры (Белая, 2011; Каравайко, 2012. Рис. 65; Пузикова, 1997. Рис. 26). В верхнем слое Дьякова городища присутствует глиняная пластика, но ее характер совершенно иной, это исключительно антропоморфные изображения, и появляются они лишь на заключительном этапе (см. ниже).

В то же время прослеживаются и черты преемственности. Например, сохранялись в употреблении глиняные грузики дьякова типа, предназначенные скорее всего для плетения шнуров (Савенкова, 2016). Их форма эволюционно менялась, размеры уменьшались от нижнего слоя к верхнему слою (рис. 131).

Мало изменилась поселенческая система и структура землепользования. В среднем течении Москвы-реки почти все городища с познедьяковскими слоями имеют в основании слои раннедьяковского времени. В то же время в поселенческой системе произошли некоторые изменения на макроуровне - плотнее стало заселено верховье Москвыреки, и почти запустел район ее нижнего течения (Кренке, 2011). Правда, надо отметить, что на городище Настасьино на р. Северке, а также на городище у с. Городище на p. Коломенке были получены радиоуглеродные даты для укреплений, указывающие на начало позднедьяковского этапа. Однако в имеющихся публикациях нет данных о наличии типичных позднедьяковских находок на этих памятниках (Энговатова, 2009).

Перечисленные особенности позволяют предположить, что на территорию Москворечья в финале I тыс. н.э. пришло новое население, близкое по культуре к тому, что проживало здесь ранее. Смешение пришлого и местного населения создало новую общность, которая начала интенсивно развиваться, что уже через один-два века привело к созданию развитой позднедьяковской культуры с выраженными культурными особенностями.

Важный вопрос, на который необходимо ответить - откуда пришло в Москворечье новое население, давшее импульс культурной трансформации?

В литературе уже давно было высказано мнение, что «культурный импульс» на территорию бассейна верхнего Днепра и Волго-Окского междуречья исходил из днепровского региона в финальный период существования зарубинецкой культуры (Третьяков, 1966а). Основой для таких предположений служило, в первую очередь, изучение керамического комплекса. Появление на верхнем Днепре керамики типа «среднего слоя Тушемли», т.е. горшков с отогнутым дугообразно наружу венчиком, орнаментированным насечками, защипами, связывалось с процессом распространения на северо-восток позднезарубинецких традиций. 
Е.А. Шмидт предложил называть керамику данного стиля «восточно-балтийским типом» (Шмидт, 2003. С. 145).

Сомнения относительно того, откуда исходили культурные импульсы, достигшие бассейна Москвы-реки, возникали в силу того, что горшки с профилированным дугообразным венчиком, насечками и вдавлениями по краю, отчасти похожие на позднедьяковские, типичны также для памятников позднескифского (скифоидного) и позднегородецкого облика, а затем и сарматского времени в Верхнем Подонье и Посеймье (Козмирчук, Разуваев, 2001. Рис. 3; Пузикова, 1997. Рис. 7-9; Разуваев, 1998. Рис. 8; 2008).

Таким образом, необходимо взвесить «за» и «против» версий южного («скифского») и юго-западного (зарубинецкого) влияния.

Более детальное сопоставление керамики «типа среднего слоя Тушемли» и позднедьяковской показало, что речь может идти о сходстве, но не о тождестве (Кренке, Лопатин, 1997). Например, некоторые типы орнаментации, известные на горшках из нижнего горизонта верхнего слоя Дьякова городища (см. ниже) совершенно отсутствуют в среднетушемлинских комплексах.

Датировка среднетушемлинских комплексов не ранее I в. н.э., как считают Н.В. Лопатин и А.Г. Фурасьев (2007а. С. 85), создает препятствие для того, чтобы считать их прототипами позднедьяковской керамики, так как, согласно радиоуглеродной хронологии Дьякова городища, трансформация дьяковской культуры в позднедьяковскую произошла ранее - во II-I вв. до н.э. Однако это препятствие может быть преодолено, так как основания для нижней датировки среднетушемлинской культуры не так уж надежны. А.И. Дробушевский, основываясь на тех же материалах, что и Н.В. Лопатин с А.Г. Фурасьевым, в качестве начальной для среднетушемлинского комплекса предлагает дату II-I вв. до н.э. (Дробушевский, 2012. С. 47).

Важной «подсказкой» служат находки слабопрофилированных горшков с венчиками, орнаментированными вдавлениями, и поверхностью, обработанной штриховкой. Керамика этого типа характерна для чечерской группы зарубинецких памятников, занимавших течение p. Сож (Дробушевский, 2012). Единичные находки керамики со штрихованной поверхностью известны в Верхнем Поднепровье (Лопатин, Фурасьев, 2007a; Дробушевский, 2011). Очень важно, что штрихованная керамика есть на городище Дьяково в основании верхнего позднедьяковского слоя (Кренке, 2011. Рис. 192, 193) и на Троицком городище в нижнем горизонте верхнего слоя (Розенфельдт, 1971. Рис. 13, 15).

Верхняя дата чечерской группы памятников определяется не позднее середины I в. н.э. (Дробушевский, 2012. С. 46). В связи с этим А.И. Дробушевский предполагает, что культурные импульсы из района зарубинецкой культуры на северо-восток могли датироваться более ранним временем - II-I вв. до н.э. (Дробушевский, 2012. С. 47). Такая хронология очень хорошо согласуется с археологическими и радиоуглеродными датировками основания верхнего слоя Дьякова городища, где была найдена керамика со штрихованной поверхностью.
Итак, важно подчеркнуть, что единичные находки штрихованной керамики ${ }^{4}$ в позднедьяковских комплексах начального этапа их формирования указывают на западные или юго-западные влияния.

В пользу «западной» версии свидетельствуют находки глиняных грузиков дьякова типа. Их ареал на рубеже эр или несколько ранее существенно расширился именно в западном направлении, охватив как Москворечье, так и Поднепровье. Это указывает на контакты населения этих регионов.

Относительно влияния скифской (скифоидной) и городецкой культур можно отметить следующее. В керамике из нижних слоев городищ, расположенных в нижнем течении Москвы-реки, датирующихся второй половиной I тыс. до н.э., можно отметить признаки этого влияния. Оно проявляется в присутствии небольшого процента сосудов с рогожными отпечатками на поверхности, орнаментации в виде сквозных проколов под венчиками (Кренке, Чаукин, 2013), профилированных форм (Талицкий, 1948. Рис. 3), схожих с городецкой и скифоидной керамикой верхнего Подонья (Бирюков, Разуваев, 2009; Козмирчук, Разуваев, 2001. Рис. 3; Разуваев, 2009). Остается неясным, однако, как точно датируются эти формы горшков в пределах второй половины I тыс. до н.э.

Важным аргументом против версии южного влияния как фактора, обусловившего сложение позднедьяковской культуры, является тот факт, что в нижнем течении Москвы-реки не известны памятники, схожие с позднедьяковскими городищами среднего и верхнего течения реки.

И.В. Ислановой было высказано предположение, что при определении региона, откуда могли прийти люди, оказавшие влияние на формирование позднедьяковской культуры, нельзя исключать Верхнее Поочье. В качестве аргумента этой версии приводится сходство с позднедьяковской керамикой некоторых горшков из нижнего слоя городища Дуна на р. Оке (Носов, 1974). Эта версия в какой-то степени перекликается с предположением В.В. Сидорова о роли в формировании позднедьяковских древностей населения городищ Каширского течения р. Оки. По В.В. Сидорову, население каширских городищ мигрировало на север не позднее II в. до н.э. (Сидоров, 2006. С. 143). Никаких обоснованных аргументов В.В. Сидоров при этом не приводит. Однако версию о существенной роли в сложении позднедьяковской культуры верхнеокского варианта днепро-двинской культуры так просто отбрасывать нельзя. К сожалению, материал из раскопок верхнеокских памятников не так хорошо стратифицирован, чтобы его можно было дробно датировать. Небольшие раскопки 2011 г. на городище Дуна дали колонку слоев с материалом (Столяров, 2015). Автор раскопок вполне обоснованно сопоставляет профилированную керамику городища Дуна (горшки типов 6 и 7), скорее всего, с древностями типа среднего слоя Тушемли (Столяров, 2015. С. 119).

\footnotetext{
${ }^{4}$ Нельзя путать с древней керамикой VII-VI вв. до н.э, поверхность которой была покрыта расчесами гребенчатого инструмента. Именно такая керамика ошибочно учитывалась И.Г. Розенфельдт в статистических таблицах в ее работах как «штрихованная».
} 
Надо отметить, что действительно имеется некоторое сходство керамики городища Дуна с позднедьяковской. Горшки с этого городища имеют лаконичную орнаментацию по краям венчиков и плечикам. Для верхнеокских памятников, как и для позднедьяковских, характерно доминирование гладкостенной керамики при очень малом проценте текстильной. Однако вышеперечисленных признаков сходства в керамике недостаточно, чтобы находить истоки позднедьяковской культуры на Верхней Оке.

Наконец, имеется еще один «ретроспективный» аргумент в пользу верхнеокской гипотезы. На развитой стадии позднедьяковской культуры Москворечье и бассейн Протвы явно входили в один вариант этой культуры. Именно в этом ареале был распространен целый набор очень специфических изделий (см. ниже). Типичные москворецкие умбоновидные серьги, накладки-бантики, прямоугольные нашивки из соединенных рядов микроскорлупок и пр., найденные на севере Калужской области, в том числе на Протве и в тарусском течении Оки (все из грабительских раскопок), дают этому новые и новые подтверждения. Клад бронзовых нашивных украшений с Ичского (Алтуховского) городища на p. Протве (Тавлинцеева, Кренке, 2017) дал типичный набор москворецких украшений, включая характерные «бантики». В связи с этим актуальной задачей являются новые раскопки городищ в бассейнах Протвы и Угры и по берегам Оки в районе устьев этих притоков.

Таким образом, рассмотрев различные направления возможных влияний, можно утверждать, что аргументов для однозначного ответа пока нет, но предпочтительнее выглядит предположение о культурных влияниях (и миграциях?), проникавших в москворецкий ареал с запада и юго-запада.

В то же время в ранних позднедьяковских вещевых комплексах очень отчетливо видно восточное (в том числе степное) влияние. Удлиненные костяные стрелы, костяные пряжки «сарматского типа» с неподвижным язычком (о них пойдет речь ниже), встреченные на дьяковских памятниках сериями, бронзовые украшения, находящие параллели в Андреевском кургане, не характерны для зарубинецких и восходящих к ним комплексов. То есть можно говорить о каком-то смешении западных и восточных культурных традиций в москворецком регионе, что, видимо, и обусловило сложение обновленной позднедьяковской культуры.

\section{ХРОНОЛОГИЯ, ХАРАКТЕРИСТИКА ВЕЩЕВОГО И КЕРАМИЧЕСКОГО КОМПЛЕКСА НАЧАЛЬНОГО ЭТАПА ПОЗДНЕДЬЯКОВСКОЙ КУЛЬТУРЫ}

\section{Хронология}

Ключевое значение для выделения набора вещей начального этапа позднедьяковской культуры имеют материалы Троицкого городища. Остановимся детально на датировке его слоев. Начало накопления нижнего слоя Троицкого городища А.Ф. Дубынин относил к IV-III вв. до н.э. (Дубынин, 1970а. С. 94). Х.И. Крис считала наиболее вероятной дату IV в. до н.э. (Крис, 1970. С. 169). А.Ф. Дубынин и Х.И. Крис основывали свои датировки на вещевых анало- гиях. И.Г. Розенфельдт полагала, что керамика нижнего слоя Троицкого городища не позволяет принять столь раннюю датировку этого слоя и относила возникновение городища к концу I тыс. до н.э. (Розенфельдт, 1971. С. 74-75).

Мнение И.Г. Розенфельдт кажется более основательным в свете раскопок Дьякова городища и радиоуглеродных датировок, полученных для Троицкого городища при повторных раскопках 1996 г. (Александровский и др., 1998). Дело в том, что в нижнем слое Троицкого городища резко доминирует гладкостенная керамика.

Несколько сотен фрагментов текстильной керамики, найденных на Троицком городище, составляют хронологически обособленный комплекс V-III вв. до н.э., не связанный (предшествующий) с основным массивом находок из нижнего слоя городища. Раскопки Дьякова городища показали, что до III в. до н.э. включительно в дьяковских комплексах Подмосковья доминировала текстильная керамика (Кренке, 2011). Следовательно, нижний слой Троицкого городища откладывался позднее этого рубежа, так как в нем доминирует гладкостенная керамика.

Вещевой комплекс из нижнего слоя Троицкого городища также не дает оснований для датирования его IV-III вв. до н.э. Важнейшим звеном в обосновании А.Ф. Дубынина и Х.И. Крис ранней даты нижнего слоя Троицкого городища является датировка набора стрел. Однако сопоставление наборов костяных стрел из нижних слоев городищ Дьяково, Боршева, Круглица (для которых есть надежные основания для датировки IV-III вв. до н.э.) и набора стрел из нижнего слоя Троицкого городища показывает их несхожесть. В нижних слоях городищ Дьяково, Боршева, Круглица нет характерных для нижнего слоя Троицкого городища узких удлиненных наконечников треугольного или подквадратного сечения. На Троицком городище отсутствуют, за единственным исключением, одношипные наконечники со скосом на противолежащей шипу стороне, которые являются наиболее характерным типом - хроноиндикатором для нижних слоев трех указанных выше городищ (Кренке, 2011. Рис. 83; Кренке, Чаукин, 2013. Рис. 4; Крис, Чернай, 1980. Рис. 2). В наборе стрел из нижнего слоя Троицкого городища выделяется группа (4-5 шт.) коротких стрел с расширением на конце черешка (Дубынин, 1970а. Табл. 1). Именно на эти стрелы в основном опирался А.Ф. Дубынин, устанавливая раннюю дату Троицкого городища. Действительно, эти стрелы ближе всего по форме к стрелам из нижних слоев городищ Дьяково, Боршева, Круглица, но не тождественны им, что не позволяет настаивать на синхронности.

Радиоуглеродный возраст, полученный по образцам угля из основания вала Троицкого городища, с наибольшей вероятностью указывает на II в. до н.э. - рубеж эр (табл. 18). В таблицу включены также даты, полученные для городищ Дьяково и Луковня 1 по образцам, надежно приуроченным к отложениям начальной фазы позднедьяковского периода.

Как видно из таблицы, радиоуглеродные датировки дают согласованные результаты, указывающие при калибровке преимущественно на I в. до н.э. - рубеж эр.

Для определения верхней границы начального этапа позднедьяковской культуры надо рассмотреть датировку 
нижнего горизонта верхнего слоя Троицкого городища и среднего горизонта верхнего слоя Дьякова городища. Именно с этими слоями связана существенная трансформация культуры, одним из наиболее ярких проявлений которой было распространение лощеной керамики. А.Ф. Дубынин датировал нижний горизонт верхнего слоя или третий пласт эталонной V зоны (глубина - 0,4-0,6 м) Троицкого городища II-III вв. н.э. Весьма показательно, что количество костяных стрел в этом пласте, судя по описям находок, превосходит количество железных стрел. Соотношение костяных и железных стрел является чутким хронологическим индикатором. На Дьяковом городище примерный паритет между костяными и железными стрелами наблюдается в культурном слое на глубине -240-260 см, который по радиоуглеродным определениям и археологическим находкам датируется не позднее I-II вв. н.э. В вышележащих слоях Дьякова городища железные стрелы доминируют над костяными. Это наблюдение заставляет предположить, что накопление третьего пласта культурного слоя Троицкого городища началось на рубеже эр и продолжалось в I-II вв. н.э. Характерными находками этого времени являются фибула «авцисса», железная двушипная втульчатая стрела, костяные пряжки с неподвижным язычком, обнаруженные в третьем пласте. Очень показательной является такая находка, как лапчатая подвеска (Дубынин, 1970а. Табл. 18, 25), находящая параллель в Андреевском кургане в Мордовии (Степанов, 1980, Табл. 44, 13). Таким образом, из вышесказанного следует, что II-III вв. являются верхней хронологической границей третьего пласта Троицкого городища, а большинство находок, вероятно, попало в него в конце I в. до н.э. - I в. н.э.

Обоснование датировки среднего горизонта верхнего слоя Дьякова городища, основанное на комплексном подходе (археологические данные+радиоуглеродные датировки), приведено в опубликованной монографии (Кренке, 2011. С. 145). Получен результат, указывающий на II или IIIII вB. н.э.

На городище Луковня 1, почти полностью раскопанном А.Г. Векслером в 1968-1982 гг., были найдены костяные пряжки, стрелы, бронзовые умбоновидные подвески и нашивки, которые, судя по материалам Дьякова городища, появляются не позднее самого начала новой эры. Стратиграфически комплекс ранних находок на городище Луковня 1 практически не вычленяется. Выделение этих вещей возможно лишь по аналогиям с находками из соответствующих горизонтов городищ Троицкое и Дьяково. Материалы городища Луковня 1 ценны тем, что по конструкциям, относящимся к началу жизни городища, была получена радиоуглеродная дата (табл. 18), указывающая на рубеж эр. Эта дата важна для установления возраста исчезновения текстильной керамики и датировки комплекса ранних находок с городища.

\section{Вещевой набор и керамика}

Перейдем к характеристике вещевого набора и керамики начального периода позднедьяковской культуры, стремясь выделить вещи: 1) специфически местные, 2) имевшие широкий ареал бытования, 3) привозные.
К числу местных «культуроопределяющих» изделий относятся в первую очередь бронзовые умбоновидные привески, о чем еще давно писал К.А. Смирнов (Смирнов, 1970. С. 185). Эволюционный ряд этих украшений (рис. 143), безусловно, восходит к более древним умбоновидным серьгам, бытовавшим в широком ареале лесной зоны от верхнего Поднепровья до Волго-Окского междуречья (Кренке, 2011. Рис. 160). Важно отметить, что в бассейне Москвы-реки примерно на рубеже эр сложился особый тип этих украшений, представленный несколькими разновидностями. Среди этих разновидностей имеются более сложные ажурные формы и более простые. Находки из дютьковского клада (Кренке, Лазукин, Тавлинцева, 2011) показали, что одновременно бытовали вещи, различавшиеся по размерам и детальности проработки элементов (рис. 137). Всего известно около 40 умбоновидных украшений москворецкого типа с 15 памятников (Кренке, 2011. С. 80). Единичные находки этих украшений известны за пределами основного ареала на территории смежных речных бассейнов - р. Оки и Верхней Волги.

В один набор с умбоновидными привесками, вероятно, входили биметаллические булавки с умбоновидным навершием. Этих находок известно значительно меньше - всего четыре (городища Кузнечики, Круглица, Подмоклово и селище Мякинино 2). В этот же набор, судя по составу кладов с городищ Щербинское и Круглица, входили ажурные квадратные нашивки, состоявшие из рядов зерни.

Именно для москворецкого региона характерны продолговатые нашивные бляшки с зубчатым краем, имевшие одну или две петельки для крепления с обратной стороны. Не менее характерны продолговатые плоские и двускатные нашивные бляшки. В кладе с Ичского городища в комплекте с этими двускатными нашивками были позднесарматские портупейные пряжки начала III в. (рис. 139-142). Судя по стратиграфии Дьякова городища, можно допустить, что двускатные нашивки несколько позднее ранних бляшек с зубчатым краем (поздние бляшки с зубчатым краем имеют плетенку по торцу и синхронны двускатным бляшкам, что показывает комплекс Ичского клада).

Глиняные грузики дьякова типа - очень характерная вещь для москворецких памятников. Кажется, здесь их концентрация выше, чем в соседних регионах, велико разнообразие форм. Только в Москворечье были найдены трехплощадочные грузики (Троицкое городище).

Основная масса изделий, встреченных в позднедьяковских памятниках Москворечья, имеет широкий ареал бытования, охватывающий Волго-Окское междуречье и сопредельные территории.

Среди костяных изделий надо выделить серию пряжек с неподвижным язычком с одной или двумя прорезями (городища Троицкое, Дьяково, Боршева, Луковня). Аналогичные по форме костяные пряжки встречены в таких удаленных регионах, как Прикамье, Башкирия, Нижнее Поволжье, Западная и Южная Сибирь (Агеев, 1992. Табл. 12; Аиихмина и др., 2006. Рис. 79, 14; Зубов, 2007; Могильников, 1992. С. 304. Табл. 124, 17; Мошкова, 1963; Тишкин, Матренин, 2010). Территориально более близкие аналогии - роговые 
пряжки с Чаплинского городища на Днепре зарубинецкой культуры (Третьяков П.Н., 1959. Рис. 14, 3) и верхнеокского городища Дешовка на р. Жиздре (Никольская, 1966. Рис. 1). П.Н. Третьяков определил пряжку из Чаплинского могильника как изделие «сарматского типа», с чем был согласен К.А. Смирнов, описывая пряжки с дьяковских памятников (Смирнов, 1974. С. 47). Эти пряжки очень хорошо согласуются с представлением о том, что начало позднедьяковского периода относится ко II-I вв. до н.э. Аналогии не случайны, а указывают на определенный хронологический горизонт и направление культурных контактов.

Многочисленные костяные стрелы в большинстве своем имеют удлиненные пропорции, сечение пера часто треугольное, квадратное, круглое (рис. 132). Из железных изделий наиболее частой находкой являются ножи и стрелы. Ножи с горбатой или спрямленной спинкой (рис. 133). Стрелы обычно двушипные с длинным черешком и узким вытянутым пером (рис. 132). Встречаются и стрелы без шипов с узким треугольным пером и уступами при переходе к черешку (рис. 132, 13). Кажется, именно с началом позднедьяковского этапа связаны находки железных серпов, которые встречаются весьма часто (рис. 133, 4-6). Очень многочисленны железные кольца-заготовки, кольца-пронизи, разнообразные стержни-шилья, булавки, в том числе со спиральным завершением. Возможно, некоторые кольца с несомкнутыми концами являлись браслетами. Типичны также пряжки, концы которых загнуты в одной плоскости с основной дугой. Редкими, но регулярно встречающимися находками являются железные топоры-кельты и наконечники копий (известно всего шесть копий - с городищ Троицкое, Щербинское, Дьяково, Барвихинское и Кунцево).

Среди бронзовых украшений распространены нашивные круглые бляшки с плетенкой по краю, бляшки-скорлупки и комбинации из них, спиральные многовитковые браслеты, гривны (рис. 144, 2) с раскованными концами (клады второй Щербинский и с городища Круглица).

Привозные изделия представлены редкими бронзовыми украшениями, такими как лапчатая привеска с Троицкого городища, нашивные бляшки в стиле Андреевского кургана, а также фибулой «авцисса» (очень характерна для древностей типа Андреевского кургана). Наиболее вероятный путь проникновения в лесную зону этого римского изделия пролегал с юга через посредничество сармат. Трехлопастная железная стрела с Троицкого городища (Дубьлнин, 1970а. Табл. 13, 43) также, видимо, имеет отношение к сарматским древностям. Известны единичные находки стеклянных бус, в том числе золотостеклянных (Кренке, Румянцева, 2008).

Керамический комплекс может быть охарактеризован по материалам нижнего горизонта верхнего слоя Дьякова городища (Кренке, 2011. Рис. 192, 193) и нижнего слоя Троицкого городища (Розенфельдт И.Г., 1971. Рис. 13). Доминирует грубая гладкостенная керамика, орнаментированная по венчику и плечикам, при очень незначительном присутствии горшков со штрихованной поверхностью. Формы горшков сильно разнятся по пропорциям, есть приземистые и вытянутые. Венчики эсовидной формы слабо отогнуты наружу (рис. 151). Горшки Троицкого городища более «раскрытые», диаметр их венчиков часто больше максимального диаметра тулова (Розенфельдт И.Г., 1971. Рис. 13, 7, 16), что находит аналогию в сосудах среднего слоя городища Тушемля (Лопатин, Фурасьев, 2007. Рис. 39). В то же время, орнаментация оттисками веревки, намотанной на палочку (Розенфельдт И.Г., 1971. Рис. 14, 1-10, 13; Кренке, 2011. Рис. 193, 73), сложные прочерченные узоры (Розенфельдт И.Г., 1971. Рис. 22, 3), пальчатый орнамент (отпечатки подушечки пальца) специфичны именно для дьяковской керамики и не имеют аналогий в среднетушемлинских комплексах. Горшки городищ Дьяково и Щербинское отличаются по пропорциям от горшков Троицкого городища, их плечики обычно шире горла. Это указывает на существование в пределах бассейна Москвы-реки локальных культурных традиций керамического производства.

Лощеная керамика и миски отсутствуют в комплексах нижнего слоя Троицкого городища (Розенфельдт И.Г., 1971. С. 26) и нижнего горизонта верхнего слоя Дьякова городища.

Домостроительство, планировка городищ и оборонительные сооружения. Фактически для начального этапа позднедьяковской культуры мы располагаем лишь одним памятником, который дает достоверное представление о домостроительстве и планировке - это Троицкое городище. Конструкции типа «жилых стен», обнаруженные на нем, были детально описаны ранее (Дубынин, 1970а. С. 11-15; Дубынин, Розенфельдт, 1970). Они характеризуют именно начальный период жизни памятника. Важно подчеркнуть, что на раннедьяковских городищах подобные сооружения не встречались. В раннедьяковский период площадки поселений были застроены длинными домами. Различия особенно хорошо видны при сравнении планировок раннедьяковского городища Настасьино (Энговатова, 2004. Рис. 1) и Троицкого, которые имели сходные размеры и формы площадок.

Не исключено, что сооружение подобное «жилой стене» существовало и на городище Дьяково. Не раз писалось о «стерильной» прослойке песка с пеплом, разделявшей нижний и верхний слои памятника. Однако в центре площадки и у самого ее края «стерильной» прослойки песка нет. Если посмотреть на расположение этой прослойки (вернее, двух прослоек, надстилавших одна другую) в плане, то можно увидеть, что она идет полосой шириной 6-7 м с четкими границами вдоль западного края площадки, немного отступя от него. Если учесть, что жители городища позднедьяковского этапа использовали песок именно для создания подсыпок полов построек, то можно предположить, что данная «макропрослойка» являлась подсыпкой пола «жилой стены». Ранее это предположение не высказывалось, но мне оно кажется очень логичным и много объясняющим в стратиграфии и планиграфии Дьякова городища.

На городище Кузнечики на р. Моче также была обнаружена длинная постройка вдоль края площадки. А.Ф. Дубынин считал, что она ранняя, синхронная или предшествовавшая длинному дому (постройка № 1) в центре городища (Дубынин, 1970. С. 155). С этим, однако, трудно согласиться. Ранние постройки (в том числе постройка № 1) оставили следы от стен в виде канавок в материке. Постройка 
№ 3 фиксируется лишь по ямам, канавки в материке отсутствовали. То есть уровень дневной поверхности этой постройки был на 30-40 см выше материка, так что канавки от стен уже не доставали его. Возможно, постройка № 3 была «жилой стеной» (это предполагал и А.Ф. Дубынин), существовавшей не в раннедьяковское время, а в начале позднедьяковского периода.

Степень изученности оборонительных сооружений позднедьяковских городищ низкая. Узкими малоинформативными траншеями были разрезаны системы валов и рвов городищ Бужарово, Андреевское (раскопки К.Я. Виноградова 1920-1930-х гг.), Неждино (Розенфельдт И.Г., 1964), Троицкое, Савино-Сторожевское, Барвихинское (Латьлшева, Розенфельдт, 1964), Кунцево, Коробово (Александровский u др., 1998). Данных о характере деревянных конструкций почти нет. Фактически мы мало продвинулись в понимании конструкции валов со времен описания К.Я. Виноградовым раскопок вала городища Бужарово, в теле которого, по его словам, были найдены «гнезда углей» (Виноградов. Дневник 1926 г. С. 35). Высказывались предположения, что в основания валов помещались кучки веток (Розенфельдт Р.Л., 1970; Александровский и др., 1998). Р.Л. Розенфельдт, специально изучавший оборонительные системы дьяковских городищ, пришел к выводу, что сложные укрепления, состоявшие из нескольких валов и рвов, дополненных эскарпами на склонах, относятся исключительно к позднедьяковскому времени и датируются серединой I тыс. н.э. (Розенфельдт Р.Л., 1970). Основаниями для такой датировки стал ряд аналогий и представления о датировке слоев Троицкого городища. Собственно в разрезе валов и рвов датирующих находок не было. Новые раскопки подтвердили вывод Р.Л. Розенфельдта в том смысле, что трехъярусные оборонительные конструкции относятся исключительно к позднедьяковскому времени, а также позволили уточнить датировку их создания.

Широкими раскопами были исследованы системы укреплений лишь на Настасьинском (Энговатова, 2004; 2009), Знаменском (раскопки Ю.Д. Разуваева 2005 г.), Михайловском (Смирнов, 1964) и Кунцевском городищах, где были раскопаны террасы-эскарпы на склонах (Векслер, 1975). В результате проведенных раскопок было установлено, что на раннем этапе существования Знаменского городища оно имело один вал и один ров, который несколько раз подновлялся (до трех раз). Затем была предпринята перестройка всей системы. В результате она стала состоять из трех валов и трех рвов. Из-за сыпучести грунта нельзя точно сказать, какова была глубина рвов и высота валов (скорее всего, чуть более 1 м). Общая ширина полосы оборонительной линии составляла 25 м. Возраст фортификационной системы устанавливается по керамике, найденной в погребенной почве под средним валом (Разуваев, 2012). Там была обнаружена слабопрофилированная текстильная керамика, подобная керамике из верхнего горизонта нижнего слоя Дьякова городища, которая позволяет определить terminus post quem. C подобной керамикой ассоциированы радиоуглеродные датировки, указывающие с наибольшей вероятностью на II в. до н.э. Например, датировка $2120 \pm 25$
(Hela-942), полученная по нагару со стенок горшка (Кренке, 2011. Табл. 41).

Укрепления Кунцевского городища образуют сложную трехъярусную систему. С напольной южной стороны узкий перешеек защищен тремя валами и тремя рвами. На западном и восточном склонах рвы переходят в террасы-эскарпы. На мой взгляд, это единая и одновременно созданная оборонительная система. В публикации А.Г. Векслера изложена иная точка зрения (Векслер, 1975). Он предполагает, что террасы разновременные: те, что находятся с восточной стороны склона, относятся к раннедьяковскому времени; а террасы на западном склоне - позднедьяковские. Аргументом в пользу раннедьяковского возраста служат костяные изделия и керамика с расчесами гребенчатым штампом, найденные на нижней третьей террасе на восточном склоне. Однако обращение к материалам отчетов показывает, что археологический контекст не позволяет сделать подобных выводов. В таблице 19 приведены данные, взятые из отчетов о раскопках 1970-1973 гг. (Векслер, 1971-1974). На всех террасах в предматериковых пластах и сооружениях на уровне материка преобладала грубая гладкостенная керамика, лощеная керамика представлена только на средней террасе (табл. 19). Ранние костяные стрелы и керамика с гребенчатым штампом были встречены как в нижних отложениях, так и выше на одном уровне с находками лощеной керамики, т.е. это - переотложенный материал. В основании заполнения внешнего и среднего рва была также найдена лишь грубая гладкостенная керамика. Такой состав находок с наибольшей вероятностью указывает на начало позднедьяковского этапа (до или в начале появления лощеной керамики), т.е. на I в. до н.э. - I в. н.э.

Материалы раскопок Кунцевского городища с очевидностью свидетельствуют, что по кромкам террас имелись столбовые ограды, а их площадки использовались под застройку. Сказанное не означает, что на Кунцевском городище не было в раннедьяковское время укреплений, но, видимо, они были «стерты» временем или кардинально перестроены.

Радиоуглеродные даты, полученные по образцам из основания вала на городище Коробово, свидетельствуют, что вал был возведен на рубеже эр (Александровский и др., 1998). О радиоуглеродном возрасте вала Троицкого городища писалось выше. На городище Настасьино со дна «большого дьяковского рва» по углю была получена датировка 2065 20 (Le-5898), что указывает на I в. до н.э. (Энговатова, 2004). Оборонительная система на городище у с. Городище на p. Коломенке была перестроена на рубеже эр (Сыроватко, 2010).

Таким образом, можно заключить, что в начале позднедьяковского периода, может быть, в I в. до н.э. или чуть позже городища в бассейне Москвы-реки были существенно укреплены. Городищ с трехъярусной системой укреплений известно не менее 13. На 25 городищах имеется двухъярусная система укреплений. Большинство этих городищ расположено в среднем течении Москвы-реки, долинах рек Истра и Пахра. При этом надо отметить, что «за рамками» списка остались такие мощные и хорошо укрепленные го- 
родища, как Успенское, Дьяково, Щербинское. Два из них - Успенское и Щербинское располагались на останцах. Очевидно, они имели кольцевые системы укреплений по периметру возвышенностей и дополнительные валы на въезде и у подножия останца (прослежено на Щербинском городище). К сожалению, укрепления позднедьяковского времени на этих памятниках остались неизученными.

Оборонительная система Дьякова городища, классического мысового укрепления, строилась на ином принципе. Площадку с напольной стороны защищали один ров и вал, но размеры этих сооружений, перепад высот от дна рва до гребня вала (до 12 м) значительно превосходили многоярусные оборонительные конструкции других городищ. Основа оборонительных сооружений Дьякова городища была создана в раннедьяковский период, затем они были лишь подновлены, перестраивать их, видимо, не было необходимости ${ }^{5}$.

\section{СРЕДНИЙ ЭТАП ПОЗДНЕДЬЯКОВСКОЙ КУЛЬТУРЫ}

Наиболее достоверную характеристику вещевого и керамического комплекса развитой позднедьяковской культуры дают материалы среднего горизонта верхнего слоя Дьякова городища. Пользуясь терминологией М.Б. Щукина (Щукин, 1994. С. 18), можно сказать, что развитая позднедьяковская культура стала «мисочной». Комплексы, полученные из сгоревших построек Дьякова городища, показывают, что миски и миско-горшки гладкие и подлощенные становятся непременным компонентом керамического набора. Более детальное описание керамического набора дано ниже.

Средний этап позднедьяковской культуры Москворечья характеризуется дальнейшим развитием местного стиля бронзовых украшений и активизацией внешних контактов. В этот период в Москворечье поступает значительное число импортов. Наблюдается и обратное явление - экспорт москворецких вещей в соседние регионы.

Особенно значимым для культуры населения Москворечья на этом этапе, видимо, был южный вектор контактов, влияние сарматского мира сказывается в наборе вещей и керамике. Москворечье, в свою очередь, видимо, стало «мостиком», связывавшим южный лесостепной регион с отдаленными северными и северо-западными территориями (Заволжье, бассейн оз. Ильмень, Южная Финляндия).

Конечно, с большой долей условности можно говорить о демографическом и хозяйственном «процветании» на среднем этапе позднедьяковской культуры. Некоторые факты (изложены ниже) указывают именно на это.

Хронология среднего этапа позднедьяковской культуры строится на основе анализа датированных импортов (бусы, украшения с эмалью и пр.) и данных серийного радиоуглеродного датирования стратифицированных объектов (более 40 датировок). Совокупность этих данных указывает на то,

\footnotetext{
${ }_{5}^{5}$ Вероятно, самая макушка вала Дьякова городища (примерно верхний метр) была сооружена в XVII в. Имеются документы 1692 г. о том, что на городище при царской усадьбе Коломенское был устроен «потешный городок» (Забелин, 1895. С. 660).
}

что вышеописанный комплекс материальной культуры следует датировать в пределах I (II) - IV вв. н.э.

Керамический и вещевой наборы среднего этапа позднедьяковской культуры. Технология изготовления керамики совершенствуется (рис.152, 153). Появляются весьма крупные горшки для хранения, сделанные при этом очень тщательно, симметричной формы с относительно тонкими стенками, профилированной верхней частью. По характеру обработки поверхности сосуды делятся на гладкостенные, лощеные (подлощенные), текстильные.

Реперным комплексом для характеристики керамического набора среднего позднедьяковского этапа (его начала) являются находки из постройки «Д-4» на Дьяковом городище (Кренке, 2011. С. 116). Из данной постройки, погибшей в пожаре, происходят 16 горшков, мисок и тарных сосудов, профиль которых был реконструирован полностью или более чем на половину (Кренке, 2011. Рис. 199-201). Этот комплекс (рис. 152) важен тем, что дает представление о наборе посуды, использовавшейся в одном хозяйстве. Набор включал несколько крупных тарных горшков (один подлощенный), несколько средних, вероятно, кухонных горшков, имеющих следы нагара на стенках, серию подлощенных мисок и миско-горшков. В том числе один из подлощенных миско-горшков имел объем около 7 литров. Важно отметить, что 9 из 16 горшков, которые удалось склеить, имели подлощенную поверхность. Это заставляет скорректировать представление о том, какова была реальная доля подлощенной посуды в керамическом комплексе. Статистика фрагментов из слоя Дьякова городища на соответствующей глубине дает совсем иные цифры - не более 4 \% подлощенной и лощеной керамики. Вероятно, «археологизация» лощеной столовой керамики и грубой кухонной происходила не совсем одинаково.

Профилировка стенок всех сосудов отличается стилистическим единством: дугообразный отгиб венчика, тулово с округлыми плечиками.

Кухонные горшки из комплекса постройки «Д-4» имеют лаконичную орнаментацию: края венчиков декорированы нарезками, а по плечикам идут прерывистые цепочки пальцевых защипов либо отпечатков палочки, обмотанной веревочкой. Тарные горшки орнаментированы лишь нарезками по краю венчика.

Аналогии грубым гладкостенным сосудам, представленным в постройке «Д-4», имеются в нижнем горизонте верхнего слоя Троицкого городища (Розенфельдт, 1971. Pис. $21,20,21 ; 22,37)$. Лощеные сосуды «плавных форм» также характерны для нижнего горизонта верхнего слоя Троицкого городища (Розенфельдт И.Г., 1971. Рис. 28). На Щербинском городище есть лишь единичные аналогии (Розенфельдт И.Г., 1974. Рис. 43, 43). Аналогичные лощеные миски есть на городище Варварина Гора (Буров, 2003. Рис. 26, 13).

Орнаментация позднедьяковской керамики среднего этапа выполнена с использованием того же набора приемов, что и орнаментация предшествующего этапа. Это ямки, штампы, вдавления, оттиски палочки, обмотанной веревочкой, защипы пальцами, ногтевые вдавления, про- 
черченные линии. Вариации орнаментальных композиций представлены в ряде работ (Кренке, 2011, Рис. 219; Розенфельдт И.Г., 1971. Рис. 15-18; 1974. Рис. 26-32). Наиболее сложные композиции выполнены палочкой, обмотанной веревочкой, и они характерны именно для горизонтов культурного слоя, соответствующих среднему позднедьяковскому этапу (Кренке, 2011. Рис. 198, 111; Розенфельдт И.Г., 1971. Рис. 9, 34). Новацией в орнаментации по сравнению с керамикой предшествующего этапа являлось украшение торца венчиков кольцевой канавкой, что было подмечено еще И.Г. Розенфельдт (Розенфельдт И.Г., 1974. С. 146, 147).

Если говорить о «внешних» параллелях, набору керамики из постройки «Д-4», то отчетливо прослеживается близость по форме и орнаментации (при отличиях в составе теста) с керамикой городищ и селищ севера Тульской области. Это тип VI, выделенный И.В. Белоцерковской по материалам селища Супруты (Белоиерковская, 1981. С. 199), или керамика памятников типа Упа-2 по Е.В. Столярову (Столяров, 2012), а также керамика группы памятников Ново-Клейменово, выделенной А.М. Воронцовым (Воронцов, 2007. Рис. 3). Параллели в профилировке прослеживаются в более южных памятниках типа Ишутинского городища на Красивой Мече (Разуваев, 1998. Рис. 8). Это сходство особенно заметно при сопоставлении форм крупных тарных сосудов.

Сравнение с керамикой рязано-окских могильников также позволяет увидеть некоторые общие черты. Комплекс посуды из могильников отличается от поселенческого усеченным набором форм. В погребениях представлены лишь горшки небольших и средних размеров, столовой и тарной посуды практически нет. Сходство некоторых типов керамики рязано-окских могильников с дьяковской отмечалось исследователями (Гришаков, 1993. С. 103, 104; Румянцева, 2007. С. 254). Речь идет о небольших и средних горшках с плавно отогнутым наружу венчиком, орнаментированным насечками. По терминологии В.В. Гришакова, это керамика «рязано-окского очага» (Гришаков, 1993. Рис. 40). По О.С. Румянцевой, это горшки серии 1 (Румянцева, 2007. Рис. 3). В.В. Гришаков с сомнениями, а О.С. Румянцева более уверенно предполагают, что это сходство обусловлено влиянием, распространявшимся с запада на восток. На мой взгляд, достаточных доказательств этому предположению нет. Возможно и обратное направление влияния, а также, что более вероятно, сходство обусловлено общими тенденциями в изменении «керамической моды» в I-III вв. н.э. на обширных пространствах в бассейнах Верхнего Днепра, Верхней Волги и Оки. Источники этих инноваций скорее всего следует искать на юге. Профилированная керамика позднескифских городищ лесостепи могла быть отправной точкой трансформации.

Керамика из горизонта культурного слоя Дьякова городища, непосредственно перекрывавшего постройку «Д-4» (рис. 155), демонстрирует некоторые инновации, а именно: a) венчик не дугообразный, а прямой, отогнут под углом (раструб); б) венчик вогнутый; в) на тулове в верхней части имеется ребро. При этом количество фрагментов с раструбообразным венчиком довольно большое, а сосуды с вогнутым венчиком и ребристые формы - единичны.
Подлощенные миски с вогнутыми краями (с peбром и без ребра), найденные на дьяковских городищах Щербинское, Луковня 1, Дьяково, имеют близкие аналогии на юге в регионе бассейна верхнего Дона. Здесь на городищах Чертовицкое III, Ишутино в контексте с находками сарматского времени представлены как круговые миски (прототипы), так и лепные подражания (Медведев, 1998. Рис. 5; Разуваев, 1998. Рис. 5).

На поселениях Верхнего Подонья сарматского времени очень распространены горшки с прямым, отогнутым под углом наружу венчиком-раструбом, тип 3, по А.П. Медведеву (Медведев, 1987; Бирюков, Бессуднов, 2006).

Позднедьяковская керамика развитого этапа имеет также сходство с лощеной и гладкой керамикой Подесенья, найденной на памятниках почепского типа первых веков н.э. (Терпиловский, 2004. Рис. 9, 10; Обломский, 2010. Рис. 140).

Вероятно, эти аналогии с керамикой Дьякова городища не случайны, они свидетельствуют если не о прямых, то об опосредованных контактах. Подтверждение этому имеется в наборе вещей.

Ocобое внимание привлекает позднедьяковская текстильная керамика. По своей профилировке и орнаментации эта керамика резко отличается от раннедьяковской текстильной керамики. Позднедьяковская текстильная керамика по форме не отличается от гладкостенной керамики. Для этой текстильной керамики характерна тонкостенность, развитая профилировка, больше половины венчиков орнаментировано (подсчеты проведены по материалам Дьякова городища), тогда как у раннедьяковской текстильной керамики лишь 1-2 \% венчиков орнаментировано по торцу, и характер этой орнаментации другой. Отличительной особенностью позднедьяковских текстильных горшков является то, что часто их венчик орнаментирован как с внешней, так и с внутренней стороны (коллекция городища Боршева, раскопки Х.И. Крис).

Профилированные текстильные сосуды, напоминающие по форме керамику из верхнего слоя Дьякова городища встречены на городище у с. Городищи на р. Коломенке, а также на памятниках, расположенных по р. Оке выше устья Москвы-реки - городищах Протопоповском (Талицкий, 1948), Ростиславль (Сыроватко, 2009. Рис. 65, 66), селище Сосновка IV (Сыроватко, 2009. Рис. 71). Требуется более детальное сопоставление этих комплексов между собой, чтобы установить, действительно ли они синхронны. Горшок из старых раскопок на городище у с. Городищи, хранящийся в музее г. Коломны, может быть характерным примером подобного типа керамики (рис. 154). Венчик прямой, отогнут наружу под углом в виде раструба, по торцу украшен косыми насечками. То есть налицо все признаки, характерные для керамики «сарматского времени», встреченной в широком ареале от верховьев Дона до Волго-Окского междуречья. Специфика заключается лишь в том, что поверхность покрыта «текстильными» отпечатками, очень рельефными. Этот единичный пример указывает на культурное своеобразие памятников низовьев Москвы-реки начала н.э., что уже отмечалось выше.

Комплекс женских украшений и «культурная идентич- 
ность». Очень ярко формирование «культурной идентичности» населения Москворечья II-IV вв. н.э. проявилось в развитии комплекса женских украшений. Несмотря на источниковедческую проблему, обусловленную тем, что погребения рассматриваемого населения остаются неизвестными, находки бронзовых украшений в культурных слоях поселений очень многочисленны, кроме того, имеются комплексы кладов, что позволяет сделать определенные выводы.

Уже отмечалось, что в первые века новой эры население Москворечья выработало новые, совершенно своеобразные типы украшений. В первую очередь, это серия разновидностей умбоновидных привесок, булавки с умбоновидным навершием либо с навершием из соединенных по пять скорлуповидных бляшек.

На среднем этапе позднедьяковской культуры гарнитуры украшений развиваются в двух направлениях. Во-первых, очень большое распространение получают нашивные украшения, состоявшие из комбинаций микроскорлупок (среди последних очень распространены были «бантиковидные» в виде двух соединенных вершинами треугольников, а также в виде прямоугольников, состоящих из нескольких рядов соединенных скорлупок). Во-вторых, на смену литым цельным украшениям приходят изделия с подвижными элементами, так называемые «шумящие». В первую очередь, это, видимо, головные (височные?) украшения, пришедшие на смену умбоновидным серьгам (рис. 143). При изготовлении шумящих украшений использовались такие элементы декора, как волюты, плетенки, косички, двойная зернь.

Картирование находок этих специфических украшений показало, что ядром их распространения является бассейн Москвы-реки, а также бассейн р. Протвы. Вероятно, ареал подобных находок простирается далее на запад, в бассейн верхней Угры и ее левого притока р. Воря. Здесь не было научных раскопок, но известны многочисленные находки, сделанные любителями металлодетекторного поиска.

Это может служить основанием для предположения, что именно в этом ареале проживала этнически консолидированная группа населения, культурно обособленная от соседей, но в то же время имевшая с ними широкие контакты. Это доказывается находками москворецких вещей за пределами их основного ареала. Подобные единичные находки известны в южной Финляндии, восточной Эстонии, Тверской, Вологодской, Владимирской, Рязанской, Липецкой областях и Мордовии.

Важным элементом набора украшений жителей позднедьяковских городищ Москворечья являлись сюльгамы с гладким или ложновитым корпусом, дополнительно украшенные волютами или зернью. Они найдены сериями на городищах Троицком, Щербинском, Кузнечики и Дьяково (Кренке, 2011. Рис. 140) и др. Это, видимо, местные изделия. Находка № 1368-87 с Дьякова городища представляет редкий тип (рис. 134, 15). Наиболее близкое по деталям декора изделие происходит со Щербинского городища (Дубынин, 1974. Табл. ХI, 15). Предмет с Дьякова городища отличается наличием второго кольца. Стилеобразующим элементом декора является заполнение пространства между двумя кольцами зигзагом из витой нити. По классификации застежек-сюльгам, предложенной И.В. Белоцерковской (Белоцерковская, 1999), эта находка относится к серии $1 Д$. Период бытования этой серии И.В. Белоцерковская первоначально определяла IV-первой половиной V в. н.э. (Белоцерковская, 1999. С. 171). В более поздней работе датировка предметов этой серии ограничена IV в. н.э. (Белочерковская, 2007. Рис. 7).

Сюльгамы важны тем, что ясно демонстрируют родственную связь культуры населения Москворечья с миром финских культур Средней Оки и Повольжья, в первую очередь, с культурой рязано-окских могильников.

Импорты и культурные связи. Среди позднедьяковских находок в москворецком ареале выделяется серия необычных изделий - медные пластины с изображением «человечков» и тамгообразных символов (рис. 145). Все изображения нанесены пуансоном, причем в ряде случаев с внутренней стороны изделий, т.е. техника изготовления совершенно не характерная для Москворечья. Места этих находок - городища Дьяково, Кунцевское, Троицкое, Щербинское, Луковня 1. Вне москворецкого ареала накладки найдены на Огубском городище (р. Протва) и городище Поминово (правый берег Волги, Тверская обл.). Связь этих предметов с сарматским миром несомненна. Тамгообразные изображения с городищ Дьяково и Луковня 1 достаточно сложны по своей конфигурации, так что о случайном сходстве с сарматскими тамгами не может идти речь. Тождественная тамга была найдена на скале возле с. Уйташ в Дагестане (Марковин, 2006). Близкие (но не тождественные) тамги принадлежали так называемым «аспургианам» - подвластным боспорскому царю Аспургу кочевым племенам, проживавшим на северной периферии Боспорского царства (Воронятов, 2009). Ареал распространения этих тамг - в первую очередь - Прикубанье и Приазовье. Одна находка с аспургианской тамгой происходит из Чертовицкого могильника на р. Воронеж (Медведев, 2008. С. 47. Рис. 50, 2).

На селище Солодка в Тульской области была найдена двойная медная пластина, скрепленная заклёпкой. На одной половине была изображена сарматская тамга, на другой два «человечка», тождественных изображениям с дьяковских городищ Москворечья (Ворониов, 2010а). Таким образом, «связь» тамг и «человечков» была доказана.

В статье С.В. Воронятова приведена очень ценная аналогия позднедьяковским изображениям человечков, присутствующая на сарматской подвеске из погребения у с. Липовец (Воронятов, 2012. Рис. 7).

На памятниках Москворечья, в том числе на городищах Дьяково и Боровский курган, были найдены портупейные пряжки, наконечники ремней, имеющие очень близкие аналогии в позднесарматских материалах II-III вв. (Кренке, 2011. С. 91) ${ }^{6}$. Целая серия портупейных пряжек представлена в кладе с Ичского (Алтуховского) городища на Протве (рис. 142).

То есть контакты населения дьяковских городищ с сарматским миром, безусловно, были. С.В. Воронятов на ос-

\footnotetext{
${ }^{6}$ Автор благодарен В.Ю. Малашеву за ценные консультации.
} 
новании этих относительно немногочисленных данных предлагает смелые исторические реконструкции. У нас нет никаких достоверных оснований, чтобы говорить о «сарматских женах» и «жрицах», проживавших на дьяковских городищах, как он это делает (Воронятов, 2012).

Если говорить о путях проникновения на север, в ВолгоОкское междуречье сарматского (и шире - южного) влияния, то, видимо, нужно предполагать две основных группы маршрутов - 1) по рекам Дон и Ока и 2) по рекам Десна и Днепр. Причем, если говорить об Оке, то нужно учитывать и направление от ее верховьев вниз по течению на север, так и движение на север по правым притокам Оки, таких как Сура, Цна и пр., а затем вверх по течению Оки до устья Москвы-реки.

Маршруты первой группы более короткие, их достоверность подтверждается дьяковскими находками (глиняный грузик дьякова типа, бантиковидная нашивка) в Острой луке Дона в районе с. Ксизово (Козмирчук и др., 2010). В пользу второй группы маршрутов имеются косвенные аргументы.

На нескольких москворецких позднедьяковских городищах встречены бронзовые изделия с выемчатыми эмалями. Они были найдены на городищах Барвихинском ${ }^{7}$, Дьяково, Боровский курган, Кузнечики, Луковня 1 (всего 16 предметов). Причем на городищах Дьяково (рис. 146, 1-6) и Луковня 1 (рис. 146, 7-9) эти находки представлены сериями - десять вещей в первом случае и три во втором. Видимо, все эти изделия привозные. Наибольшее распространение получили лунницы и подковообразные фибулы. Важно отметить, что практически нет примеров «гибридов» вещей с эмалями и украшений с характерными особенностями местного ювелирного стиля (плетенка, волюты, двойная зернь, шумящие подвески и пр.). Исключениями являются две подвески с городищ Троицкое и Щербинское, которые имитируют в местном стиле эмалевые украшения, известные по находкам в восточно-литовских курганах (Розенфельдт И.Г., 1982. С. 67). Датировка этих находок VI в. н.э., видимо, омоложена. Подражания не могут быть моложе времени бытования украшений с эмалями, т.е. вряд ли выходят за V в. н.э. М.М. Казанский не вполне корректно трактовал эти находки как вещи, «аналогичные» прибалтийским (Казанский, 1999. С. 404, рис. 1, 9).

Наиболее вероятный «коридор» поступления украшений с эмалями (с учетом ареалов их распространения в позднезарубинецких древностях и киевской культуре) - это юго-западные связи (от Поднепровья до Оки).

Кроме того, важно отметить, что на городище Луковня 1 была найдена подвеска с эмалевыми вставками (Векслер, 1971. Рис. 74), очень близкая по форме к фибулам-брошам типа VIIB, выделенного И.К. Фроловым (Фролов, 1974. Рис. 3, 7). Картирование фибул этого типа позволило И.К. Фролову высказать предположение, что они являлись

\footnotetext{
${ }^{7}$ Приведенные в публикации И.Г. Розенфельдт данные о находке украшения с эмалью якобы на Щербинском городище ошибочны (Розенфельдт И.Г., 1974. С. 107, 110). На самом деле В.Д. Крушков нашел фрагмент фибулы с эмалью на Барвихинском городище, но скрыл это от специалистов и дал ложную информацию о месте находки, указав на уже раскопанное Щербинское городище (инф. М.И. Гоняного).
}

продуктами производства, локализованного в северной Латвии - южной Эстонии (Фролов, 1974. С. 27). Таким образом, прямые связи с Прибалтикой вполне вероятны, учитывая также наличие дьяковской бантиковидной нашивки в оградке Ябара в Эстонии (Шмидехельм, 1955. Рис. 25).

О связях восточного и северного направления (наиболее «логичным» представляется маршрут по р. Оке и ее притокам) свидетельствуют такие находки, как парные колодки-пронизи с рифлением (Кренке, 2011. Рис. 139, № 23-83, 852-84), полая подвеска-уточка (рис. 145, № 1463-87).

Накладки-колодки кроме Дьякова городища были найдены на городищах Луковня 1 (Векслер, 1969) и Троицком (Дубынин, 1970а. Табл. 17, 11), селище Заболотье 3а (Гоняный, 2009) в Подмосковье, на городище Орлов городок на севере Тверской области (Максимов, 1980. Рис. 62). Близкие по форме парные колодки-пронизи представлены в древностях Прикамья в поздних этапах пьяноборской культуры (Голдина, 2003. Табл. 44, 282, 431; Агеев, 1992. Табл. 8) и могильниках по р. Суре (Гришаков, 2008. Рис. 2), где они входили в состав накосников.

Подвеска-уточка с Дьякова городища (рис. 145, № 1463-87) для москворецких памятников уникальна, но типична для северной периферии «дьяковских древностей». Аналогии ей встречены на памятниках, расположенных на стыке Вологодской и Тверской областей, в том числе «домике мертвых» Куреваниха XX, могильниках Чагода 1, Пугино (Башенькин, 1995. С. 5, 2; 7, 7-9), Куреваниха XVI-a (Баменькин, Васенина, 2006. Рис. 4, 32). Появляются они в интервале II в. до н.э.-I в. н.э. и бытуют в первых веках н.э. Находке с Дьякова городища близки по форме уточки из комплексов, нижняя дата которых определяется наличием украшений с эмалями, т.е. III в. н.э. (Пугино).

Подвески-уточки известны по материалам древнейшей стадии рязано-окских могильников (встречаются редко), где датируются первой половиной III в.н.э. (Белочерковская, 2007. Рис. 8, 1). Есть они в Селиксенском могильнике (Гришаков, 2008. Рис. 9) на Суре, в Желтухинском могильнике на левобережье Волги подвески-птички присутствуют в погребениях VI-VII вв. (Уткин, Черников, 1994. С. 52. Рис. 3). В Прикамье полые подвески-уточки встречены на памятниках III-V вв. н.э. азелинской культуры (Голдина, Кананин, 1989. Рис. 55, 3, 4; Ошибкина, 1979) и мазунинском этапе чегандинской культуры (Останина, 1997. Рис. 9, $2 ; 75,6)$. Ясно, что на городище Дьяково рассматриваемая находка могла попасть откуда-то с севера или востока.

Средний горизонт верхнего слоя Дьякова городища насыщен стеклянными бусами (рис. 150). В наборе преобладают золотостеклянные и единично встречаются красные пастовые (Кренке, Румянцеева, 2008). Значительная коллекция аналогичных стеклянных бус была собрана при раскопках Троицкого городища. То есть можно утверждать, что жители москворецких городищ вошли в один круг потребителей этой продукции северо-причерноморских мастерских наряду с населением, оставившим рязано-окские могильники. Вероятно, именно через посредничество рязано-окского населения эти бусы и проникали в Москворечье. Доказательством контактов служат на- 
ходки дьяковских вещей в рязано-окских могильниках (Белочерковская, 2000).

Глиняные грузики дьякова типа, безусловно, являются значимым культурным маркером, характеризующим традиции ткачества. Грузики первых веков новой эры продолжают эволюционную линию более ранних подобных изделий. Основной их морфологической особенностью становится уменьшение размеров, исчезновение двухплощадочных форм. Как отмечалось выше, появление грузиков дьякова типа в Волго-Окском междуречье относится еще к середине I тыс. до н.э. В начале I тыс. н.э. ареал грузиков дьякова типа существенно расширился в западную сторону, достигнув Литвы, Восточной Польши, Западной Белоруссии. При этом по-прежнему концентрация грузиков на памятниках Москворечья наиболее высока. Означает ли распространение грузиков Дьякова типа некую «экспансию» культурных традиций из района Москворечья остается предметом для изучения. Важно также подчеркнуть, что на восток, за пределы Московской области, эта традиция не продвинулась, что заставляет предполагать наличие некоего «избирательного культурного барьера», ведь, например, бронзовые украшения из района Москворечья попадали в соседние с востока области.

Домострочтельство и планировка городищ. Позднедьяковские постройки раскопаны на нескольких городищах. На памятниках москворецкого ареала нет свидетельств существования срубных конструкций. Конструкции построек, видимо, были столбовыми. На смену более ранним длинным домам пришли хижины квадратной или прямоугольной формы размерами около $4(5) \times 5(8,4)$ м. Обязательным элементом сооружения был тщательно подготовленный пол, использовались песчаные и глиняные подсыпки. Поверх этих подсыпок укладывалось специальное покрытие из растительных волокон, может быть, даже ткань. В сгоревших постройках на городище Дьяково были найдены куски глиняных обмазок, затыкавших углы, на которых отпечаталась ткань (Кренке, 2011. Рис. 12. цв. вклейка.). Открытый очаг округлой формы диаметром около 1 м обычно располагался близко к центру постройки на песчаной «подушке», он имел обрамление из досок или плетня. Аналогичные песчаные посыпки полов построек были прослежены на Троицком городище (Дубынин, Розенфельдт, 1970). Вдоль стенок и по углам построек были выявлены линзы глины, которые укрепляли (способствовали гидроизоляции?) пристенное пространство (постройка 38). На Троицком городище были зафиксированы также округло-многогранные постройки (№ 15, 16 и 40) диаметром 8-10 м столбовой конструкции. Слабая степень сохранности этих сооружений оставляет много вопросов относительно достоверности их реконструкции, предложенной авторами раскопок. Очевидно, постройки, существовавшие на позднедьяковских городищах, были недолговечными и пожароопасными. На городищах Дьяково и Троицкое постройки образовывали многослойные отложения, свидетельствующие о сохранении определенной планировочной традиции. В обоих случаях постройки занимали центральную зону площадки городищ, какой-либо регулярности не прослеживалось. Между постройками оставались лишь небольшие промежутки (2-3 м) пустого пространства, в которых часто оказывались скопления мусора. В случае наиболее полно исследованного Троицкого городища можно предполагать наличие небольшого свободного пространства в самом центре площадки.

По материалам полностью раскопанного Троицкого городища могут быть сделаны ориентировочные оценки численности его жителей. Критерием служит суммарная площадь построек. При расчете численности использовалась формула: число жителей равно суммарной площади построек в квадратных метрах, разделенной на шесть. Этот показатель заимствован из специальной этнографической литературы (Casselberry, 1974). Кольцевая постройка («жилые стены») имела площадь около 640 кв. м, что соответствует приблизительно 100-110 людям. Прямоугольные постройки более поздних этапов имели суммарно несколько меньшую площадь - 450-550 кв. м, что указывает на население городища в диапазоне 75-90 человек. Если учесть общее количество позднедьяковских городищ и селищ в бассейне Москвы-реки, то численность населения можно будет ориентировочно реконструировать в пределах 10-20 тыс. человек. Конечно, эти расчеты следует воспринимать как очень приблизительные.

К сожалению, имеется очень мало данных о том, что представляли собой оборонительные сооружения дьяковских городищ во II-IV вв. н.э. Можно лишь предполагать, что сооруженные ранее многоярусные оборонительные конструкции поддерживались и продолжали использоваться. Нет достоверных данных о перестройках, совершенных именно в указанный промежуток времени. Если посмотреть на многоярусные системы укреплений позднедьяковских городищ в более широкой перспективе, то можно отметить, что они вполне соответствовали эпохе - «римскому времени». Укрепленные лагеря римских легионов также имели основной внутренний вал со стеной на его гребне и дополнительные рвы с внешней стороны, затруднявшие подход к стене (Prochazka, 2009. Obr. 11).

Развитие хозяйства. Сведения о хозяйстве обеспечены коллекциями остеологических остатков, данными спорово-пыльцевых анализов образцов, взятых из культурных слоев, и определениями карпологических остатков, полученных при просеивании культурного слоя и его флотации. Эти материалы свидетельствуют о том, что хозяйство было комплексным. Очень значительную роль играло земледелие, развитие которого привело к формированию открытых ландшафтов вокруг городищ и в долине Москвыреки в целом. Нужно отметить, что цикл палеоботанических исследований еще нельзя считать завершенным. Пока мы располагаем в основном спорово-пыльцевыми диаграммами из культурных слоев городищ, конечно, сильно трансформированными из-за особенности образцов, отобранных из культурного слоя внутри поселения. Детальные фоновые разрезы пока единичны. То есть для корректной оценки соотношений основных компонентов ландшафта в пределах долины Москвы-реки и ее крупных притоков требуется сбор дополнительных данных. Если сравнивать диаграммы верхнего слоя Дьякова городища (учитывая указанные выше 
ограничения) с европейскими синхронными материалами (Evaluation of land surfaces..., 1994. Fig. 1), то можно увидеть большое сходство. Высокий процент «не древесной» пыльцы указывает на сведение леса в широких масштабах.

По материалам флотации культурного слоя Дьякова городища можно предполагать, что в первые века н.э. расширился ассортимент культур. Просо, пшеницу, ячмень теперь дополняют лен и горох. Мясная диета обеспечивалась в основном скотоводством, на первом месте по значимости в мясном балансе стояла лошадь. Развито было и речное рыболовство. Охота всегда была постоянным компонентом хозяйства. Судя по устойчивости системы расселения, жители городищ не допускали существенной переэксплуатации природных ресурсов. Свидетельством в пользу высказанного тезиса может быть факт постоянного присутствия в культурном слое довольно значительного количества костей бобра, вида очень уязвимого к хищнической добыче (Скалон, 1951). Густота поселений дьяковцев в долине Москвы-реки и ее притоков заставляет предполагать, что они имели постоянные пахотные угодья и краткосрочные перелоги. При доминировании подсечной системы земледелия расселение должно было быть существенно более рассредоточенным.

На среднем этапе позднедьяковского периода наблюдается тенденция расширения освоенной территории за счет «внутренней колонизации». Это позволяет предположить, что «экологическая емкость» собственно долины Москвы-реки была в значительной степени исчерпана, что могло стимулировать освоение новых территорий. Примером является поселение Царицыно 1. Оно расположено в нетипичном для дьяковских поселений месте на мелком притоке, удалено от долины Москвы-реки на 2,5 км. В первые века н.э. на поселении Царицыно 1 проживали люди, оставившие тарные и кухонные горшки, в культурном слое были найдены зерна культурных злаков (Кренке, Агеева и др., 2008).

\section{ФИНАЛ ПОЗДНЕДЬЯКОВСКОЙ КУЛЬТУРЫ ${ }^{8}$}

На поздней стадии развития культуры, примерно в IV в. н.э. продолжалось эволюционное развитие материального комплекса, но появились и инновации.

Эволюционное развитие прослеживается в наборе бронзовых украшений. Важно отметить, что, безусловно, существовала очень сильная, развивавшаяся «локальная ювелирная традиция», в ряде случаев «подчинявшая» внешние влияния. Уникальным примером подобного рода может служить бронзовая подвеска-гребень с Успенского городища (Кренке, 2011. Рис. 244). Возможно, в качестве исходного образца в данном случае послужил черняховский костяной гребень, но в итоге вещь очень отдалилась от оригинала. Гребень был выполнен с использованием элементов местного ювелирного стиля (трапециевидные подвески с двойной зернью, перевитая нить по периметру) и по привычной технологии литья по восковой модели.

\footnotetext{
${ }^{8}$ Существенная часть этого раздела была напечатана ранее (Кренке, 2014), в настоящий текст внесены небольшие корректировки и дополнения.
}

Выше говорилось о двух линиях развития местного ювелирного стиля - «шумящих» украшениях и вещах, состоящих из комбинаций соединенных друг с другом маленьких скорлупок. Оба эти направления соединились вместе в таких вещах, как, например, крупные нашивные украшения из клада Троицкого городища и случайная находка с Борисоглебского городища (Дубынин, 1970а. Рис. 19, 4; Розенфельдт И.Г., 1982. Рис. 16, 2).

Украшения местного стиля представлены серией височных (?) подвесок с треугольными щитками и привесками в виде трапеций или треугольников. Видимо, одновременно бытовали украшения с большими и малыми щитками. Можно предполагать, что поздняя стадия развития этих украшений представлена экземплярами, у которых привески имели вид «низких» треугольников с переходниками, «приросшими» к привескам (рис. 147, № 57-83). По типологии И.Г. Розенфельдт, она относится к типу 5 варианту $3 б$ (Розенфельдт И.Г., 1982. С. 35-37). Это украшение с двумя подвесками имеет маленький щиток, состоящий из двух рядов волют, и два кольца для привесок. Шарики зерни крупнее и составляют сплошные ряды с каждой стороны щитка. Типологическую специфику вещи определяют привески - они в виде низких треугольников с тремя группами двойной зерни и имеют «приросший» неподвижный переходник в виде плетенки, обрамленной зернью. Единственная аналогия происходит с Кунцевского городища (Розенфельдт И.Г., 1982. Рис. 8, 1). Можно согласиться с И.Г. Розенфельдт, что данная привеска является позднейшим вариантом в группе привесок с маленьким щитком. Основание для такого заключения - особая форма привески в виде именно низкого треугольника и «приросший» переходник. К данному типу очень близки украшения типа 5 варианта 3в (с подвижным переходником). Они найдены на Саввино-Сторожевском (Краснов Ю.А., Краснов Н.А., 1978) и Ростиславльском (Коваль, 2009) городищах.

Крупная привеска с Дьякова городища (рис. 147, № 173-81) относится к «классу» привесок с большим щитком. У нее имеются четыре треугольные привески, прикрепленные с помощью переходников, в основе которых - косое плетение. Ближайшая аналогия - находка с городища Луковня 1 (Розенфельдт И.Г., 1982. Рис. 8, 14). Аналогичные переходники встречены у вышеупомянутых маленьких подвесок типа 5 вариант 3в, а также у подвески с большим щитком с городища Орлов городок в Тверской обл. (Максимов, 1980. Рис. 62). Предположительно можно думать, что описанные выше украшения характеризуют местное ювелирное производство IV-V (VI?) вв. н.э.

Развитие линии подвесок с большими и малыми щитками прослеживается в других культурных контекстах на финно-угорских памятниках Волго-Окского бассейна вплоть до Х-ХІ вв. (Голубева, 1973. Рис. 5, 4; Горюнова Е.И., 1961. Рис. 39, 40). Эти украшения являются важным аргументом в пользу версии о финно-угорской этнической принадлежности жителей позднедьяковских городищ.

Новации. Новым явлением было широкое распространение совершенно не применявшейся ранее в Москворечье технологии изготовления бронзовых (?) и оловянных укра- 
шений в двусторонних глиняных и каменных формочках (рис. 148). Эти технологические новации во второй половине I тыс. н.э. имели очень широкое распространение в лесной зоне Восточной Европы от Прибалтики до рязанского Поочья (Ахмедов, 2010; Моора, 1963; VolkaiteKuliskauskiene, Jankauskas, 1992). Именно литейные формочки, но не сами украшения, были найдены большими сериями на таких москворецких городищах, как Дьяково и Луковня 1, единичные - на городищах Троицком и Боршеве, а также в смежных регионах - на городищах Кикино, Ростиславль, Огубское, селище Щурово (Сыроватко и др., 2012. Рис. 2, 13).

Ассортимент изделий, отливавшихся в формах, найденных на москворецких городищах, был достаточно широк, но в целом это разнообразные мелкие украшения: подвески, нашивные бляшки, накладки и т.п.

Аналогии прямоугольным пластинкам, декорированным поперечными линиями, которые отливали в москворецких формочках, встречены в бассейне Верхней Волги и в Прибалтике, на городищах Кикинское (Вишневский, 1998.Рис. 2, 22), Осечен (Исланова, Миреикий, 1997. С. 15. Рис. 2, 2), Хлепень (Смирнов, 1974. Табл. 9) и Рыуге в восточной Эстонии (Шмидехельм, 1959. Табл. V, 6a, 10), Старой Ладоге (Давидан, 1980. Табл. 2, 17).

Большая часть негативов на москворецких формах типична для лесной и лесостепной зон Восточной Европы, где они встречаются на памятниках второй половины I тыс. н.э. Есть негативы, отнесенные О.А. Щегловой к группе общих, «сквозных» типов украшений, распространенных не только на Северо-Западе, но и в южной части Восточной Европы. Сюда входят бляшки-розетки и круглые выпуклые нашивные бляшки (Щеглова, 2002). Важно отметить, почти тождественные литейные формы с городища Дьяково и городища Никодимово (сожжено в VII в.н.э.) в восточной Белоруссии (Седин, 1987), предназначенные для отливки конических бубенчиков или ворворок (рис. 148, 2).

Позднедьяковские литейные формочки имеют технологические отличия от более поздних мерянских. На дьяковских формочках никогда не встречаются расходящиеся веером литейные каналы. Вероятно, время бытования дьяковских литейных форм следует отнести к V-VI (VII) вв. н.э. Они являются исключительно важным хронологическим маркером, указывающим на продолжение жизни москворецких городищ в это время.

С дьяковских городищ происходит серия бронзовых трапециевидных высоких привесок (часто - с эсовидными переходниками) относительно которых можно с равной вероятностью предполагать их импортное либо местное производство (рис. 157). Семь экземпляров происходят с Дьякова городища (Кренке, 2011. Рис. 146, № 342-81; 377-81; 1404-87; 1432-87). Две привески имеют высокие пропорции, у них сохранились эсовидные переходники (вариант «А»). Две из них являются комбинированными украшениями, состоящими из трех привесок (более низких пропорций, чем вариант «А»), соединенных вместе переходниками-колечками (вариант «Б»). Оба варианта представлены в самом верхнем горизонте культурного слоя Дьякова городища.
Аналогии на других дьяковских памятниках, собранные И.Г. Розенфельдт, единичны (Розенфельдт И.Г., 1982. Рис. 5). Очень близкие аналоги привескам варианта «А» имеются в рязано-окских могильниках, например, из погребения 79 могильника Кораблино, погребения 195 могильника Заречье происходит целая серия тождественных привесок с переходниками, украшавших поясок головного венчика (Ахмедов, 2007. Рис. 26; Белоиерковская, 2007. Рис. 2; Белочерковская, Ахмедов, 2009). Относительная датировка этих погребений - период 3, по И.В. Белоцерковской, который датируется V-началом VI в. (Белочерковская, 2007. С. 201). Аналогичным образом датируется Никитинский могильник, где также встречены подобные украшения (Воронина и др., $2005)$. Есть они и в Безводнинском могильнике, где являлись элементом головного убора (Краснов, 1980. Рис. 28). Список аналогий можно существенно расширить, но приведенные выше - наиболее близки находкам с Дьякова городища.

Подвески варианта «Б» встречены на дьяковских городищах Саввино-Сторожевское, Кунцево, Дьяково, Подмоклово. Тождественная подвеска представлена в погребении 195 могильника Заречье (Белоцерковская, 2007. Pис. 8, 40), которое, как отмечалось выше, датируется Vначалом VI в. Аналогичные вещи есть и в других финских могильниках того же культурного круга - Хотимльском, Борковском (Розенфельдт И.Г., 1982. Рис. 6). Находка тождественной подвески имеется на мощинском городище Акиньшино, расположенном на правом притоке Оки, выше Алексина (Воронцов, 2010. Рис. 42). То есть ареал подвесок варианта «Б» - бассейн Оки, вероятная датировка - гуннское время или конец V-начало VI в. н.э. Одиночные трапециевидные подвески, сходные по пропорциям и размерам с подвесками, входившими в украшение варианта «Б» есть в Ратьковском могильнике (Вишневский, Новоселова, 2010. Рис. $6,12,13 ; 8,11)$, нижняя дата которого определяется VI (V?) в. н.э.

Эволюиия грузиков Дьякова типа. Такие «знаковые» вещи, как грузики дьякова типа продолжали бытовать в финальный период позднедьяковской культуры. Наибольшее количество составляли грузики типа 1 (по К.А. Смирнову), небольшой серией представлены грузики с уплощенным верхом, форма которых представляет переходный вариант между типами 1 и 7, по К.А. Смирнову (между конусом и цилиндром). Специфичен для данного периода уплощенный тип грузика в виде низкого конуса (типы 12,13 ).

Важно отметить наличие грузиков с намеренно сточенным верхом. Такая переработка превратила их в дисковидные пряслица с зубчатым краем (рис. 131, 2). Эта переделка вряд ли может быть названа «ремонтом». Можно предположить, что таким образом была реализована попытка «культурной адаптации». То есть на городище жили и работали «инокультурные» (?) люди, которые пытались переделать грузики, сделанные раннее.

Размеры всех грузиков маленькие, окончательно вышли из обихода предметы крупных и средних размеров (в коллекции с Дьякова городища сумма диаметра и высоты основной группы находится в интервале 6-7,5 см, диаметр канала по-прежнему равнялся 5-6 мм). 
Относительно увеличивается количество глиняных биконических пряслиц с широким каналом. При этом важно отметить, что в бассейне Москвы-реки не представлены пряслица мощинского типа с лощеной поверхностью и широким каналом. По-видимому, долина Оки, на участке ее течения от Серпухова до Коломны являлась «пограничным» районом, тянувшим все же, скорее, к югу, нежели к северу.

Глиняная антропоморфная пластика. В IV-V вв. н.э. в Москворечье наблюдался своеобразный «бум» мелкой пластики. Статуэтки очень однотипны (рис. 149, 12). Крестообразная фигура, голова всегда показана очень схематично, никаких черт лица не изображалось. Руки раскинуты, ноги прямые, часто сомкнуты, иногда выделены ступни, ягодицы подчеркнуты, перед плоский. На некоторых статуэтках есть орнамент, нанесенный вдавлениями тонкой палочки, встречаются отпечатки ногтей. По-видимому, какие-то важные события происходили в религиозной сфере, местный культ получил уникальное материальное выражение для лесной зоны Восточной Европы в эпоху переселения народов. Ближайшая находка глиняной антропоморфной статуэтки происходит с городища Николо-Ленивец на Угре (Никольская, 1962. Рис. 8, 2), но эта статуэтка не похожа на дьяковские (скорее, скифская?) и возраст ее неясен. Сходна с дьяковскими статуэтка из Курской области, найденная на Шуклинском городище (Никольская, 1958. Рис. 18,7$)$. Специфика глиняной мелкой пластики еще раз указывает на то, что население, проживавшее в Москворечье, имело явную культурную обособленность от соседей. Находки глиняных статуэток распространены очень неравномерно. Есть городища, где проводились большие раскопки позднедьяковских слоев, но статуэток не было найдено (Троицкое, Кунцевское, Боршева и др.). Антропоморфные статуэтки концентрируются всего на нескольких городищах. Это Успенское, Дьяково, Луковня, Щербинское, Кузнечики, Борисоглебское. Можно выдвинуть предположение, что эти памятники являлись не просто поселениями, но и сакральными центрами москворецкого региона в это время. В один «комплект» с антропоморфными статуэтками входили глиняные орнаментированные таблички. Можно предполагать, что между статуэтками и изображениями на табличках имелась смысловая связь.

Импортыл. Разнообразен состав импортов, относящихся к финальной стадии позднедьяковской культуры - от стеклянных бус до бронзовых украшений, монет и предметов вооружения. Это разнообразие само по себе, как мне кажется, указывает, скорее, на торговые контакты, нежели на след вторжений завоевателей.

Среди стеклянных бус нужно в первую очередь отметить синие 14-гранные (рис. 150, № 1420, 1446, 1451, 1460), стратиграфическое положение которых на городище Дьяково зафиксировано именно в верхней части верхнего культурного горизонта.

B IV в. н.э. дальние контакты южного направления продолжали проявлять себя в находках таких предметов импорта, как черняховская фибула с Дьякова городища (рис. 145, № 252) или бронзовая монета императора
Костантина II, чеканенная в Кизике, с городища Бушарино (находка Ю.А. Краснова).

Имеется серия импортов V-VI вв. н.э. также указывающих на условный «юг». К ним относятся найденные на городище Луковня 1 железный умбон щита, язычок пряжки с поперечными каннелюрами у основания (рис. 157, 12), фрагменты браслета с расширенными концами и браслетообразного височного кольца, техлопастная стрела с городища Кунцево (Ахмедов, Казанский, 2004. Рис. 5) и серия аналогичных стрел, найденных возле городища у СаввиноСторожевского монастыря (коллекция ЗИАиХМ). Датировку этих предметов И.Р. Ахмедов и М.М. Казанский определяют $\mathrm{V}$ в. н.э. и трактуют их в качестве свидетельства военной экспансии, которой подверглось Москворечье в V в. н.э. (Амедов, Казанский, 2004. С. 174). Понятно, что такую гипотезу трудно надежно доказать или опровергнуть. Можно отметить лишь, что датировка язычка пряжки может быть несколько расширена, середина VI в. н.э. также допустима (Ajot, 1986).

К перечисленным выше находкам примыкает щиток пряжки с Дьякова городища (рис. 157, 10) - массивный литой овальной формы с одной заклепкой в центре. Аналогии на памятниках дьякова типа отсутствуют. Очень близки находке с Дьякова городища пряжки из склепа 78 Боспорского некрополя. И.П. Засецая датирует их второй половиной V - рубежом V-VI вв. (Засецккая, 2003. С. 38, табл. 12, $36,45)$. В могильнике Дюрсо близ Новороссийска также есть пряжки с аналогичными щитками с одной заклепкой в центре. Ранний пласт погребений, где они найдены, датирован концом V-первой половиной VI в. (Дмитриев, 2003. Табл. 79, 14. С. 201). Пряжку с овальным щитком и одной заклепкой из Константиновграда И.О. Гавритухин датировал второй половиной V-первой половиной VI в. (Гавритухин, 2007. С. 32, табл. 22, 12). Сходные находки из склепа 495 в Скалистом в Крыму (Хайретдинова, 2003. Рис. 1, 9, 10) определены как обувная гарнитура и датированы первой половиной VI в. По мнению Э.А. Хайретдиновой, они произведены в Херсонесе по византийским образцам (Хайретдинова, 2003. С. 126). На Верхнем Дону в могильнике с трупоположениями на Животинном городище были найдены погребения, содержавшие портупейные пряжки, аналогичные находке с Дьякова городища. И.Р. Ахмедов и М.М. Казанский датируют эти комплексы 450-480 гг. н.э. и считают, что погребения принадлежат «носителям западной воинской цивилизации» (Ахмедов, Казанский, 2004. С. 179. Рис. 13,7$)$ и делают далее заключение, что именно лесостепной район междуречья Днепра и Дона мог быть источником инноваций для лесной зоны.

Есть слабые признаки и юго-восточных связей V в. н.э. с культурой рязано-окских могильников. Находки предметов этой культуры в Москворечье редки. Крестовидные фибулы из Можайска (Янишевский, 2012а) и Хотяжей (Алексеев, 2004), скорее, являются исключением. Показательно, что обе найдены вне контекста поселений дьякова типа.

Достоверных импортов VI-VII вв. н.э. в бассейне Москвы-реки очень мало. Их число едва выходит из первого десятка. В этот короткий список входят широкопластинчатая 
фибула со Щербинского городища (Дубынин, 1974. Табл. ХІ), которая датируется VII-VIII вв. (Горюнов, Казанский, 1978); накладка геральдической формы с городища Луковня 1 VIVII вв. (Розенфельдт И.Г., 1982. С. 113-114), двурогая одночастная поясная накладка геральдического стиля с Дьякова городища (рис. 157, 8), датируется, скорее всего, первой половиной VII в. н.э. (Кренке, 2011. С. 72-73), два браслета с расширенными концами с Успенского городища (Успенская, 1957. Рис. 46; Розенфельдт Р.Л., 1967. Рис. 36), датируемые третьей четвертью I тыс. н.э. (Родинкова, Седин, 2004. С. 244). Ближайшей к Москворечью территорией, где геральдические поясные наборы были широко представлены в конце VI - первой половине VII в. н.э., является ареал рязано-окских могильников (Ахмедов, 2010).

Две трапециевидные подвески, орнаментированные двумя рядами точек с Дьякова городища (Кренке, 2011. Рис. 146, 75-83), по предположению М.М. Казанского, относятся к вещам дунайского происхождения, попавшим в лесную зону в третьей четверти I тыс. н.э. в связи с процессом славянской колонизации (Kazanski, 2000. Fig 6, 28). И.О. Гавритухин посвятил специальную статью данному типу украшений (находка с Дьякова городища была им учтена) и пришел к выводу об их датировке VII в., но не рассматривал их как «маркер» определенной культурной или этнической общности (Гавритухин, 1997. С. 48).

На городищах Москворечья было найдено несколько вещей, указывающих на контакты с северо-западными территориями, Прибалтикой. Это, во-первых, три тисненых бляшки-обоймицы. Две из них происходят с Дьякова городища (рис. 157, б). Одна была найдена в 1984 г. (Кренке, 2011. Рис. 145, № 870-84), другая - при раскопках под руководством А.Г. Векслера (Векслер, 2007). Аналогичная бляшка была найдена им же на городище Луковня 1 (Розенфельдт И.Г., 1982. Рис. 1, 7). Они относятся к типу «квадратных», выделенному Е.Р. Михайловой (Михайлова, 2007). Орнамент выпуклый, выполнен тиснением. На пересечении диагоналей, обозначенных двойными линиями, кольцо с точкой в центре, по двум боковым краям линии из точек, верх и низ ограничены двумя параллельными линиями. Практически точные аналоги (3 экз.) представлены в псковских длинных курганах: Березно 1, кург. 6; Городня, кург. 3; Володи, кург. 1 (Михайлова, 2007. Илл. 1). Очень близкая по особенностям декора бляшка происходит из кургана Любахин 1 (Баменькин, 1995. Рис. 8). В памятниках культуры псковских длинных курганов встречены разнообразные стилистически схожие украшения, что дало основание Е.Р. Михайловой выделять их в качестве культуроопределяющих (Михайлова, 2009). Это позволяет предполагать, что находки на позднедьяковских городищах Москворечья происходят из региона культуры псковских длинных курганов. Е.Р. Михайлова приводит аргументы в пользу определения нижней даты этой культуры концом V в. н.э. (Михайлова, 2009). Курган 6 могильника Березно 1 она датирует второй половиной VI-началом VII в., привлекая при этом радиоуглеродные датировки. Имеются также предположения о несколько более ранних датировках. Так, А.Н. Башенькин относит курган Любахин 1 по набору инвентаря к V в. н.э. (Баменькин, 1995. С. 25). Косвенным подтверждением данной точки зрения являются находки из Литвы. В могильниках III-V вв. н.э. Велиона и Марвеле были найдены головные украшения, элементы которых могут рассматриваться как прототипы тисненых подвесок (Bertašius, 2005; Michelbertas, 1986. Pav. 13).

Типичными прибалтийскими украшениями являются бубенчики с полями, напоминающие шляпку (рис. 157). Три бубенчика были найдены на Дьяковом городище (Кренке, 2011. Рис. 145, № 34-81; 58-81; 57-81). Бубенчики имеют характерные эсовидные переходники для подвешивания (рис. 157, 7). Все эти находки обнаружены близко друг от друга и, возможно, принадлежали к одному украшению. Бубенчики подобной формы являются уникальной находкой в пределах Москворечья. Изготовлены методом штамповки из бронзового листа, на полях бубенчиков имеется разрез. Многочисленные аналогии известны на территории Эстонии, Восточной Латвии (Аyн, 1980. Рис. 18; Latvijas PSR Arheologija, 1974. Tab. 42,43; Urtāns, 1970; Wróblewska et all., 2005. Tab. 3). Нижняя дата находок из Латвии - VII в. н.э.

Наконец, есть импорты, указывающие на восточное направление контактов. С Дьякова городища происходит шумящая подвеска-пронизь (рис. 157, 9). Корпус полый, круглый в сечении, отлитый по модели, выполненной из нити, скрученной в цилиндр - «спиралевидный», по терминологии В.И. Вишневского (Вишневский и др., 2007. С. 96). К корпусу прикреплены снизу два кольца, в которые продеты подвески. На памятниках дьякова типа эти находки редки. Пронизь с городища Березняки (Третьяков П.Н., 1941. Рис. 37, 8), скорее всего, относится не к позднедьяковскому комплексу, а к материалам второй половины I тыс. н.э. Большая серия аналогий происходит из Ратьковского могильника. Схожие пронизи были найдены во многих других финских могильниках - Никитинском (Воронина и др., 2005. Рис. 36), Заречьинском (Белочерковская, 2007. Рис. 2, 38; 7, 23), Большое Молочное (Леонтьев, 1996. Рис. 128, 4), Сарском городище (Леонтьев, 1996. Рис. 73, 4). В Москворечье такая пронизь была найдена на поселении Хотяжи вместе с крестовидной окской фибулой $\mathrm{V}$ в. н.э. (Алексеев, 2004. Рис. 4,14$)$. Судя по находкам в рязано-окских погребениях стадии 3, по И.В. Белоцерковской, украшение может быть датировано, начиная с V в. н.э. Безусловно, данные вещи бытовали и позже - в VI-VII вв. н.э.

Нашивное украшение с городища Боршева (Розенфельдт И.Г.,1982. Рис. 15, 16) с привесками ромбической формы уникально для дьяковских памятников и имеет аналогии в финских древностях Поочья.

Бубенчики в форме бутылочки были найдены на городище Дьяково (Кренке, 2011. Рис. 144, № 332, 43-83). Для дьяковских памятников Москвы-реки вещь редкая. Многочисленные аналоги представлены в финно-угорских могильниках и поселениях в бассейнах Верхней Волги и Оки - Ратьковском (Вишневский, Новоселова, 2010. Рис. 8, 7; Вишневский и др., 2007. Рис. 7, 18, 19); Безводнинском (Краснов, 1980. Рис. 27, 29); Заречье (Белочерковская, 2007. Рис. 3, 1); селище Усть-Черная, на Сарском и МалоДавыдовском городищах (Леонтьев, 1996. Рис. 73, 14; 90, 
8; 96, 4-6). Датировка комплексов, где они встречены, находится в интервале V-VII вв. Вероятно, на Дьяковом городище данные изделия являются привозными и датируются в рамках указанного интервала.

Показательно, что перечисленные находки были найдены на тех же самых ключевых памятниках, о которых говорилось выше - это городища Успенское, Кунцево, Дьяково, Луковня 1, Щербинское, расположенные в относительно небольшом ареале среднего течения Москвы-реки и Пахры.

Керамический стиль «мошчинского круга». В IV-V вв. н.э. в Москворечье распространяется новый стиль профилировки горшков (рис. 156). Очень широкое распространение в Волго-Окском бассейне керамики этого стиля с его ведущим признаком в виде прямого венчика и переходом к округлому плечику, подчеркнутым уступом и горизонтальной каннелюрой, заставляет думать, что это прежде всего явление моды. В этом стиле изготовлялась как грубая гладкостенная, так и лощеная керамика. Можно предполагать, что исходной точкой развития этого стиля был регион верхнего Поочья, где на памятниках мощинской культуры он представлен особенно ярко. Для датировки керамики Волго-Окского междуречья, выполненных в этом стиле, важны радиоуглеродные датировки, указывающие на V-VII вв. н.э. полученные для селища Кибол-7 в Суздальской округе (Макаров и др., 2011).

Вероятно, с южным влиянием следует связывать появление в керамическом комплексе дьяковских городищ в бассейне р. Пахры глиняных сковородок (Розенфельдт И.Г., 1974. Рис. 43).

Важно подчеркнуть также, что далеко не все формы сосудов, характерные для памятников мощинской культуры представлены в Москворечье. Здесь совершено отсутствуют типичные мощинские цилиндроконические формы, не менее значимые для определения мощинской культуры, чем сосуды с прямой шейкой и горизонтальной каннелюрой при переходе к плечику. Для Москворечья характерны грубые гладкостенные сосуды для хранения припасов, имевшие вытянутые пропорции и орнаментированные отпечатками палочки с веревочкой, а также горшки малых форм с разнообразной ямочной орнаментацией, специфичные именно для этого региона. Сравнение составляющих набора вещей мощинских памятников бассейна Верхней Оки и позднедьяковских в Москворечье с очевидностью показывают их различия (следует учесть грузики дьякова типа, мелкую глиняную пластику, лощеные пряслица, бронзовые украшения). То есть границу мощинской культуры нельзя отодвигать так далеко на север, чтобы она включала бассейн Москвы-реки, как это сделано в монографии М.Б. Щукина и соавторов (Ščukin et al., 2006. Fig 42).

«Постдьяковские комплексы». В VI-VII (VIII?) вв. н.э. в развитии керамического комплекса на памятниках ВолгоОкского междуречья наблюдаются некоторые общие тенденции. К сожалению, остро ощущается недостаток материалов и надежных датировок. Тем не менее, некоторые памятники с находками керамики третьей четверти I тыс. н.э. имеются, и они могут служить отправными точками для рассуждений. Это позднемощинские городища, такие как Акиньшино на Правобережье Оки (Воронцов, 2011; 2016), позднедьяковское городище Кикино на р. Веле (Вишневский, 2007), селище Болшево-3 на р. Клязьме (Чернов, Волков, 2009), городище Бородино-2 на Москве-реке, городища Борисов городок (Янишевский, 2012а) и Маломахово (Прошкин, Фролов, 2012) в бассейне р. Протвы, селище и могильник Соколова Пустынь на р. Оке выше устья Москвыреки (Потемкина и др., 2013), селище Рогово на Верхней Волге под Ржевом (Исланова, 2016). В качестве таких общих явлений в развитии керамического комплекса можно отметить сокращение (исчезновение?) доли лощеной и орнаментированной керамики. Приоритет получают формы грубой гладкой керамики с высоким венчиком и «сглаженным ребром-уступом» в верхней части плечика при переходе к венчику. Венчик может быть либо уплощенным по торцу, либо, наоборот, приостренным, что придает его профилю «саблевидный» (по С.3. Чернову) вид. Высокий почти прямой венчик с резким переходом к плечику через уступ может рассматриваться как наследие формы сосудов мощинского круга. Особенно это преемственность ясна на примере городища Акиньшино. К материалам городища Акиньшино близка керамика распложенного относительно близко от него на противоположном берегу Оки селища Соколова Пустынь (Потемкина и др., 2013). В этот же круг входит относительно удаленный на север комплекс селища Болшево-3. Сравнение последнего с керамикой «ладожского типа» (Чернов, Волков, $2008)$ лишь по наличию ребра на плечике не выглядит убедительным, так как морфология верхней части венчика болшевских сосудов совершенно иная.

В середине-третьей четверти I тыс. н.э. от Ржевского течения Волги на северо-западе до верховьев Москва-реки и Протвы на юго-востоке получила распространение керамика, которую И.В. Исланова обозначила как «верхневолжский керамический набор» (Исланова, 2007). У этой керамики нет такой выраженной преемственности с сосудами «мощинского круга». Венчик также прямой или слабо отогнутый, но короче и толще, переход к плечу плавный, на плечике имеется сглаженное ребро-уступ, отсутствуют следы типичной для мощинской керамики каннелюры. В некоторых случаях (Борисов городок на р. Протве) ребро-валик на тулове проявляется достаточно отчетливо. Эта керамика вызывает ассоциации с керамикой Верхнего Поднепровья середины - третьей четверти I тыс. н.э. Особенно важно обратить внимание на сглаженное ребро в верхней части плечика. Этот признак характерен для горшков типа Р-4, выделенных Н.В. Лопатиным (Лопатин, Фурасьев, 2007. Рис. 1), встреченных на памятниках типа Заозерье-Узмень и затем присутствующих в культуре псковских длинных курганов. Отличие описываемой керамики «верхневолжского набора» от лепной славянской керамики роменского типа заключается, в первую очередь, в наличии «высокого» венчика и отсутствии типов орнаментации, характерных для последней. В то же время, сглаженное ребро - это признак, встречающийся и на древнейшей славянской керамике южного Подмосковья. В качестве примера можно привести курган у д. Рыжково на Протве (Бубликов и др., 2008).

Важно отметить, что керамика «верхневолжского набора» не похожа на мерянскую и сходную с ней, вроде ком- 
плекса Ратьковского могильника. Ареал распространения мерянской/муромской керамики образует особую область, которая «нависает» над Подмосковьем с востока и северо-востока.

В коллекциях позднедьяковских городищ Москворечья керамика верхневолжского набора и позднейшие ипостаси мощинских форм пока не были выявлены. При этом надо отметить, что не производился целенаправленный анализ коллекций именно с задачей выявления позднейших керамических материалов. Таким образом, вывод об отсутствии описываемого керамического комплекса в среднем Москворечье пока не может считаться окончательным. Единственным исключением является селище Саввинская слобода 2, где в заполнении ямы 10 был встречен один венчик с удлиненным саблевидным профилем (раскопки А.К. Станюковича 1998 г.).

Единичные вещевые импорты VII в. н.э., обнаруженные на городищах среднего течения Москвы-реки, пока как бы «повисают в воздухе», так как керамические комплексы, которые соответствуют этим находкам, не описаны. Данных о находках VIII-IX вв. н.э. в среднем течении Москвы-реки практически нет, лишь несколько кладов куфических монет (все, кроме клада из окрестностей городища Настасьино документированы очень слабо) заполняют лакуну.

Погребальные памятники. Информация о позднедьяковских погребениях пока очень фрагментарна. Наиболее полный материал получен за пределами Москворечья. После работ А.Н. Башенькина и М.Г. Васениной в Заволжье стали ясны многие особенности погребального обряда и конструктивные детали «домиков мертвых». В последние годы яркие погребальные памятники, синхронные финалу позднедьяковской культуры, были обнаружены на южной периферии позднедьяковского ареала. Могильники Соколова пустынь на левом берегу Оки (раскопки О.Ю. Потемкиной) и Щурово на противолежащем правом берегу (раскопки А.С. Сыроватко) дали яркие комплексы кремаций, культурно-хронологическая атрибуция которых оказалась очень непростой из-за плохой сохранности находок и сильной нарушенности памятников (Сыроватко и др., 2012). Я согласен с осторожной культурной интерпретацией могильника Соколова пустынь, предложенной О.Ю. Потемкиной (Потемкина и др., 2013. C. 151). Действительно, этот памятник на левом берегу Оки представляет собой нечто новое, не известное нам в культурном отношении. Некоторую связь с традициями позднедьяковской культуры можно лишь предполагать, но не утверждать.

На территории Москворечья известны пока лишь две достоверные находки погребальных объектов позднедьяковского времени. Это костяки, обнаруженные на краю площадки Троицкого городища и «домик мертвых» на Саввинско-Сторожевском городище в г. Звенигороде. Горшки из этого комплекса (рис. 158) имеют некоторые отличия от позднедьяковских, они без орнаментации. Кроме этого, на поверхности поймы Москвы-реки, где располагался славянский курганный могильник Хотяжи, были открыты ямки, предположительно содержавшие остатки кремаций позднедьяковского времени (раскопки А.В. Алексеева).
Перечисленных выше находок явно недостаточно для характеристики погребального обряда. Реконструкция «домика мертвых» на Саввино-Сторожевском городище (Краснов Ю.А., Краснов Н.А., 1978) весьма гипотетична, так как археологи лишь доисследовали грабительский котлован. Единственное, что можно надежно утверждать относительно этого памятника - это то, что кремированные человеческие кости там действительно присутствовали (определение антрополога Г.П. Романовой). На основании имеющихся данных можно сделать лишь ряд предположений. Вероятно, позднедьяковский погребальный обряд был «многоступенчатым». Тела умерших сначала прикапывали и подвергали мацерации. Именно так можно объяснить наличие костяков, датированных радиоуглеродным методом, на Троицком городище. На втором этапе кости выкапывали и кремировали. Кремированные кости прикапывали на площадках городищ и вне их.

Система расселения, хозяйство, реконструкция исторических процессов. Позднедьяковские памятники Москворечья IV-V вв. н.э. испытывали сильное влияние, распространявшееся с юга, но при этом продолжали сохранять свою культурную обособленность. Многие элементы в культуре (на мой взгляд, преобладающие) связывают эти памятники с восточными соседями, финским миром. Однако и западные связи несомненны. Поэтому мы можем лишь весьма схематично предполагать, что этнический облик позднедьяковского населения в Москворечье был смешанным финно-балтским.

Жизнь на москворецких городищах в IV-V вв. н.э., безусловно, продолжалась. Численность поселений, видимо, мало изменилась сравнительно с предшествовавшим этапом.

Обращают на себя внимание некоторые изменения в составе остеологических коллекций. В самых верхних горизонтах культурного слоя Дьякова городища увеличивается процентное содержание костей диких животных (Кренке, 2011. С. 149-170). В первую очередь, бобр, а также лось и медведь регулярно становились объектами добычи. С большой долей осторожности, так как материалов пока мало, можно предполагать, что произошли изменения в образе жизни и стратегии жизнеобеспечения людей, проживавших на позднедьяковских городищах. Более «агрессивная» охотничья стратегия стала привлекательней. Возможно, расширился ареал территории, подвергавшейся охотничьей эксплуатации.

Нужно отметить, что в Северной и Центральной Европе в VI-VII вв. исследователи отмечают явление восстановления лесов, сокращение открытых пространств (Evaluation of land surfaces..., 1994) сравнительно с «римским временем». Возможно, в Восточной Европе наблюдалось нечто подобное. То есть в финальный период дьяковской культуры в хозяйстве прослеживаются общеевропейские тренды.

И.Р. Ахмедов, М.Б. Щукин, М.М. Казанский предполагают, что в конце IV-V в. н.э. Москворечье стало ареной военных действий, в том числе из-за походов короля готов Германариха (ك̌čukin et all., 2006. Fig. 43). Конечно, единичные находки импортных черняховских вещей на памятниках бассейна Москвы-реки не могут служить доказательством такой реконструкции. Однако не объясненным 
остается факт спада «жизненной активности» на москворецких городищах, который можно ориентировочно датировать V-VI вв. н.э., а затем и вовсе их запустение. Возможно, что какие-то насильственные действия, приведшие к упадку культуры москворецких городищ, все же были. Учитывая, в общем-то, незначительную численность жителей Москворечья в дьяковское время, которая в лучшие времена вряд ли превышала 20 тыс. человек, можно предполагать, что «демографическое благополучие» этого населения было очень уязвимо. Нельзя не отметить хронологическое совпадение прекращения жизни на дьяковских городищах Москворечья и катастрофических потрясений, которые испытали их ближайшие соседи - рязано-окские финны около середины VII в. н.э. (Ахмедов, 2010).

Необходимо учитывать, что для «подрыва» жизненной силы населения, оставившего позднедьяковские городища, было достаточно совсем небольшой группы от одной до нескольких сотен профессиональных воинов-агрессоров, археологический след которой вряд ли может быть уловлен. История дает нам массу примеров подобного рода.

B VII-VIII (?) вв. н.э. мы видим на месте бассейна Москвыреки своеобразное белое пятно, которое лишь по периферии окаймлено памятниками типа селища Соколова Пустынь (на юге), Маломахово и Борисов городок (на юго-западе), Бородино (на западе в верховьях Москвы-реки), Болшево-3, Кикино, Ратьковский могильник (на севере). Все эти памятники имеют скорее всего финский или балтский облик.
Данные радиоуглеродного датирования. На таблице 15 представлена серия из пяти радиоуглеродных дат, приходящихся на столетний интервал 1200-1300 лет. Эти даты получены по образцам с городища Дьяково и селища Саввинская Слобода 2. Кроме того, на серии разрезов в пойме Москвыреки, расположенных в ее среднем течении (ЗБС-5, РАНИС2,Тушино) получена также серия дат (некалиброванных) в интервале радиоуглеродного возраста 1500-1200 лет от наших дней. На разрезе РАНИС-2 было определено, что угольки, давшие даты, происходили от ели. Могут быть высказаны два аргумента в пользу того, что эти пожары связаны именно с деятельностью человека: 1) поймы являются наиболее влажным элементом ландшафта в долине; 2) хронологический период VII-VIII вв. являлся влажным и холодным ${ }^{9}$.

Таким образом, можно предполагать, что в VII-VIII вв. территория среднего течения долины Москвы-реки не была совершенно обезлюдевшей, но пока не удается найти археологических памятников этого периода.

\footnotetext{
${ }_{9}^{9}$ Автор признателен коллегам Е.Г. Ершовой и А.Л. Александровскому за предоставленные материалы и консультации.
}

\section{Таблица 18. Радиоуглеродный возраст отложений начального этапа позднедьяковской культуры}

\begin{tabular}{|l|l|l|l|}
\hline Памятник & $\begin{array}{l}\text { Радиоуглеродный } \\
\text { возраст }\end{array}$ & Индекс лаборатории & $\begin{array}{l}\text { Калиброванный } \\
\text { календарный возраст } \\
\text { (в скобках - вероятность } \\
\text { калиброванного значения) })^{1}\end{array}$ \\
\hline Троицкое городище & $2090 \pm 130$ & ГИН-8815 & 240 BC -30 AD (56,2 \%) \\
\hline Троицкое городище & $2000 \pm 40$ & ГИН-8816 & 45 BC - 55 AD (68,2 \%) \\
\hline Луковня 1 городище & $2000 \pm 30$ & ГИН-3210 & 45 BC - 30 AD (59,4 \%) \\
\hline Дьяково городище & $2070 \pm 60$ & ГИН-2799 & $170 \mathrm{BC}-10 \mathrm{AD}(62,8 \%)$ \\
\hline Дьяково городище & $2120 \pm 100$ & ГИН-2788 & $240 \mathrm{BC}-40 \mathrm{BC}(51,4 \%)$ \\
\hline Дьяково городище & $1970 \pm 40$ & ГИН-3915 & $1 \mathrm{AD}-80 \mathrm{AD}(61,1 \%)$ \\
\hline Дьяково городище & $1970 \pm 60$ & $50 \mathrm{BC}-90 \mathrm{AD}(62,5 \%)$ \\
\hline
\end{tabular}

${ }^{1}$ Калибровка производилась по программе OxCal v. 3.10.

Таблица 19. Статистика керамики из раскопов на террасах Кунцевского городища по материалам отчетов А.Г. Векслера (данные по предматериковым пластам)

\begin{tabular}{|l|l|l|l|l|l|l|}
\hline $\begin{array}{l}\text { Номер раскопа, } \\
\text { пласт }\end{array}$ & \multicolumn{2}{|l|}{ 1-я терраса (верхняя) } & \multicolumn{2}{|l|}{ 2-я терраса (средняя) } & 3-я терраса (нижняя) \\
\hline Типы керамики & XVIII пл. 7-8 & XIV пл. 21 & XV пл. 12 & XVI пл. 16 & XX пл. 17-20 & XVII пл. 7-8 \\
\hline Лощеная & - & 5 & 8 & - & - & - \\
\hline $\begin{array}{l}\text { Лепная } \\
\text { гладкостенная }\end{array}$ & 24 & 80 & 9 & 41 & 24 & 23 \\
\hline Текстильная & 5 & 28 & - & - & 14 & - \\
\hline
\end{tabular}


ГЛАВА IV

\section{СЛАВЯНСКИЕ ДРЕВНОСТИ ПОДМОСКОВЬЯ}

B изучении древнерусских памятников Подмосковья наименее разработанными являются следующие темы: 1) начальный период славянской колонизации региона; 2) составление археологической карты, пространственная организация «древнерусского ландшафта» - соотношение поселений, могильников, хозяйственных угодий; 3) исследование сельских поселений, трансформации в культуре, произошедшие в XIII в., до и после монгольского завоевания.

Спорной остается общая этническая трактовка подмосковных древностей XII-XIII вв. Большинство ученых (А.В. Арциховский, В.В. Седов, Н.Г. Недошивина, Т.Н. Никольская, И.Е. Зайцева, Т.Г. Сарачева и др.) приписывали их вятичам, но другие (Т.В. Равдина) отвергали такую интерпретацию, либо придерживались «промежуточной» позиции, сближаясь все же больше к первой версии (А.А. Юшко).

Рассмотрим эти темы, привлекая новые источники и методы исследования.

\section{АРХЕОЛОГИЧЕСКИЕ ДАННЫЕ О НАЧАЛЬНОМ ПЕРИОДЕ СЛАВЯНСКОЙ КОЛОНИЗАЦИИ ПОДМОСКОВЬЯ}

Первые находки лепной славянской керамики в Московском регионе были сделаны в курганах. Единичные лепные и раннекруговые горшки происходят из раскопок 1924 г. А.Я. Брюсова на р. Рожайке (курганная группа Пузиково), 1950 г. Т.В. Равдиной в верхнем Москворечье (Шишимрово), 1945 г. А.В. Арциховского в Беседах. Первые находки подобного материала на поселениях, вероятно, были сделаны в 1930-е гг. на правом берегу Москвы-реки ниже городища Боровский курган, на селище Заозерье 1 (по Г.М. Коняшину, 1940 и О.Н. Бадеру, 1951), но материалы не публиковались и утрачены. Разведочные работы 2014 г. на этом памятнике (А.Е. Кравцов, А.М. Фатьков) обнаружили раннекруговую керамику конца XI-начала XII в.

В начале 1960-х гг. А.К. Станюковичем на правом берегу Москвы-реки было обнаружено поселение с достоверными находками славянской лепной керамики - селище Жуковка, на котором в 1965-1967 гг. провел раскопки А.Г. Векслер (Векслер, 1965, 1966, 1967). В 1985 г. памятник был дополнительно обследован Н.А. Кренке при участии Н.В. Лопатина и И.О. Гавритухина. Параллельно с раскопками селища Жуковка А.Г. Векслер раскапывал Одинцовские курганы, где в группе Одинцово-6 на правом берегу речки Самынки в насыпях была найдена аналогичная керамика. Эта курганная группа расположена всего в нескольких километрах от селища Жуковка. В насыпях были встречены единичные лепные фрагменты, преобладал раннекруговой материал. Автор раскопок ошибочно предполагал, что для сооружения курганов использовалась привозная земля. Селище под курганами было зафиксировано лишь в 1992-1994 гг. при новом обследовании этой курганной группы. Оно находилось в непосредственной близости от могильника и частично заходило на его территорию (селище Подушкино 5, № 2665 по АКР, разведки Н.А. Кренке и Б.Е. Янишевского).

В 1960-е гг. на Щербинском городище на р. Пахре были найдены вещи IX-XI вв., а недалеко, возле Стрелковских курганов, на левом берегу р. Пахры обнаружено селище с лепной керамикой.

В 1973 г. С.3. Чернов нашел селище Заозерье 2 с лепной древнерусской керамикой на левом берегу Москвы-реки, возле Боровского перевоза. На нем почти десять лет собирали подъемный материал под руководством А.Г. Векслера (Векслер, Станюкович, 1986). Топографический план памятника был снят и раскопки проведены лишь в 1993-1995 гг. (Тавлинцеева, 1996).

В 1978 г. Р.Л. Розенфельдт провел раскопки курганов в группе Шейки на Малой Истре, где были обнаружены комплексы с лепной керамикой, западноевропейскими монетами второй половины XI в. и инвентарем, типичным для москворецких памятников начального этапа славянской колонизации.

В начале 1980-х гг. древнерусское селище с лепным компонентом в керамическом комплексе было обнаружено М.И. Гоняным на р. Пахре возле с. Покров. Здесь были проведены раскопки А.К. Станюковичем и А.А. Юшко (Юшко, 1998). Аналогичный материал был выявлен на территории Данилова монастыря в Москве (Беляев, 1994).

Начиная со второй половины 1980-х гг., количество памятников с древнерусской лепной керамикой в бассейне Москвы-реки стало быстро увеличиваться. Целый «куст» селищ с лепной керамикой был найден в долине p. Пахры ниже Подольска (Жданово, Добрятино, Заболотье, Макарово, Новое Съяново 3, Большое Саврасово 2 и др.). В 1990-2000-е гг. аналогичные поселения были найдены и раскапывались в долине Москвы-реки (Данилов и НиколоУгрешский монастыри, селища Дьяково-пойма в заповеднике Коломенское, Павшино, Поречье 2 и Саввинская сло- 
бода 2 под Звенигородом, Хотяжи 1 и 2). Группа поселений с лепной керамикой была найдена возле устья р. Коломенки ,на правом берегу Москвы-реки, на территории г. Коломна.

В итоге, к настоящему времени в бассейне Москвы-реки известно не менее 28 селищ с лепной древнерусской керамикой (рис. 161).

Имеется серия публикаций по отдельным памятникам периода начальной славянской колонизации региона, так и обзорные работы (Алексеев, 2004; Беляев, 1994; Беляев и др. 2010; Векслер, Станюкович, 1986; Гоняный, 1999; Григорьев, 2005, 2005а; Кренке, 1993, 2004; Мазуров, 2001; Нефёдов, Кренке, 2012; Станюкович, Сулержицкий, 2003; Тавлинцева, 1996; Фролов и др., 2005; Чернов, Волков, 2009; Шиолянский, 1999; Юико, 1998, 2001, 2005).

Хронология и предполагаемые исходные регионы начального этапа славянской колонизации Подмосковья. Наиболее актуальными вопросами являются определение возраста памятников начального этапа славянской колонизации москворецкого бассейна и выяснение исходного региона этой колонизации.

Развернутая аргументация на эту тему представлена в работе А.В. Григорьева (Григорьев, 2005а. С. 166-171). При оценке его гипотезы следует учитывать, что А.В. Григорьеву в момент написания книги еще не были известны находки их Хотяжей и Болшева 3. А.В. Григорьев совершенно справедливо показывает слабость археологических аргументов А.А. Юшко, предлагавшей для поселения Покров 5 нижнюю датировку IX в. Столь же уязвима для критики и статья А.К. Станюковича о радиоуглеродных датировках селища Саввинская слобода 2 (Станюкович, Сулержиияий ${ }^{1}$, 2003). Фактически археологические комплексы этого памятника в статье не представлены. Опубликованные находки датируются первой половиной-третьей четвертью XI в. (Григорьев, 2005а. С. 171).

В итоге А.В. Григорьев предлагает датировку наиболее ранних москворецких памятников в приблизительном интервале 1025-1075 гг., поддерживая высказанное ранее аналогичное заключение С.В. Шполянского, основанное на материалах селища Новое Съяново 3 (Шполянский, 1999).

Однако вопрос о датировках все же нельзя считать решенным. Общий подход А.В. Григорьева, стремившегося максимально сузить датировки и увидеть через призму археологии исторические события, представляется мне неудачным.

«Втискивать» подмосковные комплексы с лепной славянской керамикой исключительно в XI в. нет оснований. Правильнее сказать, что такая керамика могла использоваться еще и в XI в. Укажу на некоторые находки, которые говорят о более ранней дате.

Топор с Щербинского городища на p. Пахре (Дубынин, 1974. Табл. 7, 5), безусловно, салтовского типа. И.Г. Розенфельдт справедливо датировала его VIII-IX вв. (Розенфельдт И.Г., 1982. С. 137).

Относительно находок с могильника и селищ Хотяжи 1

\footnotetext{
${ }^{1}$ Авторство Л.Д. Сулержицкого обусловлено лишь наличием публикуемых в статье радиоуглеродных датировок, полученных под его руководством.
}

и Хотяжи 2 есть весомые основания говорить о X в. Здесь были найдены скандинавские вещи середины $\mathrm{X}$ в. (подвеска «гнёздовского типа» и фибула) и дирхемы (Алексеев, 2004. С. 186-189). К уже опубликованным находкам следует добавить два дирхема (906/907 и 939/940 гг., по определению А.А. Гомзина) из раскопа 2009 г. на селище Хотяжи 1 (Кренке, Лазукин, 2010).

Радиоуглеродное датирование угля из ям с исключительно лепной керамикой на селище Хотяжи 1 дало результаты, сходные с результатами датирования селища Саввинская слобода 2 и отсылает к еще более раннему времени - VIII--IX вв.

На селище Хотяжи 1 были найдены предметы, аналогичные находкам в смоленских длинных курганах (датировка VIII-X вв.) - это бронзовая трапециевидная привеска с двумя рядами штампованных выпуклостей-точек в нижней части (сборы А.К. Станюковича, 2001 г., колл. ЗИАХМ), голубая стеклянная бусина 14-гранной формы (раскопки 2013 г. А.В. Лазукина).

Нужно отметить, что такие же бусины были найдены на дьяковских городищах: Троицком, Щербинском и Боровском кургане (Розенфельдт И.Г., 1982. С. 61,62). По В.Б. Ковалевской, такие бусы (тип 117) характерны для VIII-IX вв. (Ковалевская, 2000. С. 21). Для памятников севера лесной зоны Восточной Европы X-XI вв. такие бусы не характерны, а там, где присутствуют слои VIII-IX вв., они есть. Укажу на такие ключевые памятники, как Старая Ладога, городища Любша и Крутик (Носов и др., 2005. С. 62; Львова, 2009. С. 473, 474; Захаров, 2012. Рис. 7). Найдены они и на Соборной горе Смоленска (Кренке, Ершов и др., 2015. Рис. 2).

Серия находок 14-гранных голубых бус также происходит с селища Саввинская слобода 2 на Москве-реке. Здесь же была найдена мозаичная бусина - «арбузик» с зелено-желтыми полосами и красным стержнем в центре (рис. 186). Аналогичные были встречены в нижних горизонтах культурного слоя Старой Ладоги. На этом же памятнике найдена и трапециевидная бронзовая подвеска со штампованным орнаментом (канелюры по периметру), типичная для культуры смоленских длинных курганов (VIII-X вв.). В постройке 3 на селище Саввинская слобода А.К. Станюковичем были отобраны образцы угля, по которым были получены близкие даты, указывающие на интервал VIII-X вв.

В постройке 3 доминировала лепная керамика, кроме того, был найден уникальный для Подмосковья (привозной?) раннекруговой горшок с чертами формы и орнаментации (имитация валиков), характерными для западнославянских горшков типа Гросс-Раден (Горюнова B.M., 2005. Табл. 68). Эта аналогия указывает на предположительный возраст - Х в.

Весьма показательны данные о находках арабских монет, собранные А.А. Гомзиным в его диссертации (Гомзин, 2013). В бассейне Москвы-реки известно девять кладов дирхемов (не считая единичных находок кладоискателей), из которых пять имеют младшие монеты IX в. (Гомзин, 2013).

То есть имеются основания для того, чтобы говорить о присутствии в Подмосковье населения в IX-X вв. 
Материалы селищ Хотяжи 1 и Саввинская слобода 2 свидетельствуют в пользу гипотезы о «длинной хронологии» начального этапа славянской колонизации бассейна Москвыреки. Раннекруговая керамика обоих памятников имеет ряд аналогий в северо-западном регионе 2 .

При раскопках 2009 г. на селище Хотяжи 1 была изучена яма 1 с раннекруговой керамикой (рис. 181-183). Этот комплекс важен тем, что находит аналогии на северо-западе. В яме 1 было найдено около 550 фрагментов керамики, в том числе 90 \% относится к категории раннекруговой, а 10 \% к лепной славянской и раннедьяковской текстильной. Эта лепная мелкофрагментированная керамика, видимо, происходит из более раннего слоя, прорезанного ямой 1. Кроме того, в яме была найдена стеклянная бусина-пронизка, скорее всего, Х в. (рис. 178, 11)3. В комплексе представлены две ведущие формы венчиков - короткий, отогнутый наружу, и вертикальный. Есть горшок с резко суженным горлом и горшок с ребром на плечике. Орнаментация (многорядная волна, косые ряды точек) в основном нанесена гребенчатым инструментом. Близких аналогий этому комплексу в Подмосковье пока нет. Есть лишь аналогии отдельным формам горшков и орнаментации гребенчатым штампом и многорядной волной. Эти аналогии происходят с селища Новое Съяново 3 (Шполянский, 1999), Данилова монастыря в Москве (Беляев, 1994. Табл. 86). Важно отметить, что в этой керамике нет никаких намеков на «манжеты». Аналогии прослеживаются в группе раннекруговой керамики Рюрикова городища, Новгорода, Изборска и Старой Ладоги (Горюнова B.M., 2005). Очень важными признаками сходства являются вертикальные венчики, вогнутая форма верхних частей сосудов, ребристость. Этот круг аналогий наводит на дату - конец X-XI в. (Лопатин, 2009. С. 422).

Таким образом, в долине Москвы-реки перекрещиваются культурные традиции, имеющие истоки в разных географических регионах.

Нужно также отметить наличие редких ребристых форм (Саввинская слобода 2, Данилов монастырь, Жданово). Вероятно, какая-то часть населения, появившегося на Москве-реке в IX-X вв. была связана именно с северо-западным регионом. Аналогии в вещах и лепной керамике с культурой смоленских длинных курганов также вряд ли случайны.

Исходным районом, откуда шла колонизации бассейна Москвы-реки в XI в., А.В. Григорьев считает Северянскую землю (бассейн среднего течения р. Десны). Главные аргументы А.В. Григорьева - это сходство в керамике двух регионов, а также изменение баланса заселенности двух территорий. На одной количество памятников XI в. сравнительно с предшествующим временем сокращается, а на другой - увеличивается. Понятно, что последний аргумент может рассматриваться лишь в качестве косвенного. Важно отметить, что А.В. Григорьев подчеркивает наличие некоторых культурных отличий населения, переместившегося на восток, сравнительно с памятниками роменской культуры в гипоте-

\footnotetext{
${ }^{2}$ Автор признателен В.М. Горюновой за консультации.

${ }^{3}$ Автор благодарит И.Н Кузину за консультацию.
}

тическом исходном районе колонизации (Григорьев, 2005а. С. 166-167). Особенно важно наблюдение А.В. Григорьева относительно одной из наиболее «ярких» категорий украшений - височных колец «деснинского типа». Анализируя географию находок височных колец «деснинского типа», А.В. Григорьев, оставляя некоторые сомнения (Григорьев, 2005), приходит к выводу, что этот тип украшений зародился именно на «вятической» территории - где-то в ареале бассейна Средней Оки. Эти выводы были повторены и в более поздней работе А.В. Григорьева (Григорьев, 2012).

Вопрос интерпретации находок височных колец «деснинского типа», ввиду его особенной важности для рассматриваемой темы, необходимо рассмотреть подробнее.

Во-первых, скажем о хронологии этого типа украшений и его месте в типологическом эволюционном ряду височных колец. В фундаментальной работе Т.В. Равдиной, к сожалению, до сих пор не опубликованной (Равдина, 1975a), этот тип височных колец был обозначен под номером 1. На основании анализа встречаемости колец «деснинского типа» с другими вещами в погребальных комплексах Т.В. Равдиной было сделано предположение, что «семилопастные 1-2 типов синхронны монетам и когда-нибудь будут найдены вместе с монетами» (Равдина, 1975a. С. 72). Это предположение вскоре оправдалось. В 1978 г. в курганной группе Шейки на р. Малой Истре Р.Л. Розенфельдт раскопал курган № 76, где были найдены височные кольца «деснинского типа» и лучелопастное второго типа совместно с денарием, датирующимся в интервале 1059-1086 гг. (Равдина, 1988. С. 129). Таким образом, предположение Т.В. Равдиной о том, что височные кольца «деснинского» типа следует датировать «серединой или началом второй половины ХІ в.» (Равдина, 1975a. С. 233), получило важное подтверждение.

Во-вторых, следует рассмотреть географию находок колец «деснинского» типа. На момент написания работы T.В. Равдиной лишь одна находка была известна в бассейне р. Оки, все остальные находились за его пределами. В настоящее время ситуация кардинально изменилась, что отмечено в статьях А.В. Григорьева (Григорьев, $2005)$ и А.А. Попова (Попов, 2013). Концентрация находок приходится именно на бассейн средней Оки и на долину Москвы-реки (рис. 174). Сейчас об этом можно говорить совершенно уверенно. К известным в 2005 г. находкам добавились новые памятники - могильник и селища Хотяжи 1 и 2, селище Поречье 2, город Смоленск и др. Таким образом, в обширном ареале распространения колец «деснинского» типа имеется два «полюса» концентрации находок. Один - западный, в верховьях р. Десны и Сожа; второй восточный, в бассейне Москвы-реки и в бассейне верхней Оки от устья Жиздры до Протвы. Причем восточная группа находок существенно более многочисленная, всего более 50 экземпляров (Попов, 2013).

Можно ли на этом основании сделать вывод, что именно здесь и был изобретен данный тип украшений?

Существенное значение имеют результаты раскопок ювелирной мастерской второй половины XI в. в Смоленске (Кренке, Ершов и др., 2016). В материалах раскопок этой 
мастерской представлены находки двух колец деснинского типа. Весьма вероятно, что эти кольца производились в данной мастерской.

Важно подчеркнуть, что мнение Т.В. Равдиной о том, что кольца «деснинского» типа не могут рассматриваться в качестве прототипа позднейших семилопастных колец, на мой взгляд, вполне оправданно, хотя один из аргументов Т.В. Равдиной (географический) отпал. С одной стороны, между двумя группами колец существует хронологический разрыв в несколько десятилетий. С другой стороны, форма колец «деснинского» типа очень специфична. Скорее, ее можно воспринимать как некую тупиковую ветвь эволюции височных украшений. Прототипами колец деснинского типа, вероятно, являлись пятилучевые кольца с тремя шариками зерни на конце лучей (Григорьев, 2010. Рис. 3). Прототипами лопастных колец московского типа были лучевые кольца с одинарными шариками зерни на концах и полукруглыми фестонами на «зарождающемся» щитке (рис. 203). От этих колец произошли лучелопастные, а от них уже лопастные кольца. «Точка разветвления» этих двух линий развития находилась на стадии, когда спускающимся вниз лучам еще противостояли направленные вверх угловатые зубчики, а не продолговатые выступы. Судя по схеме развития лучевых колец, предложенной Е.А. Шинаковым, это произошло в IX в. (Шинаков, 1980. Рис. 1). Мы можем представить две линии развития лучевых колец. Первая линия развития закончилась в XI в. на кольцах деснинского типа; вторая линия развития продолжалась дольше. К этой линии относятся височные кольца московского типа, она завершилась в XIII в.

Таким образом, в середине-второй половине XI в. в москворецкий бассейн проникают, наполняют его, а затем резко (?) исчезают очень специфические украшения, роднящие эту территорию с южными и западными соседями.

По данным уставной грамоты Ростислава Смоленского (1136 г.), А.Н. Насонов включил западное Москворечье (вплоть до среднего течения р. Москвы) в ареал Смоленской земли (Насонов, 1951). Такая локализация восточной границы Смоленской земли весьма обоснована локализацией исторических топонимов (Бежицы, Добрятино и пр.). Следовательно, колонизация западной части Москворечья выходцами из Смоленской земли должна была начаться не позднее XI в. Скорее всего, колонизация XI в. шла по следам, проложенным еще столетием-двумя ранее. Эти данные не противоречат гипотезе А.В. Григорьева, но допускают более широкие географические рамки для определения исходного региона славянской колонизации. Исходным районом не обязательно должна была являться территория бассейна p. Десны. Междуречье Десны и Днепра, верхнее Поднепровье также могут «претендовать» на эту роль. Археологические данные не противоречат такому предположению. Лепная керамика конца первого тысячелетия н.э., найденная на памятниках Смоленщины весьма близка керамике роменской культуры и близка к находкам из Подмосковья.

Карта памятников начального периода славянской колонизации. Рассмотрим теперь более подробно карту и некоторые топографические особенности поселений, содер- жащих лепную и раннекруговую керамику. Общая карта ранних поселений в бассейне Москвы-реки с определенными оговорками, обусловленными неполнотой разведок, свидетельствует в пользу предположения, что колонизационный поток двигался вверх по течению. «Цепочка» памятников с лепной древнерусской керамикой начинается непосредственно от устья Москвы-реки (г. Коломна). В верховьях Москвы-реки (можайское течение) ранних памятников не обнаружено. Нет их и в долинах р. Рузы. Таким образом, больше оснований предполагать, что основной колонизационный поток пришел в долину Москвы-реки с юга. Комплекс памятников у д. Хотяжи, расположенный ближе к верховьям Москвы-реки, видимо, указывает на иное направление - запад или северо-запад.

Важно отметить, что ранние древнерусские памятники занимают лишь долину Москвы-реки, причем поселения занимают нижние уровни долины, на мелких притоках их нет. Памятники начального этапа древнерусского освоения занимают ту же ландшафтную нишу, что и памятники предшествовавшего им железного века. Можно даже предполагать, что ширина освоенной территории в долине в железном веке была больше, чем на начальном этапе славянской колонизации региона, так как городища дьяковской культуры обычно находятся ближе к краям долины на бровке коренного берега, часто в приустьевой части малых притоков.

На археологической карте хорошо видна «неполнота» освоения бассейна Москвы-реки древнерусскими первопоселенцами сравнительно с предшествующим этапом железного века. Свободными оставались не только верховья Москвы-реки и малые притоки, но и крупные притоки Истра, Десна, Северка, Рожайка, Моча, Десна, Пахра выше г. Подольска.

И.Е. Забелин на основании общих географических соображений и топонимических данных (Забелин, 1905), а C.3. Чернов, исходя из анализа археологического материала, предполагали, что для ранней колонизации Москворечья имели большое значение волоковые пути меридиональной направленности (Чернов, Волков, 2009). Наличие такой пары поселенческо-курганных комплексов как Болшево-3/ Даниловское весьма показательно. Открытие Даниловских селищ (работы Л.А. Беляева 1983 г.), видимо, разрешили загадку, к решению которой обращался еще И.Е. Забелин, ища «пра-Москву» на устье Яузы (рис. 187). Действительно, p. Яуза, как мы теперь видим (после открытия селища Болшево 3), функционировала как важный путь, связанный волоком с бассейном Клязьмы, но крутой мыс в ее устье (Швивая горка) совсем не подходил по своим топографическим особенностям (как и Боровицкий холм!) для создания поселения. Поселения той хронологической группы, о которых идет речь, тяготеют к плоским поверхностям поймы и первой террасы. Даниловская местность - это первый вниз по течению от устья Яузы удобный участок (расстояние по прямой $-4,3$ км), отвечавший требованиям поселенцев $\mathrm{X}$ ХІ вв. (Беляев и др., 2010).

Весьма показательны находки на Даниловском селище ребристой керамики, которую можно сопоставить с керамикой «ладожского типа» (рис. 188, 16, 18). Исследователи 
памятников северо-запада Руси отмечают, что ребристая керамика, возникнув в VIII в. в Поволховье, в конце X - начале XI в. «охватила значительную территорию Северной Руси, прекратив существование с распространением гончарного круга» (Плохов, 2005. С. 78). Показательно еще одно место находки такой керамики в Подмосковье - селище Жданово 1 на р. Пахре (раскопки М.И. Гоняного, 1997, 1998 гг. Музей «Подолье»), где был также найден привозной бронзовый футляр от весов (Гоняньй, 1999), явно указывающий на какие-то торговые контакты. На Готланде аналогичный футляр был найден с монетами третьей четверти XI в. (Гоняный, 1999. С. 141).

При рассмотрении наиболее ранних комплексов древнерусского времени нельзя обойти материалы раскопок селища Царицыно 2. Здесь была изучена ранняя яма № 2 (Нефёдов, Кренке, 2012). В этой яме была исключительно раннекруговая керамика. В публикации материал из этой ямы был отнесен к концу XI-началу XII в. Особый интерес вызывает целый сосуд из этой ямы, орнаментированный по средней части тулова зигзагом, заключенным между двумя параллельными линиями (рис. 191). По плечику и шейке идет волна. Этому сосуду имеется практически точная аналогия. Это горшок из кургана 13, раскопанного Д.А. Авдусиным в 1949 г. в Лесной группе в Гнёздово. Д.А. Авдусин датировал этот комплекс серединой X в. Горшки с такой специфической орнаментацией имеют очень четкие серийные аналогии в древнейшем слое Новгорода, датируются X в. (Горюнова B.M., 2005. Табл. 123-125). Сходство между горшком из Царицыно и приведенными аналогиями настолько велико, и орнаментация столь специфична, что игнорировать эти сопоставления нельзя, хотя они и противоречат существующим представлениям о хронологии подмосковной керамики. Радиоуглеродная датировка из


(ГИН-14211). При калибровке она указывает с наибольшей вероятностью на VIII-IX вв.

Вообще нужно отметить, что керамические аналогии дают более древние даты для подмосковных комплексов, чем вещевой набор. Например, горшок с поселения Жданово 1 (Гоняныци, 1999. Рис. 3, 9) близок по форме и орнаментации с горшком-урной из кургана 10 могильника Новоселки возле Гнёздово, который датируется первой половиной Х в. (Шмидт, 2005. С. 160, илл. 15, 4). Орнамент в виде зигзага по плечику горшка из оттисков палочки, обмотанной веревкой, типичен не только для роменской культуры (Гоняный, 1999. С. 142), но и для смоленских длинных курганов (Седов, 1970. Рис. 25, 3).

Интерпретация. Подводя итог сказанному выше, можно утверждать, что начало колонизации долины Москвы-реки (ранние проникновения славян и скандинавов?) относится к IX-X вв. Данные об этом раннем этапе очень скудны. Возможно, что в процессе начальной колонизации большое значение играли торговые (?) контакты, ориентированные по направлению север - юг, а также вдоль течения Москвыреки (клады и отдельные находки дирхемов в Хотяжах, на территории Москвы в Кунцево, Чертолье, Симоновом монастыре, возле городища Настасьино на р. Северке).
Сложение системы славянских поселений в долине среднего и нижнего течения Москвы-реки и нижнего течения Пахры, видимо, относится ко второй четверти-середине XI в. Наиболее четко маркируют этот период височные кольца «деснинского» типа, украшение с «узкой» хронологией. Появление этих поселений в Москворечье происходило в момент смены лепной керамики круговой. Имеются горшки переходных технологических форм. Их венчики и бугристые стенки выглядят лепными, орнаментация типична для лепной посуды, но при наличии полных профилей хорошо видно, что правильные конические симметричные формы могли быть получены лишь при использовании вращавшейся подставки (см. горшки из селищ Поречье 2, Саввинская Слобода 2). Характерной особенностью ранних поселений XI в. сравнительно с поселениями следующего этапа являются их относительно крупные размеры - часто более 1 га, интенсивно гумусированный культурный слой, имеющий обычно черный цвет. Примечательно, что в керамическом комплексе ранних поселений большую роль играют сосуды крупных размеров. Фактически это котлы с диаметром устья 30-40 см, высотой 30-35 см. Объем этих сосудов равнялся 15-20 литрам. Нагар на стенках этих горшков показывает, что в них готовили еду. Нужда в таких горшках может возникнуть лишь при наличии относительно крупных коллективов.

Некоторые наблюдения позволяют предполагать, что эти поселения «первой волны» существовали относительно недолго несмотря на то, что на большинстве из них встречены и более поздние вещи XII-XIII вв. Если предполагать, опираясь на эти находки, что поселения существовали непрерывно 200 лет, то возле них должны были возникнуть обширные курганные кладбища в 100 и более курганов. Такие кладбища в Подмосковье имеются, но, что примечательно, не возле ранних поселений в долине Москвы-реки, а на ее мелких притоках. Возле ранних поселений нет больших курганных кладбищ (рис. 165). Такие курганные группы, как Стрелково, Покров, Хотяжи, Беседы, Поречье, расположенные при ранних поселениях, во-первых, относительно небольшие (первые десятки курганов); во-вторых, эти курганные могильники в основном относятся к XII в. Лишь в Хотяжах А.В. Алексеевым был зафиксирован курганный могильник, синхронный исключительно раннему поселению. Численность курганов в нем достоверно не известна (все курганы были снесены в 1950-е гг.). Ориентировочная оценка А.В. Алексеева в 100 курганов мне кажется завышенной. Судя по данным карт и воспоминаниям жителей д. Хотяжи, помнившим курганы до их сноса, речь может идти о нескольких десятках насыпей.

Очень показательна ситуация, которую можно было наблюдать на археологическом комплексе Поречье возле Звенигорода до его разорения при строительстве дач (рис. 172). Здесь на очень ограниченной площади в непосредственной близости друг от друга находятся три селища и три курганных могильника, занимающие первую и вторую террасы Москвы-реки, оползневые ступени. Очевидно, что эти памятники «самостоятельны». Иначе у них был бы общий могильник. Второй вывод - памятники разновременны (их хозяйственные зоны накладываются друг на друга). Лишь 
благодаря «ступенчатости» рельефа мы увидели четко эту расчлененность. Если представить ровную поверхность, то ареалы культурных слоев трех поселений слились бы в одно пятно, а курганные могильники были бы полностью или частично распаханы. Именно в таком виде дошли до нас такие памятники, как Хотяжи, Заозерье на Москве-реке, селища в долине р. Пахры.

Еще одно важное наблюдение, которое можно сделать на основании карты памятников XI в. в Москворечье, это отсутствие центрального поселения, которое бы выделялось своими размерами и/или «статусными» находками. Поиски раннего материала XI в. на Боровицком холме в Московском Кремле оказались совершенно тщетными. Вывод Т.Д. Пановой, о том, что древнейшие археологические материалы Кремля соответствуют летописной дате (Панова, 2013), сделанный после долгой дискуссии, представляется оправданным. Не оказалось ранних материалов и на подоле Кремля, что показали раскопки ИА РАН 2007 г.

Коломна дала те материалы X(?)-XI вв., которые безуспешно искали в Москве. Однако размеры этого раннего поселения на правом берегу р. Коломенки (на более 4 га) не выделяют его из ряда других. Оно такое же, как Хотяжи 1, Даниловские селища в Москве. Предполагаемое место детинца XII-XIII вв. не совпадает с местом раннего поселения, и площадь поселения XII в. существенно (в несколько раз) больше (Мазуров, 2001. С. 276, табл. 10). То есть нет «ощущения» плавного развития. А.Б. Мазуров делает вывод, что город Коломна, видимо, возник незадолго до первого летописного упоминания в 1177 г. (Мазуров, 2001. С. 274), что, впрочем, требует дополнительной аргументации.

Если анализировать плотность памятников XI в. на карте методом ГИС, то однозначно вырисовывается зона их концентрации на р. Пахре, на участке от города Подольска до устья р. Рожайки (рис. 162). Возможно, именно здесь находился «центр» всей поселенческой системы XI в.

Базируясь на очень приблизительных данных о площади ранних поселений XI в. и их количестве, можно предполагать, что общая численность жителей на них равнялась не более чем нескольким (двум-трем?) тысячам человек. Их материальная культура еще не приобрела признаков «специфичности», выделяющих москворецкие памятники следующего столетия.

Актуальный вопрос заключается в том, что произошло далее с ранними поселениями второй половины XI в.? Расселились ли их жители по малым притокам Москвыреки или в Москворецкий регион в конце XI-начале XII в. пришло новое население с другой хозяйственной и поселенческой стратегией? Попытка ответа на эти вопросы представлена в следующих разделах.

\section{АРХЕОЛОГИЧЕСКАЯ КАРТА ДРЕВНЕРУССКИХ ПАМЯТНИКОВ И ПРОСТРАНСТВЕННАЯ ОРГАНИЗАЦИЯ ЗЕМЛЕПОЛЬЗОВАНИЯ

$$
\text { B XII-XIII BEKAX }
$$

Задача составления карты древнерусских памятников (курганов) Московского региона была поставлена еще А.П. Богдановым в 1865 (Богданов, 1865. С. 8). Пафос
А.П. Богданова был обусловлен тем, что уже тогда курганы исчезали на глазах.

Нужно отметить, что к моменту, когда писал А.П. Богданов, существовало несколько подробных топографических карт московских окрестностей с нанесенными на них курганами. Самая древняя из них, но очень качественная - это «План села Черная Грязь» 1775 г. Курганы изображены также на карте 1826 г. (рис. 166), снятой полковником Кахановым 2-м («Карта глазомерной съемки окрестностей Москвы между Звенигородскою и Тульскою большими дорогами», масштаб 200 сажень в дюйме). Две подробные топографическая карты Москвы и ее окрестностей с нанесением на них курганов были выполнены по материалам съемок 1838-1839 гг. офицерами Военно-топографического депо под руководством ген.лейт. Ф.Ф. Шуберта. Одна карта была выполнена в масштабе 1:42 000 (420 м в сантиметре) и охватывала окрестности Москвы до р. Пахры на юге, на западе граница этой карты проходит в районе устья р. Истры, на востоке включает р. Пехорку. Курганы отмечались «осознанно», иногда с подписью «кург.» или «курганы». Дело в том, что Ф.Ф. Шуберт был профессиональным нумизматом и увлекался историей. Курганы отмечались преимущественно лишь в том случае, если они находились на открытой местности. Всего на «карту Шуберта» нанесены 62 курганные группы при 38 населенных пунктах. Лишь одна из этих курганных групп (Новленское) сохранилась до настоящего времени, но в 1920-е гг. еще многие из них существовали. Эту карту учел в своей работе О.Н. Бадер (1947).

Наиболее детальную карту военно-топографического бюро масштаба 1:21 000 (в 1 см 210 м) никто из археологов ранее не использовал (рис. 167). Впервые информация данной карты была учтена при составлении каталога археологических памятников Москвы, изданного в 2004 гг. (Кренке, 2004a). Съемка для этой карты была произведена с конца апреля по июль 1838 г. Рамки карты не выходят за пределы современной Москвы (южная граница проходит по с. Дьякову). На этой карте с особой тщательностью нанесены курганные могильники по речке Очаковке (топограф Реберг); в окрестностях Черемушек и Зюзина (топограф Бородин); в районе Филей, Гладышева и Матвеевского (топографы Егоров 4-й и Егоров 5-й). Высокая детальность данной карты позволяет представить планы курганных групп. Эта карта дает информацию, сопоставимую с планами курганных групп Владимирской губернии, составлявшихся в ходе работ А.С. Уварова в 1850-е гг.

Перед Антропологической выставкой 1878 г. был опубликован список курганов Московской губернии за подписью М.А. Саблина (Саблин, 1879). Этот список является результатом суммирования ответов уездных исправников на разосланные через губернский статистический комитет анкеты (в РГИАМ сохранилась рукопись, составленная в губернском статистическом комитете в 1878 г. «Сведения о курганах, находящихся в переделах Московской губернии» $)^{4}$. Естественно, этот список был очень приблизи-

\footnotetext{
${ }^{4}$ РГИАМ. Ф. 199. Оп. 2. Д. 94.
} 
тельным, так как в заполнении анкет не принимали участие специалисты-археологи.

В 1920-е гг. исследователи стали наносить археологические памятники Подмосковья на довольно точные топографические основы. В основном использовались листы двухверстной карты (масштаб 1:84 000). На такую карту наносил памятники звенигородской округи А.В. Чаянов (Чаянов, 2007). Карту-двухверстку Московской губернии использовал в 1927 г. студент В.Г. Карцов при составлении археологической карты р. Сетуни (Карцов, 1927; 1928). На этой же основе в первой половине 1920-х гг. была составлена археологическая карта верхнего течения Пахры (Дубынин, Киселев, 1925; 1929), Малой Истры и Маглуши (Е. Байбурт, Л.А. Евтюхова, А.В. Дмитревская, 1923-1924). Более подробную топографическую основу масштаба 1:42 000 использовали А.Я. Брюсов с коллегами при картировании курганов Рожайки и Истры (Брюсов и др., 1923). Особенно следует отметить тщательность работы учащегося (!) Сухановской школы П.А. Герасимова (Герасимов и др., 1925). Курганы в бассейне нижнего течения p. Пахры были нанесены им на топографическую основу, увеличенную до масштаба 1:25 000.

Археологические памятники центрального участка - в пределах Москвы и ее окрестностей - были картированы О.Н. Бадером. Он использовал карту Москвы и ее окрестностей масштаба 1:50 000, изданную в 1930 г. Однако наступил «период секретности», и текст О.Н. Бадера (1947) был опубликован без самой карты.

Исследователи, наиболее активно работавшие в Подмосковье по древнерусской тематике в 19601980-е гг., - Р.Л. Розенфельдт, А.А. Юшко, Т.В. Равдина обследовали, открыли и описали множество памятников, но были вынуждены использовать очень плохие, искаженные карты. В результате анализ географии расселения оказался очень схематизирован. Итоги работы по составлению археологической карты памятников Подмосковья древнерусского времени были подведены А.А. Юшко (Юшко, 1991). Она впервые попыталась оценить плотность древнерусских памятников, разбив территорию обследования на квадраты площадью 100 кв. км каждый (Юико, 1991. Рис. 2).

Методика подготовки и анализа обзорной карты археологических памятников X-ХІІІ вв. в бассейне Москвы-реки. Представленная в настоящей работе обзорная карта археологических памятников X-XIII вв. в бассейне Москвы-реки составлена на основе топографической карты 1989 г. масштаба 1:500 000 (рис. 164, 165). Ключевые участки представлены на более подробных картах. Микрорегиональные исследования было невозможно проводить без использования карт масштаба 1:10 000-1:50 000.

В основе карты лежит информация, опубликованная в изданиях «Археологическая карта России: Московская область» и «Каталог памятников археологии X-XIII вв. г. Москвы». Утраченные памятники наносились на карту наряду с сохранившимися. Примерно 150 памятников, отсутствующих в АКР, нанесено на карту под номерами 3000 и выше. Определенные сомнения вызывает определение Звенигорода как города домонгольской поры. В.А. Кучкин таковым его не считает (Кучкин, 2013), однако имеются некоторые археологические аргументы в пользу того, что город возник существенно ранее его первого упоминания (Юико, 2005).

Количество памятников больше, чем было учтено в работе А.А. Юшко (1991). Особенно это касается селищ. Их количество выросло в три раза. Увеличилось и число картированных курганных групп, в основном за счет архивно-картографических исследований. Главное отличие представляемой карты от карты, опубликованной в работе А.А. Юшко (1991. Рис. 42), - это более корректная привязка памятников к гидросети. При этом надо понимать, что и данная карта пригодна лишь для анализа закономерностей в системе расселения в древнерусское время, но не для поиска памятников на местности.

Анализ поселенческой системы. При самом общем взгляде на археологическую карту древнерусского времени бассейна Москвы-реки хорошо видно, что была интенсивно освоена не только долина основной реки и ее крупные притоки, но и сеть мелких притоков. Именно на них расположено более половины селищ и курганов. То есть вся поселенческая система состояла из множества составлявших ее подсистем (в пределах небольшого речного бассейна каждая), а те, в свою очередь, дробились на нуклеарные системы, включавшие памятники одного коллектива: селище курганный могильник - хозяйственные угодья. Начнем описание от частного к общему, начиная с подсистем. В первую очередь, именно на их реконструкцию были нацелены полевые исследования, которые проводились автором в 1980-1990-е гг.

При проведении этих полевых исследований ставились следующие вопросы.

1. В каком соотношении (пространственном и количественном) находятся поселения и курганные могильники?

2. Что представляют собой курганные могильники с большим количеством курганов - кладбища больших поселений или кладбища, маленьких поселений, которые функционировали долго?

3. Можно ли методами почвоведения, ландшафтного анализа и палеоботаническими определить местоположение пахотных и иных хозяйственных угодий?

4. Можно ли решить уравнение, в котором переменными являются размеры поселения, длительность его функционирования, размеры курганного могильника и площадь полей, чтобы рассчитать палеодемографические и палеоэкономические показатели (количество одновременно проживавших людей, площадь ресурсной зоны, необходимый минимум урожая)?

В качестве эталонных были избраны несколько микрорегионов. При их выборе предъявлялись следующие требования. Микрорегион представляет собой отдельный речной бассейн; современные нарушения ландшафта в нем незначительны, благодаря чему можно ожидать сохранение максимального количества археологических объектов; памятники микрорегиона копались, результаты раскопок известны. Таким требованиям в наибольшей степени удовлетворяли две речные долины: Язвенки-Городенки на территории парка «Царицыно» в Москве и р. Самынки, впадающей в Москву- 
реку в районе Барвихи. Частично перечисленным требованиям удовлетворяли памятники, расположенные в долинах рек Очаковка, Раменка, Чертановка, Неглинная в Москве, Туровка (левый приток Пахры) на территории заповедника «Горки-Ленинские». Именно здесь были произведены разведочные и раскопочные работы, позволившие описать структуру древнерусского исторического ландшафта в долинах малых рек, предложить некоторые количественные модели палеодемографических и хозяйственных показателей.

Описание модельных территорий следует предварить некоторыми замечаниями относительно методики археолого-почвоведческих разведочных работ. Важнейшее значение имеет визуальная диагностика погребенных пахотных горизонтов, разработанная совместно с А.Л. Александровским. Первый экспериментальный раскоп для выявления пахотного горизонта, погребенного под насыпью кургана, был поставлен в Подмосковье на курганной группе Стрелково на левом берегу р. Пахры (рис. 199). Здесь, в кургане, раскопанном в 1967 г. А.А. Юшко, был заложен раскоп, примыкавший к частично не разобранной бровке. При раскопках кургана в 1967 г. было выявлено погребение на горизонте, разборка погребенной почвы не производилась. В 1989 г. в тестовом раскопе погребенная суглинистая почва (гумусированный горизонт) снималась тонкими горизонтальными зачистками до подзола. При достижении уровня контакта гумусового слоя и подзола на поверхности последнего стали четко различимы широкие плужные борозды незначительной глубины (не более 1-2 см). В профиле подошва плужного горизонта имела вид ровной линии - резкой границы (Александровский, Кренке, 1993).

Второй пример горизонтальных и вертикальных зачисток пахотных горизонтов - раскоп на Романовом дворе в Москве (Археология Романова двора, 2009). Здесь на площади в несколько сотен квадратных метров в основании городского культурного слоя были выявлены двухчленные огородно-пахотные горизонты (рис. 201). По направлению борозд и цвету их заполнения удалось установить наличие, по крайней мере, двух этапов распашки, которая может быть сопоставлена с периодом жизни поселения, датированного второй половиной XII-первой половиной XIII в., и с периодом его запустения во второй половине XIII-начале XIV в. При этом были сделаны наблюдения над характером вертикального профиля погребенного пахотного горизонта. Полученный таким образом опыт позволил уверенно определять пахотные горизонты при наличии лишь вертикальной зачистки, без проведения трудоемких работ по проведению горизонтальных зачисток и поиску следов борозд.

Второй методический прием заключался в оценке почвоведом степени эродированности почвы под курганом или, наоборот, установлении ее повышенной мощности в результате намыва у подошвы склона. Таким образом делалась приблизительная оценка того, насколько долго производилось хозяйственное освоение участка.

Третьим методическим приемом являлся систематический отбор образцов для спорово-пыльцевого анализа из погребенных почв под насыпями курганов, из основания заполнения ровиков курганов, из культурных слоев поселений и погребенных почв, перекрытых агрогенно-делювиальными наносами.

Модельная территория Язвенка - Сухая Городенка. Речка Язвенка от истоков до ее впадения в р. Сухая Городенка имела длину 5 км (рис. 196, 197). Долина этой реки входит в Царицынский ландшафт (подробное описание см.: Низовиев, 2004). Верхний уровень рельефа (водно-ледниковые равнины) имеет отметки 165-170 м. Урез воды в реке на отметках 135-142 м. Ширина долины в верхнем течении всего около 400 м, профиль симметричный, берега крутые, ширина поймы всего около 100 м. Может быть, эти особенности отражены в названии реки. Язва, что означает пещера, барсучья нора, щель (Фасмер, 1987. Т. 4. С. 549). В среднем и нижнем течении ширина долины Язвенки увеличивается до 700 м и приобретает асимметричный профиль (левый берег более отлогий). Ширина поймы увеличивается до 150-200 м. У подошвы склонов происходит разгрузка грунтовых вод, в результате чего часть поймы (преимущественно тыловая часть) заболочена. Река Сухая Городенка крупнее Язвенки. Ее долина имеет ширину более 1 км, правый берег круче и выше левого. Видимо, уже на рубеже XVI-XVII вв. на Сухой Городенке был сооружен первый пруд (Борисов). В XVIII в. система прудов получила дальнейшее развитие и заняла пойму Язвенки до ее среднего течения. Особенности хозяйственного использования территории в XVIII-XX вв. обусловили хорошую сохранность археологических памятников на протяженных участках берегов. Даже в парке усадьбы Царицыно нарушения не столь значительны, хотя здесь проводились масштабные земляные работы в XVIII в. Курганы намеренно сохранялись владельцами для придания парку исторической «романтичности». Наличие детальной карты 1775 г. и карт XIX в. позволило точно определить местоположение некоторых утраченных курганных групп. Всего на данном участке было выявлено и обследовано 13 селищ и 15 курганных групп XII-XIII вв. (подробную историю исследований см.: Кренке, 2004б). Наибольшую информационную ценность (в силу лучшей сохранности археологических объектов) представляет верхнее и среднее течение р. Язвенки (до устья левого притока - речки Черепишной).

Курганы по берегам Язвенки, известные в литературе как Царицынские, не раз становились объектами исследований, начиная с конца XIX в. Научная документация сохранилась по материалам раскопок 1929 г. (Евтюхова, 1929), 1944 г. (Аричиховский, 1947), 1960-1961 гг. (Равдина, 1963). Помимо шурфовки и сборов подъемных материалов в 2006-2008 гг. на трех селищах были произведены раскопки (Кренке, Агеева и др., 2008; Нефёдов, Кренке, 2012), позволившие изучить постройки, давшие вещевые и керамические комплексы важные для датировки (селище Борисово 1 272 кв. м; Царицыно 3 - 144 кв. м; Царицыно 2 - 32 кв. м).

Важнейшими результатами в области установления возраста поселений и курганов можно признать следующие. Древнейшие комплексы вещей и керамики относятся к началу-первой половине XII в. (если не учитывать гнёздовскую аналогию Х в. горшку из ямы 2 на селище Царицыно 2). Почти на всех памятниках представлены материалы сере- 
дины-второй половины ХІІ в. (Кренке, 2004. С. 111-113). На селище Царицыно 2 зафиксировано наличие комплексов со значительным хронологическим разбросом - начало XII в. и первая половина - середина XIII в. (Нефёдов, Кренке, 2012). Возможно, в функционировании поселения был перерыв. Исключительно поздние комплексы, видимо, первой половины XIII в. происходят из курганного могильника «Дубки» (Орехово 2), расположенного в самых верховьях речки. Однако следует учитывать, что самый крупный центральный курган в этой группе был разграблен, можно допустить, что он был более раннего возраста. Таким образом, «разрешающая» возможность археологических датировок не позволяет говорить о поэтапном заселении. Скорее, наоборот, мы видим практически одновременно возникшие поселения и могильники, некоторые из которых, возможно, имели сложную историю - перерывы в существовании. Предположительно можно говорить о том, что самые верховья речки были заселены чуть позднее. Пространственноколичественные соотношения поселений и могильников представлены в таблице 22.

В долине р. Язвенки мы видим десять пар древнерусских памятников, включающих селище и курганный могильник. Лишь в одном случае в непосредственной близости от селища находилось два курганных могильника (селище Царицыно 3 и курганные могильники Царицыно 1 и 2). Однако можно предполагать, что где-то возле Оперного дома существовало селище, которое было полностью разрушено, так как на склоне был найден фрагмент керамики XIIXIII вв.

Прежде чем перейти к анализу деталей взаиморасположения памятников, надо отметить, что скопление древнерусских поселений и могильников приходится на территорию, освоенную в более раннее время. По нижнему течению p. Сухой Городенки и на ее притоке Язвенке известно несколько селищ железного века. На селище (городище?) железного века Царицыно 1 обнаружено три древних хронологических пласта - фатьяновской культуры, переходного периода от бронзы к железу и позднедьяковский. Таким образом, можно предположить, что выбор именно данной долины славянскими колонистами отчасти был обусловлен наличием следов культурного ландшафта прошлого.

Все десять пар селищ и курганов дают сходную картину. Селище располагается ниже по рельефу ближе к воде, курганы - выше по склону. Среднее расстояние от селища до курганов - 230 м. Нужно отметить, что подобная пространственная структура «деревня - сельское кладбище» сохранялась и в XIX в. Расстояние от деревень до кладбищ было примерно таким же - около 200-400 м (подсчет велся по карте «Москва и ее окрестности», съемка 1838-1839 гг.)

В четырех случаях (курганные группы Царицыно 2, 3, Орехово 2, 4) были зачищены погребенные почвы под курганами. Везде были найдены пахотные горизонты.

Относительно размеров селищ нужно заметить, что достоверность определения границ далеко не одинакова. Границы всех четырех формально наиболее крупных селищ из одиннадцати (Шипилово 1, Царицыно 5, Орехово 3, Орехово 2) как раз наименее достоверны. Определение границ остальных селищ можно считать достоверным, так как они подтверждены многочисленными шурфами, а в некоторых случаях, что особенно важно, границы определяет рельеф. Таким образом, размер поселений варьирует незначительно (1-2,5 тыс. кв. м). То есть речь может в основном идти об одно - трехдворных поселениях. Это предположение базируется на результатах масштабных разведок и раскопок на Куликовом поле, в ходе которых было установлено, что в среднем на 500-800 кв. м древнерусского селища приходится одна усадьба (Гоняный и др., 2003. С. 231-232).

Важно также указать на отсутствие корреляции между размерами селища и числом курганов в курганной группе. На этом основании можно предположить, что размеры курганных групп определялись прежде всего длительностью функционирования поселения.

Показательно, в частности, что при селище Царицыно 2, относительно которого по данным раскопок, сделано предположение о перерыве в функционировании, находится малочисленная курганная группа.

Вероятно, средние (10-20 насыпей) и крупные (более 20 насыпей) курганные группы были кладбищами небольших поселений, длительность существования которых была 75-150 лет.

Левый берег р. Язвенки и правый берег в пределах Царицынского парка являются участками, где археологические памятники сохранились наилучшим образом. По этому участку и следует делать выводы относительно пространственной организации ландшафта. Как отмечалось выше, все данные раскопок указывают на практическую синхронность выявленных древнерусских памятников. По левому берегу Язвенки мы видим четкий «ритм» поселений, расстояние между которыми колеблется в пределах 200-400 м. Таким образом, применяя построение «парцелл» для каждого поселения методом полигонов Тиссена (граница проходит ровно посредине прямой, соединяющей два центра поселений) с условным ограничением по дальности в 500 м, мы получаем участки площадью около 20 га. Если оперировать меньшим радиусом - 200-300 м, ориентируясь на среднее удаление курганов от поселений, то размер участков будет равняться около 10 га. Почти все эти «парцеллы» имеют естественные рубежи в виде оврагов с ручейками. Не все эти 20 га были пригодны для распашки. Если вычесть площадь крутых склонов оврагов и других «неудобий», то останется около 15 га. Курганы изначально маркировали либо дальний край поля, либо выстраивались вдоль края поля ближе к поселению. Тяготение некоторых курганных групп (Орехово 1, 2, 6; Царицыно 3 и 4) к бровкам оврагов очень заметно. По мере освоения территории, распашка, вероятно, «перешагнула» через курганные группы, и они остались в виде «островков» среди полей.

В долине Язвенки существовал свой «металлургический центр». На селище Царицыно 3 были найдены многочисленные шлаки. Прослеживаются также некоторые специфичные особенности в орнаментации раннекруговой керамики (ломаная линия в виде зигзага), характерные именно для данного микрорегиона (Кренке, Агеева и др. 2008. С. 90). Возможно, что в древнерусское время место поселения (го- 
родища?) бронзового/железного веков Царицыно 1, расположенного в центре микрорегиона, имело какой-то особый статус (сакральный?). Здесь найден уникальный глиняный светильник. О культовом использовании и почитании площадок древних городищ русским населением хорошо известно (Забелин, 1873. С. 235).

Проведенная оценка ресурсного потенциала территории методом ландшафтного анализа дала результаты, очень хорошо совпадающие с археологической реальностью (Низовцев, 2004). Пологие склоны долины между поселениями и курганами наиболее удобны для использования их в качестве пахотных или пастбищно-пахотных агрогеосистем.

Результаты спорово-пыльцевых исследований, проводившихся на разных участках долины Язвенки (верховья группа Орехово 2; средняя часть - группа Царицыно 2) показывают сходные результаты. В верхней части склонов под насыпями курганов и в основании ровиков сформировались спорово-пыльцевые спектры, указывающие на преимущественно лесной ландшафт, пыльца деревьев доминирует в общем составе спектра (деревья - 51-58 \%, травы - 21-29 \%), но наличие полей и лугов также оставило несомненный след в спектре (Гунова, 2004; Спиридонова и дp., 2008а). При этом в пойме, возле русла, совершенно иная картина (Спиридонова и др., 2008а, табл. 8). Пыльца трав составляет до 80 \% спектра (т.е. это совершенно открытое пространство).

Почвенные исследования показали, что повсеместно курганы сооружались на заброшенной пашне. Мощность пахотных горизонтов - около 8-9 см (Александровский, 2004). На покатых поверхностях погребенная распаханная почва оказалась сильно эродированной, а на плоских следы эрозии не выявлены. В основании склонов были зафиксированы напаши. Таким образом, результаты, полученные различными методами, приводят к сходным выводам об организации ландшафта в древнерусское время.

Имеющиеся данные позволяют провести некоторые палеодемографические расчеты. Число курганов в микрорегионе - 142. Это означает, что в них 184 погребения (применяется эмпирически выведенный по материалам раскопок коэффициент 1,3, обусловленный наличием впускных и парных погребений). Эти 184 человека - взрослые и подростки (малолетние дети в курганах не погребались). В традиционных обществах детская смертность достигает $70 \%$. В качестве условного ориентира можно принять Россию ХІХ столетия (Рашин, 1956. С. 192). Из этого следует, что за весь курганный период в микрорегионе Язвенки проживало и умерло 615 человек (из них 184 взрослых). Если оценивать длительность «курганного периода» в 100-150 лет, то можно определить среднюю численность группы людей, проживавших одновременно в микрорегионе - всего 184 погребения. Следовательно, в год умирало в среднем 1,21,8 человека. При допущении, что уровень взрослой и подростковой смертности составлял около 10 человек на 1000 живущих (использованы сравнительные данные для России по А.Г. Рашину), то средняя величина популяции должна была составлять 120-180 человек (взрослые и подростки). На долю каждого поселения приходится в среднем
11-16 человек или два-четыре двора. Такие показатели очень хорошо увязываются с вышеприведенными данными о размере поселений.

Попробуем оценить достоверность предлагаемой историко-ландшафтной реконструкции, подойдя к ней с другой стороны, через количественную оценку ресурсной базы. Зададимся вопросом, сколько человек могла прокормить земля в пределах предлагаемых ресурсных зон поселений, насколько эти данные совпадут с данными палеодемографической реконструкции. Наиболее ясный участок - левобережье Язвенки. Предполагаемая площадь пахотных угодий на склонах и водораздельных участках - около 70 га. Площадь перелогов (пастбищно-пахотно-лесные агрогеосистемы) примерно такая же. То есть всего около 130 десятин (при допущении, что поля простирались примерно на 500 м от поселений).

По предположению Л.В. Милова, в XVI-XVIII вв. в России бытовали комбинированные системы земледелия, сочетавшие трехполье с двупольем и перелогом (Милов, 2001. C. 21).

Нормы высева озимой ржи - полторы четверти (около 200 кг) на десятину (Милов, 2001. С. 125). На обычных или «посредственных» землях Московской губернии в XVIII в. собирали урожай ржи сам-3 или сам-4 (т.е. чистого сбора 3,8-5,7 ц с га). По данным XIX в., в крестьянских хозяйствах Московской губернии при господствующем употреблении обычной сохи и трехпольной системы урожай ржи составлял 5,6 четверти на десятину, т.е. сам-3,7, или около 5,4 ц чистого сбора с га (Брокгауз, Ефрон, 1896. Т. ХІХа (38)).

Можно предполагать, что в XII в. трехполья в Подмосковье еще не было, а было двухполье, комбинированное с перелогами и подсеками (ресурс земли это еще позволял). Зафиксированная глубина вспашки XII в. - 8-9 см (толщина погребенных пахотных горизонтов) - точно соответствует глубине вспашки в два вершка (9 см), типичной для XVIII в. (Милов, 2001. С. 80).

Исходя из предположения о существовании двуполья, можно думать, что ежегодный урожай на левобережье p. Язвенки собирался с площади поля около 60-80 десятин. При урожайности сам-3 размер снятого урожая (за вычетом зерна, оставленного для посевов) мог составлять 230-300 ц.

По данным Ф. Броделя, в диете бедняков в эпоху Средневековья зерновые давали около 80 \% калорий. Норма потребления человека в день равняется 2-3,5 тыс. калорий. В год взрослый человек потреблял до 4 ц хлебных злаков (Бродель, 1988. С. 136). Это означает, что для прокормления одного человека было необходимо около 2 га пахотных земель. То есть при принятых выше параметрах территория левобережья Язвенки могла прокормить хлебом примерно 60-75 взрослых. На рассматриваемом участке левобережья находятся 72 кургана (94 погребения взрослых и подростков). При допущении, что эти погребения совершены примерно за 100-150 лет, следует предполагать, что одновременно на левом берегу проживало около 60 человек (расчет производился при допущении уровня взрослой и подростковой смертности в 10 человек на 1000 в год). Эта числен- 
ность хорошо соответствует подсчитанной выше «экологической емкости» территории. Подчеркнем при этом, что распашка должна была подняться вверх по склонам до водораздельных равнин (в радиусе 500 м от поселений). При распашке лишь склонов на удалении 200-300 м от поселений, жители левобережья Язвенки должны были столкнуться с дефицитом продуктов питания.

Конечно, следует думать, что размер популяции не был стабильным. В благоприятных условиях, видимо, происходил численный рост. Поэтому можно предполагать, что первое поколение распахивало лишь склоны в ближайших окрестностях поселений, а второе - третье поколение было вынуждено расширить пахотные угодья и выйти на водораздельные равнины.

Модельные территории на юго-западе и в изентре Москвы (бассейны рек Очаковка, Раменка, Чертановка, Котловка, Неглинная). Систематическое изучение древнерусских памятников, в первую очередь, выявление поселений, расположенных в бассейнах мелких рек, стекающих с Теплостанской возвышенности, было проведено после работ в долине Язвенки. До этого, начиная с конца XIX в., а особенно интенсивно в 1920-1950-е гг., здесь проводились разведки и раскопки курганов (работы А.В. Арциховского, О.Н. Бадера, Б.С. Жукова, Г.П. Латышевой, М.Г. Рабиновича, Д.Я. Самоквасова, В.И. Сизова, Г.Б. Федорова, и др.). На эту территорию имеются наиболее подробные карты XIX в. с нанесенными на них курганами. В результате, карты курганов по долинам этих речек можно считать относительно полными (рис. 195).

Наиболее древними являются курганы 1-го Черемушкинского могильника. Они датируются первой половиной XII в. Серединой XII в. датируются курганы могильника Матвеевский 3 (Равдина, 1991. С. 8-10).

Поиск поселений при курганных группах велся целенаправленно с учетом «царицынской» модели. Доступными для исследования были территории современных лесопарков - «Битцевский лес», «зона отдыха Тропарево», участки долины р. Раменки в районе ст. Матвеевская. Результаты разведки свидетельствуют о том, что основной принцип пространственного соотношения поселений и могильников (поселение ближе к воде, могильник - выше по рельефу на заброшенной пашне) был понят правильно. Всего было обнаружено 15 поселений (табл. 24).

На селищах Раменки 2, Раменки 3, Матвеевское 1, Коньково 2 были собраны коллекции керамики, которые позволяют ориентировочно относить их возникновение ко второй половине XII в. В Чертановской локальной группе ранние материалы XII в. (раннекруговая керамика, орнаментированная гребенчатым штампом и «штампом-колесиком», ранние височные кольца без боковых колечек с орнаментом первого типа, по Т.В. Равдиной) представлена лишь в курганах, расположенных в нижнем течении реки возле д. Котляковой (раскопки В.И. Сизова, 1890 г.; Д.Я. Самоквасова, 1908 г). Памятники верхнего течения p. Чертановки, видимо, относятся к концу XII-первой половине XIII в. Показательно, что самый крупный могильник здесь насчитывает всего 11 курганов. Если поселение воз- никло лишь в конце XII-начале XIII в., то крупный могильник просто не успел сформироваться. На территориях лесопарков, где сохранность археологических памятников можно считать хорошей, почти возле каждой курганной группы удавалось найти соответствовавшее ей поселение. «Цепочки» поселений и курганных групп протянулись сплошными линиями по долинам рек Чертановка - на 7,5 км, Раменка - 7,5 км, Очаковка - 3,5 км, Котловка - 3 км. «Нормальным» является симметричное расположение памятников относительно русла реки. Иногда поселения расположены напротив друг друга (№ 50 и 53 на Раменке, 71 и 71а на Очаковке, 190 и 188 на Чертановке). Ширина этих мелководных речек всего 2-5 м, и они не могли играть роль реальной преграды, но могли служить «географически оправданными» границами владений. Вероятно, ресурсными территориями каждого из таких поселений, расположенных визави, являлись склоны лишь одного берега реки.

«Стандартная» ширина территории интенсивного освоения долин составляла 500-600 м. Курганные группы, вынесенные от реки на расстояние 500-1000 м, свидетельствуют о том, что в «курганное время» началось освоение водораздельных пространств. Малочисленность таких памятников (в каждом из выделенных микрорегионов их не более двух-трех), свидетельствует о том, что процесс освоения водоразделов находился в начальной стадии. В то же время «узкие» водоразделы, такие как междуречье Очаковки и Смородинки; Чертановки и ее правого притока Дубинкиной речки, видимо, были освоены целиком. Не случайно курганные группы тянутся по осевым линиям этих междуречий. Продвижение курганов на междуречья интересно сопоставить с наличием малоосвоенных речных долин. Сравним, например, долины рек Чертановки и Городни, сходных по ландшафтным характеристикам. Выявляются значительные различия в количестве памятников. Долина р. Городни была освоена значительно слабее, чем долина р. Чертановки. То есть к концу курганного периода ресурс земель речных долин еще не был исчерпан, тем не менее, началось освоение новой ландшафтной ниши - земель водоразделов.

Показательно, что верховья речек, выходящие к водоразделу, по которому проходит трасса современного Калужского шоссе, были очень плотно освоены в конце XIIXIII в. Возможно, уже тогда существовала сухопутная дорога к Москве, оказывавшая влияние на формирование системы расселения.

Размер поселений и могильников свидетельствует о том, что колонизацию осуществляли небольшие группы. Более половины курганных групп насчитывают от одного до пяти курганов, более половины поселений имеют площадь 1-3 тыс. кв. м.

Таким образом, ближайшая сельская округа Москвы в XII-XIII вв. в основном состояла из многочисленных мелких поселений, расположенных по речным долинам правобережья. Левобережье было освоено существенно слабее, прежде всего из-за ландшафтных особенностей (Низовцев, 2004a).

Из левых притоков Москвы-реки наиболее плотно была освоена долина р. Неглинной. Здесь, в центре Москвы, 
под культурным слоем города обнаружено несколько зон с находками XII-XIII вв., оставшимися от существовавших здесь сельских поселений, которые тянутся по обоим берегам (Кренке, 2009. Рис. 28). По правому берегу p. Неглинной, начиная от устья, шла сплошная цепь поселений на протяжении около 1 км. Расстояние между поселениями было не более 200-400 м (т.е. схема расселения, прослеженная в долине р. Язвенки, здесь повторяется). К сожалению, лишь один памятник - Романов двор - дает полноценную информацию. Его расположение на удалении в 300 м от русла реки на высоком береговом уступе (высота над рекой - 14 м) не типично для поселений XII-XIII вв. В качестве ближайшей аналогии можно указать лишь селище Шипилово 1 на р. Сухой Городенке (Кренке, Бакунова и др., 2008. Рис. 11). Во второй половине XIII в. такое расположение поселений стало обыкновенным. Вероятно, на расположение поселения на Романовом Дворе повлияло его соседство с городом на Боровицком холме, с которым оно возникло приблизительно одновременно. Очевидно, что лес в окрестностях Боровицкого холма был сведен очень быстро на значительном расстоянии. Следовательно, ландшафт был «открытым», что благоприятствовало использованию территории для застройки. Во-вторых, могло сказаться влияние крепости, под стенами которой должна была существовать свободная от застройки «зона безопасности». Раскопы на Романовом дворе зафиксировали распашку, вплотную подступавшую со всех сторон к жилым постройкам (рис. 201).

Всего в границах Московской кольцевой автодороги выявлено 135 курганных могильников (1034 курганов) и 52 селища древнерусского времени. Это позволяет сделать ориентировочные подсчеты числа жителей ближайшей сельской округи города. Общее число погребенных в курганах можно принять за 1350 (используется коэффициент 1,3 к числу курганов). При продолжительности «курганного периода» в 150 лет и уровне взрослой и подростковой смертности, равной 10 человек на тысячу в год, такое количество погребений оставит группа размером в 900 человек. Допустимо предполагать, что сельское население, вовлеченное в освоение среднего течения р. Москвы, имело естественный прирост. В работах, посвященных демографии «фронтиньеров», приводятся данные о том, что у второго поколения колонистов наблюдается наибольшая рождаемость (Boguki, 1988). Учитывая это, можно полагать, что численность группы, осваивавшей территорию современной Москвы, возрастала быстрыми темпами. Кроме того, город мог стать центром притяжения населения. Следовательно, в конце XI-XII в. на этой территории могли проживать первые сотни людей, а через сто лет их число могло возрасти до двух тысяч. Другой метод подсчета исходит из площади поселений. Совокупная площадь 38 поселений в пределах современной Москвы составляет 10 га. Исходя из числа курганных групп, можно думать, что поселений было примерно в три - четыре раза больше. Соответственно их площадь могла составить 30-40 га. Важно сравнить эти данные с площадью города Москвы.

Площадь города Москвы в ХІІІ в. составляла около 50 га (Кремль + Китай город до Большого Черкасского переулка с вычетом площади в 14 га, занятой неудобьями). А.Б. Мазуров предложил методику реконструкции численности населения города Коломны, которую можно применить и для Москвы (Мазуров, 2001. С. 287). По этой методике коэффициент заселенности принимается за 0,5 ; площадь усадьбы - около 400 кв. м; число людей в усадьбе - 4-5. При такой методике подсчета численность населения Москвы в первой половине XIII в. равнялась 3000 человек (Коломны, имевшей площадь 35 га - 1700-2000 человек). Возможно, что полученные оценки численности городского населения завышены (см. об этом далее).

Модельная территория в бассейне р. Самынки. Река Самынка (Кобыленка) имеет протяженность 7 км (рис. 198). Она впадает справа в Москву-реку в 21 км западнее (выше по течению) от Кремля. В верхнем и среднем течении река имеет пойму шириной 100-200 м. Профиль долины - симметричный. Она имеет развитый профиль, перепад высот от бортов долины до русла реки - около 40 м. Ширина долины - около 1,2 км. Имеется два крупных оврага с водотоками, впадающих в р. Самынку справа, и один - слева.

Первые сведения о курганах в долине р. Самынки восходят еще к И.Е. Забелину («От Раздоров влево, близ Подушкино - городище при речке Кобыленке, в лесу в 5 верстах - курганы. Возле Шульгина, полверсты от Раздоров, 2 кургана на поле» ${ }^{5}$ ). В 1958 г. А.Г. Векслер провел разведку в долине речки и выявил несколько курганных могильников. После этого здесь начались многолетние работы. Музей истории Москвы под руководством А.Г. Векслера вел раскопку курганов до 1970-х гг. Т.В. Равдина провела детальное изучение полученных комплексов, определила их возраст (Равдина, 1989).

В 1992 и 1994, 1996 гг. разведки проводились Н.А. Кренке, С.В. Шполянским, Б.Е. Янишевским. Были выявлены новые курганные группы и селища. В первую очередь обследовалась территория возле наиболее крупных курганных групп. Дополнительные разведки провели О.В. Двуреченский (2004 г.) и А.В. Лазукин (2006 г.), обнаружив при этом по одному новому курганному могильнику. В результате было выявлено 19 курганных могильников (с учетом разделения группы 7 на две части) и 7 селищ домонгольского времени. В 1994 г. А.Л. Александровский провел изучение почв в районе селища Одинцово 6. Разведку данного микрорегиона нельзя считать завершенной, так как селища выявлены далеко не все. Наиболее существенным результатом является то, что были определены параметры поселений при больших курганных группах Одинцово 6 и Одинцово 7 и проведены палеогеографические исследования.

Древнерусское освоение долины Самынки (как и в случае долины Язвенки) шло вслед за освоением данной территории в железном веке. В низовьях этой реки расположено Барвихинское городище, а на одном из правых притоков Самынки, в ее верховьях были обнаружены позднедьяковские находки. Селище Жуковка, относящееся к железному веку и начальному этапу славянской колони-

\footnotetext{
${ }^{5}$ ОПИ ГИМ. Фонд Забелина. Ед. хр. 5. Л. 44. Цит. по: Формозов А.А. Историк Москвы И.Е. Забелин. М., 1984. С. 76.
} 
зации расположено на бровке берега Москвы-реки рядом с устьем Самынки.

Наиболее интригующим сюжетом при анализе данной территории являются комплексы памятников, включающие крупные могильники. Курганный могильник Одинцово 6, насчитывающий 101 курган, - один из крупнейших в Подмосковье. В насыпи курганов, примыкающих к бровке оврага, была обнаружена лепная и раннекруговая керамика (рис. 202). Под насыпями был зафиксирован пахотный горизонт. Шурфами и зондажами было выявлено селище Одинцово 6 размером около $100 \times 40$ м, примыкающее к могильнику с юга, и частично перекрытое насыпями курганов. Селище занимало выположенный участок склона. Источником воды для жителей этого поселения, вероятно, служил родник, находящийся в овраге, правом притоке Самынки. Шурф размером 16 кв. м выявил яму от постройки с материалом XII в. Среди комплексов из раскопанных курганов наиболее ранние относятся к первой половине ХІІ в., по Т.В. Равдиной. Шурфы и зондажи зафиксировали следы интенсивной распашки, относящейся к эпохе XV-XVI вв. Эта распашка существенно «смазала» картину и делает все наши наблюдения предположительными.

Судя по размерам селища, поселение было небольшим, может быть, пять дворов, не более. Большое количество курганов, следовательно, объясняется длительностью функционирования кладбища (и поселения). Среди раскопанных курганов нет явных комплексов XI в., но, судя по находкам лепной керамики, поселение возникло не позднее конца XI в. Вероятно, самые древние курганы остались не раскопанными. Таким образом, можно предполагать, что курганный могильник формировался за период более 150 лет, чем и объясняются его размеры.

Изучение второго крупного могильника в группе, Одинцово 7, насчитывавшего 80 курганов, расположенного на правом притоке Самынки, позволило сделать следующие наблюдения. Расположение курганов этого могильника позволяет допускать, что, на самом деле, могильников было два. На плане ясно видны две зоны концентрации курганов, расстояние между группами было совсем небольшим. Свободное пространство, разделяющее группы, не более 20 м в поперечнике. Вероятно, могильники росли навстречу друг другу, так как расстояние между наиболее крупными курганами, составлявшими центры каждого из двух скоплений, равняется приблизительно 100 м. Территория подвергалась мощному хозяйственному воздействию в XVXVI вв., так как в непосредственной близости от курганной группы, к северу от нее, находятся некрополь и селище Рождествено XIV-XVI вв. Это заставляет с осторожностью относиться к результатам нашей шурфовки, имевшей целью определить границы поселений, примыкавших к курганным группам. Можно быть уверенным относительно того, что по бровке правого берега оврага имеются две зоны концентрации находок (два поселения), разделенные промежутком в 200 м. Размеры же этих памятников определены очень предположительно. Возможно, что одно из селищ крупное, размером до 1 га.

Археологический комплекс древнерусских памятников в долине Самынки позволяет сделать важные выводы. Очевидно, что люди, основавшие поселения здесь, руководствовались совершенно иной поселенческо-хозяйственной стратегией, чем поселенцы первой волны, селившиеся по пойме и первой террасе Москвы-реки. Они забрались вверх по долине малой речки на 4 километра (селище Одинцово 6) и начали осваивать именно ее берега. Долина собственно Москвы-реки оставалась, видимо, вне зоны их активной хозяйственной деятельности. Судя по наличию лепной и раннекруговой керамики на поселении Одинцово 6, начало этого нового этапа колонизации датируется не позднее конца XI в., т.е. «зазор» между первой и второй волнами колонизации был совсем небольшим.

Комплексы памятников, очень сходные по своей структуре с самынскими курганами и селищами, расположены по берегам соседних малых речек - Слезни и Вяземки.

Результаты, полученные при рассмотрении модельных территорий, находят много аналогий в системе древнерусского расселения, изученной при детальных комплексных исследованиях в районе Куликова поля (Гоняньй и др., 2007). На Куликовом поле мы видим те же принципы освоения древнерусскими поселенцами ландшафтов долин малых рек, сходную по густоте систему поселений, распространявшихся часто до самых верховьев речек и балок. Доминировавшим размерным классом поселений и в Москворечье, и на Куликовом поле были небольшие (малодворные), площадью не более нескольких тысяч квадратных метров. На Куликовом поле были выявлены и более крупные поселения, предположительно являвшиеся центрами поселенческих гнезд. В Подмосковье также есть поселения, для которых определены размеры более 10000 кв. м. (Юшко, 1991, рис. 3, Кренке, 2003. Табл. 1), однако степень их изученности слабая. Наиболее достоверные результаты были получены лишь по одному из таких крупных селищ - Мякинино 1, но оно оказалось уникальным в своем роде. Исследователи связывают его с пунктом, где находился «Войницкий мыт» (Коваль, 2014).

На Куликовом поле были выявлены поселения, расположенные на водоразделах вдоль сухопутной дороги (Гоняныцй u др., 2007. Рис. 10). В Подмосковье таких ясно выраженных скоплений поселений нет, но на модельной территории юга современной Москвы, как отмечалось выше, прослеживается группировка памятников, возможно, тяготевших к сухопутной дороге.

\section{ИССЛЕДОВАНИЕ КАРТЫ ДРЕВНЕРУССКИХ КУРГАНОВ БАССЕЙНА МОСКВЫ-РЕКИ МЕТОДОМ ГИС 6}

Рассмотрим теперь карту древнерусских памятников в пределах всего бассейна Москвы-реки. Общее количество учтенных древнерусских памятников в москворецком бассейне весьма впечатляющее - 1265 (829 курганных групп, 426 селищ и поселений на площадках городищ железного века, 3(2?) 7 города и 7 городищ). На карту (рис. 165) были нанесены 819 курганных групп (табл. 25).

\footnotetext{
${ }^{6}$ Раздел написан совместно с А.Н. Кренке.

${ }^{7}$ Статус Звенигорода остается спорным.
} 
Наибольшая концентрация памятников наблюдается (перечислены в порядке убывания) в среднем течении Москвы-реки, в среднем и нижнем течении р. Пахры и ее притоке р. Рожайке, в бассейне р. Истры, бассейне p. Северки (табл. 25). Очевидно, что количество учтенных памятников меньше реально существовавших поселений и могильников. Селищ, как минимум, должно быть в два раза больше, чтобы соответствовать числу курганных групп. Трудно оценить количество курганных групп, исчезнувших бесследно. Единственным показателем здесь могут служить селища XI-XIII вв., при которых нет могильников. Число таких селищ не так уж мало среди выявленных памятников, не менее 25 \%. Таким образом, приблизительная оценка исходного числа древнерусских поселений и могильников в бассейне Москвы-реки - около 2000.

Методика и термины. Для анализа системы расселения методом ГИС-технологий была выбрана лишь одна наиболее представительная и более поддающаяся объективному анализу категория памятников - курганы. Сделав так, мы исходили из установленных ранее закономерностей в количественном и пространственном соотношении поселений и курганных могильников (Кренке, 2003; 2004а; Кренке, Бакунова и др., 2008). Каждому поселению соответствовала отдельная курганная группа. Она располагалась, как правило, вблизи поселения на удалении не более 500 м. При крупных курганных группах размещаются относительно небольшие поселения площадью в несколько тысяч кв. м., такие же, как и при маленьких курганных группах. Эти данные указывают на то, что численность курганов в группе определялась прежде всего длительностью функционирования поселения. Таким образом, анализируя карту курганов, мы фактически рассматриваем поселенческую систему. В идеале в будущем можно будет анализировать карту именно поселений. Пока же по нашей оценке лишь треть существовавших древнерусских поселений региона была найдена, тогда как курганы зафиксированы почти все.

Изучение древнерусских древностей Подмосковья позволило прийти к выводу, что было две волны древнерусской колонизации региона. Первая относится ко второй половине XI в. Древности этого периода представлены почти исключительно селищами, расположенными в долине Москвыреки и Пахры. Вторая волна, датирующаяся рубежом XIXII вв.-первой половиной XIII в. представлена поселениями и курганами, расположенными как в долине основных рек, так и по мелким притокам.

В качестве основного инструмента пространственного анализа использовался алгоритм вычисления плотности заданных точечных объектов на местности. Алгоритм разбивает всю территорию на элементарные единицы (пиксели) и выставляет каждому пикселю условное значение плотности, соответствующее количеству объектов в некой зоне поиска вокруг пикселя. В данном случае размер пикселя равнялся $100 \times 100$ м. Управляющим параметром алгоритма является «чувствительность», которая задает радиус зоны поиска объектов для каждой элементарной единицы. Плотность может рассчитываться как с учетом веса каждой точки, так и без него. В первом случае, например, курганная группа из
10 курганов создает такую же плотность, как пять групп по два кургана. Во втором случае все группы считаются «равноправными» вне зависимости от количества курганов. Расчеты были проведены обоими способами.

Был проведен ряд расчетов плотностей с различными значениями чувствительности. Значения подбирались, исходя из археологической семантики используемых дистанций. В итоге, как основные значения «чувствительности» были приняты 5 и 10 км. Таким образом, было построено четыре карты плотности (рис. 168, 169).

Смысл такого подхода заключался в том, чтобы в первом случае выявить локальные центры поселенческой системы, а во втором - выявить положение «центральной области поселенческой системы», если таковая имелась. Параметры выбранных радиусов не вполне случайны. Пятикилометровый радиус - это стандарт при расчете ресурсных зон поселений. Неоднократно высказывались соображения, что расстояние, равное примерно одному часу пешего хода или 5 км, - это пространственный порог удаленности полей от поселений и вообще порог зоны интенсивной хозяйственной эксплуатации. Десятикилометровый радиус - это фактически «зона хорошей осведомленности» - расстояние, на которое можно отойти за один день, что-то сделать и вернуться обратно в исходную точку.

Как уже отмечалось выше, в результате микрорегиональных исследований было установлено, что численность курганов в группе не имеет положительной корреляции с размером поселения. То есть размер курганной группы определялся прежде всего длительностью функционирования могильника (и поселения соответственно). Таким образом, учитывая численность курганов в группе, мы не оцениваем, пусть даже косвенно, плотность одновременно жившего населения, а оцениваем количество населения, жившего на данной территории за весь рассматриваемый исторический период. Можно условно назвать этот показатель «интенсивность освоенности ландшафта» (рис. 169, 1). Данное определение очень условно. Содержание понятия «интенсивность освоенности ландшафта» состоит в том, что мы можем установить определенную численность людей, живших и умерших на определенной территории в исторический отрезок времени, полагая при этом, что данная территория осознавалась этими людьми как «своя земля», «земля предков», имела сакральное значение, являлась основой их этнолокального самоопределения, социальной и культурной общности.

Нет сомнений, что данный показатель имеет важное историческое значение, а его смысл нужно детализировать в будущих исследованиях.

Подход, когда численность курганов в группе не учитывалась, дает характеристику плотности расположения памятников. Фактически это показатель плотности поселенческой системы. Поскольку нет объективных данных для хронологического «расслоения» всего массива на более дробные хронологические группы, то 150-летний период с начала XII в. по середину XIII в. воспринимается как единый.

Результаты анализа. Перейдем теперь к анализу полученных генерализованных карт. 
В первом случае, когда радиус чувствительности точек равнялся 5 км (рис. 169), карта «интенсивности освоенности ландшафта» дает нам своеобразную «цепочку» локальных центров, выстроившихся с интервалом 5-10 км вдоль долины верхнего и среднего течения Москвы-реки (от устья p. Исконы до устья Пахры), в нижнем течении р. Пахры и ее притоке Рожайке, а также в верховьях р. Пехорки. Всего можно насчитать 15 таких локальных центров, не считая одного совершенно изолированного, расположенного в верховьях р. Рузы. Первое место (наиболее интенсивный цвет на карте) занимает локальный центр, расположенный в бассейне р. Самынки.

«Карта плотности памятников» дает совершенно иную картину. Ясно выделяются два наиболее значимых центра 1) в районе Теплостанской возвышенности в черте современной Москвы, включая долины мелких речек, стекающих с нее; 2) на «стрелке» междуречья Москвы-реки и Пахры. Размеры этих двух центров невелики - диаметры около 10-15 км.

Если оценивать степень освоения бассейна Москвы-реки в целом, то хорошо видно, что долины основных водных артерий освоены почти сплошь. Исключение составляют неосвоенные верховья Москвы-реки, Пахры, Десны, Мочи, Коломенки. Четко выделяется пустая зона от Исконы до среднего течения Рузы, отделяющая памятники верховьев p. Рузы от москворецких. Также пустая зона протянулась по водоразделу на левобережье Москвы-реки между реками Руза и Истра. Узкая полоса неосвоенной земли окаймляет с севера бассейн р. Северки, отделяя ее от основного массива памятников.

При подсчете с радиусом чувствительности точек в 10 км (рис. 170) картина меняется довольно существенным образом. Карта «интенсивности освоенности ландшафта» рисует четыре локальных центра (перечислены далее в порядке значимости): 1) «стрелка» междуречья Москвы-реки и Пахры, включая устье р. Рожайки, смыкающаяся с бассейнами р. Сетуни, Раменки, Очаковки; 2) район долины Москвы-реки от Дунино до Успенского, включая бассейн ее правого притока Большой Вяземки; 3) бассейны левых притоков Москвы-реки Закзы - Самынки - Чаченки; 4) верховья р. Пехорки.

Карта плотности памятников показывает один «суперцентр» - правобережье Москвы-реки, начиная от бассейна p. Раменки, Очаковки до «стрелки» междуречья Москвыреки и Пахры. Размеры этого пятна - $15 \times 37$ км. При этом центр тяжести находится в северо-западной части ареала (долины правых притоков Москвы-реки от р. Раменки до p. Людовки). При таком уровне генерализации хорошо видно, что фактически вся территория бассейна Москвыреки входила в зону освоения.

Также для курганных групп были рассчитаны полигоны Тиссена и расстояния до ближайшего соседа (рис. 168, 2). Построение полигонов Тиссена - это метод, суть которого в том, что каждый полигон содержит только одну точку (курганную группу), и любое место в пределах этого полигона находится ближе к связанной с ним точке, чем к точке любого другого полигона. То есть граница двух соприкасаю- щихся полигонов Тиссена проходит через середину отрезка расстояния между соседними точками.

Полигоны можно интерпретировать как «жизненное пространство» каждой курганной группы. В данном случае максимальный размер полигона был ограничен кругом вокруг курганной группы с радиусом 5 км, таким образом можно оценить компактность курганных групп, при этом отдельно стоящие группы (курганы) не будут искажать общей картины.

Обе полученные гистограммы (рис. 171) имеют логарифмический характер. Половина минимальных расстояний между соседними курганными группами приходится на диапазон 300-1000 м. Примерно 35 \% минимальных расстояний приходится на диапазон от 1000 до 3000 м. Также существует класс совсем близкорасположенных памятников, расстояние между которыми менее 300 м (их $6 \%$ ).

Полигоны Тиссена дают нам представление о степени парцеллизации культурного ландшафта. 35 \% территории «принадлежащих» отдельным курганным группам, составляет от 2 до 400 га. Около 40 \% «парцелл» имеют площадь от 400 до 2000 га. Маленькие парцеллы сосредоточены по долине Москвы-реки, в ее среднем течении и в нижнем течении р. Пахры. Средняя толщина «коридора», заполненного маленькими парцеллами, составляет 7 км

Обсуждение и вblводы. Примененный подход с двумя уровнями генерализации и двумя способами подсчета плотности точек позволяет выделить «две стороны медали»локальную структуризацию и главный центр. Полигоны Тиссена позволяют дополнительно выделить «центральную» и «периферийную» зоны. Центральная зона (семикилометровый коридор в среднем течении Москвы-реки, нижнем течении р. Пахры и ее притока Рожайки) при любом способе подсчетов выделяется как зона постоянного расселения, где далеко не все объекты синхронны, а, видимо, сменяли друг друга. Это следует из того, что «жизненное пространство» каждого памятника в этой зоне крайне мало - менее 200 га, а расстояния между соседними точками в среднем менее 600 м. Именно эта территория может считаться как максимально окультуренный ландшафт и ядром расселения. Визуально хорошо прослеживается граница ядра (мелкофрагментированные парцеллы) и периферийной зоны. Также можно сделать выводы: 1) при заданном радиусе в 5 км для построения полигонов вся территория образует непрерывный ансамбль; 2) периферийная зона «вытекает» из одного ядра.

Локальная структуризация поселенческой системы видна, главным образом, на картах интенсивности освоенности ландшафта. Этот факт ценен сам по себе, так как показывает методическую ценность подсчета плотности памятников именно с учетом числа курганов в группах. При использовании радиуса в 5 км наиболее четко выявляется серия компактных локальных центров, что имеет существенную историческую значимость. Два наиболее ярко выделенных цветом локальных центра - в бассейне р. Самынки и в среднем течении р. Рожайки - вероятно, указывают на их особую значимость на ранней фазе колонизации. При изменении параметров подсчета плотности в сторону уве- 
личения радиуса чувствительности точек эти центры «размываются». Применение радиуса чувствительности в 10 км (рис. 170) фактически рисует процесс слияния нескольких локальных центров (в районе междуречья Москвы-реки и Пахры) в один, «ослабление» мелких локальных центров в среднем и верхнем течении Москвы-реки. Выявленные на карте интенсивности освоения локальные центры второго порядка имеют существенное историческое содержание. Это очаги колонизации второй колонизационной волны (первая волна славянской колонизации региона XI в. почти не оставила курганов, и здесь не рассматривается). Данные раскопок это подтверждают. В Горышкино были найдены курганы с обрядом трупосожжения, поселения и курганы Самынки, Рожайки и Пехорки дали комплексы с лепной и раннекруговой керамикой конца XI в.

Таким образом, переход от одной карты к другой можно воспринимать как процесс исторического развития. Карта с радиусом чувствительности 5 км лучше отражает раннюю ситуацию раздробленности, карта с радиусом чувствительности в 10 км лучше характеризует относительно позднюю ситуацию «консолидации» конца XII-XIII вв.

Оба метода подсчета с учетом количества курганов и без их учета при радиусе чувствительности точек в 10 км согласованно выделяют одну наиболее насыщенную область (выше она была названа ядром) - простирающуюся по правому берегу Москвы-реки, от долины р. Сетуни (в черте современной Москвы) до р. Пахры. При этом карта с радиусом в 5 км рисует два «полюса» в этой области (возможно, так было на раннем этапе!). Эта сравнительно небольшая территория (площадь не более 500 кв. км) являлась ядром сельского расселения в бассейне Москвы-реки (центр первого порядка). Именно здесь следует видеть центр сложения своеобразной культуры региона, искать мастерские, производившие «этноопределяющие» украшения (семилопастные височные кольца, перстни браслеты, гривны и пр.). В пределах этой области уже были выявлены уникальные артефакты - раннекруговой горшок X-XI вв. на селище Царицыно 2, находки височных колец начала XIII в. с изображениями на лопастях, имевшими сложную семантическую нагрузку (ромбы, свастики, «книжные» плетенки). Вероятно, именно в пределах этого региона находились места (место?), где решались важнейшие вопросы (административные, в том числе судебные, бытовые, сакральные) жизни всей москворецкой группы славян.

Город Москва максимально приближен к этой области, но не включен в нее, а наоборот, «противостоит». Видимо, эти пространственные соотношения далеко не случайны, за ними кроются определенные социальные антагонизмы.

Видимо, москворецкое сельское население XII-XIII вв. и княжеский город составляли биполярную структуру. Эта биполярность ярко проявилась в противоречивом поведении «московлян»/«москвичей» (термины летописи) в 1175 г. и в роковом 1238 г. По свидетельству летописей, в обоих случаях под предводительством князя они сначала выступали против врагов, но затем, не вступая в бой, возвращались к своим домам.

Таким образом, установив пятикилометровые зоны для плотностей и полигонов Тиссена, мы получили компактный и пространственно непрерывный ансамбль расселения. Разделение на ядро и периферийную зону целиком не отражает разнообразия расселения. Очевидно, что существовали несколько типов зон (плотности освоения/расселения), обусловленных природными, а, возможно, социальными и хозяйственными факторами. Возможный путь к выделению и дальнейшему анализу этих зон находится в области исследования оптимальных «жизненных пространств», при которых не нарушается непрерывность освоения территории. Так можно подойти к обоснованному районированию сельского расселения.

Весьма показательно расположение особенно крупных курганных групп (к таким относились группы в 40 и более курганов). Всего таких групп известно 30. Как было показано выше, такие группы следует интерпретировать как кладбища, функционировавшие особенно долго (а не как могильники крупных поселений), т.е. это своеобразные «очаги колонизации». Причем это «очаги колонизации» второй волны. Выше уже отмечалось, что расположение ранних поселений с лепной керамикой не совпадает с расположением многокурганных могильников. Почти все могильники с большим количеством курганов расположены на разных мелких притоках Москвы-реки, в долине самой главной реки они единичны, если не считать ее верхнего течения. При этом модель освоения верхнего течения вообще сильно отличается от модели освоения Звенигородско-Московского течения реки. Малые притоки остались так и не освоенными в верхнем течении, все памятники сконцентрированы в пределах долины Москвы-реки. Лишь начиная с реки Сетуни, устье которой возле д. Бушарино (правый приток), и далее вниз по течению фактически до самого устья мы видим картину, когда основная заселенность приходится именно на притоки.

В характере освоения притоков также наблюдаются важные различия. Некоторые притоки были освоены полностью, от устья до самых истоков. Наиболее выразительно этот тип освоения виден на примере речек, начинающихся на Теплостанской возвышенности в Москве, в «треугольнике» междуречья Москвы-реки и Пахры. До самых верховьев были освоены некоторые (но не все) речки между Москвой и Звенигородом. Выше Звенигорода малые притоки если и были освоены, то лишь частично в их нижнем и среднем течениях. Выделяются также «полным» освоением долины рек Северки, Рожайки и Пехорки. Причем на двух последних есть и серии крупных могильников, и ранние находки лепной/раннекруговой керамики. На р. Северке крупных могильников нет, а раннекруговая керамика встречается (рисунки М.В. Талицкого керамики с городища Настасьино; Коваль, 2004. Рис. 47, 1).

Плотное освоение долины р. Рожайки и ее притоков контрастирует с малочисленностью памятников на р. Моче.

Таким образом, судя по карте памятников, в начале XII в. начался новый этап освоения бассейна Москвыреки. Заселяются верховья Москвы-реки и ее левого притока Рузы ${ }^{8}$. Особенность освоения данного участка в том,

\footnotetext{
${ }^{8}$ Ранние курганные группы с материалами XI в., расположенные в самых верховьях р. Рузы, видимо, вообще имеют мало отношения к процессу заселения бассейна Москвы-реки. Они, скорее, представляют собой памятники, связанные с колонизацией бассейна Верхней Волги.
} 
что памятники сконцентрированы в долине крупных рек Москвы-реки и Рузы, притоки оставались практически свободными. Вторая особенность - малочисленность курганов в верховьях Москвы-реки выше Можайска и в среднем течении р. Рузы при довольно большом количестве поселений XII-XIII вв., выявленных здесь. Отчасти здесь сказался эффект «археологии водохранилищ». Затопленной оказалась пойма, эрозии подвержена первая терраса, находки оказались доступными для обозрения на береговых пляжах водохранилищ, что существенно повысило эффективность археологических разведок. Причина малочисленности курганов скорее всего в том, что они были здесь тотально распаханы. Менее вероятно, но все же не исключено другое предположение, что здесь существовал иной обряд погребения. Проблема археологической идентификации голяди и ее локализации так и остается открытой. Очевидно, что эта балтская этническая группа использовала круговую керамику древнерусского типа, подобно тому, как это делали пруссы в Прибалтике. Поэтому имеющиеся незначительные коллекции керамики из подъемных материалов с селищ вопроса решить не могут.

Если придерживаться предположения, что многокурганные группы маркируют длительно функционировавшие и, соответственно, ранние «очаги колонизации», то к таким нужно отнести следующие: 1) правобережье Москвы-реки от Звенигорода до Барвихи; 2) район Спас-Тушино - Мякинино на Москве-реке; 3 ) долину Истры в ее среднем и нижнем течении; 4) нижнее течение Пахры; 5) долину Рожайки и ее левый приток р. Рогожку; 6) бассейн р. Пехорки.

Характерно, что правобережье Москвы-реки южнее города в этот список внести нельзя. Здесь есть несколько ранних памятников первой половины - середины ХІІ в. (курганы Черемушки, Котляково, Беседы, селища Царицыно 2. Борисово 1), но подавляющее большинство - более поздние. То есть город Москва был устроен в 1156 г. в уже освоенной местности, но все же между «очагами заселения», и сам затем стал фактором, влиявшим на формирование сельской округи. Можно предполагать, что повышенная концентрация памятников в этом районе была обусловлена отчасти «притяжением» города и путей, ведших к нему. Весьма показательны в этом отношении «сгустки» памятников (поселений и курганов) в районах Беляево - Коньково - Теплый Стан; в верховьях р. Битцы; на р. Десне. Возможно, они маркируют сухопутную дорогу к городу Москве.

Базируясь на приведенные выше данные о суммарном количестве курганов в бассейне Москвы-реки, можно сделать приблизительные демографические подсчеты. При учете коэффициента 1,3 получается, что в 7671 кургане погребено около 10000 человек. Можно предполагать, что примерно 25-50 \% курганов не дошли до нас. Тогда число 10000 возрастет до 15 000. При смертности 10 человек на тысячу в год (без детской) такое количество погребений за 150 лет оставит группа со средней численностью в 10000 человек (взрослых и подростков).

Как сказано выше, при расчете численности населения Москвы на середину XIII в., по методике А.Б. Мазурова, была получена цифра около 3 тыс. человек. Следовательно, городское население региона (Москва + Коломна) составляло 5000 человек. Эти цифры для сельского и городского населения плохо согласуются друг с другом (слишком велик процент городского населения, ведь даже в XIX в. доля городского населения в центральных губерниях Европейской России не превышала 5 \%). Из данного противоречия может быть два выхода. Первый - допустить, что количество сельского населения было существенно больше. Второй - что численность городского населения завышена. Численность сельского населения действительно была больше, так как к населению бассейна Москвы-реки нужно добавить еще население бассейна верхней Клязьмы, но даже сделав это, соотношение городского и сельского населения останется не очень правдоподобным. Как мне кажется, вероятность погрешности при вычислении городского населения была больше, так как данных для определения размеров городов мало, плотность застройки точно не известна. В этом случае реконструируемую численность городского населения следует уменьшить, как минимум в два-три раза, т.е. Москва начала XIII в. насчитывала 1000-1500, а Коломна - 6001000 человек.

\section{НЕКОТОРЫЕ АСПЕКТЫ МАТЕРИАЛЬНОЙ КУЛЬТУРЫ}

О двух этапах древнерусского освоения Подмосковья писалось и раньше (Юшко, 2001), однако пока остается неразработанным вопрос о том, как связаны эти этапы между собой, можно ли говорить о «двух волнах» колонизации.

Второй, не менее актуальный вопрос, - это этническая и культурная интерпретация ярких вещевых комплексов, прежде всего, височных колец из подмосковных курганов и селищ.

Как уже отмечалось выше, не позднее начала XII в. в поселенческой структуре Москворечья происходит резкое изменение. Стремительно осваиваются малые притоки Москвы-реки. В комплексах наиболее ранних памятников на малых речках встречена раннекруговая или даже в единичных случаях лепная керамика. Возникает вопрос: что произошло? Население из долины Москвы-реки рассеялось по притокам, или появляется новая волна колонистов с иной хозяйственной и поселенческой стратегией?

Прежде чем перейти к изложению аргументов в пользу того или иного ответа на поставленные вопросы, необходимо дать краткий обзор эволюции керамики в регионе.

Классификаичя и хронология древнерусской керамики московского региона. Существенные шаги для разработки этих вопросов уже предпринимались (Коваль, 2008; Розенфельдт Р.Л, 1968; Равдина, 1991; Чернов, 2005). Исследователями древнерусской керамики СевероВосточной Руси применялись различные подходы к ее классификации, которые можно сгруппировать следующим образом. Во-первых, «прагматически-обобщенный» (Г.П. Смирнова для Новгорода; А.Е. Леонтьев для Ростова; М.В. Малевская-Малевич для Новогрудка), когда выделяется примерно восемь ведущих типов. Во-вторых, «прагматически-детализированный» (О.М. Олейников для Твери; В.А. Буров для Новгородской области; В.А. Лапшин для 
Суздаля), когда выделялось около 100 вариантов. Имеются и примеры, когда выделялось около 30 типологических разновидностей (Н.А. Макаров для Русского севера; М.В. Седова для Ярополча-Залесского; И.Ю. Стрикалов для Рязани). Под словом «прагматический» в данном случае понимается то, что исследователи основное внимание уделяли именно задаче разделения материала на группы, а не разработке и следованию неким методическим принципам классификации. Третий подход заключается как раз в разработке классификации с ранжированными по иерархии признаками (Е.К. Кадиева для Ростова и Суздаля). Конструктивно-технологическим можно назвать подход, примененный В.Ю. Ковалем для классификации керамики Ростиславля Рязанского, когда в форме верхней части сосуда выделяется «конструктивная схема». Пятый подход был реализован В.М. Горюновой при работе с материалом Рюрикова городища. Его можно назвать технологическим, так как группы керамики выделялись на основании предположений о технологии изготовления горшков в русле идей А.А. Бобринского. Наконец, шестой подход операционно-морфологический (по Н.Н. Грибову для Нижнего Новгорода; И.Г. Сарачеву для Днепровского левобережья), когда при классификации учитывалась не просто форма венчика, но и те операции, в результате которых эта форма создавалась.

Исследователи, занимавшиеся керамикой Москвы и Подмосковья, применяли обобщенно-прагматический подход (рис. 190). Ими были описаны лишь наиболее распространенные разновидности форм и орнаментов, в то время как эволюция керамического набора детально не прослеживалась. Безусловно, в будущем необходима разработка более подробного «типологического листа», учитывающего вариации форм и соотношения их с орнаментами и видами глин, которые являются важными хронологическими индикаторами. В данной работе представлено распределение по шкале времени ранее выделенных морфологических групп. В результате раскопок в Москве и Подмосковье за последние 20 лет были получены «реперные» керамические комплексы, которые с большой надежностью могут быть выстроены в хронологической последовательности. Основания для такой уверенности дают как керамические материалы (например, соотношение лепной, раннекруговой и круговой керамики в комплексах), так и набор сопутствующих находок, радиоуглеродные датировки.

Наиболее раннюю стадию характеризует наборы из слоя Данилова монастыря в Москве/селища Хотяжи 1. В них представлена как лепная, так и раннекруговая керамика. Набор находок характерен для XI в. (Беляев $и$ др., 2010). Нижняя дата точно не определена. Наличие керамики с ребром, близкой к «ладожскому типу», указывает на возможность отнесения нижней хронологической границы к Х в., вероятно, его второй половине. Из выделенных ранее типологических групп для данного набора характерна группа 2 (простая конфигурация) в ее наиболее архаичной форме короткий слабоотогнутый венчик. Орнаментация «богаче» и разнообразнее, чем во все последующие периоды: применялись разнообразные штампы, пальцевые вдавления и пр.
Предположительно возраст данного набора керамики определяется в интервале 950-1100 гг.

Вторая стадия представлена комплексами из ям селища Дьяково-пойма на территории заповедника «Коломенское» (рис. 189) и ямы 2 селища Царицыно 2 (рис. 191). В этих комплексах уже практически нет лепной керамики, но представлены архаичные типы орнаментации - оттиски палочки, обмотанной нитью, насечки по венчику, отпечатки гребенки. Среди форм представлены как варианты группы 2, так и «манжетовидные» венчики (группа 6, по С.3. Чернову). Ориентировочная датировка этих комплексов 1050-1150 гг.

Третья стадия - «переходная» от раннекруговой к развитой круговой («курганной») керамике. Орнаменты нанесены гребенкой и зубчатым колесиком, еще встречается волна. Появляются горшки, сделанные из белой глины; наблюдается преобладание профилированных форм, в том числе имеются горшки с манжетовидными венчиками, архаичные слабопрофилированные горшки единичны. Массовыми типами становятся «общедревнерусские» горшки с эсовидным профилем и округлым валиком, завершающим венчик (группа 1, по Р.Л. Розенфельдту, Т.В. Равдиной и С.З. Чернову) и воронковидным венчиком (группа 7 по С.3. Чернову, она же группа 3 по Т.В. Равдиной и Р.Л. Розенфельдту). Типичными комплексами являются материалы из ям на селище Борисово 1 в Москве (рис. 192), Романов двор, яма 8. Для комплекса ямы 8 с Романова двора имеется радиоуглеродная датировка (910 \pm 40 лет), укладывающаяся с вероятностью 68,2 \% в интервал 1030-1190 гг.

Ориентировочный возраст третьей стадии - 11501200 гг.

Четвертая стадия представлена профилированными формами (в первую очередь, группы 1,3 и 7 по С.3. Чернову), край венчика часто заглажен, завернут наверх. Доминирует линейный орнамент, существенный процент керамики из белой глины. Именно эта керамика наиболее широко представлена в Подмосковных курганах и московском городском слое домонгольского времени. Типичные комплексы - яма 1 на Романовом дворе (рис. 193), постройка под Казанским собором на Красной площади, ранний слой Богоявленского монастыря в Китай-городе. Имеются многочисленные радиоуглеродные датировки в интервале 840-870 лет радиоуглеродного возраста.

Ориентировочный календарный возраст четвертой стадии - около 1200 г. (плюс-минус два десятилетия).

Пятую стадию характеризуют горшки и корчаги с венчиками «обтекаемой» формы, развившиеся из группы 1 (группа 5, выделенная С.3. Черновым, является разновидностью), с тонкими стенками (горшки), линейным орнаментом. Зарождается «косая волна», исчезает керамика из белой глины. Типичный комплекс - яма 1 на селище Царицыно 2 (рис. 194). Для него имеются радиоуглеродные датировки, указывающие на календарный интервал 1220-1264 гг.

Ориентировочный возраст пятой стадии - 1230 1250-е гг.

Вернемся к вопросам, поставленным в начале этого раздела. Имеются данные, указывающие на большую вероят- 
ность версии о том, что в освоении малых притоков приняло участие новое население. Керамические комплексы памятников на малых речках, даже самые ранние (селище Царицыно 2, Борисово 1) содержат фрагменты горшков из светложгущихся глин (белоглиняные). Это принципиальным образом отличает данные комплексы от наборов керамики из ранних поселений ХІ в. в долине Москвы-реки и Пахры, где нет совсем керамики из белой глины.

В.Ю. Коваль, привлекший внимание к феномену распространения светлоглиняной керамики в Москворечье в XII в. (Коваль, Хижняков, 2005; Коваль, 2008), предложил интерпретировать его как результат переселения сюда выходцев из южнорусских областей, скорее всего, Рязанщины или Чрниговщины (Коваль, Хижняков, 2005. С. 179; Коваль, 2008, С. 175). Подтверждение тому, что в Подмосковье присутствовали в XII в. южнорусские переселенцы В.Ю. Коваль видит в том, что здесь встречены такие украшения, как трехбусинные и перстнеобразные височные кольца. В.Ю. Коваль приводит в качестве аргумента против версии о торговле керамикой (вверх по Москве-реке) наблюдение, что светлоглиняных горшков мало в Коломне и на городище Настасьино на Северке.

Мне кажется, что такая интерпретация не очень соответствует материалу. Светлоглиняная керамика в Москворечье не имеет положительной корреляции с находками трехбусинных колец. Наоборот, в могильниках XII в., насыщенных типичными семилопастными кольцами москворецкого типа (например, Беседы), много светлоглиняной керамики. На городище Настасьино основная масса средневекового материала датируется начиная со второй половины XIII в., поэтому там нет светлоглиняных горшков.

В комплексах XII в. как южнее г. Москвы, например, селища Царицыно 3, Борисово 1 (Нефёдов, Кренке, 2008. Табл. 22-31; Кренке, Агеева и др., 2008), Большое Саврасово (Гоняный и др., 2010), так и в верхнем Москворечье (селище Хотяжи 1, раскопки 2009 г.) светлоглиняная керамика составляет от 7 до 45 \%. На мой взгляд, такое сочетание горшков в комплексах маленьких поселений в 1-3 двора указывает именно на то, что в распоряжении каждой малой семьи был набор разнородных горшков, сделанных из местного и привозного сырья. Видеть причину этого явления в торговых связях вполне допустимо (очень вероятно, что маршрут пролегал по Москве-реке). Нарушение торговых связей и общий упадок благосостояния после нашествия 1238 г., видимо, способствовал исчезновению белоглиняной керамики в Москворечье ${ }^{9}$.

С другой стороны, понятно, что сами по себе горшки не перемещаются, стремительное массовое изменение вкусов и образование разветвленной торговой сети маловероятно.

\footnotetext{
${ }^{9}$ В моем распоряжении имеется этнографический пример на данную тему. При обследовании в 1980 г. усадеб гончаров в Курской области на р. Сейм рядом с д. Авдеево в ходе бесед было установлено, что в самые тяжелые 1930-1940-е гг., когда из-за колхозов и войны лошадей не стало, гончары деревни Кожля, специализировавшейся именно на керамическом производстве, в том числе игрушек, полностью перешли на красножгущуюся глину, залегавшую рядом, но затем восстановили использование белой глины, за которой надо было ездить.
}

Видимо, приток нового населения в бассейн Москвы-реки в первой половине XII в. все-таки был. Вместе с этим населением, а затем и в результате торговли распространились по подмосковным малым речкам горшки из светлой, порой совершенно белой глины.

Очень показательно, что украшения, специфичные для населения долины Москвы-реки второй половины XI в., а именно височные кольца «деснинского типа» или их обломки, отсутствуют в памятниках первой половины XII в. на малых притоках Москвы-реки. Сравним это с тем, что «археологическая жизнь» у семилопастных височных колец была достаточно долгая. Обломки украшений XII в. встречаются на памятниках середины-второй половины XIII в. Можно предположить, что бабушки людей, заселивших притоки, не носили кольца «деснинского типа», а носили лучелопастные кольца (тип 2), из которых развились ранние лопастные (типы 3 и 4 по Т.В. Равдиной). Здесь нужно указать на одно исключение - это комплексы памятников в бассейне p. Рожайки. Здесь дважды (Битягово, Судаково) были найдены в комплексах начала ХІІ в. пятилопастные кольца, родственные кольцам «деснинского» типа. Возможно, часть населения, осевшего первоначально на средней Пахре, затем сдвинулась на юг по долине Рожайки.

Классификация орнаментов семилопастных виcoчных колец. Семь человек изучали семилопастные височные кольца московского типа - В.И. Сизов (Сизов, 1895), А.В. Арциховский (Аричиховский, 1930), Б.А. Рыбаков (Рыбаков, 1948), Т.В. Равдина (Равдина, 1968; 1978), Т.Н. Макарова (Макарова, Равдина, 1992), И.Е. Зайцева, Т.Г. Сарачева (Зайцева, Сарачева, 2011). Задача по описанию основной хронологической канвы развития этого типа украшений была в результате успешно решена, а вот при историко-этнической интерпретации этих украшений исследователи пришли к противоположным заключениям.

Т.В. Равдина, сделавшая больше всех в изучении этой категории украшений, выявила эффективные хронологические маркеры - в том числе два типа орнамента, которым украшалась верхняя часть лопастей. Таким образом, по орнаменту предлагалось разделять весь массив украшений на две хронологические группы. Более детальная хронологическая атрибуция велась по признакам формы и размеров.

Т.Н. Макарова совместно с Т.В. Равдиной провели скрупулезный анализ «дополнительных» орнаментов на кольцах, выявили две основные традиции и сделали тонкие наблюдения, касающиеся предполагаемых мастерских и мест производства. Однако «основной орнамент» на щитках не был с такой тщательностью рассмотрен. На это обратили внимание в своей монографии И.Е. Зайцева и Т.Г. Сарачева.

Задача заключается в том, чтобы продолжить изучение основного и дополнительного орнаментов на семилопастных височных кольцах с двоякой целью: 1) для выявления более дробных хронологических стадий развития орнамента; 2) для выявления локальных традиций, не зависевших сильно от времени. Конечно, «сверхзадача» заключается в достижении понимания этнической сути (если таковая была) данного яркого украшения.

При классификации использовались следующие по- 
нятия, описывающие отдельные элементы орнамента: 1) линия; 2) полоса (пространство, ограниченное двумя параллельными линиями), может быть заштрихована или не заштрихована; 3 ) фестоны (треугольные либо полукруглые, направленные вниз и вверх, заштрихованные и не заштрихованные), опирающиеся на полосу; 4) фестоны, висящие/ опирающиеся на линию (в тех случаях, когда основания треугольников примыкают к линии, а не к полосе); 5) сегмент, месяц (фигуры, образованные линиями или полосами на щитке); 6) дополнительная линия (линия, прочерченная параллельно полосе); 7) заштрихованная полоса, заходящая на зубчики (имеются в виду зубчики, выступающие вверх над щитком); 8) арочки (полукружия орнаментальной полосы или линии, заходящие своими концами на лопасти).

Прежде, чем перейти к описанию выделенных типов и хронологических стадий, необходимо сделать общие замечания относительно «логики» их эволюции и развития орнамента.

Видимо, еще в IX в. произошло разветвление линии развития лучевых колец на две группы/традиции (Шинаков, 1980. Рис. 2). Одна «ветка» (группа «А» по Е.А. Шинакову) сохраняла архаичную форму внутренних зубчиков (в виде треугольников, обращенных вверх), а концы лучей декорировались тремя шариками зерни. Эта линия развития завершилась в XI в. кольцами типа деснинские/сельцо. Вторая «ветка» (группа «В» по Е.А. Шинакову) отличалась тем, что концы внутренних зубчиков на кольцах стали украшаться шариками зерни. В результате форма внутренних зубчиков постепенно эволюционировала, и они превратились в продолговатые выступы, похожие на рожки на голове жирафа. Концы лучей этих колец украшались одним шариком зерни. Этот шарик, постепенно «расплывшись», превратил лучи в лопасти. Эта линия развития завершилась в XIII в. кольцами московского типа (рис. 203).

Таким образом, височные кольца типа деснинские/ сельцо являются «двоюродными», но не прямыми родственниками лучелопастным кольцам московского типа.

На лучевых кольцах X в. орнаментальными средствами передавалась исходная круглая форма основы кольца. Верхняя часть кольца - дужка - практически не менялась, а нижняя часть кольца имитировалась орнаментальными средствами. На щитке изображалась двойная дуга. Причем эти дуги могли быть как гладкими, так и выглядеть как сочетание гладкой и зерненной. Зерненная дуга переросла в заштрихованные полосы более поздних колец. Линия развития этого элемента орнамента - постепенный уход от формы исходной двойной дуги. Две ее составляющие постепенно «раздвигались» друг от друга. Вначале между дугами возник небольшой «просвет» (зачаточный щиток), затем дуги раздвинулись еще больше и образовали «молодой месяц». В процессе дальнейшего развития месяц рос и превратился в полукруг/сегмент (рис. 204).

На щитках лучевых колец X в. под двойными дугами имелись полукруглые фестоны. Эти полукруглые фестоны постепенно на лопастных кольцах преобразились в треугольные фестоны, а затем в «арочки».

На основании наблюдений над вышеописанными из- менениями орнамента, можно выделить несколько относительных хронологических стадий. «Привязки» этих стадий к календарной хронологии не вполне точны. В качестве реперов были приняты следующие факты: 1) совместное нахождение лучелопастных колец и колец типа деснинские/ сельцо в могильнике Шейки вместе с монетами второй половины XI в. (Равдина, 1988. С. 129); 2) находки развитых лопастных колец московского типа в культурном слое Великого Новгорода в ярусе, датированном 1197-1224 гг. (Седова, 1981. С. 4, 13); 3) предполагаемое прекращение производства височных колец во второй половине XIII в., возможно, в результате татаро-монгольского нашествия. Примерно равная длительность хронологических стадий, описанных далее, также является условностью. Однако в настоящее время более точные данные отсутствуют.

Хронологические стадии выделяются по следующим признакам (рис. 204).

Стадия 1. На щитке дугообразные линия и заштрихованная полоса (две полосы), расположенные вплотную или почти вплотную друг к другу, появляются треугольные фестоны. Датировка 1050-1080 гг. по набору вещей и монетам из могильника Шейка.

Стадия 2. Полосы (или линия и полоса) постепенно расходятся, между ними образуется пустое пространство щитка в виде «молодого месяца», треугольные фестоны становятся непременным атрибутом. Датировка 1080-1120 гг.

Стадия 3. Полосы раздвигаются еще больше, образуя пустое пространство щитка наподобие «зрелого месяца». Фестоны, как правило, треугольной формы и двойные. Появляются заштрихованные треугольные фестоны. Отдельные производители сохраняют архаичную традицию фестонов полукруглой формы. Датировка 1120-1150 гг.

Стадия 4. Верхняя заштрихованная полоса выпрямляется (как и спинка щитка), теперь две полосы образуют фигуру в виде сегмента (редко сохраняется форма месяца). Фестоны обычно штрихуются, появляются дополнительные линии-арочки, заходящие на лопасти. Датировка 11501190 гг. Появляются первые дополнительные орнаменты на щитках - «лоза».

Стадия 5. Заштрихованные полосы на щитке образуют фигуру в виде сегмента (редко сохраняется форма месяца), повсеместно распространены заштрихованные арочки. Развиваются элементы дополнительного орнамента на лопастях и щитке - «три-четыре точки», ромбы, свастики, «книжный узор», растительные мотивы. Имеется датировка по дендрошкале Новгорода 1197-1224 гг.

Стадия 6. Появляются различные новые элементы основного орнамента. Линия дополняет заштрихованные арочки, полоса идет каймой по лопасти, на щитке дополнительная заштрихованная полоса. Датировка 1220-1250 (?) гг.

Сравнение орнаментов, нанесенных на кольца разных хронологических стадий, показало, что можно выделить три «традиции» орнаментального оформления именно верхней части щитка (характер оформления верхнего участка щитка под зубчиками). Эти традиции оформления верхней части щитка «не реагируют», или почти не реагируют на время. Кольца трех традиций соблюдают общие закономерности 
эволюции формы (что означает наличие тесных контактов производителей разных традиций).

Нужно отметить, что есть кольца, у которых верхний ярус орнамента под зубчиками пропущен или почти не виден, как на некоторых ранних кольцах традиции 2. По публикациям об этом трудно судить, так как авторы иллюстраций могли допустить погрешность в рисунке.

Описание признаков орнаментальных традиций.

Традиция 1 - под зубчиками ломаная одинарная или двойная линия, следующая контуру зубчиков (рис. 204, 205). На ранних лучевых кольцах деснинского типа хорошо видно, что ломаная линия дублирует контур зубчиков. То есть эта традиция очень древняя, начало ее не позднее XI в., но лучелопастных колец этой традиции, относящихся к хронологической стадии 1, пока не найдено (древнейший пример традиции - лишь кольца деснинского типа). Традиция 2 - под зубчиками треугольные фестоны вершинами вверх, появляются не позднее последней четверти XI в. Традиция 3 - под зубчиками заштрихованная полоса, заходящая на них, появляется не позднее конца XI - начала XII в. на второй хронологической стадии развитии орнамента.

Традиция 1 условно названа «архаичной», наиболее ранним примером является кольцо из могильника Хотяжи, которое можно отнести по орнаменту к первой хронологической стадии. Орнамент традиции 1 встречен на кольцах ${ }^{10}$ развитых морфологических типов из курганов на Москвереке (Биостанция МГУ, Горышкино 1), памятников на p. Рожайке (Мещерское, Ивино), на верховьях Пахры (Конаково), а также на верхней Оке (Серенск, Бельково), Жиздре (Войлово), Угре (раскопки В.И. Сизова), правобережье Оки (Дятлово, Кривишино), в верховьях Упы (г. Болохово) и Дона (Бобрик-Гора, Устье 2, Исаковские выселки). Видимо, это какая-то особая группа (?) мастерских, которые пронесли почти без изменений через всю линию развития формы и орнаментации колец один архаичный признак, восходящий к XI в. В целом, география перечисленных выше находок указывает на южный регион. Вероятно, эти кольца где-то здесь производились. Трудно решить, где - на Рожайке, в Верхнем Поочье или на Верхнем Дону?

Традиция 2 (рис. 204) представлена кольцами, у которых в верхней части щитка под зубчиками были треугольные фестоны, обращенные вверх. Судя по форме, эти кольца происходят от лучелопастных. Встречены на городище Слободка на р. Навле (Никольская, 1987. Рис. 65, 10). Близкие по форме украшения найдены в верхнем Поочье, особенно в серной части этого региона (городище Акиньшино, Доброе, Слободка 2, Леоново, Кохановка, Старая Рязань). Кольца с родственным, но несколько более развитым орнаментом встречены в Верхнеокском регионе, в том числе особенно на р. Угре (Ступеньки, Желанье, Климово, Бочарово, Слевидово), проникают на север вплоть до Дмитровского p-на (Михайловское), Купанского (Переяславль-Залесский), Верхней Волги (Юрьевец, Бесково), на запад - до р. Десны под Новгород-Северским (Пушкари) и даже до Друсты возле г. Цесис в Латвии; несколько находок происходят из верх-

\footnotetext{
${ }^{10}$ Использованы данные картотеки, составленной Т.В. Равдиной.
}

него (Можайск, могильник Хотяжи), среднего (Саввинская слобода, Беседы, Одинцово 7) Москворечья, а также басс. Пахры (Стрелково). Крайняя западная находка - г. Смоленск. Серия находок обнаружена на Оке - это городище Тешилов, курганы Кременье и Доброе. Более развитые формы встречены в районе Звенигорода (Волково, Биостанция МГУ), на Истре (Аносино), Рожайке (Пузиково), в Косино, а также есть находки на верхней Оке и Угре (Пронск, Иваново-поле, Желанье); в верховьях Дона (Прудки 1, Устье 2, Голино 4).

Имеются примеры скрещивания традиции 2 и традиции 1 (пример - кольца из могильников Вишенки на Рузе, Горышкино 1 на Москве-реке). Это наиболее типологически поздние находки этой традиции (с орнаментальными арочками), относящиеся к началу хронологической стадии 5.

Как видим, находки этой традиции распространены широко. Скорее всего, кольца этой традиции связаны с мастерскими, находившимися среднем-верхнем течении Москвыреки. Может быть, были еще сходные мастерские где-то в районе басс. Пахры и на верхней Оке (на Угре?). На поздних стадиях развития колец, в конце XII в., производство мастерских этой традиции сильно сокращается (прекращается?). Видимо, традиция 2 прервалась где-то на рубеже стадий 4 и 5.

Третья традиция была наиболее продуктивной (рис. 204, 205). Особенность ее оформления - заштрихованная дуга, заходящая на зубчики, в верхней части щитка. Наиболее ранний пример - на кольце из курганного могильника Беседы, которое, видимо, датируется началом XII в. Этот элемент орнамента практически не изменялся на всем протяжении дальнейшего развития. Масса колец этой группы развитых форм встречена в бассейне верхней Клязьмы, по всему течению Москвы-реки, в бассейнах Пехорки и Пахры, на Рожайке, на Угре (Бочарово) и верхней Оке от Воротынска и Зарайска (Смедово, Дятлово) до Рязани (Борковский могильник) и Дону (Бобрик-Гора). Именно с этой линией развития (на развитом этапе) связаны знак «три-четыре точки» и книжный орнамент (рис. 205). Судя по наиболее ранней находке, мастерскую-родоначальницу можно условно локализовать в районе с. Беседы. Конечно, это лишь предварительное суждение, которое может быть пересмотрено.

Украшения третьей традиции являлись продукцией нескольких мастерских, расположенных в Москворечье. В этом убеждает то, что и геометрические, и растительные дополнительные орнаменты сочетаются с определяющим стилистическим признаком третьей традиции («заштрихованная полоса, заходящая на верхние зубчики»). В какой-то из мастерских «третьей традиции» долго сохранялся архаичный признак - полукруглые фестоны на лопастях (в сочетании с другими признаками, указывающими на третью хронологическую стадию, пример - Черемушки). В других мастерских этой традиции данный признак был давно изжит (еще на второй хронологической стадии).

На связи между производителями, носителями разных традиций, указывают единичные находки, совмещающие эти традиции на одном предмете. В качестве примера можно привести кольцо из группы Горышкино (рис. 204).

Для классификации орнаментов височных колец предлагается система номенклатуры (А-Б-В), состоящая из трех 
элементов: А) хронологическая стадия; Б) номер традиции; В) индивидуальные особенности типа.

Всего было выделено 26 единиц классификации. Этот список, вероятно, будет дополнен в будущем. Ниже дано описание типов в хронологическом порядке.

Тип 1-1-1. На щитке заштрихованная дугообразная полоса и над ней линия-дуга. Сверху под зубчиками ломаная линия, снизу полукруглые фестоны, вписанные в треугольные. Кольцо обнаружено в могильнике Хотяжи (Алексеев, 2004. Рис. 7, 10).

Тип 1-2-1. На щитке две дугообразных полосы, нижняя из них заштрихована, на верхнюю опираются треугольные фестоны, на нижней висят полукруглые фестоны, вписанные в треугольные фестоны. Найдены в Старой Рязани, Ступеньках (см.: Зайцева, Сарачева, 2011. Рис. 43, 4, 5).

Тип 1-2-2. На щитке две дугообразных заштрихованных полосы, на нижней висят треугольные не заштрихованные фестоны. В Москворечье найдены на селищах Хотяжи 2 и Заозерье, в Поочье и на Дону - Акиньшино, Слободка 2.

Тип 1-2-3. На щите одна полоса дугообразной формы, заштрихованная, фестоны сверху, опирающиеся на полосу (вероятно, тип возник как результат смешения типов 1 и 2). Известно 4 образца (Судаково и Битягово на Рожайке, СпасТушино, городище Мощины). Возможно, данный тип возни под воздействием колец типа Сельцо.

Тип 2-2-1. На щитке вверху дугообразная линия, на которую опираются треугольные фестоны, внизу щитка дугообразная заштрихованная полоса, отделенная от верхней дуги. На заштрихованной полосе висят двойные треугольные фестоны. В Москворечье - могильники Хотяжи, Биостанция, Одинцово 7, Беседы, Матвеевское, а также на Оке - Тешилов, Доброе, Кременье, Ступеньки (Юхнов), Ст. Рязань, Михайловское (Дмитровский р-н), Юрьевец (Ярославская обл.) и Бесково (Тверь).

Тип 2-3-1. На щитке сверху заштрихованная полоса, заходящая на зубчики, под ней не заштрихованная полоса, на которой висят треугольные незаштрихованные фестоны. Известно три находки (Беседы, Чернево, Чертаново).

Тип 3-1-1. Под зубчиками ломаная линия. Заштрихованные полосы образуют месяц. На нижней полосе висят треугольные фестоны. Серенск.

Тип 3-2-1. На щитке две заштрихованные дугообразные полосы, образующие месяц, фестоны только снизу. Хотяжи 2, Шишимрово, Зюзино.

Тип 3-2-2. На щитке две заштрихованные дугообразные полосы, образующие месяц, снизу - дополнительная линия, на которой висят двойные треугольные фестоны. Матвеевское.

Тип 3-3-1. Вверх - заштрихованная полоса, заходящая на зубчики, снизу с ней смыкается другая заштрихованная полоса. Обе полосы образуют месяц. Снизу - дополнительная линия, на которой висят треугольные незаштрихованные фестоны. Один из наиболее массовых типов. Не менее 49 пунктов находок. Хотяжи 1, Хотяжи 2, Обухово, Блошино (Ногинск), Салтыковка 2, Милеет (Пехорка), Рождествено, Чернево, Черемушки, Таганьково, Верхогрязье, Иславское, Николина Гора, Лопаткино (Рожайка), Одинцово 6,
Одинцово 2, Одинцово 7, Пузиково, Мякинино 1, Кутьино 1a, Новленское, Волхонка, Котляково, Зюзино, Матвеевское, Ст. Дарьино, Александровка (Рожайка), Фили, Боброво, Стрелково, Покров, Константиново (Рожайка), Михайловская слобода, Битягово, С-Знаменский скит, Спас-Тушино, Тушино, Чашниково, Льялово, Волково, Копки, Биостанция, Залесье (Гнилуша), Воскресенский посад (Северка), Ачкасово, Смедово, на Оке - Апоничищи (Зарайск), Полецкое, городище Акиньшино, Милославские, Окаемово, Пронск, Доброе, Чекалин.

Тип 3-3-2. В верхней части щитка заштрихованная полоса, заходящая на зубчики, внизу дугообразная незаштрихованная полоса, на которой висят треугольные незаштрихованные фестоны. Богородское на Десне.

Тип 3-3-3. Заштрихованные полосы образуют «зрелый месяц». Снизу дополнительная линия, на которой висят полукруглые фестоны, вписанные в треугольные. Черемушки (Бадер, 1947. Рис. 9).

Тип 4-1-1. Под зубчиками двойная ломаная линия, заштрихованные полосы образуют сегмент, внизу фестоныарочки не заштрихованы. Конаково (Пахра).

Тип 4-2-1. На щитке две заштрихованные полосы образуют сегмент, верхние треугольные фестоны заштрихованы, нижние двойные - нет. Устье 2, Голино 4 (Гоняный, 2005), Косино, Волково, Пузиково, Аносино, Беседы, Серенск, Косая Гора (Юхнов).

Тип 4-2-2. Под зубчиками фестоны, опирающиеся на незаштихованную полосу, образующую сегмент с нижней заштрихованной полосой, на последней висят треугольные заштрихованные фестоны. Биостанция, Новгород, Серенск, Акиньшино.

Тип 4-3-1. Заштрихованные полосы на щитке образуют месяц, на дополнительной линии снизу висят заштрихованные треугольные фестоны. Беседы, Милет, Одинцово 2, Александровка (Рожайка), Битягово, Шустино (Дмитровский р-н), Дятлово (Зарайск), Апоничищи (Зарайск).

Тип 4-3-2. Треугольные фестоны имеют форму, переходную к арочкам, висят не на дополнительной линии, а на заштрихованной полосе, дополнительная линия расположена выше полосы внутри «месяца» на щитке.

Тип 5-1-1. Под зубчиками двойная ломаная линия. На щитке заштрихованные полосы образуют сегмент, внизу заштрихованные арочки. Колесовка 5, Исаковские Выселки (Дон).

Тип 5-1-2. Под зубчиками двойная ломаная линия. Заштрихованные полосы образуют месяц, к нижней примыкают фестоны-арочки без штриховки. Исаковские выселки (Дон).

Тип 5-1-3. Под зубчиками двойная штрихованная ломаная линия. Полосы без штриховки образуют сегмент. К нижней полосе примыкают заштрихованные фестоныарочки. Горышкино 1, Вишенки.

Тип 5-3-1. Заштрихованная полоса заходит на зубчики, две заштрихованные полосы образуют сегмент. Внизу заштрихованные арочки, которые не смыкаются с полосой, расположенной выше. Один из наиболее распространенных типов, не менее 45 пунктов. Хотяжи, Устье 2 (Дон), 
Монастырщина 5 (Дон), Дубки (Орехово 2), Иславское, Чертаново, Беседы, Муромцево (Дмитровсий р-н), Войлово, Богдановка (Коломна), Палецкие, Бочарово (Угра), Воскресенский Посад (Северка), Тишково, Бессониха (Коломна), Воротынск, Балятино, Конаково, Константиново, Битягово, Одинцово 6, Останкино 2, Мещерское, Ивино, Серенск, Новгород, Кутьино 1а, Пузиково, Одинцово 7, Новлинское, Б. Саврасово 1, Ознобишино 5, Ст. Дарьино, Фили, Кремль, Зюзино, Таганьково 3, Кудрино (ст. Мамонтовская), Рождествено, Чернево, Волково, Копки, Чертаново, Коньково, Тропарево.

Тип 5-3-2. Под зубчиками заштрихованная полоса, заходящая на них, она же образует кайму с арочками по всему щитку. Кикина Протока, Семивраги.

Тип 6-1-1. Под зубчиками двойная ломаная линия, в центре щитка - «зрелый месяц» из заштрихованных полос, снизу - заштрихованные арочки и дополнительная линия. Бобрик-Гора (Дон), Донской, Дятлово (Зарайск), Войлово (Жиздра), Мещерское (Рожайка).

Тип 6-3-1. Щиток как у типа 5-3-1, но имеется еще дополнительная линия над заштрихованными арочками. Могила Бобрик-Гора (Дон), Вороново (Ярославль), ПереяславльРязанский, Апоничищи (Зарайск), Одинцово 6, Боброво, Косино, Крымское (Верея), Шмарово (Лихвин).

Тип 6-3-2. Заштрихованная полоса заходит на зубчики, усложненный тип с дополнительной заштрихованной полосой на щитке. Место неясно, дар Брокара (Сизов, 1895).

Картирование находок семилопастных колец, проведенное Т.В. Равдиной (Равдина, 1975; 1978), делает вероятным предположение, что именно бассейн Москвы-реки являлся основным местом, где вырабатывались новые типы, шло основное производство и сбыт украшений этой категории. Тесно связанными с Москворецким регионом были верхнее течение р. Клязьмы, а также северная часть верхнего Поочья от устья Упы до устья Москвы-реки, нижнее течение Угры. Новые находки лишь усиливают наблюдения, сделанные Т.В. Равдиной.

Единственная, но существенная поправка к выводам Т.В. Равдиной заключается в том, что производство семилопастных колец в Москворечье началось не на «пустом месте». Здесь ранее бытовали височные украшения родственного, но другого типа («деснинские»). Кроме того, становится ясно, что на правобережье Оки в Тульской области и в калужском течении Оки находки семилопастных колец типов 5 и 6 по Т.В. Равдиной, т.е. развитых второй половины XII-начала XIII в., не являются редкостью, свидетельствуя о тесных связях регионов.

В работе, посвященной семилопастным кольцам с дополнительной орнаментацией, Т.В. Равдина и Т.Н. Макарова сделали очень важное наблюдение. По предположению исследовательниц, существовали, по крайней мере, две группы мастерских по изготовлению височных колец, в конце XIIначале XIII в. они располагались где-то на правом берегу Москвы-реки (Макарова, Равдина, 1992. С. 81). Продукция этих мастерских различалась по стилистическим особенностям «дополнительной» орнаментации на лопастях и щитках колец.
Новые исследования (Зайцева, Сарычева, 2011. С. 177) внесли не так много добавлений в список находок колец с дополнительной орнаментацией, составленный Т.В. Равдиной и Т.Н. Макаровой. Укажем находку из Борисовских курганов в Москве (раскопки 1961 г. Н.Л. Подвигиной), где на лопасти был гравирован ромб с косым крестом в центре и три точки на щитке. Это кольцо очень близко кольцу из курганов в Чертаново (Макарова, Равдина, 1992. Рис. 5, 1). А. Фатьков при доисследовании в 2015-2016 гг. курганов в Таганьково (Дарьино-1) обнаружил лопасть кольца с книжным орнаментом и косым крестом ${ }^{11}$.

Орнамент - «три/четыре точки» есть на кольцах из 21 пункта. Это курганы возле д. Чертаново, с. Косино, Мякинино (раскопки А.В. Энговатовой, 2005 г.), курган у д. Ащерино (раскопки 1996 г.), Одинцово 7 и с. Беседы (в публикации В.В. Енукова эта особенность не отражена) у границ Москвы. Курганные группы в районе Звенигорода: Таганьково, Горышкино 1 (колл. Звенигородского музея), Волково, Саввинская слобода, селище Таганьково. Этот же орнамент на кольцах из курганов у с. Рождествено на р. Истре, Черневе на р. Баньке, Захряпино на р. Рузе (Розенфельдт РЛ., 1964), Красково Владимирской обл. (картотека Т.В. Равдиной), д. Кривишино (р. Осетр). Кольцо с «тремя точками» было обнаружено в курганном могильнике Хотяжи (Алексеев, 2004. Рис. 7, 16) в верховьях Москвы-реки, а другое - в низовьях Москвы-реки возле д. Ворыпаевки (Мазуров, 1999). Еще одно кольцо с теми же «тремя точками» над лопастями (подзорчатыми) было обнаружено Б.В. Грудинкиным в 1995 г (Грудинкин, 1995) на селище Чекалин 2 (левый берег Оки выше устья Жизды) ${ }^{12}$.

Кольца с дополнительной растительной орнаментацией были обнаружены в верховьях Дона на Куликовом поле. Это селища Голино-4, Колесовка 5, Устье 2, Устье 3 (Гоняный, 2005; Гоняныц̆, 2014), селище Десна 3 в Подмосковье (Прошкин, 2014).

Таким образом, общее число пунктов находок височных колец с дополнительной орнаментацией достигло 64 (Т.Н. Макаровой и Т.В. Равдиной было известно 48).

Локализация мастерской, изготавливавщей кольца c «книжным» орнаментом. В комплексе с книжным орнаментом на лопастях встречаются различные геометрические композиции (ромбы с крестами, свастики и пр.), а также «три-четыре точки» над лопастями. Компактная группа таких находок находится на юге современной Москвы (Фили, Матвеевское), особенно в бассейнах рек Язвенка - низовьях р. Чертановки и Городни (курганные группы Орехово 2, Зюзино, Волхонка, Борисово, Чертаново, Ащерино, Беседы). Наиболее показателен и однозначно узнаваем «книжный» орнамент. Одно такое кольцо, не известное Т.В. Равдиной и Т.Н. Макаровой, было найдено в могильнике Горышкино 1 (колл. Звенигородского музея), другое было обнаружено недавно в Таганьково.

Можно предположить несколько вариантов относи-

\footnotetext{
${ }_{11}^{11}$ Автор благодарен А. Фатькову за предоставленную информацию. ${ }^{12}$ Автор благодарит О.Л. Прошкина, М.И. Гоняного, О.Н. Заидова, Н.Е. Чалых, С.С. Ширинского и А.В. Лазукина за предоставленные сведения.
} 
тельно того, где располагалось селище, где велось производство. Во-первых, можно предположить, что оно находилось в низовьях р. Чертановки и не сохранилось до наших дней, либо возле курганной группы Беседы на Москве-реке. Именно в Беседах было найдено наиболее раннее кольцо «третьей традиции» (см. выше), к которой относятся кольца с книжным орнаментом на лопасти и «тремя точками». Вовторых, нельзя полностью исключать того, что производство могло размещаться на селище Мякинино 1. Аргументы «за» Мякинино 1 - наличие следов ювелирного производства на поселении (Зайцеева, Сарачева, 2011. С. 73-75), находка кольца с дополнительным орнаментом «три точки» в одном из мякининских курганов (раскопки А.В. Энговатовой). Аргументы «против» - отсутствие каких-либо следов производства на селище Мякинино 1 именно височных колец, единичность находки в курганном могильнике, отсутствие находок в Мякинино серег с «книжным орнаментом». Наконец, район Звенигорода также перспективен для поисков. Именно в этом районе в курганных группах Иславское, Горышкино, Таганьково, Волково, Саввинская слобода найдены кольца с дополнительным орнаментом.

Ареал распространения продукции этой мастерской весьма велик - это, в первую очередь, окрестности Москвы, но и верхнее Москворечье, p. Руза, р. Истра, р. Рожайка (Константиново) и даже отдаленные территории на Оке от устья Упы до низовий Осетра. На востоке - до ЮрьевПольского р-на Владимирской области (Красково). На северо-западе - до Великого Новгорода.

Сложнее решить, где располагались мастерские, производившие височные кольца с дополнительным растительным орнаментом. Серия очень близких и сложных по орнаментике колец происходит из четырех пунктов - Успенского, Орехово 1, Прудищ, г. Вязьмы (Равдина, Макарова, 1992. Рис. 7, 8; Арцииховский, 1947. Рис. 3). Трудно локализовать эту мастерскую точнее, чем «правобережье среднего течения Москвы-реки». Нужно отметить, что кольца с дополнительным растительным орнаментом имеют основной орнамент, относящийся к «третьей традиции» (см. ниже), такой же как и на условно выделенной мастерской, наносившей дополнительный «книжный» орнамент. Более того, в курганах Захряпино на р. Рузе и в Таганьково на р. Слезне встречены кольца с растительным орнаментом и «тремя точками». Это дает основание думать, что и кольца с растительным орнаментом и с «книжным» производились в близких, тесно связанных между собой мастерских. При этом, как уже отмечалось выше, пространственный «разнос» их продукции был велик.

Еще один пример дальних связей: кольца из Захряпино на р. Рузе и Никольского на Клязьме с вычурным растительным орнаментом (Макарова, Равдина, 1992. Рис. 7, 3; Розенфельдт, 1964. Рис. 42, 1), вероятно, были сделаны одним мастером, однако, расстояние между находками около 70 км (60-100 км от предполагаемого места производства на правобережье р. Москвы).

Кольца с орнаментом на щитке в виде «бегущей лозы». Этот орнамент легко «узнаваем» и поэтому привлекает внимание. В Москворечье орнамент встречен в одном пункте - на височном кольце из курганной группы на Биостанции МГУ (Макарова, Равдина, 1992. Рис. 6), расположенной на правом берегу Москвы-реки в 10 км выше Звенигорода. Кольцо очень близкое, возможно, сделанное в той же форме (Макарова, Равдина, 1992. С. 76), было найдено в курганах Разсохи на правом берегу Оки в низовьях р. Осетр. В низовьях Осетра располагаются и курганы Кривишино, где также найдено кольцо с лозой на щитке (Зайцева, Сарачева, 2011. Рис. 87). Серия обломков колец с «бегущей лозой» на щитке были обнаружены в компактном регионе верхнего Подонья на селищах Колесовка 5, Устье 2, Устье 3 возле крепости Дубок и выше по течению Дона на селище Голино 4 (Гоняный, 2005. Рис. 42, 12).

Изделия с дополнительным орнаментом «лоза» на щитке относятся к трем разным традициям основного орнамента. Видимо, в верхнедонском регионе происходило смешение традиций. Это наблюдение хорошо соответствует представлениям о том, что верховья Дона были колонизованы населением, пришедшим туда в конце XII в. (Гоняныци, 2005).

На мой взгляд, логично предполагать, что, мастерская, производившая кольца с дополнительным орнаментом «бегущая лоза», изначально находилась где-то в Москворечье, возможно, в районе Волково - Луцино.

Обнаружение москворецкой продукции на Куликовом поле на удалении 300 км к югу очень показательно. Мы видим масштабы расстояний, на которые перемещались украшения (и мастера?).

\section{Культурное и этническое развитие населения Москворечья в X-начале XIII века}

1) B IX-первой половине XI в. формируется сеть торговых путей по Москве-реке и транзитные маршруты из бассейна средней Оки на Верхнюю Волгу и появляются (в Х в.?) первые очаги заселенности, связанные с ними. 2) Во второй половине XI в. долина среднего течения Москвыреки и долина ее правого притока р. Пахры (нижнее течение) были колонизованы населением, видимо, пришедшим сюда с юга, из-за Оки. Отдаленной исходной точкой колонизационного движения, возможно, являлся северянско-радимический ареал. Путь проникновения колонистов в Московоречье не вполне ясен, возможно, они двигались вверх по Москве-реке. Но нельзя исключить и «прямую» дорогу по долине р. Рожайки и затем на Пахру. Численность этого населения равнялась 2-3 тысячам человек, эта группа подразделялась на довольно крупные коллективы, не менее нескольких десятков человек в каждом. В этой группе активно репродуцировался специфический тип височных украшений - кольца «деснинского типа». Колонисты «первой волны» столкнулись на Москвереке с почти нетронутой дикой природой. На это указывает очень высокий процент (до 45 \% - Юшко, 1998; 31 \% на Хотяжах, по Н.В. Сердюк) охотничьей добычи в списках фауны из ранних поселений. На городищах железного века доля диких животных в составе остеологических коллекций была существенно меньше. 3) В начале XII в. в ре- 
гион проникает новое население с иной социальной структурой и иной поселенческо-хозяйственной стратегией, иными традициями керамического производства (привыкшее делать горшки из беложгущихся глин, сырьевые ресурсы которых имеются на правобережье р. Оки, не употреблявшее в быту горшков-котлов, а использовавшее горшки малых форм). Эта вторая волна колонистов, видимо, также пришедших с юга, стремительно расселилась по малым притокам Москвы-реки и притокам ее притоков. При выборе мест для поселений учитывался такой фактор, как наличие следов предшествующего освоения данного места. Склоны долин малых притоков интенсивно распахивались, постепенно зоны освоения поднимались вверх по склонам к водораздельным гребням. Показательно, что в составе остеологических коллекций резко снижается (или исчезает совсем) доля костей диких животных (Археология Романова двора, 2009. С. 217).

Колонисты «второй волны», так же, как и колонисты «первой волны», имели сходный с ними женский убор, обязательной принадлежностью которого было наличие специфических височных украшений, что для территории Древней Руси начала XII в. было уже архаизмом. Ремесленники, относившиеся ко «второй волне», развивали линию лучелопастных височных серег, успешно генерировали новые формы и орнаменты, что делало москворецкий регион уникальным сравнительно со всеми соседними сельскими территориями. Примерно 50 лет это развитие продолжалось совершенно свободно. В 1156 г. (если верить Тверской летописи) появился княжеский город Москва, а затем Коломна.

А.В. Григорьев высказал очень интересную мысль, что рост производства традиционных лучевых височных колец на территории Поочья в конце X в. мог быть «ответом» на давление Руси (Григорьев, 2010. С. 226). Возможно, нечто подобное происходило в середине XII в. в Москворечье, когда здесь появился княжеский город. Видимо, в это время здесь происходил процесс «этнической консолидации». Продолжался рост населения, ширилось «окультуривание» ландшафта малых долин, эволюционно развивались типы украшений. При этом наблюдается явление, очень характерное для начальных периодов контакта «аборигенов» и внешнего рынка. Аборигенам «навязывается» мода носить крупные украшения, требовавшие много металла. Взамен они вынуждены отдавать много своей местной продукции, охотничьей добычи. Именно эти явления мы видим в XIIIXV вв. в Пруссии, в XVIII-XIX вв. на севере Западной Сибири и в Северной Америке и т.д. Украшения жителей Подмосковья, начиная с середины XII в., стремительно растут в размерах. Видимо, жители региона обладали достаточными ресурсами для покупки дорогого металла. На этом этапе начинается активная «экспансия» продукции ремесленников, проживавших на подмосковных селищах (а может быть, и формирование новых ремесленных центров), на юг, в бассейн Угры, на правобережье Оки. Вероятно, контакты с этим регионом были интенсивными в течение всего XIIначала XIII в. как с исходной территорией колонизации, сырьевой базой керамического производства.

Набор украшений жителей москворецкого региона ни в коем случае нельзя трактовать как «украшения вятичей», в чем я полностью согласен с Т.В. Равдиной. Такая трактовка является избыточно упрощенной и противоречит географии и хронологии археологических находок и летописных упоминаний вятичей. В XII-XIII вв. Москворечье выступает как регион, где происходило интенсивное развитие набора украшений. В том числе развитие форм наиболее яркого украшения всего набора - семилопастных колец. Генерирование новых типов вещей происходило в мастерских, локализованных в пределах бассейна Москвы-реки. Здесь же продукция находила наиболее массовый спрос.

Видимо, формирование набора украшений косвенным образом отражало процесс новой этнической консолидации, возникновение новой этнической группы. К вятичам $\mathrm{X}$-XI вв. этот процесс прямого отношения не имел, хотя, вероятно, глубокие генеалогические корни москворецкого населения и восходили (частично ?) к вятичам. Для обозначения семилопастных колец целесообразно вернуться к более «этнически нейтральной» и корректной терминологии, предложенной В.И. Сизовым - «височные кольца московского типа».

При этнической характеристике москворецкого населения надо опираться на летописные свидетельства не XI в., а XII-XIII вв. Их, как уже упоминалось, два - 1175 и 1238 гг. (Кучкин, 1996): «Москьвляни же слышавше, оже на нъ Ярополкъ, и възвратившися въспять блюдуче домов своихъ» (1175) «Москвичи же побьгоша, ничего же не видъвше» (1238).

Летописные обозначения «московляне»/«москвичи» можно с уверенностью считать этнонимом. Все признаки показывают, что на Москве-реке в XII XIII вв. «кристаллизовалось» новое этническое образование, которое, хоть и имело какие-то вятические корни, но отнюдь не может быть сведено к ним.

\section{ТРАНСФОРМАЦИЯ КУЛЬТУРЫ ВО ВТОРОЙ ПОЛОВИНЕ \\ XIII ВЕКА ПОСЛЕ ТАТАРО-МОНГОЛЬСКОГО НАШЕСТВИЯ} 1238 ГОДА

Исчезновение курганного обряда приблизительно в середине XIII в. и смена его на христианский, в значительной степени сделало археологов «слепыми», лишив важнейших «подсказок». Судить о культуре населения Подмосковья второй половины XIII в. можно, главным образом, по результатам изучения поселений. Среди наиболее крупных раскопок памятников этого времени следует перечислить исследования селища Назарово-2 (2012 г., Н.А. Кренке) на p. Прорванихе в бассейне р. Воря и селища Ознобишино-5 на р. Моче (Шполянский, 2003), селища Царицыно 2 на р. Язвенке (Нефёдов, Кренке, 2012). Поселение этого времени было изучено на городище Настасьино на р. Северке (Коваль, 2004). Постройка середины ХІІІ в. (сруб 1) была раскопана в Историческом проезде на Красной площади в Москве (Чернов, 1991). На изменения в системе расселения указывают данные разведок, проведенных в бассейнах р. Вори и Пехорки С.3. Черновым (Чернов, 2003; 2004); в бассейне Пахры - М.И. Гоняным. На Москве-реке также 
проводились разведочные работы Звенигородской экспедицией ИА РАН, выявившей памятники ХІІІ в., в том числе на территории биостанции МГУ возле Луцино.

При раскопках селищ Назарово 2 и Царицыно 2 была получена компактная серия радиоуглеродных датировок, указывающих именно на вторую половину XIII в. (см. каталог радиоуглеродных датировок, приложение II). Таким образом, вещевые и керамические комплексы этих поселений могут рассматриваться в качестве реперных.

Рассмотрим вначале некоторые особенности расположения поселений, датирующихся серединой-второй половиной XIII в. по микрорегионам.

В бассейне р. Вори С.3. Чернов описывает «разрыв преемственности в развитии сельскохозяйственной инфраструктуры» (Чернов, 2003. С. 219). Он описывает ситуации, когда старые места домонгольских поселений оказались заброшенными, а новые поселения, возникшие во второй половине XIII в., располагались в непосредственной близости, иногда на другой стороне оврага. На мой взгляд, говорить об отсутствии преемственности в данном случае надо с большой осторожностью. Ведь смещение поселения на первые сотни метров от брошенного жилья может указывать на наличие определенной преемственности. Люди видели старое место жилья, но решили его избегать и построились рядом. В таком поведении можно увидеть преемственность. C.3. Чернов также отмечает, что во второй половине XIII в. продолжился процесс освоения мелких притоков Вори Талицы и Прорванихи. С этим можно полностью согласиться. Поселение Назарово 2, выявленное отрядом под руководством С.3. Чернова и затем раскопанное нами в 2012 г., является ярким примером. Поселение было основано на совершенно новом месте выше по течению Прорванихи, в километре от участка, где располагались курганы XII-XIII вв. (рис. 214). Существенных изменений в топографической приуроченности поселений не произошло. Лишь некоторые поднялись чуть выше по рельефу сравнительно с домонгольскими селищами. Многие поселения второй половины XIII в. по-прежнему тяготеют к бровкам берега.

В бассейне верхней Пехорки наблюдалась преемственность поселенческой структуры (Чернов, 2003; 2004).

В бассейне р. Пахры, на ее правых притоках, например, таких как р. Моча, во второй половине ХІІІ в. появились многочисленные новые селища (Шполянский, 2003). Ситуация здесь напоминает ту, что мы видим на правобережье возле города Москвы на столетие раньше. Мелкие притоки осваиваются людьми до самых истоков.

Удивительная плотность поселений была выявлена по правому борту долины Москвы-реки выше г. Звенигорода. На участке протяженностью в 2 км по кромке первой террасы и в пойме в пределах территории Биостанции МГУ и дачного поселка Луцино было зафиксировано 5 селищ с материалом XIII в. (рис. 206-213). В том числе одно из этих поселений являлось кузнечно-металлургическим центром (ЗБС-7), судя по многочисленным находкам шлаков. При этом нужно отметить, что поселений ХІІ в. здесь отмечено не было.

Таким образом, во второй половине XIII в. наблюдается процесс развития поселенческой структуры, существо- вавшей ранее, а также происходил «новый виток» освоения долины главной речной магистрали региона.

Рассмотрим подробнее, что представляли собой эти новые поселения, на примере двух памятников - селищ Назарово 2 и Ознобишино 5, раскопанных практически целиком.

Несмотря на некоторые различия в топографической ситуации, обусловленные тем, что долина р. Мочи, на правом берегу которой находится селище Ознобишино 5, проработана лучше, чем долина р. Прорванихи, можно отметить и значительное сходство. В обоих случаях поселения находились на высоте 3-5 м над уровнем реки и на удалении около 100 м от ее русла. Планы обоих поселений обнаруживают разительное сходство. На возвышенном участке находились жилые постройки и примыкавший к ним «двор», фиксируемые по многочисленным столбовым ямам (рис. 215). С жилыми постройками связана основная масса находок вещей и керамики. От основной жилой постройки сохранились подпечная яма и округлый погреб. Возможно, что в Назарово 2 было два жилых дома, стоявших рядом. Синхронность этих построек, в частности, устанавливается по наличию склеек фрагментов горшков, происходящих из разных ям. С.В. Шполянский предложил интерпретировать селище Ознобишино 5 как однодворное поселение, в котором, кроме основных жилых построек, были еще легкие летние сооружения с печами (Шполянский, 2003). Такая интерпретация представляется очень вероятной. В Назарово 2 было два (а может быть, и три) двора. На обоих селищах имеются серии ям, которые выстроились вдоль реки ниже по склону от основных жилых построек. Скорее всего, это некие хозяйственные сооружения. Расстояние до них от основных жилых построек - от 10 до 30 м. Сходство керамики и идентичность радиоуглеродных дат, полученных в Назарово 2 (табл. 26), указывают на одновременность всех сооружений.

Очень показательны вещевые наборы. Изделий из железа относительно немного - серии ножей, удила, овальное кресало. На обоих памятниках найдено по стреле. Обе стрелы монгольского времени. В Назарово 2 - это обломок срезня (узкая лопаточка), в Ознобишино 5 - «кунжутолистный» наконечник. Бронзовые украшения представлены обломками изделий «прошлой эпохи». Это фрагменты семилопастных височных колец, плетеные браслеты, пластинчатые перстни. Встреченные в мусорном завале подпола обломки этих украшений конца XII - начала XIII в. явно не характеризуют набор, который носили женщины из Назарово 2. Скорее, это некие «семейные реликвии», ставшие не очень нужными. Примечателен в этом отношении комплекс находок из одновременного селища ЗБС-7 на Москве-реке. Здесь в яме постройки были встречены обломанные лопасти от височного семилопастного кольца и щиток кольца, переделанный в обойму рукояти ножа (рис. 208). Примечательно также почти обязательное присутствие в комплексах нательных христианских крестиков. По-видимому, бронзовые украшения оказались тем сегментом культуры, который претерпел резкие изменения. Дефицитное сырье шло на производство предметов 
христианской пластики и утвари. Новых типов украшений в рядовой крестьянской семье мы не видим. С другой стороны, появляется такая существенная новация, как железная и чугунная посуда. В Назарово 2 была найдена сковорода и фрагмент котла. Если сковороды встречаются в древнерусских памятниках, то котлы - нет. Эта категория находок характерна для русских памятников центрального региона именно ордынского времени, что стало ясно после раскопок на Куликовом поле (Гоняныцй, 2005. Рис. 43).

Существенны трансформации керамического комплекса. Как отмечалось выше, совершенно «выпадает» керамика, изготовленная из белой глины. Формы горшков переживают эволюционное развитие. Горшки с эсовидным профилем венчика постепенно переродились в горшки со слегка наклонными наружу либо почти прямыми венчиками, черновой край которых заглажен и «прижат». Горшки с венчиками-раструбами, которые ранее составляли совершенно обособленную группу, на новой стадии развития сближаются с горшками, производными от эсовидных (рис. 219). Их венчики почти прямые или чуть наклонные наружу. Край формировался с помощью усилия, направленного от мастера вниз и наружу, в результате чего образовывались специфические «наплывы» и загибы на торцах венчиков. В орнаментации диагностическое значение имеет распространение одинарной волны, часто заходившей на шейку горшка. Характерны также косые насечки, которых практически не было раньше. Сохраняется орнаментация горизонтальными линиями. Примером уникальной системы орнаментации является горшок из селища Царицыно 2 (рис. 194). Его тулово разделено на зоны горизонтальными линиями и многорядными волнами. Поверх наложены вертикальные полосы многорядной волны, делящие горшок на четыре части.

Важно отметить, что многие из поселений второй половины XIII в. исчезают на рубеже XIII-XIV вв. Так произошло с селищами Назарово 2, Ознобишино 5, ЗБС-7 и др. Видимо, именно с первой половиной XIV в. связана новая трансформация системы расселения, выход поселений на водоразделы. Рассмотрение этого процесса выходит уже за рамки данной работы.
Выводы

Составлена карта всех известных на сегодняшний день древнерусских памятников бассейна Москвы-реки, насчитывающая 1268 объектов.

Анализ этой карты в целом и ключевых участков, а также особенностей набора археологических находок позволил установить этапы и особенности освоения региона славянским населением. Предложена следующая последовательность. Древнейшие проникновения и установление торговых путей относятся к IX-X вв. В XI в. произошла массовая колонизация долины Москвы-реки славянским культурно однородным населением. В начале XII в. происходит проникновение в регион второй волны колонизации. Это население по ряду культурных признаков (поселенческо-хозяйственная стратегия, украшения, керамика) отличалось от первопоселенцев и освоило большинство мелких притоков, входящих в бассейн Москвы-реки. В конце XII-начале XIII в. наблюдается активизация контактов москворецкого региона с соседними южными областями (правобережье Оки, бассейны Угры и Жиздры). Вектор этих контактов был преимущественно ориентирован с севера на юг. В середине XIII в., после шока, пережитого в результате татаро-монгольского нашествия, москворецкий регион возрождается быстрыми темпами, растет число поселений, продолжается освоение долин малых рек, не вовлеченных в систему расселения на предыдущем этапе. В материальной культуре прослеживаются существенные изменения, связанные с утратой устоявшихся контактов, сменой культурных ориентиров и приоритетов. С другой стороны, совершенно отчетливо проявляется преемственность, позволяющая утверждать, что освоение региона продолжалось тем же населением, которое проживало здесь ранее.

Проведенное изучение ключевых участков региона с привлечением методик естественно-научных исследований позволило получить данные о системе организации землепользования в XII-XIII вв., особенностях взаиморасположения поселений, хозяйственных угодий, могильников. Сделать подсчеты численности населения микрорегионов и всего изучаемого региона в целом.

Таблица 20. Радиоуглеродные даты по селищу Хотяжи 1 (ямы с лепной керамикой славянского типа)

\begin{tabular}{|l|l|l|l|}
\hline Лабораторный номер & Дата & Калиброванная дата & Место отбора образца \\
\hline гИН 15001 & $1080 \pm 30$ & $950-1000$ гг. н.э. (45,9 \%) & $\begin{array}{l}\text { Хотяжи 1, 2013 г. } \\
\text { Раскоп 3, яма 58 }\end{array}$ \\
\hline гИН 15002 & $1280 \pm 50$ & $\begin{array}{l}670-780(68,2 \text { \%) гг. н.э. } \\
650-890(95,4 \text { \%) гг. н.э. }\end{array}$ & $\begin{array}{l}\text { Хотяжи 1, 2013 г. } \\
\text { Раскоп 3, участок 2, яма 51 }\end{array}$ \\
\hline
\end{tabular}

Таблица 21. Радиоуглеродные даты постройки 3 на селище Саввинская слобода 2 (по: Станюкович, Сулержицкий, 2003)

\begin{tabular}{|l|l|l|l|}
\hline Лабораторный номер & Дата & Калиброванная дата & Место отбора образца \\
\hline ГИН-9655 & $1250 \pm 70$ & $680-870$ гг. н.э. $(68,2 \%)$ & Саввинская слобода 2, постройка 3, зачистка дна \\
\hline ГИН-9656 & $1240 \pm 90$ & $680-890$ гг. н.э. $(68,2 \%)$ & Саввинская слобода 2, постройка 3 развал печи \\
\hline ГИН-9657 & $1100 \pm 80$ & $870-1030$ гг. н.э. $(63,8 \%)$ & Саввинская слобода 2, постройка 3, подпечная яма \\
\hline
\end{tabular}


Таблица 22. Размерно-топографические характеристики поселений и связанных с ними курганных могильников в долине р. Язвенки

\begin{tabular}{|c|c|c|c|c|c|c|}
\hline Поселение & $\begin{array}{l}\text { Расстояние до реки /высота } \\
\text { над водой / высота БСВ }\end{array}$ & $\begin{array}{l}\text { Размеры } \\
\text { поселения (кв. м) }\end{array}$ & $\begin{array}{l}\text { Расстояние } \\
\text { до могильника }\end{array}$ & $\begin{array}{l}\text { Курганный } \\
\text { могильник }\end{array}$ & $\begin{array}{l}\text { Число } \\
\text { курганов }\end{array}$ & \begin{tabular}{|l} 
Высота \\
в БСВ
\end{tabular} \\
\hline Борисово 1 & $\begin{array}{l}100 \mathrm{~m} \\
127-129 \mathrm{~m}\end{array}$ & 900 & $?$ & & & \\
\hline$?$ & & & & Шипилово 2 & $5(?)$ & \\
\hline Царицыно 3 & \begin{tabular}{|l|}
$80-100 ~ м$ \\
$21-23 ~ м$ \\
$153-157$ м
\end{tabular} & 2400 & $\begin{array}{l}150 \mathrm{~m} \\
90 \mathrm{~m}\end{array}$ & $\begin{array}{l}\text { Царицыно } 1 \\
\text { Царицыно } 2\end{array}$ & $\begin{array}{l}5 \\
23\end{array}$ & $\begin{array}{l}149-150 \mathrm{~m} \\
164-165 \mathrm{~m}\end{array}$ \\
\hline Царицыно 4 & \begin{tabular}{|l|}
$80-110 \mathrm{~m}$ \\
$12-14 \mathrm{M}$ \\
$146-148 \mathrm{~m}$
\end{tabular} & 900 & $100 \mathrm{~m}$ & Царицыно 3 & 13 & $155-157 \mathrm{M}$ \\
\hline Орехово 3 & \begin{tabular}{|l}
$70 \mathrm{M}$ \\
$5-8 \mathrm{~m}$ \\
$142-145 \mathrm{~m}$
\end{tabular} & 5000 & 200 & Орехово 6 & $4^{1}$ & $163 \mathrm{M}$ \\
\hline Орехово 4 & \begin{tabular}{|l}
$10 \mathrm{M}$ \\
$3-5 \mathrm{~m}$ \\
$143-145 \mathrm{~m}$
\end{tabular} & 2500 & 280 & Орехово 5 & 28 & $167-171 \mathrm{M}$ \\
\hline Орехово 5 & \begin{tabular}{|l}
$40 \mathrm{~m}$ \\
$1-5 \mathrm{~m}$ \\
$141-145 \mathrm{~m}$ \\
\end{tabular} & 2700 & 300 & Орехово 4 & 12 & $169-171 \mathrm{M}$ \\
\hline Орехово 6 & \begin{tabular}{|l}
$40 \mathrm{M}$ \\
$3-5 \mathrm{~m}$ \\
$14-149 \mathrm{M}$ \\
\end{tabular} & 1800 & 400 & Орехово 2 & 14 & $166-170 \mathrm{M}$ \\
\hline
\end{tabular}

${ }^{1}$ Количество курганов в данной группе не особенно достоверно. Группа находится под забором радиостанции, вероятно, часть курганов уничтожена.

\section{Таблица 23. Данные о курганах в долинах малых рек на юго-западе Москвы}

\begin{tabular}{|l|l|l|l|}
\hline Название реки & $\begin{array}{l}\text { Число курганных } \\
\text { групп }\end{array}$ & $\begin{array}{l}\text { Общее число } \\
\text { курганов }\end{array}$ & $\begin{array}{l}\text { Число курганов } \\
\text { в наиболее крупной группе }\end{array}$ \\
\hline Раменка, Смородинка, нижнее течение Очаковки & 20 & $99(139)$ & $26(40)^{2}$ \\
\hline Верховья Очаковки & 9 & 80 & 23 \\
\hline Котловка и Коршуниха & 15 & 91 & 22 \\
\hline Чертановка & 23 & 90 & 11 \\
\hline
\end{tabular}

${ }^{2}$ Разночтения обусловлены тем, признавать ли курганами значки на карте 1838 г. в районе Гладышева.

Таблица 24. Топографические особенности древнерусских селищ на юго-западе Москвы

\begin{tabular}{|l|l|l|l|}
\hline Номер на карте & Название селища & Расстояние от русла реки & Высота над водой \\
\hline & Матвеевское 1 & 50 & $9-16$ \\
\hline & Матвеевское 2 & $5-90$ & $2-7$ \\
\hline & Раменки 1 & 50 & $5-10$ \\
\hline & Раменки 2 & $60-80$ & $2-4$ \\
\hline & Раменки 3 & $30-40$ & $5-7$ \\
\hline
\end{tabular}


Продолжение табл. 24

\begin{tabular}{|l|l|l|l|}
\hline Номер на карте & Название селища & Расстояние от русла реки & Высота над водой \\
\hline & Раменки 4 & $40-50$ & $2-7$ \\
\hline & Раменки 5 & 15 & $5-6$ \\
\hline & Теплый стан 3 & 25 & $7-13$ \\
\hline & Теплый стан 1 & 50 & $7-9$ \\
\hline & Теплый стан 2 & 30 & $4-8$ \\
\hline & Коньково 2 & $30-60$ & $4-8$ \\
\hline & Коньково-1 & $20-60$ & $5-7$ \\
\hline & Зюзино 3 & $30-50$ & $18-20$ \\
\hline & Дубинкин лес 3 & 50 & $13-15$ \\
\hline & Чертаново 1 & 20 & $8-10$ \\
\hline
\end{tabular}

Таблица 25. Древнерусские памятники XI-XIII вв. по течению р. Самынки

\begin{tabular}{|c|c|c|c|c|c|c|}
\hline Поселение & $\begin{array}{l}\text { Расстояние до реки / } \\
\text { высота над водой / } \\
\text { высота БСВ }\end{array}$ & $\begin{array}{l}\text { Размеры } \\
\text { поселения } \\
\text { (кв. м) }\end{array}$ & $\begin{array}{l}\text { Расстояние до } \\
\text { могильника }\end{array}$ & $\begin{array}{l}\text { Курганный } \\
\text { могильник }\end{array}$ & \begin{tabular}{|l|} 
Число \\
курганов / \\
возраст, по: \\
Равдина, 1989
\end{tabular} & $\begin{array}{l}\text { Расстояние до } \\
\text { реки / высота в } \\
\text { БСВ }\end{array}$ \\
\hline & & & & Одинцово 12 & 1 & \\
\hline & & & & $\begin{array}{l}\text { Подушкинское } \\
\text { лесничество }\end{array}$ & 2 & $150 / 160$ \\
\hline & & & & Одинцово 5 & $\begin{array}{l}\text { 8/XII в., } \\
\text { не начало }\end{array}$ & $400 / 175$ \\
\hline \multirow[t]{3}{*}{ Одинцово 3} & $100 / 11 / 157$ & 4200 & 300 & Одинцово 3 & 14/середина XII в. & $450 / 183$ \\
\hline & & & 280 & Одинцово 18 & 2 & $430 / 180$ \\
\hline & & & & Одинцово 2 & 9/середина XII в. & $250 / 195$ \\
\hline Одинцово 6 & 120/14-17/164-166 & ок. 4000 & примыкает & Одинцово 6 & $\begin{array}{l}\text { 101/первая и вторая } \\
\text { половины XII в. }\end{array}$ & 70-200/158-167 \\
\hline Одинцово 8 & 70/9-10/161-162 & $?$ & 30 & Одинцово 8 & 10/XII в. & 100/160-162 \\
\hline Одинцово 1 & 50/5-7/157-159 & 800 & 300 & Одинцово 1 & 22/XII B. & 400/187-189 \\
\hline \multirow[t]{5}{*}{$\begin{array}{l}\text { Одинцово } 7 \\
\text { Одинцово } 5\end{array}$} & \begin{tabular}{|l|}
$30 / 6-15 / 175-184$ \\
$50 / 7-12 / 175-180$
\end{tabular} & $\begin{array}{l}10000 \\
900\end{array}$ & $\begin{array}{l}100 \\
200\end{array}$ & $\begin{array}{l}\text { Одинцово } 7 \\
\text { Одинцово 7a }\end{array}$ & $\begin{array}{l}42 / \mathrm{XII} \text { в. } \\
38\end{array}$ & $\mid 200-400 / 185-191$ \\
\hline & & & & Одинцово 11 & 6 & 250/177-181 \\
\hline & & & & Одинцово 16 & 3 & 200/180-181 \\
\hline & & & & Одинцово 19 & 1 & $100 / 200$ \\
\hline & & & & & Всего: 285 & \\
\hline
\end{tabular}

\section{Таблица 26. Численность курганных групп и курганов в бассейне Москвы-реки}

\begin{tabular}{|l|l|l|}
\hline Регион & Численность курганных групп & Количество курганов \\
\hline Москва-река и мелкие притоки & 455 & 4406 \\
\hline Руза и Озерна & 34 & 536 \\
\hline бассейн р. Истры & 71 & 806 \\
\hline бассейн р. Пахры & 208 & 1594 \\
\hline бассейн р. Северки & 62 & 329 \\
\hline Всего & $\mathbf{8 2 9}$ & $\mathbf{7 6 7 1}$ \\
\hline
\end{tabular}




\section{Заключение}

B ажнейшие результаты проведенного исследования можно суммировать следующим образом.

Решень проблемы хронологии, стратиграфии (взаимосвязи) и периодизации археологических объектов и культур на территории Подмосковья от неолита до Средневековья, определена их корреляция с основными изменениями природной обстановки во второй половине голочена.

Разработка этих тем опирается на: 1) серийное радиоуглеродное датирование; 2) стратиграфию культурного слоя эталонных памятников, раскопанных автором (Дьяково городище железного века), однослойные археологические объекты (поселения протофатьяновского типа и фатьяновской культуры ЗБС-5, РАНИС-пойма, ЗБС-4; средневековые селища в черте Москвы, на территории Звенигородской биостанции, в заповедниках «Коломенское» и «Царицыно»); 3) стратиграфию природных пойменных отложений; 4) комплексные археолого-естественно-научные исследования с участием геоморфолога, почвоведа, палеоботаников.

Установлено, что стратиграфию пойменных отложений Москвы-реки определяют четыре погребенные почвы, формировавшиеся на временном отрезке от атлантического периода до современности. К этим почвам приурочены памятники неолита (почва 4, возраст 7000-4900 ${ }^{14} \mathrm{C}$ л.н.), бронзового века (почва 3, возраст 4000-3900 ${ }^{14} \mathrm{C}$ л.н.), железного века и Средневековья (почвы 2, возраст 2500$500{ }^{14}$ С л.н.; 1а, возраст 300-200 л.н.).

Подтверждены и уточнены датировки льяловской неолитической культуры. Памятники ее развитого и финального этапов в долине Москвы-реки охватывают отрезок времени от конца V тыс. до н.э. до начала второй четверти IV тыс. до н.э. Финал льяловской культуры совпадает с резкими природными изменениями. В этот период начинается перестройка растительного покрова. Полуоткрытые, местами остепненные участки долины Москвы-реки занимает еловый лес. Меняется паводковый режим реки в сторону его активизации. Во второй четверти IV тыс. до н.э. в регионе появляются представители новой культурной группы неолита - носители гребенчатой и лапчатой керамики. В это время отмечается серьезный спад в общей заселенности территории.

Обоснованы новые датировки комплекса шнуровых и постшнуровых культур. Появление в долине Москвы-реки носителей традиции шнуровой керамики/культуры шаровидных амфор можно отнести к концу второй четверти III тыс. до н.э.; формирование местной фатьяновской куль- туры - к середине III тыс. н.э. Финал фатьяновской культуры относится к последней четверти III тыс. до н.э.

Постшнуровые культуры - абашевская и «фатьяноидная» - лишь «по касательной» соприкасались с фатьяновской. Время их бытования в изучаемом регионе определяется первой четвертью II тыс. до н.э.

Памятники культуры текстильной керамики, которые следует относить к второй-четвертой четверти II тыс. до н.э., в москворецком регионе почти не представлены.

К последней четверти II тыс. до н.э.-первой четверти I тыс. до н.э. относится фаза преддьяковской культуры, охватывающая финал бронзового века и начальный период железного. Финал этой культурной фазы характеризуется возникновением древнейших укрепленных поселений в регионе.

Разработана детальная хронология и периодизация дьяковской культуры. Во второй четверти I тыс. до н.э. формируется дьяковская (раннедьяковская) культура, пик развития которой приходится на V-III вв. до н.э., а финал - на II в. до н.э. В этот период наблюдались существенные изменения природной обстановки в долине Москвы-реки и изменение ее паводкового режима. Поверхности высокой поймы перестали заливаться и стали удобными для всех видов хозяйственной деятельности.

Спорные вопросы позднедьяковской хронологии удалось решить на основе взаимопроверяемых независимых данных - радиоуглеродных дат, комплексов находок, выделенных по стратиграфическим данным. В том числе учтены импорты первых веков новой эры (стеклянные античные бусы, вещи позднесарматского круга древностей; восточноевропейские изделия с выемчатыми эмалями и пр.).

Установлено, что смена раннедьяковской культуры в регионе на позднедьяковскую не сопровождалась спадом в его заселенности, а лишь незначительной пространственной перестройкой системы поселений. Выделен период I-III вв., на который приходится «пик» развития позднедьяковской культуры и формирование ее самобытных особенностей. В IV-V вв. происходила ее трансформация в результате внутренней эволюции и внешних воздействий. В V-VI вв. отмечаются культурные инновации и общий упадок, завершившийся в VII в. полной дезинтеграцией системы.

Выделена малочисленная группа «постдьяковских» древностей VII-VIII вв., занимающих периферию ареала москворецкой группы позднедьяковских памятников. 
Обоснована хронология и периодизация славянской колонизации Подмосковья. Классифицирована керамика и украшения, получены радиоуглеродные даты. Важнейшим этапом стал конец I тыс. н.э., когда на территорию долины Москвы-реки и Пахры проникли славянские переселенцы, скорее всего, из верховьев Днепра и бассейна Верхней Оки (первая волна колонизации). Во второй половине XI в. культура этого населения имеет яркие особенности, из украшений для них характерны височные кольца деснинского типа (возможно, результат смоленского влияния). На рубеже XI-XII вв. в регионе появляются новые славянские колонисты (вторая волна колонизации), вероятно вытеснившие и/или ассимилировавшие колонистов первой волны.

B XII-XIII вв. на территории Москворечья формируется московский вариант древнерусской культуры и прослеживается процесс этнической консолидации местного населения, зафиксированный этнонимами «московляне»/«москвичи», упомянутыми летописями.

На основе серийного радиоуглеродного датирования и изучения однослойных комплексов поселений удалось выявить и описать древности второй половины XIII в. Финал этого этапа совпадает с серьезными изменениями природной обстановки (наступление малого ледникового периода), которые на локальном материале характеризуются новой фазой активизации режима паводков Москвы-реки.

На рубеже XIII-XIV вв. наблюдается трансформация поселенческой системы, формирование ее сотовой структуры, освоение водоразделов, что диктовалось ростом населения и, возможно, отчасти стимулировалось ухудшением условий для хозяйственной эксплуатации низких уровней долин крупных рек.

Созданы археологические карты бассейна Москвыреки для нескольких хронологических срезов: неолита, бронзового века, железного века, древнерусского времени, которые обобщили материаль всех предылущчих источников и исследований новейтего времени (всего более 1700 памятников). Анализ особенностей материальной культуры и пространственного расположения памятников позволил скорректировать имевшиеся представления о времени и этапах заселения бассейна Москвы-реки. В том числе карта древнерусских памятников москворецкого бассейна насчитывает более 1200 объектов, из которых большинство (829) составляют курганные группы. В результате анализа методами ГИС карт древнерусских памятников выявлена пространственная структура заселенности территории, определены зоны главной концентрации населения на разных этапах славянской колонизации региона, определены участки наибольшей освоенности ландшафта.

Проведена серия комплексных археолого-естественно-научных исследований памятников разных типов и возрастов.

В результате достигнуто совершенствование самой методики таких комплексных исследований, определены наиболее перспективные объекты исследований для получения достоверной научной информации. Такие как, например, погребенные почвы в толще речного аллювия и на конусах выноса в тыловой части поймы; системы торфяников, харак- теризующих поперечный профиль долины (пойма, склоны, водораздел); почвы под валами городищ, курганами и делювиально-агрогенными шлейфами на бровках берегов и склонах. Установлена специфика спорово-пыльцевых данных, полученных по культурным слоям.

Главными итогами этих исследований стало установление особенностей хозяйственной деятельности людей в разньле периоды, пространственноой организации землепользования, в том числе антропогенного воздействия на ландшафт, начиная с неолитического времени, и преемственности в использовании возникающих ландшафтных нии бронзового века к железному веку.

Для неолитического периода установлено, что в период льяловской культуры долина Москвы-реки была местом постоянных поселений. В результате археолого-палинологических исследований сделана реконструкция растительности долинных ландшафтов, отличающаяся по степени подробности от имевшихся ранее. Получены данные об антропогенных изменениях растительности - сведении леса. В том числе получены данные о присутствии в спектрах пыльцы cerealia-type (типа культурных злаков). Это является указанием на необходимость проведения дальнейших детальных исследований для ответа на вопрос: были ли у неолитического населения москворецкого региона начатки производящего хозяйства?

Для периода бронзового века исключительно важным было открытие и изучение раскопками поселений фатьяновской культуры. Результаты проведенных палинологических исследований с большой вероятностью указывают на локальное сведение леса и наличие земледелия у жителей исследованных фатьяновских поселений. Остеологические данные показывают, что в стаде присутствовали лошади и крупный рогатый скот.

Установлено, что в абашевское время активизировалось антропогенное воздействие на растительность (сведение леса). Весьма вероятно, что люди абашевской и фатьяноидной культур занимали различные экологические ниши. Первые эксплуатировали земли долины Москвы-реки и другие, удобные для скотоводства и земледелия участки, а вторые были в большей степени ориентированы на охоту и рыбную ловлю, сочетавшиеся со скотоводством.

Подтверждено, что памятники финального бронзового века с текстильной керамикой и каменным инвентарем, расположенные на бровках высоких берегов в долине Москвыреки и Истры, могут рассматриваться как непосредственные предшественники культуры городищ железного века.

Для железного века источником наиболее полных данных стали материалы раскопок Дьякова городища и серии памятников начальной фазы дьяковской культуры. Реконструкция хозяйства базируется на надежной фактологической основе благодаря проведению массовой флотации культурного слоя для отбора из него зерен, выполнению серии спорово-пыльцевых исследований, изучению обширной остеологической коллекции (более 20000 костей). Все эти материалы указывают на существенное развитие земледелия и скотоводства. Количественные соотношения зерен различных культур, костей разных видов животных позволяют проследить опре- 
деленную динамику развития форм земледелия и скотоводства, а также их соотношение с другими формами хозяйства. Наиболее вероятным представляется вывод о том, что в железном веке сформировались устойчивые агроландшафты вокруг городищ, существовали поля длительного использования. Установлено по материалам исследований в заповеднике «Царицыно», что процесс земледельческого освоения долин малых правых притоков Москвы-реки стартовал не позднее позднедьяковского времени, что заложило основу дальнейшего их освоения в Средневековье.

Применение метода анализа анатомического набора остеологических остатков позволило скорректировать представления о роли охоты в железном веке. Оказалось, что доля охотничьей добычи в балансе диеты была более высокой, чем следует из простого подсчета костей.

В результате изучения памятников древнерусского времени XI-XIII вв. были установлены закономерности в организации поселенческой системы и структуры землепользования. Исследовались и сравнивались эталонные микрорегионы (памятники в бассейнах небольших речек). Локализованы древние поля, установлены пространственные и количественные соотношения курганных могильников и поселений. Эти микрорегиональные исследования имеют принципиальное значение для реконструкции палеодемографических и палеоэкономических параметров.

В результате диахронного анализа археологических памятников, расположенных в бассейне Москвы-реки удалось установить, что начиная с бронзового века (а местами и с неолита), существовала преемственность в освоении территории. «Устойчивый» культурный ландшафт «локальными пятнами» сложился в долине Москвы-реки уже в железном веке. Тем не менее, Средневековье характеризуется существенно более интенсивным воздействием на ландшафт, сравнительно с железным веком. Следы этого воздействия проявляются практически повсеместно в спорово-пыльцевых диаграммах, построенных по колонкам, отобранным как в долине, так и на водораздельных болотах.

Получены данные о том, как менялась заселенность территории в интервале 6000-700 лет тому назад. Существенно дополнены представления о развитии материальной культуры в регионе, степени его культурной обособленности и одновременного взаимодействия с культурами других регионов.

В результате архивных работ были использованы весьма ценные источники. Проанализирована археологическая информация (изображения курганов), содержащаяся на картах начала XIX в., крупномасштабных картах Москвы 1930-х-1960-х гг., которые ранее никем из археологов не привлекались для работы. Учтены значимые материалы (отчеты, архивная документация, коллекции) малоизвестных работ предшественников, занимавшихся железным веком и средневековыми памятниками Подмосковья А.В. Чаянова, К.Я. Виноградова, Л.И. Пимакина.

Основной массив использовавшихся в работе данных получен в ходе полевых работ (1981-2013 гг.). Были проведены раскопки археологических памятников, которые могут считаться ключевыми в Московском регионе для различных ар- хеологических периодов: 1-я Звенигородская неолитическая стоянка, поселения фатьяновской культуры ЗБС-4, ЗБС-5, РАНИС-пойма, Царицыно 1, поселения позднего бронзового века Дютьково (Олимп); городища железного века Дьяково, Луковня 2, Луцино 2, Коробово, Дютьково, селище Чертов городок, погребение железного века Дунино 4; селища древнерусского времени - Хотяжи 1, Дьяково-пойма, Царицыно 2, Борисово, Назарово 2, Романов двор в Москве. Проведено комплексное (с применением методов палеоботаники, почвоведения, геоморфологии, радиоуглеродного датирования) изучение стратиграфии пойменных отложений Москвы-реки и культурных ландшафтов микрорегионов в Битцевском парке, заповедниках Царицыно и Коломенское, леспаркхозе Горки-Ленинские, Звенигородской биостанции МГУ.

В итоге были получены представления о материальной культуре (керамике, в том числе бытовой, кремневом инвентаре, жилищах) и хозяйстве.

Особое значение для разработки темы происхождения фатьяновской культуры имеет исследование протофатьяновского поселенческого объекта ЗБС-5, содержавшего находки, выполненные в традициях культур шнуровой керамики Прибалтики, Польши и Западной Украины, а также культуры шаровидных амфор. Это позволяет считать названные культуры в числе компонентов, соединение которых стало основой формирования фатьяновской культуры в западной части Волго-Окского междуречья.

Анализ керамики поселений РАНИС-пойма, Царицыно 1, погребения могильника Луцино-Газовик, позволил утверждать, что население долины Москвы-реки поддерживало тесные связи с относительно удаленным регионом Ярославского Поволжья. Получены также новые данные, освещающие контакты фатьяновской культуры и среднеднепровской. Описаны особенности керамики, характерной для финальной стадии культуры.

Установлено, что на стадии перехода от бронзового века к железному на преддьяковской фазе развития памятники москворецкого региона обладали культурным своеобразием, синкретичностью, сочетанием «северных» и «южных» черт, что соответствовало его срединному географическому положению. Постепенно черты, восходящие к традиции культуры текстильной керамики, получили преобладающее значение и стали доминирующими на стадии сложения раннедьяковской культуры.

Формирование раннедьяковской культуры, произошедшее в VI-V вв. до н.э., характеризовалось многочисленными культурными инновациями и быстрым ростом населения. Экологическая емкость долины Москвы-реки была почти исчерпана. Наряду с очень специфичными местными особенностями культуры, которые проявлялись в керамическом производстве, наборе костяного инвентаря, наблюдаются и «надкультурные» явления. Так, престижные украшения из бронзы роднят раннедьяковскую культуру с соседней днепро-двинской.

На основе раскопок уникального для раннедьяковской культуры объекта - погребения по обряду трупосожжения на селище Дунино 4 и привлечения других данных 
о находках человеческих костей на дьяковских городищах была сформулирована гипотеза о «многоступенчатом» погребальном обряде.

На позднедьяковском этапе в первые века новой эры в Москворецком бассейне сформировалась очень своеобразная культура, ареал которой, видимо, включал и бассейн р. Протвы, но не переходил на правый берег Оки на юге и р. Клязьму на севере. Внешние связи этой культурной группы существенно расширились на пике ее развития. Радиус культурных контактов достигал 500 и более километров, при этом культурное своеобразие москворецкого населения отнюдь не утрачивалось и не «размывалось» вплоть до V-VI вв. н.э.

Вторая половина I тыс. до н.э. - это период существенного спада заселенности региона, который почти полностью обезлюдел в VIII - первой половине IX в.

Анализ особенностей материальной культуры и пространственного расположения средневековых памятников позволил скорректировать имевшиеся представления о времени и этапах колонизации славянами бассейна Москвыреки. Первая существенная волна славянской колонизации относится к концу І тыс. н.э.-второй половине ХІ в. Выявлено более 20 поселений этого периода. Главная концентрация приходилась на долину нижнего течения р. Пахры, заселена была также долина Москвы-реки. Это население обладало набором культурных особенностей. Форма керамики и височных украшений роднят его с населением бассейна Верхней Оки.

На рубеже XI-XII вв. в регионе появляется новая группа славянского населения, также, видимо, с юга (юго-запада), из-за Оки, использовавшая поселенческо-хозяйственную стратегию, отличную от колонистов «первой волны». Новое население активно осваивает, в первую очередь, долины мелких притоков Москвы-реки и Пахры.

Посчитанные разными методами показатели плотности памятников и интенсивности освоенности ландшафта продемонстрировали, что зона наибольшей концентрации этих показателей локализуется в компактном ареале правобережья Москвы-реки от территории современной Москвы до стрелки междуречья Москвы-реки и Пахры. Видимо, именно в этом регионе размещалось наиболее массовое производство характерных украшений - семилопастных колец московского типа.

Разработанная новая классификация орнаментов височных украшений позволила выявить три локальные традиции и шесть хронологических стадий развития. Процесс этнической консолидации населения москворецкого региона, особенно активно протекавший во второй половине XII-начале XIII в., был существенно «деформирован» татаро-монгольским нашествием. На послемонгольских памятниках были зафиксированы признаки, указывающие на очевидную преемственность населения второй половины XIII в. с домонгольскими жителями той же территории, но характер материальной культуры сильно изменился. Вероятно, оказались недоступными использовавшиеся ранее сырьевые ресурсы для производства керамики из белой каолиновой глины, медь и олово для бронзовых луженых украшений. Тем не менее, количество населения увеличивалось. Стратегия топографического размещения поселений во второй половине XIII в. оставалась прежней, можно отметить лишь более активное освоение долины Москвы-реки. B XIV в. уплотнение населения привело к возникновению принципиально новой модели пространственно-топографической закономерности расположения поселений, поднявшихся на водораздельные холмы.

Диахронныцй пространственный анализ поселенческой структуры региона с помощью различных методов выявил преемственность структуры освоения региона. Начиная с периода развитого неолита (льяловская культура), в бассейне Москвы-реки, расположенном в центре Волго-Окского междуречья, несколько раз формировались обособленные культурные образования (фатьяновская культура раннего этапа, позднедьяковская, москворецкая группа древнерусского населения XII-XIII вв.), географически налагающиеся друг на друга. Наибольшее сходство имеют ареалы и центры концентрации генетически, казалось бы, не связанных позднедьяковской культуры начала I тыс. н.э. и москворецкого варианта древнерусской XII-XIII вв. Гипотеза о роли «месторазвития» находит здесь подтверждение. 


\section{Приложение I}

\section{КАТАЛОГ ПАМЯТНИКОВ ЖЕЛЕЗНОГО ВЕКА В БАССЕЙНЕ МОСКВЫ-РЕКИ ${ }^{1}$}



\footnotetext{
${ }^{1}$ Принятые сокращения: гор. - городище; мест. - местонахождение; сел. - селище.
} 


\begin{tabular}{|c|c|c|c|c|c|c|c|c|}
\hline № & Название & $\begin{array}{l}\text { Фамилия исследователя, } \\
\text { год обследования }\end{array}$ & $\begin{array}{l}\text { Площадь } \\
\text { поселения } \\
\text { (кв. м) }\end{array}$ & $\begin{array}{l}\text { Раскопано } \\
\text { (кв. м), в } \\
\text { скобках - } \\
\text { год раскопок }\end{array}$ & $\begin{array}{l}\text { Средняя } \\
\text { толщина } \\
\text { слоя (м) }\end{array}$ & \multicolumn{3}{|l|}{ Находки } \\
\hline 21 & Сел. Новинки & Розенфельдт Р.Л., 1975. & $?$ & - & 0,7 & - & - & + \\
\hline 22 & Сел. Костино & Янишевский Б.Е., 1991-1993. & 3000 & - & 0,3 & - & - & + \\
\hline 23 & Гор. Чепасово & $\begin{array}{l}\text { Розенфельдт Р.Л., } 1979 . \\
\text { Янишевский Б.Е., } 1991 .\end{array}$ & $1200-1300$ & - & 0,5 & - & $?$ & + \\
\hline 26 & $\begin{array}{l}\text { Гор. (сел.?) } \\
\text { Морево }\end{array}$ & Иванов, 1929. & $?$ & - & $?$ & - & + & $?$ \\
\hline 27 & Сел. Григорово & $\begin{array}{l}\text { Краснов Н.А., Краснов Ю.А., } \\
1957 . \\
\text { Янишевский Б.Е., } 1990 .\end{array}$ & $?$ & - & 0,2 & - & - & + \\
\hline 28 & Сел. Григорово-1 & Алексеев А.В., 1999. & $?$ & - & 0,6 & - & + & $?$ \\
\hline \multirow[t]{2}{*}{29} & Сел. Григорово & Кравцов А.Е., 1970-е гг. & $?$ & - & $?$ & - & + & $?$ \\
\hline & Сел. Григорово 2 & Кренке 2011. & $?$ & 2 & 0,4 & - & + & + \\
\hline 34 & $\begin{array}{l}\text { Гор. Алтыново } \\
\text { (Бережки) }\end{array}$ & $\begin{array}{l}\text { Розенфельдт Р.Л., } 1978 . \\
\text { Алексеев А.В., 2000, } 2003 .\end{array}$ & 1100 & - & 0,5 & - & - & + \\
\hline 35 & Сел. Хотяжи-1 & $\begin{array}{l}\text { Станюкович А.К., 1999-2001. } \\
\text { Кренке Н.А., } 2009 . \\
\text { Лазукин А.В., } 2013 . \\
\end{array}$ & $?$ & \begin{tabular}{|l|}
8 \\
$100(2009)$ \\
$80(2013)$ \\
\end{tabular} & 0,4 & - & + & + \\
\hline 36 & $\begin{array}{l}\text { Сел. Никифорово } \\
\text { (Хотяжи-2) }\end{array}$ & Алексеев А.В., 1999. & 12600 & - & $?$ & - & + & + \\
\hline 37 & Сел. Власово & Алексеев А.В., 2003. & $?$ & - & $?$ & - & + & - \\
\hline 38 & \begin{tabular}{|l|}
$\begin{array}{l}\text { Гор. Рязань } \\
\text { (Улитино) }\end{array}$ \\
\end{tabular} & $\begin{array}{l}\text { Краеведы, } 1967 . \\
\text { Розенфельдт Р.Л., } 1978 .\end{array}$ & 4500 & - & 0,5 & - & + & + \\
\hline 39 & Сел. Бушарино & $\begin{array}{l}\text { Краснов Н.А., Краснов Ю.А., } \\
1957 .\end{array}$ & $?$ & - & 0,2 & - & $-(?)$ & + \\
\hline 40 & Гор. Бушарино & $\begin{array}{l}\text { Виноградов К.Я., } 1927 . \\
\text { Краснов Н.А., Краснов Ю.А., } \\
\text { 1957, } 1971 . \\
\text { Розенфельдт Р.Л., } 1977 . \\
\text { Янишевский Б.Е., 1989, } 1990 . \\
\text { Кренке Н.А, 2018. }\end{array}$ & $1000-2000$ & $\begin{array}{l}- \\
\\
16 \\
12 \\
\end{array}$ & 0,6 & - & + & + \\
\hline 41 & $\begin{array}{l}\text { Мест. Волково } \\
\text { (в кургане) }\end{array}$ & Арциховский А.В., 1940 & $?$ & $?$ & & + & $?$ & + \\
\hline
\end{tabular}









\begin{tabular}{|c|c|c|c|c|c|c|c|c|}
\hline № & Название & $\begin{array}{l}\text { Фамилия исследователя, } \\
\text { год обследования }\end{array}$ & $\begin{array}{l}\text { Площадь } \\
\text { поселения } \\
\text { (кв. м) }\end{array}$ & $\begin{array}{l}\text { Раскопано } \\
\text { (кв. м), в } \\
\text { скобках - } \\
\text { год раскопок }\end{array}$ & $\begin{array}{l}\text { Средняя } \\
\text { толщина } \\
\text { слоя (м) }\end{array}$ & \multicolumn{3}{|l|}{ Находки } \\
\hline 54 & $\begin{array}{l}\text { Гор. у д/о } \\
\text { «Связист» } \\
\text { N } 55,73243 \\
\text { E } 036,83474 \\
\text { N } 55,73236 \\
\text { E } 036,83521\end{array}$ & $\begin{array}{l}\text { Каснов Н.А., Краснов Ю.А., } \\
\text { 1957, 1969, } 1973 . \\
\text { Юшко А.А., } 1978 . \\
\text { Розенфельдт Р.Л., } 1975 . \\
\text { Янишевский Б.Е., } 1990 . \\
\text { Станюкович А.К., } 2002 .\end{array}$ & $1200-1500$ & $\begin{array}{l}60(1990) \\
8(2002)\end{array}$ & 0,5 & + & + & + \\
\hline 57 & Сел. Игнатьево & Виноградов К.Я., 1927. & $?$ & - & $?$ & - & - & + \\
\hline 58 & Сел. Мозжинка III & $\begin{array}{l}\text { Краснов Н.А., Краснов Ю.А., } \\
1957 .\end{array}$ & $?$ & - & 0,3 & - & + & + \\
\hline 59 & Сел. Мозжинка II & $\begin{array}{l}\text { Краснов Н.А., Краснов Ю.А., } \\
1957 . \\
\text { Янишевский Б.Е., } 1992 .\end{array}$ & $600-800$ & $\begin{array}{l}\text { около } 10 \\
(1992)\end{array}$ & 0,3 & - & + & + \\
\hline 60 & $\begin{array}{l}\text { Гор. Мозжинка-1 } \\
\text { Мыс } \\
\text { N 55,73469 } \\
\text { Е 036,89149 } \\
\text { Центр } \\
\text { N 55,73491 } \\
\text { E 036,89148 }\end{array}$ & $\begin{array}{l}\text { Виноградов К.Я., } \\
\text { Колобов В.М., 1929-1930. } \\
\text { Краснов Н.А., Краснов Ю.А., } \\
\text { 1953, } 1957 . \\
\text { Розенфельдт Р.Л., } 1981 . \\
\text { Янишевский Б.Е., } 1992 .\end{array}$ & $1000-1500$ & - & 0,5 & - & + & + \\
\hline 63 & Сел. Дунино 8 & $\begin{array}{l}\text { Алексеев А.В., 2004, } 2005 . \\
\text { Кравцов А.Е., } 2008 .\end{array}$ & 80 & 199 & 0,3 & + & + & + \\
\hline 64 & Сел. Дунино 9 & Алексеев А.В., 2004. & & 1 & 0,3 & - & + & $?$ \\
\hline 65 & Гор. Дунино & $\begin{array}{l}\text { Дервиз Г.В., } 1940 . \\
\text { Дервиз Г.Г., 1968, } 1969 . \\
\text { Розеноельдт, 1978. } \\
\text { Янишевский Б.Е., } \\
\text { Чернов С.З., 1996. } \\
\end{array}$ & 1600 & $\begin{array}{l}\text { около } 30 \\
(1940,1968, \\
1969)\end{array}$ & 1,0 & + & + & + \\
\hline 66 & Сел. Дунино-2 & Розенфелььд Р.Л. (1985?). & $?$ & - & $?$ & - & $?$ & + \\
\hline 282 & Сел. Дунино 6 & Чернов С.3., 2011. & $?$ & - & $?$ & - & + & - \\
\hline 281 & Сел. Аксиньино & Лазукин А.В., 2006. & $?$ & - & 0,4 & - & - & + \\
\hline 67 & $\begin{array}{l}\text { Сел. Николина } \\
\text { Гора }\end{array}$ & Чаянов А.В., 1928, 1929. & $?$ & - & $?$ & - & $\begin{array}{l}\text { + (сетчатая } \\
\text { керамика в } \\
\text { кургане) }\end{array}$ & $-(?)$ \\
\hline 68 & $\begin{array}{l}\text { Гор. Николина } \\
\text { гора } \\
\text { Вал } \\
\text { N 55,73480 } \\
\text { Е 037,03654 }\end{array}$ & Кренке Н.А., 2009. & 3000 & 4 & 0,2 & - & + & $?$ \\
\hline 69 & $\begin{array}{l}\text { Мест. Таганьково } \\
\text { (в кургане) }\end{array}$ & Раскопки С.С. Ширинского & $?$ & раскопки & $?$ & - & + & - \\
\hline
\end{tabular}









\begin{tabular}{|c|c|c|c|c|c|c|c|c|}
\hline \multirow[t]{2}{*}{ № } & \multirow[t]{2}{*}{ Название } & \multirow{2}{*}{$\begin{array}{l}\text { Фамилия исследователя, } \\
\text { год обследования }\end{array}$} & \multirow{2}{*}{$\begin{array}{l}\text { Площадь } \\
\text { поселения } \\
\text { (кв. м) }\end{array}$} & \multirow{2}{*}{$\begin{array}{l}\text { Раскопано } \\
\text { (кв. м), в } \\
\text { скобках - } \\
\text { год раскопок }\end{array}$} & \multirow{2}{*}{$\begin{array}{l}\text { Средняя } \\
\text { толщина } \\
\text { слоя (м) }\end{array}$} & \multicolumn{3}{|l|}{ Находки } \\
\hline & & & & & & $\begin{array}{l}\text { VIII-VI вB. } \\
\text { до н.э. }\end{array}$ & $\begin{array}{l}\text { V-II вв. } \\
\text { до н.э. }\end{array}$ & $\begin{array}{l}\text { I в. до н.э.- } \\
\text { VII в. н.э. }\end{array}$ \\
\hline 88 & Сел. «Кружок» & $\begin{array}{l}\text { Криштафович Н.О., 1890-е гг. } \\
\text { Гак Е.И., } 2003\end{array}$ & $?$ & $2(2003)$ & 0,45 & - & + & + \\
\hline 89 & $\begin{array}{l}\text { Сел. (городище?) } \\
\text { Пенягинское }\end{array}$ & $\begin{array}{l}\text { Мачульский Е.Н., } 1968 . \\
\text { Розенфельдт Р.Л., } 1968 . \\
\text { Крис Х.И., 1970, 1972, } 1975 . \\
\text { Кренке Н.А., Чернов С.3., } \\
\text { Янишевский Б.Е., } 1999 .\end{array}$ & 1500 & - & 0,35 & + & + & + \\
\hline 90 & Сел. Мякинино 7 & Янишевский.Б.Е., 2005. & $?$ & 2 & 1,0 & - & + & $?$ \\
\hline 91 & Сел. Мякинино-1 & $\begin{array}{l}\text { Кравцов А.Е., Трусов А.В., } \\
1992,1993 . \\
\text { Энговатова А.В., Коваль В.Ю., } \\
2003 .\end{array}$ & $?$ & раскопки & $?$ & - & + & + \\
\hline 92 & Сел. Мякинино-3 & Кренке Н.А., 2000, 2002. & Более 100 & 2 & $0,2-0,3$ & - & + & - \\
\hline 93 & Сел. Мякинино-2 & $\begin{array}{l}\text { Векслер А.Г., } \\
\text { Розенфельдт О.Р., } \\
\text { Зубарев Н.В., Коваль В.Ю., } \\
\text { 1993-1998. } \\
\text { Энговатова А.В., Коваль В.Ю., } \\
2002 .\end{array}$ & $?$ & \begin{tabular}{|l|}
5225 \\
$(1993-1998)$ \\
$2000(2002)$ \\
\end{tabular} & $?$ & - & + & + \\
\hline 94 & Сел. Мякинино-5 & $\begin{array}{l}\text { Энговатова А.В., Коваль В.Ю., } \\
2002 .\end{array}$ & $?$ & 2,5 & $?$ & - & - & $\begin{array}{l}+(1 \\
\text { фррагмент })\end{array}$ \\
\hline 95 & Сел. Мякинино-6 & Коваль В.Ю., 2002. & $?$ & $4(2002)$ & 0,8 & - & - & + \\
\hline 96 & $\begin{array}{l}\text { Гор. } \\
\text { Спас-Тушино } 1\end{array}$ & $\begin{array}{l}\text { Виноградов К.Я., } 1927 . \\
\text { Бадер О.Н., } 1933 . \\
\text { Медведев Ю.П., } 1938 . \\
\text { Косинский В.В., } 1959 . \\
\text { Крис Х.И., 1970. } \\
\text { Розенфельдт Р.Л., } 1974 . \\
\text { Балинский И. М., } 1977 . \\
\text { Кренке Н.А., Чернов С.З., } \\
1991 .\end{array}$ & 2000 & 28 (1959) & 0,7 & + & + & + \\
\hline 97 & $\begin{array}{l}\text { Гор. Спас- } \\
\text { Тушино-2 }\end{array}$ & $\begin{array}{l}\text { Сотрудники МИРМ, } 1951 . \\
\text { Розенфельдт Р.Л., 1968, } 1970 . \\
\text { Крис Х.И., } 1970 . \\
\text { Балинский И.М., } 1977 . \\
\text { Кренке Н.А., Чернов С.3., } \\
1991 .\end{array}$ & 800 & - & $?$ & + & + & + \\
\hline 98 & Сел. Барышиха & $\begin{array}{l}\text { Мачульский Е.Н., } 1968 \text { гг. } \\
\text { Кренке Н.А., Ершов И.Н., } 2014 .\end{array}$ & $?$ & $2(2014)$ & 0,8 & - & + & $?$ \\
\hline 99 & Гор. Тушино & $\begin{array}{l}\text { Ходаковский 3.Я., } 1821 . \\
\text { Виноградов К.Я., } 1927 . \\
\text { Розенфрельдт Р.Л., 1970-е гг. }\end{array}$ & $2000(?)$ & $?$ & $0,7-0,8$ & - & + & + \\
\hline 100 & Сел. Никольское & $\begin{array}{l}\text { Оболдуева Т.Г., Бадер М.А., } \\
\text { 1930-е гг. }\end{array}$ & $?$ & - & до 1,6 & - & + & + \\
\hline 101 & Сел. Алешкино & $\begin{array}{l}\text { Армягов С.Е., } 1971 . \\
\text { Векслер А.Г., } 1972 . \\
\text { Шеляпина Н.С. 1970-е гг. }\end{array}$ & 1200 & - & 0,4 & - & + & $+(?)$ \\
\hline 102 & Сел. Химкинское & Рабинович М.Г., 1950-е гг. (?) & $?$ & $?$ & $?$ & $?$ & $?$ & $?$ \\
\hline 103 & $\begin{array}{l}\text { Сел. } \\
\text { Троице-Лыково-1 }\end{array}$ & $\begin{array}{l}\text { Криштафович Н.И., 1890-е гг. } \\
\text { Бадер О.Н., } 1940 . \\
\text { Шеляпина Н.С., 1970-е гг. }\end{array}$ & $?$ & - & $?$ & - & + & $?$ \\
\hline 104 & Сел. Татарово & Станюкович А.К., 1977. & $?$ & - & $?$ & - & + & $+(?)$ \\
\hline 105 & Гор. Кунцево & $\begin{array}{l}\text { Ходаковский З.Я., } 1821 . \\
\text { Калайдович К.Ф., до } 1822 . \\
\text { Броссе М.И., 1844. } \\
\text { Забелин И.Е., } 1873 . \\
\text { Городцов В.А., 1923. } \\
\text { Векслер А.Г., 1960, 1962-1965, } \\
\text { 1968, 1970-1973. }\end{array}$ & 2000 & $\begin{array}{l}1300(1960 \\
1962-1965, \\
1968 \\
1970-1973)\end{array}$ & 0,8 & + & + & + \\
\hline
\end{tabular}









\begin{tabular}{|c|c|c|c|c|c|c|c|c|}
\hline № & Название & $\begin{array}{l}\text { Фамилия исследователя, } \\
\text { год обследования }\end{array}$ & $\begin{array}{l}\text { Площадь } \\
\text { поселения } \\
\text { (кв. м) }\end{array}$ & $\begin{array}{l}\text { Раскопано } \\
\text { (кв. м), в } \\
\text { скобках - } \\
\text { год раскопок }\end{array}$ & $\begin{array}{l}\text { Средняя } \\
\text { толщина } \\
\text { слоя (м) }\end{array}$ & \multicolumn{3}{|l|}{ Находки } \\
\hline 127 & $\begin{array}{l}\text { Сел. Дьяково-2 } \\
\text { (Дьяково-пойма) }\end{array}$ & $\begin{array}{l}\text { Пахтунов С., 1970-е гг. } \\
\text { Кренке Н.А., 1983, } 1985 .\end{array}$ & $200(?)$ & 180 & 0,1 & - & + & + \\
\hline 128 & Гор. Дьяково & $\begin{array}{l}\text { Калайдович, К.Ф., до } 1821 . \\
\text { Ходаковский З.Я., } 1821 . \\
\text { Самоквасов Д.Я., } 1872 . \\
\text { Филимонов Г.Д., } 1875 . \\
\text { Сизов В.И., 1889, 1890, } 1893 . \\
\text { Готье Ю.В., } 1921 . \\
\text { Бадер О.Н., } 1926 . \\
\text { Виноградов К.Я., } 1935 . \\
\text { Кренке Н.А., 1981-1987. } \\
\text { Векслер А.Г., Бойцов И.А., } \\
\text { 2001-2003. }\end{array}$ & 2200 & $\begin{array}{l}150(\mathrm{XIX} \text { в. }) \\
50(1935) \\
290 \\
(1981-1987) \\
44(2001)\end{array}$ & 3,0 & + & + & + \\
\hline 129 & $\begin{array}{l}\text { Сел. Дьяково-3 } \\
\text { (Дьяково-южное) }\end{array}$ & $\begin{array}{l}\text { Кренке Н.А., 1992, } 1995 . \\
\text { Векслер А.Г., Бойцов И.А., } \\
2001 .\end{array}$ & 10 & 3 (1995) & 0,6 & - & - & + \\
\hline 130 & $\begin{array}{l}\text { Местонахожде- } \\
\text { ние к югу за } \\
\text { валом Дьякова } \\
\text { городища }\end{array}$ & $\begin{array}{l}\text { Кренке Н.А., 1996, } 1997 . \\
\text { Векслер А.Г., Бойцов И.А., } \\
2001 .\end{array}$ & $?$ & - & 0,2 & - & $-(?)$ & + \\
\hline 134 & Сел. Братеево & Макаренков Б.А., 1950. & $?$ & - & $?$ & - & + & $?$ \\
\hline 135 & Сел. Шипилово & $\begin{array}{l}\text { Бакунова Т.Н., Кренке Н.А., } \\
2006 .\end{array}$ & $?$ & 24 & 0,5 & - & - & + \\
\hline 136 & Гор. Капотня & $\begin{array}{l}\text { Городцов В.А., до } 1893 . \\
\text { Макаренков Б.А., } 1949 . \\
\text { Векслер А.Г., 1975, } 1976 . \\
\text { Кренке Н.А., 1995. } \\
\text { Чернов С.З., } 1996 .\end{array}$ & 1500 & - & $0,6(?)$ & + & + & + \\
\hline 137 & $\begin{array}{l}\text { Местонахождение } \\
\text { у Капотнинского } \\
\text { гор. }\end{array}$ & Чернов С.3., 1996. & - & 1 & 0,3 & + & + & - \\
\hline 138 & Сел. Капотня & Станюкович А.К., 1974. & $?$ & - & $?$ & - & $?$ & $?$ \\
\hline 139 & Сел. Беседы & $\begin{array}{l}\text { Дукельский В., } 1983 \text { (1985?). } \\
\text { Станюкович А.К., } 1986 .\end{array}$ & $?$ & - & $?$ & - & + & $?$ \\
\hline 140 & $\begin{array}{l}\text { Большой } \\
\text { беседский курган } \\
\text { № } 12 \text { (керамика в } \\
\text { насыпи) }\end{array}$ & Арциховский А.В., 1946. & - & раскопки & - & - & + & - \\
\hline 141 & Сел. Остров & Розенфельдт Р.Л., 1974. & $?$ & - & $?$ & - & $?$ & $?$ \\
\hline
\end{tabular}









\begin{tabular}{|c|c|c|c|c|c|c|c|c|}
\hline № & Название & $\begin{array}{l}\text { Фамилия исследователя, } \\
\text { год обследования }\end{array}$ & $\begin{array}{l}\text { Площадь } \\
\text { поселения } \\
\text { (кв. м) }\end{array}$ & $\begin{array}{l}\text { Раскопано } \\
\text { (кв. м), в } \\
\text { скобках - } \\
\text { год раскопок }\end{array}$ & $\begin{array}{l}\text { Средняя } \\
\text { толщина } \\
\text { слоя (м) }\end{array}$ & \multicolumn{3}{|l|}{ Находки } \\
\hline 159 &  & $\begin{array}{l}\text { Чернай И.Л., } 1999 . \\
\text { Чернай И.Л., Кренке Н.А., } \\
\text { Лопатина О.А., } 2001 .\end{array}$ & 2000 & - & $0,2-0,5$ & + & + & - \\
\hline 160 & $\begin{array}{l}\text { Гор. Боршева } \\
\text { GPS координаты } \\
\text { Вал } \\
\text { N } 55^{\circ} 39893 \\
\text { E } 038^{\circ} 32466 \\
\text { Центр } \\
\text { N } 55^{\circ} 39933 \\
\text { E } 038^{\circ} 32484 \\
\text { Mыс } \\
\text { N } 55^{\circ} 39965 \\
\text { E } 038^{\circ} 32524\end{array}$ & $\begin{array}{l}\text { Ходаковский З.Я., } 1821 \\
\text { (1822?). } \\
\text { Розенфельдт Р.Л., 1960, } 1967 . \\
\text { Крис Х.И., 1973-1979. }\end{array}$ & 2000 & $\begin{array}{l}800 \\
(1973-1979)\end{array}$ & 1,5 & + & + & + \\
\hline 161 & Гор. Михалево & $\begin{array}{l}\text { Сидоров В.В., } 1988 . \\
\text { Кренке Н.А., Чаукин С.Н., } 2013 .\end{array}$ & $\begin{array}{l}\text { Около } \\
1000\end{array}$ & - & 0,9 & - & + & + \\
\hline 162 & $\begin{array}{l}\text { Сел. Юрасово } \\
\text { (погост Гвоздна) }\end{array}$ & Юшко А.А., 1976. & $?$ & - & $?$ & - & $?$ & $?$ \\
\hline 163 & Сел. Петровское & Розенфельдт Р.Л., 1986. & 1500 & - & 0,3 & - & $?$ & + \\
\hline 164 & $\begin{array}{l}\text { Сел. Городище } \\
\text { (устье р. Отры) }\end{array}$ & $\begin{array}{l}\text { Розенфельдт Р.Л., } 1977 . \\
\text { Сыроватко А.С., } \\
\text { начало 1990-х гг. }\end{array}$ & $?$ & - & 0,5 & - & + & + \\
\hline 168 & $\begin{array}{l}\text { Сел. } \\
\text { Константиново }\end{array}$ & Сборы краеведов. & $?$ & - & $?$ & - & - & + \\
\hline 169 & $\begin{array}{l}\text { Гор. Ачкасово } \\
\text { в уроч. Городена } \\
\text { (погост Красно) }\end{array}$ & $\begin{array}{l}\text { Талицкий М.В., } 1936 . \\
\text { Юшко А.А., } 1972 . \\
\text { Розенфрельдт Р.Л., 1979, 1980, } \\
1986 . \\
\text { Сыроватко А.С., } 1997 .\end{array}$ & $\begin{array}{l}\text { Около } \\
1500\end{array}$ & - & $?$ & - & + & $?$ \\
\hline 170 & Сел. Городена & $\begin{array}{l}\text { Талицкий М.В., } 1936 . \\
\text { Сыроватко А.С., } 1997 .\end{array}$ & $?$ & - & $?$ & - & + & $?$ \\
\hline 171 & Мест. Цемгигант 2 & $\begin{array}{l}\text { Жданов, 2001. Черкасов В.В., } \\
2006 .\end{array}$ & $?$ & 200 & $?$ & - & + & $?$ \\
\hline 172 & Сел. Конев Бор & Сыроватко А.С., 1998. & $?$ & - & $?$ & - & - & + \\
\hline 173 & Мест. Молитвино & $\begin{array}{l}\text { Гужов А.И., 1940-е гг. } \\
\text { Сыроватко А.С., } 2001 .\end{array}$ & $?$ & 3 & $?$ & - & + & - \\
\hline 174 & $\begin{array}{l}\text { Мест. ул. Б. } \\
\text { Запрудная }\end{array}$ & Черкасов В.В., 2005. & $?$ & 32 & $?$ & - & + & - \\
\hline 175 & $\begin{array}{l}\text { Гор. в г. Коломна } \\
\text { «Блюдечко» } \\
\text { (Кремль) }\end{array}$ & $\begin{array}{l}\text { Виноградов К.Я., } 1935 . \\
\text { Милонов Н.П., 1935, } 1937 . \\
\text { Мазуров А.Б., } 1995 .\end{array}$ & $?$ & Около 400 & 0,25 & - & + & + \\
\hline 176 & $\begin{array}{l}\text { Мест. Троицы на } \\
\text { Репне }\end{array}$ & Свед. А.С. Сыроватко. & $?$ & - & $?$ & - & + & - \\
\hline
\end{tabular}






3. Памятники по течению р. Озерны и по берегам оз. Тростенского

\begin{tabular}{|c|c|c|c|c|c|c|c|c|}
\hline 183 & Гор. Карасино & Виноградов К.Я., 1926. & 1500 & $60(1926)$ & 0,3 & - & + & + \\
\hline 184 & $\begin{array}{l}\text { Сел. Тростенская- } \\
\text { северная }\end{array}$ & $\begin{array}{l}\text { Сидоров В.В., 1968, 1969, } \\
1971 .\end{array}$ & 500 & 62 & 0,3 & - & + & + \\
\hline 185 & $\begin{array}{l}\text { Гор. } \\
\text { у с. Городище }\end{array}$ & $\begin{array}{l}\text { Виноградов К.Я., } 1925 . \\
\text { Сидоров В.В., } 1969 . \\
\text { Сидоров В.В., Балинский И.М., } \\
\text { 1973-1975. }\end{array}$ & 2500 & $\begin{array}{l}400(1969, \\
1973-1975)\end{array}$ & 0,3 & - & + & + \\
\hline 186 & Сел. Никольское-1 & Сидоров В.В., 1968-1971. & $?$ & - & $?$ & $?$ & $?$ & $?$ \\
\hline 188 & \begin{tabular}{|l|} 
Сел. Никольское-3 \\
(Никольское \\
Правое)
\end{tabular} & Сидоров В.В., 1972-1975. & $?$ & - & $?$ & $?$ & $?$ & $?$ \\
\hline 189 & Сел. Усть-Рассоха & Сидоров В.В., 1970, 1976. & 1200 & - & 0,3 & - & - & + \\
\hline 190 & \begin{tabular}{|l|} 
Сел. Нижнее \\
Сляднево \\
(«Мары») \\
\end{tabular} & $\begin{array}{l}\text { Виноградов К.Я., 1924, } 1926 . \\
\text { Сидоров,В.В., } 1976 . \\
\text { Розенфельдт Р.Л., } 1978 .\end{array}$ & $?$ & $14(1926)$ & 0,4 & - & + & + \\
\hline 192 & Гор. Темшинское & $\begin{array}{l}\text { Виноградов К.Я., } 1926 . \\
\text { Розенфельдт Р.Л., } 1960,1976 . \\
\text { Сотрудники Рузского музея, } \\
\text { 1970-е гг. } \\
\text { Янишевский Б.Е., Кренке Н.А., } \\
2000 . \\
\end{array}$ & 1500 & $3(1926)$ & 0,7 & - & + & + \\
\hline 193 & $\begin{array}{l}\text { Гор. } \\
\text { Михайловское }\end{array}$ & $\begin{array}{l}\text { Виноградов К.Я., } 1926 \\
\text { Розенфельдт Р.Л., 1956, } 1957 . \\
\text { Дубынин А.Ф., 1962. } \\
\text { Янишевский Б.Е., Кренке Н.А., } \\
2000 .\end{array}$ & 1400 & $\begin{array}{l}16(1926) \\
640 \\
(1957,1962)\end{array}$ & 0,4 & - & + & + \\
\hline
\end{tabular}









\begin{tabular}{|c|c|c|c|c|c|c|c|c|}
\hline № & Название & $\begin{array}{l}\text { Фамилия исследователя, } \\
\text { год обследования }\end{array}$ & $\begin{array}{l}\text { Площадь } \\
\text { поселения } \\
\text { (кв. м) }\end{array}$ & \begin{tabular}{|l} 
Раскопано \\
(кв. м), в \\
скобках - \\
год раскопок
\end{tabular} & $\begin{array}{l}\text { Средняя } \\
\text { толщина } \\
\text { слоя (м) }\end{array}$ & \multicolumn{3}{|l|}{ Находки } \\
\hline 216 & $\begin{array}{l}\text { Гор. «Дятлова } \\
\text { поляна» }\end{array}$ & $\begin{array}{l}\text { Смирнов К.А., } 1958 . \\
\text { Крис Х.И., } 1972 . \\
\text { Розенфельдт Р.Л., } 1975 .\end{array}$ & 1500 & - & 0,4 & - & + & + \\
\hline 218 & $\begin{array}{l}\text { Сел. } \\
\text { Степановское-3 }\end{array}$ & Гак Е.И., 2003 & $?$ & - & $?$ & - & + & $?$ \\
\hline 219 & $\begin{array}{l}\text { Сел. } \\
\text { Дмитровское-2 }\end{array}$ & $\begin{array}{l}\text { Гак Е.И., } 2003 \\
\text { Цыбин М.В., } 2007\end{array}$ & $?$ & 2 & 0,4 & + & + & $?$ \\
\hline \multicolumn{9}{|c|}{ 5. Памятники в бассейне р. Пахры } \\
\hline 285 & Гор. Клоково & $\begin{array}{l}\text { Миненко В.В., Кренке Н.А., } \\
2014\end{array}$ & 1000 & - & $?$ & - & + & + \\
\hline 222 & Сел. Десна & Станюкович А.К., 1978. & $?$ & раскопки & 0,1 & - & + & $+(?)$ \\
\hline 223 & Сел. Конаково & Розенфельдт Р.Л., 1978. & 1000 & - & $?$ & - & $-(?)$ & + \\
\hline 224 & Сел. Городок-1 & Гоняный М.И., 2008 & $?$ & раскопки & $?$ & - & - & + \\
\hline 283 & Гор. Красное & Миненко В.В., 2012, 2014 & 2000 & & ? & - & + & + \\
\hline 227 & Сел. Поливаново & Гоняный М.И., 1985 & $?$ & - & $?$ & - & $?$ & + \\
\hline 228 & Гор. Луковня-1 & $\begin{array}{l}\text { Богоявленский С.К., до } 1920 \text { г. } \\
\text { Розенфрельдт Р.Л., } 1962 . \\
\text { Юшко А.А., } 1968 . \\
\text { Векслер А.Г., 1968-1970, } 1973, \\
\text { 1975, 1976, } 1982 .\end{array}$ & 1200 & $\begin{array}{l}1050 \\
\text { (раскопки } \\
\text { Векслера) }\end{array}$ & 0,8 & - & + & + \\
\hline 229 & Гор. Луковня-2 & $\begin{array}{l}\text { Гоняный М.И., 1970-е гг, } 1992 . \\
\text { Розенфельдт Р.Л., } 1991 . \\
\text { Кренке Н.А., 1985, } 1987 .\end{array}$ & 950 & $\begin{array}{l}15 \\
(1985,1987)\end{array}$ & 0,2 & - & + & $?$ \\
\hline 230 & Сел. Лемешево-1 & $\begin{array}{l}\text { Розенфельдт Р.Л., } 1981 . \\
\text { Гоняный М.И., } 1990 .\end{array}$ & 500 & - & 0,2 & - & - & + \\
\hline 231 & Сел. Лемешево-3 & Гоняный М.И., 1990. & 1500 & - & $?$ & - & + & + \\
\hline 284 & Сел. Акишево-2 & & & & & & & \\
\hline 232 & Сел. Кутьино & Гоняный М.И., 1981. & $\begin{array}{l}\text { менее } \\
1000\end{array}$ & - & $?$ & - & - & + \\
\hline 233 & Гор. Роднево & $\begin{array}{l}\text { Розенфельдт Р.Л., 1961, } 1966, \\
1974 . \\
\text { Гоняный М.И., } 1992 .\end{array}$ & 1500 & $\begin{array}{l}0,5 \\
60(1992)\end{array}$ & 0,5 & - & + & + \\
\hline 234 & Гор. «Кузнечики» & $\begin{array}{l}\text { Богоявленский С.К., до } 1920 \text { г. } \\
\text { Дубынин А.Ф., 1963, } 1965 .\end{array}$ & 1300 & 1200 & 0,7 & - & + & + \\
\hline
\end{tabular}




\begin{tabular}{|c|c|c|c|c|c|c|c|c|}
\hline № & Название & $\begin{array}{l}\text { Фамилия исследователя, } \\
\text { год обследования }\end{array}$ & $\begin{array}{l}\text { Площадь } \\
\text { поселения } \\
\text { (кв. м) }\end{array}$ & $\begin{array}{l}\text { Раскопано } \\
\text { (кв. м), в } \\
\text { скобках - } \\
\text { год раскопок }\end{array}$ & $\begin{array}{l}\text { Средняя } \\
\text { толщина } \\
\text { слоя (м) }\end{array}$ & \multicolumn{3}{|l|}{ Находки } \\
\hline 236 & $\begin{array}{l}\text { Мест. } \\
\text { Ознобишино } \\
\text { (в насыпи кург } \\
\text { Ознобишино-1) }\end{array}$ & Гоняный М.И., 2005 & $?$ & раскопки & $?$ & - & - & + \\
\hline 237 & Сел. Дубровицы-3 & $\begin{array}{l}\text { Гоняный М.И., } 1981 . \\
\text { Гоняный М.И., Кренке Н.А., } \\
1985 .\end{array}$ & 1000 & - & $?$ & - & + & $?$ \\
\hline 238 & Сел. Дубровицы-2 & $\begin{array}{l}\text { Гоняный М.И., } \\
\text { Станюкович А.К., } 1981 . \\
\text { Гоняный М.И., 1990, } 1991 .\end{array}$ & Около 400 & $\begin{array}{l}176 \\
(1990,1991)\end{array}$ & До 1 м & + & + & - \\
\hline 240 & $\begin{array}{l}\text { Гор. Остафьево } \\
\text { (Рязаново) }\end{array}$ & $\begin{array}{l}\text { Кондратьев И.И., } 1989 . \\
\text { Гоняный М.И., } 1994 .\end{array}$ & $\begin{array}{l}\text { Около } \\
2000\end{array}$ & 56 & $?$ & - & + & + \\
\hline 241 & $\begin{array}{l}\text { Сел. Рыбино } \\
\text { (Ерино) }\end{array}$ & Гоняный М.И., 1983. & менее 800 & 4 (1983) & 0,2 & - & + & $+(?)$ \\
\hline 242 & Сел. Студенцы & Гоняный М.И., 1981, 1982. & менее 800 & 4 & 0,1 & - & + & $-(?)$ \\
\hline 243 & $\begin{array}{l}\text { Сел. Подолье } \\
\text { (г. Подольск) }\end{array}$ & Гоняный М.И., 1994. & $?$ & 189 & $?$ & - & + & - \\
\hline 244 & $\begin{array}{l}\text { Сел. (гор.?) } \\
\text { Борисово }\end{array}$ & $\begin{array}{l}\text { Юшко А.А., } 1967 . \\
\text { Кренке Н.А., } 1985 .\end{array}$ & 700 & $1(1985)$ & 0,4 & - & + & - \\
\hline 248 & Сел. Жданово-1 & Гоняный М.И., 1996. & $?$ & 344 & $?$ & - & - & + \\
\hline 249 & $\begin{array}{l}\text { Сел. Жданово-2 } \\
\text { (Добрятино) }\end{array}$ & Гоняный М.И., 1996. & $?$ & - & $?$ & - & $?$ & $?$ \\
\hline 250 & $\begin{array}{l}\text { Сел. Бяконтово } \\
\text { («Святой } \\
\text { колодец») }\end{array}$ & $\begin{array}{l}\text { Кренке Н.А., Лопатин Н.В., } \\
1985 .\end{array}$ & $?$ & 4 (1985) & 0,2 & - & + & + \\
\hline 251 & Сел. Конопелка-1 & Кренке Н.А., 1985. & $\begin{array}{l}\text { менее } \\
2000\end{array}$ & - & 0,2 & - & + & + \\
\hline 252 & Гор. Щербинское & $\begin{array}{l}\text { Керцелли Н.Г., до } 1876 \text { г. } \\
\text { Виноградов К.Я., } 1925 . \\
\text { Дубынин А.Ф., 1961, } 1963, \\
1964 . \\
\text { Александрова О.И., } \\
\text { Кренке Н.А., } 2007\end{array}$ & 1700 & $\begin{array}{l}72(1925) \\
1584(1961 \\
1963,1964)\end{array}$ & 0,8 & + & + & + \\
\hline 253 & $\begin{array}{l}\text { Сел. } \\
\text { Борисоглебское }\end{array}$ & Гоняный М.И., 2008. & $?$ & & & & & \\
\hline 254 & $\begin{array}{l}\text { Гор. } \\
\text { Борисоглебское }\end{array}$ & $\begin{array}{l}\text { Сотрудники Сухановского } \\
\text { музея, } 1923 . \\
\text { Розенфрельдт Р.Л., 1963, 1964, } \\
1974 .\end{array}$ & 1400 & 27,5 & 1,0 & - & + & + \\
\hline
\end{tabular}














\section{Приложение II}

\section{КАТАЛОГ РАДИОУГЛЕРОДНЫХ ДАТ ПО ПАМЯТНИКАМ НЕОЛИТА, БРОНЗОВОГО И ЖЕЛЕЗНОГО ВЕКОВ, СРЕДНЕВЕКОВЫХ, РАСПОЛОЖЕННЫХ В БАССЕЙНЕ МОСКВЫ-РЕКИ}

Дis атировки сгруппированы по памятникам. Полужирным шрифтом выделены даты, признанные соответствующими возрасту слоя, вмещавшего образцы, по которым они были получены. Курсивом даны даты, которые по техническим параметрам признаны малонадежными (сделаны с большим разбавлением образца, среднеквадратическое отклонение 250 и более лет), а также даты, относящиеся либо к средневековым объектам, располагавшимся на городищах железного века, либо, очевидно, более древние, чем время существования городищ, либо противоречащие массиву однородных датировок, полученных для того же объекта (слоя).

В списках дат по памятникам, раскопки которых проводились без участия автора, разделение дат на валидные и невалидные производилось не всегда. Датировки этих памятников даны обычным шрифтом.
Калибровка производилась по программе (версия 4.1) Вашингтонского университета (Stuiver, Raimer, 2000), а также по Оксфордской программе, версия 3,9 (Bronk, Ramsey, 2003).

AD - Anno Domini - наша эра; BC - Before Christ - до нашей эры

ГИН- Геологический институт РАН, Москва; ИГАН Институт географии РАН, Москва; Ле - ИИМК РАН, СанктПетербург; Кi - радиоуглеродная лаборатория Ин-та геохимии природной среды, Киев; GrN и GrA - лаборатория в Гронингене (Голландия); Hela - лаборатория университета в Хельсинки; UGAMS - лаборатория Университета штата Джорджия (США); UOC - лаборатория университета Оттава (Канада).

\section{1. НЕОЛИТИЧЕСКИЕ ПАМЯТНИКИ}

1-я Звенигородская стоянка, раскопки Н.А. Кренке, 2010 г.

\begin{tabular}{|c|c|c|c|c|}
\hline Возраст ${ }^{14} \mathrm{C}$ & $\begin{array}{l}\text { Лабораторный } \\
\text { номер }\end{array}$ & $\begin{array}{l}\text { Калиброванный } \\
\text { календарный возраст }\end{array}$ & Материал & $\begin{array}{l}\text { Место отбора образца (квадрат, } \\
\text { нивелировочная отметка в см, слой) }\end{array}$ \\
\hline $5370 \pm 30$ & UGAMS-7954 & $\begin{array}{l}4330-4290 \text { BC }(16,6 \%) \\
4260-4220 \text { BC }(24,2 \%) \\
4200-4160 \text { BC }(20,3 \%) \\
4130-4110 \text { BC }(4,8 \%) \\
4060-4050 \text { BC }(2,3 \%)\end{array}$ & нагар & $\begin{array}{l}\text { Звенигородская стоянка, со стенки горшка } \\
\text { льяловской культуры фррагм. № } 230\end{array}$ \\
\hline $4960 \pm 30$ & UGAMS-7955 & $3775-3700$ BC $(68,2 \%)$ & горелые орехи & $\begin{array}{l}\text { Почва } 4 \text { (культурный слой) кв. 10, } \\
\text { глубина -412-432 }\end{array}$ \\
\hline $4920 \pm 100$ & Ki-16752 & $\begin{array}{l}3910-3870 \text { BC }(6,3 \%) \\
3810-3630 \text { BC }(59,3 \%) \\
3560-3540 \text { BC }(2,6 \%)\end{array}$ & $\begin{array}{l}\text { Угли и углистая } \\
\text { масса }\end{array}$ & $\begin{array}{l}\text { Почва } 4 \text { (культурный слой), } \\
\text { глубина -489 }\end{array}$ \\
\hline $6030 \pm 110$ & Ki-16753 & $5060-4770$ BC $(68,2 \%)$ & гумус & $\begin{array}{l}\text { Почва } 4 \text { кв. В-8 вост. борт, } \\
\text { глубина }-480-500\end{array}$ \\
\hline $4750 \pm 140$ & Ki-16756 & $3670-3360$ BC $(68,2 \%)$ & гумус & $\begin{array}{l}\text { Почва 4а, кв. В-8 вост. борт, } \\
\text { глубина }-380-400\end{array}$ \\
\hline
\end{tabular}




\section{2. ПАМЯТНИКИ БРОНЗОВОГО ВЕКА}

\begin{tabular}{|c|c|c|c|c|}
\hline Возраст ${ }^{14} \mathrm{C}$ & $\begin{array}{l}\text { Лабораторный } \\
\text { номер }\end{array}$ & $\begin{array}{l}\text { Калиброванный } \\
\text { календарный возраст }\end{array}$ & Материал & $\begin{array}{l}\text { Место отбора образца (квадрат, } \\
\text { нивелировочная отметка в см, слой) }\end{array}$ \\
\hline \multicolumn{5}{|c|}{ Поселенческий объект Звенигородская биостанция (ЗБС-4), раскопки Н.А. Кренке, 2011, 2012 гг. } \\
\hline $3650 \pm 70$ & ГИН-14854 & $2140(68,2 \%) 1920$ & угли & $\begin{array}{l}\text { горизонт горелых камней шурф 1, кв. } 10 . \\
\text { Абашевская культура }\end{array}$ \\
\hline \multicolumn{5}{|c|}{ Поселенческий объект Звенигородская биостанция (ЗБС-5), раскопки Н.А. Кренке, 2012, 2013 гг. } \\
\hline $6980 \pm 50$ & ГИН-14969 & $\begin{array}{l}\text { 5970BC }(7,7 \%)-5950 \mathrm{BC} \\
\text { 5910BC }(60,5 \%)-5780 \mathrm{BC}\end{array}$ & почва & \begin{tabular}{|l|l} 
ЗБС-5 почва 4 шурф 1 (почва, поверх которой \\
залегали находки льяловские и протофратьяновские)
\end{tabular} \\
\hline $4114 \pm 38$ & UOS 3728 & $\begin{array}{l}2860(20,0 \%)-2810 \mathrm{BC} \\
2700(43,3 \%)-2580 \mathrm{BC}\end{array}$ & уголь & 2012 шурф 1 кв. 16 глубина -193 \\
\hline $4132 \pm 38$ & UOC-3730 & $2710(32,2 \%) 2620 \mathrm{BC}$ & уголь & 2012 шурф 1 кв. 8 глубина -170 \\
\hline \multicolumn{5}{|c|}{ Поселение РАНИС-пойма, раскопки Н.А. Кренке, А.В. Лазукина, 2005, 2006, 2009 гг. } \\
\hline $4100 \pm 25$ & UGAMS-7956 & $2670-2570$ BC (51,9 \%) & угли & РАНИС-2009. участок 5, очаг. глубина +81 \\
\hline $4118 \pm 35$ & Hela-2538 & $\begin{array}{l}2700-2620 \mathrm{BC} \\
(36,4 \%)\end{array}$ & угли & $\begin{array}{l}\text { РАНИС-2009 } \\
\text { Участок } 3+89 \text { образец № } 2 \text { очаг }\end{array}$ \\
\hline $4095 \pm 34$ & Hela-2537 & $2680-2570$ BC $(53,6 \%)$ & угли & РАНИС-2009 Участок 3 глубина +85 обр. № 3 очаг \\
\hline $4134 \pm 34$ & Hela-2536 & $2760-2630$ BC $(49,2 \%)$ & угли & $\begin{array}{l}\text { РАНИС-2009 } \\
\text { Участок } 5 \text { глубина +80 плашка в очаге } \\
\end{array}$ \\
\hline $4400 \pm 100$ & ГИН-137771 & $\begin{array}{l}3320-3230 \text { BC }(15 \%) \\
3180-3150 \text { BC }(22 \%) \\
3120-2900 \text { BC }(50,9 \%)\end{array}$ & гумус & $\begin{array}{l}\text { Почва } 3 \\
\text { Шурф } 3 \text {, северный борт. верх }+55 \text { +65, }\end{array}$ \\
\hline
\end{tabular}

\section{3. ПАМЯТНИКИ ЖЕЛЕЗНОГО ВЕКА}

\begin{tabular}{|c|c|c|c|c|}
\hline Возраст ${ }^{14} \mathrm{C}$ & $\begin{array}{l}\text { Лабораторный } \\
\text { номер }\end{array}$ & $\begin{array}{l}\text { Калиброванный } \\
\text { календарный возраст }\end{array}$ & Материал & $\begin{array}{l}\text { Место отбора образца (квадрат, } \\
\text { нивелировочная отметка в см, слой) }\end{array}$ \\
\hline \multicolumn{5}{|c|}{ Городище Троицкое, раскопки А.Ф. Дубынина, 1958 г.; Н.А. Кренке и Б.Е. Янишевского, 1996 г. } \\
\hline $1810 \pm 120$ & ГИН-11188 & AD $74(236) 383$ & $\begin{array}{l}\text { кость } \\
\text { человека }\end{array}$ & A-VI-3585 \\
\hline $2000 \pm 40$ & ГИН-8816 & BC 43 (BC 2, 4, 16) AD 54 & уголь & $\begin{array}{l}\text { разрез вала, западная стенка, кв. } 1 \text {-195, } \\
\text { основание насыпи }\end{array}$ \\
\hline $2090 \pm 130$ & ГИН-8815 & BC 354 (94) AD 54 & уголь & разрез вала, западная стенка, кв. 2, -160 \\
\hline $2280 \pm 100$ & ГИН-11187 & BC 404 (384) 202 & $\begin{array}{l}\text { кость } \\
\text { человека }\end{array}$ & A-VI-3585 \\
\hline
\end{tabular}














\begin{tabular}{|c|c|c|c|c|}
\hline Возраст ${ }^{14} \mathrm{C}$ & $\begin{array}{l}\text { Лабораторный } \\
\text { номер }\end{array}$ & $\begin{array}{l}\text { Калиброванный } \\
\text { календарный возраст }\end{array}$ & Материал & \begin{tabular}{|l|} 
Место отбора образца (квадрат, \\
нивелировочная отметка в см, слой)
\end{tabular} \\
\hline $2120 \pm 35$ & Hela-942 & BC 198 (167) 64 & $\begin{array}{l}\text { нагар на стенке } \\
\text { горшка }\end{array}$ & $\begin{array}{l}\text { кв. } 122 \text { (глубина -300-305); кв. } 123 \\
\text { (глубина -305-330); } \\
\text { кв. } 131 \text { (глубина -300-305) }\end{array}$ \\
\hline $2140 \pm 110$ & ГИН-3906 & BC $363(195,173) 3$ & уголь & $\begin{array}{l}\text { кв. 123, глубина -305-309, из профриля восточной } \\
\text { стенки }\end{array}$ \\
\hline $2150 \pm 80$ & ГИН-3187 & BC $357(197,190,176) 54$ & уголь & кв. 87, материк \\
\hline $2160 \pm 50$ & ГИН-3904 & BC $352(199,186,184) 119$ & уголь & $\begin{array}{l}\text { кв. } 117, \text { глубина }-400, \text { углистый } \\
\text { столбик }\end{array}$ \\
\hline $2170 \pm 60$ & ГИН-3183 & BC $357(200) 119$ & уголь & вал, кв. А-4, глубина -345 \\
\hline $2170 \pm 100$ & ГИН-4179 & BC $381(200) 54$ & уголь & кв. 137, глубина -195-200 \\
\hline $2180 \pm 50$ & ГИН-3181 & BC $357(342,324,202) 169$ & уголь & вал, средний ярус, глубина -190-200 \\
\hline $2180 \pm 250$ & ГИН-2779 & $\begin{array}{l}\text { BC } 499(342,324,202) A D \\
75\end{array}$ & уголь & $\begin{array}{l}\text { восточная половина раскопа, слой } 2, \\
\text { глубина }-250-290\end{array}$ \\
\hline $2200 \pm 200$ & ГИН-3470 & $\begin{array}{l}B C 408(349,318,228,221 \\
\text { 207) } A D 16\end{array}$ & уголь & кв. 145 , глубина $-127-133$ \\
\hline $2230 \pm 50$ & ГИН-2800 & $\begin{array}{l}\text { BC } 385(357,286,258,243, \\
234) 202\end{array}$ & уголь & кв. 6 , глубина -367, плашка \\
\hline $2230 \pm 50$ & ГИН-2792 & $\begin{array}{l}\text { BC } 385(357,286,258,243, \\
\text { 234) } 202\end{array}$ & кость & $\begin{array}{l}\text { кв. 25-27, глубина }-338-354, \text { из } \\
\text { коричневой органической } \\
\text { прослойки 3а }\end{array}$ \\
\hline $2240 \pm 180$ & ГИН-2907 & BC $479(360,273,260) 50$ & почва & $\begin{array}{l}\text { коричневая органическая прослойка, } \\
\text { разделявшая горизонты верхнего слоя, } \\
\text { глубина около }-240\end{array}$ \\
\hline $2240 \pm 50$ & ГИН-4021 & BC $388(360,273,260) 50$ & уголь & кв. 146, глубина -395, прослой угля с материка \\
\hline $2260 \pm 100$ & ГИН-3188 & BC $401(377,266,264) 183$ & уголь & $\begin{array}{l}\text { восточная половина раскопа, } \\
\text { сооружение в материке } \\
\end{array}$ \\
\hline $2290 \pm 130$ & ГИН-2781 & BC 479 (387) 183 & уголь & кв. 21-23, глубина -375-385 \\
\hline $2330 \pm 100$ & ГИН-2793 & BC $500(397) 234$ & кость & кв. 30, глубина -245-250 из вымостки \\
\hline $2330 \pm 100$ & ГИН-3182 & BC 500 (397) 234 & уголь & вал, нижний ярус, -300 \\
\hline $2370 \pm 60$ & ГИН-2796 & BC $502(403) 392$ & почва & $\begin{array}{l}\text { кв. 7, западная стенка, коричневая } \\
\text { органическая прослойка } 2\end{array}$ \\
\hline $2380 \pm 120$ & ГИН-3180 & BC $761(404) 264$ & уголь & вал, верхний ярус, глубина -170-190 \\
\hline $2380 \pm 30$ & ГИН-3185 & BC 475 (404) 399 & уголь & $\begin{array}{l}\text { вал, кв. А-5, глубина }-356-358, \\
\text { столбики }\end{array}$ \\
\hline $2390 \pm 70$ & ГИН-3910 & BC $756(406) 395$ & уголь & кв. 102,116 , глубина -375 , плаха \\
\hline $2390 \pm 100$ & ГИН-2797 & BC $760(406) 386$ & почва & кв. 7, западная стенка, КОП 3 \\
\hline $2510 \pm 60$ & ГИН-3913 & $\begin{array}{l}792(762,678,671,607 \\
602) 520\end{array}$ & уголь & $\begin{array}{l}\text { кв. } 149,156,157, \text { глубина }-360 \text {, «зола } 1 \text { », жилище, } \\
\text { плаха }\end{array}$ \\
\hline $2550 \pm 60$ & ГИН-2790 & BC 799 (786) 550 & уголь & $\begin{array}{l}\text { кв. 21-23, глубина -360-370, серая супесь под } \\
\text { коричневой органической прослойкой } 3\end{array}$ \\
\hline $2620 \pm 200$ & ГИН-3466 & BC 973 (801) 411 & уголь & кв. 143 , глубина -208, зола \\
\hline $2630 \pm 110$ & ГИН-3912 & BC 897 (802) 673 & уголь & кв. 133, глубина -390 , «зола 2» \\
\hline $2740 \pm 120$ & ГИН-3916 & $\begin{array}{l}\text { BC } 1005(896,875,862 \\
847,845) 800\end{array}$ & уголь & кв. $119,126,134$, глубина -263-265, плаха \\
\hline $2790 \pm 210$ & ГИН-2782 & $\begin{array}{l}\text { BC } 1259(966,964,921) \\
794\end{array}$ & уголь & кв. 45, глубина -295-297 \\
\hline $2870 \pm 300$ & ГИН-3905 & BC 1432 (1013) 791 & уголь & $\begin{array}{l}\text { кв. } 112-144, \text { доски из канавы } \\
\text { в материке }\end{array}$ \\
\hline $3740 \pm 400$ & ГИН-3465 & BC 2856 (2141) 1622 & уголь & кв. 166, глубина -244 \\
\hline $5200 \pm 500$ & ГИН-2787 & BC 4536 (3982) 3383 & уголь & кв. 21-23, глубина -360-370 \\
\hline $9250 \pm 79$ & ГИН-2780 & $\begin{array}{l}8602(8523,8508,8476) \\
8302\end{array}$ & уголь & кв. 45, глубина -280-288 \\
\hline
\end{tabular}

${ }^{1}$ Нивелировки на площадке отличаются от системы 1981 г. на 155 см (прибавлять +155 для перевода в систему 1981 г.), нивелировки рва сделаны в третьей системе. 


\begin{tabular}{|c|c|c|c|c|}
\hline Возраст ${ }^{14} \mathrm{C}$ & $\begin{array}{l}\text { Лабораторный } \\
\text { номер }\end{array}$ & $\begin{array}{l}\text { Калиброванный } \\
\text { календарный возраст }\end{array}$ & Материал & \begin{tabular}{|l} 
Место отбора образца (квадрат, \\
нивелировочная отметка в см, слой)
\end{tabular} \\
\hline \multicolumn{5}{|c|}{ Дьяково городище, раскопки А.Г. Векслера, 2001-2004 гг.1 } \\
\hline $1180 \pm 60$ & Ki-10426 & $776(885) 958$ & & Раскоп 1 \\
\hline $1500 \pm 50$ & ИАГН-2502 & AD 431 (596) 657 & уголь & ров, кв. 7-В, глубина -160 \\
\hline $1610 \pm 60$ & Ki-10434 & AD $395(428) 536$ & & ров, кв. 5Е, глубина -202-207, КОП с углем \\
\hline $1620 \pm 65$ & Ki-10419 & AD $384(425) 535$ & & $\begin{array}{l}\text { ров, кв. 3Е, глубина -220-230, серо-бурый } \\
\text { суглинок со щебнем }\end{array}$ \\
\hline $1630 \pm 60$ & Ki-10430 & AD 360 (421) 531 & & $\begin{array}{l}\text { ров, кв. 4/5-6 (Г-Е), глубина -221-260, серо- } \\
\text { бурый суглинок }\end{array}$ \\
\hline $1680 \pm 80$ & Ki-11996 & & $\Pi / \Pi$ & $\begin{array}{l}\text { Раскоп } 1 \text { на площадке, верхняя часть КС, } \\
\text { уг. } 1.13, \text { осн. }-100-105 \text { см }\end{array}$ \\
\hline $1710 \pm 60$ & Ki-10420 & $\begin{array}{l}\text { AD } 245(265,267,341,375) \\
414\end{array}$ & & ров, кв. 4Е, поверхность рыжей глины \\
\hline $1720 \pm 50$ & ИГАН-2678 & AD 252 (341) 407 & & кв. 4/5-6 (Г-Е) темно-бурая супесь, глубина -244 \\
\hline $1720 \pm 70$ & Ki -11696 & & & $\begin{array}{l}\text { Дьяково-въезд, раскоп 2, уг. } 3 \text { КС над горизонтом } \\
\text { А1 почвы }\end{array}$ \\
\hline $1730 \pm 110$ & ИГАН-2501 & AD $248(268,274,334) 398$ & & ров, кв. А-5, глубина $-190-200$ \\
\hline $1735 \pm 60$ & Ki-10421 & $\begin{array}{l}\text { AD } 239(261,279,293,296 \\
323) 394\end{array}$ & & ров, кв. 1-4 (Г-Е), серая глина \\
\hline $1800 \pm$ & Ki-11700 & & уголь & $\begin{array}{l}\text { Раскоп } 1 \text { на площадке, А10, край очага, }-275- \\
280\end{array}$ \\
\hline $1820 \pm 30$ & ИГАН-2680 & AD $145(230) 245$ & & $\begin{array}{l}\text { ров, темно-бурая супесь с углями, } \\
\text { глубина -200-220 }\end{array}$ \\
\hline $1820 \pm 45$ & Ki-11225 & AD $130(223) 244$ & уголь & кв. 8/Б, глубина -137-150 \\
\hline $1840 \pm 45$ & Ki-11224 & $\begin{array}{l}\text { AD } 92(134,159,170,196, \\
\text { 209) } 240\end{array}$ & уголь & кв. 7/6, глубина -137-150 \\
\hline $1850 \pm 30$ & ИГАН-2679 & AD $129(146,190) 231$ & & $\begin{array}{l}\text { ров, 4/5-6 (Г-Е), бурая супесь, } \\
\text { глубина }-212-222\end{array}$ \\
\hline $1860 \pm 60$ & Ki-10550 & AD 78 (131) 238 & уголь & $\begin{array}{l}\text { ров, кв. 5-10, линия Г-Е, глубина -128-233, } \\
\text { 170-265, обожженная глина }\end{array}$ \\
\hline $1860 \pm 60$ & Ki-10423 & AD 78 (131) 238 & & $\begin{array}{l}\text { ров, кв. 4/5-6, (Г-Е), основание серо-бурого } \\
\text { суглинка }\end{array}$ \\
\hline $1860 \pm 60$ & Ki-10433 & AD 78 (131) 238 & & ров, глубина -220, серо-бурый суглинок \\
\hline $1870 \pm 50$ & Ki-11218 & AD 78 (129) 225 & уголь & кв. ВГ-ІІІ, глубина -291-301 \\
\hline $1890 \pm 60$ & Ki- 10429 & AD $34(91,98,126) 217$ & & $\begin{array}{l}\text { ров, кв. 5Г, глубина }-259, \\
\text { серо-бурый суглинок }\end{array}$ \\
\hline $1920 \pm 70$ & Ki-11698 & & гор-т А1 почвы & $\begin{array}{l}\text { Дьяково-въезд, раскоп 2, углист. } \\
\text { гор-т } 1 \text { под маломощным КС }\end{array}$ \\
\hline $1980 \pm 60$ & Ki-10418 & BC 43 (AD 25, 43, 47) AD 79 & & $\begin{array}{l}\text { ров, кв. } 2 \text { E, глубина }-203, \\
\text { серо-бурый суглинок со щебнем }\end{array}$ \\
\hline $2050 \pm 60$ & Ki-11686 & & & $\begin{array}{l}\text { Раскоп } 1 \text { на площадке, А10, уг. пр. } \\
\text { глубина -239-241 }\end{array}$ \\
\hline
\end{tabular}




\begin{tabular}{|c|c|c|c|c|}
\hline Возраст ${ }^{14} \mathrm{C}$ & $\begin{array}{l}\text { Лабораторный } \\
\text { номер }\end{array}$ & $\begin{array}{l}\text { Калиброванный } \\
\text { календарный возраст }\end{array}$ & Материал & $\begin{array}{l}\text { Место отбора образца (квадрат, } \\
\text { нивелировочная отметка в см, слой) }\end{array}$ \\
\hline $2080 \pm 60$ & Ki-11684 & & & $\begin{array}{l}\text { Раскоп } 1 \text { на площадке, А6, уг. пр. над пов. КОП, } \\
\text { глубина -215 }\end{array}$ \\
\hline $2090 \pm 100$ & Ki-11997 & & & Раскоп 1 на площадке, A7, -255-260 \\
\hline $2110 \pm 60$ & Ki-11685 & & & $\begin{array}{l}\text { Раскоп } 1 \text { на площадке А5, уг. и тлен под св-желт. } \\
\text { суп, -243-248 }\end{array}$ \\
\hline $2120 \pm 50$ & Ki-11220 & BC 201 (167) 54 & уголь & кв. 2А, глубина - 255-260 \\
\hline $2140 \pm 70$ & Ki-10548 & BC $352(195,173) 54$ & уголь & нижний слой, кв. ЗГ, глубина -315 \\
\hline $2180 \pm 30$ & ИГАН-2925 & BC $352(342,324,202) 174$ & почва & $\begin{array}{l}\text { нижняя коричневая органическая прослойка, } \\
\text { глубина -275-285 }\end{array}$ \\
\hline $2200 \pm 75$ & Ki-10556 & $\begin{array}{l}\text { BC } 383(349,318,228,221 \\
\text { 207) } 168\end{array}$ & уголь & нижний слой, КОП, глубина -275-285 \\
\hline $2250 \pm 60$ & Ki-10424 & BC $393(363,269,262) 204$ & & ров, кв. 4Е, серо-бурый суглинок \\
\hline $2260 \pm 50$ & Ki-11694 & & & $\begin{array}{l}\text { Раскоп } 1 \text { на площадке, А6, просл. уг. над песком, } \\
\text { глубина -205 }\end{array}$ \\
\hline $2260 \pm 50$ & Ki-11694 (?-HK) & & & $\begin{array}{l}\text { Раскоп } 1 \text { на площадке, A7, } \\
\text { основание КОП 2, глубина -280 }\end{array}$ \\
\hline $2270 \pm 60$ & Ki-10547 & BC 397 (380) 209 & уголь & $\begin{array}{l}\text { погребенная почва, кв. 4A, } \\
\text { глубина -325-350 }\end{array}$ \\
\hline $2270 \pm 45$ & Ki-11221 & BC 395 (380) 214 & уголь & кв. 1A-1Б \\
\hline $2305 \pm 80$ & Ki-11701 & & & $\begin{array}{l}\text { Дьяково-въезд, раскоп 2, уг. } 4 \text {, } \\
\text { засыпка в трещины культурного слоя между } \\
\text { блоками }\end{array}$ \\
\hline $2310 \pm 70$ & Ki-10553 & BC 404 (393 ) 260 & уголь & нижний слой, кв. 2Г, глубина -315 \\
\hline $2340 \pm 60$ & Ki- 10551 & BC 408 (398) 383 & уголь & $\begin{array}{l}\text { погребенная почва, кв. 1F, } \\
\text { глубина -315-325 }\end{array}$ \\
\hline $2340 \pm 60$ & Ki-10554 & BC 408 (398) 383 & уголь & $\begin{array}{l}\text { погребенная почва, кв. 3Г, } \\
\text { глубина -337-340 }\end{array}$ \\
\hline $2380 \pm 45$ & Ki-11222 & BC $482(404) 397$ & уголь & кв. $1 \mathrm{~A}$ \\
\hline $2380 \pm 80$ & Ki-12007 & & карбонаты & $\begin{array}{l}\text { Раскоп } 1 \text { на площадке, зола } \\
\text { между КОП } 1 \text { и КОП } 2\end{array}$ \\
\hline $2400 \pm 60$ & Ki-10552 & BC 756 (408) 398 & уголь & $\begin{array}{l}\text { погребенная почва, кв. 4A, } \\
\text { глубина -330 }\end{array}$ \\
\hline $2410 \pm 30$ & ИГАН-2682 & BC 513 (409) 403 & уголь & 2ВГ, горелая плаха, -327, раскоп 1 \\
\hline $2410 \pm 30$ & ИГАН-2926 & BC 513 (409) 403 & уголь & $\begin{array}{l}\text { основание культурного слоя, } \\
\text { глубина 3,5 м }\end{array}$ \\
\hline $2430 \pm 50$ & Ki-12021 & & уголь & Раскоп 1 на площадке, слой серого суглинка \\
\hline $2430 \pm 80$ & Ki-10555 & \begin{tabular}{|l|} 
BC $762(498,493,483,465$ \\
$449,441,426,424,413) 400$
\end{tabular} & уголь & $\begin{array}{l}\text { погребенная почва, кв. 3В, } \\
\text { глубина -319 }\end{array}$ \\
\hline $2450 \pm 45$ & Ki-11223 & BC $760(536,532,520) 408$ & уголь & раскоп 2003 г. \\
\hline $2460 \pm 70$ & Ki-10546 & $\begin{array}{l}\text { BC } 765(756,716,711,704 \\
539,528,523) 406\end{array}$ & почва & $\begin{array}{l}\text { погребенная почва, кв. ЗА/Б, } \\
\text { глубин -341 }\end{array}$ \\
\hline $2480 \pm 70$ & Ki-10545 & $\begin{array}{l}\text { BC } 787(758,684,660,645 \\
586,584,543) 409\end{array}$ & уголь & $\begin{array}{l}\text { погребенная почва, кв. 2Г, } \\
\text { глубина }-325\end{array}$ \\
\hline $2480 \pm 70$ & Ki-10549 & $\begin{array}{l}\text { BC } 787(758,684,660,645 \\
586,584,543) 409\end{array}$ & уголь & $\begin{array}{l}\text { погребенная почва, кв. 2А, } \\
\text { глубина -332 }\end{array}$ \\
\hline $2520 \pm 50$ & Ki-11693 & & уголь & $\begin{array}{l}\text { Дьяково-въезд, западная } \\
\text { прирезка к траншее } 1\end{array}$ \\
\hline $2530 \pm 50$ & Ki-12022 & & уголь & $\begin{array}{l}\text { Раскоп } 1 \text { на площадке, слой } \\
\text { серого суглинка }\end{array}$ \\
\hline $2630 \pm 30$ & ИГАН-2683 & BC 810 (803) 796 & уголь & $\begin{array}{l}\text { 2А, серый суглинок, плахи, } \\
\text { глубина -325, раскоп } 1\end{array}$ \\
\hline $2990 \pm 70$ & Ki-12017 & & почва & $\begin{array}{l}\text { Раскоп } 1 \text { на площадке, переход } \\
\text { от почвы к серому слою }\end{array}$ \\
\hline $5190 \pm 100$ & Ki-12011 & & почва & $\begin{array}{l}\text { Раскоп } 1 \text { на площадке, почва } \\
\text { под КС, В1h }\end{array}$ \\
\hline
\end{tabular}









\begin{tabular}{|c|c|c|c|c|}
\hline Возраст ${ }^{14} \mathrm{C}$ & $\begin{array}{l}\text { Лабораторный } \\
\text { номер }\end{array}$ & $\begin{array}{l}\text { Калиброванный } \\
\text { календарный возраст }\end{array}$ & Материал & $\begin{array}{l}\text { Место отбора образца (квадрат, } \\
\text { нивелировочная отметка в см, слой) }\end{array}$ \\
\hline $3150 \pm 200$ & ГИН-8461 & $\begin{array}{l}B C 1679(1426,1420,1414) \\
1130\end{array}$ & уголь & вал, кв. 13, глубина 60 см от поверхности \\
\hline \multicolumn{5}{|c|}{ Городище Боровский курган, раскопки Н.А. Кренке, 2004 г. } \\
\hline $2170 \pm 60$ & Ki-12511 & BC $357(200) 119$ & уголь & $\begin{array}{l}\text { зачистка восточного борта } \\
\text { выемки, глубина от поверхности 110-120 см, низ } \\
\text { верхнего слоя. }\end{array}$ \\
\hline \multicolumn{5}{|c|}{ Городище Селецкое, раскопки И.Л. Черная, 1975-1978 гг. } \\
\hline $2160 \pm 30$ & ГИН-4775 & BC $348(199,186,184) 169$ & уголь & Участок С1, слой 3, основание \\
\hline $2570 \pm 60$ & ГИН-4774 & BC 802 (791) 600 & уголь & Участок С1, слой 6 \\
\hline \multicolumn{5}{|c|}{ Городище Настасьино, раскопки А.В. Энговатовой, 1998-2000 гг. (по Энговатовой, 2004) } \\
\hline $505 \pm 18$ & Лe-5896 & AD $1414(1423) 1434$ & уголь & Горн, кв. R/F -5-6 \\
\hline $590 \pm 40$ & ГИН-10533 & $\begin{array}{l}\text { AD } 1304(1329,1343,1395) \\
1406\end{array}$ & уголь & Раскоп 2, кв. А-21, глубина -137 \\
\hline $640 \pm 40$ & ГИН-10534 & $\begin{array}{l}\text { AD } 1295(1302,1369,1382) \\
1393\end{array}$ & уголь & Раскоп 2, кв. А-22, глубина -165-179 \\
\hline $1000 \pm 20$ & Лe-5797 & AD $1017(1021) 1026$ & уголь & Кв. Б-1, яма № 6 \\
\hline $1900 \pm 60$ & Лe-5893 & AD $31(86,102,122) 210$ & уголь & $\begin{array}{l}\text { Постройка, раскоп 6, кв. Ж/3-6, пласт 9б, } \\
\text { глубина -175 }\end{array}$ \\
\hline $1920 \pm 90$ & ГИН-10519 & BC 36 (AD 78) AD 216 & уголь & Раскоп 1, кв. А-3, пласт XII \\
\hline $1960 \pm 120$ & ГИН-10522 & $\begin{array}{l}\text { BC } 91(\text { AD 31, 38, 53) AD } \\
209\end{array}$ & $\begin{array}{l}\text { древесный } \\
\text { тлен }\end{array}$ & $\begin{array}{l}\text { Раскоп 1, постройка 1, кв. В-7, } \\
\text { глубина -73 }\end{array}$ \\
\hline $1970 \pm 110$ & ГИН-10530 & $\begin{array}{l}\text { BC } 91(\text { AD 28, 41, 50) AD } \\
131\end{array}$ & грунт & Раскоп 4, кв. Л-21, МН-20 \\
\hline $1980 \pm 25$ & Лe-5883 & BC 17 (AD 25, 43, 47) AD 58 & уголь & $\begin{array}{l}\text { Раскоп 6, кв. Д-9, 10, пласт 6а, } \\
\text { глубина -89-91 }\end{array}$ \\
\hline $1980 \pm 35$ & Лe-5892 & BC 37 (AD 25, 43, 47) AD 68 & уголь & $\begin{array}{l}\text { Раскоп 6, кв. Е-9, пласт 7б, } \\
\text { глубина -122, у очага }\end{array}$ \\
\hline $2020 \pm 65$ & Лe-5882 & BC $90(46) 1$ & уголь & $\begin{array}{l}\text { Раскоп 6, кв. И-9, пласт 5б, } \\
\text { глубина -155 }\end{array}$ \\
\hline $2050 \pm 25$ & Ле-5889 & BC $94(85,84,52) 5$ & уголь & $\begin{array}{l}\text { Раскоп 6, кв. Е-10, пласт 7a, } \\
\text { глубина -109 } \\
\end{array}$ \\
\hline $2065 \pm 20$ & Лe-5898 & BC $168(94) 49$ & уголь & $\begin{array}{l}\text { Яма 113, раскоп 5, кв. Г-3, } \\
\text { глубина -50 }\end{array}$ \\
\hline $2090 \pm 30$ & ГИН-10518 & BC $166(94) 51$ & грунт & $\begin{array}{l}\text { Раскоп 1, яма на валу, кв. Б-4 } \\
\text { глубина } 60 \text { см }\end{array}$ \\
\hline $2090 \pm 25$ & Лe-5887 & BC 167 (108) 55 & уголь & $\begin{array}{l}\text { Раскоп 6, кв. Е-10, пласт 7а, } \\
\text { глубина -112 }\end{array}$ \\
\hline $2095 \pm 20$ & Лe-5888 & BC 167 (108) 55 & уголь & $\begin{array}{l}\text { Вал, раскоп 6, кв. 3-04, пласт 8б, } \\
\text { глубина -203-208 }\end{array}$ \\
\hline $2100 \pm 90$ & ГИН-10523 & BC $347(146,142,113)$ AD 1 & грунт & $\begin{array}{l}\text { Раскоп 1, Постройка 1, кв. А-6, } \\
\text { глубина -63 }\end{array}$ \\
\hline $2100 \pm 30$ & Лe-5884 & BC $171(146,142,113) 53$ & уголь & $\begin{array}{l}\text { Раскоп 6, кв. Ж-8, пласт 5б, } \\
\text { глубина -131 }\end{array}$ \\
\hline $2135 \pm 20$ & Лe-5897 & BC 198 (171) 121 & уголь & $\begin{array}{l}\text { Вал, раскоп 6, кв. Ц/Ч-8, } \\
\text { глубина -50 }\end{array}$ \\
\hline $2150 \pm 80$ & Лe-5881 & BC $357(197,190,176) 54$ & почва & Очаг, раскоп 6, кв. 3-10, пласт 5а, глубина -125 \\
\hline $2190 \pm 65$ & Лe-5886 & $\begin{array}{l}\text { BC } 376(347,321,227,223, \\
\text { 204) } 168\end{array}$ & уголь & $\begin{array}{l}\text { Раскоп 6, кв. Д-2, пласт 8б, } \\
\text { глубина -153 }\end{array}$ \\
\hline $2190 \pm 120$ & ГИН- 10536 & $\begin{array}{l}\text { BC } 393(347,321,227,223 \\
\text { 204) } 54\end{array}$ & грунт & $\begin{array}{l}\text { Раскоп 4, кв. К-21, } \\
\text { глубина -148 }\end{array}$ \\
\hline $2200 \pm 300$ & Лe-5806 & $\begin{array}{l}\text { BC } 761(349,318,228,221 \\
\text { 207) AD } 122\end{array}$ & уголь & Кв. 3-16, пласт 4а \\
\hline $2220 \pm 100$ & Лe-5807 & $\begin{array}{l}\text { BC } 396(354,291,256,251, \\
232,217,213) 167\end{array}$ & уголь & Раскоп 4 \\
\hline $2230 \pm 40$ & Ле-5880 & $\begin{array}{l}\text { BC } 381(357,286,258,243, \\
\text { 234) } 204\end{array}$ & уголь & $\begin{array}{l}\text { Вал, раскоп 6, кв. А-5, } \\
\text { глубина -73 }\end{array}$ \\
\hline
\end{tabular}




\begin{tabular}{|c|c|c|c|c|}
\hline Возраст ${ }^{14} \mathrm{C}$ & $\begin{array}{l}\text { Лабораторный } \\
\text { номер }\end{array}$ & $\begin{array}{l}\text { Калиброванный } \\
\text { календарный возраст }\end{array}$ & Материал & $\begin{array}{l}\text { Место отбора образца (квадрат, } \\
\text { нивелировочная отметка в см, слой) }\end{array}$ \\
\hline $2240 \pm 70$ & ГИН-10525 & BC $393(360,273,260) 200$ & уголь & $\begin{array}{l}\text { Раскоп 1, кв. А-4, } \\
\text { глубина }-100-110\end{array}$ \\
\hline $2260 \pm 60$ & Ле-5895а & BC $396(377,266,264) 206$ & уголь & $\begin{array}{l}\text { Постройка, раскоп } 6, \text { кв. E-9, } \\
\text { пласт } 86, \text { глубина }-128\end{array}$ \\
\hline $2300 \pm 120$ & Лe-5885 & BC $479(390) 202$ & почва & $\begin{array}{l}\text { Раскоп 6, кв. Е-6, пласт 6б, } \\
\text { глубина -118 }\end{array}$ \\
\hline $2370 \pm 80$ & Лe-5799а & BC 537 (403) 386 & уголь & Кв. М-19, пласт 4, глубина -173 \\
\hline $2390 \pm 150$ & ГИН-10524 & BC 780 (406) 260 & грунт & Раскоп 1, кв. Б/В-12, глубина -80 \\
\hline $2460 \pm 80$ & Лe-5899 & $\begin{array}{l}\text { BC } 781(756,716,711,704 \\
539,528,523) 404\end{array}$ & почва & $\begin{array}{l}\text { Яма 198, раскоп 5, кв. Д-20, } \\
\text { глубина -96 }\end{array}$ \\
\hline $2620 \pm 120$ & ГИН-10537 & BC 897 (801) 564 & уголь & Раскоп IV, пласт VI \\
\hline $2630 \pm 150$ & ГИН-10532 & BC 918 (802) 543 & уголь & $\begin{array}{l}\text { Раскоп 3, кв. Л-18, } \\
\text { глубина -158-164 }\end{array}$ \\
\hline $2630 \pm 180$ & Лe-5895 & BC $971(802) 520$ & & $\begin{array}{l}\text { Раскоп 6, кв. Е-9, пласт 8б, } \\
\text { глубина -128 }\end{array}$ \\
\hline $2630 \pm 140$ & ГИН-10535 & BC 905 (802) 552 & уголь & $\begin{array}{l}\text { Раскоп 3, кв. К-16, } \\
\text { глубина -148-155 }\end{array}$ \\
\hline $2680 \pm 180$ & Лe-5802 & BC 1005 (826) 564 & уголь & Раскоп 3, пласт 7б, кв. E-12 \\
\hline $2740 \pm 100$ & Лe-5805 & $\begin{array}{l}\text { BC } 1000(896,875,862, \\
847,845) 804\end{array}$ & уголь & Раскоп 3, глубина -163-171 \\
\hline \multicolumn{5}{|c|}{ Городище Городна, раскопки А.С. Сыроватко, 2009 г. } \\
\hline $2040 \pm 25$ & ГИН-12721в & $60 \mathrm{BC}(58,0 \%) 5 \mathrm{AD}$ & уголь & $\begin{array}{l}\text { Шурф 3, прослойка под слоем } \\
\text { прокаленной глины }\end{array}$ \\
\hline $2580 \pm 60$ & ГИН-13293 & $840 \mathrm{BC}(93,3 \%) 510 \mathrm{BC}$ & уголь & Шурф 3, прослойка в основании слоя \\
\hline $2360 \pm 50$ & ГИН-13540 & $520 \mathrm{BC}(66,9 \%) 380 \mathrm{BC}$ & уголь & Насыпь вала \\
\hline $2180 \pm 70$ & гИН-13541 & $370 \mathrm{BC}(66,6 \%) 160 \mathrm{BC}$ & уголь & Насыпь вала \\
\hline $2070 \pm 40$ & ГИН-13542 & $120 \mathrm{BC}(51,6 \%) 40 \mathrm{BC}$ & уголь & Насыпь вала \\
\hline \multicolumn{5}{|c|}{ Городище у села Городищи, раскопки А.С. Сыроватко 1996-1998 гг. } \\
\hline $1860 \pm 40$ & ГИН-9409 & AD $84(131) 226$ & уголь & $\begin{array}{l}\text { слой заполнения рва, кв. 11, } \\
\text { глубина -304 }\end{array}$ \\
\hline $1950 \pm 40$ & ГИН-9427 & AD $4(34,36,61) 117$ & уголь & врезка 2 \\
\hline $1980 \pm 100$ & ГИН-9408 & $\begin{array}{l}\text { BC } 91(A D 25,43,47) A D \\
128\end{array}$ & уголь & слой насыпи вала, кв. 7 \\
\hline $2060 \pm 40$ & ГИН-9426а & BC $150(50) 1$ & уголь & $\begin{array}{l}\text { слой угля под прокаленной } \\
\text { глиной }\end{array}$ \\
\hline $2100 \pm 100$ & ГИН-9407 & $\begin{array}{l}\text { BC } 350(146,142,113) A D \\
16\end{array}$ & уголь & $\begin{array}{l}\text { слой насыпи вала, кв. } 7,8, \\
\text { глубина -57 }\end{array}$ \\
\hline $2150 \pm 40$ & гИН-9426 & BC $348(197,190,176) 119$ & уголь & основание насыпи вала \\
\hline
\end{tabular}




\begin{tabular}{|c|c|c|c|c|}
\hline Возраст ${ }^{14} \mathrm{C}$ & $\begin{array}{l}\text { Лабораторный } \\
\text { номер }\end{array}$ & $\begin{array}{l}\text { Калиброванный } \\
\text { календарный возраст }\end{array}$ & Материал & $\begin{array}{l}\text { Место отбора образца (квадрат, } \\
\text { нивелировочная отметка в см, слой) }\end{array}$ \\
\hline $2250 \pm 40$ & ГИН-9427а & BC $388(363,369,362) 209$ & уголь & $\begin{array}{l}\text { слой угля под прокаленной } \\
\text { глиной }\end{array}$ \\
\hline \multicolumn{5}{|c|}{ Городище Луковня 1, раскопки А.Г. Векслера, 1982 г. } \\
\hline $2000 \pm 30$ & ГИН-3210 & BC $60-80$ AD $(95,4 \%)$ & уголь & \\
\hline $2240 \pm 80$ & ГИН-5450 & BC $396(360,273,260) 182$ & уголь & $\begin{array}{l}\text { Внешний вал, конструкция } \\
\text { в основании, глубина -168-170 }\end{array}$ \\
\hline $2240 \pm 50$ & ГИН-5447 & BC $388(360,273,260) 182$ & уголь & $\begin{array}{l}\text { Внешний вал, верхний горизонт } \\
\text { углей, глубина }-112-125\end{array}$ \\
\hline $2090 \pm 30$ & ГИН-6595 & BC $168(94) 49$ & кость & Пласт 3 \\
\hline $2160 \pm 40$ & ГИН-7169 & BC $350(199,186,184) 124$ & \begin{tabular}{|l} 
кость \\
(метаподий \\
лося)
\end{tabular} & Пласт 4 \\
\hline $2160 \pm 60$ & ГИН-7168 & BC $354(199,186,184) 112$ & $\begin{array}{l}\text { кость } \\
\text { (лопатка КРС) }\end{array}$ & Пласт 1 \\
\hline $2270 \pm 60$ & ГИН-6596 & BC 397 (380) 209 & кость & Пласт 4 \\
\hline $2300 \pm 40$ & ГИН-7171 & BC 399 (390) 264 & \begin{tabular}{|l|} 
кость \\
(метаподий \\
лося) \\
\end{tabular} & Пласт 6 \\
\hline $2300 \pm 50$ & ГИН-7170 & BC 400 (390) 262 & \begin{tabular}{|l} 
кость \\
(метаподий \\
лошади)
\end{tabular} & Пласт 5 \\
\hline \multicolumn{5}{|c|}{ Селище Бяконтово (Святой колодец), раскопки Н.А. Кренке, Н.В. Лопатина, 1985 г. } \\
\hline
\end{tabular}

\section{4. СРЕДНЕВЕКОВЫЕ ПАМЯТНИКИ}

\begin{tabular}{|c|c|c|c|c|}
\hline Возраст ${ }^{14} \mathrm{C}$ & $\begin{array}{l}\text { Лабораторный } \\
\text { номер }\end{array}$ & $\begin{array}{l}\text { Калиброванный } \\
\text { календарный возраст }\end{array}$ & Материал & $\begin{array}{l}\text { Место отбора образца (квадрат, } \\
\text { нивелировочная отметка в см, слой) }\end{array}$ \\
\hline \multicolumn{5}{|c|}{ Селище Саввино-Сторожевское-2, раскопки А.К.Станюковича 1997-1999 гг. } \\
\hline $1240 \pm 90$ & ГИН-9656 & AD $673(776) 892$ & уголь & Постройка 3 \\
\hline $1250 \pm 70$ & ГИН-9655 & AD $681(775) 886$ & уголь & Постройка 3, основание \\
\hline $1460 \pm 40$ & ГИН-10845 & AD $561(605,610,616) 644$ & уголь & Постройка 5 \\
\hline $1520 \pm 140$ & ГИН-9653 & AD 406 (542) 658 & уголь & Постройка 3 \\
\hline $1600 \pm 210$ & ГИН-9652 & AD 235 (430) 656 & уголь & развал очага на дне ямы 10 \\
\hline $1670 \pm 100$ & ГИН-9654 & AD 245 (397) 530 & уголь & Постройка 3, основание \\
\hline $1830 \pm 70$ & ГИН-12726 & AD 119 (222) 319 & уголь & Раскоп 1, постройка 5 \\
\hline \multicolumn{5}{|c|}{ Селище Хотяжи 1, раскопки Н.А. Кренке, А.В. Лазукина, 2009 г. } \\
\hline $1420 \pm 50$ & ГИН-14238 & $595(67,2 \%) 665$ AD & уголь & Раскоп 2 , дно ямы 1 глубина -399 \\
\hline
\end{tabular}




\begin{tabular}{|c|c|c|c|c|}
\hline Возраст ${ }^{14} \mathrm{C}$ & $\begin{array}{l}\text { Лабораторный } \\
\text { номер }\end{array}$ & $\begin{array}{l}\text { Калиброванный } \\
\text { календарный возраст }\end{array}$ & Материал & $\begin{array}{l}\text { Место отбора образца (квадрат, } \\
\text { нивелировочная отметка в см, слой) }\end{array}$ \\
\hline \multicolumn{5}{|c|}{ Селище Хотяжи 1, раскопки Н.А. Кренке и А.В. Лазукина, 2009, 2013 гг. } \\
\hline $1420 \pm 50$ & ГИН-14238 & $595(67,2 \%) 665$ AD & уголь & раскоп 2, дно ямы 1 глубина -399 \\
\hline $967 \pm 24$ & UOC-6371 & $\begin{array}{l}1020(26,8 \%) 1050 \mathrm{AD} \\
1090(24,4 \%) 1120 \mathrm{AD} \\
1140(17 \%) 1160 \mathrm{AD}\end{array}$ & уголь & раскоп 1, яма 1 \\
\hline $1280 \pm 50$ & ГИН 15002 & $\begin{array}{l}670-780(68,2 \%) \text { AD } \\
650-890(95,4 \%)\end{array}$ & уголь & раскоп 1, яма 51 \\
\hline \multicolumn{5}{|c|}{ Селище Царицыно-2, раскопки Н.А. Кренке, В.С. Нефёдова, 2004, 2008 гг. } \\
\hline $1270 \pm 60$ & ГИН-14211 & $650(95,4 \%) 900 \mathrm{AD}$ & уголь & Яма 2, низ заполнения \\
\hline \multicolumn{5}{|c|}{ Романов двор в Москве, раскопки Н.А. Кренке, 1996-2002 гг. } \\
\hline $1000 \pm 40$ & ГИН-9575 & $992(68,2 \%) 1146 \mathrm{AD}$ & уголь & Постройка в раскопе 1998 г. \\
\hline $730 \pm 40$ & ГИН-9577 & $1260(68,2 \%) 1282 \mathrm{AD}$ & уголь & Постройка в раскопе 1998 г. \\
\hline $870 \pm 40$ & ГИН-9581 & $1045(68,2 \%) 1218 \mathrm{AD}$ & уголь & Постройка в раскопе 1998 г. \\
\hline $680 \pm 70$ & ГИН-11829 & $1278(68,2 \%) 1390 \mathrm{AD}$ & уголь & $\begin{array}{l}\text { Углистое пятно, прорезанное } \\
\text { бороздами распашки XIII-XIV вв. Раскоп 6, кв. } 79\end{array}$ \\
\hline $670 \pm 30$ & ГИН-11830 & $1289(68,2 \%) 1382 \mathrm{AD}$ & уголь & Яма 3, раскоп 6, кв. 78 \\
\hline $910 \pm 40$ & ГИН-11957 & $1037(68,2 \%) 1206 \mathrm{AD}$ & уголь & Яма 8, раскоп 7, кв. 92 \\
\hline $890 \pm 50$ & ГИН-11956 & $1040(68,2 \%) 1216 \mathrm{AD}$ & уголь & Яма 7, раскоп, 7 кв. 102 \\
\hline $815 \pm 25$ & Ki-14278 & $1216(68,2 \%) 1260 \mathrm{AD}$ & кора & $\begin{array}{l}\text { Подол, раскоп 2, слой коры } \\
\text { в основании культурного слоя. Шурф } 1\end{array}$ \\
\hline $1290 \pm 50$ & Ki-14279 & $675(68,2 \%) 880$ AD & гумус & $\begin{array}{l}\text { Подол, почва под культурным слоем, раскоп } 2 \text {, } \\
\text { шурф } 1\end{array}$ \\
\hline \multicolumn{5}{|c|}{ Красная площадь в Москве (Казанский собор), раскопки Л.А. Беляева, Н.А. Кренке, С.3. Чернова, 1990 г. } \\
\hline $820 \pm 30$ & ГИН-7179 & $1210(65,8 \%) 1265$ AD & уголь & Казанский собор, постройка 1. Плаха 11 \\
\hline $820 \pm 20$ & ГИН-7181 & $1216(68,2 \%) 1256 \mathrm{AD}$ & уголь & $\begin{array}{l}\text { Казанский собор, постройка } 1 . \\
\text { Плаха } 12\end{array}$ \\
\hline $1020 \pm 15$ & GrA-22473 & $1000(68,2 \%) 1022 \mathrm{AD}$ & уголь & $\begin{array}{l}\text { Казанский собор, постройка } 1 . \\
\text { Плаха } 12\end{array}$ \\
\hline $830 \pm 30$ & ГИН-7183 & $1185(68,2 \%) 1260 \mathrm{AD}$ & уголь & $\begin{array}{l}\text { Казанский собор, постройка } 1, \\
\text { лага }\end{array}$ \\
\hline $880 \pm 160$ & ГИН-7184 & $1010(68,2 \%) 1290 \mathrm{AD}$ & уголь & Казанский собор, постройка 1, столб \\
\hline $930 \pm 40$ & ГИН-7180 & $1030(68,2 \%) 1160 \mathrm{AD}$ & уголь & Казанский собор, постройка 1 \\
\hline $865 \pm 40$ & Ki-5894 & $1150(51,4 \%) 1240 \mathrm{AD}$ & уголь & Казанский собор, постройка 1 \\
\hline $925 \pm 25$ & GrN-22474 & $1030(68,2 \%) 1160 \mathrm{AD}$ & уголь & Казанский собор, постройка 1 \\
\hline
\end{tabular}









\section{Приложение III СПИСОК ДРЕВНЕРУССКИХ (ДОМОНГОЛЬСКИХ) ПАМЯТНИКОВ В БАССЕЙНЕ МОСКВЫ-РЕКИ}

\author{
КУРГАНЫ \\ Москва-река \\ $1025^{1}$ Синичкино - кург? \\ 1035 Тушков городок - 4 кург. \\ 1036 Тушков городок 1 кург. \\ 978 Аксаново - 4 кург. \\ $3119^{2}$ Ильинская слобода - \\ 4 кург (по Богоявленскому) \\ 3120 Исавицы - ? кург. \\ (по Янишевскому) \\ 3116 Глазово $1-4$ кург. \\ (по Богданову) \\ 3127 Глазово 2 - ? кург. \\ (по Янишевскому) \\ 3128 Горетово 1 - 1 кург. \\ (по Янишевскому) \\ 3131 Красновидово 1 - ? \\ (по Янишевскому) \\ 988 Бурцево - 4 кург. \\ 1024 Пуршево - 1 курган \\ 984 Тесово - 40 курганов
}

985 Шишимровский - 30 кург.

1011 Красный Стан 2 -

46 кург.

1010 Красный Стан 1 - 21 кург. 1012 Красный Стан 3 - 21 кург.

1013 Красный Стан 4 - 5 кург.

1154 Костино - 1 кург.

1153 Костино 2 - 22 кург.

1152 Костино 1 - 4 кург

1211 Товарково - 26 кург.

1216 Чапасово - 19 кург.

1084 Акулово - 2 кург.

1118 Воробъево - ?

1210 Тимохино - 2 кург.

1156 Лобково - 13 кург.

1205 Старая Руза - 25 кург.

1092 Ботино - 15 кург.

1148 Кожино - более 100 кург.

1165 Молодиково - 2 кург.

1146 Игнатьево - 1 кург.

1145 Игнатьево 2 - 6 кург.

1144 Игнатьево 1 - 11 кург.

1 Номера соответствуют изданию АКР. Московская область. М. $1994-$ 1997.

${ }^{2}$ Номера 3000 и выше - дополняют нумерацию АКР
1127 Горбово - 2 кург.

1085 Артюхино (Григорово) -

12 кург.

1192 Поречье - 6 кург.

1149 Колюбакино - 3 кург.

1119 Воскресенск - ?

326 Григорово $1-3$ кург.

327 Григорово 2 - 14 кург.

3000 Агафоново - 1 кург.

3001 Хотяжи (Мышкино) около 100 (по Алексееву). 3002 Никифоровское - 1 кург. 3003 Никифоровское - 32 кург. 313 Власово - 10 кург. 387 Никольское - 6 кург. 410 Шарапово - 1 кург.

310 Бушарино 1 - 10 кург.

311 Бушарино 2 - 22 кург. 63-н ${ }^{3}$ Волково 1 - 38 кург. 3004 Волково 2 (Копки) 11 кург.

3005 ЗБС 1 - 11 кург.

3006 ЗБС 2 - 2 кург.

305 Аниково - 22 кург.

3007 Михайловское 1 - ?

3008 Михайловское 2 - ?

302 Анашкино - 1 кург.

308 Белозерово - 6 кург.

381 Мартьяново - 23 кург.

412 Шихово 2 - 8 кург.

411 Шихово 1 - 3 кург.

414 Шихово 4 (Новоши-

хинские) - 4 кург.

413 Шихово 3 - 8 кург.

3009 Шихово

4 (Новошихинские 2, 3) -

2+4 кург. по Станюковичу

415 Шихово 5 - 1 кург.

408 Часцы 1 - 1 кург.

409 Часцы 2 - 1 кург.

395 Саввинская слобода 1 25 кург.

3010 Саввинская слобода 2 (Разводненский) - 1 кург.

369 Кораллово 1 - 20 кург.

${ }^{3}$ Индекс «Н» - означает, что номер соответствует нумерации несохранившихся памятников в АКР
370 Кораллово 2 - 12 кург. 371 Кораллово 3 - 8 кург. 351 Звенигород 1 - 12 кург. 352 Звенигород 2 - 6 кург. 353 Звенигород 3 - 2 кург. 354 Звенигород 4 - 2 кург. 367 Клопово 1 - 11 кург. 3011 Тимохово - 5 кург. 3012 Клопово 2 - 1 кург (по Алексееву)

312 Введенское - 13 кург. 3013 Марьино - 3 кург. 3014 Чигасово 1 - 9 кург. 3015 Чигасово 2 - 2 кург. 3016 Чигасово 3 - 1 кург. 368 Козино - 3 кург.

66-н Ершово - 2 кург.

65-н Грязь - 16 кург. 2656 Аксиньино - 11 кург. 356 Звенигород 6 - 23 кург. 2669в Поречье 3 - 22 кург. 355 Звенигород 6 - 72 кург. 335 Дунино 2 - 10 кург.

334 Дунино 1 (Иславские) 50 кург.

391 РАНИС 1 - 20 кург. 3017 РАНИС 2 - 7 кург. 320 Горышкино 3 - 19 кург. 314 Горки-X 1 - 8 кург. 315 Горки X 2 - 16 кург. 2657 Горки X 3 - 4 кург. 2658 Горки X 4 - 14 кург.

3018 Горки X 5 - 1 кург (дача

№ 4 не нанесен на карту)

318 Горышкино 1 - 23 кург.

319 Горышкино 2 - 3 кург.

64-н Горышкино 2a - 2 кург. 321 Горышкино 4 - 27 кург. 322 Горышкино 5 - 6 кург. 323 Горышкино 6 - 3 кург. 2659 Горышкино 7 - 27 кург. 2660 Горышкино 8 - 18 кург. 2661 Горышкино 9 - 3 кург. 3019 Горышкино 10 - 3 кург. (рядом с Горышкино 7)

3020 Горышкино 11 - 7 кург. (рядом с Горышкино 2)

3021 Горышкино 12 - 13 кург. 3022 Горышкино 13 - 4 кург.
416 Ямщина - 8 кург. 379 Малые Вяземы - 1 кург. 407 Хлюпино - 1 кург. 338 Захарово - 1 кург. 399 (2676) Успенское 1 (Таганьково 3) - 26 кург. 2677 Успенское 1 - 4 кург. 398 (2672) Таганьково 1 - 8 кург. 398 (2673) Таганьково 1a 13 кург.

2674 Таганьково 5 - 2 кург. 328 Ст. Дарьино 1 - 15 кург. 329 Ст. Дарьино 2 - 40 кург. 2678 Успенское 2 - 26 кург. 68-н Успенское 4 - 24 кург. 3031 Слезня $1-3$ кург 3032 Слезня $2-2$ кург. 3033 Слезня 3 - 1 кург. 375 Лапино - 7 кург. 397 Солослово - 4 кург.

372 Лайково 1 (Одинцово 13)5 кург.

373 Лайково 2 (Одинцово 15) 12 кург.

374 Лайково 3 (Одинцово 14) 7 кург.

401 Уборы 1 - 2 кург.

402 Уборы 2 - 1 кург.

291 Одинцово 1 - 22 кург.

292 Одинцово 2 - 9 кург.

293 Одинцово 3 - 14 кург.

294 Одинцово 4 - 2 кург.

295 Одинцово $5-8$ кург.

296 Одинцово 6 - 101 кург.

297 Одинцово 7 - 80 кург.

298 Одинцово 8 - 10 кург.

299 Одинцово 9 - 15 кург.

300 Одинцово 10 - 3 кург.

301 Одинцово 11 - 6 кург.

307 Одинцово 12 (Барвиха) -

1 кург.

3023 Одинцово 16 - 3 кург.

3024 Одинцово 17 - 4 кург.

3025 Одинцово 18 (3a) - 2 кург. (Двуреченский)

3026 Одинцово 19 - 1 кург. (Лазукин)

3027 Одинцово 20 - 1 кург. (в лестничестве) 
3028 Шульгино - 2 кург.

392 Ромашково 2 - 2 кург.

393 Ромашково 1 - 10 кург.

3029 Ромашково 3 - 2 кург.

(по Розенфельдт)

2670 Ромашково 4 - 1 кург.

386 Немчиново $1-5$ кург.

(паспорт Соколова)

3044 Немчиново 2 - 6 кург. (по Карцову)

3045 Немчиново 3 - 7 кург. (по Карцову)

3046 Немчиново 4 - 2 кург. (по Карцову)

3047 Немчиново 5 - 4 кург. (по Карцову)

3041 Румянцево 1 - 1 кург. (по Карцову)

3042 Румянцево 2 - 1 кург. (по Карцову)

3040 Саларьево - 4 кург.

3043 Измалково - 4 кург. (по Карцову)

384 Мякинино - 30 кург.

127 Чернево - 19 кург.

128 Павшино - 1 кург.

129 Ангелово - 11 кург.

131 Бузланово $1-8$ кург.

132 Бузланово $2-2$ кург.

138 Воронки - 4 кург.

139 Губайлово - 4 кург.

143 Михайловка 1 (Воронки 1) 6 кург.

143а Михайловка 2 - 13 кург.

143в Ново-Никольское - 1 кург.

145 Сабурово - 1 кург.

659 Машкино - 18 кург.

665 Сходня - 3 кург.

664 Подрезково $2-8$ кург.

663 Подрезково $1-8$ кург.

14-м Митино (Великая могила) - 6 кург.

15-м Спас-Тушино 2 - 65 кург.

16-м Спас-Тушино 1 - 15 кург.

19-м Пенягино 1 - 1 кург.

24-м Тушино 2 - 2 кург.

25-м Тушино 1 - 2 кург.

28-м Алёшкино 1 - 2 кург.

29-м Алёшкино 2 - 2 кург.

30-м Никольское-Химки 1 11 кург.

33-м Крылатское 1 - 3 кург.

38-м Фили 1 - 40 кург.

39-м Серебряный Бор 1 - 2 кург.

40-м Сетунь 2 - 18 кург.

41-м Сетунь 1 - 16 кург.

42-м Спас 1 - 1 кург.

43-м Очаково 1 - 12 кург.

44-м Очаково 2 - 1 кург.

47-м Матвеевское 2 - 2 кург.

48-м Матвеевское 1 - 3 кург.

49-м Матвеевское 3 - 4 кург.

51-м Раменки 1 - 3 кург. 52-м Раменки 2 - 2 кург.

54-м Очаково 4 - 3 кург.

55-м Очаково 3 - 8 кург.

56-м Очаково 5 - 2 кург.

57-м Никольский 1 - 26 кург.

57а-м Никольский 3 - 6 кург.

58-м Никольский 2 - 1 кург.

59-м Никулинский $2-8$ кург.

60-м Никулинский 3-2 кург.

61-м Никулинский 1 - 6 кург.

62-м Тропарево 1 - 5 кург.

63-м Тропарево 2 - 3 кург.

64-м Богородское 2 - 4 кург.

65-м богородское 1 - 7 кург.

66-м Воронцово 1 - 9 кург.

67-м Коньково 2 - 15 кург.

68-м Коньково 1 - 2 кург.

69-м Коньково 3 - 5 кург.

70-м Коньково 4 - 23 кург.

72-м Теплый Стан $3-8$ кург.

73-м Теплый Стан 2 - 13 кург.

74-м Теплый Стан 4 - 6 кург.

75-м Теплый Стан 1 - 4 кург.

76-м Воробьево 1 - 1 кург.

78-м Нескучный сад 1 - 2 кург.

81-м Черемушки 3 - 4 кург.

82-м Черемушки 2 - 3 кург.

83-м Черемушки 1 - 15 кург.

84-м Шаболово 1 - 2 кург.

85-м Шаболово 2 - 2 кург.

86-м Верхние Котлы 1 - 9 кург.

87-м Нагатино 1 - 1 кург.

94-м Деревлево 1 - 6 кург.

95-м Деревлево 2 - 5 кург.

96-м Зюзино 4 - 2 кург.

98-м Зюзино 1 - 9 кург.

99-м Зюзино 2 - 13 кург.

100-м Волхонка 1 - 16 кург.

101-м Узкое 1 - 4 кург.

102-м Коньково 5 - 2 кург.

104-м Зюзино 6 - 9 кург.

105-м Зюзино 5 - 4 кург.

106-м Зюзино 3 - 11 кург.

107-м Узкое 2 - 2 кург.

108-м Узкое 3 - 3 кург.

109-м Узкое 4 - 2 кург.

110-м Узкое 5 - 3 кург.

111-м Узкое 6 - 1 кург.

112-м Чертаново 9 - 3 кург.

114-м Чертаново 7 - 1 кург.

115-м Чертаново 8 - 4 кург.

116-м Чертаново 6 - 3 кург.

117-м Чертаново 5 - 3 кург.

118-м Чертаново 4 - 6 кург.

119-м Чертаново 3 - 1 кург.

120-м Чертаново 2 - 2 кург.

121-м Чертаново 1 - 10 кург.

122-м Котляково 1 - 7 кург.

123-м Котляково 2 - 2 кург.

124-м Сабурово 1 - 13 кург.

125-м малое Голубино 1 - 6 кург.

126-м Малое Голубино 2 -

24 кург. 127-м Большое Голубино 1 3 кург.

128-м Ясенево 1 - 5 кург.

128а-м Ясенево 2 - 2 кург.

129-м Бирюлево 1 - 4 кург

130-м Бирюлево 2 - 4 кург.

131-м Красное 1 - 1 кург.

132-м Покровское 2 - 3 кург.

133-м Покровское 1 - 3 кург.

135-м Орехово 2 - 14 кург.

138-м Орехово 4 - 12 кург.

139-м Орехово 5 - 28 кург.

140-м Орехово 6 - 4 кург.

141-м Царицыно 4 - 8 кург.

142-м Царицыно 3 - 13 кург.

145-м Орехово 7 - 3 кург.

145а-м Орехово 8 - 2 кург.

146-м Орехово-3 - 1 кург.

147-м Орехово 1 - 12 кург.

149-м Царицыно 2 - 23 кург.

150-м Царицыно 1 - 5 кург.

151-м Царицыно 5 - 12 кург.

152-м Шипилово 2 - 5 кург

153-м Шипилово 1 - 10 кург

154-м Братеево 5 - 4 кург.

155-м Братеево 2 - 5 кург.

156-м Братеево 1 - 5 кург.

157-м Братеево 4 - 2 кург

158-м Братеево 3 - 19 кург.

160-м Борисово 1 - 21 кург.

161-м Зябликово 1 - 1 кург.

164-м Чагино 1 - 15 кург.

166-м Останкино 1 - ?

167-м Лосиный Остров 1 7 кург.

169-м Лосиный Остров 2 3 кург.

174-м Ст. Яуза - 5 кург.

177-м Могильцы на Остоженке

178-м Могильцы на Тверской

180-м Косино 1 - 3 кург.

181-м Косино 2 - 2 кург.

182-м Косино 3 - 21 кург.

183-м Руднево - 5 кург.

184-м Каменная плотина 2 7 кург.

185-м Каменная плотина 1 10 кург.

186-м Черемушки 4 - 4 кург.

187-м Черемушки 5 - 9 кург.

189-м Беляево 1 - 8 кург.

192-м Чертаново 10 - 1 кург.

194-м Матвеевское 4 - 14 кург.

195-м Фили 2 - 5 кург.

199-м Раменки 3 - 8 кург.

201-м Студеный овраг могильник

205-м Очаково 6 - 3 кург.

206-м Коньково 6 - 1 кург.

208-м Шаболово 3 - 1 кург.

211-м Гладышево 1 - 40 кург.

212-м Андреевский 1 - 3 кург.

160а Беседы 1 - 26 кург.
1606 Беседы 2 - 29 кург.

160в Беседы 3 - 1 кург.

158 Ащерино 1 - 2 кург.

62-н Ащерино 2 - 2 кург.

3030 Ащерино 3 (Зябликово 3) 1 кург.

43-н Дроздово - ?

55-н Слобода 1 - 10 кург.

56-н Слобода 2 - 3 кург.

253 Котельники - 2 кург.

36 Новомилет - 4 кург.

37 Павлино - 33 кург.

17 Акатово 1 - 71 кург.

18 Акатово 2 - 5 кург.

28 Лукино - 4 кург.

15 Балашиха - 11 кург.

44 Салтыковка - 24 кург.

45 Черное - 6 кург.

9-н Никольское-Трубецкое 27 кург.

11-н Руднево - 112 кург.

1-н Балашиха 1 - ? кург.

2-н Балашиха 2 - 30 кург.

3-н Дятловака - 50 кург.

5-н Маришкино - 3 кург.

6-н Милет 1 - 20 кург.

7-н Милет 2 - 23 кург.

8-н Милет 3 - 5 кург.

10-н Пуршево - 40 кург.

12-н Русавкино-Поповщина 12 кург.

13-н Савино - 40 кург.

257 Марусино - 30 кург. 258 Токарево 1 - 11 кург.

259 Токарево 2 - 19 кург.

260 Токарево 3 - 7 кург.

261 Токарево 4-1 кург.

200 Картино - 10 кург.

235 Мисайлово 1 - 6 кург.

236 Мисайлово 2 - 2 кург.

49-н Мисайлово 3 - 2 кург.

189 Дальние Прудищи 1 -

17 кург.

188 Дальние Прудищи 2 2 кург.

39-н Дальние прудищи 3 3 кург.

40-н Дальние Прудищи 4 1 кург.

41-н Дальние Прудищи 5 1 кург.

213 Коробово 1 - 2 кург.

214 Коробово 2 - 3 кург.

215 Коробово 3 - 7 кург.

216 Коробово 4 (Витовка) 2 кург.

217 Коробово $5-8$ кург.

218 Коробово 6 - 1 кург.

46-н Коробово 7 - 3 кург.

48-н Коробово 8 - 1 кург. 
173 Богданиха 2 - 22 кург. 174 Богданиха 3 - 9 кург. 175 Богданиха $4-23$ кург. 176 Богданиха 5 - 16 кург. 31-н Богданиха 6 - 1 кург. 32-н Богданиха 7 - 9 кург. 33-н Богданиха 8 - 5 кург. 156 Андреевское 1 - 3 кург. 157 Андреевское 2 - 2 кург. 24-н Андреевское 3 - 12 кург. 25-н Андреевское 4 - 8 кург.

22-н Андреевское 1 - 3 кург. 23-н Андреевское 2 - 2 кург. 1623 Титово 1 - 4 кург. 1624 титово 2 - 2 кург. 1625 Титово 3 - 6 кург. 1600 Островцы - 56 кург. 1596 Ниж Мячково - 10 кург. 1547 Еганово 1 - 15 кург. 33-н Еганово 2 - 1 кург. 1564 Каменно-Тяжино - ? кург. 1576 Кулаково - 1 кург. 1589 Михайловская слобода 1 (Дурниха) - 27 кург.

1591 Михайловская слобода 3 1 кург.

38-н Михайловская слобода 4 7 кург.

3130 Дурниха 1 (Семеновский руч. Пр б - 7 кург. (по Шуберту)

3131 Дурниха 2 (Семеновский руч. Лб - 7 кург по Шуберту)

3132 Дурниха 3 - 3 кург (Семеновский руч. по Шуберту)

3133 Зенино - 1 кург. (по Шуберту - Бадеру)

1616 Синьково - 2 кург.

1619 Софьино - 2 кург.

1533 Вялки - 6 кург.

1509 Раменское - 4 кург.

1572 Копнино 1 - 42 кург.

3068 Копнино 2 - 15 кург.

3069 Копнино 3 - 2 кург.

1515 Блошино - 30 кург.

1544 Дементьево 1 - 4 кург.

1545 Дементьево 2 - 10 кург.

1609 Починки - 1 кург.

1526 Велино 1 - ? кург.

1527 Велино 2 - 1 кург.

27-н Бронницы - 1 кург.

1524 Бронницы (НиколоБоршевский) - 40 кург.

1585 Марьинка - 3 кург.

1622 Татаринцево - 5 кург.

1594 Морозово (Боршевский) 1 8 кург.

1595 Морозово 2 - 1 кург. 1620 Старниково - 1 кург. 48-н Толмачево - 5 кург. 37-н Коробово - 1 кург.
1568 Колоколово - 10 кург. 1592 Михеево 1 - 11 кург. 1593 Михеево 2 - 7 кург. 1608 Поддубье - ? кург. 1543 Давыдово 1 - 1 кург. 1380 Анциферово 1 - 36 кург. 1381 Анциферово 2 - 48 кург. 1422 Заполицы - 1 кург. 1427 Куровское - 18 кург. 1443 Слободище - 2 кург. 1465 Яковлевское - 7 кург. 1936 Воропаево - 2 кург. 1946 Маришкино - 3 кург. 1944 Константиново - 1 кург. 1934 Бочевино - 1 кург. 1949 Осташево - 1 кург. 1954 Ратчино - 2 кург. 1928 Ачкасово 1 - 3 кург. 1931 Ачкасово 2 - 1 кург. 1932 Ачкасово 3 - 1 кург.

1-н Воскресенск (пять крестов) - 7 кург. 1956 Суворово - 12 кург. 2157 Андреевское - 1 кург.

2181 М. Уварово - 8 кург. 2187 Мячково - 29 кург. 2190 Никульское - 8 кург. 2191 Пески - 4 кург. 2207 Черкизово - 1 кург. 2197 Соловцово - 1 кург. 3135 Люберцы - 2 кург. (по Шуберту - Бадеру)

3136 Панки - 5 кург. (по Шуберту)

Всего в долине Москвы-реки и мелких притоков 455 групп, в которых 4406 курганов

p. Руза, Озерна

1324 Княжьи горы - 140 кург. 11 век

1323 Жилые горы - 63 кург. 11 в.

1328 Паново - 1 курган 1321 Дубронивка - 17 кург.

57-Н Ивановское 1 - 17 кург

58-Н Ивановское 2 - 40 кург. 59-Н Ивановское 3 - 4 кург

769 Лисавино - 7 кург.

762 Клетки - 9 кург

768 Лазарево - 12 кург.

1206 Старокурганный - 7 кург.

1197 Рыбушкино - 38 кург.

1188 Палашкино 1 - 24 кург.

1189 Палашкино

2 (Захряпино) - 15 кург.

1116 Волынщино - 26 кург.

1117 Волынщино 1 кург.

1115 Волково 1 кург.

1114 Волково - 5 кург.

39-н Вишенки 1 - 4 кург. 40-н Вишенки 2 - 3 кург 41-н Вишенки 3 - 1 кург 1086 Барынино - 11 кург. 1108 Ваюхино - 4 кург.

1109 Ваюхино - 1 кург.

1110 Ваюхино 2 - 1 кург.

1182 Онуфриево - ?

1198 Сафониха - 5 кург.

1170 Нижнее Сляднево 1 39 кург.

1171 Нижнее Сляднево 2 9 кург.

1143 Ивойлово 15 кург.

1172 Нижнее Сляднево 1 кург

1105 Бутьково 1 - 19 кург.

1106 Бутьково 2 - 9 кург.

43-н Глиньково - 4 кург.

Всего в басс. Рузы и Озерны 34 групा, в которых 536 курганов

p. Истра и притоки

936 Конаково - 2 кург.

53-н Поповка - 1 кург.

1228 Горки - 7 кург.

1273 Татищево - 7 кург.

1276 Шевлино - 1 кург.

1235 Ложки - ? кург.

51-н Поваровка 1 - 14 кург.

52-н Поваровка 2 - 6 кург.

1262 Пешки - ? кург.

1248 М. Снопово - 1 кург.

1263 Повадино - 6 кург.

1266 Полежайки - 5 кург.

1271 Соколово - 8 кург.

1220 Бережки - 2 кург.

1268 Пятница - 2 кург.

1239 Лопотово $2-3$ кург.

1238 Лопотово $1-8$ кург.

11-н Кутузово 1 - 6 кург.

$12-$ - Кутузово 2 - 29 кург.

13-н Кутузово 3 - 3 кург.

14-н Кутузово 4 - 3 кург.

15-н Кутузово 5 - 12 кург.

914 Раково - 6 кург.

881 Ламишино - 17 кург.

911 Полевщина 1 - 24 кург.

912 Полевщина 2 - 2 кург.

918 Сафонтьево 4 кург.

887 Максимовка 1 - 8 кург.

888 Максимовка 2 - 1 кург.

869 Ермолино - 1 кург.

915 Рычково - 9 кург.

879 Курсаково (Марково) 6 кург.

920 Филатово 1 - 15 кург.

3139 Филатово 2 - 3 кург.

919 Скрябино - 10 кург.

2581 Кострово - 6 кург.

890 Мансурово 1 - 6 кург.

891 Мансурово 2 (Шейка 1) 122 кург.

892 Мансурово 3 - 40 кург.
893 Мансурово 4 - 50 кург. 894 Мансурово 5 - 1 кург. 922 Хволово - 1 кург. 925 Ябедино 2 - 6 кург. 924 Ябедино 1 - 2 кург. 9-н Истра (Сычевский) - 6 кург. 855 Истра - 20 кург.

877 Качаброво - 12 кург.

18-н Санниково 1 - 65 кург. 19-н Санниково 2 - 43 кург. 3137 Санниково 3 - 1 кург. 897 Обновленный Труд 1 12 кург.

898 Обновленный Труд 2 2 кург.

884 Лужки 1 - 18 кург.

16-н Рождествено 1 - 5 кург. (локализован в ниж. Рожд.) 17-н Рождествено 2 - 2 кург. 880 Ламаново - ? кург. 2569 Борисково - 2 кург. 860 Аносино 1 - 7 кург. 3138 Аносино 4 - 1 кург. 861 Аносино 2 - 20 кург. 862 Аносино 3 - ? кург. 870 Зеленково - 11 кург.

902 Павловская слобода 1 45 кург.

903 Павловская слобода 2 22 кург.

904 Павловская слобода 3 9 кург.

905 Павловская слобода 4 1 кург.

906 Павловская слобода 5 1 кург.

148 Степановское 1 - 13 кург.

149 Степановское 2 - 14 кург.

150 Степановское 3 - 6 кург.

150а Степановское 4 - 1 кург.

3139 Петровское - 1 кург.

Всего в басс. Истры 71 группа, в которых 806 курганов

Бассейн р. Пахры p. Битиза и Купеленка 34-н Бутово - 2 кург.

181 Вырубово - 4 кург.

161 Битца (Дубровский) 1 2 кург.

3037 Битца (Дубровский) 2 1 кург.

3038 Булатниково - 3 кург. (по Шуберту)

35-н Тарычево - ок. 12 кург.

243 Расторгуево 1 - 11 кург.

244 Расторгуево 2 - 12 кург. (числ. по Герасимову)

245 Расторгуево 3 - 2 кург.

3039 Ермолино - 1 кург (по Шуберту) 
44-н Ермолино - 6 кург.

53-н Сапроново $1-4$ кург. 54-н Сапроново 2 - ? кург. 195 Дыдылдино 1 - 2 кург. 196 Дыдылдино 2 - 5 кург. 249 Таболово - 3 кург. 28-н Белеутово 1 - 7 кург. 29-н Белеутово

(Васильевский) - 2 кург.

На р. Битце и Купеленке 18 групп, в них 79 курганов

p. Гвоздянка

163 Боброво $1-3$ кург.

164 Боброво $2-6$ кург.

165 Боброво 3 - 5 кург.

166 Боброво 4 - 9 кург.

30-н Боброво 5 - 4 кург.

224 Лопатино 1 - 4 кург.

225 Лопатино 2 - 3 кург.

226 Лопатино (Суханово 1 кург.)

248 Суханово - 3 кург. (лес Таган)

3134 Суханово - 1 кург. (на поле по Шуберту)

538 Спирово 1 - 3 кург.

539 Спирово 2 - 2 кург.

512 Потапово 1 - 7 кург.

513 Потапово 2 - 2 кург.

514 Потапово 3 - 9 кург.

3049 Потапово 4 - 1 кург (по Герасимову 1923)

На р. Гвоздянке 15 групп, в них 62 кургана

p. Десна

1039 Афинеево 1 - 6 кург.

1039 Афинеево 2 - 12 кург.

1047 Елизарово - 4 кург.

1070 Пятовское - 2 кург.

192 Десна - 3 кург.

197 Изварино 1 - 15 кург.

198 Изварино 2 - 16 кург.

199 Изварино 3 - 12 кург.

202 Кнутово 1 - 26 кург.

203 Кнутово 2 - 12 кург.

222 Ликово - 30 кург.

227 Марьино - 15 кург.

238 Окатово (ин-т

полиомиелита) - 5 кург.

240 Передельцы - 1 кург.

246 Расторопово - 4 кург.

247 Станиславль - 1 кург.

42-н Десна (Пенино) - 2 кург.

544 Студенцы $1-8$ кург.

545 Студенцы $2-8$ кург.

546 Студенцы 3 - 13 кург.

547 Студенцы 4 - 4 кург.

548 Студенцы 5 - 2 кург.

484 Молодцы 1 - 4 кург.

484 Молодцы 2 - 4 кург.
423 Алхимово - 4 кург.

424 Армазово - 4 кург.

497 Остафьево - 2 кург.

523 Рязаново - 9 кург.

520 Рыбино 1 - 4 кург.

521 Рыбино 2 - 7 кург.

522 Рыбино 3 - 8 кург.

На р. Десне 31 группа, в них 247 курганов

p. Пахра

1053 Игнатово - 3 кург.

457 Конаково 1 - 16 кург.

458 Конаково 2 - 2 кург.

78-н Раево - 2 кург.

564 Шаганино $1-3$ кург.

565 Шаганино $2-7$ кург.

517 Пыхчево - 2 кург.

69-н Власьево - 4 кург.

510 Поливаново 1 - 11 кург.

511 Поливаново 2 - 5 кург.

2706 Поливаново 3 - 2 кург.

480 Луковня $2-12$ кург.

479 Луковня $1-3$ кург.

448 Дубровицы - 5 кург.

450 Ерино 1 - 22 кург.

452 Ерино 3 - 2 кург.

430 Беляево (Сальковский) 8 кург.

73-н Лемешево - 2 кург.

434 Борисовка - 2 кург.

542 Стрелково (Ордынцы) 25 кург.

502 Плещеево - 1 кург.

70-н Добрятино - 10 кург.

453 Жданово - 18 кург.

440 Быковка 3 - 22 кург. (числ. по Герасимову)

438 Быковка 1 - 2 кург.

505 Покров - 23 кург.

3061 Щербинка - 1 кург.

(по карте Герасимова 1923 г)

3062 Заболотье 1 - 1 кург. (по карте 1923 )

3063 Заболотье 2 - 1 кург. (по карте 1923 )

553 Услонь - 1 кург.

482 Макарово - 3 кург.

432 Бол. Брянцево - 4 кург.

36-н Горки - 56 кург.

185 Горки-Ленинские 1 59 кург.

186 Горки-Ленинские 2 3 кург.

38-н Горки-Ленинские 3 9 кург

3035 Новое Съяново - 2 кург. (по писцовой 1685 г.)

3036 Новое Съяново - 2 кург. (по писцовой 1685 г.)

103 Павловское - 1 кург. (по карте 1923 г.)

3034 Новленское 2 - 1 (?) кург.
100 Новленское 1 - 25 кург.

96 Малинки (Жуково) - 6 кург. (Гоняный 2008)

229 Мещерино 1 - 7 кург.

230 Мещерино 2 (Старое Съяново) - 8 кург.

231 Мещерино 3 (Старое Съяново 1) - 11 кург.

232 Мещерино 4 (ГоркиЛенинские 4) - 4 кург.

233 Мещерино 5 - 2 кург.

120 Чурилково 1 - 4 кург.

121 Чурилково 2 - 35 кург. (числ. по Герасимову 1923)

20 -н Чурилково 3 - 1 кург.

93 Лукино - 2 кург.

119 Чулпаново - 10 кург.

111 Семивраги 1 - 34 кург.

112 Семивраги 2 - 6 кург.

62 Воеводино 1- 5 кург.

14-н Воеводино 2 - 5 кург.

60п Вяльково - 18 кург.

66 Жеребятьево - 5 кург.

15-н Жеребятьево - 4 кург.

17-н Котляково - 20 кург.

172 Богданиха 1

(Куприяниха 1) - 6 кург.

19-н Куприяниха - 3 кург.

1514 Б. Саврасово - 8 кург.

179 Володарский - 6 кург.

81 Колычево - 4 кург.

16-н Колычово - 12 кург.

3055 Колычово - 1 кург.

3152 Тупицыно - 2 кург.

(Сорокин, 2004)

3143 Истомиха 1 - 1 кург.

(Гоняный 2011)

3144 Истомиха 2 - 11 кург. (Гоняный 2011)

3058 Бол. Юсупово - 2 кург (по Богоявл.)

3059 Мал. Юсупово - 2 кург. (по Богоявл.)

1581 Мал. Саврасово 2 11 кург.

3060 (1570, 1571, 35-н)

Константиновское -

15 кург. (по карте

Герасимова 1923 г.)

46-н Прудки - 2 кург.

1561 Зеленая Слобода

(Редькинский) $1-2$ кург.

1612 Редькино - 9 кург.

1548 Жданское - 4 кург.

1607 Плетениха - 3 кург.

1549 Жуково 1 - 19 кург.

1550 Жуково 2 - 2 кург.

1551 Жуково 3 - 1 кург.

1562 Зеленая слобода 2 -

10 кург.

1563 Зеленая слобода 3 - 1 кург.

На р. Пахре 82 группы, в которых 706 курганов
P. Моча

71-н Климовск (Гривно) - ? кург.

79-н Сергеевка - 5 кург.

463 Костишово - 1 кург.

3064 Хлыново - 2 кург (по Богоявл.)

494 Ознобишино 1 - 11 кург. 495 Ознобишино 2 - 2 кург. 496 Ознобишино 3 - 11 кург.

76-н Ознобишино - 1 кург.

535 Сатино-Татарское - 10 кург.

На р. Моче 9 групп, в них 43 кургана

p. Рожайка

42-н Молоди - ? кург.

2497 Никоново 1 - 4 кург.

2498 Никоново 2 - 13 кург.

2499 Никоново 3 - 5 кург.

43-н Никоново 4 - 18 кург.

44-н Тупичино 1 - 8 кург.

45-н Тупичино 2 - ? кург.

46-н Тупичино 3 - 1 кург.

47-н Шарапово - 1 кург.

39-н Любучаны - 5 кург.

2481 Гавриково - 6 кург.

3068 Лубинина - 2 кург.

(по карте 1923 г.)

40-н Мещерское 1 - 6 кург.

41-н Мещерское 2 - 3 кург.

41-н Мещерское 3 - 2 кург. (по карте 1923 г.)

3067 Ивино 1 - 2 кург.

38-н Ивино 2 - 5 кург.

420 Александровка 1 - 15 кург.

421 Александровка 2 (Скабеевский $)-4$ кург.

74-н Лопаткино - 3 кург.

75-н Лопаткино - 4 кург.

3048 Скабеево - 1 кург (по Брюсову 1923)

558 Хрястолово $1-2$ кург.

559 Хрястолово 2 - 5 кург.

560 Хрястолово 3 - 1 кург.

3150 Михалицы - 6 кург (по Гоняному)

74 Ивановское 4 (Пузиково 1, Пузиково 3) - 63 кург.

3050 Пузиково 2 - 5 кург. (по Брюсов 1923 г.)

73 Ивановское 3 (Пузиково 3, Пузиково 2) - 3 кург.

72 Ивановское 2 (Пузиково 4, Пузиково 1) - 17 кург.

3051 Пузиково 5 - 1 кург.

71 Ивановское

1 (Тургеневский) - 32 кург.

3052 Ивановское 5 - 2 кург. (по Брюсов 1923 г.)

115 Судаково - 4 кург.

54 Битягово 1 - 20 кург.

55 Битягово $2-4$ кург. 
56 Битягово 3 - 50 кург.

3054 Битягово 5 - 7 кург (у мельницы)

57 Битягово $4-34$ кург.

57 Битягово 6 - 31 кург. (по НК $)^{4}$

98 Никитское $1-24$ кург.

3053 Никитское 2 - 1 кург. (по Брюсов 1923)

30 Авдотьино 1(Ушморы) 6 кург.

3053 Авдотьино 2 - 1 кург. (по РЛ, 1988)

67 Заборье - ? кург.

83 Константиново 1 - 9 кург.

84 Константиново 2 - 9 кург.

85 Константиново 3 - 3 кург.

3056 Константиново 4 - 1 кург.

3057 Константиново 5 - 6 кург.

На Рожайке 50 групп, в них 455 курганов

Всего в басс. Пахры 207 групп, в которых 1592 кургана

p. Северка

63 Гальчино - 3 кург.

75 Карачарово - 3 кург.

90 Купчинино 1 - 6 кург.

91 Купчинино 2 - 7 кург.

109 Растуново - 7 кург.

2563 Тишково 1 - 10 кург.

2564 Тишково 2 - 1 кург.

94 Ляхово $1-5$ кург.

95 Ляхово 2 - 9 кург.

102 Острожки - 3 кург.

118 Успенское - 14 кург.

3065 Барыбино - 7 кург. (по Богоявл.)

1597 Никоновское $1-8$ кург.

1598 Никоновское 2 - 2 кург.

2431 Авдотьино 1 - 14 кург.

2432 Авдотьино 2 - 3 кург.

2474 Четряково - 1 кург.

2461 Милино - 10 кург.

2473 Хонятино - 21 кург.

2462 Нефедьево 2 кург.

2435 Б. Алексеевское - 6 кург.

2455 М. Ивановское - 1 кург.

2478 Ярцево - 1 кург.

2447 Каменка - 2 кург.

35-н Мещерино - 3 кург.

2464 Полупирогово - 2 кург.

2459 Марьинка - 2 кург.

2433 Беспятово - 2 кург.

2434 Бессоново - 2 кург.

2440 Городня - 9 кург.

2475 Чиркино - 1 кург.

2463 Новоселки - 3 кург.

2199 Субботово 1 - 1 кург.

4 Я разделил группу на две части, судя по плану, есть прогал в 50 м.
2200 Субботово 2 - 1 кург.

21-н Шкинь - 1 кург.

12-н Воропаевка - 2 кург.

18-н Северское - 2 кург.

20-н Федосьино - 2 кург.

2193 Подберезники - 1 кург.

2194 Речки - 4 кург.

2158 Богдановка - 5 кург.

p. Гнилуша

92 Кутузово - ? кург.

104 Пестово 1 - 16 кург.

105 Пестово $2-7$ кург.

106 Пестово 3 - 10 кург.

107 Пестово 4 - 6 кург.

113 Скрипино - 5 кург.

1510 Агашкино - ? кург.

1512 Ивановское 1 - 9 кург.

1513 Ивановское 2 - 1 кург.

43-н Нащекино - 2 кург.

1537 Головина (Николо-

Гнилушенский) 1 - 20 кург.

1538 Головина $2-7$ кург.

1539 Головина 3 - 6 кург.

1552 Залесье 1 - 4 кург.

1553 Залесье 2 - 12 кург.

1554 Залесье 3 - 2 кург.

1555 Залесье 4 - 7 кург.

1601 Пестовка 1 - 6 кург.

1602 Пестовка 2 - 10 кург.

1603 Пестовка 3 - 4 кург.

1604 Пестовка 4 - 6 кург.

Всего в басс. Северки -

62 группы, в них

329 курганов

\section{СЕЛищА 11-13 вв.}

3149 Валуево 2 (Гоняный 2012)

3113 Можайск 3

3114 Можайск 1

2642 Троица 2

2643 Троица 3

3129 Горетово 4

3130 Горетово 5

2634 Красновидово 1

3132 Ковалево

3133 Косьмово 2

3117 Тетерино 2

3118 Новинки 1

3121 Бурцево 2

3122 Долгинино городище

3123 Бурцево 1

3124 Красный Стан 2

3125 Красный Стан 3

3126 Большое Тесово

1017 Мышкино

982 Бабынино

1033 Тушков городок

1034 Тушков городок селище

977 Аксаново
1005 Колоцкое

1020 Новое Село 1

1021 Новое Село 2

996 Гидроузел

1002 Клементьево

1009 Красный Стан 1

1081 городище Руза

1083 Акатово

1089 Беляная Гора

1104 Бутьково

1107 Ваюхино

1111 Вишенки 1

1120 Глазово 1

1121 Глазово 2

1122 Глазово 3

1126 Горбово

1139 Городище

1151 Костино

1157 Лызлово

1164 Молодиково

1166 Мытники

1175 Никольское 1

1176 Никольское 2

1177 Никольское 3

1181 Онуфриево

1184 Оселье

1185 Палашкино 1

1194 Ремянница

1200 Скирманово

1202 Слобода

1203 Старая Руза городище

1204 Старая Руза

1207 Сытьково

1208 Сычево

1212 Углынь

1214 Фролково

1217 Щербинки (Неждино)

854 Истра

865 Вельяминово городище

883 Лужки

889 Мансурово (Шейка)

895 Обновленный Труд

900 Павловская слобода 1

901 Павловская слобода 2

913 Раково

917 Санниково 2

921 Хволово

1272 Средниково

660 Подрезково (Сходненское) 1

661 Подрезково (Сходненское) 2

662 Подрезково (Сходненское) 3

130 Архангельское городище

147 Степановское

3153 Дмитровское 2 (на Истре, по Гаку)

290 Одинцово

304 Андреевское

317 Горышкино 2

324 Григорово 1

332 Дунино 1

337 Жуковка (с лепной керамикой)

347 Звенигород 1 (Колтарово)

350 Звенигород 4 (Поречье 1)
3127 Игнатьево - единичный венчик лепной (находка Лазукина Кренке 2012 г.)

2669a Поречье 1

(2-е Поречьевское)

$2669 б$ Поречье

2 (3-е Поречьевское)

с лепной керамикой

3070 Дунино 7

3071 Дунино 11

67-н Успенское городище

3072 Горки X 1

3073 Горки X 2

405 Успенское 2

404 Успенское 1 (древнерусские находки есть по Валяеву, Лазукину)

3075 Горышкино 10 (Кренке, Лазукин без отчета)

3074 Таганьково 4 (по Валяеву)

360 Знаменское

362 Иславское

365 Каринское 1

382 Михайловское 1

385 Назарьево

2662 Подушкино 2

2664 Подушкино 4

2665 Подушкино 5 с лепной керамикой в кургане

2666 Подушкино 6

2667 Подушкино 7

2671 Саввинская слобода 2 с лепной керамикой

3076 Хотяжи 1

3077 Хотяжи 2

(Никифоровское)

3078 Павшино (по Гаку)

3154 Немчиново (Баранов Супренков 2014)

11-м Митино $1^{5}$

12-м Спас-Тушино 4

17-м Спас-Тушино 2

18-м Спас-Тушино городище

20-м Мякинино 2

21-м Мякинино 1

214-м Мякинино 4

26-м Тушинское городище

27-м Алешкино 1

31-м Троице-Лыково

34-м Кунцевское городище

35-м Кунцево 1

36-м Фили 2

37-м Фили 1

45-м Краснолужское

46-м Матвеевское 1

50-м Матвеевское 2

53-м Раменки 1

70а-м Коньково 2

71-м Теплый Стан 1

77-м Андреевское 1

79-м Нескучный сад 1

5 -м означает московский список памятников. 
80-м Даниловское 1

80а-м Даниловское 2 с лепной керамикой

88-м Коломенское 1

89-м Коломенское 3

90-м Дьяково 1

91-м Дьяково 2 лепная единично

92-м Дьяково городище

93-м Дьяково 3

103-м Коньково 1

113-м Чертаново 1

134-м Орехово 4

136-м Орехово 6

137-м Орехово 5

143-м Орехово 4

148-м Орехово 2

159-м Братеево 1

162-м Капотня городище

163-м Капотня 1

168-м Лосиный Остров

170-м Андроньев монастырь

171-м Гравороново

173-м Устье Яузы

188-м Дубинкин дес 3

190-м Зюзино 3

191-м Курьяново 1

193-м Аннино 1

196-м Раменки 2

197-м Раменки 3

198-м Раменки 4

200-м Раменки 5

202-м Моховая, 9

204-м Теплый Стан 3

207-м Теплый Стан 2

209-м Нескучный сад 2

213-м Нескучный сад 3

214-м Мякинино 4

218-м Царицыно 2

219-м Орехово 8

220-м Орехово 7

221-м Царицыно 3

223-м Моховая, 10

224-м Царицыно 4

225-м Борисово 1

226-м Борисово 2

227-м Шипилово

228-м Царицыно 5

151 Андреевское 1

152 Андреевское 2

159 Беседы (лепная керамика)

3128 Николо-Угрешский монастырь (по Чернову, 2009)

3129 Акатово 2

(раннекруговая?

по Чернову, 2009)

6 Балашиха 5

9 Балашиха 8

12 Балашиха 11

14 Балашиха 13

19 Горбово 1
20 Горбово 2

21 Горбово 3

22 Горбово 4

24 Гущенка 2

25 Лукино 1

34 Никольское-Трубецкое 3

38 Пехра-Покровское 1

42 Пехра-Покровское 5

168 Богданиха 2

169 Богданиха 3

171 Богданиха 5

177 Внуково (Акатово)

3142 Мешково 1 (Гоняный 2008)

178 Володарский городище

183 Горки-Ленинские 2

184 Горки-Ленинские 3

2606 Горки-Ленинские 4

2607 Горки-Ленинские 5

2611 Горки-Ленинские 9

2602 Белеутово

2605 Горки 3

3140 Боброво 2 (Гоняный 2013)

120 Чурилково 1 (Миненко 2012)

3151 Чурилково 2 (Сорокин 2004, 2008)

190 Десна 1

3152 Десна 3

193 Дыдылдино 1

201 Кнутово

205 Коробово 1

210 Коробово 6

211 Коробово 7

219 Лаптево

228 Мещерино

234 Мисайлово

239 Остров

240 Пенино

241 Писково

242 Пуговичино

256 Соколова гора городище

1516 Боршева городище

1517 Боршева селище (лепная керамика)

1522 Бронницы

(Николо-Романьское)

1528 Верея 1

1529 Верея 2

1530 Верея 3

1531 Верея 4

1534 Гжель

1536 Головина (НиколоГнилушенское)

1541 Давыдово 1

1558 Заозерье 2 поселение (лепная керамика)

1559 Заозерье 1 селище

1566 Колоколово 1

1567 Колоколово 2

1573 Коробово (Тишковское)

1574 Кривцы (Ивань)

1577 Малахово
1588 Круглица городище

1610 Редькино

1627 ф-ка Спартак (Верейское городище)

1629 Боровский курган городище

1630 Чулково

2747 Софьино

1926 Воскресенск

1927 Аргуново 1

1928 Аргуново 2

1929 Ачкасово городище

1937 Городище поселение

1938 им Цюрупы 1 (Белые пески)

1939 им. Цюрупы 2

1953 Расловлево

1958 Юрасово

1374 Анциферово 1

1375 Анциферово 2

1376 Анциферово 3

1378 Анциферово 5

1379 Анциферово 6

1424 Куровское 1

1425 Куровское 2

1428 Минино

1436 Рудне-Никитское

2149 Коломна 1 (Блюдечко). Лепная керамика

3079 Коломна селище на л.б. Коломенки (по Мазурову)

2145 Коломна городище 1

2151 Коломна 3 (Староголутвин)

2164 Городищи-Юшково 1 городище

2165 Городищи-Юшково 2 городище

2166 Городищи-Юшково 3

2180 М. Уварово

2184 Молитвино

2185 Мячково (Настасьино) городище

2195 Северское

2202 Федосьино, городище

2206 Черкизово 2

2208 Шкинь

3141 Острожки 3 (Гоняный 2008)

2466 Проскурниково

2470 Троице-Лобаново

2471 Федоровское

3080 Афинеево (раскопки Двуреченского 2013 г.)

420 Александровка

425 Батыбино 1

426 Батыбино 2

427 Батыбино 3

428 Безобразово

429 Беляево

3147 Бол. Брянцево 2 (Гоняный, 2000)

433 Борисовка

435 Бородино (Кузнечики) городище
436 Булатово 1

437 Булатово 2

444 Дубровицы 1

447 Дубровицы поселение

449 Ерино

454 Иваньково

3145 Истомиха 2 (Гоняный, 2011)

3146 Истомиха 4 (Гоняный, 2011)

456 Конаково

459 Костишово 1

460 Костишово 2

461 Костишово 3

462 Костишово 4

466 Кутьино 1

467 Кутьино 2

468 Кутьино 3

469 Кутьино 4

470 Лемешево 1

471 Лемешево 2

472 Лемешево 3

473 Лопаткино

478 Луковня

481 Макарово с лепной керамикой

485 Никольское

486 Ознобишино 1

487 Ознобишино 2

488 Ознобишино 3

489 Ознобишино 4

490 Ознобишино 5

491 Ознобишино 6

492 Ознобишино 7

493 Ознобишино 8

498 Песье 1

499 Песье 2

500 Песье 3

503 Покров 1 с лепной керамикой

504 Покров 2

506 Поливаново 1

507 Поливаново 2

508 Поливаново 3

509 Поливаново 4

519 Рыбино

524 Сальково

525 Перемышль-Московский

526 Сатино-Татарское 1

528 Сатино-Татарское 3

529 Сатино-Татарское 4

530 Сатино-Татарское 5

531 Сатино-Татарское 6

532 Сатино-Татарское 7

533 Сатино-Татарское 8

534 Сатино-Татарское 9

536 Северо

537 Сергеевка

3148 Спирово 1 (Гоняный 2000)

540 Стрелково 1

541 Стрелково 2 с лепной керамикой

543 Студенцы 


551 Троицкое 2
552 Троицкое 3
554 Хлыново 1
555 Хлыново 2
562 Шаганино
565 Шубино
566 Щапово 1
567 Щапово 2
568 Щапово 3
564 Щапово 4
570 Щапово 5
3082 Щапово 6
3083 Щапово 7
2679 Подол 1
2680 Алхимово
2690 Жданово 1 с лепной
$\quad$ керамикой
2691 Жданово 2 (Добрятино 1)
$\quad$ с лепной керамикой
2692 Захарьино 3
2693 Захарьино 1
2694 Захарьино 2
51 Битягово 1
52 Битягво 2
53 Битягово 3
61 Воеводино
64 Горчиха 1
65 Горчиха 2
69 Ивановское 2
76 Колычево 1

\begin{tabular}{|c|c|}
\hline 78 Колычево 3 & 3101 Мозжинка (по Алексееву) \\
\hline 79 Колычево 4 & 3102 Козино (по Алексееву) \\
\hline 99 Новленское & 3103 на Алтыновском городище \\
\hline 110 Семивраги & 3104 Тимохово (по Алексееву) \\
\hline 117 Успенское & 3105 Б. Вяземы (по Алексееву) \\
\hline 123 Щербинки городище & 3106 Ямщина (по Алексееву) \\
\hline находки раннеслав. & 3107 Васильевское \\
\hline 124 Щербинки городище & (по Алексееву) \\
\hline 2 (Борисоглебское) & 3108 Марьино (по Алексееву) \\
\hline 125 Щербинки & 3109 Агафоново (по Алексееву) \\
\hline 3081 Заболотье 2. Лепная & 3110 Аносино 1 (по Ковалю) \\
\hline керамика (по Гоняному) & 3111 Аносино 2 (по Ковалю) \\
\hline 3084 ЗБС 1 & 3112 Б. Саврасово 1 \\
\hline 3085 ЗБС 2 & (по Гоняному) \\
\hline 3086 ЗБС 3 & 3113 Б. Саврасово 2 \\
\hline 3087 ЗБС 4 & (по Заидову) с лепной \\
\hline 3088 Луцино-Дачи 1 & керамикой \\
\hline 3089 ЗБС 7 & 2548 Жеребятьево 2 \\
\hline 3090 Дютьково 3 (Олимп) & 2549 Жеребятьево 3 \\
\hline 3091 Власово (по Алексееву) & 2550 Котляково 1 \\
\hline 3092 Аниково (по Алексееву) & 2552 Красино 1 \\
\hline 3093 Бушарино (по Алексееву) & 2553 Красино 2 \\
\hline 3094 Луцино 1 (по Алексееву) & 2554 Новое Съяново 2, лепная \\
\hline 3095 Луцино 2 (по Алексееву) & керамика \\
\hline $\begin{array}{l}3096 \text { Мартьяново } \\
\text { (по Алексееву) }\end{array}$ & $\begin{array}{l}2555 \text { Новое Съяново 3, лепная } \\
\text { керамика }\end{array}$ \\
\hline 3097 Клопово (по Алексееву) & 2558 Татарское 1 \\
\hline 3098 Скит Саввы (по Алексееву) & 2559 Татарское 2 \\
\hline 3099 Дютьково (по Алексееву) & 2560 Татарское 3 \\
\hline 3100 Введенское (по Алексееву) & 2561 Татарское 4 \\
\hline
\end{tabular}

2565 Ям 2

2566 Ям 3

2567 Ям 4 (Старое Пахрино) лепная керамика по Гоняному

ГОРОдищА

1138 Городище

1141 Городище

1190 Покров городище

Шорново

50-н Щербинки (Неждино)

3115 Можайск

476 Луковня городище

1 Балашиха городище

\section{ГОРОДА}

Москва

Коломна

Звенигород

\section{КЛАДЫ И НАХОДКИ ДИРХЕМОВ}

Городище Настасьино Симонов монастырь Храм Христа Спасителя Городище Кунцево Хотяжи 1 


\section{Литература и архивные источники}

Агеев Б.Б. Пьяноборская культура. Уфа., 1992.

Акты социально-экономической истории Северо-Восточной Руси конца XIV - начала XVI в. М., 1958. T. 2.

Александровский А.Л. Палеопочвенные данные // Культура средневековой Москвы: Исторические ландшафты. М., 2004. T. 1. С. 105-107.

Александровский А.Л. Погребенные почвы в разрезе поймы Москвы-реки у поселка РАНИС // Археология Подмосковья/отв. ред. А.В. Энговатова. М., 2008. Вып. 4. С. 344-346.

Александровский А.Л., Кренке Н.А. Изучение средневековых пахотных горизонтов в Москве и Подмосковье // КСИА. М., 1993. Вып. 208. С. 20-31.

Александровский А.Л., Кренке Н.А., Нефёдов В.С. Палеорельеф высокой поймы Днепра на территории Гнёздовского археологического комплекса // РА. 2005. № 1. С. 112-123.

Александровский А.Л., Кренке Н.А., Низовцев В.А., Спиридонова Е.А., Янишевский Б.Е. Пойменный ландшафт в долине Москвы-реки в железном веке и Средневековье // Культура средневековой Москвы: Исторические ландшафты/отв. ред. Н.А. Кренке, С.3. Чернов. М., 2004. Т. 1. С. 189-202.

Александровский А.Л., Кренке Н.А., Спиридонова Е.А., Янишевский Б.Е. Изучение валов и погребенных под ними почв на дьяковских городищах Троицкое, Луковня 2 и Коробово в Подмосковье // ТАС. Тверь, 1998. Вып. 3. С. 333-351.

Александровский А.Л., Панин А.В. Закономерности формирования поймы реки Москвы в контексте ее освоения человеком // Археология Подмосковья. М., 2013. Вып. 9. C. 249-256.

Алексеев A.B. Группа памятников древнерусского времени у д. Хотяжи // Археология Подмосковья. М., 2004. Вып. 1. C. 177-192.

Алексеев А.В. Памятники древнерусского времени в окрестностях Звенигорода: (материалы к археологической карте) // Археология Подмосковья. М., 2005. Вып. 2. С. 111-118.

Антипина E.E. Ростиславльское городище дьяковского времени: археозоологические материалы из раскопок 20022006 годов // Аналитические исследования лаборатории естественно-научных методов. М., 2009. Вып. 1. С. 146171.

Антипина E.E. Домашние животные и жизнеобеспечение городища Настасьино (ранний железный век) //
Аналитические исследования лаборатории естественно-научных методов. М., 2013. Вып. 3. С. 142-158.

Антипина Е.Е., Лебедева Е.Ю. Опыт комплексных археобиологических исследований земледелия и скотоводства: модели взаимодействия // РА. 2005. № 4. С. 70-78.

Анучин Д.Н. Доисторическая Москва // Москва в ее прошлом и настоящем. М., 1909. С. 36-53.

Артеменко И.И. Племена Верхнего и Среднего Поднепровья в эпоху бронзы. М., 1967.

Артеменко И.И. Белынецкий могильник // Восточная Европа в эпоху камня и бронзы. М., 1976. С. 155-175.

Артеменко И.И. Могильник среднеднепровской культуры в урочище Стрелица // Энеолит и бронзовый век Украины. Киев, 1976а. С. 69-95.

Артеменко И.И. Культуры шнуровой керамики // Эпоха бронзы лесной полосы СССР/отв. ред. О.Н. Бадер, Д.А. Крайнов, М.Ф. Косарев. М., 1987. С. 35-50.

Артеменко И.И. Связи племен среднеднепровской культуры // Межплеменные связи эпохи бронзы на территории Украины. Киев, 1987а. С. 6-15.

Археологическая карта России: Калужская область/под ред. А.В. Кашкина. М., 2006.

Археологическая карта России: Московская область. М., 1994-1997. Ч. 1-4.

Археология Мордовского края. Саранск, 2008.

Археология Романова Двора. М., 2009.

Арииховский А.В., Курганы вятичей. М., 1930.

Аричиховский A.B. Археологические данные о возникновении феодализма в Суздальско-Смоленской земле // ПИДО. Л., 1934. № 11-12. С. 35-60.

Аричиховский А.В. Царицынские курганы // МИА. М.; Л., 1947. № 7. С. 77-81.

Аун М. Курганные могильники Восточной Эстонии во второй половине I тыс. н.э. Таллин, 1980. 136 с.

Ахмедов И.Р. Инвентарь мужских погребений // Восточная Европа в середине I тыс. н.э.: Раннеславянский мир. М., 2007. Вып. 9. С. 137-185.

Ахмедов И.Р. Проблема «финального» периода культуры рязано-окских финнов // Археология Восточной Европы в I тыс. н.э.: Раннеславянский мир. М., 2010. Вып. 13. C. 7-34.

Ахмедов И.Р., Казанский М.М. После Аттилы: Киевский клад и его культурно-исторический контекст // Культурные трансформации и взаимовлияния в Днепровском регионе 
на исходе римского времени и в раннем Средневековье. СПб., 2004. С. 168-202.

Ахмедов И.Р., Луньков В.Ю., Лунькова Ю.В. Абашевские комплексы Старшего Никитинского могильника (по материалам исследований 2002-2004 гг.) // КСИА. М., 2013. Вып. 230. С. 162-181.

Ашихмина Л.И., Черных Е.М., Шаталов В.А., Вятский край на пороге железного века: костяной инвентарь ананьинской эпохи. Ижевск, 2006.

Бадер О.Н. Материалы к археологической карте Москвы и ее окрестностей // МИА. М.; Л., 1947. № 7. С. 88-167.

Бадер О.Н. Древние городища на Верхней Волге // МИА. М.; Л., 1950. № 13. С. 90-132.

Бадер О.Н., Возникновение Москвы в свете археологических данных // Учен. зап. Пермского гос. ун-та. Пермь, 1951. T. VI. Вып. 4. С. 49-67.

Бадер О.Н., Халиков А.Х. Памятники балановской культуры // САИ. М., 1976. Вып. В1-25.

Бахрушин Ю.А. Воспоминания. М., 1994. (История Москвы с древнейших времен до наших дней).

Башенькин А.Н. Культурно-исторические процессы в МологоШекснинском междуречье в конце I тыс. до н.э. - I тыс. н.э. // Проблемы истории Северо-Запада Руси. СПб., 1995. Вып. 3. С. 3-29.

Башенькин А.Н., Васенина М.Г. Поселение и погребальное сооружение Куреваниха XVI и XVI-a на р. Мологе // Археология: история и перспективы. Ярославль, 2006. С. 406-416.

Белая Н.Н. Глиняная пластика скифского времени ДнепроДонской лесостепи: Автореф. дисс. ... канд. ист. наук. М., 2011.

Белочерковская И.В. Керамика некоторых поселений раннего железного века на Верхней Упе // СА. 1981. № 2. С. 197206.

Белоцерковская И.В. Ажурные застежки из могильника Кораблино // Тр. ГИМ. М., 1999. Вып. 103. С. 154-176.

Белочерковская И.В. Верхнеокские элементы в культуре рязано-окских могильников // Научное наследие А.П. Смирнова и современные проблемы археологии Волго-Камья. М., 2000. С. 99-108. (Тр. ГИМ; Вып. 122).

Белоцерковская И.В. Инвентарь женских погребений // Восточная Европа в середине I тыс. н.э.: Раннеславянский мир. М., 2007. Вып. 9. С. 186-213.

Белочерковская И.В., Ахмедов И.Р. Работы археологических экспедиций ГИМ на Оке: некоторые итоги и перспективы изучения рязано-окских могильников III-VII вв. н.э. // Археологические открытия 1991-2004: Европейская Россия. М., 2009. С. 283-298.

Беляев Л.А. Древние монастыри Москвы по данным археологии. М., 1994.

Беляев Л.А., Кренке Н.А., Шуляев С.Г. Докремлевская Москва: новые данные по топографии и керамике даниловских селищ X/XI-XIV вв. // РА 2010. № 1. С. 104-116.

Березанская С.C. О земледелии в культурах шнуровой керамики на Украине // Памятники древнейшей истории Евразии. М., 1975. С. 192-198.

Бирюков И.Е., Бессуднов А.Е. Поселение сарматского вре- мени в районе Острой луки Дона // Археологические памятники Восточной Европы. Воронеж, 2006. Вып. 12. С. $156-162$.

Бирюков И.Е., Разуваев Ю.Д. Поселение скифо-сарматского времени у с. Каменка на верхнем Дону // Верхнедонской археологический сборник. Липецк, 2009. Вып. 4. С. 137152.

Богданов А.П. Курганное племя Московской губернии. М., 1865.

Большов С.В. Средневолжская абашевская культура. Йошкар-Ола, 2003.

Бочкарёв В.С. «Радиокарбонная революция» и проблема периодизации памятников эпохи бронзы Восточной Европы // Принципы датирования памятников эпохи бронзы, железного века и Средневековья: Мат-лы российско-германского коллоквиума (2-3 декабря 2013 г., Санкт-Петербург). СПб., 2013. С. 59-78.

Братченко С.Н. Катакомбне «бароко» $з$ овами та петлями в системі орнаментації // Матеріали та дослидження з археолгії східной України. Луганськ, 2007.С. 103-109.

Бродель Ф. Материальная цивилизация, экономика и капитализм. XV-XVIII вв. М., 1986. Т. 1: Структуры повседневности: возможное и невозможное.

Брокгауз Ф.А., Эфрон И.А., Энциклопедический словарь. СПб., 1896. Т. ХІХа.

Брюсов А.Я. Льяловская стоянка на р. Клязьме в Московской обл. // СА. 1960. № 3. С. 277-282.

Брюсов А.Я., Липеровская Е.Н., Городиов М.В. Отчет о разведках, произведенных студентами Факультета общественных наук 1-го Московского университета в Воскресенском и Подольском уездах Московской губернии // Архив ИИМК РАН. 1923. Ф. 2. 1923. Д. № 95.

Бубликов В.В., Прошкин О.Л., Добровольская М.В. Курганный могильник Рыжково на реке Протве // Археология Подмосковья. М., 2008. Вып. 4. С. 108-123.

Булычев Н.Н. Журнал раскопок 1898 г. по берегам Оки. М., 1899.

Бунак В.В. Род Ното, его возникновение и последующая эволюция. М., 1980.

Бунятян К.П. Городоцько-здовбицька культура: проблемна ситуація // Археологія. 2008. № 3. С. 10-20.

Буров В.А. Городище Варварина Гора. М., 2003.

Векслер А.Г. Отчет об археологических работах в Москве и Подмосковье в 1965 г. // Архив ИА РАН. Р-1. 1965. № 3088, 3088a.

Векслер А.Г. Отчет об археологических раскопках в Одинцовском районе Московской области в 1966 г. // Архив ИА РАН. Р-1. 1966. №3277, 3277а.

Векслер А.Г. Отчет об археологических раскопках в Одинцовском районе Московской области в 1967 г. // Архив ИА РАН. Р-1. 1967. № 3552, 3552а.

Векслер А.Г. Отчет об археологических раскопках городища Луковня в Подольском р-не Московской обл. в 1969 г. // Архив ИА РАН. Р-1. 1969. № 4049

Векслер А.Г. Семиверхие курганы вятичей в Одинцове под Москвой // Древние славяне и их соседи. М., 1970. С. 122-125. 
Векслер А.Г. Отчет об археологических раскопках Кунцевского городища в г. Москве и Луковнинского городища в Московской области в 1970 г. // Архив ИА РАН. Р-1. 1971. № 4196.

Векслер А.Г. Отчет об археологических раскопках Кунцевского городища и Одинцовского могильника в 1971 г. // Архив ИА РАН. Р-1. 1972. № 4516.

Векслер А.Г. Отчет об археологических раскопках Кунцевского городища в Москве в 1972 г. // Архив ИА РАН. Р-1. 1973. № 4810.

Векслер А.Г. Отчет об археологических раскопках Кунцевского городища в Москве и Луковнинского городища в Московской области в 1973 г. // Архив ИА РАН. P-1. 1974. № 5089.

Векслер А.Г. Террасы Кунцевского городища в Москве // Памятники древнейшей истории Евразии. М., 1975. С. 259-264.

Векслер А.Г. Позднедьяковские находки на Жуковском селище под Москвой // Вопросы древней и средневековой археологии Восточной Европы. М., 1978. С. 153-158.

Векслер А.Г. Спасательная археология Москвы. М., 2007.

Векслер А.Г., Станюкович А.К. Раннесредневековое поселение у Боровского перевоза в Подмосковье // КСИА. М., 1986. Вып. 183. С. 76-80.

Виноградов К.Я., Древнейшие следы культуры славян и финнов в Воскресенском уезде Московской губернии. Воскресенск, 1925.

Виноградов К.Я. Дневник археологических раскопок 1926 г. // Архив Московского областного краеведческого музея.

Виноградов К.Я. Три этапа культуры у Ивановой горы на p. Рузе. М.: Волоколамский историко-художественный и краевой музей, 1929.

Виноградов К.Я. Новые данные о памятниках фатьяновского типа // ПИДО. Л., 1934. № 11-12. С. 71-76.

Виноградов К.Я. Материалы к археологической карте среднего и нижнего течения р. Протвы // Макариевские чтения. Можайск, 1994. Вып. 2. Ч. 2. С. 88-112.

Вишневский В.И., 1989. Керамический комплекс городища Кубринское 1 // СА. № 4. С. 163-171.

Вишневский В.И. Селище раннежелезного века Веськово 1 на Плещеевом озере // Археологические памятники ВолгоКлязьминского междуречья. Иваново, 1990. Вып. 4. С. 11-14.

Вишневский В.И. Новые материалы о земледелии племен дьяковской культуры Верхнего Поволжья // РА. 1994. № 3. С. 223-226.

Вишневский В.И. Кикинское городище // ТАС. Тверь, 1998. Вып. 3. С. 359-366.

Вишневский В.И. Керамический комплекс посуды Кикинского городища // ТАС. Тверь, 2007. Вып 6. Ч. 2. С. 85-93.

Вишневский В.И. Максимковское селище дьяковской культуры на р. Клязьме // ТАС. Тверь, 2009. Вып. 7. С. 465473.

Вишневский В.И., Кирьянова Н.А., Добровольская М.В. Ратьковский раннесредневековый финно-угорский могильник: хронология, культура, обряд // РА. 2007. № 2. C. 89-107.
Вишневский В.И., Новоселова Т.Н. Раннесредневековый финно-угорский могильник на Ратьковском городище: (результаты раскопок 2006-2007 годов) // Археология Подмосковья. М., 2010. Вып. 6. С. 67-82.

Волкова E.B. Новинковские могильники фатьяновской культуры. М., 2010.

Воронина Р.Ф., Зеленцова О.В., Энговатова А.В. Никитинский могильник. М., 2005.

Воронцуов A.M. Памятники типа Ново-Клеймёново в первой четверти I тыс. н.э. на территории Окско-Донского водораздела // РА. 2007. № 3. С. 80-93.

Воронщов А.М. Отчет об археологических исследованиях в Суворовском и Кимовском районах Тульской области в 2009 г.: Раскопки на городище Акиньшино Суворовского района // Архив ИА РАН. Р-1. 2010. Р-1. 36870

Воронцзов A.M. Тамги на предметах мощинской культуры // Лесная и лесостепная зоны Восточной Европы в эпохи римских влияний и Великого переселения народов. Тула, 2010a.

Воронщов A.M. К вопросу о поздней дате мощинской культуры // Тр. ХІХ Всероссийского археологического съезда. Санкт-Петербург; Москва; Великий Новгород, 2011. Т. 2. C. $14-15$.

Воронцов А.М. Памятники мощинской культуры в третьей четверти I тыс. н.э. // Раннесредневековые древности лесной зоны Восточной Европы V-VII вв. н.э.: Раннеславянский мир. М., 2016. Вып. 17. С. 221-260.

Воронятов C.B. О функции сарматских тамг на сосудах // Гунны, готы и сарматы между Волгой и Дунаем. СПб., 2009. C. 80-98.

Воронятов C.B. О проблеме появления сарматских тамг и антропоморфных изображений в ареалах позднедьяковской и мощинской культур // Российский археологический ежегодник. СПб., 2012. № 2. С. 412-432.

Гаврилова И.В. Фатьяноидная керамика Костромского Поволжья // Изыскания по мезолиту и неолиту. Л., 1983. С. 101-109.

Гавритухин И.О. Маленькие трапециевидные подвески с полоской из прессованных точек по нижнему краю // Гістарична-археалагічны зборнік. Мінск, 1997. № 12. C. 43-53.

Гавритухин И.О. Ингумации, связанные с культурой оседлого населения, и отдельные находки постгуннского времени // Восточная Европа в середине I тыс. н.э.: Раннеславянский мир. М., 2007. Вып. 9. С. 30-32.

Гадзячкая О.С. Новые раскопки Тургиновского могильника // КСИА. М., 1971. Вып. 127. С. 65-71.

Гадзяџкая О.C. Памятники фатьяновской культуры: Ивановско-Горьковская группа. М., 1976. (САИ; Вып. В121).

Гадзячикая О.С. Фатьяновский компонент в культуре поздней бронзы: (Волго-Клязьминское междуречье) // СА. 1992. № 1. С. 122-141.

Гак Е.И. Материалы финальной бронзы с многослойного поселения Подол 1 и их культурная интерпретация // Историко-археологические чтения памяти Н.И. Троицкого. Тула, 1997. Вып. 1. С. 73-76. 
Гак Е.И. Поселения эпохи бронзы на северной окраине донской лесостепи. М., 2011.

Гак Е.И., Гоняный М.И. Многослойное поселение Подол 1 в исторической части города Подольска: результаты исследований и интерпретация материалов // Археология Подмосковья. М., 2007. Вып. 3. С. 9-19.

Герасимов П.А., Ахламов Д., Костомаров В., Археологическая карта нижнего течения р. Пахры // Архив ИИМК РАН. Ф. 2. Оп. 1. Д. 101. 1925 г.

Голдина Р.Д. Тарасовский могильник $\mathrm{I}-\mathrm{V}$ вв. на Средней Каме. Ижевск, 2003. Т. 2.

Голдина. Р.Д., Кананин В.А. Средневековые памятники верховьев Камы. Свердловск, 1989.

Голубева Л.А. Весь и славяне на Белом озере Х-XI вв. М., 1973.

Гомзин А.А. Восточное монетное серебро IX-начала XI в. в среднем и нижнем Поочье: Дисс. ... канд. ист. наук. Рукопись. М., 2013.

Гоняный М.И. Археологические памятники начального этапа славянской колонизации среднего течения р. Пахры в Подмосковье // Тр. ГИМ. М., 1999. Вып. 111. С. 128-146.

Гоняный М.И. Археологические памятники района Куликова поля // Куликово поле и Донское побоище 1380 г. М., 2005. С. 95-162.

Гоняный М.И. Отчет о научно-исследовательских археологических раскопках, проведенных в 2009 г. на поселении Заболотье За в Домодедовском районе Московской обл. // Архив ИА РАН. Р-1. 2009. № 37601.

Гоняный М.И. Находки вятичского круга древностей конца XII-XIII в. на сельских археологических памятниках бассейна верховьев Дона // Славяне и иные языцы.... К юбилею Натальи Германовны Недошивиной. М., 2014. С. 65-91. (Тр. ГИМ; Вып. 198).

Гоняный М.И., Александровский А.Л., Гласко М.П. Северная лесостепь бассейна верхнего Дона времени Куликовской битвы. М., 2007.

Гоняный М.И., Каи М.Я., Наумов А.Н. Древнерусские археологические памятники конца XII-первой четверти XIV века в приустьевой части Непрядвы на Куликовом поле // Русь в XIII веке: древности темного времени. М., 2003. С. 228-252.

Гоняный М.И., Кренке Н.А. Структура расселения дьяковцев в бассейне р. Пахры // СА. 1988. № 3. С. 54-62.

Гоняный М.И., Шебанин Г.А., Шеков А.В. Средневековое поселение у деревни Большое Саврасово в Ленинском районе Московской области // Археология Подмосковья. М., 2010. Вып. 6. С. 164-179.

Городияов В.А. Старшее Каширское городище. М.; Л., 1933. (Изв. ГАИМК; Вып. 85).

Городияов В.А. Подчеремский клад // СА. 1937. № 2 С. 113-150

Горюнов Е.А., Казанский М.M. О происхождении широкопластинчатых фибул // КСИА. М., 1978. Вып. 155. C. 25-31.

Горюнова В.M. Раннегончарная керамика Рюрикова городища и общие тенденции развития раннегончарных комплексов городских центров Северной Руси X-начала XI в. // Носов Е.Н., Горюнова В.М., Плохов А.В. Городище под
Новгородом и поселения северного Приильменья. СПб., 2005. С. 82-121.

Горюнова Е.И. Этническая история Волго-Окского междуречья // МИА. М., 1961. № 94.

Григорьев А.В. Об этнической принадлежности височных колец «деснинского типа» // Вопросы археологии, истории, культуры и природы Верхнего Поочья. Калуга, 2005. C. 22-24.

Григорьев А.В. Славянское население водораздела Оки и Дона. Тула, 2005a.

Григорьев А.В. Лучевые серьги (височные кольца) культур роменского круга древностей // Верхнедонской археологический сборник. Липецк, 2010. С. 219-226.

Григорьев А.В. Население междуречья Днепра и Дона в VIII - первой половине XI в. // Древнейшие государства на территории Восточной Европы. 2010 г. М., 2012. C. 94-127.

Гришаков В.В. Керамика финно-угорских племен правобережья Волги в эпоху раннего средневековья. Йошкар-Ола, 1993.

Гришаков В.В. Хронология мордовских древностей III-IV вв. Верхнего Посурья и Примокшанья // Пензенский археологический сборник. Пенза, 2008. Вып. 2. С. 82-137.

Грудинкин Б.В. Отчет об археологических разведках в 1995 г. в Калужской и Тульской областях // Архив ИА РАН. Р-1. 1995. № 23183.

Грудинкин Б.В. Комплекс поселений около д. Воронино // Вопросы археологии, истории и культуры Верхнего Поочья. Калуга, 2013.

Гуляев В.И. Зооморфная рукоять ножа со Старшего Каширского городища // КСИА. М., 1963. Вып. 94. С. 101-104.

Гунова В.С. Палинологические данные // Культура средневековой Москвы: Исторические ландшафты. М., 2004. Т. 1. C. 107-111.

Гунова В.С., Кирьянова Н.А., Кренке Н.А., Низовиев В.А., Спиридонова E.A. Земледелие и система землепользования в долине Москвы-реки в железном веке // РА. 1996. № 4. С. 93-120

Гурина Н.Н., Крайнов Д.А. Льяловская культура // Неолит Северной Евразии. М., 1996. С. 173-180.

Давидан О.И. Бронзолитейное дело в Ладоге // Археологический сборник Гос. Эрмитажа. Л., 1980. Вып. 21. С. 59-67.

Дайга И.В. О литейных формах и литейном деле на территории Латвии (до ХІІІ в.) // СА. 1960. № 3. С. 78-92.

Данильченко В.П. Остеологический материал Селецкого городища // КСИА. М., 1984. Вып. 178. С. 29-33.

Данильченко В.П., Карху А.А. Фаунистические определения материалов поселения Воймежное 1 // Древние охотники и рыболовы Подмосковья. М., 1997. С. 130-132.

Диков Е.И. Отчет о раскопках Зареченской стоянки в 1968 г. Ногинск, 1968.

Дмитриев А.В. Могильник Дюрсо - эталонный памятник древностей V-IX веков // Крым, Северо-Восточное Причерноморье и Закавказье в эпоху средневековья: IVХІІІ века. М., 2003. С. 200-206.

Добровольская М.В., Медникова М.Б. «Медные люди» эпохи 
бронзы: реконструкция состояния здоровья и социального статуса // Археология, этнография и антропология Евразии. 2011. № 2 (46). С. 143-156.

Доктуровский В.С. Определение возраста Льяловской стоянки по пыльце в торфе // Русский антропологический журнал. 1925. Т. 14. С. 83-84.

Древние охотники и рыболовы Подмосковья/ред. А.В. Энговатова. М., 1997.

Дробушевский А.И. Уваровичское рало // Гістарычнаархеалагічны зборниік. Мінск, 1996. Вып. 10. С. 5-7.

Дробушевский А.И. Этнокультурные изменения в междуречье Днепра и Десны на рубеже новой эры // Гістарычнаархеалагічны зборниік. 2011. № 26. С. 76-83.

Дробушевский А.И. Древности чечерской группы (типа Кистени - Чечерск) и памятники типа Абидни Белорусского Поднеровья // Acta Archaeologica Albaruthenica. Мінск, 2012. Vol. VIII. С. 33-68.

Дубынин А.Ф. Городище Кузнечики в Подмосковье // СА. 1970. № 1. С. 152-164.

Дубынин А.Ф. Троицкое городище // Древнее поселение в Подмосковье. М., 1970а. С. 5-98. (МИА; № 156).

Дубынин А.Ф. Щербинское городище // Дьяковская культура. М., 1974. С. 198-281.

Дубынин А.Ф., Киселев С.В. Отчет о произведенной студентами 1 МГУ А.Ф. Дубыниным и С.В. Киселевым археологической разведке по течению р. Пахры // Архив ИИМК РАН. Ф. 2. 1925. № 200.

Дубынин А.Ф., Киселев С.В. Материалы для археологической карты Московской губернии: Археологическая разведка по верхнему течению р. Пахры // Московский краевед. М., 1929. Вып. 2 (10). С. 3-6.

Дубынин А.Ф., Розенфельдт И.Г. Постройки Троицкого городища // Древнее поселение в Подмосковье. М., 1970. С. 99-135. (МИА; № 156).

Дукельский В.Ю. Отчет о разведках в Московской области в 1976 г. // Архив ИА РАН. Р-1. 1977. № 6364.

Дукельский В.Ю. Отчет о работах Музея истории и реконструкции г. Москвы на территории Рузского и Чеховского районов Московской обл. в 1977 г. // Архив ИА РАН. Р-1. 1977a. № 6684.

Евтюхова Л.А. Дневник раскопок курганов у дер. Орехово Ленинской вол. Московской губ. // Архив ИИМК. Ф. 2. Оп. 1. Д. 227. 1929 г.

Егорейченко A.A. Культуры штрихованной керамики. Минск, 2006.

Екимов Ю.Г. Поселение поздняковской культуры под Тулой // Археологические памятники среднего Поочья. Рязань, 1992. С. 62-75.

Емельянов A.B. Отчет об охранных научно-исследовательских археологических работах, проведенных на селище Кулаково 3 в Раменском районе Московской области в 2010 г. // Архив ИА РАН. 2011. Без номера.

Енуков В.В. Беседские курганы // СА. 1987. № 3. С. 190-201.

Еремеев И.И., Дзюба О.Ф. Очерки исторической географии лесной части пути из варяг в греки. СПб., 2010.

Ершова Е.Г. Результаты спорово-пыльцевого анализа погребенных почв бронзового века в пойме Москвы-реки //
Археология Подмосковья/отв. ред. А.В. Энговатова. М., 2014. Вып. 10. С. 26-28.

Ершова Е.Г., Березина Н.А., Карина Е.В. Растительность долины Москвы-реки в суббореальном периоде (на рубеже неолита и бронзового века) по данным спорово-пыльцевого анализа // Археология Подмосковья/отв. ред. А.В. Энговатова. М., 2013. Вып. 9.С. 257-267.

Ершова Е.Г., Кренке Н.А. Изучение природных и культурных ландшафтов железного века в долине Москвы-реки методами палинологии и археологии // Вестник археологии, антропологии и этнографии. Тюмень, 2014. № 3. С. 159172.

Жилин М.Г. Костылева Е.Л., Уткин А.В., Энговатова А.В. Мезолитические и неолитические культуры Верхнего Поволжья. М., 2002.

Жуков Б.С. Неолитическая стоянка вблизи с. Льялова, Московского уезда // Русский антропологический журнал. 1925. Т. 14. С. 37-78.

Жуков Б.С. К вопросу о стратиграфии и культуре неолитической стоянки близ с. Льялова Московского уезда // Русский антропологический журнал. М.; Л., 1927. T. 16. Вып. 1-2. С. 58-74.

Жульников А.М. О фатьяноидной керамике на древних поселениях южного побережья Белого моря // Человек, адаптация, культура. М., 2008. С. 413-424.

Забелин И.Е. Кунцево и Древний Сетунский стан. М., 1873.

Забелин И.Е. Домашний быт русских царей в XVI и XVII столетиях. М., 1895. Ч. 2. 782 с.

Забелин И.Е. История города Москвы. М., 1905.

зайцева И.Е., Сарачева Т.Г. Ювелирное дело «земли вятичей» во второй половине XI-XIII в. М., 2011.

Зальцман Э.Б. Поселения культуры шнуровой керамики на территории Юго-Восточной Прибалтики. М., 2010.

Зареикая Н.Е., Костылева Е.Л. Новые данные по абсолютной хронологии льяловской культуры // ТАС. Тверь, 2011. Вып. 8/отв. ред. И.Н. Черных. С. 175-183.

Засеикая И.П. Боспорский некрополь как эталонный памятник древностей IV-начала VII века // Крым, СевероВосточное Причерноморье и Закавказье в эпоху Средневековья: IV-XIII века. М., 2003. С. 31-40.

Захаров С.Д. Белоозеро // Русь в IX-X вв.: Археологическая панорама. Москва; Вологда, 2012. С. 213-239.

Зеликсон Э.М. О палеогеографической интерпретации спорово-пыльцевых спектров с большим содержанием пыльцы орешника // Изв. АН СССР. Сер. геогр. 1977. № 2. C. 102-112.

Зерницкая В.П., Симакова Г.И., Павлова И.Д. Признаки хозяйственной деятельности человека в пыльцевых спектрах голоцена Беларуси // Гистарычна-археалагічны зборнік. Минск, 2001. № 16. С. 5-19.

Зубов С.Э. Кипчаковский культурно-хронологический горизонт в системе пьяноборской культуры // Уфимский археологический вестник. Уфа,. 2007. Вып. 6-7. C. $72-88$.

Иванов Д.А. Керамика эпохи финальной бронзы - начала раннего железного века с Дубровичского 1 селища // Археология Подмосковья. М., 2011. Вып. 7. С. 26-34. 
Изюмова С.A. О бронзолитейном производстве Сатинского городища // СА. 1967. № 1. С. 122-139.

Исланова И.В. Верхневолжье и Валдай // Восточная Европа в середине I тыс. н.э. М., 2007. С. 301-332.

Исланова И.В. Городище Отмичи. М., 2008.

Исланова И.В. Раннесредневековые группы памятников на Северо-Западе Восточной Европы // Раннесредневековые древности лесной зоны Восточной Европы V-VII вв. н.э.: Раннеславянский мир. М., 2016. Вып. 17. С. 136-220.

Исланова И.В., Мирецкий А.В. Находки с городища Осечен // Тверь, Тверская земля и сопредельные территории в эпоху Средневековья. Тверь, 1997. Вып. 2. С. 12-19.

Каверзнева Е.Д., Фоломеев Б.А. Радиоуглеродная хронология памятников эпохи энеолита - ранней бронзы озерной мещеры // Археологический сборник. М., 1998. С. 5-19. (Тр. ГИМ; Вып. 96).

Казанский М.M. О балтах в лесной зоне России в эпоху великого переселения народов // Археологические вести. СПб., 1999. № 6. С. 404-419.

Каравайко Д.В. Памятники юхновской культуры НовгородСеверского Полесья. Киев, 2012.

Карху А.А. Орнитокомплекс поселения Ивановское VII // Жилин М.Г., Костылева Е.Л., Уткин А.В., Энговатова А.В. Мезолитические и неолитические культуры Верхнего Поволжья. М., 2002. С. 102-104.

Карцов В.Г. Разведки В. Карцова в бассейне р. Сетунь Московского у. // Архив ИИМК РАН. Ф. 2. Оп. 1. 1927. № 203.

Кариов В.Г. К материалам по составлению археологической карты Московской губернии: археологическая карта бассейна р. Сетунь // 1 МГУ. Сборник научно-археологического кружка. М., 1928. Вып. 1. С. 9-11.

Качанова В.И. О заселении Московского края в эпоху дьяковской культуры // Археологические памятники Москвы и Подмосковья. М., 1954. С. 7-38.

Кириллова И.В. Фауна млекопитающих поселения Ивановское VII // Жилин М.Г., Костылева Е.Л., Уткин А.В., Энговатова А.В. Мезолитические и неолитические культуры Верхнего Поволжья. М., 2002. С. $92-$ 101.

Кирьянова Н.А. Отчет о раскопках Ханевского фатьяновского могильника // Архив ИА РАН. Р-1. 1970. № 4551: Крайнов Д.А. Отчет Верхне-Волжской археологической экспедиции.

Кирьянова Н.А. Фатьяновский могильник у д. Ханево // Восточная Европа в эпоху камня и бронзы. М., 1976. C. $143-154$.

Кирьянова Н.А. О находках зерен культурных растений I тыс. до н.э. - I тыс. н.э. на территории лесной зоны Восточной Европы // II Городцовские чтения. М., 2005. С. 226-230. (Тр. ГИМ; Вып. 145).

Климанов В.А., Серебрянная Т.А. Изменения растительности и климата на Среднерусской возвышенности в голоцене // Изв. АН СССР. Сер. геогр. 1986. № 1. С. 26-37.

Ковалевская В.Б. Компьютерная обработка массового археологического материала из раннесредневековых памятников Евразии. М., 2000. 361 с.
Коваль В.Ю. Исследование керамического материала // Средневековое поселение Настасьино. М., 2004. С. 21-39.

Коваль В.Ю. Отчет об археологических исследованиях на городище Ростиславль и селище Сосновка IV в Озерском районе Московской обл. в 2004 г. // Архив ИА РАН. Р-1. 2004a. № 27261.

Коваль В.Ю. Светлоглиняная керамика в Подмосковье: Звенигородский регион // Археология Подмосковья. М., 2008. Вып. 4. С. 161-180.

Коваль В.Ю. Отчет о работах Ростиславльской археологической экспедиции в 2009 г. // Архив ИА РАН. Р-1. 2009. № 37968 .

Коваль В.Ю. «Ростиславльский курган» (вал городища эпохи раннего железного века на Ростиславле) // Археология Подмосковья. М., 2011. Вып. 7. С. 35-57.

Коваль В.Ю. Фортификация Ростиславльского городища раннего железного века в контексте памятников дьяковской культуры // Археология Подмосковья. М., 2012. Вып. 8. C. 53-69.

Коваль В.Ю. О местоположении Войницкого мыта // Археология Подмосковья. М., 2014. Вып. 10. С. 111-128.

Коваль В.Ю., Хижняков О.И. Средневековые поселения в селе Аносино на Истре: (к вопросу о керамике верхнего Москворечья в XII в.) // Археология Подмосковья. М., 2005. Вып. 2. С. 153-183.

Козенкова В.И. Кобанская культура: Восточный вариант М., 1977. (САИ; Вып. В2-5).

Козенкова В.И. Материальная основа быта кобанских племен: Западный вариант. М., 1998. (САИ; Вып. В2-5).

Козмирчук И.А., Обломский А.М., Разуваев Ю.Д. Раскопки у с. Ксизово Задонского района в 2009 г. // Археологические открытия в Ельце и его исторической округе 2009 г. Елец, 2010.

Козмирчук И.А., Разуваев Ю.Д. Городище «Малый липяг» у с. Крутогорье на верхнем Дону // Верхнедонской археологический сборник. Липецк, 2001. Вып. 2. С. 71-88.

Коняшин Г.М. Материалы к археологической карте среднего течения Москва-реки (Раменский, Ухтомский и Бронницкий районы) // Тр. НИИ краеведческой и музейной работы. М., 1940. Т. І. С. 175-188.

Короткевич Б.С. Ранний железный век в верховьях Западной Двины и Ловати: Дисс. ... канд. ист. наук. Рукопись. СПб., 2004.

Короткевич Б.С. Городище Анашкино - памятник раннего железного века в верховьях Западной Двины // II Городцовские чтения. М., 2005. С. 195-203. (Тр. ГИМ; Вып. 145).

Косменко М.Г. Археологические культуры периода бронзы железного века в Карелии. СПб., 1993.

Кравиов А.Е., Сорокин А.Н. Зооморфная скульптурка со стоянки Григорово 1 // КСИА. М., 1984. Вып. 177. С. 71-74.

Крайнов Д.А. Кухмарский курганный могильник // КСИА. Вып. 88. М., 1962. С. 51-63.

Крайнов Д.А. Памятники фатьяновской культуры: Московская группа. М., 1963. (САИ; Вып. В1-19).

Крайнов Д.А. Древнейшая история Волго-Окского междуречья. М., 1972. 
Крайнов Д.А. Болшневский могильник фатьяновской культуры // Памятники древнейшей истории Евразии. М., 1975. C. 173-180.

Крайнов Д.А. Фатьяновские памятники Калининской области // КСИА. М., 1986. Вып. 185. С. 92-97.

Крайнов Д.А. Волосовская культура // Эпоха бронзы лесной полосы СССР. М., 1987. С. 10-28.

Крайнов Д.А. Фатьяновская культура // Эпоха бронзы лесной полосы СССР. М., 1987a. С. 58-76.

Крайнов Д.А., Гадзячякая О.С. Фатьяновская культура: Ярославское Поволжье. М., 1987. (САИ; Вып. В1-22).

Крайнов Д.А., Уткин А.В. Курганный могильник Кухмарь на Плещеевом озере // Поздний неолит и культуры ранней бронзы лесной полосы Европейской части СССР. Йошкар-Ола, 1991. С. 147-159. (Археология и этнография Марийского края. Вып. 19).

Краснов Ю.А. Отчет об археологических работах в Кунцевском районе Московской области летом 1958 г. // Архив ИА РАН. Р-1. 1958. № 1718.

Краснов Ю.А. К истории раннего земледелия в лесной полосе Европейской части СССР // СА. 1965. № 2. С. 57-74.

Краснов Ю.А. Раннее земледелие и животноводство в лесной полосе Восточной Европы. М., 1971.

Краснов Ю.А. Безводнинский могильник. М., 1980. 224 с.

Краснов Ю.А. Введение // Археологическая карта России: Московская область. М., 1994. Ч. 1. С. 9-55.

Краснов Ю.А., Краснов Н.А. Новые памятники льяловской культуры // СА. 1959. № 1. С. 249-252.

Краснов Ю.А., Краснов Н.А. Обследование памятников дьяковской культуры в долине Москвы-реки // СА. 1963. № 1. С. 204-218

Краснов Ю.А., Краснов Н.А. Погребальное сооружение на городище «дьякова типа» // Вопросы древней и средневековой археологии Восточной Европы. М., 1978. С. 140-152.

Кренке Н.А. Вал Дьякова городища // КСИА. М., 1986. Вып. 186. С. 90-95.

Кренке Н.А. Селище Дьяково-пойма - древнерусская деревня XI-XII вв. в Коломенском // Коломенское: Материалы и исследования. М., 1993. Вып. 3. С. 7-33.

Кренке Н.А. «Чертов городок» - селище железного века в окрестностях села Коломенское // РА. 1995. № 3. С. 165179.

Кренке Н.А. Ближайшая сельская округа Москвы в XIIXIII вв. // Русь в XIII веке. М., 2003. С. 151-167.

Кренке Н.А. Археологическая карта Коломенского в древнерусский период // Культура средневековой Москвы: Исторические ландшафты. М., 2004. Т. 1. С. 203-214.

Кренке Н.А. Каталог памятников археологии X-XIII вв. на территории Москвы // Культура средневековой Москвы: Исторические ландшафты. М., 2004а. Т. 1. С. 319-378.

Кренке Н.А. Система поселений и землепользования в долине р. Язвенки в XII-XIII вв. // Культура средневековой Москвы: Исторические ландшафты. М., 2004б. Т. 1. C. 77-124.

Кренке Н.А. Археологические работы А.В. Чаянова в долине Москвы-реки в 1928-1929 гг. // Археология Подмосковья. М., 2007. Вып. 3. С. 23-25.
Кренке Н.А. Формирование культурного ландшафта в бассейне Москвы-реки от бронзового века к Средневековью // РА. 2007a. № 1. С. 64-78.

Кренке Н.А. Археология парка «Царицыно». М., 2008.

Кренке Н.А. Комплексы XII-XIII вв.: характеристика объектов, вещевых находок и керамики // Археология Романова Двора. М., 2009. С. 47-58.

Кренке Н.А. Дьяково городище: культура населения Москвыреки в I тыс. до н.э. - I тыс. н.э. М., 2011.

Кренке Н.А. Отчет о раскопках на территории Звенигородской биостанции МГУ и разведках в Одинцовском районе Московской области в 2012 г. М. // Архив ИА РАН. Р-1. 2013. № 36693.

Кренке Н.А. Абашевская находка в долине Москвы-реки // Археология Подмосковья. М., 2014. Вып. 10. С. 29-35.

Кренке Н.А. Москворецкие памятники фатьяновской кульуры // РА. 2014а. № 4. С. 5-18

Кренке Н.А., Агеева К.Е., Григорян С.Б., Ершов И.Н., Кравиов А.Е., Леонова Е.В. Поселение Царицыно $1 / /$ Археология парка «Царицыно». М., 2008. С. 49-80.

Кренке Н.А., Александрова О.И. Разведки на территории Москвы // Археологические открытия 2006 г. М., 2009. C. 102 .

Кренке Н.А., Александровский А.Л., Войцик А.А., Елкина И.И., Ершов И.Н., Ершова Е.Г., Лазукин А.В., Мазуркевич А.Н., Панин А.В., Кудрявцев А.А., Лавриков М.В., Воронкин В.А. Новые исследования 1-й Звенигородской неолитической стоянки на Москве-реке // Археология Подмосковья/отв. ред. А.В. Энговатова. М., 2012. Вып. 8. С. 16-28.

Кренке Н.А., Александровский А.Л., Ершов И.Н., Ершова Е.Г., Лазукин А.В. Памятники шнурового и «постшнурового» горизонтов бронзового века на Москве-реке // КСИА. М., 2014. Вып. 231. С. 208-223.

Кренке Н.А., Александровский А.Л., Ершова Е.Г. Природные и антропогенные ландшафты в долине Москвы-реки по материалам комплексного исследования 1-й Звенигородской неолитической стоянки // Изв. РАН. Сер. геогр. 2014. № 5. C. 99-115.

Кренке Н.А., Бакунова Т.Н., Нефёдов В.С., Руаков П.Е. Древнерусские поселения на Верхне-Царицынском, Шипиловском и Борисовском прудах // Археология парка «Царицыно». М., 2008. С. 81-92.

Кренке Н.А., Ершов И.Н. Городище Васильково на реке Нерль // РА. 2016. № 1. С. 37-50.

Кренке Н.А., Ершов И.Н., Аникин И.С., Войцик А.А., Муренцева Т.Ю., Раева В.А., Лавриков М.В., Столярова Т.В. Новые данные об археологии Соборной горы в Смоленске // КСИА. М., 2015. Вып. 240. С. 141-149.

Кренке Н.А., Ершов И.Н., Лазукин А.В., Войцик А.А., Раева В.А., Рожанская И.Н. Поселенческие объекты круга культур шнуровой керамики в долине Москвыреки // Археология Подмосковья. М., 2013. Вып. 9. C. 14-29.

Кренке Н.А., Ершов И.Н., Муренцева Т.Ю., Хаврин С.В. Ювелирная мастерская XI в. на Рачевке в Смоленске // КСИА. М., 2016. Вып. 245. Ч. 2. С. 7-29

Кренке Н.A., Лазукин А.B. Отчет об археологических 
раскопках на поселении РАНИС-пойма в Одинцовском районе Московской обл. в 2009 г. // Архив ИА РАН. 2010.

Кренке Н.А., Лазукин А.В., Алексеев А.В., Ершов И.Н., Кравиов A.E., Леонова E.B. Поселение фатьяновской культуры РАНИС-пойма // Археология Подмосковья/отв. ред. А.В. Энговатова. М., 2008. Вып. 4. С. 320-339.

Кренке Н.А., Лазукин А.В., Елкина И.И., Ершов И.Н., Леонова E.B., Чернов С.3. Исследование памятников эпохи бронзы - раннего железа в районе Звенигорода // Археология Подмосковья. М., 2010. Вып. 6. С. 34-50.

Кренке Н.А., Лазукин А.В., Тавлинцева Е.Ю. Клад украшений с городища Дютьково // РА. 2011. № 1. С. 134-148.

Кренке Н.А., Лопатин Н.В. Петрографический анализ керамики городищ Дьяково и Тушемля // РА. 1997. № 1. С. 60-67.

Кренке Н.А., Лопатина О.А. Городище Боровский курган // Археология Подмосковья. М., 2008. Вып. 4. С. 367-392.

Кренке Н.А., Нефёдова Е.С. Краткая биография Константина Яковлевича Виноградова // Макариевские чтения. Можайск, 1994. Вып. 2, ч. 2. С. 86-87.

Кренке Н.А., Румянцева О.С. Стеклянные бусы Дьякова городища // РА. 2008. № 2. С. 95-106.

Кренке Н.А., Сулержищкий Л.Д. Хронология городищ «дьякова типа» в бассейне Москвы-реки в свете результатов радиоуглеродного датирования // РА. 2006. № 2. С. 121-133.

Кренке Н.А., Тавлинцева Е.Ю., Чаукин С.Н. «Клад» бронзовых украшений I-II вв. н.э. с городища Круглица // Оки связующая нить. Ступино, 2013. С. 55-64.

Кренке Н.А., Цепкин Е.А. Рыболовство на Москве-реке с V в. до н.э. по VII в. н.э. // СА. 1991. № 1. С. 104-111.

Кренке Н.А., Чаукин С.Н. История исследований городища Круглица в 1956 и 1957 гг. // Археология Подмосковья. М., 2012. Вып. 8. С. 78-85.

Кренке Н.А., Чаукин С.Н. Городище дьякова типа Круглица на Москве-реке // РА. 2013. № 1. С. 106-118.

Крийска А. Некоторые вопросы возникновения земледелия в Восточной Прибалтике // ТАС. Тверь, 2009. Вып. 7. C. 39-48.

Крийска А., Лавенто М. «Текстильная керамика» в Эстонии в свете датирования нагара на фрагментах сосудов с использованием ускорительной масс-спектрометрии (AMS) // Радиоуглерод в археологических и палеэкологических исследованиях. СПб., 2007. С. 243-250.

Крис Х.И. Костяные и железные наконечники стрел // Древнее поселение в Подмосковье. М., 1970. С. 145-169. (МИА; № 156).

Крис Х.И. Предметы звериного стиля из дьяковских городищ // СА. 1981. № 1. С. 171-180.

Крис Х.И., Чернай И.Л. Городища дьякова типа Боршева и Селецкое // КСИА. М., 1980. Вып. 162. С. 75-81.

Крис Х.И., Чернай И.Л., Данильченко В.П. О раннем периоде дьяковских городищ // Древности Евразии в скифо-сарматское время. М. 1984. С. 130-137.

Крыввальиэвіч М.M. Могільнік сярэдзіны III - пачатку II тысячагоддзяу да н.э. на Верхнім Дняпры - Прорва 1. Мінск, 2006.

Крывальщэвіч М.М. Старыя Юрковічы 1 - культурна-хранала- гічныя аспекты «шнуравога» комплексу // Матэрыялы па археологіі Беларусі. Мінск, 2010. № 18. С. 219-242.

Крыввальиэвіч М.M. Сярэднедряпроӯская культура: Археалогія Беларусі. Мінск, 2011. Т. 2. С. 340-342.

Кузнецов П.Ф. Территориальные особенности и временные рамки переходного периода к эпохе поздней бронзы Восточной Европы // Бронзовый век Восточной Европы: характеристика культур, хронология и периодизация: Мат-лы междунар. научн. конф. «К 100-летию периодизации В.А. Городцова бронзового века Восточной Европы». Самара, 2001. С. 178-182.

Кузьмина О.В. Керамика абашевской культуры // Вопросы археологии Поволжья. Самара, 1999. Вып. 1. С. 154-205.

Кучкин В.A. Москва в XII - первой половине XIII в. // Отечественная история. 1996. № 1. С. 3-13.

Кучкин В.A. Политическая география русских княжеств второй половины XI-XV веков // Вопросы географии. М., 2013. Т. 136: Историческая география. С. 243-257.

Кухаренко Ю.В. Первобытные памятники Полесья. М., 1962. (САИ; Вып. Б1-18).

Кухаренко Ю.В. Полесье и его место в процессе этногенеза славян // Полесье/отв. ред. В.В. Мартынов Н.И. Толстой. М., 1968. С. 18-46.

Латылева Г.П., Розенфельдт И.Г. Раскопки барвихинского городища // КСИА. М., 1964. Вып. 102. С. 82-89.

Лебедева Е.Ю. Культурные растения Ростиславля: археоботанические материалы из дьяковского городища и древнерусского города // Археология и естественно-научные методы. М., 2005. С. 159-180.

Лебедева Е.Ю. Результаты археоботанического анализа образцов с селища «Храм Цереры»// Археология парка «Царицыно». М., 2008. С. 72-76.

Лебедева Е.Ю. Продолжение археоботанических исследований на Ростилавльском городище дьяковской культуры // Аналитические исследования лаборатории естественно-научных методов. М., 2009. Вып. 1. C. 245-257.

Лебедева E.Ю. К истории земледелия дьяковской культуры: археоботанические исследования в Настасьино // Аналитические исследования лаборатории естественно-научных методов. М., 2013. Вып. 3. С. 202-243.

Леонтьев А.Е. Археология мери. М., 1996.

Лингдольм B. Моллюски из слоев торфяника близ села Льялова, Московского уезда, содержащих стоянку неолитического человека // Русский антропологический журнал. 1925. Т. 14. С. 86-90.

Лопатин Н.В. О керамике Изборска ХІ в. // Великий Новгород и средневековая Русь. М., 2009. С. 419-431.

Лопатин Н.В., Фурасьев А.Г. Северные рубежи раннеславянского мира в III-V веках н.э. М., 2007.

Лопатин Н.В., Фурасьев А.Г. Северо-запад России и север Белоруссии // Восточная Европа в середине I тыс. н.э.: Раннеславянский мир. М., 2007а. Вып. 9. С. 276-300.

Лопатина О.А. Керамика Старшего Каширского городища и ее культурно-хронологический контекст // II Городцовские чтения. М., 2005. С. 216-225. (Тр. ГИМ; Вып. 145).

Лопатина О.А. Древнейшая керамика каширских городищ 
раннего железного века // Археология Подмосковья. М., 2009. Вып. 5. С. 417-432.

Лопатина О.А. Некоторые технологические данные о керамике Дьякова городища и городищ дьякова типа // Кренке Н.А. Дьяково городище. М., 2011. С. 127-134.

Лопатина O.A. О происхождении одного вида отпечатков на поверхности «текстильной» керамики // КСИА. М., 2015. Вып. 240. С. 163-171.

Лопатина О.А., Тавлинцева Е.Ю. Поздняя профилированная «текстильная» керамика городища Ростиславль // De mare ad mare. Москва; Смоленск, 2017. С. 345-361

Лошенков М.И. Михалевское городище // Старажытнасці Бабруйшчыны. Бабруйск, 1998. С. 83-104.

Лукина Н.В. Формирование материальной культуры хантов. Томск, 1985.

Луньков В.Ю., Энговатова А.В. Курганный могильник Орлово 1: (Абашевская культура в Волго-Окском междуречье) // Абашевская культурно-историческая общность: истоки, развитие, наследие. Чебоксары, 2003. С. 193-197.

Львова 3.А. Стеклянные бусы Любши // Краеугольный камень. М., 2010. Т. 1. С. 467-478.

Лявданский А.Н. Некоторые данные о каменном веке и культуре бронзовой эпохи в Смоленской губернии // Научн. изв. Смоленского гос. ун-та. Смоленск, 1927. T. IV. Вып. 3. С. 218-257.

Мазуркевич А.Н. Первые свидетельства проявления производящего хозяйства на северо-западе России // Пушкаревские чтения. 2003. Вып. 2. С. 77-83.

Мазуров А.Б. Одна из первых находок вятических древностей // РА. 1999. № 4. С. 221-224.

Мазуров А.Б. Средневековая Коломна в XIV-первой трети XVI в. M., 2001.

Макаров Н.А., Захаров С.Д., Бужилова А.П. Средневековое расселение на Белом озере. М., 2001.

Макаров Н.А., Федорина А.Н., Зайцева Г.И., Гроотс П.М. Радиоуглеродные даты памятников раннего железного века-Средневековья в Суздальском ополье// РА. 2011. №4 C. $35-51$.

Макарова Т.Н., Равдина Т.В. Семилопастные височные кольца с орнаментом // РА. 1992. № 4. С. 68-82.

Максимов А.Д. Отчет о раскопках городища Орлов городок и разведках на оз. Селигер в 1980 г. // Архив ИА РАН. Р-1. 1981. № 8477 .

Максимов Е.В., Петрашенко В.А. Славянские памятники у с. Монастырёк на среднем Днепре. Киев, 1988.

Манюхин И.С. Позднекаргопольская культура // Археология Карелии. Петрозаводск, 1996. С. 220-237.

Марковин В.И. Наскальные изображения предгорий Дагестана. М., 2006.

Медведев А.П. Керамика сарматского времени лесостепного Подонья // Археологические памятники эпохи железа восточноевропейской лесостепи. Воронеж, 1987. С. 93 111.

Медведев А.П. ІІІ Чертовицкое городище // Археологические памятники Верхнего Подонья первой половины I тыс. н.э.: Археология восточноевропейской лесостепи. Воронеж, 1998. Вып. 12. С. 42-84.
Медведев А.П., Ранний железный век лесостепного Подонья. M., 1999.

Медведев А.П. Сарматы в верховьях Танаиса. М., 2008.

Медведь А.Н. Стрелы раннего железного века с городища Ростиславль // Археология Подмосковья. М., 2007. Вып. 3. С. 52-57.

Медведь А.Н. Укрепления раннего железного века на городище Ростиславль: (предварительные итоги исследования) // Археология Подмосковья. М., 2009. Вып. 5. C. $448-454$.

Мерперт Н.Я. Древнеямная культурно-историческая область и вопросы формирования культур шнуровой керамики // Восточная Европа в эпоху камня и бронзы. М., 1976. С. $103-127$.

Мещеряков Д.П. Торфяник у села Льялова как место неолитической стоянки // Русский антропологический журнал. 1925. T. 14. С. $79-82$.

Микляев А.М. Каменный - железный век в междуречье Западной Двины и Ловати // Петербургский археологический вестник. СПб., 1995. Вып. 9. С. 7-40.

Милов Л.В. Великорусский пахарь и особенности российского исторического процесса. М., 2001.

Мимоход Р.А. Лолинская культура: Северо-западный Прикаспий на рубеже среднего и позднего бронзового века. М., 2013.

Михайлова E.P. Тисненые бляшки-обоймицы из памятников культуры псковских длинных курганов // А.В.: Сборник научных трудов в честь 60-летия А.В. Виноградова. СПб., 2007. C. $158-164$.

Михайлова E.P. Культура псковских длинных курганов: Проблемы хронологии и развития материальной культуры: Автореф. дисс. ... канд. ист. наук. СПб., 2009.

Могильников B.A. Саргатская культура // Степная полоса Азиатской части СССР в скифо-сарматское время. М., 1992. C. 292-311.

Моора $X$. Об оловянных украшениях и их изготовлении в Прибалтике // Munera archeologia Iosepho Kostrzewski. Poznań, 1963. S. 355-365.

Мошкова М.Г. Памятники прохоровской культуры. М., 1963. (САИ; Вып. Д1-10).

Мурашко О.А. Популяционные аспекты этногенетических процессов у некоторых групп населения севера и северо-востока Сибири // Этническая культура: динамика основных элементов. М., 1984. С. 139-152.

Насонов А.Н. «Русская земля» и образование территории древнерусского государства: Историко-географическое исследование. М., 1951.

Нейштадт М.И. История лесов и палеогеография СССР в голоцене. М., 1957.

Нефёдов В.С., Кренке Н.А. Древнерусское селище Царицыно 3 // Археология парка «Царицыно». М., 2008. C. 93-100.

Нефёдов В.С., Кренке Н.А. Древнерусское селище Царицыно 2 // Археология Подмосковья. М., 2012. Вып. 8. C. $137-154$.

Нефёдова Е.С., Янишевский Б.Е. Бронзовый литой браслет с насечками с городища дьякова типа // Новгород и 
Новгородская земля: история и археология. Новгород, 1990. Вып. 3. С. 39-43

Низовиев B.A. Ландшафтно-экологические условия и системы природопользования в древнерусский период в долине Язвенки // Культура средневековой Москвы: Исторические ландшафты. М., 2004. Т. 1. С. 116-120.

Низовцев В.A. Ландшафтные условия и их влияние на формирование системы природопользования на территории современной Москвы // Культура средневековой Москвы: Исторические ландшафты. М., 2004а. Т. 1. С. 41-50

Никитин А.Л. Многослойное поселение Польцо // СА. 1975. № 3. C. $118-140$.

Никитин А.Л. Эпоха бронзы на Плещеевом озере // СА. 1976. № 1. С. $69-86$.

Никольская Т.Н. Шуклинское городище // КСИА. М., 1958. Вып. 72. С. 66-77.

Никольская Т.Н. Культура племен бассейна Верхней Оки в І тыс. н.э. М.; Л., 1959. (МИА; № 72).

Никольская Т.Н. Городище у д. Николо-Ленивец // СА. 1962. № 1. С. 221-240.

Никольская Т.Н. К этнической истории бассейна Верхней Оки // КСИА. М., 1966. Вып. 107. С. 9-16.

Никольская Т.Н. Городище Слободка. М., 1987.

Носов Е.Н. Лепная керамика городища Дуна // КСИА. М., 1974. Вып. 140. С. 3-10.

Носов Е.Н., Горюнова В.М., Плохов А.В. Городище под Новгородом и поселения северного Приильменья. СПб., 2005

Обломский А.М. Памятники типа Почеп// Позднезарубинецкие памятники на территории Украины: Раннеславянский мир. М., 2010. Вып. 12. С. 45-53.

Обломский А.М., Сыроватко А.С., Сапрыкина И.А. Об одном типе подвесок-коньков на территории лесной и лесостепной зон Восточной Европы // КСИА. М., 2012. Вып. 226. С. 169-177.

Основания регионалистики: Формирование и эволюция историко-культурных зон/под ред. А.С. Герда, Г.С. Лебедева. СПб., 1999.

Орлов С.Н. Городище эпохи раннего железа в низовьях реки Ловати // КСИА. М., 1962. Вып. 87. С. 42-45.

Останина Т.И. Население среднего Прикамья в III-V вв. Ижевск, 1997.

Ошибкина С.В. Погребальный обряд азелинской культуры по материалам могильника Тюм-Тюм // КСИА. М., 1979. Вып. 158. С. 71-78.

Панин А.B. Предварительные данные по истории формирования поймы Москвы-реки в районе Успенского РАНИС // Археология Подмосковья. М., 2008. Вып. 4. C. 340-343.

Панин А.В., Сидорчук А.Ю. Макроизлучины («большие меандры»): проблемы происхождения и интерпретации // Вестн. МГУ. Сер. 5: Геогр. 2006. № 6. С. 14-22.

Панин А.В., Сидорчук А.Ю., Борисова О.К., Баслеров С.В. Изменения руслового режима Москва-реки в конце последней ледниковой эпохи и голоцене // Tp. VI конференции «Динамика и термика рек, водохранилищ и прибрежной зоны морей». М., 2004. С. 432-435.
Панова Т.Д. Историческая и социальная топография Московского Кремля. М., 2013.

Патрушев В.С. Булавки Старшего Ахмыловского и Акозинского могильников // КСИА. М., 1984. Вып. 178. C. 21-24.

Патрушев В.С. Марийский край в VII-VI вв. до н.э.: (старший Ахмыловский могильник). Йошкар-Ола, 1984a.

Пимакин Л.И. Предварительный отчет об исследовательских работах, произведенных по открытому листу № 8 от 23/IV-1956 в Раменском районе Московской области // Архив ИА РАН. Р-1. 1956. № 1396.

Пимакин Л.И. Предварительное сообщение о продолжении исследования городища «Круглица» в 1957 г. // Архив ИА PAH. Р-1. 1957. № 2144.

План села Черная Грязь с принадлежащими к оному деревнями и землями // РГВИА. Ф. 846. Оп. 16. Д. 19682.

Плохов А.В. Лепная керамика Рюрикова городища // Городище под Новгородом и поселения северного Приильменья. СПб., 2005. С. 74-81.

Попов А.А. Анализ плотности распространения височных колец типа «сельцо» в ARCGIS 9.3.1 DESKTOP // Вопросы археологии, истории, культуры и природы Верхнего Поочья. Калуга, 2013.

Потемкина О.Ю., Сыроватко А.С., Добровольская М.В., Клещенко Е.А., Свирина Н.Г., Олейник А.Б. Соколова Пустынь - новый погребальный памятник позднедьяковского времени (итоги работ 2011-2012 гг.) // Оки связующая нить. Ступино, 2013. С. 146-156.

Прошкин О.Л. Отчет о раскопках селища Десна 3 в 2012 г. Отчет об археологических исследованиях на селище Икша-1 (Дмитровский район Московской области), на селище Десна-3 (г. Москва) и на городище «Чертово Городище» (Козельский район Калужской области) в 2012 г. Том 1. Отчет об археологических исследованиях на селище Икша-1 (Дмитровский район Московской области), на селище Десна-3 (г. Москва). // Архив ИА РАН. P-1. 2014. № 40973.

Прошкин О.Л., Фролов А.С. Ранние периоды поселения Маломахово в бассейне р. Протвы // Археология Подмосковья. М., 2012. Вып. 8. С. 96-114.

Пряхин А.Д. Погребальные абашевские памятники. Воронеж, 1977.

Пряхин А.Д., Халиков А.Х. Абашевская культура // Эпоха бронзы лесной полосы СССР/отв. ред. О.Н. Бадер, Д.А. Крайнов, М.Ф. Косарев. М., 1987. С. 124-131.

Пузикова А.И. Марицкое городище в Посеймье. М., 1981.

Пузикова А.И. Памятники скифского времени бассейна р. Тускарь. М., 1997.

Рабинович М.Г. Отчет о раскопках в Москве на территории Зарядья в 1949 г. // Архив ИА РАН. Р-1. 1949. № 345, 345а.

Рабинович М.Г. Отчет о раскопках в Москве на территории Зарядья в 1950 г. // Архив ИА РАН. Р-1. 1950. № 526.

Рабинович М.Г. Записки советского интеллектуала. М., 2005.

Равдина Т.В. Царицынские курганы // СА. 1963. № 4. С. $213-$ 217.

Равдина T.B. Типология и хронология лопастных височных колец // Славяне и Русь. М., 1968. С. 136-142. 
Равдина T.B., 1975. Древнейшие семилопастные височные кольца // СА. № 3. С. 218-223.

Равдина Т.В. Хронология «вятических» древностей: Дисс. ... канд. ист. наук. М., 1975a.

Равдина T.B. Семилопастные височные кольца // Проблемы советской археологии. М., 1978. С. 181-187.

Равдина Т.В. Погребения X-XI вв. с монетами на территории Древней Руси: Каталог. М., 1988. 150 с.

Равдина Т.В. Описание курганных могильников для свода памятников культуры Московской области: Рукопись. М., 1989.

Равдина Т.В. Керамика из датированных погребений в курганах Подмосковья // Московская керамика: новые данные по хронологии. М., 1991.

Разуваев Ю.Д. Ишутинское городище на Красивой Мече // Археологические памятники Верхнего Подонья первой половины І тыс. н.э. Воронеж, 1998. С. 85-96.

Разуваев Ю.Д. Городецкие поселения степного Подонья: пространственно-хронологический анализ // Тр. второго (XVIII) Всерос. археологического съезда в Суздале. М., 2008. Т. 2. С. 170-172.

Разуваев Ю.Д. Городецкая керамика на скифоидных городищах верхнего Дона // Верхнедонской археологический сборник. Липецк, 2009. Вып. 4. С. 126-131.

Разуваев Ю.Д. Отчет о раскопках Знаменского городища в Московской области в 2005 г. М., 2012.

Раушенбах В.М. Неолитическая стоянка у д. Б. Буньково // КСИИМК. М., 1950. № 32. С. 151-156.

Раушенбах B.M. Древнейшая стоянка льяловской культуры // CA. 1964. № 2. C. 188-191.

Раушенбах В.М. Племена льяловской культуры // Окский бассейн в эпоху камня и бронзы. М., 1970. С. 35-78. (Тр. ГИМ; Вып. 44).

Раушенбах B.M. Новое местонахождение льяловской культуры // КСИА. М., 1979. Вып. 157. С. 52-56.

Раушенбах В.М. Торфяниковая стоянка у с. Заречье// Изыскания по мезолиту и неолиту СССР. Л., 1983. С. 78-83.

Раушенбах B.M. Неолитические поселения у с. Заречье // Новые материалы по истории племен Восточной Европы в эпоху камня и бронзы. М., 1985. С. 48-68. (Тр. ГИМ; Вып. 60).

Рашин А.Г. Население России за 100 лет. М., 1956.

Родинкова B.E., Седин А.А. Браслеты Никодимова городища // Восточная Европа в Средневековье. М., 2004. С. 234-246.

Розенфельдт И.Г. Неолитические стоянки на Тростенском озере // КСИА. М., 1964. Вып. 97. С. 104-106.

Розенфельдт И.Г. Керамика Троицкого городища // Древнее поселение в Подмосковье: (Троицкое городище). М., 1971. С. 6-79. (МИА; № 184).

Розенфельдт И.Г. Об относительной хронологии дьяковских городищ // КСИА. М., 1973. Вып. 133. С. 108-115.

Розенфельдт И.Г. Керамика дьяковской культуры // Дьяковская культура. М., 1974. С. 90-216.

Розенфельдт И.Г. Древности западной части Волго-Окского междуречья в VI-IX вв. М., 1982. 179 с.

Розенфельдт Р.Л. Захряпинские курганы XII-XIII вв. на р. Рузе // КСИА. М., 1964. Вып. 99. С. 103-105.
Розенфельдт Р.Л. Разведки и раскопки дьяковских городищ в Подмосковье в 1960-1963 гг. // КСИА. М., 1964а. Вып. 102. С. 104-113.

Розенфельдт Р.Л. Археологические разведки в Подмосковье в 1964-1965 гг. // КСИА. М., 1967. Вып. 112. С. 107-111.

Розенфельдт Р.Л. Московское керамическое производство XII-XVII вв. М., 1968. 124 с. (САИ; Вып. Е 1-39).

Розенфельдт Р.Л. Городище Потылиха // КСИА. М., 1969. Вып. 119. С. 100-103.

Розенфельдт Р.Л. К вопросу об оборонительных сооружениях Троицкого городища // Древнее поселение в Подмосковье. М., 1970. С. 136-144. (МИА; № 156).

Розенфельдт Р.Л. О глиняных жертвенниках // Славяне и их соседи. М., 1970а. С. 60-63.

Розенфельдт Р.Л. Новлянский фатьяновский могильник // CA. 1971. № 2. С. 213-216.

Розенфельдт Р.Л. Курганы у бывшего Серафимо-Знаменского монастыря на р. Рожае в Московской области // КСИА. М., 1973. Вып. 135. С. 62-65.

Розенфельдт Р.Л. Раскопки у с. Битягово в 1968-1970 гг. // CA. 1973a. № 1. С. 192-199.

Румянцева О.С. Керамика центральной группы могильников // Восточная Европа в середине I тыс. н.э.: Раннеславянский мир. М., 2007. Вып. 9. С. 247-272.

Рыгбаков Б.А. Ремесло Древней Руси. М., 1948.

Саблин М.A., Список курганов Московской губернии // ИОЛЕАиЭ. М., 1879. Т. ХХХУ. ВЫП. 1. С. 185-188.

Савенкова М.M. О функциональном назначении «рогатых кирпичей» и грузиков «дьякова типа» // Зап. ИИМК РАН. СПб., 2016. Вып. 13. С. 111-122.

Савицккй П.Н., Географический обзор России - Евразии: Россия особый географический мир. Прага, 1927.

Самолюк В.О. Поселення стжижовської культури на р. Іква на Волині // Археологія. 2007. № 3. С. 58-72.

Сапрыкина И.А. Литейные формы из раскопок Мутёнковского городища // II Городцовские чтения. М., 2005. С. 204-210. (Тр. ГИМ; Вып. 145).

Сапрыкина И.А. К вопросу об умбоновидных подвесках дьяковской культуры // РА. 2006. № 4. С. 36-40.

Сапрыкина И.А., Энговатова А.В. Химический состав цветного металла дьяковского времени из раскопок городища Настасьино // ТАС. Тверь, 2002. Вып. 5. С. 477-493

Свешніков І.К. Історія населення Перекарпаття, Поділля і Волині в кінці III-на початку II тисячоліття до нашої ери. Київ, 1974.

Свешников И.К. Культура шаровидных амфор. М., 1983. (САИ; Вып. В1-27).

Свирежев Ю.М. Нелинейные волны, диссипативные структуры и катастрофы в экологии. М., 1987.

Седин A.A. Отчет об исследованиях на городищах Восточной Белоруссии в 1987 г. // Архив ГНУ «Институт истории НАН Беларуси». 1987. № 1011. С. 7-8, рис. 82-83.

Седов В.В. Славяне Верхнего Поднепровья и Подвинья. М., 1970.

Седова М.В. Ювелирные изделия древнего Новгорода. М., 1981.

Cидоров B.B. Отчет о полевой работе археологического от- 
ряда Московского областного краеведческого музея в 1969 г. // Архив ИА РАН. Р-1. 1969. № 4003.

Сидоров В.В. География неолита Подмосковья // Памятники древнейшей истории Евразии. М., 1975. С. 94-101.

Сидоров В.В. Стоянки на Святом озере у Шатуры // СА. 1975a. № 3. C. 107-117.

Сидоров B.В. Льяловская культура в западной части ВолгоОкского междуречья: Автореф. дисс. ... канд. ист. наук M., 1986.

Сидоров В.В. Маслово Болото 7 - поселение льяловской культуры // СА. 1986а. № 4. С. 116-137.

Сидоров B.B. Погребения льяловской культуры в Подмосковье // Археологические памятники ВолгоКлязьменского междуречья. Иваново, 1990. Вып. 4. C. 28-31.

Сидоров В.В. Волосовские жилища поселений Маслова Болота // Тверской археологический сборник. Тверь, 2002. Вып. 5. С. 348-362.

Сидоров В.В. Керамика стоянки Ибердус 1 (из раскопок Б.А. Куфтина) // Археология восточноевропейской лесостепи. Пенза, 2003. С. 179-195.

Сидоров В.B. Мутенковское городище // Археология Подмосковья. М., 2004. Вып. 1. С. 108-127.

Сидоров В.В. Каширская культура в железном веке бассейна Оки // Обнинский краеведческий сборник. Обнинск, 2006. C. 136-145.

Сидоров В.В. Контакт культур на Средней Оке в эпоху бронзы: Неолит и бронзовый век // Оки связующая нить. Ступино, 2009. С. 60-69.

Сидоров В.В. Существовала ли дубровичская культура // Оки связующая нить. Ступино, 2011. С. 116-122.

Сидоров В.В. Переход к эпохе бронзы в центре Русской равнины // Оки связующая нить. Ступино, 2013. 172-192.

Сидоров В.В., Трусов А.В. Луково Озеро 1 - Стоянка льяловской культуры // СА. 1980. № 2. С. 126-143.

Сидоров В.B., Энговатова A.B. Ханевский могильник и древнейшие памятники фатьяновской культуры // Археологические памятники Волго-Клязьминского междуречья. Иваново, 1992. Вып. 7. С. 28-36.

Сидоров B.В., Энговатова А.В. Протоволосовский этап или культура? // Тверской археологический сборник. Тверь, 1996. Вып. 2. С. 164-182.

Сидоров B.B., Энговатова А.В. Керамика с лапчатым орнаментом // Древние охотники и рыболовы Подмосковья. М., 1997. С. 63-66.

Сизов В.И. О происхождении и характере курганных височных колец и преимущественно так называемого московского типа // Археологические известия и заметки. 1895. № 6. С. 177-188.

Сизов В.И. Дьяково городище близ Москвы // Тр. 9-го Археологического съезда. М., 1897. Т. 2. С. 256-267.

Скалон В.Н. Речные бобры Северной Азии. М., 1951.

Смирнов К.А. Новые городища дьякова типа в бассейне реки Москвы // КСИА. М., 1964. Вып. 102. С. 90-97.

Смирнов К.A. Части костюма и украшения, найденные на Троицком городище // Древнее поселение в Подмосковье. М., 1970. С. 179-191. (МИА; № 156).
Смирнов К.А. Дьяковская культура // Дьяковская культура. М., 1974. С. 7-89.

Смирнов К.А. Жилище на городище у д. Лесничино на p. Вазузе // СА. 1992. № 1. С. 48-56.

Смирнова Г.И. Западно-Подольская группа памятников в свете исследований к концу ХХ столетия // Древности скифской эпохи. М., 2006. С. 66-92.

Спиридонова Е.А., Алешинская А.С. Периодизация неолита-энеолита Европейской России по данным палинологического анализа // РА. 1999. № 1. С. 23-33.

Спиридонова Е.А., Алешинская А.С., Кочанова М.Д. Результаты палинологических исследований в пойме реки Москвы у поселка РАНИС // Археология Подмосковья. М., 2008. Вып. 4. С. 347-356.

Спиридонова Е.А., Алёшинская А.С., Кочанова М.Д. Формирование культурного ландшафта на территории Царицынского парка (по палинологическим данным) // Археология парка «Царицыно». М., 2008а. С. 19-26.

Спиридонова Е.А., Алешинская А.С., Кочанова М.Д. Особенности природной среды и хозяйственного использования территории в окрестностях поселения Настасьино в бронзовом и железных веках // Аналитические исследования лаборатории естественно-научных методов. М., 2011. Вып. 2. С. 293-309.

Список с писцовых книг Звенигородского уезда письма и меры князя Ивана Шаховского и подьячего Ивана Волкова. 1623-1626 гг. // РГАДА. Ф. 1209. Поместный приказ. Оп. 1. Ед. хр. 11832.

Ставищкий B.B. Бронзовый век Посурья и Примокшанья. Пенза, 2005.

Станкевич Я.В. К истории населения Верхнего Подвинья в I и начале II тыс. н.э. // МИА. М.; Л., 1960. № 76. С. 7-324.

Станюкович А.К., Сулержицкий Л.Д. К проблеме абсолютной хронологии раннесредневековых памятников Верхнего Москворечья // Вопросы археологии, истории, культуры и природы Верхнего Поочья: Мат-лы Х Региональной научн. конф. Калуга, 2003.

Степанов П.Д. Ош Пандо. Саранск, 1967.

Степанов П.Д. Андреевский курган. Саранск, 1980.

Столяров Е.В. Памятники типа Упа 2 // Лесная и лесостепная зоны Восточной Европы в эпохи римских влияний и великого переселения народов: Конференция 3. Тула, 2012. С. 79-118.

Столяров Е.В. Городище Дуна: к характеристике горизонтов эпохи раннего железного века (по материалам работ 2011 года) // Археология Подмосковья. М., 2015. Вып. 11. C. 98-121.

Столяров Е.В. Поселение 1 у деревни Жабынь на правобережье Верхней Оки: к вопросу культурно-хронологической атрибуции материалов раннего железного века // Археология Подмосковья. М., 2017. Вып. 13. С. 9-18.

Сулержиикий Л.Д., Фоломеев Б.А. Радиоуглеродная хронология памятников с текстильной керамикой бассейна Средней Оки // Финно-угры в России. Йошкар-Ола, 1993. Вып. 1. С. 20-34.

Султанов H. Памятник Александру II в Кремле Московском // Строитель. СПб., 1898. № 15-18. 
Сыроватко А.С. Юго-восточное Подмосковье в железном веке: к характеристике локальных вариантов дьяковской культуры. М., 2009.

Сыроватко А.С. Радиоуглеродная хронология фортификации коломенской группы памятников // Археология Подмосковья. М., 2010. Вып. 6. С. 19-23.

Сыроватко А.C. Период финальной бронзы в Москворечье: Состояние источников и проблема их интерпретации // ТАС. Тверь, 2013. Вып. 9/отв. ред. И.Н. Черных. C. 360-373.

Сыроватко А.С., Сапрыкина И.А. Клад рубчатых браслетов на реке Оке // Археология Подмосковья. М., 2011. Вып. 7. С. 72-76.

Сыроватко А.С., Трошина А.А., Антипина Е.Е. К вопросу об облике культур финальной бронзы (по материалам стоянки Зарудня) // ТАС. Тверь, 2013. Вып. 9/отв. ред. И.Н. Черных. С. 374-389.

Сыроватко А.С., Трошина А.А., Зареикая Н.Е., Панин А.В. Природные ландшафты Щуровского могильника: хронология, скорость и характер изменений // Тр. III (XIX) Всерос. археол. съезда. Санкт-Петербург; Москва; Вел. Новгород, 2011. T. 2. C. 406-407.

Сыроватко А.С., Трошина А.А., Спиридонова Е.А. Хронология Щуровского могильника по естественно-научным данным // Лесная и лесостепная зоны Восточной Европы в эпохи римских влияний и великого переселения народов: Конференция 3. Тула, 2012. С. 119-132.

Сыроватко Н.А. Городище Дьяково и Щербинское: к вопросу о реконструкции построек // РА. 2008. № 4. С. 119-124.

Сыроватко Н.А., Сыроватко А.С. К вопросу об облике построек городищ Кузнечики и Щербинское // Археология Подмосковья. М., 2009. Вып. 5. С. 409-416.

Сычевская Е.К. Состав промысловых уловов и характер рыбного промысла у жителей поселения Ивановское VII // Жилин М.Г., Костылева Е.Л., Уткин А.В., Энговатова А.В. Мезолитические и неолитические культуры Верхнего Поволжья. М., 2002. С. 105-107.

Тавлинцева Е.Ю. Результаты раскопок селища Заозерье-2 в 1993-1995 гг. // Археологические памятники Москвы и Подмосковья. М. 1996.. С. 45-59. (Тр. Музея истории г. Москвы; Вып. 9).

Тавлинцева Е.Ю., Кренке Н.А. Клад с городища Алтухово // Европа от латена до Средневековья: Раннеславянский мир. М., 2017. Вып. 19. С. 184-191.

Тавлинцева Е.Ю., Лопатина О.А. Тигли и литейные формы Ростиславльского городища // Археология Подмосковья. М., 2009. Вып. 5. С. 465-475.

Талищкий М.B. Керамика Протопоповского городища // СА. 1948. Вып. Х. С. 227-234.

Терпиловский Р.В. Славяне Поднепровья в первой половине I тыс. н.э. Lublin, 2004.

Тимофеев В.И. Памятники культуры шнуровой керамики восточной части Калининградской области (по материалам исследований 1970-1980-х гг.) // Древности Подвинья. СПб., 2003. С. 119-133.

ТимофеевВ.И.,ЗайцеваГ.И.,ДолухановП.М.,ШукуровА.М.
Радиоуглеродная хронология неолита Северной Евразии. СПб., 2004.

Тишкин А.A., Матренин С.C. Комплексный анализ роговых пряжек хуннуского и жужанского времени из могильника Яломан-ІІ (Центральный Алтай) // Изв. Алтайского гос. ун-та. Барнаул, 2010. Вып. 4. Т. 2. С. 220-228.

Третьяков В.П. К вопросу о памятниках льяловского типа в Волго-Окском междуречье // КСИА. М., 1966. Вып. 106. C. $11-15$.

Третьяков В.П. Древности в бассейне р. Катыни // СА. 1972. № 4. С. 199-210.

Третьяков П.Н. К истории племен Верхнего Поволжья в первом тысячелетии н.э. М.; Л., 1941. (МИА; № 5).

Третьяков П.Н. Чаплинское городище // Памятники зарубинецкой культуры. М.; Л., 1959. (МИА; № 70).

Третьяков П.Н. О ранних и поздних городищах дьякова типа // Pronksiajast varase feodalismini. Tallinn, 1966.

Третьяков П.Н. Финно-угры, балты и славяне на Днепре и Волге. М.; Л., 1966а.

Третьяков П.Н. Городище Осыно // СА. 1976. № 3. С. 203216.

Успенская A.B. Отчет о раскопках и разведках в Звенигородском районе Московской области в 1955 г. по открытому листу № 78 // Архив ИА РАН. Р-1. 1955. № 1166.

Успенская А.В. Успенское городище // КСИИМК. М., 1957. Вып. 68. С. 117-122.

Успенская А.В., Краснов Ю.А. Новая неолитическая стоянка в Подмосковье // КСИИМК. М., 1959. № 75. С. 90-91.

Уткин А.В., Черников В.Ф. Желтухинский грунтовый могильник // Проблемы средневековой археологии волжских финнов. Йошкар-Ола, 1994. С. 41-56.

Фасмер М. Этимологический словарь русского языка: В 4 т. М., 1986-1987.

Филимонов С.Б. Историко-краеведческие материалы архива обществ по изучению Москвы и Московского края. M., 1989.

Фоломеев Б.А. К вопросу о памятниках «дубровичского» типа бассейна Средней Оки // КСИА. М., 1975. Вып. 141. С. 33-41.

Фоломеев Б.А. Тюков городок // СА. 1975a. № 1. С. 154 170 .

Фоломеев Б.А. Окские городища // Археологические памятники раннего железного века Окско-Донского междуречья. Рязань, 1993.

Фоломеев Б.А. Шишкинское городище // Древности Оки. М., 1994. С. 138-157. (Тр. ГИМ; Вып. 85).

Фоломеев Б.А. Фактура текстильной керамики бассейна Средней Оки // Археологические памятники среднего Поочья. Рязань, 1998. Вып. 7. С. 79-105.

Фоломеев Б.А., Александровский А.Л., Гласко М.П., Гуман М.А. Климентовская стоянка // Наследие В.А. Городцова и проблемы современной археологии. М., 1988. С. 168-191. (Тр. ГИМ; Вып. 68).

Фоломеев Б.А., Челяпов В.П. Этнокультурная ситуация в бассейне средней Оки в энеолите (середина III - рубуж IIIII тыс. до н.э.) // ТАС. Тверь, 2000. Вып. 4. Т. 1. С. 344-351. 
Формозов А.А. Исследователи древностей Москвы и Подмосковья. М., 2007.

Фосс M.E. Древнейшая история севера Европейской части СССР. М., 1952. (МИА; № 29).

Фосс М.Е. Неолитическая стоянка Бисерово озеро // КСИИМК. М., 1959. Вып. 75. С. 26-39.

Фролов А.С. Отчет о раскопках в 1984 году стоянки Заозерье 1 в Раменском районе Московской обл. // Архив ИА РАН. Р-1. 1985. № 10424.

Фролов И.К. Фибулы-броши с выемчатой эмалью // КСИА. М., 1974. Вып. 140. С. 19-27.

Фролов М.В., Беляев Л.А., Гончарова Н.Н., Евдокимов Г.С., Лебедева Е.Ю., Чернов С.3. Раскопки фундаментов Никольского собора Николо-Угрешского монастыря // Археологические открытия 2004 года. М., 2005. С. 240-243.

Хайретдинова Э.А. Обувные наборы V-VII вв. из юго-западного Крыма // МАИЭТ. Вып. Х. Симферополь, 2003. C. $125-160$.

Халиков А.Х., Лебединская Г.В., Герасимова М.М. Пепкинский курган // Тр. Марийской археологической экспедиции. Йошкар-Ола, 1966. Т. 3.

Хотинский Н.А. Голоцен северной Евразии. М., 1977.

Хотинский Н.А., Фоломеев Б.А., Гуман М.А. Археологопалеогеографические исследования на Средней Оке // СА. 1979. № 3. С. 63-81.

Цалкин В.И. Животноводство и охота в лесной полосе Восточной Европы в раннем железном веке. М., 1962. (МИА; № 107).

Цветкова И.К. Племена рязанской культуры // Окский бассейн в эпоху камня и бронзы. М., 1970. С. 97-153. (Тр. ГИМ; Вып. 44).

Цветкова И.К. Погребение волосовской культуры на стоянке Владыченская-Береговая 2 // Новые материалы по истории племен Восточной Европы в эпоху камня и бронзы. М., 1985. С. 69-79. (Тр. ГИМ; Вып. 60).

Чаянов А.В. Отчет об археологических работах в Звенигородском уезде в 1928 и 1929 гг. // Археология Подмосковья. М., 2007. Вып. 3. С. 26-40.

Чернай И.Л. Пектораль из Селецкого городища // СА. 1980. № 4. С. 248-251.

Чернай И.Л. Выработка текстиля у племен дьяковской культуры // СА. 1981. № 4. С. 70-86.

Чернов C.3. К хронологии московской керамики XIII - ceредины XV в. // Московская керамика: новые данные по хронологии. М., 1991. С. 20-32.

Чернов С.3. Сельское расселение в Московском княжестве второй половины XIII в.: «традиционные» и «инновационные» модели выхода из кризиса (по материалам археологических исследований 1976-1993 гг. волостей Воря и Пехорка) // Русь в XIII в. М., 2003. С. 168-227.

Чернов С.3. Сельское расселение и ландшафты на Пехорке: загадка хозяйственного подъема в Мещере при первых московских князьях // Культура средневековой Москвы: Исторические ландшафты. М., 2004. Т. 1. С. 126-188

Чернов С.3. Культура средневековой Москвы. М., 2005. T. 2: Домен московских князей в городских станах.
Чернов С.3., Волков И.В. Болшево-3 - древнерусское поселение ХІ в. на Верхней Клязьме // Археология Подмосковья. М., 2009. Вып. 5. С. 112-136.

Черных Е.Н., Кузьминьх С.В., Орловской Л.Б. Металлоносные культуры лесной зоны вне системы Циркумпонтийской провинции: проблемы радиоуглеродной хронологии IV-III тыс. до н.э. // Аналитические исследования лаборатории естественно-научных методов/отв. ред. Е.Н. Черных, В.И. Завьялов. М., 2011. Вып. 2. С. 24-62.

Шадыро В.И. Ранний железный век северной Белоруссии. Минск, 1985.

Шинаков Е.A. Классификация и культурная атрибуция лучевых височных колец // СА. 1980. № 3. С. 110-127.

Шишлина Н.И., Плихт Й., Зазовская Э.П. Костяные булавки бронзового века: результаты радиоуглеродного датирования // РА. 2013. № 4. С. 35-44.

Шмидехельм M.X. Археологические памятники периода разложения родового строя на Северо-востоке Эстонии. Таллин, 1955.

Шмидехельм М.X. Городище Рыуге в юго-восточной Эстонии // Вопросы этнической истории народов Прибалтики. М., 1959. C. 154-185.

Шмидт Е.А. Племена верховьев Днепра до образования древнерусского государства: Днепро-двинские племена (VIII в. до н.э. - III в. н.э.). М., 1992.

Шмидm E.A. Погребальный комплекс культуры шаровидных амфор в верховьях Днепра // РА. 1992а. № 4. С. 156161.

Шмидm E.A. Верхнее Поднепровье и Подвинье в IIIVII вв. н.э.: Тушемлинская культура. Смоленск, 2003.

Шмидт E.A. Курганный могильник у пос. Новоселки // Смоленские древности. Смоленск, 2005. Вып. 4. С. 146-211.

Шпилев А.Г. Зооморфные украшения скифского времени из Курской области // Материалы и исследования по археологии Днепровского левобережья. Курск, 2012. Вып. IV. С. $165-169$.

Шполянский C.B. Новые данные по хронологии памятников начального этапа славянской колонизации Москворечья // Тр. ГИМ. 1999. Вып. 103. С. 142-153.

Шполянский С.В. Изучение малодворных сельских поселений на примере раскопок селища XIII века у села Ознобишино в Подмосковье // Русь в ХІІІ в. М., 2003. С. $253-$ 264.

Шполянский C.B. Размещение курганов бассейна Пахры как источник по изучению процесса заселения региона в XII - середине XIII в. // Археология Подмосковья. М., 2004. Вып. 1. С. 154-176.

Щеглова О.А. Свинцово-оловянные украшения VIII-X вв. на северо-западе Восточной Европы // Ладога и ее соседи в эпоху Средневековья. СПб., 2002. С. 134-150.

Щукин М.Б. На рубеже эр. СПб., 1994.

Энговатова А.В. Керамический комплекс волосовской культуры // Древние охотники и рыболовы Подмосковья. М., 1997. С. 62 .

Энговатова A.B. Хронология эпохи неолита ВолгоОкского междуречья // ТАС. Тверь, 1998. Вып. 3. С. 238-246. 
Энговатова A.B. Отчет о раскопках городища Настасьино в 2000 г. М., 2000.

Энговатова A.B. Хронология городища Настасьино по данным радиоуглеродного анализа // Археология Подмосковья. М., 2004. Вып. 1. С. 142-152.

Энговатова A.B. Дьяковское городище Настасьино в Подмосковье // Археологические открытия 1991-2004: Европейская Россия. М., 2009. С. 269-280.

Юшко А.А. Московская земля IX-XIV вв. М., 1991.

Юшко А.А. Ранние славяне в Подмосковье // Историческая археология: традиции и перспективы. М., 1998. С. 32-335.

Юшко А.А. Этапы и закономерности освоения славянским населением Московской земли // КСИА. М., 2001. Вып. 211. С. 51-57.

Юшко А.А. Звенигород Московский и удел звенигородских князей М., 2005.

Юшкова М.А. Эпоха бронзы и ранний железный век на Северо-Западе России: Дисс. ... канд. ист. наук. Рукопись. СПб., 2011.

Якеменко Б.Г. Суханово. М., 2008.

Янишевский Б.Е. Новые памятники археологии раннего железного века в верховьях рек Москвы и Протвы // Вопросы археологии, истории и культуры верхнего Поочья. Калуга, 2012. С. 28-34.

Янишевский Б.Е. Раскопки на Борисовом городке в 2009 г. // Археология Подмосковья. М., 2012а. Вып. 8. С. 229-245.

Ajot José. La Necropole Merovingienne de la Croix de Minot a Curtil-Sous-Burnand (Saône-et-Loire) // Mémoires de l'Association Française d'Archeologie Mérovingienne. Rouen, 1986. Vol. 1.

Alexandrovskiy A.L., Ershova E.G., Krenke N.A. Buried lateHolocene luvisols of the Oka and Moskva river floodplains and their anthropogenic evolution according to soil and pollen data // Quaternary International. 2016. Vol. 418. P. 37-48 http:// dx.doi. org/10.1016/j.quaint.2015.12.094

Alexandrovskiy A., Krenke N. Stages of soil formation on floodplains in the Centre of the Russian plain // Dobrzańska H., Jerem E., Kalicki T. (eds.). The geoarchaeology of river valleys. Budapest, 2004. P. 171-184. (Archaeolingua; Series Minor 18).

The archaeology of the cultural landscape/Ed. L. Larsson, J. Callmer, B. Stjernquist. Stockholm, 1992.

Atlas-monograph «evolution of landscapes and climates of Northern Eurasia». Late Pleistocene - Holocene - elements of prognosis/Ed. A.A. Velichko. Moscow, 2010. Iss. 3.

Bertašius M. Marvelè: Ein Gräberfeld Mittellitauens. Kauno, 2005. Bd. I.

Bitner-Wróblewska A.B., Ciglis J. Radinš A. Latvias Arheologiskās Senlietas Polijas Krātuvēs. Riga, 2005.

Boguki P. Forest Farmers and Stockherders: Early Agriculture and Its Consequences in North-Central Europe. Cambridge, 1988.

Bunyatyan K.P., Pozikhovskyi O.L. A settlement of the Horodotsko-Zdovbytska culture near Ostroh // Ukrainian Archaeology. Київ, 2011. Р. 38-56.

Carpelan C., Parpola A. Emergence, contacts and dispersal of proto-indo-European, proto-uralic and proto-aryan in archaeological perspective // Early Contacts between Uralic and
Indo-European and Archaeological Considerations. Helsinki, 2001. P. 55-150.

Casselberry S.E. Futher refinement of formula for determining population from floor area // World archaeology. 1974. Vol. 6 (1). P. 117-122.

Czebreszuk J., Szmyt M. The $3^{\text {rd }}$ Millennium BC in Kujawy in the Light of ${ }^{14} \mathrm{C}$ dates // Die absolute Chronologie in Mitteleuropa 3000-2000 v. Chr. Poznań, 2001. S. 177-208.

Czebreszuk J., Szmyt M.Z. Badań nad formami osadnictwa kultury ceramiki sznurowej w Polsce północnej // Матэрыялы па археологіі Беларусі. Мінск, 2010. № 18. С. 209-218.

Dumpe B. Agrās tekstilās keramikas faktūru veidošanas ipatnības // Arheologia un etnogrāfija. Riga, 2006. № 23. P. 71-84.

Dynamic of Terrestrial Landscape Components and Inner Marine Basins of Northern Eurasia During the Last 130.000 years (Atlas-monograph)/Ed. A.A. Velichko. Moscow, 2002.

Ershova E.G., Alexandrovskiy A.L., Krenke N.A. Paleosoils, paleovegetation and Neolithic occupation of the Moskva River floodplain, Central Russia // Quaternary International. 2014. Vol. 324. P. 134-145.

Ershova E.G., Alexandrovskiy A.L., Krenke N.A., Korkishko D.V. New pollen data from paleosols in the Moskva river floodplain (Nikolina Gora): Natural and anthropogenic environmental changes during the Holocene // Quaternary International. 2015. Vol. 420. P. 294-305. http:// dx.doi. org/10.1016/j.quaint.2015.10.086

Ershova E.G., Alexandrovskiy A.L., Krenke N.A. Evolution of landscapes of the Moskva river floodplain in the Atlantic and Subboreal: pedological and palynological records // Catena. 2016. Vol. 137. P. 611-621. http:// dx.doi.org/10.1016/j. catena.2014.12.034

Evaluation of land surfaces cleared from forest in the Roman Iron Age and the time of migrating Germanic tribes based on regional pollen diagrams/Ed. B. Frenzel. Stuttgart; Jena; New York, 1994. 134 p. (Paläoklimaforschung = Paleoclimate research; Bd. 12).

Forssander J.E. Die Schwedische Bootaxtkulturen und ihre kontinentale europaischen Voraussetzungen. Lund, 1933.

Furholt $M$. Die absolutchronologische Datierung der Schnurkeramik in Mitteleuropa und Südskandinavien. Bonn, 2003.

Gimbutas M. Bronze Age cultures in Central and Eastern Europe. Paris; London, 1965.

Graudonis J. Nocietinātās apmetnes Daugavas lejtecē = Укрепленные поселения в низовьях Даугавы. Riga, 1989.

Grigalavičiene E. Sokiškių piliakalnis // Lietuvos Archeologija. Vilnius: Mokslas, 1986. № 5. P. 89-137.

Grigalavičiene E. Kerelie piliakalnis // Lietuvos Archeologija. 1992. № 8 .

Indreko R. Asva linnus-asula // Muistse Eesti Linnused. Tartu, 1939.

Kadrow S., Machnik J. Kultura mierzanowicka. Kraków, 1997.

Kazanski M. Les slaves dans la zone forestière D'Europe orientale au Début du moyen âge // Les centres proto-urbans russes entre Scandinavie, Byzance et Orient. Paris, 2000. 
Kempisty A., Włodarczak P. Cemetery of corded ware culture in Zerniki Górne. Warsaw, 2000.

Kilian L. Haffküstenkultur und Ursprung der Balten. Bonn, 1955.

Krenke N., Erschov I., Erschova E., Lazukin A. Corded ware, Fatjanovo and Abashevo culture sites on the flood-plain of the Moskva River // Sprawozdania Archeologiczne. Krakow, 2013. № 65. P. 415-426.

Kriiska $A$. The beginning of farming in the Eastern Baltic // The East European Plain in the Eve of Agriculture // BAR. Internatial series. 1964. Oxford, England, 2009. P. 159-179.

Kriiska A., Lavento M., Peets J. New AMS dates of the Neolithic abd Bronze Age ceramics in Estonia: preliminary results and interpretations // Estonian Journal of Archaeology. 2005. Vol. 9. № 1. P. 3-31.

Kryvaltsevich M., Kovalyukh N. Radiocarbon dating of the middle Dnieper culture from Belarus // Baltic-Pontic Studies. Poznań, 1999. Vol. 7. P. 151-162.

Krzak Z. The Złota Culture. Wroclaw; Warszawa; Krakow; Gdansk, 1976.

Lang $V$. The Bronze and Early Iron Ages in Estonia. Tartu, 2007.

Latvijas PSR Arheologija. Riga, 1974.

Luchtanas A. Žalvario apdirbimas ankstyvuosiuose Rytų Lietuvos piliakalniuose // Lietuvos Archeologija. Vilnius, 1981. № 2. P. 5-17.

Machnik J. Studia nad kultura ceramiki sznurowej w Małopolsce. Wrocław; Warszawa; Kraków, 1966.

Michelbertas M. Senasis geležius amžius Lietuvoje. Vilnius, 1986.

Milisauskas S. Early Neolithic settlement and society a Olszanica. Ann Arbor, 1986. (Memoirs of Museum anthropology Univ. of Michigan; № 19).

Naroll $R$. Floor area and settlement population // American Antiquity. 1962. Vol. 27. Iss. 4. P. 587-589.

Novenko E.Yu., Volkova E.M., Nosova M.B., Zuganova I.S. Late Glacial and Holocene landscape dynamics in the southern taiga zone of East European Plain according to pollen and macrofossil records from the Central Forest State Reserve (Valdai Hills, Russia) // Quaterny International. 2009. T. 207. P. 93-103.

Prochazka $R$. Vývoj opevňovaci techniky na Moravĕ a českém Slezsku v raném středověku. Brno, 2009.

Reimer P.J., Baillie M.G.L., Bard E., Bayliss A., Beck J.W., Blackwell P.G., Bronk Ramsey C., Buck C.E., Burr G.S., Edwards R.L., Friedrich M., Grootes P.M., Guilderson T.P., Hajdas I., Heaton T.J., Hogg A.G., Hughen K.A., Kaiser K.F., Kromer B., McCormac F.G., Manning S.W., Reimer R.W., Richards D.A., Southon J.R., Talamo S., Turney C.S.M., Plicht J. van der, Weyhenmeyer C.E. IntCal09 and Marine09 radiocarbon age calibration curves, 0-50,000 years cal BP // Radiocarbon. 2009. Vol. 51. P. 1111-1150.

Rimantiene $R$. Nida Senujų baltų gyvenvietè. Vilnius: Mokslas, 1989.

Ščkin M., Kazanski M., Sharov O. Des les goths aux huns: Le nord de la mer noire au Bas - empire et a l'epoque des grandes migrations BAR International Series 1535. Oxford, 2006.

Shmidt E.A., Szmyt M. Ritual complex of the Globular amphora culture on the upper Dnieper Basin (Russia) // BalticPontic Studies. Poznań, 1996. Vol. 4. P. 79-86.

Smirnow K.A. Ties between the Population of the Volga-Oka Area and the inhabitants of the Steppe and Forest-Steppe in $1^{\text {st }}$ Millennium B.C. // ISKOS. 1984. № 4. P. 126-131.

Struve K., Die Einzelgrabkultur in Schleswig-Holstein. Neumünster, 1955.

Szmyt M. Between West and East: People of the Globular Amphora Culture in Eastern Europe: 2950-2350 BC // BalticPontic Studies. Poznań, 2010. Vol. 8.

The archaeology of the cultural landscape/Ed. L. Larsson, J. Callmer, B. Stjernquist. Stockholm, 1992.

The cultural landscape during 6000 years in southern Sweden/ Ed. B.E. Berglund. Copenhagen, 1991. (Ecological Bulletins; № 41).

Vasks A. Tigel̦i un lejamveidnes Brikul̦ u nocientinātajā apmetnē // Arheologija un etnografija. Riga, 1994. № 17.

Vassar A. Iru Linnapära // Muistse Eesti Linnused. Tartu, 1939.

Urtāns V. Bronzas zvaninu rotas VII-XI gs. // Изв. АН Латв. CCP. 1970. № 8.

Volkaite-Kuliskauskiene R., Jankauskas K. Iš Senosios Lietuvių amatininkystes istorijos (alavas senuosiose lietuvių papuošaluose) // Lietuvos Archeologija. Vilnius. 1992. № 8. P. $135-170$.

Włodarczak P. Kultura ceramiki sznurowej na Wyżynie Małopolskiej. Kraków, 2006.

Wróblewska A.B., Ciglis J, Radiņš A. Latvias Arheologiskās Senlietas Polijas Krātuvēs. Riga, 2005.

Zaltsman E. Chronological problems with sites of the Primorskaya culture on the north-eastern coast of the Vistula Lagoon // Sprawozdania Archeologiczne. Krakow, 2016. Vol. 68. P. 263-300.

Zvelebil M. The agricultural transition and the origins of Neolithic society in Europe // Documenta Praehistorica. 2001. Vol. XXVIII. P. 1-29.

Zvelebil M., Lillie M. Transition to agriculture in Eastern Europe // Europe's first farmers/Ed. T.D. Price. Cambridge, 2000. P. 57-92. 


\section{Принятые сокращения}

АКР - Археологическая карта России.

БНЦ УрО РАН - Башкирский научный центр Уральского отделения Российской академии наук.

ВООПИиК - Всероссийское общество охраны памятников истории и культуры.

ГАЗ - Гістарична-археалагічны зборнік.

ГАИМК - Государственная академия истории материальной культуры.

ГИМ - Государственный исторический музей.

ГЭ - Государственный Эрмитаж.

ИА НАН - Институт археологии Национальной академии наук Украины.

ИА РАН - Институт археологии Российской академии наук.

ИВП РАН - Институт водных проблем Российской академии наук.

ИИМК РАН - Институт истории материальной культуры Российской академии наук.
ИОЛЕАИЭ - Известия общества любителей естествознания антропологии и этнографии.

КСИА - Краткие сообщения Института археологии РАН.

КСИИМК - Краткие сообщения института истории материальной культуры.

МАИЭТ - Материалы по археологии, истории и этнографии Таврии.

МИА - Материалы по археологии СССР.

МОИП - Московское общество испытателей природы

ПИДО - Проблемы истории докапиталистических обществ.

РА - Российская археология.

РАНИОН - Российская ассоциация научно-исследовательских институтов общественных наук.

РАНИС - Работники науки и искусства.

СА - Советская археология.

САИ - Свод археологических источников.

ТАC - Тверской археологический сборник. 


\section{ИЛЛЮСТРАЦИИ}
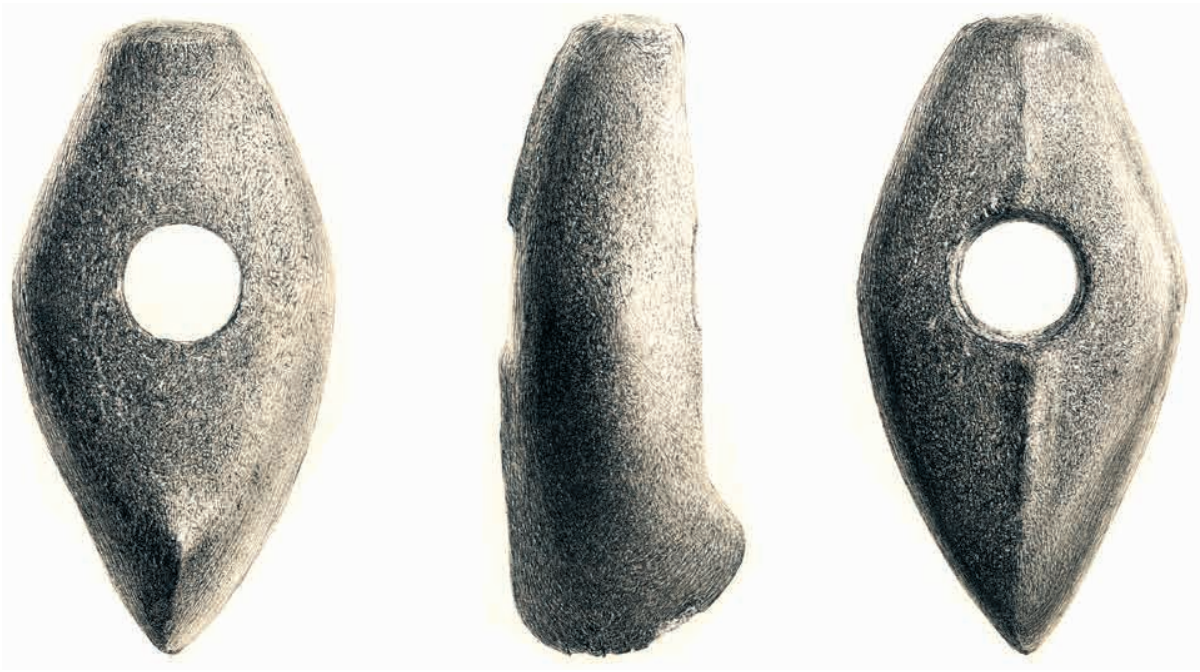


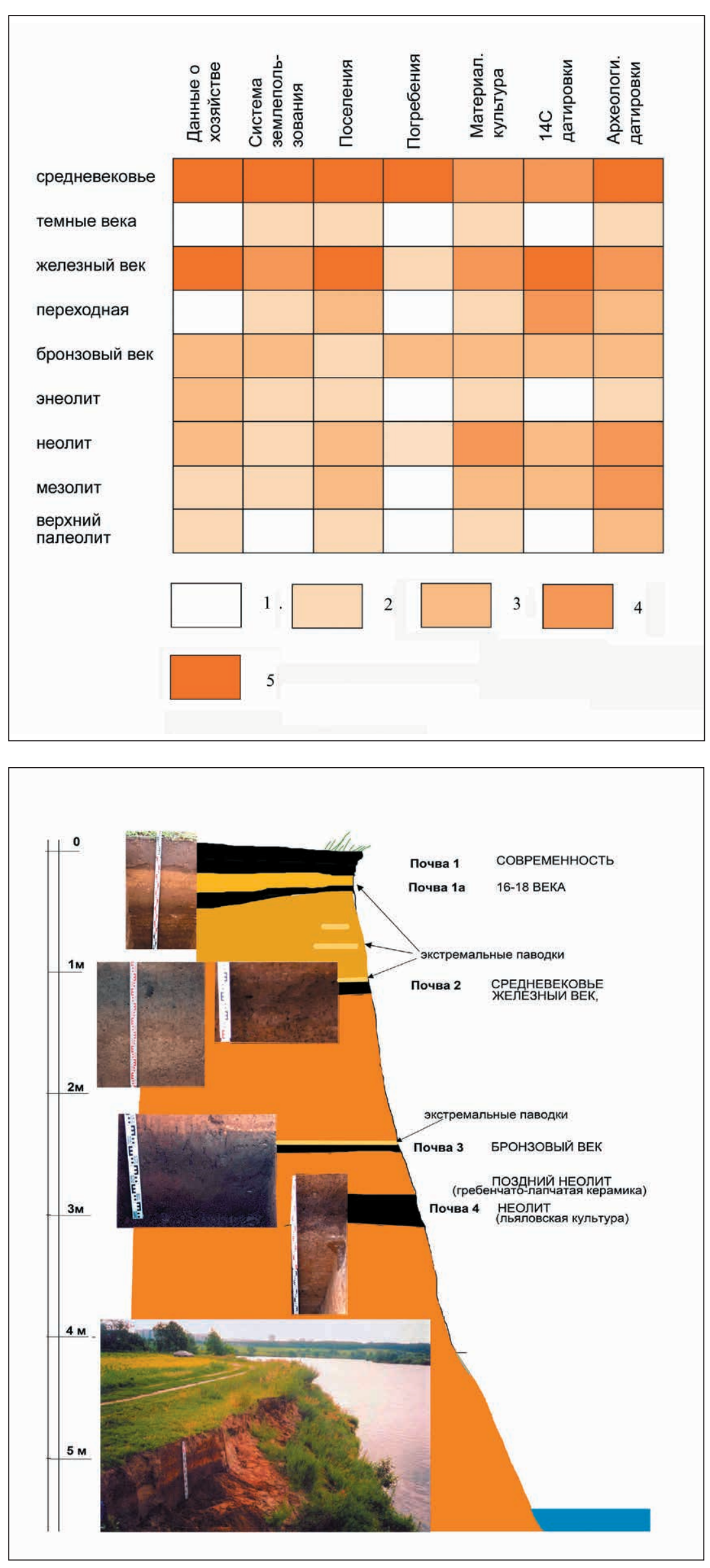

РИС. 1. ЭКСПЕРТНАЯ ОЦЕНКА ИЗУЧЕННОСТИ РАЗЛИЧНЫХ ПАРАМЕТРОВ АРХЕОЛОГИЧЕСКИХ КУЛЬТУР ПОДМОСКОВЬЯ ПО 5-БАЛЛЬНОЙ ШКАЛЕ

1 - нет данных; 2 - мало данных; 3 - фрагментарные данные; 4 - много данных; 5 - изобилие данных
РИС. 2. СВОДНЫЙ РАЗРЕЗ СТРОЕНИЯ ПОЙМЕННЫХ ОТЛОЖЕНИЙ В ДОЛИНЕ МОСКВЫ-РЕКИ (БЕЗ УЧЕТА ПОГРЕБЕННЫХ ПОЧВ, РАСПОЛОЖЕННЫХ ГЛУБЖЕ ПОЧВЫ 4) на врезке - фото 1994 г. правобережной поймы в Мякинино) 




РИС. 3. НЕОЛИТИЧЕСКИЕ СТОЯНКИ И ОТДЕЛЬНЫЕ НАХОДКИ В БАССЕЙНЕ МОСКВЫ-РЕКИ

Курсивом даны единичные находки, регулярным шрифтом - стоянки. Круги диаметром 30 км показывают «ресурсные зоны» с центром в районе скоплений памятников:

1 - Григорово 1; 2 - Григорово 2; 3 - Бережки; 4 - Рязань; 5 - Каринское; 6 - Звенигородская биостанция-5; 7 - Рыбушкино; 8 - Саввинская слобода; 9 - Скит Саввы; 10 - 1-я Звенигородская стоянка; 11 - 2-я Звенигородская стоянка; 12 - 3-я Звенигородская стоянка; 13 - Аксиньинское болото; 14 - Успенское; 15 - Петрово-Дальнее; 16 - Щукино; 17 - Алёшкино; 18 - Дьяково; 19 - Редькино; 20 - Чулково; 21 - Заозерье; 22 - Верея; 23 - Новое Село; 24 - Виноградово; 25 - Городище; 26 - Старо-Голутвин монастырь; 27 - Коломна (ул. Б. Запрудная); 28 - Коломна, полигон Артучилища; 29 - оз. Глубокое; 30 - Брикет, стоянка 8; 31 - Городище, стоянка 4 (Тростенская 6); 32 - Городище, стоянка 6 (Тростенская 12); 33 - Городище, стоянка 7 (Семенова речка-Воронка); 34 - Городище (стоянка Тростенская); 35 - Городище (стоянка Тростенская 1); 36 - Никольская, стоянка 2; 37 - Никольская-правая, стоянка; 38 - Никольское, стоянка; 39 - Буланино, стоянка; 40 - Брикет, стоянка 9; 41 - Брикет, стоянка; 42 - Глиньково стоянка Дальний остров; 43 - Никольская, стоянка; 44 - Бороденки, стоянка 2; 45 - Бороденки, стоянка 1; 46 - Скирманово, стоянка (Усть-Рассоха); 47 - Нижнее Сляднево, стоянка (Гряда); 48 - Нижнее Сляднево; 49 (1196 АКР) - Ракитино; 50 - Рыбушкино, стоянка; 51 - Копцево; 52 - Подольск (Подол); 53 - Егорьевск; 54 - Вишневая, стоянка; 55 - Усть-Вольная; 56 - Беливо 1А; 57 - Беливо 1В; 58 - Беливо 1Г; 59 - Беливо 2; 60 - Беливо 3; 61 - Беливо 4Б; 62 - Беливо 4В; 63 - Беливо 6; 64 - Беливо 6В; 65 - Беливо 7; 66 - Беливо 8; 67 - Беливо 9; 68 - Беливо 10; 69 - Беливо 14; 70 - Радомка 1; 71 - Беливское оз 1; 72 - Беливо 5А; 73 - Загряжская 2; 74 - Слободищи 1; 75 - Слободищи $3 ; 76$ - Слободищи 4; 77 - Соболево 1; 78 - Тереньково 1; 79 - Тереньково 2; 80 - Тереньково 7; 81 - Тереньково 5; 82 - Тереньковское кладбище 2; 83 - Тереньково поселение 1; 84 - Тереньково поселение 3; 85 - Тереньково поселение 4; 86 - Хотеичи 2; 87 - Хотеичская; 88 - гор. Круглица; 89 - гор. Знаменское, раскопки 2005 г.; 90 - Серебренноборская; 91 - Кулаково-3; 92 - городище Руза (колл. Рузского музея нвф-2055); 93 - городище Троицкое (Дубынин, 1974); 94 - селище Хотяжи-1 (раскопки 2013 г.); 95 - Чудцево, стоянка льяловск. (АКР № 2600); 96 - Пречистое 1 (АКР № 2587); 97 - Пречистое 2 (АКР № 2588); 98 - «Нижнее течение р. Рузы» (по: КрасновЮ.А., Краснов Н.А., 1959); 99 - Новодевичий монастырь, раскопки 2018 г. (керамика) 



Б
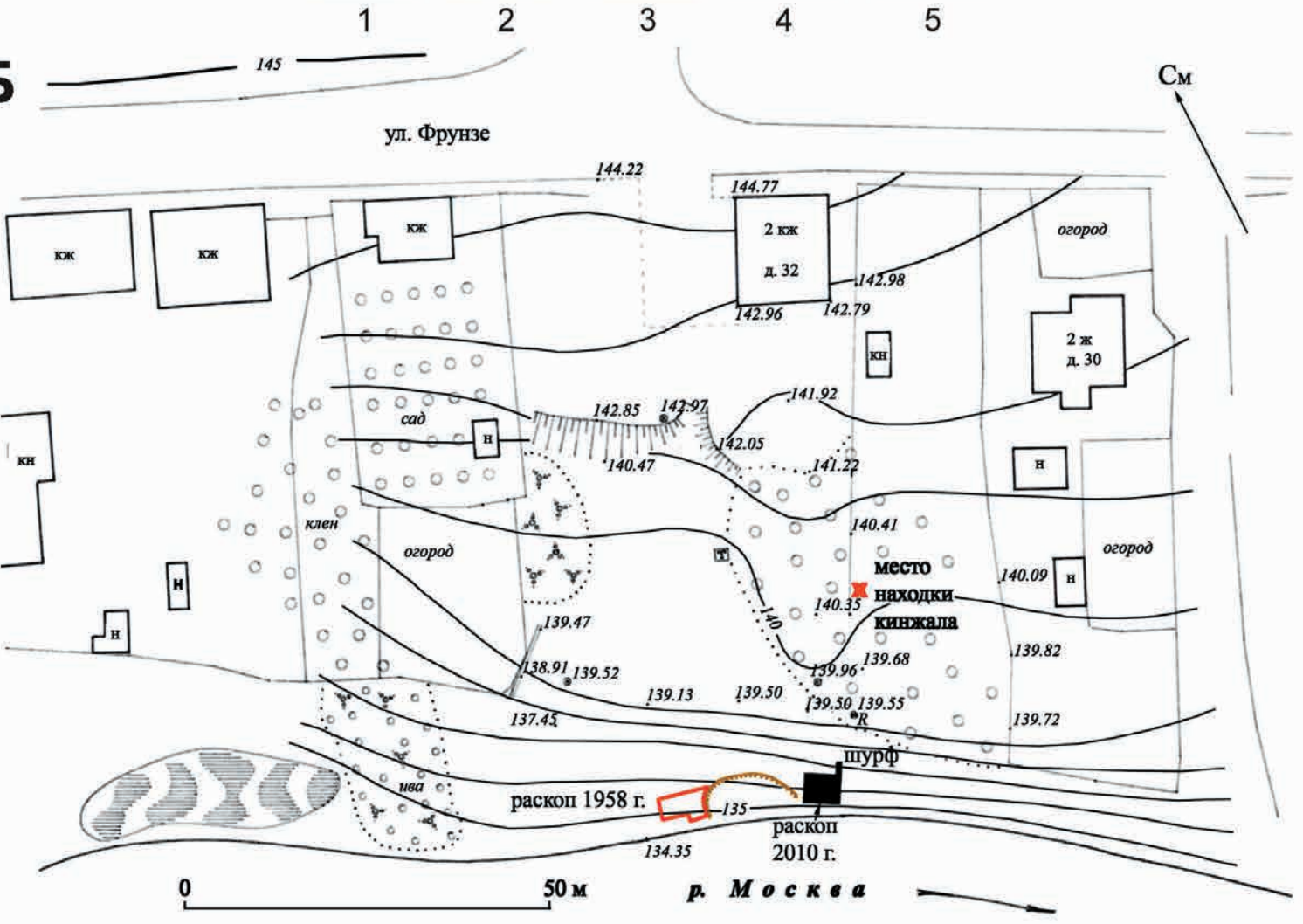

5

РИС. 4. ГЕОМОРФОЛОГИЧЕСКАЯ КАРТА (А) ОКРЕСТНОСТЕЙ ЗВЕНИГОРОДСКОЙ СТОЯНКИ (ПО: ПАНИН, 2008) И ТОПОГРАФИЧЕСКИЙ ПЛАН 1-Й ЗВЕНИГОРОДСКОЙ стоянки (Б)

Условные обозначения: 1 - пойма позднеголоценовая высотой 2-3 м; 2 - пойма ране- и среднеголоценовая высотой 5-6 м; 3 - «промежуточная терраса» высотой 7-8 м; 4 - поздневалдайский террасовый комплекс высотой 8-15 м; 5 - границы городской застройки 




РИС. 5. ПЛАН РАСКОПА 2010 Г. НА 1-Й ЗВЕНИГОРОДСКОЙ СТОЯНКЕ 




северный борт

кв. Д 8

кв. Г 8



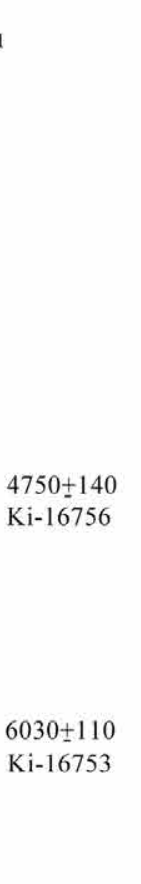

схема раскопа

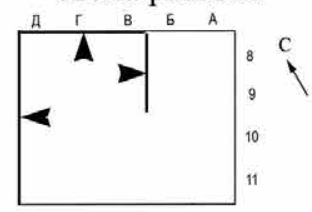

0

Условные знаки:



восточный борт

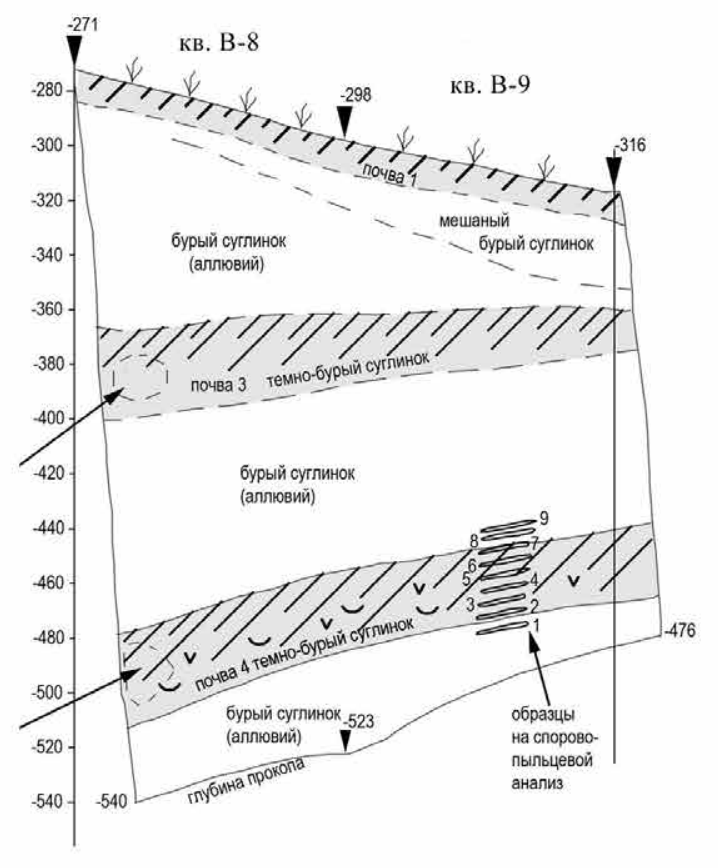

РИС. 6. ПРОФИЛИ БОРТОВ РАСКОПА 2010 Г. НА 1-Й ЗВЕНИГОРОДСКОЙ СТОЯНКЕ 




РИС. 7. ГОРШКИ НЕОЛИТИЧЕСКОЙ ЛЬЯЛОВСКОЙ КУЛЬТУРЫ, РАЗВИТОГО $(1,2)$ И ПОЗДНЕГО (3) ЭТАПОВ 1 - Старо-Голутвин монастырь, 2 - 1-я Звенигородская стоянка, 3 - стоянка ЗБС-5 


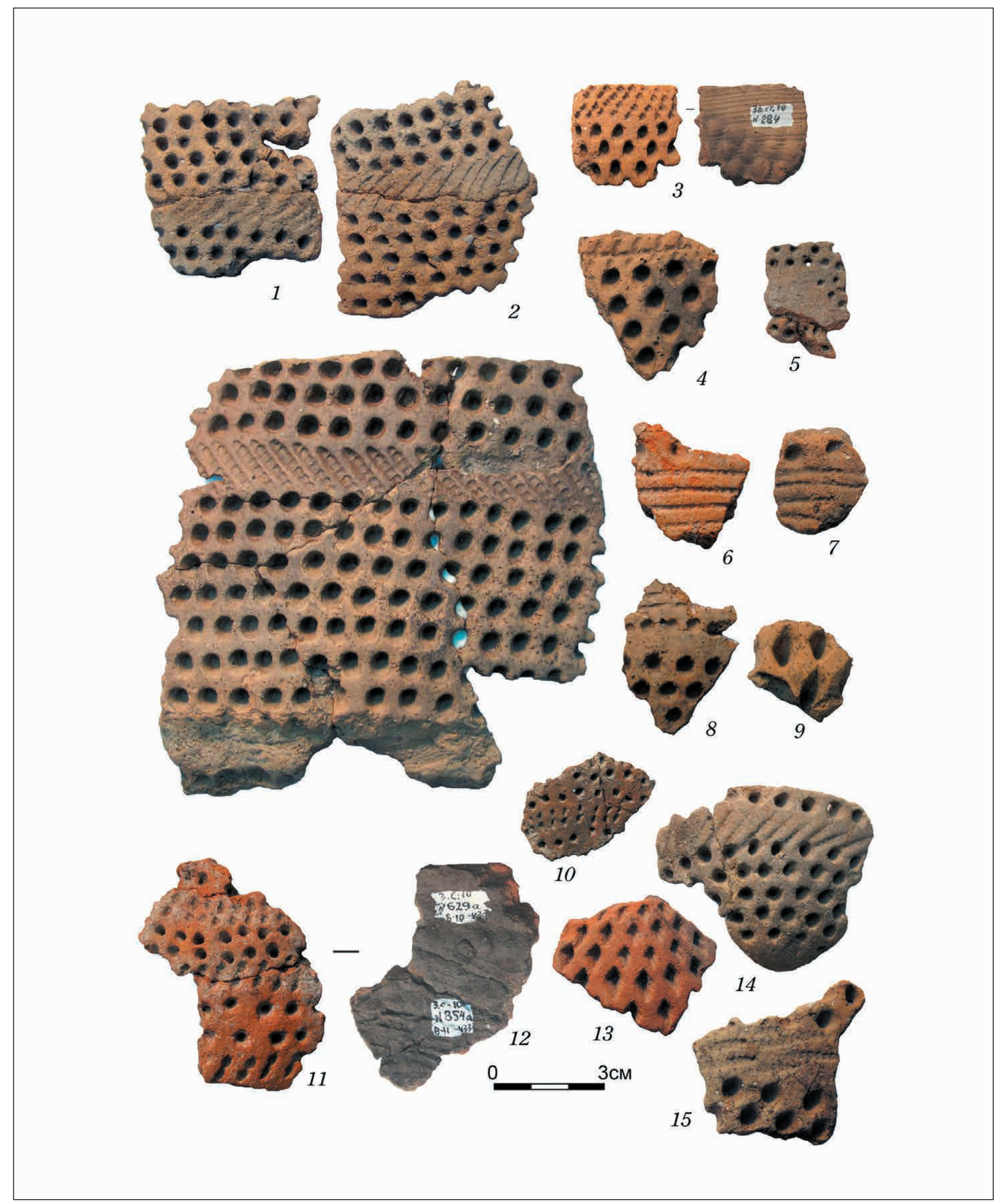

РИС. 8. ФРАГМЕНТЫ ГОРШКОВ ЛЬЯЛОВСКОЙ КУЛЬТУРЫ ИЗ РАСКОПОК 2010 Г. 1-Й ЗВЕНИГОРОДСКОЙ СТОЯНКИ 



6



РИС. 9. ФРАГМЕНТЫ ВЕНЧИКОВ ГОРШКОВ ЛЬЯЛОВСКОЙ КУЛЬТУРЫ ИЗ РАСКОПОК 2010 Г. 1-Й ЗВЕНИГОРОДСКОЙ СТОЯНКИ 


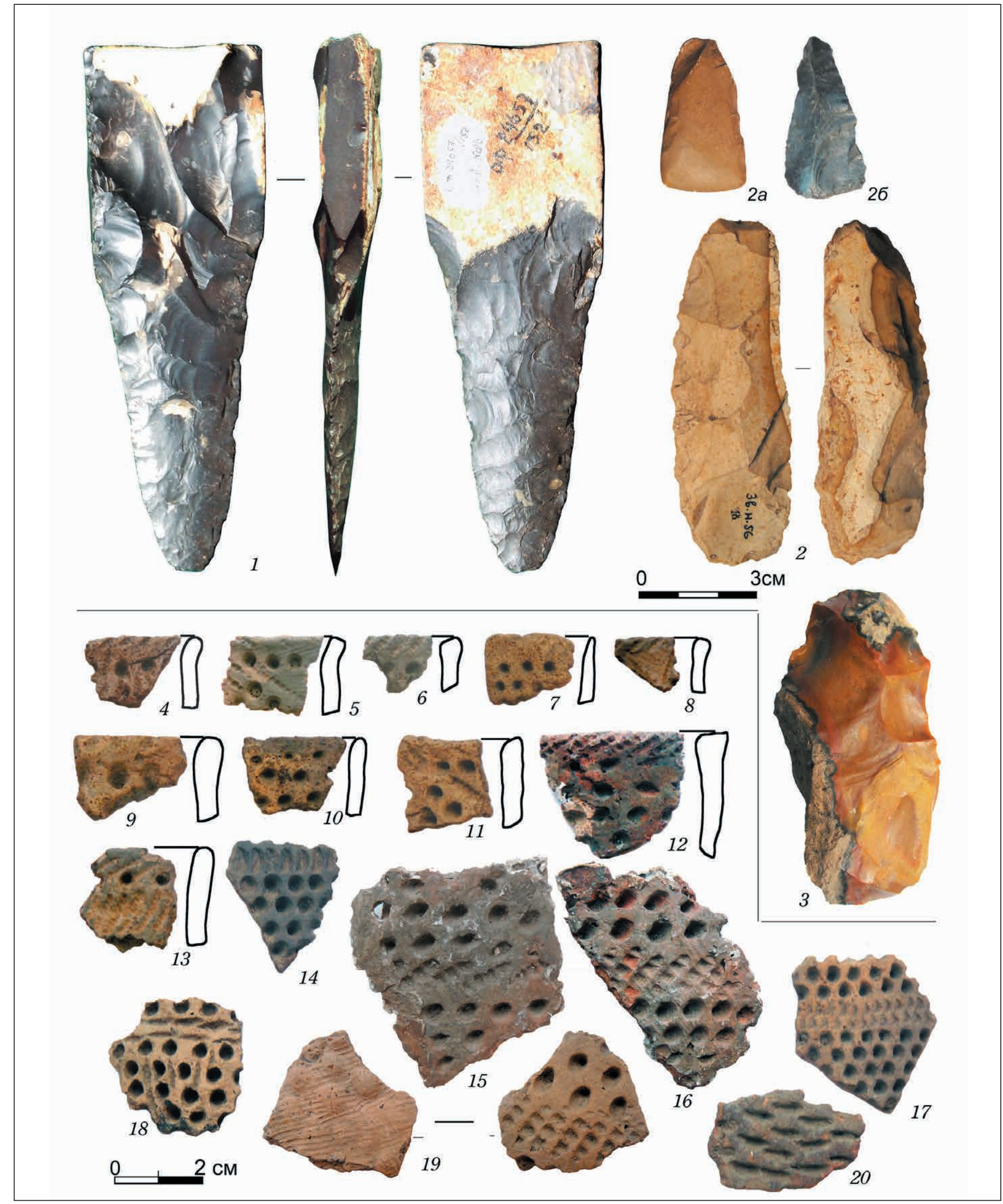

РИС. 10. КАМЕННЫЕ ОРУДИЯ И КЕРАМИКА ЛЬЯЛОВСКОЙ КУЛЬТУРЫ ИЗ РАСКОПОК И СБОРОВ НА ТЕРРИТОРИИ 1-Й ЗВЕНИГОРОДСКОЙ СТОЯНКИ 1958 и 1977 гг.

Фонды Звенигородского музея и Музея истории Москвы 


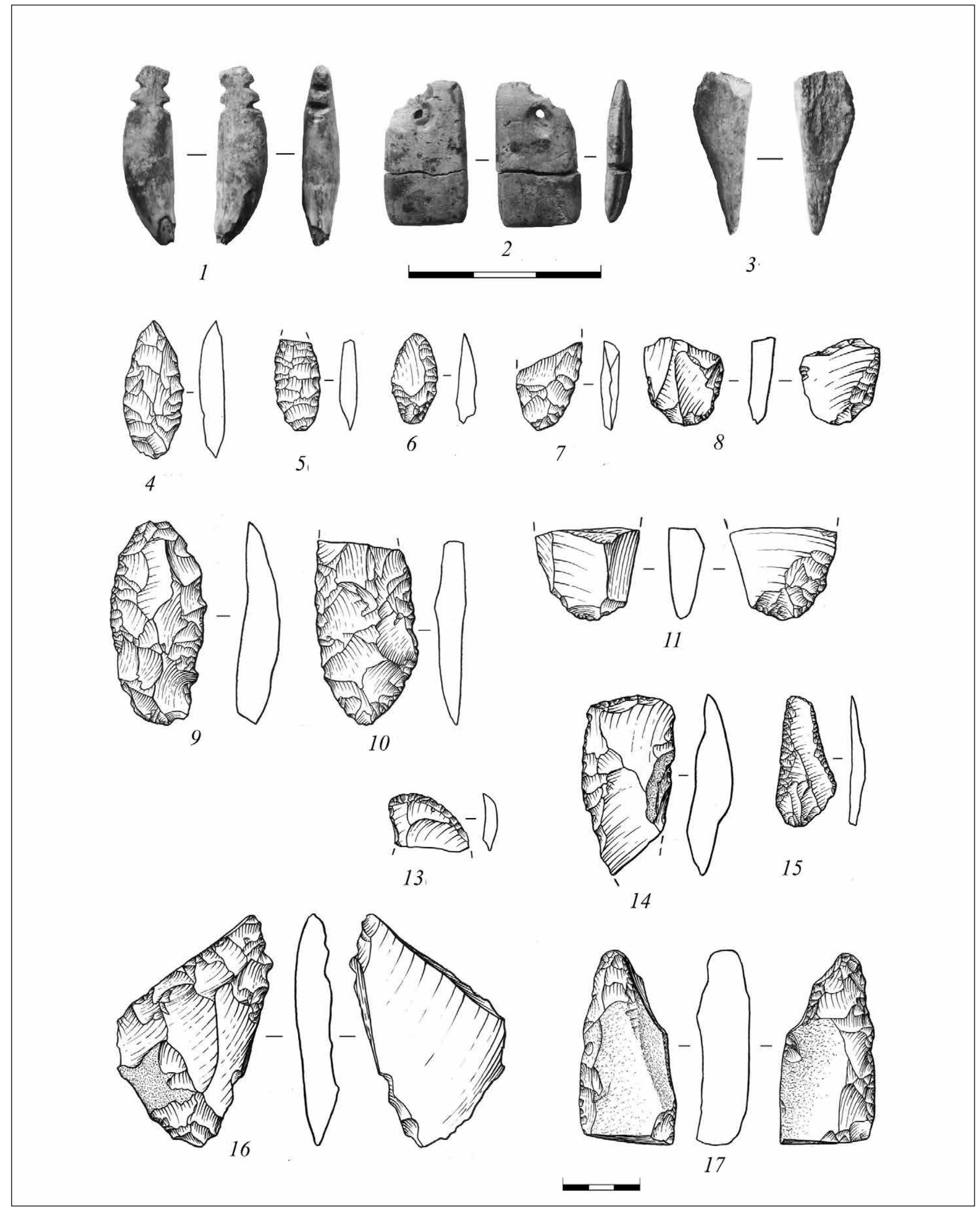

РИС. 11. 1-Я ЗВЕНИГОРОДСКАЯ СТОЯНКА. МАТЕРИАЛЫ РАСКОПОК 2010 Г. ИЗДЕЛИЯ ИЗ КОСТИ (ВЕРХНИЙ РЯД) И КРЕМНЕВЫЕ ОРУДИЯ. Рис. А.В. Трусова 




РИС. 12. КРЕМНЕВЫЕ ОРУДИЯ ИЗ РАСКОПОК 1-Й ЗВЕНИГОРОДСКОЙ СТОЯНКИ 


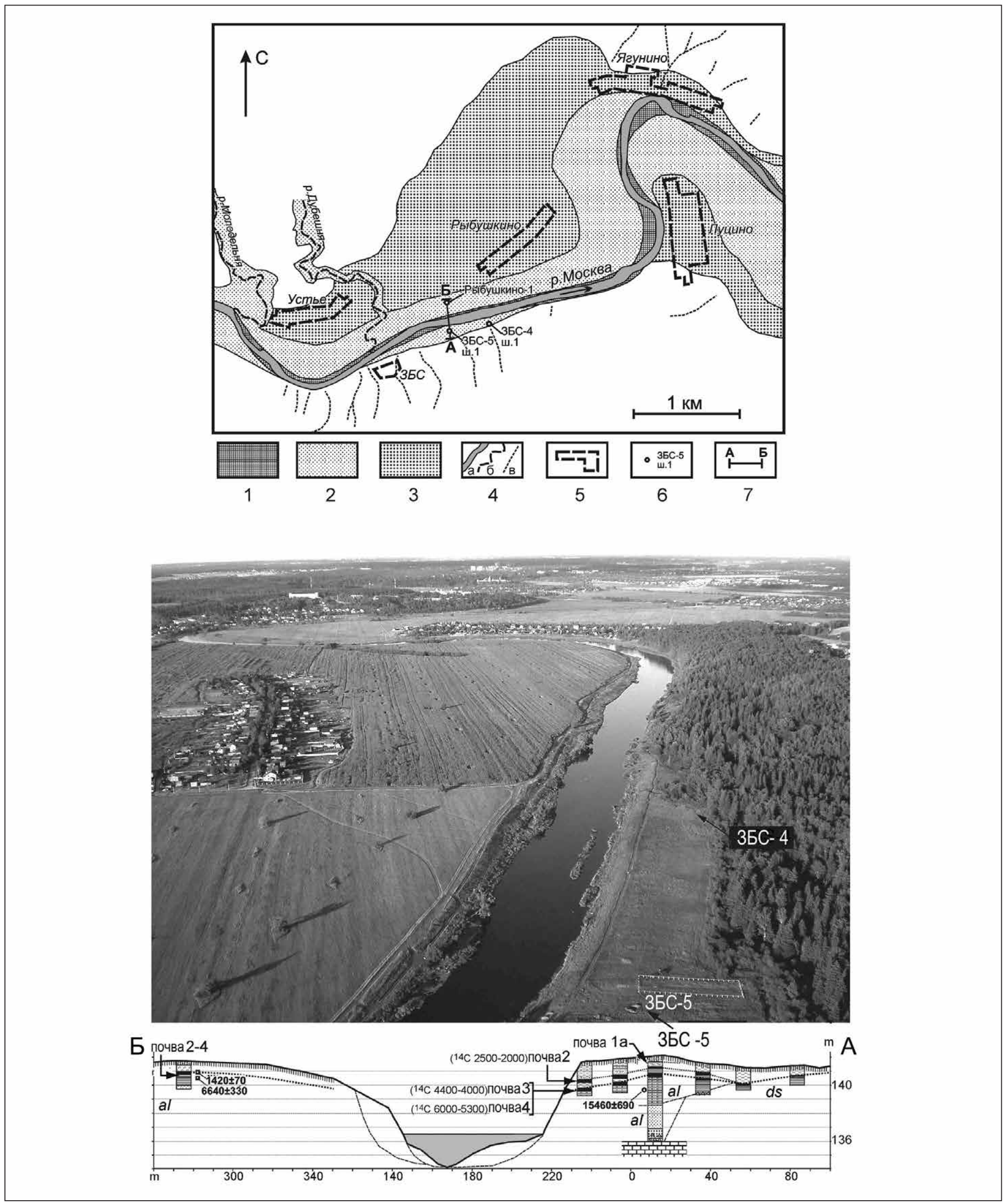

РИС. 13. ОБЩИЙ ВИД, ПОПЕРЕЧНЫЙ ПРОФИЛЬ И ГЕОМОРФОЛОГИЧЕСКАЯ КАРТА ДОЛИНЫ МОСКВЫ-РЕКИ В ПРЕДЕЛАХ ЗВЕНИГОРОДСКОЙ БИОЛОГИЧЕСКОЙ СТАНЦИИ (пО: ПАНИн, 2008)

1 - голоценовая пойма (высота 3-5 м), 2 - доголоценовая пойма (высота 5-7 м), 3 - поздневалдайский террасовый комплекс (высота 7-12 м), 4 - гидрография, 5 - населенные пункты, 6 - шурфы, 7 - линия профиля 


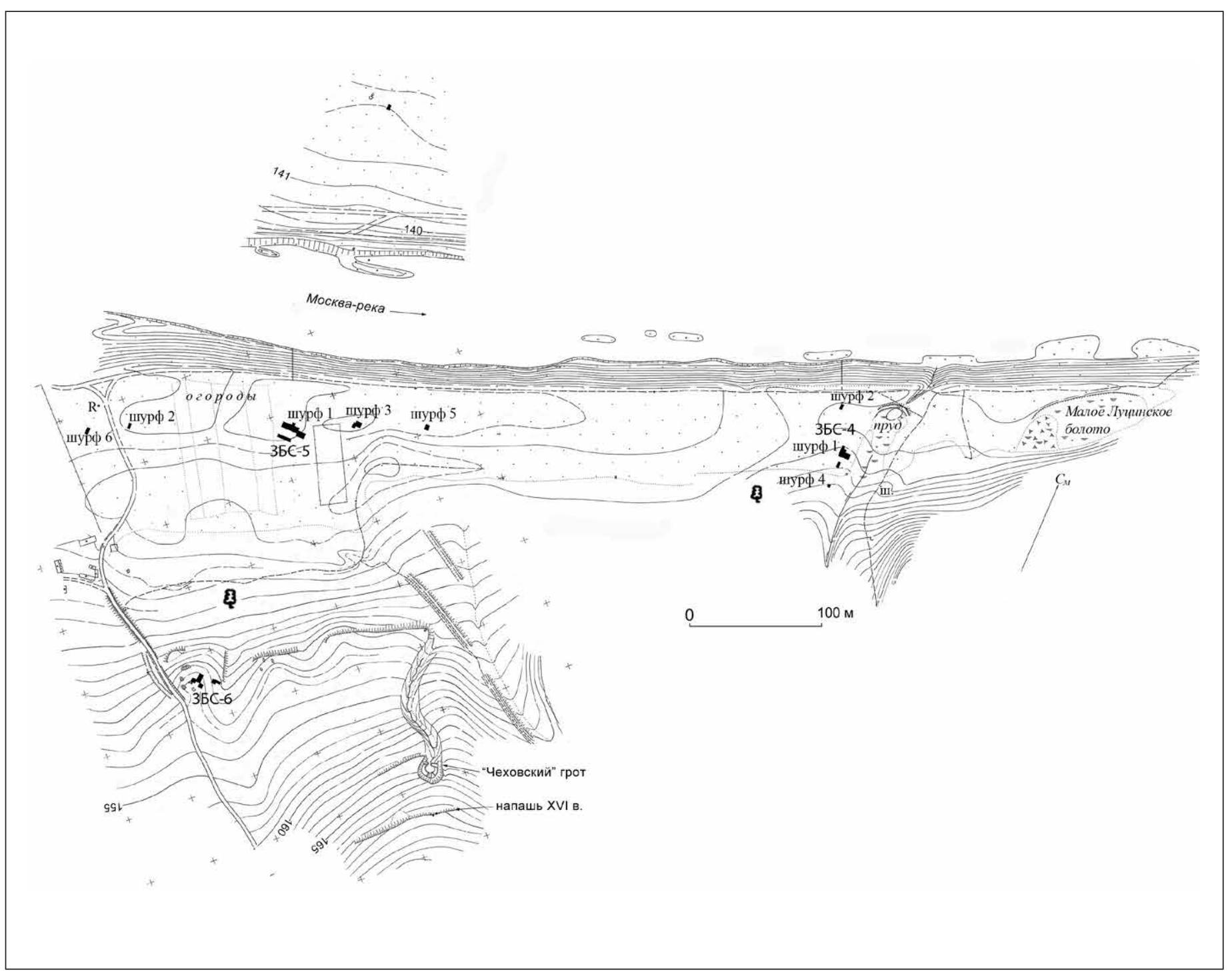

РИС. 14. ТОПОГРАФИЧЕСКИЙ ПЛАН ПОЙМЫ ПРАВОГО БЕРЕГА МОСКВЫ-РЕКИ В ПРЕДЕЛАХ ЗВЕНИГОРОДСКОЙ БИОЛОГИЧЕСКОЙ СТАНЦИИ 

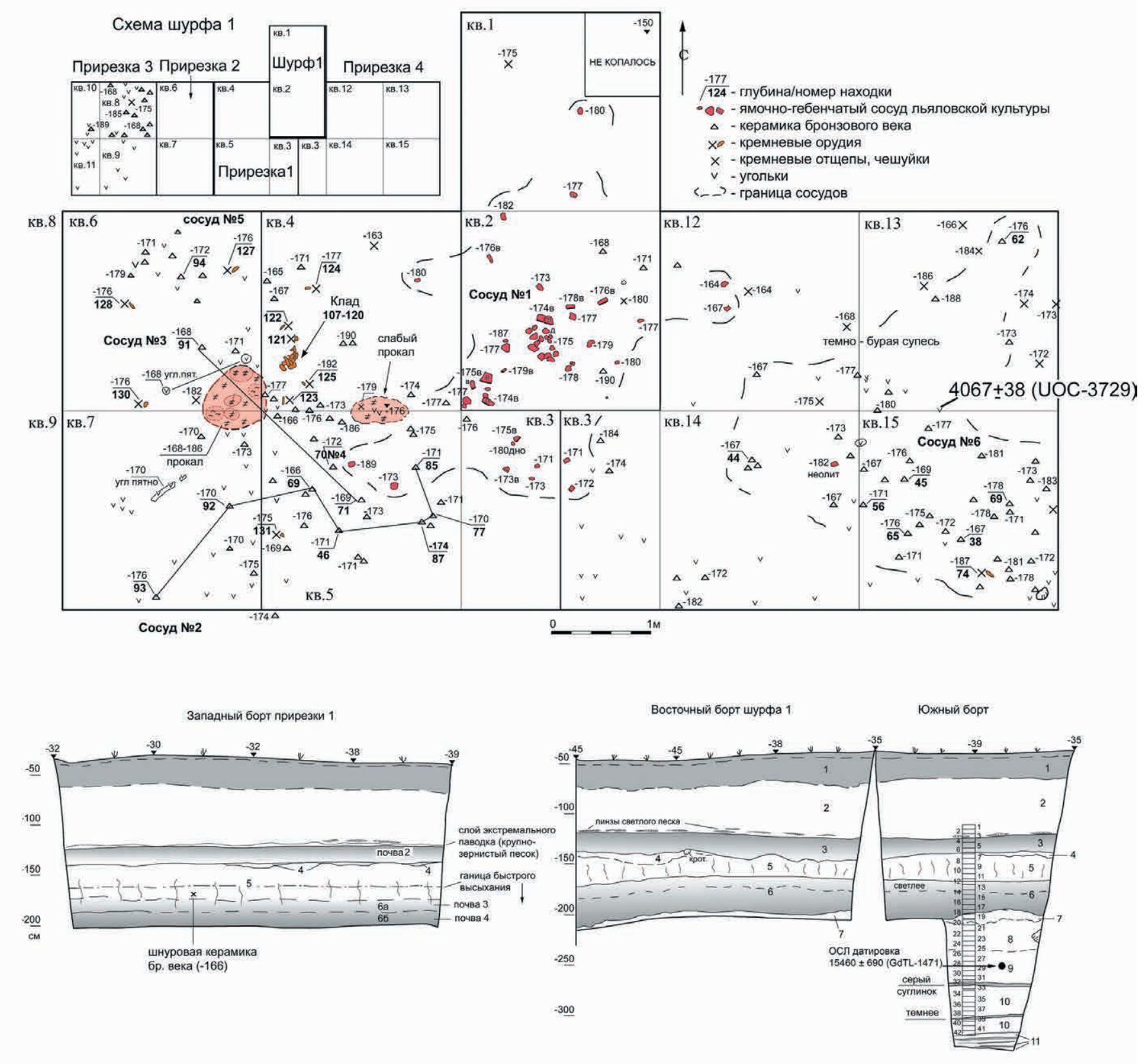

РИС. 15. ПЛАН И ПРОФИЛИ РАСКОПА НА СТОЯНКЕ ЗБС-5 


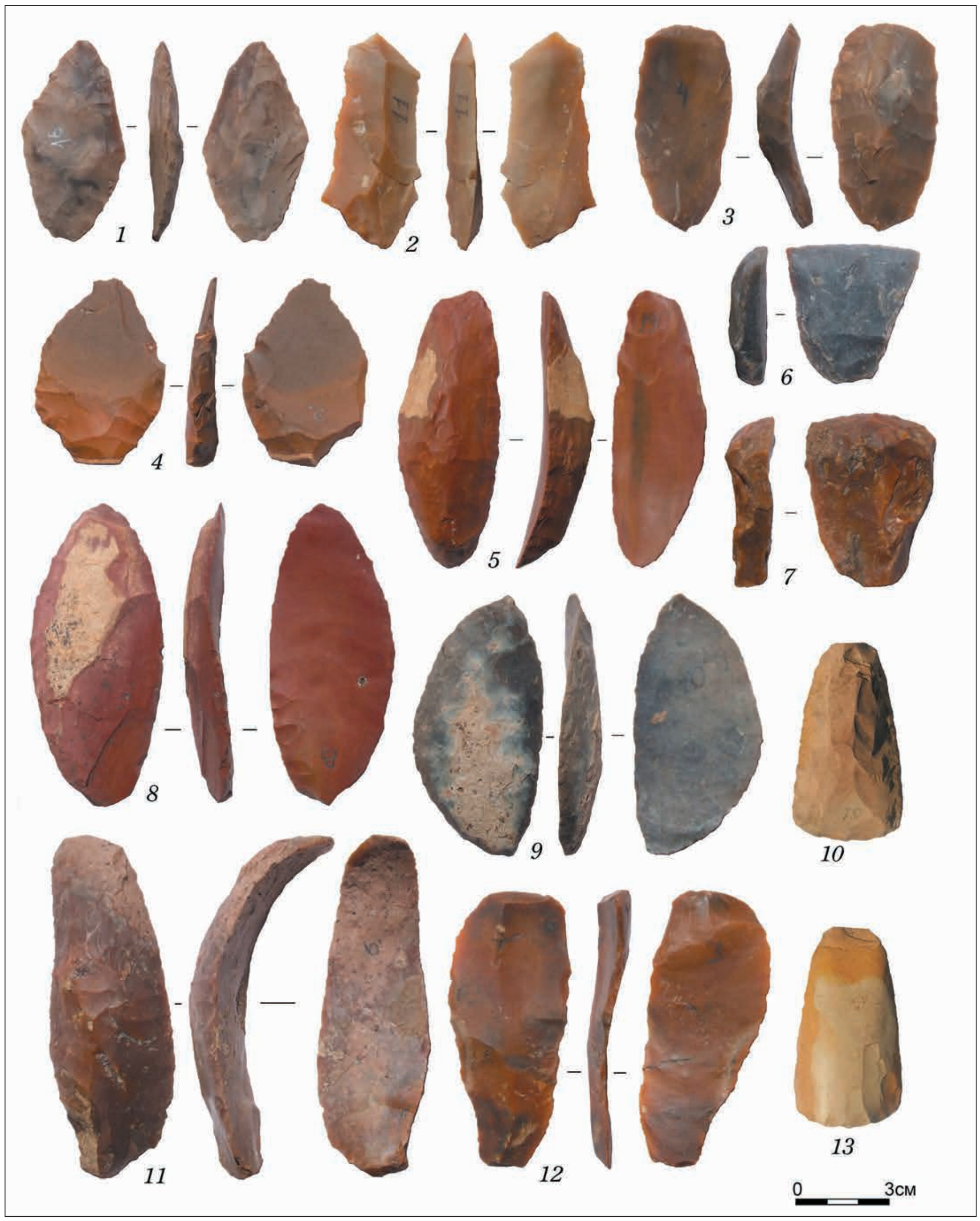

РИС. 16 КРЕМНЕВЫЕ ОРУДИЯ ЛЬЯЛОВСКОЙ КУЛЬТУРЫ СО СТОЯНКИ ЗБС-5.

Фото В.А. Раевой 



№119


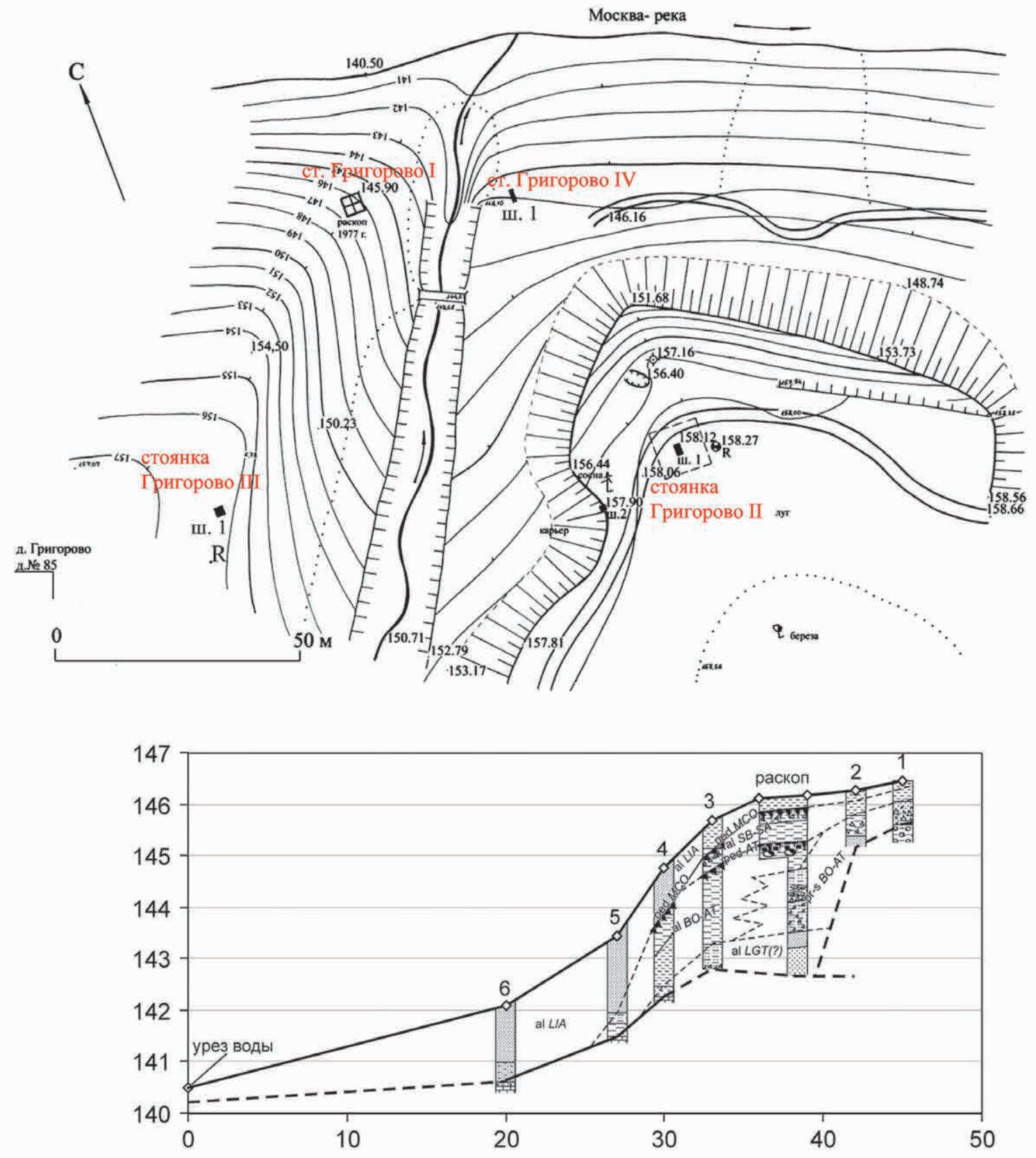

литология:

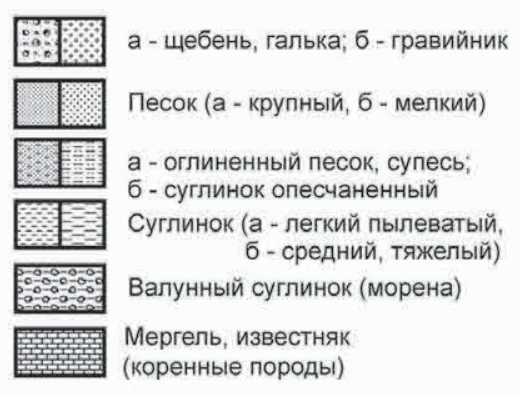



РИС. 18. ПЛАН И ГЕОМОРФОЛОГИЧЕСКИЙ ПРОФИЛЬ (ПО А.В. ПАНИНУ) НА УЧАСТКЕ СТОЯНОК ГРИГОРОВО 1-4 



РИС. 19. РАБОТЫ НА СТОЯНКЕ ГРИГОРОВО 4 В 2012 Г. И ПРОФИЛЬ ТРАНШЕИ 


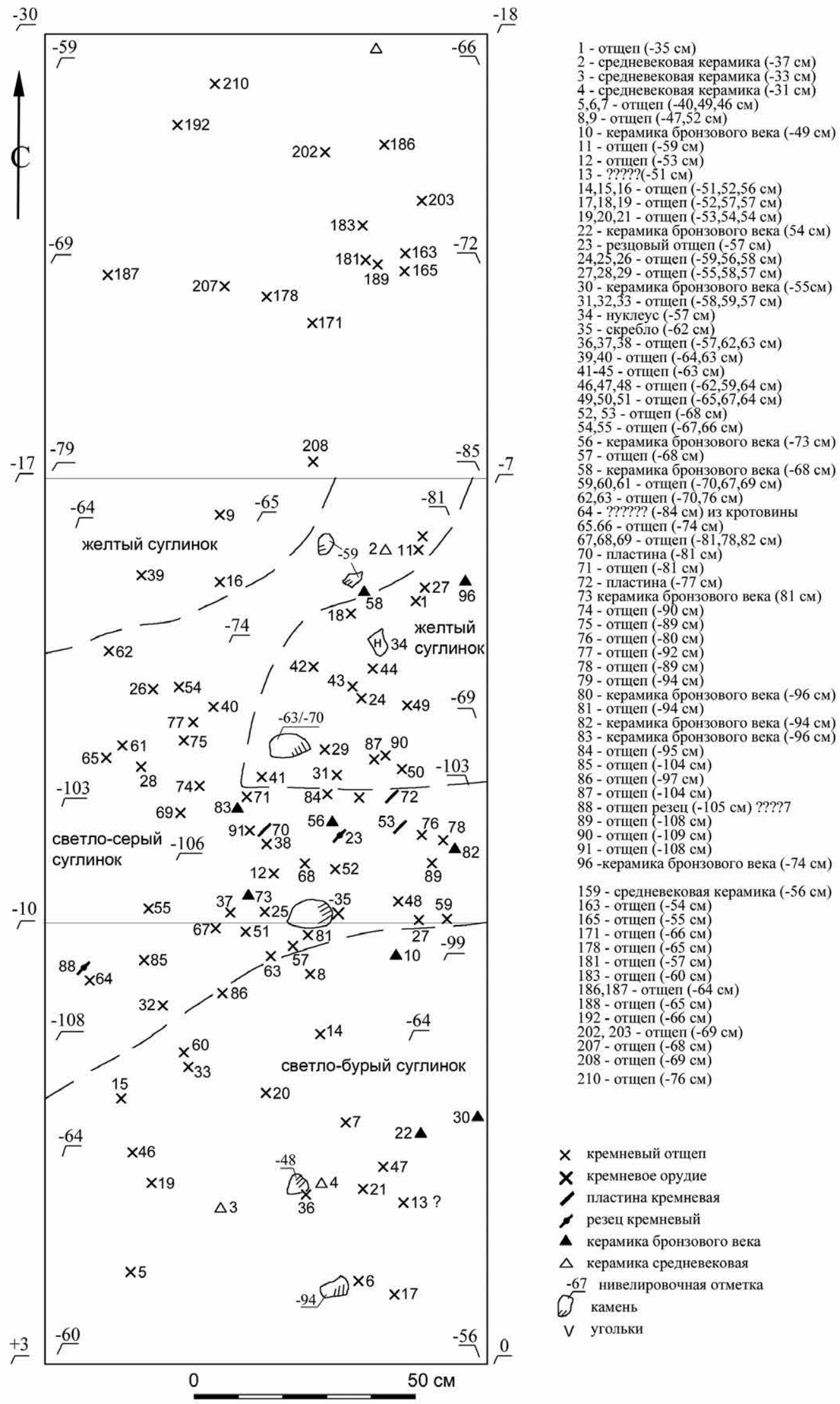

РИС. 20. ПЛАН ТРАНШЕИ 2012 Г. НА СТОЯНКЕ ГРИГОРОВО 4 


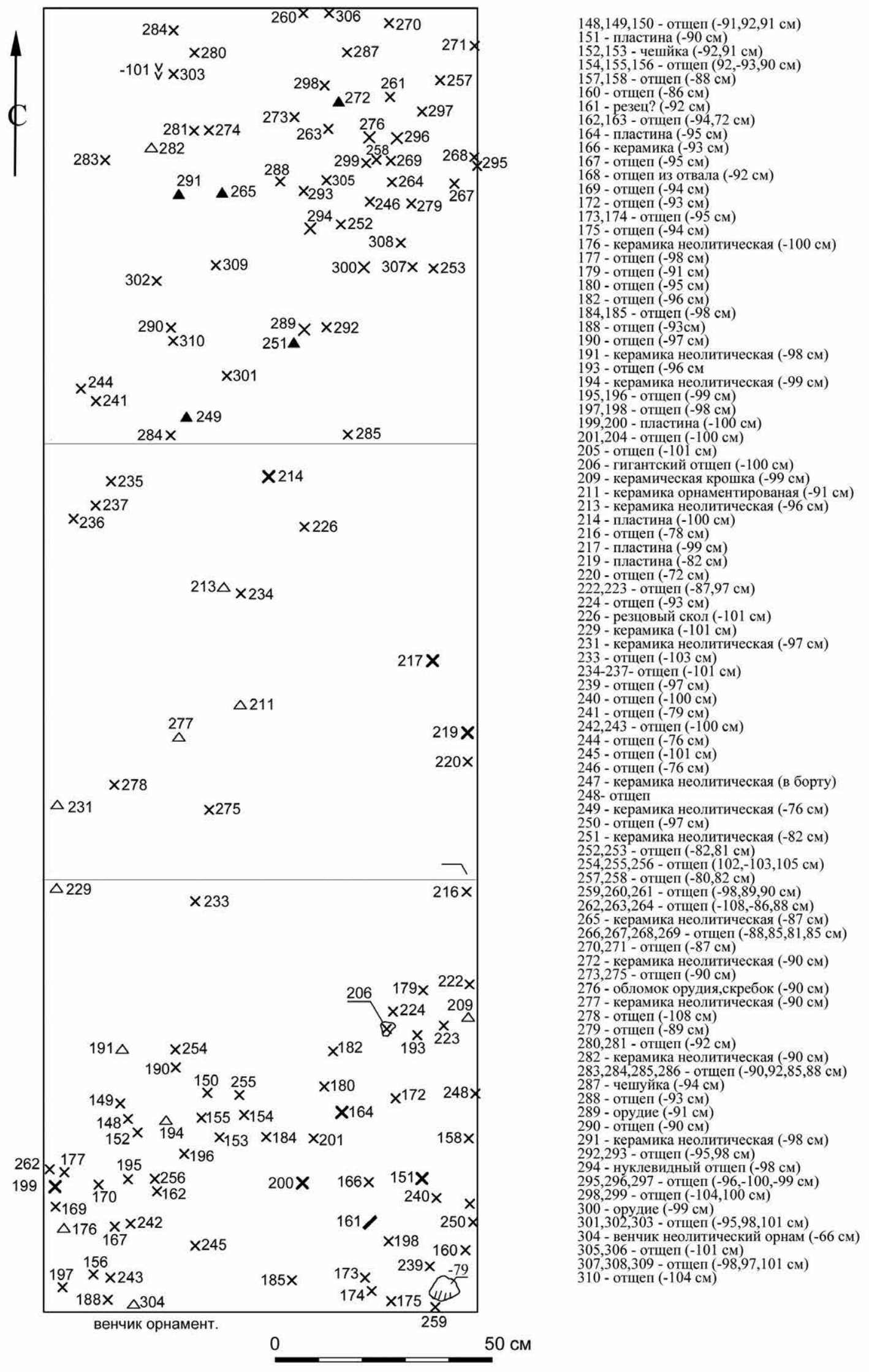

РИС. 21. ПЛАН ТРАНШЕИ 2012 Г. НА СТОЯНКЕ ГРИГОРОВО 4 


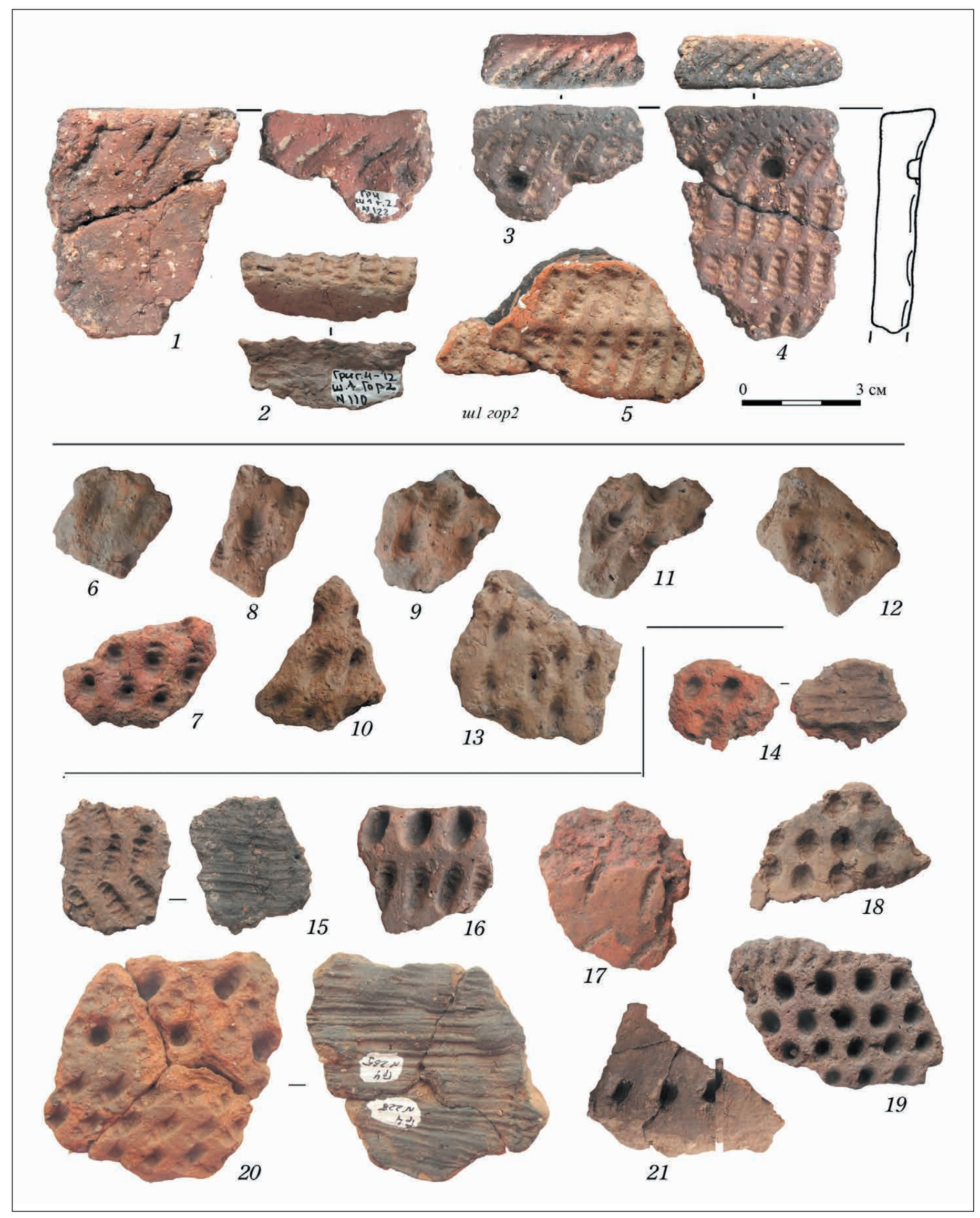

РИС. 22. КЕРАМИКА СО СТОЯНКИ ГРИГОРОВО 4: ЛАПЧАТАЯ, ГРЕБЕНЧАТАЯ, ПРОТОВОЛОСОВСКАЯ И ЛЬЯЛОВСКАЯ КЕРАМИКА 


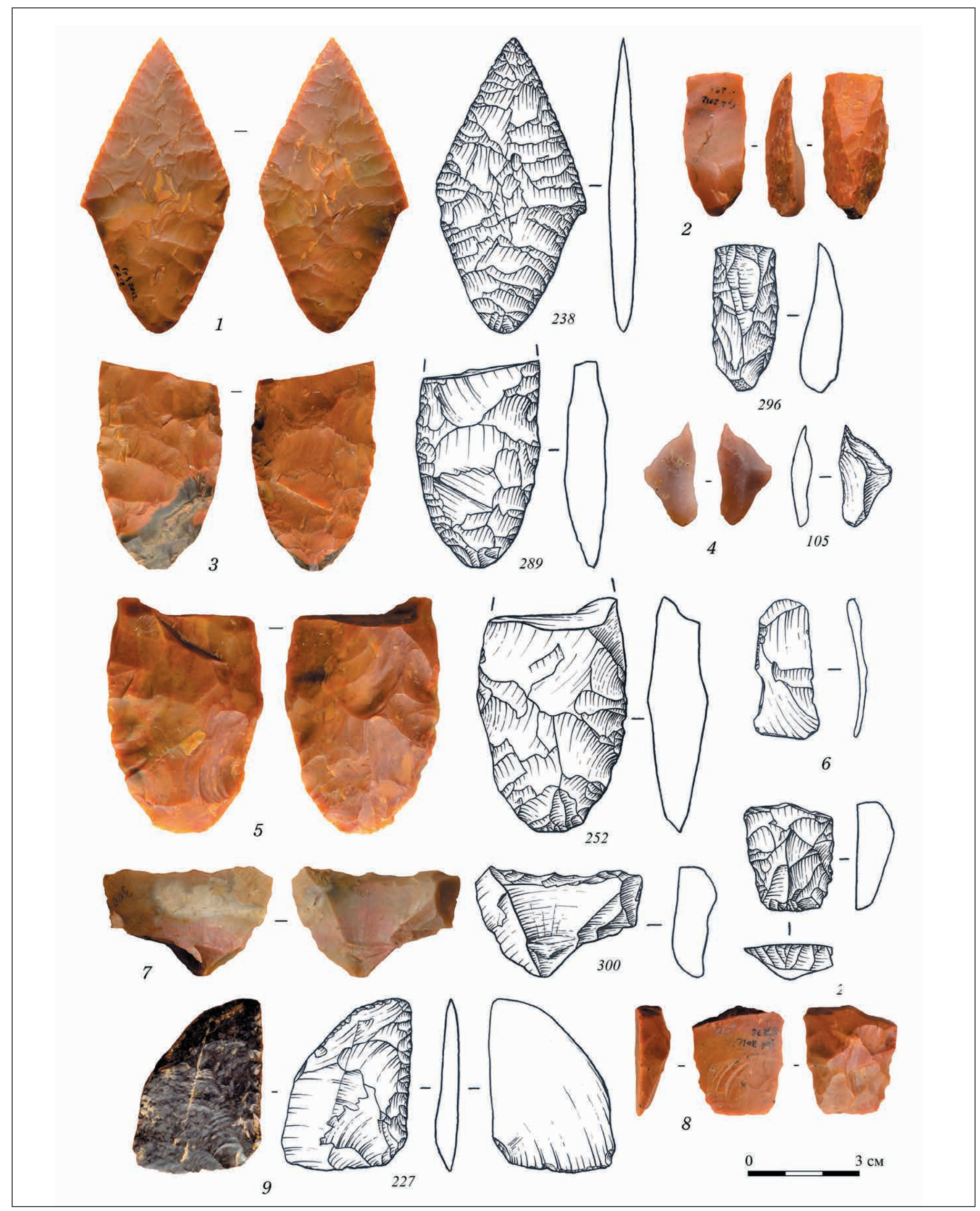

РИС. 23. КРЕМНЕВЫЕ ОРУДИЯ СО СТОЯНКИ ГРИГОРОВО 4, РАСКОПКИ 2012 Г.

Рис. А.В. Трусова 


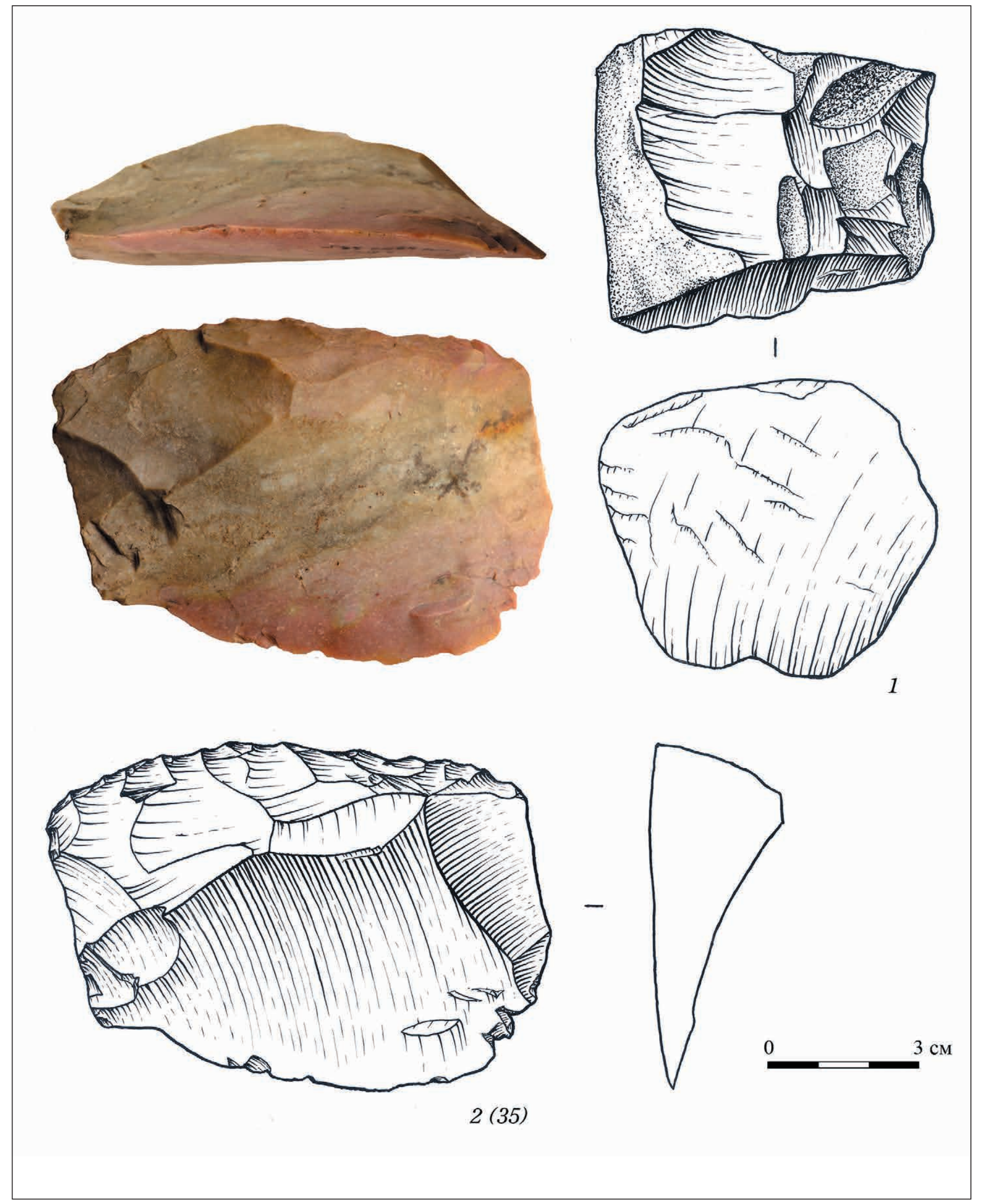

РИС. 24. КРЕМНЕВЫЙ НУКЛЕУС И СКРЕБЛО ИЗ СТОЯНКИ ГРИГОРОВО 4.

Рис. А.В. Трусова 


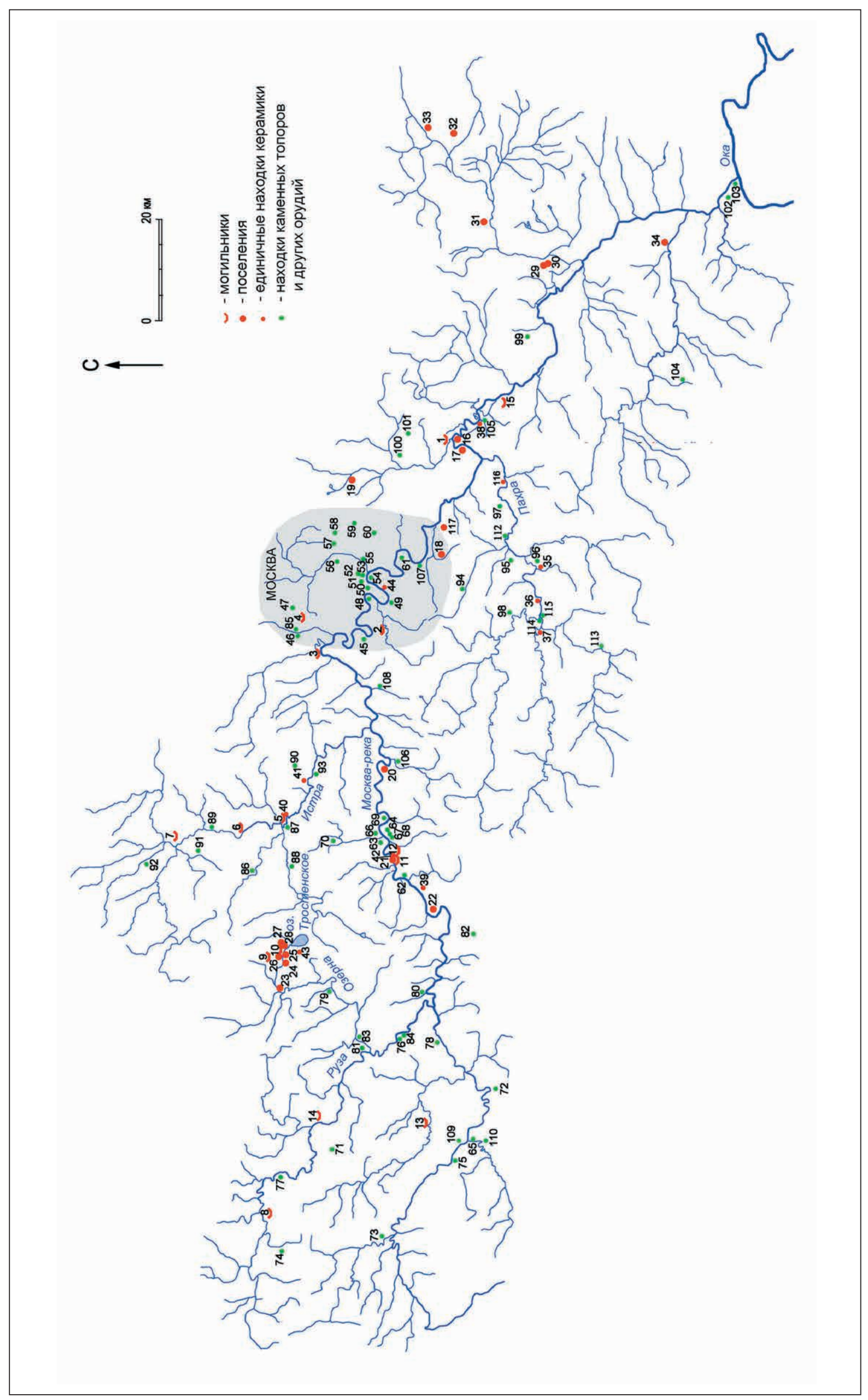


ó

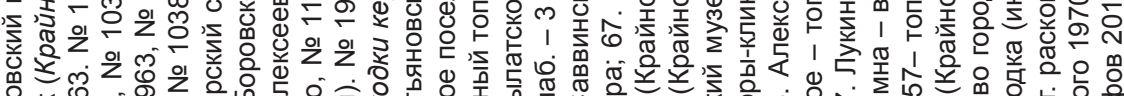

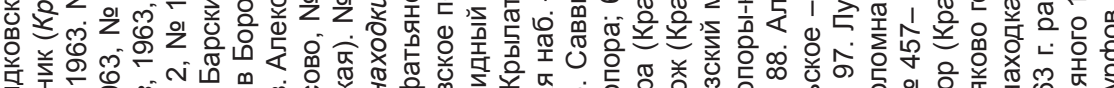

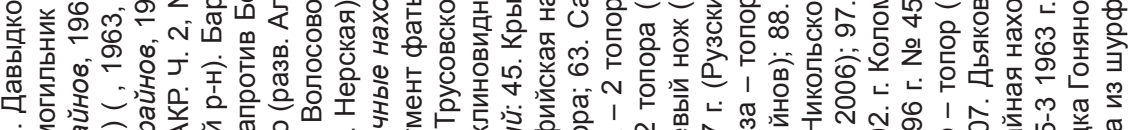

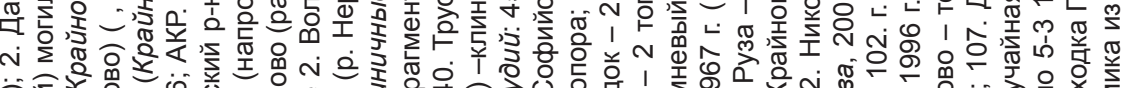

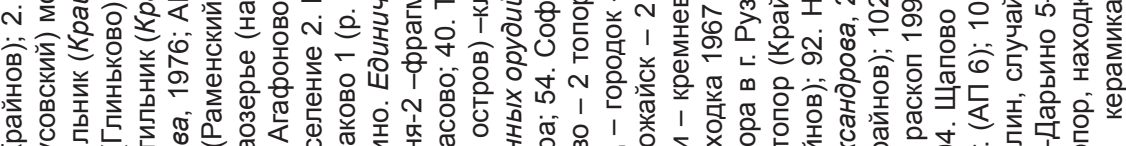

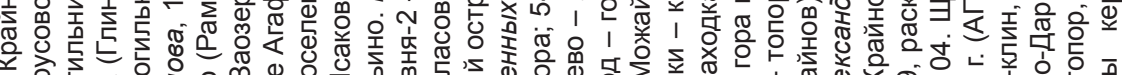

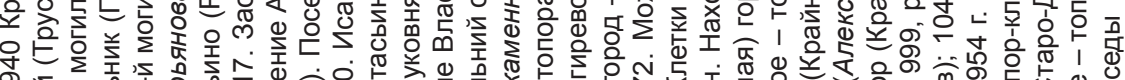

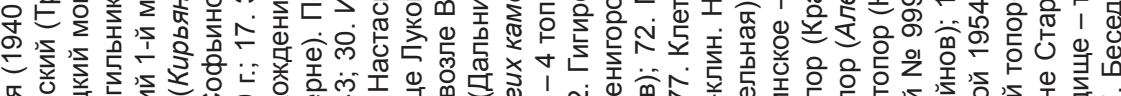

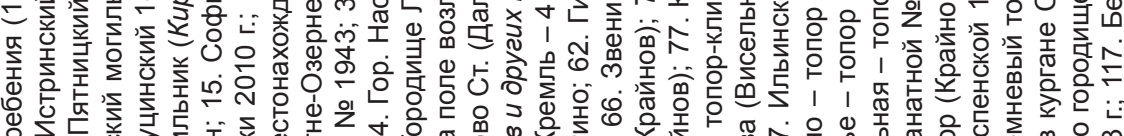

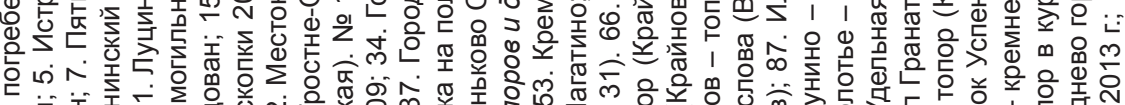

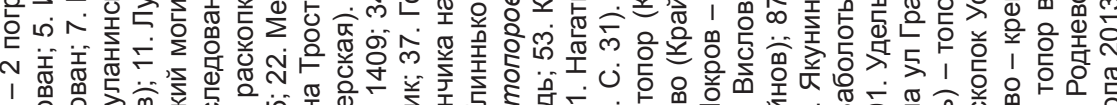
10 0

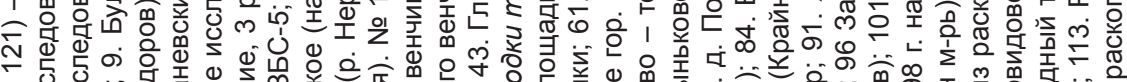
ol

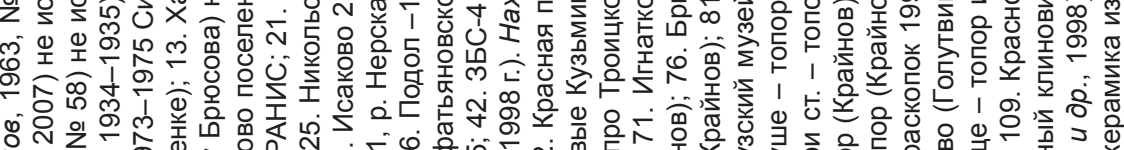

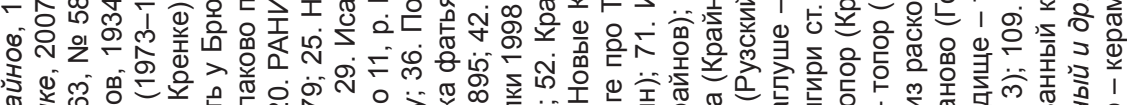



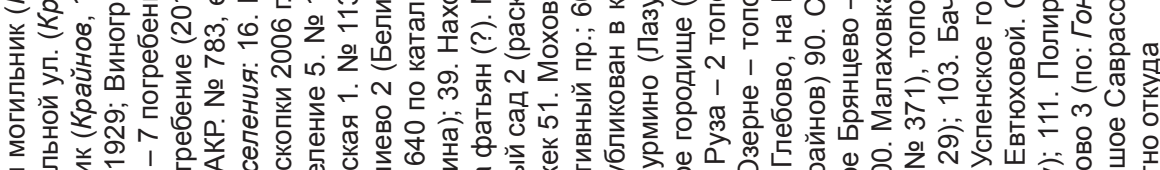

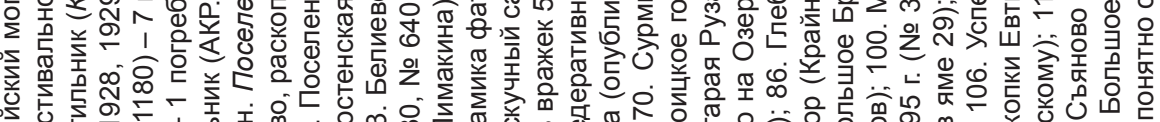
, 娄











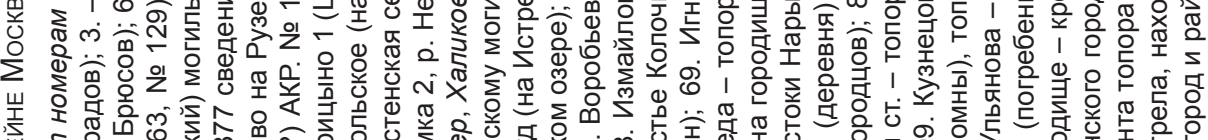

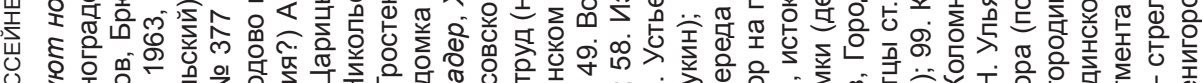

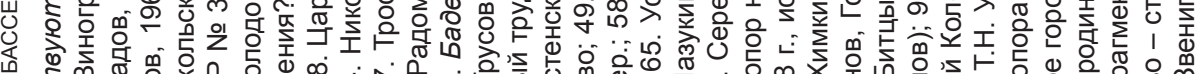


क ह





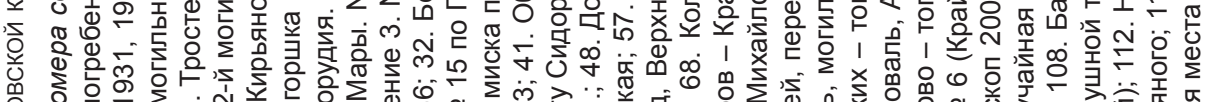





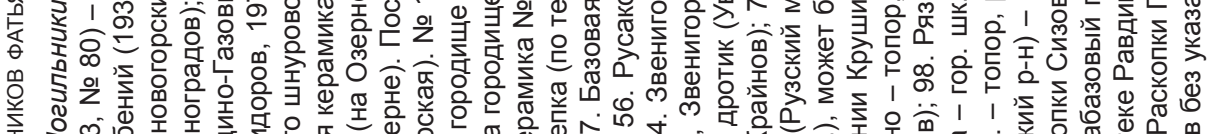

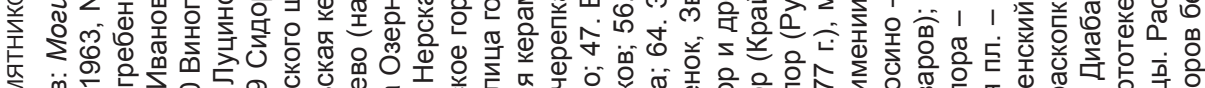



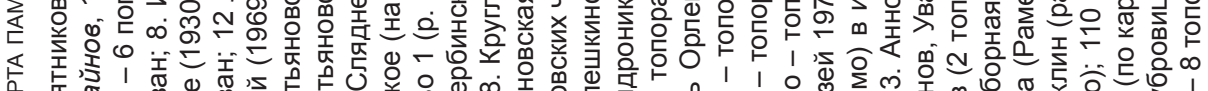

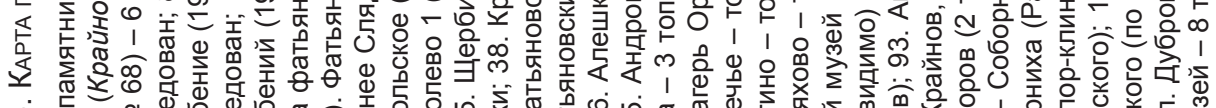



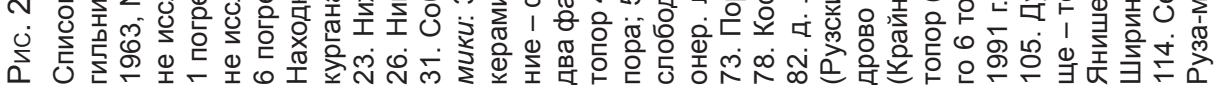



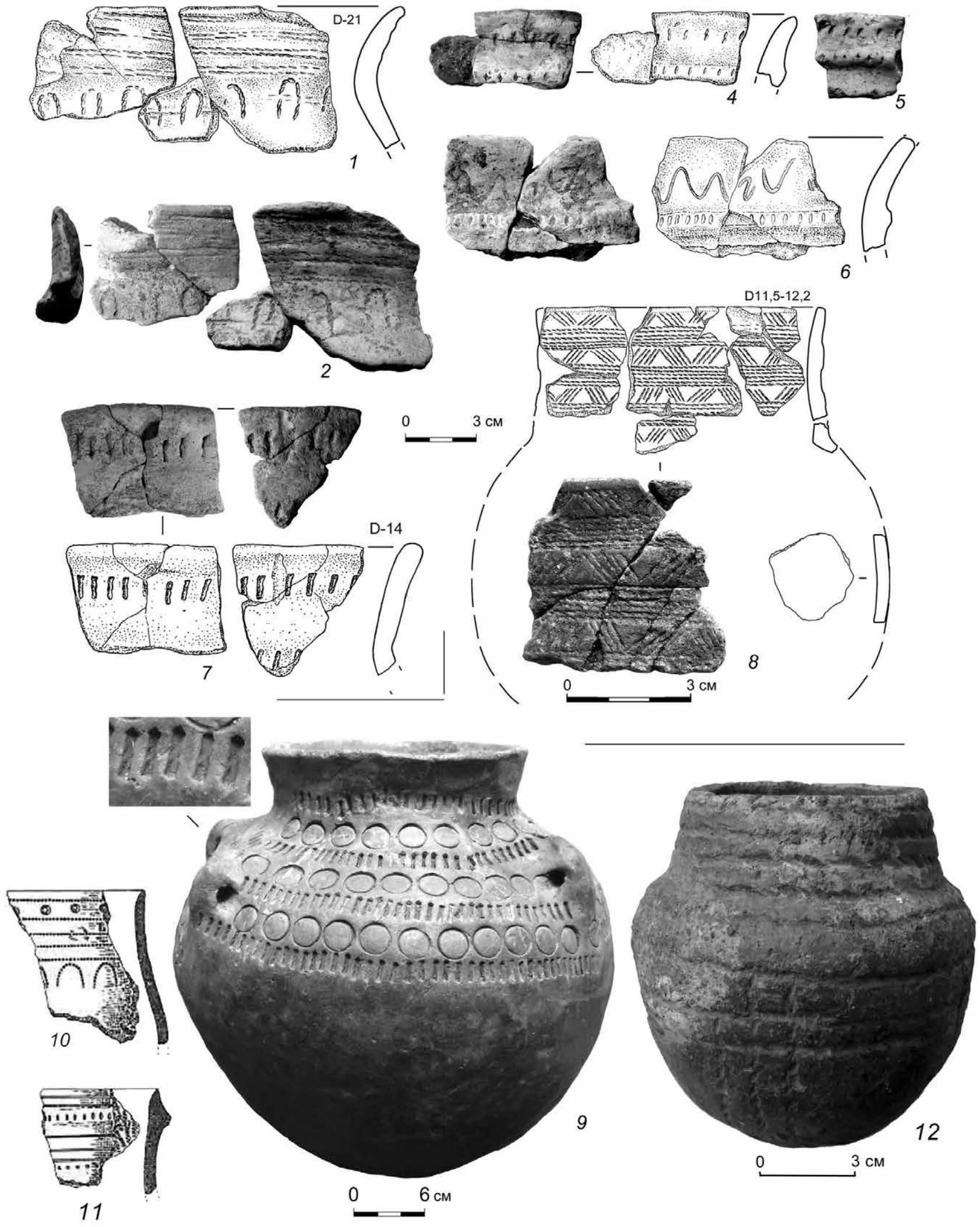

РИС. 26. КЕРАМИКА «ПРОТОФАТЬЯНОВСКОГО» ЭТАПА СО СТОЯНКИ ЗБС-5 (1-8) И АНАЛОГИИ ЕЙ ИЗ МОГИЛЬНИКА КУЛЬТУРЫ ШАРОВИДНЫХ АМФОР ТУРИНЩИНА (9) И СТОЯНКИ НИДА $(10,11)$; ГОРШОК ИЗ УРОЧИЩА БАРСКИЙ САД (РАМЕНСКИЙ МУЗЕЙ) - 12 


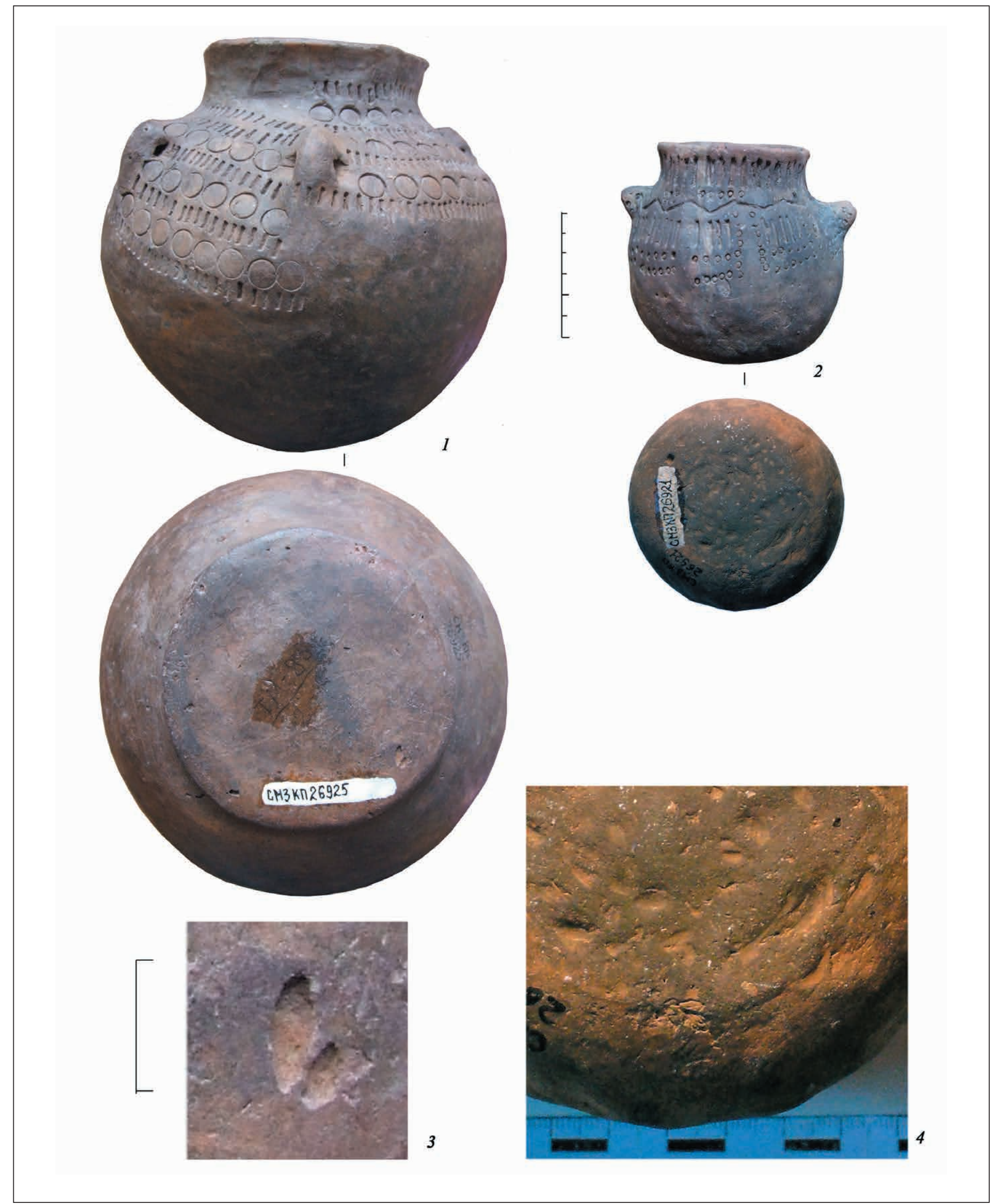

РИС. 27. ОТПЕЧАТКИ ЗЕРЕН КУЛЬТУРНЫХ ЗЛАКОВ НА ДНИЩАХ ГОРШКОВ КУЛЬТУРЫ ШАРОВИДНЫХ АМФОР ИЗ ТУРИНЩИНЫ (РАСКОПКИ Е.А. ШМИДТА, СмОЛЕНСКИЙ МУЗЕЙ) 


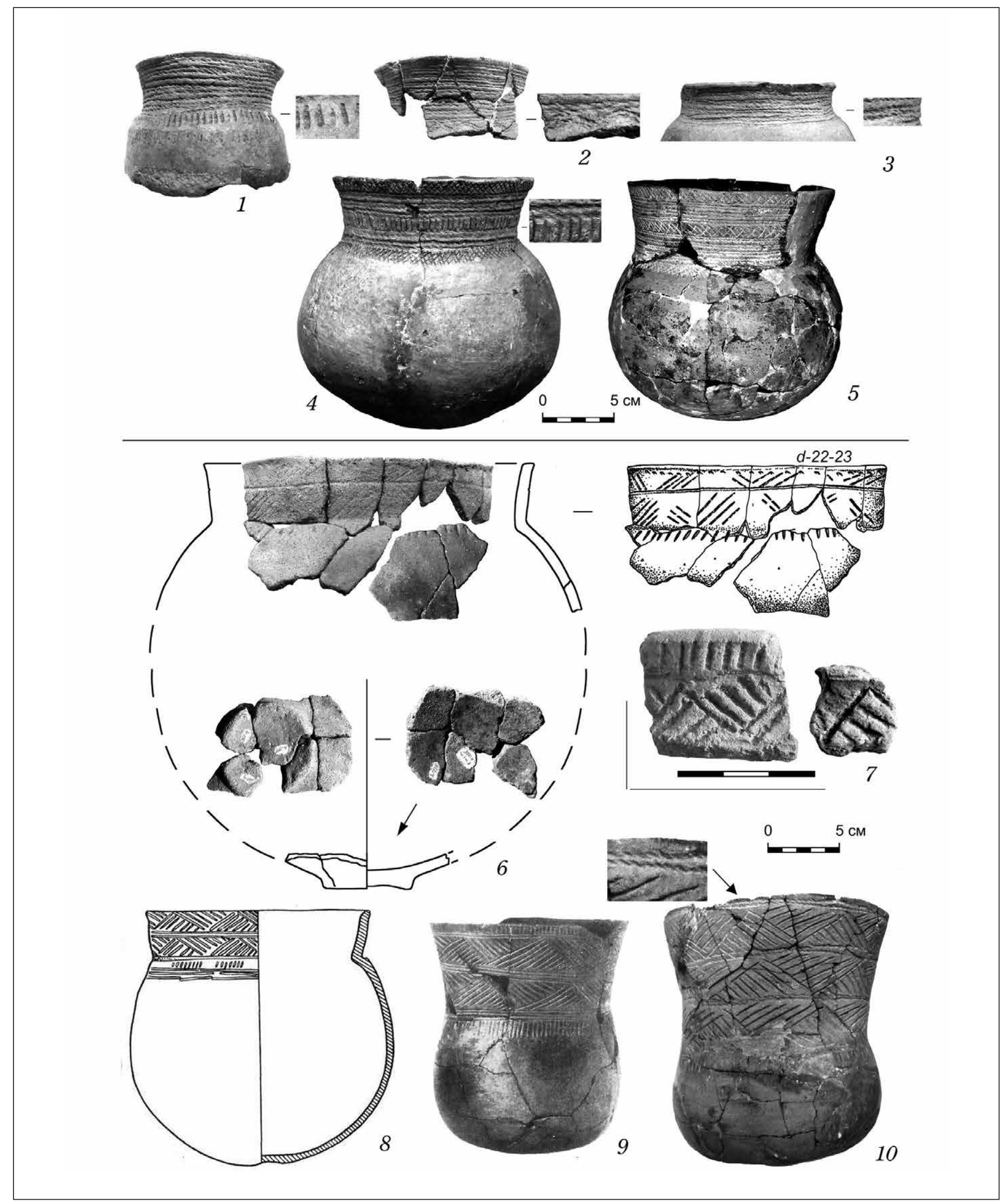

РИС. 28. ГОРШКИ РАННЕФАТЬЯНОВСКОГО ЭТАПА (ВВЕРХУ)

1 - Икшинский, 2 - Давыдковский, 3, 4 - Кузьминский, 5-Ханево; керамика развитого этапа фатьяновской культуры аналогичная среднеднепровской культуре (внизу): 6 - ЗБС-4, 7 - РАНИС, 8 - Ханево; среднедепровские могильники Срелица (9) и Белынец (10) 


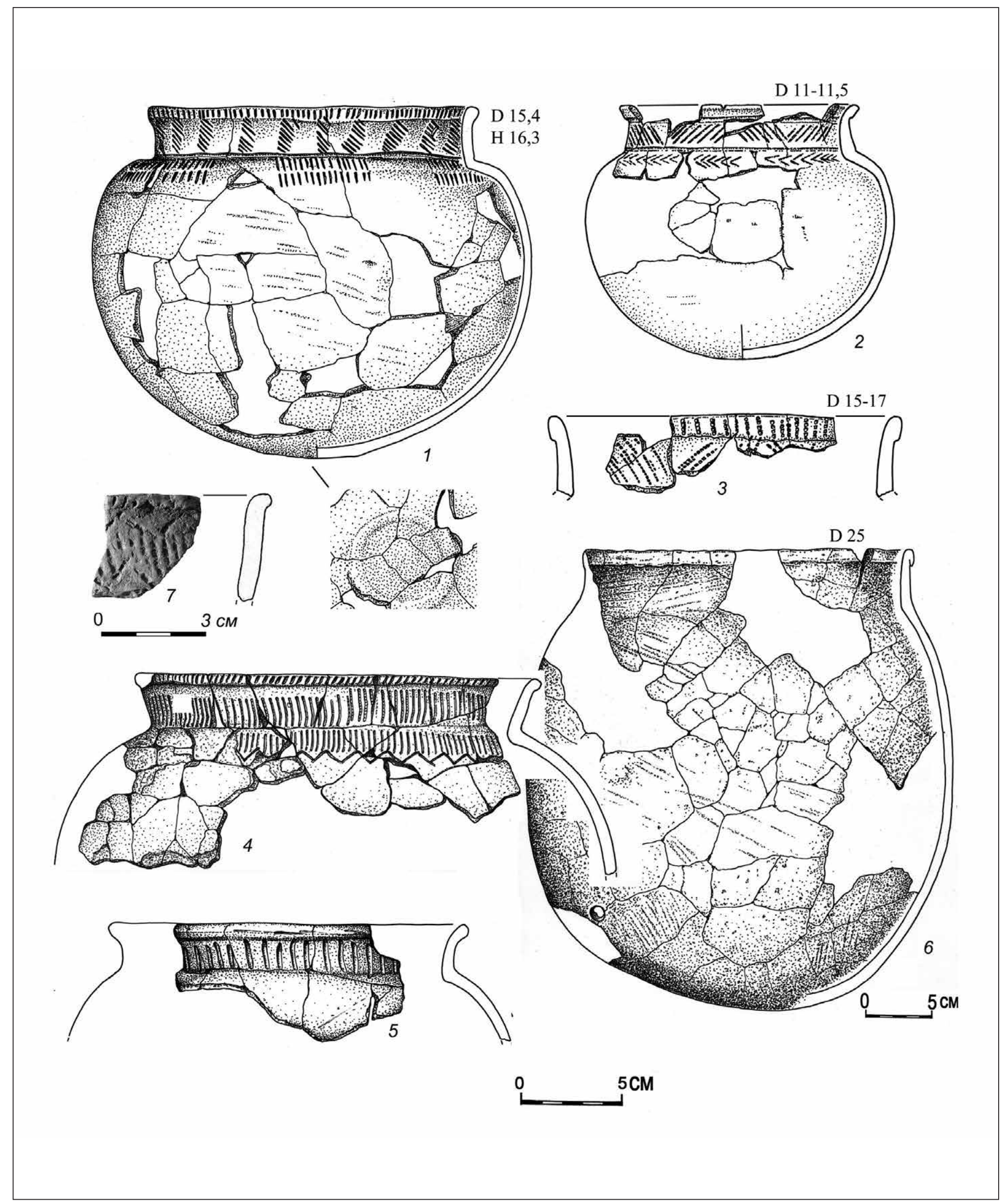

РИС. 29. ФАТЬЯНОВСКИЕ ГОРШКИ РАЗВИТОГО ЭТАПА КУЛЬТУРЫ. РЕСТАВРАЦИЯ И РИСУНОК В.А. РАЕВОЙ 1-3 - Луцино-Газовик; 4-7 - РАНИС 


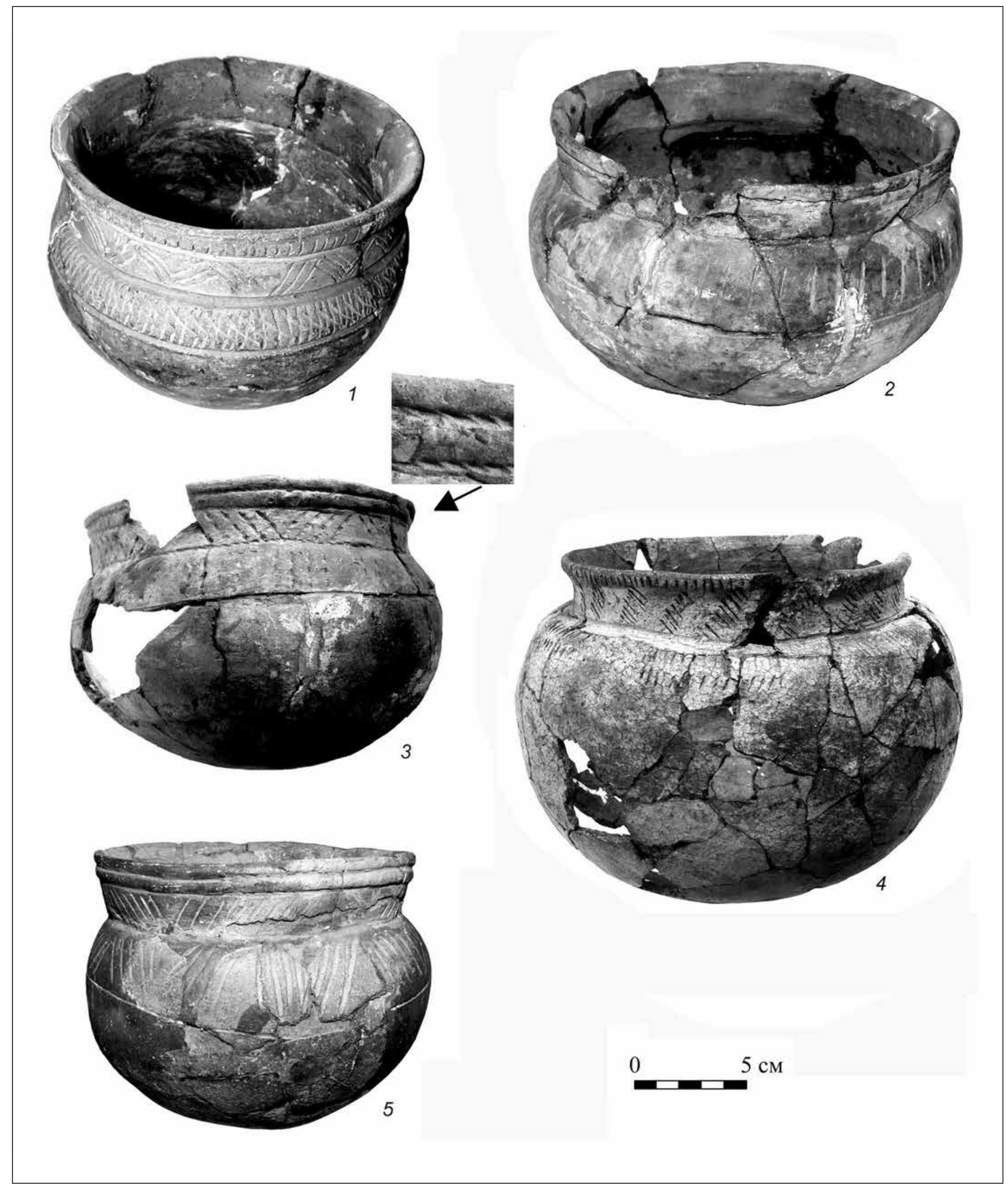

РИС. 30. ГОРШКИ РАЗВИТОГО (4) И ПОЗДНЕГО (1-3, 5-8) ЭТАПОВ ФАТЬЯНОВСКОЙ КУЛЬТУРЫ В ПОДМОСКОВЬЕ

Могильники: Истринский, погребение $1(1,2)$; Тростенский, погребение 3; могила 4 (3); Луцино-Газовик, погребение 1 (4); Саурово (5) 


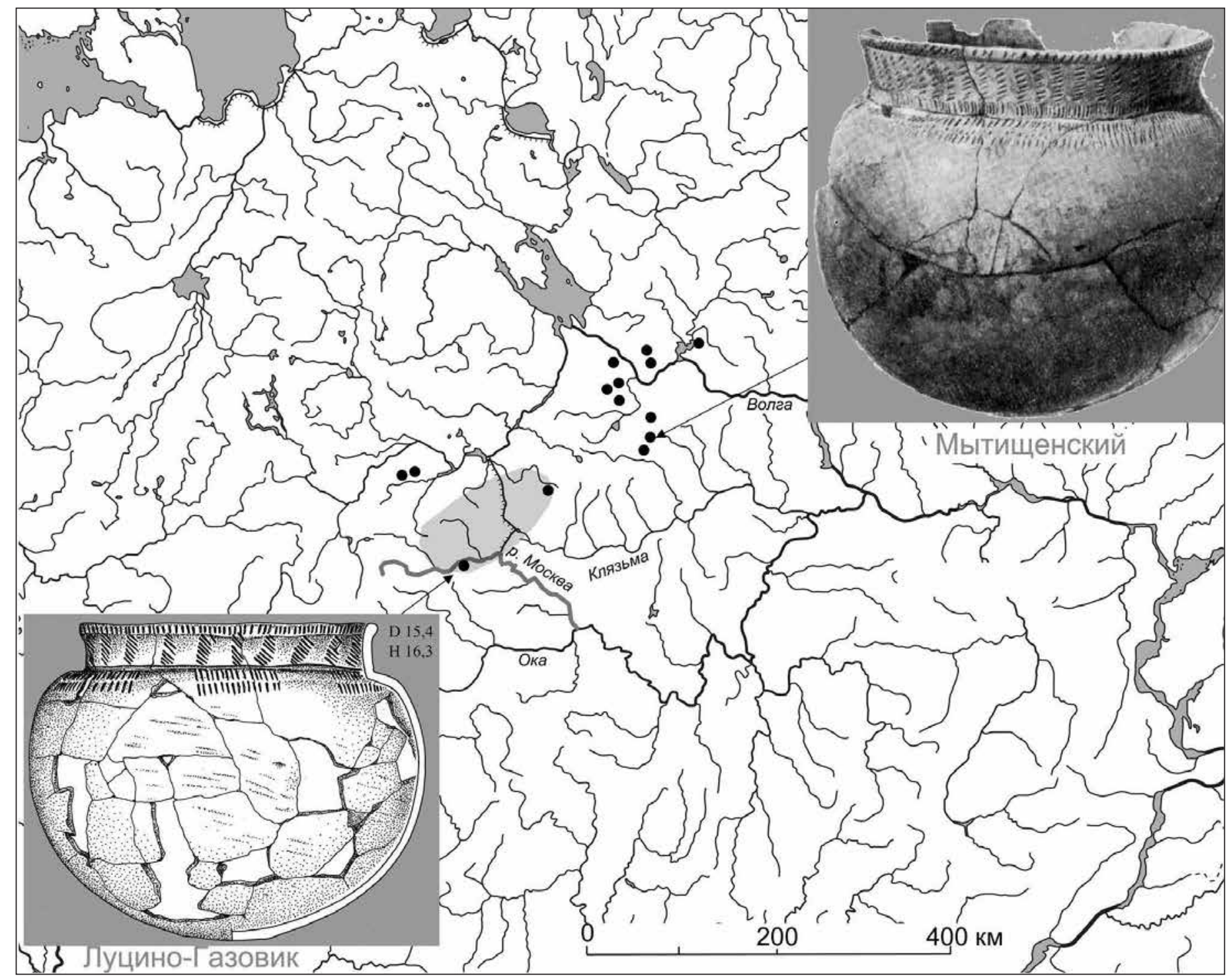

РИС. 31. КАРТА РАСПРОСТРАНЕНИЯ РАННИХ ФАТЬЯНОВСКИХ ПАМЯТНИКОВ В ПОДМОСКОВЬЕ (СЕРЫЙ АРЕОЛ) И КАРТА РАСПРОСТРАНЕНИЯ ОРНАМЕНТА № 31 (ПО: ГАДЗЯЦКАЯ, 1976) НА ГОРШКАХ ПОЗДНЕГО ЭТАПА ФАТЬЯНОВСКОЙ КУЛЬТУРЫ 


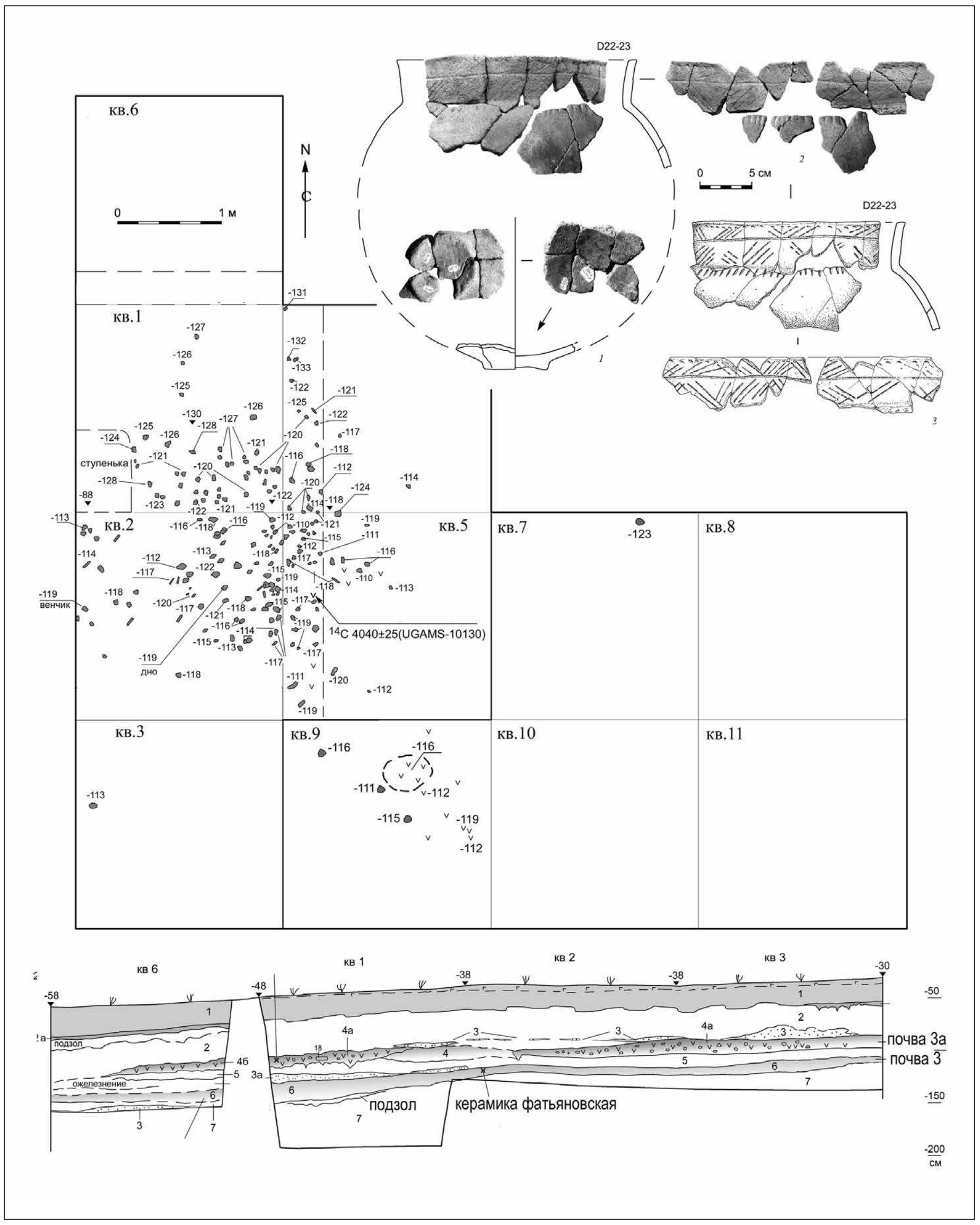

РИС. 32. ПЛАН РАСКОПА НА ОБЪЕКТЕ ЗБС-4 НА УРОВНЕ ПОГРЕБЕННОЙ ПОЧВЫ 3 С РАЗВАЛОМ ФАТЬЯНОВСКОГО ГОРШКА 




РИС. 33. ПЛАН РАСКОПА НА ОБЪЕКТЕ ЗБС-4 НА УРОВНЕ ПОГРЕБЕННОЙ ПОЧВЫ ЗА С РАЗВАЛОМ КАМНЕЙ И НАХОДКОЙ ВЕНЧИКА АБАШЕВСКОГО ГОРШКА 

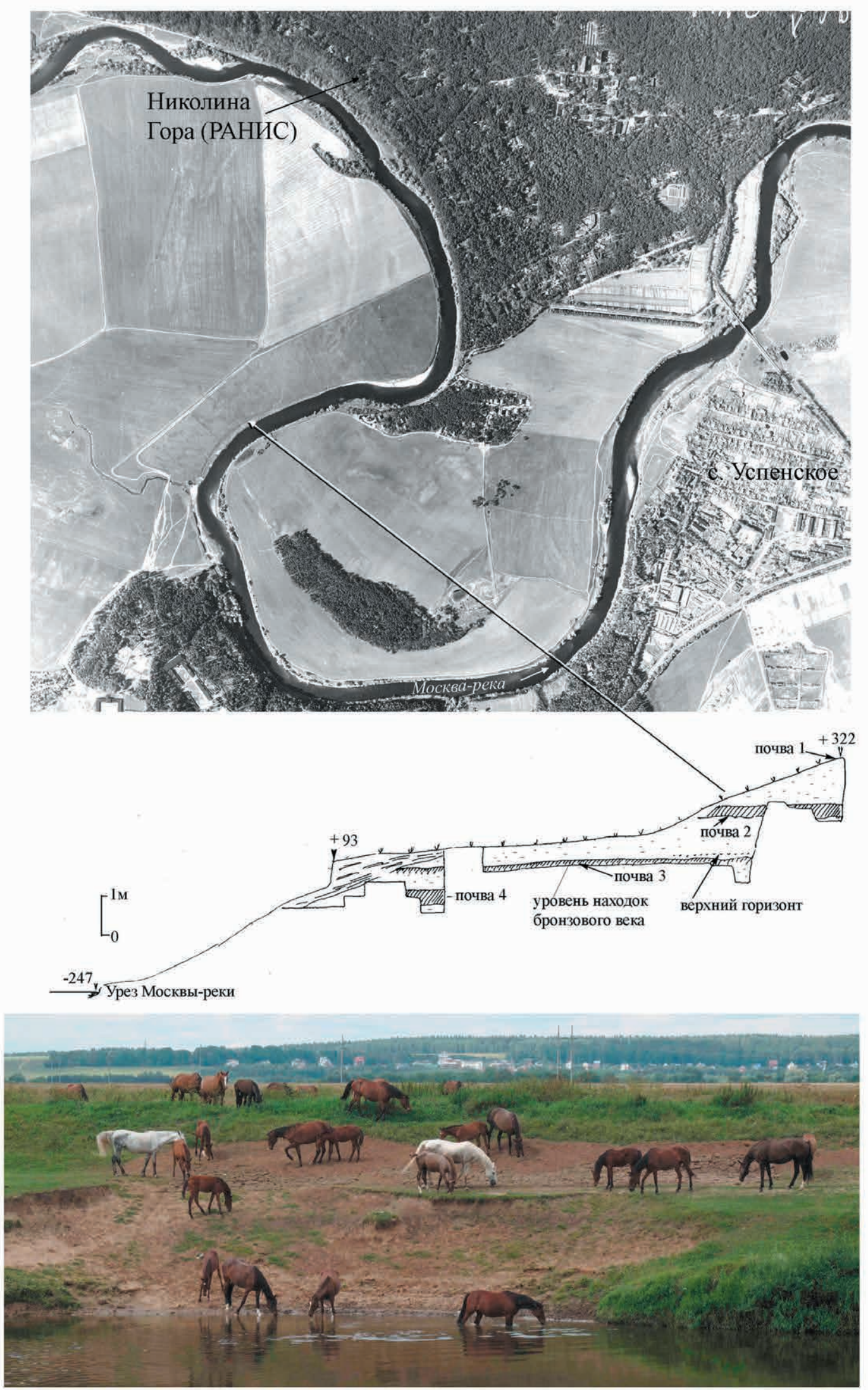

РИС. 34. РАЗРЕЗ ПОЙМЕННЫХ ОТЛОЖЕНИЙ И ВИД НА ПОСЕЛЕНИЕ ФАТЬЯНОВСКОЙ КУЛЬТУРЫ РАНИС-ПОЙМА. АЭРОФОТОСЪЕМКА 

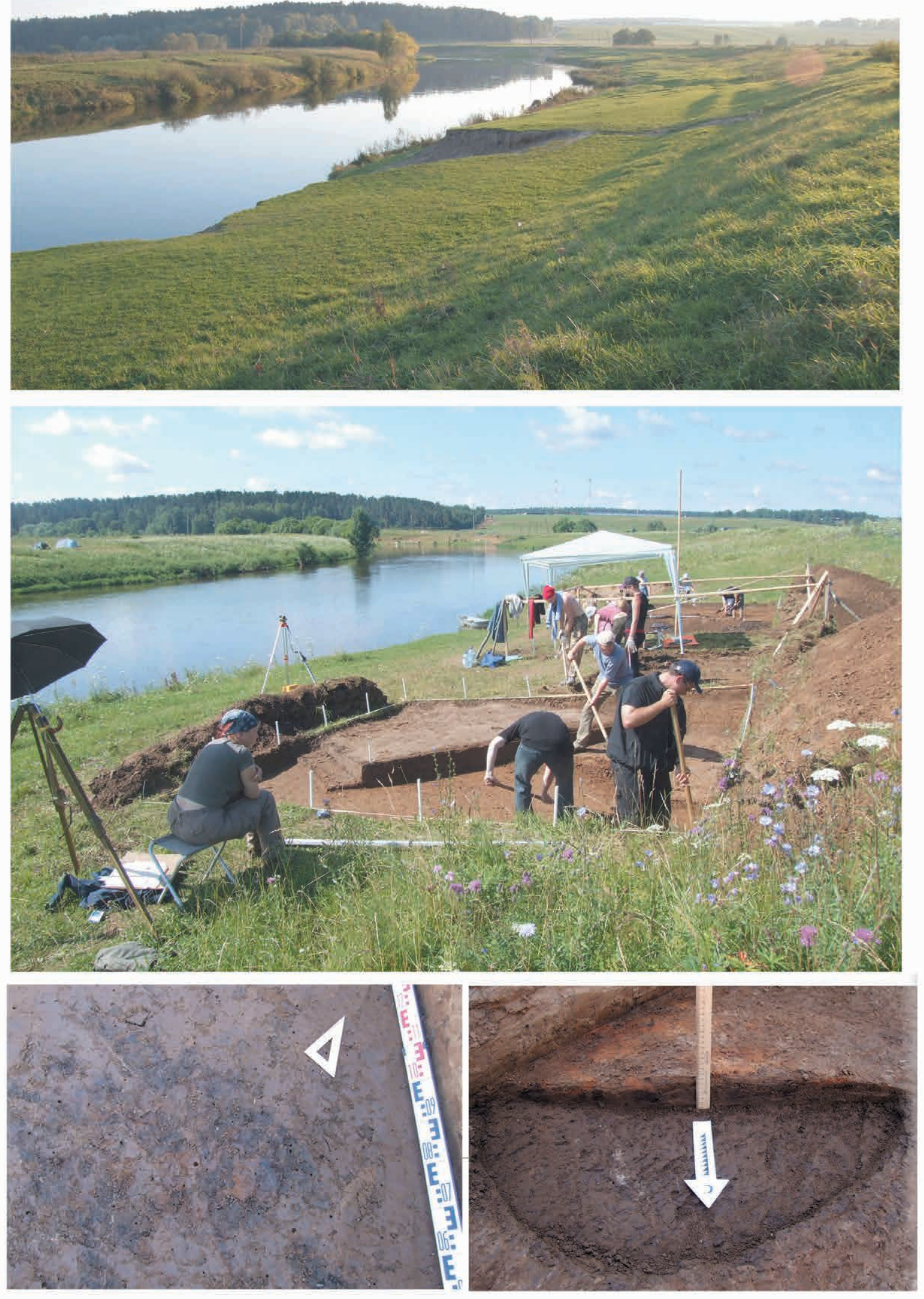

РИС. 35. ПОСЕЛЕНИЕ РАНИС-ПОЙМА ДО И ВО ВРЕМЯ РАСКОПОК. ВНИЗУ - ПЯТНО ОЧАГА 


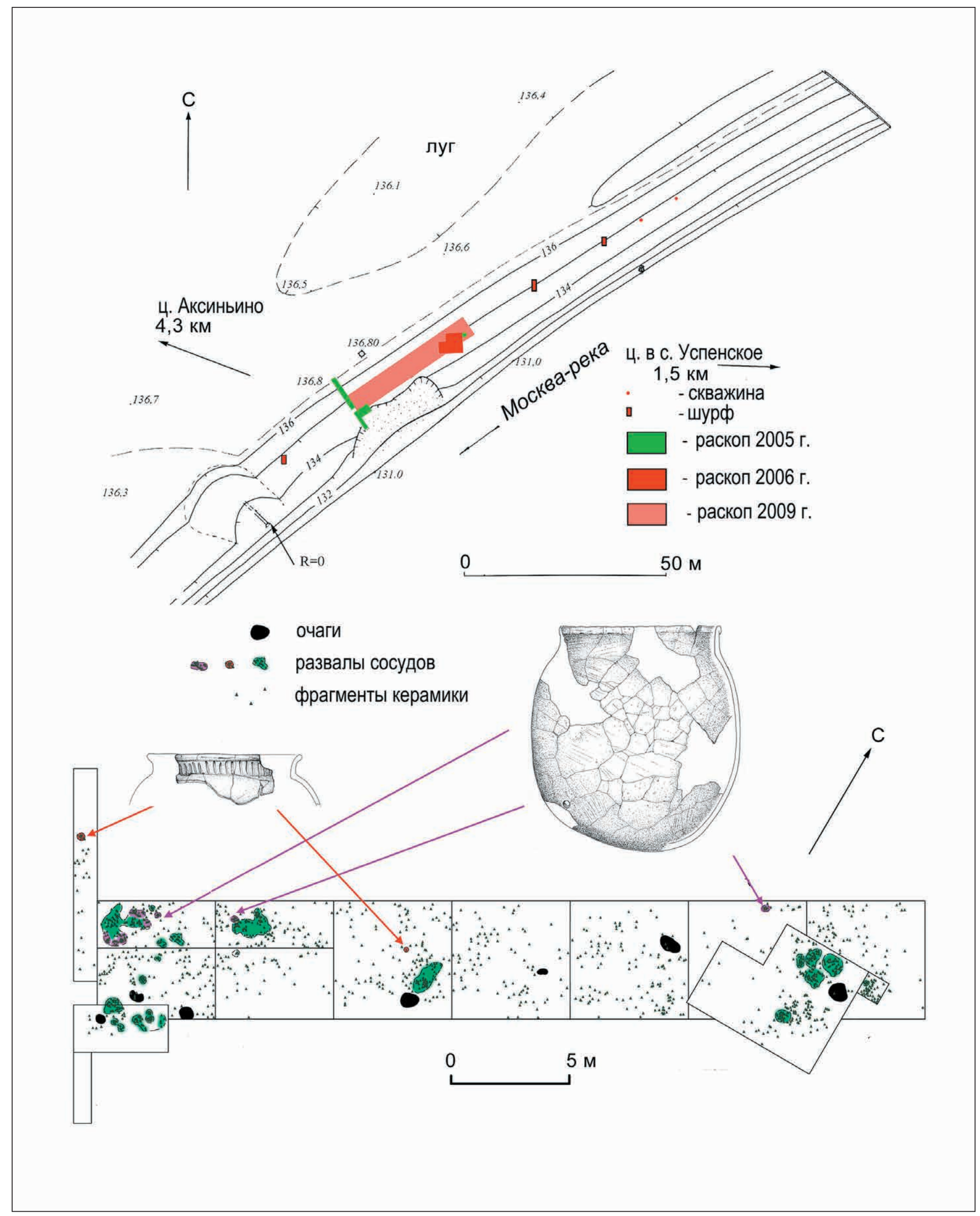

РИС. 36. ПЛАН ПОСЕЛЕНИЯ РАНИС-ПОЙМА С РАСКОПАМИ 2005, 2006 И 2009 ГГ.; ПЛАН РАСКОПА СО СКОПЛЕНИЯМИ КЕРАМИКИ 


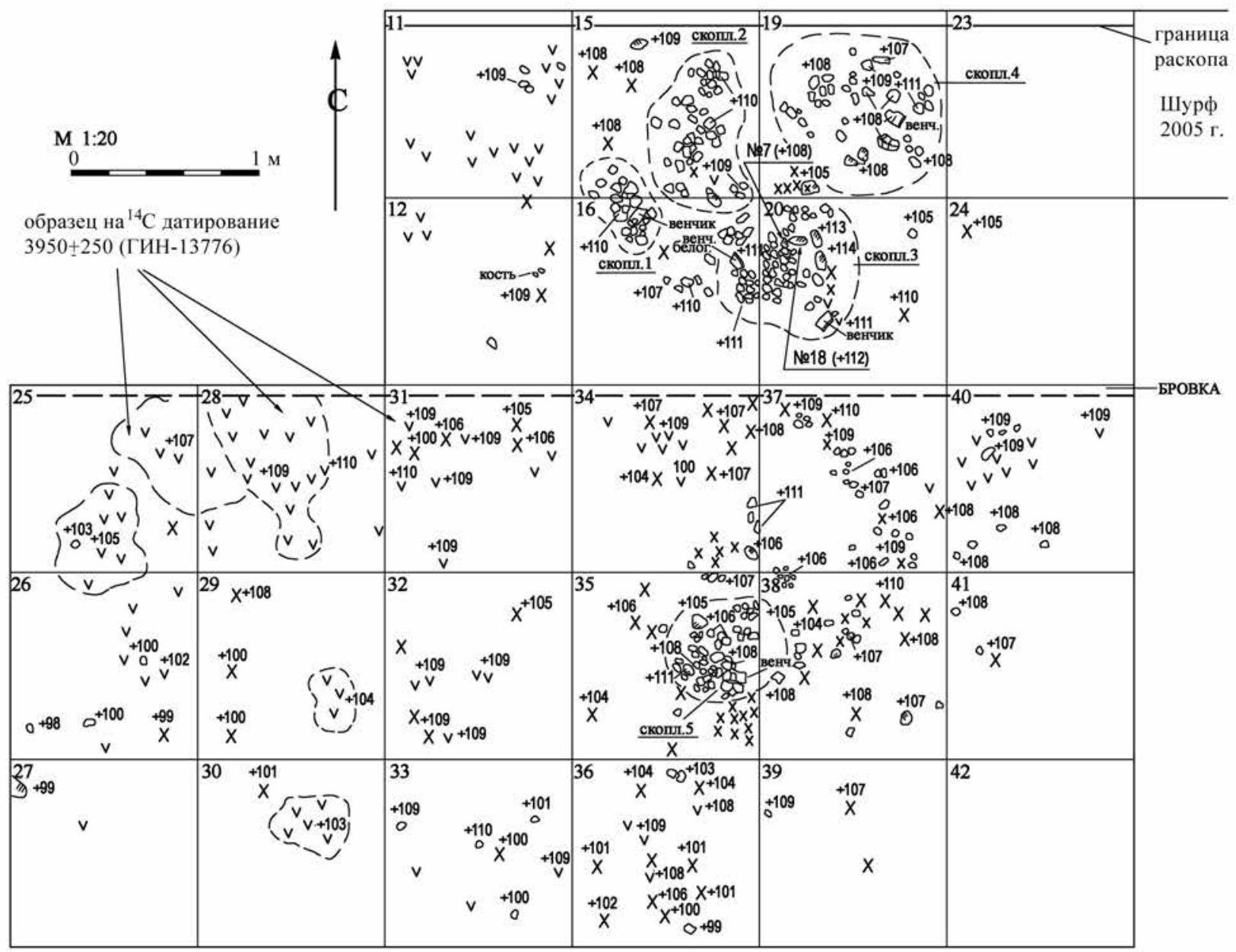

Северный борт (бровка)

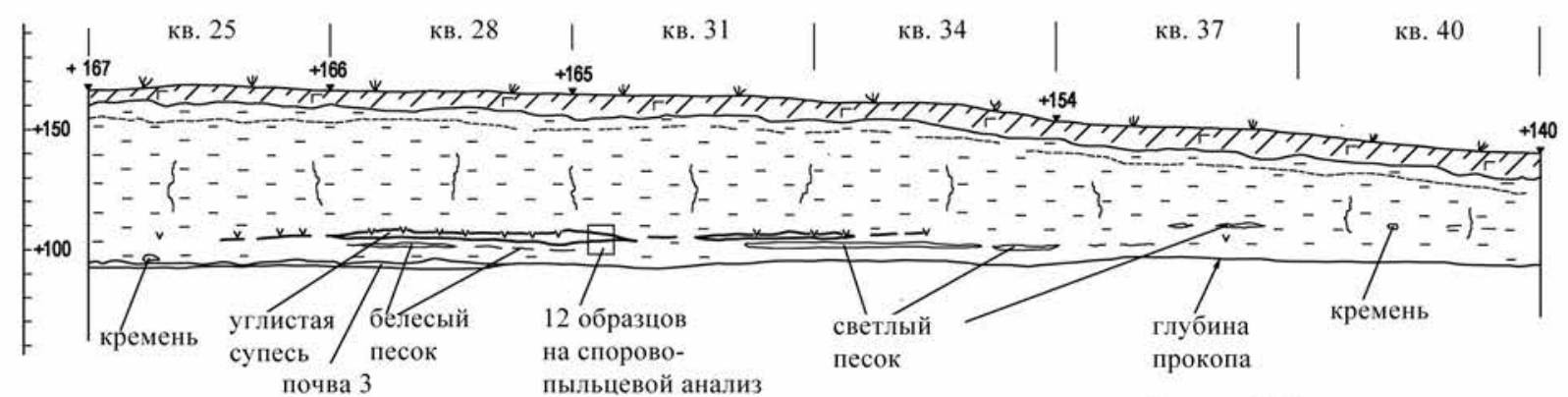

Южный борт

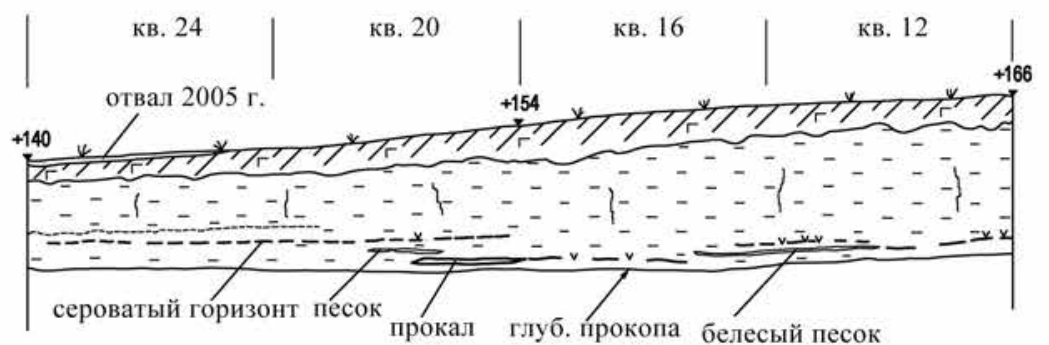

Западный борт

Кв. $12 \quad$ кв. $11 \quad \mid$

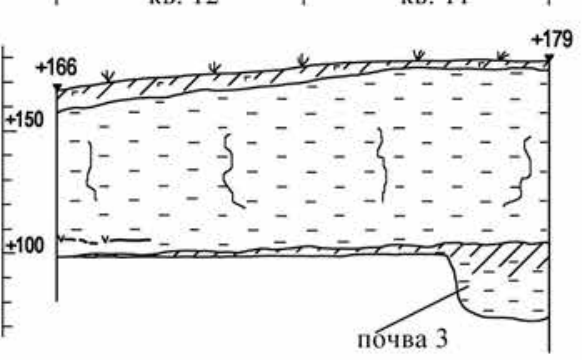

РИС. 37. ПОСЕЛЕНИЕ РАНИС-ПОЙМА. ПЛАН РАСКОПА 2006 Г. ПО УРОВНЮ ОСНОВНОГО ГОРИЗОНТА НАХОДОК 


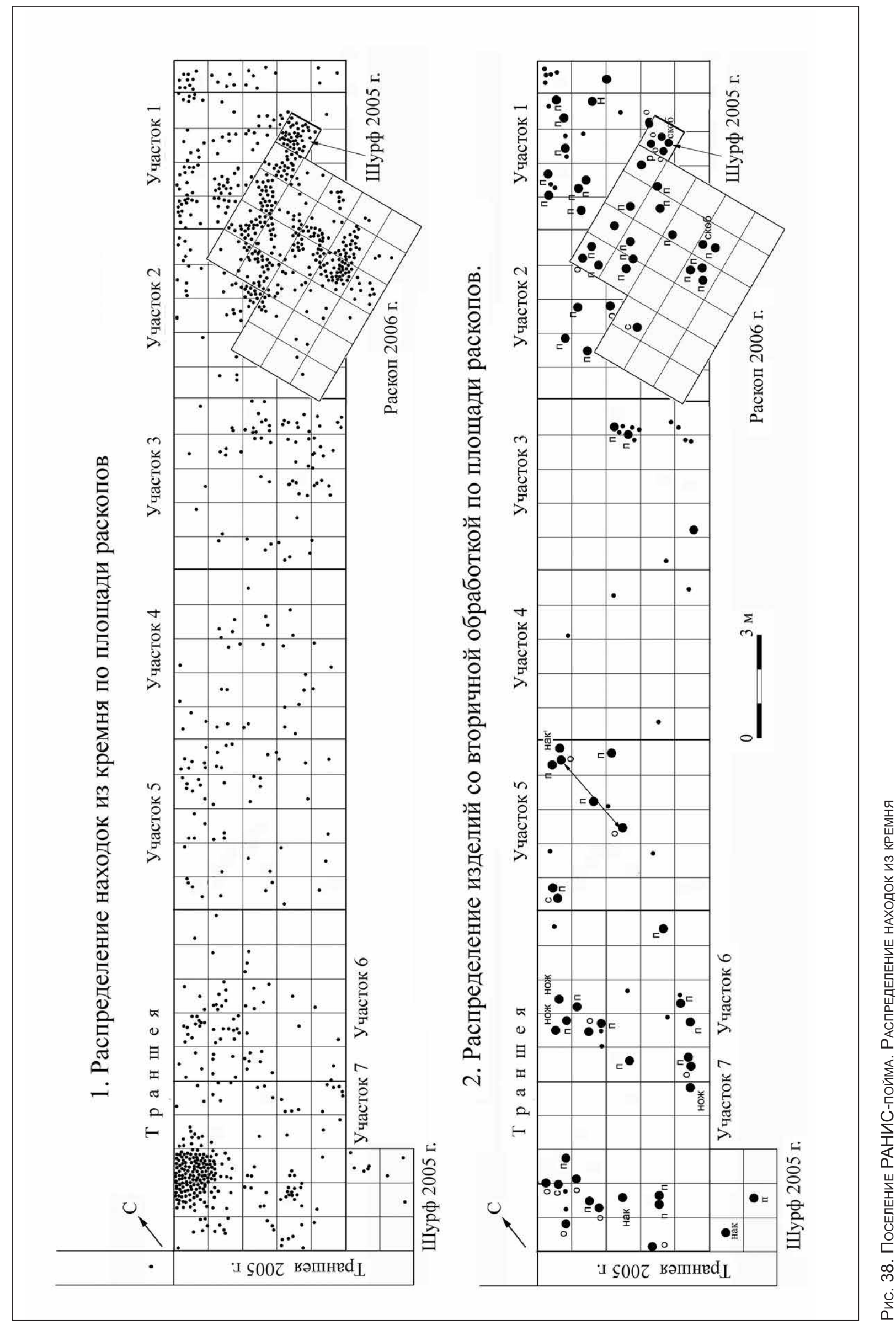




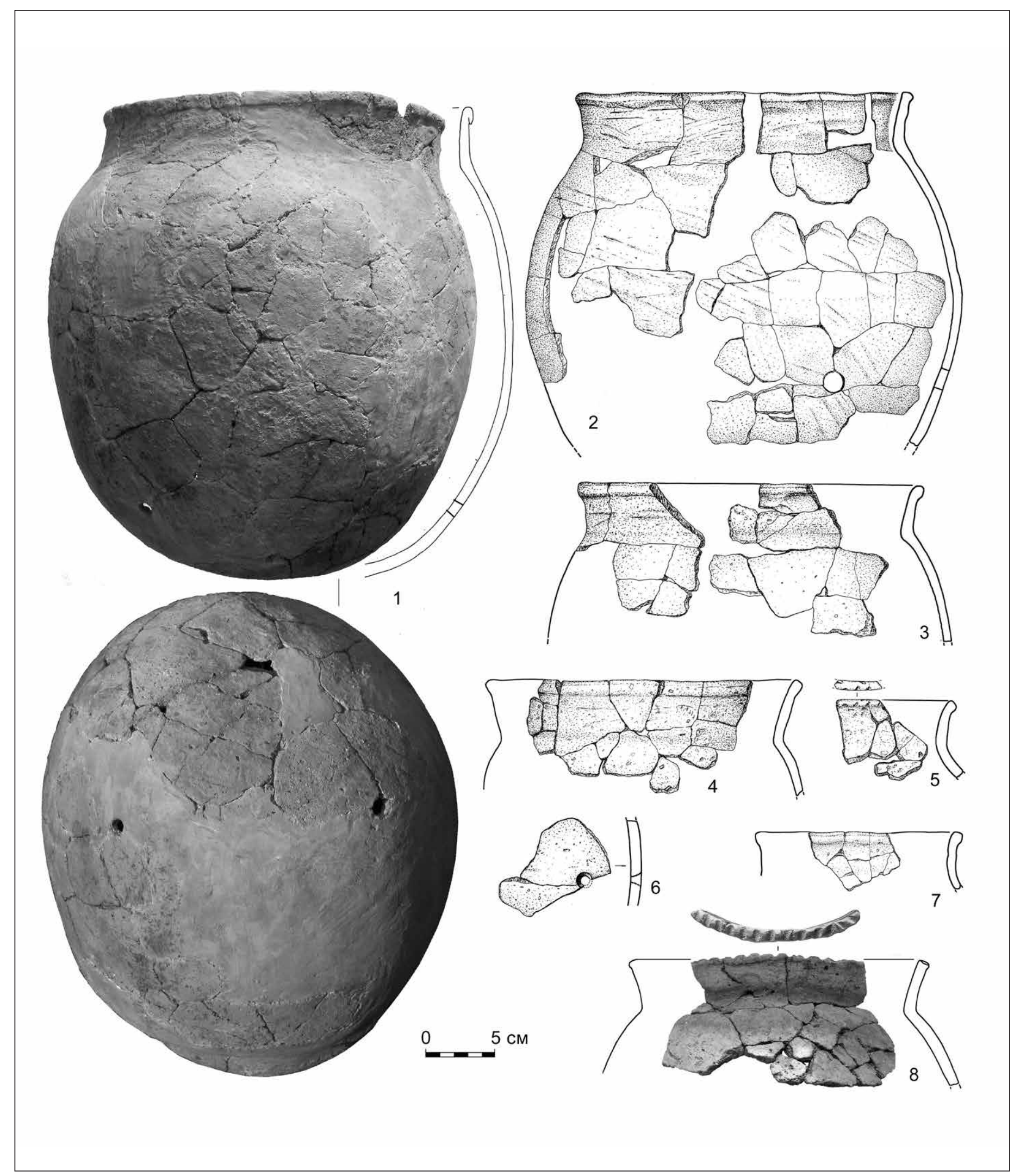

РИС. 39. ГОРШКИ С ОТВЕРСТИЯМИ ДЛЯ ХРАНЕНИЯ МОЛОЧНЫХ ПРОДУКТОВ ИЗ РАСКОПОК ПОСЕЛЕНИЯ РАНИС-ПОЙМА 


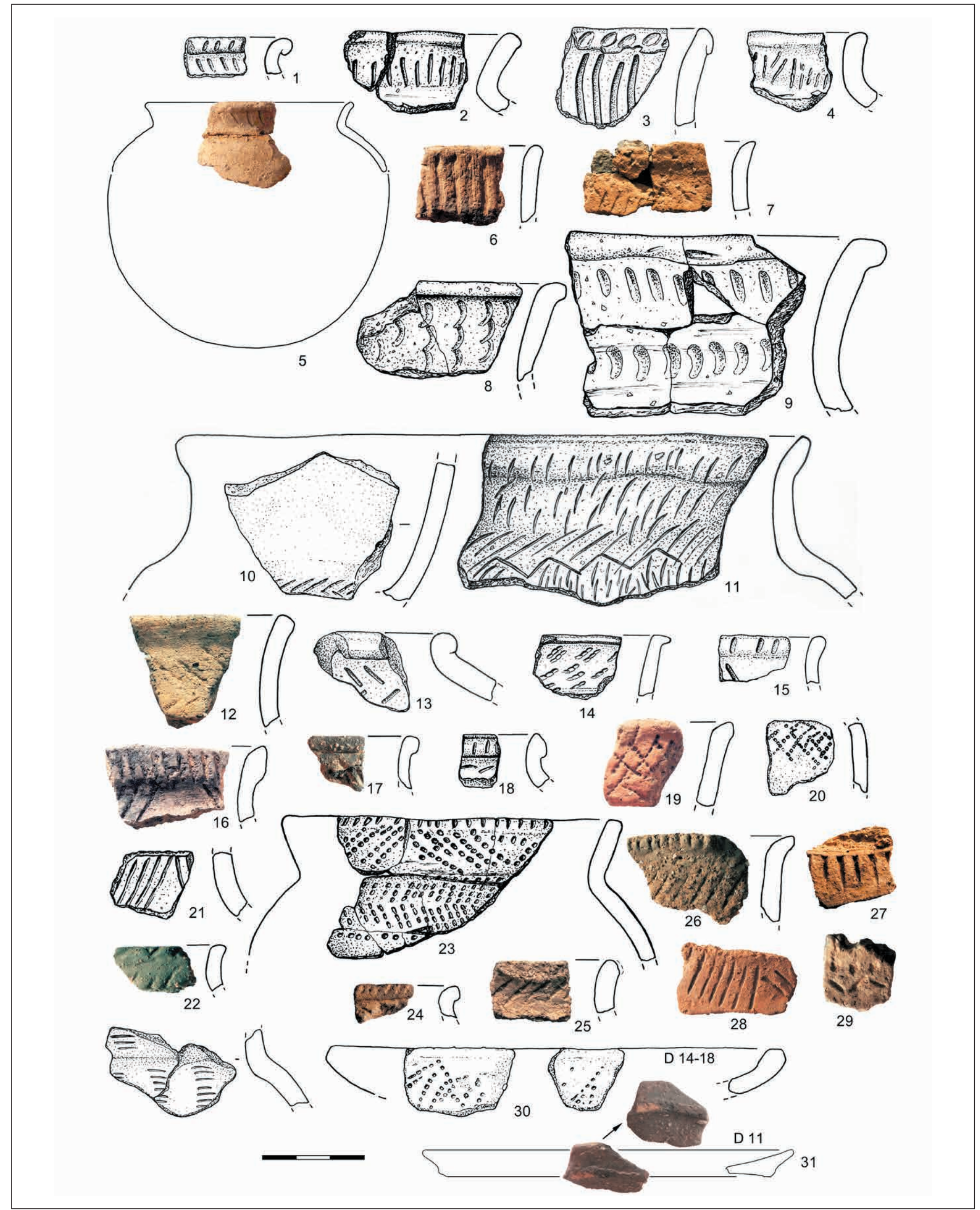

РИС. 40. ОРНАМЕНТИРОВАННАЯ КЕРАМИКА ИЗ РАСКОПОК ПОСЕЛЕНИЯ РАНИС-ПОЙМА.

Рис. В.А. Раевой 


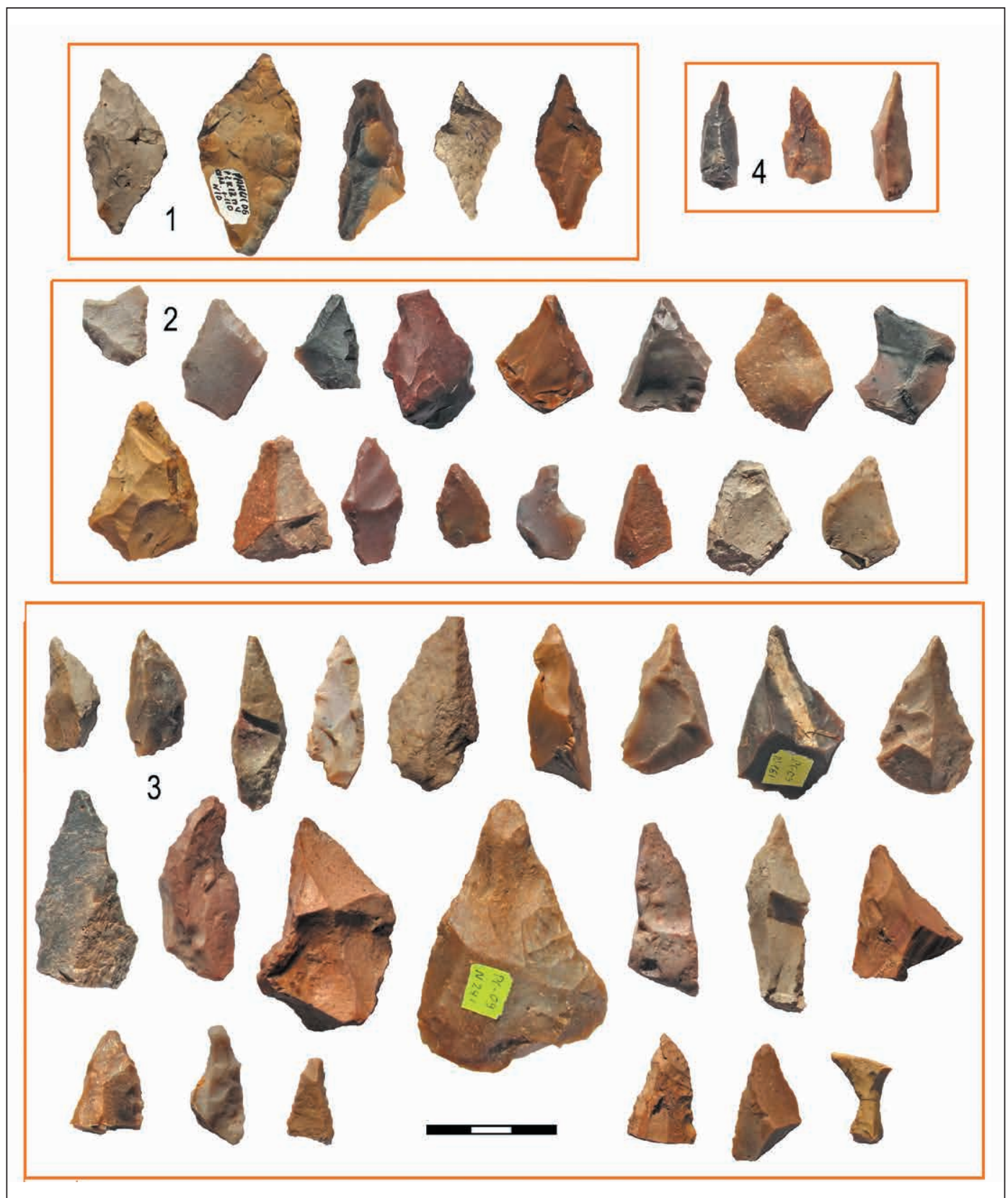

РИС. 41 КРЕМНЕВЫЕ ПРОКОЛКИ И ПЕРФОРАТОРЫ ИЗ РАСКОПОК ПОСЕЛЕНИЯ РАНИС-ПОЙМА

1 - перфораторы двойные; 2 - перфораторы на плоских отщепах; 3 - перфораторы на массивных отщепах и сколах; 4 - острия-проколки на пластинчатых отщепах (по И.Н. Ершову)

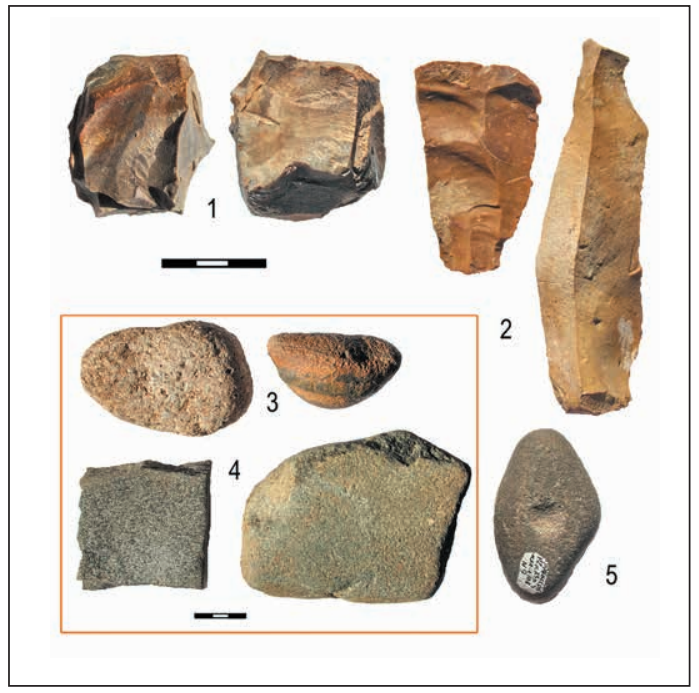

Рис. 42. Нуклеус (1),

ПЛАСТИНЫ (2), ОТБОЙНИКИ

(3), ШЛИФОВАЛЬНЫЕ ПЛИТЫ

(4), «ПОДСТАВКА» С НАЧАТОЙ СВЕРЛИНОЙ (5) ИЗ РАСКОПОК ПОСЕЛЕНИЯ РАНИС-ПОЙМА 


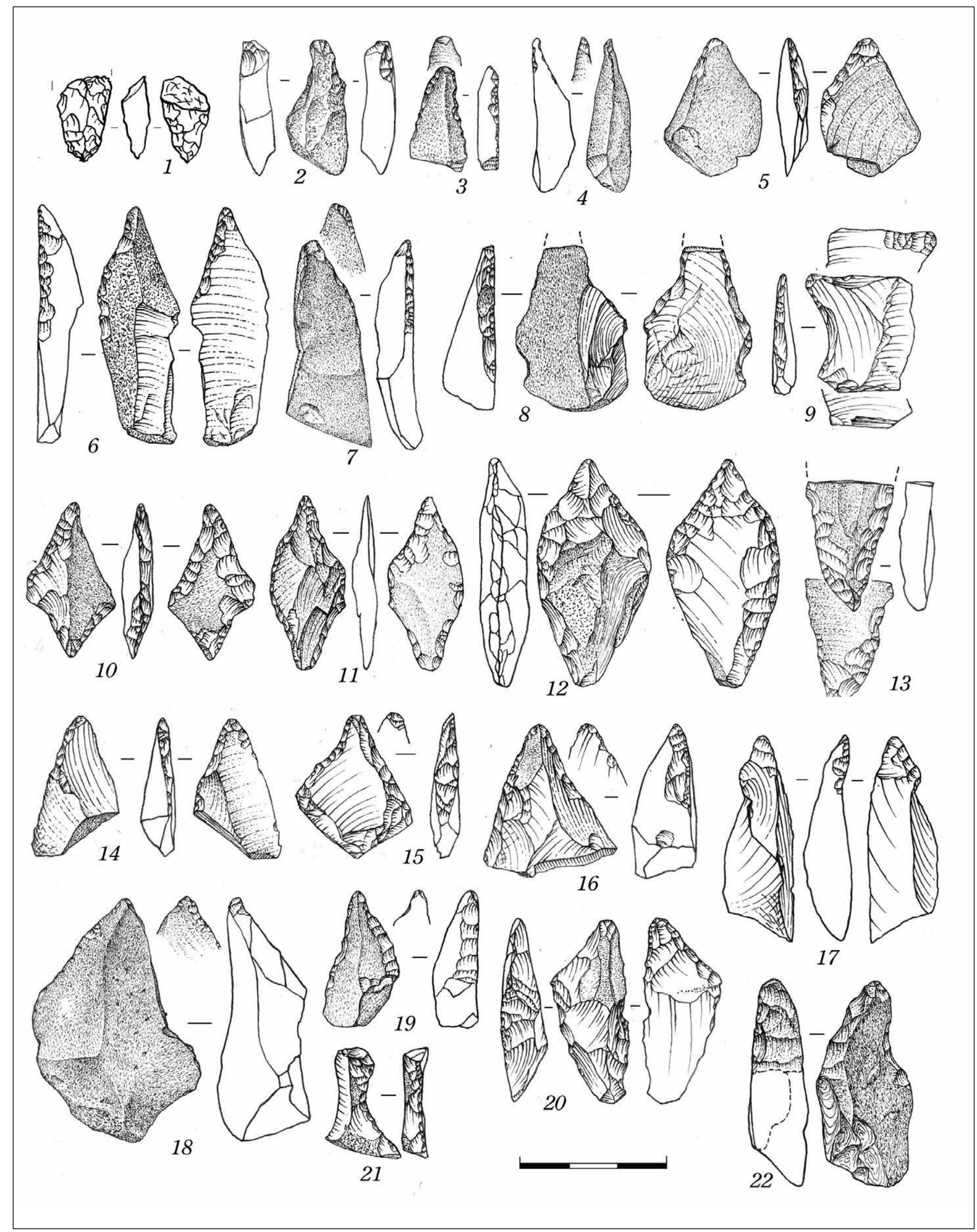

РИС. 43. ЧЕРЕШОК СТРЕЛЫ И ПЕРФОРАТОРЫ ИЗ РАСКОПОК ПОСЕЛЕНИЯ РАНИС-ПОЙМА 


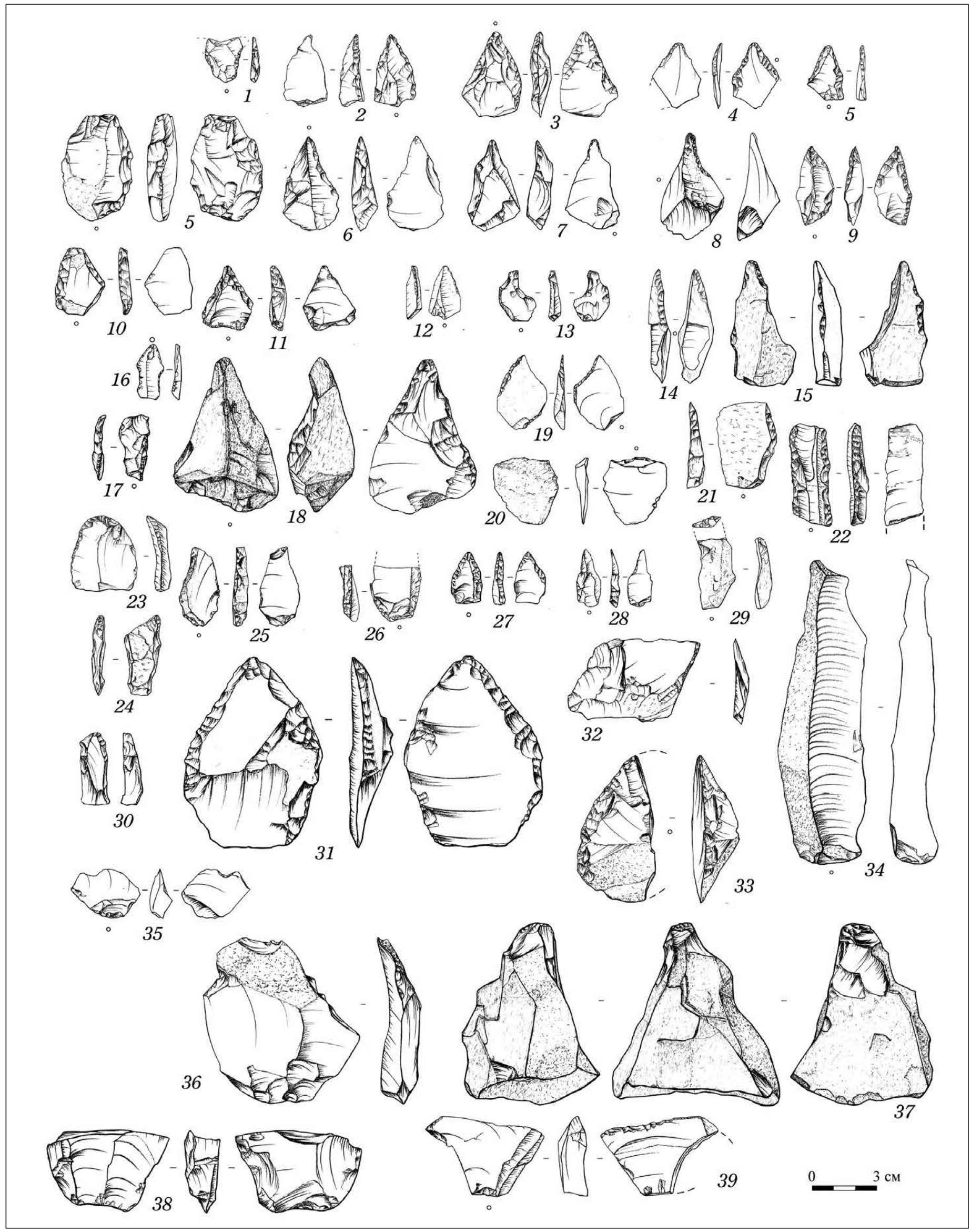

РИС. 44. КРЕМНЕВЫЕ ОРУДИЯ, ОТЩЕПЫ С РЕТУШЬЮ И НУКЛЕВИДНЫЕ ОТЩЕПЫ ИЗ РАСКОПОК ПОСЕЛЕНИЯ РАНИС-ПОЙМА 


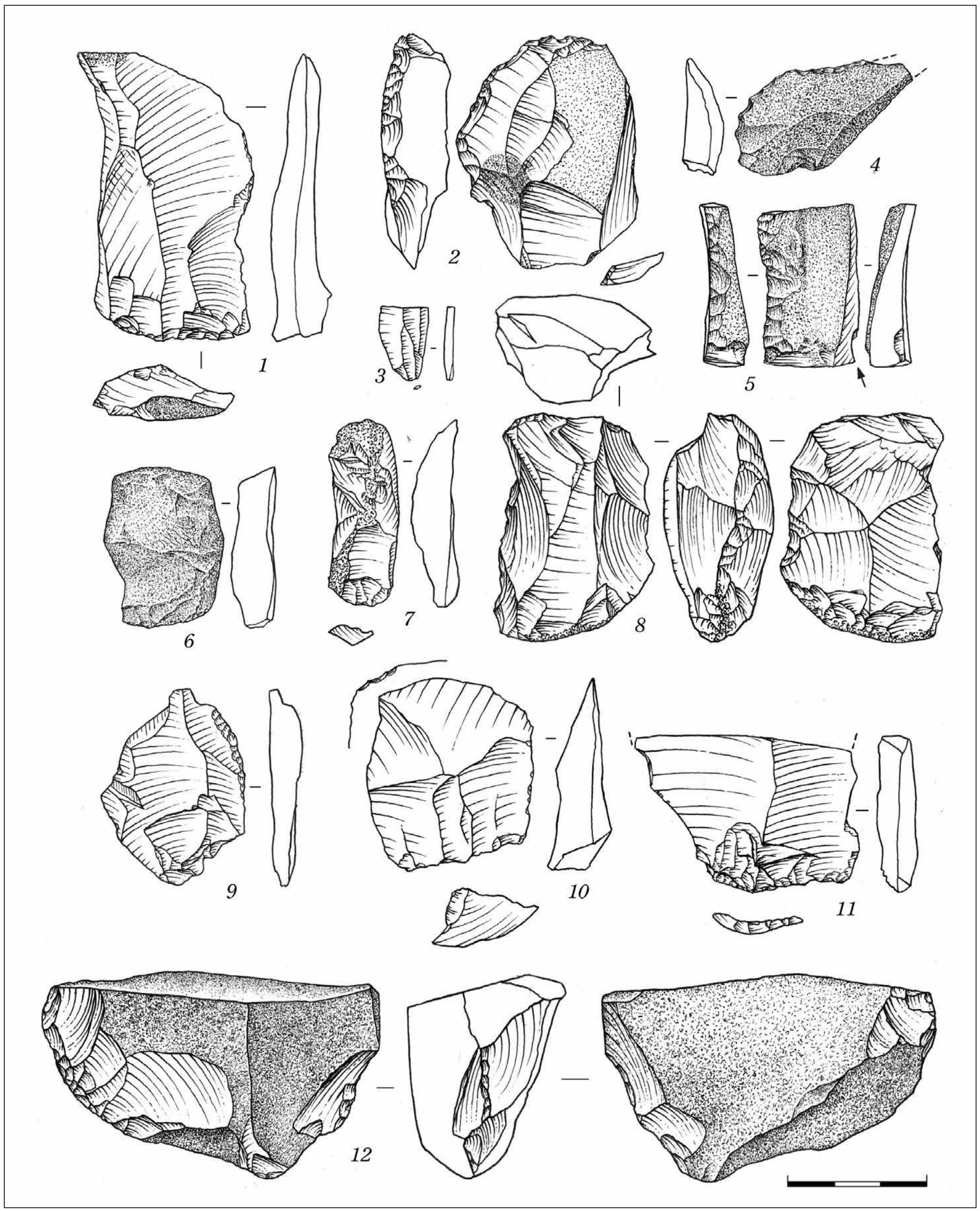

РИС. 45. ОТЩЕПЫ С РЕТУШЬЮ И НУКЛЕУС ИЗ РАСКОПОК ПОСЕЛЕНИЯ РАНИС-ПОЙМА.

Рис. А.Е. Кравцова 


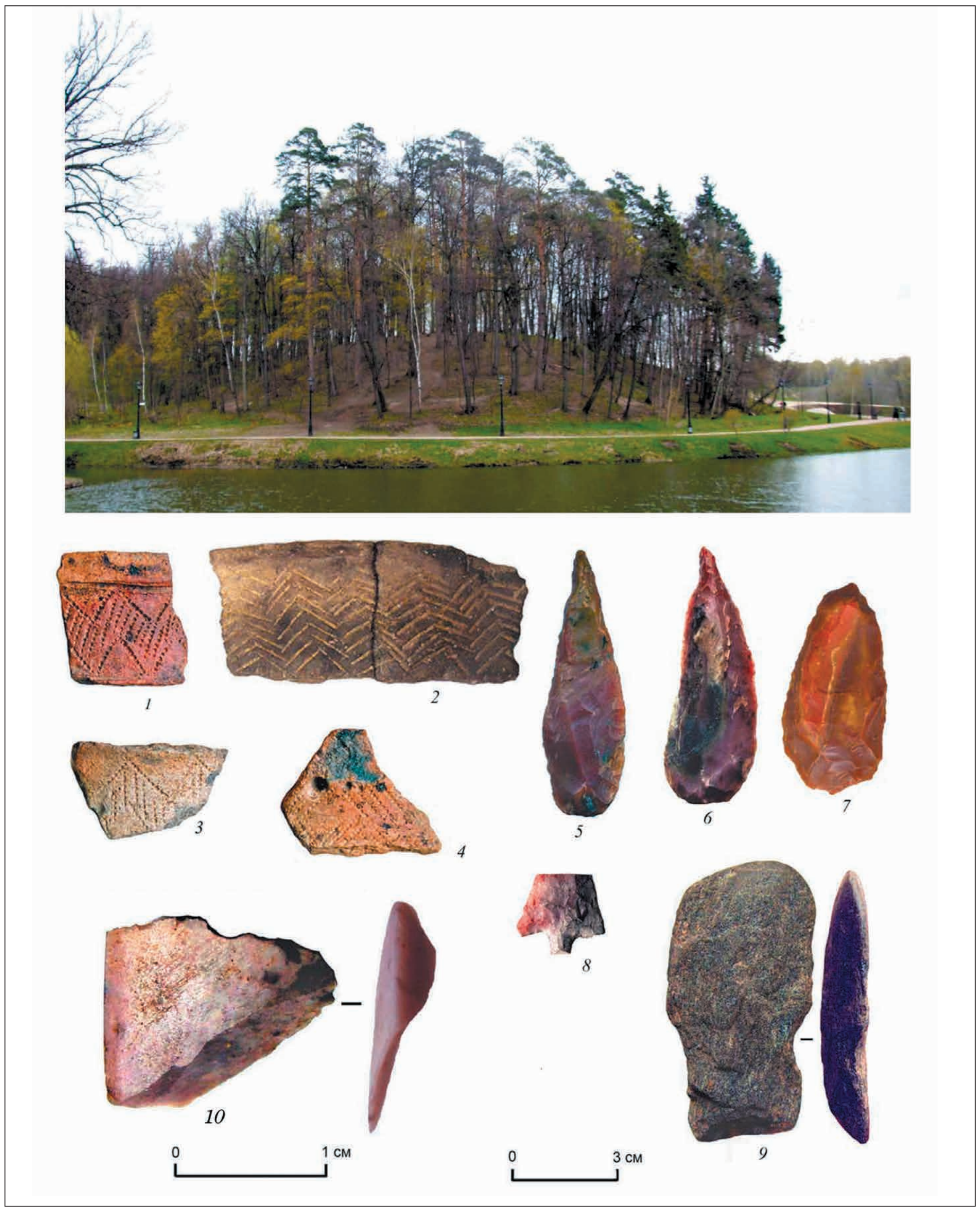

РИС. 46. ВИД НА ПОСЕЛЕНИЕ ЦАРИЦЫНО 1 И ФОТО НАХОДОК ФАТЬЯНОВСКОЙ КУЛЬТУРЫ 


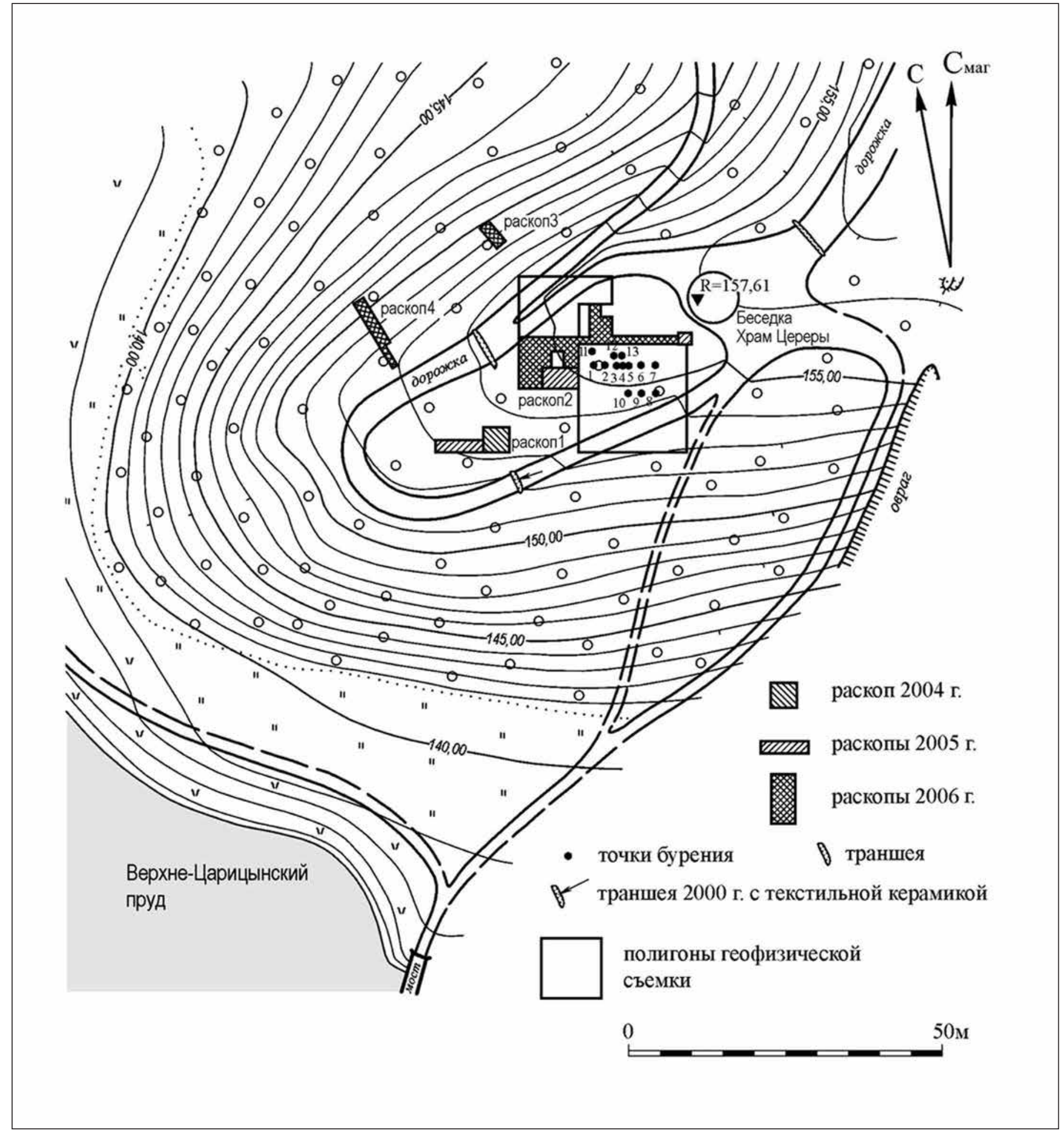

РИС. 47. ТОПОГРАФИЧЕСКИЙ ПЛАН ПОСЕЛЕНИЯ ЦАРИЦЫНО 1 С НАНЕСЕННЫМИ РАСКОПАМИ 


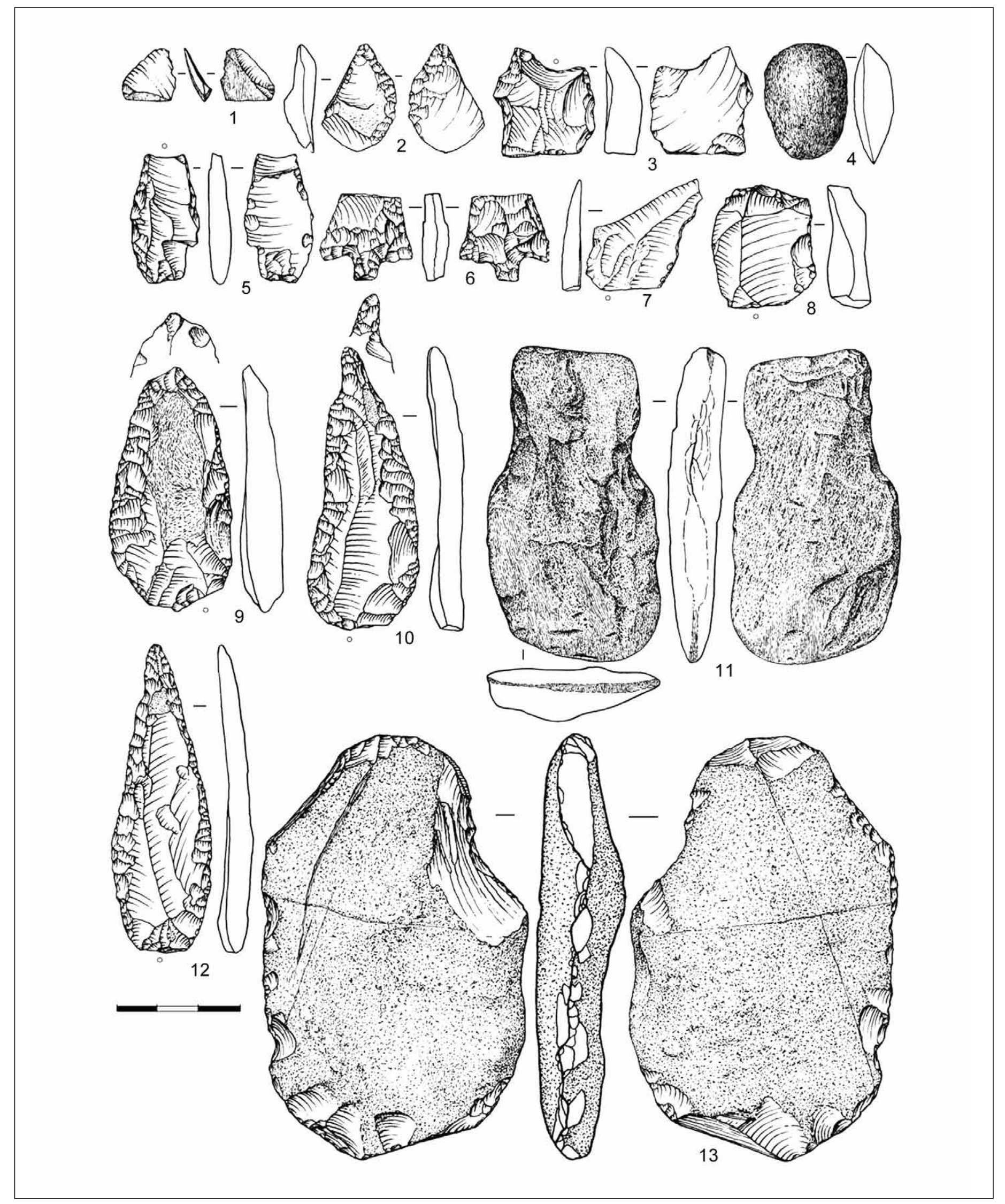

РИС. 48. КОМПЛЕКС КАМЕННЫХ ОРУДИЙ ФАТЬЯНОВСКОЙ КУЛЬТУРЫ С ПОСЕЛЕНИЯ ЦАРИЦЫНО 1.

Рис. А.Е. Кравцова 


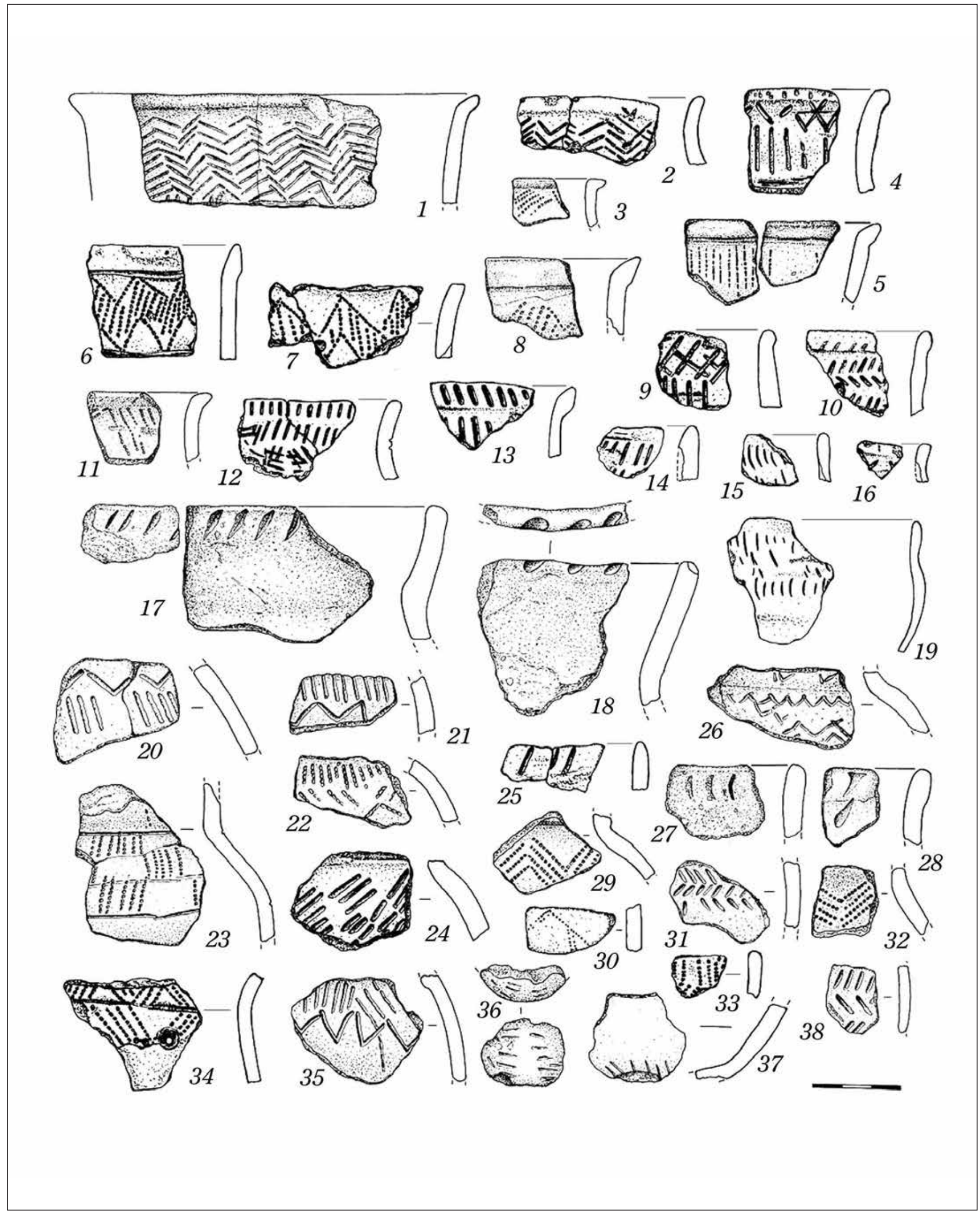

РИС. 49. ОРНАМЕНТИРОВАННАЯ ФАТЬЯНОВСКАЯ КЕРАМИКА С ПОСЕЛЕНИЯ ЦАРИЦЫНО 1 

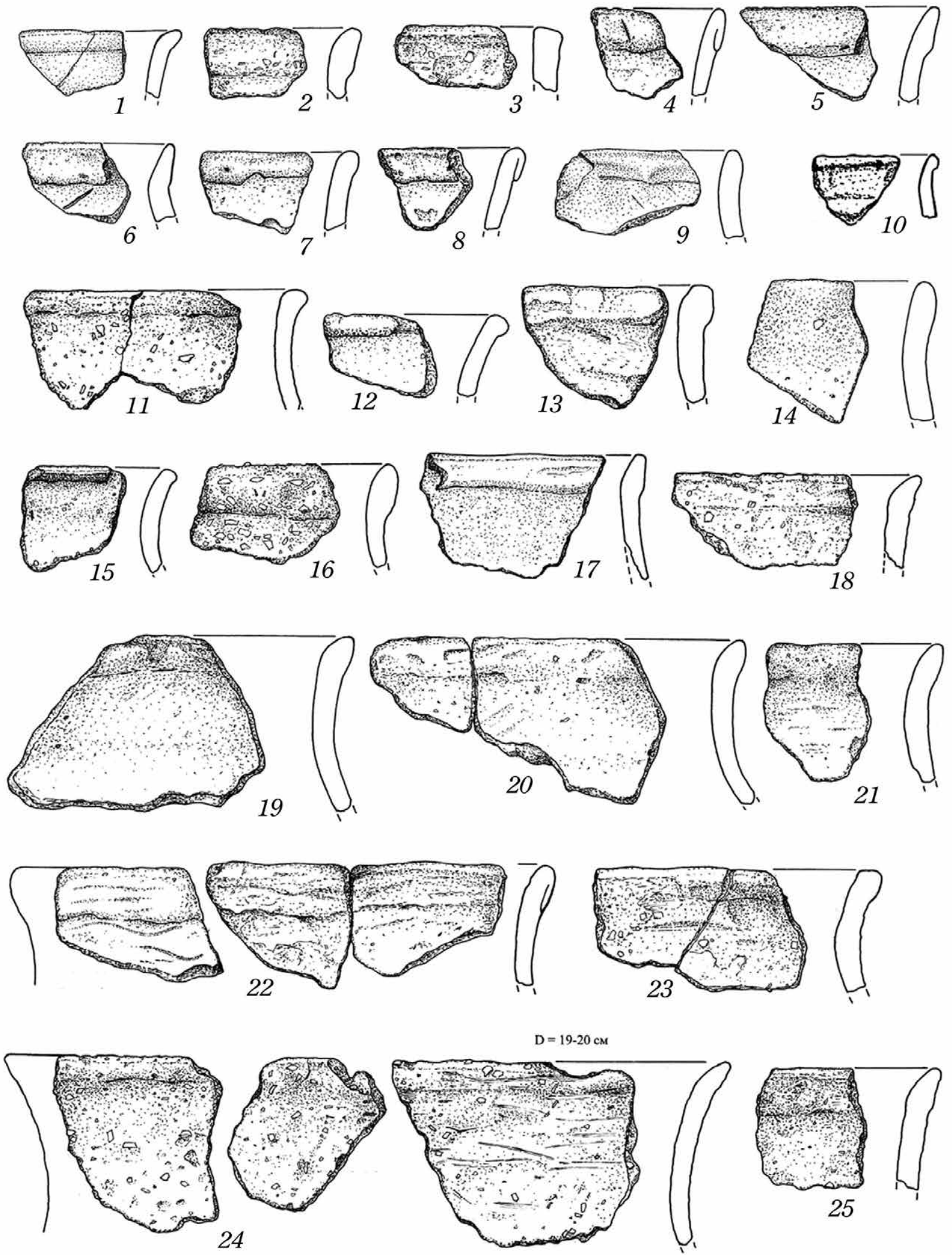

РИС. 50. НЕОРНАМЕНТИРОВАННАЯ ФАТЬЯНОВСКАЯ КЕРАМИКА С ПОСЕЛЕНИЯ ЦАРИЦЫНО 1 

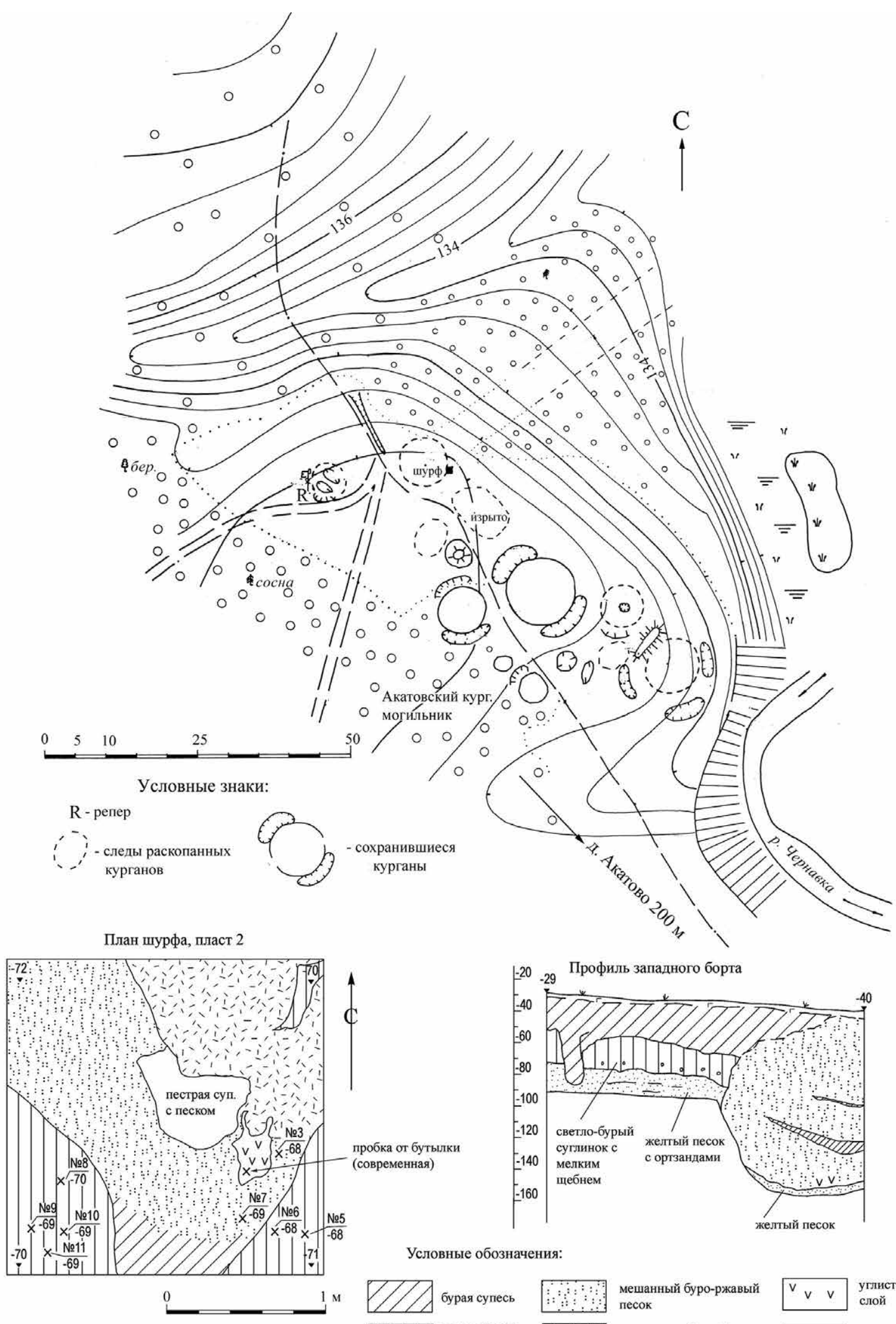

Условные обозначения:
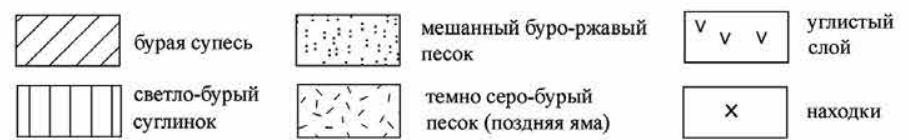

РИС. 51. ТОПОГРАФИЧЕСКИЙ ПЛАН ПОСЕЛЕНИЯ ФАТЬЯНОВСКОЙ КУЛЬТУРЫ АКАТОВО И ЧЕРТЕЖИ ШУРФА 2006 Г. 

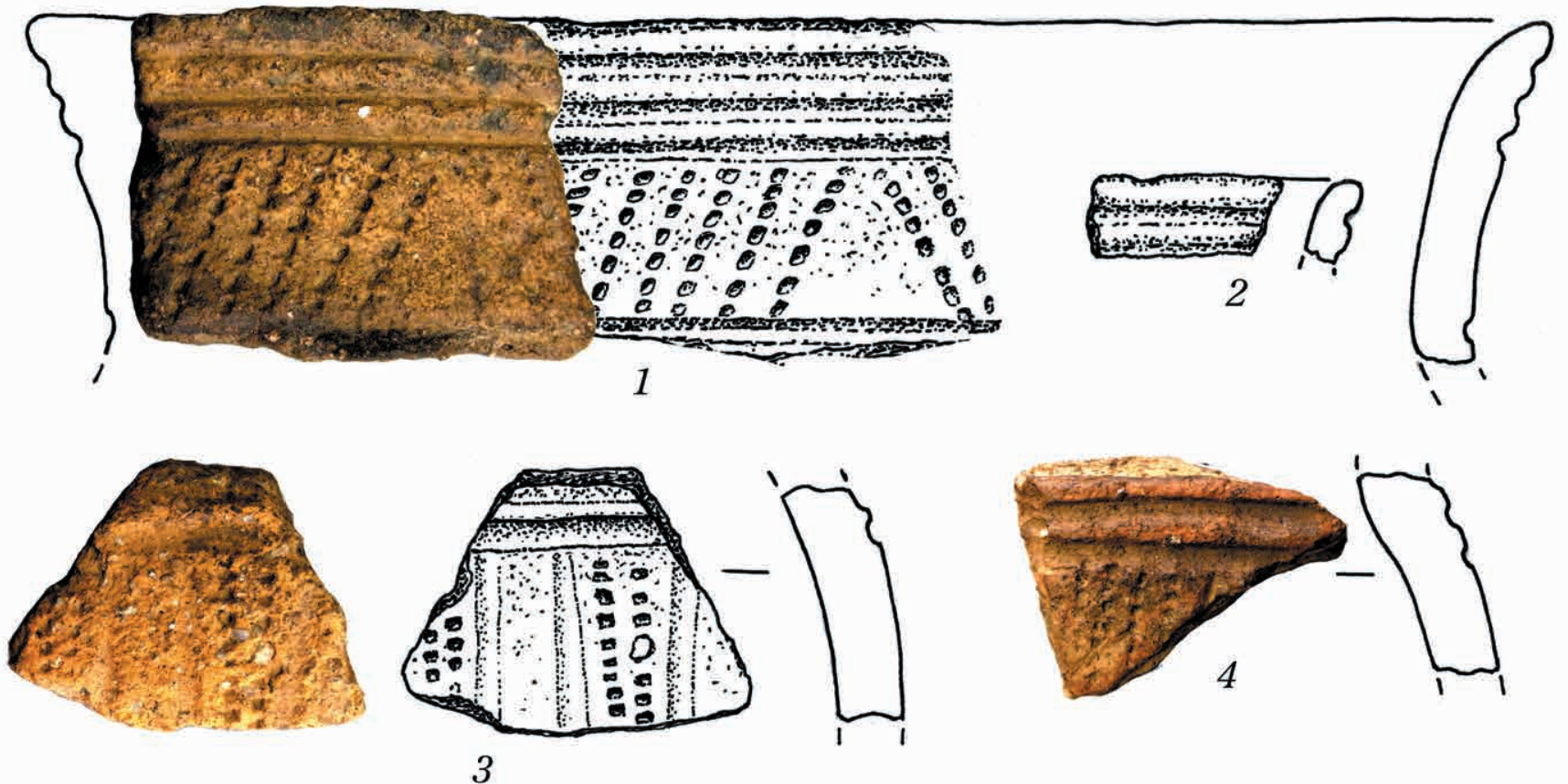

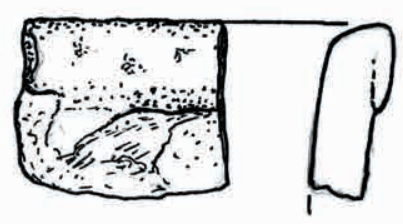

5
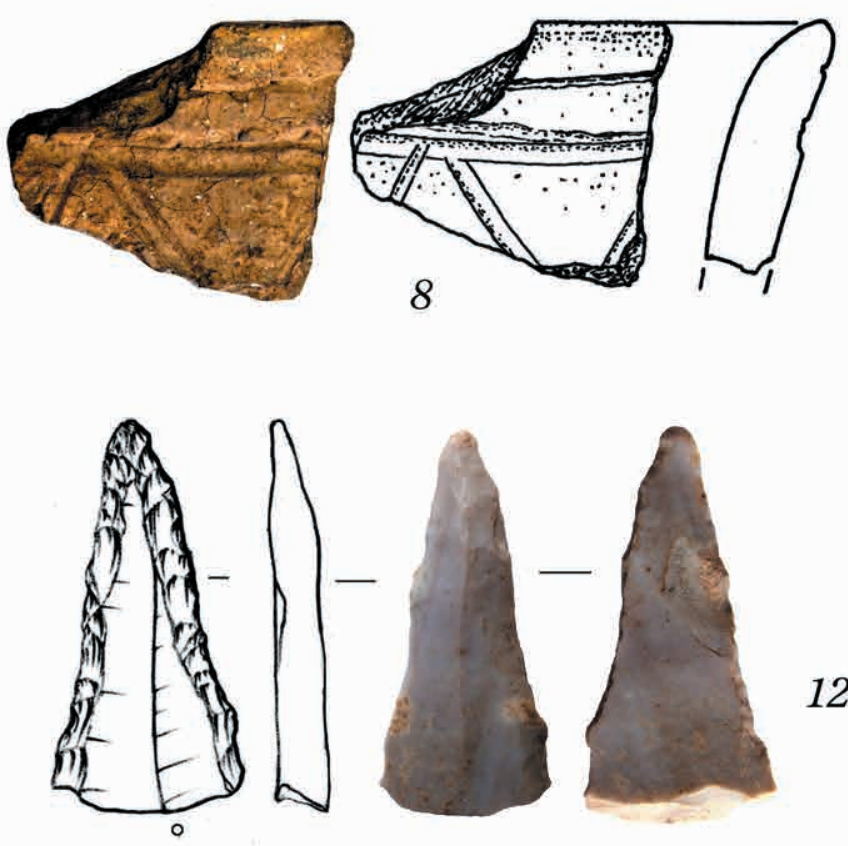

12

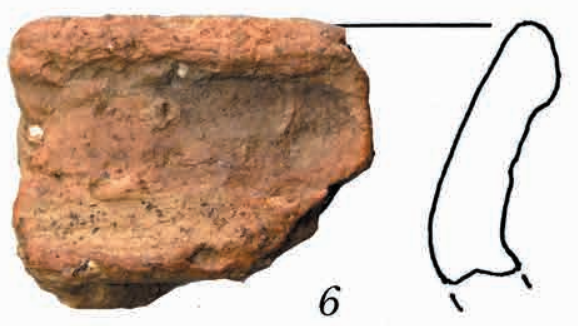

6

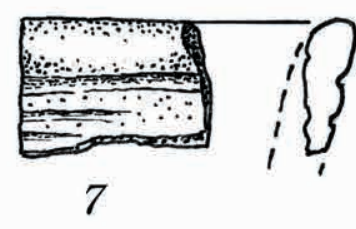

7
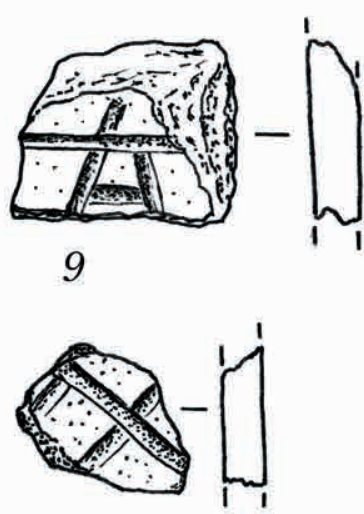

11

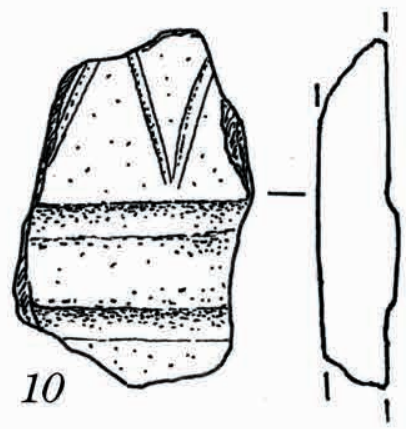

0 $3 \mathrm{~cm}$

РИС. 52. ПОСЕЛЕНИЕ ФАТЬЯНОВСКОЙ КУЛЬТУРЫ АКАТОВО

1-11 - керамика из шурфа 2006 г.; 12 - острие-перфоратор из кремня 


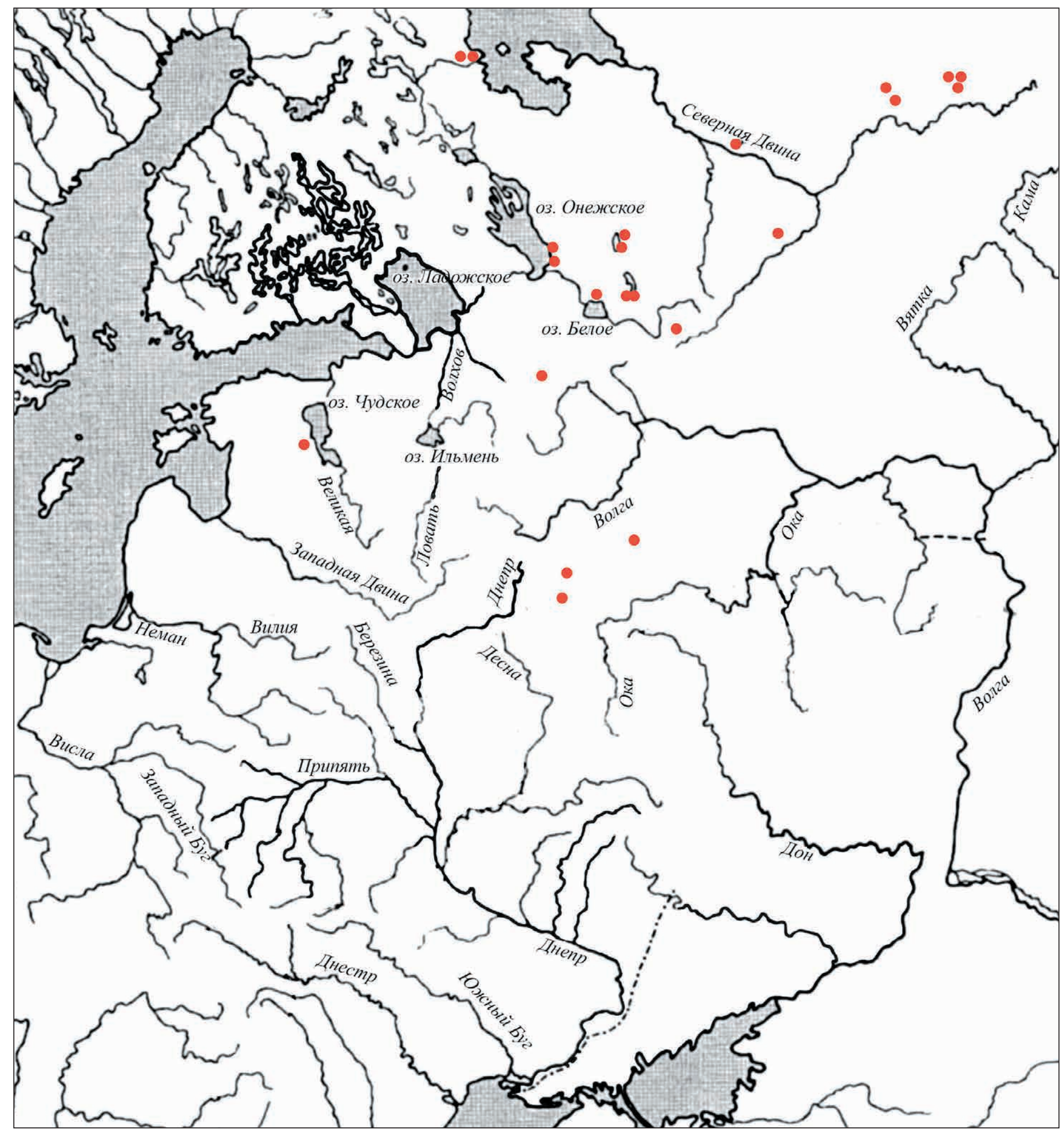




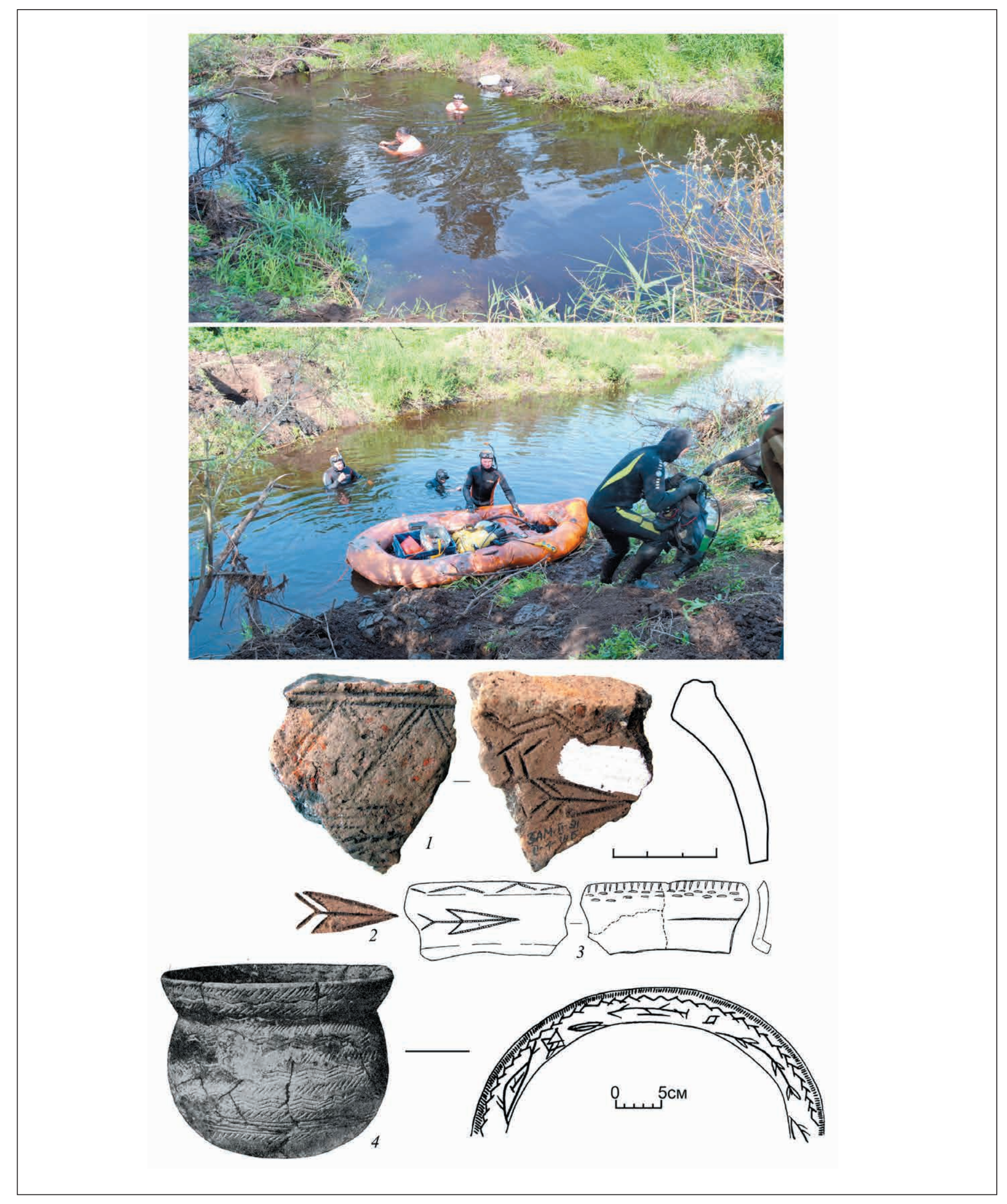

РИС. 54. ПОДВОДНЫЕ РАБОТЫ В РУСЛЕ РЕКИ СУЛАТЬ (ВВЕРХУ); ПИКТОГРАММЫ НА ФАТЬЯНОИДНОЙ КЕРАМИКЕ

1, 2 - стоянка Замостье 2, 3- Сахтыш 1; 4 - горшок из абашевского могильника Кухмарь (по: Крайнов, 1962) 


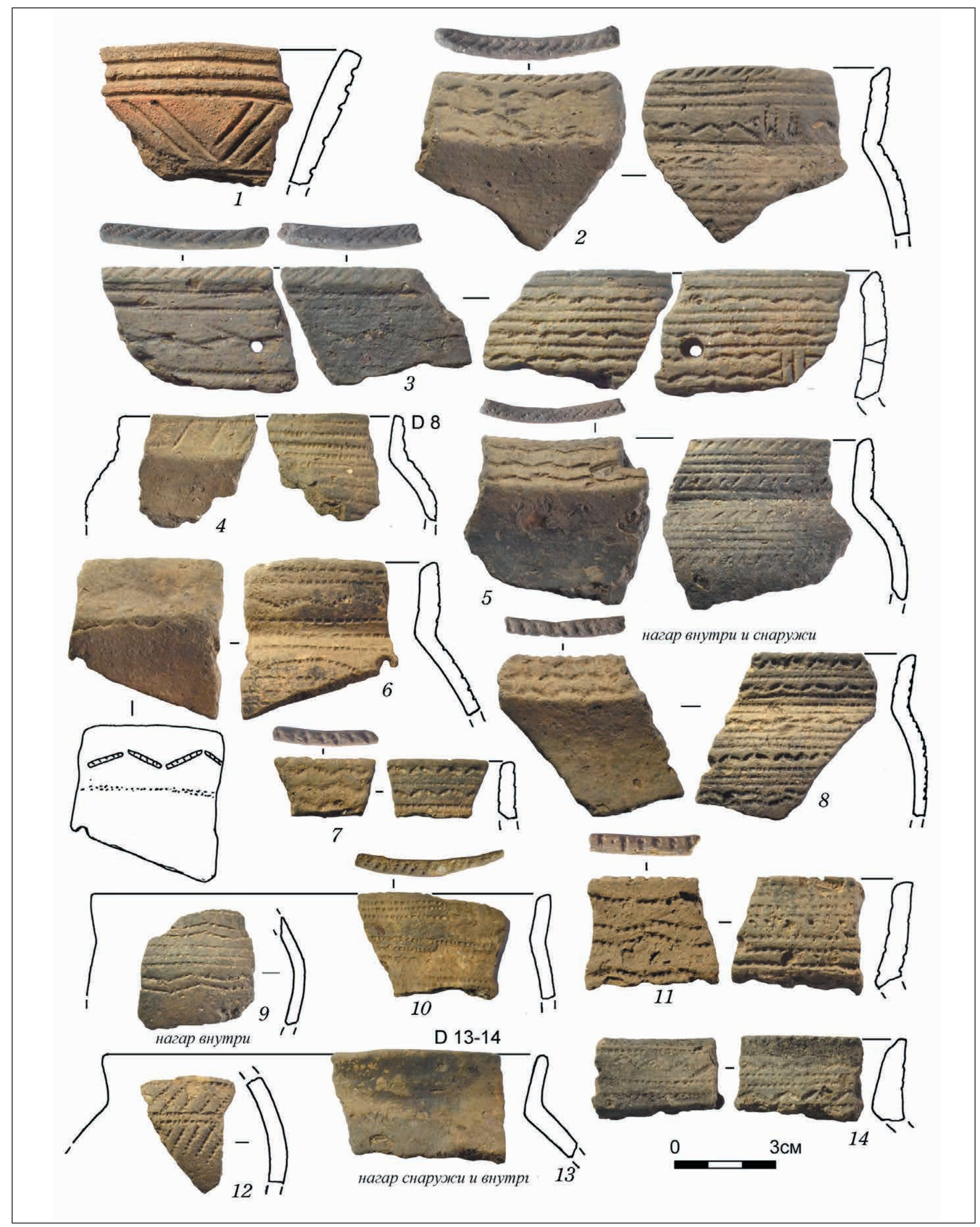

РИС. 55. ФАТЬЯНОВСКАЯ (1) И ФАТЬЯНОИДНАЯ (2-14) КЕРАМИКА ИЗ РУСЛА РЕКИ СУЛАТЬ 


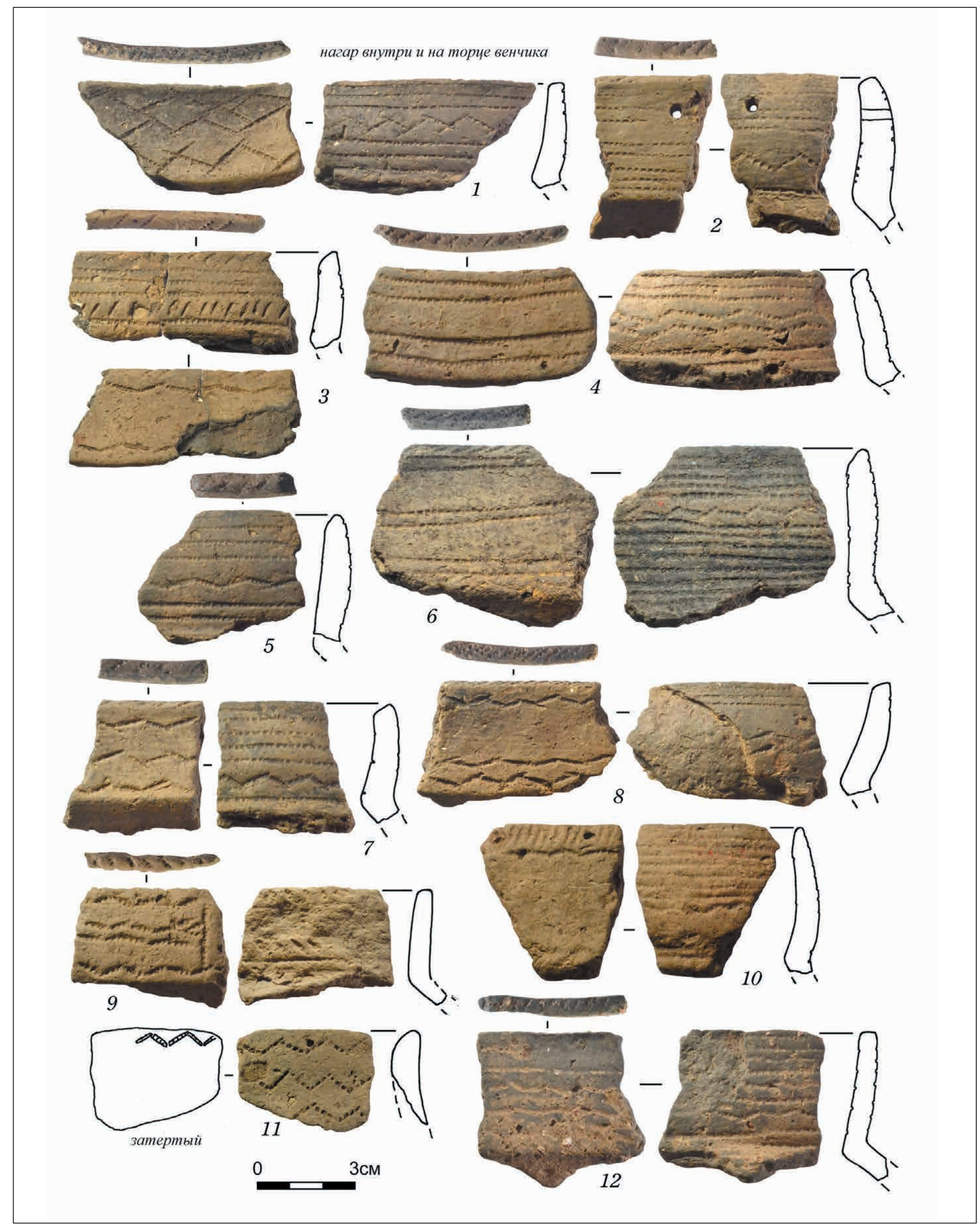

РИС. 56. ФАТЬЯНОИДНАЯ КЕРАМИКА ИЗ РУСЛА РЕКИ СУЛАТЬ 


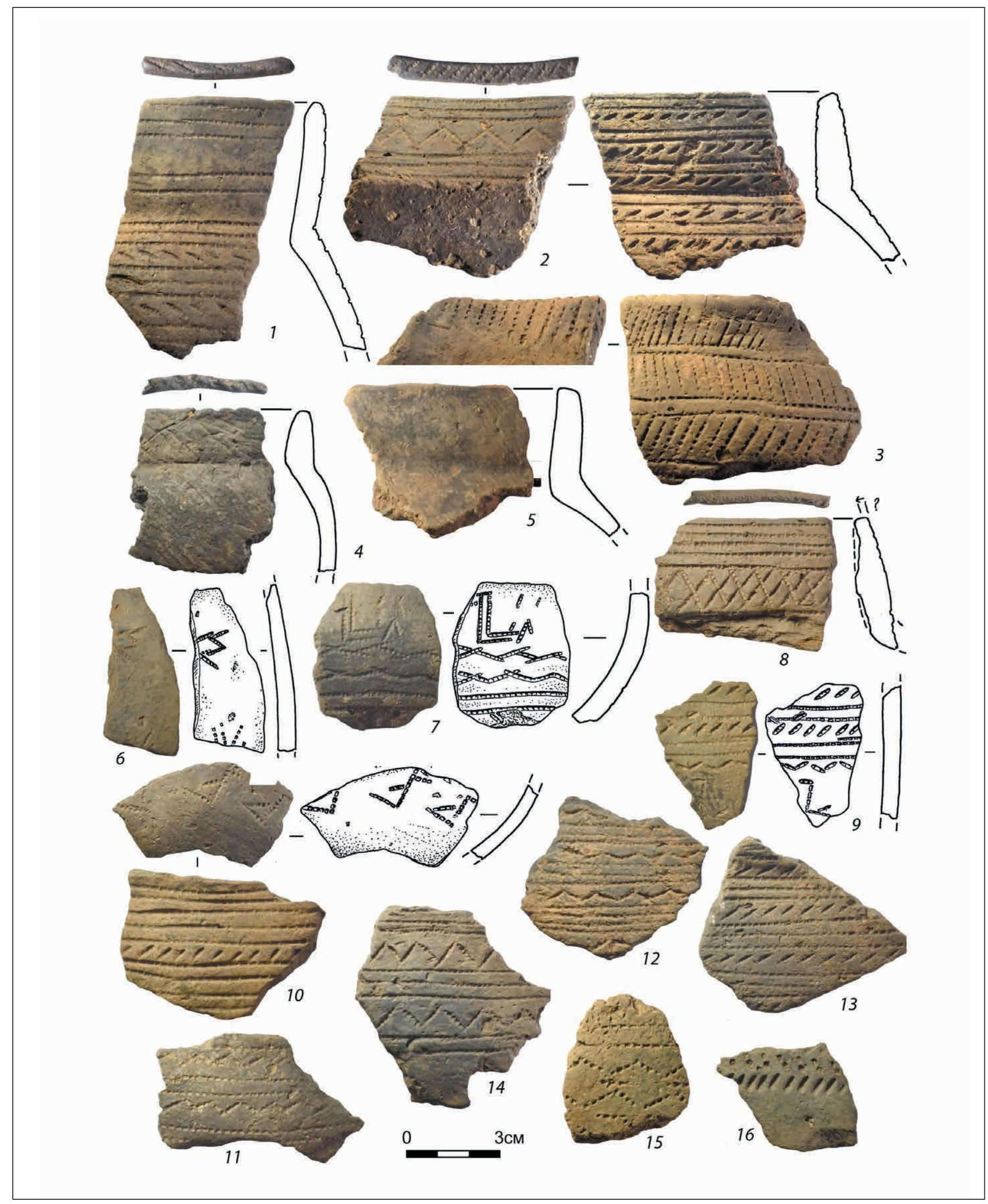

РИС. 57. ФАТЬЯНОИДНАЯ КЕРАМИКА ИЗ РУСЛА РЕКИ СУЛАТЬ 

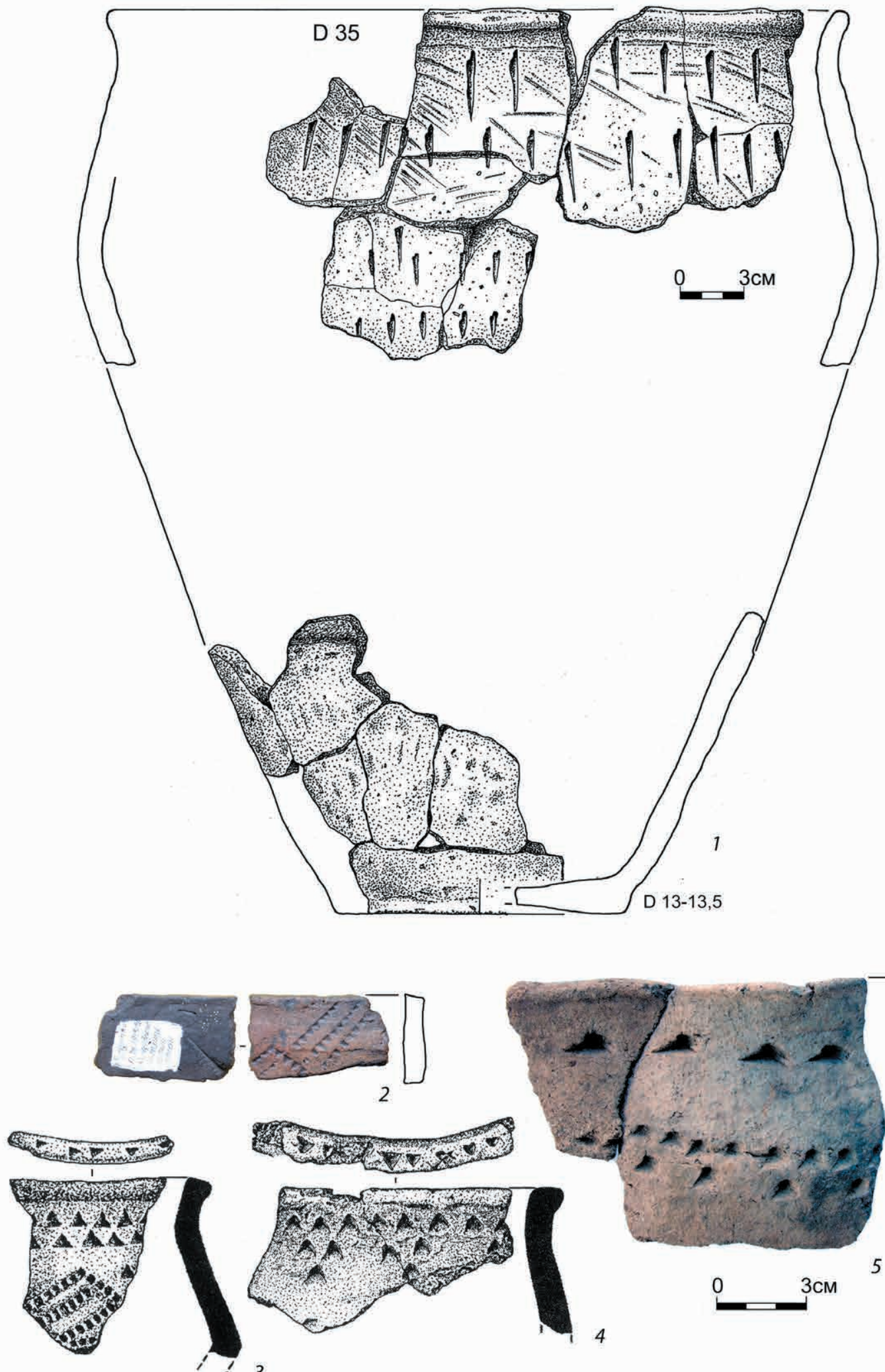






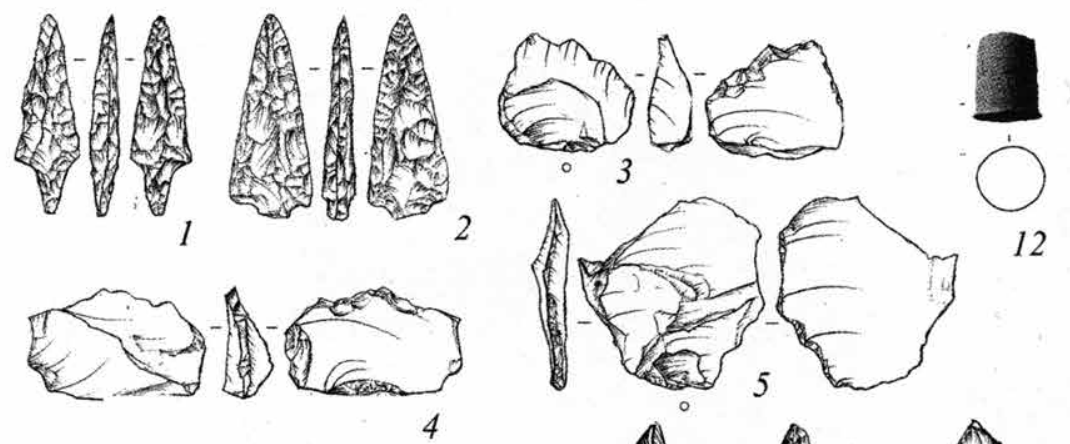

12
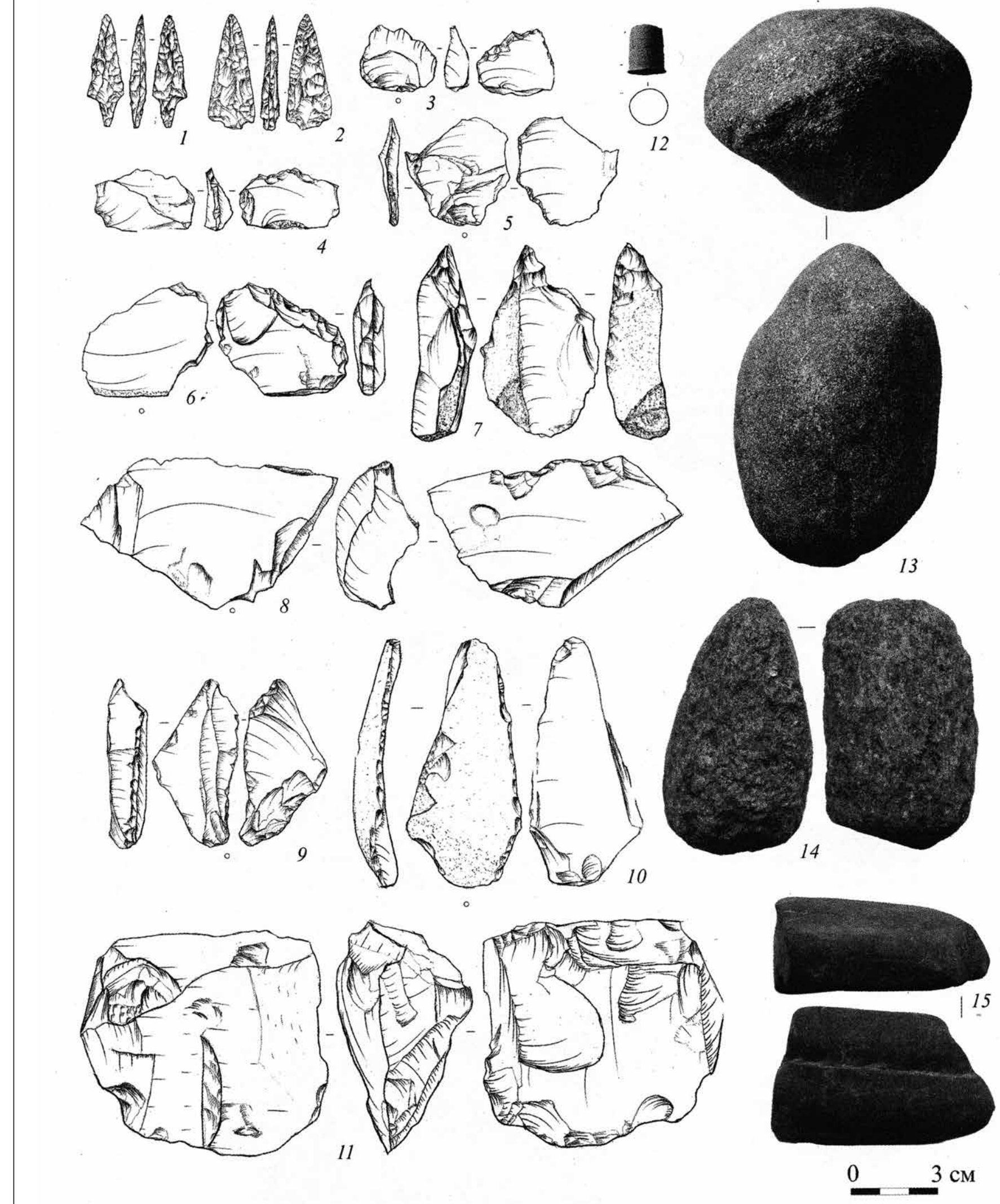

РИС. 60. КРЕМНЕВЫЕ СТРЕЛЫ, ОРУДИЯ НА ПЛАСТИНАХ И ОТЩЕПАХ, НУКЛЕУС, СВЕРЛИНА ОТ ТОПОРА, ОТБОЙНИКИ ИЗ РАСКОПОК ПОСЕЛЕНИЯ ОЛИМП 


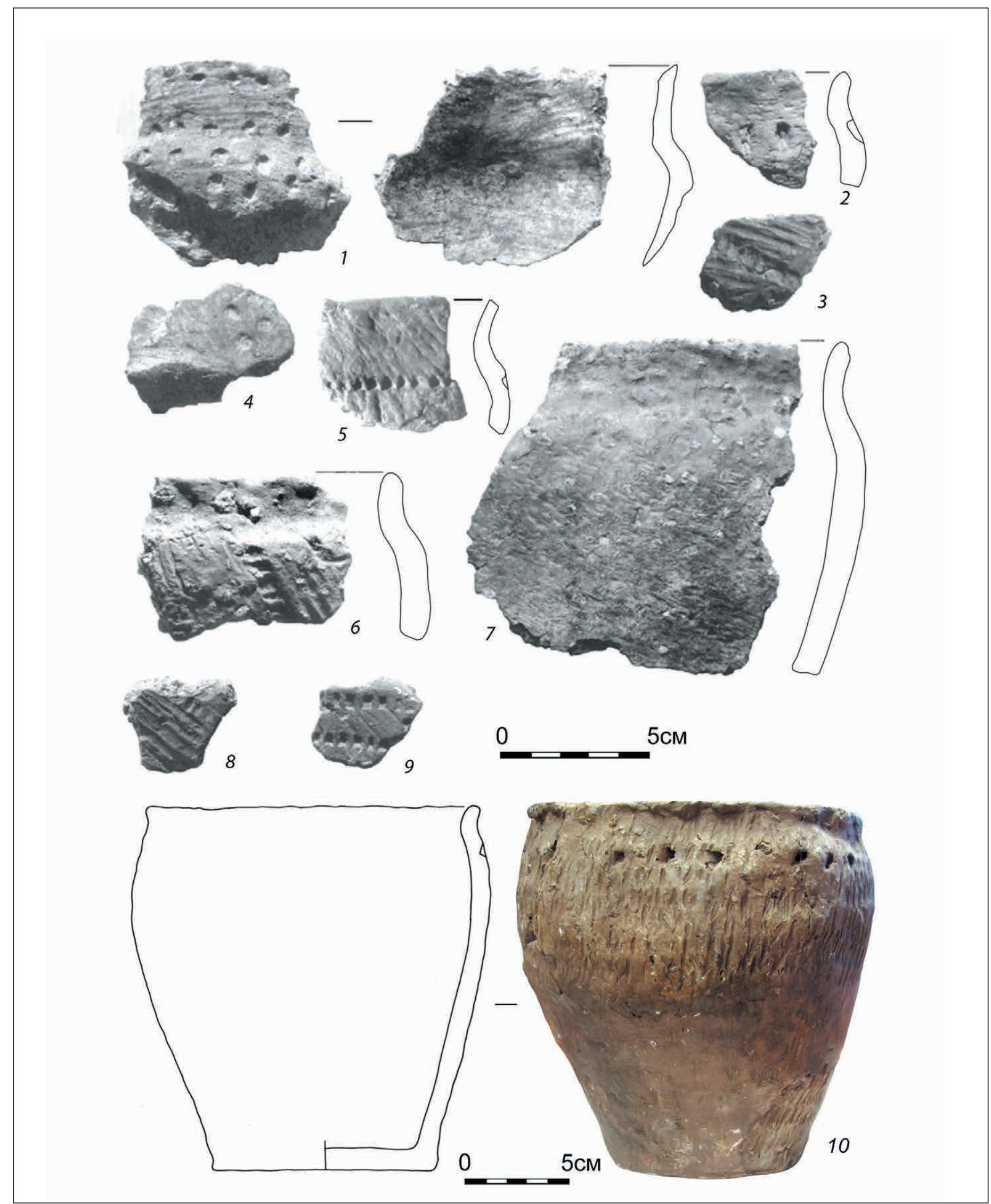

РИС. 61. КеРАМИКА С ПОСЕЛЕНИЯ ОЛИМП (1-9) И ИЗ ПОГРЕБЕННОЙ ПОЧВЫ СЕЛЕЦКОГО ГОРОДИЩА (ВНИЗУ) ИЗ РАСКОПОК И.Л. ЧЕРНАЯ (МУЗЕЙ В БРОНнИЦАХ) 


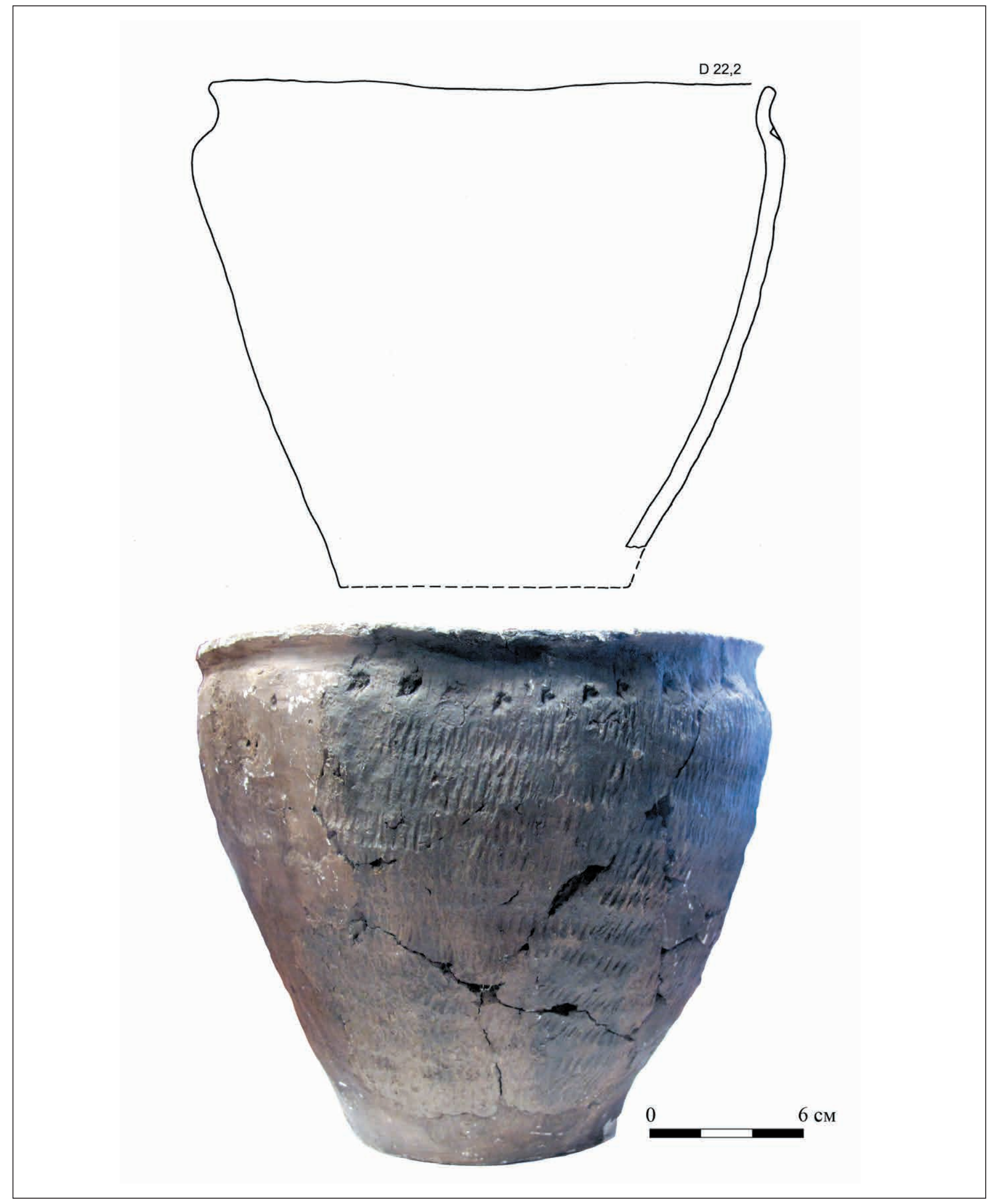

РИС. 62. СЕЛЕЦКОЕ ГОРОДИЩЕ, ГОРШОК № 1 ИЗ ПОГРЕБЕННОЙ ПОЧВЫ (РАСКОПКИ И.Л. ЧЕРНАЯ, БРОННИЦКИЙ МУЗЕЙ) 


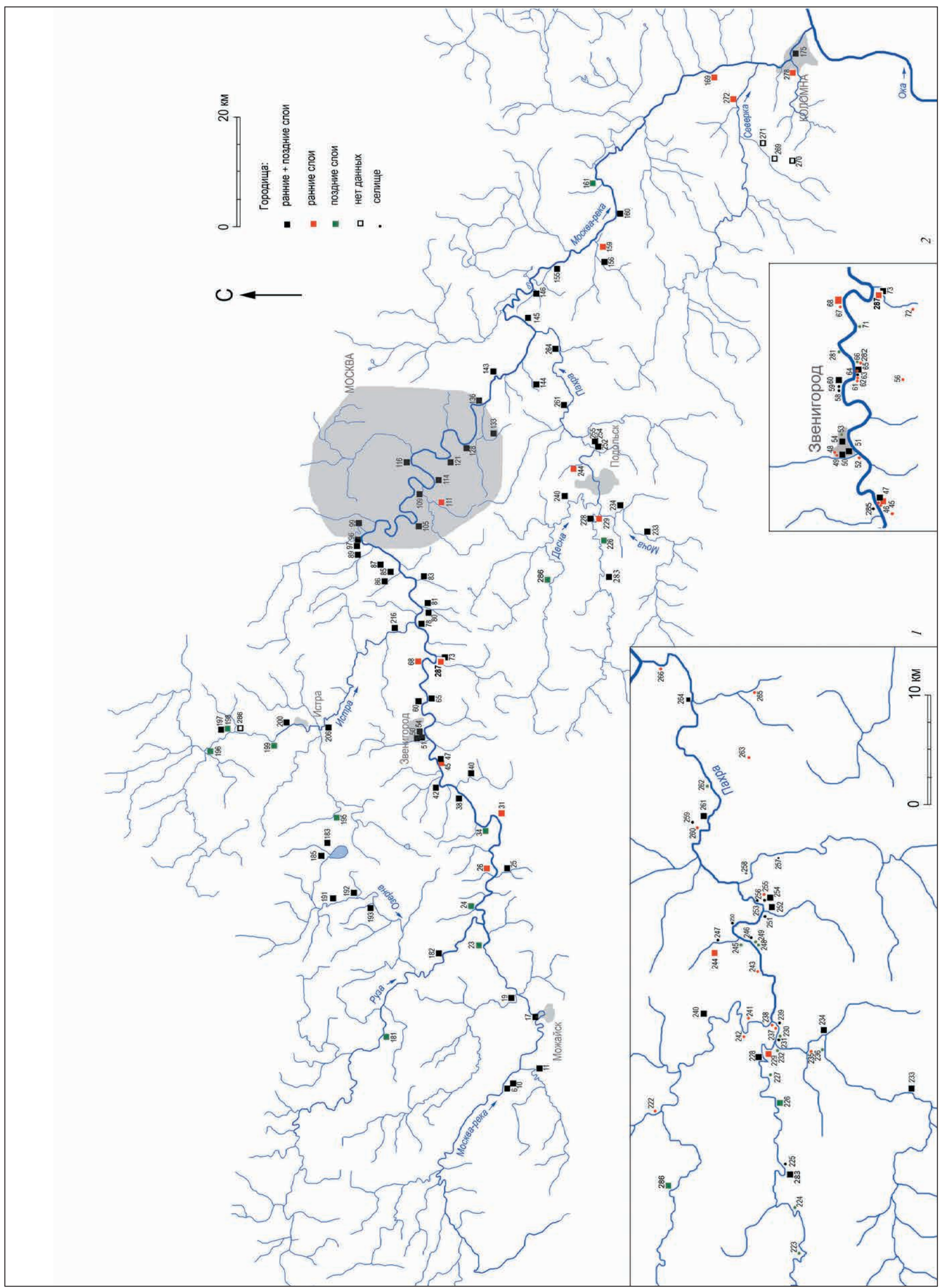




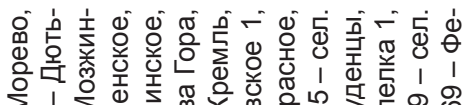

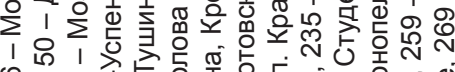

幽西定

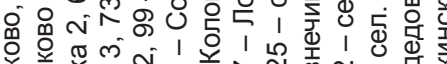

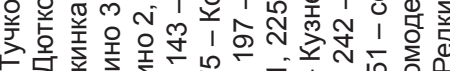

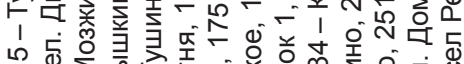

బ

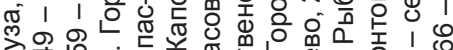

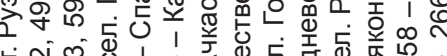

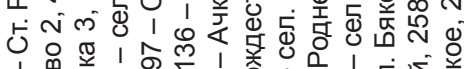

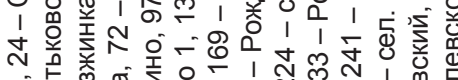

ó

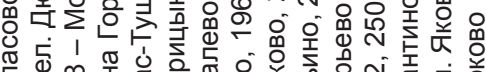

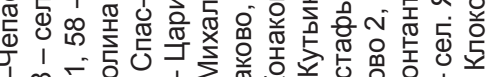

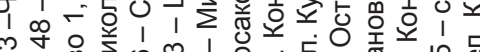

N -

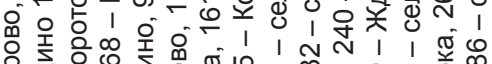

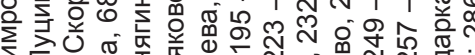

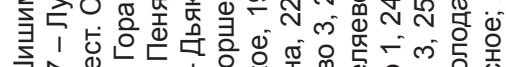

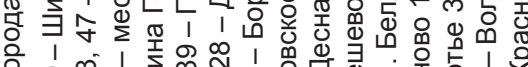

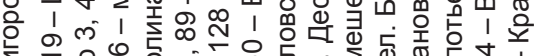

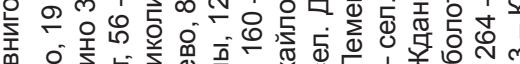
商

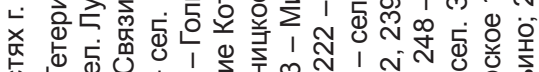

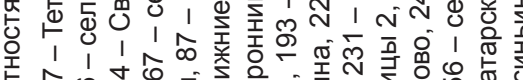

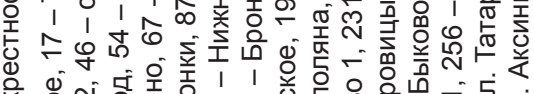

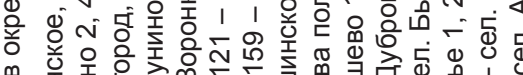

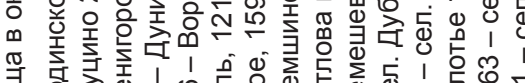

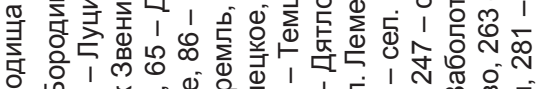

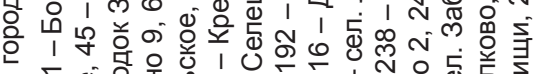

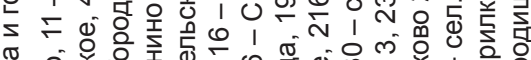
単

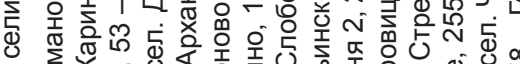

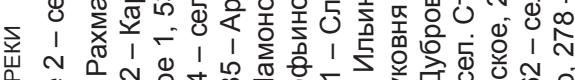

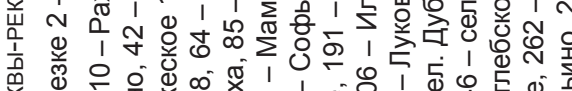

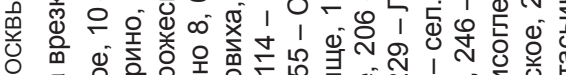

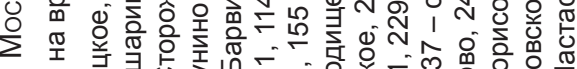

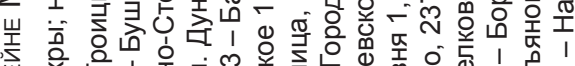

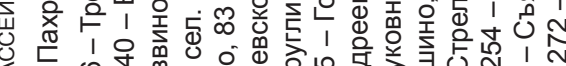

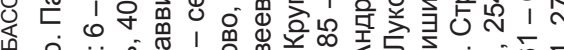
ద

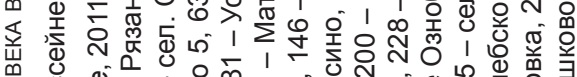

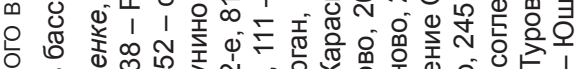
要

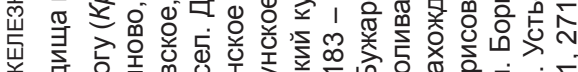

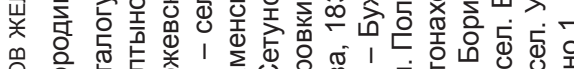

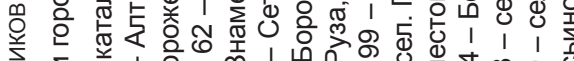
年

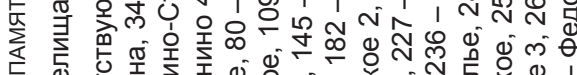

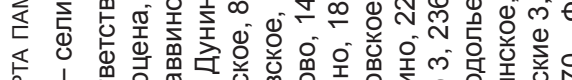

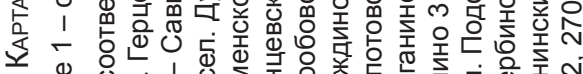

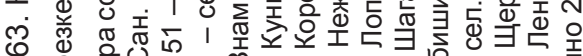
0 0. 蛋 更 


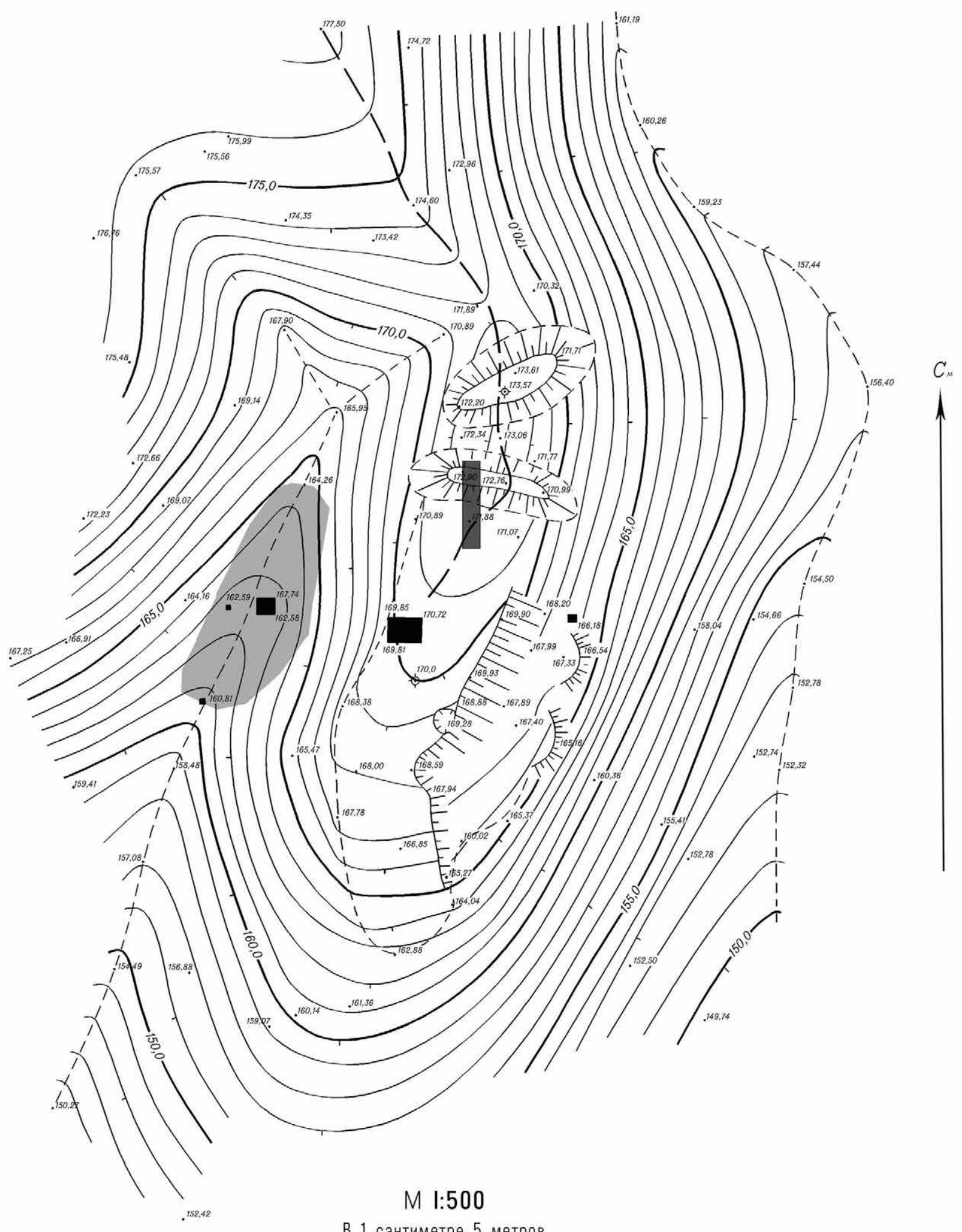

В 1 сантиметре 5 метров

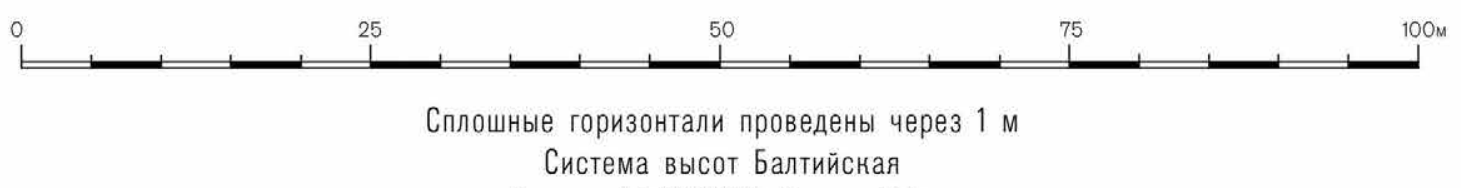

Съемна 15.10.2008 Петров В.В. 

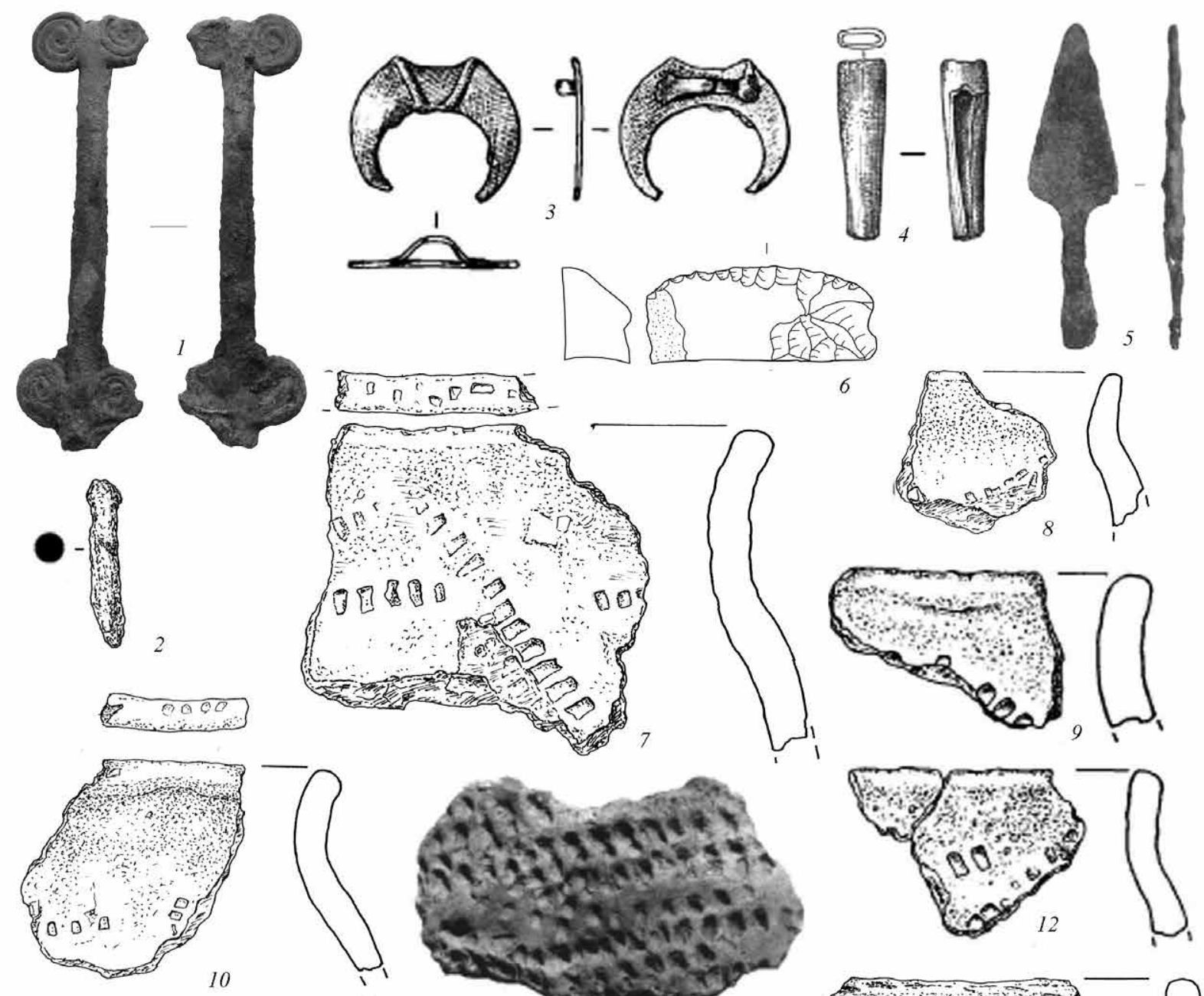

10
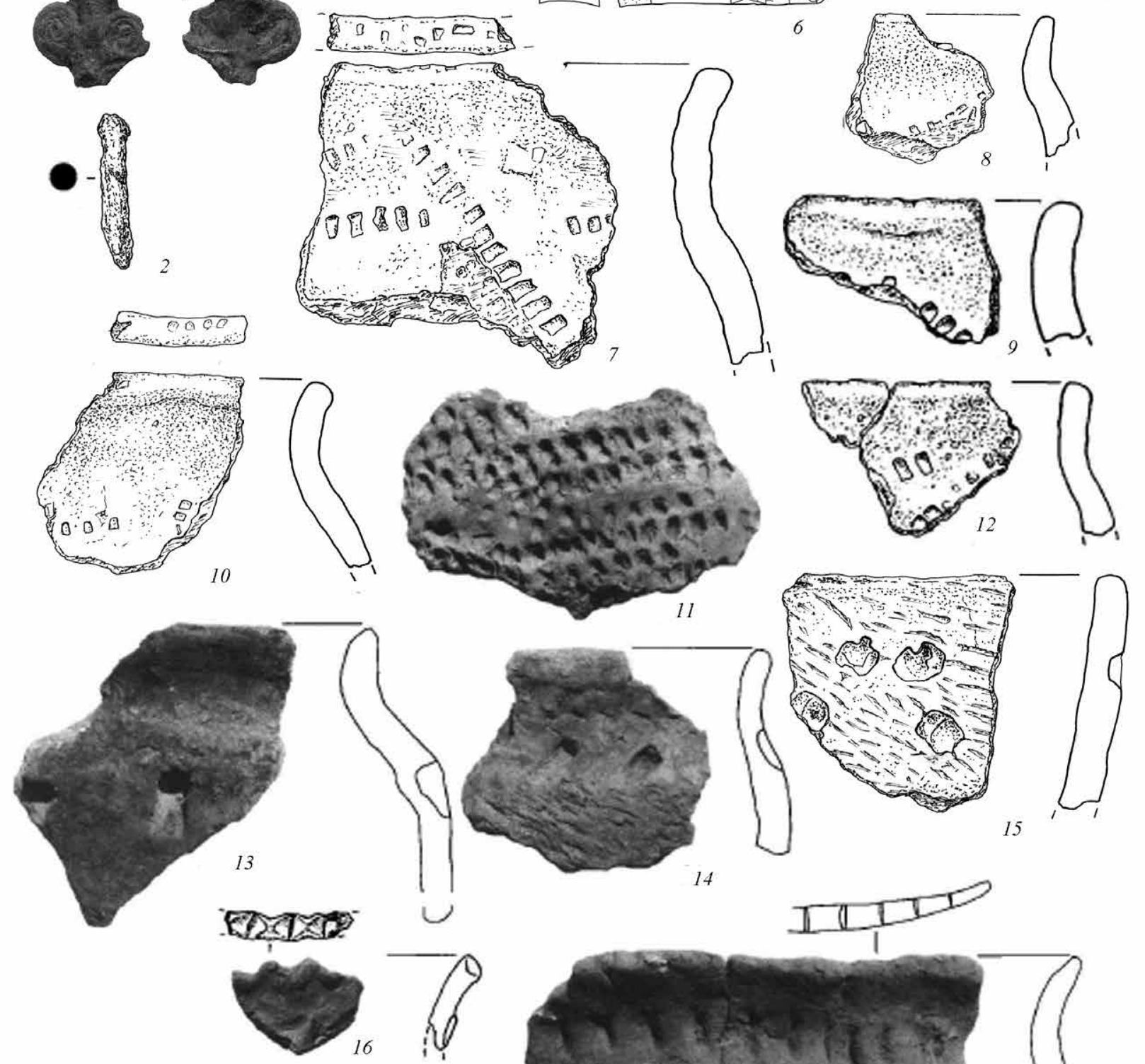

$4 \mathrm{~cm}$
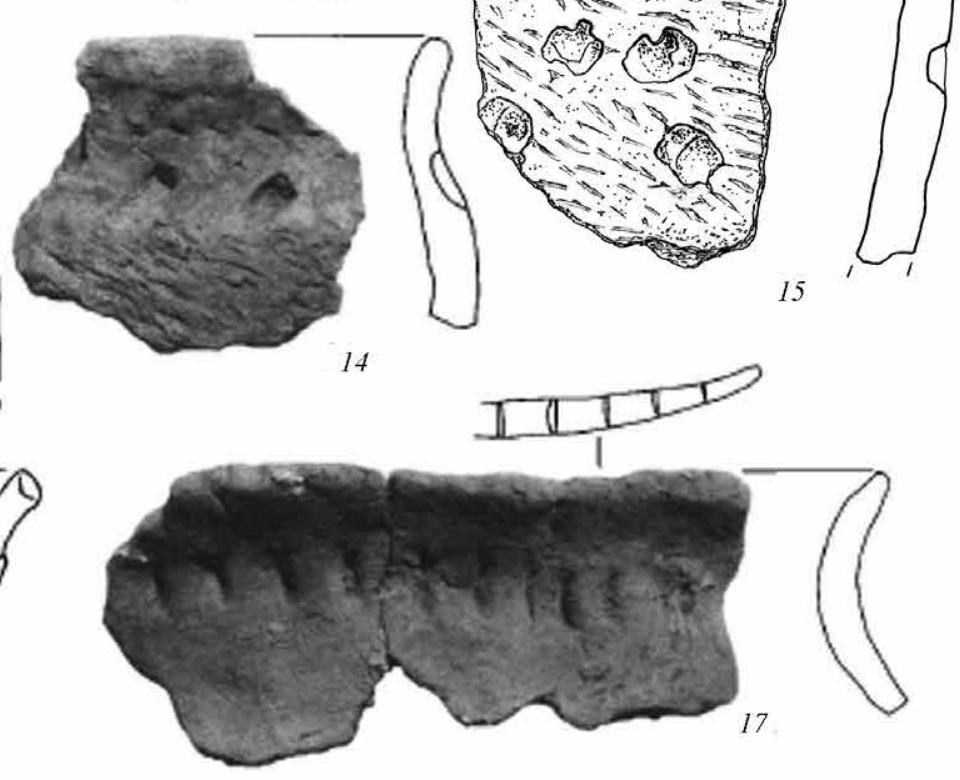

Рис. 65. НАходки с городищА Дютьково

1 - железо + бронза; 2, 5- железо; 3, 4- бронза, 6- кремень; 7-17-глина 


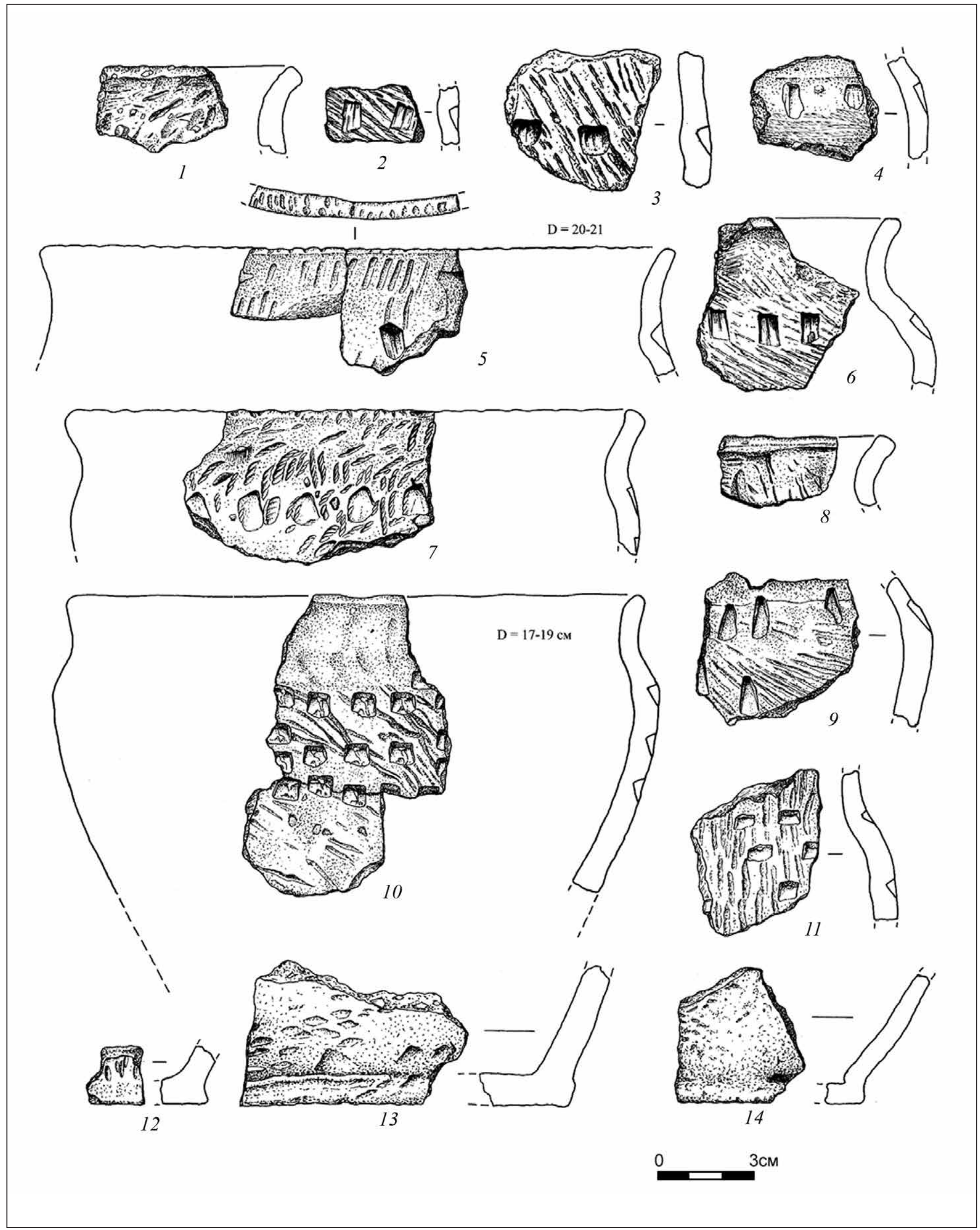

РИС. 66. ТЕКСТИЛЬНАЯ КЕРАМИКА РУБЕЖА БРОНЗОВОГО/ЖЕЛЕЗНОГО ВЕКОВ С ТЫЧКОВЫМ ОРНАМЕНТОМ ИЗ РАСКОПОК СЕЛИЩА ЦАРИЦЫНО 1 


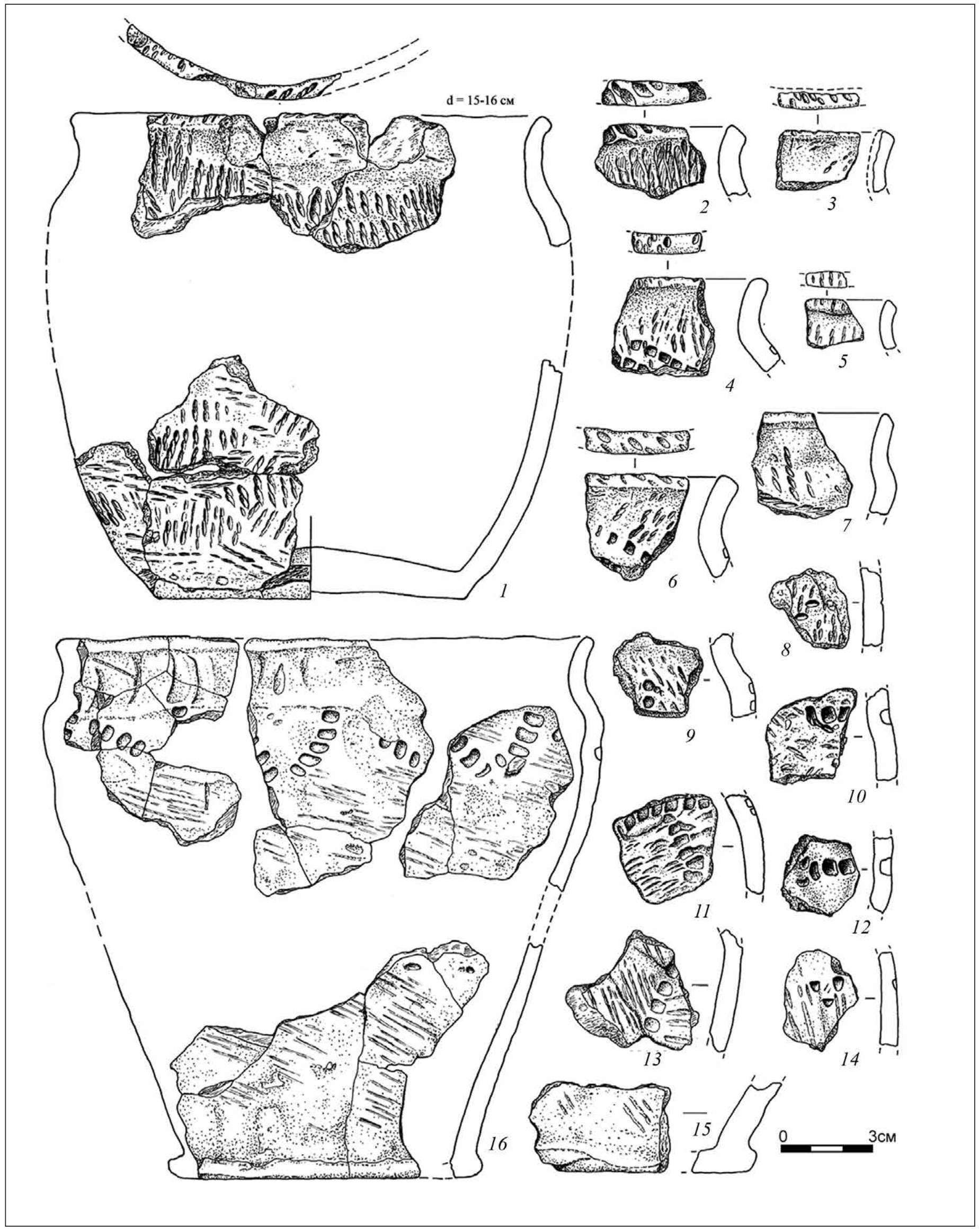

РИС. 67. ТЕКСТИЛЬНАЯ КЕРАМИКА РУБЕЖА БРОНЗОВОГО/ЖЕЛЕЗНОГО ВЕКОВ С ГРЕБЕНЧАТЫМ ОРНАМЕНТОМ ИЗ РАСКОПОК СЕЛИЩА ЦАРИЦЫНО 1 


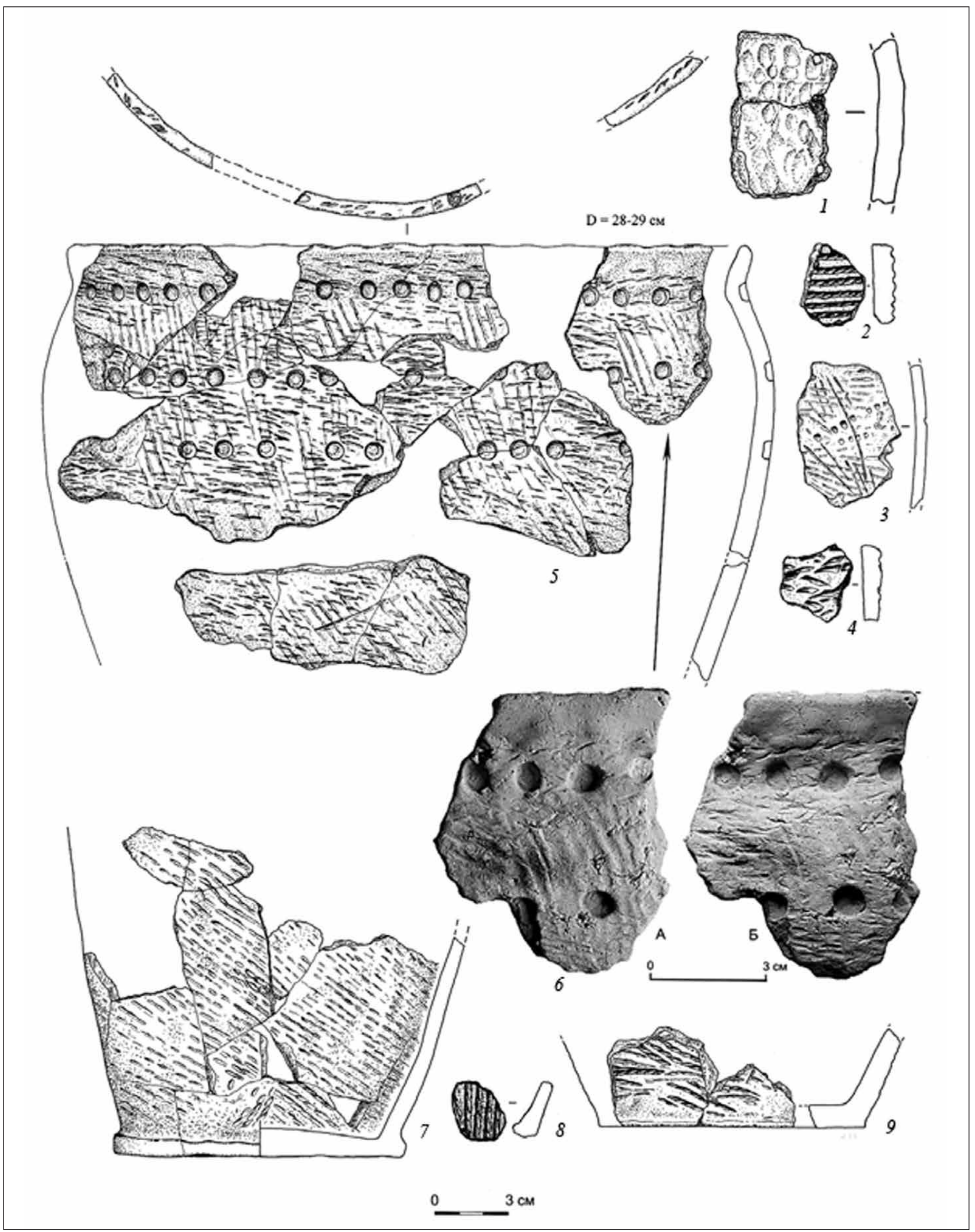

РИС. 68. ТЕКСТИЛЬНАЯ КЕРАМИКА РУБЕЖА БРОНЗОВОГО/ЖЕЛЕЗНОГО ВЕКОВ С ЯМОЧНЫМ ОРНАМЕНТОМ ИЗ РАСКОПОК СЕЛИЩА ЦАРИЦЫНО 1 


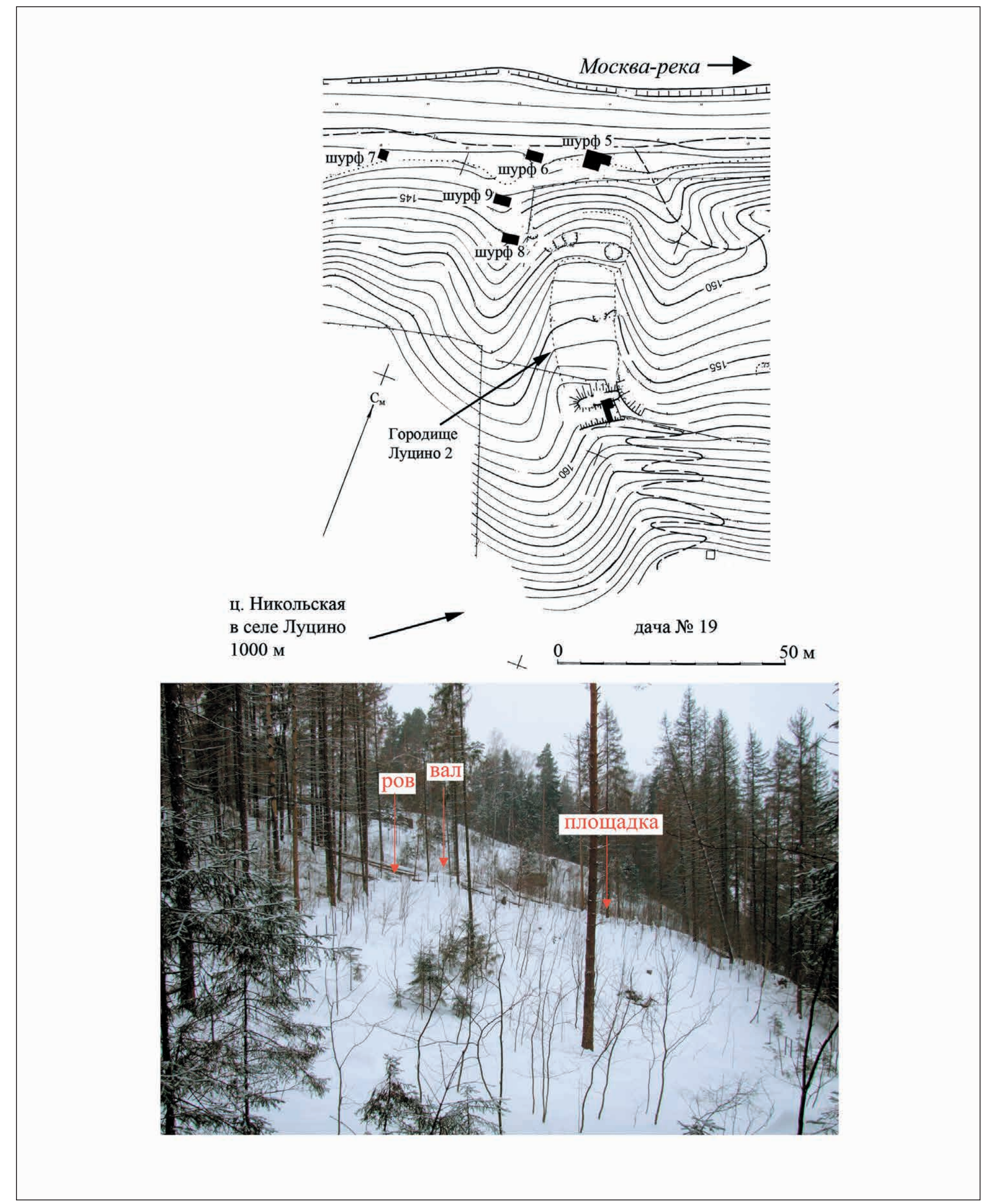

РИс. 69. ПЛАН (ВВеРХУ) С ШУРФАМИ 2010 и 2012 ГГ. И ФОТО (ВНИЗУ) ГОРОДИЩА ЛУЦЦИНО 2 


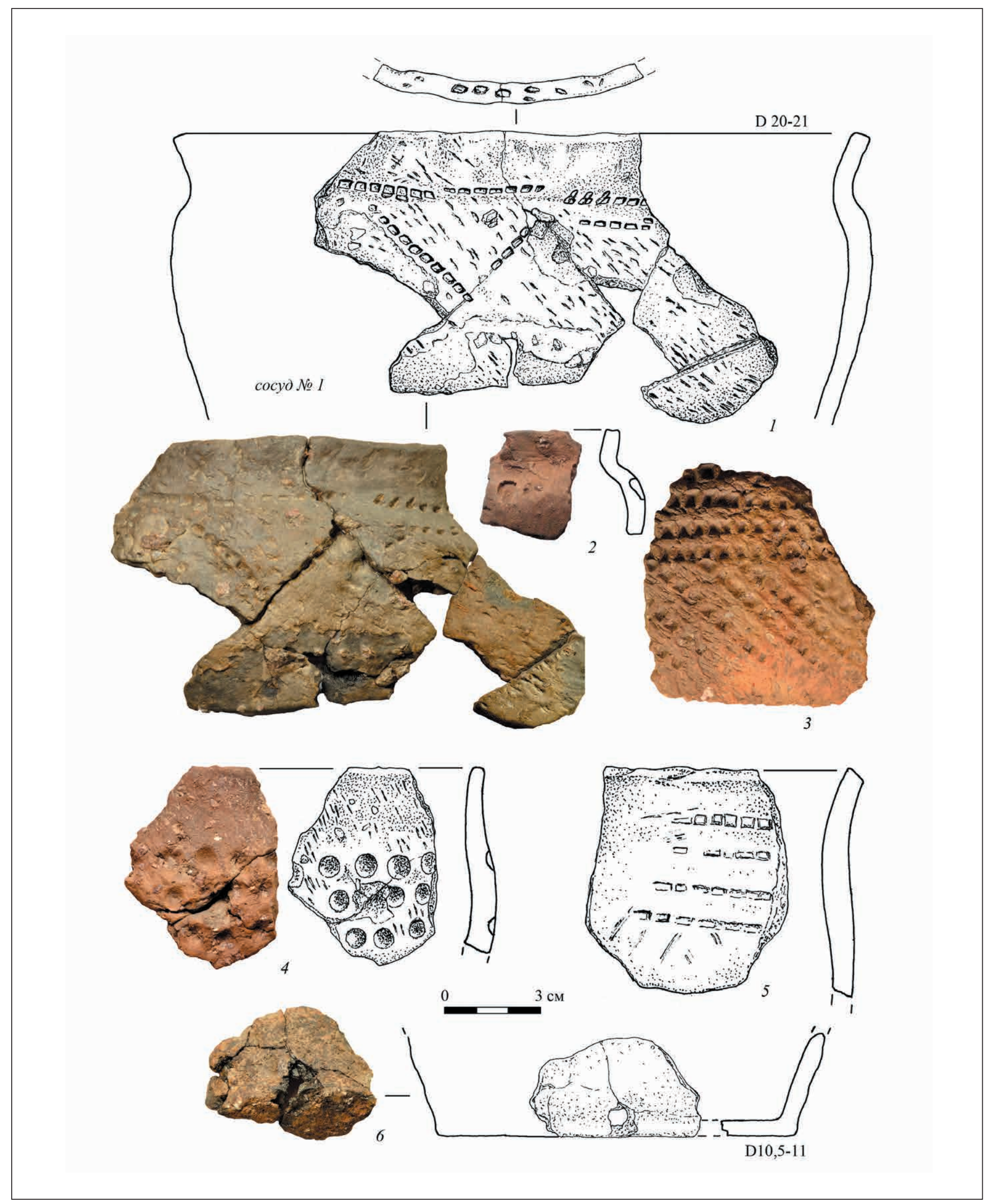

РИС. 70. КЕРАМИКА НАЧАЛЬНОГО ЖЕЛЕЗНОГО ВЕКА С ЯМОЧНЫМ И ГРЕБЕНЧАТЫМ ОРНАМЕНТОМ ИЗ ШУРФОВ У ПОДНОЖИЯ ПЛОЩАДКИ ГОРОДИЩА ЛУЦИНО 2 


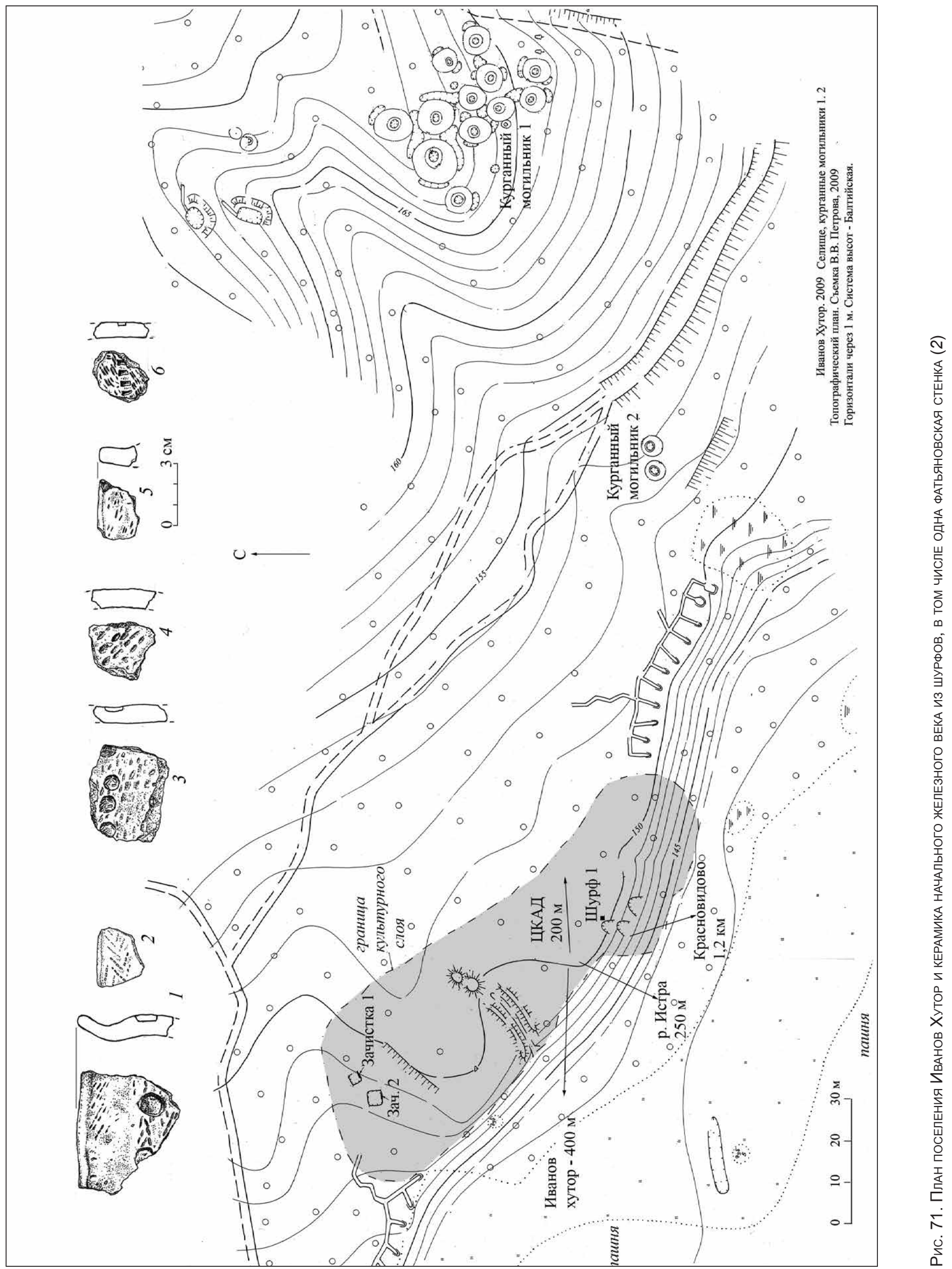




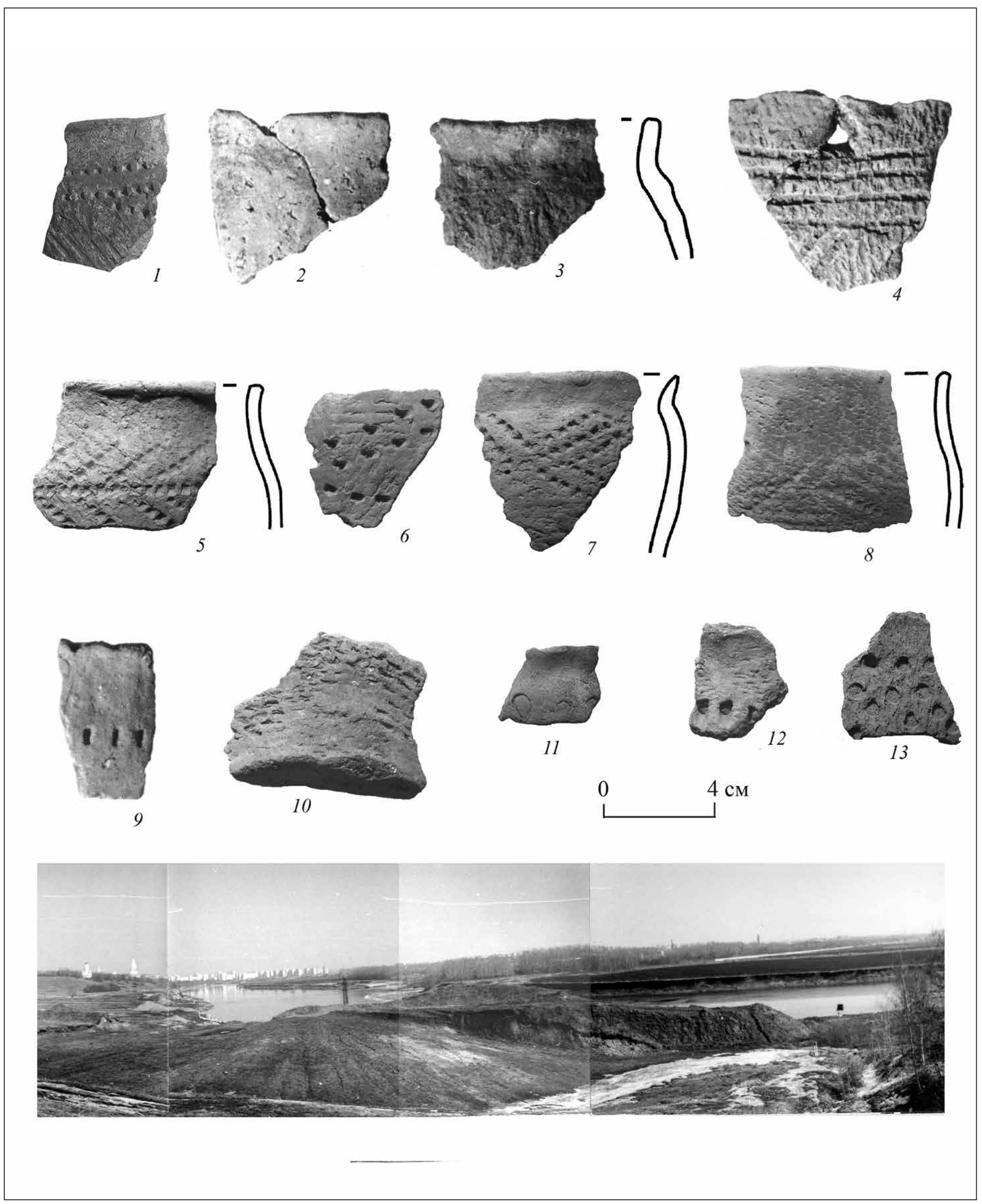

РИС. 72 КЕРАМИКА НАЧАЛЬНОГО ЖЕЛЕЗНОГО ВЕКА ИЗ РАСКОПОК СЕЛИЩА ЧЕРТОВ ГОРОДОК (ВВЕРХУ); ВИД НА УТРАЧЕННЫЙ ПАМЯТНИК ЧЕРТОВ ГОРОДОК (1981 г.) 

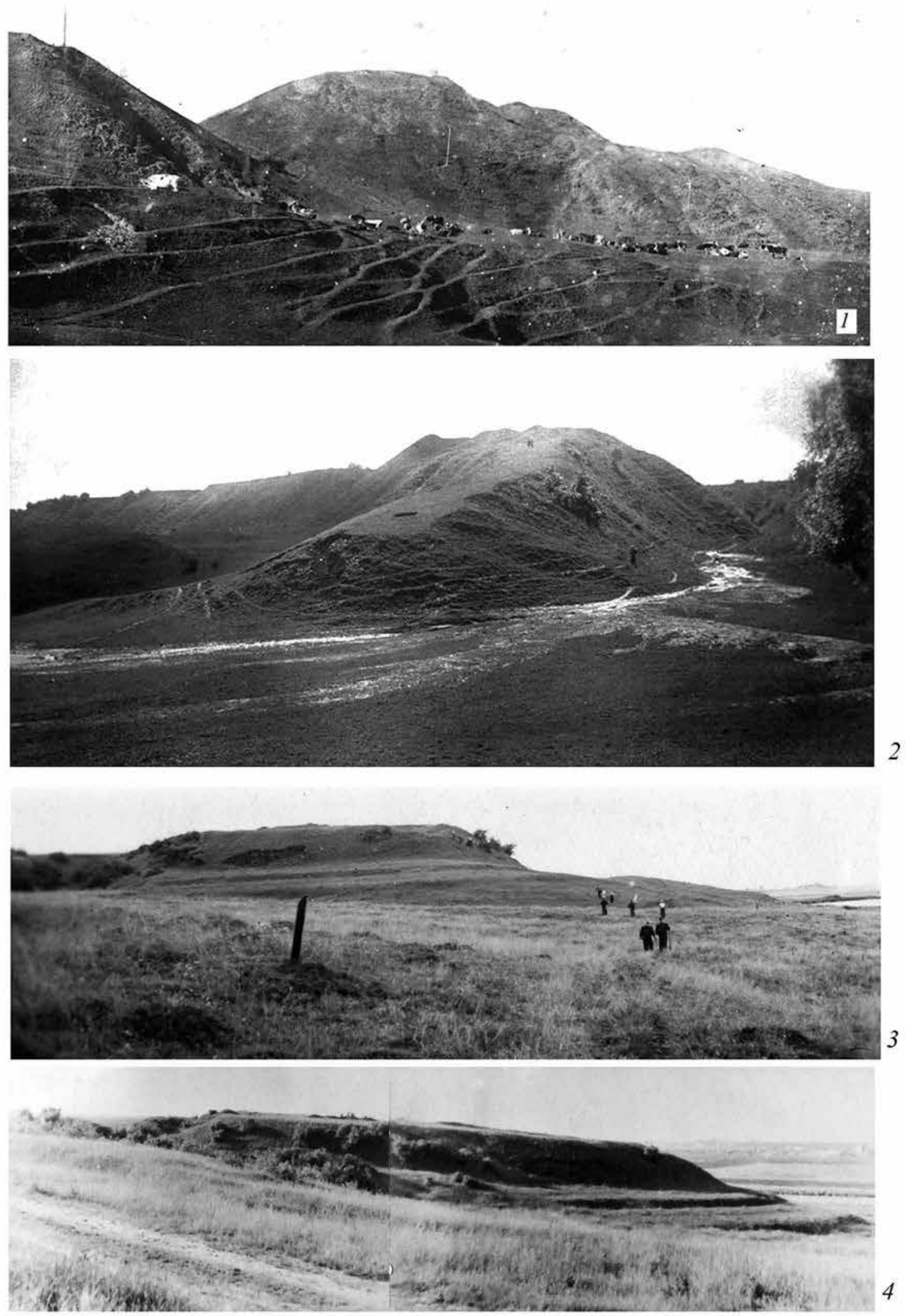

РИС. 73. ВИДЫ ДЬЯКОВА ГОРОДИЩА, ФОТО И.Ф. БАРЩЕВСКОГО. 1935 Г. (1, 2); ВИДЫ НА ГОРОДИЩЕ КРУГЛИЦА (3, 4), ФОТО Л.И. ПИМАКИНА. 1956 Г. 


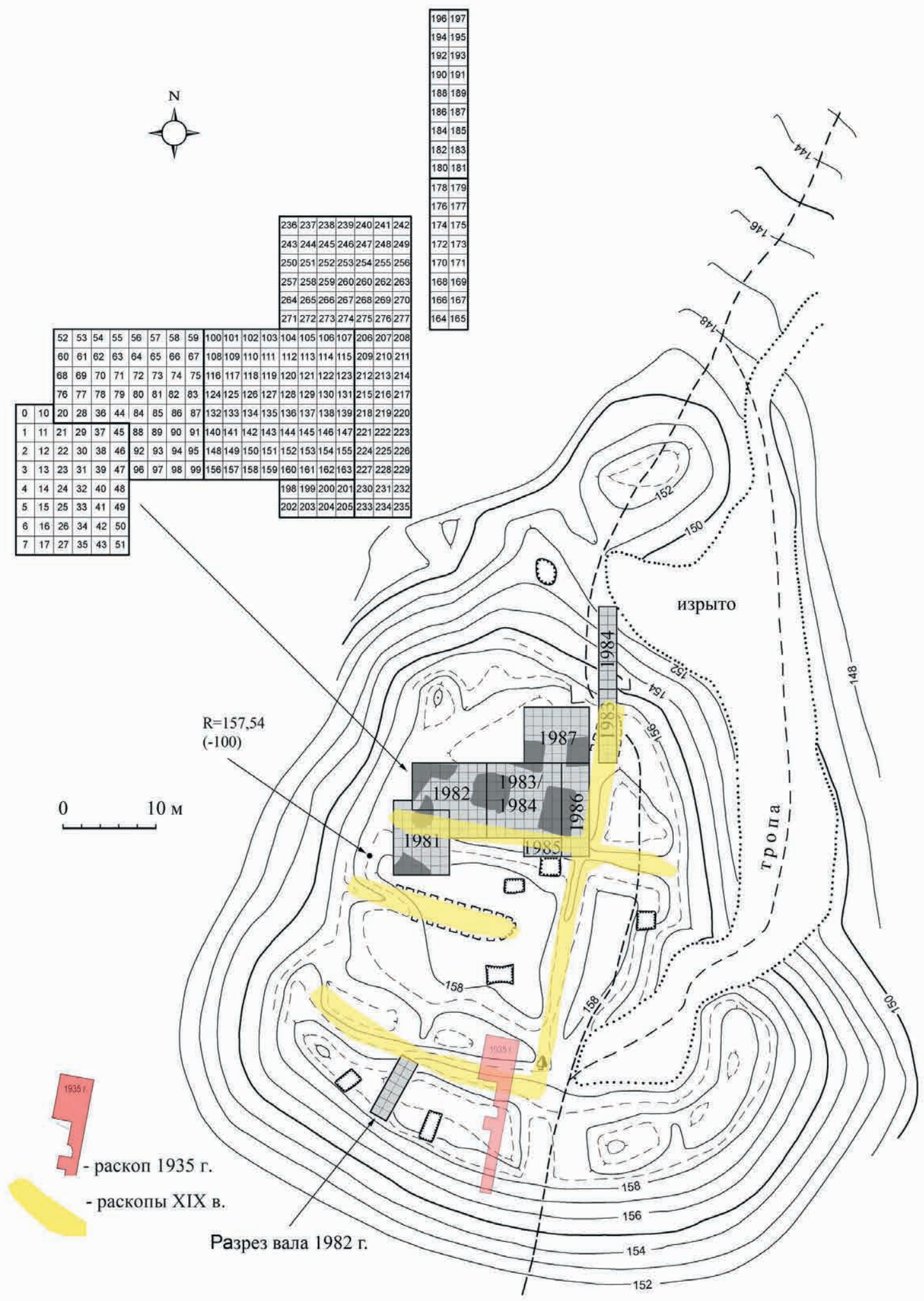

РИС. 74. ПЛАН ДЬЯКОВА ГОРОДИЩА С НАНЕСЕННЫМИ РАСКОПАМИ 

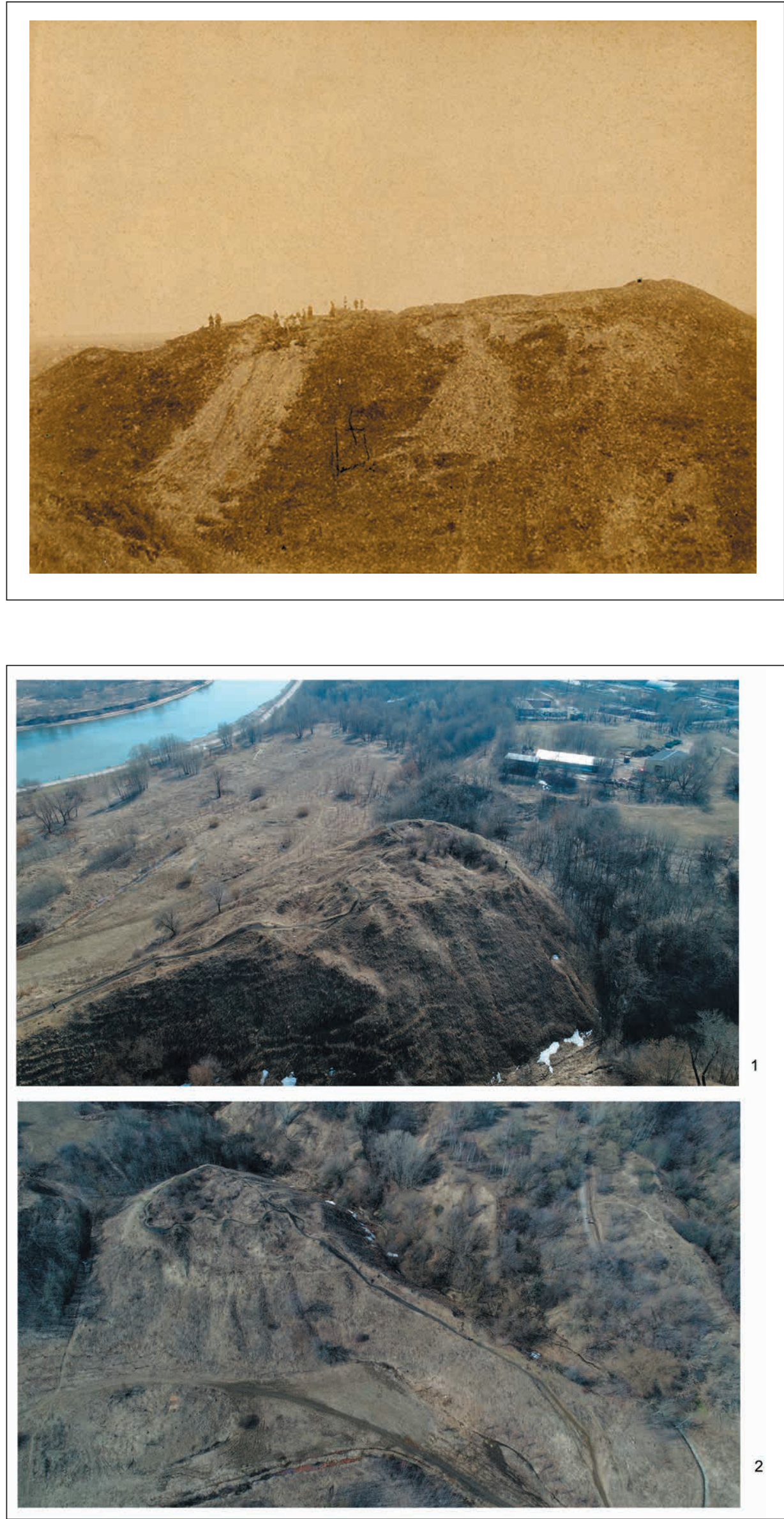

РИС. 75. ДЬЯКОВО ГОРОДИЩЕ ВО ВРЕМЯ АРХЕОЛОГИЧЕСКИХ РАСКОПОК 1890 Г. ФОТО А.Н. ХАРУЗИНА (МУЗЕЙ «КОЛОМЕНСКОЕ») 


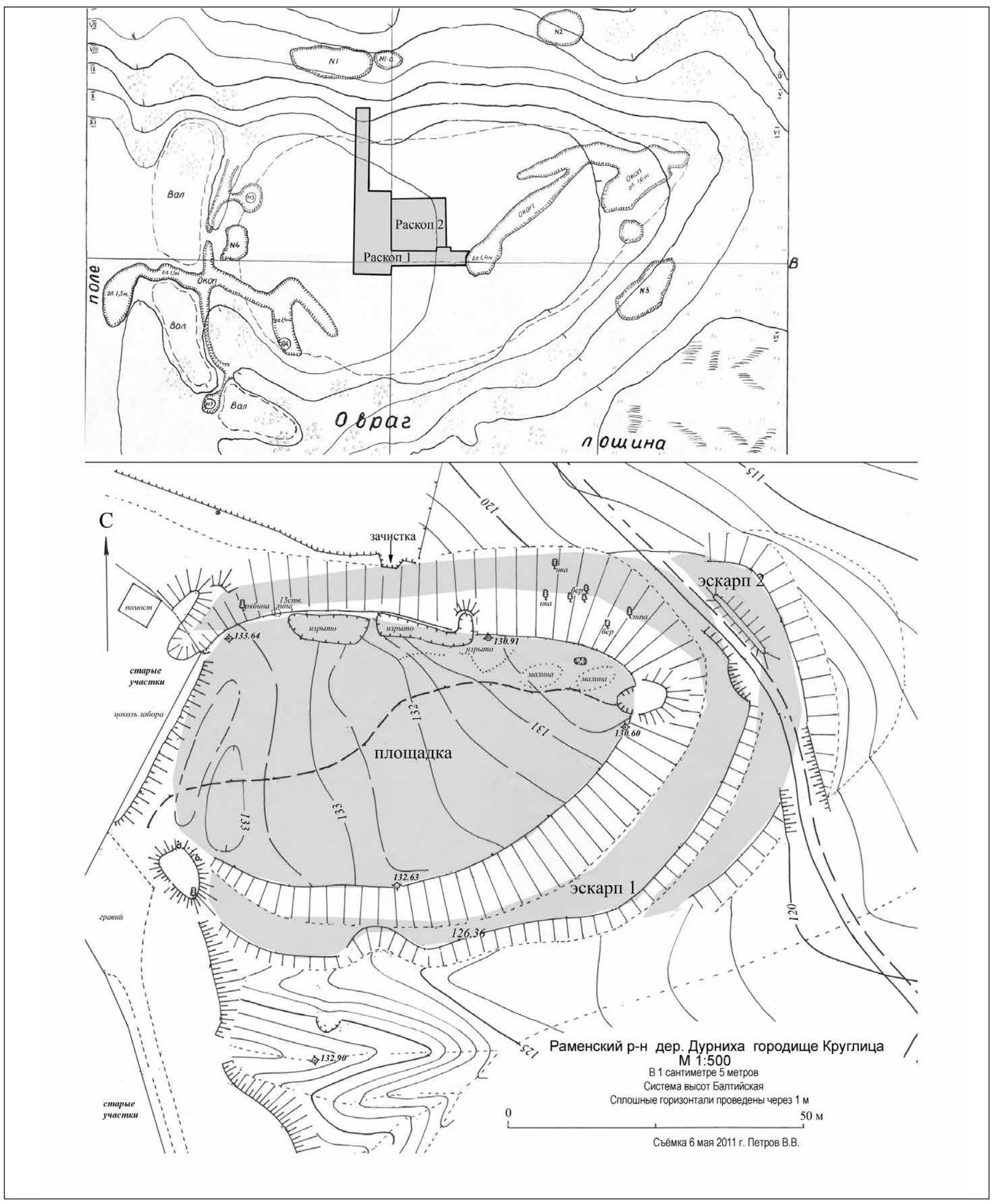

Рис. 77. ПЛАНЫ ГОРОДИЩА КРУГЛИЦА

Вверху съемка 1956 г. Л.И. Пимакина, внизу современная топосъемка 


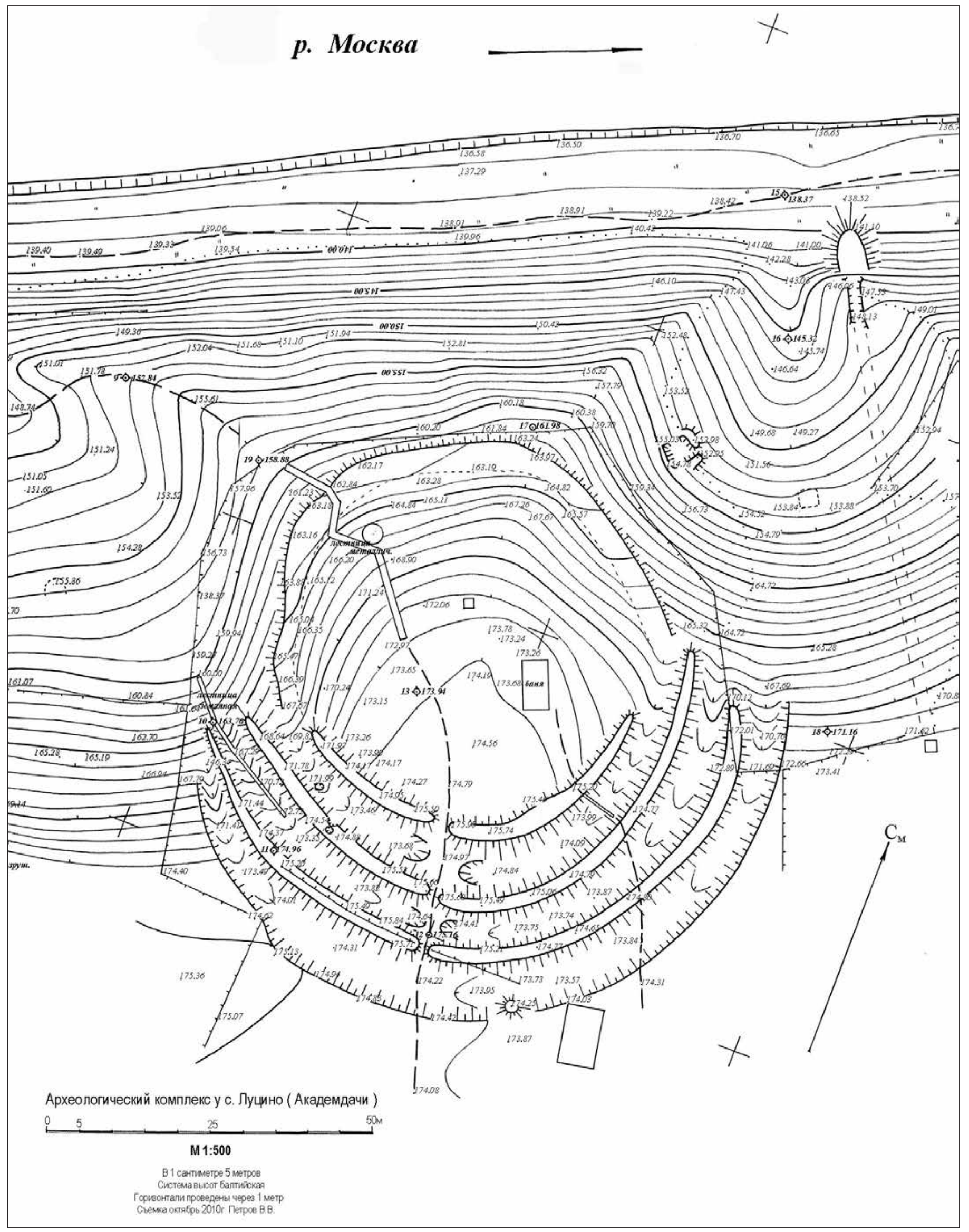

РИС. 78. ПЛАН ГОРОДИЩА ЛУЦИНО 1 

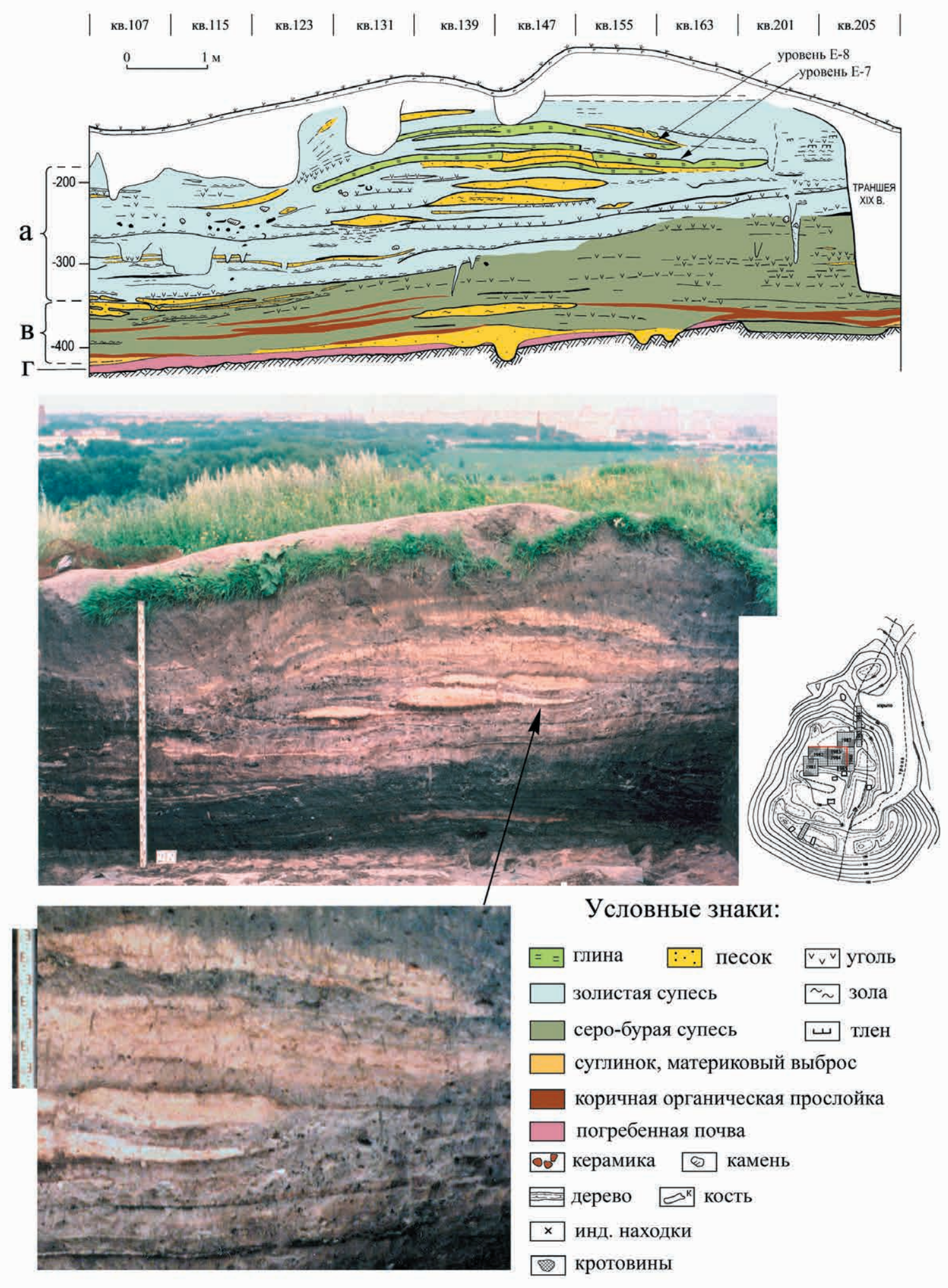

РИС. 79. РАЗРЕЗ КУЛЬТУРНОГО СЛОЯ ДЬЯКОВА ГОРОДИЩА, ВОСТОЧНАЯ СТЕНКА РАСКОПА 1983/1984 ГГ. 

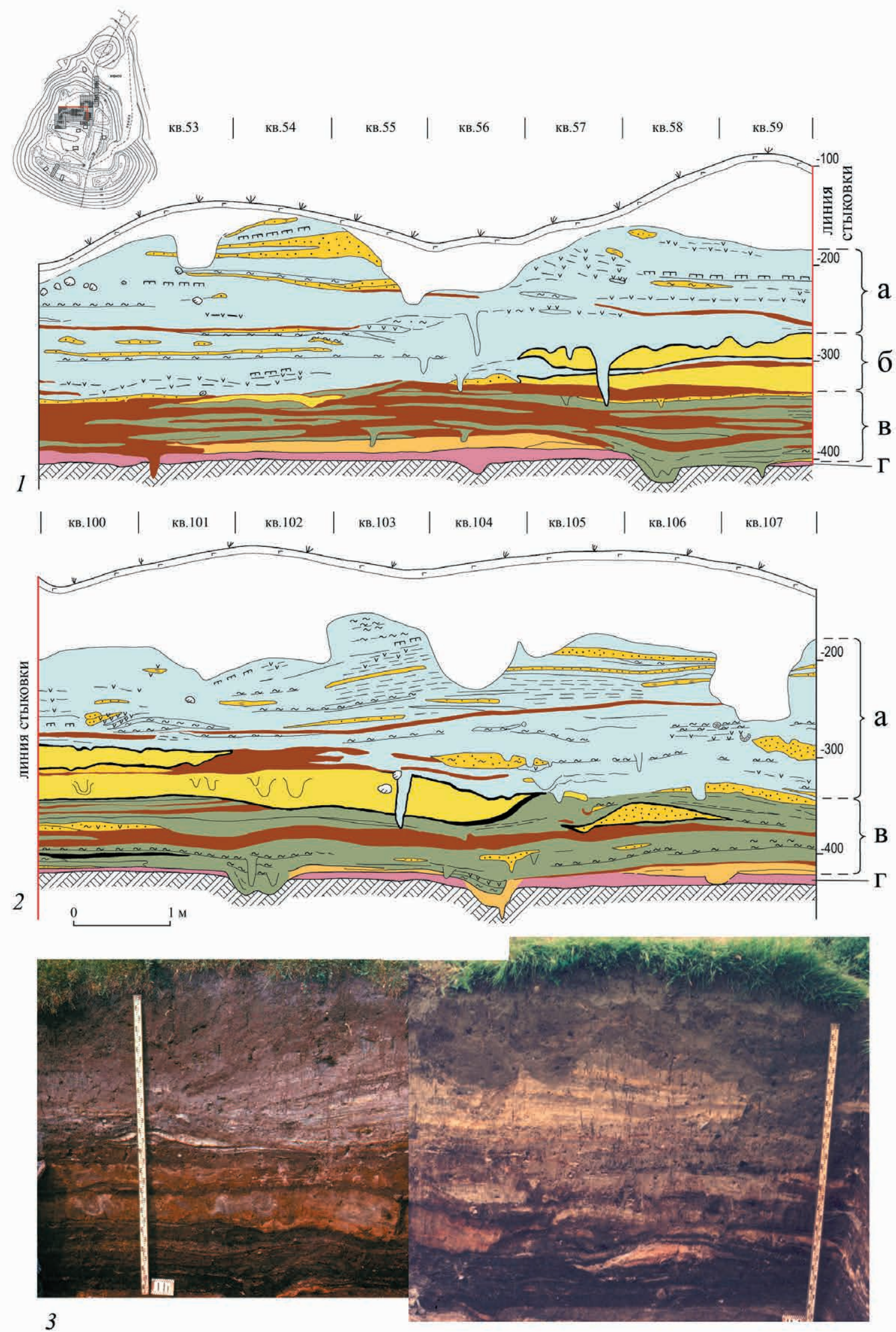

РИС. 80. РАЗРЕЗЫ КУЛЬТУРНОГО СЛОЯ ДЬЯКОВА ГОРОДИЩА, СЕВЕРНАЯ И ВОСТОЧНАЯ СТЕНКИ РАСКОПОВ 1982, $1983 / 1984$ ГГ. 


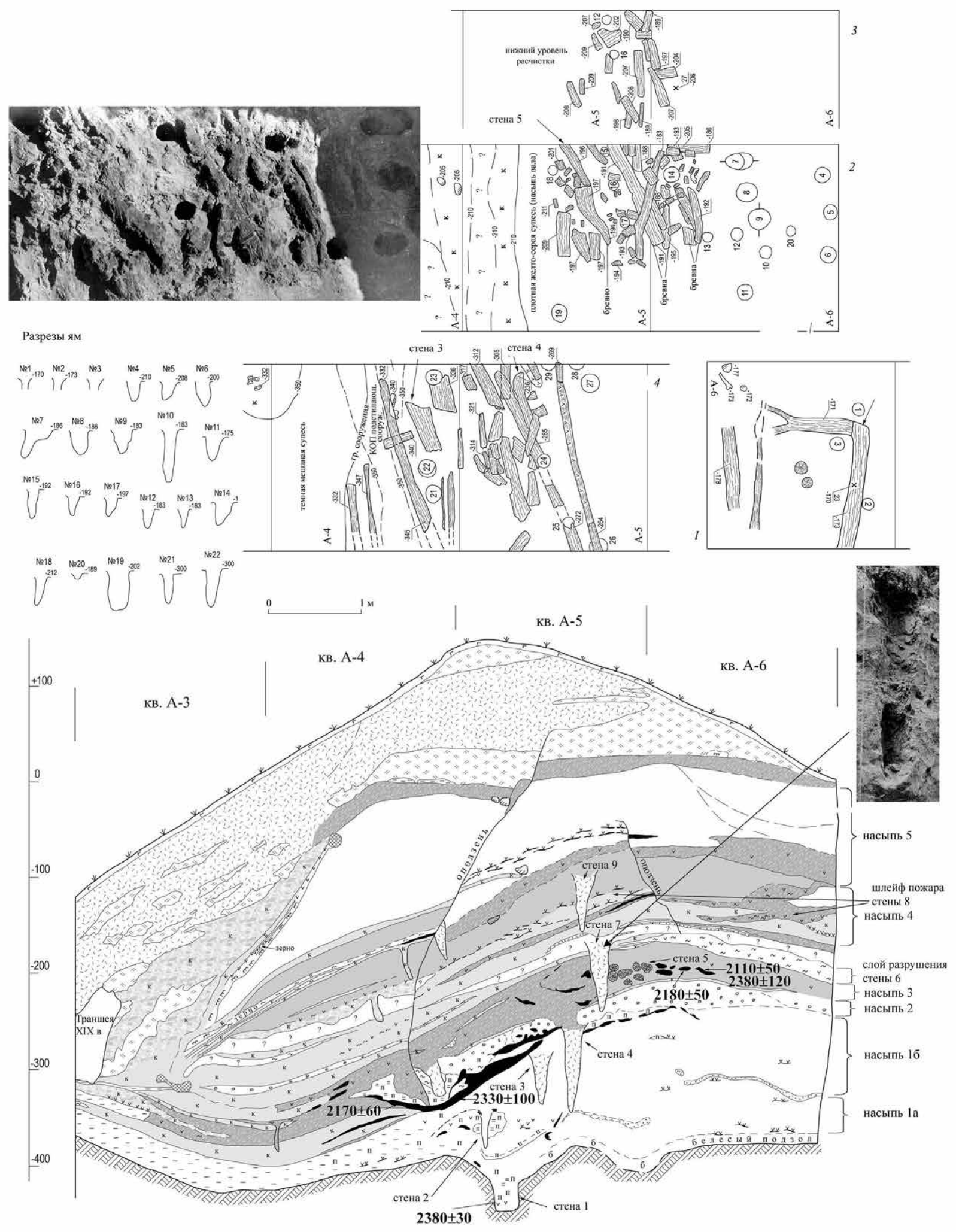

РИС. 81. РАЗРЕЗ ВАЛА ДЬЯКОВА ГОРОДИЩА, 1982 Г. 

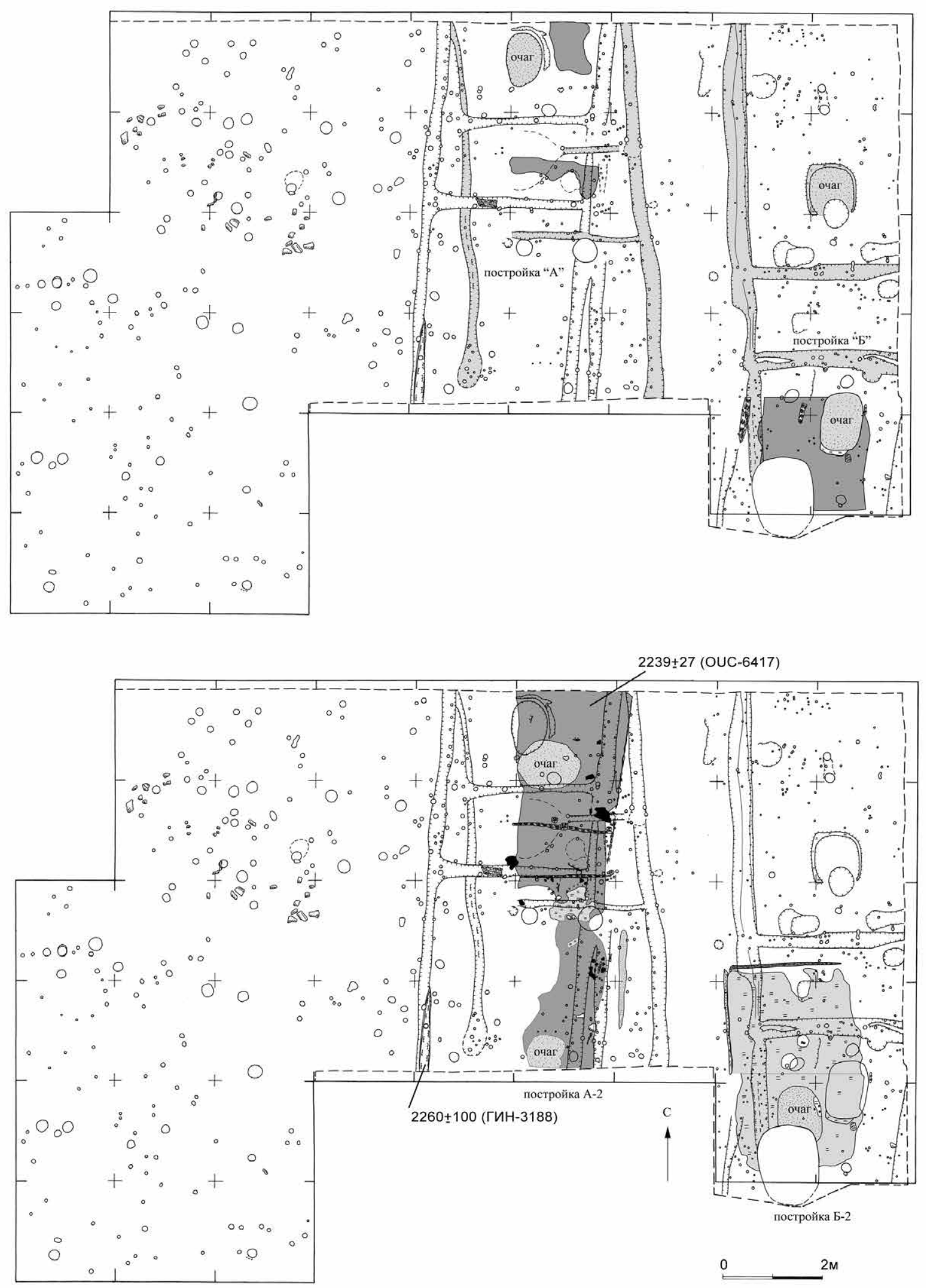

РИС. 82. ДЬЯКОВО ГОРОДИЩЕ, РАСКОП НА ПЛОЩАДКЕ. ДВА НИЖНИХ УРОВНЯ ПОСТРОЕК 

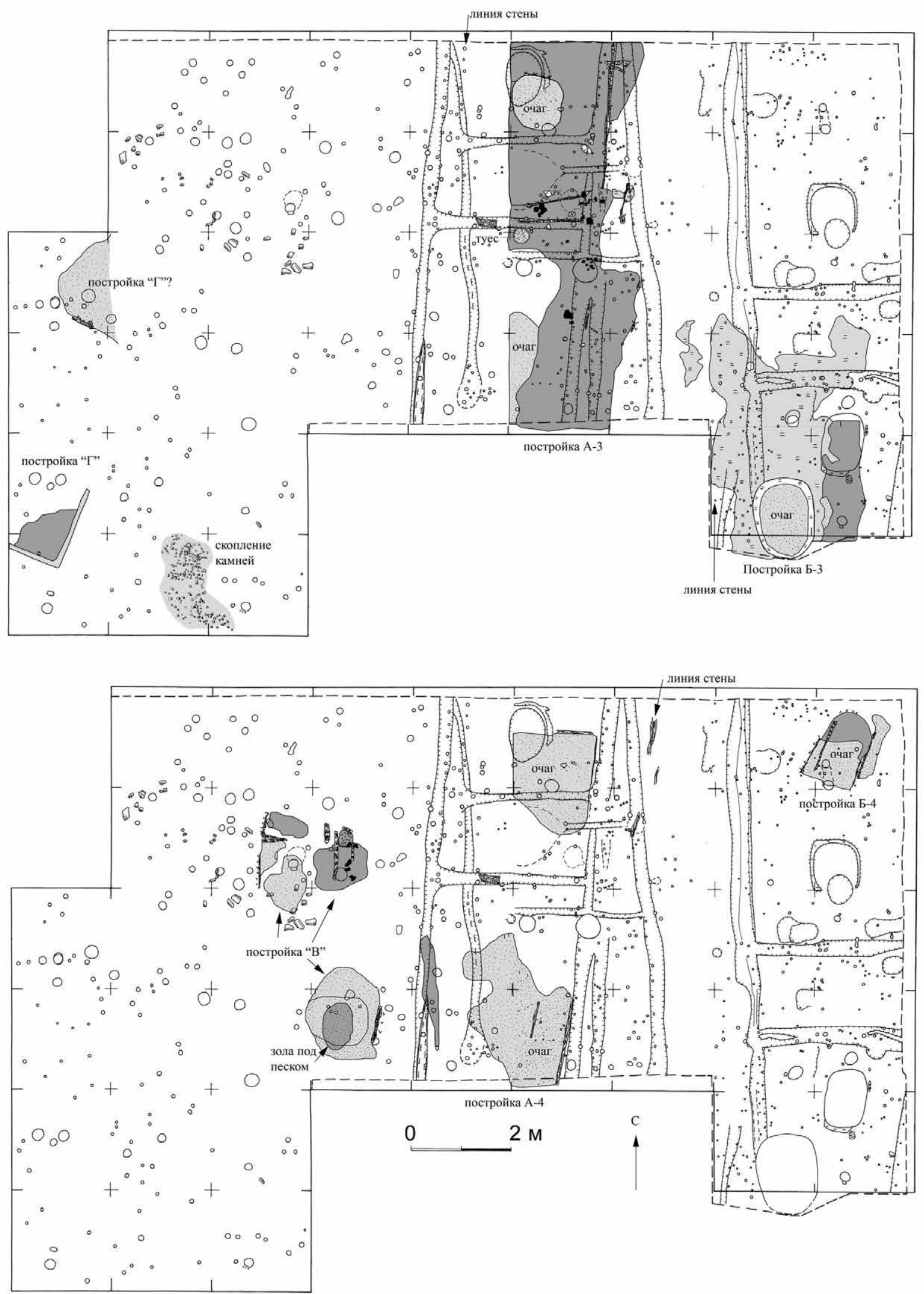

РИС. 83. ДЬЯКОВО ГОРОДИЩЕ РАСКОП НА ПЛОЩАДКЕ. ПОСТРОЙКИ ТРЕТЬЕГО И ЧЕТВЕРТОГО УРОВНЕЙ (СЧИТАЯ СНИЗУ) 

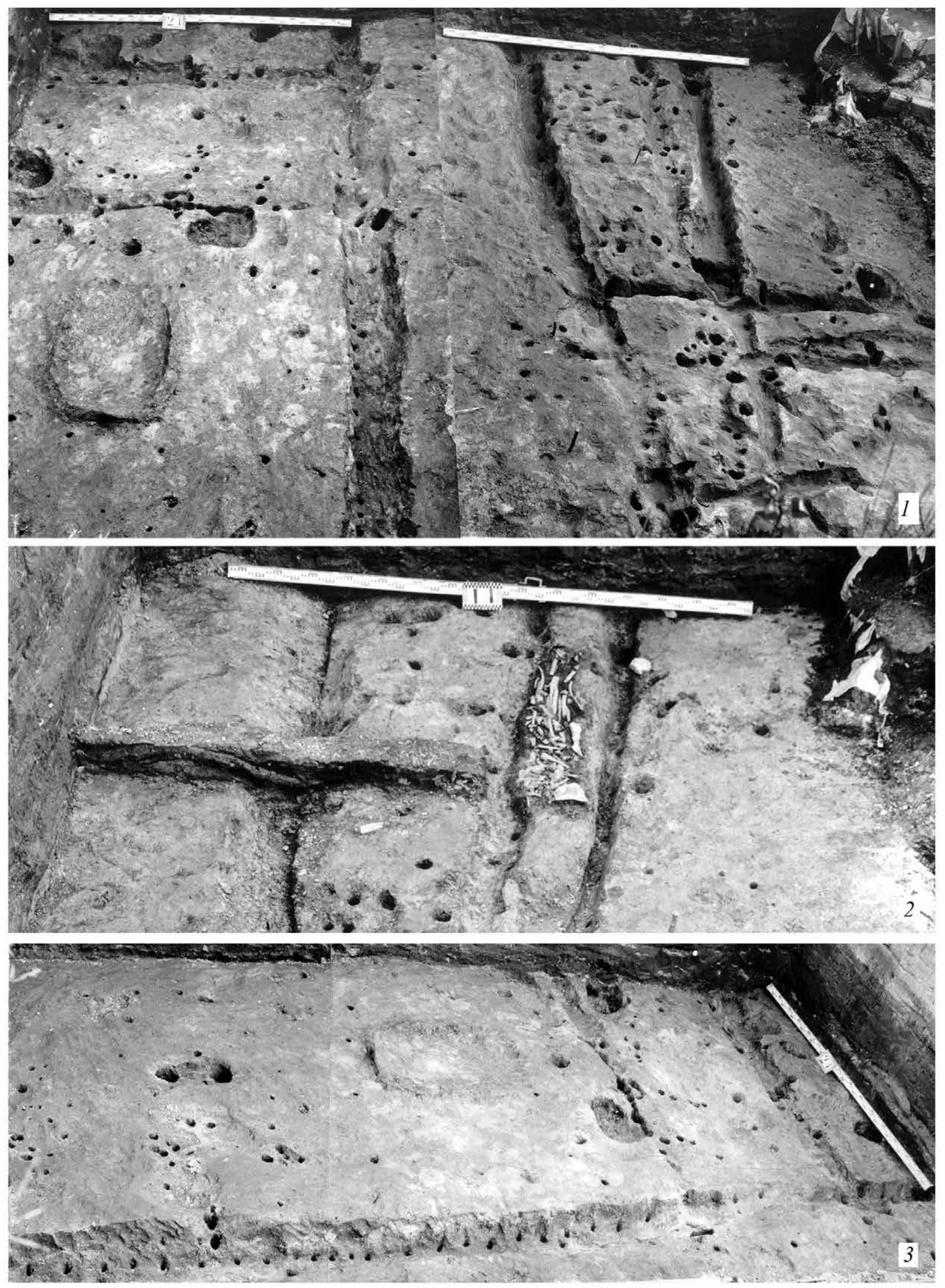

РИС. 84. ДЬЯКОВО ГОРОДИЩЕ. ЗАЧИЩЕННАЯ ПОВЕРХНОСТЬ МАТЕРИКА С ОСТАТКАМИ ПОСТРОЕК ТИПА ДЛИННЫХ ДОМОВ 

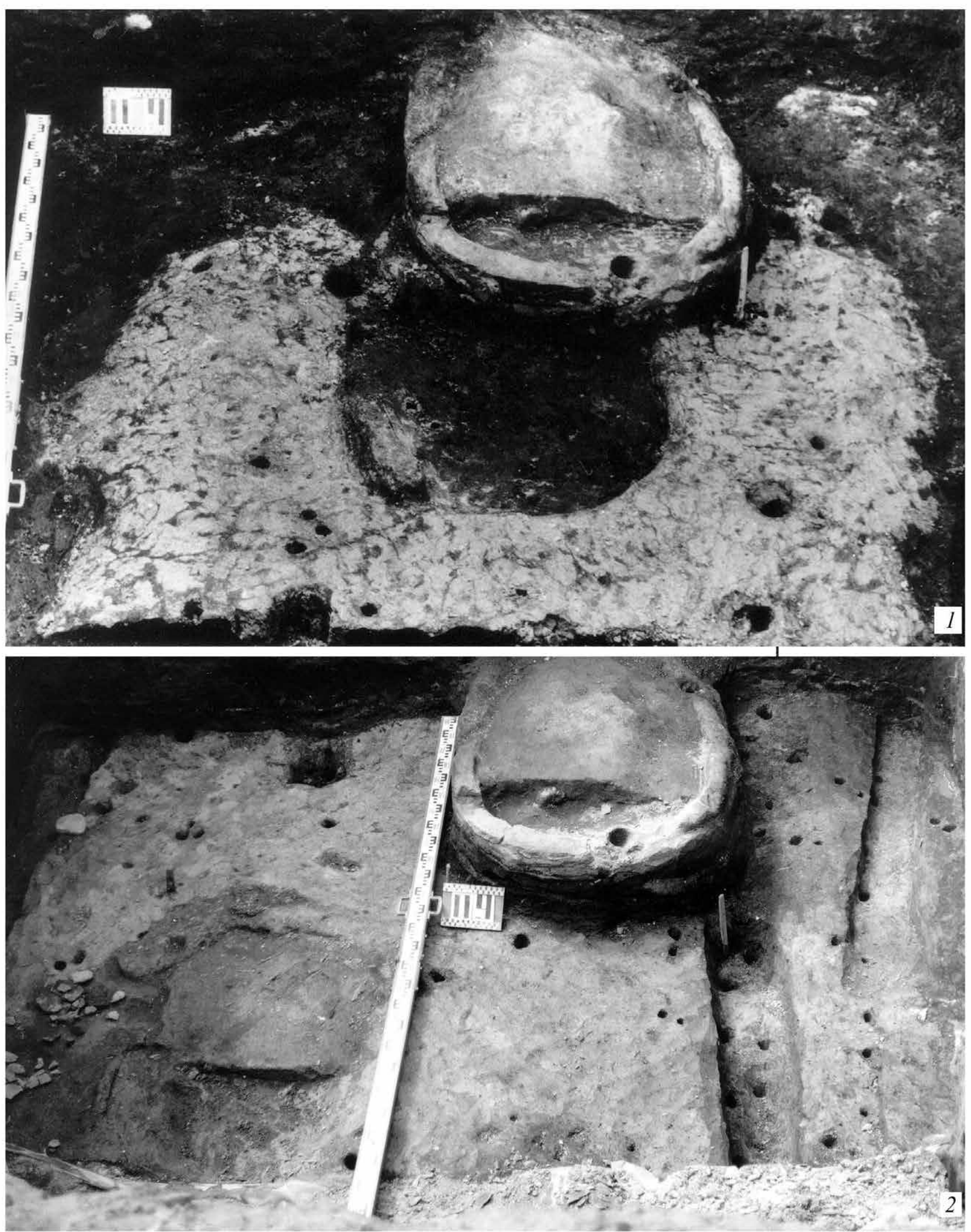

РИС. 85. ДЬЯКОВО ГОРОДИЩЕ. ГЛИНОБИТНЫЕ ОЧАГИ И ОБМАЗАННЫЕ ГЛИНОЙ ПОЛЫ В ПОСТРОЙКЕ НИЖНЕГО СЛОЯ 


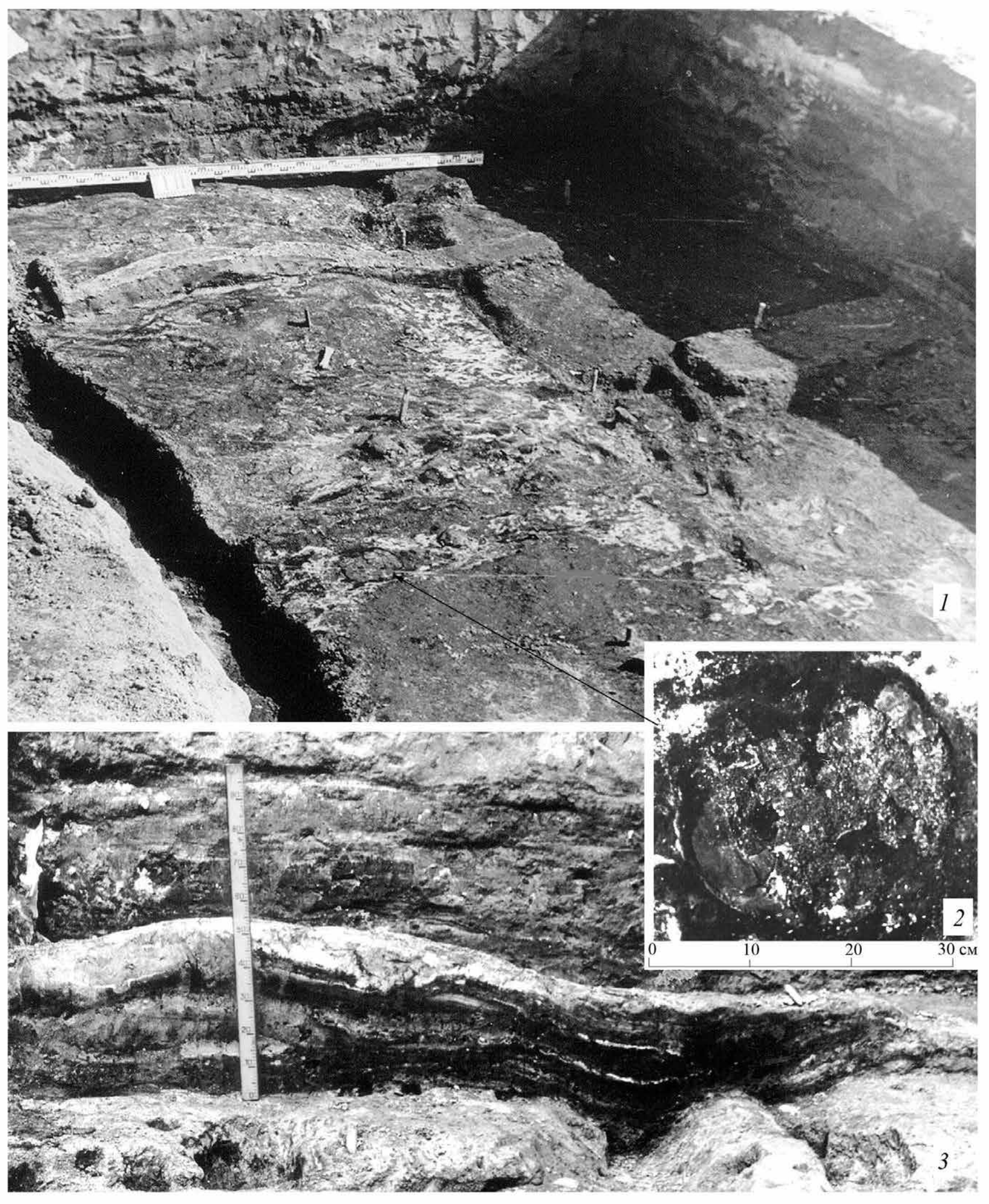

РИС. 86. ДЬЯКОВО ГОРОДИЩЕ. ЗАЧИСТКА ПОВЕРХНОСТИ ПОЛА ПОСТРОЙКИ В НИЖНЕМ СЛОЕ (ВВЕРХУ); ДНИЩЕ БЕРЕСТЯНОГО ТУЕСА НА ПОЛУ, ПРОФИЛЬ БРОВКИ ЧЕРЕЗ ОЧАГ (ВНИЗУ) 


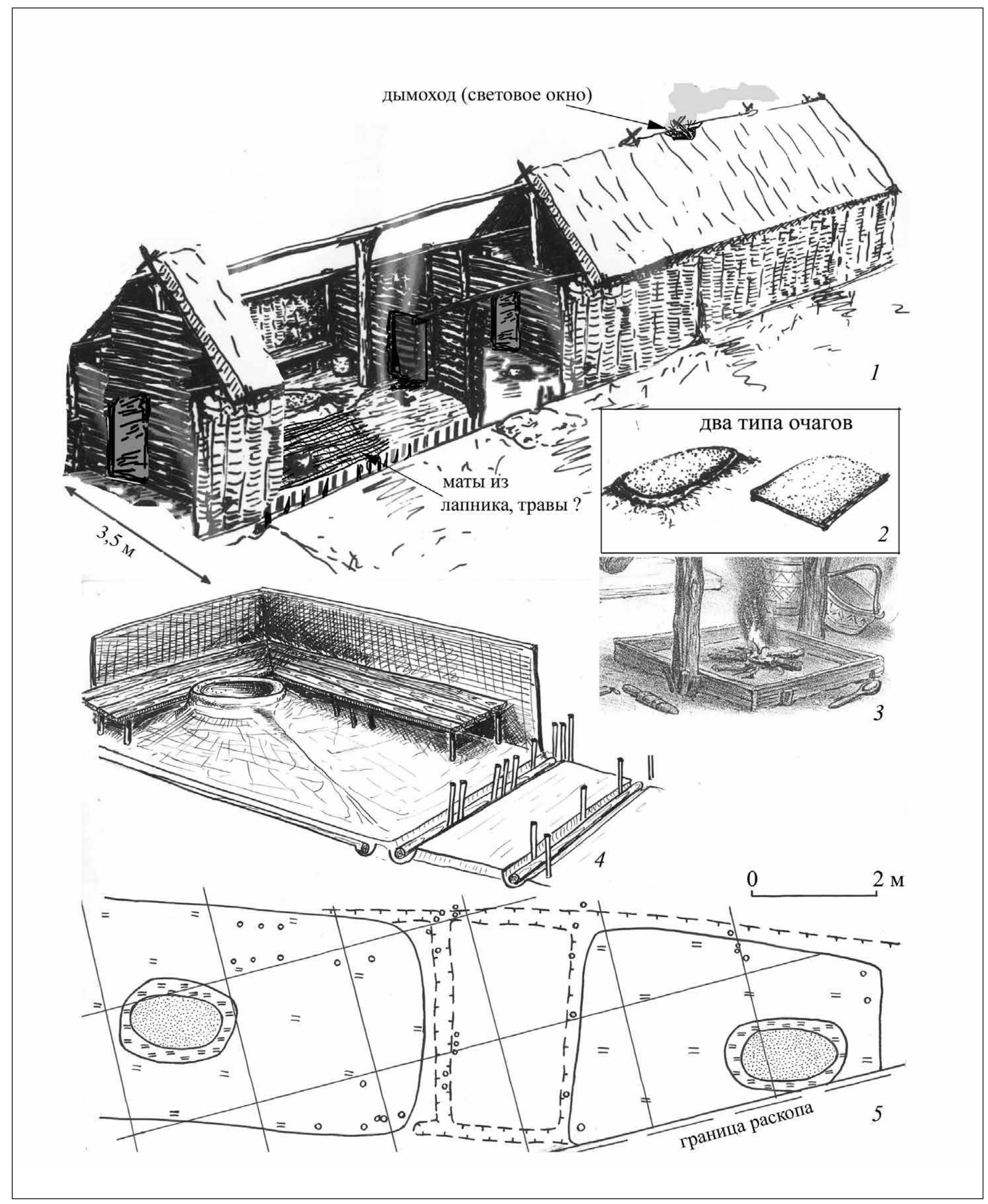

РИС. 87. РЕКОНСТРУКЦИЯ ВНЕШНЕГО ВИДА ЖИЛИЩА ТИПА ДЛИННОГО ДОМА ПО МАТЕРИАЛАМ РАСКОПОК ГОРОДИЩА БОРШЕВА. СРАВНИТЕЛЬНЫЙ МАТЕРИАЛ ОЧАГ У ХАНТОВ (3) 
западный борт раскопа 1

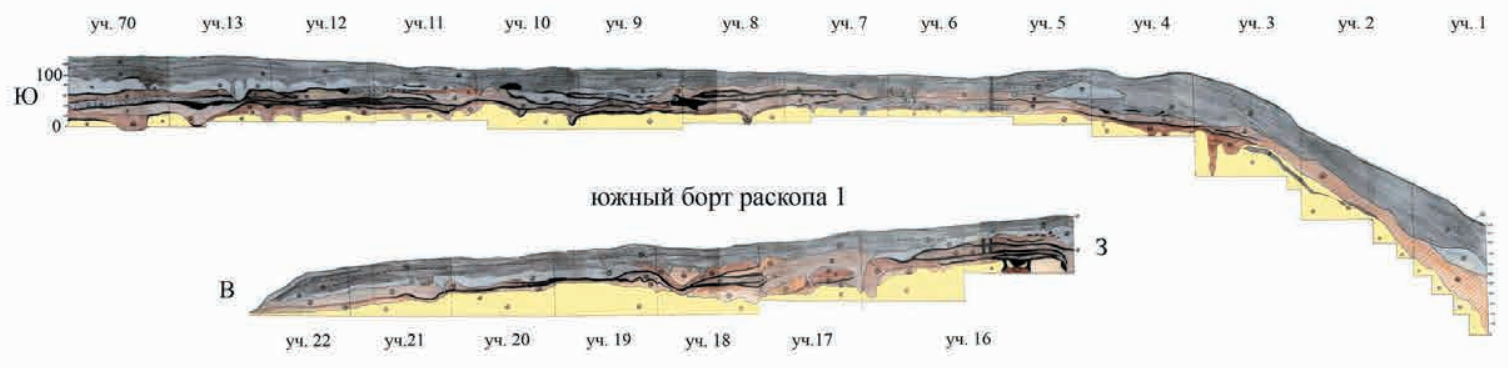

северный борт раскопа 2
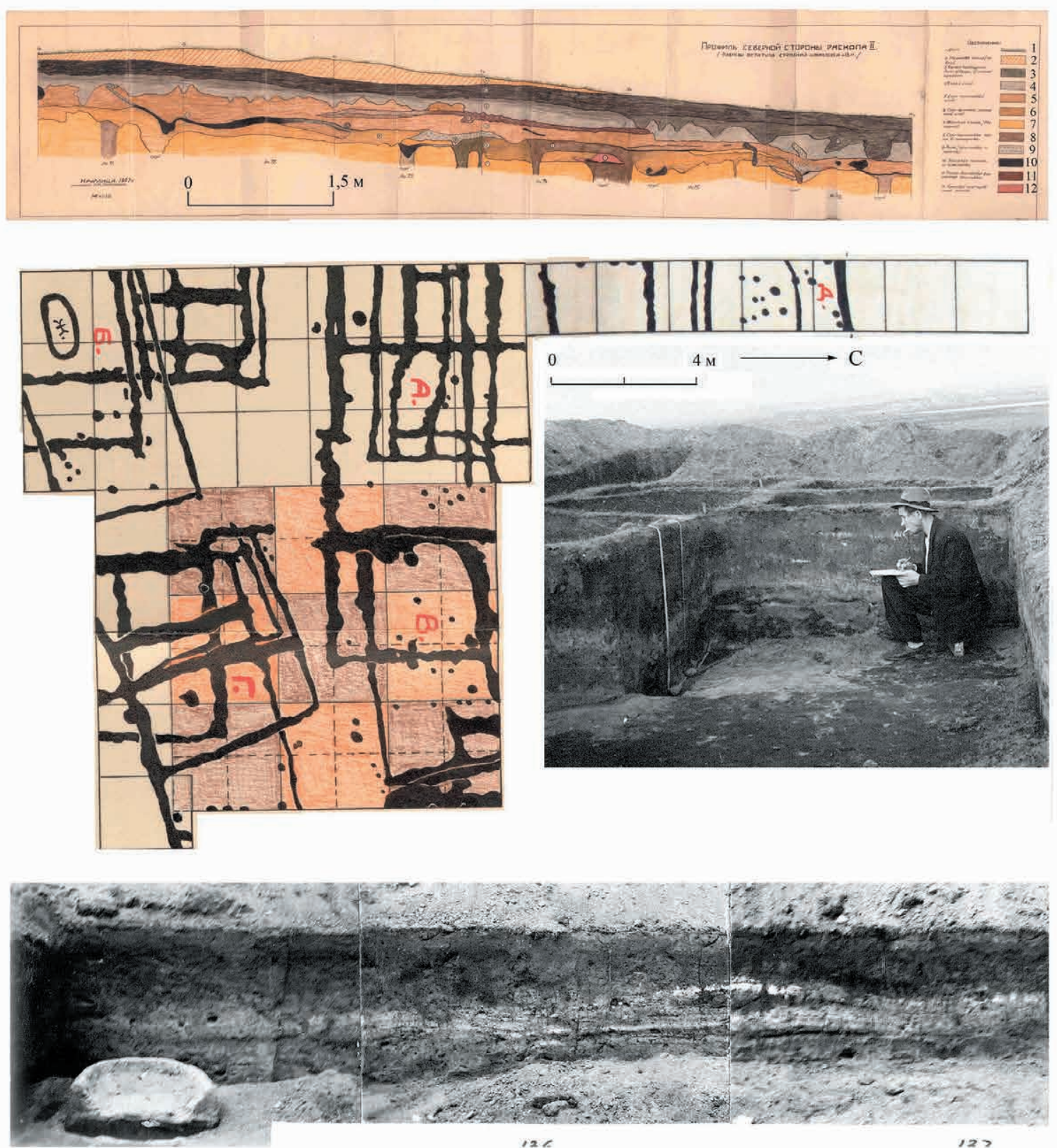

122

123

РИС. 88. МАТЕРИАЛЫ РАСКОПОК ГОРОДИЩА КРУГЛИЦА ИЗ ОТЧЕТОВ Л.И. ПИМАКИНА 1956 И 1957 ГГ. ПРОФИЛЬ БОРТА РАСКОПА, ПЛАН ЗАЧИСТКИ МАТЕРИКА, ФОТО ОЧАГА 

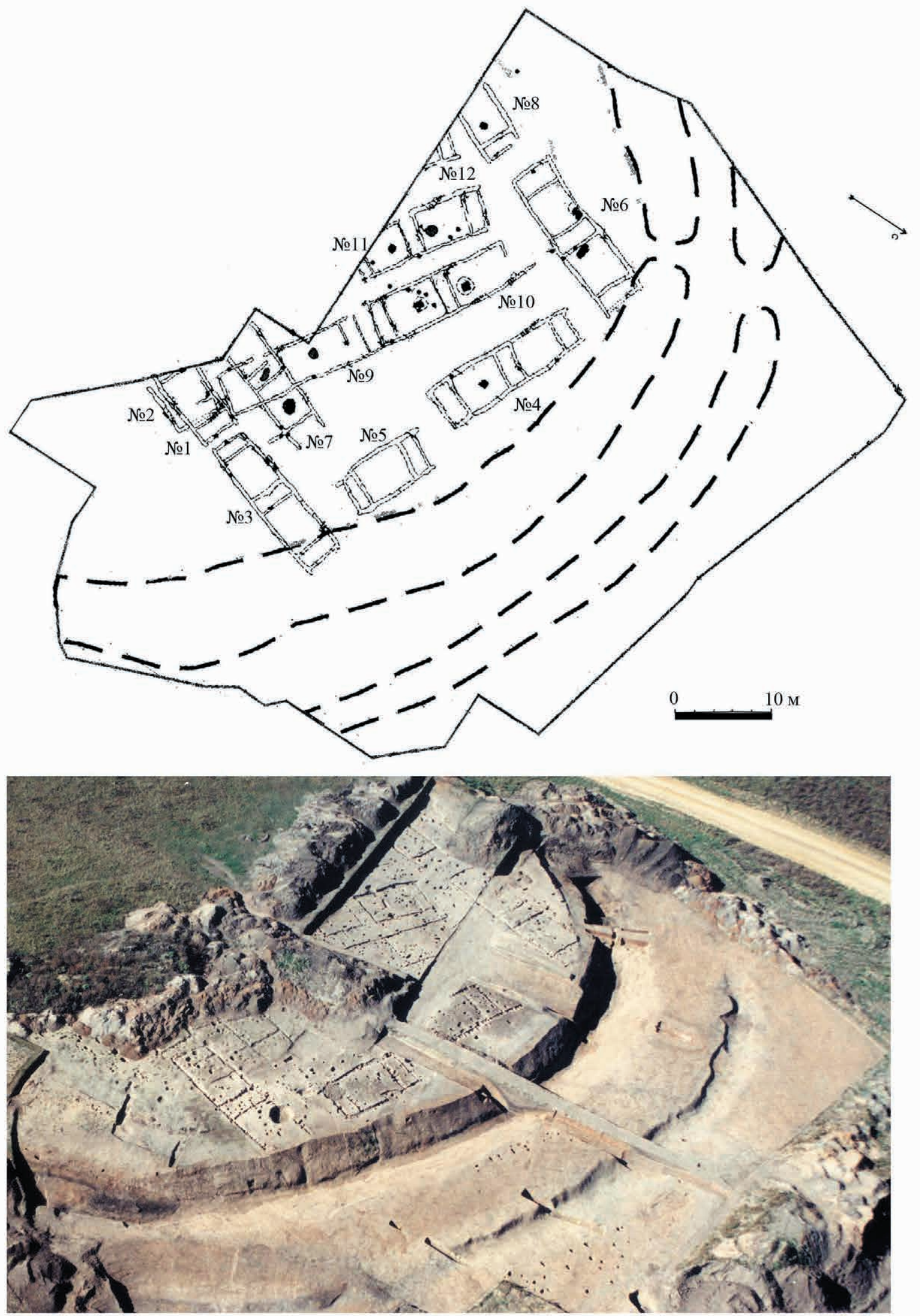

РИС. 89. ПЛАН И ФОТО РАСКОПА ГОРОДИЩА НАСТАСЬИНО (ПО: ЭНГОВАТОВА, 2004, 2009) 


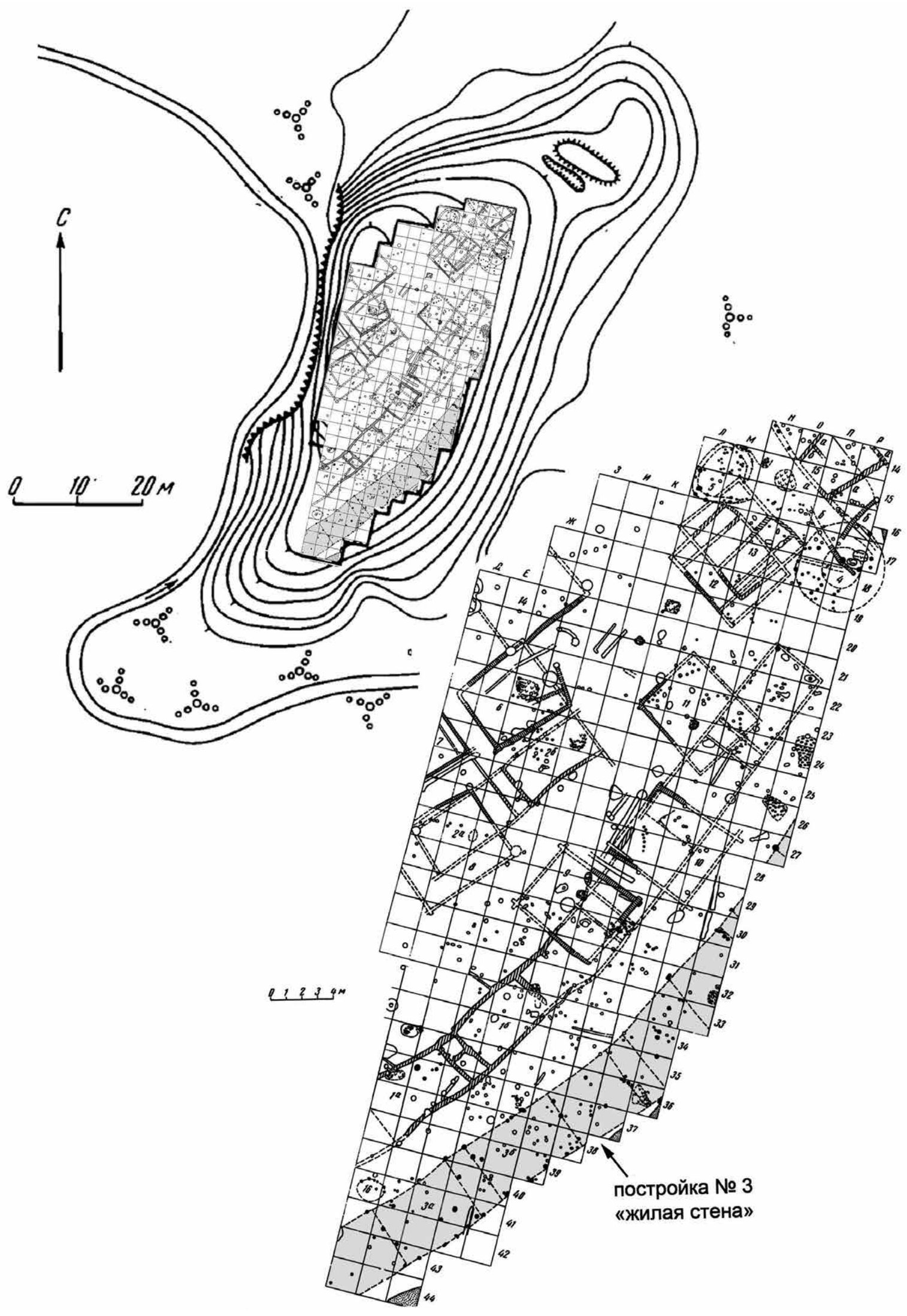

РИС. 90. ТОПОГРАФИЧЕСКИЙ ПЛАН И ПЛАН РАСКОПА НА ГОРОДИЩЕ КУЗНЕЧИКИ (ПО: ДУБЫНИН, 1970) 


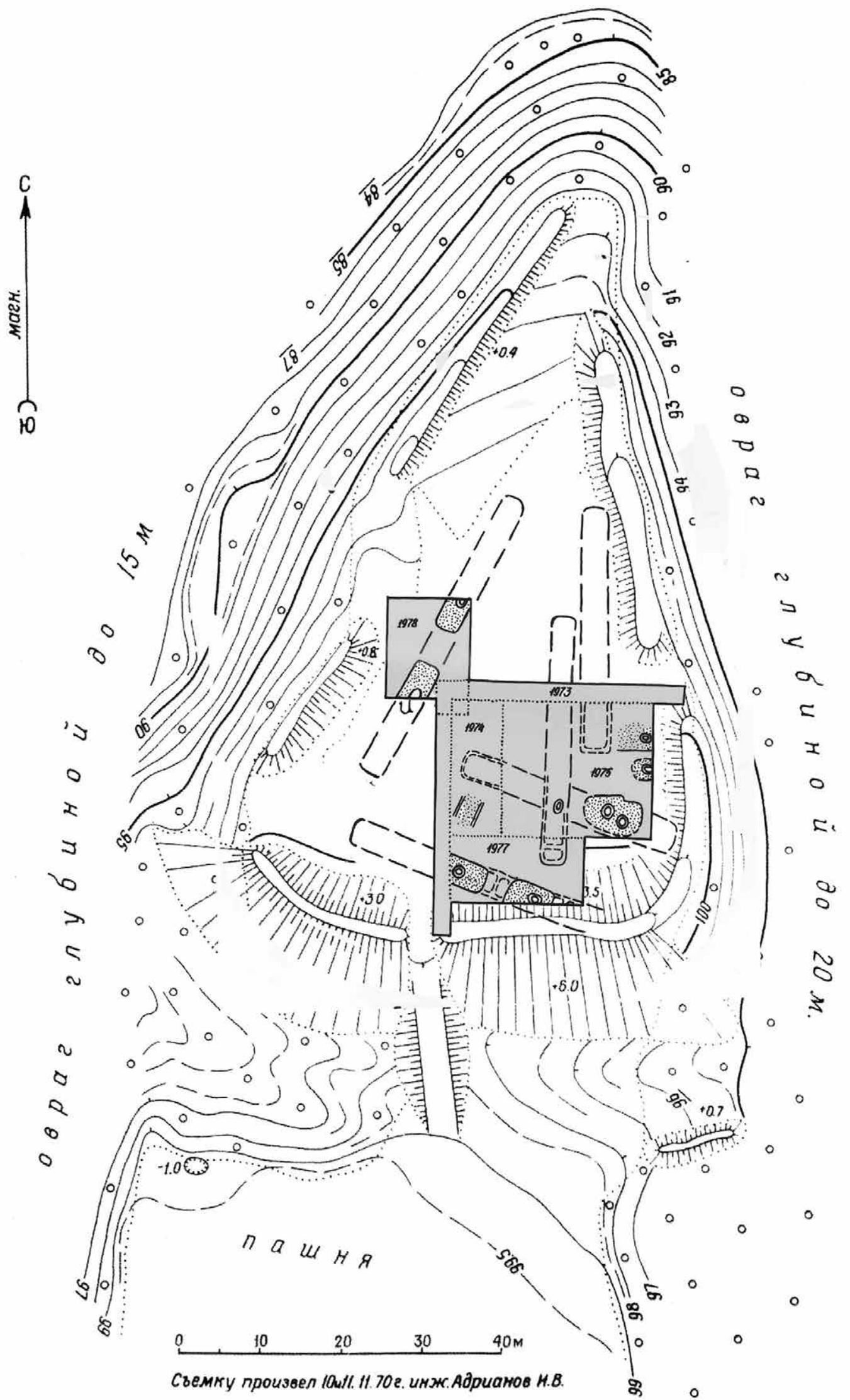

РИС. 91. ПЛАН ГОРОДИЩА БОРШЕВА С НАНЕСЕННЫМИ РАСКОПАМИ И ПОСТРОЙКАМИ (ПО ОТЧЕТАМ Х.И. КРИС) 

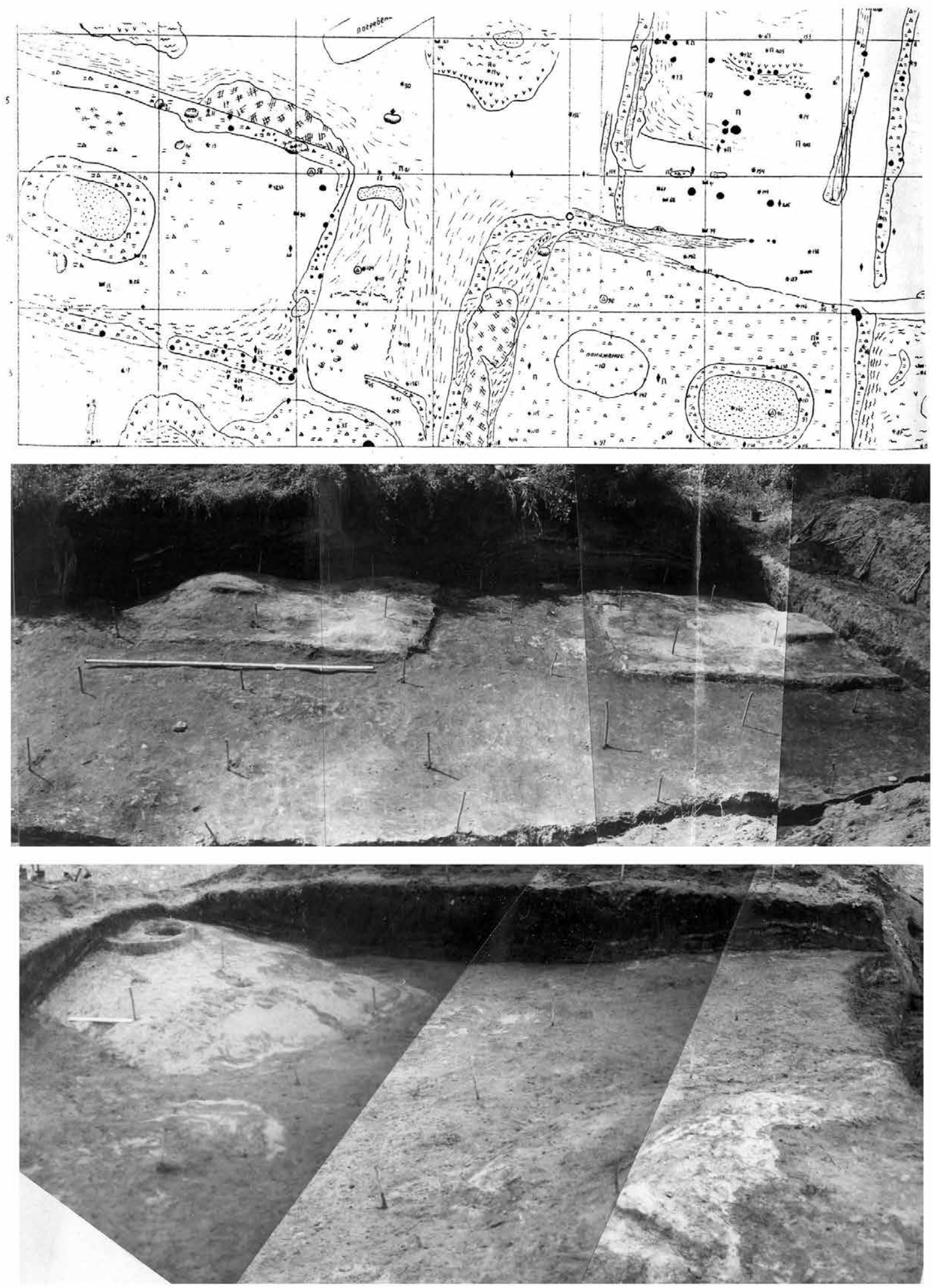

РИС. 92. ПОСТРОЙКИ ТИПА ДЛИННЫХ ДОМОВ НА ГОРОДИЩЕ БОРШЕВА (ПО ОТЧЕТАМ Х.И. КРИС) 


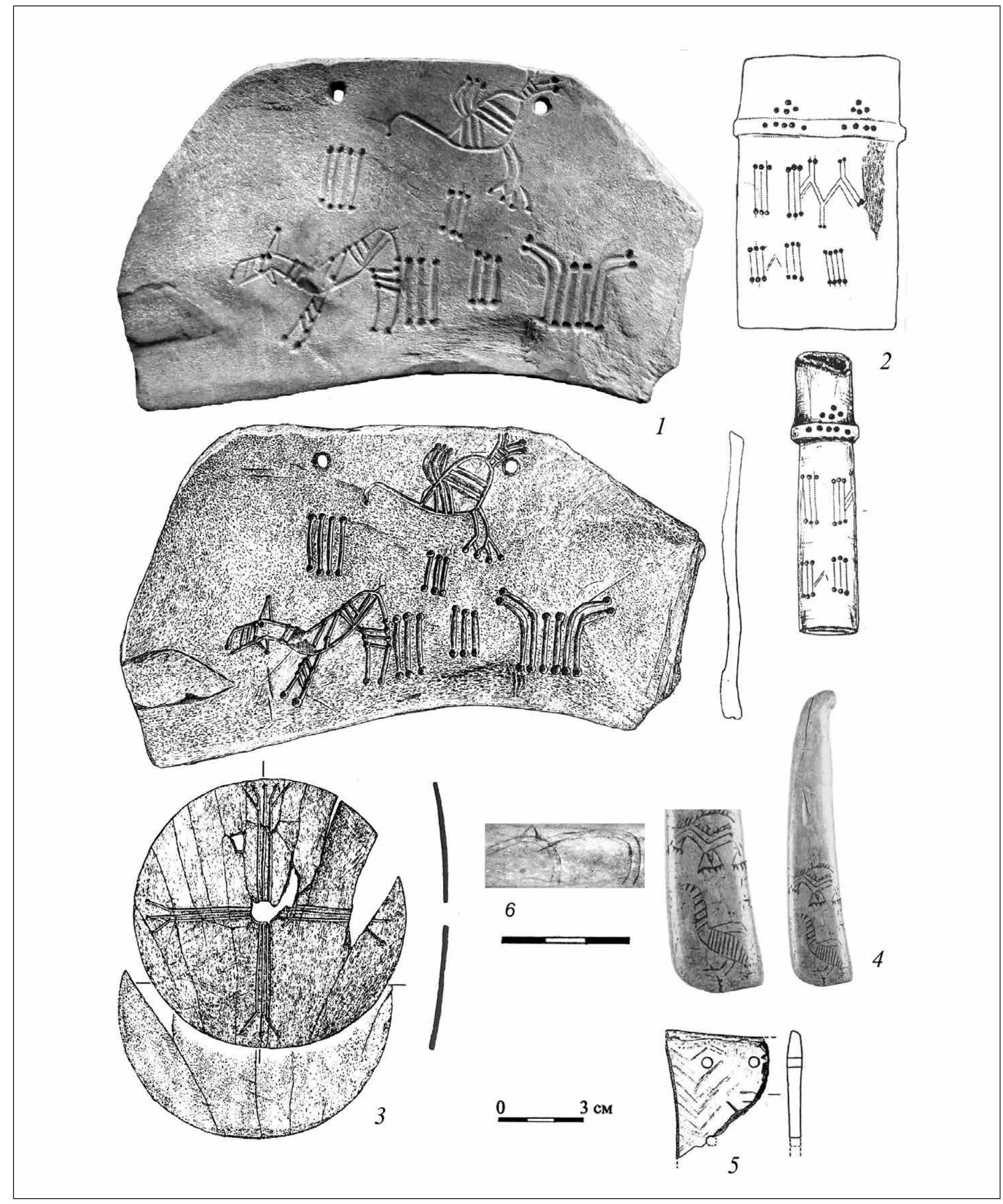

РИС. 93. ПРЕДМЕТЫ ИСКУССТВА ИЗ РАСКОПОК РАННЕДЬЯКОВСКИХ ГОРОДИЩ

1 - Боршева, 2 - Бабушкино, 3, 6 - Настасьино (по А.В. Энговатовой, 2009), 4 - Мамоново, 5 - Боровский курган (Исторический музей, Музей истории Москвы). 1, 3 - рисунки А.Е. Кравцова 


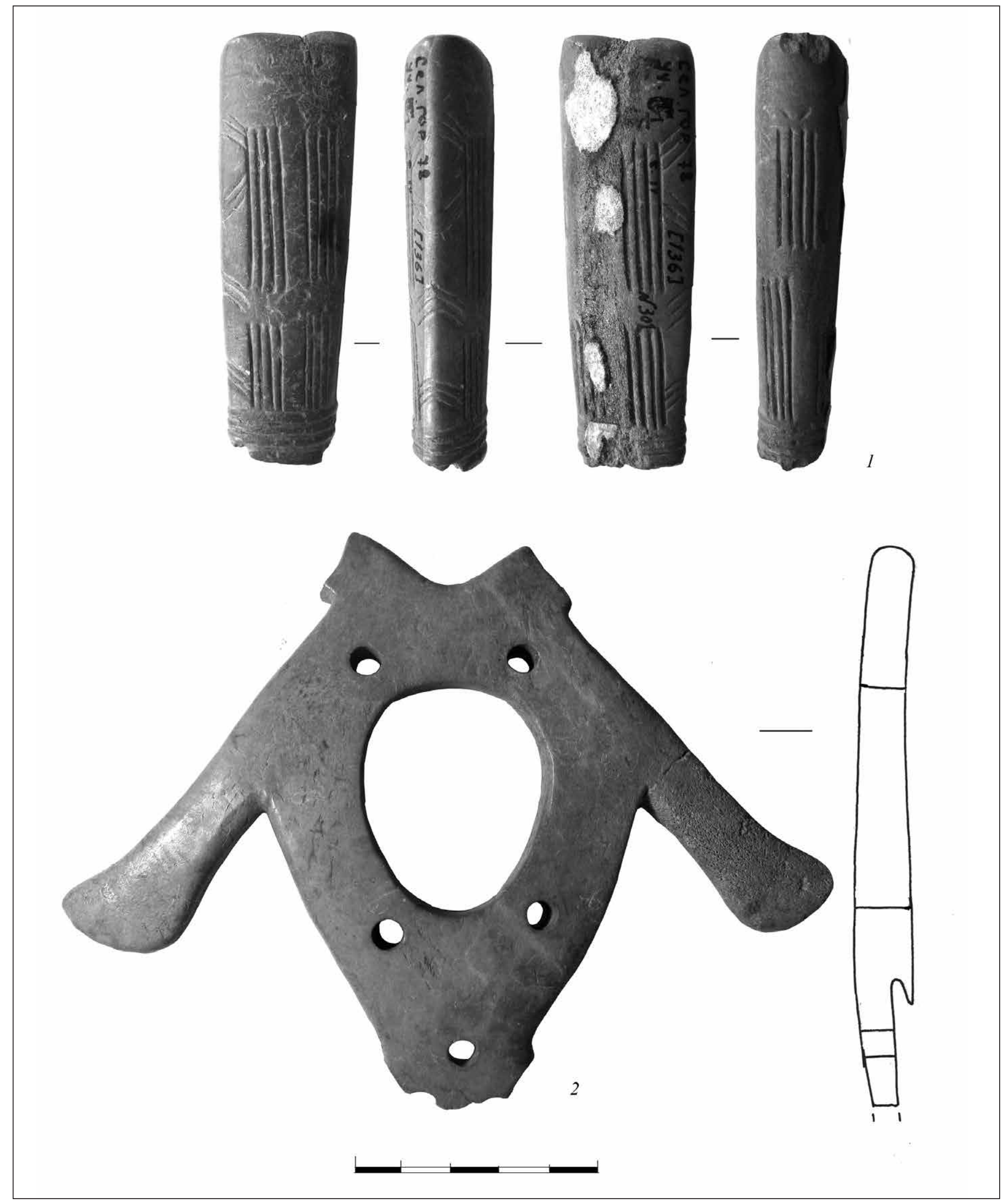

РИС. 94. КОСТЯНЫЕ ИЗДЕЛИЯ ИЗ НИЖНЕГО СЛОЯ СЕЛЕЦКОГО ГОРОДИЩА (РАСКОПКИ И.Л. ЧЕРНАЯ, БРОННИЦКИЙ МУЗЕЙ) 


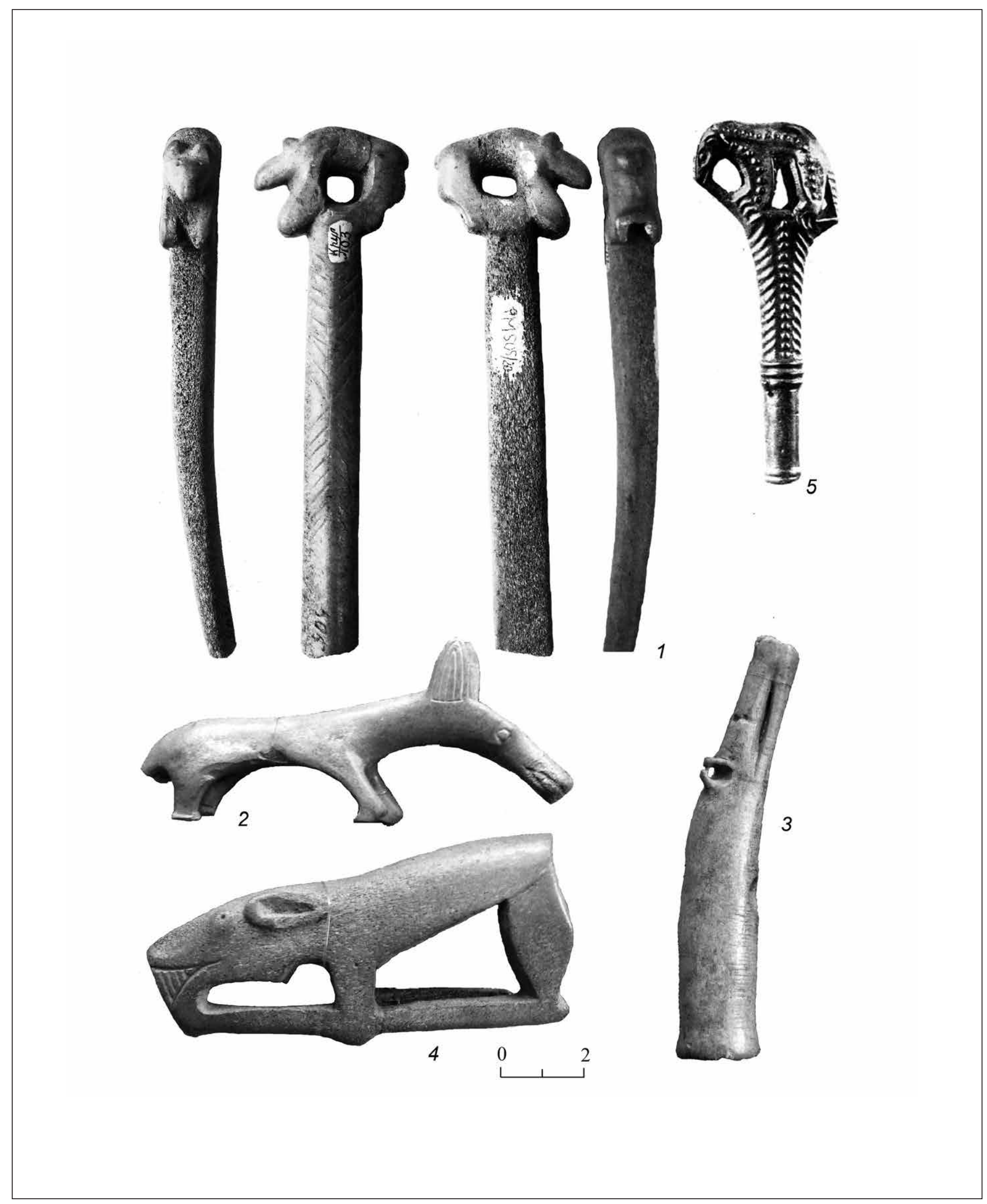

РИС. 95. ОБЪЕМНЫЕ СКУЛЬПТУРНЫЕ ИЗОБРАЖЕНИЯ С ДЬЯКОВСКИХ ГОРОДИЩ

1 - Круглица, 2, 3 - Дьяково, 4 - Боршева, 5 - сравнительный материал из Подчеремного клада (по: Городцов, 1937) 


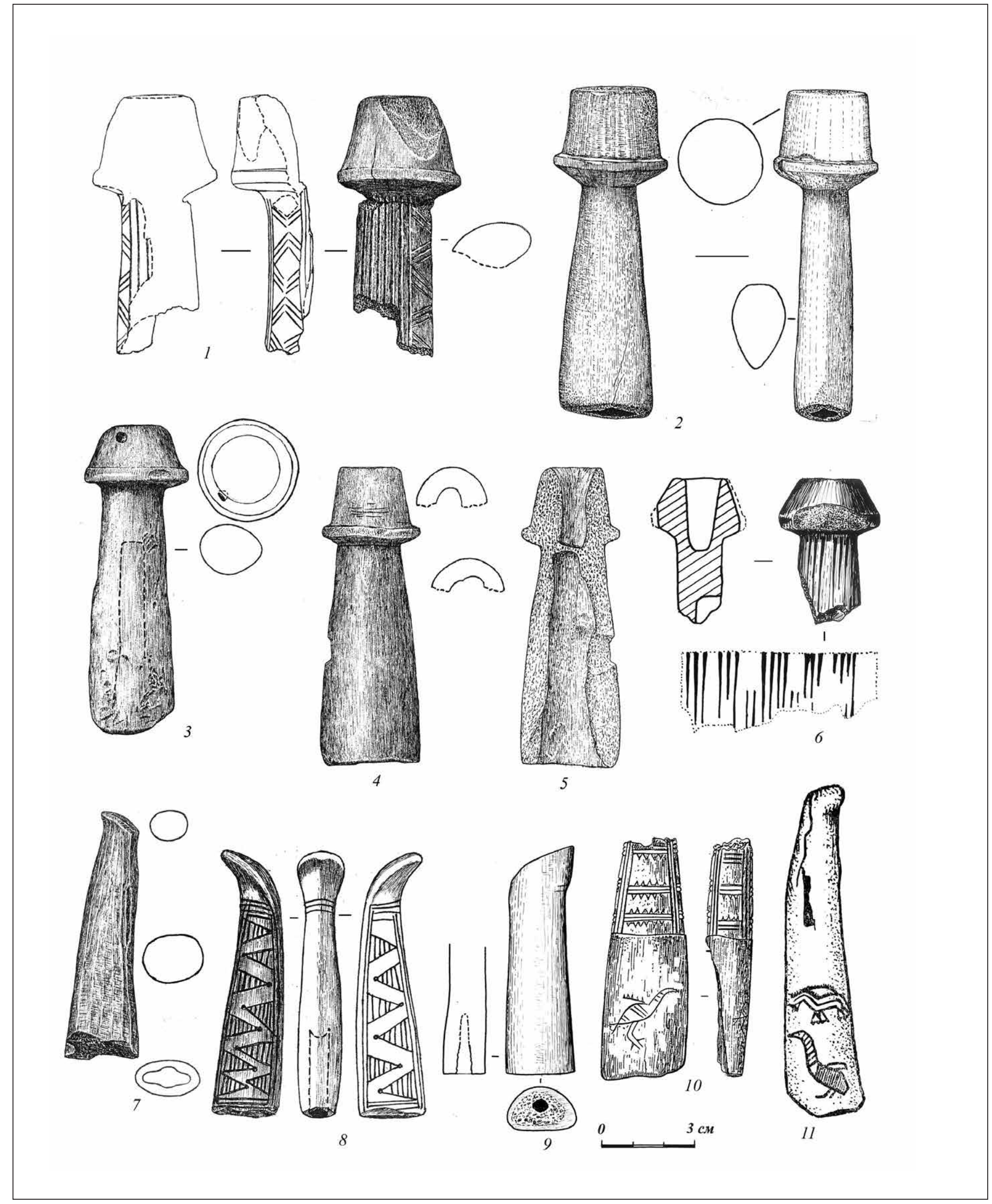

РИС. 96. КОСтЯНЫЕ РУКОЯТИ НОЖЕЙ С ДЬЯКОВСКИХ ГОРОДИЩ

1-5 - Боршева, 6 - Дунино, 11 - Мамоново, 7-10 - селище Дубровицы (раскопки М.И. Гоняного) 


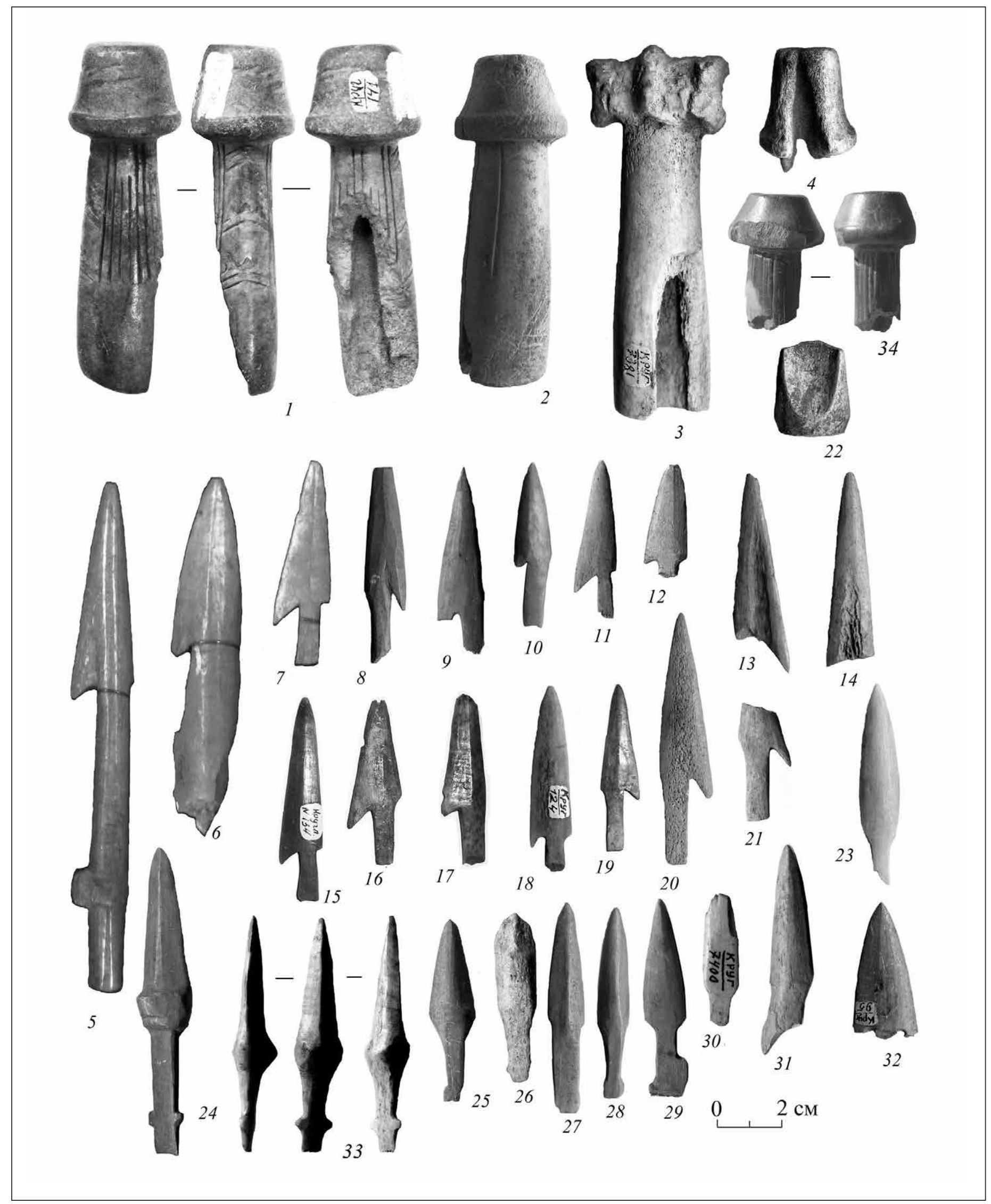

РИС. 97. КОСтЯНЫЕ РУКОЯТИ И СТРЕЛЫ С ГОРОДИЩ 


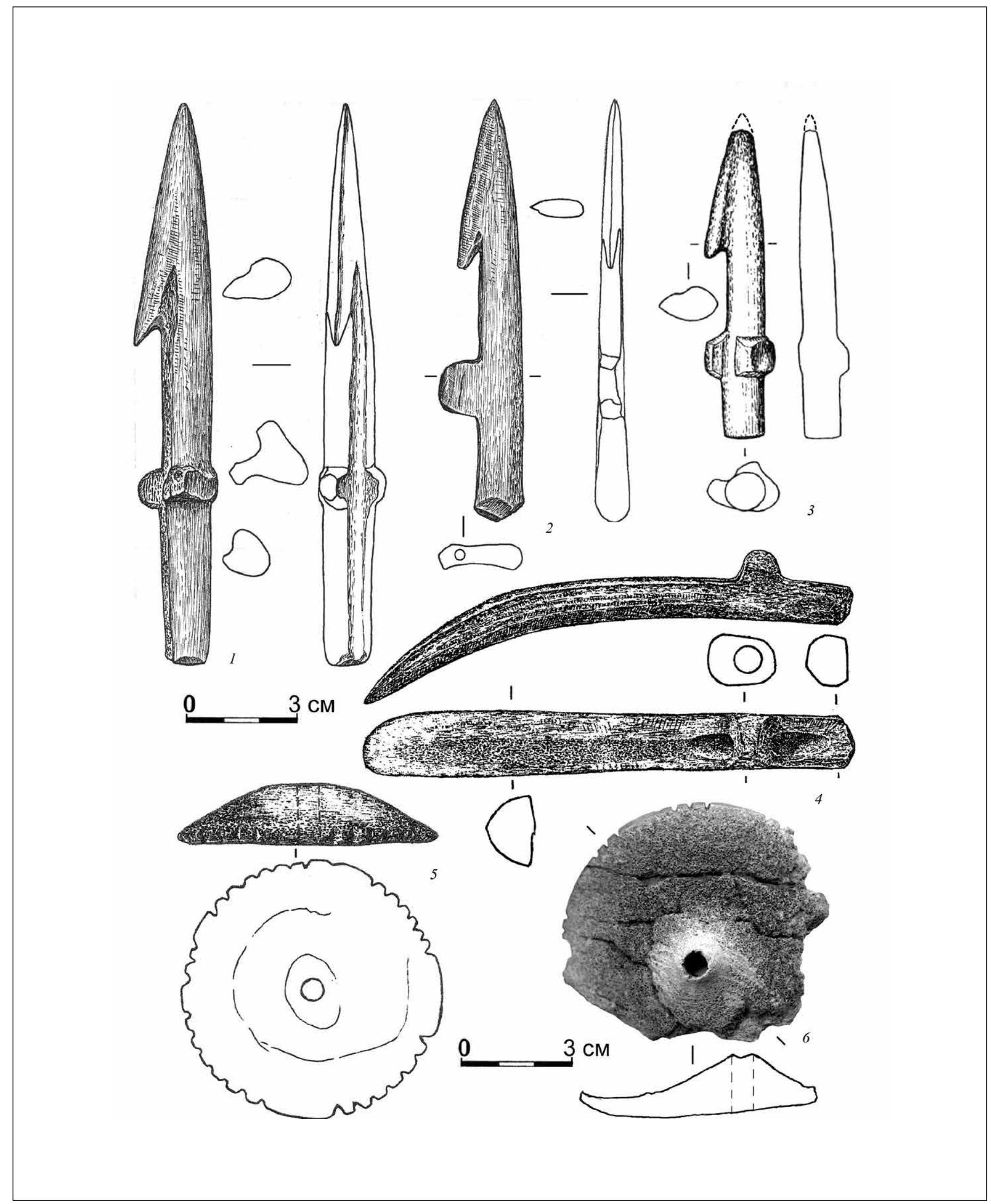

РИС. 98. КОСТЯНЫЕ ГАРПУНЫ, КОЧЕДЫК И ГРУЗИКИ

1, 2, 4, 5 -городище Боршева, 6 - Круглица, 3 - Боровский курган. Рисунки А.Е. Кравцова 

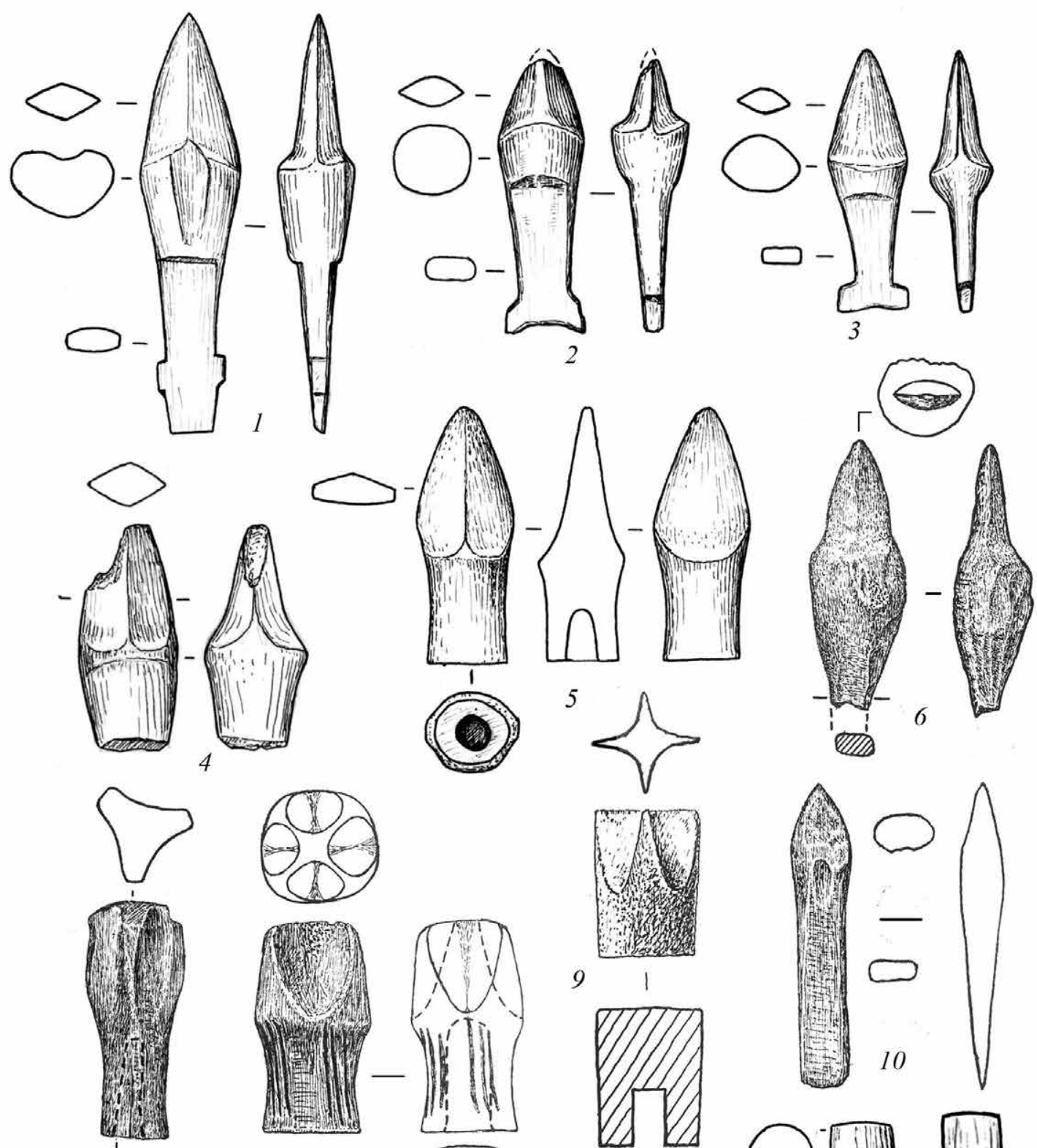

(2) 7

8
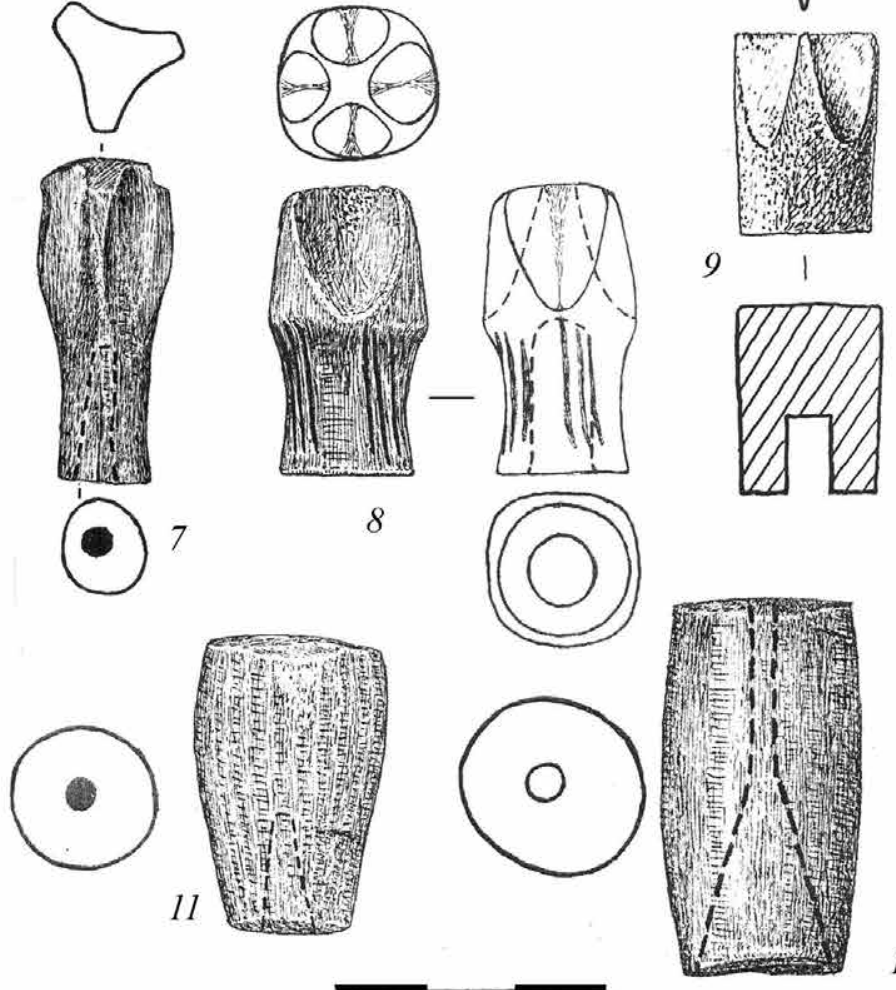

9
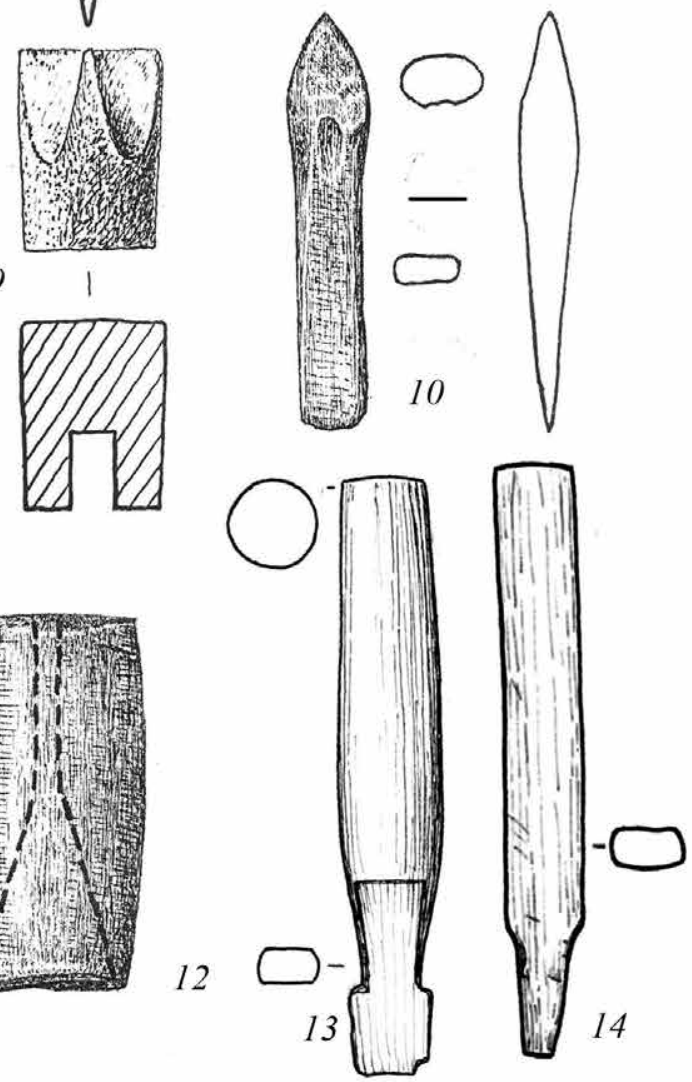

РИС. 99. КОСТЯНЫЕ УТЯЖЕЛЕНО-ВЫТЯНУТЫЕ ЧЕРЕШКОВЫЕ И ВТУЛЬЧАТЫЕ СТРЕЛЫ С ГОРОДИЩ 

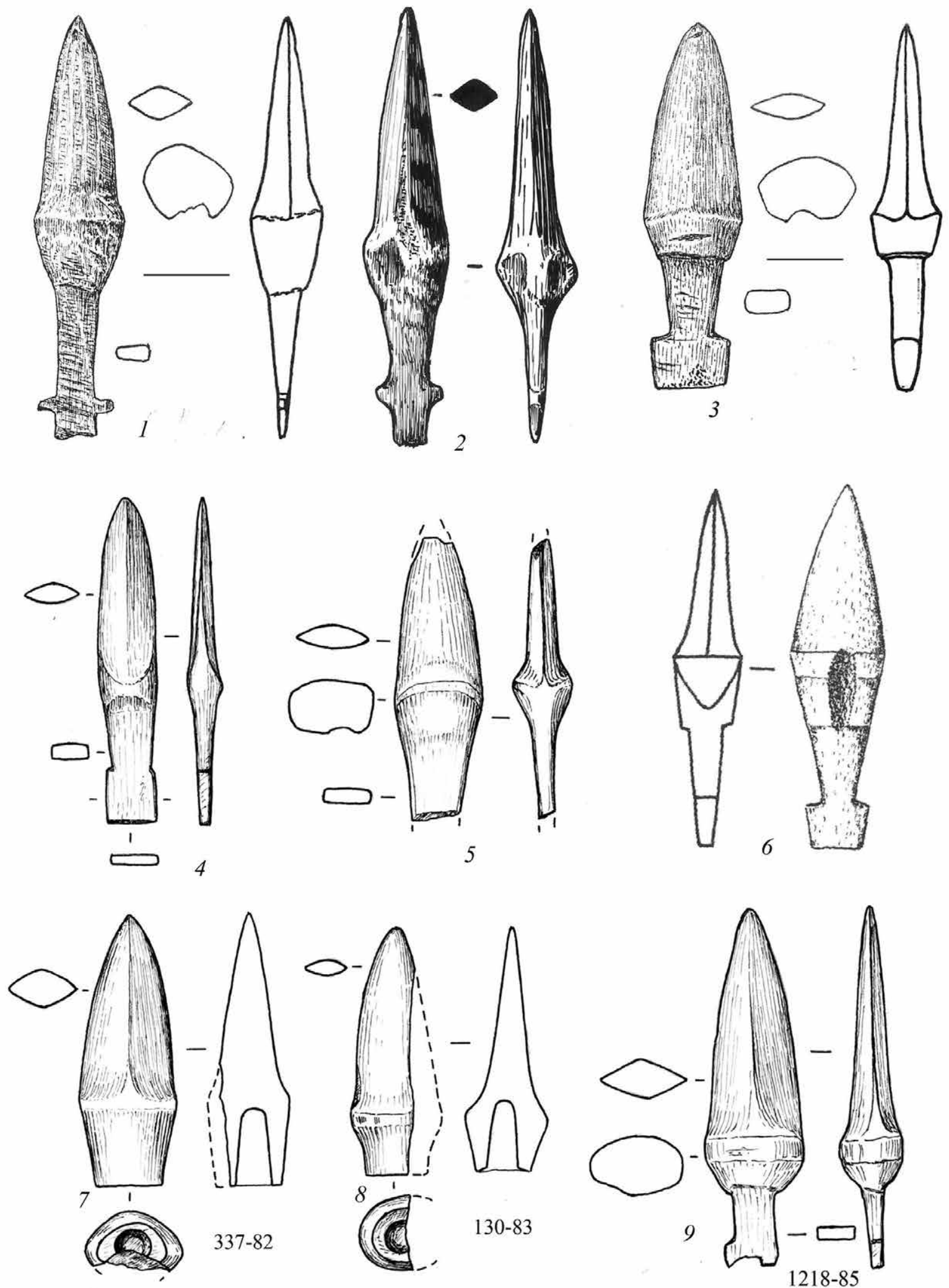

РИС. 100. КОСТЯНЫЕ УТЯЖЕЛЕНО-УКОРОЧЕННЫЕ И ПРИТУПЛЕННЫЕ СТРЕЛЫ С ГОРОДИЩ 1-5, 13 - Дьяково, 6-12, 14 - Настасьино, Боршева 


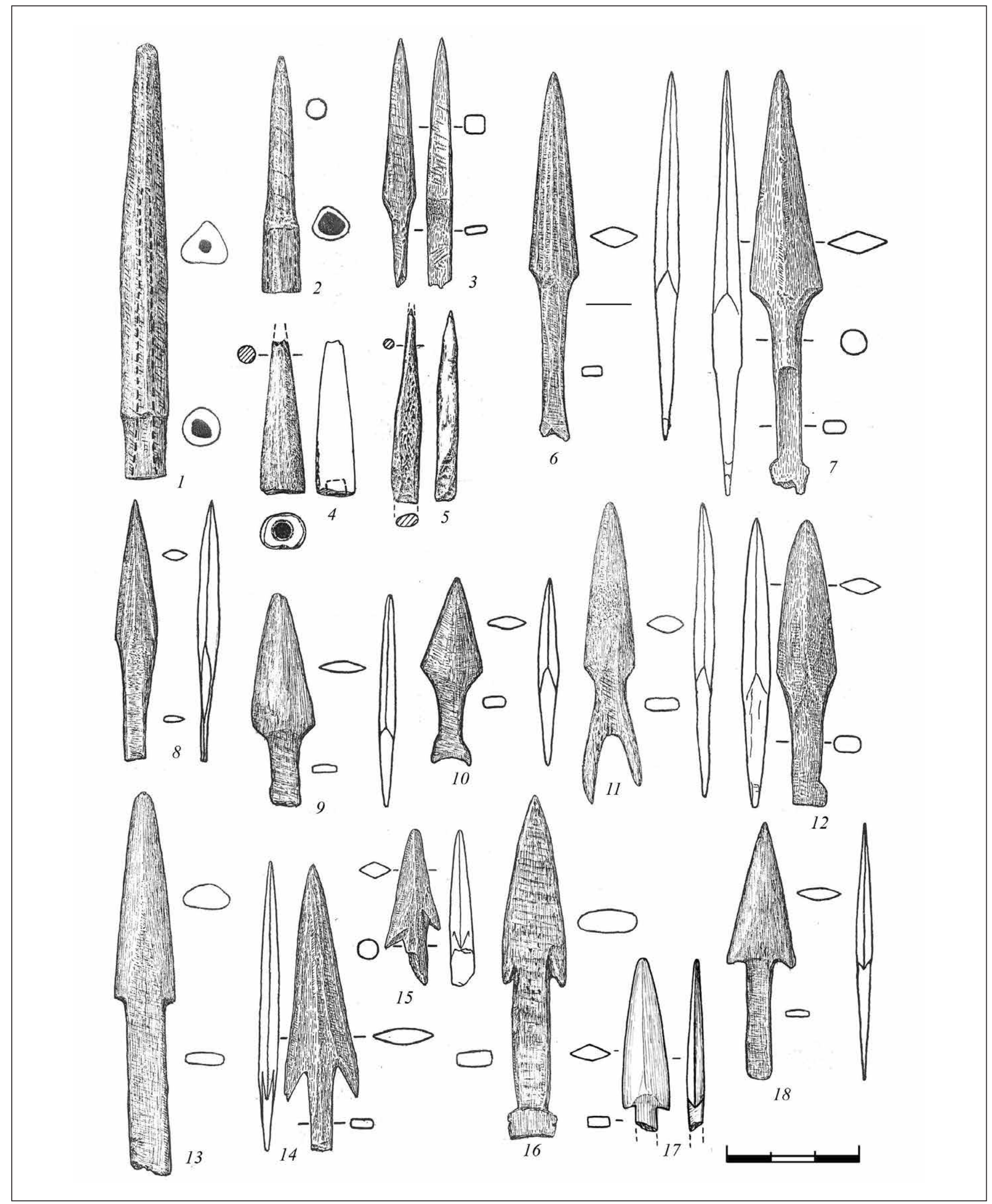

РИС. 101. КОСТЯНЫЕ СТРЕЛЫ: ШИЛООБРАЗНЫЕ, ТРЕУГОЛЬНО-УДЛИНЕННЫЕ С УСТУПОМ, ТРЕУГОЛЬНО-УДЛИНЕННЫЕ ДВУШИПНЫЕ. ГОРОДИЩА БОРШЕВА (1-3, 6-16, 18), Дьяково (17), Кунцево $(4,5)$ 


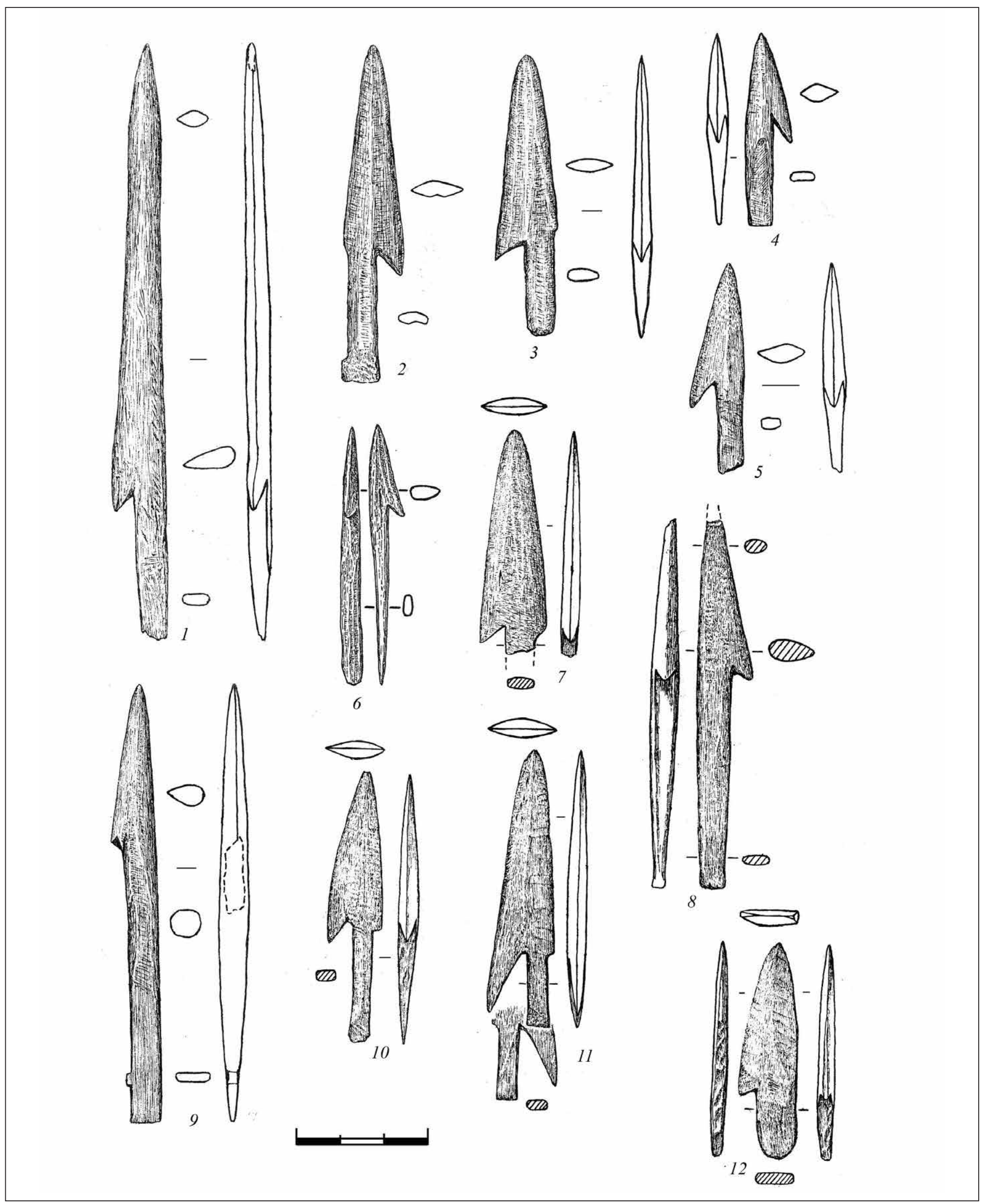

РИС. 102. КОСтЯНЫЕ СТРЕЛЫ: УДЛИНЕННЫЕ ОДНОШИПНЫЕ, ОДНОШИПНЫЕ С УСТУПОМ, ОДНОШИПНЫЕ. ГОРОДИЩЕ БОРШЕВА Рисунки А.Е. Кравцова 


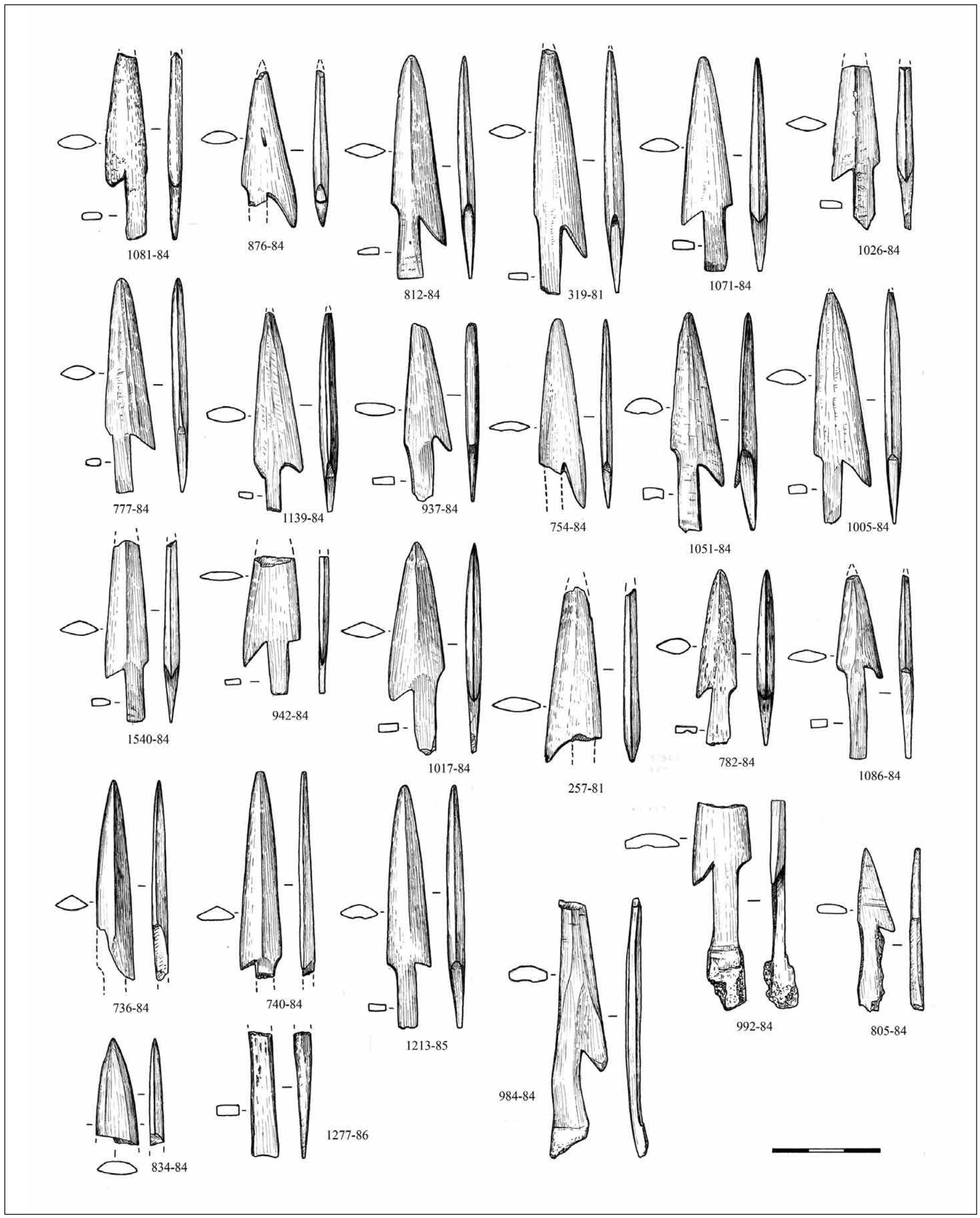

РИС. 103. КОСТЯНЫЕ СТРЕЛЫ ОДНОШИПНЫЕ С УСТУПОМ. ГОРОДИЩЕ ДЬЯКОВО. НИЖНИЙ СЛОЙ.

Рис. В.А. Раевой 


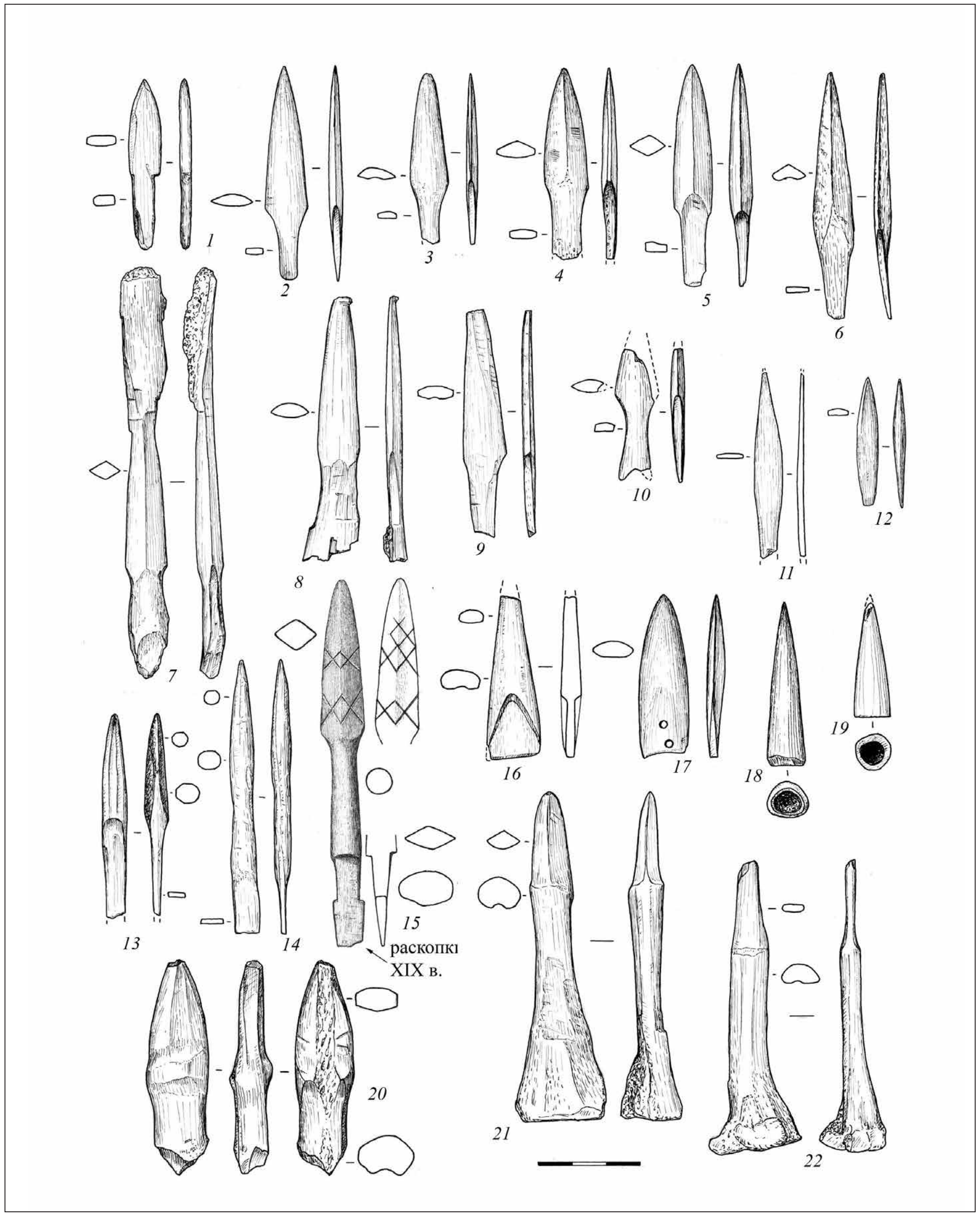

РИС. 104. КОСТЯНЫЕ СТРЕЛЫ ТРЕУГОЛЬНО-УДЛИНЕННЫЕ И ПУЛЕВИДНЫЕ; ЗАГОТОВКИ СТРЕЛ. ГОРОДИЩЕ ДЬЯКОВО. НИЖНИЙ СЛОЙ. 


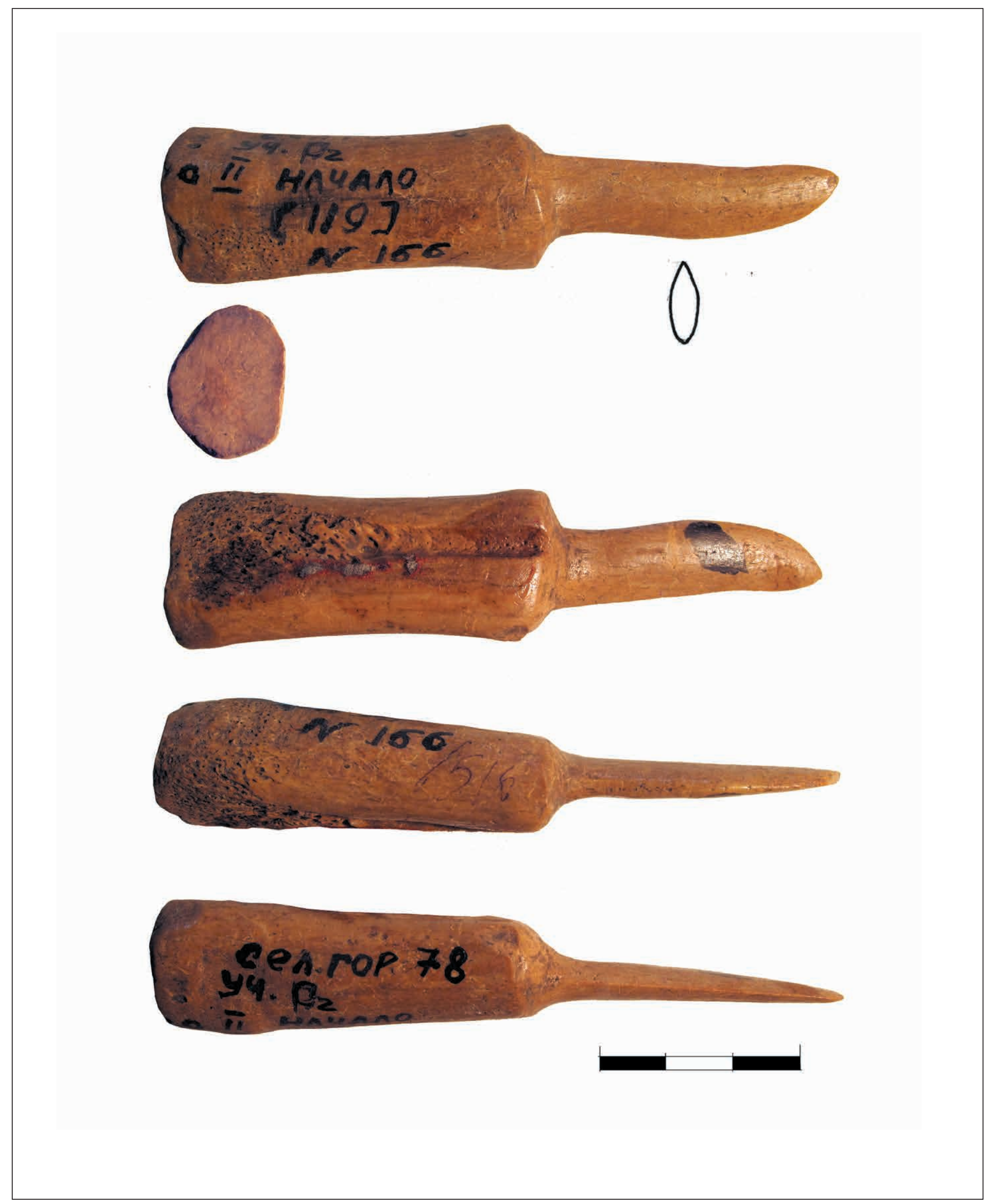

РИС. 105. КОСТЯНОЙ НОЖ С СЕЛЕЦКОГО ГОРОДИЩА (РАСКОПКИ И.Л. ЧЕРНАЯ, БРОННИЦКИЙ МУЗЕЙ) 

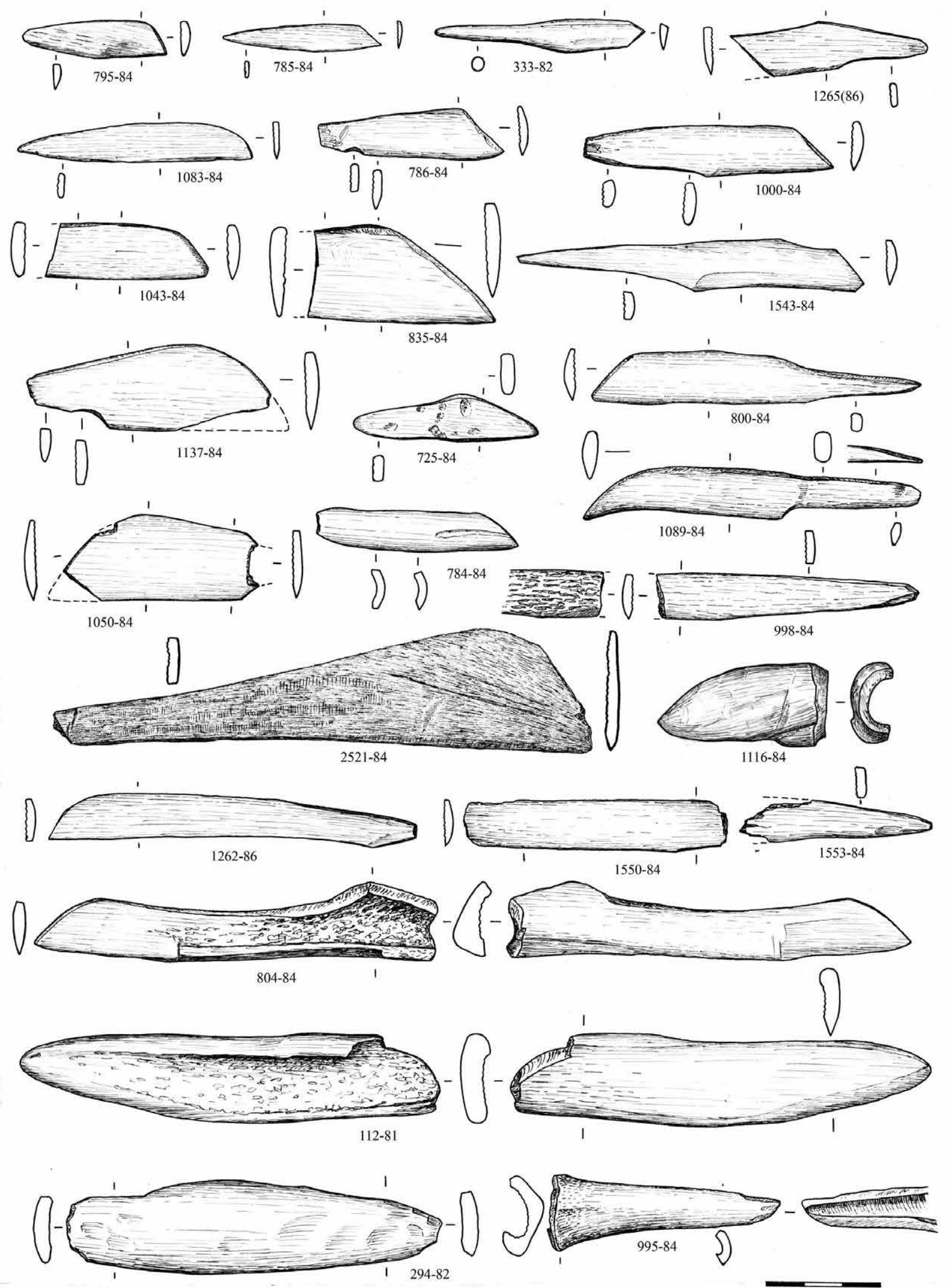

РИС. 106. КОСтЯНЫЕ НОЖИ. ГОРОДИЩЕ ДЬяКОВО. НИЖНИЙ СЛОЙ.

Рис. В.А. Раевой. А.Е. Кравцова 

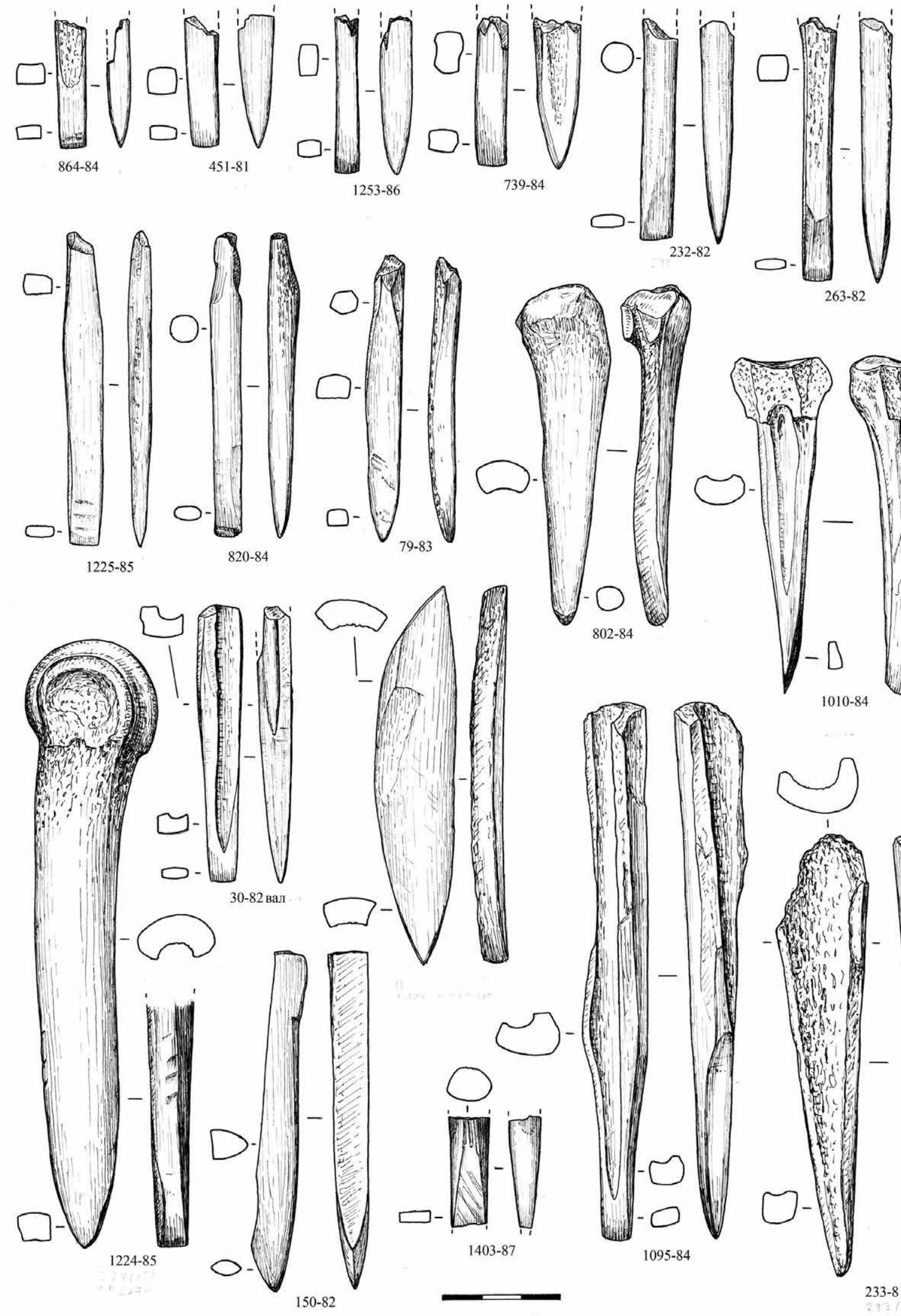


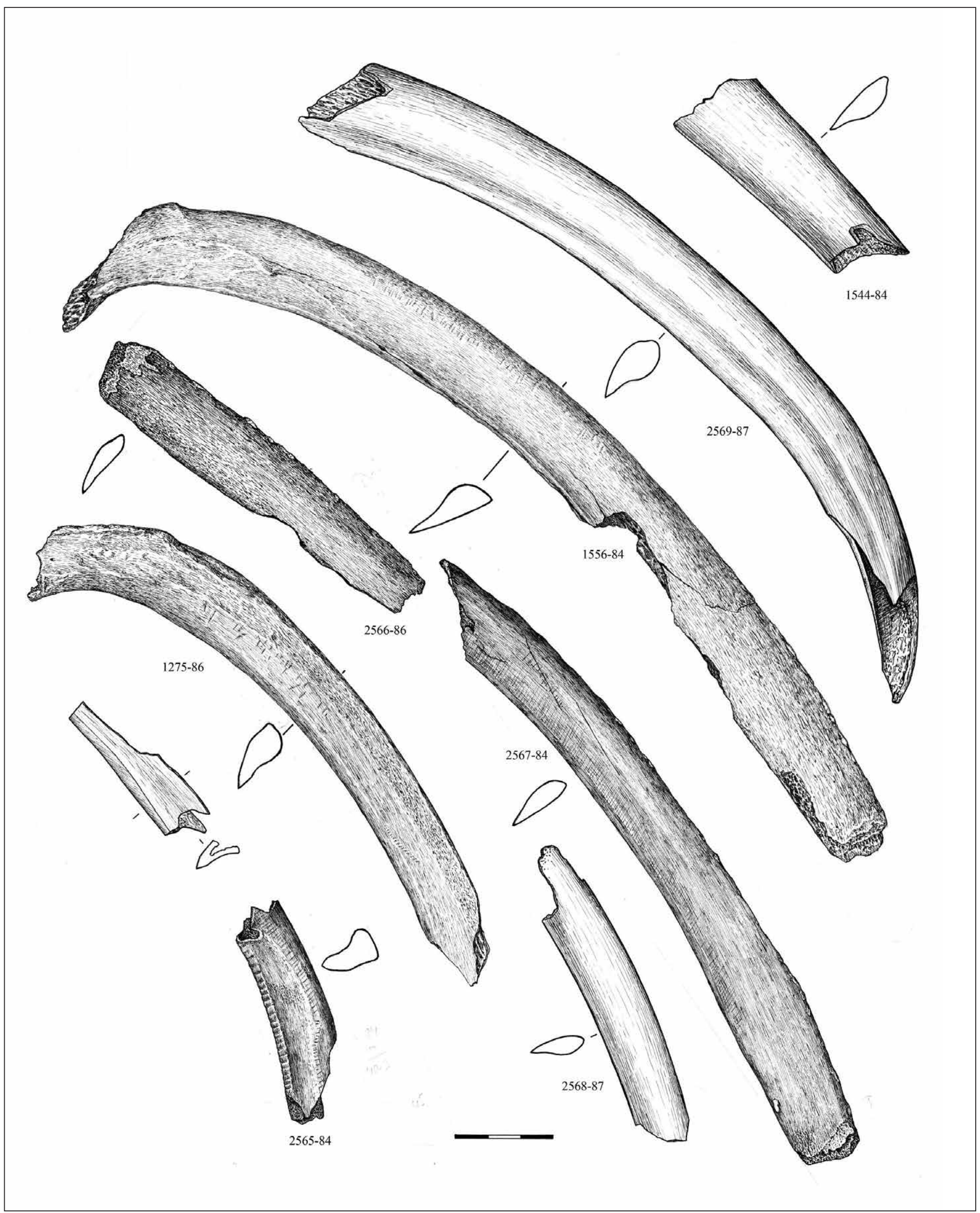

РИС. 108. КОСТЯНЫЕ СТРУГИ-СЕРПЫ ИЗ РЕБЕР. ГОРОДИЩЕ ДЬЯКОВО. НИЖНИЙ СЛОЙ.

Рис. В.А. Раевой. А.Е. Кравцова 


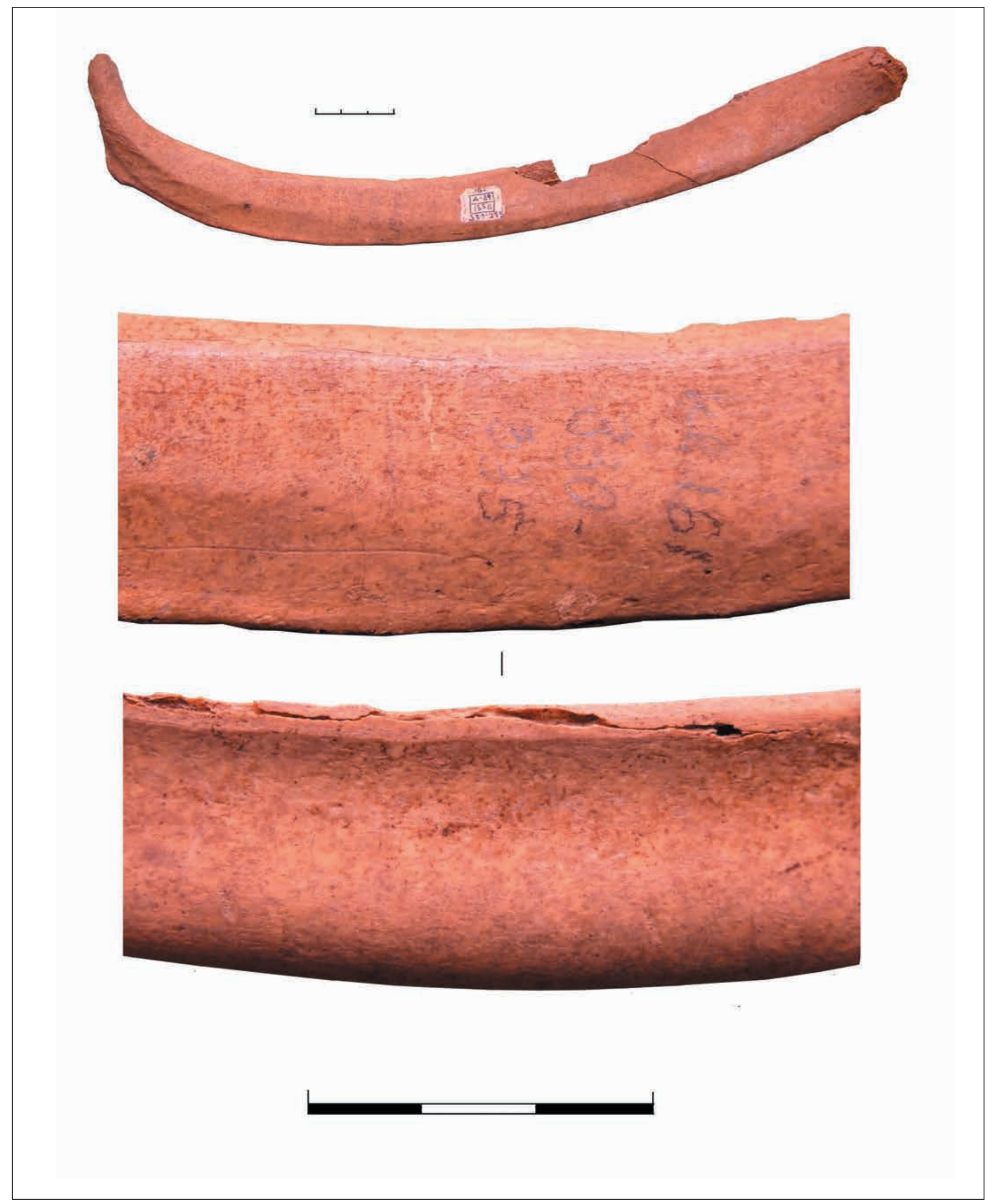

РИС. 109. СТРУГ-СЕРП (?) ИЗ НИЖНЕГО СЛОЯ ДЬЯКОВА ГОРОДИЩА

Макрофоото, показывающее характер заполировки 


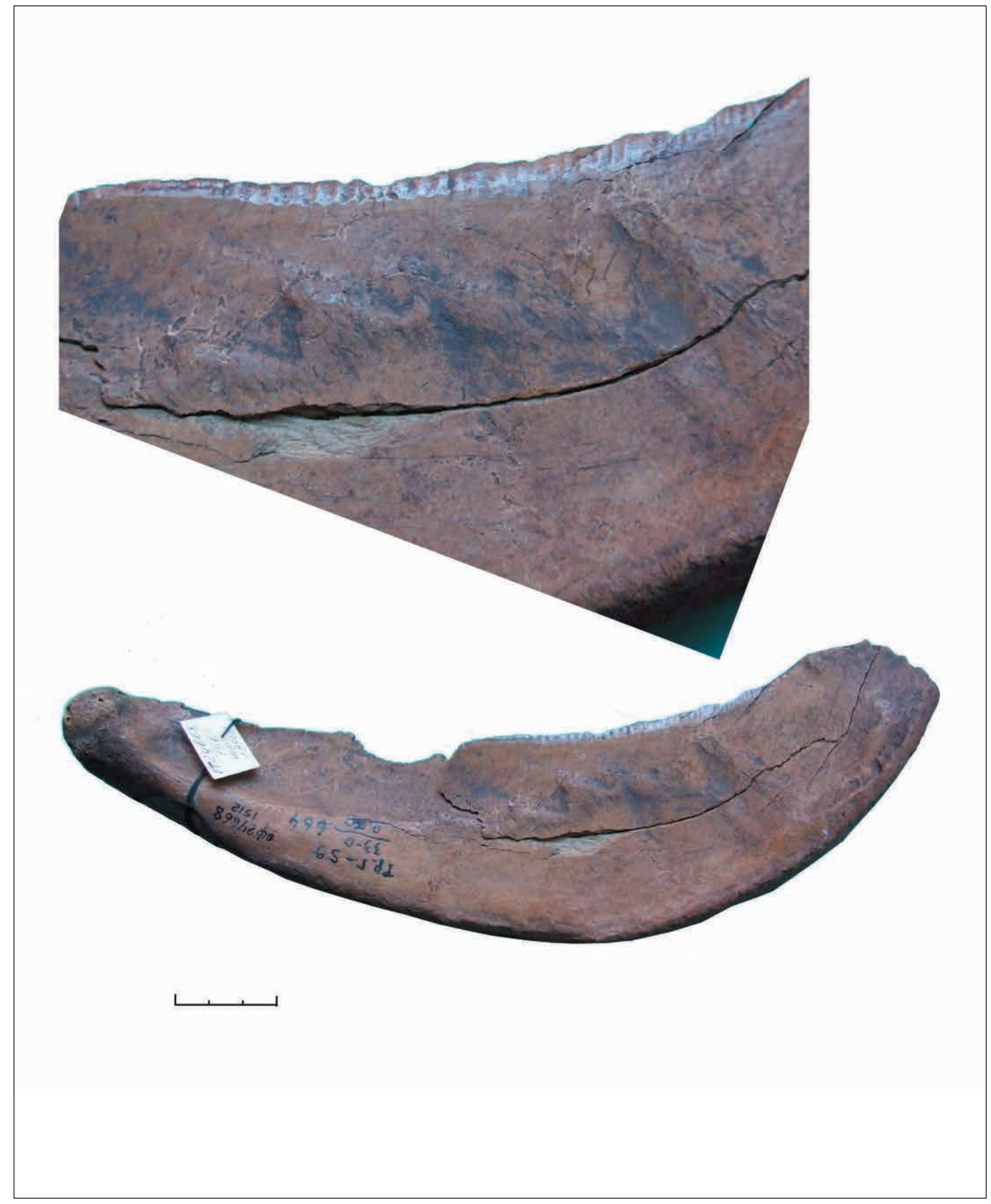

РИС. 110. СТРУГ ИЗ НИЖНЕЙ ЧЕЛЮСТИ ЛОШАДИ (?). ТРОИЦКОЕ ГОРОДИЩЕ Макрофото, показывающее характер следов износа 


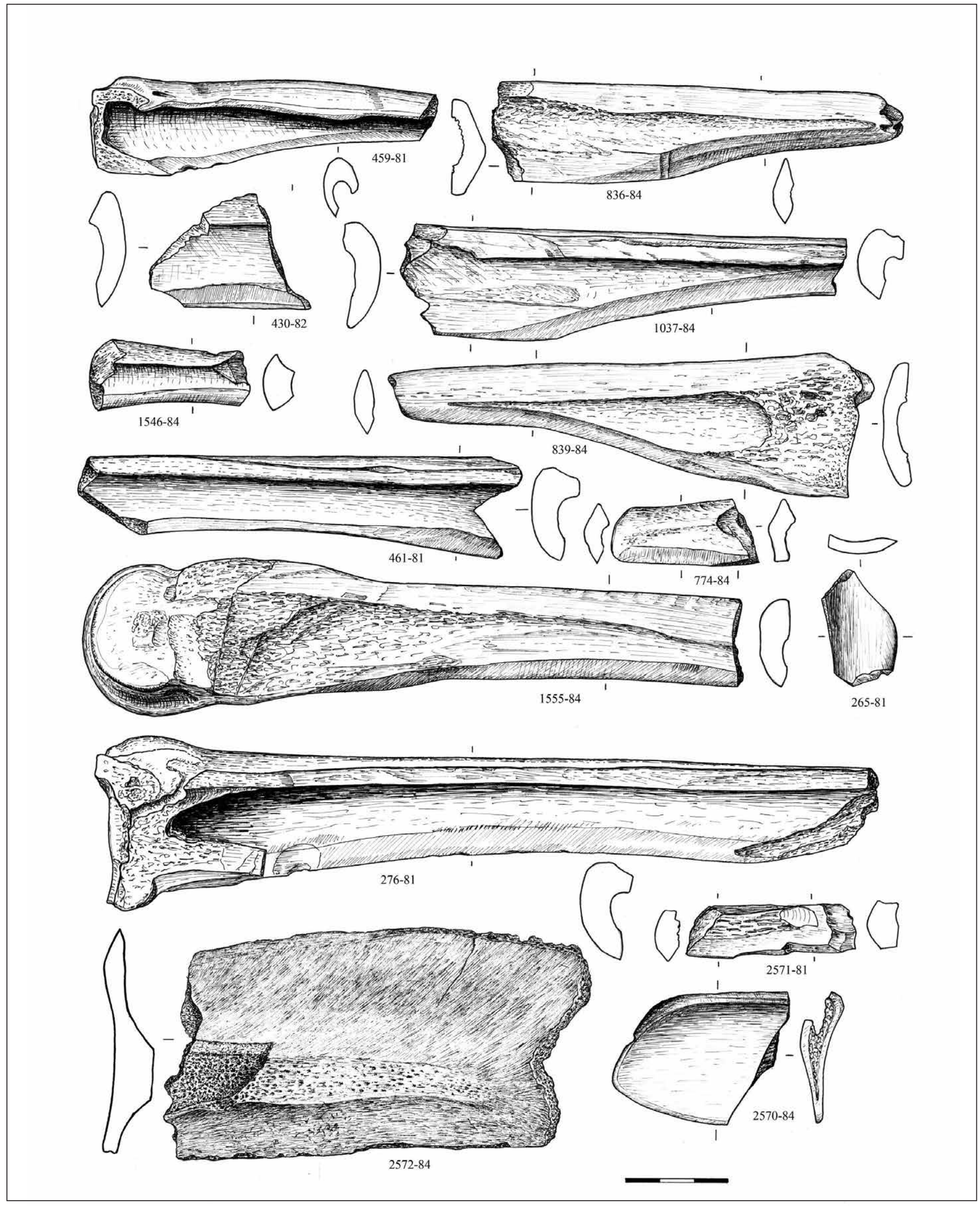

РИС. 111. КОСТЯНЫЕ СКОБЕЛИ ИЗ МЕТОПОДИЙ И ЛОПАТОК. ГОРОДИЩЕ ДЬЯКОВО. НИЖНИЙ СЛОЙ.

Рис. В.А. Раевой 


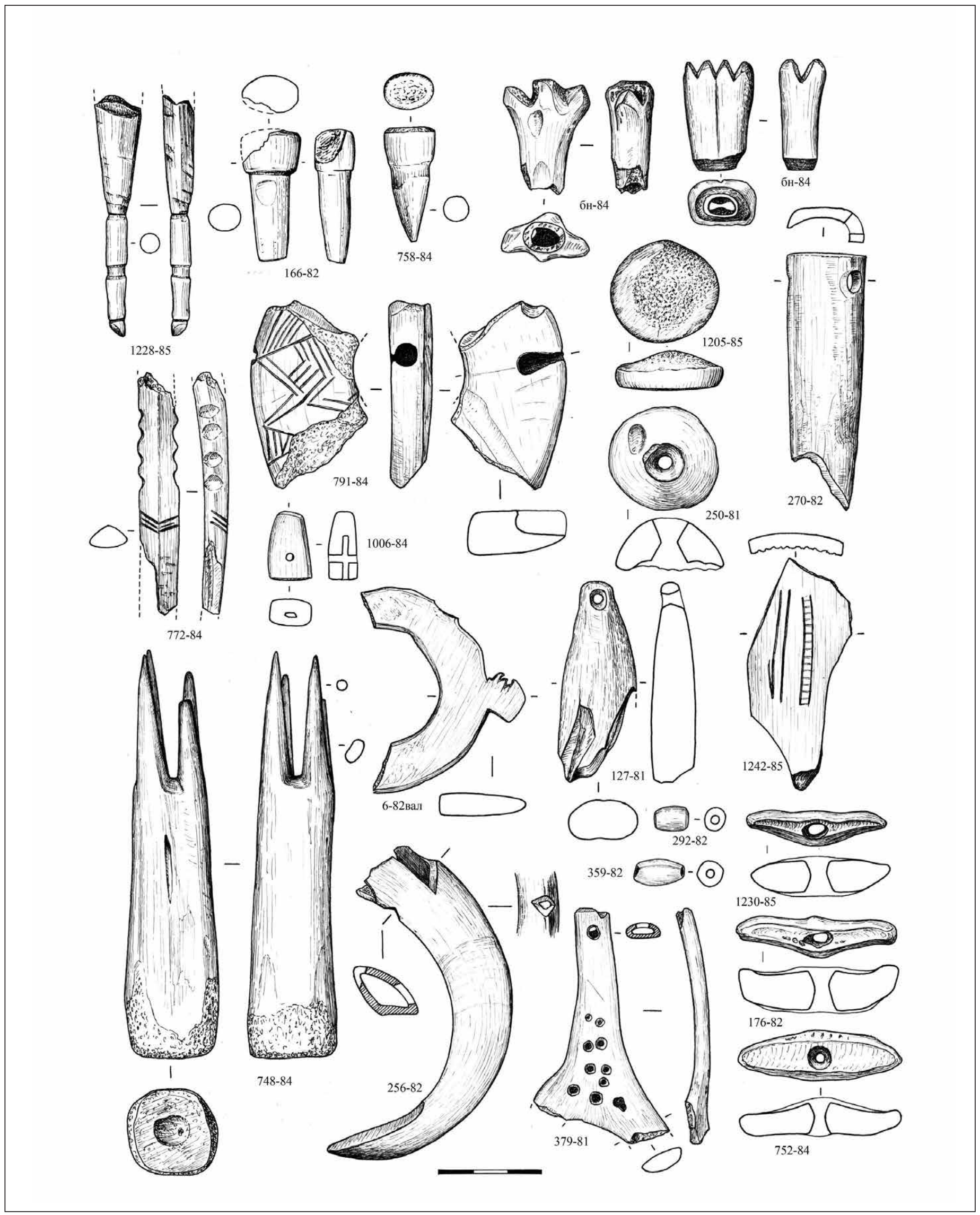

РИС. 112. КОСтЯНЫЕ ИЗДЕЛИЯ (ПУГОВИЦЫ, ЗАТЫЧКИ И ПР.). ГОРОДИЩЕ ДЬЯКОВО. НИЖНИЙ СЛОЙ.

Рис. В.А. Раевой 


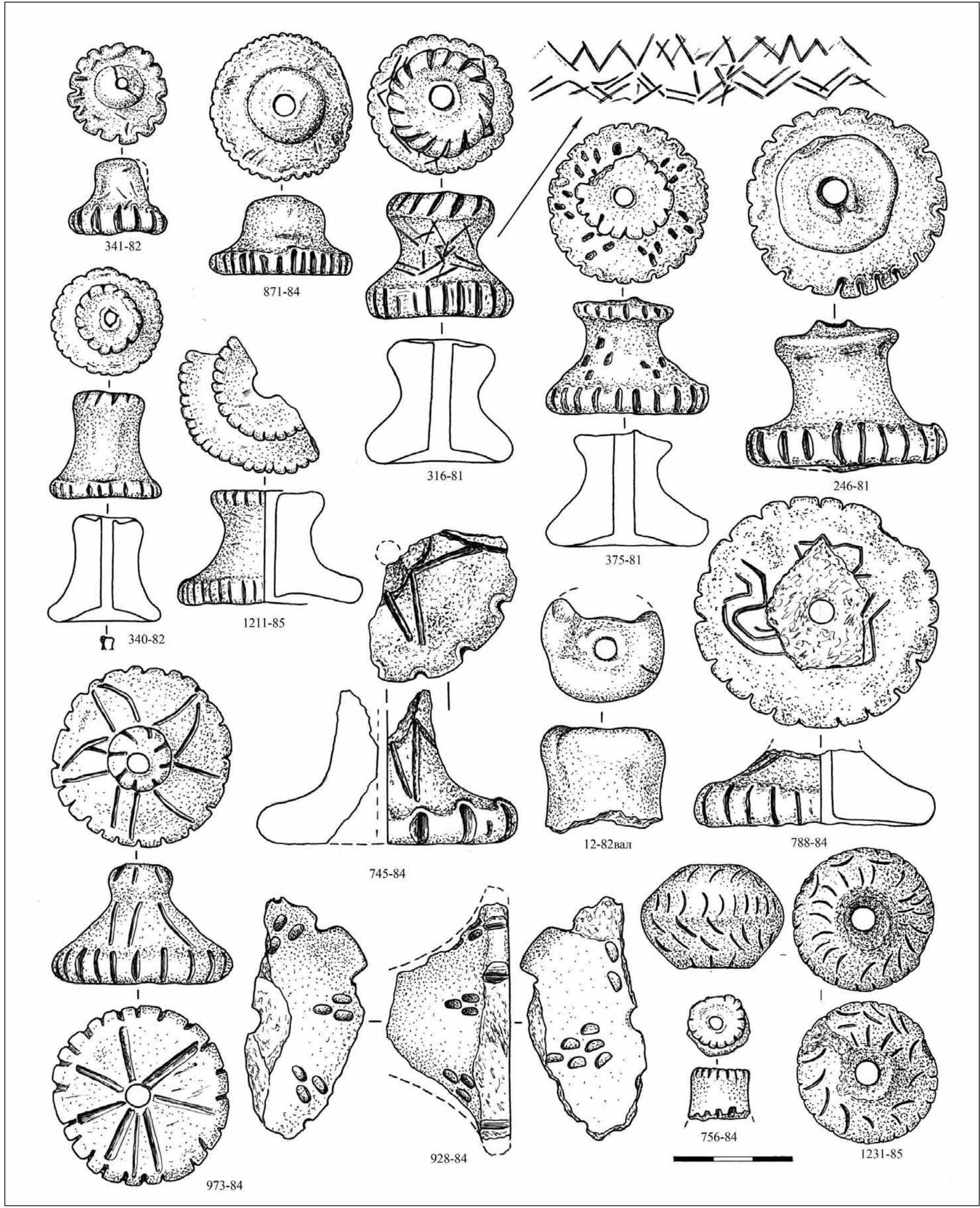

РИС. 113. ГЛИНЯНЫЕ ГРУЗИКИ ДЬЯКОВА ТИПА. ГОРОДИЩЕ ДЬЯКОВО. НИЖНИЙ СЛОЙ.

Рис. В.А. Раевой 


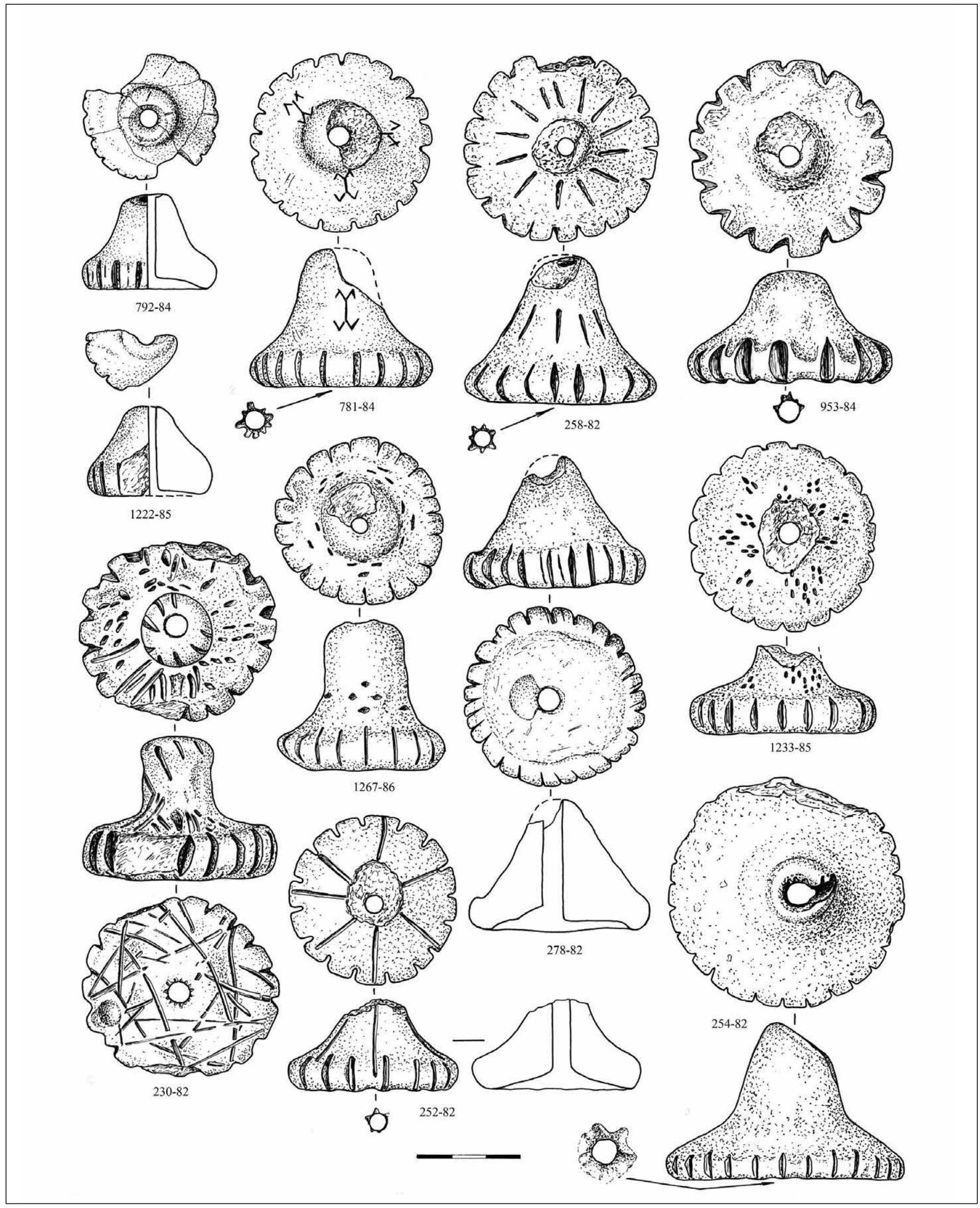

РИС. 114. ГЛИНЯНЫЕ ГРУЗИКИ ДЬЯКОВА ТИПА. ГОРОДИЩЕ ДЬЯКОВО. НИЖНИЙ СЛОЙ.

Рис. В.А. Раевой 


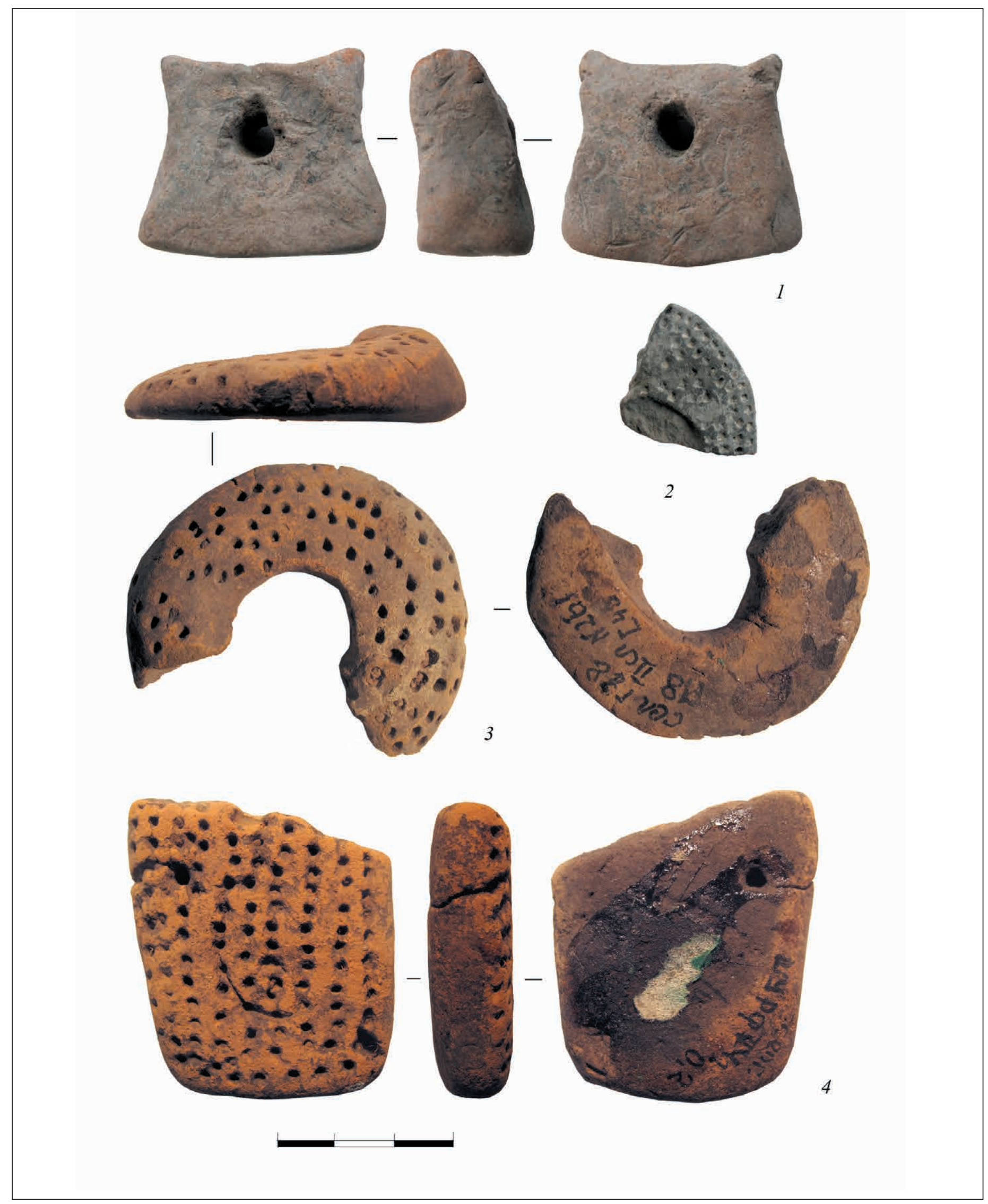

РИС. 115. МОДЕЛЬ РОГАТОГО КИРПИЧА (1) И ОРНАМЕНТИРОВАННЫЕ ИЗДЕЛИЯ (2-4), ГЛИНА

Селецкое городище (раскопки И.Л. Черная, Бронницкий музей) 

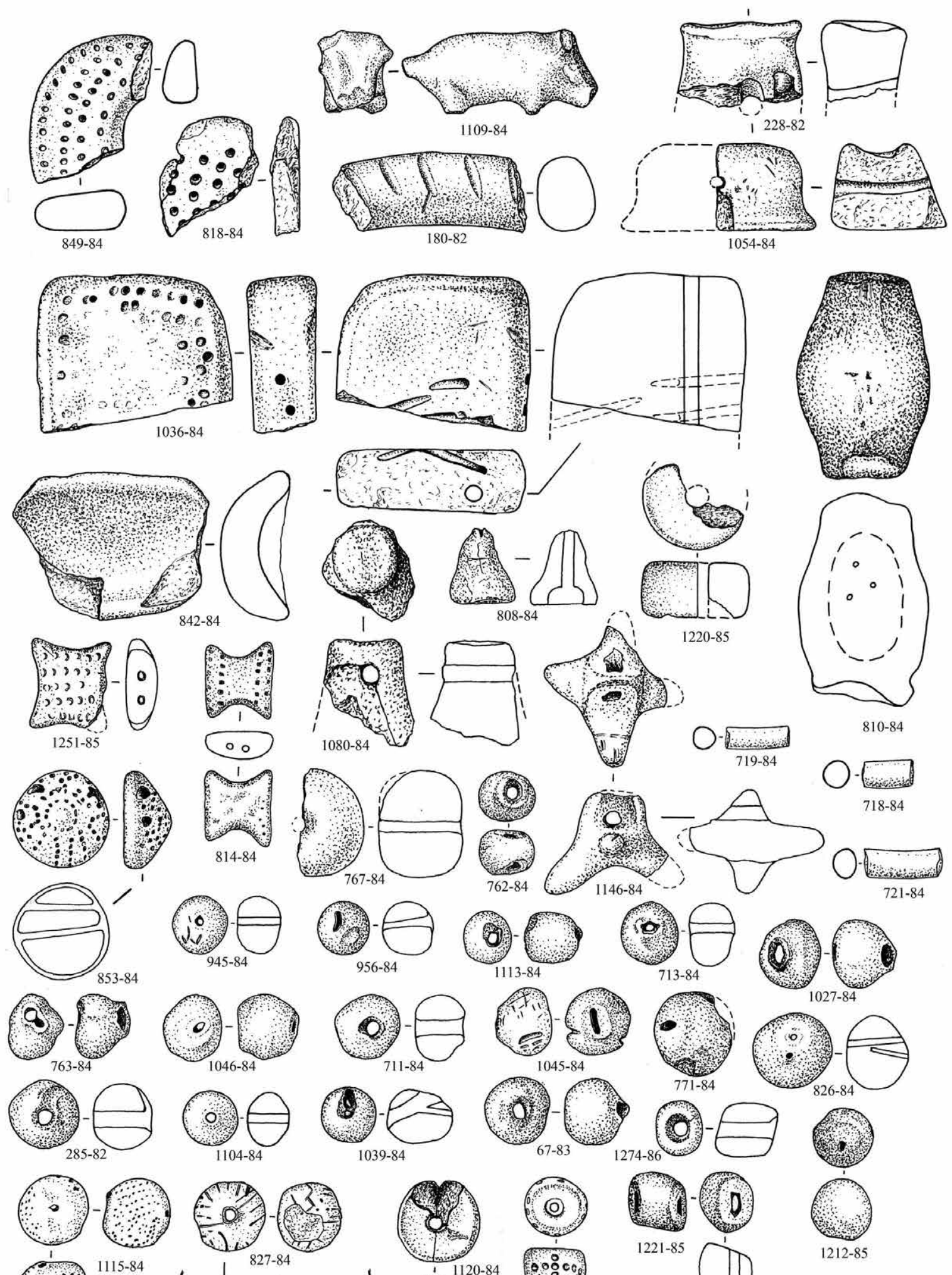

1039-84
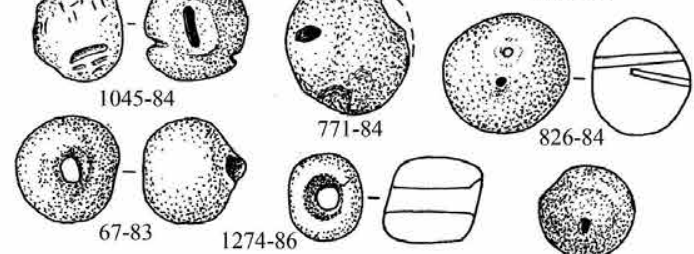

$1 \%$
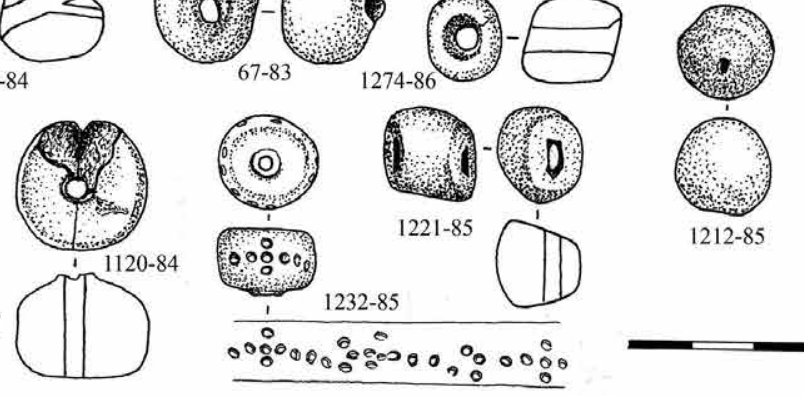

РИС. 116. МЕЛКАЯ ГЛИНЯНАЯ ПЛАСТИКА. ГОРОДИЩЕ ДЬЯКОВО. НИЖНИЙ СЛОЙ.

Рис. В.А. Раевой 

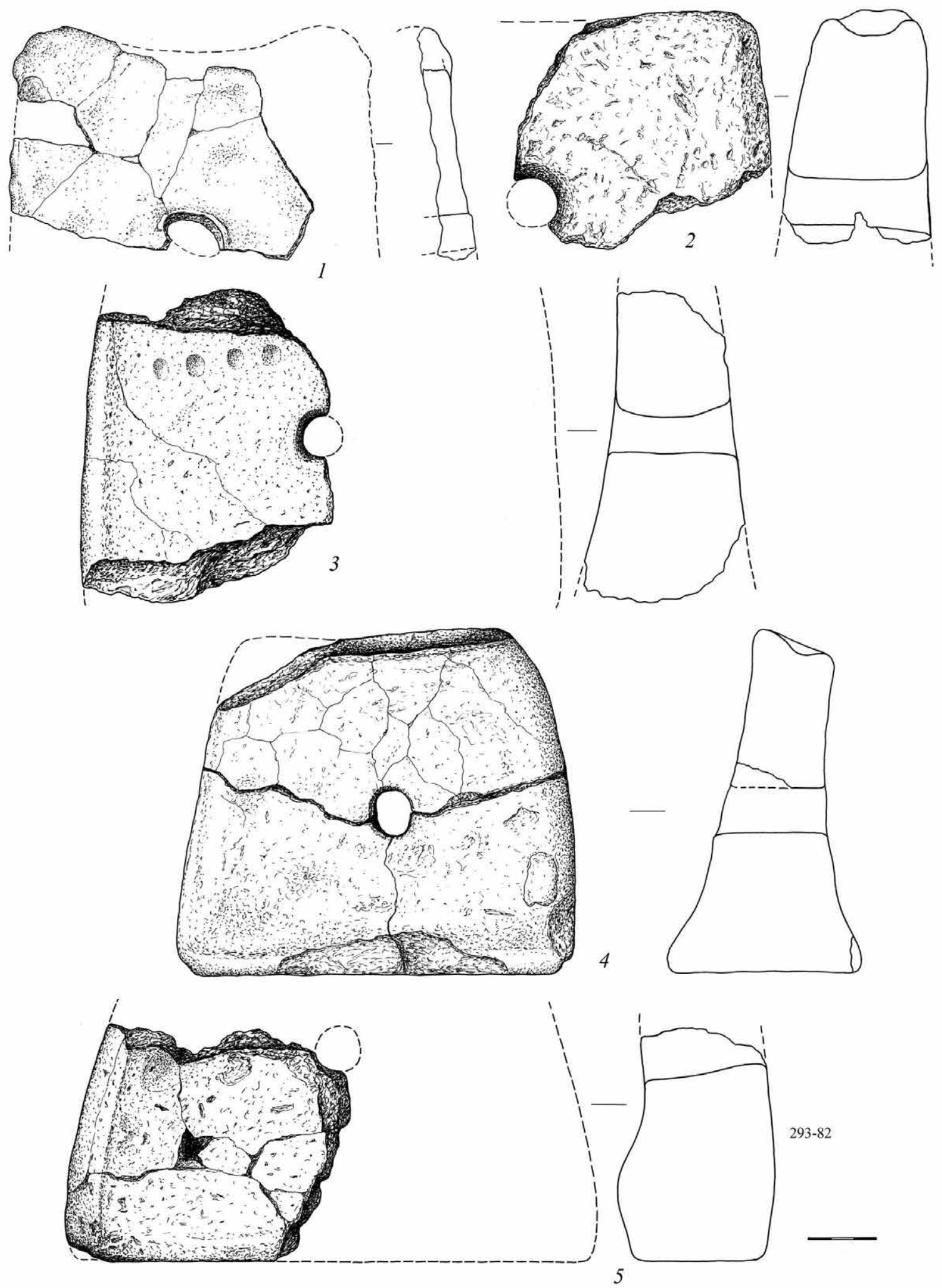

РИС. 117. ГЛИНЯНЫЕ РОГАТЫЕ КИРПИЧИ. ГОРОДИЩЕ ДЬЯКОВО. НИЖНИЙ СЛОЙ.

Рис. В.А. Раевой 


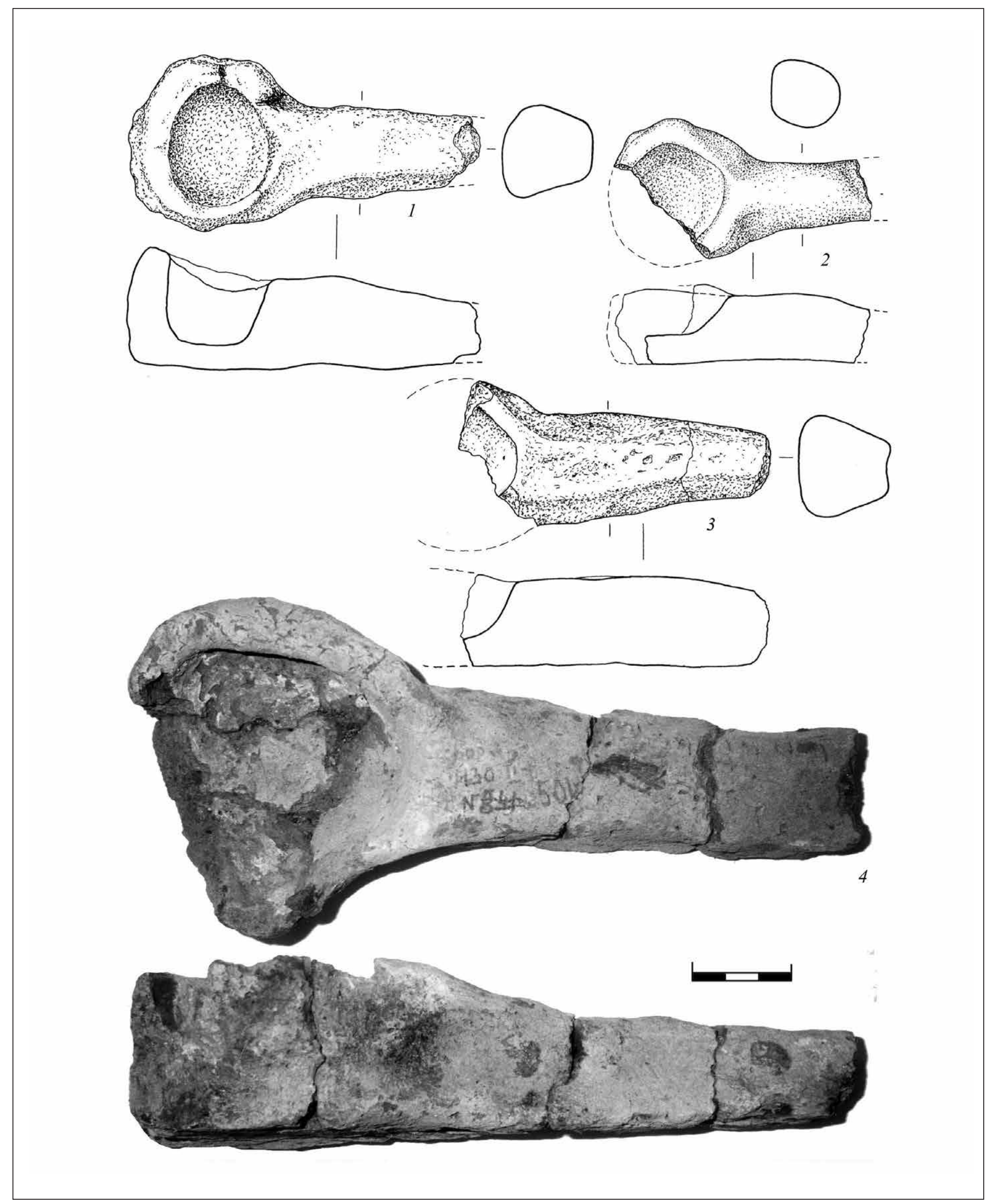

РИС. 118. ГЛИНЯнЫЕ ЛЬЯЧкИ

1-3 - городище Дьяково, нижний слой, 4 - городище Боршева 


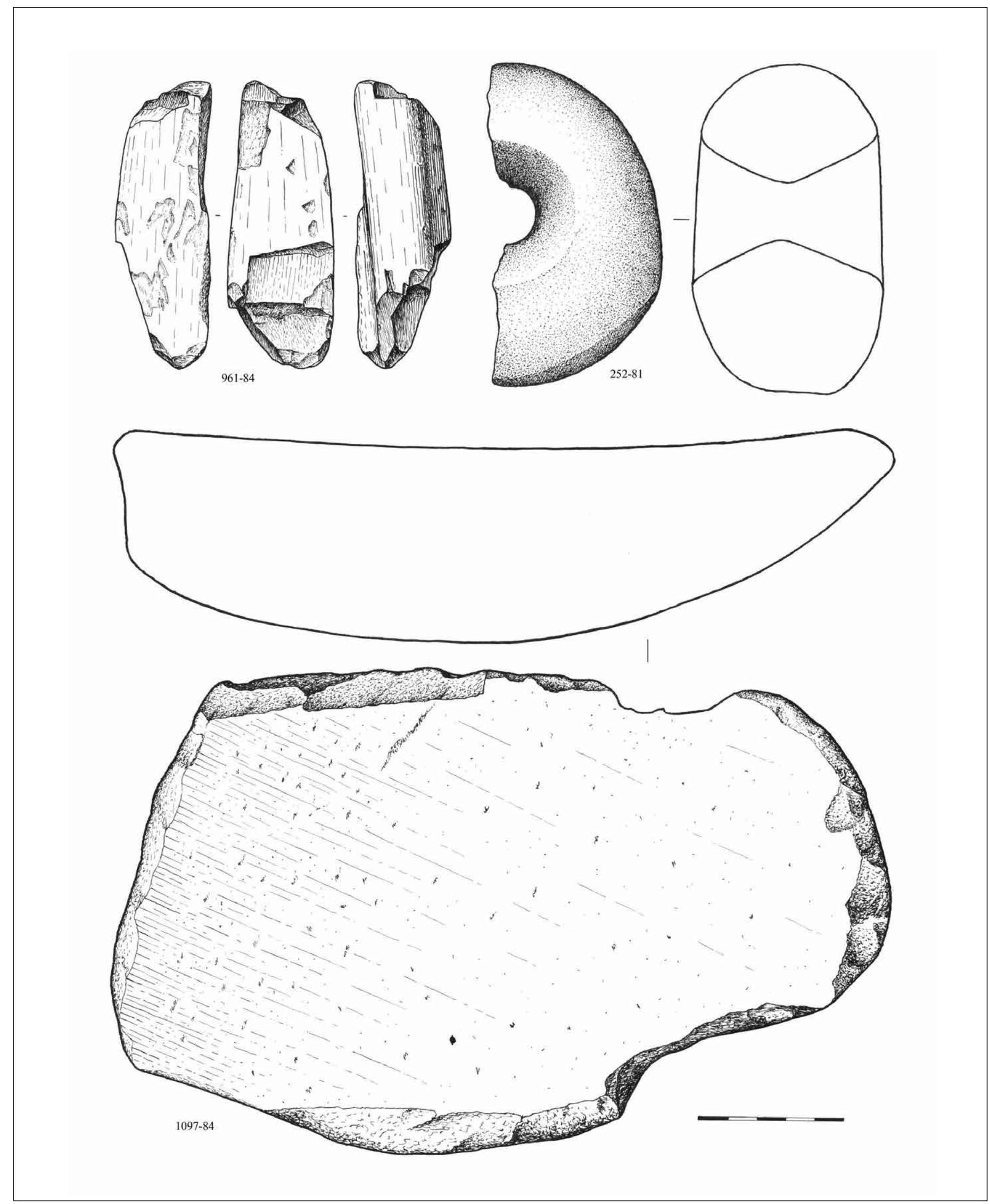

РИС. 119. КАМЕННЫЕ ИЗДЕЛИЯ. ГОРОДИЩЕ ДЬЯКОВО, НИЖНИЙ СЛОЙ.

Рис А.В. Трусова 


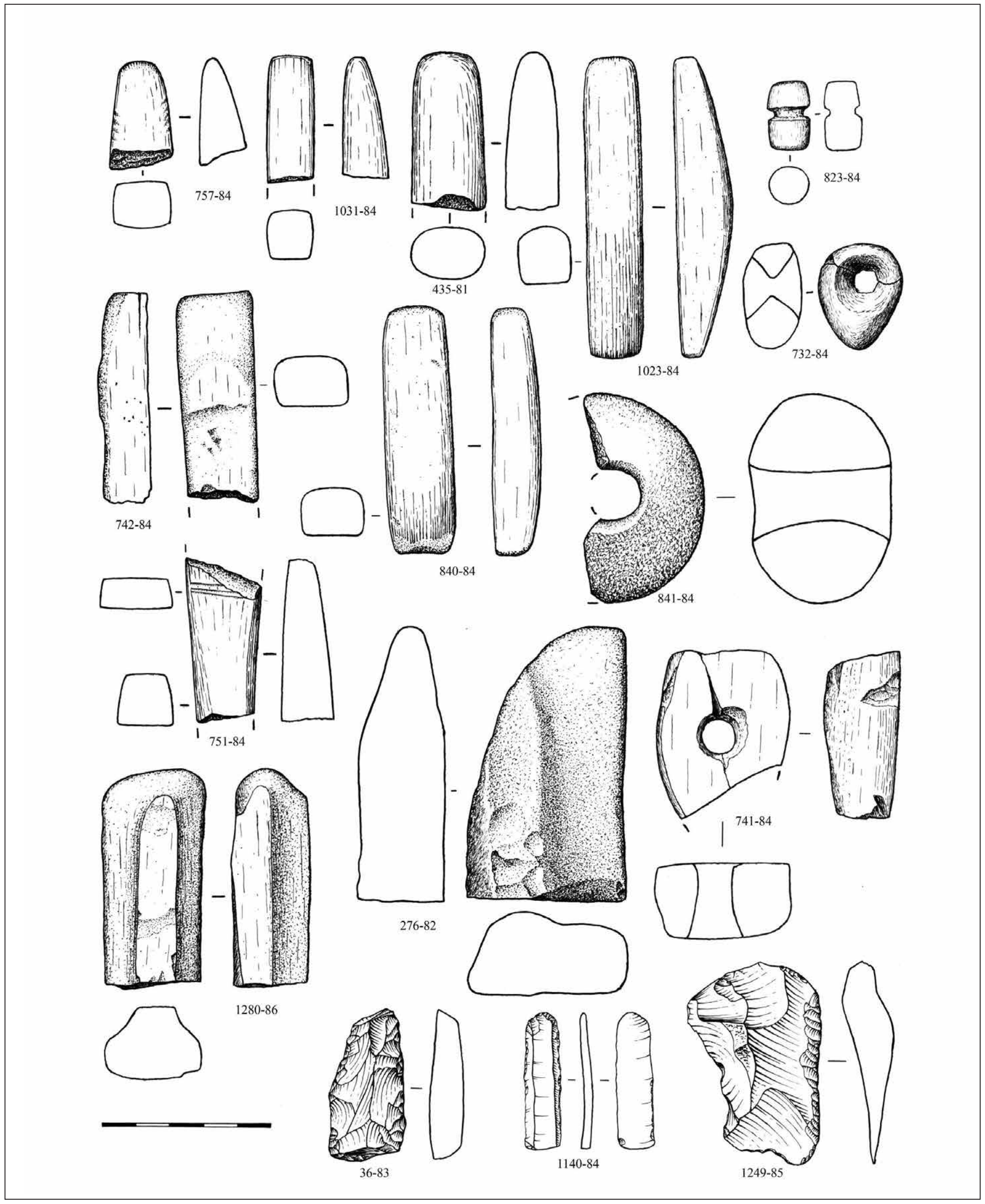

РИС. 120. КАМЕННЫЕ УТЮЖКИ, КАМНИ СО СВЕРЛИНОЙ, ОРУДИЯ С РЕТУШЬЮ НЕОЛИТА И БРОНЗОВОГО ВЕКА Городище Дьяково, нижний слой. Рис А.В. Трусова 

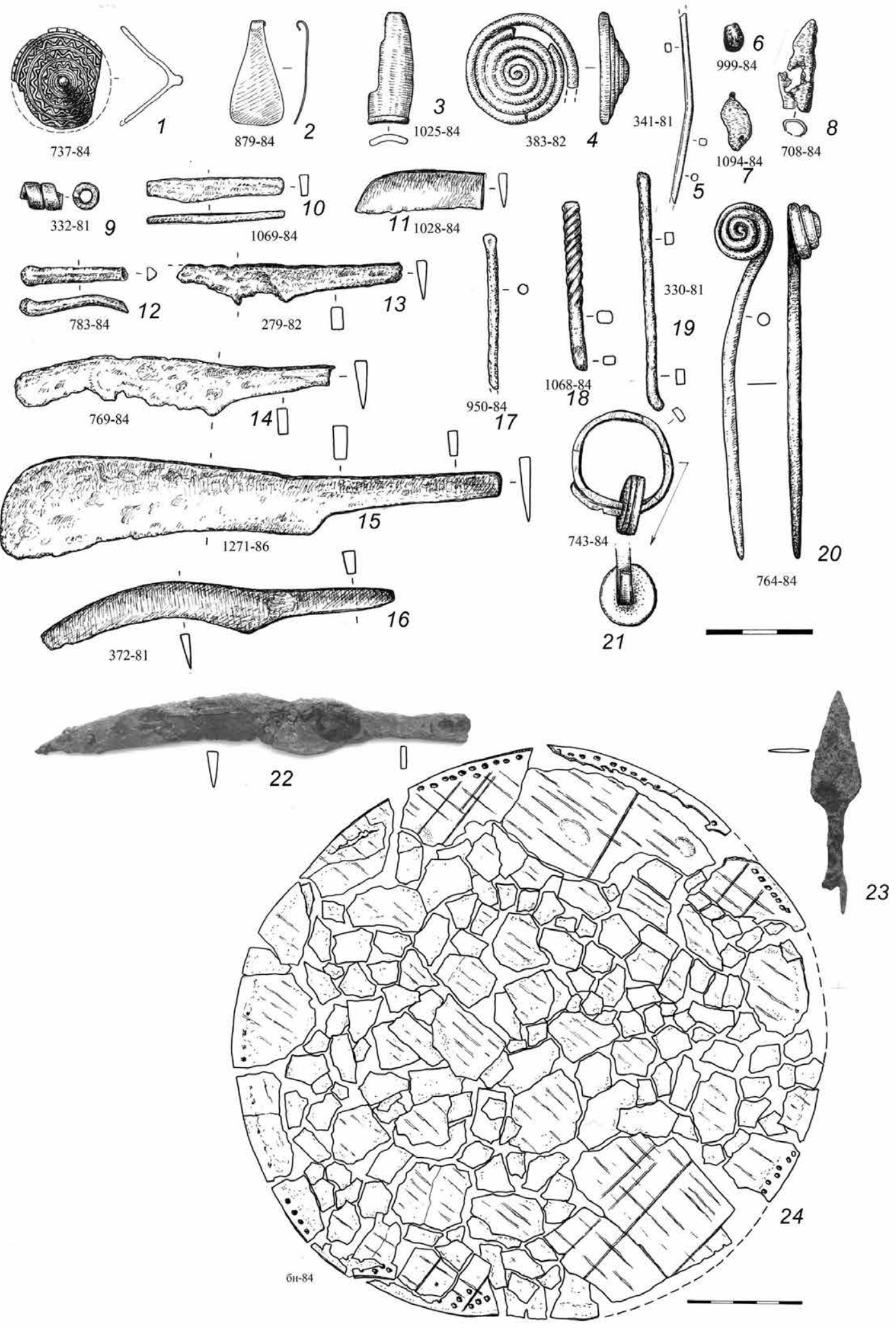

РИС. 121. МЕТАЛЛИЧЕСКИЕ ИЗДЕЛИЯ И ДНО БЕРЕСТЯНОГО ТУЕСА ИЗ НИЖНЕГО СЛОЯ ДЬЯКОВА ГОРОДИЩА (1-21, 24) И СЕЛЕЦКОГО ГОРОДИЩА (22, 23) 1-9 - бронза; 10-20, 22, 23 - железо; 21 - железо + белый металл; 24 - береста. Рис. В.А. Раевой 


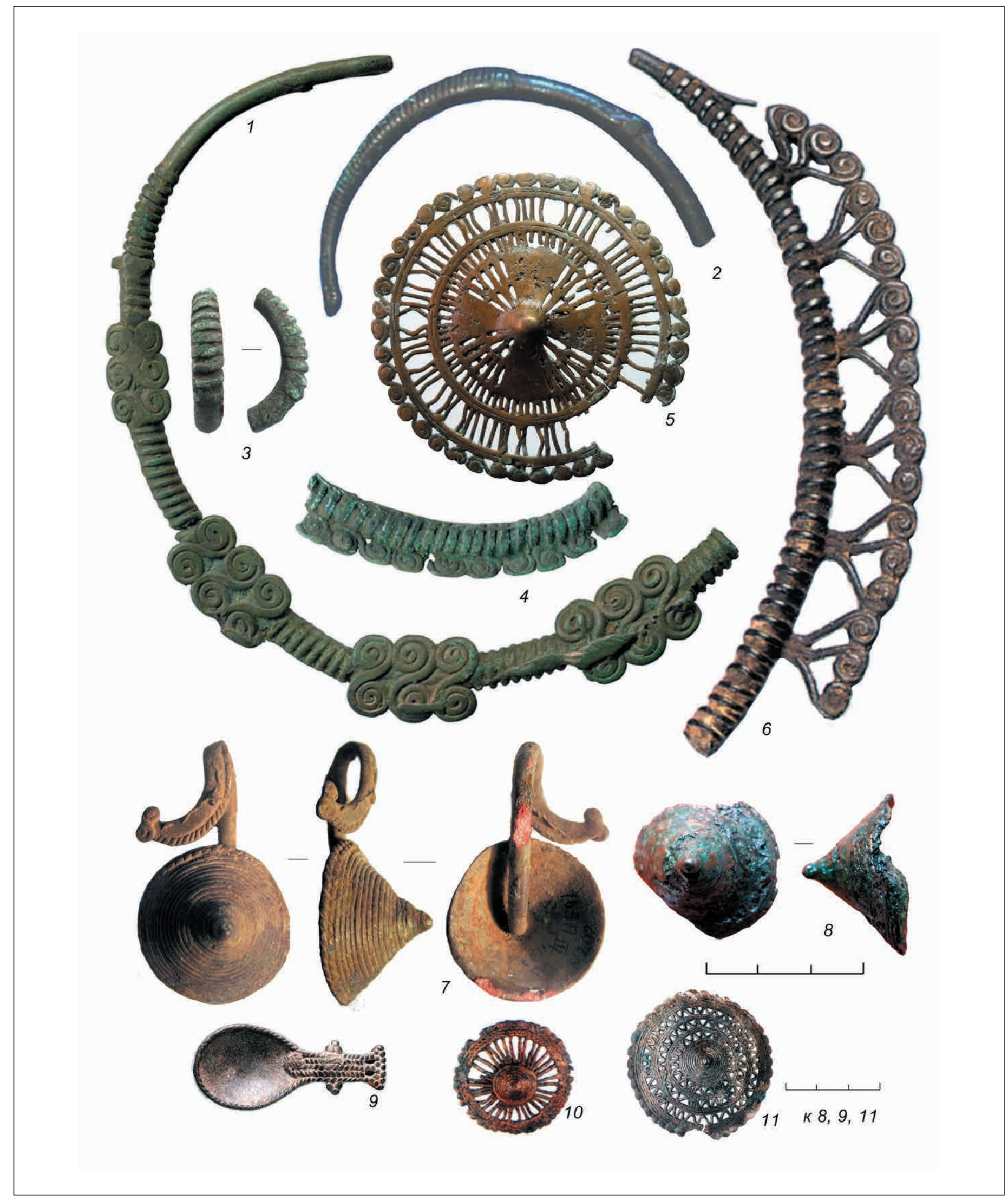

РИС. 122. БРОНЗОВЫЕ РАННЕДЬЯКОВСКИЕ УКРАШЕНИЯ ИЗ ГОРОДИЩ

1, 3, 4 - Знаменское (по: Разуваев, 2012); 2 - «Связист»; 5 - Кунцево; 6, 10 - Мамоново; 7 - Селецкое; 8 - Дьяково; 9 , 11 - Настасьино (по: Энговатова, 2009) 


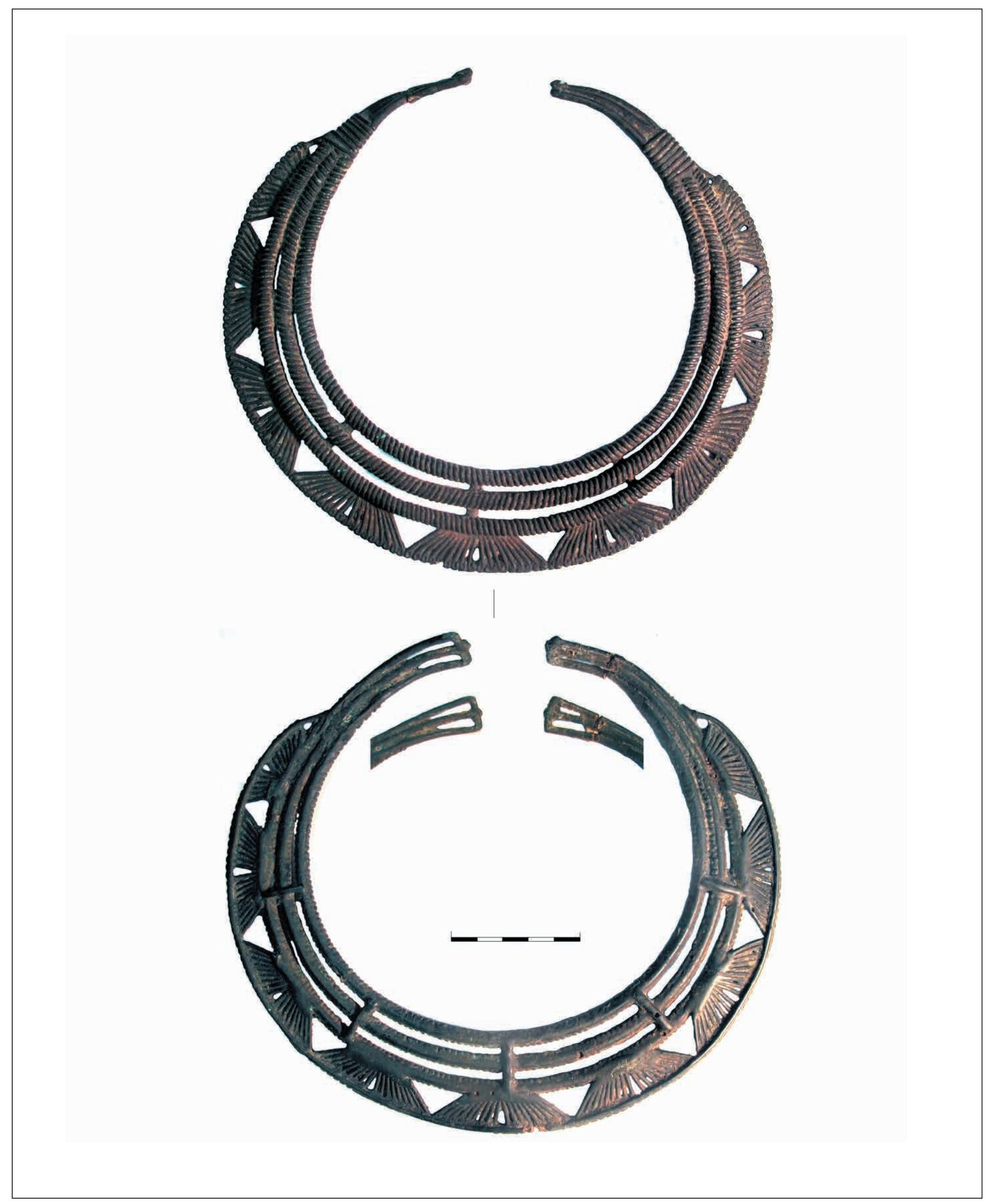

РИС. 123. ГРИВНА БРОНЗОВАЯ ИЗ НИЖНЕГО СЛОЯ СЕЛЕЦКОГО ГОРОДИЩА

Раскопки И.Л. Черная, Бронницкий музей 

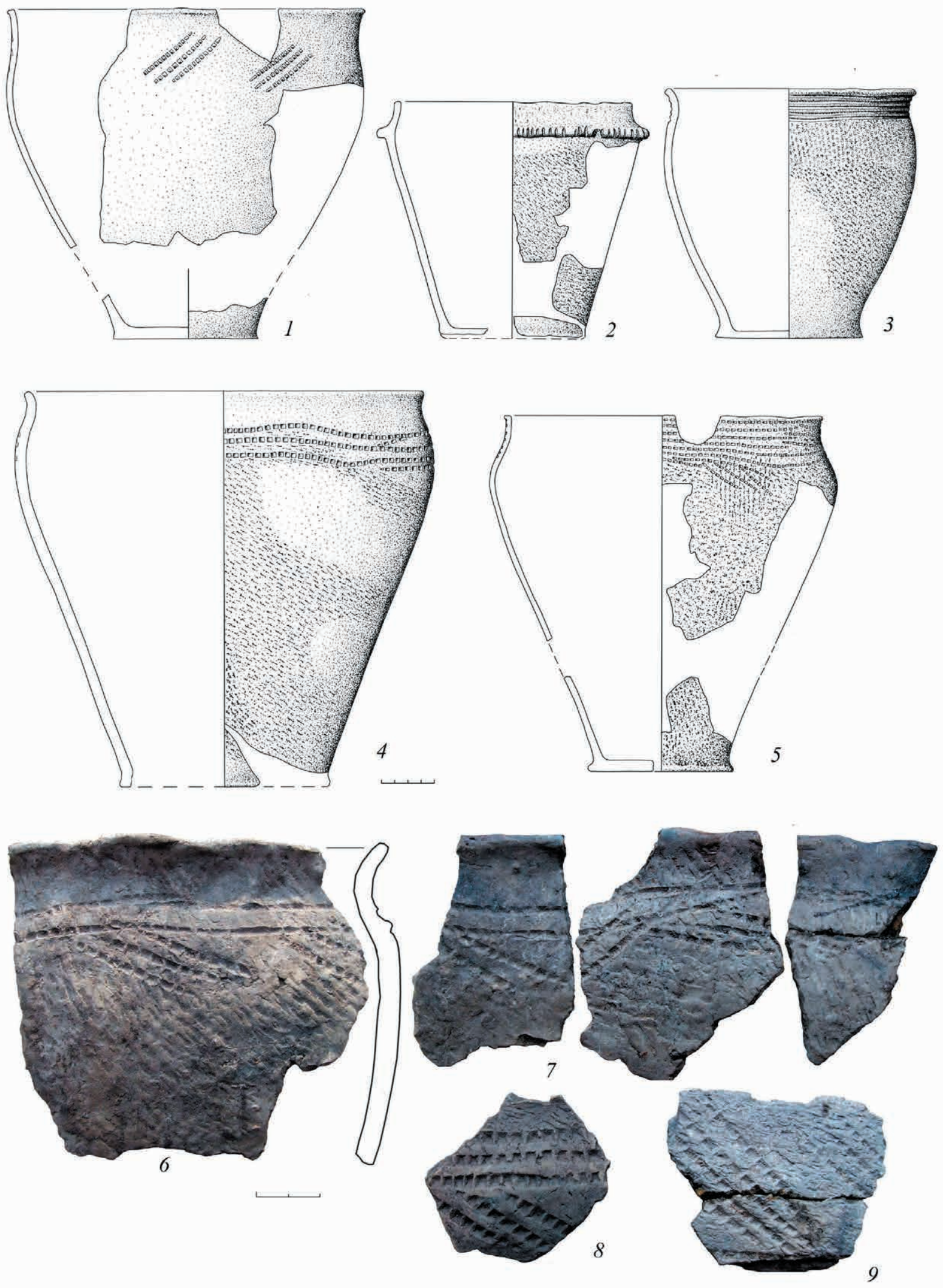

РИС. 124. ГОРШКИ НАЧАЛЬНОГО ЭТАПА ДЬЯКОВСКОЙ КУЛЬТУРЫ

1-5 -городище Знаменское (по: Разуваев, 2012); 6-9 - городище Дунино 

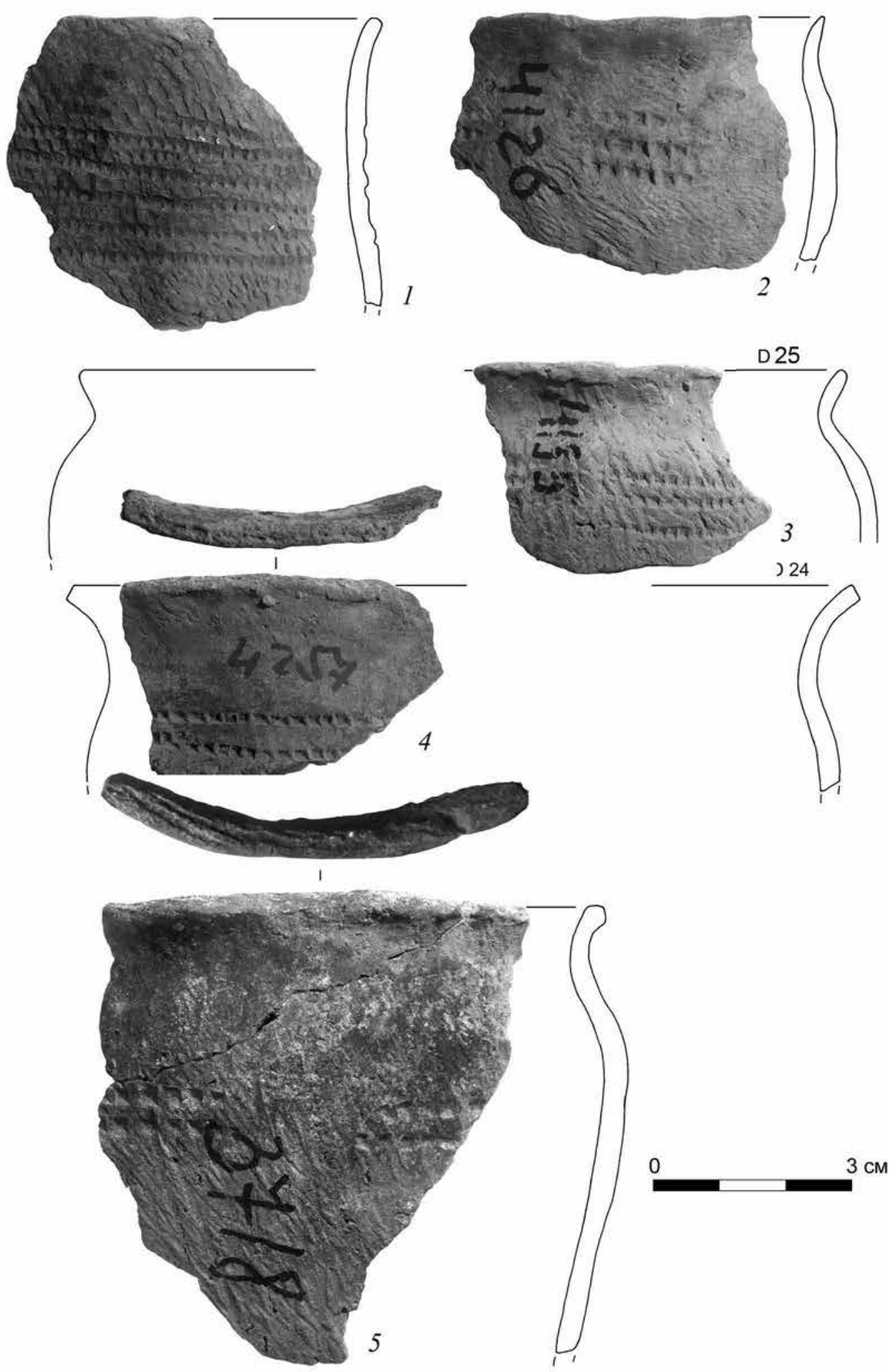

РИС. 125. ГОРШКИ НАЧАЛЬНОГО ПЕРИОДА ДЬЯКОВСКОЙ КУЛЬТУРЫ

Селецкое городище (Бронницкий музей) 


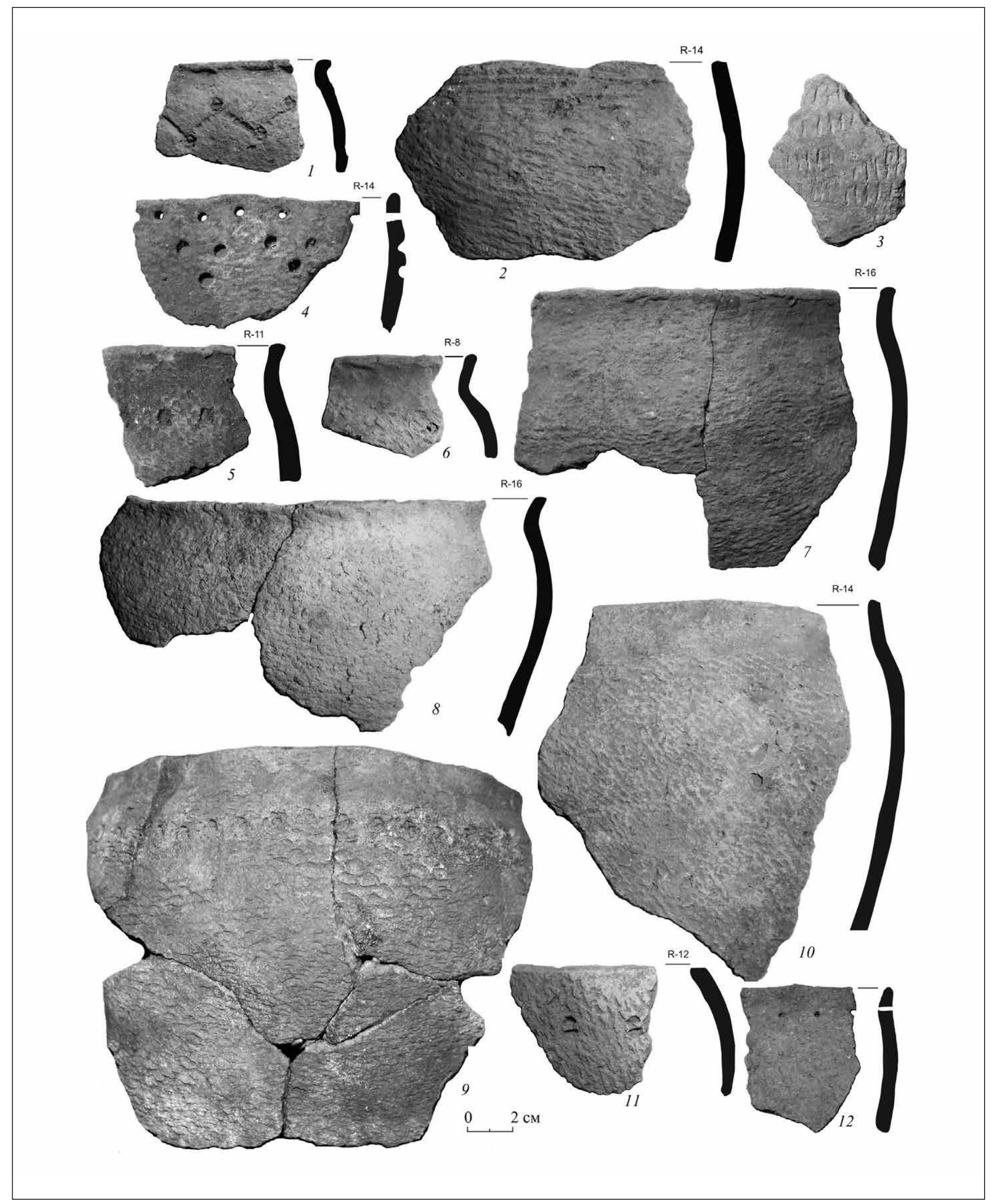

РИС. 126. РАННЕДЬЯКОВСКАЯ ТЕКСТИЛЬНАЯ КЕРАМИКА

Городище Круглица (Московский областной краеведческий музей) 


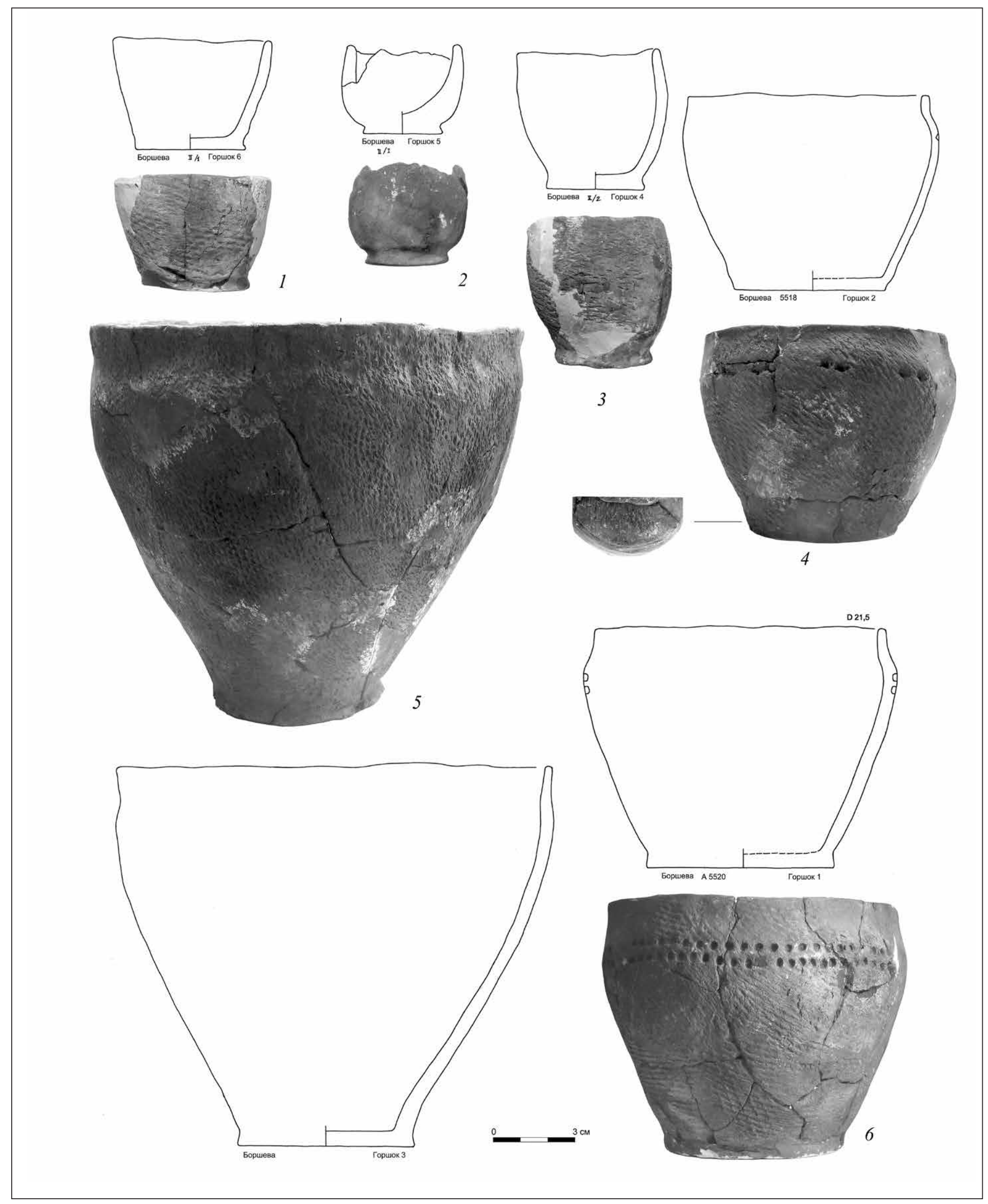

РИС. 127. ГОРШКИ ИЗ НИЖНЕГО СЛОЯ ГОРОДИЩА БОРШЕВА

Раскопки Х.И. Крис, Бронницкий музей 


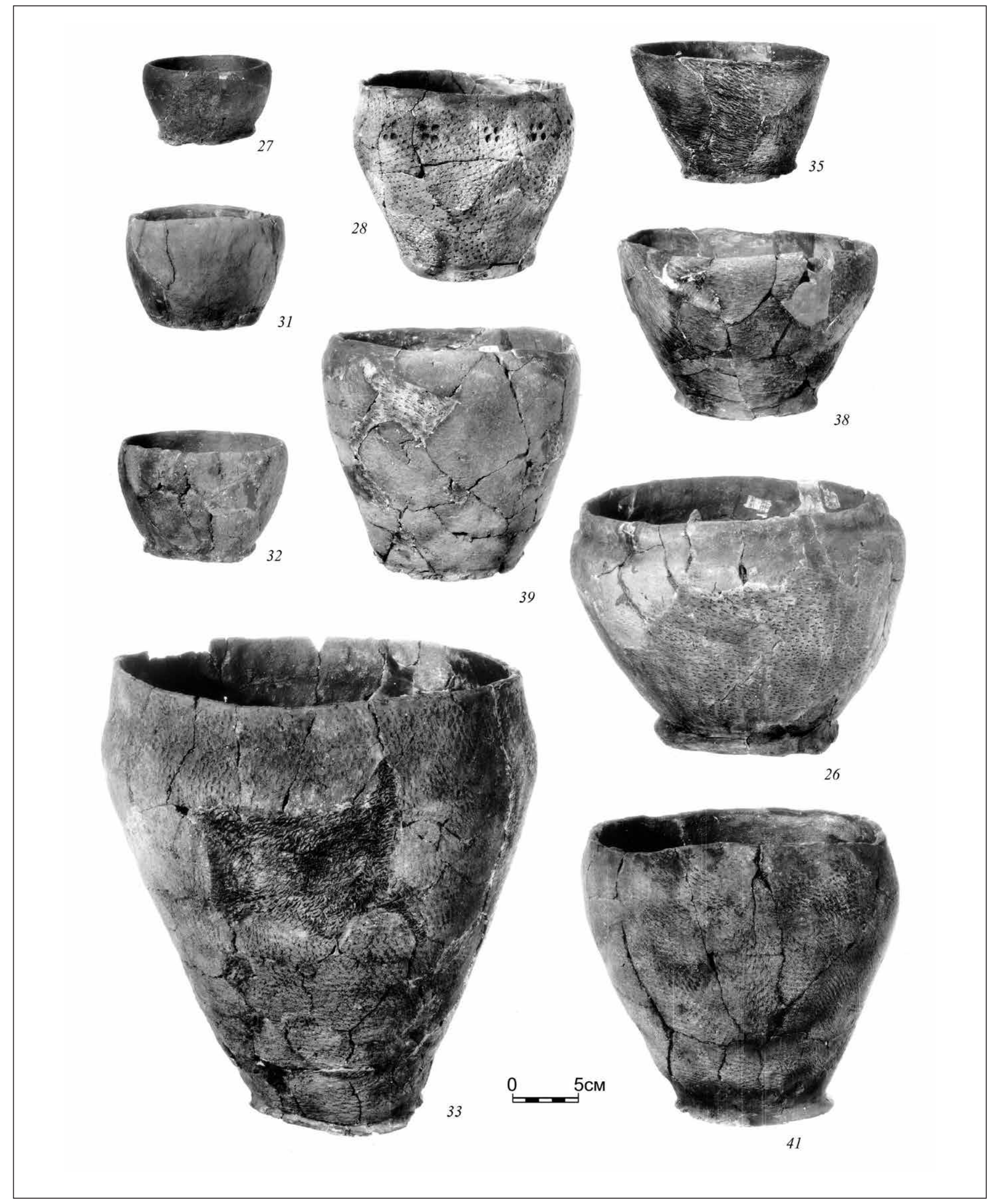

РИС. 128. РАННЕДЬЯКОВСКАЯ ТЕКСТИЛЬНАЯ КЕРАМИКА. ГОРОДИЩЕ ДЬЯКОВО (МУЗЕЙ ИСТОРИИ МОСКВЫ) 


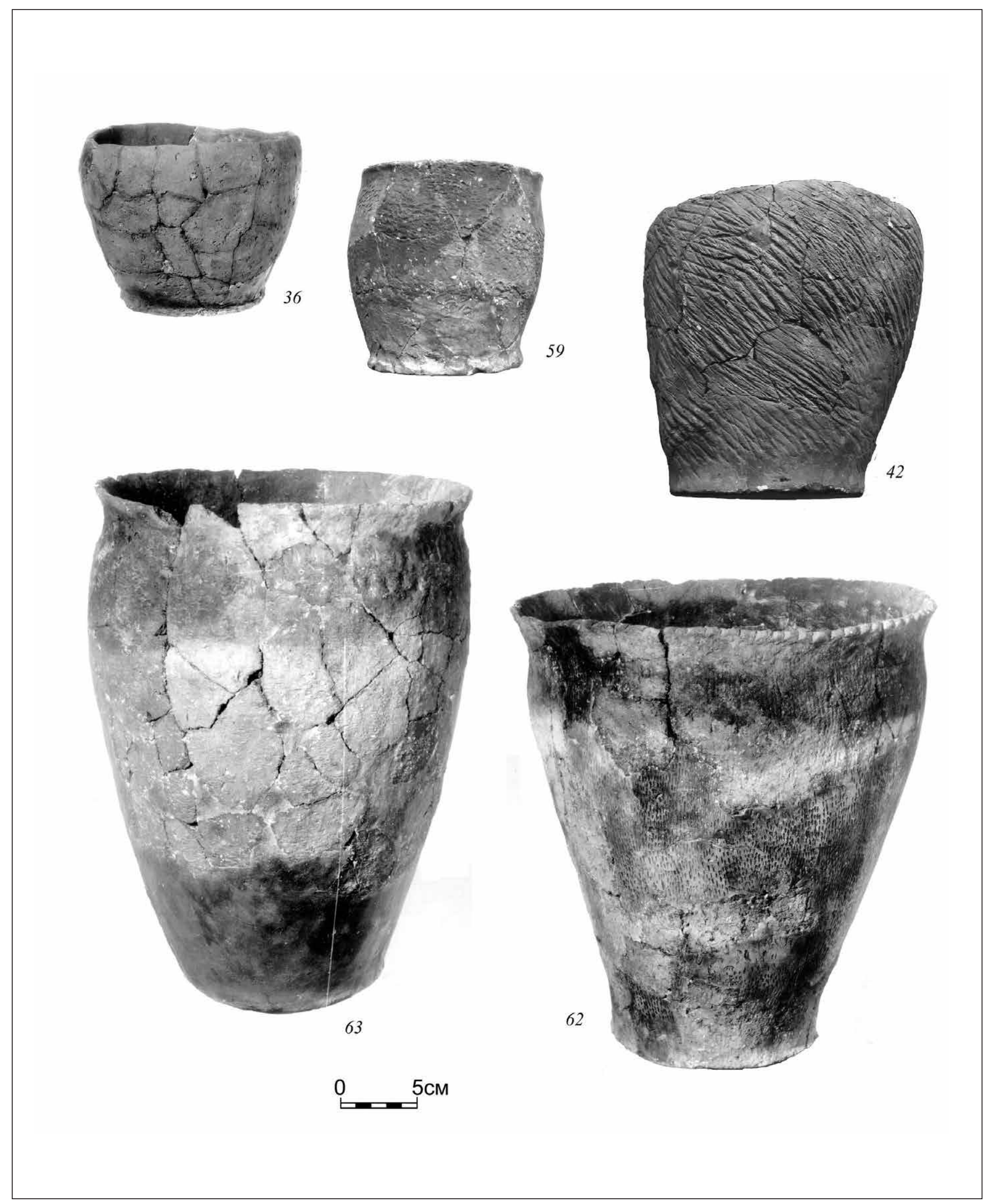

РИС. 129. РАННЕДЬЯКОВСКАЯ ТЕКСТИЛЬНАЯ И ГЛАДКОСТЕННАЯ КЕРАМИКА. ГОРОДИЩЕ ДЬЯКОВО

Горшки № 63 и 62 из верхней части нижнего слоя городища (Музей истории Москвы) 

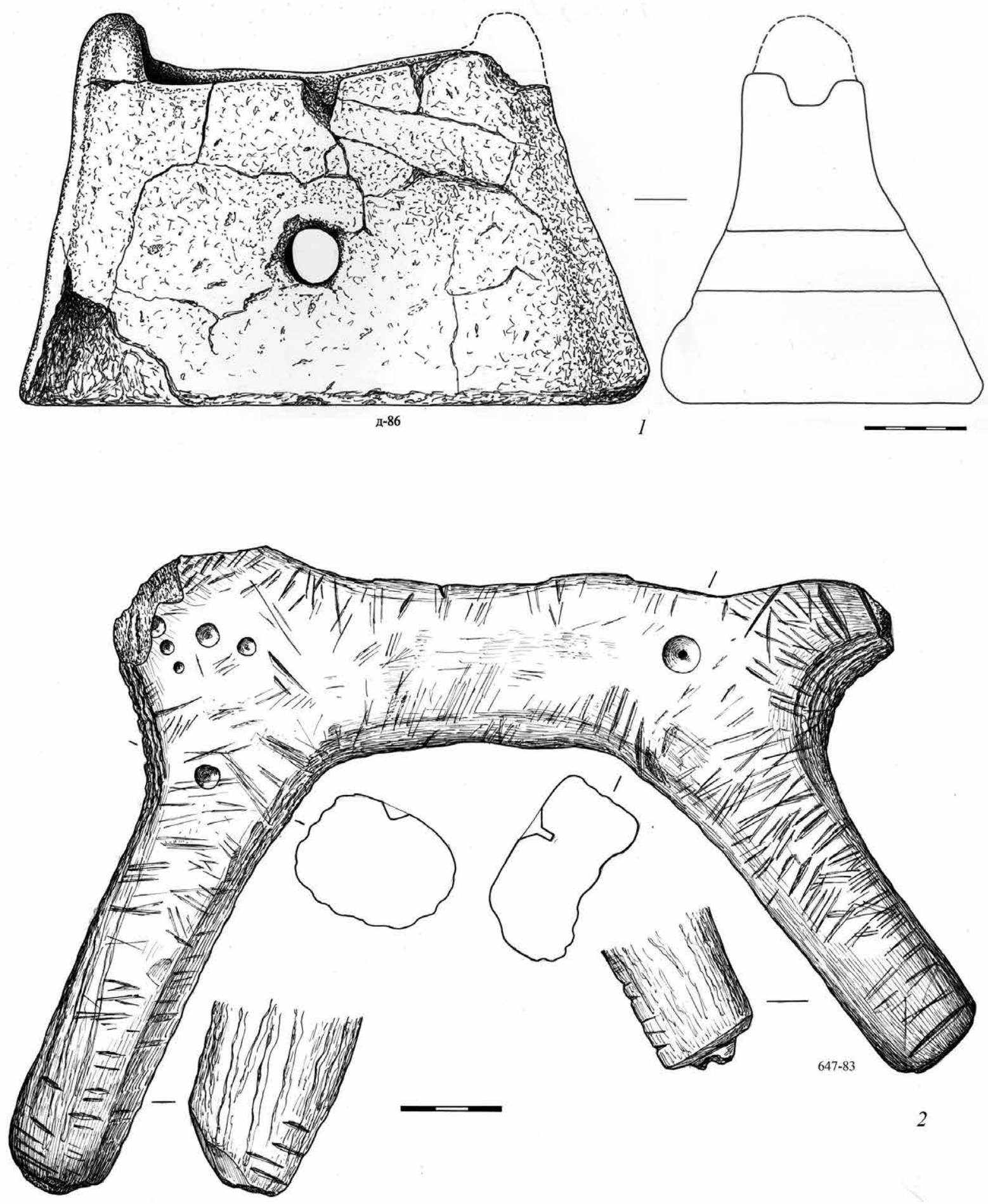

РИС. 130. ГЛИНЯНЫЙ РОГАТЫЙ КИРПИЧ И ВЕРСТАК ИЗ РОГА ЛОСЯ ИЗ ВЕРХНЕГО СЛОЯ ДЬЯКОВА ГОРОДИЩА.

Рис. В.А. Раевой 

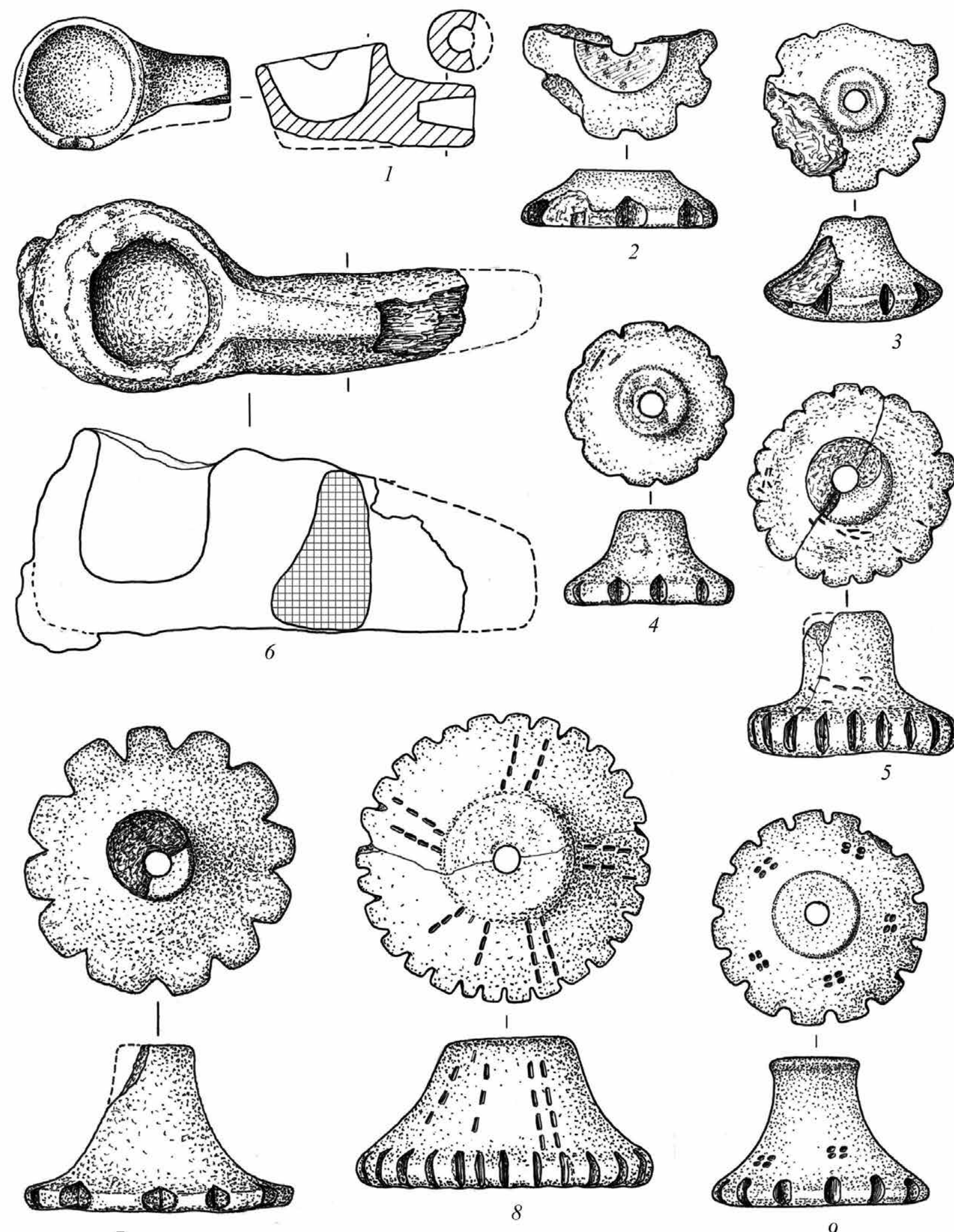

8
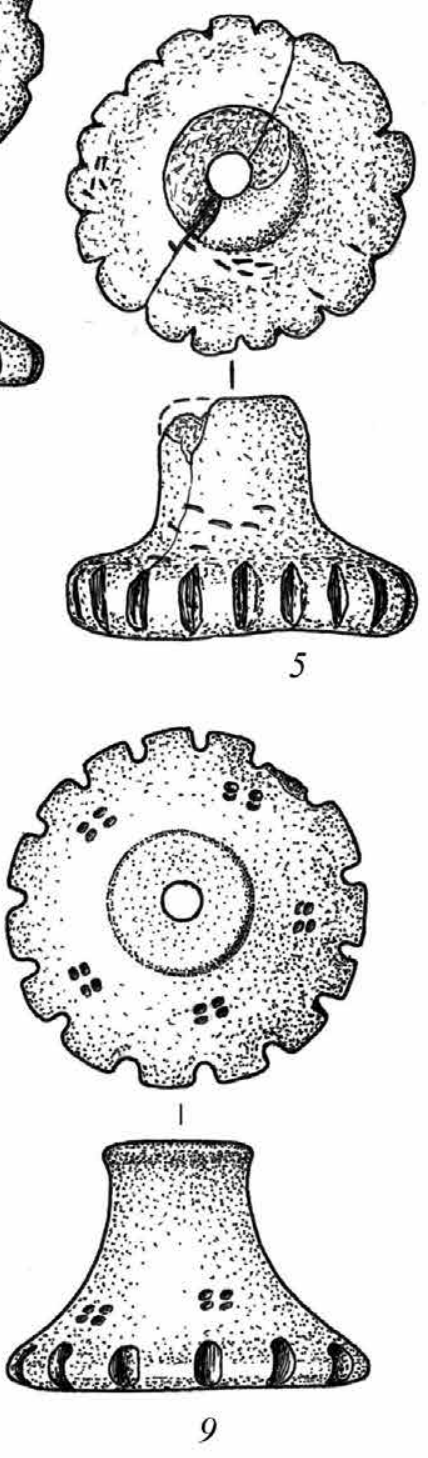

РИС. 131. ГЛИНЯНЫЕ ЛЬЯЧКИ И ГРУЗИКИ ДЬЯКОВА ТИПА ИЗ ВЕРХНЕГО СЛОЯ ДЬЯКОВА ГОРОДИЩА Внизу более ранние вещи, вверху - поздние. Рис. В.А. Раевой 

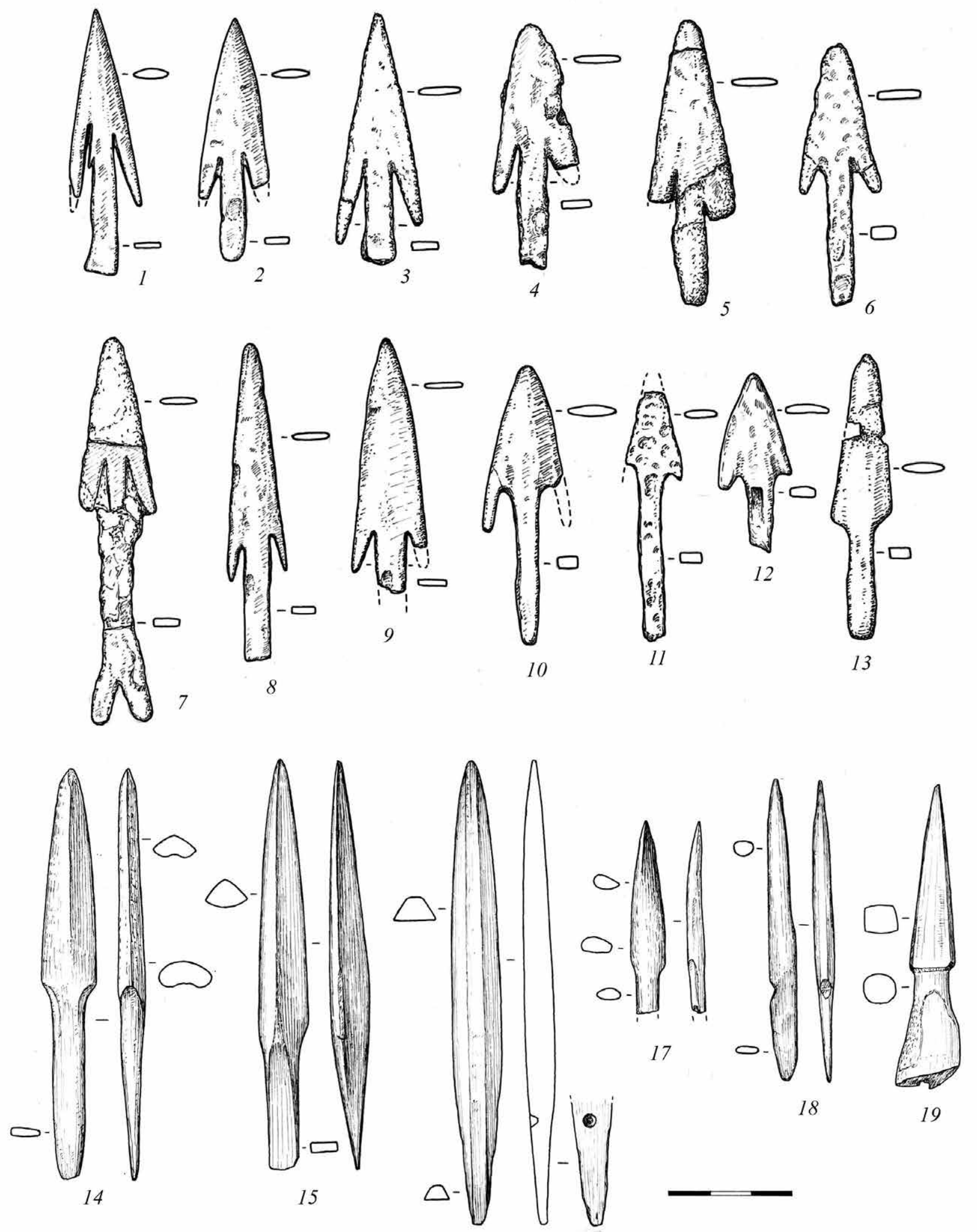

РИС. 132. ЖЕЛЕЗНЫЕ (1-13) И КОСтЯНЫЕ СТРЕЛЫ (14-19) ИЗ ВЕРХНЕГО СЛОЯ ДЬЯКОВА ГОРОДИЩА Внизу более ранние вещи. Рис. В.А. Раевой 


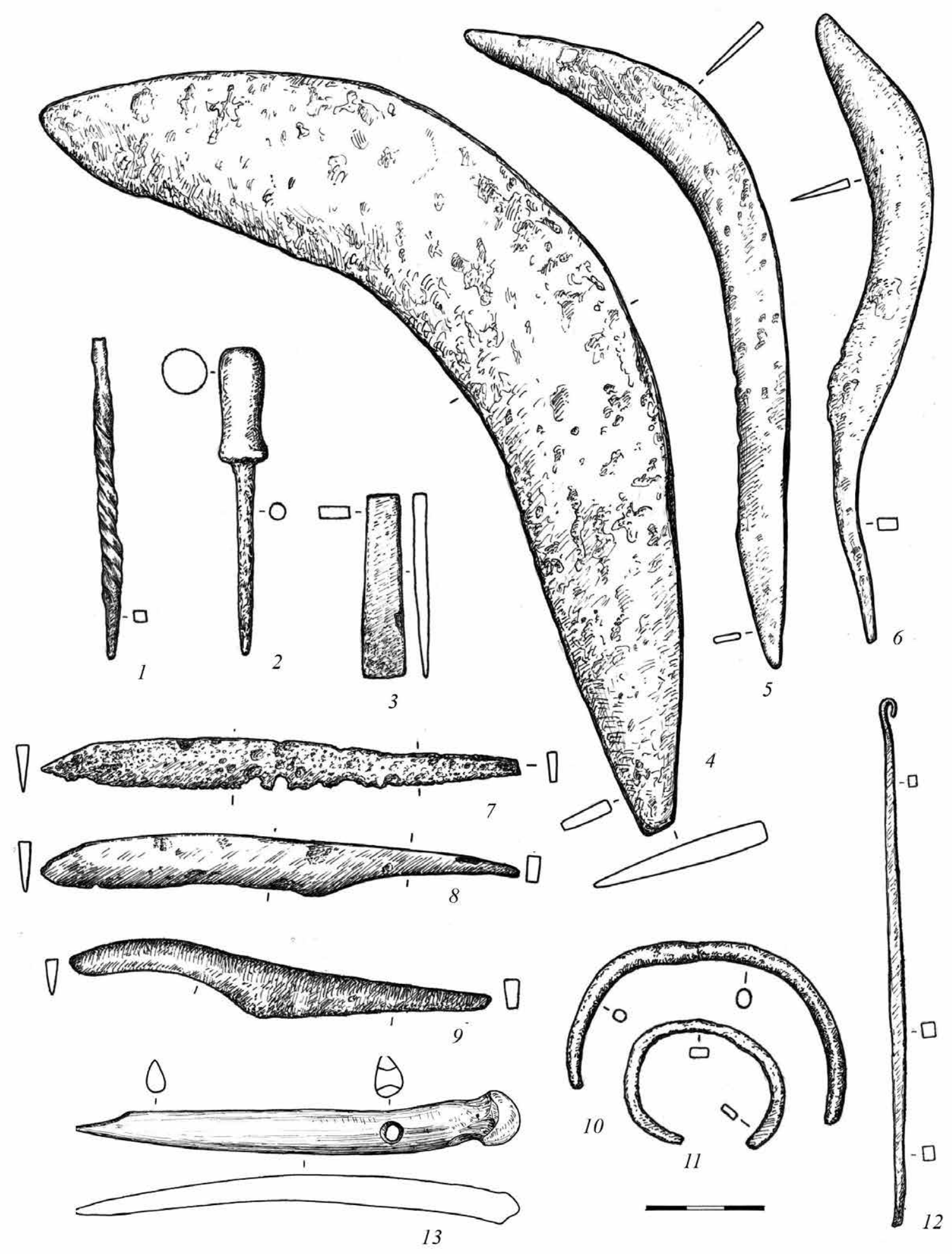

РИС. 133. ЖЕЛЕЗНЫЕ ШИЛЬЯ $(1,2)$, ДОЛОТО (3) СЕРПЫ (4-6), НОЖИ (7-9), КОЛЬЦА $(10,11)$, ВЯЗАЛЬНЫЙ КРЮЧОК (12) И КОСТЯНОЙ КОЧЕДЫК (13) ИЗ ВЕРХНЕГО СТОЯ ДЬЯКОВА ГОРОДИЩА 


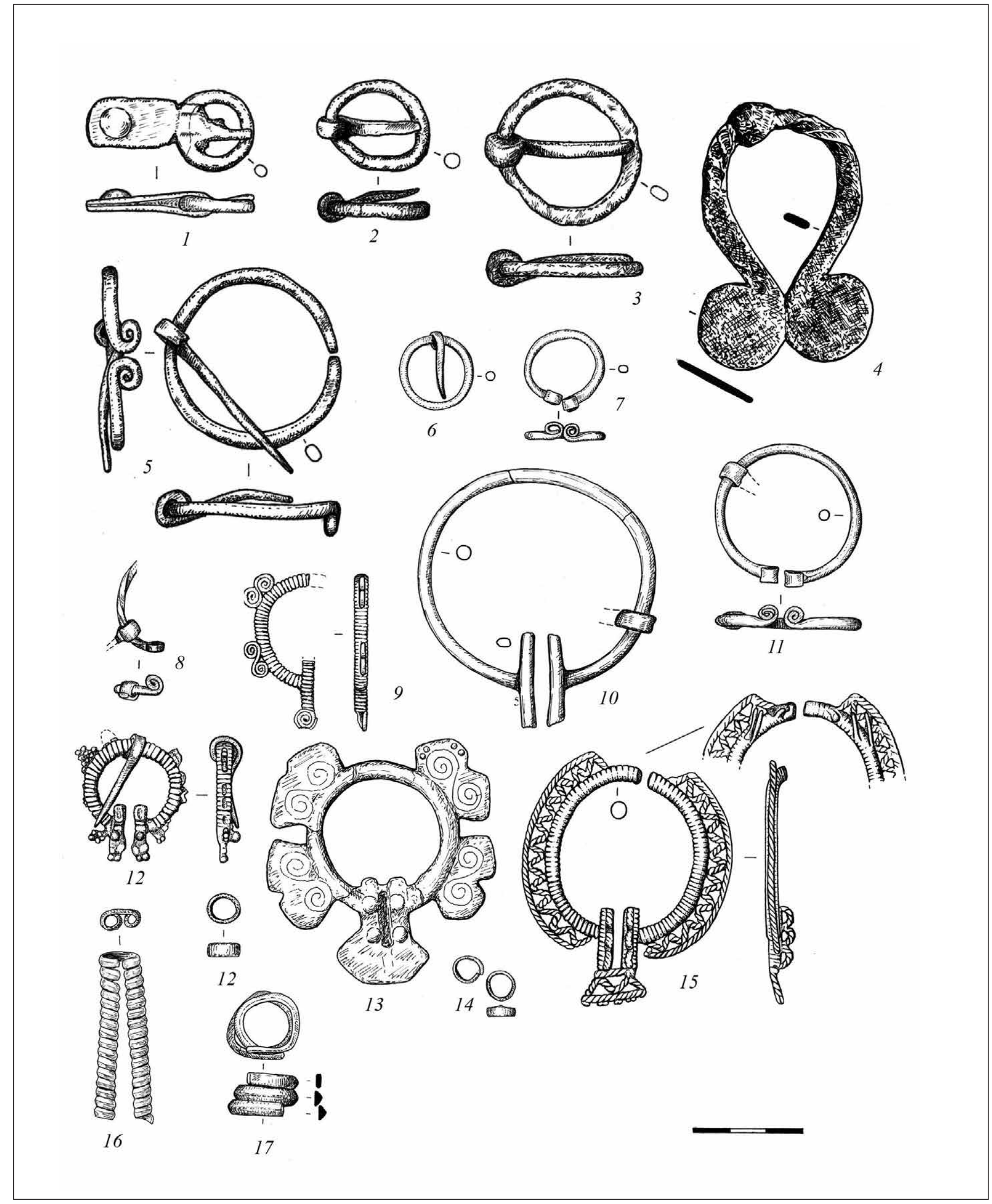

РИС. 134. ЖЕЛЕЗНЫЕ (1-5) И БРОНЗОВЫЕ (6-17) ПРЯЖКИ, ПРОНИЗКИ ИЗ ВЕРХНЕГО СЛОЯ ГОРОДИЩА ДЬЯКОВА (1-3, 5-17) И ДУНИНО (4) 


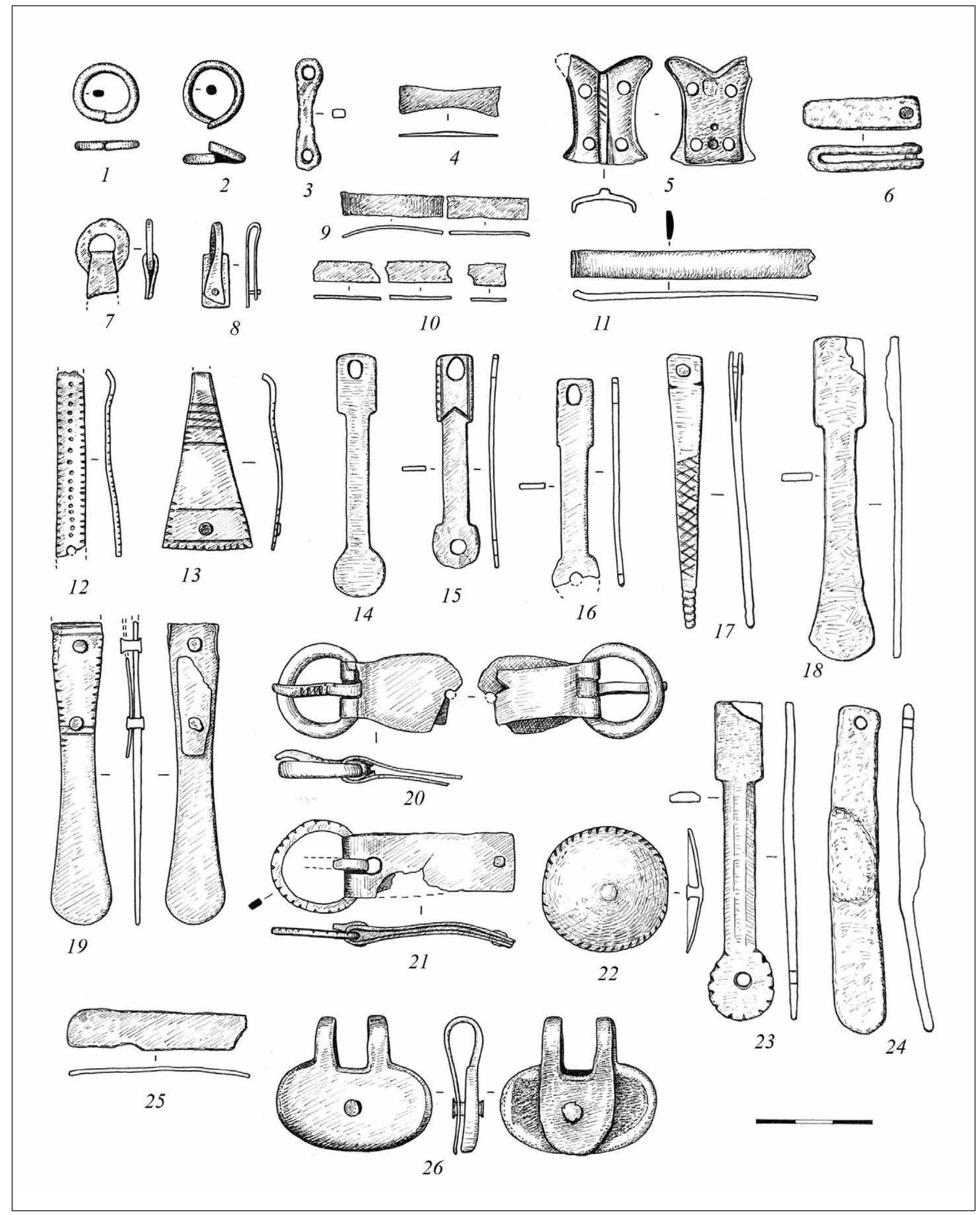

РИС. 135. БРОНЗОВАЯ РЕМЕННАЯ ГАРНИТУРА ИЗ ВЕРХНЕГО СЛОЯ ДЬЯКОВА ГОРОДИЩА 


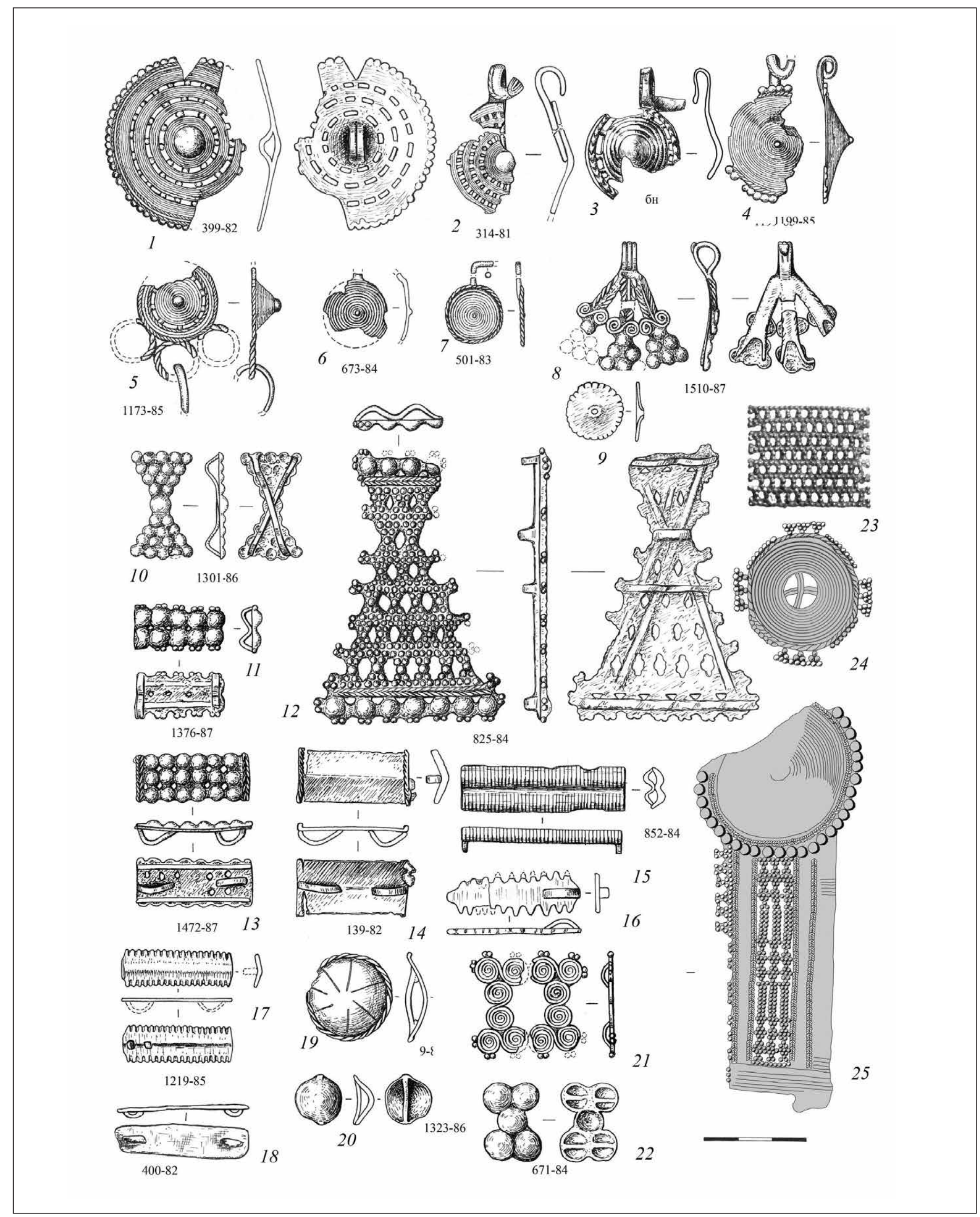

РИС. 136. БРОНЗОВЫЕ УКРАШЕНИЯ ИЗ ВЕРХНЕГО СЛОЯ ГОРОДИЩ ДЬЯКОВО (1-22) И КРУГЛИЦА (23-25) 


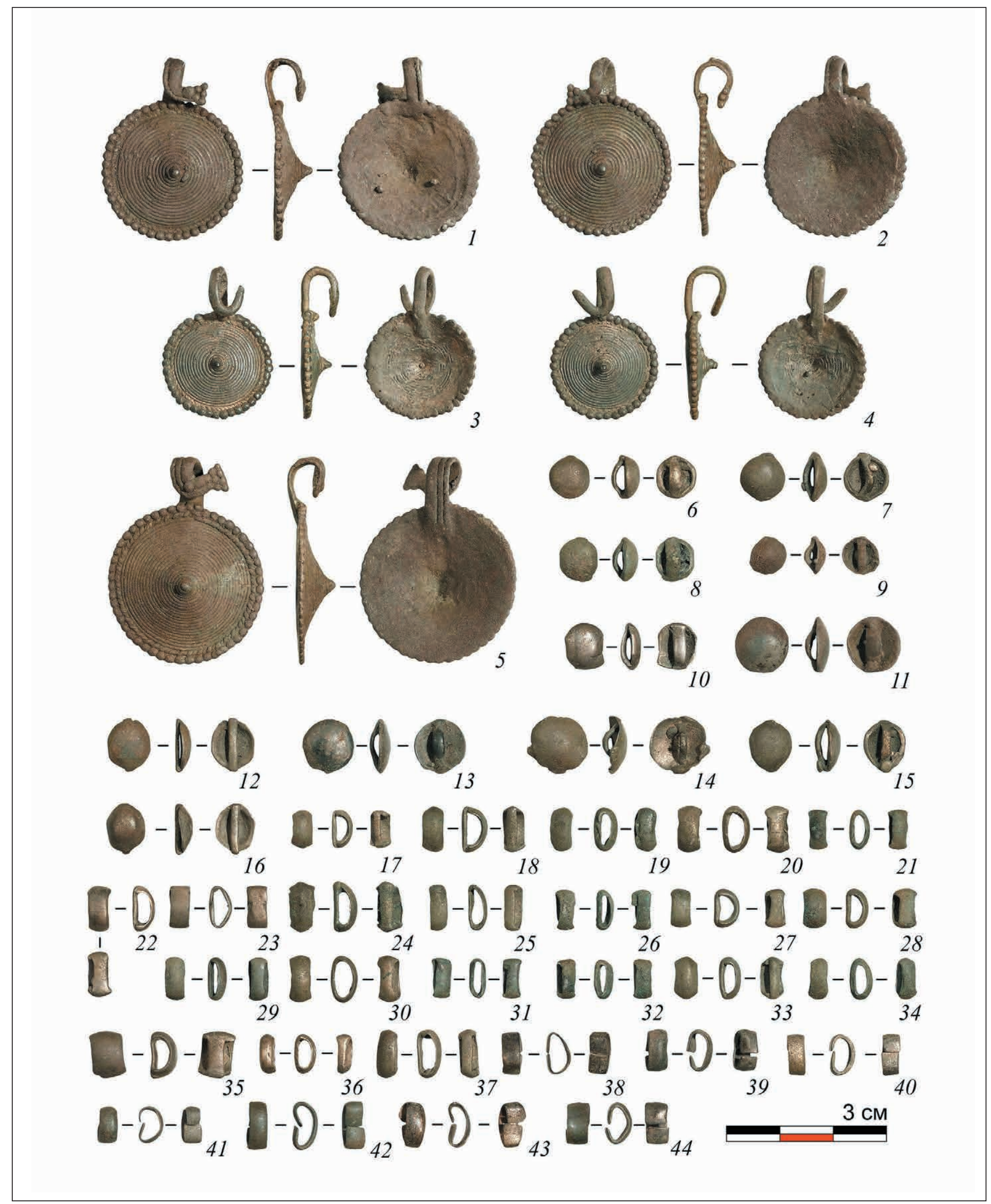

РИС. 137. БРОНЗОВЫЕ УКРАШЕНИЯ ИЗ КЛАДА С ГОРОДИЩА ДЮТЬКОВО 

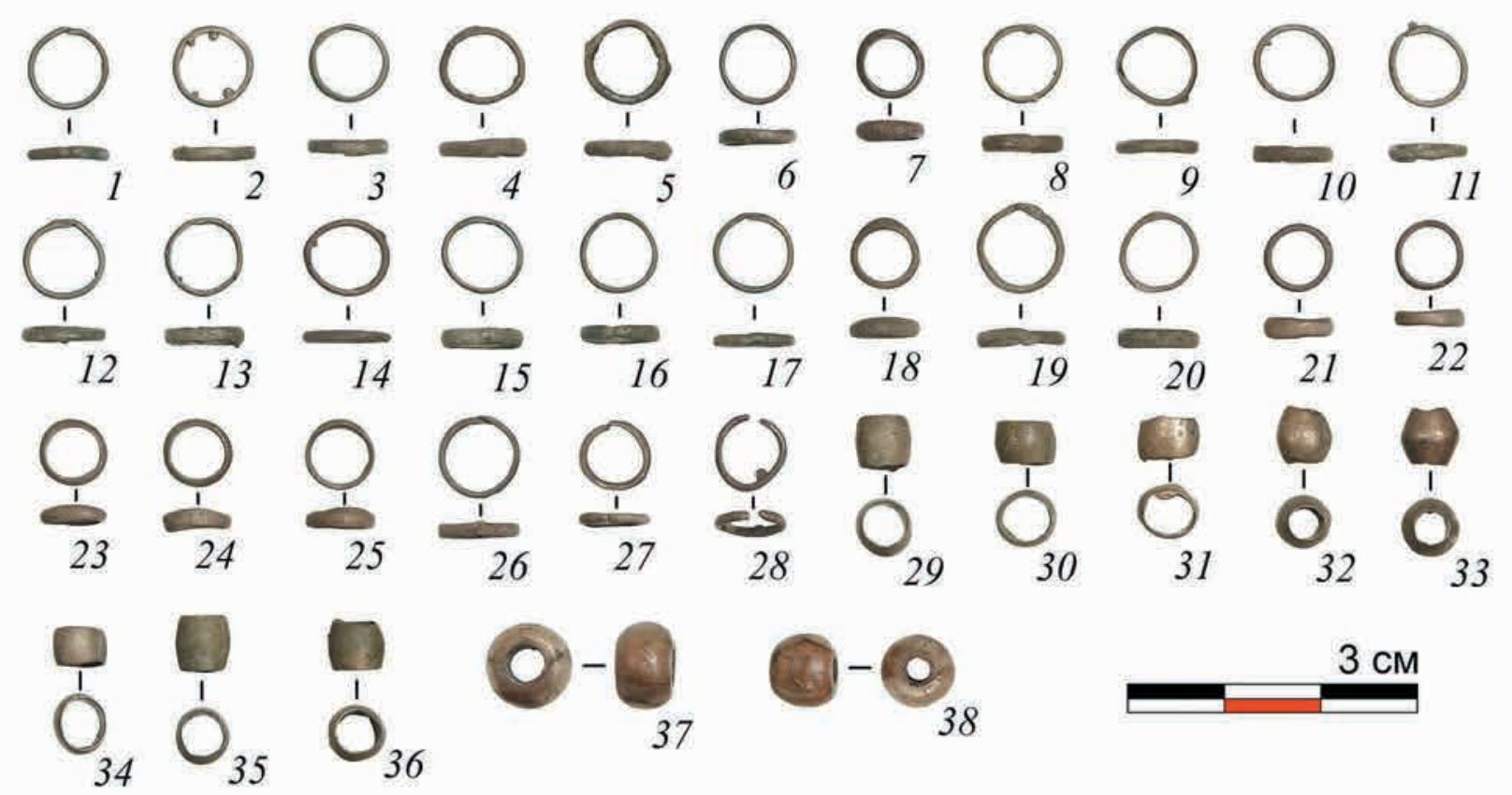

$3 \mathrm{~cm}$

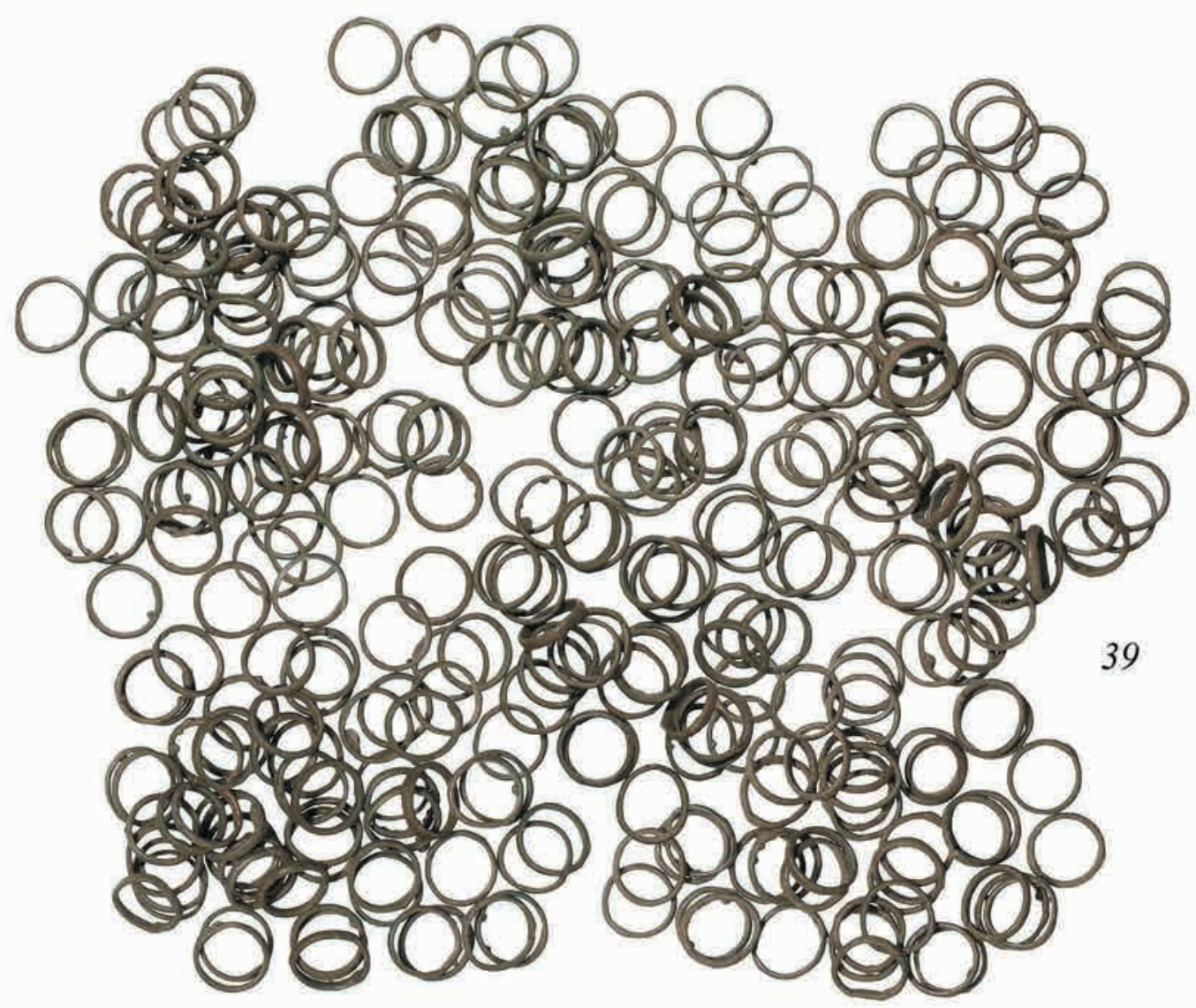

РИС. 138. БРОНЗОВЫЕ УКРАШЕНИЯ ИЗ КЛАДА С ГОРОДИЩА ДЮТЬКОВО 




РИС. 139. БРОНЗОВЫЕ УКРАШЕНИЯ ИЗ АЛТУХОВСКОГО КЛАДА (МУЗЕЙ ИСТОРИИ МОСКВЫ) 


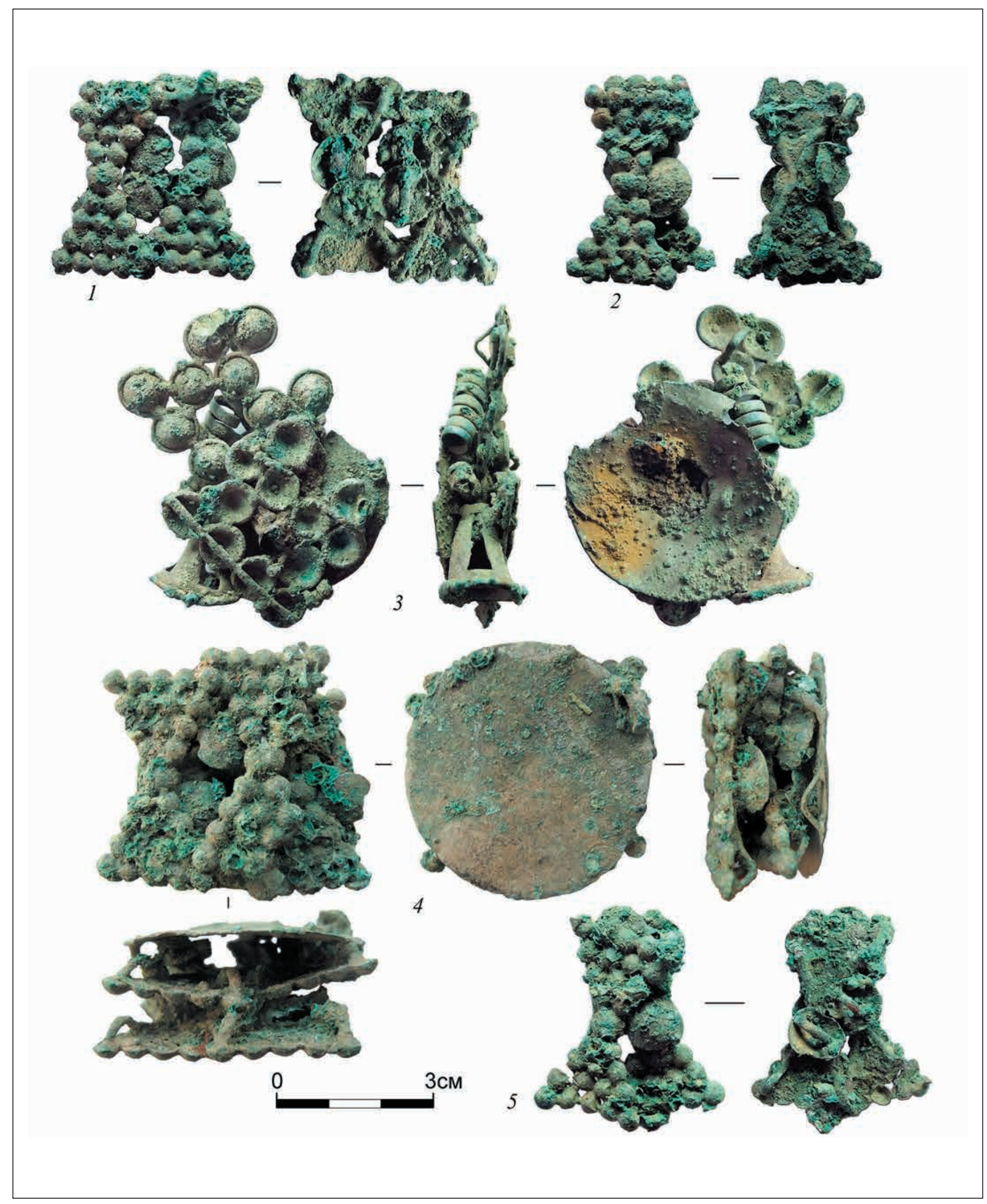

РИС. 140. БРОНЗОВЫЕ УКРАШЕНИЯ ИЗ АЛТУХОВСКОГО КЛАДА (МУЗЕЙ ИСТОРИИ МОСКВЫ) 


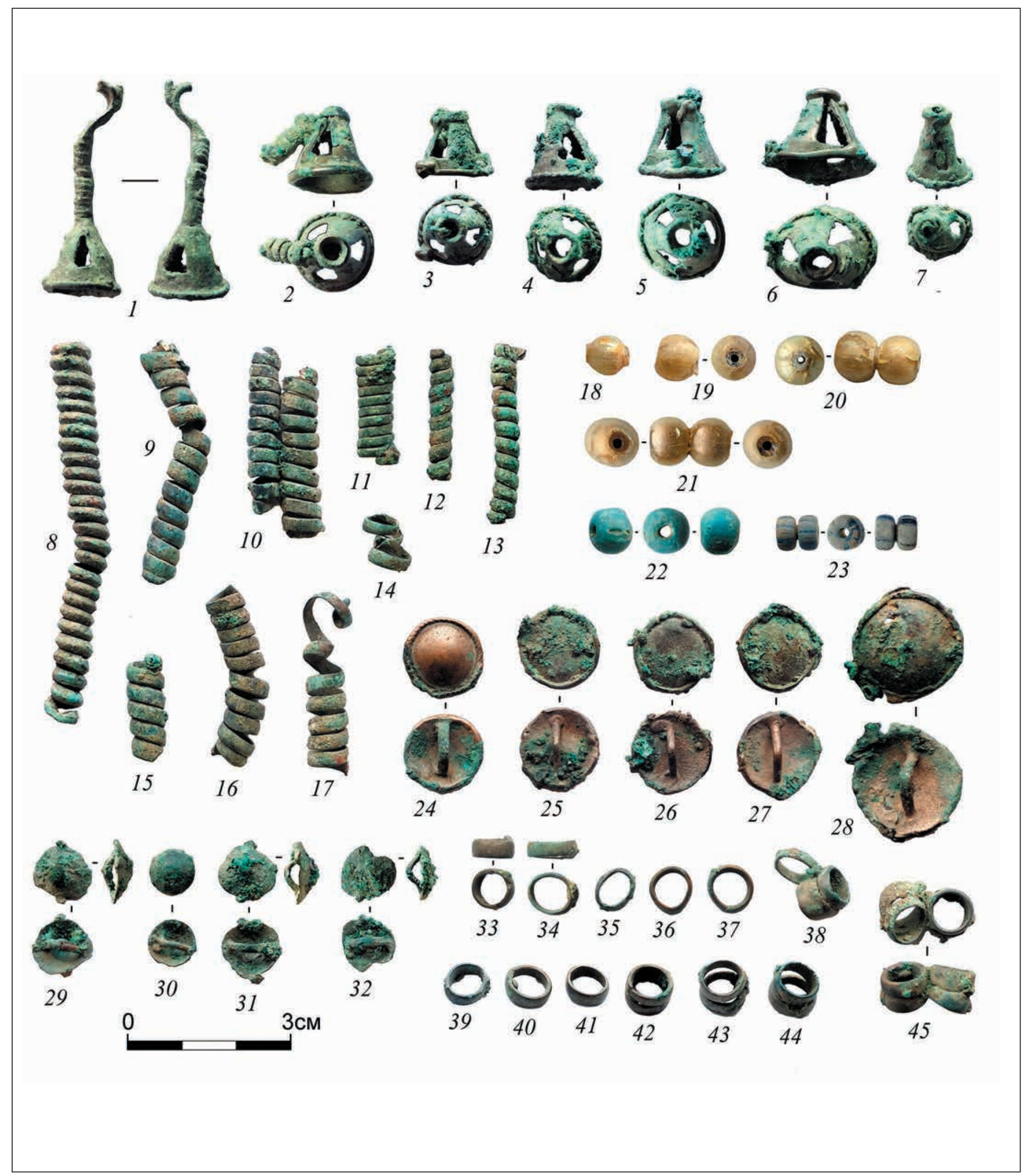

РИС. 141. БРОНЗОВЫЕ УКРАШЕНИЯ И СТЕКЛЯННЫЕ БУСЫ ИЗ АЛТУХОВСКОГО КЛАДА (МУЗЕЙ ИСТОРИИ МОСКВЫ) 


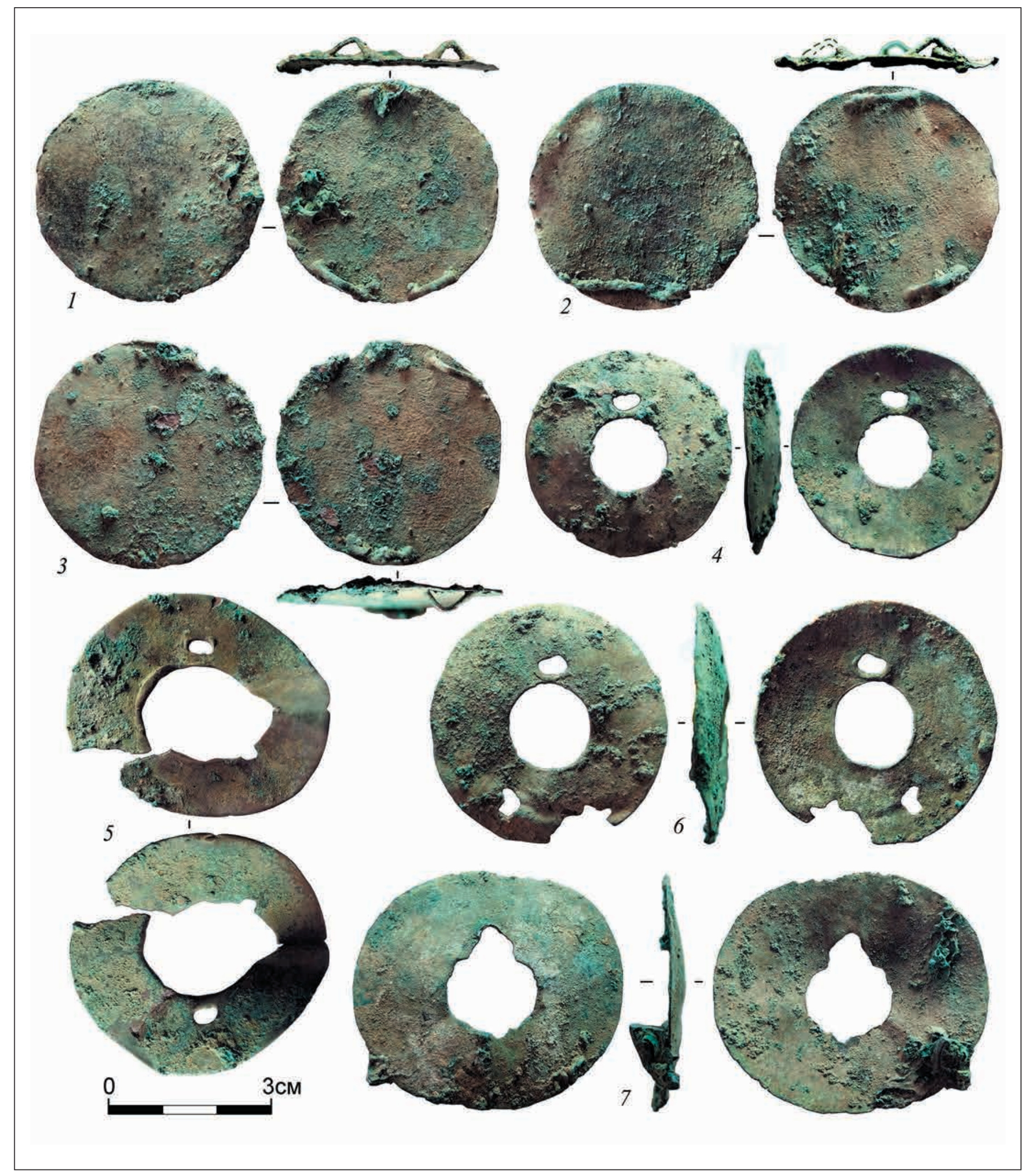

РИС. 142. БРОНЗОВЫЕ ПОРТУПЕЙНЫЕ ПРЯЖКИ ИЗ АЛТУХОВСКОГО КЛАДА (МУЗЕЙ ИСТОРИИ МОСКВЫ) 


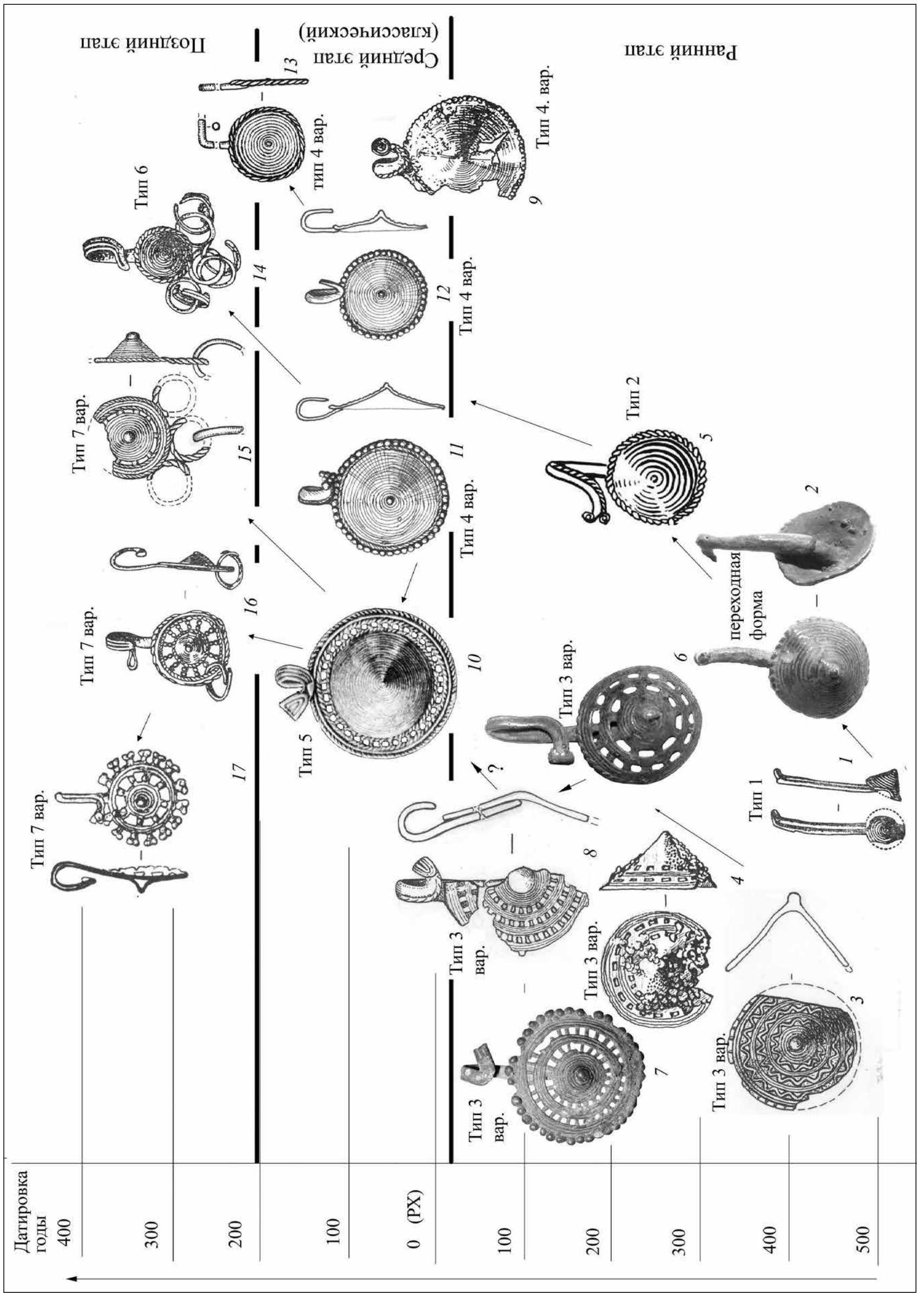




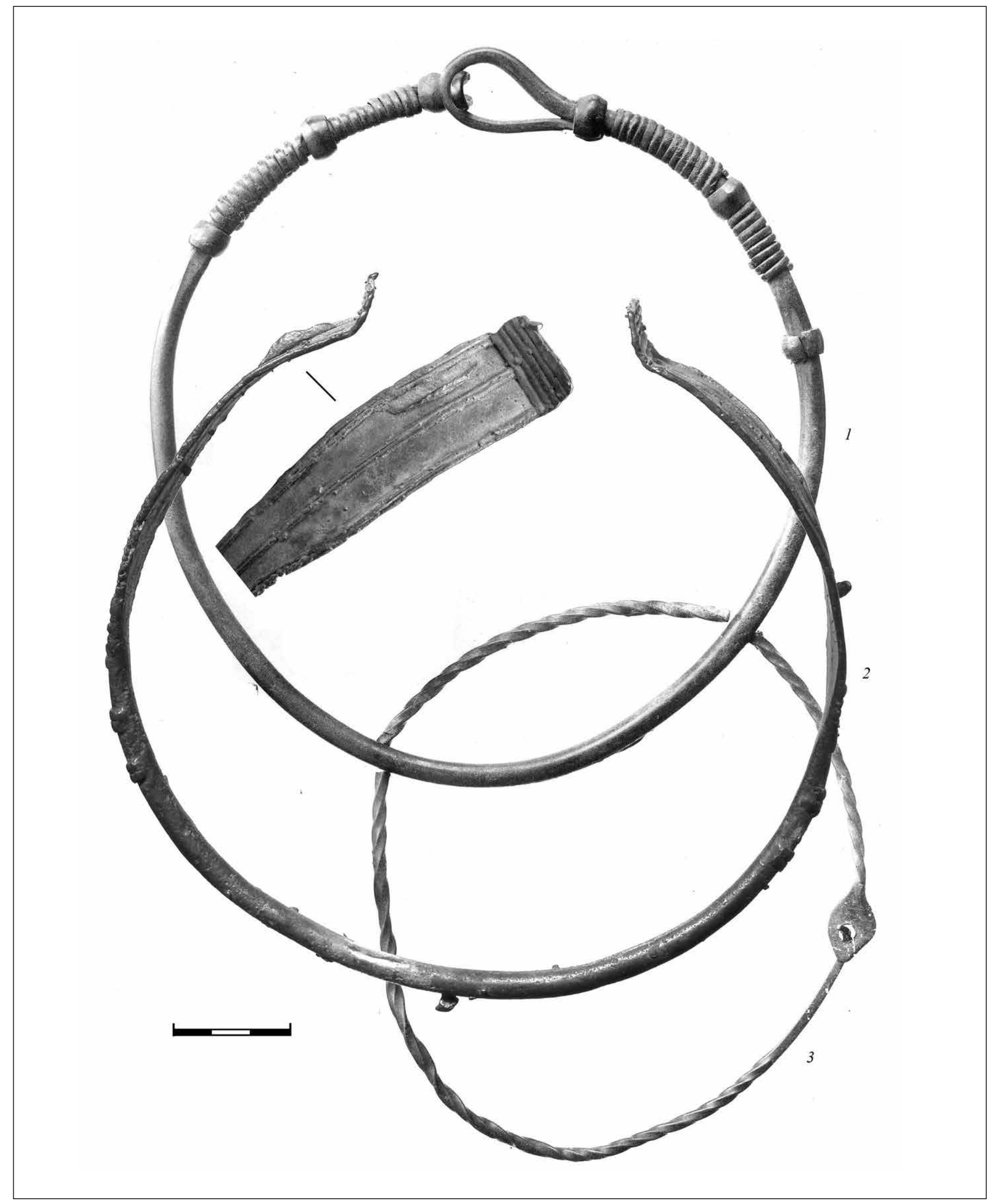

РИС. 144. БРОНЗОВЫЕ ГРИВНЫ С ГОРОДИЩ ДЬЯКОВО $(1,3)$ И ЩЕРБИНСКОЕ (2). ГОСУДАРСТВеННЫЙ ИСТОРИЧЕСКИЙ МУЗЕЙ, МУЗЕЙ В.И. ЛЕНИНА В ПодОЛЬСКЕ 

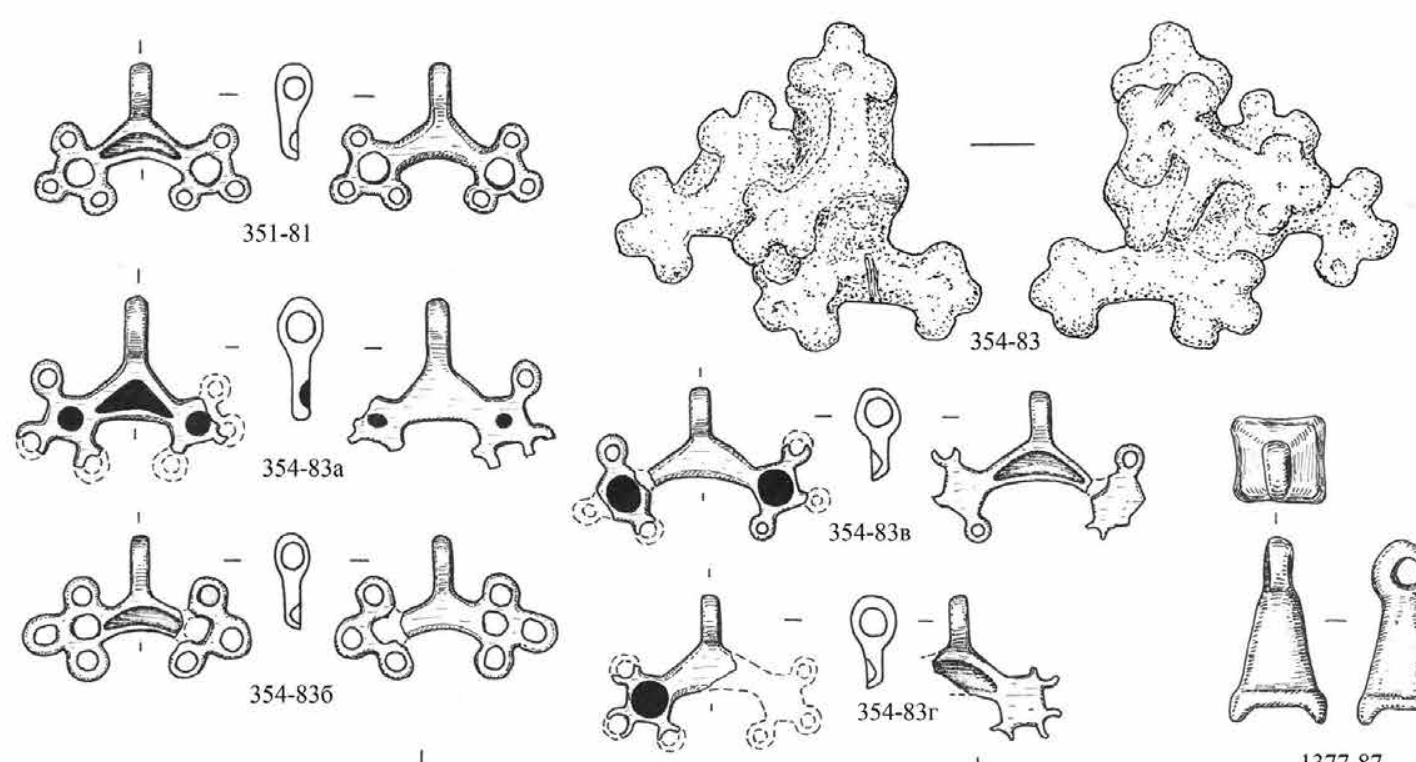

[i]
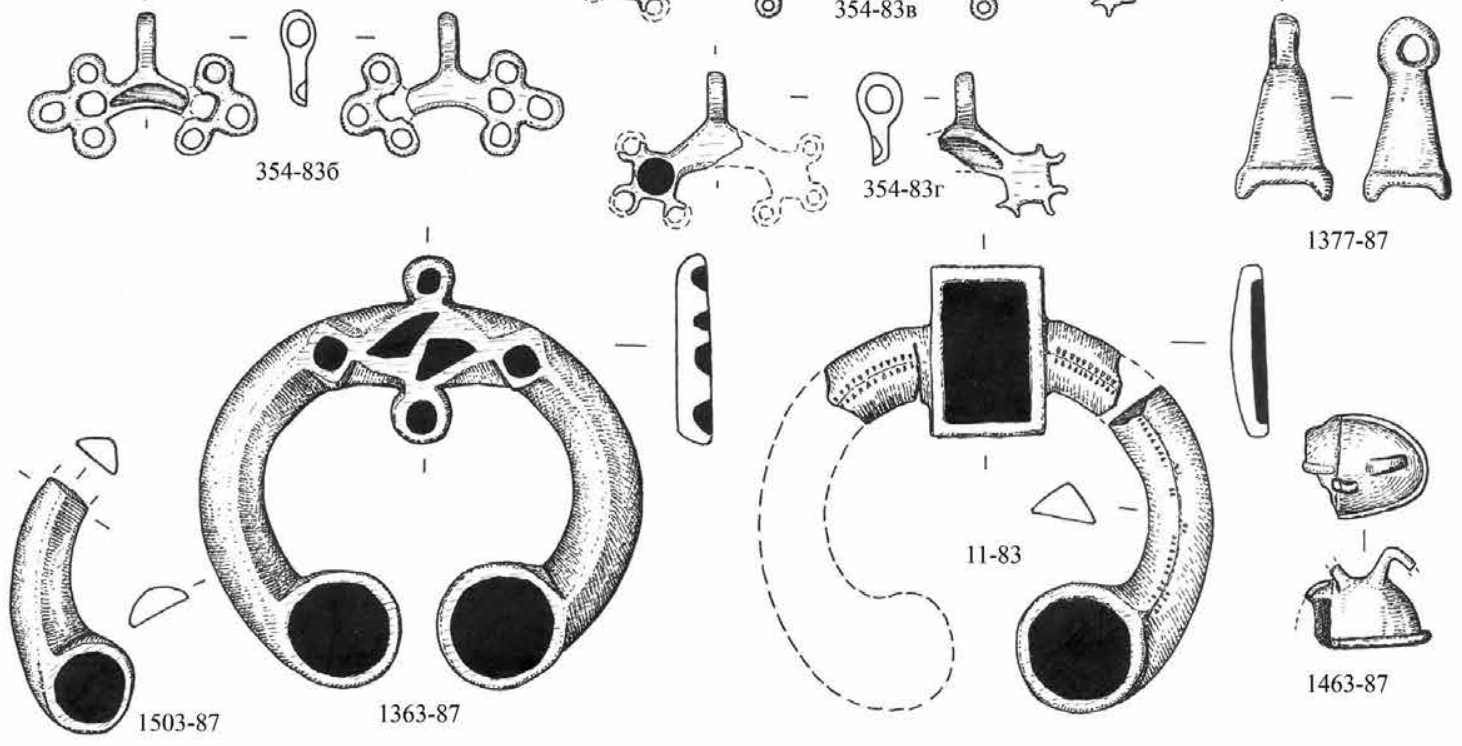

$1377-87$
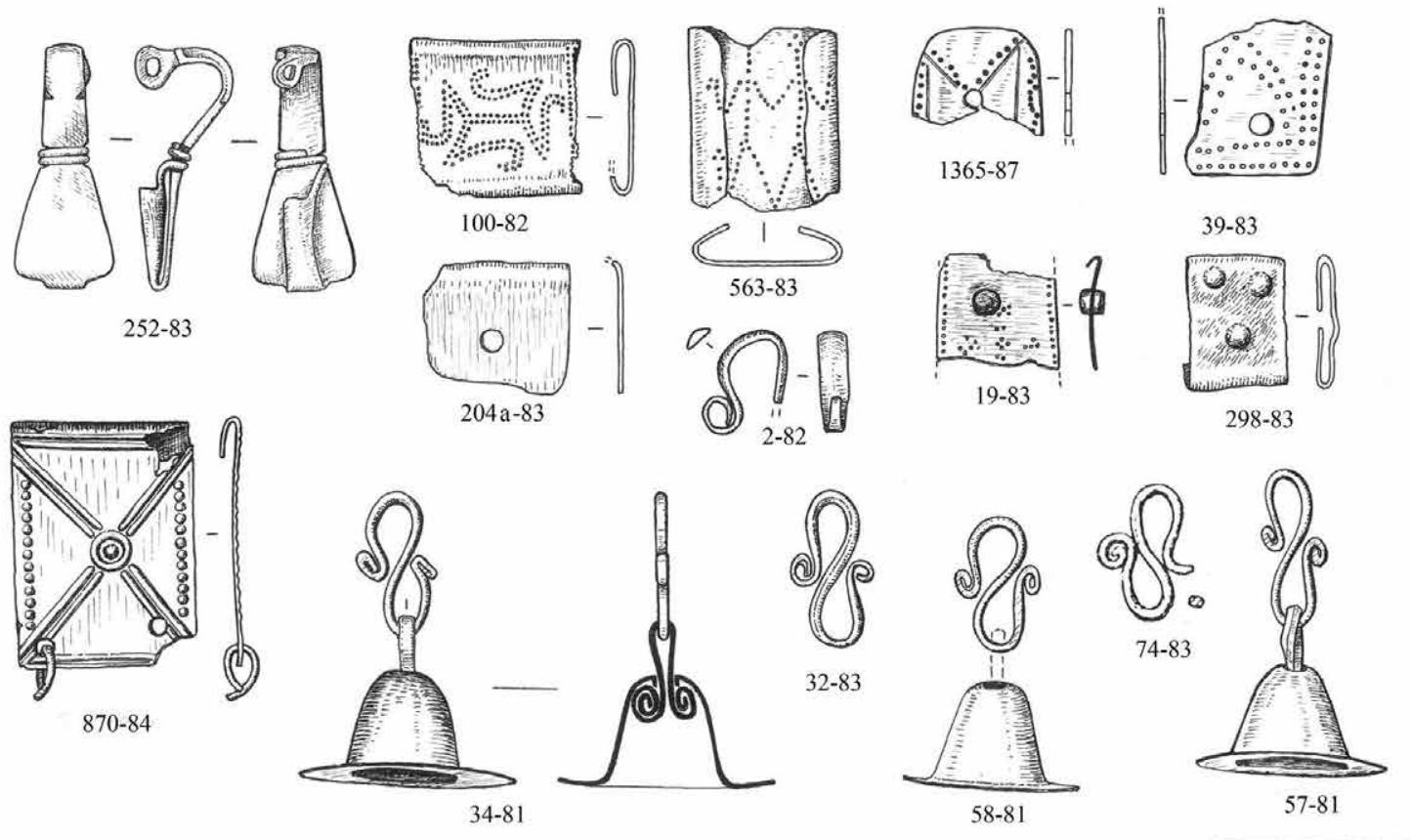

РИС. 145. УКРАШЕНИЯ С ЭМАЛЯМИ И НЕКОТОРЫЕ ТИПЫ ДРУГИХ ПРИВОЗНЫХ ИЗДЕЛИЙ ИЗ ВЕРХНЕГО СЛОЯ ДЬЯКОВА ГОРОДИЩА (МУЗЕЙ ИСТОРИИ МОСКВЫ) 


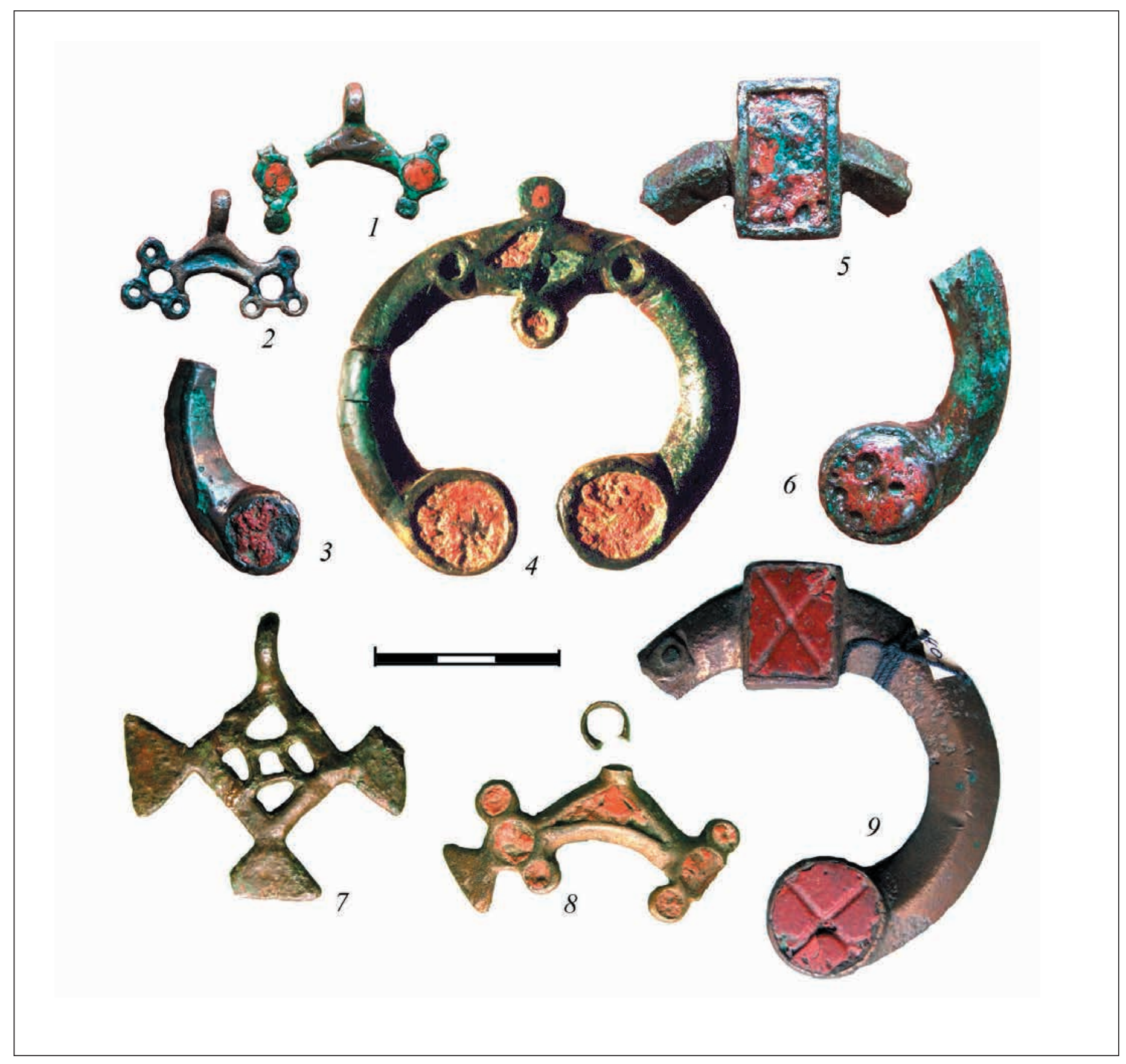

РИС. 146. УКРАШЕНИЯ С ЭМАЛЯМИ С ГОРОДИЩ ДЬЯКОВО (1-6) И ЛУКОВНЯ 1 (7-9). МУЗЕЙ ИСтОРИИ МоскВЫ 

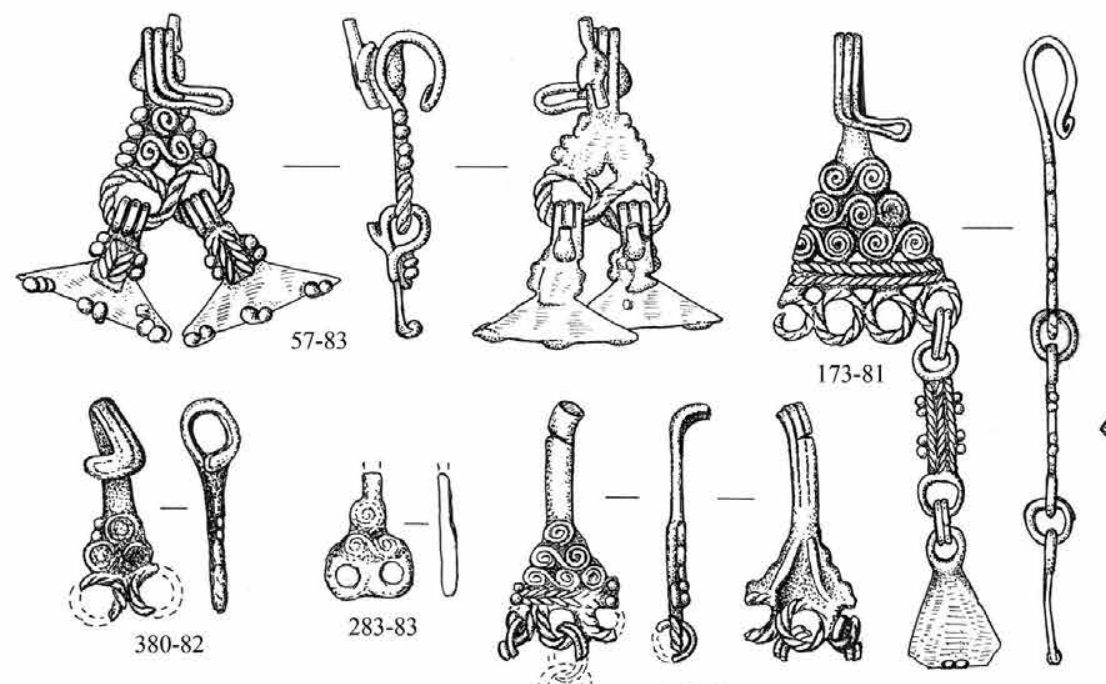

(a)
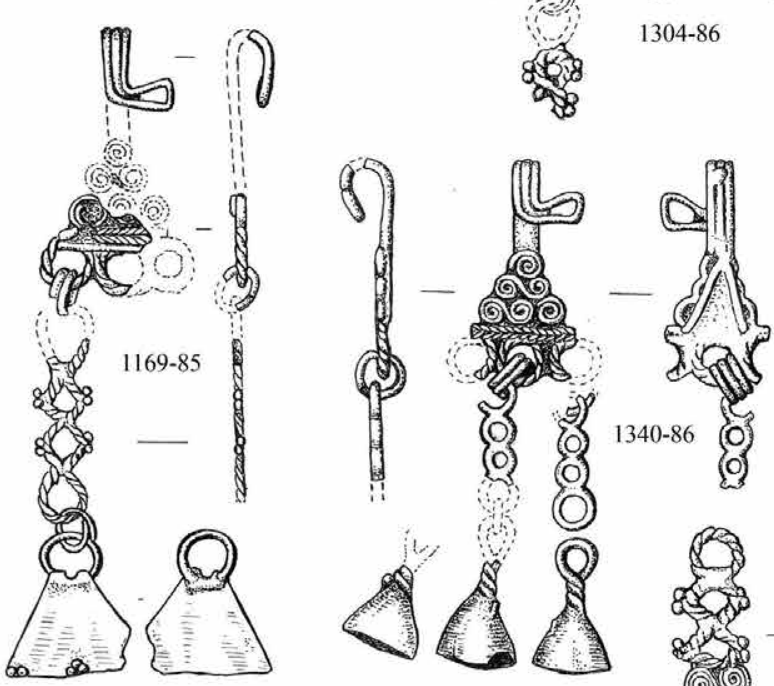

6.
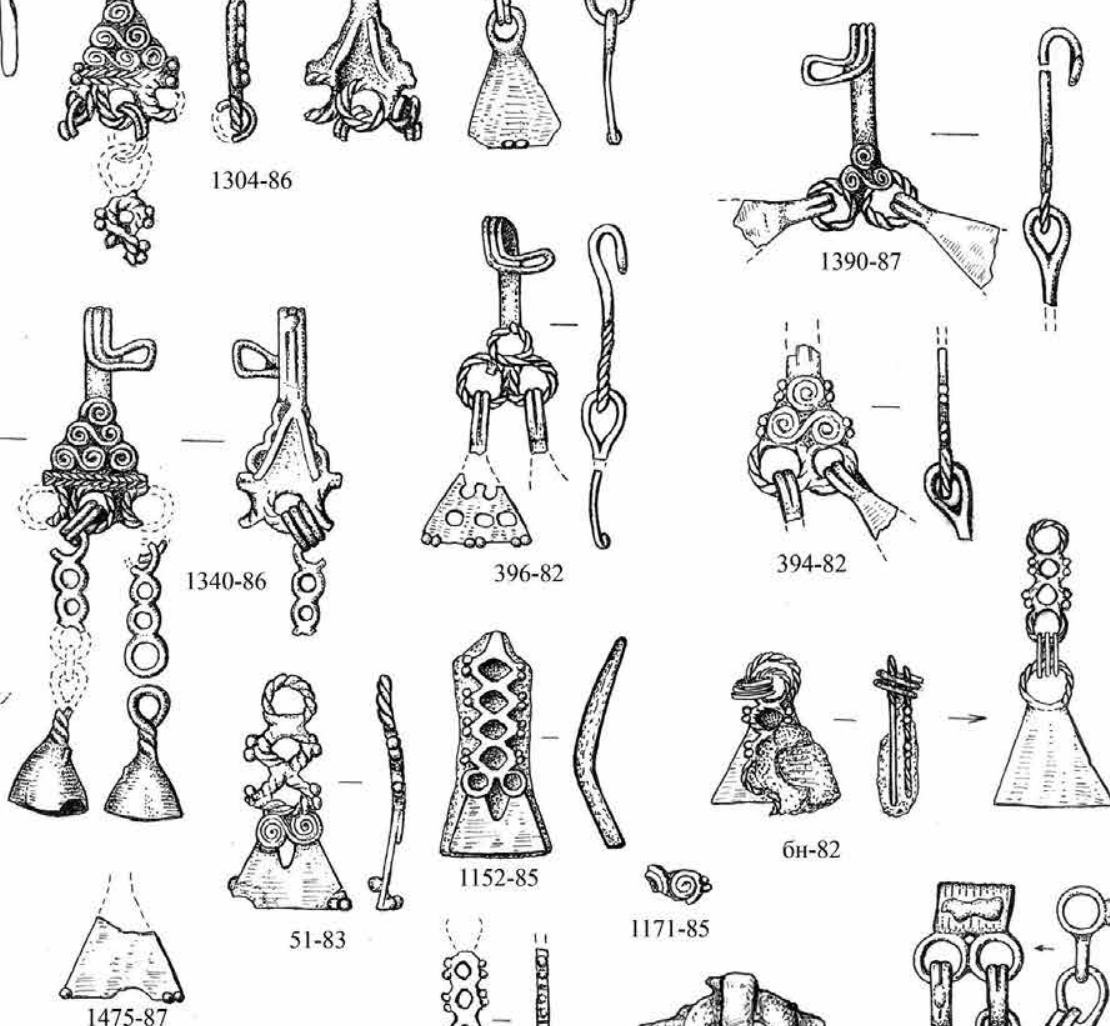

1152-85

gूo

$\frac{a n d}{406-82}$ - की
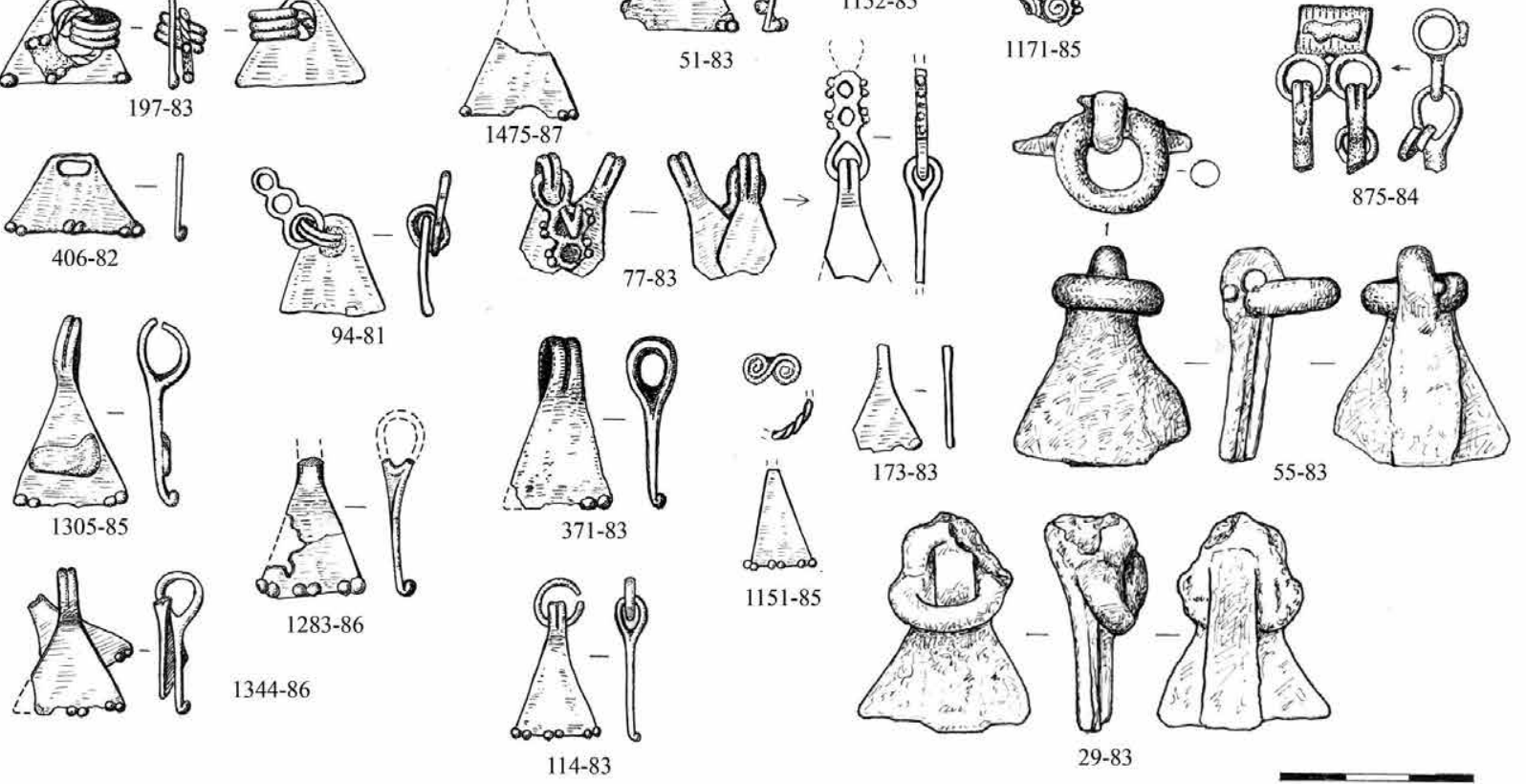

РИС. 147. ПОЗДНЕДЬЯКОВСКИЕ БРОНЗОВЫЕ И ЖЕЛЕЗНЫЕ (№ 55-83; 29-83) ВИСОЧНЫЕ УКРАШЕНИЯ ИЗ ВЕРХНЕГО СЛОЯ ДЬЯКОВА ГОРОДИЩА 

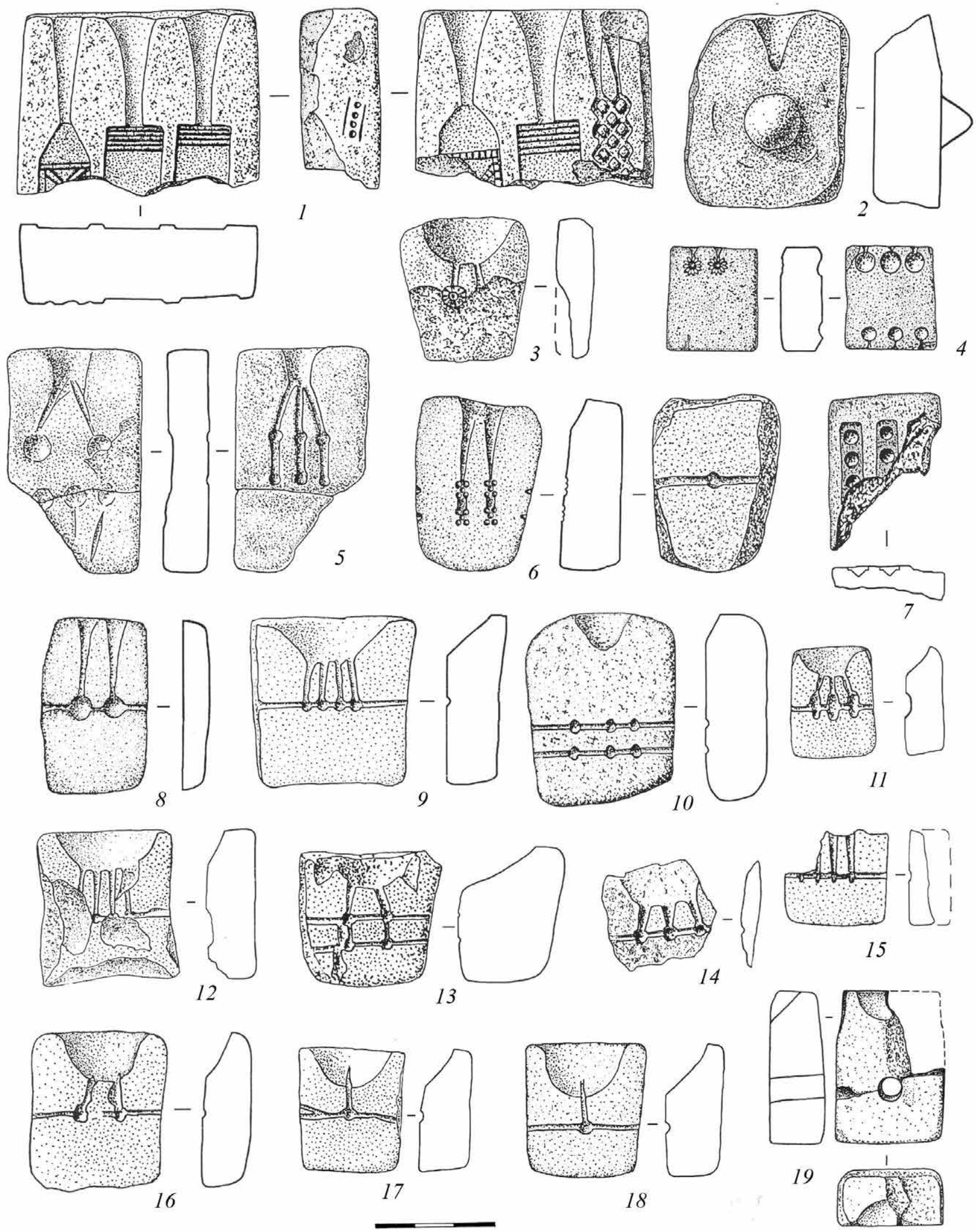

РИС. 148. КАМЕННЫЕ И ГЛИНЯНЫЕ ЛИТЕЙНЫЕ ФОРМОЧКИ ИЗ ВЕРХНЕГО СЛОЯ ДЬЯКОВА ГОРОДИЩА 


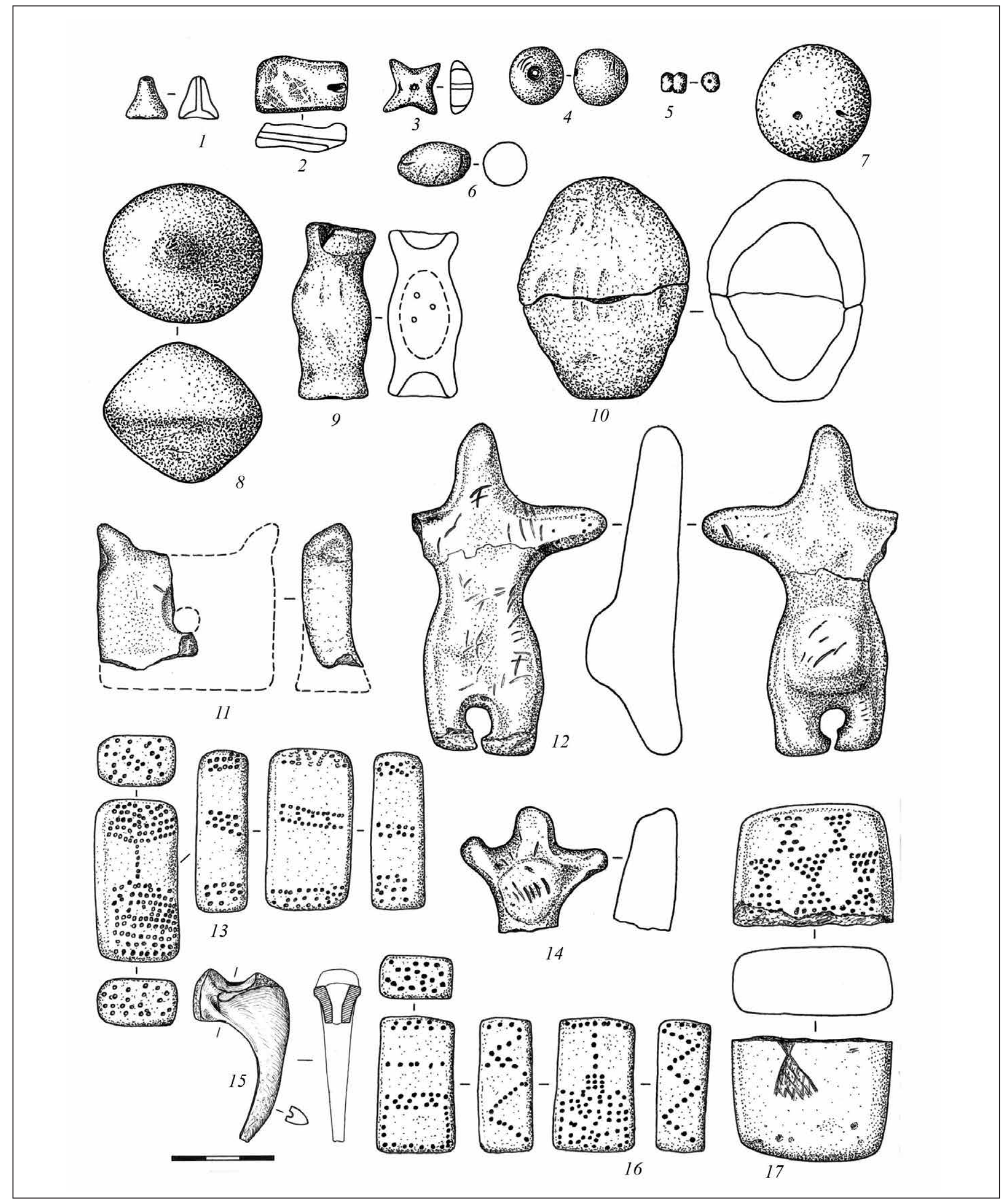

РИС. 149. ГЛИНЯНЫЕ БУСЫ, ПОГРЕМУШКА, ШАРИКИ ДЛЯ ПРАЩИ (?), КУЛЬТОВЫЕ ИЗДЕЛИЯ И ПОДВЕСКА ИЗ КОГТЯ МЕДВЕДЯ ИЗ ВЕРХНЕГО СЛОЯ ДЬЯКОВА ГОРОДИЩА.

Рис. В.А. Раевой 


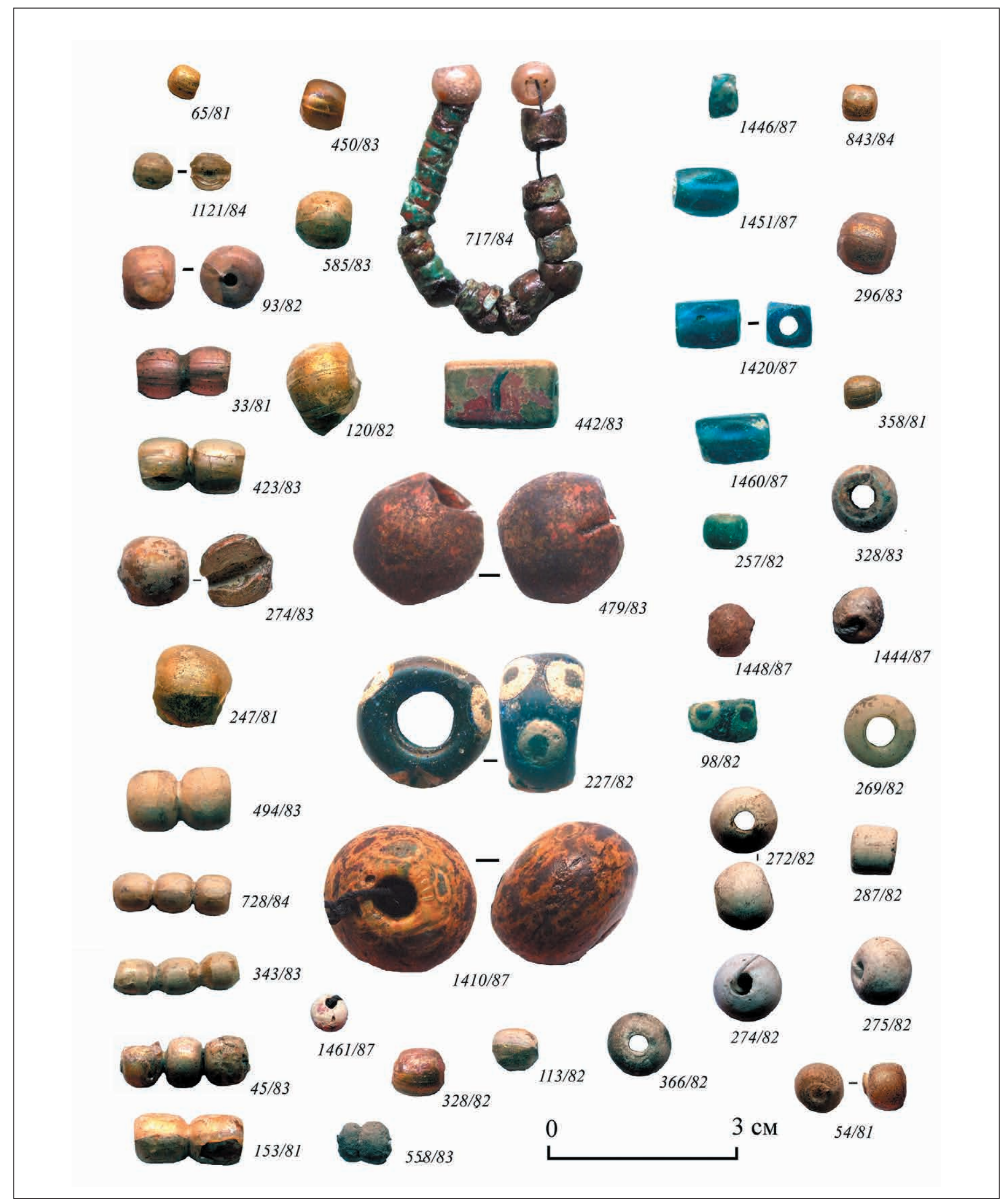

РИС. 150 СТЕКЛЯННЫЕ И ПАСТОВЫЕ БУСЫ ИЗ РАСКОПОК ДЬЯКОВА ГОРОДИЩА 


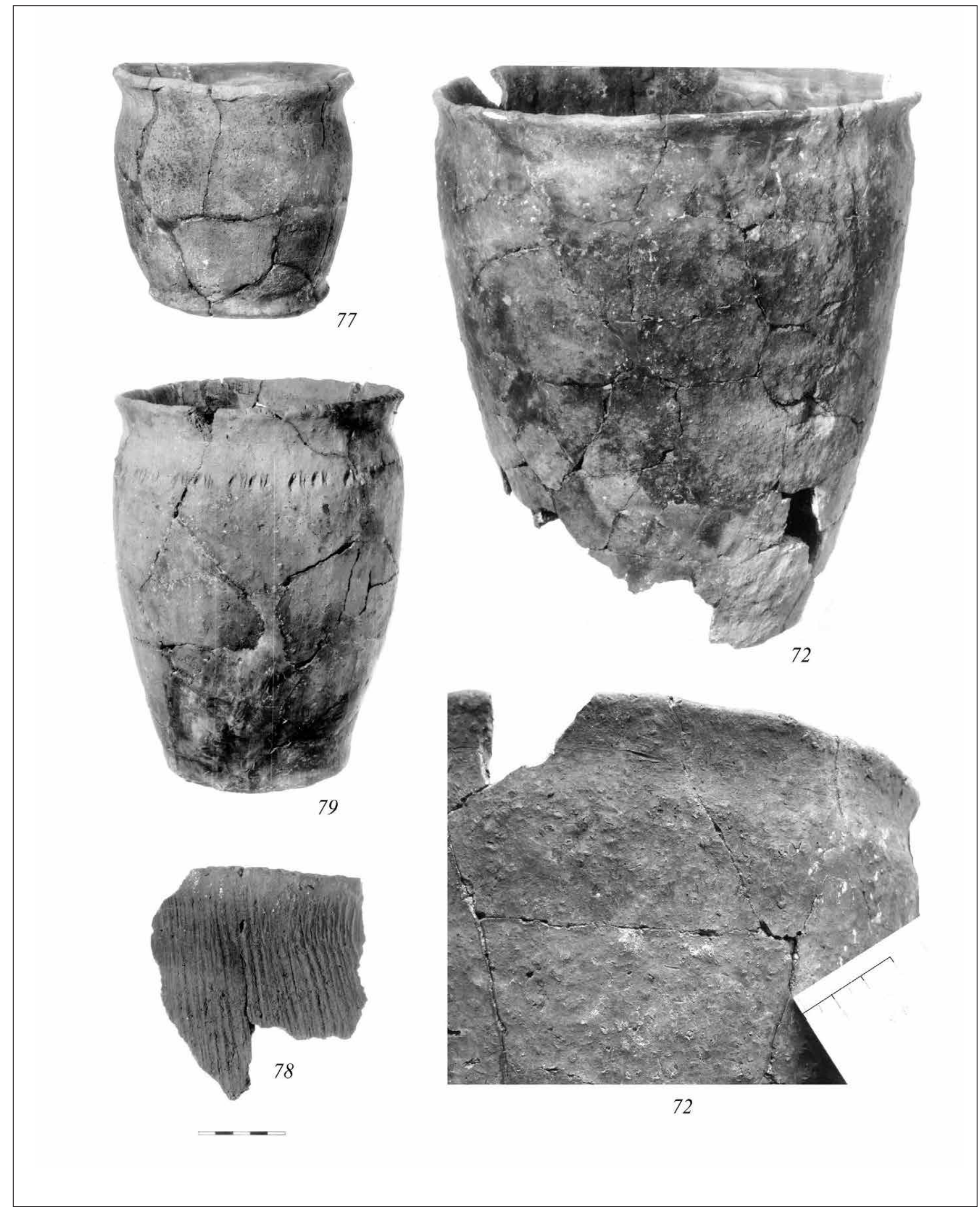

РИС. 151. ГЛАДКОСТЕННАЯ И ШТРИХОВАННАЯ КЕРАМИКА ИЗ НИЖНЕГО ГОРИЗОНТА ВЕРХНЕГО СЛОЯ ДЬЯКОВА ГОРОДИЩА 

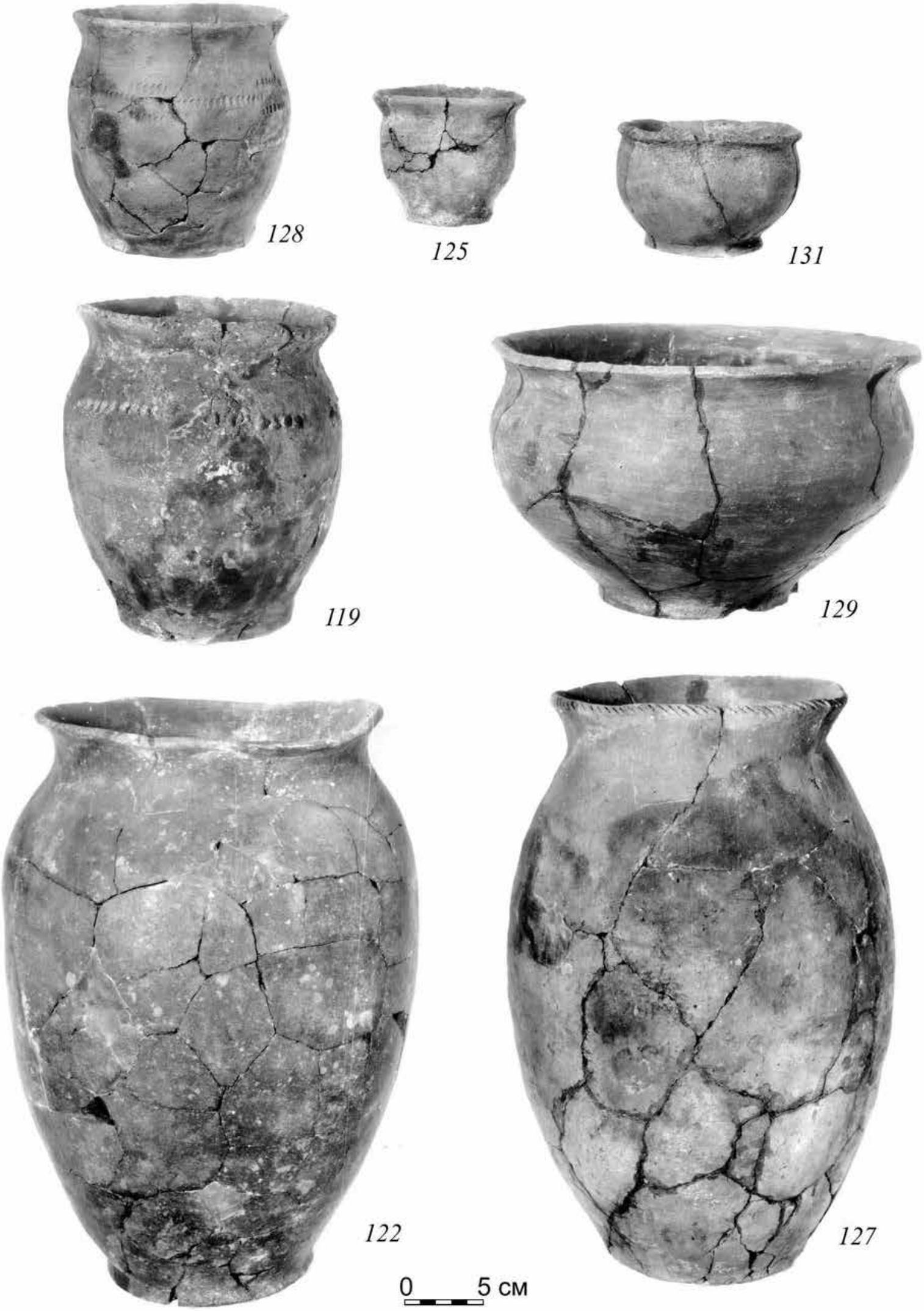

РИС. 152. ГЛАДКОСТЕННАЯ И ПОДЛОЩЕНАЯ КЕРАМИКА ИЗ ПОСТРОЙКИ Д-4 В СРЕДНЕМ ГОРИЗОНТЕ ВЕРХНЕГО СЛОЯ ДЬЯКОВА ГОРОДИЩА 


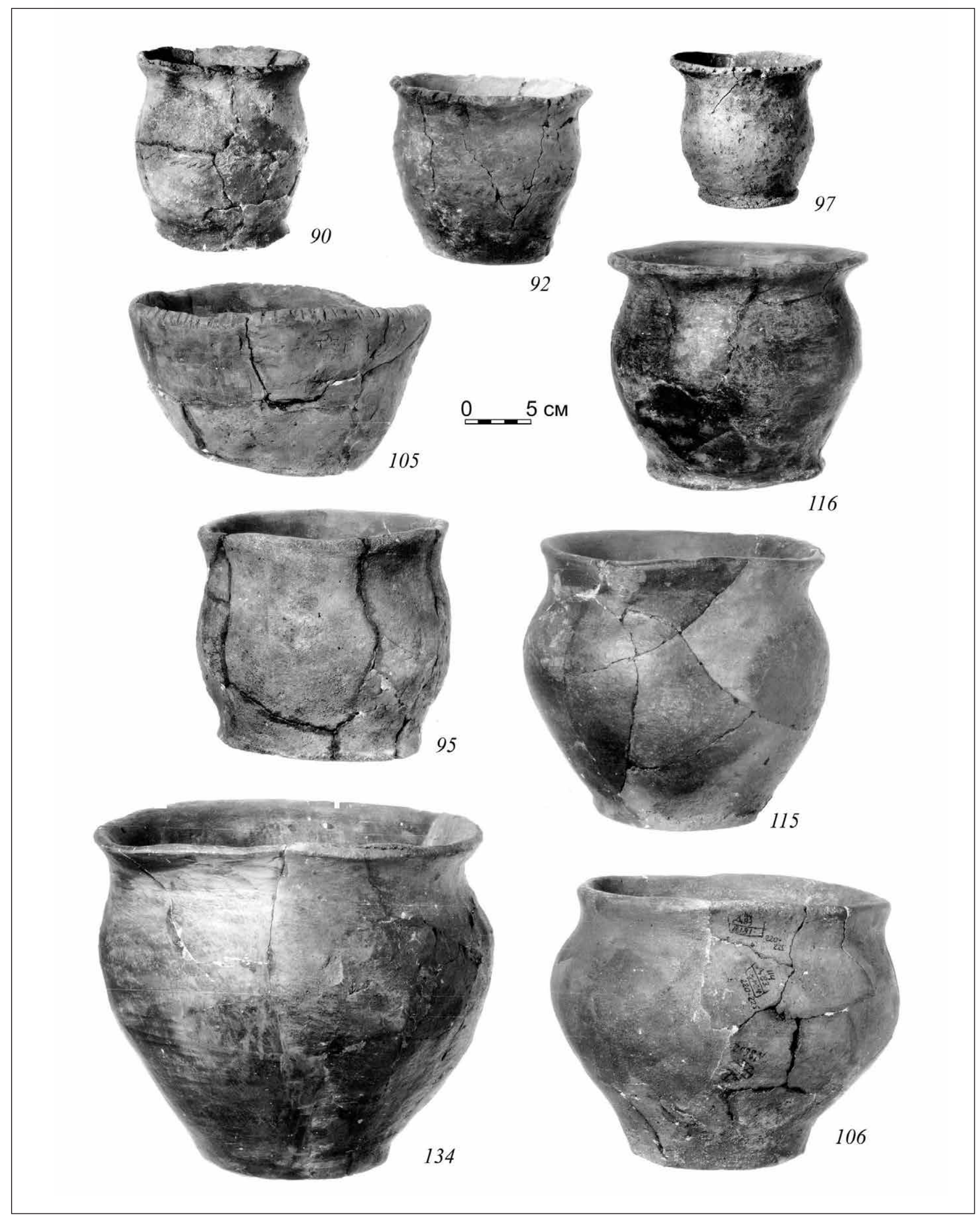

РИС. 153. ГЛАДКОСТЕННАЯ И ПОДЛОЩЕНАЯ КЕРАМИКА ИЗ СРЕДНЕГО ГОРИЗОНТА ВЕРХНЕГО СЛОЯ ДЬЯКОВА ГОРОДИЩА (ГЛУБИНА -210-260) 


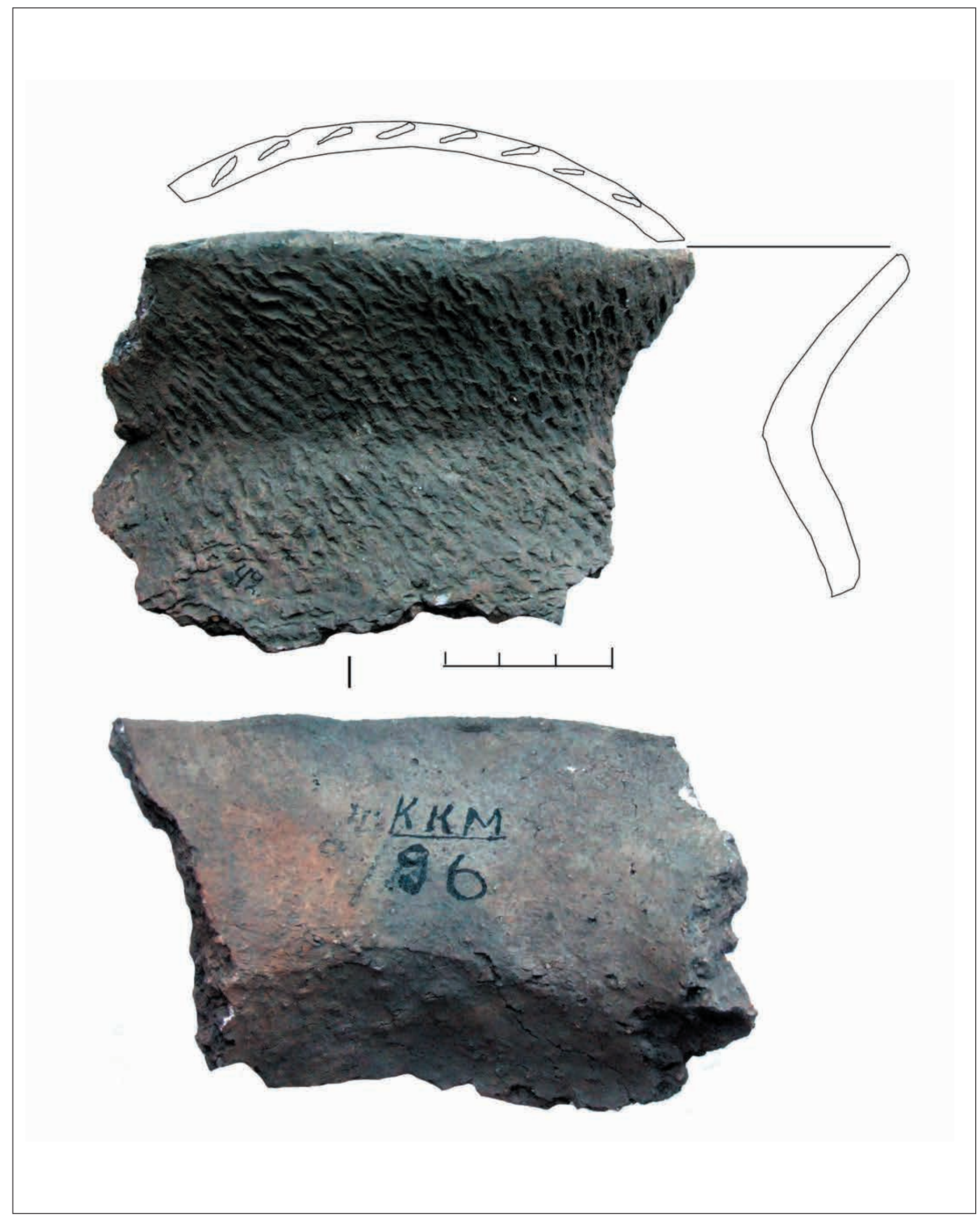

РИС. 154. ТЕКСТИЛЬНЫЙ ФРАГМЕНТ С ГОРОДИЩА У С. ГОРОДИЩЕ КОЛОМЕНСКОГО РАЙОНА (КОЛОМЕНСКИЙ КРАЕВЕДЧЕСКИЙ МУЗЕЙ) 


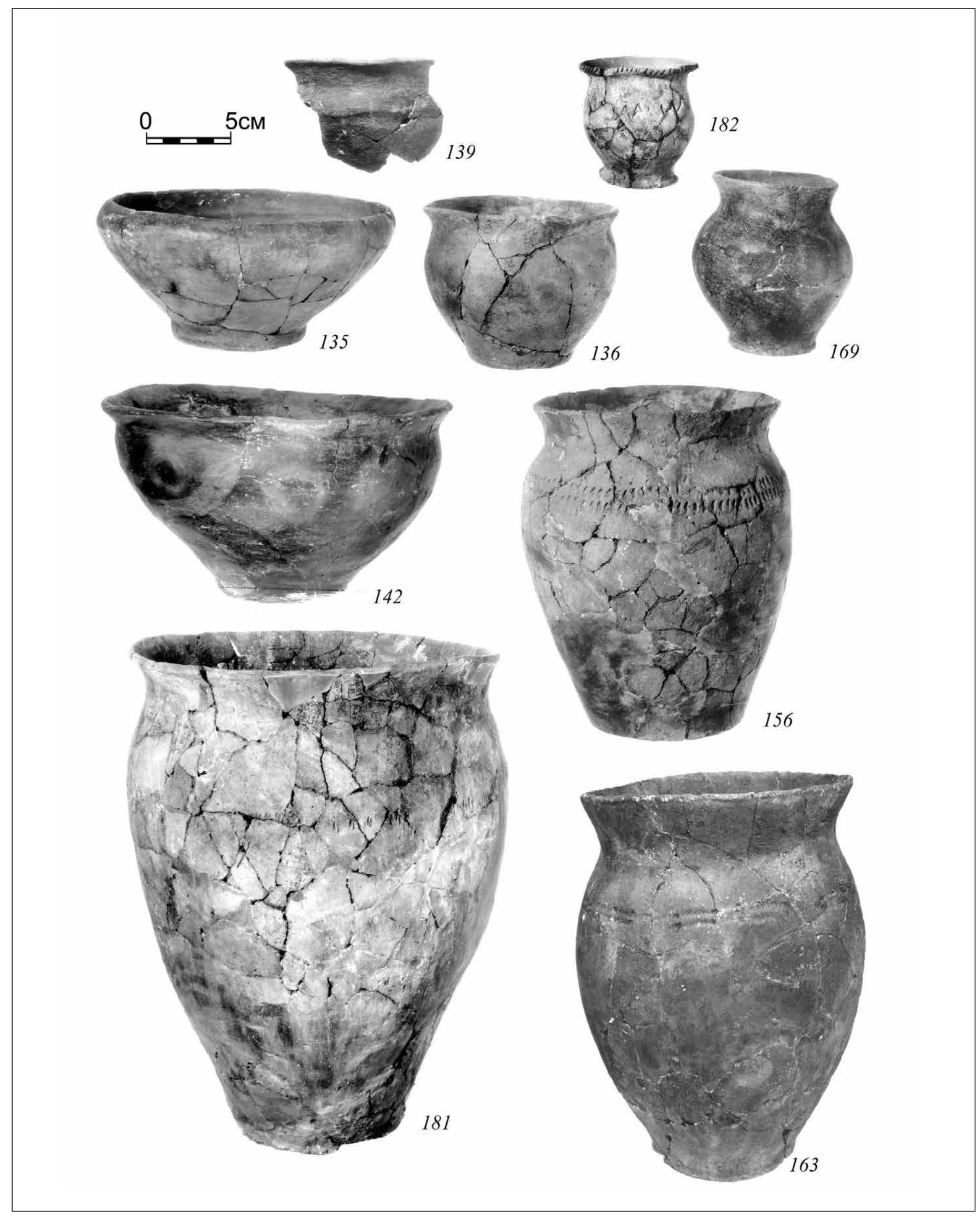

РИС. 155. ГЛАДКОСТЕННАЯ И ПОДЛОЩЕНАЯ КЕРАМИКА ИЗ СРЕДНЕГО ГОРИЗОНТА ВЕРХНЕГО СЛОЯ ДЬЯКОВА ГОРОДИЩА (ГЛУБИНА -160-210) 


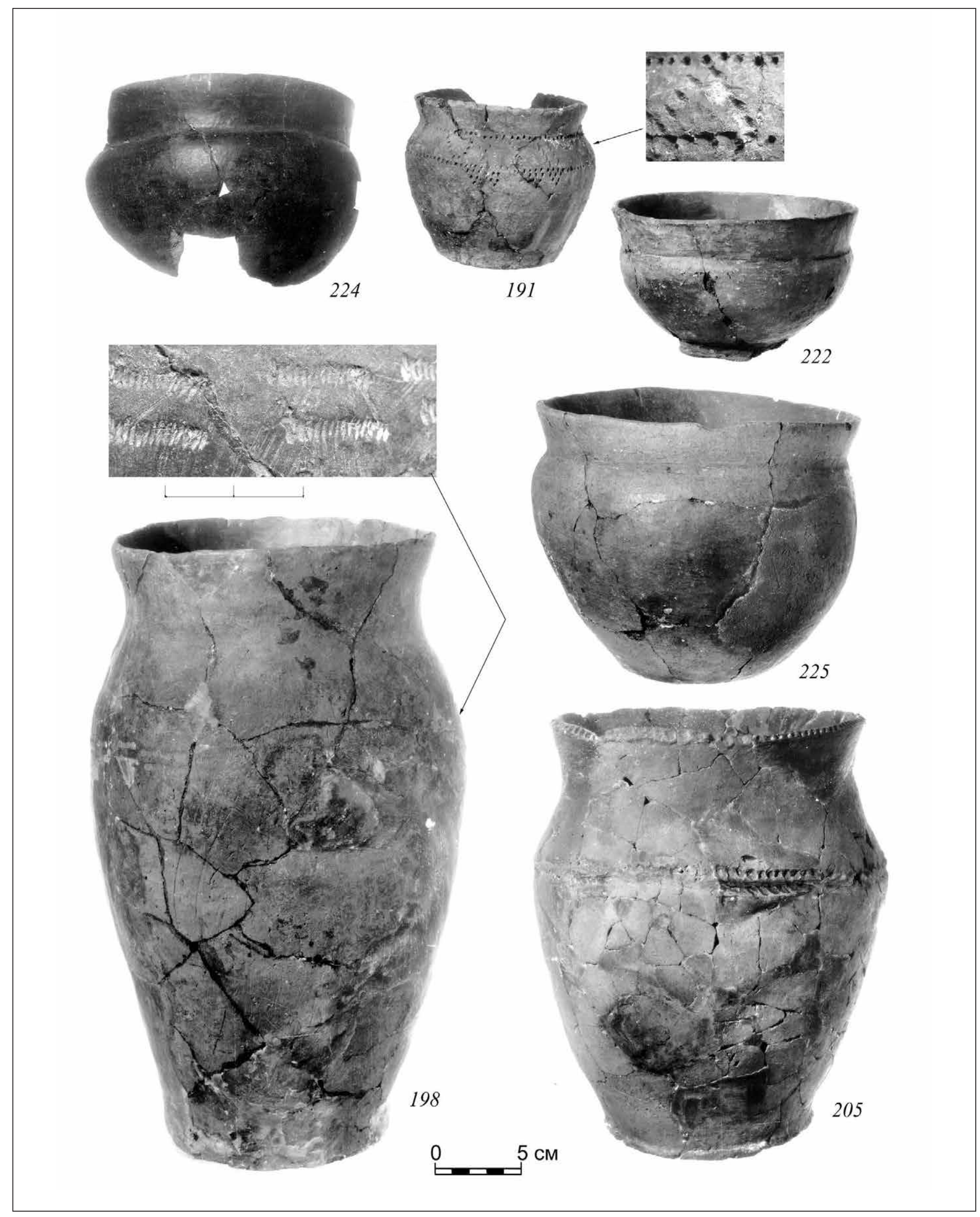

РИС. 156. ГЛАДКОСТЕННАЯ И ПОДЛОЩЕНАЯ КЕРАМИКА ИЗ ВЕРХНЕГО ГОРИЗОНТА ВЕРХНЕГО СЛОЯ ДЬЯКОВА ГОРОДИЩА (ГЛУБИНА -110-160) 


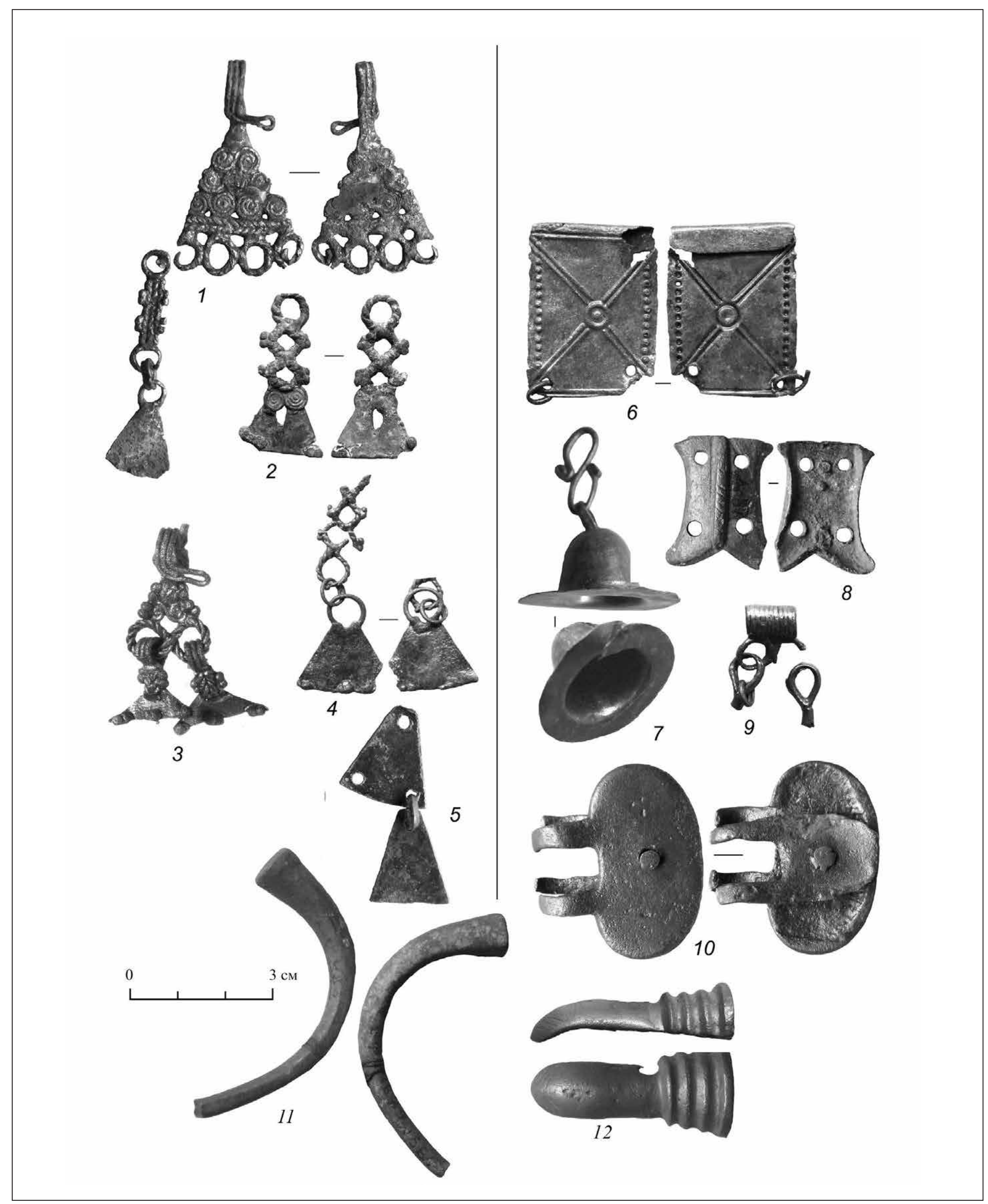

РИС. 157. БРОНЗОВЫЕ ВЕЩИ, ХАРАКТЕРНЫЕ ДЛЯ ФИНАЛЬНОГО ЭТАПА ДЬЯКОВСКОЙ КУЛЬТУРЫ

Слева - местное производство; справа - привозные изделия. Городища Дьяково $(1-10)$ и Луковня $1(11,12)$ 


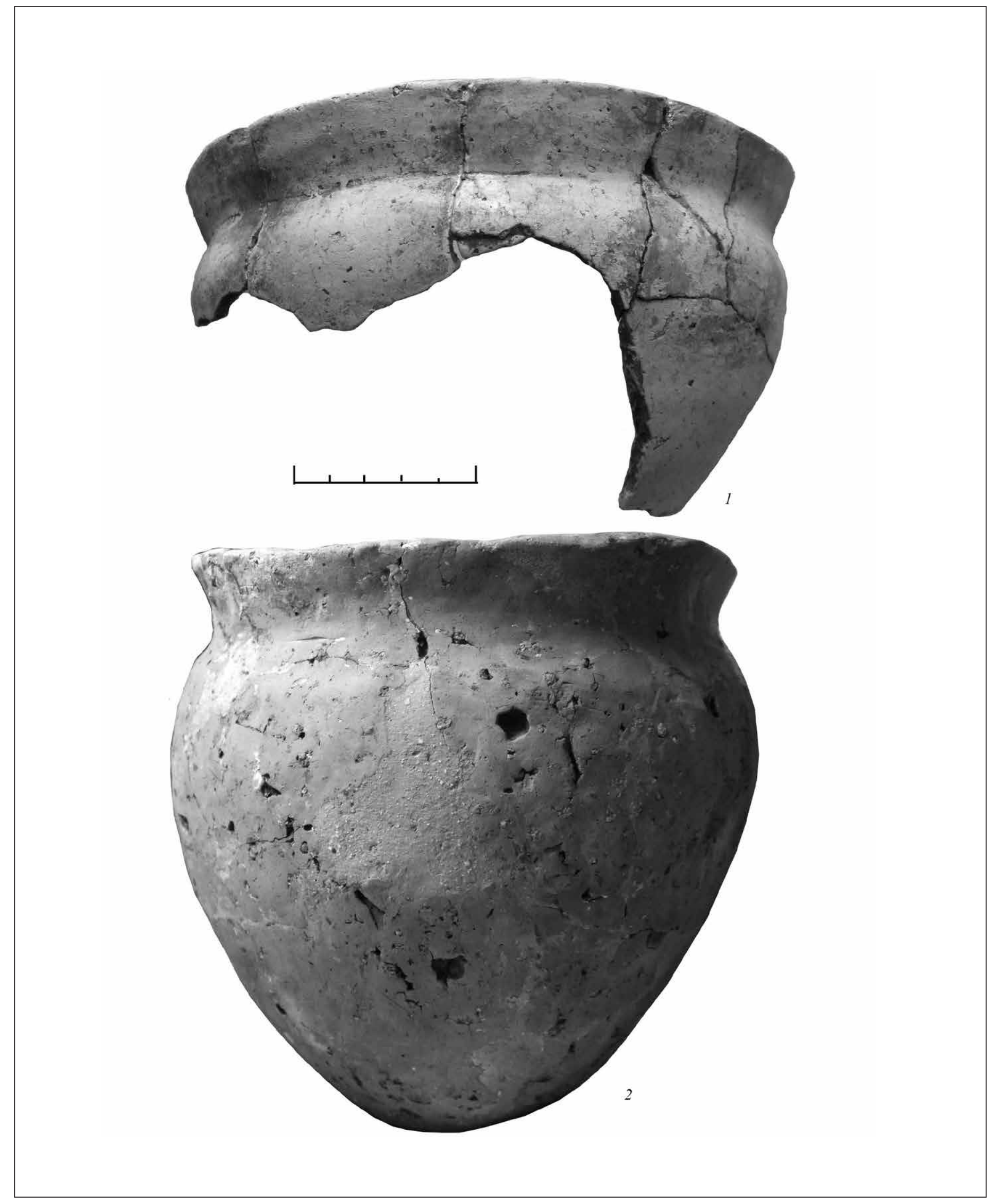

РИС. 158. ГОРШКИ ИЗ КОМПЛЕКСА «ДОМИКА МЕРТВЫХ» НА ГОРОДИЩЕ ВОЗЛЕ САВИНО-СТОРОЖЕВСКОГО МОНАСТЫРЯ (ЗВЕНИГОРОДСКИЙ ИСТОРИКОАРХИТЕКТУРНЫЙ И ХУДОЖЕСТВЕННЫЙ МУЗЕЙ) 


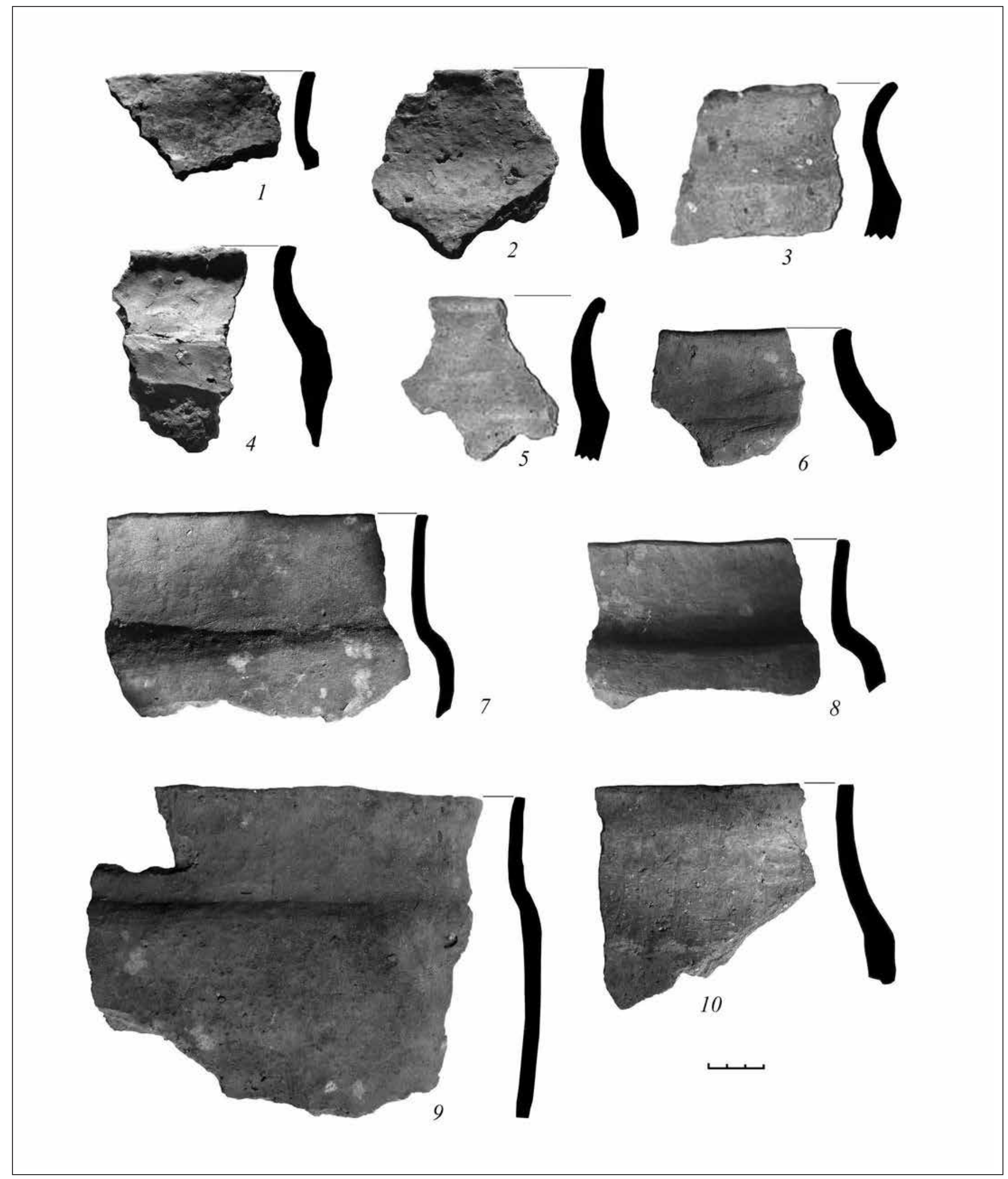

РИС. 159. КЕРАМИКА «ПОСТДЬЯКОВСКОГО॥ ПЕРИОДА И ФИНАЛА ПОЗДНЕДЬЯКОВСКОЙ КУЛЬТУРЫ VII-VIII ВВ. С ПАМЯТНИКОВ ПОДМОСКОВЬЯ 1-5 - селище Бородино (по Б.Е. Янишевскому); 6-10 - городище Кикино (по В.И. Вишневскому) 


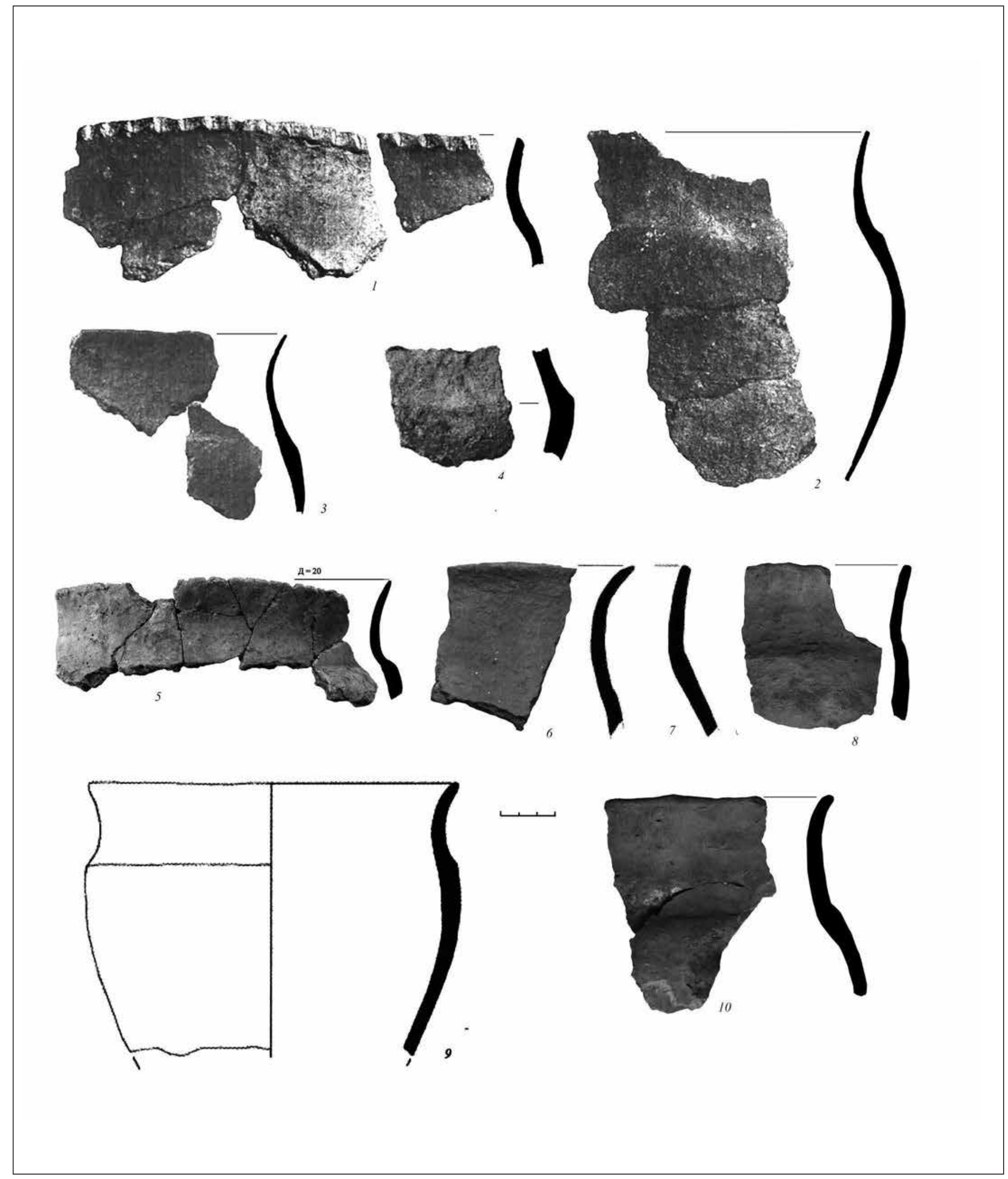

РИС. 160. КеРАМИКА «ПОСтДЬЯКОВСКОГО» ПЕРИОДА VII-VIII вВ. В ПОДМОСКОВьЕ И ПООчьЕ

1-4 - селище Болшево 3 (по: Чернов, 2009); 5 - поселение Соколова Пустынь (по: Потемкина и др., 2013); 6-10 - городище Акиньшино (по: Воронцов, 2011) 


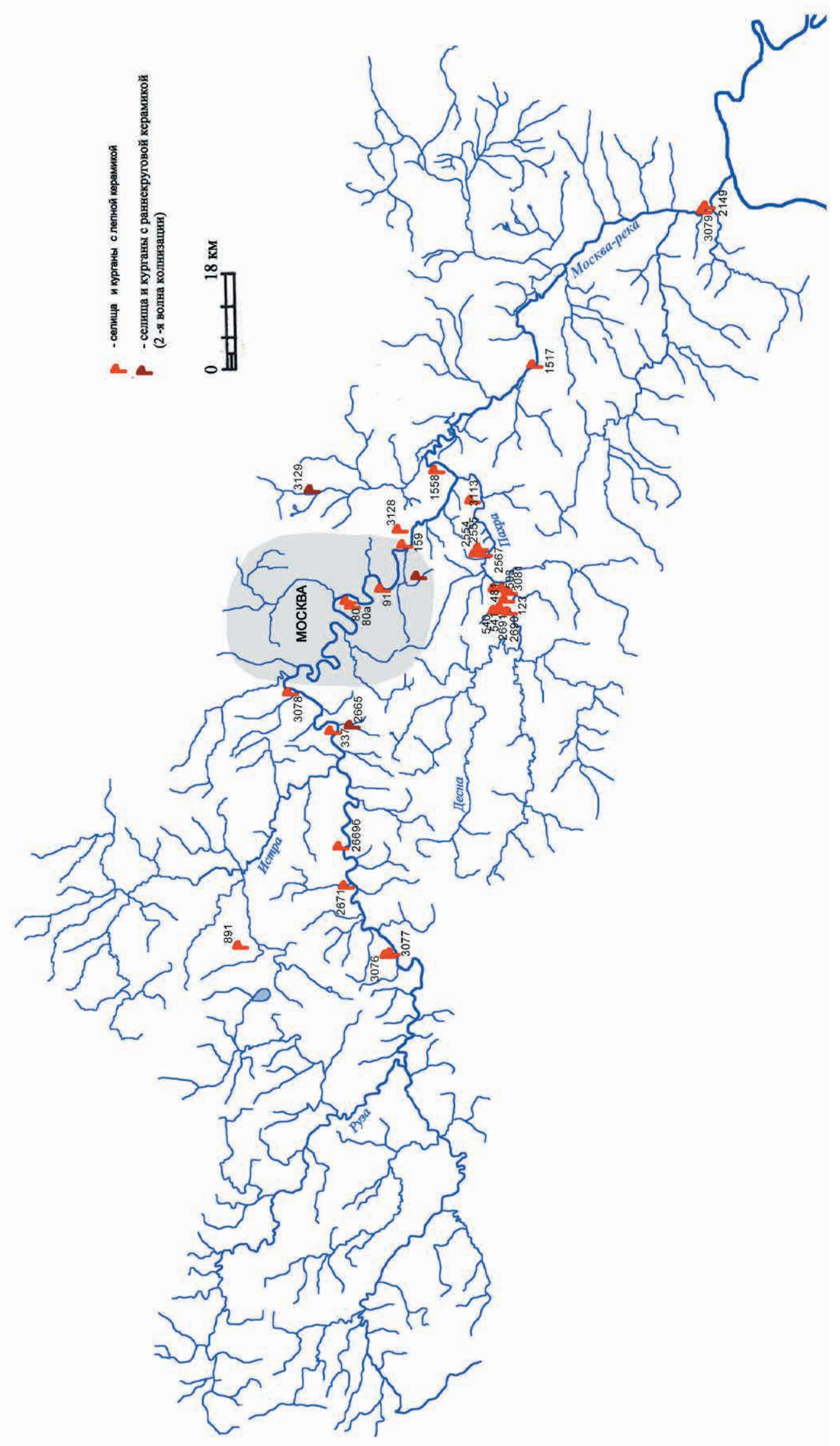

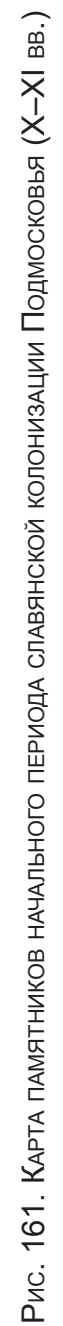




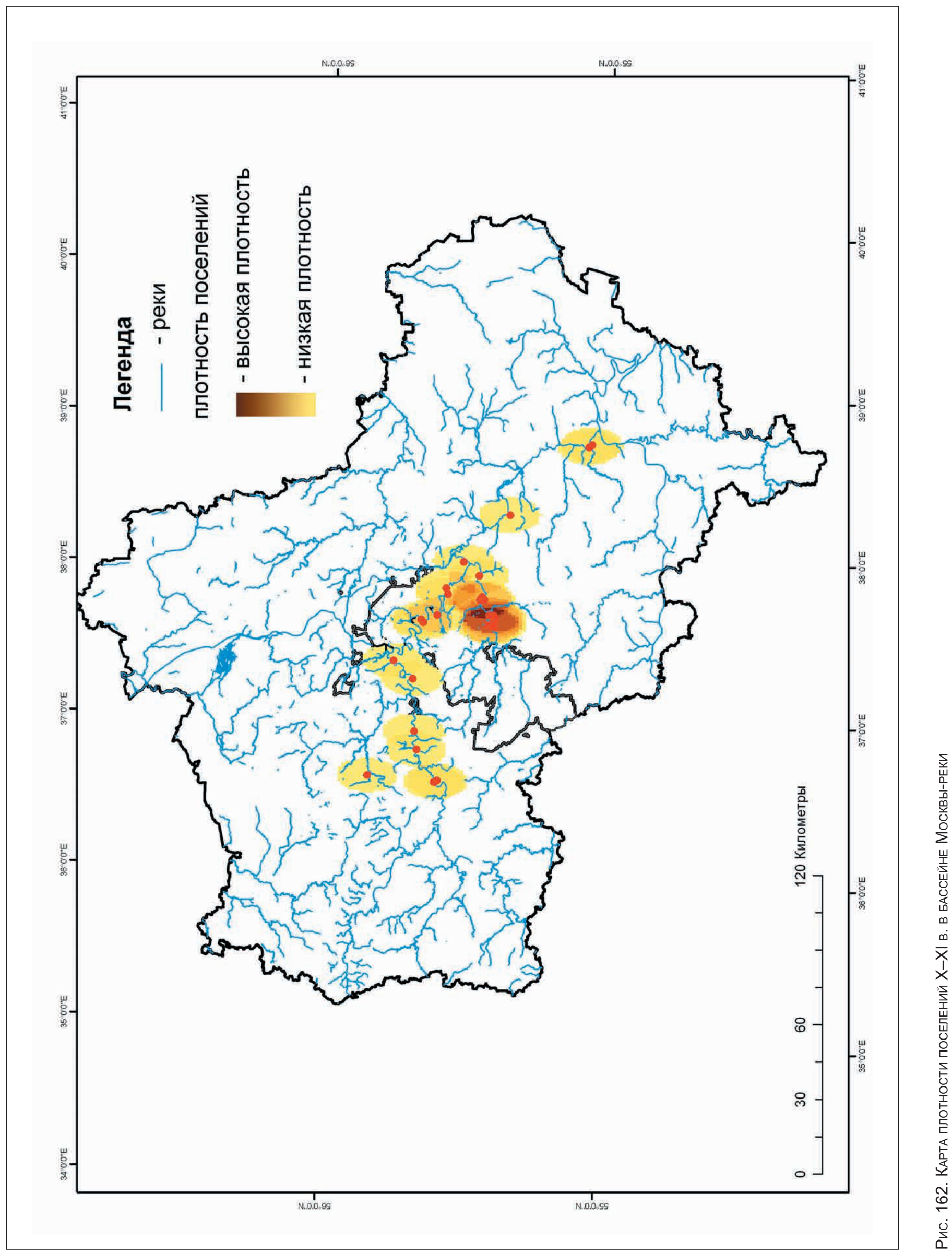




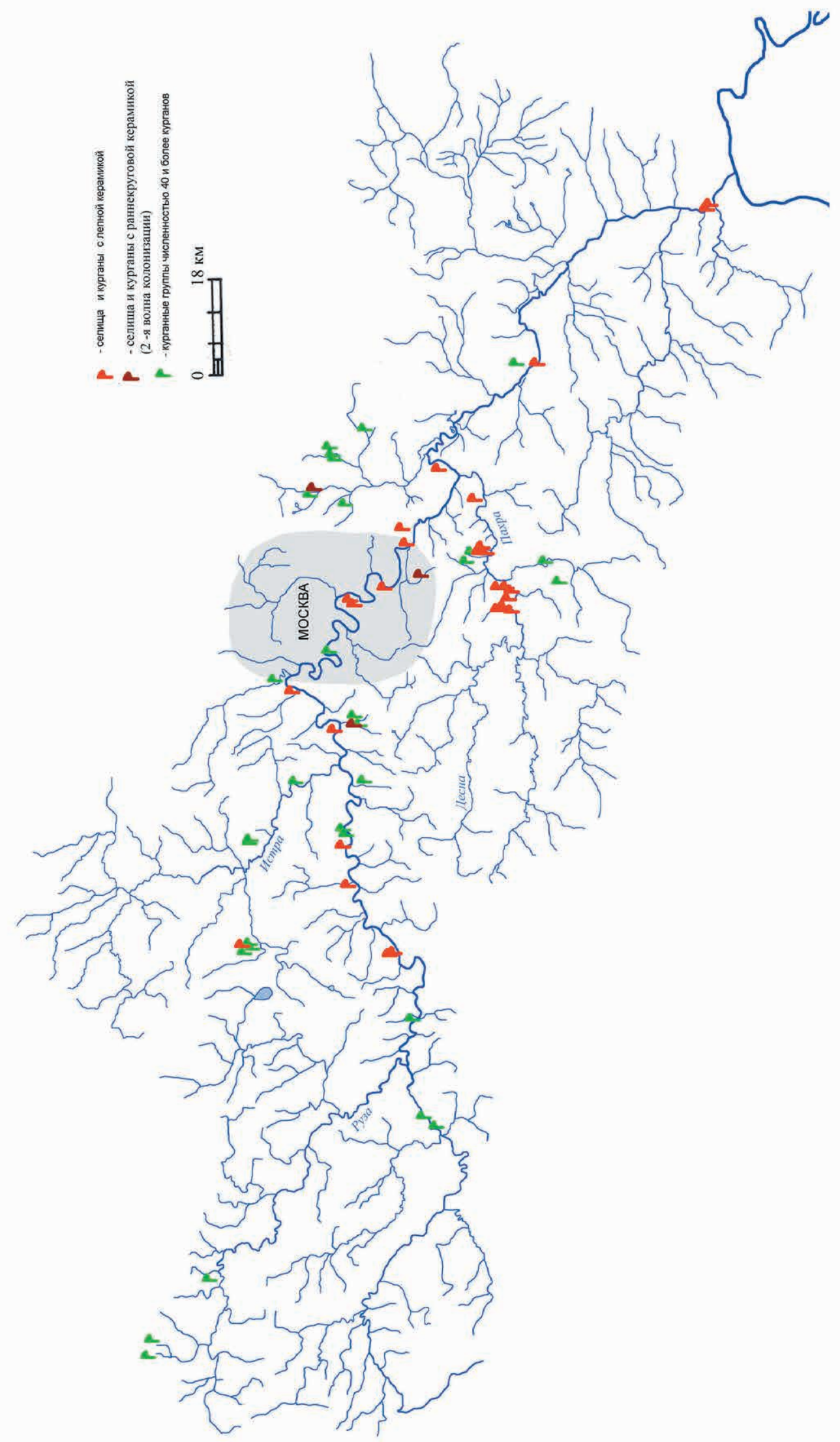

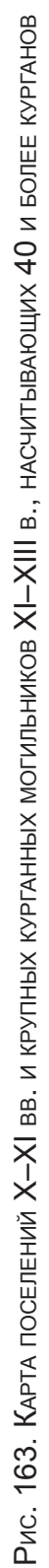




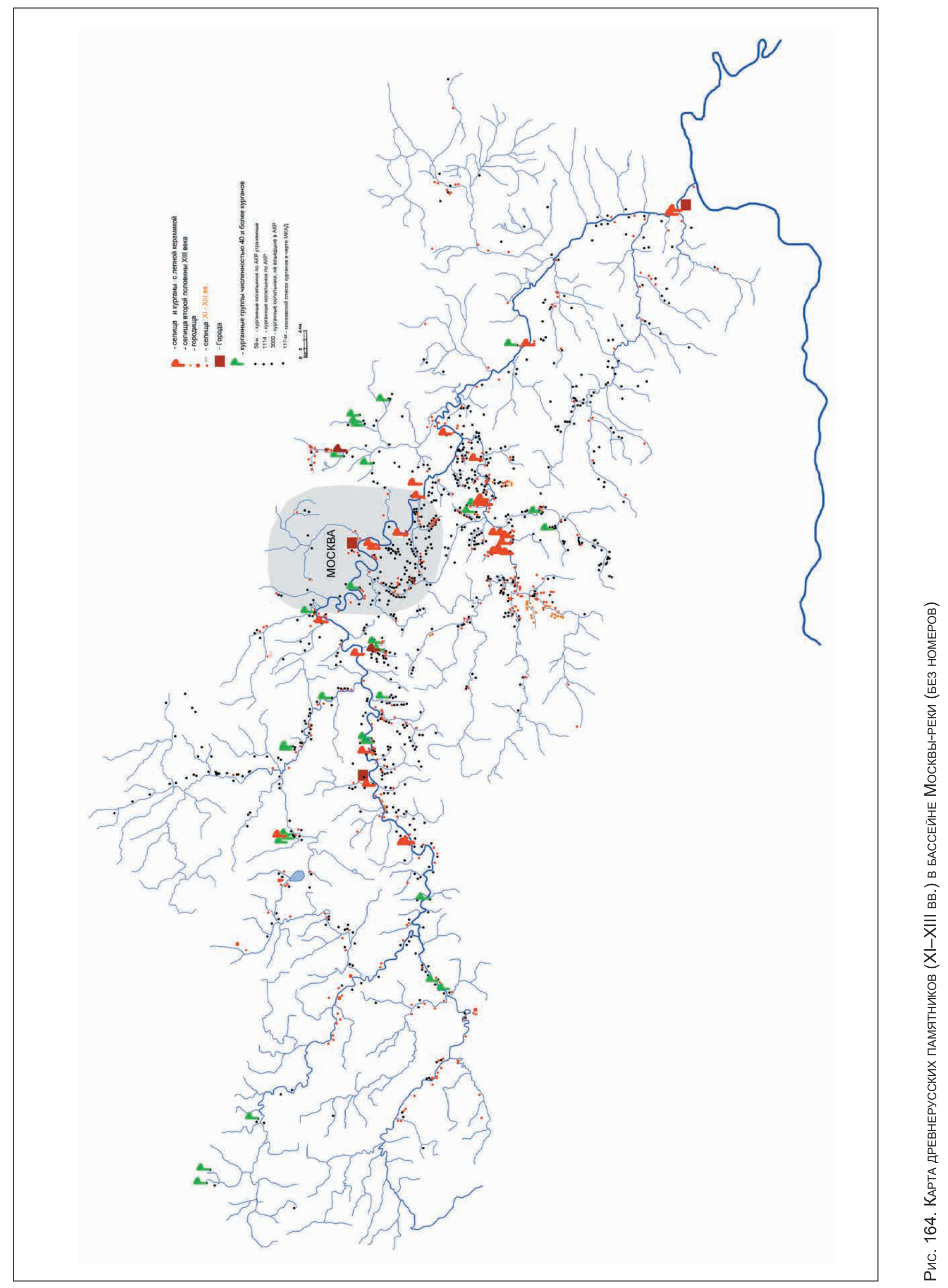




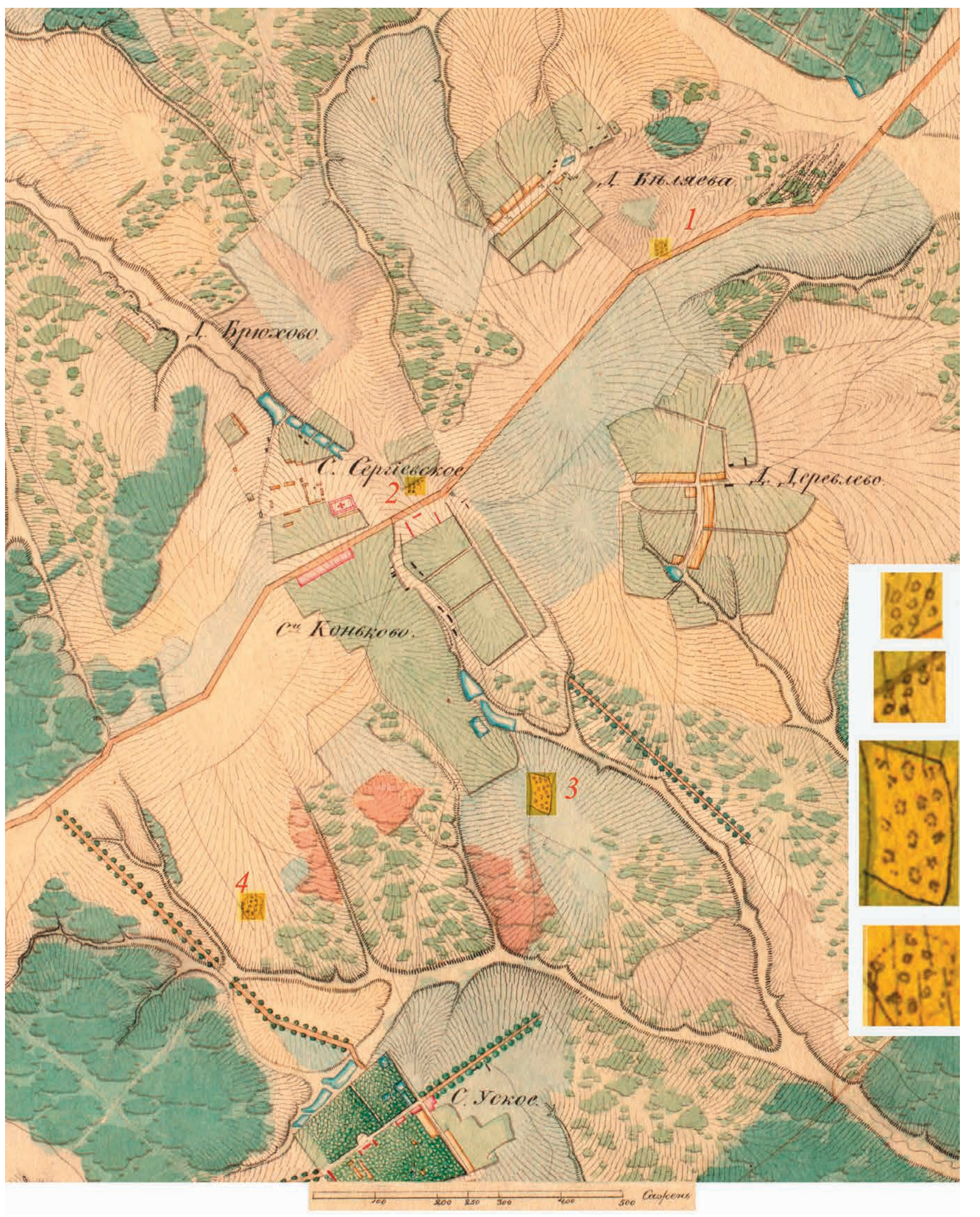

РИС. 166. ФРАГМЕНТ КАРТЫ ОКРЕСТНОСТЕЙ МОСКВЫ 1826 Г., НА КОТОРОЙ ИЗОБРАЖЕНЫ КУРГАНЫ (ОТМЕЧЕНЫ КРАСНЫМИ ЦИФРАМИ. - Н. КРЕНКЕ) В РАЙОНЕ БЕЛЯЕВО - КОНЬКОВО

РГВИА. Ф. 846. Оп. 16. Д. 19691. Л. 23. На врезке - увеличенное изображение курганных групп 


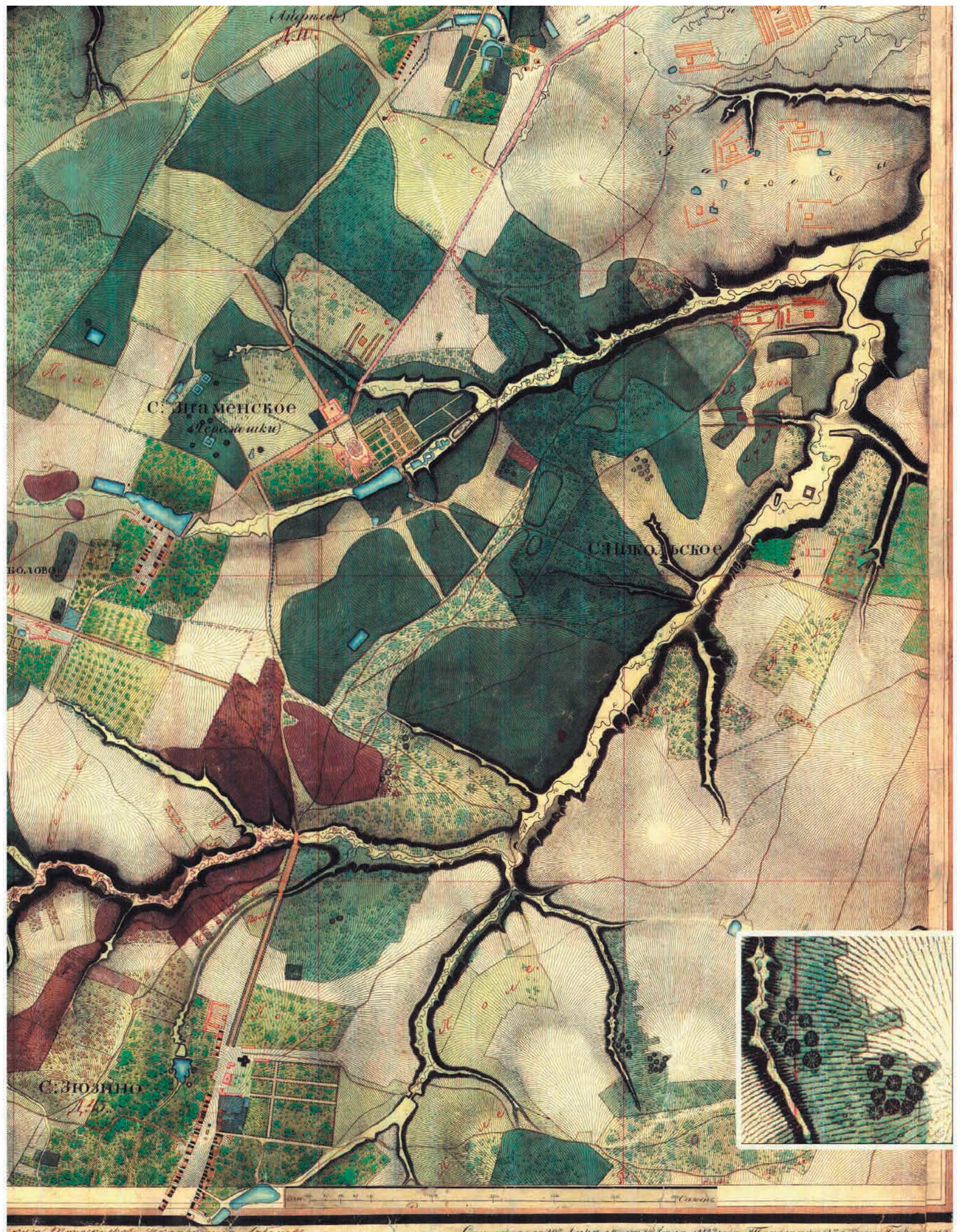

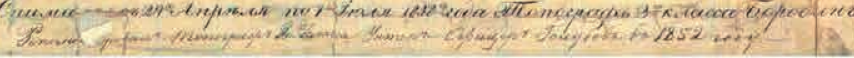

РИС. 167. ФРАГМЕНТ КАРТЫ ОКРЕСТНОСТЕЙ МОСКВЫ 1838 Г. В РАЙОНЕ ЗЮЗИНО - ЧЕРЕМУШКИ, НА КОТОРОЙ ИЗОБРАЖЕНЫ КУРГАНЫ 

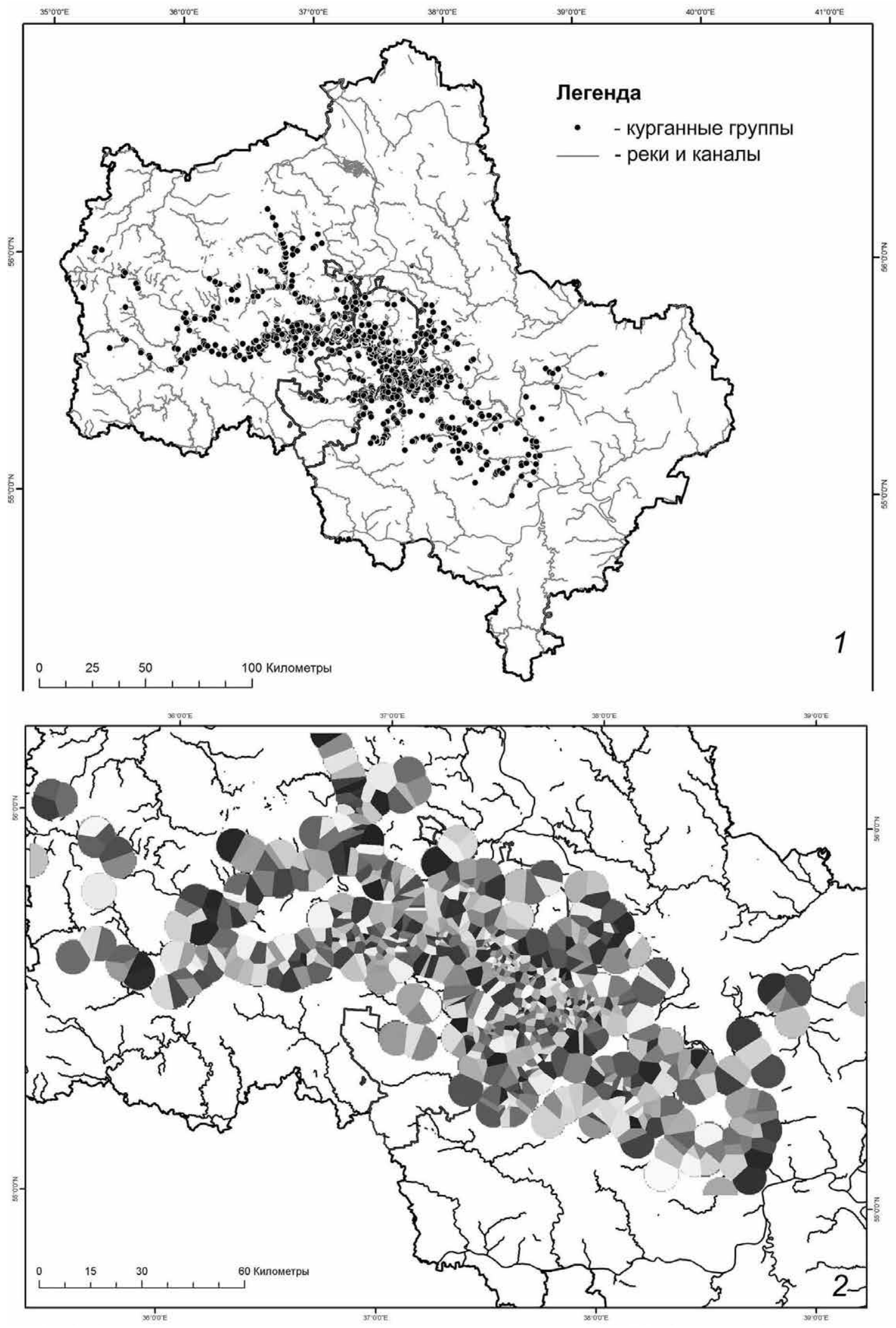

РИС. 168. КАРТА ИСХОДНЫХ ДАННЫХ - КУРГАННЫЕ ГРУППЫ ХІ-ХІІІ ВВ. В БАССЕЙНЕ МОСКВЫ-РЕКИ; ПОЛИГОНЫ ТИССЕНА, ХАРАКТЕРИЗУЮЩИЕ РАЗМЕР ЗЕМЕЛЬНЫХ ВЛАДЕНИЙ ДРЕВНЕРУССКИХ ПОСЕЛЕНИЙ 


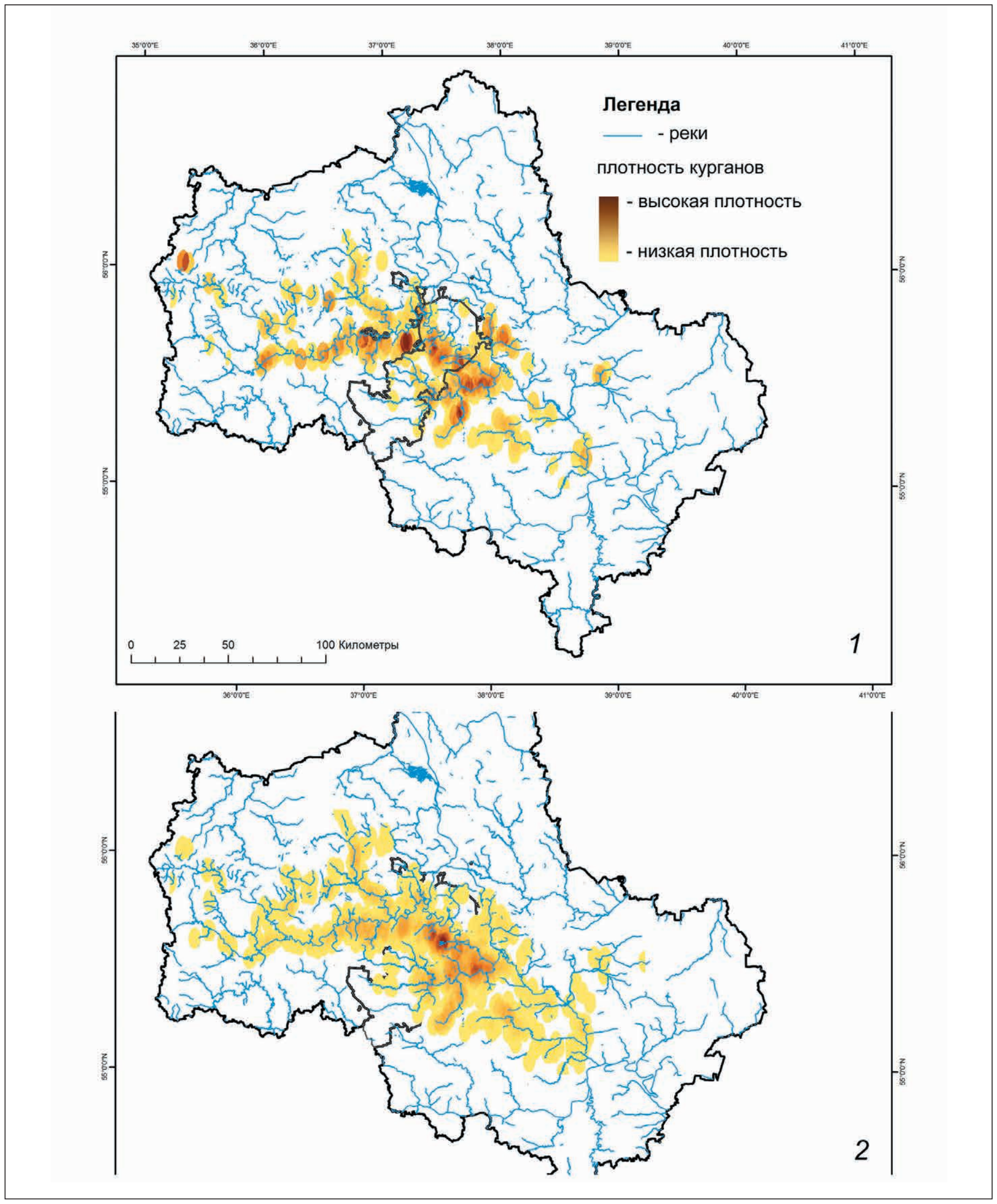

РИС. 169. ГЕНЕРАЛИЗОВАННЫЕ КАРТЫ КУРГАНОВ БАССЕЙНА МОСКВЫ-РЕКИ С РАДИУСОМ ЧУВСТВИТЕЛЬНОСТИ ТОЧЕК 5 КМ

1 - с учетом числа курганов в группах (карта интенсивности освоения ландшафта); 2 - без учета данных о количестве курганов в группе (карта плотности памятников). Составлены А.Н. Кренке 


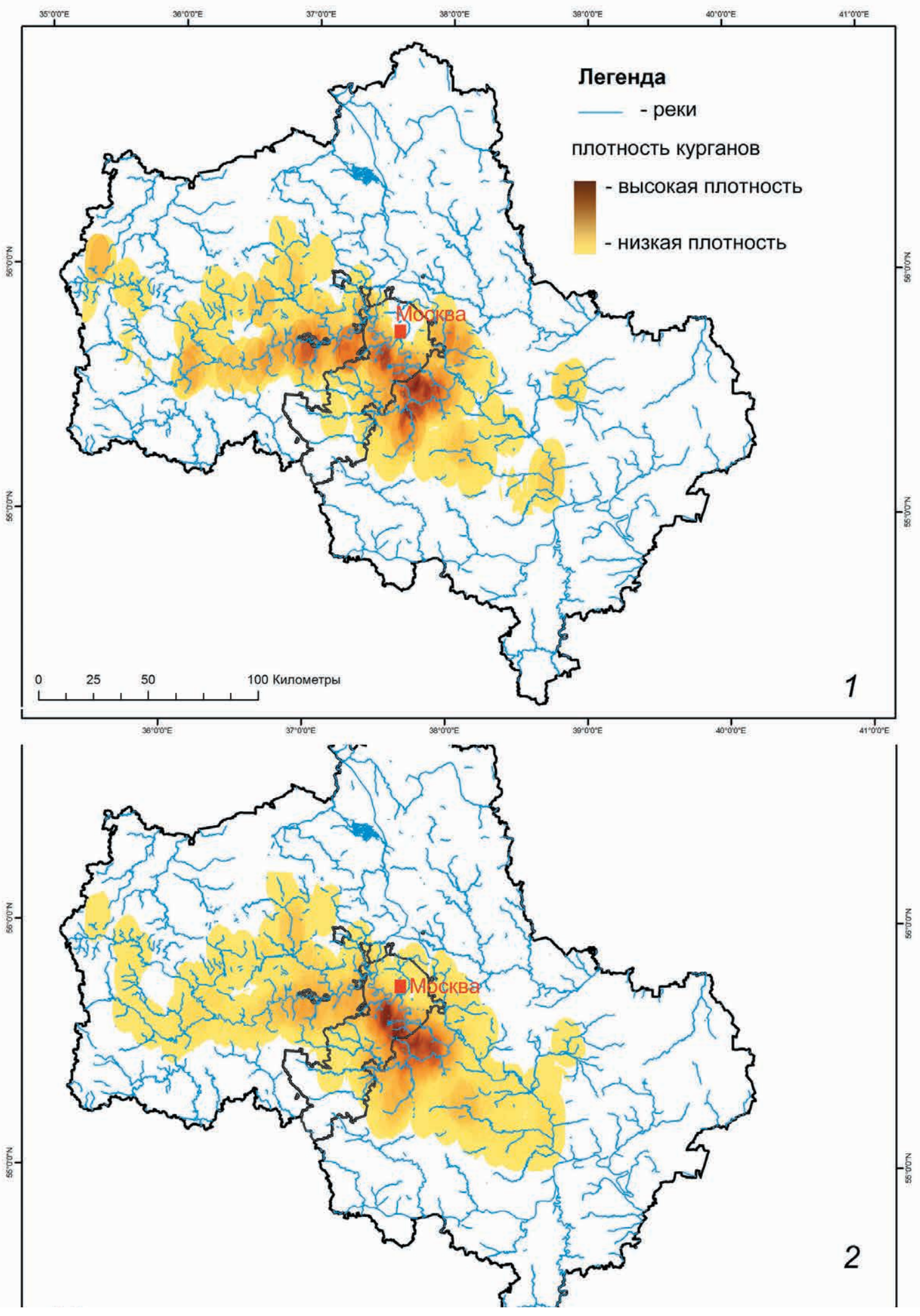

РИС. 170. ГЕНЕРАЛИЗОВАННЫЕ КАРТЫ КУРГАНОВ БАССЕЙНА МОСКВЫ-РЕКИ С РАДИУСОМ ЧУВСТВИТЕЛЬНОСТИ ТОЧЕК 10 КМ 1 - с учетом числа курганов в группах (карта интенсивности освоения ландшафта); 2 - без учета данных о количестве курганов в группе (карта плотности памятников). Составлены А.Н. Кренке 

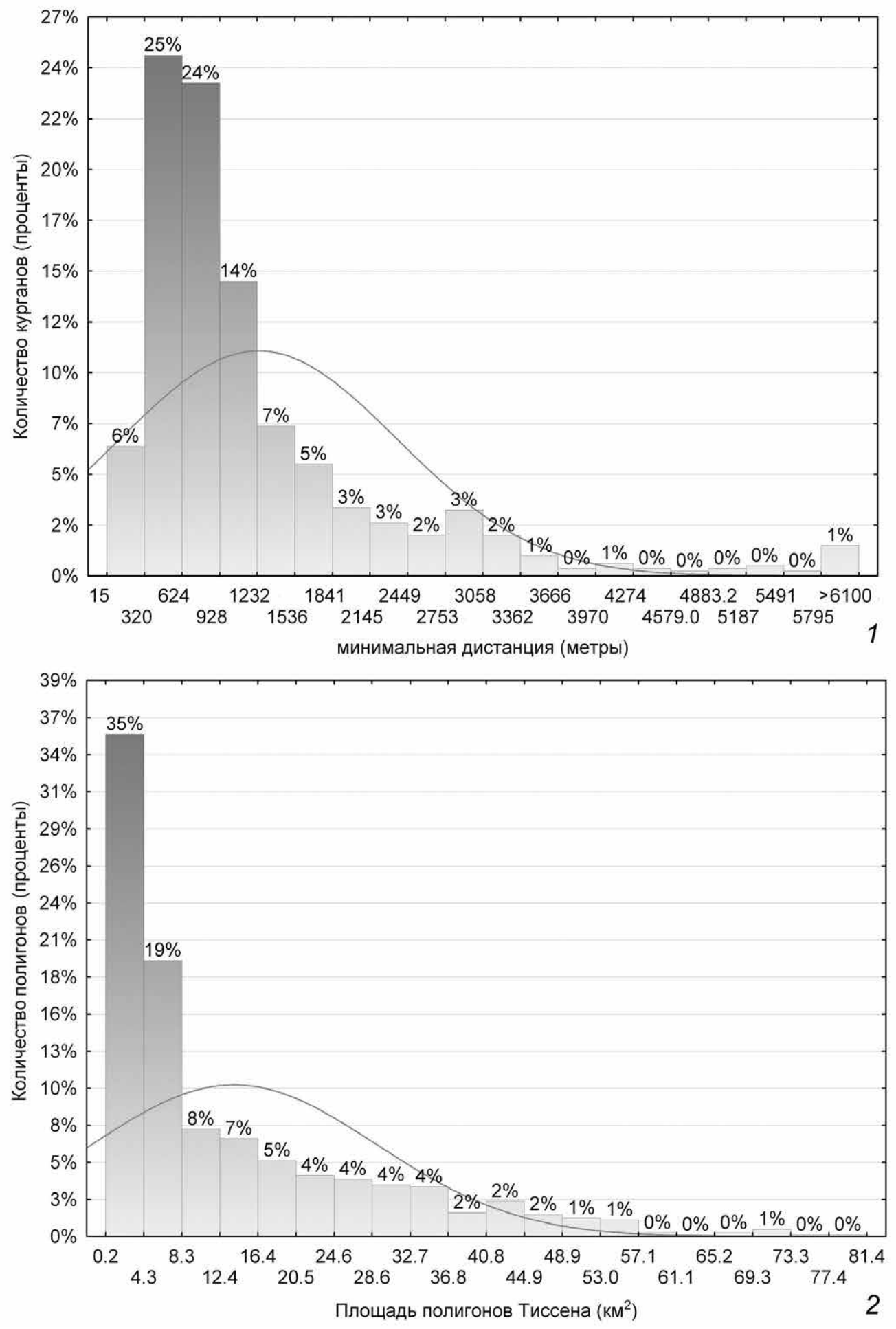

РИС. 171. ГИСТОГРАММЫ МИНИМАЛЬНЫХ РАССТОЯНИЙ МЕЖДУ БЛИЖАЙШИМИ ТОЧКАМИ (КУРГАННЫМИ ГРУППАМИ) (1) И ПЛОЩАДИ ПОЛИГОНОВ ТИССЕНА (2) Составлены А.Н. Кренке 


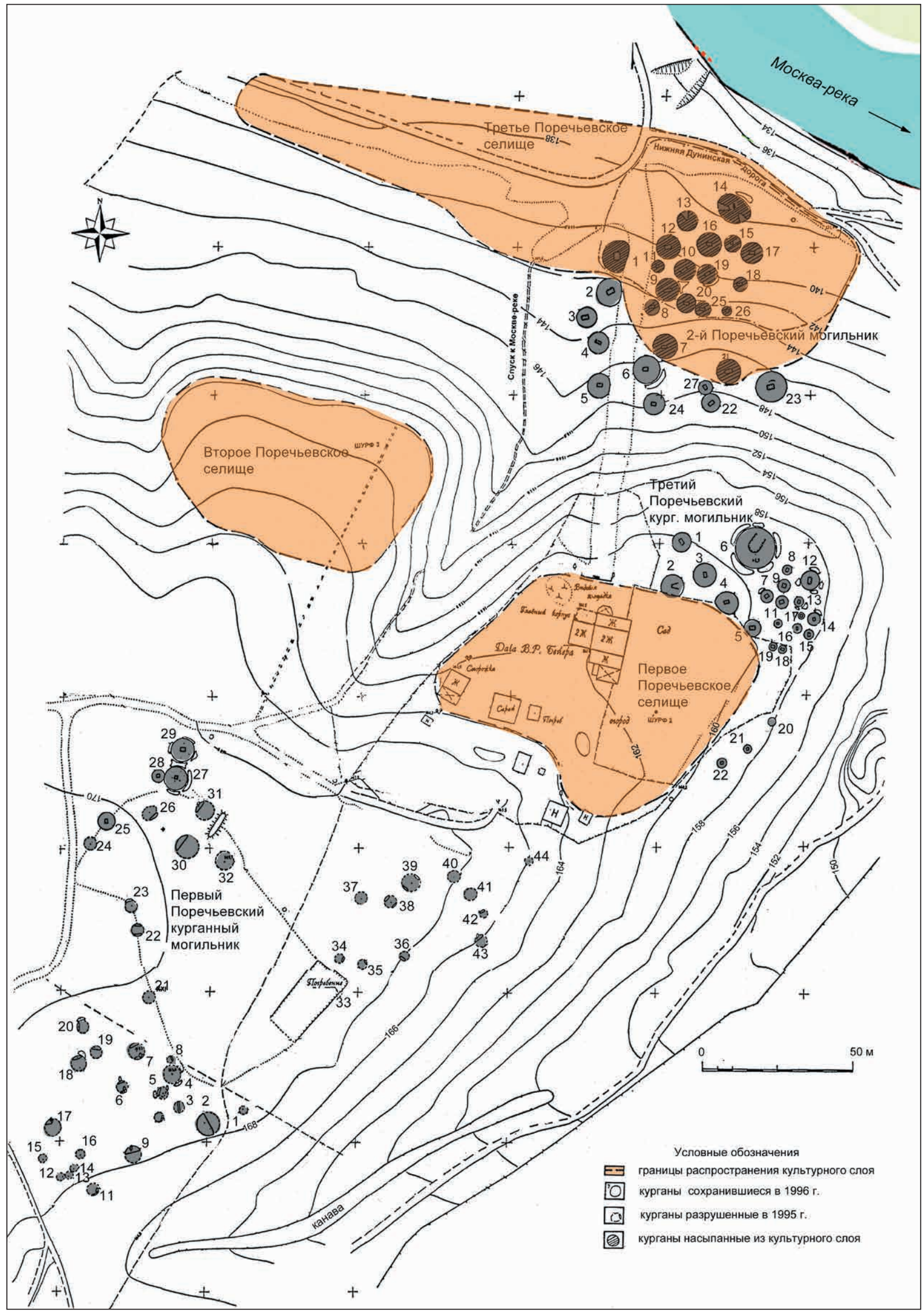

РИС. 172. КОМПЛЕКС ДРЕВНЕРУССКИХ ПАМЯТНИКОВ XI-ХІІІ ВВ. В РАЙОНЕ ПОРЕЧЬЯ (ПО С.З. ЧЕРНОВУ) 


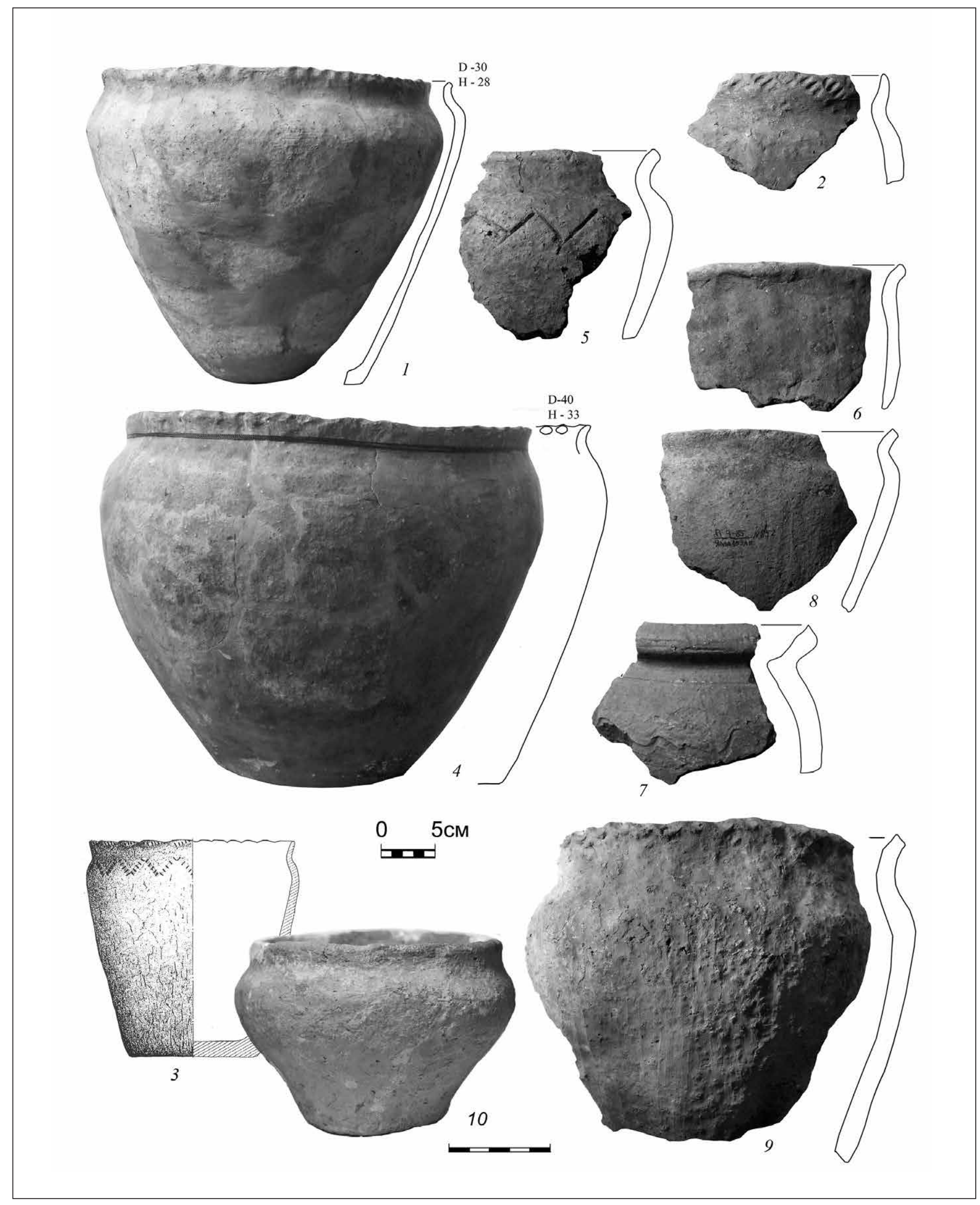

РИС. 173. ЛЕПНЫЕ И РАННЕКРУГОВЫЕ ГОРШКИ X-XI В.

Селища: 1 - Поречье, 2, 5-9 - Покров 5, 3 - Жданово, 4 - Саввинская слобода 2, 10 - Пузиково 

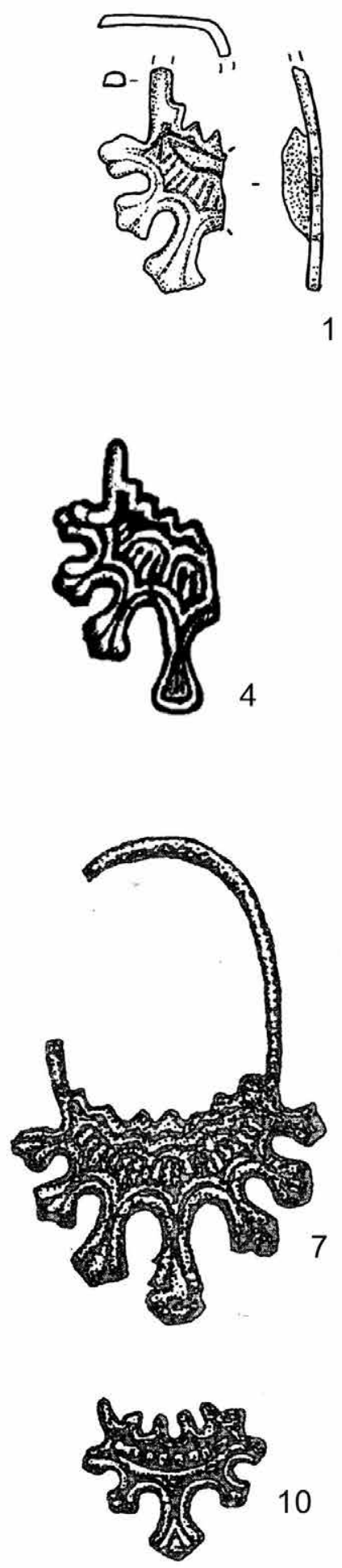
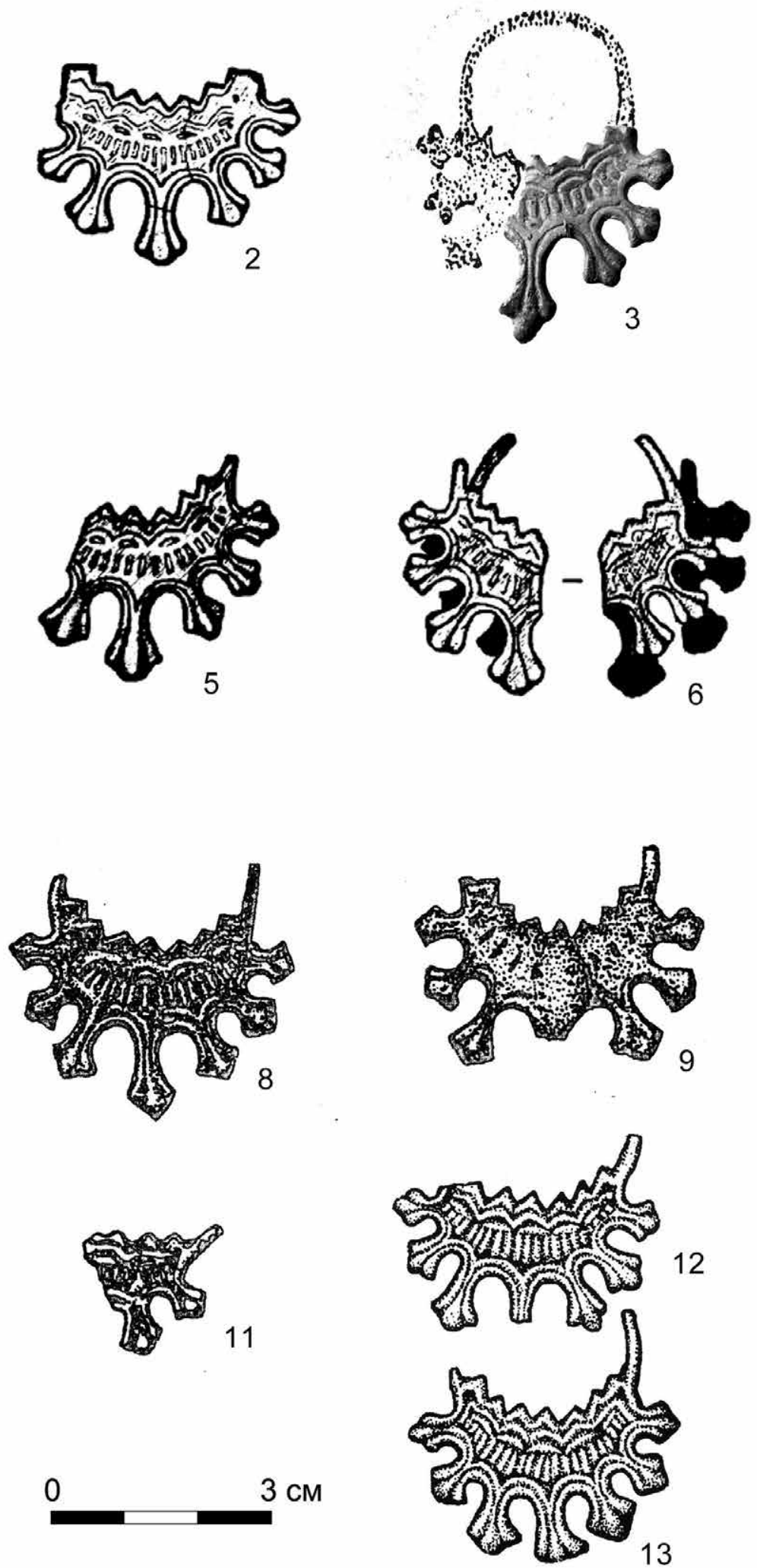

РИС. 174. КОЛЬЦА «ДЕСНИНСКОГО ТИПА» ВТОРОЙ ПОЛОВИНЫ ХІ В. С ПОДМОСКОВНЫХ ПАМЯТНИКОВ: СЕЛИЩА ХОТЯЖИ 1(1), ХОтЯЖИ 2 (4-6), ДАНИЛОВ монастырь (3), Съяново 3 (7-11), ЖДаново $(12,13)$, могильник ХотяЖи $(2)$ 

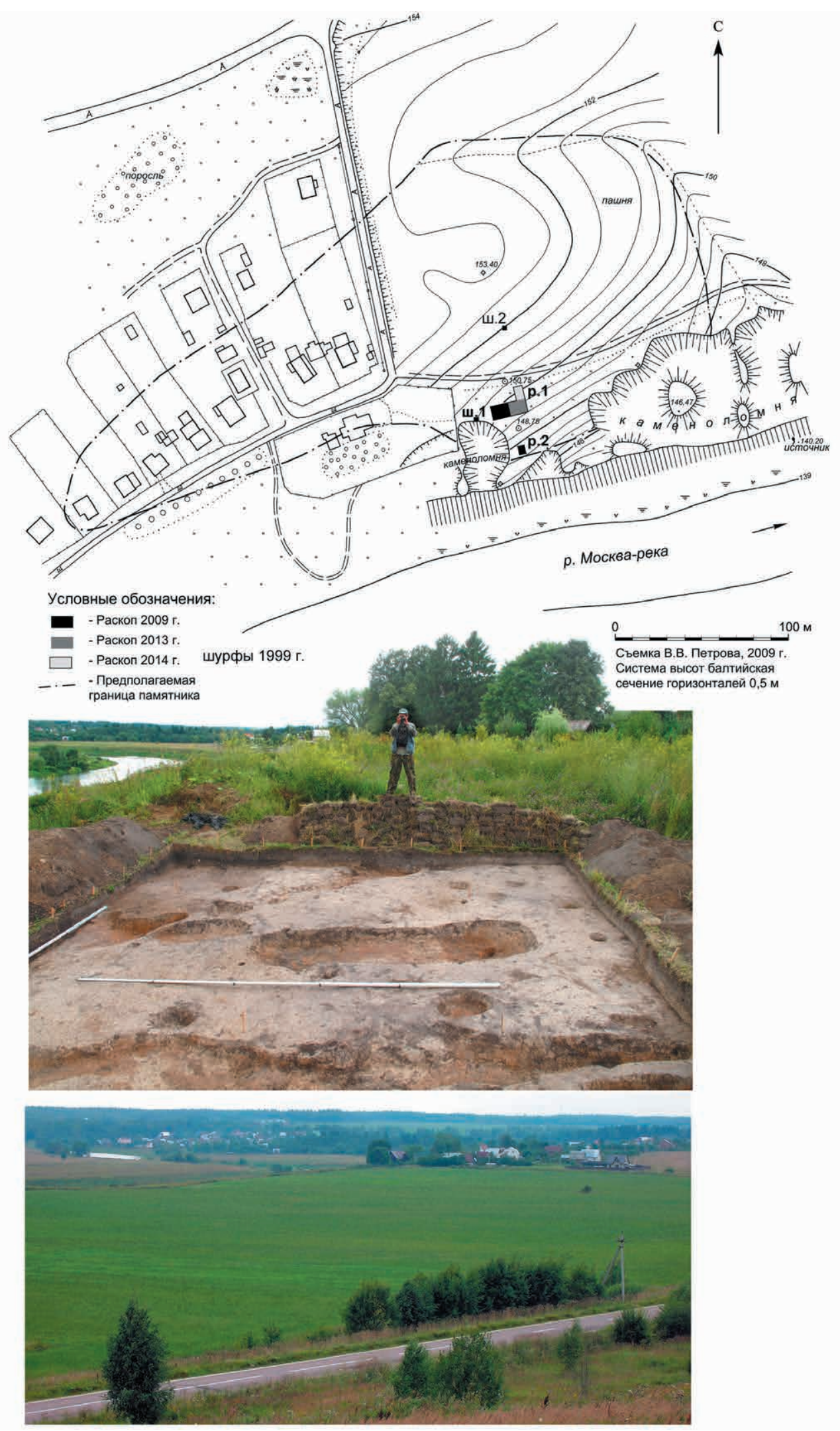

РИС. 175. ПЛАН СЕЛИЩА ХОТЯЖИ 1 (ВВЕРХУ), ВИД НА РАСКОП 1 В 2009 Г. С ЯМОЙ № 1 (В ЦЕНТРЕ), ВИД НА СЕЛИЩЕ ХОТЯЖИ 1 С АПАРИНОЙ ГОРЫ В 2009 г. (внизу) 


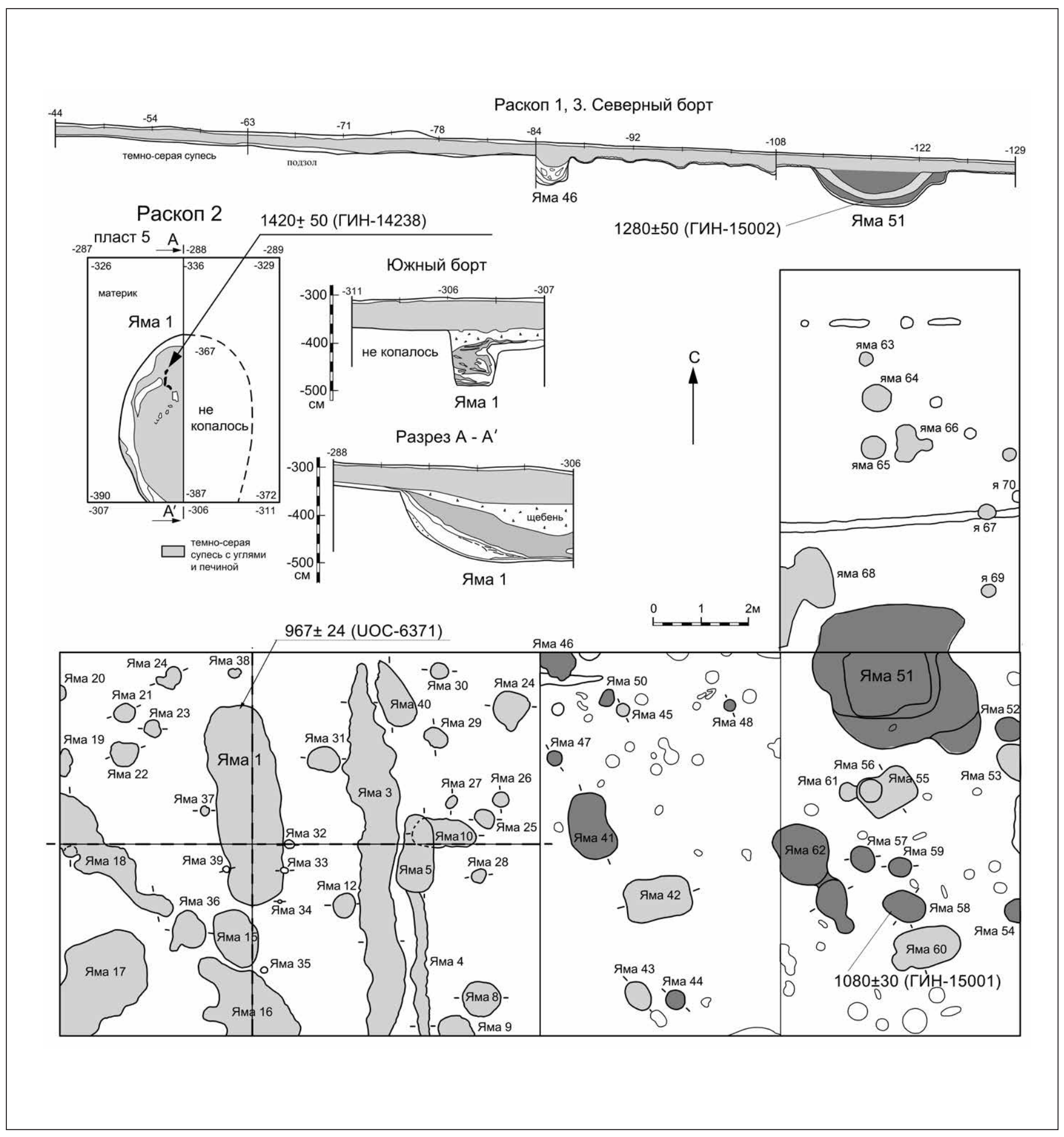

РИС. 176. ПЛАНЫ И ПРОФИЛИ РАСКОПОВ 2009 И 2013 ГГ. НА СЕЛИЩЕ ХОТЯЖИ 1

Раскопки Н.А. Кренке и А.В. Лазукина 


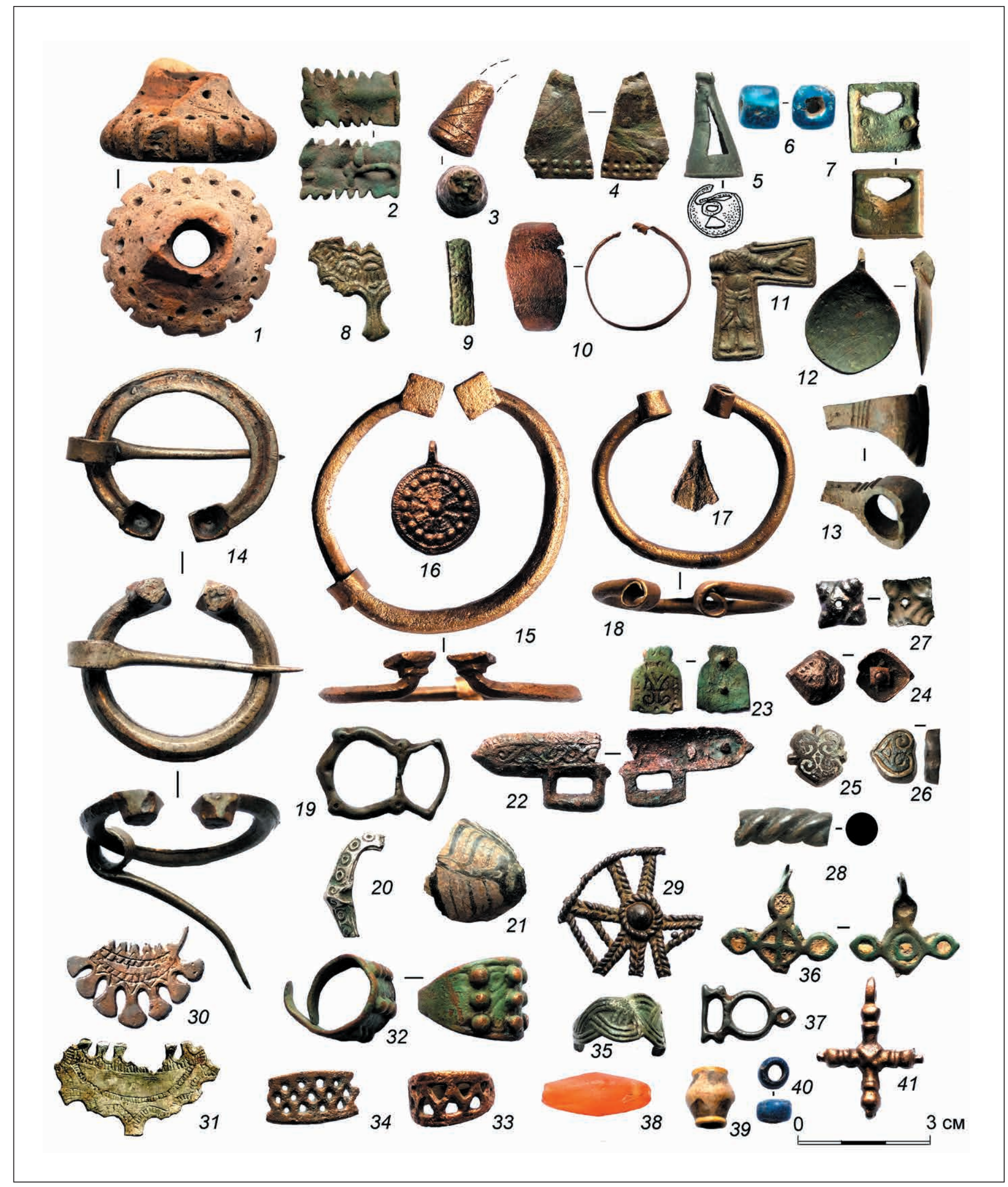

РИС. 177. НАХОДКИ ИЗ РАСКОПОВ 2009 Г. И ПОДЪЕМНЫЙ МАТЕРИАЛ, СОБРАННЫЙ А.К. СТАНЮКОВИЧЕМ НА СЕЛИЩЕ ХОТЯЖИ 1 


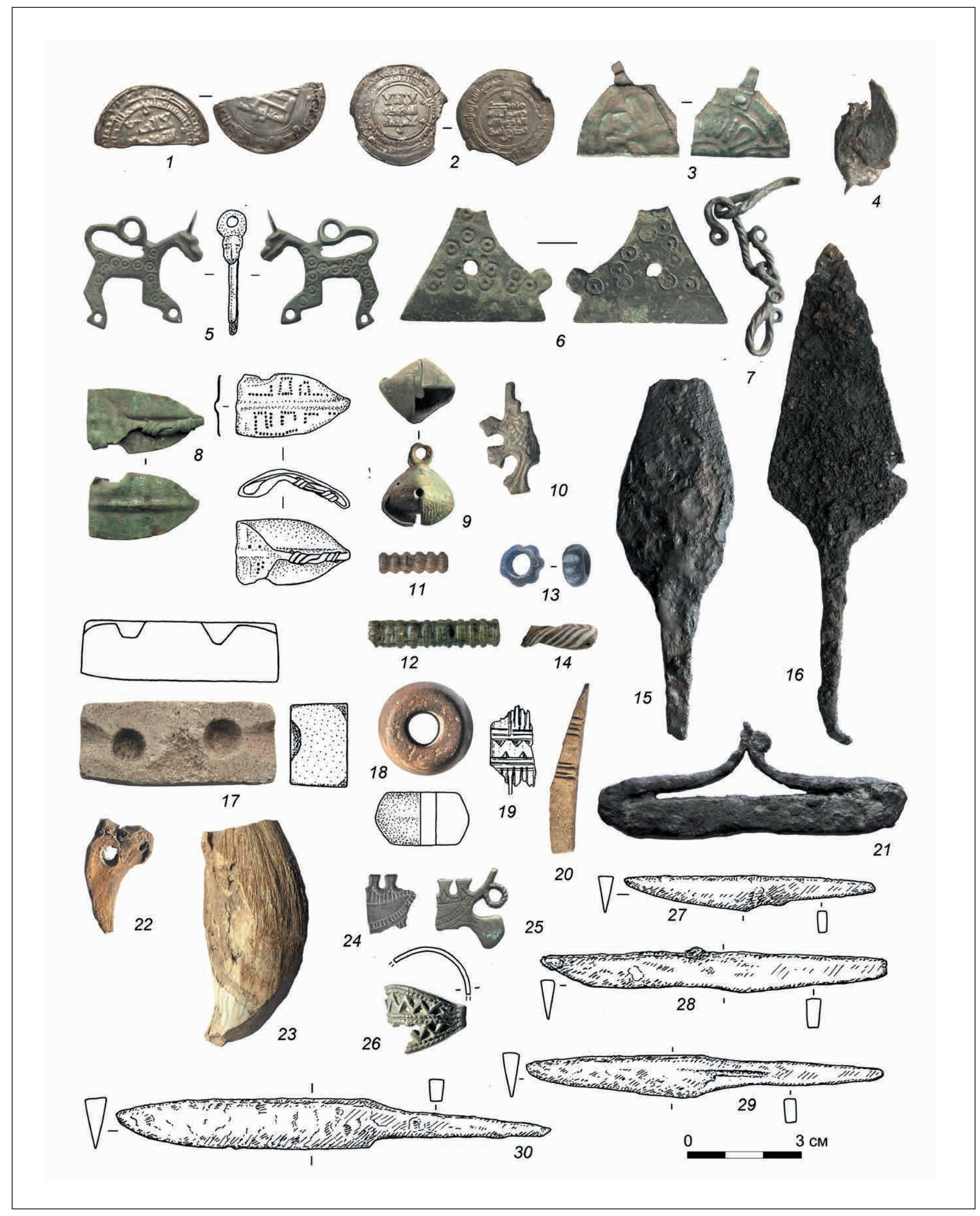

РИС. 178. НАХОДКИ ИЗ РАСКОПОВ 2009 Г. НА СЕЛИЩЕ ХОТЯЖИ 1 


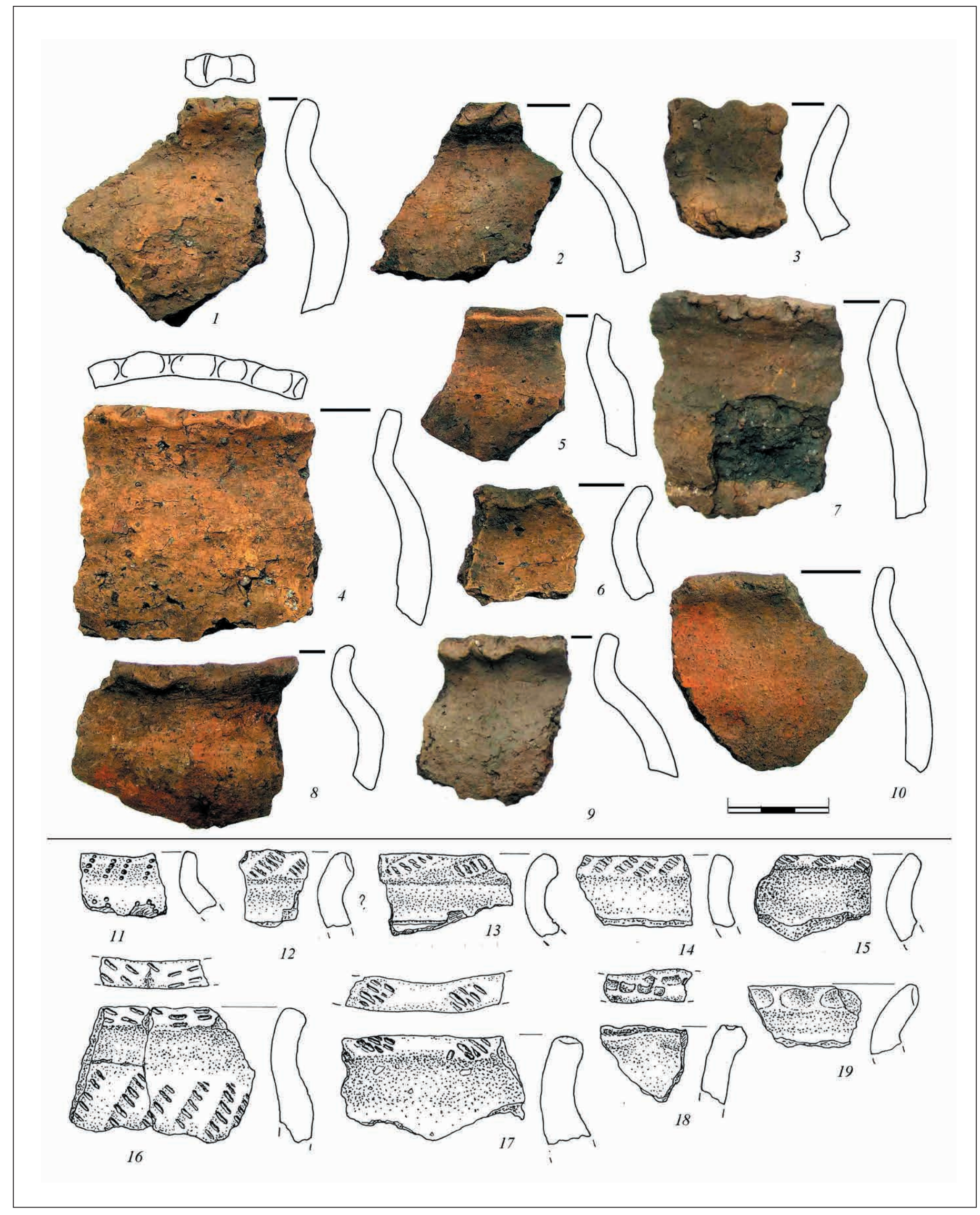

РИС. 179. ЛЕПНАЯ КЕРАМИКА ИЗ РАСКОПОВ 2009 и 2013 ГГ. НА СЕЛИЩЕ ХОТЯЖИ 1 

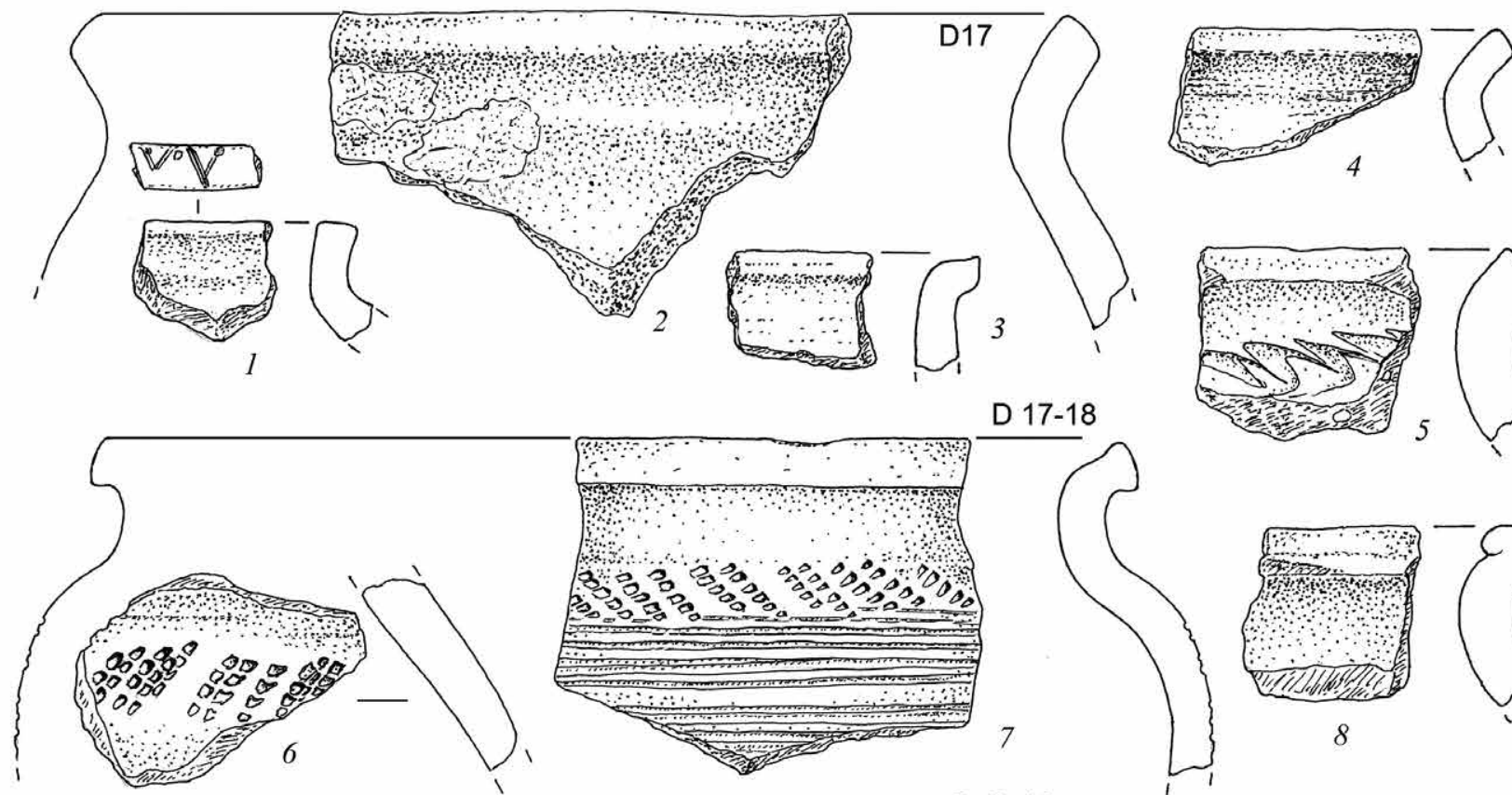

17-18

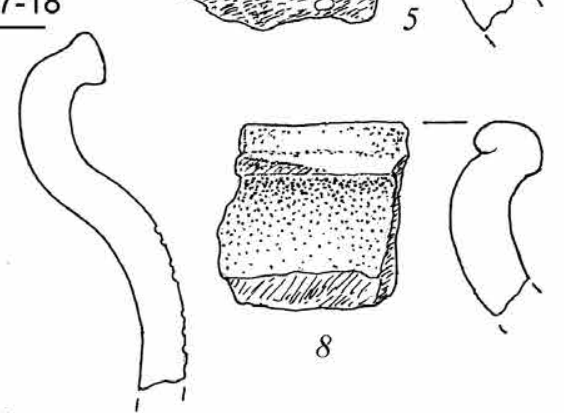

D 18-19
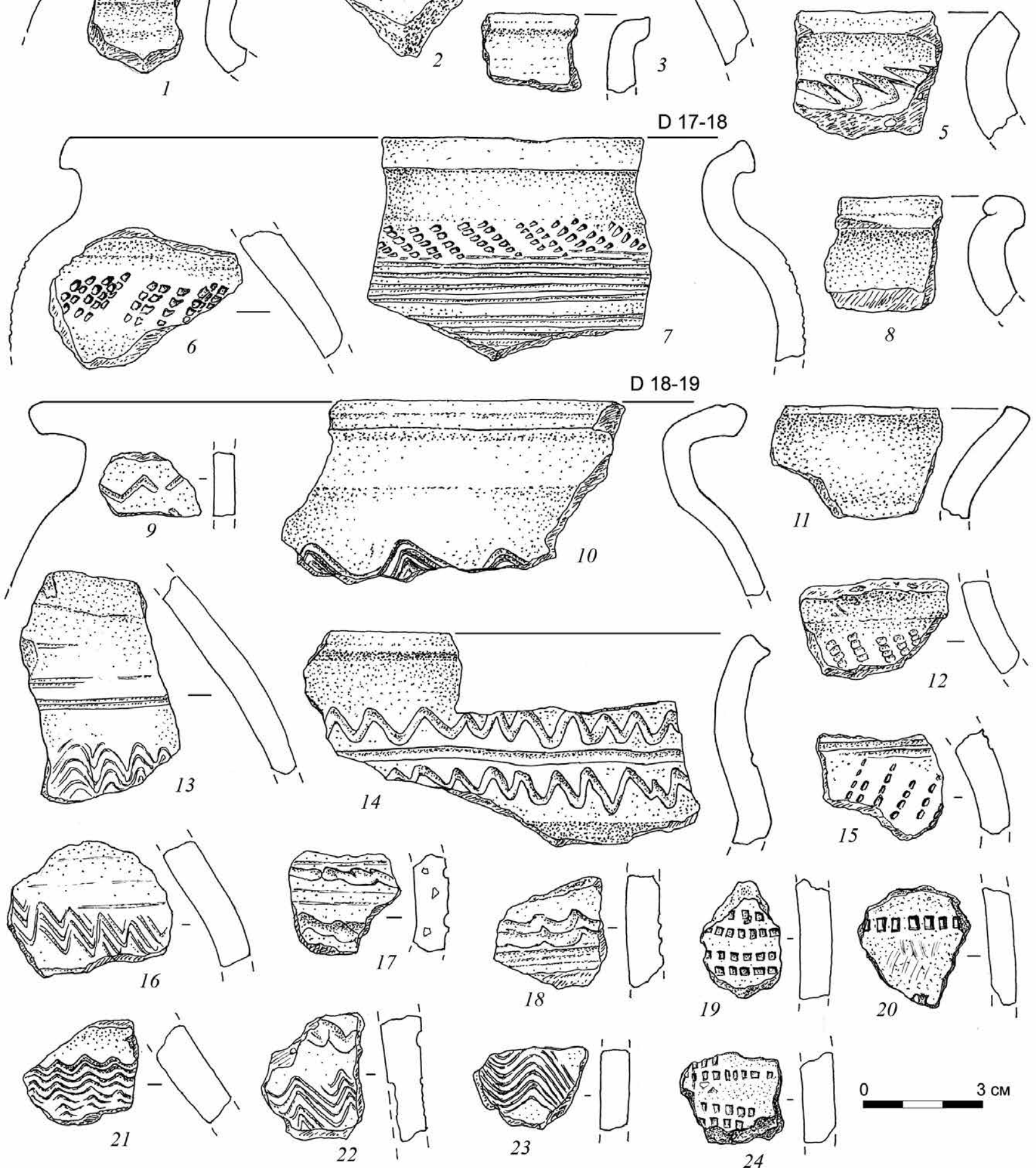

РИС. 180. РАННЕКРУГОВАЯ КЕРАМИКА ИЗ ЯМЫ 1 в РАСКОПЕ 1 НА СЕЛИЩЕ ХОТЯЖИ 1 

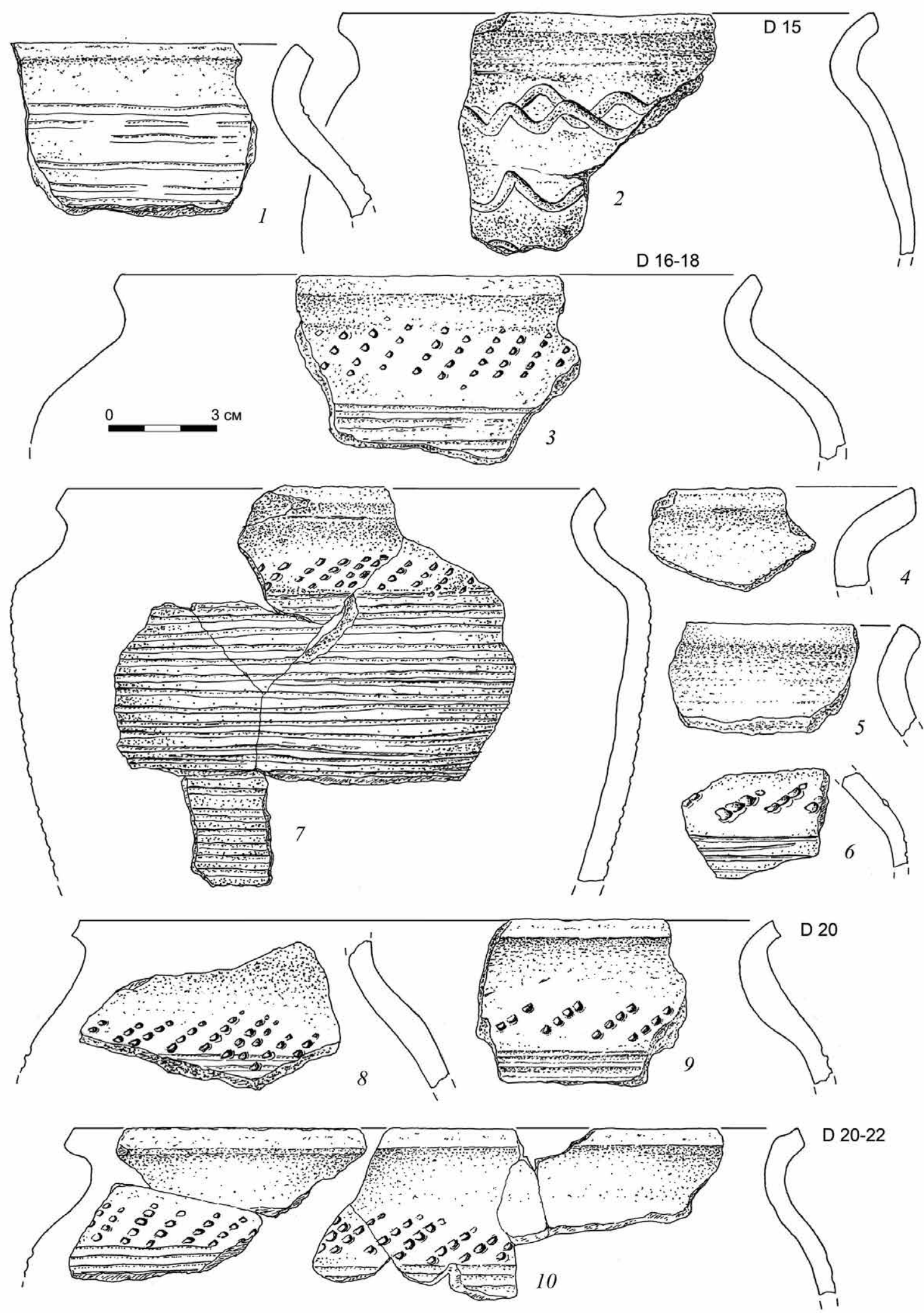

РИС. 181. РАННЕКРУГОВАЯ КеРАМИКА ИЗ ЯМЫ 1 В РАСКОПЕ 1 НА СЕЛИЩЕ ХОТЯЖИ 1 


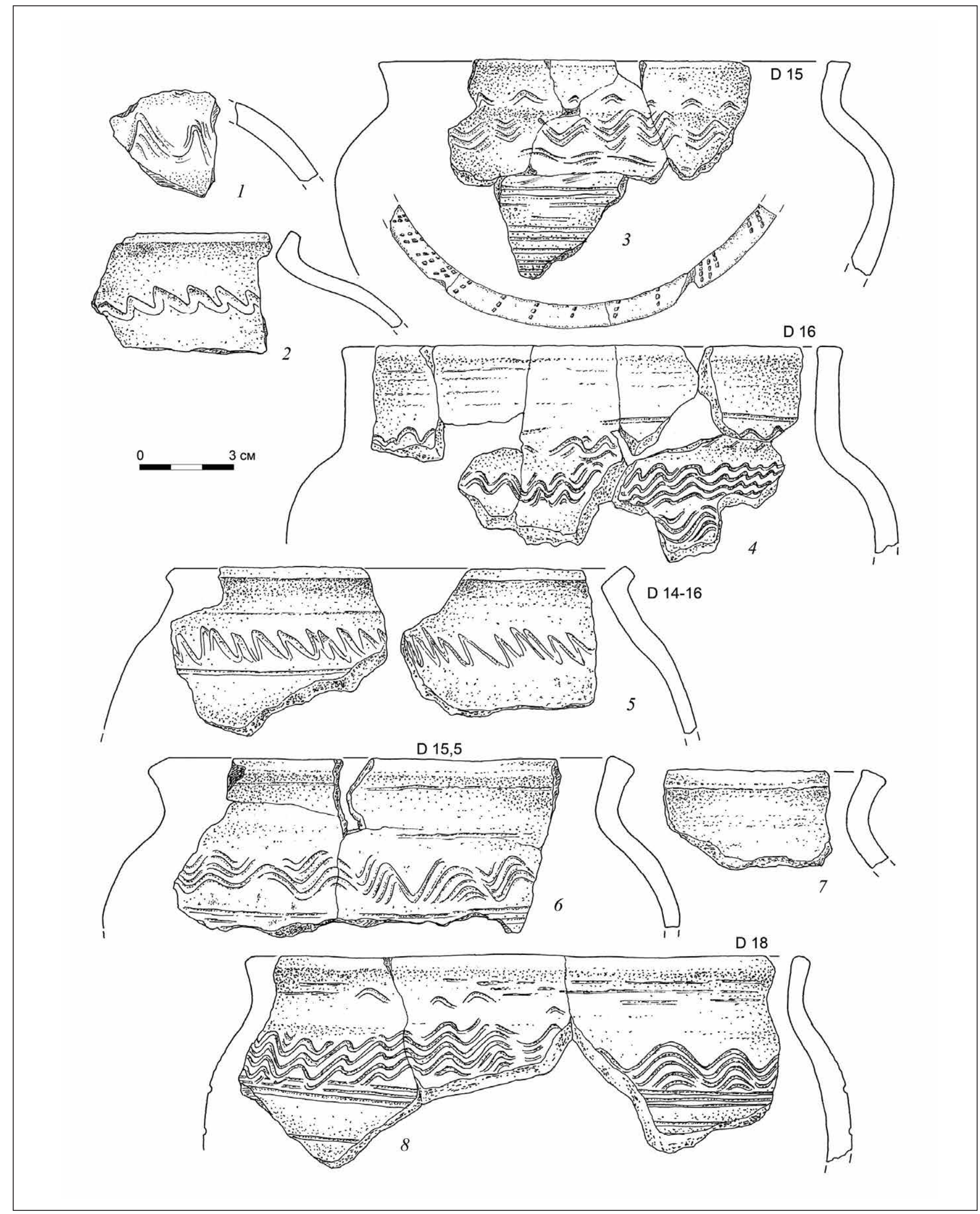

РИС. 182. РАННЕКРУГОВАЯ И ЛЕПНАЯ КЕРАМИКА ИЗ ЯМЫ 1 НА СЕЛИЩЕ ХОТЯЖИ 1 


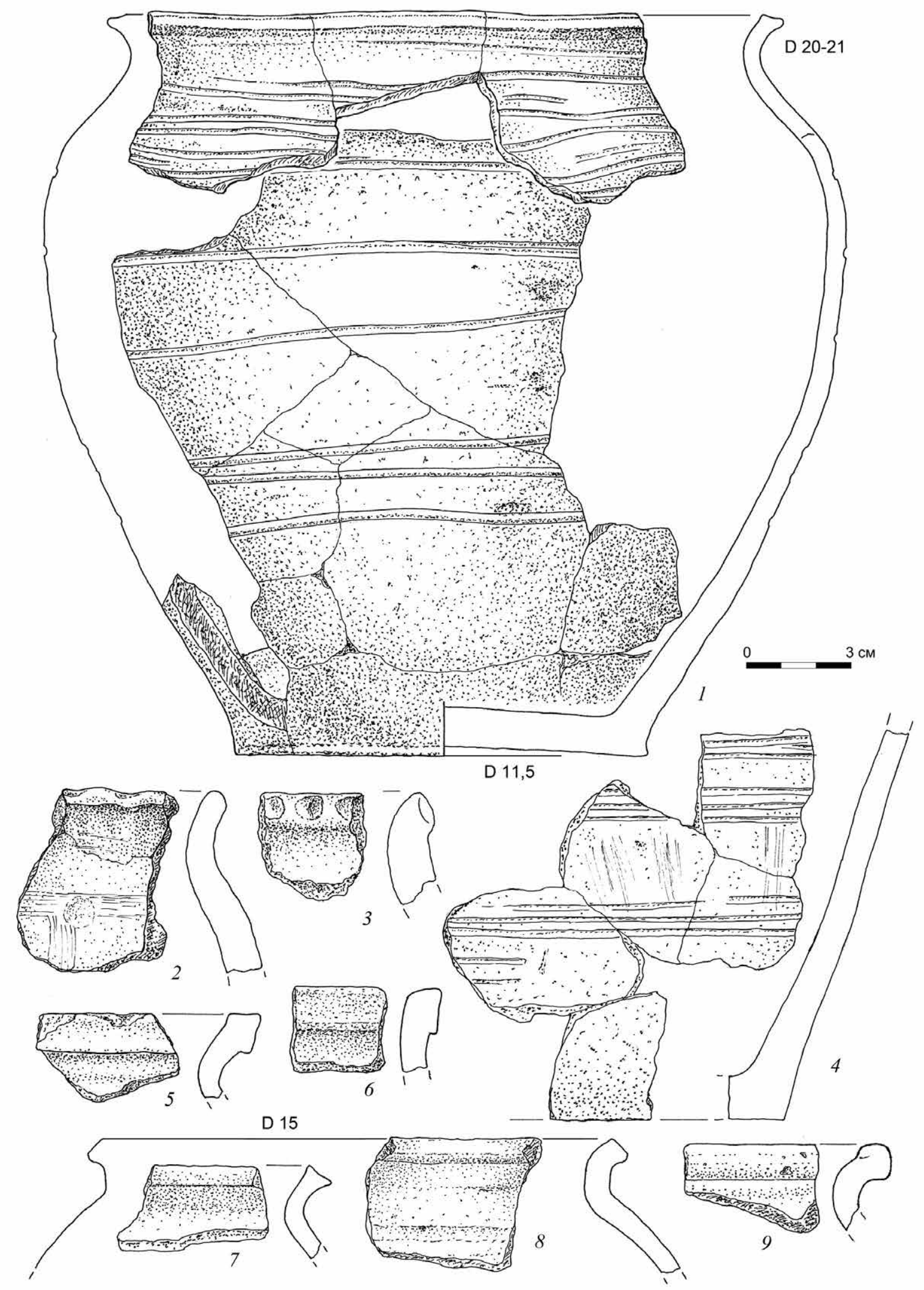

РИС. 183. РАННЕКРУГОВАЯ И ЛЕПНАЯ КЕРАМИКА ИЗ ЯМЫ 1 НА СЕЛИЩЕ ХОТЯЖИ 1 

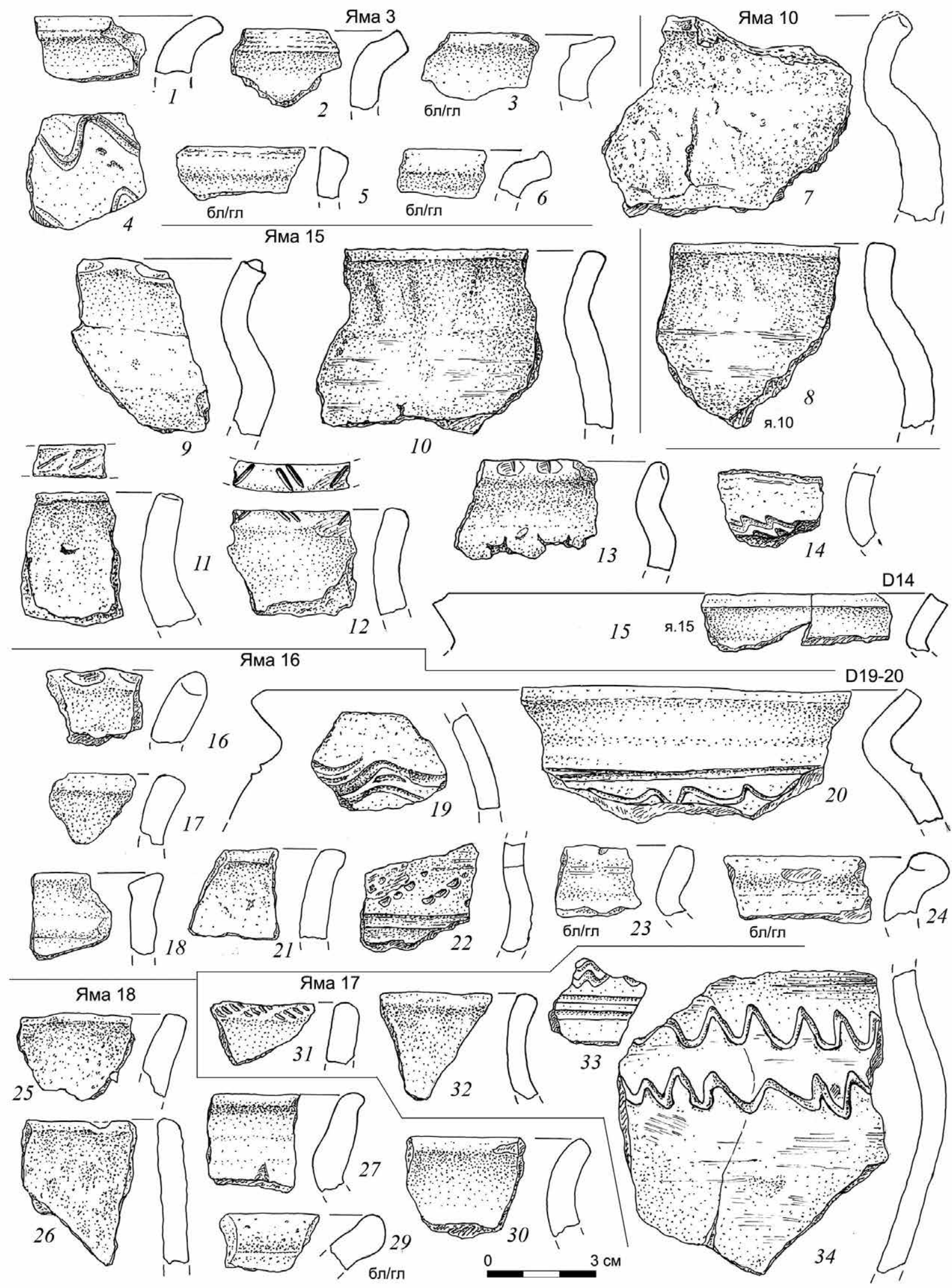

РИС. 184. ЛЕПНАЯ И РАННЕКРУГОВАЯ КЕРАМИКА ИЗ ЯМ В РАСКОПЕ 1 НА СЕЛИЩЕ ХОТЯЖИ 1 
Яма 1 (верх)
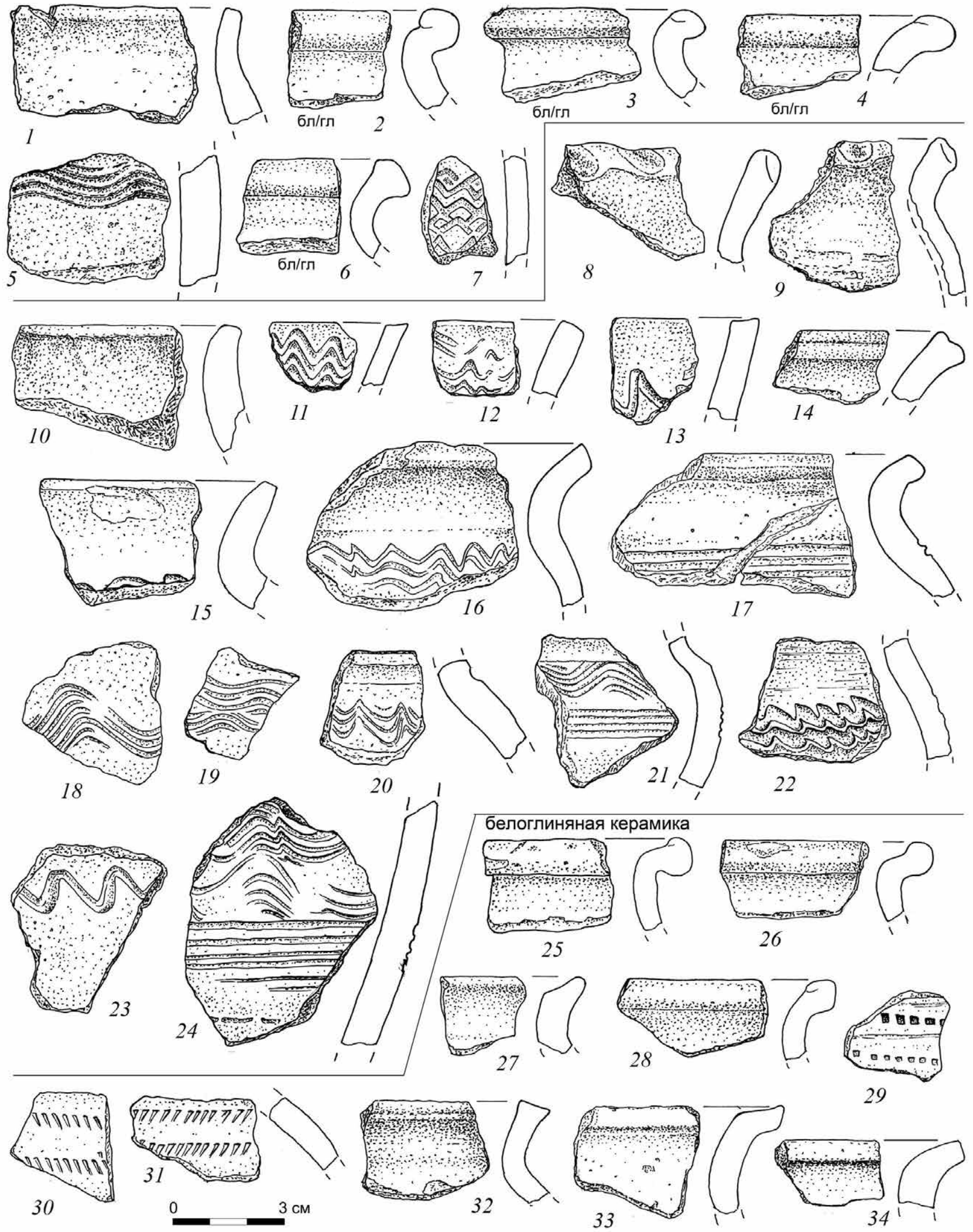

29

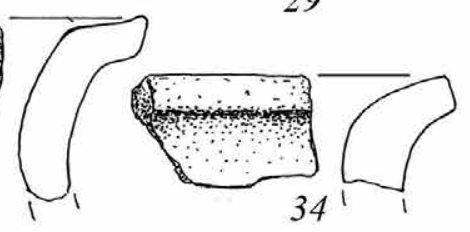

РИС. 185. КРУГОВАЯ И ЛЕПНАЯ КЕРАМИКА ИЗ РАСКОПА 2 НА СЕЛИЩЕ ХОТЯЖИ 1 


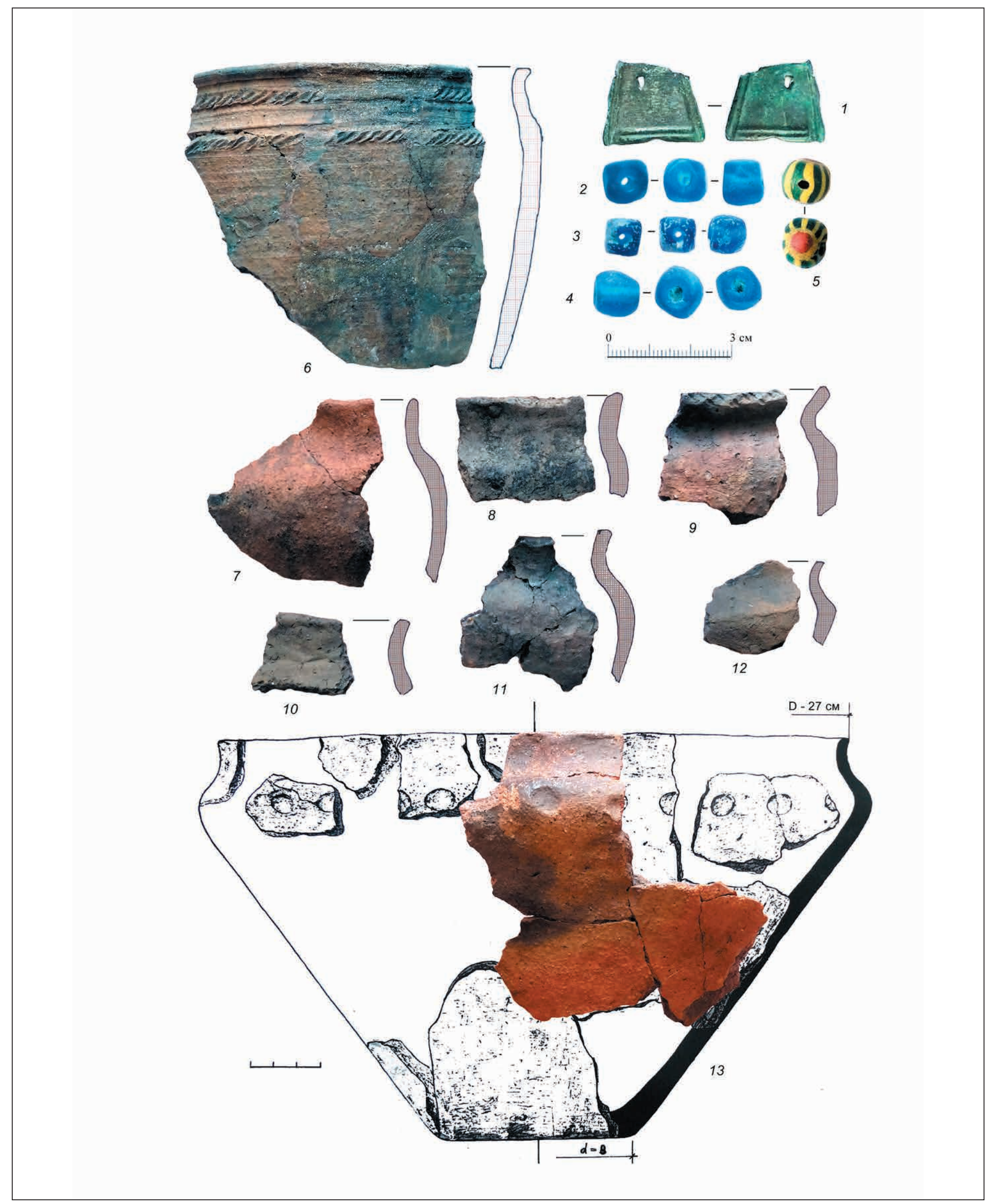

РИС. 186. КЕРАМИКА И НАХОДКИ С СЕЛИЩА САВВИНСКАЯ СЛОБОДА 2

Раскопки А.К. Станюковича, Звенигородский музей 


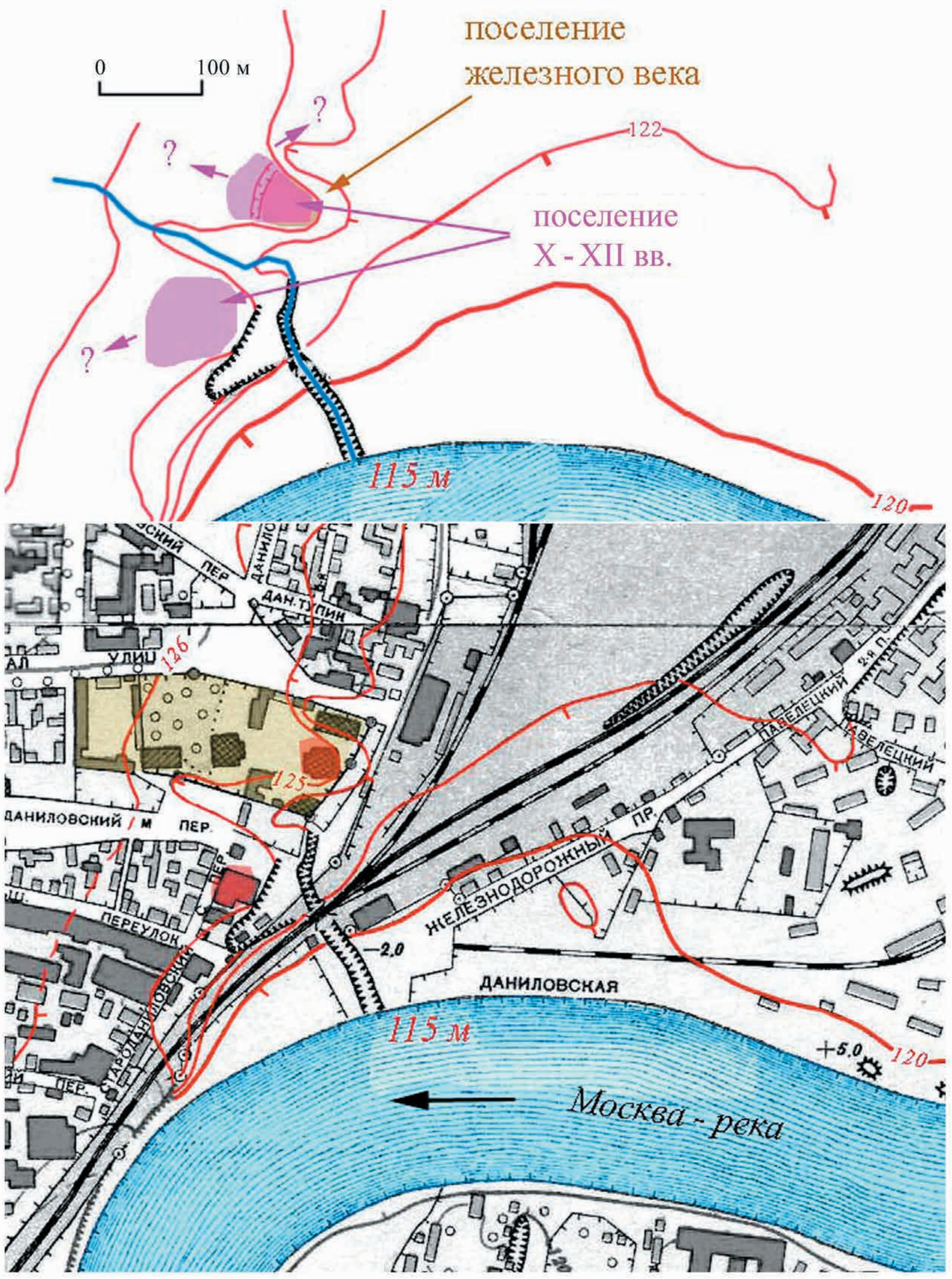

РИС. 187. ТОПОГРАФИЧЕСКИЙ ПЛАН ПОСЕЛЕНИЙ X-XI ВВ. НА ТЕРРИТОРИИ ДАНИЛОВА МОНАСТЫРЯ И ВОЗЛЕ НЕГО 


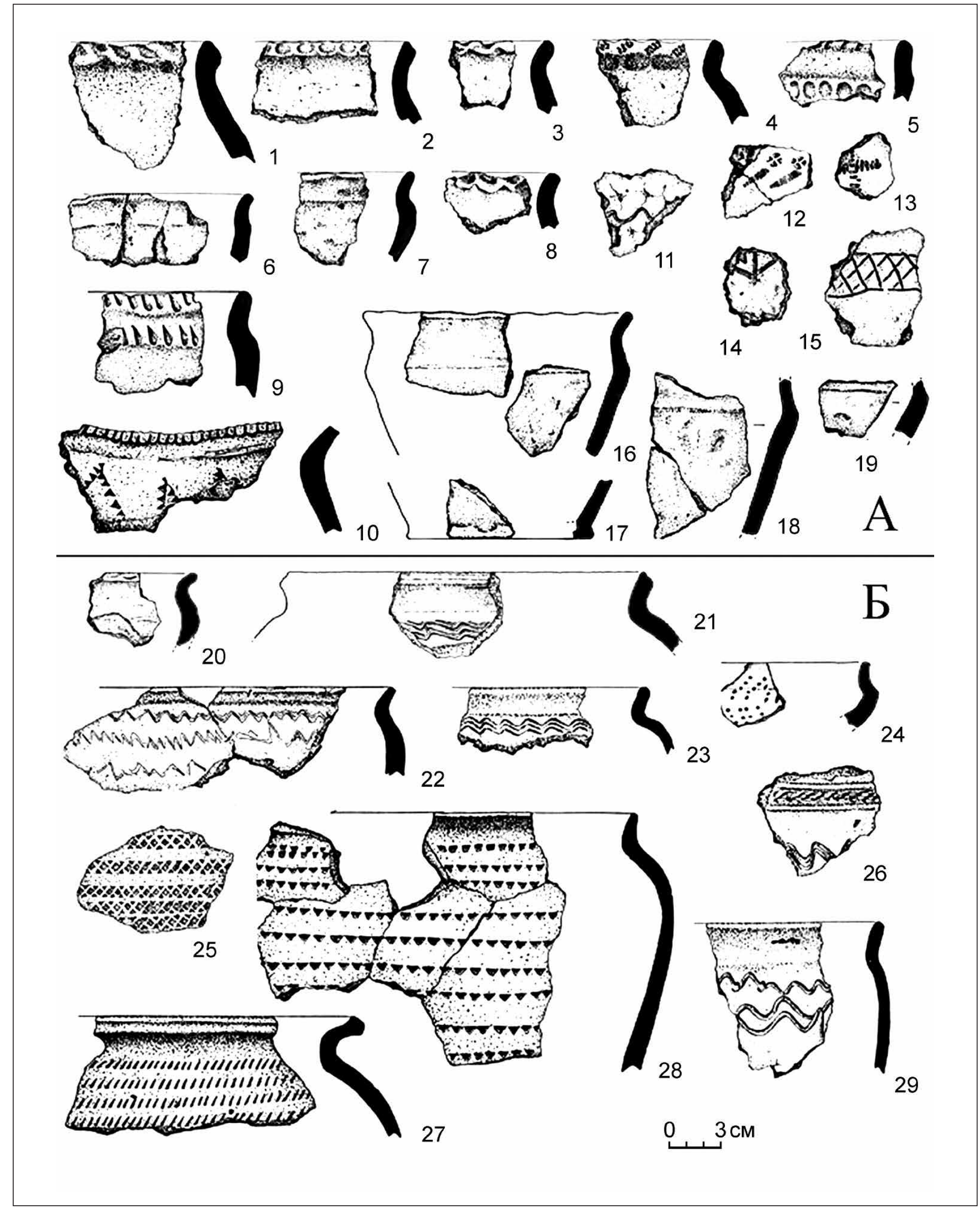

РИС. 188. ЛЕПНАЯ (А) И РАННЕКРУГОВАЯ (Б) КЕРАМИКА Х-ХІ В. ДАНИЛОВСКОГО МОНАСТЫРЯ ИЗ РАСКОПОК Л.А. БЕЛЯЕВА (ПО БЕЛЯЕВ, 1994 С ДОБАВЛЕНИЯМИ АВТОРА) 


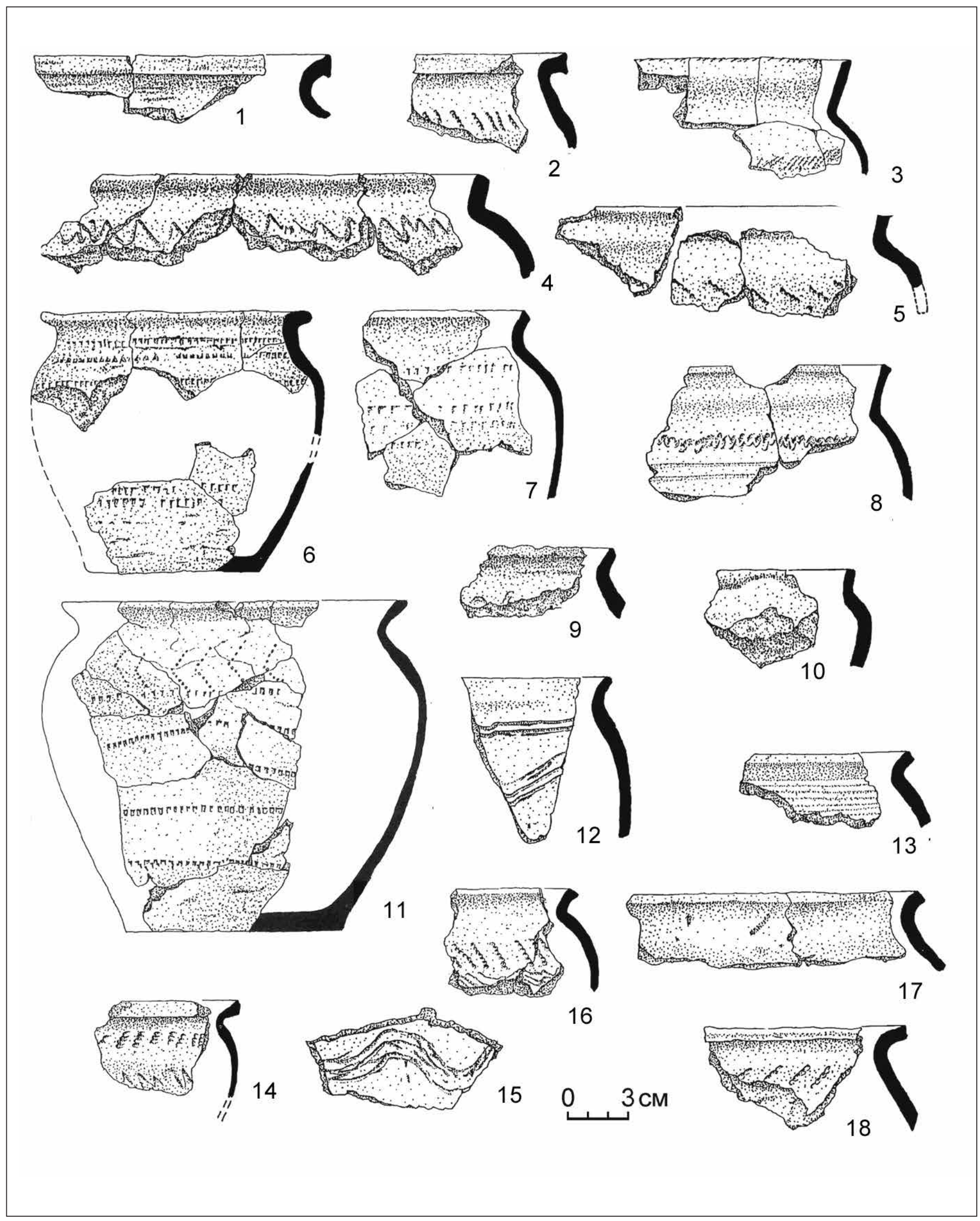

РИС. 189. ЛЕПНАЯ И РАННЕКРУГОВАЯ КЕРАМИКА ХІ - НАЧАЛА ХІІ В. С ПОСЕЛЕНИЯ ДЬЯКОВО-ПОЙМА 


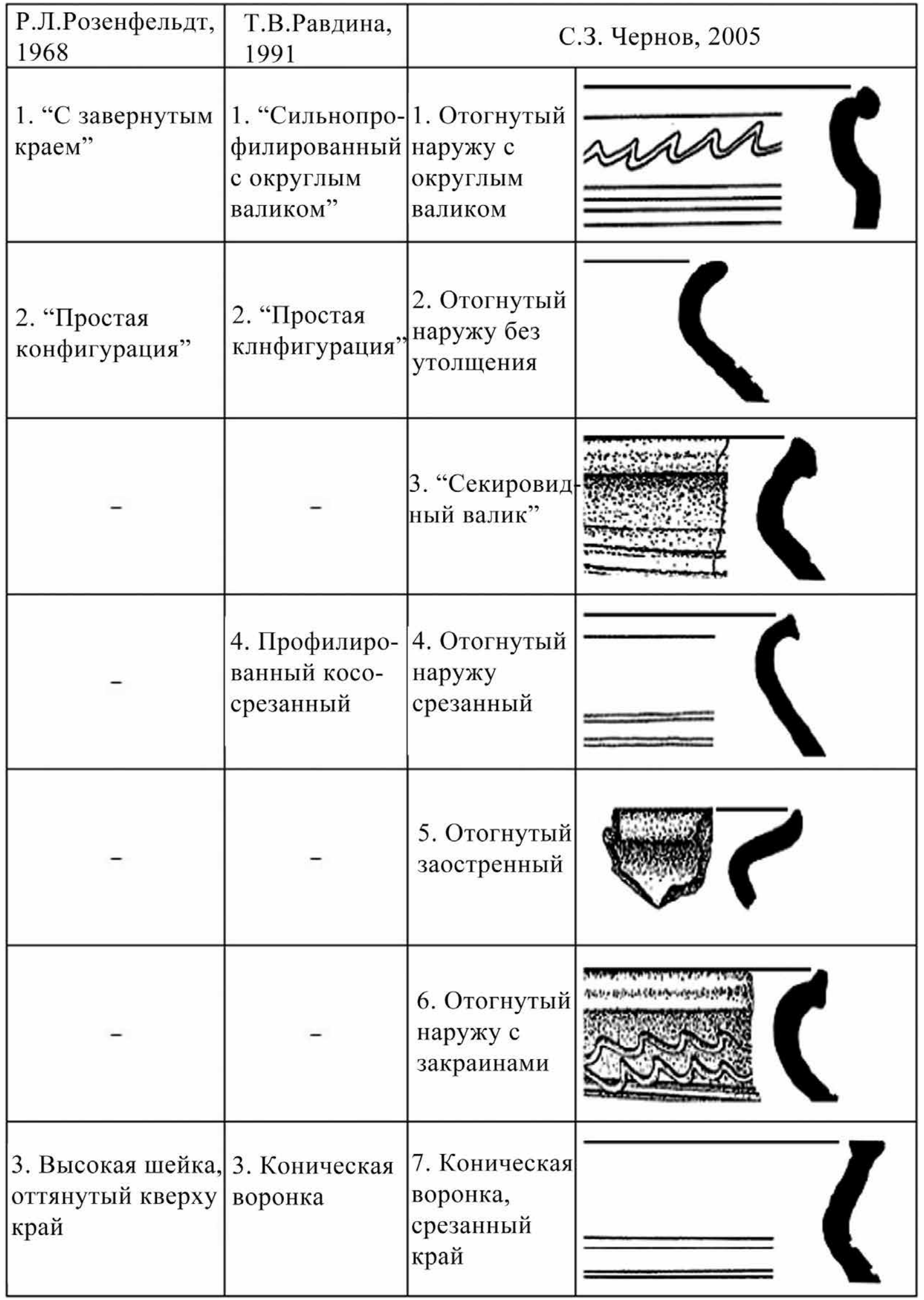

РИС. 190. ТИПОЛОГИЯ ДРЕВНЕРУССКОЙ КЕРАМИКИ МОСКОВСКОГО РЕГИОНА ПО Р.Л. РОЗЕНФЕЛЬДТУ, Т.В. РАВДИНОЙ, С.3. ЧЕРНОВУ 


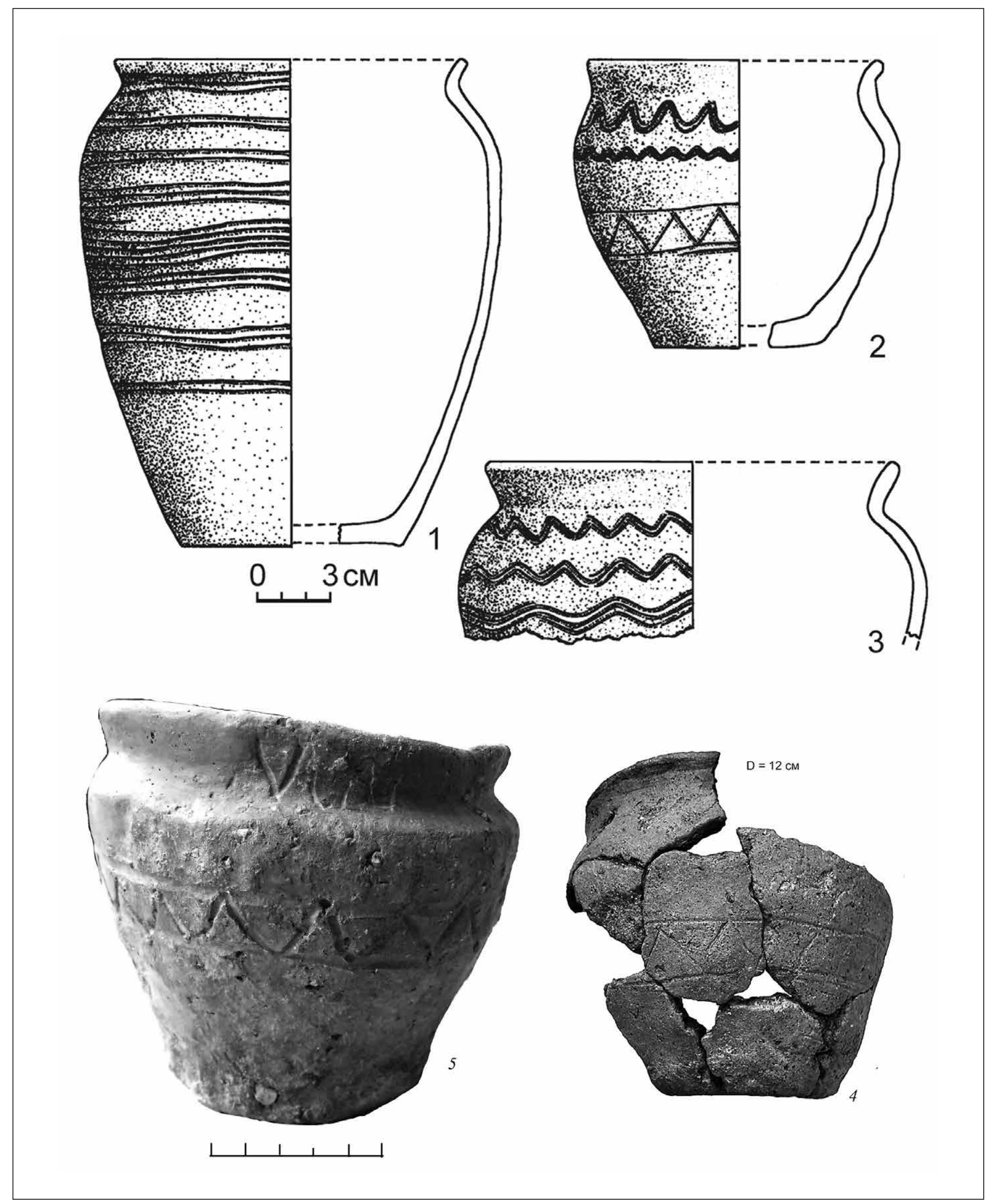

РИС. 191. РАННЕКРУГОВАЯ КЕРАМИКА ИЗ ЯМЫ 2 НА СЕЛИЩЕ ЦАРИЦЫНО 2 И ГОРШОК (5) ИЗ КУРГАНА № 13 ЛЕСНОЙ ГРУППЫ В ГНЁЗДОВО (СМОЛЕНСКИЙ КРАЕВЕДЧЕСКИЙ МУЗЕЙ) 

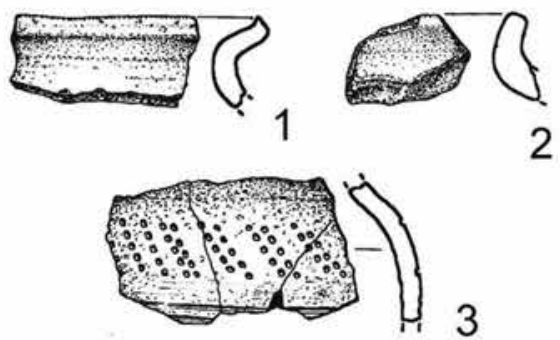

2

3
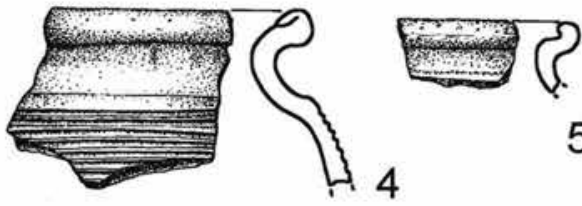

4

5
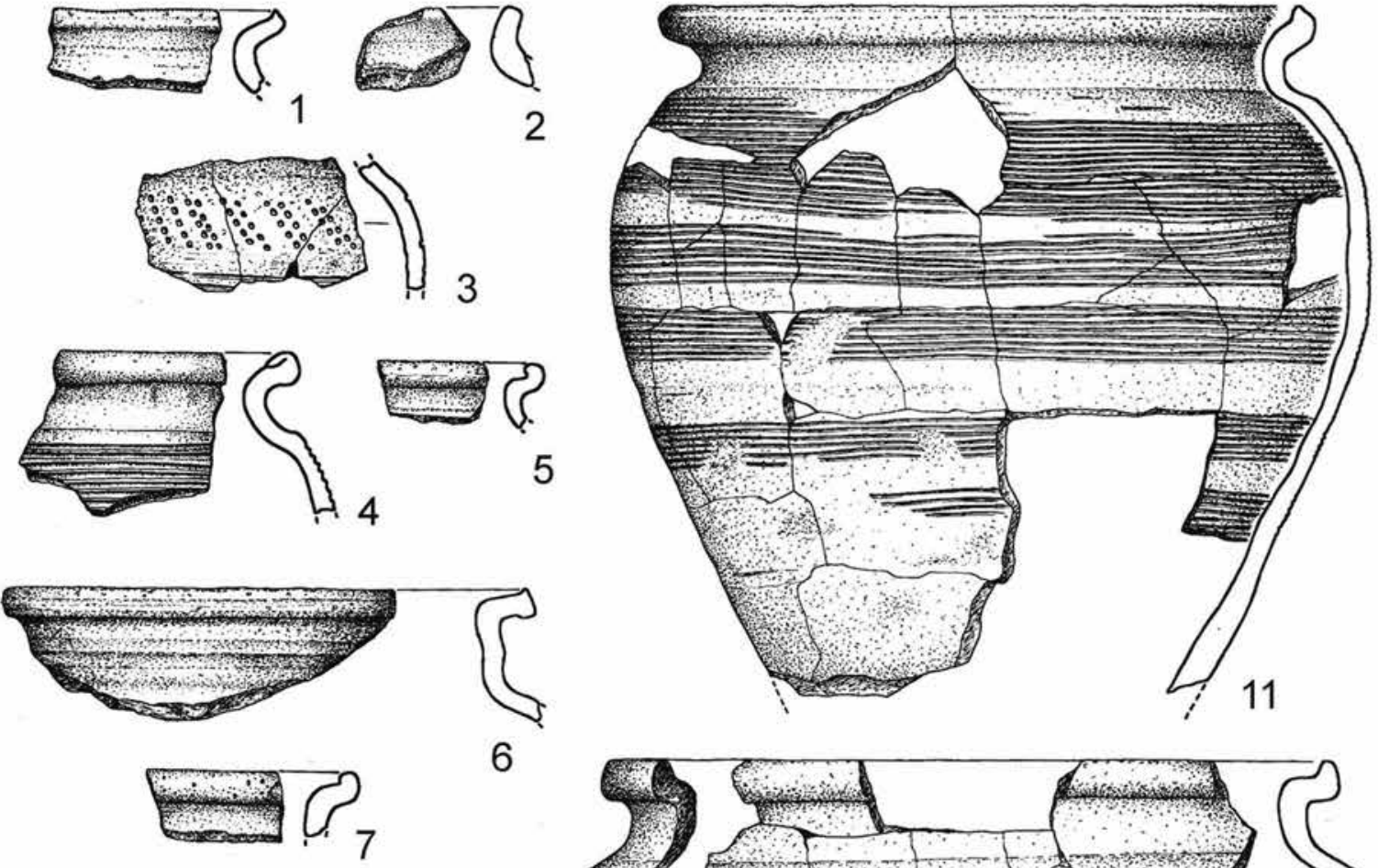

6

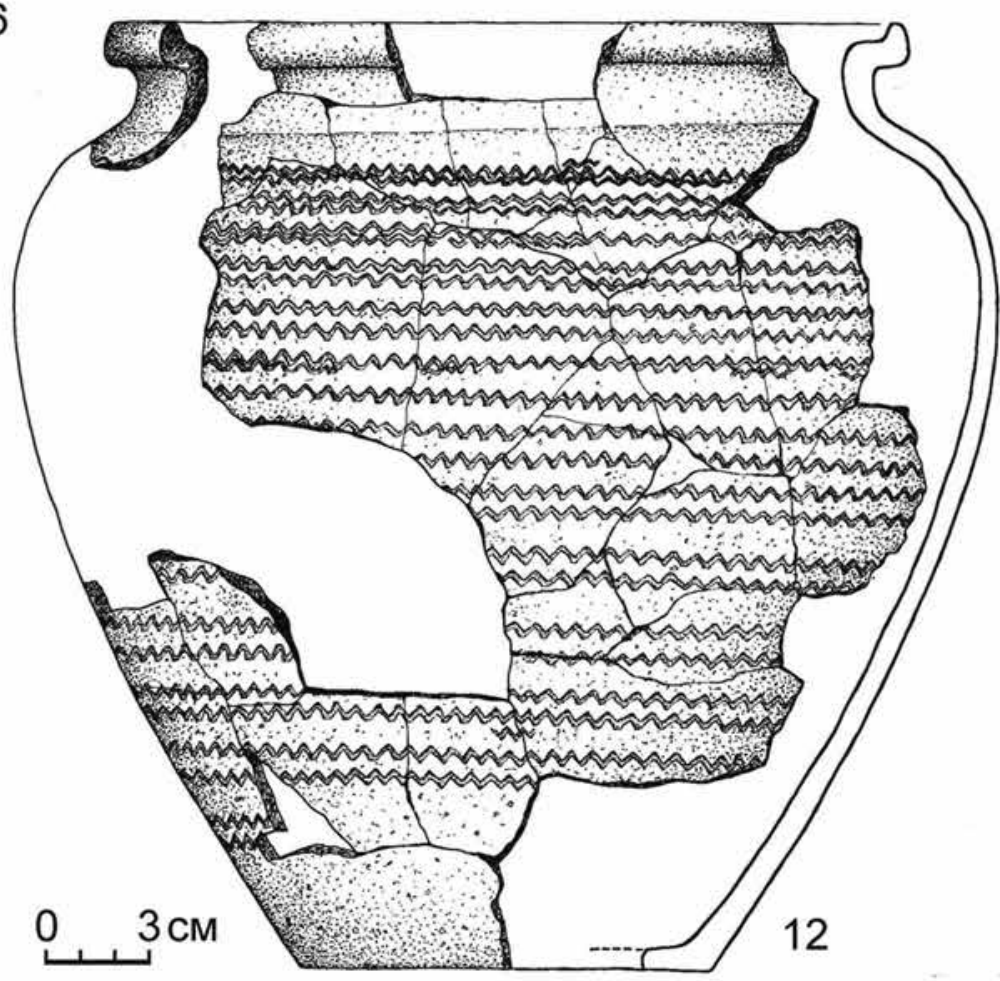

РИС. 192. КЕРАМИКА ХІІ В. ИЗ РАСКОПОК СЕЛИЩА БОРИСОВО 1 

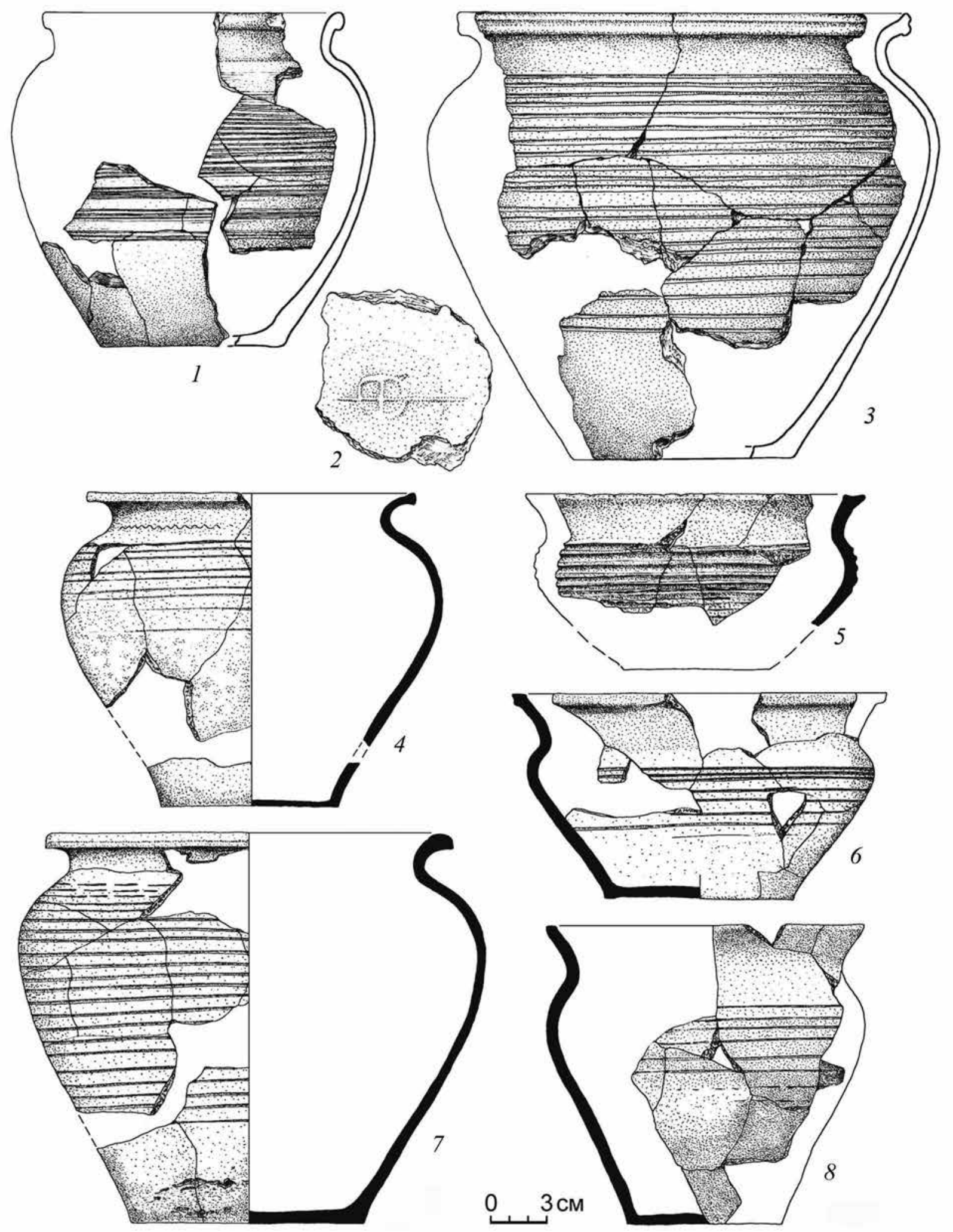

РИс. 193. ГОРШКИ XII-XIII вв. ИЗ РАСКОПОК НА РОМАНОвОМ ДвОРЕ В МОСКВЕ 


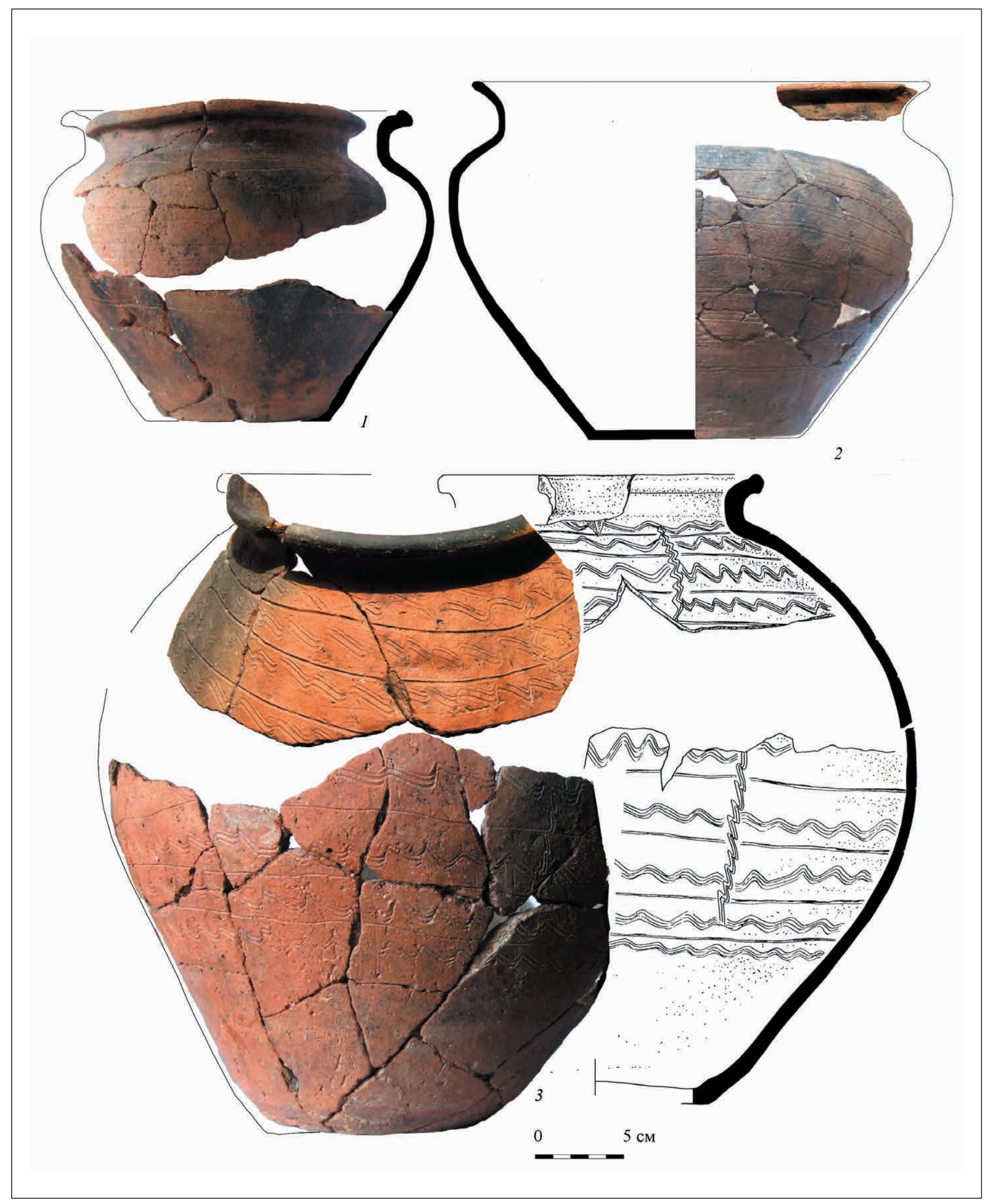

РИС. 194. ГОРШКИ ХІІІ В. ИЗ РАСКОПОК ЯМЫ № 1 НА СЕЛИЩЕ ЦАРИЦЫНО 2 


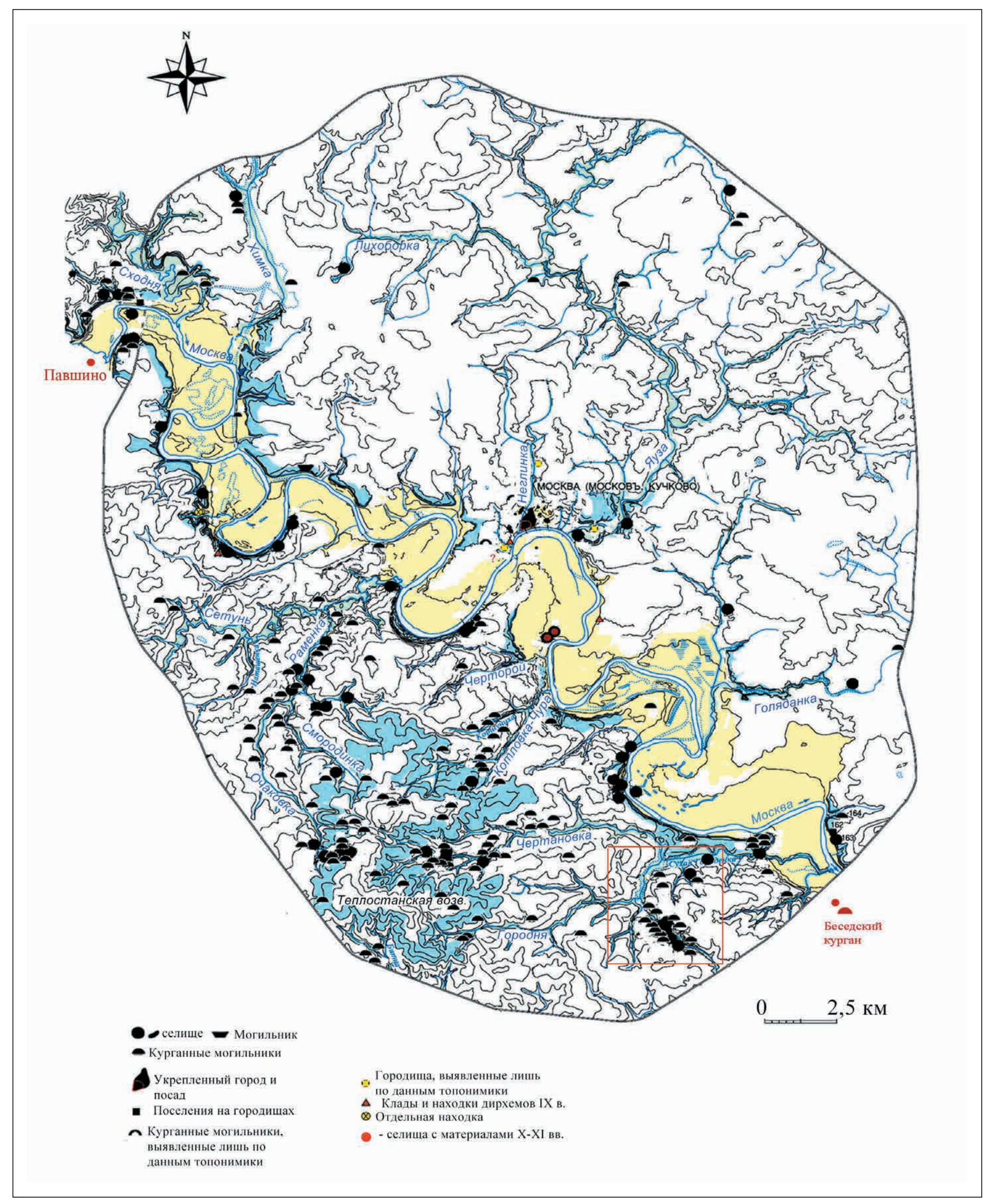

РИС. 195. КАРТА ДРЕВНЕРУССКИХ ПАМЯТНИКОВ МОСКВЫ X-XIII вВ. 


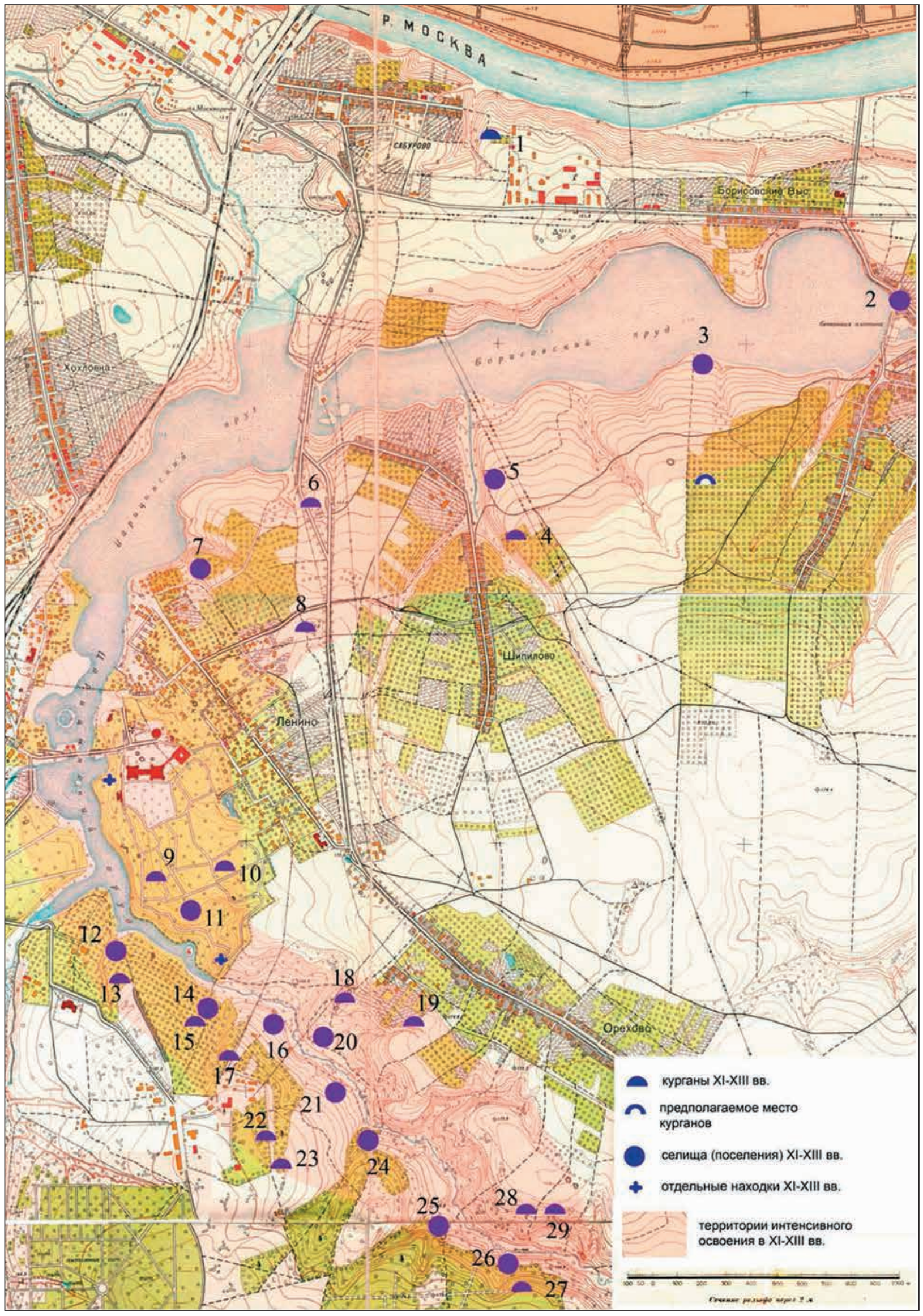

РИС. 196. КАРТА ДРЕВНЕРУССКИХ ПАМЯТНИКОВ В ДОЛИНЕ РЕК СУХАЯ ГОРОДЕНКА И ЯЗВЕНКА НА ЮГО-ВОСТОКЕ МОСКВЫ 


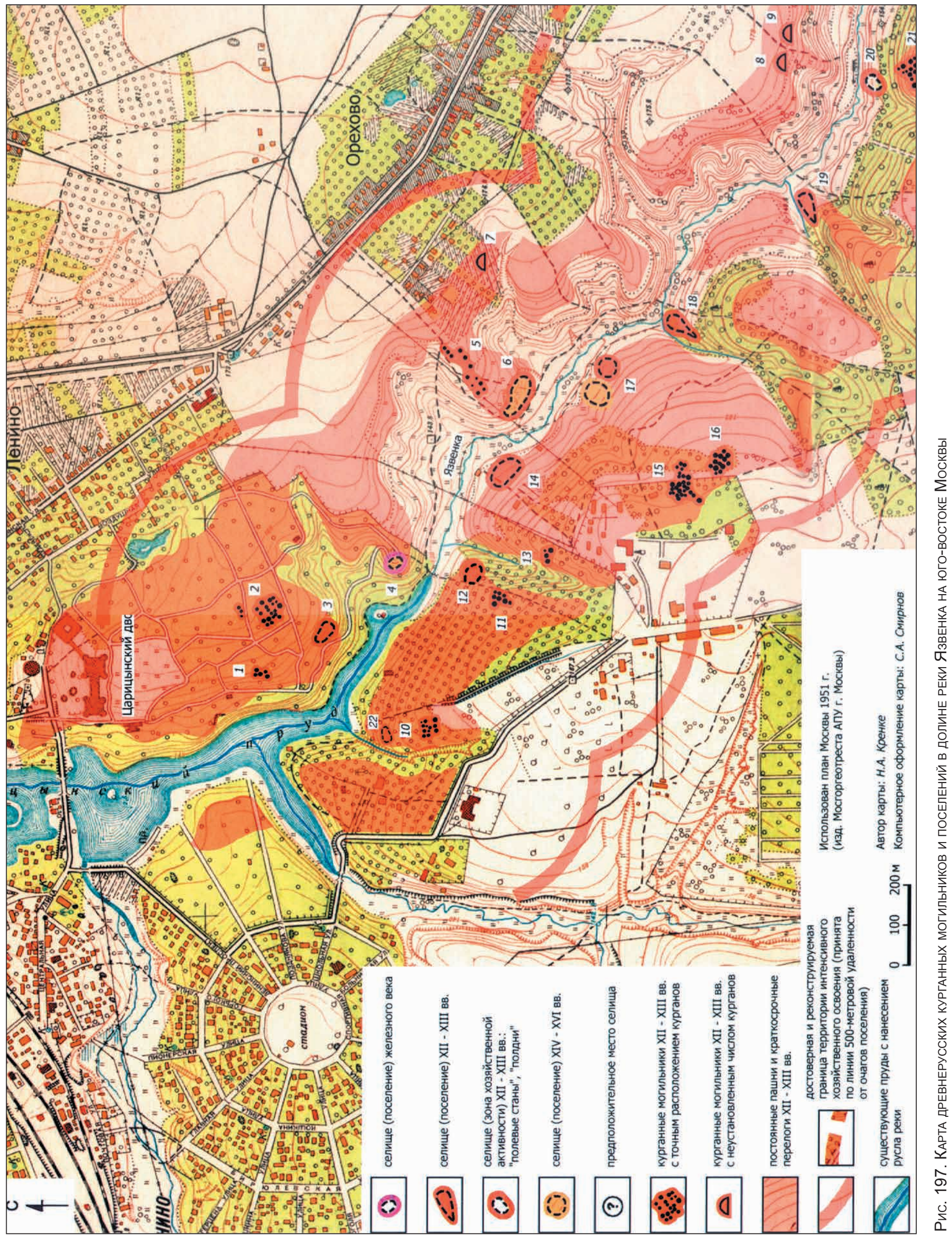



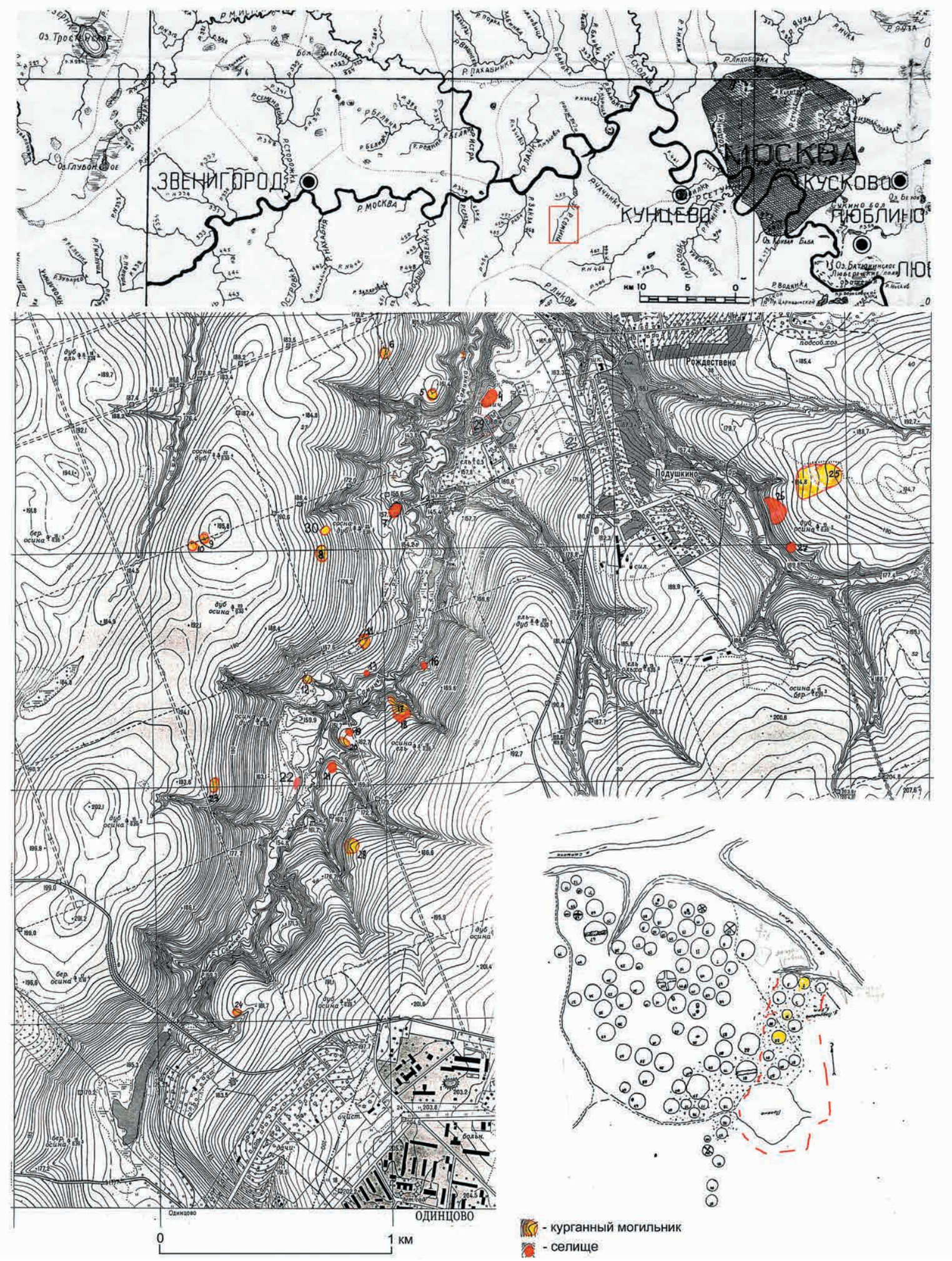

РИС. 198. КАРТА ДРЕВНЕРУССКИХ ПОСЕЛЕНИЙ И МОГИЛЬНИКОВ В ДОЛИНЕ Р. САМЫНКИ На врезке - курганный могильник Одинцово 6

Номерами обозначены: селища: 4 - Одинцово-2; 7 - Одинцово 3; 13 - Одинцово 9; 16 - Одинцово 10; 18 - Одинцово 6; 19 - Одинцово 8; 21 - Одинцово 4; 22 - Одинцово 1; 26 - Одинцово 7; 27 - Одинцово 5; курганные могильники: 5 - Одинцово 4; 6 - Одинцово 5; 8 - Одинцово 3; 9 - Одинцово 2; 10 - Одинцово 17; 11 - Одинцово 9; 12 - Одинцово 10; 17 - Одинцово 6; 20 - Одинцово 8; 23 - 1; 24 - Одинцово 16; 25 - Одинцово 7; 28 - Одинцово 11; 30 - Одинцово 18; 29 - курган в лесничестве 

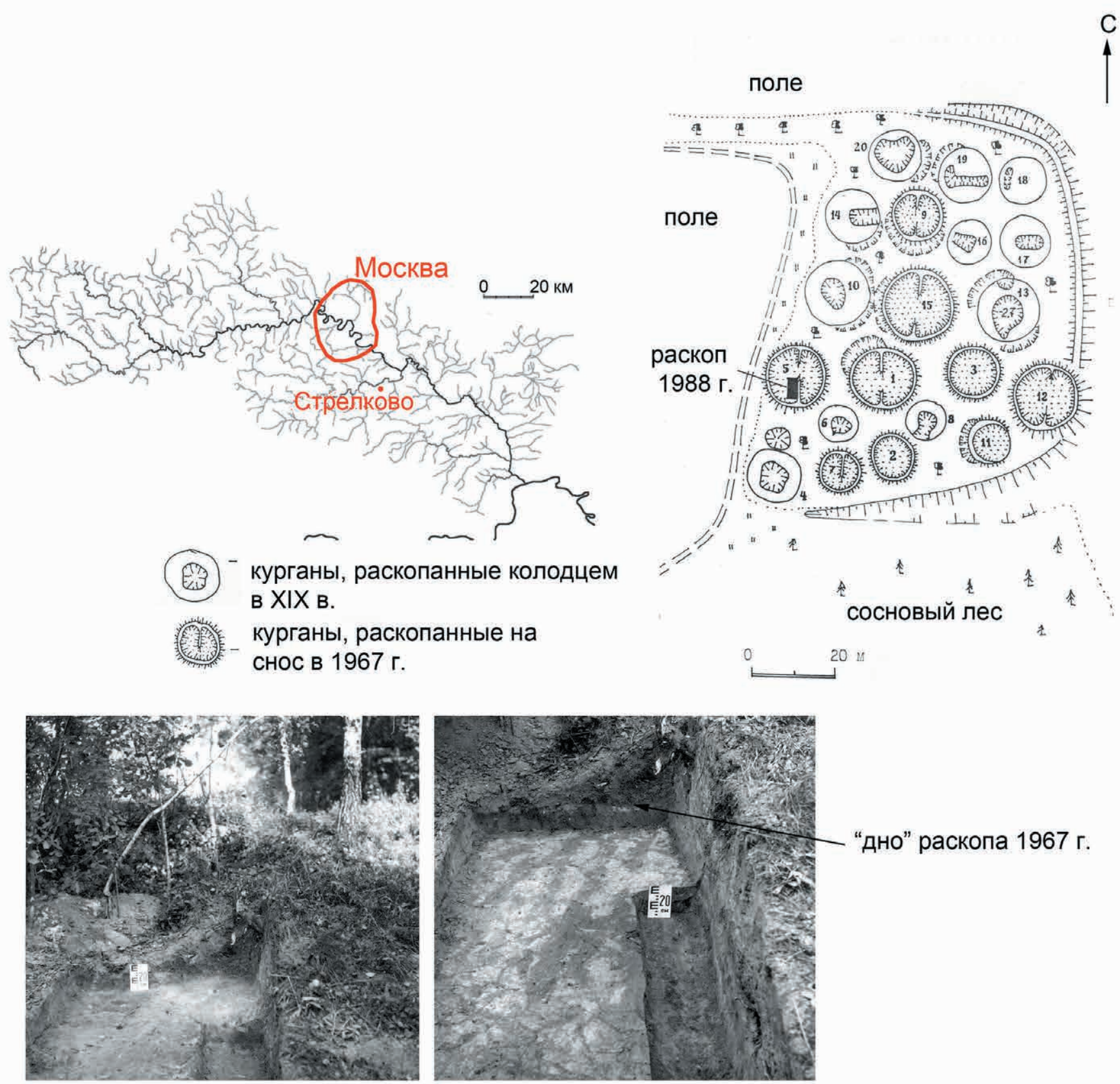

\section{“дно" раскопа 1967 г.}
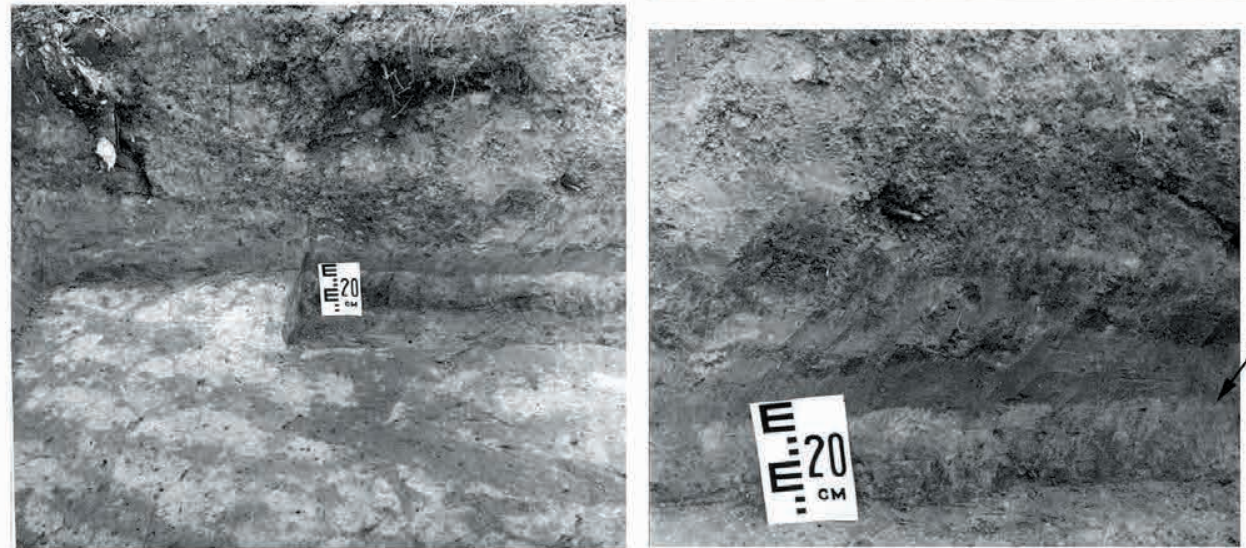

резкая ровная граница основания пахотного горизонта

РИС. 199. ПЛАН КУРГАННОЙ ГРУППЫ СТРЕЛКОВО НА Р. ПАХРЕ И ПАХОТНЫЕ БОРОЗДЫ ХІІ В., ОБНАРУЖЕННЫЕ ПОД НАСЫПЬЮ КУРГАНА В СТРЕЛКОВО 


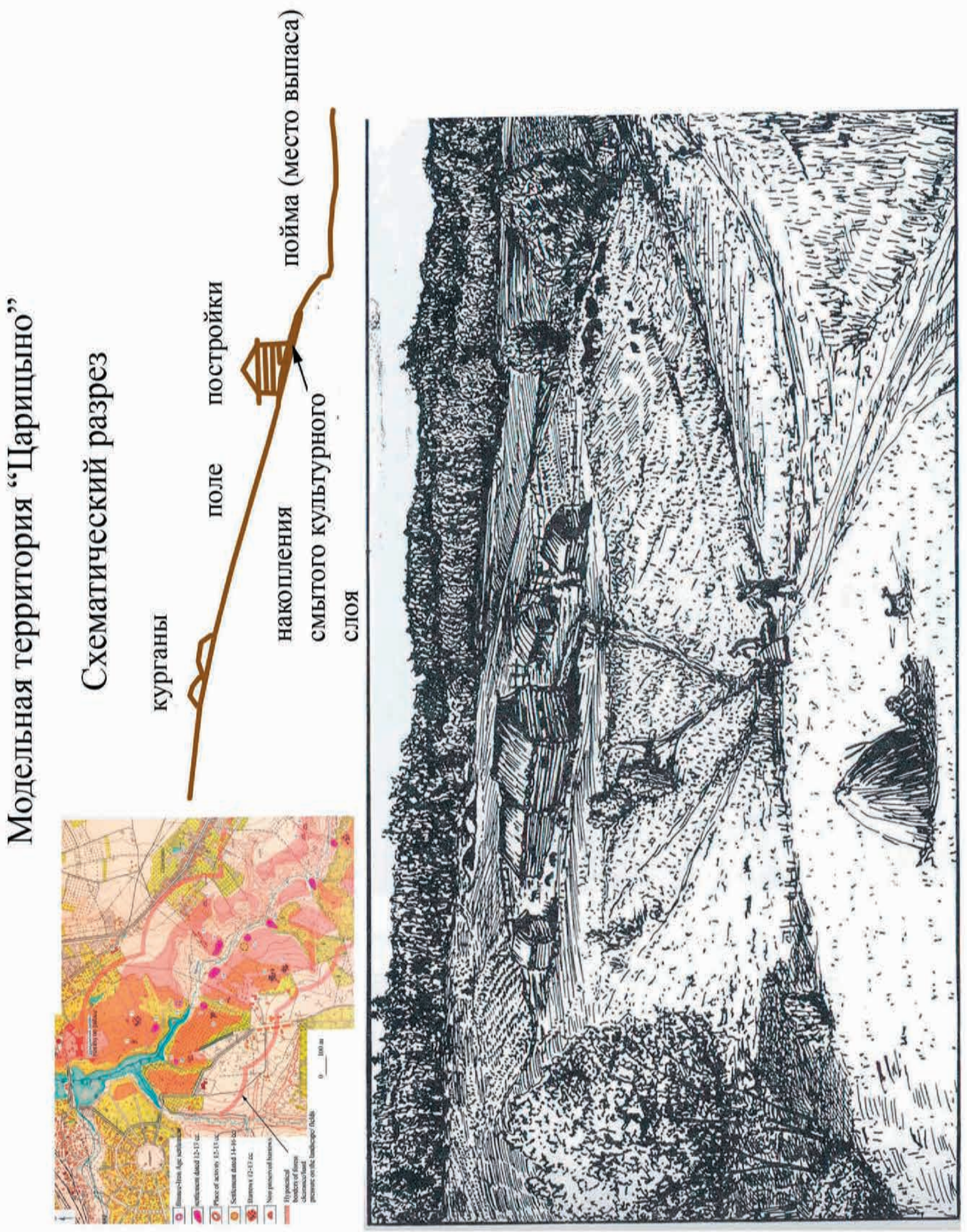










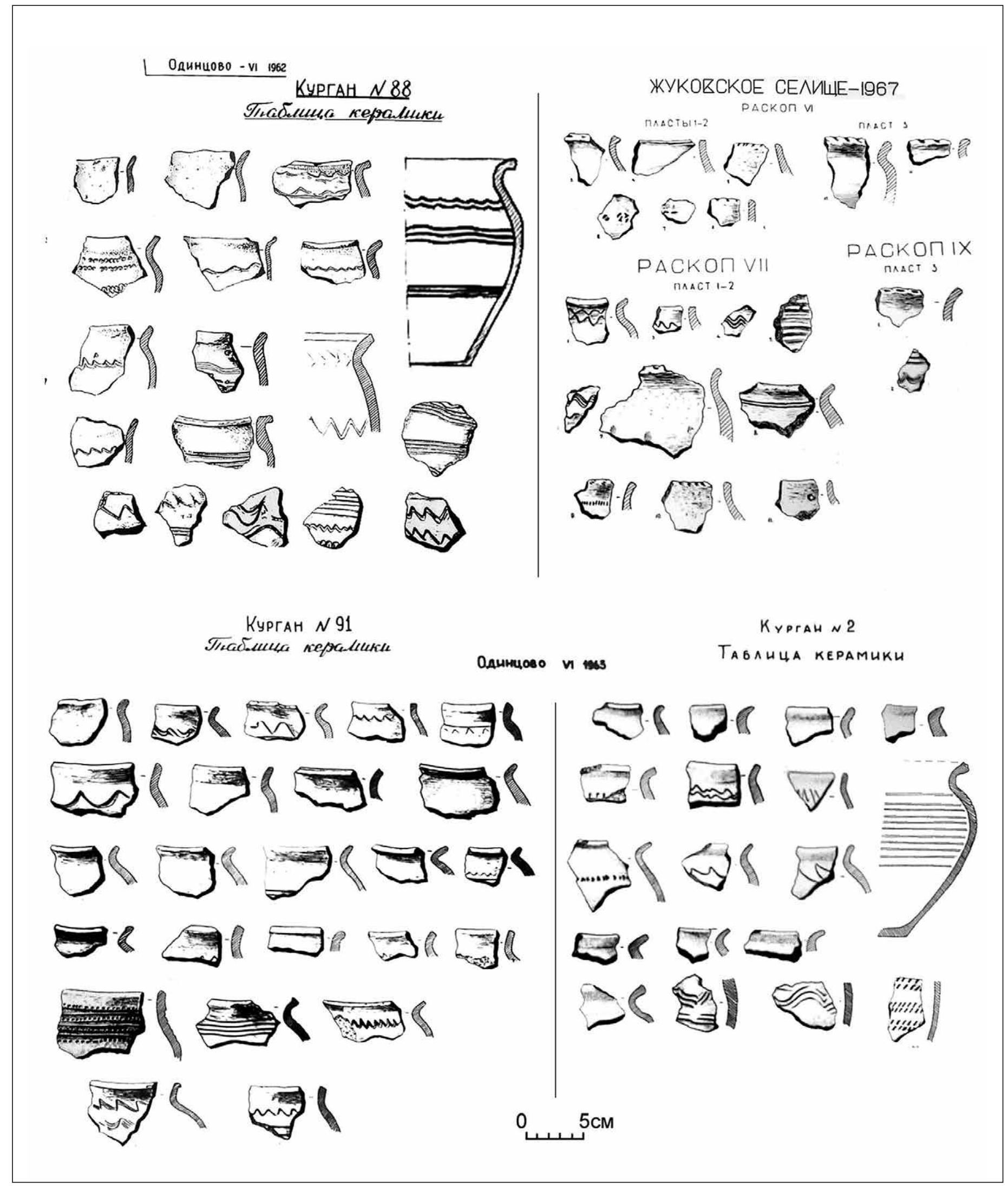

РИС. 202. ЛЕПНАЯ И РАННЕКРУГОВАЯ КЕРАМИКА XI-XII ВВ. ИЗ РАСКОПОК НА СЕЛИЩЕ ЖУКОВКА И КУРГАННОЙ ГРУППЫ ОДИНЦОВО 6 (ПО ОТЧЕТАМ А.Г. ВЕКСЛЕРА) 


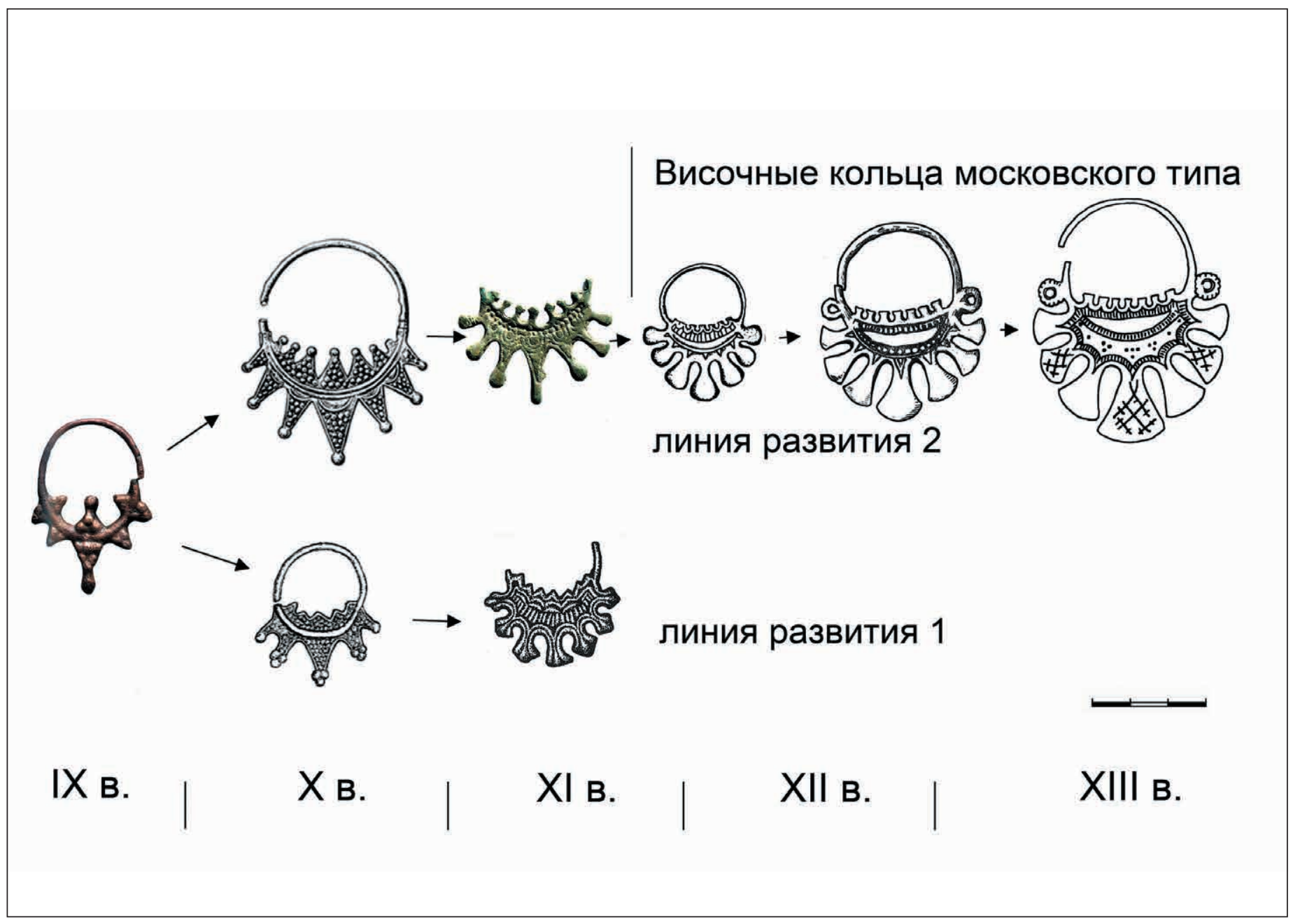

РИС. 203. СХЕМА РАЗВИТИЯ ЛУЧЕВЫХ И ЛОПАСТНЫХ КОЛЕЦ 


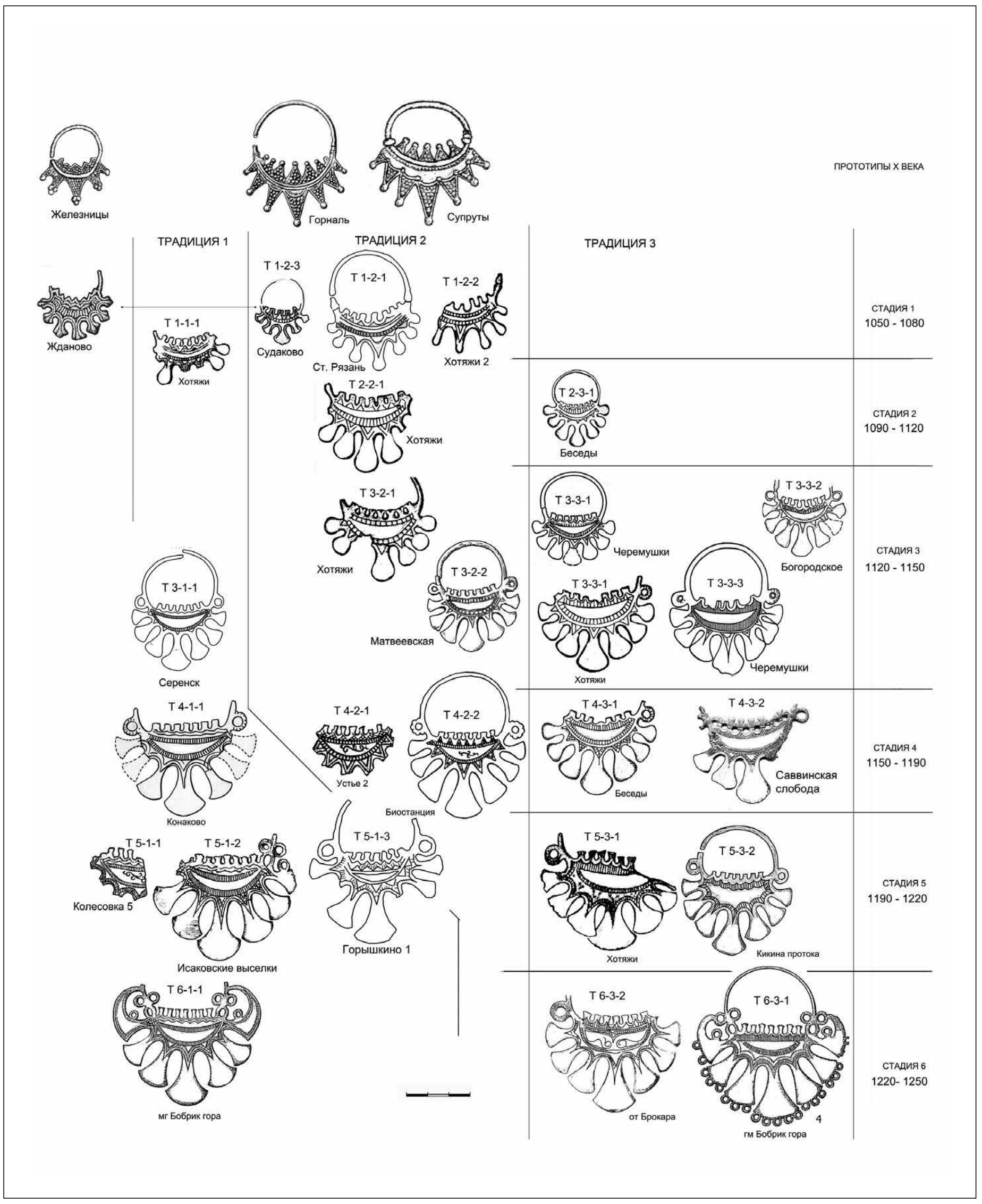

РИС. 204. КЛАССИФИКАЦИЯ ОРНАМЕНТОВ НА ВИСОЧНЫХ КОЛЬЦАХ МОСКОВСКОГО ТИПА 


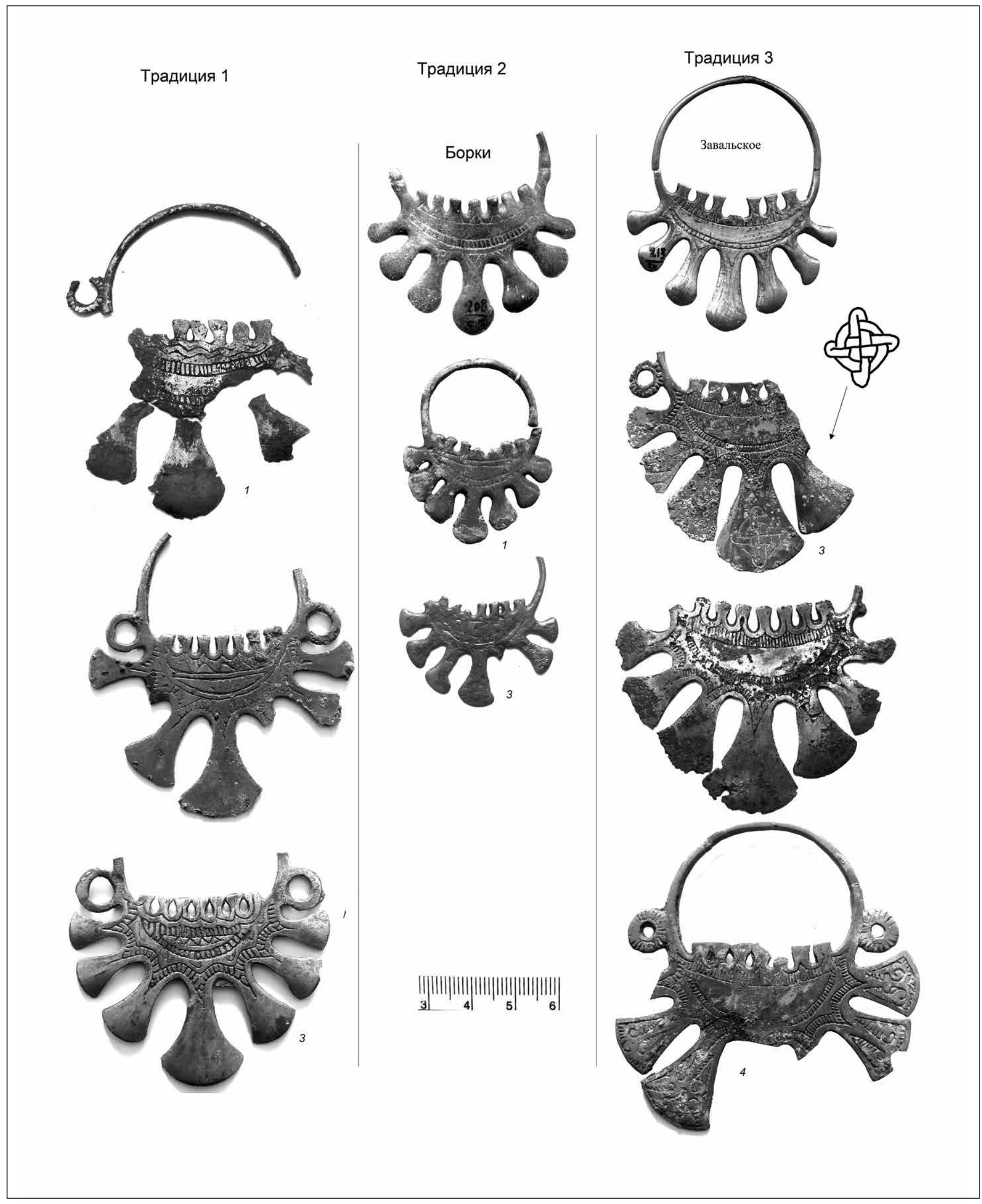

РИС. 205. ВИСОЧНЫЕ КОЛЬЦА МОСКОВСКОГО ТИПА ТРЕХ ОРНАМЕНТАЛЬНЫХ ТРАДИЦИЙ 

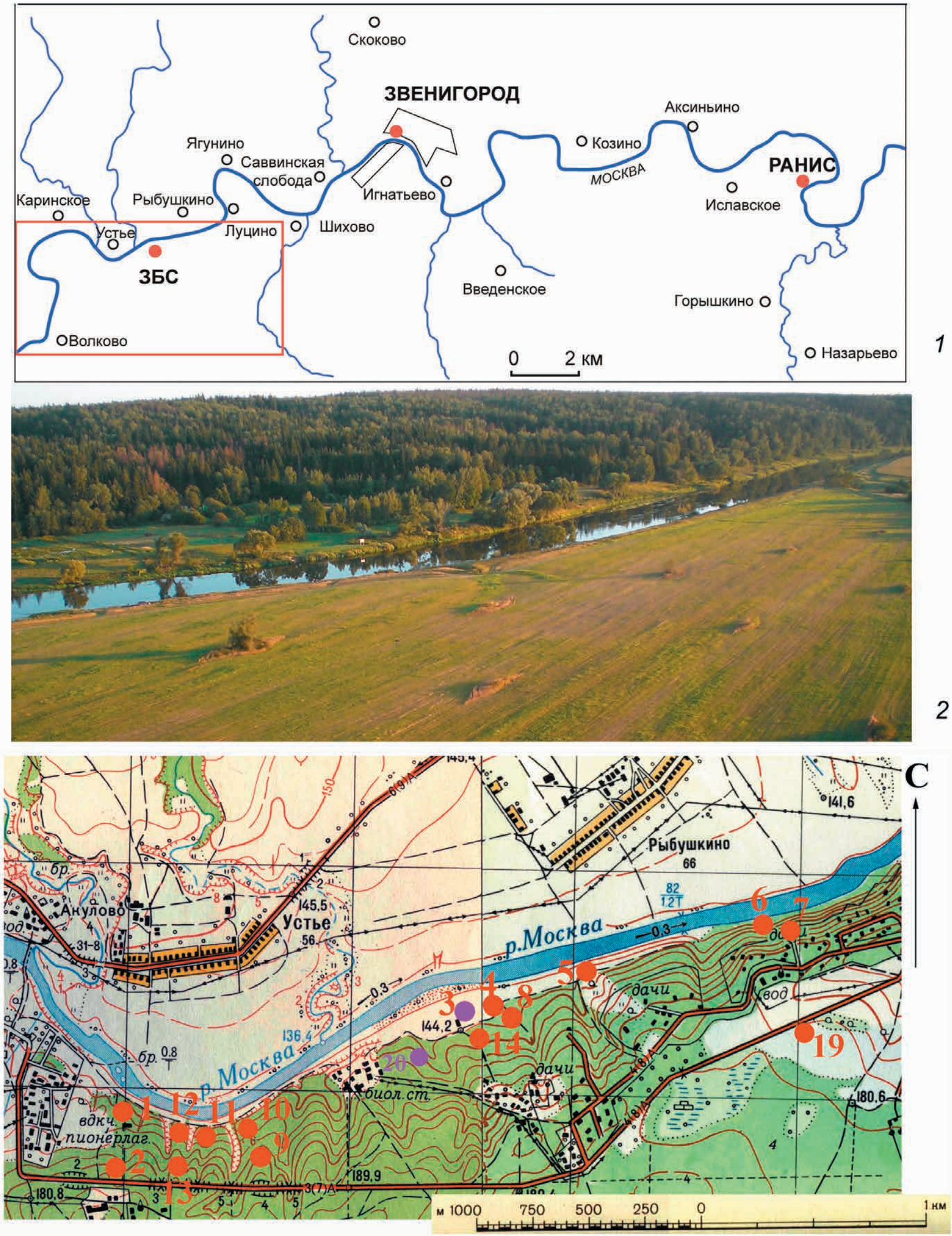

РИС. 206. ПОКРЫТЫЙ ЛЕСОМ ПРАВЫЙ БЕРЕГ МОСКВЫ-РЕКИ НА ТЕРРИТОРИИ БИОСТАНЦИИ МГУ В ЛУЦИНО, ГДЕ В ХІІІ В. РАСПОЛАГАЛИСЬ ПОСЕЛЕНИЯ 


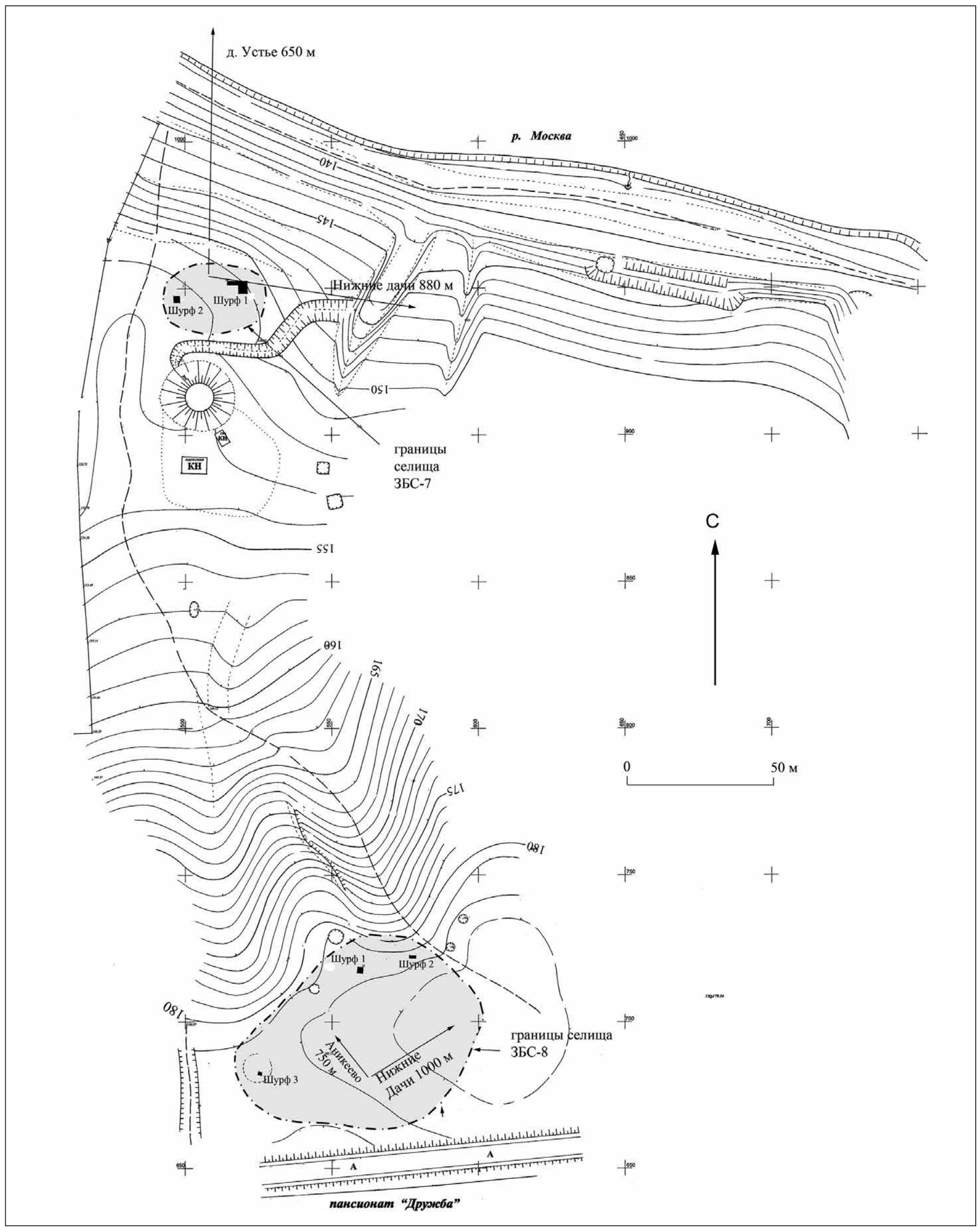

РИС. 207. ПЛАН ПОСЕЛЕНИЙ ЗБС -7 И ЗБС -8. СЪЕМКА 2012 Г. В.В. ПЕТРОВ. ГОРИЗОНТАЛИ ЧЕРЕЗ 1 М 

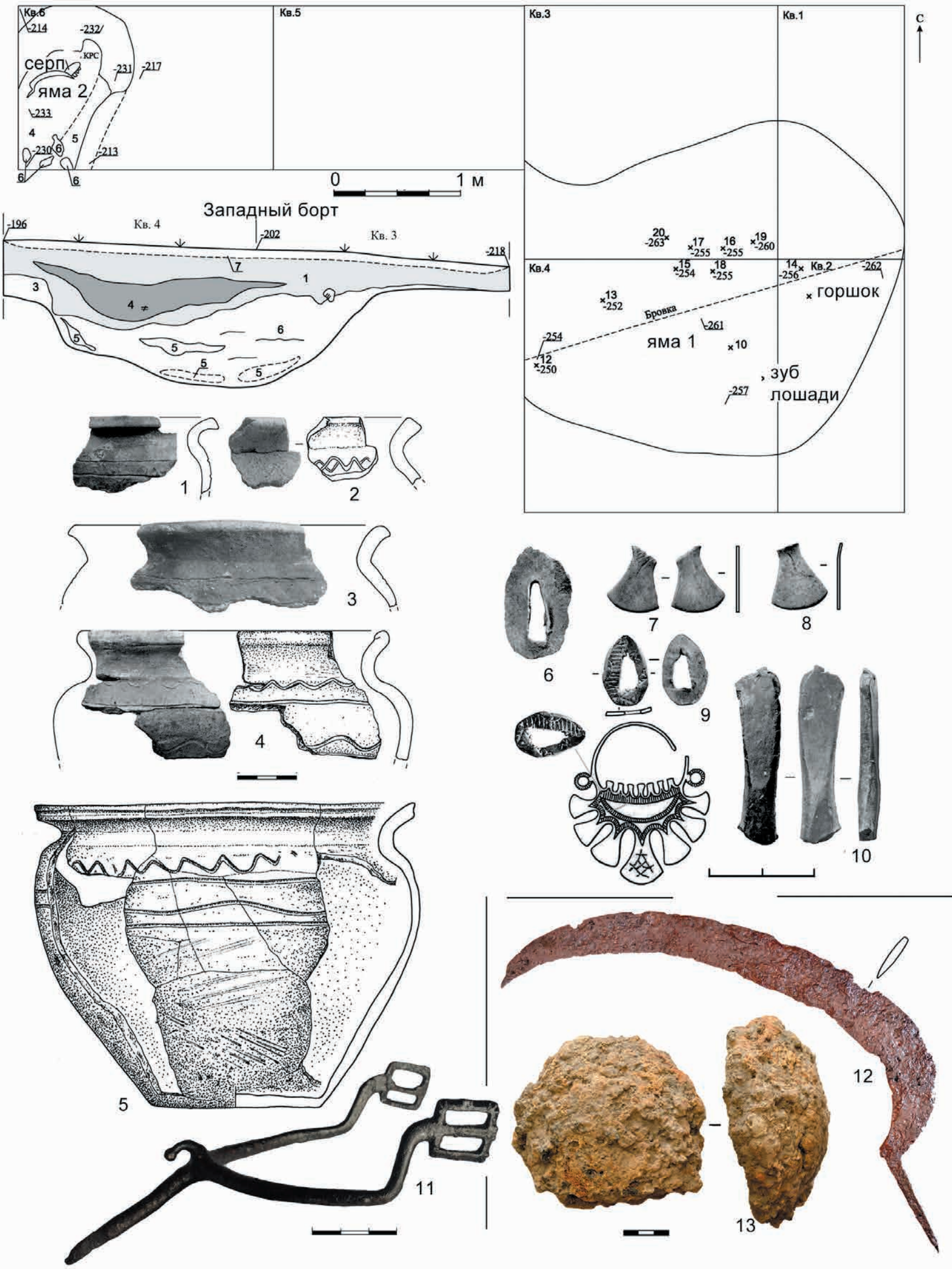

РИС. 208. ПЛАН РАСКОПА НА СЕЛИЩЕ ЗБС -7 И НАХОДКИ ИЗ НЕГО: ОБОЙМА НОЖА, СДЕЛАННАЯ ИЗ ЛОПАСТИ СЕМИЛОПАСТНОГО ВИСОЧНОГО КОЛЬЦА (9); ЛОПАСТИ ВИСОЧНЫХ КОЛЕЦ $(7,8)$; СЕРП (12), ШПОРА XII-XIII ВВ. (11); ЖЕЛЕЗНЫЙ ШЛАК (13), КЕРАМИКА (1-5) 


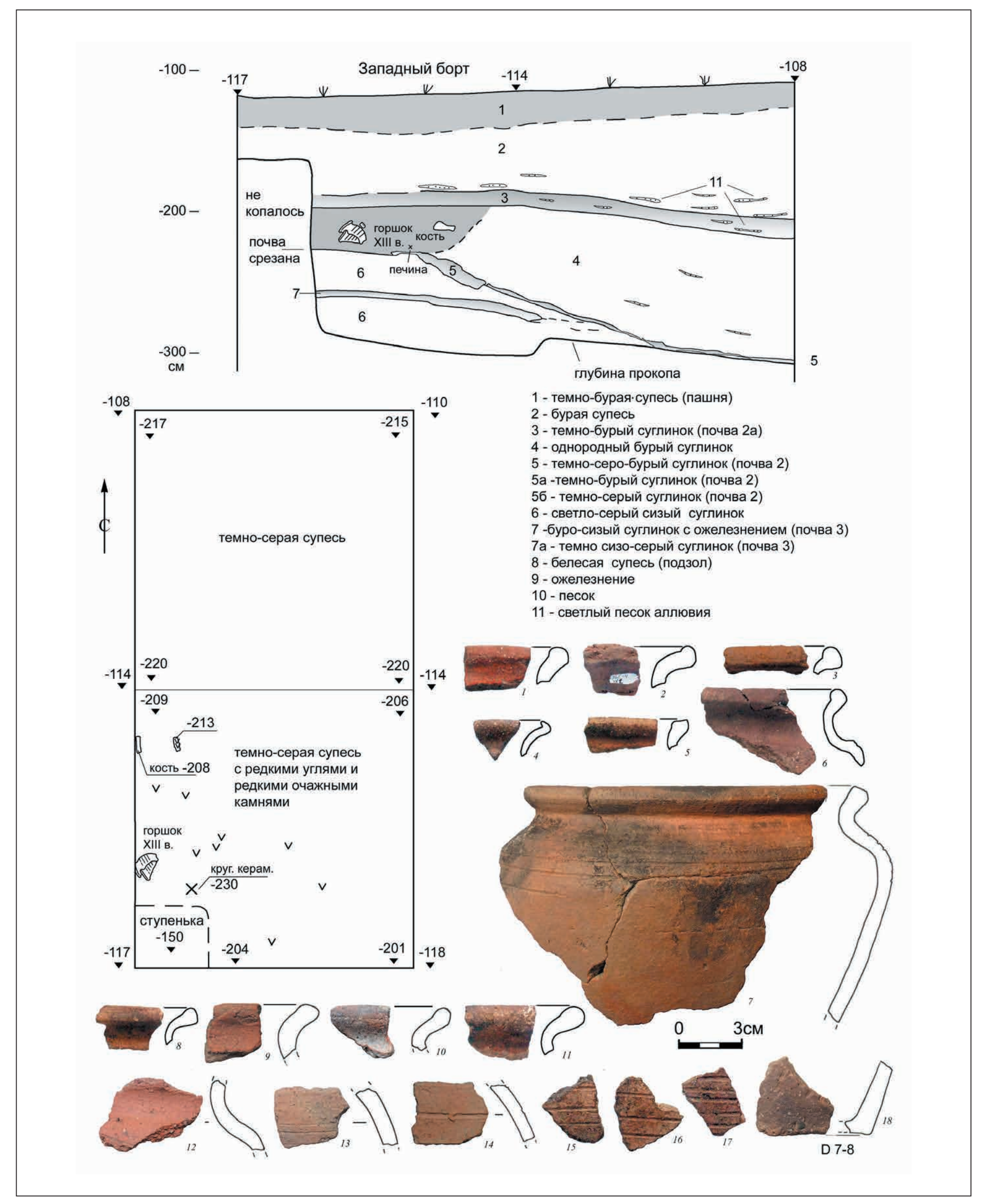

РИС. 209. ПЛАН И ПРОФИЛЬ ШУРФА НА СЕЛИЩЕ ЗБС-4 И КЕРАМИКА ИЗ НЕГО 

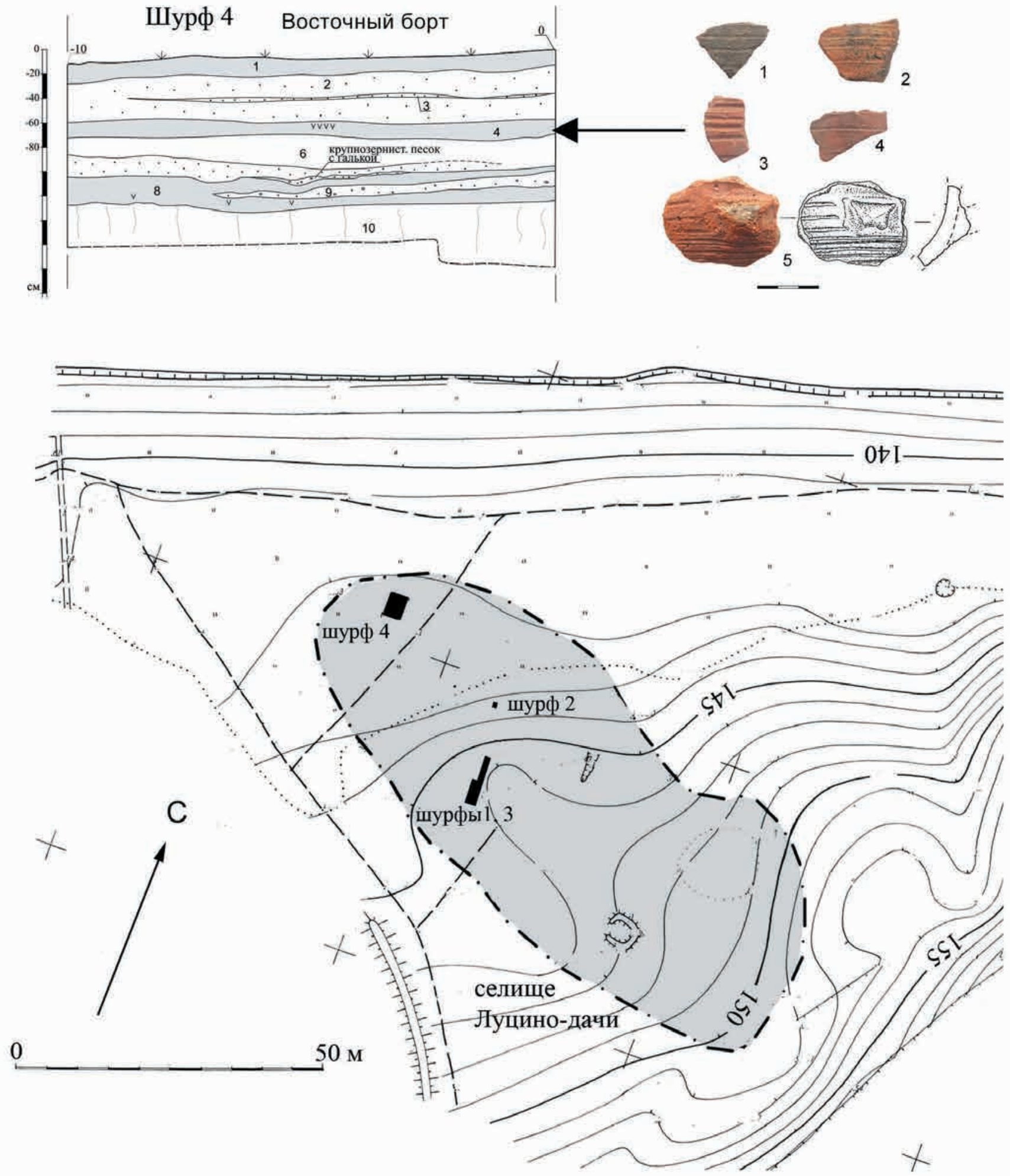

РИС. 210. ПЛАН СЕЛИЩА ЛУЦИНО-ДАЧИ; ПРОФИЛЬ ШУРФА 4 И НАХОДКИ ИЗ НЕГО 


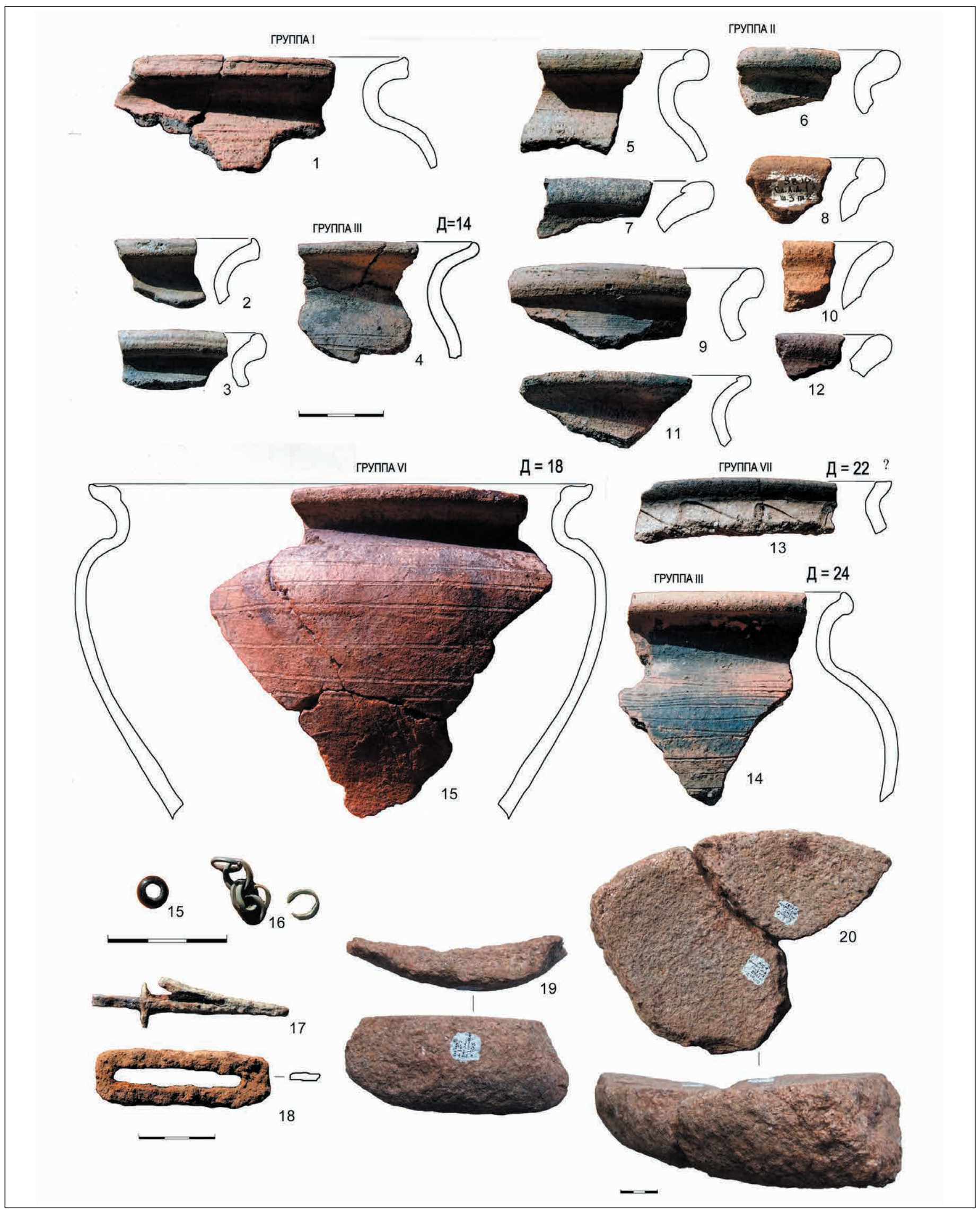

РИС. 211. НАХОДКИ ИЗ ШУРФОВ НА СЕЛИЩЕ ЛУЦИНО-ДАЧИ 


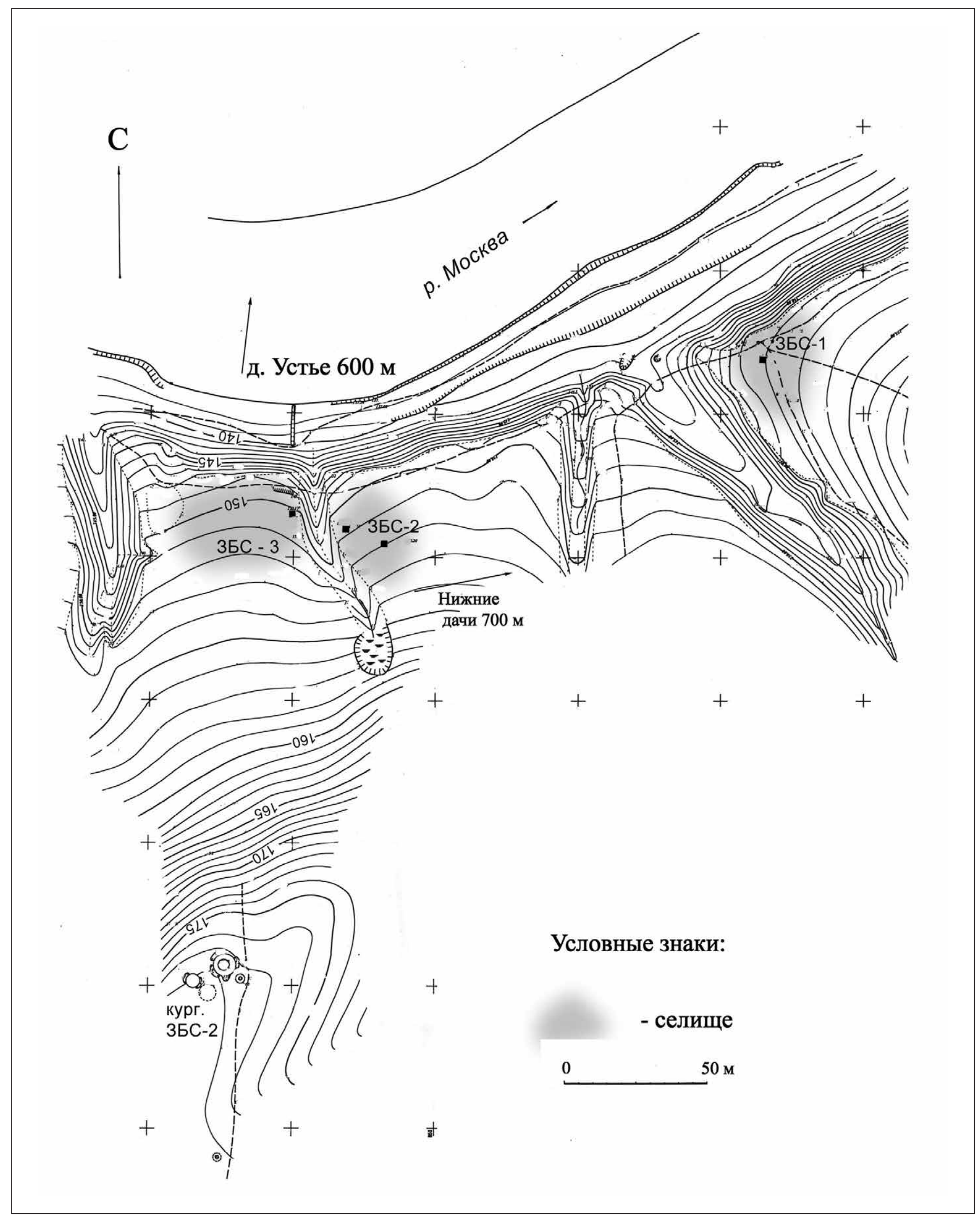

РИС. 212. ПЛАН СЕЛИЩ ЗБС-1, ЗБС-2, ЗБС-3 И КУРГАННОЙ ГРУППЫ ЗБС-2 




РИС. 213. НАХОДКИ С СЕЛИЩ ЗБС-1, ЗБС-2 И ЗБС-3 


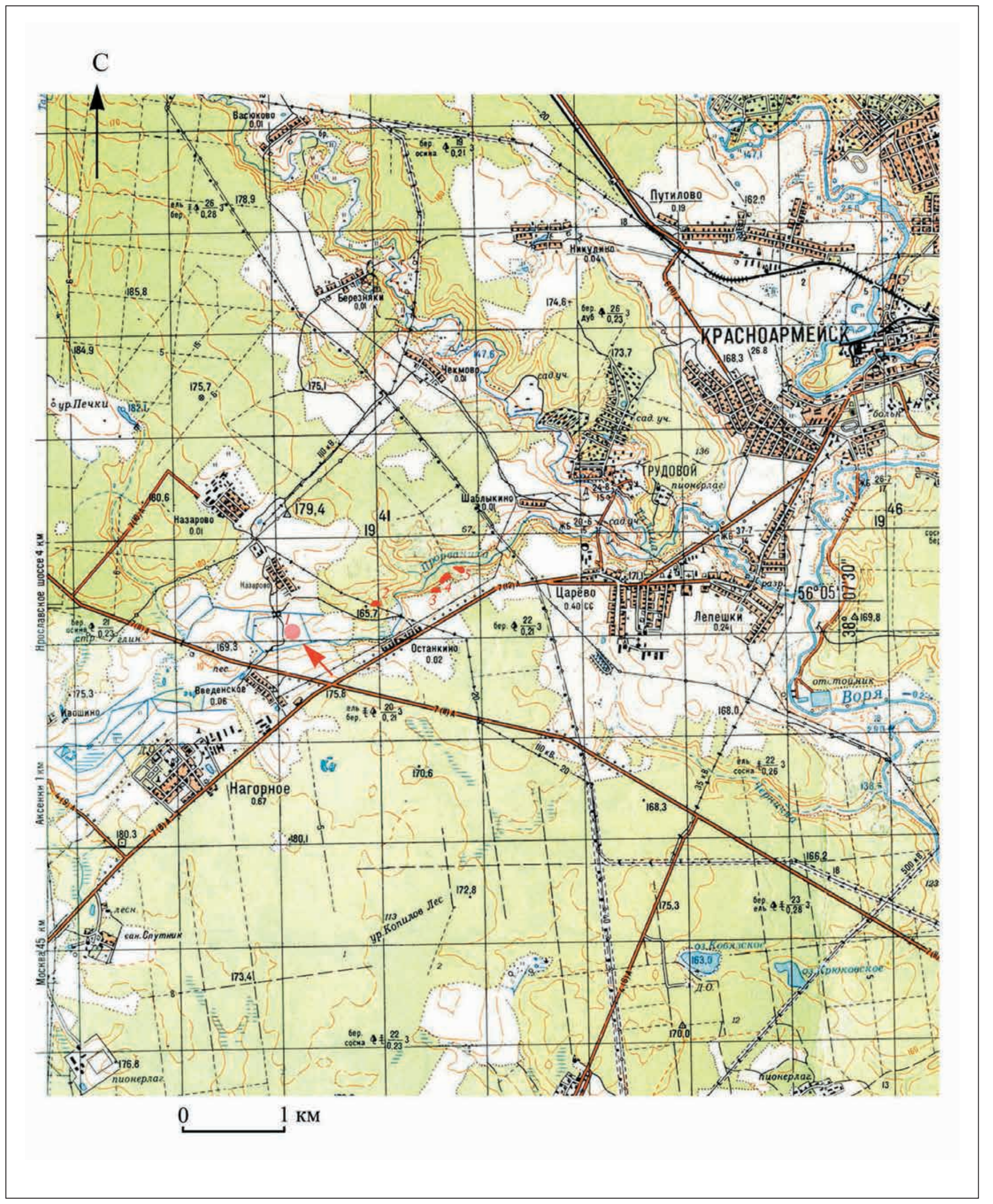

РИС. 214. ПОЛОЖЕНИЕ СЕЛИЩА НАЗАРОВО 2 (1) НА ТОПОГРАФИЧЕСКОЙ КАРТЕ

Красными символами показаны курганная группа Останкино 1 (2); курганная группа Царево-1 (3); селище Царево 1 (4); городище Царево 1 (5) 


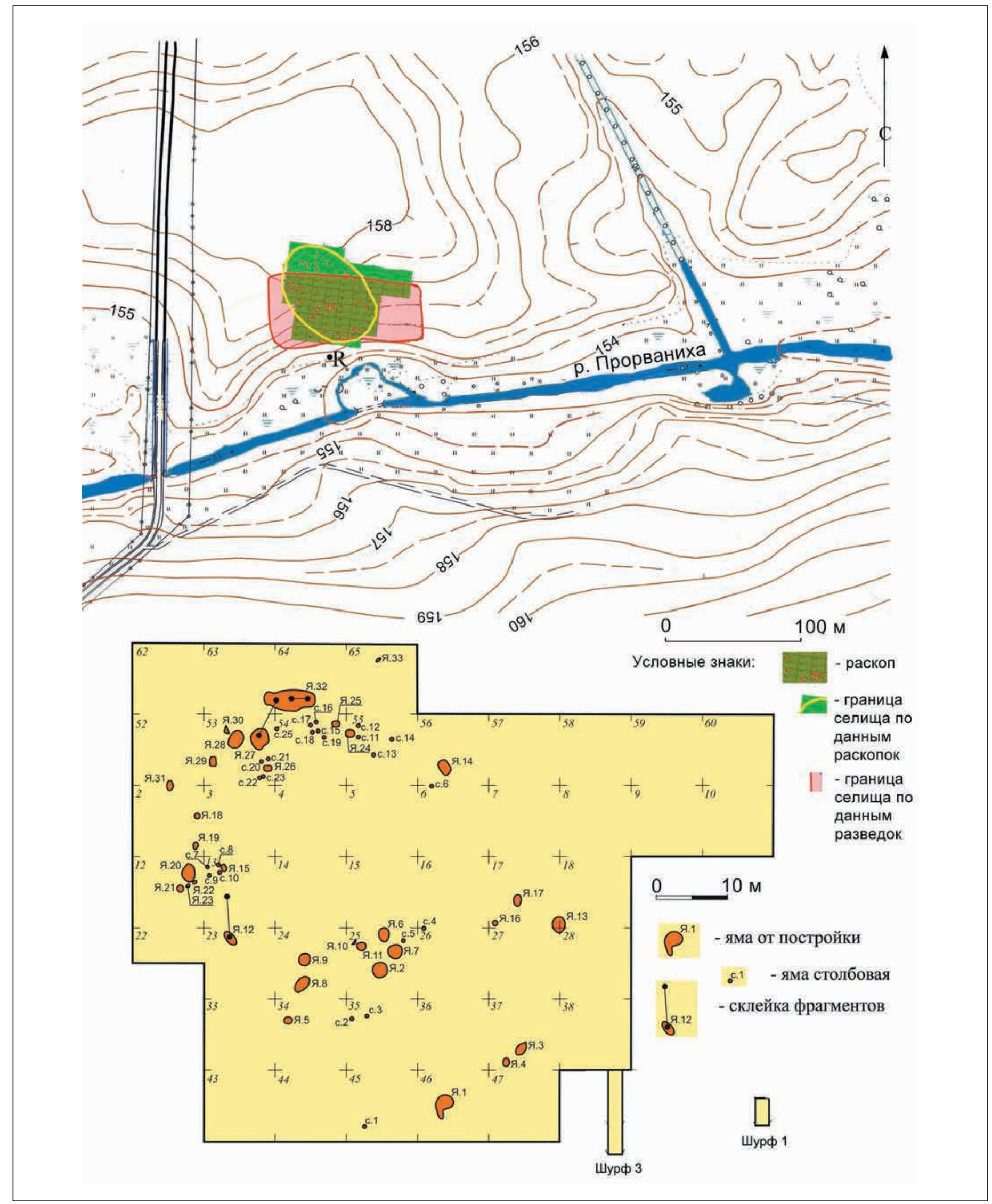

РИС. 215. ТОПОГРАФИЧЕСКИЙ ПЛАН СЕЛИЩА НАЗАРОВО 2 (ЖЕЛТЫМ ЦВЕТОМ ПОКАЗАНЫ УТОЧНЕННЫЕ ПОСЛЕ РАСКОПОК ГРАНИЦЫ ПАМЯТНИКА) И ПЛАН РАСКОПА 2012 г. 


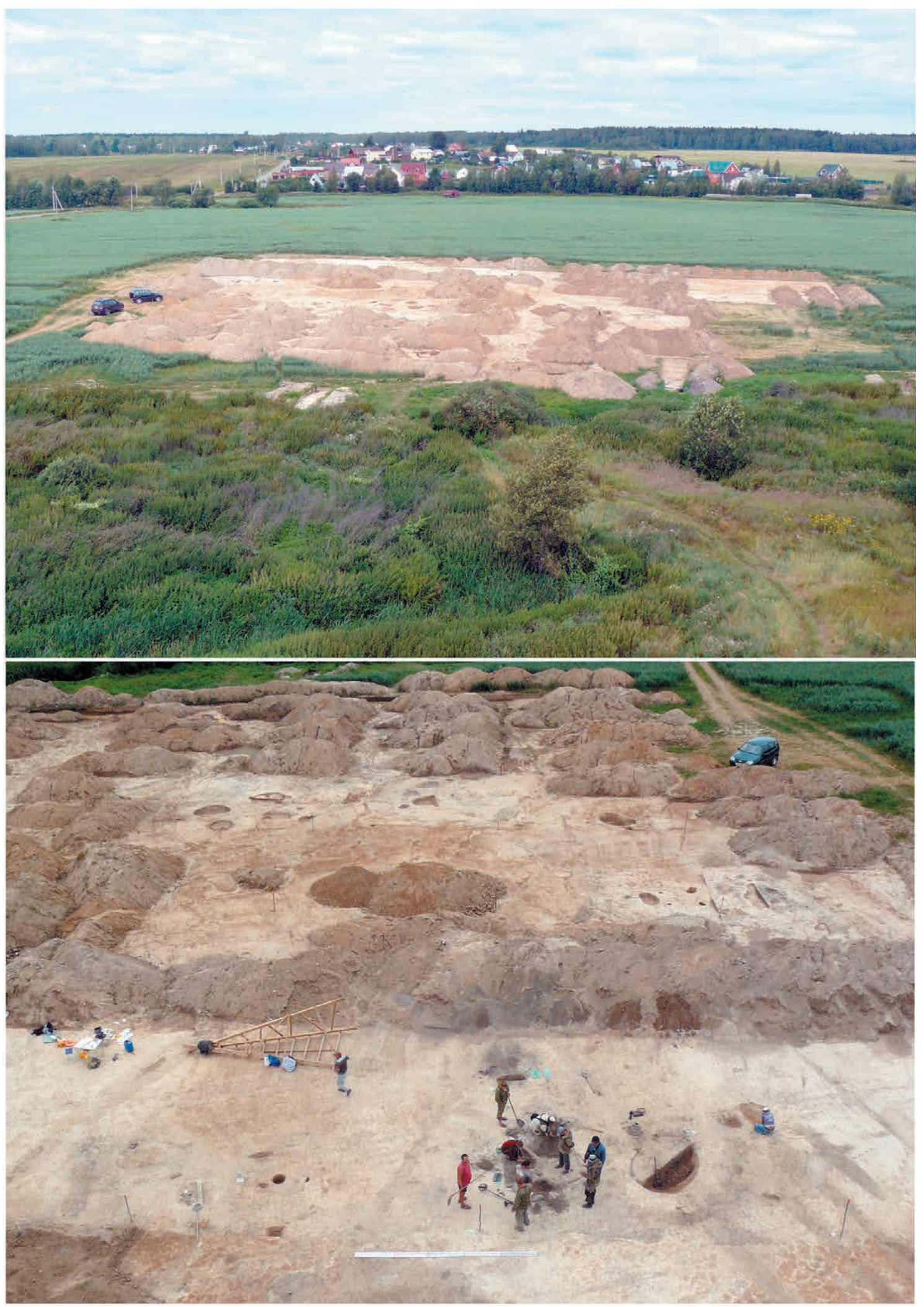

РИС. 216. СЕЛИЩЕ НАЗАРОВо 2, ВИДЫ НА РАСКОП 2012 Г.: ВВеРХХ - С ЮГА; ВНИЗУ - С СЕВеРА 




РИС. 217. ЖЕЛЕЗНЫЕ ИЗДЕЛИЯ ИЗ РАСКОПОК СЕЛИЩА НАЗАРОВО 2 


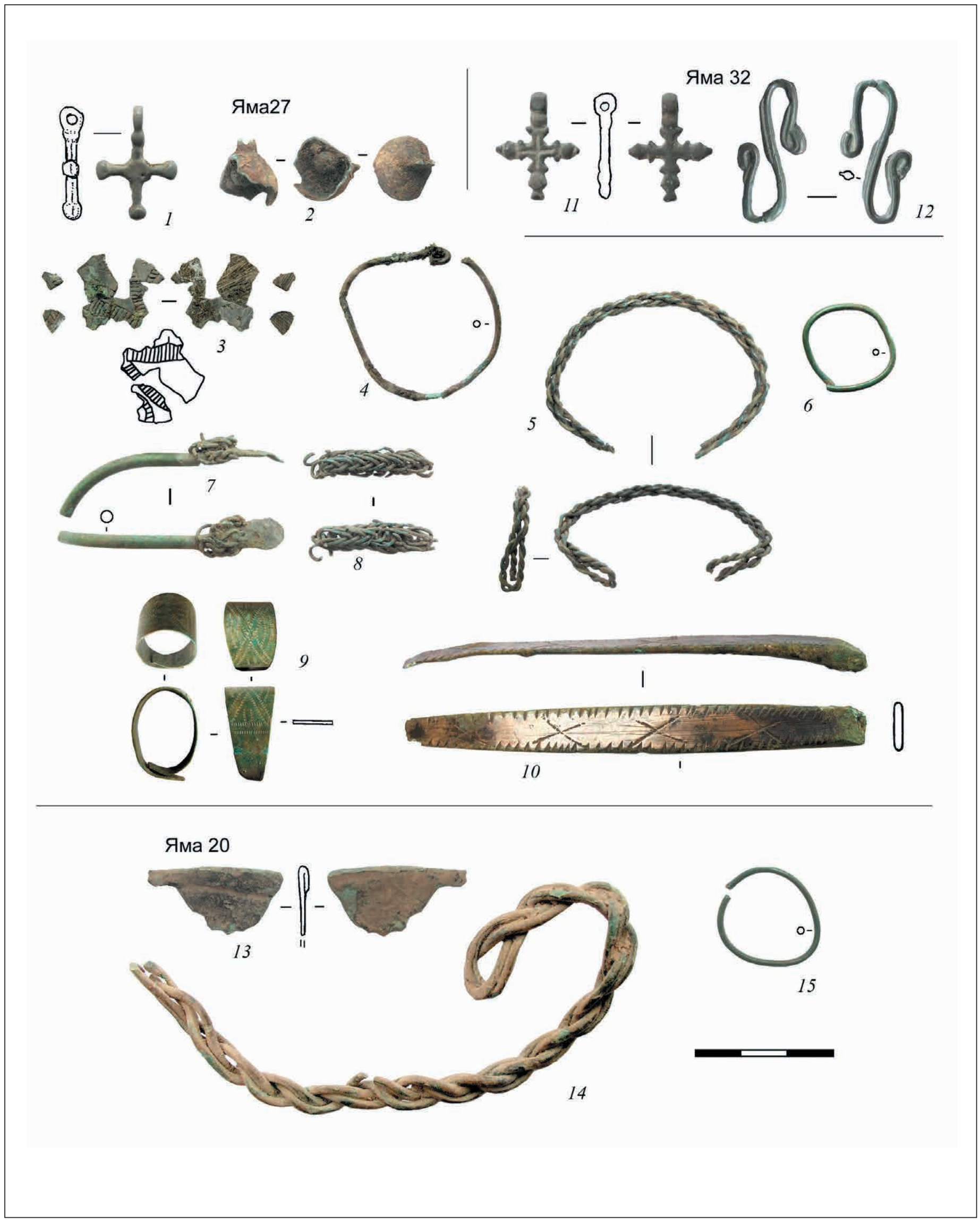

РИС. 218. БРОНЗОВЫЕ ИЗДЕЛИЯ ИЗ РАСКОПОК СЕЛИЩА НАЗАРОВО 2 



РИС. 219. КЛАССИФИКАЦИЯ И «ГЕНЕТИЧЕСКИЕ» СВЯЗИ ТИПОВ КЕРАМИКИ ХІІІ В. ПО МАТЕРИАЛАМ СЕЛИЩА НАЗАРОВО 2 (ПО Н.Н. ГРИБОВУ) 



РИС. 220. ГОРШКИ, ХАРАКТЕРИЗУЮЩИЕ ГРУППЫ А И Б ТИПОЛОГИЧЕСКОЙ СХЕМЫ Комплексы ям 13, 14, 32. Селище Назарово 2 


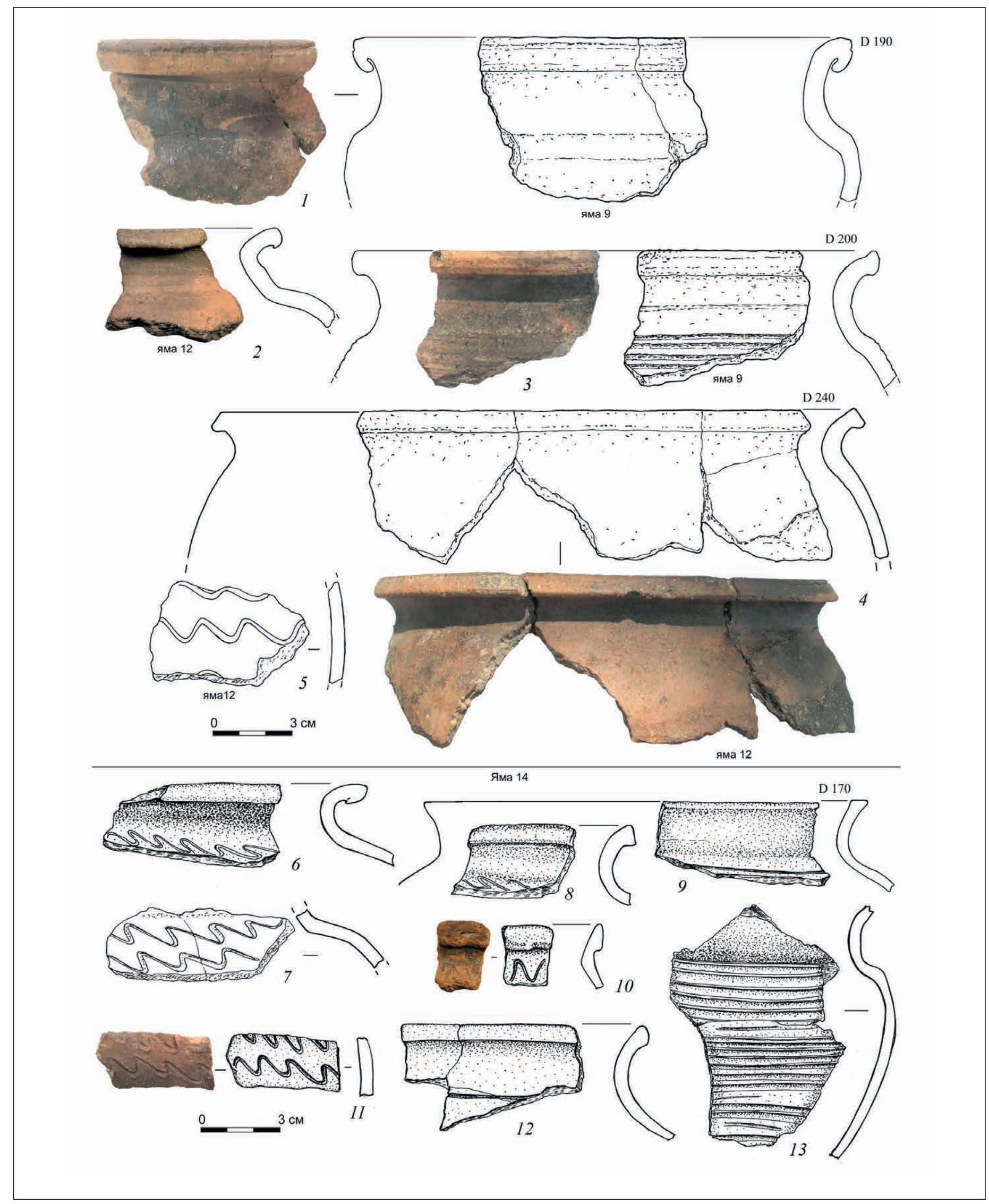

РИС. 221. КОМПЛЕКСЫ КЕРАМИКИ ИЗ ЯМ 12 и 14 НА СЕЛИЩЕ НАЗАРОВО 2 


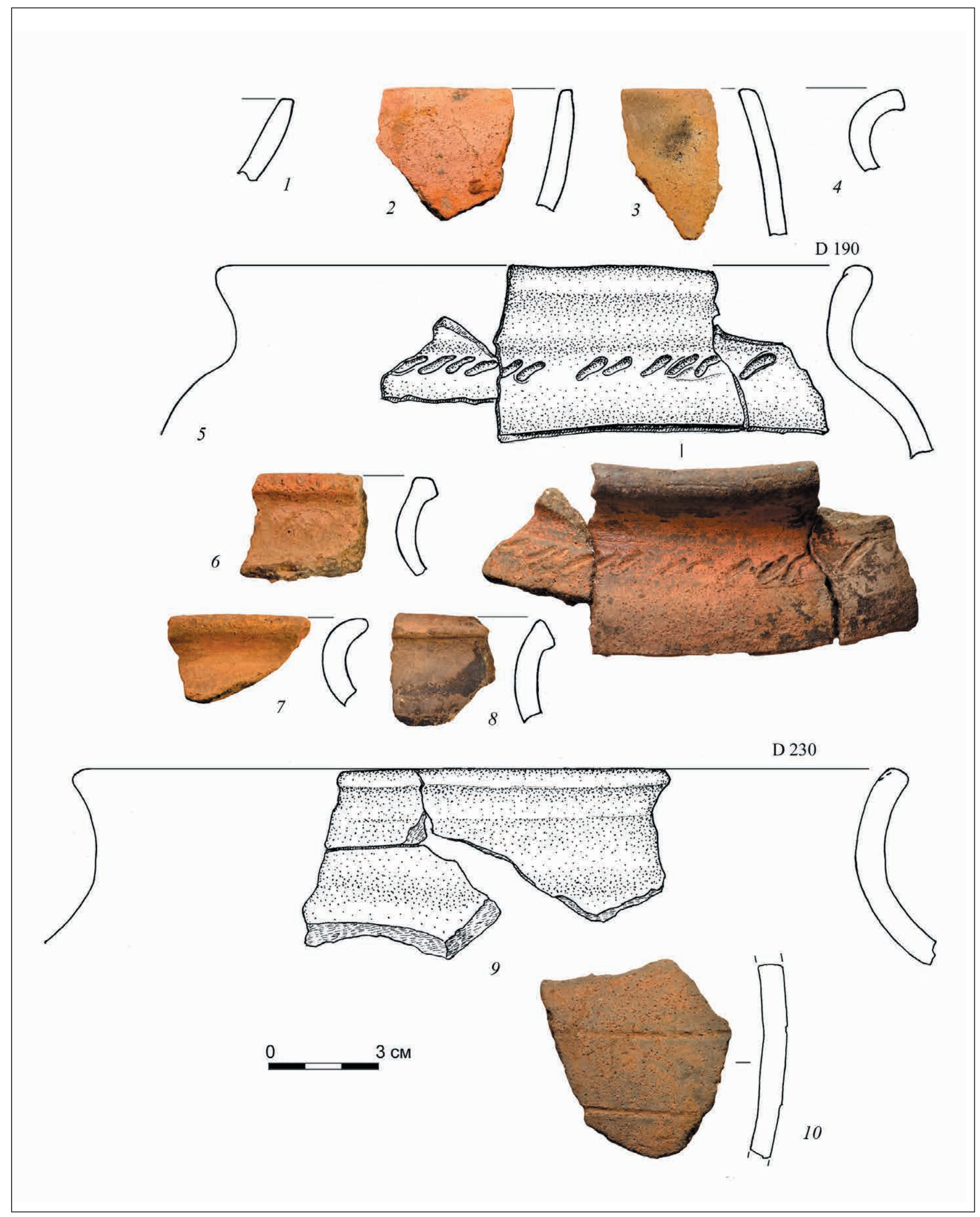

РИС. 222. КОМПЛЕКС КЕРАМИКИ ИЗ ЯМЫ 14. СЕЛИЩЕ НАЗАРОВО 2 

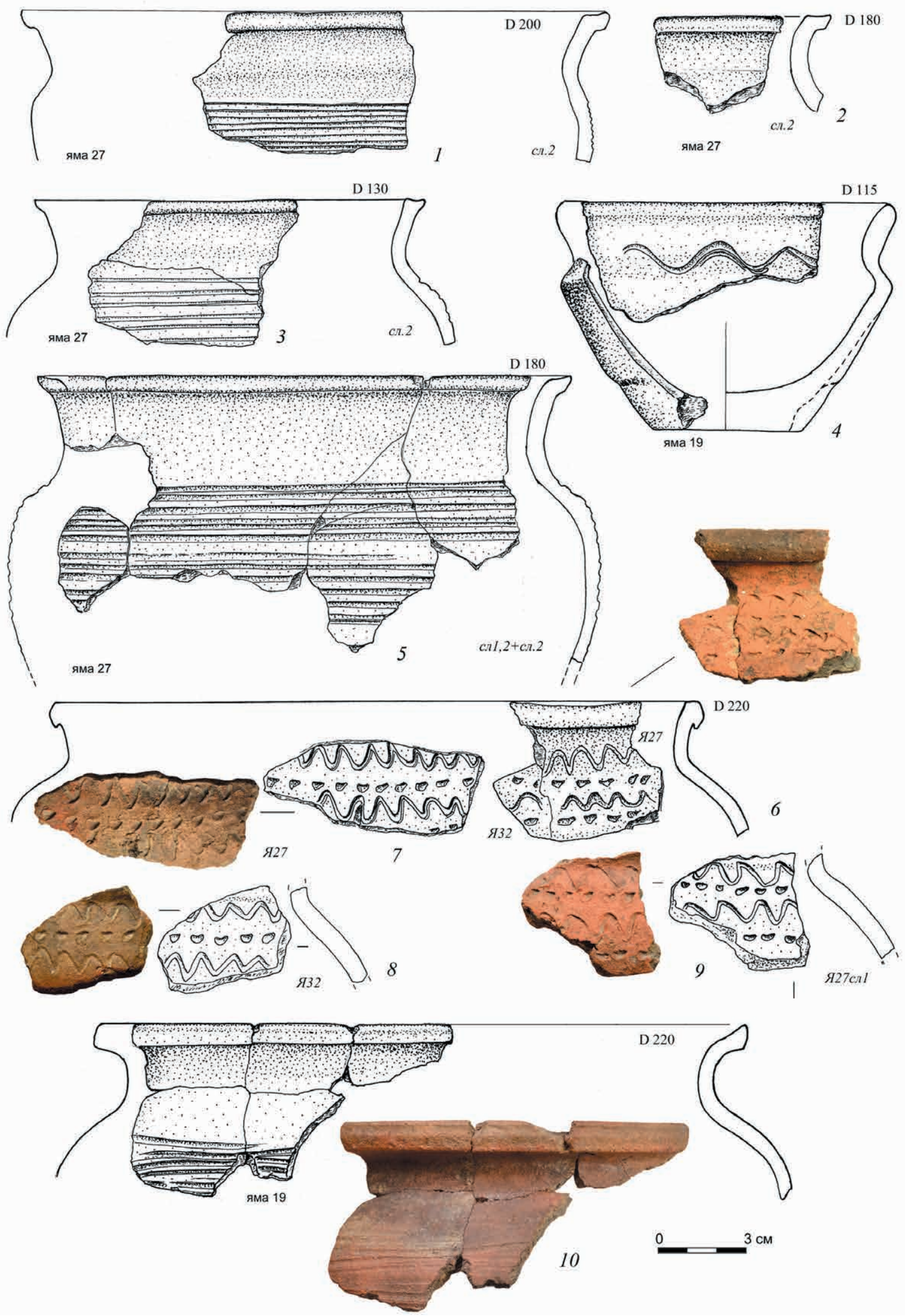

РИС. 223. КОМПЛЕКСЫ КЕРАМИКИ ИЗ Ям 19 и 27. СЕЛИЩЕ НАЗАРОВо 2 


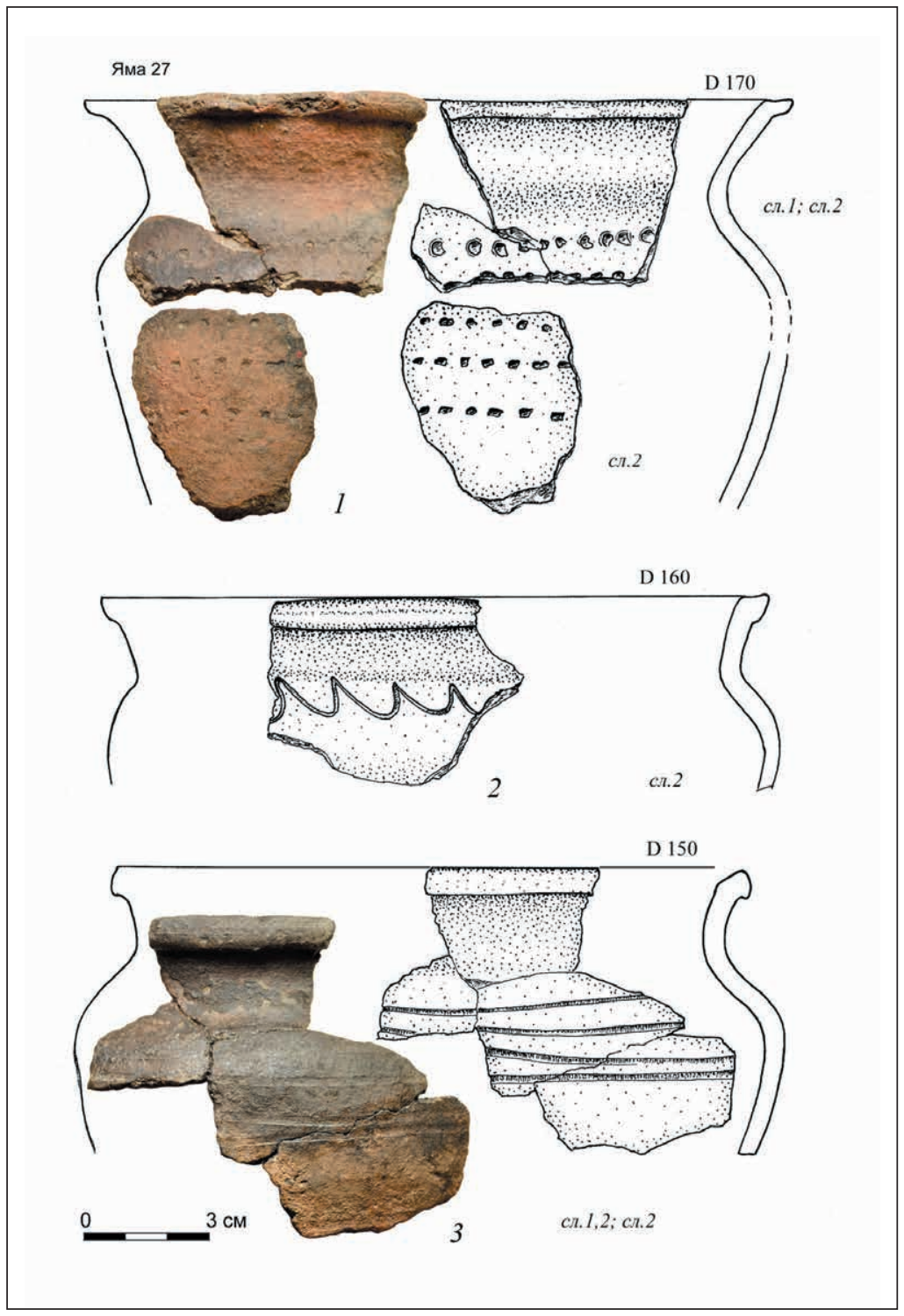

РИС. 224. КОМПЛЕКС КЕРАМИКИ ИЗ ЯМЫ 27. СЕЛИЩЕ НАЗАРОВО 2

РИС. 225. ЗОНЫ КОНЦЕНТРАЦИИ АРХЕОЛОГИЧЕСКИХ ПАМЯТНИКОВ В БАССЕЙНЕ МОСКВЫ-РЕКИ

1 - неолит; 2 - фратьяновская культура бронзового века; 3 - дьяковская культура железного века; 4 - древнерусские памятники X-XIII вв. Составлена А.Н. Кренке и В.Н. Кренке
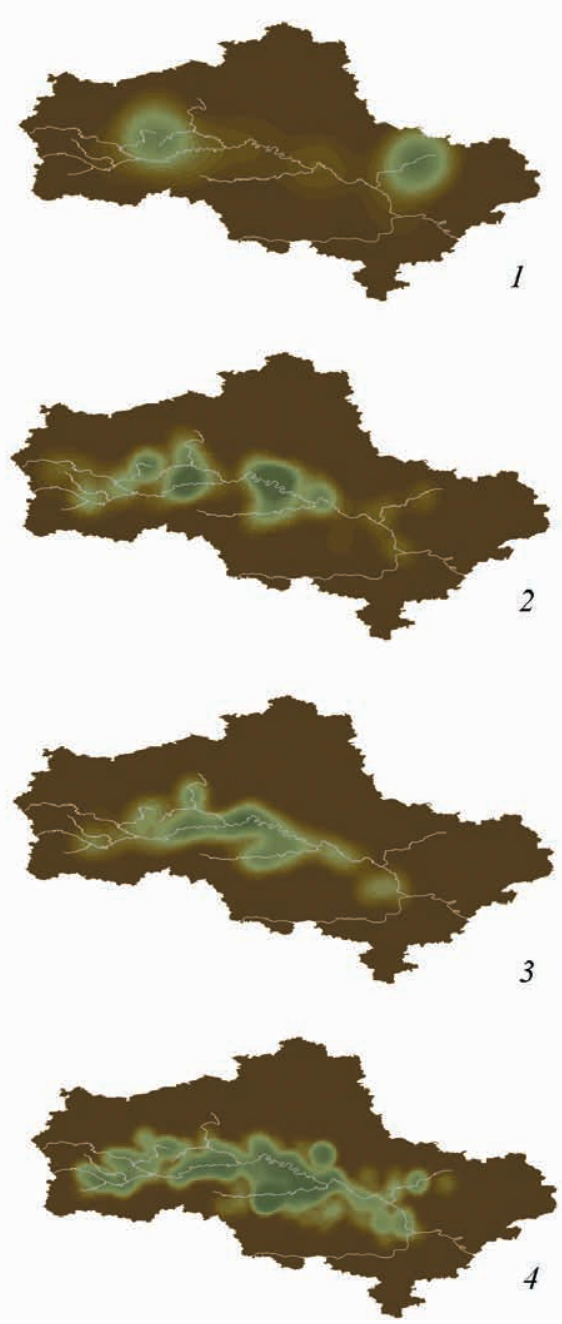